a The a

Manchester

Spenser

$\rightarrow$ - $\rightarrow$

Pastoral Poetry

of the English

Renaissance

An anthology

$\rightarrow$ -

EDITED BY

$\infty$

EDITED BY
SUKANTA CHAUDHURI




\section{Pastoral Poetry of the English Renaissance}

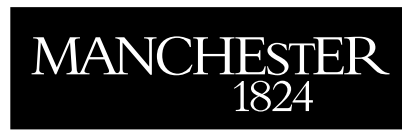

Manchester University Press 


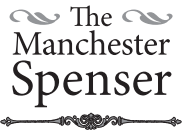

The Manchester Spenser is a monograph and text series devoted to historical and textual approaches to Edmund Spenser - to his life, times, places, works and contemporaries.

A growing body of work in Spenser and Renaissance studies, fresh with confidence and curiosity and based on solid historical research, is being written in response to a general sense that our ability to interpret texts is becoming limited without the excavation of further knowledge. So the importance of research in nearby disciplines is quickly being recognised, and interest renewed: history, archaeology, religious or theological history, book history, translation, lexicography, commentary and glossary - these require treatment for and by students of Spenser.

The Manchester Spenser, to feed, foster and build on these refreshed attitudes, aims to publish reference tools, critical, historical, biographical and archaeological monographs on or related to Spenser, from several disciplines, and to publish editions of primary sources and classroom texts of a more wide-ranging scope.

The Manchester Spenser consists of work with stamina, high standards of scholarship and research, adroit handling of evidence, rigour of argument, exposition and documentation.

The series will encourage and assist research into, and develop the readership of, one of the richest and most complex writers of the early modern period.

\section{General Editor J.B. Lethbridge \\ Associate General Editor Joshua Reid}

Editorial Board Helen Cooper, Thomas Herron, Carol V. Kaske,

James C. Nohrnberg \& Brian Vickers

Also available

Literary Ralegh and visual Ralegh Christopher M. Armitage (ed.)

A Concordance to the Rhymes of The Faerie Queene-Richard Danson Brown

\& J. B. Lethbridge

A Supplement of the Faery Queene: By Ralph Knevet Christopher Burlinson \& Andrew Zurcher (eds)

Monsters and the poetic imagination in Edmund Spenser's The Faerie Queene: 'Most ugly shapes and horrible aspects' Maik Goth

Celebrating Mutabilitie: Essays on Edmund Spenser's Mutabilitie Cantos Jane Grogan (ed.)

Castles and Colonists: An archaeology of Elizabethan Ireland Eric Klingelhofer

Shakespeare and Spenser: Attractive opposites J.B. Lethbridge (ed.)

A Fig for Fortune: By Anthony Copley Susannah Monta Brietz

Spenser and Virgil: The pastoral poems Syrithe Pugh

Renaissance erotic romance: Philhellene Protestantism,

Renaissance translation and English literary politics Victor Skretkowicz

God's only daughter: Spenser's Una as the invisible Church-Kathryn Walls 


\title{
Pastoral Poetry of the English Renaissance
}

\author{
An anthology
}

\author{
@ \\ edited by \\ SUKANTA CHAUDHURI
}

Manchester University Press 
Introduction, critical apparatus etc. copyright (c) Sukanta Chaudhuri 2016

The right of Sukanta Chaudhuri to be identified as the editor of this work has been asserted by him in accordance with the Copyright, Designs and Patents Act 1988.

This electronic version has been made freely available under a Creative Commons (CC-BY-NC-ND) licence, thanks to the support of Knowledge Unlatched, which permits non-commercial use, distribution and reproduction provided the author(s) and Manchester University Press are fully cited and no modifications or adaptations are made. Details of the licence can be viewed at https:// creativecommons.org/licenses/by-nc-nd/3.0/

Published by Manchester University Press Altrincham Street, Manchester M1 7JA, UK

www.manchesteruniversitypress.co.uk

British Library Cataloguing-in-Publication Data

A catalogue record for this book is available from the British Library

Library of Congress Cataloging-in-Publication Data applied for

ISBN 9780719096822 hardback

First published 2016

The publisher has no responsibility for the persistence or accuracy of URLs for any external or third-party internet websites referred to in this book, and does not guarantee that any content on such websites is, or will remain, accurate or appropriate.

Typeset in Minion

by Julian Lethbridge 


\section{Contents}

Acknowledgements

page xii

Practices and conventions

xiii

Abbreviations

xvi

Introduction

xix

1. Idyll VIII Theocritus, tr. anon. 1

2. Idyll XI Theocritus, tr. anon. 3

3. The Pastoral Wooing Theocritus (?), tr. Edward Sherburne 5

4. Fragments Theocritus and Virgil, tr. 'T.B.' 6

5. Epitaph on Bion Moschus (?), tr. Thomas Stanley 7

6. Eclogue I Virgil, tr. William Webbe 10

7. Eclogue II Virgil, tr. Abraham Fraunce 12

8. Eclogue IV Virgil, tr. Abraham Fleming 14

9. Eclogue X Virgil, tr. Abraham Fleming 17

10. Georgic II. 458-542 Virgil, tr. Abraham Cowley 19

11. Georgic III. 295-9, 322-38, 404-7, 440 ff. Virgil, tr. Richard Robinson 22

12. Epode II Horace, tr. Sir Richard Fanshawe 23

13. On the Rustic Life Anonymous, tr. John Ashmore 25

14. The Consolation of Philosophy, Book II, Poem 5 Boethius, tr. Queen $\begin{array}{ll}\text { Elizabeth I } & 25\end{array}$

15. Eclogue IV. 1-75 Mantuan, tr. George Turberville 26

16. Eclogue VI. 54-105 Mantuan, tr. Alexander Barclay 30

17. Eclogue VII. 1-50 Mantuan, tr. Thomas Harvey 33

18. Robene and Makyne Robert Henryson 35

19. From Of Gentleness and Nobility John Rastell (?), John Heywood (?) 38

20. To His Little Field Marcantonio Flaminio, tr. John Ashmore 41

21. Kala's Complaint Basilio Zanchi, tr. William Drummond of Hawthornden 42

22. 'O eyes, that see not him' Jorge de Montemayor, tr. Bartholomew Yong 42

23. 'Passed contents' Jorge de Montemayor, tr. Bartholomew Yong 44

24. 'I pray thee keep my kine' Alonso Perez, tr. Bartholomew Yong 45

25. Prologue to the Eclogues Alexander Barclay 46

26. Eclogue I.175-304 Alexander Barclay 49

27. Eclogue III.455-524 Alexander Barclay 53

28. Eclogue IV.37-66, 93-232 Alexander Barclay 54

29. 'Oh! Shepherd, Oh! Shepherd' Anonymous 58 
30. 'Hey, troly loly lo, maid, whither go you?' Anonymous 59

31. Harpelus' Complaint Anonymous 60

32. Eclogue II: Dametas Barnabe Googe 62

33. Golden Age Chorus Torquato Tasso, tr. Samuel Daniel 63

34. Golden Age Chorus Giovanni Battista Guarini, tr. Richard Fanshawe 65

35. 'Along the verdant fields' Jean Chassanion, tr. Thomas Beard 66

36. Song Jean Passerat, tr. William Drummond of Hawthornden 67

37. 'There where the pleasant Eske' Antonio Beffa, tr. William Drummond $\begin{array}{lr}\text { of Hawthornden } & 68\end{array}$

38. The Shepherd's Calendar, 'April' Edmund Spenser 69

39. 'O ye nymphs most fine' William Webbe 73

40. The Shepherd's Calendar, 'June' Edmund Spenser 75

41. The Shepherd's Calendar, 'July' Edmund Spenser 78

42. From Colin Clout's Come Home Again Edmund Spenser 83

43. Astrophel Edmund Spenser 89

44. The Faerie Queene VI.ix.5-36 Edmund Spenser 94

45. The Faerie Queene VI.x.5-30 Edmund Spenser 100

46. From The Lady of May Philip Sidney 105

47. 'Come, shepherd's weeds...' Philip Sidney 106

48. 'My sheep are thoughts' Philip Sidney 106

49. 'And are you there Old Pas?' Philip Sidney 107

50. 'O sweet woods' Philip Sidney 110

51. 'You goat-herd gods' Philip Sidney 111

52. 'Since that to death' Philip Sidney 112

53. 'Philisides, the shepherd good and true' Philip Sidney (?) 115

54. Of the Quietness That Plain Country Bringeth Thomas Churchyard 116

55. From A Revelation of the True Minerva Thomas Blenerhasset 117

56. Argentile and Curan William Warner 119

57. Amyntas: The Second Lamentation Thomas Watson, tr. Abraham Fraunce 122

58. Amyntas: The Last Lamentation Thomas Watson, tr. Abraham Fraunce 124

59. An Old-Fashioned Love, Epistle 1 John Trussel (?) 126

6o. The Argument of Amyntas John Finet (?) 129

61. 'Arcadian Syrinx' Abraham Fraunce 130

62. A Tale of Robin Hood Anonymous 131

63. From Daphnis and Chloe Angel Day 133

64. An Eclogue Gratulatory to Robert Earl of Essex George Peele 134

65. From Descensus Astraeae George Peele 138

66. Apollo and Daphne, from the Bisham Entertainment Anonymous 140

67. An Eclogue Between a Shepherd and a Herdman Arthur Gorges 142

$\begin{array}{ll}\text { 68. The Country Lass Arthur Gorges } & 144\end{array}$

69. The Herdman's Happy Life William Byrd 145

70. 'Though Amarillis dance in green' William Byrd 146

$\begin{array}{ll}\text { 71. The Shepherd's Ode Robert Greene } & 147\end{array}$

72. Doron's Jig Robert Greene 149

73. Doron's Eclogue Joined with Carmela's Robert Greene 149

74. The Description of the Shepherd and his Wife Robert Greene 150

75. The Shepherd's Wife's Song Robert Greene 152 
76. The Song of a Country Swain at the Return of Philador Robert Greene 153

77. Of the Vanity of Wanton Writings Robert Greene 155

78. Old Damon's Pastoral Thomas Lodge 157

79. Coridon's Song Thomas Lodge 158

80. A Pleasant Eclogue between Montanus and Coridon Thomas Lodge 159

81. Phillis, Sonnet 4 Thomas Lodge 162

82. Phillis, Sonnet 12 Thomas Lodge 162

83. To Reverend Colin Thomas Lodge 162

84. The Passionate Shepherd to his Love Christopher Marlowe 164

85. The Nymph's Reply to the Shepherd Walter Ralegh (?) 165

86. Another of the Same Nature Anonymous 165

87. Psalm 23 tr. Sir John Davies 166

88. On Lazy and Sleeping Shepherds Andrew Willett 167

89. Coridon to his Phillis Edward Dyer (?) 167

90. 'One night I did attend my sheep' Barnabe Barnes 168

91. 'Sing sing (Parthenophil)' Barnabe Barnes 169

92. From Oenone and Paris Thomas Heywood 170

93. From Amphrisa the Forsaken Shepherdess Thomas Heywood 173

94. Mercury's Song Thomas Heywood 174

95. From The Affectionate Shepherd, The Second Day Richard Barnfield 174

96. From 'The Shepherd's Content' Richard Barnfield 176

97. Cynthia, Sonnet XV Richard Barnfield 179

98. Cynthia, Sonnet XVIII Richard Barnfield 179

99. From Moderatus Robert Parry 180

100. Damon's Ditty Francis Sabie 181

101. 'Shepherd, i'faith now say' Robert Sidney 182

102. 'Day which so bright didst shine' Robert Sidney 183

103. Chloris, Sonnet 3 William Smith 185

104. Chloris, Sonnet 5 William Smith 185

105. Description of Arcadia, from The Shepherd's Complaint John Dickenson 185

106. From The Shepherd's Complaint John Dickenson 186

107. 'In a field full fair of flowers' Anonymous 188

108. The Unknown Shepherd's Complaint Anonymous 189

109. To Thomas Strangways Thomas Bastard 190

110. Sonnet from Sundry Christian Passions Henry Lok 191

111. 'The Lord he is my shepherd' Nicholas Breton 191

112. 'Upon a dainty hill' Nicholas Breton 192

113. 'In time of yore' Nicholas Breton 193

114. 'Fair in a morn' Nicholas Breton 193

115. 'Fair Phillis is the shepherds' queen' Nicholas Breton 194

116. A Pastoral of Phillis and Coridon Nicholas Breton 195

117. 'In the merry month of May' Nicholas Breton 197

118. 'The fields are green' Nicholas Breton 197

119. A Shepherd's Dream Nicholas Breton (?) 198

120. Coridon's Supplication to Phillis Nicholas Breton 199

121. The Second Shepherd's Song Nicholas Breton 199

122. A Farewell to the World Nicholas Breton 201 
123. 'Peace, Shepherd' Anonymous 204

124. 'When I was a little swain' Nicholas Breton (?) 206

125. A Pastoral Riddle Anonymous 207

126. Upon a Kiss Given John Lilliat 207

127. The Shepherdess Her Reply John Lilliat 208

128. An Excellent Pastoral Ditty John Ramsey (?) 209

129. On the Reported Death of the Earl of Essex Anonymous 210

130. Votum Primum John Mansell (?) 213

131. The Page's Pleasant Rustick Anonymous 214

132. Theorello. A Shepherd's Idyllion Edmund Bolton (?) 216

133. The Shepherds' Song for Christmas Edmund Bolton (?) 218

134. Phillida's Love-Call to Her Coridon, and His Replying Anonymous 219

135. Damætas' Jig in Praise of His Love John Wootton 221

136. Wodenfride's Song in Praise of Amargana 'W.H.' 222

137. A Poor Shepherd's Introduction Robert Chester 223

138. Eclogue upon the Death of Sir Philip Sidney 'A.W' 223

139. A Dialogue between Two Shepherds in Praise of Astraea Mary

140. Fiction How Cupid Made a Nymph Wound Herself with His Arrows
Anonymous

141. 'A shepherd poor' Francis Davison 230

142. From The Ocean to Cynthia Walter Ralegh 236

143. Epitaph on Robert Cecil Walter Ralegh 236

144. 'Feed on my flocks' Henry Chettle 237

145. A Pastoral Song between Phillis and Amarillis Henry Chettle (?) 237

146. The Shepherds' Spring Song Henry Chettle 238

147. The Good Shepherd's Sorrow Anonymous 241

148. The Shepherd's Lamentation Anonymous 243

149. Fair Dulcina Complaineth Anonymous 246

150. A Pleasant Country Maying Song Anonymous 248

151. The Country Lass Martin Parker (?) 250

152. The Obsequy of Fair Phillida Anonymous 254

153. The Shepherd and the King Anonymous 255

154. The Lover's Delight Anonymous 260

155. Phillida Flouts Me Anonymous 263

156. Robin Hood and the Shepherd Anonymous 266

157. The Arcadian Lovers Anonymous 269

158. The Beautiful Shepherdess of Arcadia Anonymous 270

159. 'As at noon Dulcina rested' Anonymous 273

160. Idea the Shepherd's Garland, Eclogue VII Michael Drayton 276

161. Idea the Shepherd's Garland, Eclogue VIII Michael Drayton 281

162. Eclogue IX, 1606 Michael Drayton 291

163. From Poly-Olbion Michael Drayton 296

164. The Shepherd's Sirena Michael Drayton 304

165. The Description of Elizium Michael Drayton 311

166. The Muses'Elizium, Nymphal VI Michael Drayton 313

167. The Muses' Elizium, Nymphal X Michael Drayton 318 
168. From Pastoral Elegy III William Basse

169. Laurinella, of True and Chaste Love William Basse

170. Phillis Giovan Battista (Giambattista) Marino, tr. William Drummond of Hawthornden

171. A Shepherd Inviting a Nymph to His Cottage Girolamo Preti, tr. Edward Sherburne

172. 'Jolly shepherd and upon a hill as he sat' Thomas Ravenscroft

173. 'Come follow me merrily' Thomas Ravenscroft

174. To His Loving Friend Master John Fletcher George Chapman

175. Hymn to Pan, from The Faithful Shepherdess John Fletcher

176. A Sonnet Honoré d'Urfé, tr. John Pyper(?)

177. 'Close by a river clear' Honoré d'Urfé, tr. John Davies(?)

178. From Christ's Victory and Triumph Giles Fletcher

179. The Complaint of the Shepherd Harpalus David Murray

180. 'A jolly shepherd that sat on Sion Hill' Anonymous 334

181. 'Alas, Our Shepherd' William Alabaster 338

182. The Shepherd's Speech from Himatia-Poleos Anthony Munday 338

183. To His Much Loved Friend Master W Browne Christopher Brooke 339

184. An Eclogue between Willy and Wernocke John Davies of Hereford 341

185. The Shepherd's Hunting, Eclogue V George Wither 346

186. From Fair-Virtue George Wither 351

187. Hymn for a Sheep-Shearing George Wither 356

188. Hymn for a Shepherd George Wither 357

189. From Britannia's Pastorals, Book I William Browne 358

190. From Britannia's Pastorals, Book II William Browne 371

191. To Penshurst Ben Jonson 376

192. To Sir Robert Wroth Ben Jonson 378

193. Hymns from Pan's Anniversary Ben Jonson 380

194. A New Year's Gift Sung to King Charles, 1635 Ben Jonson 382

195. From The Careless Shepherdess Thomas Goffe 384

196. Damon and Moeris William Drummond of Hawthornden 385

197. Erycine at the Departure of Alexis William Drummond of Hawthornden 389
198. Alexis to Damon William Alexander
390

199. A Pastoral Elegy on the Death of Sir Anthony Alexander William

Drummond of Hawthornden

200. Fragment of a Greater Work William Drummond of Hawthornden 393

201. From 'Damon: or a Pastoral Elegy' George Lauder 394

202. Hermes and Lycaon Edward Fairfax 395

203. The Solitude Antoine Girard Saint-Amant, tr. Thomas, Third Baron

\section{Fairfax}

204. Amor Constans Christopher Morley 403

205. The Shepherds' Dialogue of Love Anonymous 407

206. Technis' Tale Richard Brathwait 408

207. The Shepherds' Holiday Richard Brathwait 413

208. 'Tell me love what thou canst do?' Richard Brathwait 415

209. Song: 'Love as well can make abiding' Mary Wroth 416

210. 'A shepherd who no care did take' Mary Wroth 417 
211. 'You pleasant flowery mead' Mary Wroth 423

212. Of Jack and Tom King James I 424

213. From Taylor's Pastoral John Taylor $\quad 425$

214. 'Woodmen Shepherds' James Shirley 431

215. An Eclogue between a Carter and a Shepherd Nicholas Oldisworth 431

216. A Sonnet William Herbert, Earl of Pembroke 433

217. An Ode upon Occasion of His Majesty's Proclamation Richard Fanshawe 434

218. Songs from Fuimus Troes Jasper Fisher 437

219. Piscatory Eclogue VII Phineas Fletcher 438

220. To My Beloved Thenot in Answer of His Verse Phineas Fletcher 445

221. From The Purple Island Phineas Fletcher 446

222. Christmas, Part II George Herbert 451

223. To My Noblest Friend, I. C. Esquire William Habington 452

224. That a Pleasant Poverty Is To Be Preferred Before Discontented Riches Abraham Cowley 453

225. The Country Life Abraham Cowley, tr. by himself 454

226. Eclogue to Master Jonson Thomas Randolph 455

227. An Eclogue Occasioned by Two Doctors Disputing upon Predestination Thomas Randolph

228. An Eclogue on the Palilia on Cotswold Hills Thomas Randolph 461

229. A Dialogue betwixt a Nymph and a Shepherd Thomas Randolph 464

230. Lycidas John Milton 465

231. Ode IV.21: From the Song of Songs Casimir Sarbiewski, tr. George Hills 469

232. The Praise of a Religious Recreation Casimir Sarbiewski, tr. George Hills 471

233. The Spring Thomas Carew 473

234. To Saxham Thomas Carew 474

235. On Westwell Downs William Strode 475

236. Thenot's Abode Anonymous 476

237. All Hail to Hatfield Anonymous 477

238. Tom and Will Sidney Godolphin (?) 484

239. The Shepherd's Oracle Francis Quarles 486

240. Scenes from a Pastoral Play Jane Cavendish and Elizabeth Brackley 493

241. A Pastoral upon the Birth of Prince Charles Robert Herrick 495

242. A Pastoral Sung to the King Robert Herrick 497

243. To His Muse Robert Herrick 498

244. The Hock-Cart Robert Herrick 499

245. A New-Year's Gift Sent to Sir Simeon Steward Robert Herrick 500

246. A Dialogue Weeping the Loss of Pan Mildmay Fane 501

247. My Happy Life, to a Friend Mildmay Fane 502

248. In Praise of a Country Life Mildmay Fane 506

249. From Psyche Joseph Beaumont 506

250. A Pastoral Dialogue between Coridon and Thyrsis Anonymous 509

251. The Shepherds Henry Vaughan 511

252. Daphnis: An Elegiac Eclogue Henry Vaughan 513

253. From The Shepherd's Holiday William Denny 516

254. 'Jack! Nay prithee come away' Patrick Cary 518

255. The Pleasure of Retirement Edward Benlowes 519 
256. A Description of Shepherds and Shepherdesses Margaret Cavendish

257. A Shepherd's Employment Is Too Mean an Allegory for Noble Ladies

Margaret Cavendish

258. Similizing the Sea to Meadows and Pastures Margaret Cavendish

259. Jack the Plough-Lad's Lamentation Thomas Robins (?)

260. A Pastoral Dialogue Thomas Weaver

261. The Isle of Man Thomas Weaver

262. Upon Cloris Her Visit after Marriage William Hammond

528

263. A Pastoral Song: With the Answer Anonymous

264. A Pastoral Song Anonymous

265. A Song Anonymous

531

266. The Land-Schap between Two Hills Eldred Revett 532

267. The Milkmaids Anonymous

533

268. Coridon and Strephon Aston Cokayn

534

269. The Old Ballet of Shepherd Tom Anonymous 536

270. The Jolly Shepherd Anonymous 537

271. To My Ingenious Friend Master Brome Izaak Walton 538

272. Pastoral on the King's Death Alexander Brome 539

273. A Dialogue betwixt Lucasia and Rosania Katherine Philips 540

274. A Country Life Katherine Philips 541

275. Eclogue Charles Cotton 542

276. An Invitation to Phillis Charles Cotton 544

277. On the Execrable Murder of Charles I Anthony Spinedge 546

Index of authors $\quad 547$

Index of titles and first lines $\quad 550$ 


\section{Acknowledgements}

A book like this incurs many debts both to persons and to institutions. Many friends and colleagues have lent valuable support and advice. They include Glenn Black, Michael Brennan, Swapan Chakravorty, Aparna Chaudhuri, Nandini Das, Paul Gehl, Warwick Gould, John Gouws, Philip Hardie, Nicholas Mann, Subha Mukherji, Asim Mukhopadhyay, David Norbrook, Rita Roy, Peter Shillingsburg, James Simpson of Edinburgh, James Simpson of Harvard, Jan Usher, Helen Vincent and Henry Woudhuysen. Special thanks to Amlan Das Gupta, whom I have troubled more times and over more matters than I can recall. Debapriya Basu rendered invaluable help with preparing the hugely complicated copy for publication, as did Hrileena Ghosh for a shorter period.

My thanks to the staff of the following centres for their support, sometimes beyond the call of duty: the British Library; the Senate House Library, University of London; the Warburg Institute; the Bodleian Library; the libraries of Christ Church and Corpus Christi Colleges, Oxford; the Cambridge University Library; the Pepys Library, Magdalene College, Cambridge; the National Library of Scotland; Edinburgh University Library; Loyola University Library, Chicago; the Newberry Library, Chicago; the Houghton Library, Harvard; the Indian National Library; and Jadavpur University Library. For prompt supply of material, I thank the Folger Shakespeare Library; the Rosenbach Library, Philadelphia; the Harry Ransom Center, University of Texas in Austin; the Brotherton Library, University of Leeds; and Hatfield House.

I am grateful to the School of Advanced Study, University of London, for a professorial fellowship to carry out the first round of research for this book; to Loyola University, Chicago, for a visiting professorship that I later used for this purpose among others; and to Jadavpur University for its liberal leave policy. Warmest thanks to Elizabeth and William Radice, Subha Mukherji, Susan Powell, Francesca Orsini and Peter Kornicki, Kate and Bryan Ward Perkins, and Pablo Mukherjee and Eliza Hilton for their generous hospitality, which alone made many library visits possible.

Brian Vickers and Helen Cooper have been the most discerning and considerate of general editors, and my debt to Julian Lethbridge grows by the day. Let that to my wife and colleague Supriya remain unspoken.

Sukanta Chaudhuri Jadavpur University

March 2016 


\section{Practices and conventions}

Pastoral Poetry of the English Renaissance contains the text of the poems with brief headnotes giving date, source and other basic information, and footnotes with full annotation. It includes a brief introduction, an index of authors and an index of titles and first lines. The Companion to Pastoral Poetry of the English Renaissance (MUP 2016) contains a full introduction to English Renaissance pastoral, textual notes, and all other apparatus.

\section{Choice of texts and editorial policy}

Virtually all texts have been freshly edited from original manuscripts and early printed editions, accessed in the original or in electronic or photographic copies. In two cases (nos. 248 and 254), later printed editions have been followed as I could not consult the manuscripts.

As a rule, the earliest printed edition has been taken as control text. A different printed edition has sometimes been preferred: most often with poems published earlier and reprinted in England's Helicon, as the latter is most likely to be attuned to the pastoral conventions of the time. In all other cases, the choice is explained in the textual notes in the Companion. The same applies where a manuscript text has been used in preference to an early printed version.

The chief exceptions to this practice are the poems by Sidney and Spenser. These major poets have been intensively edited by specialist scholars: a new fragmentary exercise seemed both rash and superfluous. Here the first printed version has been taken as the control text, and checked against standard modern editions.

Where the only version is in manuscript, it has of course been taken as control text. If there is more than one manuscript, the one with the clearest or fullest text has been followed: sometimes, where the choice seemed indifferent, the most readily accessed. Any special factor is explained in the textual notes.

Ballads pose a special problem, as items known to be in circulation in the late sixteenth or early seventeenth century only survive in versions from the late seventeenth century. In such cases, the earliest version (insofar as it can be determined) has been followed; variants in other versions have not been recorded except for some special point of interest.

For the orally circulated song 'Oh shepherd, oh shepherd' (no. 29), with no early manuscript or print version, a modern-spelling twentieth-century transcript has been followed. 


\section{Record of variants}

Except in the case of ballads (see above), all substantive variants have been recorded in the textual notes contained in the Companion. Spelling and punctuation variants have been ignored except for a few cases of special interest. Where a variant reading materially affects the interpretation, it has also been noted in the commentary in this volume.

The collation usually takes into account alternative printed versions of proximate date. The span of dates varies with the work: usually not later than the mid-seventeenth century, but in a few special cases until the late seventeenth or early eighteenth century.

It was sometimes not feasible to collate all manuscript versions, especially of popular pieces like 'In the merry month of May' or 'Cloris, since thou art fled away'. The following policy has been followed:

- Where the best or only witness is a manuscript, it has been consulted irrespective of location.

- In other cases, all manuscript versions in the British Library and Bodleian Library have been collated for substantive variants. Manuscripts at other locations have been collated in cases of special interest.

Even minor variants in substantive readings (e.g., of articles, conjunctions and prepositions) have been noted: less for their interpretative value (often nil) than for the trajectories of text circulation that they chart, offering fascinating insights on unconscious changes in widely circulated texts.

\section{The order of the poems}

The poems have been placed in rough chronological order, with the following provisos:

- All poems by the same author are grouped together at the date of publication of the earliest item.

- When (as so often) exact dates are not available, approximate dates, or a median date of the author's active life, are used.

- Anonymous manuscript poems are placed by date of manuscript (often very approximate).

- Translations are placed by the date of the original, subject to the above principles. With classical authors, such dates are usually very broad or conjectural.

- In a few cases, the chronological order has been modified to keep related poems together. Thus Tasso's and Guarini's Golden Age choruses, of 1573 and 1590 respectively, are placed together, as are all poems about the shepherd Amyntas. Webbe's quantitative version of Spenser's 'April' follows that poem, before other eclogues from The Shepheardes Calender. Ralegh's 'Nymph's Reply' (with another 'reply' from England's Helicon, 1600) follows Marlowe's 'The Passionate Shepherd to His Love', separately from Ralegh's other poems. Henry Chettle has been placed a little later than warranted so that his poem on the succession of James I does not precede poems on Elizabeth as a living monarch.

- Poems relating to Queen Elizabeth and Philip Sidney from A Poetical Rhapsody (1602) are placed at that date, though they were probably written much earlier. The poems on the death of Charles I range too widely in date to be grouped together: one was written well after the Restoration, by a man born three years after Charles's execution. 
- The special problem with ballads is noted above. With a few exceptions determined by subject or by known date of composition, they have been placed at a point roughly between the reigns of Elizabeth and James.

\section{Spelling and punctuation}

Other than no. 29 in modern spelling (see above), all poems are in the original spelling of the control text except, of course, for emendations. Old-spelling titles have been used in the headnotes and textual notes, but capitalization and use of lower-case $u$ and $\mathrm{v}$ have been standardized. Modern spelling has been used in the titles and first lines of poems when printed as headings.

In reproducing headings and other paratext from early editions, font and capitalization have been standardized, as they are usually quite arbitrary in the original, dictated by space and visual effect rather than intrinsic meaning.

The original punctuation has been retained as much as possible, with a few silent changes to avoid misleading the modern reader. However, some poems needed a higher degree of intervention. Some manuscript texts have virtually no punctuation, which needed to be inserted. All cases of major re-punctuation are indicated in the headnotes. 


\section{Abbreviations}

$16 c$ (etc., for centuries)

Fr. French

Gk. Greek

It. Italian

Lat. Latin

Sp. Spanish

Aen. Aeneid

Ecl. Eclogue

Epig. Epigram

FQ The Faerie Queene

Georg. Georgic(s)

Helicon England's Helicon (1600)

Met. (Ovid's) Metamorphoses

SC The Shepheardes Calender

Addl. Additional

BL British Library

Bod. Bodleian Library, Oxford

Rawl. Rawlinson

bk book

edn edition

esp. especially

foll. following

ms(s) manuscript(s)

prob. probably

ref. reference

trans. translated, translation

$O E D$ 1st cit. the first citation of the word in this sense (usually at a later date than here) $O E D$ last cit. the last citation of the word in this sense (usually at an earlier date than here)

$O E D$ only cit. the only example of the word in this sense located by $O E D$. 


\section{Books cited in abbreviated form}

Klawitter Richard Barnfield, The Complete Poems, ed. George Klawitter, Selinsgrove: Susquehanna University Press, 1990.

Dunlap Thomas Carew, The Poems ... with His Masque Coelum Britannicum, ed. Rhodes Dunlap, Oxford: Clarendon Press, 1949.

Chappell William Chappell, Old English Popular Music, 2 vols., London: Chappel \& Co., 1893.

Hebel Michael Drayton, Works, ed. J. W. Hebel, Kathleen Tillotson and Bernard H. Newdigate, Oxford: Basil Blackwell, 1931-41.

Kastner William Drummond, The Poetical Works, ed. L. E. Kastner, 2 vols., Edinburgh: Scottish Text Society, 1913.

Chambers \& Sidgwick Early English Lyrics, Amorous, Divine, Moral and Trivial, ed. E. K. Chambers and F. Sidgwick, London: A. H. Bullen, 1907.

Pemberton Elizabeth I, Queen Elizabeth's Englishings, ed. Caroline Pemberton, London: Kegan Paul, Trench, Trubner for Early English Text Society, 1899.

Bradner Elizabeth I, The Poems, ed. Leicester Bradner, Providence, RI: Brown University Press, 1964.

Lea and Gang Edward Fairfax, Godfrey of Bulloigne ... together with Fairfax's Original Poems, ed. Kathleen M. Lea and T. M. Gang, Oxford: Clarendon Press, 1981.

Cain Mildmay Fane, The Poetry, ed. Tom Cain, Manchester: Manchester University Press, 2001.

Fogle French Rowe Fogle, A Critical Study of William Drummond of Hawthornden, New York: King's Crown Press, 1952.

Patrick Robert Herrick, The Complete Poetry, ed. J. Max Patrick, Garden City, NY: Doubleday, 1963.

Martin Robert Herrick, The Poems, ed. L C Martin, London: Oxford University Press, 1965.

Herford \& Simpsons Ben Jonson, Ben Jonson, ed. C. H. Herford and Percy and Evelyn Simpson, 11 vols., Oxford: Clarendon Press, 1925-52.

Carey \& Fowler John Milton, The Poems, ed. John Carey and Alastair Fowler, London: Longmans, 1968.

Rudick Walter Ralegh, The Poems: A Historical Edition, ed. Michael Rudick, Tempe, AZ: Arizona Center for Medieval and Renaissance Studies \& Renaissance English Text Society, 1999.

Parry Thomas Randolph, The Poems and Amyntas, ed. John Jay Parry, New Haven, CT: Yale University Press, 1917.

Thorn-Drury Thomas Randolph, The Poems, ed. G. Thorn-Drury, London: Etchells \& Macdonald, 1929.

Fordoński and Urbański Casimir Sarbiewski, Casimir Britannicus, ed. Krzysztof Fordoński and Piotr Urbański, London: MHRA, 2008.

Skretkowicz Philip Sidney, The Countess of Pembroke's Arcadia (The New Arcadia), ed. Victor Skretkowicz, Oxford: Clarendon Press, 1987.

Robertson Philip Sidney, The Countess of Pembroke's Arcadia (The Old Arcadia), ed. Jean Robertson, Oxford: Clarendon Press, 1973.

Duncan-Jones and van Dorsten Philip Sidney, Miscellaneous Prose, ed. Katherine Duncan-Jones and Jan van Dorsten, Oxford: Clarendon Press, 1973. 
Ringler Philip Sidney, The Poems, ed. William A. Ringler, Jr, Oxford: Clarendon Press, 1962.

Tilley Morris Palmer Tilley, A Dictionary of the Proverbs in England in the Sixteenth and Seventeenth Centuries, Ann Arbor, MI: University of Michigan Press, 1950.

Sidgwick George Wither, The Poetry, ed. F. Sidgwick, 2 vols., London: A. H. Bullen, 1902. 


\section{Introduction}

Pastoral is one of the few literary modes whose genesis can be clearly traced. While poems reworking pristine rustic experience might have existed earlier, the pastoral mode as now recognized originated with the Greek poet Theocritus in the third century BCE. More correctly put, Theocritus provided a model that others followed to create the mode.

There were few 'others' in Hellenistic Greece. A handful of poems, only one or two authentically pastoral, have been ascribed (often doubtfully) to two poets, Bion and Moschus. Of Theocritus' own thirty idylls ('little pictures' or 'sketches', often of doubtful authorship), only twelve are pastoral. What set the seal on the mode was its adoption by Virgil in the first century BCE, in ten poems sometimes closely imitating Theocritus. These selections (eclogae) from his early work have lent the name 'eclogue' to the typical pastoral poem of moderate length and varied subject-matter, often incorporating an inset song or song-contest.

Virgil too had few followers in classical times - only two minor poets, Calpurnius and Nemesianus. But his immense stature as the pre-eminent Latin poet, continuing through the Middle Ages and the Renaissance, set before every aspiring poet the career-pattern of the 'Virgilian cycle', moving from pastoral to didactic poems on farming (the Georgics) and finally to martial and courtly epic in the Aeneid. This was also held to reflect the course of human civilization. From the late Middle Ages, the Virgilian eclogue became a dominant poetic genre.

There was another reason for this. Theocritus' idylls had presented, if in somewhat idealized and sometimes mythicized form, the life of actual shepherds in Cos and Sicily. Only once, in Idyll 7, is there any suggestion that the shepherds may stand for people from another world, maybe the poet's own. Virgil, however, seems to have introduced a measure of allusion in his Eclogues, beginning with the first, where the shepherd Tityrus, secure while his fellows are dislodged from the land, is held to represent Virgil himself, thanking the Emperor Augustus for his patronage.

The extent and nature of the allusion is often uncertain; but scholiasts have confirmed what any reader might suspect, that it is there. When Virgilian pastoral was revived in the late Middle Ages by Dante, Petrarch and Boccaccio (chiefly the latter two), they insisted that allusion was intrinsic to pastoral. Through the ensuing Renaissance and beyond, 'pretty tales of wolves and sheep' (in Sidney's phrase) ${ }^{1}$ were conventionally held to conceal deep hidden meanings - biographical, political, didactic,

1 Philip Sidney, A Defence of Poetry (The Apologie for Poetrie), in Miscellaneous Prose of Sir Philip Sidney, ed. Katherine Duncan-Jones and Jan van Dorsten, Oxford: Clarendon Press, 1973, 95.3-4. 
religious. Most critical theory of the pastoral in that age (or indeed later) has stressed this allegorical function.

But the Middle Ages also opened fresh springs of rustic poetry, harking back to folk tradition and restoring the setting of actual rural and shepherd life. Embodied in new lines of lyric and song, such poetry became increasingly sophisticated, often through classical elements drawn not only from Virgil but from the nature-settings of Horace's Odes and the mythic world of Ovid's Metamorphoses. Various lines of poetry began to develop, addressing the pastoral concerns of nature and myth but striking out in other directions as well. It seems pointless to quibble about how much of this is strictly pastoral: it is all part of a wider pastoral universe, whose provinces merge and shift.

Formal pastoral acquires new life in the Renaissance by drawing on a great range of themes and settings. The translations in this book reflect much of that range, besides the seminal classical models, Virgil above all. But interestingly, some crucial medieval and Renaissance voices are absent - Petrarch's Latin eclogues (Bucolicum Carmen) and Sannazaro's Italian romance Arcadia above all. They were not translated into English until the twentieth century: their influence in Renaissance England derived from the original texts or, in Sannazaro's case, French or Spanish translations.

To map the extent and variety of Renaissance pastoral, we might use a term now out of fashion, 'art-pastoral', with its obverse, allusive pastoral. Pure art-pastoral presenting imaginary shepherds in a fictive pastoral setting, removed from real-life concerns and untouched by allusion - is relatively rare and often rather thin. It is hard to analyse, and often not worth analysing. Scholars from classical scholiasts to modern academics have engaged much more with allusive pastoral, often theorizing the latter to define the rationale of the mode.

It is worth stressing that, whatever its later transformations, pastoral began as the poetry of a distinct aesthetic universe, implicitly set against the more complex life of court or city to which its exponents belong. This world of the imagination throws contrasting light on the poet's own world. The otherness of pastoral is the starting premise of the mode. Its allusive accommodation of the real world always redefines the latter's terms: if it does not, the exercise is pointless.

Yet what justifies the exercise is the metaphoric infusion of imaginary pastoral life with the concerns and activities of real and more complex communities. The shepherd rules over his sheep like a king, and cares for them like a priest. He is versed in nature lore, a 'wise shepherd' comparable to academic scholars. In pastoral convention, he spends much of his time in poetry and song, just like the poet writing about him; and offers love to shepherdesses in terms assimilable to the Petrarchan convention, where such poets often found their theme.

These metaphoric latencies make the pastoral of allusion something more than a set of coded references. Casting other and more complex matters in pastoral form is to place them within an implicit frame of comment. The pastoral of the European Renaissance exploited this potential unevenly, but at its best in subtle and innovative ways. Allusive content might also enter the wider body of rural and nature-poetry noted above. Conversely, the allusive eclogue might take in the simple celebration of nature and rural life, in realistic or idealized vein.

This collection comprises Early Modern British pastoral poetry, including translations. The earliest piece in the book is 'Robene and Makyne' by the Scottish poet Robert Henryson, who flourished in the late fifteenth century. This striking poem is 
not backed up by any general pastoralism in the Scottish poetry of that age. The varied and notable pastoral productions of William Drummond in the seventeenth century draw on new resources of classical and continental poetry. In England, the pastoral output of the early Tudor period is limited. Besides a general body of 'plowman literature' (exemplified in Of Gentylnes and Nobilitye), the only notable instances are the eclogues of Alexander Barclay, which blend some direct allusion with a great deal of moralizing, social satire and rustic realism. There is also the singular 'Harpelus' Complaint' in Tottel's Miscellany (Songs and Sonnets) of 1557, strikingly anticipating the lyric fictions of later Elizabethan art-pastoral. Ignoring the indifferent eclogues of Barnabe Googe and the sporadic rural poetry of Churchyard or Turberville, English pastoral comes into its own with Spenser's The Shepheardes Calender, published anonymously in 1579 .

The Calender has its due share of allusion and moralizing in many veins. It is possible to write a consistent commentary on the twelve eclogues ('proportionable to the twelue monethes') in these terms. But what is exceptional is the quantum of non-allusive material, the creation of an entire shepherd community that, while it might reflect Spenser's circle and his times, acquires the status of an autonomous fiction. The Calender presents a world radically distinct from the real and contemporary, even while notably overlapping with it. Just so, later, would the land of Faerie in Spenser's magnum opus absorb the reality of Elizabethan times within a notably different chivalric and supernatural universe.

It is also a pastoral universe. The Faerie Queene has two cantos of open pastoralism in Book VI; but the whole work is suffused with the mythicized nature-settings, and alternative social orders and value-systems located there, that characterize pastoralism in the widest sense. This pervasive pastoralism also marks the Spenserian poets of the early seventeenth century, most notably their doyen Michael Drayton. Even more clearly than in Spenser himself, pastoral is one of the major modes addressed by Drayton through his life, from the very Spenserian beginnings in Idea The Shepheards Garland to the transmogrified pastoral of The Muses Elizium, a fragile mythicized setting conveying a marked political message. The same compound appears more openly in Drayton's younger followers: their early flagship volume The Shepheards Pipe leads on to the sustained pastoralism of William Browne's overtly Spenserian Britannia's Pastorals, no less than to the varied social and moral critique of the prolific George Wither.

Needless to say, Spenser's influence is not confined to the Spenserians. We need to retrace our steps to the late sixteenth century, starting with the other major influence on English Renaissance pastoral: the work of Sir Philip Sidney. The undoubted 'Sidney cult' (however we assess it) during his brief life acquired new and greater force when his works began to be posthumously published in the 1590s through the efforts of his sister Mary Herbert, Countess of Pembroke, and his associate Fulke Greville. Chief among these works were the old and new (and soon amalgamated) versions of Sidney's chivalric-pastoral romance, The Countesse of Pembrokes Arcadia. This contained four substantial groups of 'eclogues' - of much more varied nature than the term usually covers - as well as a great deal of other verse embedded in the narrative. Taken in its entirety, Sidney's Arcadia offered a rich store of pastoral poetry, comprising most major themes and conventions of European Renaissance pastoral. And while a great deal of personal and political allegory has been extracted from the Arcadia, its fictional setting means that most individual poems are autonomous aesthetic entities. 
Sidney's romance led the field in England but not in Europe. Its title reflects the Italian Jacopo Sannazaro's Arcadia (published 1504, written much earlier), a set of eclogues linked by incremental prose narrative. The Arcadia established a model of pastoral romance virtually for the first time in Europe, barring the single though notable instance of Longus' Greek romance Daphnis and Chloe (2nd century CE). Next to Sannazaro's own, the most influential romance was Jorge de Montemayor's Spanish Diana (1559), with sequels by Alonso Perez and Gaspar Gil Polo. This work was translated into English by Bartholomew Yong. Other than Sidney's magnum opus, the earlier English examples are slight in comparison but add up to a sizeable corpus: Greene and Lodge's romances in the forefront, supplemented by more loosely structured works like John Dickenson's The Shepheardes Complaint. These in turn shade off into collections of disjunct pieces with a common background narrative, like Richard Barnfield's The Affectionate Shepherd, Nicholas Breton's The Passionate Shepherd and Barnabe Barnes's Parthenophil and Parthenophe. The seventeenth century adds to all these categories, most substantially in major romances like The Countesse of Montgomeries Urania by Sidney's niece, Lady Mary Wroth.

Sixteenth-century Europe saw a parallel development in pastoral drama, from brief opera-like entertainments to full-fledged plays. There is a substantial Italian line of the latter from the mid-sixteenth century, taking in Tasso's Aminta (1573) and Giovanni Battista Guarini's Il pastor fido (The Faithful Shepherd, 1590). Again, the influence spread to other languages. If Shakespeare's As You Like It is the most celebrated instance in English, and The Winter's Tale provides the best-known pastoral interlude, a line of plays typified by John Fletcher's The Faithful Shepherdess (and continuing into Charles I's reign) are closer to the Italian model.

Pastoral romance and drama typically present a circular plot in which courtly characters leave their accustomed haunts, spend time in the country so as to effect a change in their state, and finally return to a revitalized court. The chief characters are usually royal or noble, and the plot-structure reflects the actual hegemony of court and city controlling the pastoral imagination. But paradoxically, the clear separation of the court can allow the country to be more clearly and distinctly defined within its structurally limited sphere: the shepherds can be shepherds because they no longer have to double as courtiers or city-dwellers. Though the shepherdess heroine often proves a royal foundling, her companions assert their own identity and ethos to the end.

This is the design that Spenser takes to singular philosophic heights in Book VI of The Faerie Queene: there is little or nothing to match it anywhere in European pastoral. But more generally, pastoral romance and drama (especially the former), though derived from courtly genres of wider scope, offer a range of pastoral structures of unprecedented depth and detail. The eclogue was simply not capacious enough for the purpose: moreover, it had to condense the multiple, often contrary metaphoric content of the pastoral trope within a single narrow fiction. More simply and directly, pastoral romance and drama provided a storehouse of songs and lyrics, and the romance some formal eclogues as well, embedded in the narrative. This collection includes many such pieces, though it eschews dramatic scenes and extracts. In a few cases, a modicum of dramatic dialogue has been retained to make sense of a song embedded in it. There are also some extracts from verse romances, verse chronicles, and short epics or epyllia, sometimes telling a complete story, sometimes enshrining a single narrative moment.

Poems extracted from romance and drama are matched by a wide range of 
independently composed lyrics, matching the body of formal eclogues. In fact, barring Thomas Watson's Latin Amyntas (translated into English by Abraham Fraunce) and Drayton's Idea The Shepheardes Garland, there are relatively few formal eclogues of note in the sixteenth century, always excepting Spenser and Sidney's work. (The seventeenth adds substantially to the tally.) Song-exchanges and debates in the romances shade off into briefer, more purely song-like interjections. Like similar stand-alone items in miscellanies and single-author volumes, these poems blend the indigenous pastoral lyric drawn from medieval tradition with the more finished products of Italianate Renaissance song-lyric. Often individually slight, even inconsequential, all this adds up to a formidable corpus, strongly and innovatively contributing to the total pastoral presence in English Renaissance poetry. They can also constitute a substantial individual output, as strikingly seen in the work of Nicholas Breton. Continental models may also be found for pastoral redactions of popular forms like the sonnet. The art-pastoral basic to this entire body of poems makes for an unusual orientation of the mode in imaginative and ideological terms.

Though song-like in effect, these poems were usually not set to music in the first instance. But there is an assumed musical element in their structure that might be brought out and defined by a later composer. Such poems shade off into pieces composed formally as songs, akin in material to Italian or other continental songbooks and often modelled on them. But all in all, the volume of non-musical pastoral lyric appears to be notably greater in English than in other European languages. The seal was set on this very distinct development by the remarkable anthology England's Helicon (1600). Its editorship has been variously attributed to John Bodenham, Nicholas Ling, one 'A.B.' and the publisher John Flasket.

Helicon taps every conceivable source of material: volumes of verse, romances, dramas, entertainments. Some pieces appear there for the first time, which may also be the last. Only a fraction of the contents are formal eclogues. Every now and then the editor tweaks the language of a non-pastoral piece to make it fit the bill; but this testifies to an accepted notion of the mode, even to specific models of form and diction. Helicon may be the product of one man's focused fancy: barring The Phoenix Nest reflecting the Sidney cult, there is no other printed miscellany of the period devoted to a single theme, genre or mode. But equally, Helicon testifies to a marked pastoral presence in the literary sensibility of the age, almost amounting to a pastoral culture.

Most strikingly even at a brief glance, Helicon illustrates the variety of Elizabethan pastoral - to be extended still further in the next century. Between the late sixteenth and the mid-seventeenth century, there is a greatly diverse body of pastoral across a field loosely demarcated by the eclogue, the ode, the country poem and the private poetic address, though these genres lose their identity in the traffic of themes and forms. We find courtly and personal compliment, political and philosophical allegory, intricate though often obscure personal allusion, and simpler private exchanges between friends or lovers. These blend into independent pastoral fictions - sometimes grafted on the more extended fiction of a romance or play - buttressing the status of pastoral as an organic vein of the Renaissance English imagination. The pastoral idiom can be the chosen vehicle of major lines of social and intellectual practice. Readers can choose examples of any vein they please from the wide selection gathered in this book.

A pastoral culture is crystallized in court compliment and entertainment, even in the serious business of politics. The cult of Queen Elizabeth had a famously pastoral 
aspect, shading into the mythic. It was exploited for courtly entertainment, especially (and appropriately) on the Queen's progresses through the countryside, lodging at the country seats of favoured courtiers. In James I's day, and Charles I's even more, an elaborate and removed pastoral artifice became a staple vein of entertainment at the royal court itself, in masques and the exclusive world of private theatres. On a very different plane, pastoral had always been an option for devisers of city pageants and public entertainments. All in all, pastoral made its way into performative fictions through all kinds of channels for all kinds of purposes, with a corresponding range of formal guises.

But even as the Jacobean court was practising one vein of pastoral, others gained strength in opposition to court culture, or at least to the royal image and policies. The deceptively remote pastoral of the late Drayton, and its more robust foil in the younger Spenserians, marks one line of growth. Another was the nuanced progression of an intrinsically conservative genre, the country-house poem. While necessarily celebrating a quasi-feudal order, it could play off the rural version of that ethos, enshrined in a nobleman's country seat, against its court-centred avatar. Pastoral provides a means for this establishmentarian genre to deconstruct itself while stopping well short of true subversion.

But there is also a more demotic line of pastoral, challenging the political and economic order in more fundamental ways. Here the shepherd stands for the common man, even the dispossessed. Such pastoral rarely approaches the raw realism and protest voiced by Barclay a century earlier: everything else apart, the diction of pastoral (as of virtually all poetry) has grown more refined in the interim. More often now, the common shepherd-spokesman may be allied to the Puritan middle class; but even when the voice belongs to the relatively privileged (or greatly so, as with Margaret Cavendish), the ideological fracture at the heart of pastoral can be used to good purpose.

Cavendish belongs to an eminent line of Royalists. With the Puritan-Royalist divide, as with so many others, opposite sides employ the same pastoral tropes and metaphoric strategies to their contrary ends. This is most piquantly shown in the persistent use of the pastoral to mourn the death of Charles I. One such instance masquerades in ballad form as 'Jack the Plough-lad's Lamentation'. Another is composed long after the Restoration by Anthony Spinedge, born three years after Charles's execution. Earlier, Royalist pastoral had been largely confined to a species of privileged artifice, even where it carried direct political allusion. Clearly, the Royalist camp is now better apprised of the varied uses of the mode. But it is the Puritan Milton, perhaps not yet fully set in the doctrinal mould, who provides in 'Lycidas' the most elaborate and striking elegiac construct of the age, mourning the death of a less prominent figure.

'Jack the Plough-lad' illustrates the focused political use of a line of popular pastoral, as developed in the broadside ballad. The broadside incorporates a surprising amount of pastoral. Its commonest purpose is to present shepherds to political advantage, alongside other rustics and subalterns. But it also runs to simple love-poetry crossing Petrarchan convention with the more naive indigenous love-lyric. Yet other ballads are directly allusive, presenting contemporary events in pastoral garb. All in all, the broadside illustrates an unexplored encounter of the genuinely popular with the mock-popular of the standard pastoral mode.

In another, overtly non-political line of development, the pastoral generates a landscape-poetry that can point in the direction of either nature or art. Topographical 
poetry achieves a heroic scale in Drayton's Poly-olbion, always within touching distance of the pastoral and sometimes homing in directly upon it. Another branch explores the new visual aesthetics of the 'landskip', as in Strode or (more strikingly) Eldred Revett. At much the same time, Margaret Cavendish opens up speculative angles on the encounter of 'real' nature and the pastoral. And a pan-European line, strikingly instanced in the French Antoine Saint-Amant's 'The Solitude', infuses the landscape with a dramatic, almost Gothic vein of sentimental melancholy.

The ultimate encounter of opposite planes might be said to occur in some instances of religious pastoral. The Bible yields its own pastoral material, most famously in Psalm 23 but with more metaphoric potential in the allied but distinct topos of Christ the Good Shepherd. This topos enters into piquant interaction with the trope of 'pastoral care' in the clergy, and its extension in ecclesiastical allegory. The shepherds of the Nativity are simpler in metaphoric function. There are also innovations like the pastoral setting for gospel narrative in Giles Fletcher (matching his brother Phineas' secular exercise in The Purple Island), and the idiosyncratic allegorical fancy of Thomas Benlowes. A more sustained vein, seen in many languages across Europe, is the age's new spiritual interest in the 'book of nature': in its central line of practice, Christianizing the structure of Horace's Second Epode in a model made popular by the Polish neo-Latin poet and cleric Casimir Sarbiewski.

This account may explain why I have referred to pastoral all through not as a genre or convention but as a mode. It operates in the Renaissance as an infinitely versatile trope, a frame of reference in which to cast any sector of human experience so as to throw new light upon it, as one might hold up an object to the light at a particular angle. It is a way of thought - at times, by only a moderate hyperbole, a way of life.

Paradoxically, pastoral's vast reach and popularity might also explain why there are so few masterpieces in the mode. It was practised by countless people of varying ability for a range of themes and purposes. In deference to the Virgilian model, poetasters began writing pastorals but went no further. Other, more skilled and persistent practitioners turned to the mode in the intervals of weightier exercises higher up in the scale of genres. (Pastoral, like satire, was conventionally placed at the bottom of a hierarchy whose top rungs were occupied by epic and tragedy.)

Renaissance pastoral is best considered as a total phenomenon, in which individual works blend organically to acquire a greater significance than they might command as stand-alone items. This also produces fascinating patterns of dissemination and circulation, both of individual texts and, more significantly, of specific tropes and conventions. The detailed introduction in the Companion will discuss these features of the mode. Meanwhile, here is the poetry.

\section{Further reading \\ (arranged by date of publication)}

Walter W. Greg, Pastoral Poetry and Pastoral Drama, London: A. H. Bullen, 1906.

Bruno Snell, 'Arcadia: The Discovery of a Spiritual Landscape', in The Discovery of the Mind, trans. Thomas G. Rosenmeyer, Cambridge, MA: Harvard University Press, 1953.

Thomas G. Rosenmeyer, The Green Cabinet. Theocritus and the European Pastoral Lyric, Berkeley, CA: University of California Press, 1969. 
Peter Marinelli, Pastoral, London: Methuen, 1971.

Laurence Lerner, The Uses of Nostalgia. Studies in Pastoral Poetry, London: Chatto and Windus, 1972.

Renato Poggioli, The Oaten Flute. Essays on Pastoral Poetry and the Pastoral Ideal, Cambridge, MA: Harvard University Press, 1975.

Helen Cooper, Pastoral. Medieval into Renaissance, Ipswich: D. S. Brewer, 1977.

William A. McClung, The Country House in English Renaissance Poetry, Berkeley, CA: University of California Press, 1977.

James Turner, The Politics of Landscape. Rural Scenery and Society in English Poetry 1630-1660, Oxford: Basil Blackwell, 1979.

James Sambrook, English Pastoral Poetry, Boston: Twayne, 1983.

Andrew V. Ettin, Literature and the Pastoral, New Haven, CT: Yale University Press, 1984.

The Pastoral Mode. A Casebook, ed. Bryan Loughrey, London: Macmillan, 1984.

Annabel M. Patterson, Pastoral and Ideology. Virgil to Valéry, Berkeley, CA: University of California Press, 1987.

Sukanta Chaudhuri, Renaissance Pastoral and Its English Developments, Oxford: Clarendon Press, 1989.

E. Kegel-Brinkgreve, The Echoing Woods. Bucolic and Pastoral from Theocritus to Wordsworth, Amsterdam: J. C. Gieben, 1990.

Paul J. Alpers, What Is Pastoral?, Chicago: University of Chicago Press, 1996.

Andrew McRae, God Speed the Plough. The Representation of Agrarian England, 15001660, Cambridge: Cambridge University Press, 1996.

Thomas K. Hubbard, The Pipes of Pan. Intertextuality and Literary Filiation in the Pastoral Tradition from Theocritus to Milton, Ann Arbor, MI: University of Michigan Press, 1998.

Ken Hiltner, What Else Is Pastoral? Renaissance Literature and the Environment, Ithaca, NY: Cornell University Press, 2011. 


\title{
Pastoral Poetry of the English Renaissance
}

\author{
1 TheOCRITUS IDYLL VIII
}

Translated anonymously from the Greek

From Sixe Idillia ... chosen out of ... Theocritus (1588). This idyll is part of the core Theocritus canon, though scholars have doubted his authorship; some have suggested that the poem amalgamates what were originally separate pieces.

\section{THE VIII. IDILLION. \\ Argument}

Menalcas a Shephearde, and Daphnis a Netehearde, two Sicilian lads, contending who should sing best, pawne their whistles, and choose a Gotehearde, to be their Iudge. Who giueth sentence on Daphnis his side. The thing is imagined to be don in the Ile of Sicily by the Sea shore of whose singing, this Idillion is called BvCOLIASTAE, that is, Singers of a Neteheards song.

\section{BVCOLIASTÆ.}

\section{Daphnis. Menalcas. Gotehearde.}

With louely Netehearde Daphnis on the hills, they saie,

Shepehearde Menalcas mett, vpon a summers daie.

Both youthfull striplings, both had yeallow heades of heare,

In whistling both, and both in singing skilfull weare.

Menalcas first, behoulding Daphnis, thus bespake.

Menalcas. Wilt thou in singing, Netehearde Daphnis, vndertake

To striue with me? for I affirme, that at my will

I can thee passe.

thus Daphnis aunswerde on the hill.

Daphnis. Whistler Menalcas, thou shalt neuer me excell

In singing, though to death with singing thou shouldst swell.

piper

Menalcas. Then wilt thou see, and something for the victor wage?

Daphnis. I will both see, and something for the victor gage.

Menalcas. What therefore shal we pawne, that for vs maie befit?

Daphnis. Ile pawne a calfe, a wennell lambe laie thou to it.

Menalcas. Ile pawne no lambe, for both my Syre and Mother fell Are verie hard, and all my sheepe at evne they tell.

pledge, stake newly weaned cruel, harsh

Daphnis. What then? What shall he gaine that winns the victore?

Menalcas. A gallant Whistell which I made with notes thrise three, Joinde with white waxe, both evne belowe and evne aboue,

This will I laie, my Fathers thinges I will not moue.

Daphnis. And I a Whistle haue with notes thrise three arowe, Joinde with white waxe, both evne aboue, and evne belowe.

I latelie framde it, for this finger yet doth ake

With pricking, which a splinter of a reede did make.

But who shall be our Iudge, and give vs audience?

Menalcas. What if we call this Goteheard heere, not far from hence, Whose dog doth barke harde by the kids?

the lusty boies

Did call him, and the Gotehearde came to heare their toies.

trifles, sport

The lustie boies did sing, the Gotehearde iudgement gaue.

Menalcas first by lot vnto his whistle braue

Did sing a Neteheards song, and Neteheard Daphnis than

Did sing by course, but first Menalcas thus began.

then

fine, splendid

Menalcas. Yee Groues, and Brookes deuine, if on his reede Menalcas euer sung a pleasant laie,

18 thrise three] A panpipe could have four to twelve, though usually seven, reeds. 20 moue] stir, shift, hence ?disturb, meddle with. 31 a Neteheards song] But the song clearly suits Menalcas the shepherd. 
Fat me these Lambes; if Daphnis here wil feede

His calfes, let him haue pasture toe I praie.

Daphnis. Yee pleasant Springs, and Plants, would Daphnis had

As sweete a voice as haue the Nightingales;

Feede me this heard, and if the sheepeheards lad

Menalcas cums, let him haue al the dales.

Menalcas. Tis euer spring, their meades are euer gaie,

There strowt the bags, their sheepe are fatly fed

Where Daphne cums; go she awaie,

Then both the sheepheard there, and grasse is ded.

Daphnis. There both the Ewes and Gotes bring forth their twins,

Their Bees doe fil their hiues, there Okes are hie

Where Milo treades; when he awaie begins

To goe, both Neteheard, and the Nete waxe drie.

Menalcas. O husband of the Gotes! O wood so hie!

O kids, come to this brooke, for he is there;

Thou with the broken hornes, tel Milo shie,

That Proteus kept Sea-calfes, though God he were.

Daphnis. Nor Pelops kingdome may I craue, nor gould,

Nor to outrunne the windes vpon a lea;

But in this caue Ile sing, with thee in hould,

Both looking on my sheepe, and on the sea.

Menalcas. A tempest marreth trees, and drought a spring,

Snares unto foules, to beastes, netts are a smarte,

Loue spoiles a man. O Ioue, alone his sting

60

I haue not felt, for thou a lover art.

Thus sung these boies by course, with voices strong,

Menalcas then began a latter song.

Menalcas. Wolfe, spare my kids, and spare my fruitful sheepe,

And hurt me not, though but a lad these flockes I gide;

Lampur my dog, art thou indeede so sound asleepe?

Thou shouldst not sleepe, while thou art by thy Masters side.

My sheepe, fear not to eate the tender grasse at will,

Nor when it springeth vp againe, see that you faile;

Goe to, and feed apace, and al your bellies fill,

That part your Lambes may haue, and part my milking paile.

Then Daphnis in his turne sweetly began to sing.

Daphnis. And me not long agoe faire Daphne wistle eide

As I droue by, and said I was a paragone;

Nor then indeede to her I churlishlie replide,

But looking on the ground, my way stil held I one.

Sweete is a cowcalfes voice, and sweete her breath doth smell,

A bulcalfe, and a cow doe lowe ful pleasantlie;

Tis sweete in summer by a spring abrode to dwell,

Acornes become the Oke, apples the Appletree,

And calfes the kine, and kine, the Neteheard much set out.

Thus sung these Yuthes; the Gotehearde thus did ende the dout.

Goatherd. O Daphnis, what a dulcet mouth, and voice thou hast?

Tis sweeter thee to heare, than honie-combes to tast.

Take thee these pipes, for thou in singing dost excell.

If me a Gotehearde thou wilt teach to sing so well,

This broken horned Goate, on thee bestowe I will,

Which to the verie brimm, the paile doth euer fill.

41-4, 45-8 Modern editors usually transpose these quatrains and interchange the speakers. $\quad 43$ strowt the bags] (The sheep's) udders are swollen with milk. $\quad 50$ he] his beloved Melo (51). $\quad 52$ Proteus] a shape-changing sea-god, often conceived as a shepherd of seals and dolphins. 53 Pelops] son of Tantalus, king of Phrygia, and himself king of Pisa in Elis. 53-56, 57-6o Modern editors usually transpose the speakers, assuming a quatrain by Daphnis has been lost after 46. Otherwise, Menalcas ends up (as here) with the unfair advantage of an additional quatrain. 68 Make sure to do so again when it regrows. $\quad \mathbf{7 2}$ wistle] wistly: closely, intently. eide] eyed, look at. Or ?whistle-eyed, rendering a Gk phrase meaning 'with meeting brows', regarded as a sign of beauty; but this leaves the clause without a verb. 
So then was Daphnis glad, and lept, and clapt his handes, And danst, as doth a fawne, when by the damm he standes. Menalcas greeud, the thing his mind did much dismaie, And sad as Bride he was, vpon the marrige daie.

Since then, among the Shepeheards, Daphnis chiefe was had, And tooke a Nimphe to wife, when he was but a lad.

DAPHNIs his Embleme. Me tamen vrit amor.
Menalcas his Embleme.

At haec Daphne forsan probes.

GoteHEARdes Embleme.

Est minor nemo nisi comparatus.

\section{TheOcritus IDYll XI \\ Translated anonymously from the Greek}

From Sixe Idillia ... out of ... Theocritus (1588). Polyphemus, a Cyclops or one-eyed giant, features in Homer's Odyssey; but his love for Galatea, a Nereid or sea-nymph, is first treated by Theocritus and later by Ovid (Met. XIII.780).

\section{THE XI. IDILLION. Argument.}

Theocritus wrote this Idillion to Nicias a learned Physition, wherein he sheweth by the example of Polyphemus, a Gyant in Sicilie, of the race of the Cyclopes, who loued the water Nymph Galatea, that ther is no medecine so soueraigne against loue, as is Poetry. Of whose loue-song, as this Idillion is termed Cyclops, so he was called Cyclops, because he had but one eie, that stood like a circle in the middest of his forehead. Cyclopes literally 'circle-eyed'

\section{CyCLOPS.}

O Nicias, there is no other remedie for loue,

With ointing, or with sprinkling on, that euer I could proue,

Beside the Muses nine. This pleasant medsun of the minde

smearing with medicine

Growes among men, and seems but lite, yet verie hard to finde.

As well I wote you knowe, who are in Phisicke such a leeche,

medicine; doctor

And of the Muses so belov'd, the cause of this my speeche,

A Cyclops is, who liued heere with vs right welthele,

wealthily

That anchent Polyphem, when first he loued Galate;

When with a bristled beard, his chin and cheekes first clothed were.

He lov'd her not, with roses, apples, or with curled heare,

But with the Furies rage, al other thinges he little plide.

For often to their fould, from pastures green, without a guide

His sheepe returned home, when all the while he singing laie

In honor of his loue, and on the shore consumde awaie

From morning vntil night, sicke of the wound, fast by the hart,

Which mighty Venus gaue, and in his liuer stucke the dart.

For which, this remedie he found, that sitting oftentimes

Vpon a rocke, and looking on the Sea, he sung these rimes.

O Galatea faire, why dost thou shun thy louer true?

More tender than a Lambe, more white than cheese when it is new,

[skittish

91 sad as Bride] at the prospect of leaving her home and family. $\quad \mathbf{9 4 , 9 5}$ No emblems in the original: introduced here following Spenser's SC. 94 Me tamen vrit amor] Love still burns me up. At haec Daphne forsan probes] But Daphne, perhaps you [too] will experience this. 95 Est minor ... comparatus] No man is inferior except by comparison. $\mathbf{0 . 1}$ Nicias] a physician and friend of Theocritus, mentioned in several poems. 3 the Muses nine] i.e., poetry. 4 Growes ... lite] Gk means 'painless for humans'. $\quad 7$ liued heere with vs] Contrary to Homer, Theocritus places Polyphemus in Sicily, perhaps because Galatea finally marries the Sicilian Acis. Theocritus prob. hailed from Sicily, but the reference may simply be to Sicily as the home of pastoral poetry. $\mathbf{8}$ anchent] ancient: (a) of ancient times (b) old. 10 curled heare] locks of hair as love-tokens. 11 Furies rage] mad rage, ?with suggestion of the Furies or avenging goddesses: violently, destructively. plide] worked at, applied himself to. 16 liuer] supposed seat of the passions. dart] arrow of love. 
More wanton than a calfe, more sharpe than grapes vnripe I finde.

You vse to come, when pleasant sleepe my senses all doe binde.

But you are gone againe, when pleasant sleepe dooth leaue mine eie,

And as a sheep you run, that on the plaine a Woolfe doth spie.

I then began to loue thee, Galate, when first of all

You with my mother came, to gather leaues of Crowtoe small

Vpon our hil, when I as vsher, squirde you all the waie.

Nor when I sawe thee first, nor afterward, nor at this daie,

Since then could I refraine; but you, by loue, nought set thereby.

But well I knowe, fair Nimphe, the verie cause why you thus flie.

Because vpon my front, one onlie brow, with bristles strong

From one eare to the other eare, is stretched al along.

Nethe which, one eie, and on my lips a hugie nose there standes.

Yet I, this such a one, a thousand sheep feed on these lands.

And pleasant milke I drinke, which from the strouting bags is prest.

Nor want I cheese in summer, nor in Autumne of the best,

playful

come regularly

attended, escorted

true

eyebrow

beneath

even such as I am

swelling

[udders

Nor yet in winter time. My cheese-rackes euer laden are,

And better can I pipe, than anie Cyclops maie compare.

$\mathrm{O}$, Apple sweet, of thee, and of my selfe, I vse to sing,

40 And that at midnight oft. For thee, aleavne faunes vp I bring,

All great with young, and foure beares whelps, I nourish vp for thee.

But come thou hither first, and thou shalt haue them all of me.

eleven

And let the blewish colorde Sea beat on the shore so nie,

The night with me in caue, thou shalt consume more pleasantlie.

There are the shadie Baies, and there tall Cypres-trees doe sprout,

And there is Iuie blacke, and fertill Vines are al about.

Coole water there I haue, distilled of the whitest snowe,

A drinke deuine, which out of wooddy Ætna mount doth flowe.

In these respects, who in the Sea and waues would rather be?

But if I seeme as yet, too rough and sauage vnto thee,

Great store of Oken woode I haue, and neuer quenched fire;

And I can well indure my soule to burne with thy desire,

With this my onely eie, then which I nothing thinke more trimme.

Now woe is me, my mother bore me not with finns to swimme,

That I might diue to thee, that I thy dainty hand might kisse,

If lips thou wouldst not let; then would I Lillies bring Iwis,

And tender Poppie toe, that beares a top like rattells red.

And these in summer time, but other are in winter bred,

So that I cannot bring them all at once. Now certainlie,

Ile learne to swimme of some or other stranger passing bie,

That I maie knowe what pleasure tis in waters deepe to dwell.

Come forth, faire Galate, and once got out, forget thee well

(As I doe sitting on this rocke) home to returne againe.

But feede my sheepe with me, and for to milke them take the paine,

And cheese to presse, and in the milke, the rennet sharpe to straine.

My mother only wrongeth me, and her I blame, for shee

Spake neuer yet to thee, one good or louelie worde of me,

And that, although shee daily sees, how I awaie doe pine.

But I will saie my head and feete doe ake, that shee maie whine

And sorrowe at the hart, because my hart with griefe is swolne.

O Cyclops, Cyclops, wither is thy wit and reason flowne?

If thou wouldst baskets make, and cut downe browzing from the tree,

And bring it to thy Lambes, a great deal wiser thou shouldst be.

21 sharpe] tart, acid. 26 my mother] the sea-nymph Thoosa, with whom Galatea, herself a sea-nymph, might naturally resort. Crowtoe] among other plants, the wild hyacinth, named in the original. 27 vsher] 'A male attendant on a lady' (OED 2b 1st cit. 1621). 31 one onlie brow] i.e., a single continuous stretch of brow. $\quad 33$ hugie nose] The original refers to broad nostrils. $\quad 41$ All great with young] obviously impossible for fawns. The translator has followed a common textual corruption of the Gk. The correct word means collared, or with collar-like markings on the neck. 48 Ætna mount] Polyphemus' cave was near Mount Etna. The volcanic area around Naples and Sicily was credited with underground caverns where the Cyclops tended the forges of Vulcan the divine artisan. 49 In these respects] By comparison with this, as against this. $\mathbf{5 2 - 3}$ (In that fire) I will burn both my soul and my only eye. Literal fire merged with the metaphorical fire of love. 72 browzing] shoots and leaves to feed animals. 
Goe coie some present Nimphe, why dost thou follow flying wind?

Perhaps an other Galate, and fairer thou shalt find.

For manie maidens in the euening tide with mee will plaie,

And all doe sweetlie laugh, when I stand harkning what they saie,

And I some bodie seeme, and in the earth doe beare a swaie.

Thus Polyphemus singing, fed his raging loue of ould,

Wherein he sweeter did, than had he sent her summes of gould.

Poly phem's Embleme.

Vbi Dictamum inueniam?

\section{Theocritus(?) The Pastoral Wooing}

Translated from the Greek by Edward Sherburne

Theocritus' Idyll 27 in the standard numbering of Stephanus' 1566 edition. This translation first published in Sherburne's Poems and Translations (1651). The extant Greek text is incomplete, lacking the opening, and is almost certainly not by Theocritus. The translation omits two lines of general conclusion, not part of the core poem.

The Pastorall Wooing. Daphnis, and Shepheardess. Theocrit. Idyl. 28.

Daphnis. Paris the Swain, away coy Helen bare:

And I, a Swain, am kiss'd by one more fair.

Shepheardess. Brag not rude Hind; Kisses are empty things.

Daphnis. From empty Kisses yet sweet pleasure springs.

Shepheardess. I'l wash my mouth, wipe off thy Kisses stain.

Daphnis. Wip'st thou thy Lips? then let us kiss again.

Shepheardess. Go kiss your Cows; you fit to kiss a Maid!

Daphnis. Be not so proud: your youth will quickly fade.

Shepheardess. Grapes though they're dry, yet still are Grapes we see,

And Roses although wither'd, Roses be.

Daphnis. Let's sit and talk beneath this Myrtles shade.

Shepheardess. No; your smooth Tongue me once before betraid.

Daphnis. Beneath these Elms then sit and hear me play.

Shepheardess. Play to your self; I not your Musick weigh.

Daphnis. Take heed lest thou the Wrath of Venus find!

Shepheardess. Venus her worst; be but Diana kind.

Daphnis. Oh say not so: lest her excited Rage

Thee in unextricable Snares ingage.

Shepheardess. Do what she can, find we Diana's Grace.

Hold off your hands, or else I'l scratch your Face.

Daphnis. Love, which no Maid e'er did, thou must not fly.

Shepheardess. By Pan I will: why dost thou press so nigh?

Daphnis. I fear he'l make thee stoop to thy first Love.

Shepheardess. Though woo'd by many, none I did approve.

Daphnis. Amongst those many, here, behold! I sue.

Shepheardess. Why, my kind Friend, what would'st thou have me do?

The married Life with troubles is repleat.

Daphnis. No Cares, Joys only Marriage doth beget.

Shepheardess. They say, Wives of their Husbands live in fear.

Daphnis. Of whom do Women? rather domineer.

Shepheardess. But thought of Child-bed Pains makes me afraid.

Daphnis. Diana, whom thou serv'st, will be thy Aid.

74 coie] court, flirt with. present] ready, available. 8o sweeter] more successfully, though his love had no such outcome. 81 Vbi Dictam[n] um inveniam?] 'Where shall I find dittany?' Dictamnum or dittany is a medicinal plant, used to cure Aeneas' wound in Virgil, Aeneid 12.412: here a cure for love. Here too, the Emblem, lacking in the original, is introduced on Spenser's model in SC. 1 Paris the Swain] Paris kept sheep on Mount Ida. 1-2 In the standard modern reading, the girl tries to brush off her lover's advances in 1; but he replies in 2, implying that she, like Helen, is willing to be won. 9-10 Somewhat differently structured from the standard modern text. 15 the wrath of Venus] for having scorned love: a familiar topos. The Shepherdess retorts that she wishes to please Diana, goddess of chastity. $\quad 19$ Do ... find we] Let her do what she can, provided we find. 30 Of whom do women live in fear? Rather, they domineer (over men). $\quad 32$ Diana in another aspect is Lucina, goddess of childbirth. 
Shepheardess. But bearing Children will my Beauty wrong.

Daphnis. In Children thou wilt see thy self still young.

Shepheardess. What Dowry wilt thou give if I consent?

Daphnis. My Flocks, my Groves, my Fields, be thou content.

Shepheardess. Swear, that, when married, thou wilt ne'r forsake me.

if it satisfies you

Daphnis. By Pan I will not, so thou please to take me.

Shepheardess. Thou'lt give me Beds, and House, and Sheep to breed?

Daphnis. Both House, and Beds, and the fair Flocks I feed.

Shepheardess. What shall I to my aged Father say?

Daphnis. He, when he hears my Name, will soon give way.

Shepheardess. How art thou call'd? for Names do often please.

Daphnis. Daphnis my name, my Father's Lycidas, My Mother's Nomeea.

Shepheardess. Of an honest Line

Thou com'st, nor we of no more mean than thine.

Daphnis. Yet not so great to make your Pride aspire,

For as I tak't, Menalcas is your sire.

Shepheardess. Shew me your Stalls, and Groves.

Daphnis

Witness how high my Cypress Trees do rise.

Come let thine Eyes

Shepheardess. Feed Goats whilst I survay the Shepheard's Bounds.

Daphnis. Graze bullocks whilst I shew the Nymph my Grounds.

Shepheardess. What do'st? Why thrust'st thy hand into my Brest?

Daphnis. Thus thy soft, swelling Bosome should be prest.

Shepheardess. Help Pan! I faint; Swain, take thy hand away.

Daphnis. Fear not sweet Nymph; nor tremble with dismay.

Shepheardess. 'Twill spoyle my Coat should I i'th'durt be thrown.

Daphnis. No; see! on this soft hide I'l lay thee down.

Shepheardess. Ah Me! Why hast thou loosd my virgin Zone?

60

Daphnis. To Venus this be an Oblation.

Shepheardess. Heark! see! somebody comes; I hear a Noise.

offering, sacrifice

Daphnis. The Cypress Trees are whispering of our Joyes.

Shepheardess. Th' hast torn my Cloaths, and me quite naked layd.

Daphnis. I'l give thee better.

Shepheardess. Words no deeds e'r paid.

Daphnis. Would I could send my soul into thee now!

Shepheardess. Oh Phoebe, pardon! I have broke my Vow.

Daphnis. A Calf to Love, a Bull to Venus burn.

Shepheardess. A Maid I came, a Woman shall return.

Daphnis. And be a Mother-Nurse to pretty Boyes.

Thus intertalk' $d$ they 'mid'st the active Joyes

Of close Embraces; when at length they rose,

And being up, to feed her Flock she goes

With blushing Face, but with a lightsome Heart,

Whilst to his Heards he no less pleas'd doth part.

\section{Theocritus and Virgil: Fragments \\ Translated from Greek and Latin by 'T.B.'}

From A Ritch Storehouse or Treasurie for Nobilitye and Gentlemen (1570), a translation of Johann Sturm's Nobilitas Literata.

46 nor we ... thine] Nor are we of meaner lineage than you. nor ....no] double negative. $\quad$ 51-2 Goats ... bullocks] Following (or starting?) the pastoral hierarchy of neatherds, shepherds and goatherds (in that order). 51 Bounds] limits (of his land or fields). 70-74 Thus intertalk'd they etc.:] 1651 text attributes to the Shepherdess, but clearly a comment by the narrator. Standard modern Gk. text has two more lines omitted by Sherburne. 


\section{[From Theocritus, Idyll I.4-6]}

If he shall choose the horned Scire, The female Goate shall be thine hire. sire, male goat But if he doe the female take,

Thou with a Kidde shalt merie make. Kiddes flesh is good and sweete perdee, Vntill at Paile they milked bee.

\section{[From Virgil, Eclogue I.1-8]}

Melibee. O happie art thou Tityrus, that vnder Beechen tree,

Thy song in Pipe of slender Ote, doste sounde with voyce so free.

But we alas our Countrie costes, and pleasant fieldes forsake:

We flie our natiue soyle, but thou in shade thy ease doste take,

And makste the woodes for to resounde alowde faire Amaryll.

Tityrus. O Melibey our God to vs this quiet state did will,

For he, for aye shall be my God, vpon his Altar stone

Oft shall the tender Lambe bee slaine, from sheepfoldes of our owne.

\section{Moschus(?) EPitaph on Bion}

\section{Translated from the Greek by Thomas Stanley.}

Greek text attributed to Moschus ( $f$. c.150 BCE - earlier than Bion, so that this poem cannot be his). This translation first published in the second part of Stanley's Poems (1651), with separate title-page entitled 'Anacreon. Bion. Moschvs. [etc.]'.

Epitaph on Bion the Pastoral Poet.

Mourn, and your grief ye Groves in soft sighs breath,

Ye Rivers drop in tears, for Bions death:

His losse ye Plants lament, ye Woods bewaile,

Ye Flowers your odours with your griefs exhale;

In purple mourn, Anemony and Rose;

Breathe Hyacinth that sigh, and more, which grows

Upon thy cheek; the sweet voic'd Singers gone:

Begin Sicilian Muse, begin your mone.

Ye Nightingales that mourn on thickest boughs,

Tell gentle Arethusa's stream which flows

Through Sicily, Bion the Shepherds dead,

And with him Poetry and Musick fled.

Begin Sicilian, \& $\prec$.

Strimonian Swans vent from your mournful throats

3 Ote] pipe or stalk of the oat plant. $\mathbf{1 6}$ of our owne] A conventional premise of pastoral: its idealized shepherds owned their flocks, unlike the wretched shepherds of the present day. Title, Bion] Greek lyric poet ( $f$ l. $100 \mathrm{BCE}$ ). None of his surviving work is markedly pastoral, though there is a celebrated quasi-pastoral 'Lament for Adonis'. 5 Anemony] a flower generated by Venus from the dead Adonis' blood, hence associated with mourning. But in Bion's 'Lament for Adonis' (hence here) Venus' tears generate the anemone and Adonis' blood the rose. 6 Hyacinth] Hyacinthus was a youth beloved of Apollo but accidentally killed by him. From his blood sprang the hyacinth flower, whose marks resemble the grieving Gk exclamation AI AI. There is a poem about Hyacinthus ascribed to Bion. 10 Arethusa] the fountain Arethusa, sacred to poetry: on the island of Ortygia near Syracuse in Sicily, traditional home of pastoral poetry, hence specially associated with pastoral. 14 Strimonian Swans] Strymon is a river in Orpheus' homeland Thrace. Swans are supposed to sing before they die. 
(Gliding upon the waves) such dying notes

As heretofore in you the Poet sung;

Tell the Oeagrian, tell the Thracian young

Virgins, the Dorick Orpheus hence is gone;

Begin Sicilian Muse, begin your mone.

He never more shall pipe to his lov'd flock,

Laid underneath some solitary Oak,

But songs of Lethe now, by Pluto taught;

The Hils are dumb; the Heifers that late sought

The Bull lament, and let their meat alone. Begin Sicilian Muse, begin your mone.

Apollo wept thy death, thy silenc'd reeds

Satyrs, Priapusses in mourning weeds

And Fawns bewail: 'mongst woods the Nymphs that dwell

fauns, minor wood-gods

In fountains weep, whose tears to fountains swell;

Eccho 'mongst rocks her silence doth deplore,

Nor words (now thine are stopt) will follow more;

Flowers fade; abortive fruit falls from the trees;

The Ews no Milk, no Honey give the Bees,

But wither'd combs; the sweetness being gone

Of thy lov'd voice, Honey itself hath none.

Begin Sicilian Muse begin your mone.

So Dolphin never wail'd upon the strand;

So never Nightingale on craggy land;

So never Swallow on the mountains mourn'd;

Nor Halcyons sorrows Ceyx so return'd. Begin Sicilian, \& $c$.

So Cerylus on blew waves never sung;

In Eastern vales, the bird from Memnon sprung

Aurora's son so mourn'd not, hovering o're

His Sepulcher, as Bion they deplore. Begin Sicilian, \& c .

Swallows and Nightingales, whom he to please

Once taught to sing, now sitting on high trees

Sing forth their grief in parts, the rest reply,

And Doves with murmuring keep them company. Begin Sicilian, \&c.

Who now can use thy Pipe, or dare betray

Such boldness to thy Reeds his lips to lay?

They yet are by thy lips and breath inspir'd,

And Eccho thence hath harmony acquir'd;

Pan keeps thy Pipe, but will its use decline,

Fearing to prove his own skill short of thine. Begin Sicilian, \&c.

Thee Galathea wails, whom heretofore

Thy songs delighted sitting on the shore:

The Cyclops sung not so; She through the Sea

in turn, as in a part-song

blown or breathed into

17-18 Oeagrian ... Virgins] Oeager was king of Thrace and (by the muse Calliope) father of Orpheus. Hence Oeagrides $=$ Orpheus' sisters (Virgins), by extension the Muses. Thracian young Virgins] translating 'Bistonian nymphs' in original, Bistonia being a place in Thrace. 18 Dorick] pastoral: Theocritus wrote in the Doric dialect. Bion is being called the Orpheus of pastoral. 22 Lethe] A river (of forgetfulness) in the underworld or Pluto's kingdom. 27 Priapusses] Priapus, conspicuously phallic god of fertility associated with the conventionally lustful fauns and satyrs. The plural is used generically of this whole class of wood-gods - like Panes ('Pans') in the Gk, rendered by Stanley as Fawns (28). 37 Dolphin] So certain mss. Standard Gk text refers to Sirens. 4o Halcyon, Ceyx] In one version of the legend, Ceyx dies in a shipwreck, his beloved Alcyone throws herself into the sea for grief, and both are turned into birds (perhaps kingfishers). $\quad 42$ Cerylus] a fabulous sea-bird. 43 Memnon] son of Tithonus and Aurora (Dawn). His ashes generated a flock of birds visiting his tomb every year. This entire section (37-45) obscure in the original. All allusions are to humans metamorphosed into birds: the point seems to be that they mourn more deeply for Bion than for their original griefs. 50 Doves] not in original. $\quad 55$ Eccho] The nymph Echo was punished by Juno by having no independent utterance or control over her tongue; but the echo of Bion's songs lingering in his pipe is harmonious. Cf. 30-31. 56 Pan keeps thy pipe] Gk has: 'Shall I take your pipe to Pan?' 59 Galathea] a nymph beloved of the Cyclops Polyphemus. His love recounted in Theocritus XI (see no.2), and mentioned in two poems by Bion. 
(Though him she fled) darted kind looks at Thee;

And now in desert sands she sits, the deep

Forsaking quite, and doth thy Oxen keep.

Begin Sicilian, \&cc.

With thee (lov'd Swain) dy all the Muses joyes,

The kisses of young Maids and amorous Boyes;

The Cupids weep about thy Sepulcher;

Thee Venus did beyond the kisse prefer

Which from Adonis dying she receiv'd.

Thou hast new cause, great River, to be griev'd,

New sorrow, Melus: Homer first by death

Was seiz'd (Calliopes harmonious breath);

Then thy fair Son thy troubled waves deplor'd,

And over all the Sea their current roar'd;

Thou now must languish for another Son:

Both Fountains lov'd: the Pegascean One,

The other courted Arethusa's spring:

One did of Tyndarus fair Daughter sing,

Thetis great Son, and Menelaus wrong;

Nor wars nor tears, Pan was the others song,

And Shepherds: As he sung he us'd to feed

His flock, milk Cows, or carve an oaten reed,

Taught the Youth courtship, in his bosom love

He nurs'd, and Venus only did approve.

Begin Sicilian, \&c.

Thy death each City, every Town resents;

Above her Hesiod Ascra thee laments;

Lesse Pindar by Boetian woods is lov'd;

Less with Alcaeus fate was Lesbus mov'd;

Their Poets losse lesse griev'd the Ceian town;

Parus lesse love t'Archilochus hath shown;

Thy verse 'bove Sapphos Mytilene admires;

All whom th'indulgence of the Muses fires

With pastoral heat, bewail thy sad decease;

The Samian glory mourns Sicelides;

Amongst Cydonians (whose late mirth their pride)

Licidas weeps; his grief by Hales tide

Philetas, 'mongst Triopians, doth diffuse,

Theocritus 'mongst those of Syracuse;

And with Ausonian grief my verse is fraught;

feels or mourns deeply

68 The Cupids] Erotes, infant figures accompanying the infant Cupid. 69 Adonis] a hunter beloved of Venus; killed by a boar, to Venus' distracted grief. Bion's 'Lament for Adonis' describes her kissing his dead body. $\quad 72$ Melus] Meles, a river in Smyrna, birthplace of Bion and, reputedly, of Homer. 73 Calliope] Muse of epic poetry and thus of Homer. 77 Pegasaan] Hippocrene under Mount Helicon, sprung from the hoof-beat of the winged horse Pegasus: sacred to all the Muses, but here specially associated with Homer and the epic. 78 Arethusa] contrastingly associated with Bion and the pastoral: see 1on. $\quad 79$ Tyndarus fair Daughter] Helen of Troy. Tyndar[e] us was married to Helen's mother Leda, though Helen was begotten by Zeus. 8o Thetis great Son] Achilles. Menelaus wrong] when Paris abducted his wife Helen. These allusions to the Iliad contrast with Bion's pastoral theme. 85 approve] ?try, put to test (OED 8). Gk has 'who aroused the passion of Venus herself.' 88 Ascra] a town in Boeotia, on Mount Helicon; abode of Hesiod. $\quad 89$ Pindar] born in Thebes, the principal city of Boeotia. 90 Alcaeus] was born and dwelt in Mytilene on the island of Lesbos. 91 the Ceian town] Simonides was born on the island of Ceos. Standard Gk text cites Teos, the home of Anacreon. 92 Archilochus] belonged to Paros. 93 Sappho] belonged to Lesbos and probably, like Alcaeus, to Mytilene. 96 Samian] of the island of Samos. The poet cannot be identified: perhaps Pythagoras, a musician as well as philosopher and mathematician. Sicelides] Sicilians, perhaps the Sicilian or pastoral muses (as in Virgil IV.1). 96-9 The Samian glory ... doth diffuse] A late interpolation, rejected by modern editors but accepted in the Renaissance. Impairing chronology, ' $\mathrm{Li}$ cidas, Philetas, Theocritus and the poet himself are all presented as Bion's disciples (Scholers, 102) mourning his death. 97-8 Cydonians] Cretans. Licidas] probably Epimenides. 97 whose ... pride] Their now deceased cause of joy (i.e., 'Licidas') was their pride. 98-9 Hales ... Philetas ... Triopians] Conflating two rivers called Hales, in Asia Minor and in Cos. Triopium was in Asia Minor, while the poet Philetas belonged to Cos. 100 Theocritus] Theocritus hailed from Syracuse. Standard Gk text implies 'You are a Theocritus [i.e., as good as, or better than, Theocritus] even to Syracuse'. 101 Ausonian] Italian. The unknown poet, like Moschus, seems to hail from Southern Italy. 
Such thy own Scholers by thy self were taught,

Who as thy heirs claim Dorik poesie;

Thy wealth to others, verse thou left'st to me. Begin Sicilian, \& $\sim$.

Alas though time the garden Mallows kill,

The verdant Smallage and the flowry Dill,

Yet these revive, and new the next year rise;

Smallage: types of parsley or celery

But Man, though ne're so great, so strong, so wise,

Once dead, inclos'd in hollow earth must keep

A long, obscure, inexcitable sleep.

unwakable

And thou art thus laid silent in the ground;

For thy sweet voice we onely hear the sound

Of the hoarse Frogs unintermitted grone. Begin Sicilian Muse, begin your mone.

Cam'st thou by Poyson Bion to thy death?

Scapt that the Antidote of thy sweet breath?

What cruel Man to thee could poyson bear?

Against thy musick sure he stopt his ear. Begin Sicilian, \& $c$.

But a just vengeance is reserv'd for all;

Meantime, with others, I bewail thy fall.

Might I like Orpheus view the states below,

And like Alcides, or Ulisses go

To Pluto's court, I would enquire if there

To him thou singst, and what thou singst would hear;

Court Her with some Sicilian past'ral strain,

Who sporting on Sicilian Aetna's plain

Sung Dorik laies; thine may successful be,

130 And as once Orpheus brought Euridice

Thee back perhaps they to these hills may bring:

Had I such skill, to Pluto I would sing.

\section{Virgil Eclogue I}

Translated from the Latin by William Webbe.

First published in Webbe's A Discourse of English Poesie, 1586, to illustrate the principles of quantitative verse in English. Punctuation modified.

The Argument of the first Aeglogue.

Vnder the personne of Tityrus Vyrgill beeing figured himselfe, declareth to Melibeus an nother Neateheard, the great benefittes that he receyued at Augustus hand, who in the spoyle of Mantua gaue him hys goods and substaunce againe. spoyle: sack, destruction

Melibous. Tityrus.

[Melibøus.] Tityrus, happilie thou lyste tumbling vnder a beech tree, All in a fine oate pipe these sweete songs lustilie chaunting

We, poore soules goe to wracke, and from these coastes be remooued,

?sprawled,

And fro our pastures sweete: thou Tityr, at ease in a shade plott

Makst thicke groues to resound with songes of braue Amarillis.

Tityrus. O Melibous, he was no man but a God who releeude me:

Euer he shalbe my God: from this same Sheepcot his alters

103 Dorik poesie] pastoral poetry. See $18 \mathrm{n}$.

them visited the underworld (Pluto's court).

123-4 Orpheus, Alcides (Hercules), Vlisses] All of or Pluto from the plains below Etna. Orpheus appealed to him to return his wife Eurydice from the dead. Sicilian] pastoral, from Theocritus' birthplace. The standard Greek text does not say Persephone sung Doric (i.e., pastoral) lays, only that she was familiar with them, so that Bion himself might charm her by singing them. $\quad \mathbf{0 . 2}$ Neateheard] used of all herdsmen. Both speakers actually keep sheep and goats. spoyle of Mantua] After Octavian (the future Emperor Augustus) defeated Brutus and Cassius at Philippi in 42 BCE, he seized many farmlands in Mantua, Virgil's native region, to settle his discharged soldiers. Virgil I is commonly read as the poet (as Tityrus) offering thanks to Augustus for saving his land and granting him its freehold. 4 Tityr] See 13n. shade plot] demanded by the metre: perhaps a compound, 'shade-plot'. 
Neuer a tender Lambe shall want, with blood to bedew them.

This good gift did he giue, to my steeres thus freelie to wander,

And to my selfe (thou seest) on pipe to resound what I listed.

Melibous. Grutch thee sure I doo not, but this thing makes me to wonder,

Whence comes all this adoo: with grieeuous paine not a little

Can I remooue my Goates: here, Tityre, skant get I forward

Poore olde crone, two twyns at a clappe ith boysterous hasilles

Left she behind, best hope i' my flock laid hard on a bare stone.

Had not a lucklesse lotte possest our mindes, I remember

Warnings oft fro the blast burnt oake we saw to be sent vs.

Oft did a left hand crow foretell these thinges in her hull tree.

But this God let vs heare what he was, good Tityre tell me.

Tityrus. That same Cittie so braue which Rome was wont to be called,

wished, fancied

Foole did I thinke, to be like this of ours, where we to the pastures

Wonted were to remooue from dammes our young prettie Cattell.

Thus did I thinke young whelpes and Kids to be like to the mothers,

Thus did I wont compare manie great thinges with many little.

[begrudge, envy

But this aboue all townes as loftily mounteth her high head,

As by the lowe base shrubbes tall Cypresse shooteth aboue them.

Melibous. And what did thee mooue that needs thou must goe to see Rome?

Tityrus. Freedome: which though late, yet once lookt backe to my pore state,

After time when haires from my beard did ginne to be whitish:

Yet lookt back at last and found me out after a long time,

When Amarill was once obtainde, Galatea departed:

For (for I will confesse) whilst as Galatea did hold mee,

Hope did I not for freedome, and care had I none to my cattell.

Though many faire young beastes our folde for the aulters aforded

And manie cheeses good fro my presse were sent to the Cittie,

Seldome times did I bring anie store of pence fro the markett.

Melibaus. O Amarill, wherefore to thy Gods (very much did I meruaile)

Heauilie thou didst praie? Ripe fruites vngathered all still:

hard: painfully

unhappy fate

lightning-struck

Tityrus is not at home: these Pyne trees Tityre mist thee.

Fountaines longd for thee: these hedgrowes wisht thy return home.

Tityrus. What was then to be doone? from bondage could not I wind out:

Neither I could haue found such gentle Gods anywhere els.

There did I see (Melibæe) that youth whose hestes I by course still

Fortnights whole to obserue on the Alters sure will I not faile.

Thus did he gentlie graunt to my sute when first I demaunded:

Keepe your heardes, poor slaves, as erst, let bulles to the makes still.

mates; Melibous. Happy olde man, then thou shalt haue thy farme to remaine still, always

Large, and large to thy selfe, others nought but stonie grauell

And foule slymie rush wherewith their lees be besprinkled.

leas, pastures,open land

Heere no unwoonted foode shall grieue young theaues who be laded,

Nor the infections foule of neighbours flocke shall annoie them.

Happie old man. In shaddowy bankes and coole prettie places,

Heere by the quainted floodes and springs most holie remaining,

Here, these quicksets fresh which lands seuer out fro thy neighbors

marvel,

[wonder

nobly, generously

13 Tityre] So here and later, apparently as Lat. vocative (3 syllables); but Tityr (4) presumably for the metre. skant get I forward] I can scarcely make it go. 14 Ewes normally have one lamb at a time: to give birth to two is specially laborious. crone] old ewe. at a clappe] at once. ith] in the. Boisterous] 'Strong- or coarse-growing, rank' (OED 6). 18 Corresponding line in Lat. usually omitted as mistaken import from Virgil IX.15. left hand crow] In Roman augury, a raven (Lat. cornix) croaking on the augur's left was an ill omen, but a crow a good one. hull] holly (OED hull $n^{3}$, citing this line); ? hollow (cf. hull, shell or outer covering: $O E D$ hull $n^{1}$ : no adjectival use recorded). 21-2 where we $\ldots$ prettie Cattell] The original means 'where we used to drive our new-weaned lambs.' 33 cattell] ?chattels, property. Lat. peculi, 'of [my] property or wealth', though peculium too originally meant (property in the form of) cattle. 34 i.e. He sacrificed many beasts to placate the gods. 37-8 Another inept rendering of the sense 'Now I understand what I wondered at: why you, Amarillis, prayed so diligently to the gods'. $\quad 38$ vngathered] not from neglect, but for Tityrus to enjoy. $\quad 43$ hestes] vows, pledges (of sacrifice to Augustus). 44 Fortnights whole] Lat. has 'twice six days a year'. 46 let ... still] let bulls couple with their mates. 48 Large] (a) free, in freehold (b) [sufficiently] big: a play only possible in English. 48-9 others ... besprinkled] Lat. implies that Tityrus' own fields are also damaged, but still good enough. $\mathbf{5 3}$ quainted floodes] acquainted (familiar) streams. $\mathbf{5 4}$ quicksets] live slips of plants used as hedges. 
And greene willow rowes which Hiblæ bees doo reioice in, Oft fine whistring noise shall bring sweete sleepe to thy sences. Vnder a Rock side here will proyner chaunt merrie ditties.

Neither on highe Elme trees, thy beloude Doues loftilie sitting,

Nor prettie Turtles trim, will cease to crooke with a good cheere.

60 Tityrus. First, therefore swift buckes shall flie for foode to the skies ward,

And from fish withdrawn, broade seas themselues shal auoid hence:

First, (both borders broke) Araris shal run to the Parthanes,

And likewise Tygris shall againe runne backe to the Germanes:

pruner, vine-dresser

Ere his countnaunce sweete shall slippe once out from my hart roote.

Melibrus. We poor soules, must some to the land cald Affrica packe hence,

Some to the farre Scythia, and some must to the swift flood Oaxis,

Some to Britannia coastes quite parted farre fro the whole world.

Oh these pastures pure, shall I nere more chance to behold yee?

And our cottage poore with warm turues couerd about trim.

$70 \quad$ Oh these trim tilde landes, shall a rechlesse souldier haue them?

clear, undefiled

And shall a Barbarian haue this croppe? see what a mischiefe

Discord vile hath araisde! for whom was our labour all tooke?

Now Melibæe, ingraft pearie stocks, sette vines in an order.

Now goe (my braue flocke once that were) O now goe my kidlings.

Neuer againe shall I now in a greene bowre sweetelie reposed

See ye in queachie briers farre a loofe clambring on a high hill.

Now shall I sing no Iygges, nor whilst I doo fall to my iunkets,

Shall ye, my Goates, cropping sweete flowres and leaues sit about me.

turtle-doves; coo

Tityrus. Yet thou maist tarrie heere, and keepe me companie this night,

All on a leauie couch: good Aples ripe I doo not lacke,

become

[void or empty

Chestnutts sweete good store, and plentie of curddes will I set thee.

Marke i'the Towne how chimnie tops doo beginne to be smoaking,

And fro the Mountaines high how shaddowes grow to be larger

tilled, cultivated

handsome,

[splendid

dense; aloft,

[high up

made of leaves

village,

[settlement.

\section{Virgil Eclogue II}

Translated from the Latin by Abraham Fraunce

First published in Fraunce's The Lawiers Logike (1588), Book II. Composed, in Fraunce's words, 'in English hexameters, verse for verse' - i.e., each line of the English precisely matching a line in the Latin. Fraunce achieves this objective in most lines, despite the difference in syntax and word-order between the two languages.

Seelly shepheard Corydon lou'd hartily faire lad Alexis,

His maisters dearling, but saw no matter of hoping.

Only amid the forest thick set with broad-shadoe beachtrees

Daily resort did he make: thus alone to the woods, to the mountains

With broken speeches, fond thoughts most vainly reuealing.

O hardharted Alexis: I see my verse to be scorned,

My selfe not pitied, my death by thee lastly procured.

Now do the beasts euen seeke for cooling shade to refresh them,

Grene lyzards now too in bushes thorny be lurking;

And for faint reapers by the suns rage, Thestylis hastning,

Strong-smelling wilde thime and garlyke beates in a mortar.

But whilst I trace thee, with sun beames all to bescorched,

55 Hiblæ] Hybla, a town in Sicily renowned for its honey. The form Hibloe may reflect Lat. genitive. 61 The seas will recede and leave their fish dry on the ground. Another inept rendering. $\quad 62$ Araris] a river in France. Parthanes] Parthians, from central Asia near the Caspian Sea. 62-3 The translation talks of natural cataclysms, but the Latin of the tribes being exiled. The 'borders' are of rivers in the English, territories in the Latin. 63 Tygris] The river Tigris in modern Iraq, while the Germanic tribes largely inhabited the region of modern Germany. 65 Affrica] northern Africa, a Roman province. 66 Scythia] an indeterminate region of east and north-east Europe and adjoining parts of Asia. Oaxis] a river in Crete. $\quad 69$ turues] blocks of turf used to roof cottages. 70 rechlesse] reckless, heedless (of the spirit and associations of the land). The Latin has impius, 'godless' 73 ingraft pearie stocks] graft your pear trees: an ironic evocation of pursuits no longer possible. 77 Iygges] jigs, a kind of song as well as dance. iunkets] a kind of cream cheese; broadly, any pastoral repast. 1 Seelly] humble, rustic, simple-souled. 'Seely' or 'silly shepherd(s)' is a stock poetic phrase. 5 fond] (a) foolish, futile (b) affectionate. $\quad 11$ To make soup for the men's mid-day meal. 
Groues by the hoarschirping grashoppers yeeld a resounding.

echo

Wast not far better t'haue borne with surly Menalcas,

And sore displeased, disdainfull, proud Amaryllis,

Although thou white were, although but swarty Menalcas?

swarthy

O thou faire white boy, trust not too much to thy whitnes:

Faire white flowers fall downe, black fruits are only reserued.

Thou carest not for mee, my state thou knowst not, Alexis:

What flocks of white sheepe I do keepe, of milke what abundance.

On Sicil high mountains my lambs feed, more then a thousand:

New mylke in summer, new mylke in winter I want not.

My song's like Thebane Amphions song, when he called

His wandring bullocks, on Greekish mount Aracynthus.

Neyther am I so fowle: I saw my selfe by the seashore,

When seas al calme were: I doubt not, but by thy censure,

Daphnis I shall surpasse, vnles my face do deceaue mee.

$\mathrm{O}$, let this be thy will, to frequent my rustical harbors

And simple cotages, and sticke in forkes to vphold them,

And driue on forward our flocke of kids to the mallowes:

Wee wil amid the forest contend Pans song to resemble:

Pan was first that quils with waxe ty'de ioyntly together.

Pan is good to the sheepe, and Pan is good to the sheepsman.

Neither think it a shame to thy self t'haue plaid on a cornpipe:

For, that he might do the same with skil, what did not Amyntas?

Damotas long since did giue me a pipe for a token,

Compact of seuen reedes, all placed in order, vnæquall:

And thus sayd, when he dy'de: One vsed it onely beefore thee.

Thus sayd Damotas, this greeued foolish Amyntas.

Also two prety kids doe I keepe, late found in a valley

Dangerus; and their skins with mylke white spots be bedecked,

Of dams milke not a drop they leaue; and for thee I keepe them.

Thestylis of long time hath these kids of me desired;

And they shalbe her own, for that thou skornst what I giue thee.

Come neare, ô faire boy, see the nymphs bring here to the lillies

With full stuft baskets: faire Nais now to thy comfort

White violets gathering, and poppies daintily topping,

Daffadil ads to the same, and leaues late pluckt fro the sweet Dill.

Then mingling Casia with diuers sauory sweet flowrs,

With yelowish Marygold, she the tender Crowtoe bedecketh.

Ile plucke hoare quinces, with soft downe all to besmeared,

And Chessnuts which were loued of my sweet Amaryllis.

Add wil I wheateplumbs too: for this fruit will be regarded,

And you laurell leaues will I plucke, and thee, prety myrtle

Next to the laurell leaues: for so plast, yeeld ye the sweet sent.

Th'art but a foole Corydon, for first gifts mooue not Alexis,

Then, though thou giue much, yet much more giue wil Iolas.

But what alas did I mean, poore foole? I do let go the southwind

Into the flowrs, and boares send forward into the cleare springs.

Whom flyest thou mad man? Many gods haue also resorted,

And Paris of olde Troy, to the woods. Let towers by Minerua

except in your judgment

fresh

Built, by Minerua be kept; and woods of vs onely regarded.

20 From this point, many echoes of Theocritus XI, where the Cyclops Polyphemus woos Galathea. 23 Amphion] Said to have raised a wall round Thebes by his music. He and his twin brother Zethus, sons of Zeus, were brought up as shepherds. He belonged to Boeotia, where Virgil places Mt Aracynthus (actually in Aetolia). 29 cotages] makeshift huts or shelters (OED 2), like those of shepherds on remote pastures. forkes to vphold them] forked staves to prop them up. 31 contend ] (a) endeavour, attempt (b) compete (as in a singing-match). 32 quils] reeds, used to make a pan-pipe. 36 Damoetas] This passage has created the figure of a master-shepherd of song: cf. Milton, 'Lycidas' (no. 230) 36. 38 One] Damoetas himself. 40-44 The clearest of many echoes of Theocritus III, where a shepherd pines for Amaryllis. $\quad \mathbf{5 1}$ hoare Unripe quinces have greyish-white down. $\quad 53$ wheateplumbs] 'wheat-plums', misrendering cerea pruna, 'waxen plums'. 56 first gifts] ?gifts given in advance of Iolas', allowing the latter to outvie them. 58-9 I do let ... springs] I am destroying my own prosperity and happiness. 61 Paris] He kept sheep on Mount Ida. 61-2 towers by Minerua Built] Athens, of which Athena (Minerva) was the tutelary goddess. This identifies the setting (as in most of Virgil's eclogues) as Greece. 
Grim Lionesse runneth to the wolfe, and wolfe to the yong gote,

And wanton yong gote to the flowring tetrifol hastneth,

And Corydon to Alexis: a selfe joy draweth on each man.

But see the plow coms home, hangd fast by the yoke to the bullocks,

And shadoe by Phobus declining double appeareth;

Yet do I burne with loue: for what meane can be to louing?

Ah Corydon, Corydon, what mad rage hath thee bewitched?

Thy vin's scarce halfe cut, pestred with leaues of her elme tree:

Leaue this churlish boy, and bend thy selfe to thy busnes,

With twigs and bulrush some needefull thing be a making:

middle course,

[moderation

vine; burdened,

[encumbered

Thou shalt find others though th'art disdaind of Alexis.

\section{Virgil Eclogue IV}

\section{Translated from the Latin by Abraham Fleming.}

First published in Fleming's The Bucoliks of Publius Virgilius Maro ... together with his Georgiks or Ruralls (1589). These unrhymed translations are entirely different from Fleming's rhymed versions of 1575. The text below omits random brackets around certain words in the 1589 text. Salient marginal notes by Fleming incorporated below with the marker '[Fleming]'. The eclogue appears to celebrate the birth of a son to the poet's patron, the statesman Gaius Asinius Pollio. But so extravagant is the fantasy, postulating a return of the Golden Age, that the poem was later taken as a conscious or unconscious prophecy of the birth of Christ. In the Christian Middle Ages, Virgil thereby came to be venerated as a proto-Christian seer.

The fourth Eclog of Virgill intituled Pollio, or the birth day of Soloninus.

\section{The Argument}

Asinius Pollio, an excellent orator and captaine of the Germane host vnder Augustus, after his taking of the citie Salonoe in Dalmatia, hauing triumphed, he was aduanced to the office of a consull. Not long after this, he begat a sonne, whom he named Salonius, in memorie of the citie Salonoe, which he had conquered and taken. For this yoong babes sake newly borne, as also (and that principallie) to please the father, who was in great fauour, and might doo much with Augustus, Virgill (whom Pollio greatly esteemed, releeued and maintained) in this eclog describeth the birth day of the said Salonius. Wherein this is to bee marked, that such thinges as the prophetesse Sybilla of Cuma foretold of the comming and birth of Christ (as Lactantius, Eusebius, and Augustine doo testifie), the poet, vtterly ignorant of that diuinitie, applieth to the happinesse of Augustus his gouernment, and also to the child Salonine. And because this eclog, as likewise two more, are of somwhat a loftier stile than beseemeth the argument of a pastorall deuise, the poet beginneth very modestly with an honest confession or preface, as followeth.

In this eclog the poet speaketh alone.

O Muses of Sicilia ile let's greater matters sing,

Shrubs groues and bushes lowe delight and please not euery man,

If we doo sing of woods, the woods be worthy of a consull.

let the woods be

$\mathbf{6 4}$ tetrifol] error for 'tree-trefoil' or 'tree-clover', Lat. cytisus. (See OED tetrifolie.) $\mathbf{6 5}$ a selfe joy] the same pleasure or desire. Corydon's analogies for his love are of a predatory or devouring nature. 70 her elme tree] i.e., that up which the vine is trailed. o.1 Soloninus] Pollio's newborn son: 'Salonius' in the Argument. See headnote. $\quad 0.2$ Germane host] the Germanian army of the Roman Empire. Ancient Germania extended eastward to Dalmatia (modern Croatia). $\quad 0.7$ releeued] assisted, saved from difficulties. $\quad 0.8$ prophetesse Sibylla of Cuma] The Cumaean Sibyl, most celebrated of the Sibyllae or wise women of antiquity. Supposed author or propagator of the Sibylline books of prophecy, whose Book III largely concerns prophecies of a future Golden Age. These were discussed and imitated by Jewish and Christian writers, including the Christian fathers cited here: Lactantius, Divinarum institutionum libri VII.24 (Patr. Lat. VI.143-4); Eusebius, Oration of Constantine to the Assembly of the Saints, chs.19-21; Augustine, The City of God X.27 and XVIII.23, citing Lactantius. All three texts cite Virgil IV extensively alongside presumed sources in the Sybilline books. 0.9-10 vtterly ignorant] Often thought that though the Sibylline books consciously prophesied the birth of Christ, Virgil used the material without realizing its significance. o.11 two more] VI and X, according to the early commentator Donatus. beseemeth] befits. $\mathbf{0 . 1 2}$ deuise] composition. honest] frank. confession] declaration, acknowledgement. $\quad 0.14$ alone] in his own voice, not in dialogue form. 1. Muses of Sicilia] pastoral muses, Sicily being Theocritus' supposed birthplace. 2 bushes lowe] Lat. myrica. 'Myrica, wilde brier, or tamariske properly. Plin[y] lib[er] 13.' [Fleming]-i.e., Pliny, Natural History XIII.34. $\quad 3$ 'Let our pastoralls be such as may beseeme a consull to read.' [Fleming] Pollio became consul in $40 \mathrm{BCE}$. 
Now is the last age come whereof Sibyllas verse foretold,

And now the virgin come againe, and saturnes kingdome come,

Now is a sonne, an offspring new sent downe from heauen high.

O chaste Lucina fauour thou the boy that's now in birth,

By whom the yron nation first shall cease and haue an end,

And ouer all the world this golden age shall rise and spring.

O Pollio, truly of this age the beauties and the hew

appearance

10

Shall then begin when thou art consull, and the moneths great

Shall then begin forward to go, and orderly proceed.

I, any marke or notes of our offense doo yet remaine,

The same made void, deliver shall the earth from endlesse feare.

Thou being guide and gouernor, he (Cæsar I doo meane)

Shall take his life of gods aboue and also he shall see

Most noble states with heauenly gods mingled in companie,

And he likewise himselfe shalbe of them beheld and seene,

And shall with fathers vertues rule the world in quiet set:

$\mathrm{O}$ child the ground shall yeeld to thee hir first fruits, little gifts,

No dressing thereupon bestowd, in places euery where,

Even yuie spreding of itselfe with gentle lady flowre,

And beanes of Æygipt mingled with that plesant bearefoot herbe.

The little gotes themselues shall beare home to their maisters house

Their dugs stuft full of milke, the herds of cattell shall not feare

The lions great and terrible, the very cradle too

Wherein the infant lies shall yeeld faire louelie floure to thee.

The serpent perish shall and dy, the herbe of poison too,

Which is deceptfull, it shall die and withering fall away,

And deintie grapes of Syria shall very common grow.

But herewithall when as thou shalt the fame and praises read

Of noble men, and therewithall thy father's acts and deeds,

And shall perceiue and vnderstand what heauenlie vertue is,

Then shall the feeld wax yellowish by little and by little,

With soft and tender eares of corne, and ruddie grapes shall hang

On thorne untrimd and wilde, hard okes shall sweat honny like deaw:

But yet of old deceipt and guile a few marks shall remaine,

Which may commaund to try the sea with ships, and compasse townes

4-5 Fleming omits a line of the original: 'The great cycle of the centuries begins anew'. History was commonly seen as repeating, over and over, the cycle of the Four Ages. 5 'Some take this to be a prophesie of Christ, but how vnproperly let the learned iudge.' [Fleming]. virgin] Astraea, goddess of justice, who left the earth after the Golden Age: Virgil, Georg. II.473-4. saturnes kingdome] Saturn's rule over Latium, as king rather than god, is associated with the Golden Age. 7 Lucina] goddess of childbirth. 8 yron nation] the people of the Iron Age, the last and worst age of human history. 9 golden age] Lat. talks of a golden race or nation (gens aurea), followed by some words left untranslated: 'Your own Apollo is now king.' 'Your' refers to Lucina, identified with Diana and hence Apollo's sister. 11 moneths great] Fleming interprets wrongly as 'Julie and August'. Actually one of the twelve ages or parts (each under a zodiacal constellation) of the 'Great' or Platonic Year, an astronomical cycle of nearly 26,000 years also marking a major epoch of human history. moneth] bisyllabic form current till $17-c$, here required by the metre. 13 I] Aye. offense] Lat. sceleris, evil deeds; for Christian readers, could suggest original sin, just as the Golden Age could be assimilated to Paradise before the Fall. 15 he (Cæsar I doo meane)] The Lat. clearly 'means' the newborn child. 19 in quiet set] 'Brought into quietnesse and peace.' [Fleming]. 21 No dressing ... bestowd] without cultivation, spontaneously. 22 lady flowre] 'Baccar. fuell. lib[er]3 Strab[o] lib[er]17.' [Fleming] Fuell, misprint for (Leonhart) Fuchs: the 'asarum or baccar' is described in his De Historia Stirpium (1551), ch.3. Strabo's Geography 17.1.15 actually describes the Egyptian bean (see 23n). Perhaps Fleming had the 'lady's foxglove' in mind (OED lady $\left.\mathrm{C}_{3} \mathrm{c}\right)$. Baccar, the plant in Vigil's Lat., has not been identified but is often rendered as 'foxglove'. 23 beanes of Æygipt] 'Aron, dragon woorts, or preests pintle.' [Fleming] Aron, arum. Dragonwort, priest's pintle: two names for Arum maculatum. Virgil's word, colocasia, is identified with another plant of the genus Arum. bearefoot herb] 'See after in the georg[ics].' [Fleming] Bearfoot or bear's foot, the acanthus, the plant mentioned in the Lat. (also in Georg. IV.123, as Fleming points out). 29 deceptfull] ?treacherous, harmful in a way belied by its appearance. 30 grapes of Syria] 'Vines.' [Fleming] The Lat. talks of Assyrium ... amomum, Assyrian balsam. 'Syria' and 'Assyria' were often equated. 33 heauenlie vertue] Lat. virtus, valour rather than any spiritual quality. 36 deaw] 'Or made of the deawe of heauen.' [Fleming] Dew was thought to descend from heaven: sometimes identified with manna. 38-9 compasse townes With walles] to guard against sieges, i.e. anticipating war. ships] There was no navigation in the Golden Age - i.e., neither military invasion nor commerce. 
With walles, and cut in furrowes deepe into the ground with plow.

Another Typhis then shall liue, another Argus too,

Which may conuey and carry chosen men of noble race.

Then also other warres shalbe, and once againe to Troy

Achilles great and valiant shalbe set out and sent.

Then hereupon soone after that thy yeares and settled age

Hath made thee be a man, the merchant he shall leaue the sea,

The ship of pine tree shall not change hir merchandize and wares.

All kind of ground all kind of things shall carrie yeeld and beare,

exchange,

The earth shall bide no rake, the vine no hedgebill shall abide,

[trade in

The plowman now shall loose the yokes from strong and sturdy buls.

The wooll shall learne to counterfeit colours of diuers kinds,

But in the medowes shall the ram his woollen fleeses change

Now into purple sweetly red, now yellow saffron hew:

A colour bright and flaming red shall of its owne accord

Cloth and adorne the lambs a-feeding in the pasture field.

The fatall ladies all agreeing in the stedfast law

And mightie power of destinie, said to their spindels thus:

Run on such seasons, golden times and happie ages still!

$\mathrm{O}$ deere offspring and child of gods, O great increase of Ioue,

Great honours vndertake: the time ordaind will shortly be.

Behold the world now staggering with burthen crooked bent,

The land, the coasts of sea, the heauen profound and passing high,

Behold how all things ioy at this same golden time to come.

$\mathrm{O}$ that the last part of my life might last so long to me,

My breath also, as might suffice to tell thine acts and deeds,

Not Orph of Thrace should pass me then in sweet melodious songs,

Nor Linus neither, though the mother of the one were by,

And th'others father present too: Calliope the muse

Is Orpheus' mother, and of Line Apollo father faire.

Though Pan should striue with me in song, Arcadia being iudge,

Even Pan would say hee's ouercome, Arcadia being iudge.

$\mathrm{O}$ little boie begin to know thy mother by thy laughing:

Ten months brought vnto mother thine both long and tedious toiles.

O little boy begin to know thy mother by thy laughing,

At whom thy parents laughed not when thou wast but a babe

Ne god thought worthie of his boord, ne goddesse of hir bed.

39 furrowes ... plow] In the Golden Age, there was no need to farm the land, which spontaneously yielded crops (47-9). 40 Typhis] pilot of the Argo (Argus), the ship of Jason and his band, the Argonauts. 43 set out] equipped and despatched, as for war (OED to set out II.6a). 46 ship], 'Mast.' [Fleming] Masts of ships were made from pine trunks. pine tree] 'See after in the Georg[ics].' [Fleming] - Georg. I.254-6, where the pine tree is mentioned alongside, but not linked to, a reference to navigation. 47 In such a situation, trade will become unnecessary. 48 hedgebill] an implement for cutting hedges, creepers etc. 49 buls] 'Or oxen.' [Fleming]. 50 The Lat. uses opposite wording to the same end: wool will not 'counterfeit' colours with dyes but grow on the sheep's backs in various colours. $\quad 53$ colour bright] Lat. Sandix, vermilion, but here usually translated as 'scarlet'. 'Sandix. Adrianus Junius de metallis.' [Fleming] Junius de metallis, the section on metals in Junius' encyclopedic Nomenclator omnium rerum (1577, with a dedication to Fleming) whose English version, The Nomenclator, or Remembrance (1585), Fleming edited and indexed. $\mathbf{5 5}$ fatall ladies] the three Moirae, Parcae or Fates. $\mathbf{5 6}$ spindels] on which the Fates spun the thread of a person's life. $\mathbf{5 8}$ great increase of Ioue] 'By whom Iupiters honor is increased'. [Fleming] Lat. magnum incrementum Iovis: ?mighty foster-child of Jupiter; ?mighty progeny of a Jupiter (i.e., mighty king); ?mighty ancestor of such a Jupiter-like king. 64 breath] Lat. spiritus, (a) breath (b) inspiration. 66 Linus] harvest god associated with song and music. 67 mother... father] Orpheus was the son of the Muse Calliope, and Linus of Apollo (as well as Calliope by one tradition). $\quad \mathbf{7 1}$ laughing] 'Make thy mother merrie with laughing.' [Fleming] The Lat. is more like 'know (or greet) your mother with a smile'. 72 toiles] 'Through paines of childbirth.' [Fleming]. 75 'Whom none of the gods thought good enough to eat, and drink with them, nor any of the goddesse[s] would take to husband: and this is meant of Vulcan.' [Fleming] Wrong translation: Lat. has 'He on whom his parents have not smiled is not honoured at the table of any god or the bed of any goddess.' 
9 Virgil Eclogue X

\author{
Translated from the Latin by Abraham Fleming.
}

First published in Fleming's The Bucolikes of Publius Virgilius Maro (1575), completely different from Fleming's later unrhymed renderings (1589). The poem presents Virgil's friend, the poet and administrator Gaius Cornelius Gallus, as dying of love. The traditional conjectures are indicated in the Argument. The poem follows Theocritus I in broad outline, but with a new inwardness of sentiment in Gallus' dying utterance. This is also Virgil's most elaborate presentation of the imaginary pastoral landscape of Arcadia. Salient marginal notes by Fleming incorporated below with the marker '[Fleming]'.

\title{
The Argument or contentes of the tenth and laste Ecloge. Gallus.
}

Cornelius Gallus an excellent and passing Poet, and chiefe gouernour of Ægipte, who when he loued Cytheris th'arlot out of measure, Volumnius his freewoman, whome the Poet heere calleth Lycoris, and she recompensed him not with lyke loue againe: But despisyng him, hunted after Anthonie into Fraunce, Cornelius was thought to haue taken this refusall marueilous heuelie. Virgil therefore in this Ecloge comforteth him, but in such sort, that he slideth not from shepheardes personages, nor countrey comparisons: And all for the most part which is contained in this Ecloge is drawne out of Theocritus his Thirsis, where he largelie writeth of the lyke love of Daphnis. length

passing: surpassing, notable; Volumnius his: Volumnius'; slideth: slips, deviateslargelie: in detail, at

\section{The Ecloge. Poeta alone.}

O Arethusa, graunt this labour be my last in deede,

A fewe songes vnto Gallo, but them let Lycoris reede,

Needes must I sing, to Gallo mine what man would songs deny?

So when thou ronnest under Sicane seas, where froth doth fry,

Let not that bytter Doris of the salt streame mingle make:

Beginne, the carefull loues of Gall' to sing let's vndertake.

Whiles that the flatt nos'd gotes dooe crop the tender sprigs and shouts,

We sing not vnto deafe men we, the woods sound all abouts.

full of care, sorrowful

What woods, what hils, what groues did keepe and hold you in perforce,

Ye Naiad' Nimphes, when Gall' in loue consumed as a corse?

?about us

For neyther dyd Parnassus mounte, nor Pindus tottering hyll,

Nor yet Aonia, Aganipp' make hinderaunce of your wyll.

The Bay trees dyd lament his case, the shrubs did him bemone,

And Menal' mount where pine trees grow, cold Lices rocks of stone

Both wept and wailde him, as he laye vnder a hyll alone.

The sheepe about him stand, of them we dooe vs not repent

Nor of thy cattell thee repent, O Poet excellent:

Adonis fayre by waterside doth sheepe and Oxen feede.

o.2Volumnius his freewoman] a woman released from slavery by her original master Volumnius. 0.7 Theocritus his Thirsis] Idyll I. 1 Arethusa] A fountain in Sicily: see 4-5n. This eclogue has classically associated Arethusa with pastoral. 2 Gallo] Lat. dative and ablative of Gallus, fitting the syntax here and in 3. Lycoris] 'Lycoris a verie faire and a wise woman, but a harlot, called by a counterfaite [poetic, fictional] name of cytheris whom Cornelius Gallus ardentlie loued.' [Fleming] In fact, she is called Lycoris here; Cytheris might have been her actual name. (See 'Argument'.) 4 Sicane] 'The adiectiue of Sicanus, of Sicani, people of spaine as some dooe suppose, so called because of the floud Sicoris, which runneth by them.' [Fleming] Actually, Sicanus means Sicilian, from the Sicani who settled there in ancient times. fry] seethe, foam (OED fry $\mathrm{v}^{1} 5 \mathrm{a}$ ). 4-5 A reminder not to mingle the Sicilian (pastoral) strain with the satirical. The nymph Arethusa was pursued in Arcadia by the river-god Alpheus, transported under the sea and transformed into a fountain near Syracuse in Sicily, her fresh water never mingling with the sea-water during her passage. $\quad 5$ Doris] 'The daughter of Oceanus and Tethis, heere by the figure metomonia [sic], it is taken for the sea whiche is salt and bitter.' [Fleming]. 7 shouts] shoots. 10 Naiad] 'The Nimphes or muses of springes, fountaines and flouds.' [Fleming]. 11 Parnassus] 'A hill in the countrey called Phocis.' [Fleming] Famously sacred to the Muses. Pindus] 'A hill in Thessalia.' [Fleming]. 12 Aonia, Aganipp[e]] 'Bothe wordes are referred to one meaning, for Aganippe is a fountaine made holie to the muses, and is called Hypocrene, it is also called the fountain Aonia. [Fleming] Actually, Aonia is a part of Boeotia where Mount Helicon is situated, with two separate springs, Aganippe and Hippocrene, at its foot. make hinderance of your will] Prevent you from satisfying your wish (to come to Gallus). 13 bay trees] laurels. shrubs] Lat.myricae (tamarisks). Cf. 8.2. 14 Menal' mount] Maenalus: see 55n. Lices] Lycaeus. 'A promontorie or stepe hill in Arcadia, dedicate or consecrate to Pan.' [Fleming] Pan's birthplace, though more celebrated for the worship of Zeus. 18 Adonis] 'The sonne of Cyniras and Mirrha, who was intierly loued of Ladie Venus, the same was a beutifull and well fauoured shepheard.' [Fleming] He was both hunter and shepherd. 
The shepheards came, the heardmen came, alack they made no speede, And from the woods, and winter oakes, came Menalc' fatt in deede. All dooe demaunde, this loue whence y'st? Apollo came to thee And sayde What Gallus art thou madd? Lycoris, all thy glee your only source of joy Through frost, and snow, and Castles rough, another haunteth shee. pursues, Siluanus came, about his hed a countrey gareland was,

The florishing fenell shakeing, and the lyllyes white which passe.

Pan of Arcadia God he came, and vnto vs appeard

With wallwoort berryes red as bloud, and vermelon besmeard.

And wyll there be no meane? sayth he, loue cares not for such things,

Deepe launceing loue with trickling teares, nor felds with watry springs cutting, piercing

Nor bees with Tetryfoll, nor gotes with greene leaues fylled be,

But he full sadde, yet shall you sing, Arcadians you, sayde he, sated, satisfied

These things vpon your hylls: in songs Th'arcadians skil know we.

If that your pype would whistle vp my loue, which boyles in brest,

My brused bones beleeue mee, $\mathrm{O}$, how sweetelye should they rest.

The keeper of your flocke I would you me appointed had,

Or orderer of your vines and grapes, in purple colour clad.

Sure whether Phillis, or Amintas, rageing loue me racke,

Or what soeuer furie else, What if Amyntas blacke? madness

(Blacke Violets bee, and Floures deluce that colour dooe not lacke.)

Among the Willowes and the Vines, in shade should lye with me,

Phillis should gather garlandes, and Amyntas sing should he.

Lycoris, heere be fountaines freshe, and heere be medowes softe,

Heere pleasaunt woods, my life I could spend with thee in this crofte.

Now frantique loue in armes of Mars, who strikes a bloody blow,

Among sharpe weapons keepeth me, and many a furious foe,

Thou from thy countrey straying farre, I would it were not soe,

The snowye Alpes and frosen Rhene without me all alone

(Ah flinty peece) behold it, oh, least the cold hurt fleshe and bone,

And least thy lytle tender feete the sharp yse cutte and pearse.

Ile goe, and songs which I haue made in Chalcide comly vearse

In Sicily shepheards oaten pype alofte I wyll rehearse. 'Tys certaine that in woods, where wilde beasts lurck in den and Caue,

I wyll abyde the rather, I, and all my loues ingraue

In tender trees: they shall spring vp, and you my loues shall growe.

Then wyl I view mount Menalus, where Nimphes walk to and froe,

Then wyll I hunt the bristled Bore, no colde wyll I refuse

Parthenian Woods to raunge about with Dogs with cryes and hues.

Now, as it seemes, through rocks I goe \& woods which Eccho sound,

[or pasture small field mad

Rhine Sicilian; high, aloud

19 shepherds ... heardmen] The Lat. mentions a shepherd and some swineherds. 20 winter oakes] The Lat. talks of acorns. Menalc'] Menalcas, presumably a swineherd, as in the Lat., he handles mast. fat] The Lat. has uvidus, wet: perhaps from picking mast in the woods, perhaps by soaking them in water. 21 Apollo] No doubt as god of poetry. 23 Castles] Lat. castra, here 'battle-camp': rare English use, $O E D$ last cit. 1483. $\quad 24$ Siluanus] 'The God of woods, forrests, groues, parckes, and such like places, besette and planted with trees.' [Fleming]. 28 meane] means, method: misrendering Lat. modus, here 'end'. cares not for] cares nothing for, does not heed. 30 Tetryfoll] an error for 'tree-trefoil' or 'tree-clover', Latin cytisus. See OED tetrifolie. $\mathbf{3 1}$ he] Gallus, who delivers the following speech. 33 whistle up] play the story of my love. 35-6 i.e., He wishes he had led a humble life among the other shepherds. 36 orderer] dresser, pruner. in purple colour clad] referring to the grapes. 37 Phillis, Amintas] possible loves had he lived humbly with the other shepherds. 39 Floures deluce] the lily, which of course is white. Curiously replaces the blueberry (vaccinia) in the Lat. $\mathbf{4 4}$ Mars] 'The god of battaile, he is called Mars qui maribus preest [he who leads men], because he aydeth and assisteth men in battaile: \&.' [Fleming]. 46 Thou ... farre] ablative absolute: 'While you are straying far'. straying] Transitive use $(O E D$ 2d) with 'Alps ... Rhine' as object. 48 flinty peece] ?hard stony stretch of road (cf. OED piece $\mathrm{n} 6 \mathrm{~b}$ ). behold] ?look out for, be careful of. $\quad 50$ Chalcide] Gallus modelled poems on those of Euphorion of Chalcis. (Chalcide, ?adjectival form, 'Chalcidian'). 53 (the second) I] either 'I' or 'aye'. 55 Menalus] 'A hyil in Arcadia, dedicated and made holie to Pan the god of musicke.' [Fleming] Cf. 14. 57 Parthenian] 'Parthenius a hill of Arcady, so called $\alpha \pi$ ó $\tau \omega v \pi \alpha \rho \theta \dot{\varepsilon} v \omega v$, a Virginibus, of chaste maidens and gentlewomen which vsed to hunt the Deere thereabouts.' [Fleming]. hues] shouts (OED hue $\left.\mathrm{n}^{2}\right)$. 
I lyft in Parthian bow of horne, Cydonian arrowes rounde To shoote, as though this practise were a plaster for my wound.

Nowe let that God in mens yll happes to waxe more gentle learne.

raise, fit

action misfortunes;

[grow, be

on

We looke one T'hamadriades, and on our sonnets stearne,

As much displeas'de: ye Woods geue back, geue place to passe againe:

We cannot chaunge him we one whitte, for all our toyle and paine.

Not if we should in chilling colde vp Hebrus ryuers swyll

Or beare in watery Winter time the snowe one Scithon hyll,

on

Nor yet if Aethiopia sheepe in Cancers smothering heate

We grase, when barks both drie and dye one elme trees tall and greate.

Loue ouercommeth euery thing, to loue lets leaue a seate.

allow a place, enthin

That thus your Poet chaunted hath, O Muses, 'tys inoughe,

Whiles sytting styll he baskets makes of rushe and bending boughe.

Pierides, you for Gallo' shall these sonnets larger make,

For Gall', whose loue each houre in me as much increse doth take

As dooth the alder greene shoote vp when spring time dooth awake.

Let's ryse, the shade is wont to bring to singers lytle joye,

The Juniper shade vnpleasaunnt is, shades dooe all fruites anoye,

Trudge home ye gotes, the euening coms, trudge, 'tys no time to toy.

10 Virgil Georgic II.458-542

Translated from the Latin by Abraham Cowley.

Appended to Cowley's essay 'Of Agriculture', along with three translations from Horace and one from Cowley's own Latin treatise on plants, all related to country life. First published among Cowley's Essays in his Works (1669).

Oh happy, (if his Happiness he knows)

The Country Swain, on whom kind Heav'n bestows

At home all Riches that wise Nature needs;

Whom the just Earth with easie plenty feeds.

'Tis true, no morning Tide of Clients comes,

And fills the painted Chanels of his rooms,

Adoring the rich Figures, as they pass,

In Tap'stry wrought, or cut in living Brass;

Nor is his Wool superfluously dy'd

With the dear Poyson of Assyrian pride:

Nor do Arabian Perfumes vainly spoil

The Native Use, and Sweetness of his Oyl.

In stead of these, his calm and harmless life

Free from th'alarms of fear, and storms of Strife,

Does with substant'al blessedness abound,

And the soft wings of Peace cover him round:

59 Parthian] 'Of the Parthians we have spoken before, in the arte of shooteing they excelled, and in that practise preuailed much against the Romaines in battayle, as the Romane historyes declare.' [Fleming]. of horne] common mistranslation of Latin cornu, actually meaning 'made of cornel wood'. See 61.13n. Cydonian] 'The adiectiue of Cydonia, a citie in Crete. ... and in this citie there growe reedes verie fytte for arrowes to bee made of.' [Fleming] The Cydonians were famous archers. $\quad 61$ that god] Love. $\quad \mathbf{6 2 - 3}$ Even the beautiful hamadryads (wood nymphs), and even songs, now displease me. 62 stearne] ?sad, gloomy (as they treat of unhappy love: cf. OED 6b), hence moving, emotive. 65 Hebrus] 'A floud in Thracia wherein the people called Cicones, bordering vppon the same floud cast Orpheus hed after they had slaine him.' [Fleming]. 66 Scithon] 'A hyll in 'Thracia full of snowe.' [Fleming] Actually a peninsula (Sithonia), in Macedonia rather than Thrace proper. $\mathbf{6 7}$ Aethiopia] 'A countrey in Africa, lying betwixt Arcadia and Ægipt, so called after the name of Æthiops, the sonne of Vulcanus, the sunne in that countrey hath a vehement and scortcheing heate.' [Fleming]. Cancer] The ruling constellation at the height of summer. $\mathbf{7 2}$ Pierides] the Muses. you ... make] 'You will make the most of them to Gallus, present them to Gallus as strongly as possible'. 77 euening] The Lat. has Hesperus, the evening star. 4 The Lat. adds proclus discordibus armis, 'far from the clash of arms'. 6 Chanels] river-beds or courses, continuing the metaphor in 'Tide' (5). 10 Poyson of Assyrian pride] purple dye supplied by merchants of Tyre in Syria (wrongly identified with Assyria). 14 fear ... and Strife] The original also talks of fraud. 16 No equivalent in the Lat. The following lines are a free, somewhat expanded rendering. 
Through artless Grots the murm'ring waters glide;

Thick Trees both against Heat and Cold provide,

From whence the Birds salute him; and his ground

With lowing Herds, and bleating Sheep does sound;

And all the Rivers, and the Forests nigh,

Both Food, and Game, and Exercise supply.

Here a well hard'ned active youth we see,

Taught the great Art of chearful Poverty.

Here, in this place alone, there still do shine

Some streaks of Love both humane and Divine;

From hence Astraea took her flight, and here

Still her last Foot-steps upon Earth appear.

'Tis true, the first desire which does controul

All the inferior wheels that move my Soul,

Is that the Muse me her high-Priest would make;

Into her holyest Scenes of Myst'ry take,

And open there to my minds purged eye

purified, cleansed

Those wonders which to Sense the Gods deny;

How in the Moon such change of shapes is found:

The Moon, the changing worlds eternal bound.

What shakes the solid Earth, what strong disease

Dares trouble the firm Centre's antient ease;

What makes the Sea retreat, and what advance:

Varieties too regular for chance.

What drives the Chariot on of Winters light,

And stops the lazy Waggon of the night.

But if my dull and frozen Blood deny

To send forth the Sp'rits that raise a Soul so high,

In the next place, let Woods and Rivers be

My quiet, though unglorious destiny.

In Life's cool vale let my low Scene be laid;

Cover me, Gods, with Tempe's thickest shade.

Happy the man, I grant, thrice happy he

Who can through gross effects their causes see:

Whose courage from the deeps of knowledg springs,

in second place, as the next best alternative

Nor vainly fears inevitable things;

But does his walk of virtue calmly go,

Through all th' allarms of Death and Hell below.

Happy! but next such Conqu'rors, happy they,

Whose humble Life lies not in fortunes way.

They, unconcern'd from their safe distant seat,

Behold the Rods and Scepters of the great.

The quarrels of the mighty without fear,

And the descent of foreign Troops they hear.

Nor can ev'n Rome their steddy course misguide,

With all the lustre of her per'shing Pride.

Them never yet did strife or av'rice draw,

Into the noisy Markets of the Law,

The Camps of Gowned War, nor do they live

By rules or forms that many mad men give.

outward or material appearances

17 artless Grots] natural caves, as opposed to artificial landscaped ones in vogue since mid-16c. The original only has speluncae, caves. $\mathbf{2 6}$ humane] combining the senses of modern 'human' and 'humane'. 27 Astraea] goddess of justice. Left the world on its decline at the end of the Golden Age. 29-30 first desire .... inferior wheels] Image of the primum mobile (first mover), the outermost sphere in the Ptolemaic scheme of the universe, which imparts motion to all the other spheres. The image, and the note of religious mystery in $32-4$, added by the translator. 36 changing ... bound] The moon is the outer limit of the sublunary world, subject to change; beyond it is the eternal celestial world. 40 Varieties ... chance] i.e., guided by providence. Not in original. $4 \mathbf{1 - 2}$ What drives ... the night] i.e. Why days are short in winter and long in summer. Referring to the constellations of the Chariot and the Wagon (Wain), part of the Great Bear. 48 Tempe] a beautiful valley in Thessaly. This reference replaces a long string of allusions in the original. 51 courage] purpose, spirit (OED $2,3)$. $\quad 55$ next $]$ The original presents the two as equal. such Conqu'rors] the above philosophers, who have conquered fate. 56 lies not in fortunes way] is not affected by changes of fortune. 57- 80 depart considerably from the original. 
Duty for Nature's Bounty they repay,

And her sole Laws religiously obey.

Some with bold labor plough the faithless main,

Some rougher storms in Princes Courts sustain.

Some swell up their sleight Sails with pop'lar fame,

sail the seas;

[treacherous, dangerous

Charm'd with the foolish whistlings of a Name.

Some their vain wealth to earth again commit;

With endless cares some brooding o'r it sit.

Country and Friends are by some Wretches sold,

To lie on Tyrian Beds, and drink in Gold;

No price too high for profit can be shown;

Not Brothers blood, nor hazards of their own.

Around the World in search of it they roam,

It makes ev'n their Antipodes their home;

Mean while, the prudent Husbandman is found,

In mutual duties striving with his ground,

And half the year he care of that does take,

That half the year grateful returns does make.

Each fertile month does some new gifts present,

And with new work his industry content.

This, the young Lamb, that, the soft Fleece doth yield,

This, loads with Hay, and that, with Corn, the Field:

All sorts of Fruit crown the rich Autumns Pride:

And on a swelling Hill's warm stony side,

The pow'rful Princely Purple of the Vine,

Twice dy'd with the redoubled Sun, does shine.

In th'Evening to a fair ensuing day,

With joy he sees his Flocks and Kids to play;

And loaded Kyne about his Cottage stand,

Inviting with known sound the Milkers hand;

And when from wholesom labor he doth come,

With wishes to be there, and wish't for home,

He meets at dore the softest humane blisses,

His chast Wives welcom, and dear Childrens kisses.

When any Rural Holy dayes invite

His Genius forth to innocent delight,

On Earths fair bed beneath some sacred shade,

Amidst his equal friends carelessly laid,

He sings thee Bacchus Patron of the Vine,

The Beechen Bowl fomes with a floud of Wine,

Not to the loss of reason or of strength:

To active games and manly sport at length,

Their mirth ascends, and with fill'd veins they see,

Who can the best at better tryals be.

Such was the Life the prudent Sabins chose,

From such the old Hetrurian virtue rose.

Such, Remus and the God his Brother led,

From such firm footing Rome grew the World's head.

Such was the Life that ev'n till now does raise

73 to earth again commit] (a) reduce a rich city to dust (so 505 in Lat.) (b) bury wealth in the soil (so 507 in Lat.). 76 Tyrian] (a) dyed in Tyrian purple (see 1on); (b) ?in the luxurious style associated with Tyre. in Gold] out of gold vessels. 80 their Antipodes their home] The original talks of exiles. 82 mutual duties] i.e. Soil and husbandman supplement each other's efforts. 93 to a fair ensuing day] preceding another fair day. 96 known sound] the call of cattle needing to be milked. $\mathbf{9 8}$ With wishes ... for home] i.e., He wishes to be home, and his family also wants him to return. home] adverbially: at home. 100 The original refers only to children. 101 Holy dayes] The spelling implies the double sense. $\quad 102$ Genius] temperament, bent of mind (OED 3). $\quad 104$ equal] ?of the same age; ?equal in rank - i.e. the community is not divided by rank or class. 111 Sabins] Sabines, an ancient race of central Italy, renowned for their hardy, frugal life and piety. $\quad \mathbf{1 1 2 - 4}$ The Etrurian and Roman civilizations were both highly urbanized. Virgil might mean that rural virtues lie behind their civic and imperial rise. 112 Hetrurian] Etrurian: of an ancient race based in central Italy. 113 the God his Brother] Romulus, legendary founder of Rome. Romulus and Remus were brought up by shepherds. 'The God' is Cowley's addition. Romulus was worshipped as guardian deity of Rome under the name Quirinus. 
The honor of poor Saturns golden dayes:

Before Men born of Earth and buried there,

Let in the Sea their mortal fate to share.

Before new wayes of perishing were sought,

Before those Beasts which humane life sustain,

By Men, unless to the Gods use, were slain.

11 Virgil Georgic III. 295-9, 322-38, 404-7, 440 ff.

Translated from the Latin by Richard Robinson.

First published in Robinson's A Proceeding in the Harmonie of King Dauids Harpe (1591), a partial English translation of Victorinus Strigelius' Lat. commentary on the Psalms (1563, though Robinson cites the 1576 edition on his title-page). Strigelius cites some parts of Virgil's Georgic III, on the care of livestock, in the context of Psalm 23. The Lat. version used by Robinson differs substantially from the standard modern text, especially in the last two sections, which are virtually abridgements.

He suffers in warme Cottages, his sheepe to take their meat:

arranges, allows food

Till summer season fresh and greene, returned be with heat.

And store of straw and ferne he layes, by handfuls on harde ground

Least tender beast by cold or scurffe, or gowte doe get deaths wounde.

In pleasant Summer but when as the East winds blow indeed:

He sends his flocke toth' thickets, and fatte pastures there to feede.

Whilst morning springs, and whilst the gras doth florish and reioyce:

The dewe on tender herbe distils to beasts most happyest choyse.

Before the fourth howre of the day, when drought they find and heate:

And that the Grashoppers doe burst through shrubbes with clamors great:

He bids his flocks goe to the ponds, or pooles that offer first,

are closest to hand

Or running water of the brookes, by drinke to quench theyr thyrst.

But in the hottest time of day, some shadowe vale seeks he:

shadowy, shady

Or Oke of auncient strength, which called is Ioues tree,

Whose boughes spread farre, or place he findes, where sacred shadow staies:

Within darke wood, of willowes full, for all the liuelong daies.

And then againe he watereth them, and them to feede he plyes:

urges, drives

Till Sunne be set, and euening cold the ayre to temper hyes.

And till the lightsome moystning Moone

moderate, cool; hastens radiant, giving light

116 poor] ?frugal. Saturns golden dayes] Saturn's rule (as king rather than god) over Latium was identified with the Golden Age. Cowley compresses the original at this point. 118 Let in the Sea] i.e., began to sail the ocean. There was no navigation in the Golden Age. Cowley takes this detail from Virgil IV.38-9. 120 Death on Anvils wrought] referring to the forging of sword-blades. 121-2 unless ... slain] except for sacrifice. Not in original. 9ff. In the original, the poet speaks in the first person, directly instructing the reader. 19-20 burst through shrubbes] In the original, it is clearly the sound, not the insects themselves, that rend the shrubs. 31 willowes] Lat. ilicibus, holm-oaks. 37 moystning] causing dew by its cooling effect. 
doe shine through darksome wood:

And till the Halcyon byrds by shore and Goldfinch sing a good.

The Sheepheard brings vp Spartane whelpes swift, and the Mastiue fell:

That by these Keepers he from folds, the night theefe may expell, guards

And eke restraine th'assaults of Wolues. the Sheepheard thus discreete,

The causes of Sheepes sicknesses and signes dooth marke and seeke,

By helping hand to cure the wound of each diseased beast:

And last of all beares in his armes, the Ewes with young encreast.

Or else he succours sillie Lambes, And beares each beast about

The pleasant springs, to quench theyr thyrst, And feede deuoide of doubt.

free from fear

\section{Horace Epode II}

Translated from the Latin by Sir Richard Fanshawe.

First published in Fanshawe's Selected Parts of Horace, Prince of Lyricks (1652). Follows the original fairly closely (even to the satirical close). The idiosyncratic italicizing of words in the original has been retained below.

He comprehends in this Ode divers Praises of a Countrey life: Commending it chiefly from the Tranquillity and Frugality thereof.

Happy is He, that free from Mental Toil (Like the old Mortals) ploughs his Native soil

With his own Oxen; out of debt; Nor leads A Soldiers life, still in Alarms; nor dreads

Th'enraged Sea; and flies at any Rate From Law-Suites, and the proud Porch of the Great.

always What does he then? He, lofty Poplars joyns Unto adult and marriageable Vines;

And the Wild branches with his Sickle lopt, Doth better children in their rooms adopt:

Or in a hollow Valley, from above, Beholds his lowing herds securely rove:

Or, his best Honey (which he means to keep) Puts in clean pots: or sheares his tender sheep.

Or, when plump Autumn shews his bending head With mellow Apples beautifully red,

With what a Gust his grafted Pears he pulls; And Grapes, the poor mans Purple! Whence he culs at any cost, by any means

The fairest, for thee Priap; and for thee Sylvanus, Guardian of his Husbandrie.

Under an aged Oake he loves to pass

39 Halcyon] a legendary bird, supposed to nest on the sea waves in calm weather - though (unlike here) at the winter solstice. 41-5 Compresses the original. 49-52 Greatly condenses the original. 53-6 Does not correspond to anything in the original. 53 sillie] weak, frail $\left(O E D_{2}\right)$. 0.1 comprehends] includes $(O E D$ 8). $\quad 1$ Mental Toil] Lat. negotiis, business cares. 2 old Mortals] people of the Golden Age. Lat. prisca gens, the earliest race of men. 4 Alarms] attacks, assaults (OED 9). 4-5 dreads Thenraged sea] There was no navigation in the Golden Age. 7-8 Trails vines on poplar trees. 9-10 A reference to the grafting of vines. 14 tender] (a) gentle, mild (b) delicate. 15 bending] weighed down with fruit. In the Lat., Autumn raises his head. 18 poor man's Purple] In ancient Rome, only patricians could wear clothes dyed purple. 19 Priap] Priapus, god of gardens, vineyards and trees; son of Dionysus the wine-god. 20 Sylvanus] a rural god of woods and groves. Guardian of his Husbandrie] protector of his estate. Sylvanus is also guardian of boundaries. 21 Oake] Lat. ilice, holm-oak. 
The Heates; or lolling on the matted grass.

Between deep Bankes a River rowls the while;

The Birds, they prattle, to the Trees that smile;

A purling Brook runs chiding all the way:

Which gentle slumbers to His eyes convey.

But when rough Winter thundring coms, to throw

The treasures open of the Rain and Snow:

Eyther with dogs behinde him and before

He drives into his toiles the tusked Boare:

nets

Or spreads his thinner Nets beside some Bush,

An Ambuscado for the greedy Thrush:

And (dear delights) inveigles in his snare

The Travailer-Woodcock, and the Coward-Hare.

Who, at these sports, evades not all those darts,

With which loos love assaults our vacant hearts?

But if a vertuous Wife, that bears sweet fruit

Yearly, to one; and guides the house to boot:

(Such as the Sabine, or the Sun-burnt Froe

Of him, that was chose Consul from the Plough)

Build of old Logs, 'gainst her good man comes home

Weary, a Fire as high as half the room;

And shutting in knit hurdles the glad Beasts,

With her own hand unlade their swagging Breasts;

And drawing this years Wine, from the sweet But,

Dainties unbought upon the Table put:

Your Lucrine Oysters cannot please me more,

Nor a fresh Sturgion frighted to Our shore,

Nor any rarer Fish. No Pheasant Hen,

Or Quayle, go down my Throat more sav'ry; Then

An Olive, gather'd from the fattest Bough;

Coole Endive; wholsome Mallowes; or allow

A Lamb upon some mighty Festivall;

Or Kid, from the Wolfe's jawes; That's worth them all.

Amid'st these Feasts, how sweet 'tis, to behold

The well-fed Sheep run wadling to their Fold!

To see the wearied Oxe come trayling back

Th'inverted Plough upon his drooping neck!

And the Plough-Boyes (the swarm that makes us thrive)

60

Surround the shining Hearth, content and blythe!

All this the Us'rer AlPHEUs having sed,

Resolv'd (what else) a Countrey Life to lead;

At Michaelmas calls all his Moneys in:

But at Our Lady puts them out agen.

22 Heates] summer $\left(\mathrm{OED}_{3} \mathrm{~b}\right) . \quad \mathbf{3 1}$ thinner] wide-meshed. $\mathbf{3 2}$ greedy] i.e., attracted by the bait. $\mathbf{3 4}$ Travailer] traveller, migratory. The Lat. names the crane. The birds reside in Mediterranean countries in the winter. Coward-Hare] (a) Coward (Cuwert), 'an old appellation of the hare' (OED 2a) (b) fearful, timid (Lat. pavidus). 38 to one] begotten by a single man, her husband. 39 Sabine] reputed a hardy and frugal race. Sun-burnt] from hard outdoor labour. Froe] 'frau', woman or lady (see OED frow 2). 40 him ... Plough] Cinnatus, called from the plough (on his own farm: he was a patrician and former consul) to serve as dictator of Rome when the city was threatened by invasion. The Lat. mentions Apulian wives in a general way: Apulia in S-E Italy was a thriving agricultural and pastoral region. 41 'gainst ... home] anticipating her husband's return. 46 unbought] i.e. produced on the farm. $\quad 47$ The Lucrine Lake in Campania was famous for oysters. 48 frighted] (a) frightened, i.e., driven (b) ?freighted, carried. 47-50 The Lat. mentions the parrot-fish, turbot, guinea-fowl and pheasant. 53 Festivall] The Lat. specifies the feast of Terminus, god of boundaries. 59 swarm ... thrive] The labour force on which our prosperity depends. The original, referring to slaves, is less appreciative. $\quad 63$ Michaelmas] 29 September, a 'quarter day' when payments fall due. 64 Our Lady] Our Lady's Day, 25 March, another quarter day. 
13 ON THE Rustic Life

Translated from the Latin by John Ashmore.

First published in Ashmore's Certain Selected Odes of Horace ... whereunto are added ...Sundry New Epigrammes. Anagramms. Epitaphes (1621). The original was wrongly attributed to Martial and included (Bk IV.9o) in the definitive edition of Martial by Hadrianus Junius (1568).

Asks thou, ith'Country how I spend the Day?

Early, each morning, to the gods I pray.

My Servants then, and Fields to see I goe,

And every one appoint what worke to doe.

This done, I read, and Vows to Phoebus make

To ease me, and my drouping Muse t'awake.

My Body then I rub and ore-anoynt,

And easily stretch-out each Lim and Ioynt,

Reioycing in my mind, secure and free

From debt, and the black books of Vsurie.

I dine, I drink, I sing, I wash, I play,

I sup; then, from my Rest not long do stay:

Yet, till my Lampe a little Oyle doe spend,

Som time I nightly to the Muses lend.

\section{Boethius The Consolation of Philosophy Book in Poem 5 Translated from the Latin by Queen Elizabeth I.}

From the Queen's autograph manuscript in the Public Record Office at Kew. The translation appears to date from c.1593. As Leicester Bradner points out, the Renaissance text of Boethius, used by Elizabeth, often differs from standard modern editions. This accounts for some apparent mistranslations noted by an earlier editor, Caroline Pemberton.

Happy to muche the formar Age With faithful fild Content

Not Lost by sluggy Lust, that wontz the Long fasts

to Louse by son got Acorne, that knew not baccus giftz

With molten hony mixed Nor Serike shining flise

engage, stipulate prayers

exercise, limber up (the mind) massage all over with oil in a relaxed way, to ease the muscles

With tirius venom die. Sound slipes Gave the grasse,

thir drink the running streme, Shades gave the hiest pine.

The depth of Sea they fadomd not, Nor Wares Chosen from far

Made stranger find new shores. Than wer Navies Stil

filled: full, total sluggish, idle; luxury loose, break; soon-got, ready to hand

Nor bloudshed by Cruel hate had fearful weapons staned.

What first fury to foes shuld any armes rayse,

Whan Cruel woundz he Saw and no Reward for bloude?

5 Vows to Phoebus make] i.e. read poetry, evidently to inspire his own (6). Phoebus or Apollo is god of poetry. 10 black books] revenue records of the exchequer; hence any books of accounts, but with an obvious connotation of evil. The poet is neither a borrower nor a lender, hence enjoys peace of mind. 11 wash] swim, bathe $(O E D 6 \mathrm{c})$. 2 faithful fild Content] secure and total content. Bradner reads fild as 'field', i.e., 'Content with his faithful (trusty, reliable) field'. 6-7 i.e. Honey was not adulterated with wine. 8 Serike shining flise] silk. Serica, identifiable with China, was conceived by Europeans as the source of silk. 9 tirius venom die] purple dye vended by the merchants of Tyre. Cf. Virgil, Georg. II.465. 11 the grasse] i.e. to lie on. 14-15 Nor did people visit foreign shores to obtain exotic wares. 16 stil] quiet, idle. There was no navigation in the Golden Age (Virgil IV.38-9; Ovid, Met. I.94-6.). Implying Lat. classes, navy, for the now usual classica, (battle-)trumpet.

18 weapons] Implying Lat. arma for the now usual arva, fields. 19-22 Who will fight from rage against the enemies, when he sees the cruel wounds and the lack of reward for injuries suffered? 21 he] presumably a soldier. 
Wold God agane Our formar time to wonted maners fel,

But Gridy getting Loue burnes Sorar than Etna with her flames.

$\mathrm{O}$ who the first man was of hiden Gold the waight

Or Gemmes that willing lurkt The deare danger digd?

\section{Mantuan Eclogue iv.1-75}

Translated from the Latin by George Turberville.

First published in The Eglogs of the Poet B. Mantuan Carmelitan, Turned into English Verse ... by George Turbervile Gent. (1567). The story below prefaces the poem's chief content, a tirade against women. The translation follows the original quite closely, but in a wordy and expansive way, eliminating the quick epigrammatic quality of some of the dialogue.

The. iiij. Egloge entituled Alphvs.

Alphus. Ianus.

Alphus. More leane (Oh Ianus) seemes thy Goate than ere he was of yore:

For lusty he his hornes ere this into the Welkin bore.

raised to the sky

But grouelyng now on ground he lies with lyther lolling eares,

He smelles to grasse, to touch the herbs at length of lips he feares.

Ianus. He droupes, and of his drouping doth a pleasant iest arise:

Which loke how oft I mind, doth make me laugh with smyling eyes.

And yet it is not spread abroade, but when the brute is blowne,

And that through euery countrey is this pleasant story knowne:

Then all the world wil laugh therat.

Alphus. (O Ianus) thou ere this

Werte wont to tell a mery iest in merriest wise ywis,

And with a sweete delighting voyce: Wherfore I pray thee now

Declare me why the Goat doth droupe, and tell how fell it how?

Ianus. God is my iudge twas neuer faynde of me, but done in dede,

And lately too: But shall I tell the tale withouten meede?

And chatte for nought and wast my wind? Nay, what wilt giue to mee?

What shall I haue for telling of this iest beglarde with glee?

Alphus. O friende, when so the Nightingale (that Philomela hight)

Hath built hir nest, and sitts a broode I will thy trauaile quight.

Ianus. Who so doth make such rash behests accustomed, practised I know: a space-filler

think of, recall

news has spread; brute: bruit, noise

how it befell

reward, payment

brooding on her eggs requite, repay

23-4 Would God that the earlier age again became our accustomed way of life! 27-30 Oh, who was the man who first dug for the costly danger of a mass of hidden gold or for gems that wished to remain concealed (i.e., were better left underground). 7-8 He smells the grass but is afraid to taste it. to] ?error for the. 25-6 twas neuer ... in dede] I have not made this up: it really happened. 32 beglarde] beglair'd, painted, bright (cf. OED glair v). 33-6 i.e. He will rob the nest and present the fledglings to Janus. 
by dayly proufe we see

Performes not pacted promise, but

compacted, agreed his touch is wont to flee.

Alphus. Nay, who so lends such light beliefe distrust doth beare in breast.

But for you shall be sure that I nill play the guilefull guest,

will not

Take here a pledge of promise made and bargaine earst by mee:

Take here (I say) from out my case two Flights that farre will flee.

Ianus. I will begyn: O sacred Nimphs Parnasides I pray

Do moue your iawes, and guide my tong that I may well display

My welbeloued Goates mishap And misadventure fell:

And graunt that Alphus Nightingale may hatche hir yonglings well

That I may haue that he behight

Narratio for this good tale I tell.

With pennie I a Lad did hire my little flocke to keepe:

first, before you start

feathered arrows

I gaue him charge and ouersight of all my fleezie sheepe.

what he promised

money, wages

He kepte both Kids and females eke, and Ramme goates too with care:

And ouerlook'd my flocke that I the Stripling could not spare.

Till time at last by Fortune he a prettie Mayden sawe,

(That hither came of purpose bent at water place to drawe

Such water as suffisde her tourne) and liked hir so well

As he (good Boy) by feature of hir face to fansie fell.

And from that time and dolefull day so dumpish he became,

As lesse regarde he had of sheepe, (the greater was his shame).

Lesse forced he since that the foldes and quight bereft of witte

He seemde: So deepe within his brest the Virgins shape did sitte.

When hee on bed to quiet nap his weary limmes did lay:

Where sleeping he or waking were twas very harde to say.

For when he was wide waking he such frantike coyle would keepe,

As though (his reason quite bereft) his wittes were gone to sleepe.

So dreaming was this Boy to sight, so lumpishe wore the Lad:

(a) stupid, sluggish (b) melancholy

40 touch] trial, proof (of his promise): $O E D 7 . \quad$ 41-2 He who values a promise so lightly is (a) ?of a naturally suspicious character (b) ?himself not trustworthy. 49-54 Either deliberate mock-heroic, or simply inept phrasing. $\quad 50$ Parnasides] dwellers on Parnassus, the Muses. 51 your] ?error for my. 65-6 I ... spare] He became indispensable to me. 71 Such water... tourne] As much water as she needed. May imply that her real 'turn' was to ensnare the shepherd boy. $\quad 79$ He sheared his sheep less often. (force, to shear: OED force $\mathrm{v}^{2}$; folds, sheep $\left(O E D\right.$ fold $\left.\mathrm{n}^{2} 1 \mathrm{c}\right)$. 
In sort, that gazers on surmisde that he no senses had.

This Boy bent to refresh (I say) his ouertyred mynde

With sportyng play, about the hornes with twig this Goate did bynde

Among the thickest of the briers and bushy Laundes belowe:

And so to passe away the time away the Boy dyd goe.

(And now foure days are past and gone) thus hee the Goate did tie:

The strongnesse of the Wyth and hardnesse of the Hornes to trie.

glades

Meanewhile the woods he went about and raungde the bushes rounde,

To see where that within the place mought any birds be founde.

The Mayde resorted to his thought and vndercrept his heart:

The comely countnance of the Trull could neuer thence depart,

Nor beautie of hir bourly breast his musyng mynde forgoe,

The parts not to be namde he rollde within his bulke belowe.

Meanewhile the Sunne had lodgde his light, that sielly sotted Mome

Unmyndfull of his hamperde beast afielde, came late to home.

Amid the night he callde to minde that foolishe fact of his:

And thinking to go loose the Goate in all the hast he rise.

And whilst with fearfull foote he pac'de through Dampes as darke as Hell,

Where lay much chaffe and rotten straw, into a Dyke he fell:

A place of purpose made to take the sauage Beasts by night,

A hollow vault and dungeon deepe to steepe for any wight

Once beyng in to clamber vp. Thus was the Goate by him

Fast bound with twigs, the Page in pit ycaught and dungeon dim.

No Shepheard kept the beasts as then, twas well neere three a clocke:

I musde, and went my selfe about and numbred all the flocke.

I miss'd the Goate, and maruelde much what of the beast became,

I sought about the fields: at last I calde the Boy by name.

(I tell but truth) I stoode in feare least he by Magike meane and Goate dispatched cleane.

93 in sort that] (a) in such a way that (OED sort $\left.\mathrm{n}^{2} 21 \mathrm{f}\right)$; (b) ?in disposition, character (OED sort $\left.\mathrm{n}^{2} 2\right)$. 118-19 bulke] any part of the thorax or trunk, including both the heart or breast and the belly. Might mean he was physically aroused at the thought of the girl's private parts, or simply that he kept thinking about them. 139 No shepherd was out with his flock so late. 
For Hags and Witches by report are caught amids the night

Much like, and far to Banquets borne quite out of cry and sight.

very likely - i.e., often beyond call

This dreading, I to Pasture grounde did bring my sheepe at last

To feede their fills, and whilst that I did wander all agast

In irkesome shades and ugglie nookes, and entred in the Groue:

(a) frightened (of the forest at night) (b) worried loathly, inhospitable

I hearde a farre the braying of my Goate, and how he stroue

With punching hornes and pushyng pate against the Wyth a good

I plainly sawe, and how he bette the Bushe gainst which he stoode.

This gastfull thing affrighted me, and monstrous sight to viewe

Vnlooked for. But when at length My sielly Beast I knew

vigorously, in full earnest past tense of 'beat'

And bolder wore, I went me in

grew, became among the brakes in hast:

With hooke I hewde the brembles downe and bushy briers at last.

As late in euening home I hide, all rounde about the fielde

A girnyng route of grinning folkes by fortune I behelde.

?shepherd's crook ?pruning-hook

hied, went

laughing crowd

Approching neerer to the preasse mee eche began to greete

As soone's they knew what man I was, and friendly did entreate.

Lo heere (quod they) O Ianus is a little Lad of thine

Tane vp a Woulfe his denne of late a deepe and daungerous Myne.

He wandring late about the Dounes did happen (to his payne)

Upon this caue, but now both Goate and he be founde agayne.

The Goate that had this cruell hap as yet vnlusty is:

But yet the foolish Boy of both most frantike is ywis.

The Virgin hearyng that the Lad did loue hir passyng well:

Eftsoone as proude as Pecocke wore and with disdayne did swell.

And makyng wise shee had not wist the cares he did indure,

Pretended honest lyfe the more the striplyng to allure.

taken up, landed in; wolfs

And to increase hir beautie more shee deckes both face and breast

In finest wise, and in hir gate hir lookes to ground shee keast.

Thus Foxelike shee with simple shewe and seemyng to the eyes,

of the two more crazed; I know, I think: a space-filler

soon after, quickly; grew pretending, acting as though; known affected modesty sorrows
modesty

In double breast and subtill heart hir craftie meaning plyes.

153 Banquets] 'Witches' Banquets' or gatherings, passing into the full-scale satanic 'Witches' Sabbath'. 182 entreate] ?talk, address: see $O E D$ 4, $5 . \quad 185$ Woulfe his denne] Earlier said to be a man-made animal trap. 192 vnlusty] weak. 
These are the tricks that women vse, this is the sleightfull ginne:

These are the cruell weapons that the myndes of men do winne.

Thus hoping he his Gallant girle to conquere at the last,

His wages scornde, and plide his loue, and follows hir in hast.

Wherfore now leauing Cart and plough And Oxen all alone,

To Shepheards toyle I will retourne. Frayle youth (the more the mone)

Is vassall to this furie fell and to this folly thrall:

It wanders rounde about this coast, and ouerturneth all.

\section{Mantuan Eclogue Vi.54-105}

Translated from the Latin by Alexander Barclay.

Part of Barclay's Eclogue V (237-396). Spoken by the shepherd Amintas in dialogue with Faustus. Barclay departs considerably from Mantuan's original at many points: see notes. First published c.1518-21, then as the fifth and last of Certayne Egloges appended to Barclay's trans. of Sebastian Brandt's The Ship of Fools (1570). The latter text is followed here. In some cases, the median or final $e$ seems functional, adding a necessary extra syllable in scansion. Punctuation modified in places, especially by replacing commas with full stops.

This great difference and first diuersitie

Betwene rurall men and them of the citie,

Began in this wise as Cornix to me tolde,

Whiche well coulde common of many matters olde.

First when the worlde was founded and create,

create: created

And Adam and Eue were set in their estate,

Our Lorde conioyned them both as man and wife,

To liue in concorde the season of their life,

And them commaunded mankinde to multiply,

By generation to get them progeny.

procreation

They both obeyed this swete commaundement

With faythfull heartes and labour diligent,

But would to Iesu they had bene wise and ware

From that fatall fruit which kindled all their care.

careful

But to my purpose: first Eue had children two,

A sonne and a daughter, our Lorde disposed so,

And so yere by yere two twins she brought,

When man assisteth God worketh not for nought.

By suche maner these two did them apply,

The worlde to fulfill, encrease and multiply.

At the laste our Lord at ende of fiftene yere

To Eue our mother did on a time appeare,

And in what maner nowe heare me Faustus:

Adam on the fielde foorth with his wethers was,

His flocke then he fed without all dread and feare,

Then were no wowers him nor his wife to deare,

He was not troubled that time with ielousie,

fill, populate

started; worry, woe

(a) wished (b) arranged

wooers; vex, annoy in that age

215 his Gallant girle] Named at this point in the original as Galatea. 217 His wages scornde] laid aside his living, stopped working. 222 Frayle youth] Prob. referring to young people in general. 223 is subject to this dreadful madness, i.e. love. $\quad 3$ Cornix] In Mantuan the narrator is Fulica and the listener Cornix. The shepherd who told Fulica this tale was Amyntas, the narrator in Barclay. 4 common] commune, talk (OED 6). 6-10 Adam and Eue] Lat. has muliere marem ... iungens, man and wife, later identified with Adam and Eve, and specifically says God taught them how to produce children. $8 \mathbf{8}$ season] ?adulthood, time of sexual maturity (OED 6). $\mathbf{1 8}$ When man co-operates, God's work is not in vain. The 1518 text is more orthodox: 'When God assisteth, man worketh not for nought'. 25-34 i.e. Adam could go out with his flocks without fear, as there were no other men to cuckold him in his absence. 
Then was no body to do that villany,

No horned kiddes were liuing at that time,

Long after this began this cursed crime.

Then was no cucko betwene the east and west

To lay wrong egges within a straunge nest,

Then none suspected the liuing of his wife,

Wedlocke was quiet and pleasaunt without strife.

But after when people began to multiply

Then fyrst was kindled the flame of ielousy,

For that man committeth sore dredeth he againe,

Fraude feareth falsehode, suspecting oft in vayne.

A thefe suspecteth all men of felony,

Breakers of wedlocke be full of ielousy,

And therfore all suche as with the sworde do strike

Feare to be serued with the scaberd like.

Thus while that Adam was pitching of his folde

Eve was at home and sat on the thresholde,

With all hir babes and children hir about,

Eyther on her lappe within or els without.

Nowe had she pleasour them colling and bassing,

And eft was she busy them lousing and kembing,

And busy with butter for to annoynt their necke,

Sometime she mused them pleasauntly to decke.

In the meane time while she was occupied,

Our Lorde drawing nere she sodenly espied.

Anone she blushed, reuoluing in her minde

That if our Lorde there should all those babes finde

So soone engendred, suppose he nedes must

That it was token of to great carnall lust;

And all ashamed as fast as euer she might

She hasted and hid some of them out of sight;

Some vnder hay, some vnder strawe and chaffe;

Some in the chimney, some in a tubbe of draffe;

But suche as were fayre and of their stature right

As wise and subtill reserued she in sight.

Anone came our Lorde vnto the woman nere,

And hir saluted with swete and smiling chere,

And saide: $\mathrm{O}$ woman let me thy children see;

I come to promote eche after his degree.

First was the woman amased nere for drede;

At laste she commaunded the eldest to procede,

And gaue them comfort to haue audacitie,

Though they were bolder and doubted lesse than she.

God on them smiled, and them comforted so

As we with whelpes and birdes vse to do,

And then at the laste to the moste olde of all

He saide: haue thou scepter of rowme imperiall,

Thou art the eldest, thou shalt haue most honour;

Justice requireth that thou be Emperour.

Then to the seconde he saide: it is seming

That thou be haunced to the honour of a king.

hugging and kissing

delousing and combing their hair

thought about dressing them prettily

anon, at once

alien, not one's own

manner of life, conduct

falsely, unwarrantedly

planting stakes for his sheepfold

she being wise and astute

And vnto the thirde he gaue suche dignitie,

To gide an army and noble duke to be,

And saide: haue thou here harde yron and armour,

Be thou in battayle a head and governour.

And so foorth to other as they were in degree,

bewildered, overcome

strength, support; boldness

feared

petted, soothed

puppies

Rome

enhanced, raised

29 horned kiddes] Horns were the traditional attribute of cuckoldry. kiddes] suggests even young and virile men might be cuckolded. (Lat. hirci, he-goats.) $\mathbf{3 1}$ betwene the east and west] anywhere on earth. $\quad 37 \mathrm{~A}$ man fears others may do him the same wrong he has himself committed - i.e., adulterous men are most jealous (cf. 40). $\quad 42$ scaberd] i.e. the wrong end of their own misdoings. Obvious phallic implication. 51-100 A much more lively and detailed account than in the original. $\mathbf{6 0}$ draffe] refuse, dregs, especially pigswill or refuse of malt after brewing. $\quad \mathbf{8 3} \mathbf{~ o t h e r ] ~ P l u r a l ~ f o r m ~}$ without $s$ then common. 
Eche he promoted to worthy dignitie.

Some made he Earles, some lordes, some barons,

Some squires, some knightes, some hardy champions,

valiant

And then brought he foorth the cepter and the crowne,

The sworde, the pollax, the helme and haberiowne,

The streamer, standard, the ghetton and the mace,

90 The speare and the shielde, nowe Eue had great solace.

He gaue them armour, and taught them policy

All thing to gouerne concerning chiualry.

Then made he iudges, maiors and gouernours,

Merchauntes, shiriffes and other protectours,

Aldermen, burgesses, and other in degree,

After the custome of court and of citie.

Thus all the children then being in presence,

He set in honour and rowme of excellence,

Oft time reuoluing and turning in his minde

100 The caduke honours belonging to mankinde.

post, office

In the meane season Eue very ioyfull was

That all these matters were brought so well to passe,

Then flewe she in haste for to haue pleasour more,

And them presented whom she had hid before,

And unrequired presenting them saide she,

O Lorde these also my very children be,

protectours: members of the ruling class

joy, satisfaction

These be the fruite also of my wome,

Hid for shamefastnesse within my house at home.

O Lorde moste mightie, hye father, creatour,

110 Withsaue to graunt them some office of honour.

Their heere was rugged, poudred all with chaffe,

Some full of strawes, some other full of draffe,

Some with cobwebbes and dust were so arayde

That one beholding on them might be afrayde,

Blacke was their colour and bad was their figure,

Uncomely to sight, mishapen of stature.

Our Lorde not smiled on them to shewe pleasaunce,

But saide to them thus with troubled countenaunce:

frail, transitory

Ye smell all smoky, of stubble and of chaffe,

120 Ye smell of the grounde, of wedes and of draffe,

And after your sent and tedious sauour

Shall be your rowmes and all your behauour.

None can a pitcher turne to a siluer pece,

Nor make goodly silke of a gotes flece,

And herde is also to make withouten fayle

A bright two hande sworde of a cowes tayle.

No more will I make, howebeit that I can,

Of a vile villayne a noble gentleman,

without being asked genuine, actual

Ye shall be plowmen and tillers of the grounde,

130 To payne and labour shall ye alway be bounde,

Some shall kepe oxen, and some shall hogges kepe,

Some shall be threshers, some other shall kepe shepe,

To digge and to delue, to hedge and to dike,

Take this for your lot and other labour like,

To drudge and to driuell in workes vile and rude,

This wise shall ye liue in endlesse seruitude,

vouchsafe

shaggy, unkempt

Reaping and mowing of fodder, grasse and corne,

Yet shall towne dwellers oft laugh you vnto scorne.

Yet some shall we graunt to dwell in the citie,

For to make puddinges and butchers for to be,

Coblers or tinkers or els costarde iaggers,

appearance

cheerfully, agreeably

scent; ?dislikeable, objectionable rooms, dwellings

hard

although I have the power

88-9 pollax] battle-axe. helme] helmet. haberiowne] habergeon, armoured jacket. ghetton] a kind of flag or banner. mace] weapon with spiked metal head. 101-52 Again, considerably expanded from the original. 92 all thing] Singular form then common. low-born rustic. 128 villayne] in the original sense, a 
Hostelers or daubers, or droupy water laggers, And suche other sorte whose dayly businesse

Passeth in workes and labour of vilenesse,

To stoupe and to sweate, and subiect to become,

to be subservient

And neuer to be ridde from bondage and thraldome.

Then brought our Lorde to them the carte and harowe,

The gad and the whip, the mattoke and the whelebarowe,

The spade, the shouell, the forke and the plough,

And all suche tooles, then bad he them be tough,

And never to grutche at labour nor at payne,

For if they so did it should be thing in vayne.

Thus saide the father and Lorde omnipotent,

And then he ascended vp to the firmament.

Thus began honour and thus began bondage,

And diuersitie of citie and village,

And seruile labour first in the worlde began.

Demaunde of Cornix, declare the truth he can.

This tolde me Cornix which wonned in the fen,

I trust his saying before a thousande men.

17 Mantuan Eclogue viI.1-50

Translated from the Latin by Thomas Harvey.

First published in Harvey's The Bucolicks of Baptist Mantuan in Ten Eclogues, 1656 (1655?). Closely follows Mantuan's original. Describes a vision seen by the young Pollux (usually identified with Mantuan), after which he joins the Carmelite order, though the poem was written before Mantuan himself did so. Interesting contrast with Alexander Barclay's Eclogue V.431-534, where Barclay inserts into his translation of Mantuan VI this segment of Eclogue VII, omitting all reference to Pollux's vision but adding many real or supposed shepherds from Biblical and classical sources.

EGLOGUE VII.

Treating of the Conversion of young men to Religion, when the Author began to take Religious Orders.

Intituled POLLUX.

The Argument.

Here Galbula the Shepheards praise

Mounts to the stars; relateth how

Pollux by sight of sacred raies

Converts, and doth Religion vow.

Alphus. What think'st O Galbula, that where of yore

Pollux the best of pipers, and before

The rest preferr'd, now suddainly retir'd,

And, as't by some power divine inspird,

His Pipes, Coat, Flocks and fellows he forsook,

And to religious vows himself betook,

His head doth wear an hood, his back a gown,

Like a field Larke he looks with tufted Crown:

Four daies before he did himself confine

To the religious Cloyster, a divine.

A sacred apparition, as alone

He fed his Cattle in the pastures, shone

Most clear about him, which (they say) he saw;

And ever since from us he did withdraw.

The rest I now remember not ywis;

But what O Galbula, what think'st of this?

I know, indeed: a line-filler

Galbula. As our forefathers did affirm long since

(For I will utter things of consequence,

142 Hostelers] innkeepers. daubers] plasterers. droupy] stooping (under their burden). water laggers] water-carriers. 152 it should ... vayne] (a) it would avail them nothing (b) it would be wrong of them to do so. $\quad 160$ (a) I would trust his words more than that of a thousand other men. (b) I would swear my trust in him before a thousand men. 
Which learned Vmber did of yore relate)

In the beginning, when mans first estate

God did dispose and order, he did will

Some should be shepherds, some the ground should till.

He that the ground first till'd, was rude, sharp, rough,

Like the stiff stony ground that checks the plough:

resists, blocks

But the first shepherd was a gentle childe,

More like the sheep, the sheep (a creature milde)

Which floweth milk, which are from choler clear:

(a) (Adam and Eve's) offspring (b) youth, lad

$\mathrm{He}$ (gentle) to no shepherd was severe,

Oft from his flock he brought a sacrifice

Unto the sacred Altar: There he fries

flows with

A fatted Calf sometimes, sometimes a sheep,

But oftentimes a lamb: He thus did keep

A constant course of worship, that thereby

He brought great honour to the Deity.

He so prevail'd with God, so well appeas'd

The Godhead, that the Deity was pleas'd

From the beginning to this time to fence

All Cattel with his careful Providence.

God then some shepherds of Assyria chose,

(The names I now remember not of those,

Cares so distract my minde) made kings of them,

And crown'd them with a Regal Diadem.

Those (after) cloth'd in Purple and with Gold

I saw, they conquer'd Nations proud and bold.

When Paris saw three Goddesses (with joy)

In Ida's Mountain near to famous Troy,

Or Paris, or some one, that would (alas)

Have sacrific'd his son, a shepherd was.

When Moses, frighted with Cœlestial fire,

Went bare foot on the ground to see, t'admire

The wonder, Moses was a shepherd then,

Moses, extracted from the wat'ry Fen.

Apollo from his Throne depos'd, exil'd

In Greece, and wand'ring up and down the wild

Thessalian fields, a shepherd did abide,

Laying the greatness of his state aside.

When Christ was in the stable born, a Quire

Of Heavens Angels, glorious in attire,

Did to the shepherds in the sheep cotes sing

The birth of Earths Redeemer, Heavens King.

The shepherds having then that wonder heard

Of Christs diviner birth, did not retard,

But ran with speed, the ground they lightly trod,

And were the first that saw the Son of God.

That little Infant, which on high doth reign

19 Vmber] As Mantuan explains in a 1500 letter to Thomas Wolf, Umber is Gregorio Tifernate (c.1414-c.1464), an early humanist Greek scholar and Mantuan's teacher. 20-34 Alluding to Cain and Abel (Genesis 4.1-8). $\quad 27$ from choler clear] free from anger. An excess of choler or yellow bile, one of the four humours, was thought to make a man irascible and aggressive. $\mathbf{2 8}$ gentle] (a) noble, high-minded (b) tender, soft in nature. 39 shepherds of Assyria] Abraham, Lot, Jacob and other biblical patriarchs, whom Mantuan calls Assyrios. Assyria was used loosely for much of the Middle East. $\quad$ 45-6 Paris, prince of Troy, was brought up by a shepherd on Mount Ida. Later, as himself a shepherd there, he judged a contest of beauty between Hera (Juno), Athene (Minerva) and Aphrodite (Venus). 47-8 some one] Abraham, prepared to sacrifice his son Isaac (Genesis 22.1-14); but hard to relate him to Paris. 49-52 Moses saw a bush that burnt without consuming (Colestial fire) while grazing his father-in-law Jethro's flocks (Exodus 3.1-5). bare foot] God commanded him to take off his shoes, as he stood on holy ground. wat'ry Fen] As an infant, Moses was rescued by the Pharaoh's daughter after his mother set him afloat on the river. 53-5 Apollo tended the flocks of Admetus, king of Thessaly, when condemned to serve a mortal for a year for having slain the Cyclops. He also kept sheep in Elis, when Hermes stole his flocks. (Ovid, Met. II.688). 59 sheep cotes] Actually, the Nativity shepherds were 'abiding in the field' (Luke 2.8). $\quad \mathbf{6 4}, 66$ The translator uses Christian terms for God. Here as elsewhere, Mantuan uses pagan terms for Zeus or Jupiter like tonantem, the thunderer, and regnator Olympi, ruler of Olympus. See 86-7n. 
Sole King of kings, did to those shepherds deign

condescend, vouchsafe

Himself, his Cradle to behold, before

The Wise-men or the Kings did him adore.

And God himself, himself a Shepherd styles,

Styles those his Sheep, those men who free from wiles

Are of milde nature, of a lowly minde,

Of upright heart, to no deceit inclin'd.

And lest these words of mine thou should'st conceit

As a vain dream, insolid, wanting weight,

I'le tell thee more. As from the Town I came

Into the Countrey, I beheld the same

But very lately; I these wonders all

Saw lively painted on a Churches wall.

There Sheep were painted, painted were the Lambs,

As if down lying by their bleating Dams:

A num'rous Troop of gallant horsemen there,

Dismounting from a Mountain painted were,

Whose Coronets did shine with burnish'd gold,

A noble gallant sight; which to behold,

Detain'd all passengers with wond'ring eyes.

No marvel then if of the Deities

Our Pollux one might see: for those above

Love Villages, they sheep and sheep-cotes love.

God present is with simple, single breasts,

But (with deceit displeas'd) deceit detests.

\section{Robert Henryson Robene and Makyne}

From the Bannatyne MS (1568), National Library of Scotland. Line-initial capitals and proper names regularized, and virtually all punctuation inserted. Speech-headings inserted in brackets to help track the exchanges.

Robene sat on gud grene hill

Kepand a flok of fe;

Mirry Makyne said him till,

Robene, thow rew on me.

I haif the lovit lowd and still

conceive

empty, insubstantial

in a lifelike manner

riding down

Thir yeiris two or thre;

My dule in dern bot gif thow dill

Dowtless but dreid I de.

Robene answuerit, Be ye rude

$\mathrm{Na}$ thing of lufe I knaw,

by the rood (cross)

Bot keipis my scheip undir yone wid;

Lo quhair thay raik on raw.

Quhat hes marrit the in thy mude,

Makyne, to me thow schaw,

Or quhat is lufe, or to be lude?

keeping

said to him

rue, take pity

thee (so all through)

these

Fane wald I leir that law.

wood

[Makyne speaks]

At luvis lair gife thow will leir,

Tak thair ane a b c:

Be heynd, courtass and fair of feir,

lore, instruction

basic instruction

hende: pleasant, courteous; look, demeanour

68 The Wise-men or the Kings] Lat. magos regesque, wise men and kings. In his work De sacris diebus, Mantuan accepts the magi and the kings of the Nativity as distinct. 69 himself a Shepherd] John 10.11-16. 81 gallant horsemen] ?the three kings of the Nativity and their retinue. 86-7 the Deities ... those above] Unexpected implication of many gods, reflecting Mantuan's numina and divi. Mantuan commonly used pagan terms and allusions in a Christian context, for which he was much

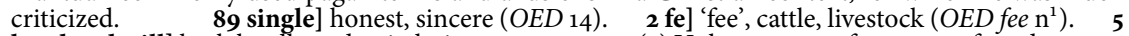
lowd and still] both loudly and quietly, in every way. $\quad 7$ (a) Unless you comfort my profound sorrow. (b) Unless you soothe my sorrow in secret (by our making love): cf.39. dern] (a) secret (OED 1) (b) deep $(O E D$ 6). $\quad \mathbf{8}$ dreid I de] I die of suffering. dreid] from dree, to suffer. $\quad 10$ I understand nothing of love. 
Wyse, hardy and fre,

So yat no denger do the deir,

Quhat dule in dern thow dre;

Preys the with pane at all poweir,

Be patient and previe.

Robene ansuerit hir agane,

I wait nocht quhat is luve,

Bot I haif mervell in certane

Quhat makis the this wanrufe.

The weddir is fair and I am fane,

My scheip gois haill aboif;

And we wald play us in this plane,

Thay wald us bayth reproif.

\section{[Makyne speaks]}

Robene, tak tent vnto my taill

And wirk all as I reid,

And thow sall haif my hairt all haill,

Eik and my madinheid.

Sen God sendis bute for baill

And for murning remeid,

In dern with the bot gif I daill,

Dowtles I am bot deid.

\section{[Robyne speaks]}

Makyne, to morne this ilk a tyde

And ye will meit me heir,

Perauenture my scheip ma gang besyd

Quhill we haif liggit full neir.

Bot mawgre haif I and I byd,

Fra thay begin to steir;

Quhat lyis on hairt I will nocht hyd,

Makyn, than mak gud cheir.

\section{[Makyne speaks]}

Robene, thow reivis me roif and rest,

I luve bot the allone.

\section{[Robyne speaks]}

Makyne adew, ye sone gois west,

The day is neir hand gone.

\section{[Makyne speaks]}

Robene, in dule I am so drest

That lufe wilbe my bone.

[Robyne speaks]

Ga lufe Makyne quhair evir thow list

For lemman I bid none.

\section{[Makyne speaks]}

Robene, I stand in sic a styll;

I sicht, and yat full sair.

\section{[Robyne speaks]}

Makyne, I haif bene heir this quhyle;

At hame God gif I wair.

[Makyne speaks]

My huny Robene, talk ane quhyle,

Gif thow will do na mair.

[Robyne speaks] bold, ?forthcoming

that

whatever; suffer, endure

privy: (a) close, intimate (b) secret, discreet

wot, know

wonder; certainly

happy, content

'an', if; dally, make love

condemn, disapprove of

?whole, loyal and also

tomorrow at the same time 'an', if

have lain

odium, reproach stir, move

rob me of; roif: rest, peace

?dressed, clad, overwhelmed bane, destruction

lover, beloved; ask for, desire

style, state sigh; that; sore

here

a while

21 denger] 'love-daunger': coyness, affected disdain or aloofness in love. deir] harm, injure. 23 Press forward with all your might. 28 wanrufe] disquiet, unrest (OED only this passage). 30 My sheep climb safely up above. $\quad 31$ plane] plain - where they would make love, neglecting the heights where the sheep are. 33-4 Listen to what I say, and do exactly as I advise. 37 since God sends remedy for sorrow. 39 unless I deal with you in secret (i.e. make love to you). 43 gang besyd] ?go astray; ?stay close by. $\quad 45-6$ But I will be scolded if I stand by idly while they stray. 
Makyne, sum uthir man begyle, For hamewart I will fair.

fare, go

Robene on his wayis went

Als licht as leif of tre;

Mawkin murnit in hir intent

And trowd him nevir to se.

Robene brayd attour ye bent,

Than Maukyne cryit on hie,

Now ma thow sing, for I am schent;

Quhat alis lufe at me?

Mawkyne went hame withowttin faill,

Full wery eftir cowth weip.

Than Robene in a ful fair daill

Assemblit all his scheip;

Be yat, sum parte of Mawkynis aill

Outthrow his hairt cowd creip.

He fallowit hir fast thair till assaill,

And till hir tuke gude keip:

sorrowful

dale

From that time

[aill ailment, affliction (i.e., love)

to approach, to accost

at any price

(a) wavering, deserting (b) parting, division

coveting, desire tomorrow; till

Abyd abyd thow fair Makyne,

A word for ony thing!

For all my luve it salbe thyne,

Withowttin departing.

All haill thy harte for till haif myne

Is all my cuvating,

My scheip to morne quhill houris nyne

Will neid of no keping.

\section{[Makyne speaks]}

Robene, thow hes hard soung and say

In gestis and storeis auld,

The man yat will nocht quhen he may

Sall haif nocht quhen he wald.

I pray to Iesu every day,

Mot eik yair cairis cauld

Yat first preissis with the to play

Be firth, forrest, or fawld.

wood; fold

\section{[Robyne speaks]}

Makyne, ye nicht is soft and dry,

The wedder is warme and fair,

An the grene woid rycht neir vs by

To walk attour all quhair.

Thair ma na ianglour vs espy,

That is to lufe contrair.

Thairin, Makyne, bath ye and I

Vnsene we ma repair.

\section{[Makyne speaks]}

Robene, yat warld is all away

And quyt brocht till ane end,

And nevir agane yairto perfay

Sall it be as thow wend,

For of my pane thow maid it play

And all in vane I spend.

heard; saying, speech gests, tales

As thow hes done, sae sall I say,

Mvrne on, I think to mend.

72 What does love have against me? 74 and wept sorrowfully. cowth] began to, hence 'did' (OED can $\mathrm{v}^{2} 3$ ). $\quad 80$ till ... keep] 'kept a close Eye upon her' (Ramsay), took good note of her. 85 to have your 'haill' heart as my own. haill] (a) whole, entire (b) happy, contented. 94-5 May their cold sorrows increase who first offer love to you. $\quad 110$ spend] ?pass my time; ?waste away. $\quad 112$ Grieve on: I intend to change. 


\section{[Robyne speaks]}

Maukyne, the howp of all my heill, My hairt on the is sett, And evirmair to the be leill Quhill I may leif but lett; Nevir to faill as vthiris feill, Quhat grace yat evir I gett.

\section{[Makyne speaks]}

Robene, with the I will nocht deill. Adew, for thus we mett.

Malkyne went hame blyth annewche Attour ye holttis hair;

Robene mvrnit and Malkyne lewche, Scho sang, he sichit sair.

And so left him bayth wo and wewche In dolour and in cair Kepand his hird vnder a huche, Amangis the holtis hair. hope; 'health', wellbeing

leal: loyal, faithful

live; without end

deal

happy enough across; holts, woods laughed sighed sorrowfully left to him; injury, harm

heuch: crag or precipice

\section{From Of Gentleness AND Nobility}

Extracted from Of Gentylnes and Nobylyte. A Dyaloge betwen the Marchaunt the Knight and the Plowman (?1525-35), variously ascribed to John Rastell and John Heywood. This dialogue on the relationship between rank or wealth and true nobility illustrates the Plowman literature associated with pastoral. Virtually all punctuation supplied and line initials regularized.

Plowman. Is not that the noblyst thyng in dede

That of all other thyngis hath least nede,

As god which reynith etern in blysse

Is not he the noblest thyng that is?

Knight. Yes, mary, no man in reason can that deny.

Plowman. Well than there is no reason therof why

But because he is the thyng omnipotent

And is in him self so suffycyent

And nedyth the helpe of no nothyr thyng

To the helpe of hys gloryous beyng,

no other (double negative)

But euery other thyng hath nede of his ayde.

Knight. Mary that is very trough and well sayde.

Plowman. And lykwyse that thynge that hath most nede

Is the thyng that is most wreched.

So suffycyency is euer noblenes

And necessyte is euer wrechydnes.

And he that hath more nede of that thyng

For the preseruacyon of hys lyuyng

Then his felow hath, his felow must nedes be

a particular thing, something

By thys same reason more noble than he.

\section{Knight. What than?}

Plowman. By the same reason it prouith lo

Ye be but caytyffes and wrechis both two

And by the same reason proue I shall

That I am the noblyst man of vs all

For I haue nede of no maner thyng

That ye can do to help of my lyffyng:

For euery thyng whereby ye do lyf

I noryssh it and to you both do gyf.

I plow I tyll and I ster the ground

Whereby I make the corn to habounde

Whereof ther is made both drynk and bred

Wyth the which dayly ye must nedis be fed.

$\mathbf{1 2 0}$ for thus we mett] i.e. Let us part as we met, when you would not love me. $\quad \mathbf{1 2 2}$ hair] hoar, grey, leafless. Conventional poetic epithet with woods, with no precise sense. 
I noryssh the catell and fowlys also,

Fyssh and herbis and other thyngis mo;

Fell, herr and woll whych the bestis do bere

skin; hair

I noryssh and preserue which ye do were

Which yf ye had not, no dowt ye shuld

Starue for lak of clothis because of colde.

So both you shulde die or lyue in necessite

If ye had not comfort and help of me.

And as for your fyne cloth and costly aray

I cannot see whi ye ought or mai

Call your self noble because ye were it

Which was made bi other menis labour and wit.

And also your delicate drinkis and viand

$\mathrm{Bi}$ other menis labours be made so pleasand.

Therefore mayster marchaunt now to you I sei

I can not see but I am able and mai

Lyf wythout you or your purueaunce

For of fode and cloth I haue suffisaunce

Of my self for lyffing necessary.

And now sir knyght to you I sey playnly

I see not that ye can any thyng do

For the commyn well or ought longyng ther to

But ech man beyng in auctoryte,

Hauyng wit, may do it as well as ye.

Therfore to spek now of necessyte

There is nother of you both but ye be

In more nede than I: therfore I sey playn

I am more noble than other of you twayn.

die, especially of cold (OED 9)

belonging, pertaining

Plowman. Nay be god I haue some what ells to do.

I must go by me a halporth of gresse

The spokes of my cart therwith to dresse.

Trow ye that I wyll leue my bysynes

For your babelyng pomp and folysshnes?

Nay by sent mary I wyll not do so

For I can now to the merket goo

An for an halpeny as much gresse by

As shall cost me in our town a peny

And I tell the playnly without any bost

A halpeny is as well sauid as lost.

Merchant. Straw for an halpeny, therin is no wast.

Tary with vs a while perhapps thou mast:

By our acquayntaunce now here get more

Than thou gatist with thy cart this monyth before.

Plowman. Straw for thi councell, torde a fart.

neither

either

grease

Trowist I wyll gyf up my plow or cart

And folow thy folish appityte and mynde?

Nay I am not yet so mad nor so blynd.

For when I am at my cart or plow

I am more meryer than other of you.

I wold not chaunge my lyf nor my lyffyng

For to be made a grete lorde or a kyng.

There is no ioy nor pleasure in this world here

But hyll bely fyll and make good chere.

Be it prynce, lorde, gentilman or knaue,

Hit is all the ioy that here he can haue.

But these couetous and ambicious wretches

They set there myndys in honoure and ryches

So much that they be neuer content:

So they lyf euer in payn and torment. 
But a man that can this meanys fynd

To haue fode and cloth and a mery mynde

And to desyre no more than is nedefull,

That is in this worlde the lyf most ioyfull,

Which lyfe in this worlde no man shall acquire

Till he subdew his insaciat desyre.

100

110
Knight. If gentyl condycyons be the cause lo

Then wyll I compare with both you two.

For I haue vsyd euer gentyll maner

And so haue myn auncestours that before were.

For furst of all when thys worlde began

Long after ther were but few people than.

Men had suffycyent of euery thyng

Wyth oute gret labour for fode and clothyng.

All thyng was in commyn among them doutles

But afterwarde when people dyd increse

Ich man to increse hys pleasure and volupte

Of goodes and landes desyryd properte

Wereof grete stryf and debate dyd aryse.

Then such as mine auncestours were that were wyse

Did studi to make laws how the people myght be

Lyffyng to gedyr in pease and vnyte

And agayns enmiys alwey defendyd

The people that tyllyd the ground and laboryd.

The people perseyuyng than theyr goodnes,

Theyr gret wyt, dyscressyon and gentylnes,

Were content to gyfe them part of the proffet

Comyng of theyr landes whych they dyd get

As corn, catell and such thynges as they wan.

But after when that coyn of money began

They chaungid those reuenuse and were content

To gyfe them in money an annyell rent.

So for theyr good and verteous condycyons

They cam furst to landes and possessyons.

So possessyons began and were furst found

Uppon a good and resonable ground.

Plowman. By gogges swete body thou lyest falsely.

All possessions began furst of tyranny.

For when people began furst to encrese

Some gafe them self all to Idylnes

And wold not labour but take by vyolence

That other men gat by labour and dylygence.

Than they that labouryd were fayne to gyfe

Them part of theyr gettinges in peas to lyfe

Or elles for theyr landis money and porcyon.

So possessyons began by extorcyon

And when such extorcyoners had oppressyd

The labouryng people, than they ordeynyd

And made laws meruelous strayte and hard

That theyr heyres myght inioy it afterward.

So the law of inherytaunce was furst begon

Whych is a thyng agayns all good reason

That any inherytaunce in the world shuld be. issue, subject of debate prove superior to

'volupty', pleasure won: got by labour, earned

disposition, nature

God's (i.e., Christ's)

begot, created

peace

portion, dowry

strait, narrow, rigid 
2o Marcantonio Flaminio To His Little Field

Translated from the Latin by John Ashmore.

First published in Ashmore's Certain Selected Odes of Horace... Whereunto are added ... sundry new Epigrammes. Anagramms. Epitaphes (1621). The original poem begins 'Umbrae frigidulae, arborum susurri' (Flaminio, Carmina, $2^{\text {nd }}$ edn., 1743, Bk. I, p.24). Ashmore follows Flaminio's structure fairly closely, but with a good deal of expansion.

Ex M. Antonio Flaminio, ad Agellum suum. Sic incipit: Vmbrae frigidula, etc.

Cool Shades, Air-fanning Groves,

With your soft Whisperings,

Where Pleasure smiling roves

Through deawie Caves and Springs,

And bathes her purple Wings:

With Flowrs inameld Ground

(Nature's fair Tapestry)

Where chattering Birds abound,

Flickring from Tree to Tree,

With Change of Melody:

flitting
variation, modulation: a musical term

Sweet Liberty and Leasures,

Where still the Muses keep,

periods of leisure

$\mathrm{O}$ ! if to those true Treasures, always; dwell

That from your Bosoms peep,

I might securely creep:

If I might spend my Daies

(Remote from publike Brawls)

Now tuning lovely Laies,

Now light-foot Madrigals,

Ne'r checkt with sudden Calls:

smooth, easy-flowing obstructed, disturbed

Now follow Sleep that goes

Rustling ith' green-wood Shade;

Now milk my Goat, that knowes

(With her yong fearfull Cade)

The Pail ith' cooly Glade,

nervous, shy; kid milking-pail

And with Boawls fild to th'Brims

Of milky Moisture new,

To water my dry'd Lims,

And t'all the wrangling Crew

Of Cares to bid Adew;

What Life then should I lead!

How like then would it bee

Vnto the Gods, that tread

Ith' starry Gallery

Of true Felicity!

But you, O Virgins sweet,

In Helicon that dwell,

That oft the Fountains greet,

When you the Pleasures tell

Ith' Country that excell:

count, enumerate

are at their best or most abundant

If I my Life, though dear,

For your far dearer sake,

To yeeld would nothing fear;

From Citie's Tumults take-mee,

And free ith' Country make-mee.

o.1 From Marco Antonio Flaminio, 'To his little field'. It begins thus: 'Cool shades, etc.' 6 Flowrs inameld] Probably a compound, 'flowers-enamelled', enamelled (painted) with flowers. 17 Brawls] (a) clamours, disturbances $\left(O E D_{2}\right)$ (b) quarrels. $\quad$ 21-2 i.e. The breeze under the shady trees is soporific. 36 Virgins] the Muses. 37 Helicon] mountain sacred to Apollo and the Muses. 38 'The fountains'; is the subject of the sentence: they greet the Muses. 


\section{Basilio Zanchi (Petreius Zanchus) Kala's Complaint \\ Translated from the Latin by William Drummond of Hawthornden.}

First published in Drummond's Poems (?1604 ?1614) among 'Madrigalls and Epigrams'. The original may be found in Delitioe CC. Italorum Poetarum, vol. 2 (1608), p.1481.

Kalas Complaint.

Kala old Mopsus wife,

Kala with fairest Face,

For whom the Neighbour Swaines oft were at strife,

As she to milke her snowie Flocke did tend,

Sigh'd with a heauie Grace,

go to do, approach

And said: What wretch like me doth leade her life?

I see not how my Taske shall haue an end:

All Day I draw these streaming Dugs in Fold,

All Night mine empty Husbands soft and cold.

in the (sheep)fold

\section{Jorge De Montemayor 'O EYES, ThAT SEE NOT Him'}

Translated from the Spanish by Bartholomew Yong.

From Yong's translation (completed May 1583, published 1598) of Jorge de Montemayor's romance Diana, Book I (1559). Closely follows the original, even retaining the rhyme-scheme with a minor variation. Diana mourns the absence of Syrenus, whose love she once pretended to scorn but later returned. During his absence, she has married another shepherd. The song is overheard by her neglected lover Sylvanus and reported to Syrenus on his return. Curiously, it makes no reference to their former love, but makes it appear as though Syrenus has left owing to Diana's apparent scorn.

O eies, that see not him, who look'd on yow

When that they were the mirrours of his sight,

What can you now behold to your content?

Greene flowrie meade where often I did vew,

And staid for my sweete friend with great delight,

The ill, which I doe feele with me lament.

Heer did he tell me how his thoughts were bent,

And (wretch) I lent an eare;

But angry more then whelplesse Beare

Presumptuous him I call'd, and vndiscreete:

And he layde at my feete,

Where yet (poore man) me thinkes I see him lye:

past tense of 'lie'

And now I wish that I

Might see him so, as then I did: O happy time were this,

Sweete shadowed riuer bankes tell me where my Syrenus is.

Yon is the riuer banke, this is the meade,

From thence the hedge appeeres and shadowed lay,

Wherein my flockes did feede the sauourie grasse:

Behold the sweete noys'd spring, where I did leade

My sheepe to drinke in heate of all the day,

When heere my sweetest friend the time did passe:

Vnder that hedge of liuely greene he was;

And there behold the place,

Where first I saw his sweetest face

And where he sawe me: happy was that day,

Had not my ill haps way

To end such happy times. O spring,

$O$ hedge, and euery thing

Is heere, but he, for whom I paine continually, and misse,

Sweete shadowed riuer bankes tell me where my Syrenus is.

2 When his gaze was reflected in them - i.e. when he was constantly looking into Diana's eyes.

whelplesse Beare] angry serpent in the original. 14 If I could see him now as I did then, this would be a happy time. $\quad 22$ liuely] fresh, vivid (OED 5a). 26 If my misfortune did not have the means. 29 paine] Combines pine and pain in the obsolete intransitive sense 'suffer pain' (OED 2). 
Heere haue I yet his picture that deceaues me,

Since that I see my Shepherd when I view it,

(Though it were better from my soule absented)

When I desire to see the man that leaues me

(Which fond deceipt time showes, and makes me rue it).

To yonder spring I goe, where I consented

To hang it on yon Sallow, then contented

willow

I sit by it, and after

(Fond loue) I looke into the water,

foolish

And see vs both, then am I so content heere,

As when his life he spent heere:

This bare deuise a while my life sustaineth;

But when no more it faineth,

poor, crude; artifice, subterfuge

My hart surcharg'd with anguish, and cries out, but yet amisse,

Sweete shadowed riuer bankes tell me where my Syrenus is.

(successfully) deceives

misguidedly,

[unhappily

Speaking to it no wordes it is replying,

And then (me thinkes) reuenge of me it taketh,

Bicause sometime an answere I despised.

scorned (to give)

But (wofull soule) I say vnto it crying,

Syrenus speake, since now thy presence maketh

Aboade, where neuer once my thoughts surmized:

Say, in my soule art thou not onely prized?

But not a word it saieth,

And as before me there it staieth,

To speake, my soule doth pray it (in conclusion).

$\mathrm{O}$ what a braue delusion,

To aske a simple picture toong or sences?

O time, in what offences

Of vainest hope is my poore soule so subiect vnto his?

Sweete shadowed riuer bankes tell me where my Syrenus is.

I neuer can go homeward with my sheepe,

When to the west the sunne begins to gyre,

turn, revolve

Nor to the foldes returne from our towne,

But euery where I see, and seeing weepe,

The sheepe cote of my ioy and sweete desire

Broken, decaied, and throwen vnto the ground:

Carelesse of lambes and sheepe, there sit I downe

A little while, untill

The herdesmen feeding on the hill

Cry out to me, saying, O Shepherdesse

What doe thy thoughts possesse,

And let thy sheepe goe feeding in the graine?

Our eies doe see it plaine:

For them the tender grasse in pleasant vales doth grow ywisse,

Sweete shadowed riuer bankes tell me where my Syrenus is.

Yet in thine owne opinion greater reason

(Syrenus) it had bene, thus to haue started

With more constraint and force then I did see yet,

But whom doe I accuse of guiltlesse treason?

For what could make him stay and not haue parted,

31-5 The picture deceives me by making me think I see the man himself, though it would be better if I did not wish to see him who has left me. I gradually discover the deceit, and deplore it. 40 And see vs both] The water reflects Syrenus's picture and Diana's face. $\mathbf{4 8}$ sometime] in the past (OED 2). 50-1 maketh Aboade] lodges, harbours - i.e., in Diana's heart. 51 thoughts] Sp. fantasia. 55 To speake ... pray it] My soul begs it to speak. 57 aske] ask of, demand from. For the syntax (double object without preposition) see OED ask $12 . \quad 59$ his] usual possessive of it till end of $16 \mathrm{c}$ : here prob. the picture, not Syrenus. $\quad 63$ towne] The scene is near the Spanish city of León. $\quad \mathbf{7 6 - 8}$ It would have been better for you to have begun your courtship in a more forceful and importunate way. (OED constraint 1). 76 in thine owne opinion] ?from your own point of view, in your own interest. 79 guiltlesse treason] innocent damage to the prospects of our love. $\quad 80$ stay ... parted] Perhaps so phrased for the rhyme: the sense demands 'part and not have stayed'. 
If fate and fortune thereto did agree yet?

No fault of thine it was, nor could it be yet

In my beleefe, haue ended

Thou wouldst in ought, or haue offended

Our loue so plaine and simple, as to leaue it

Nor will I once conceaue it,

Though many shewes and signes thereof there were yet:

O no, the fates did sweare it,

vow

With cloudes of sorrow to obscure my heauen of ioy and blisse,

Sweete shadowed riuer bankes tell me where my Syrenus is.

My song take heede thou goest where I betake thee,

commit, assign

Yet shalt thou not forsake me:

For it may be that fortune will with such a humour place thee,

mood, disposition

That may terme thee importunate and by that meanes disgrace thee.

\section{Jorge De Montemayor 'Passed contents'}

Translated from the Spanish by Bartholomew Yong.

From Yong's translation (completed May 1583, published 1598) of Jorge de Montemayor's romance $D i$ ana, Book I (1559). Like no.22, closely follows the original, even retaining the rhyme-scheme with a minor variation. Syrenus, once beloved of Diana, suddenly comes across her flock: the animals recognize and greet him. This reminds him of a love he would forget.

Passed contents,

O what meane ye?

past pleasures

Forsake me now, and doe not wearie me.

vex, tax, try my patience

Wilt thou heare me, O memorie?

My pleasant daies, and nights againe,

I have appaid with seuenfold paine:

Thou hast no more to aske me why,

requited, compensated for

For when I went, they all did die:

As thou dost see,

$\mathrm{O}$ leaue me then, and doe not wearie me.

Greene field, and shadowed valley, wheare

Sometime my chiefest pleasure was,

Behold what I did after passe:

Then let me rest, and if I beare

Not with good cause continuall feare,

Now doe you see.

O leaue me then, and doe not trouble me.

I sawe a hart changed of late,

And wearied to assure mine:

Then I was forced to recure mine

By good occasion, time and fate.

My thoughts, that now such passions hate,

$\mathrm{O}$ what meane ye?

Forsake me now and doe not wearie me.

You lambes and sheepe that in these layes,

leas, meadows

Did sometimes follow me so glad:

The merry howres, and the sad

Are passed now with all those daies:

82-7 It was no fault of yours: I will not believe that you would have ended our love by any means, or offended against it by departing. I will never think so, whatever apparent signs might indicate it. 90-93 Song, make sure that you reach the person for whom I intend you. Yet it may be better that you stay with me, for the recipient may be disposed to scorn you as being too importunate. 14-16 Now you see that I was justified in being in continual fear. 18-21 I saw a heart that had lately changed, and that now thought it wearisome to secure my love. This made me rethink my own love as the situation required. 20 recure] recover, cure, protect (from love: see $O E D$ 3a, $4 \mathrm{~b}, 6$ ). 
Make not such mirth, and wonted plaies,

accustomed

As once did ye:

For now no more you haue deceiued me.

If that to trouble me you come,

Or come to comfort me indeede:

I haue no ill for comforts neede.

But if to kill me, Then (in summe)

sorrow in need of comfort

Full well may ye

Kill me, and you shall make an end of me.

\section{Alonso Perez 'I PRAY THEe KeEP MY KINE'}

Translated from the Spanish by Bartholomew Yong.

From Yong's translation of Diana (completed May 1583, published 1598). Reprinted in Helicon. The original is from Book 6 of The Second Part of Diana (1564), Alonso Perez's sequel to Montemayor's Diana. This song by the shepherd Carizo or Carisus adapts a 'common Castillian countrey dance' song or villancico by Count Alarcos, published c.1520. The shepherdess Cardenia, wishing to meet Faustus whom she loves, asks Carisus, who loves her unavailingly, to guard her cattle in her absence. The first two lines are Cardenia's address to Carisus, the rest his reply. The first four lines, in Spanish, occur both in Yong's 1598 text and in Helicon. The translation follows the original fairly closely, apart from expanding the sixth stanza of the original into two (45-60). An adaptation, beginning 'I Prethee keep my sheep for me', is found in Henry Playford's Select Musicall Ayres and Dialogues (1653). See Rollins (ed.), Helicon, 2.136-7.

Gvarda mi las vaccas Carillo, por tu fe,

Besa mi primero, Yo te las guardaré.

I pray thee keepe my kine for mee Carillio, wilt thou? Tell.

First let me haue a kisse of thee, And I will keepe them well.

If to my charge or them to keepe

Thou dost commend thy kine, or sheepe,

For this I doe suffice:

Bicause in this I haue beene bred:

But for so much as I haue fed,

By viewing thee, mine eies,

Command not me to keepe thy beast,

Bicause my selfe I can keepe lest.

least

How can I keepe, I pray thee tell,

Thy kye, my selfe that cannot well

Defend, nor please thy kinde,

As long as I haue serued thee?

o'er, over

I am equal to the task

But if thou wilt giue vnto mee

A kisse to please my minde,

I aske no more for all my paine,

And I will keepe them very faine. willingly

kine, cattle

?someone like you, ?womankind Although I have served you so long

For thee, the gift is not so great

That I doe aske, to keepe thy neate,

But vnto me it is

A guerdon, that shall make me liue:

Disdaine not then to lend, or giue

So small a gift as this.

But if to it thou canst not frame,

Then giue me leaue to take the same.

o.1-0.4 Translated in 1-4. $\quad$ o.2, 2 Carillo] In Perez, the shepherd is called Carizo. The name 'Carill(i)o' is from the villancico on which the song is based (see headnote). 9-12 My eyes have fed or 'grazed' on your sight, so that I too am a beast of your flock: I cannot look after myself, so can hardly control the rest. Playing on the common conceit that the mistress's eyes are a pasture 27-8 If you cannot bring yourself to give me a kiss, let me take one from you on my own. Sukanta Chaudhuri - 9781526143426 
But if thou dost (my sweete) denie

To recompence me by and by,

Heereafter some rewarde to finde:

Thy promise shall relent me,

Behold how I doe please my minde,

And fauours doe content me,

That though thou speak'st it but in jest,

I meane to take it at the best.

in the most favourable way

Behold how much loue workes in mee,

And how ill recompenc't of thee,

That with the shadow of

Thy happy fauours (though delaide)

I thinke my selfe right well appaide,

Although they prooue a scoffe.

Then pitie me, that haue forgot

rewarded

jest, mockery

My selfe for thee, that carest not.

$\mathrm{O}$ in extreme thou art most faire,

And in extreme vniust despaire

O that thou wert so pitifull

Thy crueltie maintaines: supports, fosters

Vnto these torments that doe pull My soule with senselesse paines,

As thou shew'st in that face of thine,

tug, wrench, as on a rack (hence 'torments') Where pitie and milde grace should shine.

If that thy faire and sweetest face

Assureth me both peace and grace,

Thy hard and cruell hart,

Which in that white brest thou dost beare,

Doth make me tremble yet for feare

Thou wilt not end my smart:

60

In contraries of such a kinde,

Tell me what succour shall I finde?

If then yoong Shepherdesse, thou craue

A herdsman for thy beast to haue,

With grace thou maist restore

Thy Shepherd from his barren loue:

For neuer other shalt thou prooue,

That seekes to please thee more,

And who, to serue thy turne, will never shunne

The nipping frost, and beames of parching sunne.

bring back, revive

find by trial

\section{Alexander Barclay Prologue to the Eclogues}

First published by P. Treveris with Eclogues 1-3 (c.1530), then in other editions; finally included with all five Eclogues in John Cawood's edition of Barclay's translation of Sebastian Brandt's The Ship of Fools (1570). This is the text followed here.

g The Prologe.

The famous Poetes with the Muses nine

With wit inspired, fresh, pregnant and diuine,

Say, boldly indite in stile substanciall:

full of meaning, weighty indited, written

Some in Poemes hye and heroicall,

Some them delite in heauy Tragedies,

And some in wanton or mery Comedies.

Some in Satyres against vices dare carpe,

(a) talk (b) criticize, find fault

29-32 Even if you cannot immediately grant me a kiss, your promise will make me hope you will do so later on. 30 by and by] immediately (OED by and by 3 ). 31 relent] (make you) pity me. 35-6 So even your jesting promise will content me. 39-40 shadow ...fauours] i.e., the mere promise of a kiss. 
Some in sweete songes accordant with the harpe.

And eche of these all had laude and excellence

After their reason and stile of eloquence.

Who in fayre speeche could briefly comprehende

Moste fruitfull matter, men did him moste commende.

And who were fruitlesse, and in speeche superflue,

Men by their writing scantly set a qu.

Therefore wise Poetes to sharpe and proue their wit,

In homely iestes wrote many a mery fit

Before they durst be of audacitie

Tauenture thinges of weyght and grauitie.

In this saide maner the famous Theocrite

First in Siracuse attempted for to write

Certayne Egloges or speeches pastorall,

Inducing Shepherdes, men homely and rurall,

Which in playne language, according to their name,

Had sundry talking, sometime of mirth and game,

Sometime of thinges more like to grauitie,

And not exceeding their small capacitie.

Most noble Virgill after him longe while

Wrote also Egloges after like manner stile,

His wittes prouing in matters pastorall,

Or he durst venture to stile heroicall.

And in like maner nowe lately in our dayes

Hath other Poetes attempted the same wayes:

As the moste famous Baptist Mantuan,

The best of that sort since Poetes first began.

And Frauncis Petrarke also in Italy

In like maner stile wrote playne and meryly.

What shall I speake of the father auncient,

Which in briefe language both playne and eloquent,

Betwene Alathea, Sewstis stoute and bolde

Hath made rehearsall of all the storyes olde,

By true historyes vs teaching to obiect

Against vayne fables of olde Gentiles sect.

Beside all these yet finde I many mo

Which haue employed their diligence also,

Betwene Shepherdes, as it were but a fable,

To write of matters both true and profitable.

But all their names I purpose not to write,

Which in this maner made bookes infinite.

Nowe to my purpose: their workes worthy fame

theme, subject

include, pack

excessive, verbose

cue, half a farthing

fytte, (a section of) a poem

courage, boldness (no bad sense)

to venture, attempt

introducing, bringing in

ere, before

refute, oppose

enlarged them endlessly

Dull slouth eschewing, myselfe to exercise

In such small matters, or I durst enterprise

To hyer matter, like as these children do,

Which first vse to creepe, and afterwarde to go.

The birde vnused first flying from her nest

Dare not aduenture, and is not bolde nor prest

With winges abroade to flye as doth the olde,

For vse and custome causeth all thing be bolde:

And little cunning by craft and exercise

To perfect science causeth a man to rise.

But or the Paynter can sure his craft attayne,

Much froward fashion transfourmeth he in vayne.

But rasing superflue, and adding that doth want,

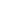


Rude picture is made both perfect and pleasant.

So where I in youth a certayne worke began,

And not concluded, as oft doth many a man:

Yet thought I after to make the same perfite,

But long I missed that which I first did write.

But here a wonder, I fortie yere saue twayne

Proceeded in age, founde my first youth agayne.

To find youth in age is a probleme diffuse,

But nowe heare the truth, and then no longer muse.

As I late turned olde bookes to and fro,

One little treatise I founde among the mo:

Because that in youth I did compile the same,

Egloges of youth I did call it by name.

And seeing some men haue in the same delite,

At their great instance I made the same perfite,

Adding and bating where I perceyued neede,

80 All them desiring which shall this treatise rede,

Not to be grieued with any playne sentence

Rudely conuayed for lacke of eloquence.

It were not fitting a heard or man rurall

To speake in termes gay and rhetoricall.

So teacheth Horace in arte of poetry,

That writers namely their reason should apply

Mete speeche appropring to euery personage,

After his estate, behauour, wit and age.

But if that any would nowe to me obiect

That this my labour shall be of small effect,

And to the Reader not greatly profitable,

And by that maner as vayne and reprouable,

Because it maketh onely relation

Of Shepherdes maner and disputation,

If any suche reade my treatise to the ende

He shall well perceyue, if he thereto intende,

That it conteyneth both laudes of vertue,

And man infourmeth misliuing to eschue,

With diuers bourdes and sentences morall,

Closed in shadowe of speeches pastorall,

As many Poetes (as I haue sayde beforne)

Haue vsed longe time before that I was borne.

But of their writing though I ensue the rate,

No name I chalenge of Poet laureate.

That name vnto them is mete and doth agree

Which writeth matters with curiositee.

Mine habite blacke accordeth not with grene,

Blacke betokeneth death, as it is dayly sene,

The grene is pleasour, freshe lust and jolite,

These two in nature hath great diuersitie.

Then who would ascribe, except he were a foole,

The pleasaunt lauret vnto the mourning cowle.

Another rewarde abideth my labour,

The glorious sight of God my sauiour,

Which is chiefe shepheard and head of other all,

To him for succour in this my worke I call,

And not on Clio nor olde Melpomene.

\author{
pleasing \\ complete \\ mislaid, could not find \\ hear; minus two, i.e. thirty-eight \\ uncertain, obscure \\ think, ponder \\ more, i.e. many others
}

deleting

'herd', herdsman

brilliant, charming

particularly; method, craft fit, suitable; assigning rank or station

narration, account

pay attention, consider carefully instructs misconduct, evil deeds jests, tales enclosed in the guise before

practised customarily follow the style

befitting, deserved

assign, bestow

awaits

76 Egloges] reviving the original meaning, 'selections'.

8o Desiring or requiring of all who may read this work. $\quad 85$ Horace] See Ars poetica 73-118. 94 disputation] ?discourse, conversation (OED 4 , only from Shakespeare). 104 Poet laureate] Not formally instituted in Barclay's day, though John Skelton assumed the title. Barclay seems to use the term in a general way. 106 curiositee] (a) care, skill (b) elegance, elaborate workmanship. 107 Mine habite blacke] as a Benedictine monk. Helps to date the poem, as Barclay later joined the Franciscans, who wore brown. $\mathbf{1 1 2}$ the pleasing or cheerful laurel crown upon the melancholy cowl (monk's hood). lauret] ?laurel crown: not in OED, but clearly so meant as contrast to the cowl. $\quad 117$ Clio, Melpomene] the Muses of history and tragedy respectively. Pastoral is valued above these grander genres owing to its association with Christ. 
My hope is fixed of him ayded to be

For to accomplishe my purpose and entent

To laude and pleasour of God omnipotent,

And to the profite, the pleasure and the mede

reward, satisfaction

Of all them which shall this treatise hear and rede.

But to the Reader nowe to returne agayne,

First of this thing I will thou be certayne,

That fiue Egloges this whole treatise doth holde,

To imitation of other Poetes olde.

In which Egloges shepheardes thou mayst see

In homely language not passing their degree,

Sometime disputing of courtly misery,

Sometime of Venus disceatfull tiranny,

exceeding their rank

Sometime commending loue honest and laudable,

Sometime despising loue false and deceyuable,

Sometime despising and blaming auarise,

Sometime exciting vertue to exercise,

Sometime of warre abhorring the outrage,

And of the same time the manifolde damage,

And other matters, as after shall appeare

To their great pleasure which shal them rede or heare.

\section{Alexander Barclay Eclogue I.175-304}

The opening (after Prologue and 'Argument') of Barclay's Eclogue I. Ecl. I-III are based on Aeneas Sylvius Piccolomini's non-pastoral work De curialium miseriis (On the Miseries of Courtiers), but this passage is Barclay's own pastoral addition. Ecl. I was first printed $c .1521$ in an edition surviving only in fragments. After three more editions of Ecl. I-III, all five Eclogues appeared in John Cawood's edition of Barclay's translation of The Ship of Fools (1570). Cawood's text followed here, with punctuation modified.

The first Egloge of the miseries and maners of the Court and Courtiers.

\section{Coridon first speaketh.}

Forsooth frende Cornix nought can my heart make light

When I remember the stormes of yester night.

The thunder and lightning, the tempest and the hayle

Hath playnely wasted our profite and auayle.

The fearefull thunder with greeuous clap and sounde

Our Corne hath beaten downe flat vnto the grounde,

With tempest after and violence of rayne

That it as I doubt shall neuer rise agayne.

The hayle hath beaten our shepe within the folde,

That all be febled as well the yong as olde,

Our milke is turned and woxen pale and soure,

The storme and tempest vpon our couches poure,

Our flocke and fieldes is all our whole riches,

Which still is subiect to suche vnhappines:

totally; auayle: profit

For after that we haue done both cost and payne,

One sodeyn tempest destroyeth all agayne.

Then farewel welfare, worse chance we nede not feare

Saue onely to sucke our clawes with the Beare.

The Citizens haue great treasour sikerly

In cofers closed auoyde of ieopardie,

Their coynes couched faste vnder locke and key,

From place to place they may the same conuay

When they of the theues perceiue the din and sounde:

But still must our corne remayne vpon the grounde,

Abiding stormes, hayle, thunder and tempest,

Till that it be for sikle ripe and prest.

129 courtly misery] The subject of the first three eclogues, based on the treatise De miseriis curialium by Aeneas Sylvius Piccolomini (Pope Pius II). 1 nought ... light] I cannot rest easy. 18 sucke our clawes] As the bear proverbially did when it had nothing to eat.

city-dwellers; securely free kept securely, hidden 
As for their riches no thunder, frost nor hayle,

No storme nor tempest can hurt or disauayle.

Suche carefull chaunces and such aduersitie

Us alway kepeth in wretched pouertie.

Cornix answereth.

O Coridon my mate I sweare so haue I blis,

Thou playnly speakest like as the matter is,

But as for my parte my minde and wit is blinde

s things really are

To knowe who gideth all wether, storme and winde,

But this thing I knowe, but yet not parfitely,

Yet bolde dare I be to speake to thee playnly,

For if that I spake it in some audience

Some men would maligne and take it for offence.

revile

If God (as men say) doth heauen and earth sustayne,

Then why doth not he regarde our dayly payne?

Our greeuous labour he iustly might deuide, causing grief or hardship; consider, examine

And for vs wretches some better life prouide.

Some nought doth labour and liueth pleasauntly,

Though all his reason to vices he apply:

But see with what sweat, what busines and payne

Our simple liuing we labour to obtayne:

Beholde what illes the shepheardes must endure

For flocke and housholde bare liuing to procure,

In feruent heate we muste intende our folde,

And in the winter almost we frese for colde:

burning, fiery; tend

Upon the harde ground or on the flintes browne

We slepe, when other lye on a bed of downe.

A thousand illes of daunger and sicknesse,

With diuers sores our beastes doth oppresse:

A thousande perils and mo if they were tolde

Dayly and nightly inuadeth our poore folde.

Sometime the wolfe our beastes doth deuour,

And sometime the thefe awayteth for his hour:

Or els the souldiour much worse then wolfe or thefe

60 Agaynst all our flocke inrageth with mischefe.

See howe my handes are with many a gall,

And stiffe as a borde by worke continuall,

My face all scoruy, my colour pale and wan,

My head all parched and blacke as any pan,

My beard like bristles, so that a pliant leeke

ingenuity, faculties, powers

With a little helpe may thrust me throw the cheeke,

And as a stockfishe wrinkled is my skinne,

Such is the profite that I by labour winne.

But this my labour should greue me much the lesse

If rest or pleasure came of my businesse:

But one sodayne storme of thunder, hayle or rayne,

Agayne all wasteth wherfore I toke this payne.

This is the rewarde, the dede and worke diuine,

Unto whose aulters poore shepheardes incline:

To offer tapers and candles we are fayne,

And for our offering, lo, this we haue agayne.

I can not declare what pitie and mercy

Wrappeth vs wretches in this harde misery,

But this wot I well, it is both right and mede,

80 There moste to succour where doth appeare most nede.

Coridon. Ho there frende Cornix, thou wadest nowe to farre,

Thy selfe forgetting thou leapest ouer the barre:

Smal is my knowledge, thou many a thing hast sene,

Yet out of the way forsoth I see thee clene

afflictions, ailments

sore, blister

scurfy, scabby

enfolds, overwhelms

fitting or deserving

go, advance

cross the limit

off course, on the wrong track

31 so haue I blis] as I may have happiness (in heaven) - i.e. be saved. 37 in some audience] ?among many people; ?among certain people. $\quad 65$ pliant leeke] presumably the stalk of the leek. $\quad 67$ stockfishe] fish split open and dried without salt, hence wrinkled. 
The king of heauen is mercifull and iust,

And them all helpeth which put in him their trust:

When we deserue he striketh not alway,

This in the pulpit I heart syr Peter say,

Yet ofte he striketh when man is obstinate,

And by no meanes will his misliuing hate:

So all these plages and inconuenience

Fales on vs wretches onely for our offence.

Cornix. For what offences? thou art mad so to say.

Were we of that sorte which did our Lorde betray,

Or that consented our Lorde to crucify?

We neuer were suche, thy selfe can testifie.

Coridon. Nowe trust me truly though thou be neuer so wroth,

I nought shall abashe to thee to say the troth:

Though we shepheardes be out of company,

Without occasion we liue vnhappely,

Seke well among vs and playnly thou shalt see

Theft, brauling, malice, discorde, iniquitie,

Wrath, lechery, leasing, enuy and couetise,

And briefly to speake, truely we want no vice.

Cornix. What, nay man pardie all we do not offence,

Yet all haue sorowe without all difference.

Say nought man but truth, do God nothing deserue

Without difference, yet be all like to sterue.

Coridon. What, ceasse man for shame, thou art of reason scant;

The wise nowe must learne wit of the ignoraunt:

I haue no knowledge saue onely of my tarre,

Yet this I perceaue, man should not seke to farre

flinch from, hesitate

justification, excuse

100

In Gods workes, he all doth for the best.

If thou findest here no easement, wealth ne rest,

What then, seke farther, for playnely so shall I,

In some place fortune beholdeth merily.

I bide no longer by saint Thomas of Kent

In suche bare places where euery day is Lent,

The frers haue store euery day of the weke,

But euery day our meat is for to seke.

I nought haue to bye, begge can I not for shame

Except that I were blinde, impotent or lame:

If suche a gadling as I should begge or craue

Of me suche mercy and pitie would men haue,

That they for almes (I sweare by Gods sockes)

In euery towne would make me scoure the stockes:

That can one Drome by many assayes tell,

With that ill science I purpose not to mell.

Here nothing I haue wherefore I nede to care,

Nowe Cornix adue, streight forwarde will I fare.

Cornix. Streight forwarde man, hei Benedicite,

All other people haue as great care as we,

Onely bare nede is all our payne and wo,

But these Towne dwellers haue many paynes mo.

Our payne is pleasour nere in comparison

Of their great illes and sore vexation.

Of all suche thinges haue I experience,

88 syr Peter] the local priest. Priests were commonly referred to as 'Sir'. 90 his misliuing hate] repent his sins. 97 though ... wroth] however angry it makes you. 99 out of company] ?not given to companionship: discontented, alienated. $\quad 107-8$ Even if you are completely virtuous, you will suffer and be destroyed like the rest. 108 sterue] starve, die $(O E D 1)$. 110 Facetiously alluding to himself as ignorant and Cornix as wise. $\quad \mathbf{1 1 1}$ tarre] tar, used to dress sheep's wounds. $\quad \mathbf{1 1 7}$ Thomas] Thomas Becket, of Canterbury in Kent. 118 Lent] when people eat sparsely to commemorate Christ's passion and death. $\mathbf{1 2 6}$ the stockes] penal instrument where petty offenders, including able-bodied vagabonds, were confined by their legs for public exposure and ridicule. 127 Drome] ?drone, idler, sluggard; ?slave or lowly person, from Dromo, a slave in Terence's The Self-Tormentor. 128 ill science] evil knowledge (of fraudulent begging). mell] meddle. 
Then mayst thou surely geue to me credence:

Whither wilt thou go to liue more quietly?

140 Man all the worlde is full of misery.

Coridon. What man, the court is freshe and full of ease,

I can drawe a bowe, I shall some lorde there please;

?lively, merry

Thy selfe can report howe I can birdes kill,

Mine arowe toucheth of them nothing but the bill;

I hurte no fleshe, nor bruse no parte at all,

Where not my shoting our liuing were but small:

Lo here a sparowe, lo here be thrushes four,

All these I killed this day within an hour.

I can daunce the raye, I can both pipe and sing,

150 If I were mery I can both hurle and sling,

I runne, I wrastle, I can well throwe the barre,

No shepheard throweth the axeltrie so farre,

If I were mery I could well leape and spring,

I were a man mete to serue a prince or king.

Wherfore to the Court nowe will I get me playne;

Adue swete Cornix, farewell yet once agayne,

Prouide for thyselfe, so shall I do for me.

Cornix. Do way Coridon, for Gods loue let be,

Nought els is the Court but euen the deuils mouth,

And place most carefull of East, west, north and south:

For thy longe seruice there nede shall be thy hyre,

Out of the water thou leapest into the fyre.

We liue in sorowe I will it not deny,

But in the Court is the well of misery.

Coridon. What man, thou seest, and in likewise see I,

That lusty courtiers go always iolily,

They haue no labour yet are they wel besene,

Barded and garded in pleasaunt white and grene,

They do nought els but reuell, slepe and drinke,

But on his foldes the poore shepheard muste thinke.

They rest, we labour, they gayly decked be

While we go ragged in nede and pouertie,

Their colour lustie, they bide no storme nor shours,

They haue the pleasoures, but all the paynes are ours,

They haue all thinges, but we wretches haue nought,

They sing, they daunce, while we sore sigh for thought.

But what bringeth them to this prosperitie,

Strength, courage, frendes, crafte and audacitie.

If I had frendes I haue all thing beside,

180 Which might in court a rowme for me prouide.

But sith courtiers haue this life continually,

They haue all pleasour and nought of misery.

Cornix. Not so Coridon, oft vnder yelowe lockes

Be hid foule scabbes and fearefull French pockes,

Their reuilde shirtes of cloth white, soft and thin

Ofte time cloketh a foule and scoruy skin.

And where we labour in workes profitable,

They labour sorer in worke abhominable.

They may haue shame to iet so vp and downe

play at hurling; wield the sling

dance
fit
directly, straight

leave off, stop talking

full of cares

source, spring

turned out, (good) to look at

When they be debtours for dublet, hose and gowne,

strut

$146 \mathrm{My}$ family could not survive if I did not shoot birds for food. 149 raye] 'a kind of round dance' $\left(O E D\right.$ ray $\left.\mathrm{n}^{8}\right) . \quad 151$ throwe the barre] a country sport. 152 axeltrie] axle-tree: axle or wheel-shaft of a cart, thrown as a country sport. $\quad \mathbf{1 6 1}$ nede ... hyre] Want or poverty will be your wages. $\quad \mathbf{1 6 2}$ water ... fyre] Barclay takes the fish's poverbial leap another stage back, not from the frying-pan but from the very water into the fire: Cornix will move from his native element, where he can survive, into destruction. 168 Barded] caparisoned, dressed (literally in bards, an article of armour). garded] ?girded. 'Barded and garded' is obviously a set phrase. 184 French pockes] pox, caused by venereal disease. 185 reuilde] rivelled, 'pleated or gathered in small folds' $(O E D) . \quad 190$ debtours] Courtiers notoriously incurred debts for their finery. 
And in the tauerne remayne they last for lag,

are the last to leave

When neuer a crosse is in their courtly bag.

They crake, they boste, and vaunt as they were wood, mad

And moste when they sit in midst of others good.

Nought haue they fooles but care and misery,

Who hath it proued all courting shall defy.

Coridon. Mary syr by this I see by experience

That thou in the Court hast kept some residence.

\section{Alexander Barclay Eclogue iII.455-524}

Published with Eclogues I-II by John Treveris (c.1530) and others; then included with the other four Eclogues in John Cawood's edition of Barclay's translation of Brandt's The Ship of Fools (1570). Cawood's text followed here, with punctuation modified.

Coridon. Because thou recountest of thy fidelitie,

Of masters and men which loueth honestie,

Nowe I remember the shepheard of the fen,

And what care for him demeaned all his men.

exhibited

And shepheard Morton when he durst not appeare,

Howe his olde seruauntes were carefull of his chere.

In payne and pleasour they kept fidelitie,

Till grace agayne gaue him aucthoritie.

Then his olde fauour did them agayne restore

To greater pleasour then they had payne before.

Though for a season this shepheard bode a blast,

The greatest winde yet slaketh at the last,

And at conclusion he and his flocke certayne

Eche true to other did quietly remayne.

My harte sore mourneth when I must specify

Of the gentle Cocke whiche sange so mirily,

$\mathrm{He}$ and his flocke were like an vnion,

Conioyned in one without discention.

All the fayre Cockes which in his dayes crewe

When death him touched did his departing rewe.

The pretie palace by him made in the fen,

The maides, widowes, the wiues and the men,

With deadly dolour were pearsed to the heart

When death constrayned this shepheard to departe.

Corne, grasse and fieldes mourned for wo and payne,

For oft his prayer for them obtayned rayne.

The pleasaunt floures for wo faded eche one,

When they perceyued this shepheard dead and gone,

The okes, elmes and euery sorte of dere

Shronke vnder shadowes, abating all their chere.

The mightie walles of Ely monastery,

The stones, rockes, and towres semblably,

The marble pillers and images echeone,

suffered, endured; storm

Swet all for sorowe when this good cocke was gone.

Though he of stature were humble, weake and leane,

His minde was hye, his liuing pure and cleane.

Where other feedeth by beastly appetite,

191-2 They linger longest in the tavern although they do not have money to pay the tally. crosse] coin, money (then often stamped with a cross). 193 crake] over-eat, hence indulge themselves, ?puff themselves up. 194 When they have to hold their own against other prosperous or successful people. $196 \mathrm{He}$ who has tested (proued) or experienced this will condemn all courtly life. 3 shepherd of the fen] John Morton, Bishop of Ely 1479-1486, then Archbishop of Canterbury. Initiated the first attempts to drain the fens. 5-14 Morton was imprisoned by Richard III for supporting the Lancastrians, but returned to favour as a principal adviser of Henry VII. $\mathbf{6}$ careful ... cheer] assiduous about his comfort and well-being. $\quad \mathbf{1 6}$ the gentle Cocke] punning reference to John Alcock, Bishop of Ely 1486-1500. 19 Cockes] applied to leaders of men, especially priests $\left(O E D \operatorname{cock}^{1} 6,7\right)$. 21 palace] Alcock built much of the Bishop's palace at Ely. $\quad 29$ deer] animal $\left(O E D_{1}\right) . \quad 34$ Swet] sweated, suffered; but also literally exuded moisture like stone in a damp atmosphere. 
On heauenly foode was all his whole delite.

And shortly after this Cocke was dead and gone

The shepheard Roger could not bide long alone,

But shortly after false death stole him away,

His worthy reporte yet liueth till this day.

When shepe wer scabbed this good shepherd was fayne

With easie salues their sores to cure agayne.

He nought pretended nor shewed of rigour,

Nor was no wolfe poore lambes to deuour.

When bushe or brambles pilled the shepes skin,

Then had he pitie and kept them close within,

Or in newe fleces did tenderly them lap,

disposed, diligent

50 And with his skirtes did oftentime them hap.

peeled, tore

The fouldes sounded with dolour and complaynt,

So that their clamour and crye bespred the yle,

His death was mourned from Ely forty mile.

These worthy heardes and many other mo

Were with their wethers in loue conioyned so,

That more they cured by witte and pacience,

Then dreadfull drome can do with violence.

Therfore all heardes vnto the wolde I trowe

Should laude their names if vertue reigned nowe,

But sith that cunning and vertue nere be gone,

Nowe be they lauded forsooth of fewe or none.

I let thy purpose: to make conclusion,

Vice liueth, vertue hath light obliuion.

But speake on Cornix, yet is it long to night,

My mind to disclose causeth my heart be light.

Cornix. To laude these pastours wherfore haste thou delite?

Coridon. All other shepheardes to vertue to excite.

\section{Alexander Barclay Eclogue iv.37-66, 93-232}

First published by Pynson as The Boke of Codrus and Mynalcas (1521), then included with the other four Eclogues in John Cawood's edition of Barclay's translation of Brandt's The Ship of Fools (1570). Cawood's text followed, with punctuation modified. This eclogue incorporates an expanded translation of Mantuan's Eclogue V, where the shepherds are named Sylvanus and Candidus. In the extract below, lines 4-10, 83-122, 141-70 follow Mantuan.

Codrus first speaketh.

Al hayle Minalcas, nowe by my fayth well met.

Lorde Jesu mercy, what troubles did thee let,

That this long season none could thee here espy?

hinder, impede

With vs was thou wont to sing full merily,

And to lye piping oftetime among the floures,

What time thy beastes were feding among ours.

In these olde valleys we two were wont to bourde,

And in these shadowes talke many a mery worde,

forest, field, countryside: a broad term; [trowe: believe, think learning

impede, interrupt

And oft were we wont to wrastle for a fall,

But nowe thou droupest and hast forgotten all.

Here wast thou wont swete balades to sing,

Of song and ditte as it were for a king,

And of gay matters to sing and to endite,

But nowe thy courage is gone and thy delite.

in both words and tune

spirit, liveliness

4o Roger] Roger Westminster, sacrist and Prior of Ely Cathedral. 45 pretended] (a) deceived (b) plotted, conspired $(O E D$ 13). $\quad 53$ isle] The Isle of Ely, then literally an island among the fens. $\quad \mathbf{5 8}$ drome] Other editions have Dromo. Cf. 26.127 n. Also, drome] drum, hence ?noisy and disorderly behaviour. Perhaps a reference to James Stanley, Bishop of Ely 1506-15, notorious for his roistering ways. $\quad 63$ I let thy purpose] interrupt your discourse. Coridon's speech, added by Barclay, interrupts Cornix's discourse on the evils of court life, rendered from Aeneas Silvius Piccolomini (see headnote to no.26). $\quad 64$ hath light oblivion] is easily forgotten. 
Trust me Minalcas nowe playnly I espy

That thou art wery of shepheardes company,

And that all pleasour thou semest to despise,

Lothing our pasture and fieldes in likewise.

Thou fleest solace and euery mery fitte,

Leasing thy time and sore hurting thy witte,

In sloth thou slombrest as buried were thy song,

Thy pipe is broken or somwhat els is wrong.

Minalcas. What time the Cuckowes fethers mout and fall, moult

From sight she lurketh, hir song is gone withall.

When backe is bare and purse of coyne is light,

The wit is dulled and reason hath no might:

Adewe enditing when gone is libertie,

Enemie to Muses is wretched pouertie.

What time a knight is subiect to a knaue

To just or tourney small pleasour shall he haue.

equally
entertainment, recreation;

[poem or piece of music

losing, wasting

hides

farewell to writing

joust

30

go in

almost

Seest thou not Codrus the fieldes rounde about

Compassed with floudes that none may in nor out.

The muddy waters nere choke me with the stinke,

At euery tempest they be as blacke as inke:

Pouertie to me should be no discomforte

If other shepheardes were all of the same sorte.

But Codrus I clawe oft where it doth not itche,

To see ten beggers and halfe a dosen riche.

Truely me thinketh this wrong pertition,

And namely sith all ought be after one.

When I first behelde these fieldes from a farre,

Me thought them pleasant and voyde of strife or warre,

But with my poore flocke approching nere and nere

Alway my pleasour did lesse and lesse appeare,

And truely Codrus since I came on this grounde

Oft vnder floures vile snakes haue I founde.

Adders and todes and many fell serpent

Infecte olde shepe with venim violent,

And ofte be the yonge infected of the olde,

That vnto these fewe nowe brought is all my folde.

Codrus. In some place is neyther venim nor serpent,

And as for my selfe I fele no greuous sent.

Minalcas. It were great maruell where so great grounde is sene,

If no small medowe were pleasaunt, swete and clene.

As for thee Codrus I may beleue right weele,

That thou no sauour nor stinke of mud dost feele,

For if a shepheard hath still remayned longe

In a foule prison or in a stinking gonge,

His pores with ill ayre be stopped so echeone

That of the ayre he feleth small sent or none.

And yet the dwellers be badder than the place,

The rich and sturdie doth threaten and manace

The poore and simple and suche as came but late,

And who moste knoweth, him moste of all they hate,

And all the burthen is on the Asses backe,

But the stronge Caball standeth at the racke.

And suche be assigned sometime the flocke to kepe

Which scant haue so muche of reason as the shepe,

And euery shepheard at other hath enuy, scratch

division, distribution (of wealth)

the closer I came

dangerous, deadly

scent

latrine, privy each one

29 When one is dominated or outvied by one's inferiors. $\quad 37$ clawe ... itche] ?I feel indignant even though I am not directly harmed. $\quad 40$ Especially as it should be the same for everyone. 47 serpent] Plural use not recorded in OED. $\quad 52$ greuous] 'offensive to the senses' (OED 2c). 64 who moste knoweth] the most capable or knowledgeable. 65-6 The horse stands idly and is fed, while the ass bears all the burden. 66 Caball] horse (Lat. caballus). racke] a frame containing fodder. 
Scant be a couple which loueth perfitely,

Ill will so reygneth that brauling, be thou sure,

Constrayned me nere to seke a newe pasture,

Saue onely after I hope of better rest:

For small occasion a birde not chaungeth nest.

Codrus. Welere thou graunted that in a large grounde

Some plot of pleasour and quiet may be founde,

So where of heardes assembled is great sorte,

There some must be good, then to the best resorte.

But leaue we all this, turne to our poynt agayne,

Of thy olde balades some would I heare full fayne,

For often haue I had great pleasour and delite

strife, conflict

almost

Except that later on; relief, repose

light cause

?whilere, a short while ago

shepherds

willingly, eagerly

To heare recounted suche as thou did endite.

Minalcas. Yea, other shepheardes which haue inough at home,

When ye be mery and stuffed is your wombe,

Which haue great store of butter, chese and woll,

Your cowes others of milke replete and full,

Payles of swete milke as full as they be able,

When your fat dishes smoke hote vpon your table,

Then laude ye songes and balades magnifie,

If they be mery or written craftily:

Ye clappe your handes and to the making harke,

And one say to other, lo here a proper warke.

But when ye haue saide, nought geue ye for our payne,

Saue onely laudes and pleasaunt wordes vayne,

All if these laudes may well be counted good,

Yet the poore shepheard must haue some other food.

Codrus. Mayst thou not sometime thy folde and shepe apply,

And after at leasour to liue more quietly,

Dispose thy wittes to make or to endite,

Renouncing cures for time while thou dost write.

Minalcas. Nedes must a Shepheard bestowe his whole labour

In tending his flockes, scant may he spare one houre:

In going, comming, and often them to tende,

Full lightly the day is brought vnto an ende.

Sometime the wolues with dogges must he chace,

Sometime his foldes must he newe compace:

And oft time them chaunge, and if he stormes doubt,

Of his shepecote dawbe the walles round about:

When they be broken, oft times them renue,

And hurtfull pastures note well, and them eschue.

Bye strawe and litter, and hay for winter colde,

Oft grease the scabbes aswell of yonge as olde,

For dreade of thieues oft watche vp all the night.

Beside this labour with all his minde and might,

For his poore housholde for to prouide vitayle,

If by aduenture his wooll or lambes fayle.

In doing all these no respite doth remayne,

But well to indite requireth all the brayne.

I tell thee Codrus, a stile of excellence stomach, belly

udders

as they can be

abundant, rich

praise highly

skilfully, expertly

poetry

work

finished speaking

although

address, deal with

assign; compose poetry

cares, duties

swiftly

erect new fencing

fear (the coming of)

repair, rebuild

avoid

family; victuals, food chance, luck

almost unbearable

Both these two workes be great, nere importable

73 rest] ?peace, repose; ?outcome, conclusion (the 'rest' or remainder). 77 sorte] (a) variety (b) band, company (OED sort $\mathrm{n}^{2} 17$ ) 97-100 i.e., Could you not divide your time between poetry and sheepkeeping? $\quad 100$ for time while] during the time that. 106 compace] compass, fence round. 108 dawbe] plaster with clay or mud (OED daub, citing this passage). 11o hurtfull] harmful (because of poisoned or contaminated grass). $\quad 111$ litter] straw lining the floor of the shed where animals are kept in winter. 115-16 Do other work to support his family if he cannot sell wool or meat. 
To my small power, my strength is muche vnable.

The one to intende scant may I bide the payne,

Then is it harder for me to do both twayne.

attend to, carry out strain, labour

What time my wittes be clere for to indite,

My dayly charges will graunt me no respite:

But if I folowe, inditing at my will,

Eche one disdayneth my charges to fulfill.

Though in these fieldes eche other ought sustayne,

Cleane lost is that lawe, one may require in vayne:

If coyne commaunde, then men count them as bounde,

Els flee they labour, then is my charge on grounde.

Codrus. Cornix oft counted that man should flee no payne,

His frendes burthen to supporte and sustayne:

Feede they thy flocke, while thou doest write and sing.

Each horse agreeth not well for euery thing.

Some for the charet, some for the cart or plough,

And some for hakneyes, if they be light and tough.

Each fielde agreeth not well for euery seede,

Who hath moste labour is worthy of best mede.

Minalcas. After inditing then gladly would I drinke,

To reache me the cup no man doth care ne thinke:

And oft some fooles voyde of discretion

$\mathrm{Me}$ and my matters haue in derision.

And meruayle is none, for who would sowe that fielde

With costly seedes, which shall no fruites yelde.

Some wanton body oft laugheth me to scorne,

And saith: Minalcas, see howe thy pilche is torne,

Thy hose and cokers be broken at the knee,

Thou canst not stumble, for both thy shone may see.

Thy beard like bristels, or like a porpos skin,

Thy cloathing sheweth, thy winning is but thin:

Such mocking tauntes renueth oft my care,

And nowe be woods of fruit and leaues bare,

And frostie winter hath made the fieldes white,

For wrath and anger my lip and tonge I bite:

For dolour I droupe, sore vexed with disdayne,

My wombe all wasteth, wherfore I bide this payne:

My wooll and wethers may scarsly feede my wombe,

And other housholde which I retayne at home.

Leane be my lambes, that no man will them bye,

ask, request

work, task; aground, frustrated thought, observed; [spare no trouble

coach or carriage horses for ordinary riding

reward

affairs, worldly situation this is no wonder

jesting or waggish person a coarse outer garment cockers, a kind of legging

porpoise earning

And yet their dammes they dayly sucke so dry,

That from the others no licuore can we wring,

Then without repast who can indite or sing.

It me repenteth, if I haue any wit,

As for my science, I wery am of it.

And of my poore life I weary am, Codrus;

Sith my harde fortune for me disposeth thus,

That of the starres and planettes eche one

To poore Minalcas well fortunate is none.

auspicious, lucky

127-8 If I take time off to write poetry, no-one else will do my work for me. $\quad \mathbf{1 3 1}$ People feel obliged to perform a task only if they are paid for it. 136 i.e. Everyone cannot do everything equally well. 150 A standard joke about holes or 'eyes' in the shoes. 157 disdayne] probably directed at rather than felt by him. 159-60 my wombe ... at home] my own stomach, let alone those of my family. 


\section{9 'OH! SHEPHERD, OH! SHEPHERD'}

One of the few authentic surviving 16 th-cent. folk-songs. ${ }^{*}$ The text follows the modern-spelling version in the Journal of the Folk-Song Society 3, 1907, as 'Sung by Mrs Davis, at Dorchester, Dec., 1906'. There is a very different Scottish version. $\dagger$ The tune is a version of the celebrated 'Greensleeves'.

'Oh! shepherd, oh! shepherd, will you come home, Will you come home, will you come home?

Oh! shepherd, oh! shepherd, will you come home To your breakfast this morning? Oh! morning.'

'What have you got for my breakfast, For my breakfast, for my breakfast?

What have you got for my breakfast, If I do come home this morning?'

'Bacon and eggs, a belly-full, A belly-full, a belly-full,

Bacon and eggs, a belly-full, If you do come home this morning.'

'My sheep they are all in the wilderness, The wilderness, the wilderness,

My sheep they're all in the wilderness, So I cannot come home this morning.'

'Oh! shepherd, oh! shepherd, will you come home, Will you come home, will you come home?

Oh! shepherd, oh! shepherd, will you come home To your dinner this morning?'

'What have you got for my dinner, For my dinner, for my dinner?

What have you got for my dinner, If I do come home this morning?'

'Pudding and beef, a belly-full, A belly-full, a belly-full,

Pudding and beef, a belly-full, If you do come home this morning.'

'My sheep they're all in the wilderness, The wilderness, the wilderness,

My sheep they're all in the wilderness, So I cannot come home this morning.'

'Oh! shepherd, oh! shepherd, will you come home, Will you come home, will you come home?

Oh! shepherd, oh! shepherd, will you come home To your supper to-night?'

'What have you got for my supper, For my supper, for my supper?

What have you got for my supper, If I do come home to-night?'

'Bread and cheese, a belly-full, A belly-full, a belly-full,

Bread and cheese, a belly-full, If you do come home to-night.'

'My sheep they're all in the wilderness,

\footnotetext{
${ }^{*}$ See C. R. Baskerevill, Modern Philology 14, 1916, p.247 n.1. †Beginning 'The shepherd's wife cries o'er the lee': see David Herd, Ancient and Modern Scottish Songs, Heroic Ballads, etc. (Edinburgh: John Wotherspoon for James Dickson and Charles Elliot, 1776), II.182-3. This was 'condensed and purified ..., so as to fit it for modern society' in Robert Chambers, The Songs of Scotland Prior to Burns (Edinburgh: W. \& R. Chambers, 1862), pp.402-3. 41, 43 Bread and cheese] 'Basin of broth' given as an alternative
} in both lines. 
The wilderness, the wilderness,

My sheep they're all in the wilderness,

So I cannot come home to-night.'

'Oh! shepherd, oh! shepherd, will you come home,

Will you come home, will you come home?

Oh! shepherd, oh! shepherd will you come home

To your lodging to-night?'

'What have you got for my lodging,

For my lodging, for my lodging?

What have you got for my lodging, If I do come home to-night?

'Oh! your house is clean swept, and your true love's there, Your true love's there, your true love's there,

Oh! your house is clean swept, and your true love's here,

If you do come home tonight.'

'Oh! I'll drive my sheep out of the wilderness,

The wilderness, the wilderness,

I'll drive my sheep out of the wilderness,

And I will come home tonight.'

\section{0 'Hey, TROLY LOLY LO, MAID, WHither Go YOU?'}

From BL MS. Addl.31922, where each stanza is repeated with variations, often more than once. In the text below, each stanza is given only once, in the fullest form. Variant refrains noted. Punctuation and line initials regularized. A typical pastourelle, of the subgroup where the woman escapes the man's clutches. Elsewhere, she may succumb; or (as in 'Where are you going to, my pretty maid?', now a nursery rhyme) dismiss the unwelcome wooer more aggressively.

Hey troly loly lo mayde whether go you?

I go to the medow to mylke my Cowe.

Then at the medow I wyll you mete

to gather the flourys both fayr and swete.

Nay god for bede that may not be.

I wysse my mother then shall vs se.

forbid

iwis: certainly, assuredly

Now in this medow fayer and grene we may vs sportt and nott be sene and yf ye wyll I shall consent.

How sey you mayde be you content?

Nay in goode feyth I wyll not melle with you.

I pray you sir lett me go mylke my cow.

Why wyll ye not geve me no comforte

that in the feldes we may vs sportt?

Nay god for bede that may not be.

I wysse my mothyr then shall vs se.

Ye be so nyce and so mete of age

that ye gretly move my corage.

Syth I loue you love me agayne,

of the right age

heart

let vs make one though we be twayne.

since

I pray you sir let me go mylk my cowe.

[Also repeated with a different refrain:

'Nay in goode feyth I wyll not mell with you $v t$ supra']

Ye haue my hert sey what ye wyll

Wherefore ye muste my mynde fulfyll

and graunte me here your maydynhed

or elles I shall for you be ded.

1 Hey, troly loly lo!] As Chambers and Sidgwick point out (Early English Lyrics, p.339), this is 'properly a refrain, although not here so used'. 11 melle] meddle, engage with. 17 nyce] delightful, attractive (OED 14c) 23 vt supra] ut supra, as above. 
I pray you sir let me $v t$ supra.

\section{[Also repeated with a different refrain:}

'Nay in goode feyth I wyll not mell with you $v t$ supra']

Then for this onse I shal you spare.

but the nexte tyme ye muste be ware

how in the medow ye mylke your Cow.

A dew ffare well and kysse me now.

I pray you sir let me $v t$ supra.

\section{[Also repeated with a different refrain:}

'Nay in goode feyth I wyll not mell with you $v t$ supra']

\section{Harpelus' Complaint}

First published in Songs and Sonnets (Tottel's Miscellany), 1557. Reprinted in all subsequent editions, and in Helicon, where it is attributed without warrant to 'L. T. [sic] Howard, Earl of Surrey'. The text below is from Tottel's first issue.

Harpelus complaynt of Phillidaes loue bestowed on Corin, who loued her not and denied him, that loued her.

Phylida was a fayer mayde, And fresh as any flowre:

Whom Harpalus the herdman prayed

To be his paramour. Harpalus and eke Corin

Were herdmen both yfere:

And Phillida could twist and spin

And therto sing full clere.

also

together

thread or yarn

But Phillida was all to coy

For Harpelus to winne

For Corin was her onely ioye,

Who forst her not a pynne.

How often would she flowers twine

forced: cared for, regarded

How often garlandes make:

Of Couslippes and of Colombine,

And all for Corins sake.

But Corin he had haukes to lure

And forced more the field:

Of louers lawe he toke no cure

For once he was begilde.

Harpalus preualed nought,

His labour all was lost:

For he was fardest from her thought

And yet he loued her most.

Therefore waxt he both pale and leane

And drye as clot of clay:

His fleshe it was consumed cleane,

His colour gone away.

His beard it had not long be shaue,

His heare hong all vnkempt:

A man most fitte euen for the graue

Whom spitefull loue had spent.

His eyes were red and all forewatched,

His face besprent with teares:

It semde vnhap had him long hatched,

preferred the (hunting) field care, heed

In middes of his dispayres.

His clothes were blacke and also bare,

As one forlorne was he:

$\mathbf{1 7}$ lure] call or train a hawk with a 'lure', a device of feathers attached to a long cord or thong. 20 because he had once been deceived in love. $\quad 33$ forewatched] ?sleepless (from keeping watch at night): not in $O E D . \quad 36$ hatched] lined his face (OED hatch, $v^{2} 3$, citing this passage). 
Upon his head alwaies he ware

A wreath of wilow tree.

His beastes he kept vpon the hyll,

And he sate in the dale:

And thus with sighes and sorowes shryll,

He gan to tell his tale.

O Harpelus, thus would he say,

Unhappiest vnder sunne:

The cause of thine vnhappy day

By loue was first begone.

For thou wentest first by sute to seeke

A Tygre to make tame:

period of life

That sets not by thy loue a leke

But makes thy grefe her game.

As easye it were, for to conuert

The frost into the flame:

As for to turne a froward hert

Whom thou so fain wouldst frame.

Corin he liueth carelesse,

He leapes among the leaues:

He eates the frutes of thy redresse:

Thou reapes, he takes the sheaues.

My beastes, a while your fode refrayne

And herken your herdmans sounde:

Whom spitefull loue alas hath slaine

Throughgirt with many a wounde.

O happy be ye beastes wilde

That here your pasture takes:

I se that ye be not begylde

Of these your faythfull makes.

The Hart he fedeth by the Hynde,

The Bucke hard by the Doo,

The Turtle Doue is not vnkinde

To him that loues her so.

The Ewe she hath by her the Ramme,

The yong Cow hath the Bulle:

The calf with many a lusty lamme

Do feede their honger full.

But wellaway that nature wrought

Thee Phillida so faire:

For I may say that I haue bought

Thy beauty all to deare.

What reason is it that cruelty

With beauty should haue part,

Or els that such great tyranny

Should dwell in womans hart?

I see therfore to shape my death

She cruelly is prest:

To thend that I may want my breathe

My dayes been at the best.

O Cupide graunt this my request

And do not stoppe thine eares:

That she may fele within her brest

The paynes of my dispayres.

Of Corin that is carelesse

That she may craue her fee:

contrary, adverse
shape or dispose (favourably)

malevolent

struck through, pierced

cheated, deceived

intent, eager; ?ready the end

41-2 conventional sign of a neglectful shepherd. Cf. 18.30-32. 49 by sute] ? of your own seeking; ?through pleading or supplication (suit). $\quad 62$ herken] Later edd. of Tottel, as well as Helicon, have hark $(e)$, which scans more smoothly. $\mathbf{6 5}$ beastes] The metre calls for the second $e$ to be pronounced, though Helicon regularizes to beasts. $\quad \mathbf{6 8}$ makes] mates, companions. $\quad \mathbf{8 1}$ is it] Tottel 1585 has is that, and Helicon is't, which make for smoother scansion. 87-8 ?My prime of life has only led to my death; ?The best outcome of my life has been to die. 92 ?the punishment for (having caused) my suffering (paynes, punishment, OED pain $\mathrm{n}^{1} 1$ ); ?the pain I have suffered. 
As I haue done in great distresse

That loued her faythfully.

But sins that I shall die her slaue,

Her slaue and eke her thrall:

Write you my frendes, vpon my graue

100

This chance that is befall.

befallen

Here lieth vnhappy Harpelus

Whom cruell loue hath slayne:

By Phillida vniustly thus

Murdred with false disdaine.

\section{Barnabe Googe Eclogue iI: Dametas}

From Googe's Eglogs, Epytaphes and Sonettes (1563). Line-initial capitals regularized.

Egloga secunda.

Dametas.

My beasts, go fede vpon the plaine, and let your herdman lye,

Thou seest her mind, and fearst thou nowe, Dametas for to dye?

Why stayest thou thus? why doste thou stay? thy life to longe doth laste:

Accounte this flud thy fatall graue, syth time of hope is paste.

river (where he will drown himself)

What meanst thou thus to linger on? thy life wolde fayne departe,

Alas: the wounde doth fester styll, of cursed Cupids darte.

No salue but this, can helpe thy sore, no thynge can moue her minde.

She hath decreed that thou shalt dye, no helpe there is to finde.

Nowe syth there is no other helpe, nor ought but this to trye,

Thou seest her mind: why fearste thou than Dametas for to dye?

Long hast thou serued, and serued true, but all alas, in vayne,

For she thy seruyce nought estemes, but deales the griefe for gayne.

For thy good wyll, (a gay rewarde) Disdayne, for Loue she gyues,

Thou louest her while thy life doth last, she hates the, wile she liues.

Thou flamste, when as thou seest her face with Heate of hye desyre,

She flames agayne, but how? (alas) with depe disdaynfull Ire.

The greatest pleasure is to the, to se her voyde of Payne,

The greatest gryefe to her agayne, to se thy Health remayne.

Thou couetste euer her to fynde, she sekes from the to flye,

desire

Thou seest her mynd, why fearst thou than Dametas for to dye?

Doste thou accounte it best to kepe thy lyfe in sorowes styll?

104 false] Obviously 'treacherous', not 'pretended': Phillida's disdain for Harpelus seems entirely genuine. 
Or thynkste thou best it now to lyue, contrarye to her wyll?

Thynkste thou thy lyfe for to retaine? when she is not content,

Canste thou addicte thy selfe to lyue? devote, apply and she to murder bent.

Doste thou entende agayne, to sewe for mercye at her handes?

As soone thou mayst go plow the rocks, and reape vpon the Sandes.

Draw nere O mighty Herd of beasts syth no man els is bye,

Your Herdman longe that hathe you kept, Dametas nowe must dye.

Resolue your Brutisshe eies to teares and all togyther crye,

Bewayle the wofull ende of Loue, Dametas now must dye.

My pleasaunt Songs, nowe shall you here no more on Mountaines hye,

I leaue you all, I must be gone. Dametas nowe must dye:

To Titirus I you resyne, in Pasture good to lye,

For Titirus shall kepe you thoughe Dametas nowe must dye.

O cursed Cause, that hath me slayne, my trothe alas to trye,

since

animal (no pejorative sense)

O Shephardes all, be Wytnesses, Dametas here doth dye.

33 Torquato Tasso golden Age Chorus

Translated from the Italian by Samuel Daniel.

A chorus from Act I of Tasso's pastoral play Aminta (1573). Trans. first published in Daniel's Works ... Newly augmented (1601), after the sonnet sequence Delia. A fairly close rendering, going by general sense rather than detail.

A Pastorall.

O Happie golden Age,

Not for that riuers ranne

With streames of milke, and hunny dropt from trees,

Not that the earth did gage

pledge, promise

Vnto the husband-man

Her voluntary frutes, free without fees:

Not for no cold did freeze,

Nor any cloud beguile,

Theternall flowring Spring

Wherein liu'd euery thing,

And whereon th'heauens perpetually did smile,

Not for no ship had brought

From forraine shores, or warres or wares ill sought.

But onely for that name,

That Idle name of winde:

That Idoll of deceit, that emptie sound

Call'd Honor, which became

2-13 An extended example of the figure paraleipsis, or saying something while formally declining to do so. 6 Daniel omits Tasso's next detail, that snakes were then without venom. voluntary] brought forth spontaneously, without cultivation: a classic feature of the Golden Age (Virgil IV.28; Ovid, Met. I.101-2). Linked to man's state before the Fall, when he did not have to 'eat bread' by 'the sweat of [his] face' (Genesis 3.19). 12-13 Another feature of the Golden Age: absence of navigation for either trade or conquest. (Virgil IV 38-9; Ovid, Met. I.94-6). 15 name of winde] a mere word, a breath. A classic premiss of Renaissance language theory. (See Shakespeare, 1 Henry IV 5.1.133-5.) nta Chaudhür - 9781526143426 charges, price

either... or 
The tyran of the minde:

And so torments our Nature without ground,

Was not yet vainly found:

reason

Nor yet sad griefes imparts

uselessly, without profit

Amidst the sweet delights

Of joyfull amorous wights.

Nor were his hard lawes knowne to free-borne harts.

But golden lawes like these

Which Nature wrote. That's lawfull which doth please.

Then amongst flowres and springs

Making delightfull sport,

Sat Louers without conflict, without flame,

Mixing in wanton sort

Whisprings with Songs, then kisses with the same

Which from affection came:

The naked virgin then

Her Roses fresh reueales,

Which now her vayle conceales,

The tender Apples in her bosome seene.

And oft in Riuers cleere

The Louers with their Loues consorting were.

Honor, thou first didst close

The spring of all delight:

Denying water to the amorous thirst

Thou taught'st faire eyes to lose

The glorie of their light,

Restrain'd from men, and on themselues reuerst.

Thou in a lawne didst first

Those golden haires incase,

Late spred vnto the winde;

Thou mad'st loose grace vnkinde,

Gau'st bridle to their words, art to their pace.

O Honor it is thou

That mak'st that stealth, which loue doth free allow.

It is thy worke that brings

Our griefes and torments thus:

But thou fierce Lord of Nature and of Loue,

The quallifier of Kings,

What doest thou here with vs

That are below thy power, shut from aboue?

Goe and from vs remoue,

Trouble the mighties sleepe,

Let vs neglected, base,

Liue still without thy grace,

And th'vse of thauncient happie ages keepe,

Let's loue, this life of ours

Can make no truce with time that all deuours.

lately, a short time ago

$$
\begin{aligned}
& \text { Let's loue: the sun doth set and rise againe, } \\
& \text { But when as our short light } \\
& \text { Comes once to set, it makes eternall night. }
\end{aligned}
$$

$\mathbf{1 8}$ tyran] tyrant: common (and etymologically authentic) variant. 21 imparts] that which is imparted or bestowed by grief. $\quad 26$ That's lawfull which doth please] The basic principle of libertinism, a later term for an old and widely current idea. Christian orthodoxy, of course, would view it as sinful. In Dante's Divine Comedy V.56, Semiramis is in hell for making libito (lust, but more generally will or pleasure) licito (legal). 27-9 Another detail from Tasso omitted here: infant Cupid-figures (amoretti) in the foliage, without the traditional bow and torch, signifying the harmless and innocent nature of this love. 30 sings] Singular verb with plural subject, then common. 31 wanton] sportive, merry; even amorous, but not pejoratively $(O E D$ 2, 3). $\quad 33$ affection] i.e. true love. $\quad 46$ lawne] a fine fabric: from examples in $O E D$, often used to cover the head. Ital. alludes to a net or snood. 49 You made frank, friendly behaviour unnatural ('shy and withdrawn' in Ital). $\quad 50$ You made women desist from frank speech and instead convey artful messages through their gait and bearing. $\mathbf{5 2}$ You make it theft to take that which love allows freely. 58 That are ... power] Ital. has 'that cannot apprehend your greatness'. 66-8 Translated from Catullus' famous poem 'Vivamus, mea dresbiahatque amemưs 1526143426 ('Let us live and love, my Lesbia'). Downloaded from manchesterhive.com at 04/26/2023 10:20:40AM 


\section{Giovanni Battista Guarini Golden Age Chorus Translated from the Italian by Richard Fanshawe.}

A chorus from Guarini's play Il Pastor Fido (1590) IV.ix. Fanshawe's transl. Il pastor fido, The faithfull Shepherd first published in 1647.

Fair golden Age! when milk was th' onely food,

And cradle of the infant-world the wood

(Rock'd by the windes); and th' untoucht flocks did bear

Their deer young for themselves! None yet did fear

The sword or poyson: no black thoughts begun

T' eclipse the light of the eternall Sun:

Nor wandring Pines unto a forreign shore

Or War, or Riches, (a worse mischief) bore. either ... or; Riches i.e., trade, merchandise

That pompous sound, Idoll of vanity,

Made up of Title, Pride, and Flattery,

Which they call Honour whom Ambition blindes,

Was not as yet the Tyrant of our mindes.

But to buy reall goods with honest toil

Amongst the woods and flocks, to use no guile,

Was honour to those sober souls that knew

No happinesse but what from vertue grew.

Then sports and carols amongst Brooks and Plains

Kindled a lawfull flame in Nymphs and Swains.

Their hearts and Tongues concurr'd, the kisse and joy

Which were most sweet, and yet which least did cloy

Hymen bestow'd on them. To one alone

The lively Roses of delight were blown;

The theevish Lover found them shut on triall,

And fenc'd with prickles of a sharp denyall.

Were it in Cave or Wood, or purling Spring,

Husband and Lover signifi'd one thing.

Base present age, which dost with thy impure

Delights the beauty of the soul obscure:

Teaching to nurse a Dropsie in the veins:

Bridling the look, but giv'st desire the reins.

Thus, like a net that spread and cover'd lies

With leaves and tempting flowrs, thou dost disguise

With coy and holy arts a wanton heart;

"Mak'st life a Stage-play, vertue but a part:

"Nor think'st it any fault Love's sweets to steal,

"So from the world thou canst the theft conceal.

But thou that art the King of Kings, create

In us true honour: Vertue's all the state

Great souls should keep. Vnto these cels return

fenced out, shut out

the same

3-4 i.e. Men did not slaughter animals for meat. Rock'd by the windes] added by Fanshawe. 4-6 None ... Sun] There was no sinful thought to defy God (the eternal sun), implying the state of man before the Fall, conventionally assimilated to the Golden Age. 7 wandring Pines] ships made of pine wood (nautica pinus, Virgil IV.37). There was no navigation in the Golden Age, for either war or trade. The original has two more lines about the sky of reason being clouded over by the senses. 9 Idoll of vanity] (a) illusory image (b) object worshipped by vanity. vanity] (a) pride (b) levity. $\quad 13$ reall goods] truly necessary or beneficial things. goods] (a) things, property (b) good things, benefits. 17 carols] originally a type of dance accompanied by a song of specific structure, with a refrain. $\quad \mathbf{1 9 - 2 6}$ Contrast the Golden Age chorus in Tasso's Aminta (no.33.14-39). There too, 'honour' is deplored as a false idol; but Tasso suggests freer mingling of the sexes, Guarini monogamy. Fanshawe does not translate Guarini's crucial reversal of a line in Tasso, changing S'ei piace, ei lice (If it pleases, it is permissible) to Piaccia, se lice (If it is permissible, it pleases). 19 Their hearts ... concurr'd] They felt the love they declared. 21-6 Mantuan IV.68-71 says adultery was unknown in Adam's day. Given Mantuan's popularity as a school text, prob. influenced Guarini. 21 Hymen] god of marriage. 27-36 The words recall Tasso's chorus (33.40-52), however different the idea. 29 Dropsie in the veins] (affected) lack of sexuality, as though one's blood were water. 30 Looking modest but indulging one's desires. 34-6 In the 1647 text, these lines and 44-6 are flagged by quotation marks as memorable 'maxims' or sentiments. 34 Stage-play] play-acting. part] an actor's part. The Ital. means 'Makes goodness a matter of seeming, and life an artifice'. 37-8 King of Kings] The original addresses true honour itself (verace Onor) as the king of kings (regnator de' regi). 
Which were thy Court, but now thy absence mourn:

From their dead sleep with thy sharp goad awake

Them who, to follow their base wils, forsake

Thee, and the glory of the ancient world.

"Let's hope: our ills have truce till we are hurld

"From that: Let's hope; the sun that's set may rise,

"And with new light salute our longing eyes.

\section{Jean Chassanion 'Along the verdant fields' \\ Translated from the French by Thomas Beard.}

From Beard's The Theatre of Gods Iudgements (1597), a translation of Jean Chassanion's Histoires memorables des grans et merveilleux jugement et punitions de Dieu (1586): a formidable discourse on 'the admirable Iudgements of God vpon the transgressours of his commandements' (as phrased on Beard's title-page), especially upon persecutors of the Christian Church or its members. This poem is from Beard's ch.16 (ch.15 in the French), the second of two 'Of those that in our age haue persecuted the Gospell in the person of the faithfull'. The translation closely follows the tenor of the original, while often differing in detail.

Along the verdant fields all richly dide

With natures paintments, and with Floraes pride:

Whose goodly bounds are liuely chrystall streames

Bygirt with bowres to keepe backe Phoebus beames:

Euen when the quenchlesse torch, the worlds great eye,

Aduanc't his rayes orethwartly from the skye,

obliquely, aslant

And by his power of heauenly influence,

Reuiu'de the seeds of springs decaied essence:

Then manie flockes vnite in peace and loue,

Not seeking ought but naturall behoue,

Past quietly vncharg'd with other care,

Saue of their feed within that pasture faire.

Those flockes a shepheard had (of power and skill)

To fould and feed and saue them from all ill:

By whose aduice they liu'd: whose wholsome voyce

They heard, and fear'd with loue, and did reioyce

Therin, with mellodie of songe and praise,

And dance, to magnifie his name allwayes.

He is their guide, they are his flocke and folde,

Nor will they be by anie else controlde;

Well knowing that whome hee takes care to feed,

Hee will preserue and saue in tyme of need.

Thus liu'd this holy flocke at harts content,

Till cruell beasts all set on rauishment,

Broke of their peace, and ran vpon with rage

Themselues, their yong, and all their heritage:

Slitting their throats, deuouring lambes and all,

And dissipating them that scapt their thrall.

Then did this iolly feast to fast transforme,

(So askt the furie of that radgefull storme)

Their ioyfull song was turn'd to mournfull cries,

And all their gladnesse chang'd to welladayes.

Wherat heauen greeuing, clad it selfe in blacke:

dispersing, scattering

demanded, compelled

cries of lament

But the earth in vprore, triumpht at their wracke.

What proffits then the sheepehooke of their guide?

Or he that lyes vpon a beacons syde

With watchfull eye to circumscribe their traine,

40 The original has 'which cannot be blessed (beati) without you'. 44-6 See 34-6n. $\quad 45$ that] i.e., our present degenerate state. 9 vnite] united. The verb is past (passed, 11). 10 behoue] behoof, benefit - i.e. they want only what is naturally and rightfully their due. 15 aduice] judgment, prudence (OED 1, 2). wholsome] beneficial, salutary. 26 heritage] ?lineage, posterity ( $O E D$ 5, only from Gower); but in view of 75,OED $3 \mathrm{~b}$ is relevant: 'The people chosen by God as his peculiar possession; the ancient Israelites; the Church of God'. $\quad 36-8$ Suggesting the ineffectuality of a shepherd who sits on a hillside watching his flock, but does not stir to protect them. $\mathbf{3 6}$ beacon] hill commanding a prospect. 
And hath no more regard vnto their paine?

To saue them from such dangers Imminent

(Say some) as are so often incident.

Tis not for that his arme wants strength to breake

All proude attempts that men of might do make,

Or that he will abandon vnto death

His owne, deare bought with exchange of his breath:

Nor must wee thinke that though they dye, they perish:

Death dyes in them, and they in death reflorish:

And this liues losse, a better life renewes,

Which after death eternally ensues.

Though then their passions neuer seeme so great:

Yet neuer comfort wants to swage their heat:

Though strength of torments bee extreame in durance,

Yet are they quencht, by hopes and faithes assurance.

For thankfull hope, if God be grounded in it,

Assures the hart and pacifies the spirit.

To them that loue and reuerence his name,

Prosperitie betydes and want of shame.

Thus can no tyrant pull them from the hands

befalls

Of mightie God, that for their safetie stands,

Who euer sees, and euer can defend:

Them whome hee loues, he loues vnto the end.

So that the more their furie ouerfloweth,

The more ech one his owne destruction soweth.

And as they striue with God in policie,

So are they sooner brought to miserie.

Like as the sauadge bore dislog'd from den,

And hotely chassed by pursute of men,

Runnes furiouslie on them that com him neare,

And lightly careth for the hunters speare.

The gentle puisant lambe, their Champion bold,

So helps to conquer all that hurts his fold,

cares little

That quickly they and all their progenie,

Confounded is and brought to miserie.

This is of Iuda the couragiouse Lyon

The conquering captaine, and the rocke of Syon,

Whose fauour is as great to Jacobs lyne:

As is his fearefull frowne to Phillistine.

\section{Jean Passerat Song}

Translated from the French by William Drummond of Hawthornden.

From Drummond's Hawthornden MS, vol.X in the National Library of Scotland. First printed in a substantially different, standard English version in Drummond's 1711 Works. The original begins 'Pastoureau, m'aimes-tu bien?'

Song of Passerat

amintas daphne

Daphne. Shephard loueth thow me vell?

Amintas. So vel that I cannot tell.

Daphne. Like to vhat good shephard say?

Amintas. Like to the faire cruel May.

Daphne. Ah how strange thy vords I find

But yet satisfie my mind.

49 passions] sufferings $\left(O E D_{3}\right) . \quad 56$ want of shame] ?absence of any cause of shame. $\quad 66$ chassed] The spelling specially evokes Fr. chasse, hunt. 69 gentle] (a) noble: Christ is presented as a knight, a puisant (powerful) champion (b) mild, tender-hearted: an oxymoron with puisant. 73 of Iuda the ... Lyon] The lion, symbol of the tribe of Judah (Genesis 49.9), was identified with Christ (Revelation 5.5). 74 rocke of Syon] Mountain near Jerusalem, site of a fortress conquered by David: hence applied to Solomon's temple in Jerusalem, the city itself, and the promised heaven or new Jerusalem. (See 1 Peter 2.6, Romans 9.33, 11.26). 75 Jacobs lyne] i.e. the Israelites. See 26n. 
Shephard, without flatterie,

Beares thow any loue to me,

Like to vhat good shephard say?

Amintas. Like to the faire cruel may.

Daphne. Better anser had it beene

To say, I loue thee as mine eiene.

Amintas. Voe is me I loue them not,

At the time they did behold

Thy sueet face and haire of gold.

Daphne. Like to vhat good shephard say?

Amintas. Like to the faire cruel May.

Daphne. But deare shephard speake mor plaine,

And I sal not aske againe;

For to end this gentle stryff

Doth thow loue me as thy lyff?

Amintas. No, for it doth eb and flow

Vith contrare teeds of grief and voe

And I now thruch loues strange force

tides

A man am not, but a dead corse.

Daphne. Like to vhat good shephard say?

Amintas. Like to thee, faire, cruel May.

Daphne. This like to thee O leaue I pray

And as my selfe, good shephard, say.

Amintas. Alas! I do not loue my selff

For I me split on beuties shelff.

Daphne. Like to vhat good shephard say?

Amintas. Like to the faire cruel May.

\section{Antonio Beffa 'There Where the Pleasant Eske'}

Translated from the Italian by William Drummond of Hawthornden.

One of two poems in Drummond's Hawthornden Manuscripts vol.X, in the National Library of Scotland, under the heading 'Pastorells from Maria Bonardo frattegiano'. This is either an error or a rough reference to a volume of Giovanni Maria Bonardo's poems, probably the revised edition of his Madrigali (Venice: Agostin Zoppini and nephews, 1598), where Bonardo's poems are interspersed with replies by his friend Antonio Beffa or Beffanegrini. The sequence of titles on fol.29r-v of the collection makes it clear that this poem is by Beffa, in response to one by Bonardo and alluding to the latter's love-affair. The two poets belonged to a 'Compagnia' or 'Accademia' de' Pastori Frateggiani' (Academy of Shepherds of Fratta Polesine, Bonardo's birthplace). The translation closely follows the Italian, except for changes introducing an autobiographical note. (See in, 4n.)

Pastorells from Maria Bonardo frattegiano

There where the pleasant Eske

Glydes full of siluer with her happy vawes,

And cleds with Emeralds both the Banks,

waves

The sheepheard Damon

His Temples girt about with verdant Bayes

Like to a stranger swaine

At the sunes rising with golden brows,

All glad sent forth these words:

Let the nobell crew of sheepheardes know,

14-16 Fr. is more elaborate: 'Because they opened the door to the pangs I suffered since the time I saw you, when my liberty was taken from me by your eyes that overpowered me'. 23-6 Fr. is different and more elaborate: 'No, because it is enslaved by a hundred and a hundred thousand afflictions, for which reason I cannot love it, being nothing more than a body without a soul by loving a lady too much.' The 1711 English text is marginally closer to this. 29-3o Leave off speaking in similes and speak directly about me. 32 split on beauties shelff] as a ship splits if it strikes the rocky coast: a metaphor absent in the French. 1 Eske] The original Mintio (Mincius) changed to the Eske, a river in Drummond's native part of Scotland. 3 Emeralds] i.e, greenery, vegetation. 4 Damon] Drummond's pastoral name, replacing the original Filisto; hence Drummond omits the epithets ran (great), almo, e divino (noble and divine) applied to Filisto. 6 i.e., His demeanour makes him seem unfamiliar and out of place even in his native haunts. But the original has Cigno peregrino, 'a wandering swan', so swaine may be=swan. 
That while these streames shall runne vnto the sea,

I while these Meads shall show aprile,

That of my sheephardesse the beautyes rare,

The speeches wise and humble,

Shall byde into my hart morning and even.

Here paus'd hee and at the suowand of the amourous accents

Era the winds, Era thee Aire did sound.

\section{Edmund Spenser The Shepherd's Calendar, 'April'}

The Shepheardes Calender (published anonymously, 1579) marks the virtual start of formal pastoral poetry in Elizabethan England. It consists of twelve eclogues named after the twelve months, resembling in title more than content The Calendar of Shepherds, an almanac-like periodical publication based on a French manual. SC presents a loosely-defined community of shepherds in their various concerns and activities, from love to celebration to mourning, and lament at the neglect of poets and poetry. A gloss to 'September' explicitly identifies Colin with Spenser (a persona he retained in all his works), and other shepherds with 'persons of diuers other his familiar freendes and best acquayntaunce'. Many political and religious concerns are introduced: in particular, three eclogues on the religious politics of the time, reflecting Spenser's support of the growing Puritan cause. But the most important running motif is the career of Colin Clout and his frustrated love for Rosalind. 'Aprill' is a celebration of Queen Elizabeth, in a song purportedly written by Colin though here sung by Hobbinoll.

Each Eclogue in the Calender is followed by notes by 'E.K.', variously identified (sometimes with Spenser himself). Salient extracts from these notes are given below, marked '(E.K.)'. Each eclogue also has one or more concluding 'Embleme' (motto or maxim), usually drawn from earlier literature or proverbial lore. Colin's song (37-153), mistakenly ascribed to Hobbinoll, is included in Helicon.

Aprill. Egloga Quarta.

ARGVMENT.

This Æglogue is purposely intended to the honor and prayse of our most gracious souereigne, Queene Elizabeth. The speakers herein be Hobbinoll and Thenott, two shepheardes: the which Hobbinoll being before mentioned, greatly to haue loued Colin, is here set forth more largely, complayning him of that boyes great misaduenture in Loue, whereby his mynd was alienate and with drawen not onely from him, who moste loued him, but also from all former delightes and studies, aswell in pleasaunt pyping, as conning ryming and singing, and other his laudable exercises. Whereby he taketh occasion, for proofe of his more excellencie and skill in poetrie, to recorde a songe, which the sayd Colin sometime made in honor of her Maiestie, whom abruptely he termeth Elysa.

Thenot. Hobbinoll.

[Thenot.] Tell me good Hobbinoll, what garres thee greete?

What? hath some Wolfe thy tender Lambes ytorne?

makes you weep

Or is thy Bagpype broke, that soundes so sweete?

Or art thou of thy loued lasse forlorne?

bereft

Or bene thine eyes attempred to the yeare,

Quenching the gasping furrowes thirst with rayne?

suited to the season

i.e., drought

Like April shoure, so stremes the trickling teares

Adowne thy cheeke, to quenche thy thristye payne.

thirsty

Hobbinoll. Nor thys, nor that, so muche doeth make me mourne,

But for the ladde, whome long I lovd so deare,

Nowe loues a lasse, that all his loue doth scorne:

He plongd in payne, his tressed locks dooth teare.

11 while ... aprile] As long as spring returns to these fields. 12-13 In the ms., these two lines enclosed in parentheses, perhaps to indicate they are in draft, awaiting revision. They do not read like a parenthesis. Rather, beautyes and speeches seem to be the joint subject of shall byde (14). 14 byde into] combining the senses of 'pass into' and 'abide in'. 16 Era] The real or poetic name of Bonardo's beloved, occurring in several poems by him and his associates. $\mathbf{0 . 2}$ Hobbinoll] A pastoral name not known before $S C$, but appearing in four eclogues there. In 'Januarye' 55-60, he is an inept seeker after Colin's love; but E. K. calls him the poet's 'very speciall and most familiar freend', even to 'some sauour of disorderly loue [or] pæderastice, though justified in terms of Platonic love. A glosse on 'September' 176 identifies Hobbinoll explicitly with the Cambridge scholar Gabriel Harvey. 0.2 Thenott] also appears in 'Februarie' and 'November'. o.6 conning] skilful, learned. 0.8 abruptly] by truncating her name. 9-11 The lad is Colin Clout, the lass Rosalind: see 'Januarie', esp. 55-60. 
Shepheards delights he dooth them all forsweare,

Hys pleasaunt Pipe, whych made vs meriment,

He wylfully hath broke, and doth forbeare

His wonted songs, wherein he all outwent.

Thenot. What is he for a Ladde, you so lament?

Ys loue such pinching payne to them, that proue?

And hath he skill to make so excellent,

Yet hath so little skill to brydle loue?

desist from, relinquish accustomed; excelled

What kind of lad is he? experience, put (it) to the test compose poetry

Hobbinoll. Colin thou kenst, the Southerne shepheardes boye:

Him Loue hath wounded with a deadly darte.

Whilome on him was all my care and ioye,

Forcing with gyfts to winne his wanton heart.

But now from me hys madding mynd is starte,

And woos the Widdowes daughter of the glenne:

So nowe fayre Rosalind hath bredde hys smart,

So now his frend is chaunged for a frenne.

frenzied; gone away

caused his pain

stranger, enemy

Thenot. But if hys ditties bene so trimly dight,

I pray thee Hobbinoll, recorde some one:

neatly, skillfully; adorned, hence composed recall, repeat

The whiles our flockes doe graze about in sight,

And we close shrowded in thys shade alone.

shaded, sheltered

Hobbinoll. Contented I: then will I singe his laye

Of fayre Elisa, Queene of shepheardes all:

Which once he made, as by a spring he laye,

And tuned it vnto the Waters fall.

Ye dayntye Nymphs, that in this blessed Brooke doe bathe your brest,

For sake your watry bowres, and hether looke, at my request:

And eke you Virgins, that on Parnasse dwell,

Whence floweth Helicon the learned well, Helpe me to blaze Her worthy praise,

Which in her sexe doth all excell.

Of fayre Elisa be your siluer song, that blessed wight:

The flowre of Virgins, may shee florish long, in princely plight

For shee is Syrinx daughter without spotte,

Which Pan the shepheards God of her begot:

So sprong the grace

Of heauenly race,

No mortall blemishe may her blotte.

21 Southerne] Spenser was born in London, but E.K. reports Colin as having moved from north to south. ('June' 18n.) The dialect of the Calender locates its community in northern England or the north Midlands. 'Southerne shepheard' has also been taken as John Young, Bishop of Rochester, in Kent, who employed Spenser (hence his 'boy') for a time. 24 Forcing] striving (OED force $\mathrm{v}^{1} 5 \mathrm{~b}$, citing this passage). 26 glenne] 'a country Hamlet or borough' (E. K.), an otherwise unknown sense. Elsewhere in Spenser, means the usual 'valley'. 41 Virgins] the Muses. 42 Helicon] 'both the name of a fountaine at the foote of Parnassus, and also of a mountaine in Bæotia' (E.K.): the first identification wrong, though found in Chaucer (House of Fame 521). 50 Syrinx daughter] Syrinx, turned into a reed to escape Pan's pursuit, had no daughter. (Ovid likens her to the virgin goddess Diana: Met. I.694-8). E.K. says Pan and Syrinx are named simply to indicate 'her graces progenie [ancestry] to be diuine and immortall'. without spotte] implies both virginity and, conceivably, immaculate birth (free of original sin) like the Virgin Mary's. Eliza's birth from such a mother implicitly endows her with a Christ-like divinity, though Spenser does not press the point. $\quad 51$ Pan] 'the most famous and victorious King, her highnesse Father, late of worthy memorye K. Henry the eyght' (E.K.) E.K. observes that in pastoral, 'Pan' is sometimes a noted king or potentate, sometimes Christ himself (and here, we may add, perhaps God the Father?). This bears out the Christian implications of Eliza's divine 'progenie' (see 50n). 51-4 grace Of heauenly race] Further continues the Christ-motif by implying divine grace and freedom from original sin (mortall blemishe). mortall] (a) deadly, hence damning (b) human. 
See, where she sits vpon the grassie greene,

(O seemely sight)

Yclad in Scarlot like a mayden Queene,

And Ermines white.

Upon her head a Cremosin coronet,

With Damaske roses and Daffadillies set:

Bayleaues betweene,

And Primroses greene

Embellish the sweete Violet.

Tell me, haue ye seene her angelick face, like Phobe fayre?

Her heauenly haueour, her princely grace can you well compare?

behaviour, demeanour

The Redde rose medled with the White yfere,

In either cheeke depeincten liuely chere. Her modest eye,

together

Her Maiestie,

present a lively expression or spirit

Where haue you seene the like, but there?

I sawe Phœbus thrust out his golden hedde, vpon her to gaze:

But when he sawe, how broade her beames did spredde, it did him amaze.

He blusht to see another Sunne belowe,

Ne durst againe his fyrye face out showe:

Let him, if he dare,

His brightnesse compare

With hers, to haue the ouerthrowe.

be defeated

Shewe thy selfe Cynthia with thy siluer rayes, and be not abasht:

When shee the beames of her beauty displayes,

O how art thou dasht?

But I will not match her with Latonaes seede,

Such follie great sorow to Niobe did breede.

Now she is a stone,

And makes dayly mone,

Warning all other to take heede.

Pan may be proud, that euer he begot such a Bellibone,

And Syrinx reioyse, that euer was her lot to beare such an one.

Soone as my younglings cryen for the dam,

To her will I offer a milkwhite Lamb:

Shee is my goddesse plaine,

And I her shepherds swayne,

Albee forswonck and forswatt I am.

cryen: plural ending in -en

fully, absolutely

although

57-9 Scarlot, Ermines, Cremosin] attributes of royalty and/or high birth. Cremosin] crimson. 6o-63 E.K. points out how the crown is set with flowers rather than 'perles and precious stones'. $\quad 65$ Phœbe] Diana: the usual comparison for the virgin queen. 68 Redde rose ... White] emblems of the Houses of Lancaster and York respectively in the Wars of the Roses. The Tudor dynasty, founded by Elizabeth's grandfather Henry VII, claimed to unite both houses in their ancestry. A political dimension to a common conceit for the mistress's complexion. 73 Phœbus] Apollo as sun-god. 77 another Sunne] standard Petrarchan conceit for the mistress's gaze. $\quad \mathbf{8 2}$ Cynthia] Diana. Cf. 65, but here the goddess is compared to the queen. 86 Latonaes seed] Apollo and Artemis (Diana), twin offspring of Leto or Latona. Niobe, wife of King Amphion of Thebes, had praised her children above Latona's, at which Apollo and Artemis slew them all. But the poet has already made such comparisons to Elizabeth's advantage. $\mathbf{8 8}$ a stone] into which Niobe was turned, but still wept for her children in streams flowing down the rock. 92 Bellibone pretty woman (Fr. belle et bonne, beautiful and good) 95 cryen for the dam] call out to their mother - i.e. are born. 99 forswonck and forswatt] exhausted and perspiring, implying he is (a) rude and unprepossessing (b) weary and frustrated. 
100

I see Calliope speede her to the place, where my Goddesse shines:

And after her the other Muses trace, with their Violines.

Bene they not Bay braunches, which they doe beare, All for Elisa in her hand to weare?

are those not; laurel carry So sweetely they play, And sing all the way,

That it a heauen is to heare.

Lo how finely the graces can it foote to the Instrument:

They dauncen deftly, and singen soote, in their meriment.

Wants not a fourth grace, to make the daunce euen?

Let that rowme to my Lady be yeuen: She shalbe a grace, To fyll the fourth place,

And reigne with the rest in heauen.

And whither rennes this beuie of Ladies bright, raunged in a rowe?

They bene all Ladyes of the lake behight, that vnto her goe.

Chloris, that is the chiefest Nymph of al,

Of Oliue braunches beares a Coronall: Oliues bene for peace, When wars doe surcease:

Such for a Princesse bene principall.

Ye shepheards daughters, that dwell on the greene, hye you there apace:

Let none come there, but that Virgins bene, to adorne her grace.

And when you come, whereas shee is in place,

See, that your rudenesse doe not you disgrace: Binde your fillets faste, And gird in your waste,

For more finesse, with a tawdrie lace. elegance, grace; a kind of silk band or kerchief symmetrical (by balancing given

runs named, called

Bring hether the Pincke and purple Cullambine, with Gelliflowres:

Bring Coronations, and Sops in wine, carnations; gillyflowers worne of Paramoures.

Strowe me the ground with Daffadowndillies,

And Cowslips, and Kingcups, and loued Lillies: The pretie Pawnce, And the Cheuisaunce,

Shall match with the fayre flowre Delice.

unidentified pansy

Now ryse vp Elisa, decked as thou art, in royall aray:

And now ye daintie Damsells may depart

pretty, graceful

100 Calliope] the Muse of epic, hence sometimes considered pre-eminent among the Muses. Epic is the fit vein to celebrate royalty. 103 Violines] perhaps stringed instruments generally, an attibute of several Muses. 109 the graces] the Charites, three goddesses of grace and beauty. The role of a 'fourth grace' to match or exceed them is here bestowed on Elizabeth, and in FQ VI.x to Colin Clout's beloved shepherdess. $\quad 120$ Ladyes of the lake] ?water-nymphs. lake] perhaps the seas surrounding Britain, ensuring her peaceful isolation from war-torn Europe (cf. 124n). A 'Lady of the Lake' with two nymphs featured in an entertainment for Queen Elizabeth on her visit to Kenilworth Castle, $1575 . \quad 122$ Chloris] usually Flora, goddess of flowers, but perhaps here more loosely as a nymph's name. $\mathbf{1 2 4}$ peace] England had enjoyed internal and external peace after a long time during Elizabeth's reign. 126 principall] befitting a prince or ruler $\left(O E D_{3}\right)$. 138 Sops in wine] 'a flowre in colour much like to a Coronation, but differing in smel and quantitye' (E.K.). $\quad 144$ flowre Delice] used of flowers of the iris family besides the (chiefly heraldic) lily. 
echeone her way,

I feare, I haue troubled your troupes to longe:

Let dame Eliza thanke you for her song.

And if you come hether,

When Damsines I gether,

I will part them all you among.

damsons, a kind of plum

Thenot. And was thilk same song of Colins owne making?

Ah foolish boy, that is with loue yblent:

Great pittie is, he be in such taking,

For naught caren, that bene so lewdly bent.

Hobbinoll. Sicker I hold him for a greater fon,

That loues the thing he cannot purchase.

But let vs homeward: for night draweth on,

And twincling starres the daylight hence chase.

Thenots Embleme.

$\mathrm{O}$ quam te memorem virgo?

Hobbinols Embleme.

$\mathrm{O}$ dea certe.

\author{
blinded \\ under a spell, bewitched \\ waywardly intent \\ surely; fool
}

\title{
39 William Webbe 'O Ye Nymphs most Fine'
}

From William Webbe's A Discourse of English Poetrie (1586): a version in the quantitative Sapphic metre of Colin's song, reported by Hobbinoll, in praise of 'Eliza' (Queen Elizabeth) in the April Eclogue of Spenser's SC. SC was published anonymously, and Webbe refers to the piece he has 'translated' as 'the new Poets sweete song of Eliza'. The pattern of Sapphic verse, as laid out by Webbe himself, is

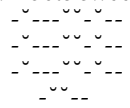

where - represents a long (in English, stressed) and " a short (in English, unstressed) syllable. The poem omits the last stanza of Hobbinoll's song, 'by reason of some let' (hindrance, interruption), says Webbe (sig.I4r). He hopes to complete it later, but does not appear to have done so.

O ye Nymphes most fine who resort to this brooke,

For to bathe there your pretty breasts at all times:

Leaue the watrish bowres, hyther and to me come

come to, frequent at my request nowe.

aquatic

And ye Virgins trymme who resort to Parnass,

Whence the learned well Helicon beginneth:

Helpe to blase her worthy deserts, that all els

blazon, describe in praise mounteth aboue farre.

Nowe the siluer songes of Eliza sing yee,

Princely wight whose peere not among the virgins

Can be found: that long she may remaine among vs, now let vs all pray.

For Syrinx daughter she is, of her begotten

Of the great God Pan, thus of heauen aryseth

All her exlent race: any mortall harde happe cannot aproche her.

excellent; misfortune

162 O quam ... virgo?] 'What should I call you, $\mathrm{O}$ virgin?'. $\quad 163 \mathrm{O}$ dea certe] 'O [you, who are] surely a goddess'. Both lines addressed by Aeneas to his mother Venus, mistaking her for Diana (Virgil, Aen. I.327-8). They match the dual celebration of Elizabeth as virgin queen and object of reverent love, the apotheosis of the Petrarchan mistress. 5 trymme] beautiful, comely $\left(O E D_{1}, 2\right) .5$ Parnass] Parnassus, mountain sacred to Apollo and the Muses. 6 Helicon] Not a well (spring) but another such mountain. The error stems from E.K.'s note in SC: see 38.42n. $\quad \mathbf{7 - 8}$ that all ... farre] that is far higher than everything else. 9 siluer] melodious (OED 6a). 13-14 Syrinx, Pan] See 38.50-51n. 15 mortall] (a) human, subject to death (b) death-dealing. 
See, she sittes most seemely in a grassy greene plott,

Clothed in weedes meete for a princely mayden,

Boste with Ermines white, in a goodly scarlett brauely beseeming.

clothes; befitting

bossed: studded, ornamented

20

Decked is that crowne that vpon her head standes

With the red Rose and many Daffadillies,

Bayes, the Primrose and violetts, be sette by: how ioyfull a sight ist.

Say, behold did ye euer her Angelike face,

Like to Phoebe fayre? or her heauenly hauour,

And the princelike grace that in her remaineth? haue yee the like seene?

Medled ist red rose with a white together

Which in either cheeke do depeinct a trymme cheere,

Her maiestie and eye to behold so comely, her like who remembreth?

Phoebus once peept foorth with a goodly guilt hewe,

For to gaze: but when he sawe the bright beames

Spread abroade fro'her face with a glorious grace, it did amaze him.

laurels

placed or woven alongside

is it

behaviour, demeanour $d w e l l s$, abides

mingled, mixed; is it paint, depict

gilt, golden

stun, dazzle

When another sunne he behelde belowe heere,

Blusht he red for shame, nor againe he durst looke:

Would he durst bright beames of his owne with hers match, for to be vanquisht.

Shew thy selfe now Cynthia with thy cleere rayes,

And behold her: neuer abasht be thou so:

When she spreades those beames of her heauenly beauty, how thou art in a dump dasht?

cast down

But I will take heede that I match not her grace,

With the Laton seede, Niobe that once did,

Nowe she doth therefore in a stone repent: to all other a warning.

Pan he may well boaste that he did begit her

Such a noble wight, to Syrinx is it ioy,

That she found such lott with a bellibone trym for to be loaden.

laden, pregnant

When my younglinges first to the dammes doo bleat out,

Shall a milke white Lambe to my Lady be offred:

For my Goddesse shee is, yea I my selfe her Heardgrome

though but a rude Clowne.

Vnto that place Caliope dooth high her,

Where my Goddesse shines: to the same the Muses

hie, hasten

After her with sweete Violines about them

cheerefully tracing.

dancing

Is not it Bay braunche that aloft in handes they haue,

17 seemely] 'of a pleasing or goodly appeareance, fair' $\left(O E D_{1}\right) . \quad \mathbf{1 9}$ scarlett] a rich cloth (not always red) for ceremonial costumes. 20 brauely beseeming] beautiful and appropriate; but beseeming might be a general term of approbation: cf. seemely (17). 26 Phœbe] Diana or Cynthia, the virgin goddess with whom Elizabeth was commonly identified. $\quad$ 31-2 her ... remembreth] Who can recall seeing anyone like her? 33-6 Common Petrarchan conceit of the mistress's eyes outshining the sun. 39-40 If he dared to challenge her brightness with his own, he would be vanquished. $\quad 41$ Cynthia] Here the actual moon and its goddess. 42 neuer ...so] Never have you been (or May you never be) so shamed (by the contrast). $\quad \mathbf{4 4}$ dump] fit of melancholy or depression. $\quad \mathbf{4 5}$ match] vie, compete with $(O E D$ 8a). $\quad 46$ Laton seed] Latona's offspring. See 38.86n. 49 found such lott] had such good luck. bellibone] beautiful and good (woman): French belle et bonne. $\quad 54$ Clowne] (a) rustic $(O E D$ 1a) (b) boorish or uncouth person $(O E D$ 1b, 2). 55 Caliope] Calliope, the epic muse. 
Eune to giue them sure to my Lady Eliza:

$\mathrm{O}$ so sweete they play and to the same doo sing too heaunly to heare ist.

See, the Graces trym to the stroake doo foote it,

Deftly dauncing, and meriment doo make them,

Sing to the instruments to reioyce the more, but wants not a fourth grace?

is wanting or lacking

Then the daunce wyll be eune, to my Lady therefore

Shalbe geune that place, for a grace she shall be

For to fill that place that among them in heaune, she may be receiued.

Thys beuy of bright Nymphes, whether ist goe they now?

Raunged all thus fine in a rowe together?

They be Ladies all i'the Lake behight soe? they thether all goe.

ranked, in a row

One that is there chiefe that among the rest goes,

Called is Chores; of Olyues she beares a

Goodly Crownett, meete for a Prince that in peace euer abideth.

ruler, monarch

All ye Sheepheardes maides that about the greene dwell,

Speede ye there to her grace, but among ye take heede

All be Virgins pure that aproche to deck her, duetie requireth.

When ye shall present ye before her in place,

See ye not your selues doo demeane too rudely:

Bynd the fillets: and to be fine the waste gyrt fast with a tawdryne.

even, balanced: two a side given

Bring the Pinckes therewith many Gelliflowres sweete,

And the Cullambynes: let vs haue the Wynesops,

With the Cornation that among the loue laddes wontes to be worne much.

is customarily

Daffadowndillies all a long the ground strowe,

And the Cowslyppe with a prety paunce let heere lye,

Kyngcuppe and Lillies so beloude of all men, And the deluce flowre.

\section{4o Edmund Spenser The Shepherd's Calendar, 'June'}

This eclogue underpins the running theme of SC: Colin's frustrated love of Rosalind, affecting his career as a poet. (The other cause for frustration, neglect and lack of reward, is developed in 'October' by another poet, Cuddie: even there, Colin's decline is chiefly ascribed to love.) On the name Hobbinol, see notes to 'Aprill'. The shepherds stand for Spenser and Gabriel Harvey. The contrast in their states recalls Virgil I and, more specifically, Petrarch I.

June. Ægloga sexta.

ARGVMENT.

This Æglogue is wholly vowed to the complayning of Colins ill successe in his loue. For being (as is aforesaid) enamoured of a Country lasse Rosalind, and hauing (as seemeth) founde place in her heart, he lamenteth to his deare frend Hobbinoll, that he is nowe forsaken vnfaithfully, and in his steede Menalcas, another shepheard receiued disloyally. And this is the whole Argument of this Æglogue.

63 stroake] tune $(O E D$ 8). $\quad 66$ a fourth grace] See 38.109n. $\quad 73$ Spenser's original is clearer: 'They bene all Ladyes of the lake behight' [called] - i.e. they are nymphs of the lake. The question mark after 'soe' may be in error for a full stop or a comma. 76 Chores] Probably in mistake for Spenser's 'Chloris'. 86 tawdryne] Webbe's special adaptation (OED) of tawdry, cheap silk 'lace' or neckwear. 88 Wynesops] 'Sops in wine': see 38.138n. 89 Cornation] carnation or clove-pink: perhaps from coronation, from its presence in a chaplet (Lat. corona). complayning] lamenting. aforesaid] in 'Januarye'. Hobbinoll] spelt indifferently with one or two l's. Menalcas] 'the name of a shephearde in Virgile; but here is meant a person vnknowne and secrete, agaynst whome he often bitterly inuayeth.' (E. K.). 


\section{HOBBINOL. COLIN Cloute.}

Hobbinol. Lo Collin, here the place, whose pleasaunt syte

From other shades hath weand my wandring mynde.

Tell me, what wants me here, to worke delyte?

The simple ayre, the gentle warbling wynde,

So calme, so coole, as no where else I fynde:

The grassye ground with daintye Daysies dight,

The Bramble bush, where Byrds of euery kynde

To the waters fall their tunes attemper right.

Collin. O happy Hobbinoll, I blesse thy state,

That Paradise hast found, whych Adam lost.

Here wander may thy flock early or late,

Withouten dreade of Wolues to bene ytost:

Thy louely layes here mayst thou freely boste.

But I vnhappy man, whom cruell fate,

And angry Gods pursue from coste to coste,

Can nowhere fynd, to shroude my lucklesse pate.

Hobbinol. Then if by me thou list aduised be,

Forsake the soyle, that so doth the bewitch:

Leaue me those hilles, where harbrough nis to see,

Nor holybush, nor brere, nor winding witche:

And to the dales resort, where shipheards ritch,

And fruictfull flocks bene euery where to see.

Here no night Rauene lodge more black then pitche,

Nor eluish ghosts, nor gastly owles doe flee.

'situation and place' (E.K.)

drawn away, accustomed is lacking to me

decked, adorned

fraught, disturbed present, display

shelter

would, wish to

harbour, shelter; is not

holly bush; briar; crooked, sinuous

[witch: witch-elm

?pass, wander

But frendly Faeries, met with many Graces,

And lightfote Nymphes can chace the lingring night,

With Heydeguyes, and trimly trodden traces,

Whilst systers nyne, which dwell on Parnasse hight,

Doe make them musick, for their more delight:

And Pan himselfe to kisse their christall faces,

Will pype and daunce, when Phobe shineth bright:

Such pierlesse pleasures haue we in these places.

Collin. And I, whylst youth, and course of carelesse yeeres

Did let me walke withouten lincks of loue,

In such delights did ioy amongst my peeres:

But ryper age such pleasures doth reproue,

My fancye eke from former follies moue
To stayed steps, for time in passing weares

(As garments doen, which wexen old aboue)

Tho couth I sing of loue, and tune my pype

Unto my plaintiue pleas in verses made:

Tho would I seeke for Queene apples vnrype,

To giue my Rosalind, and in Sommer shade

Dight gaudy Girlonds, was my comen trade, steady

wax, grow; too old white hairs

then; knew how to

deftly, nimbly; measures, dances

make, fashion; bright; habitual task

1o Paradise] Pastoral life is commonly equated with the state of innocence before the Fall: 'that earthly Paradise, in scripture called Eden; wherein Adam in his first creation was placed' (E.K.). 14-16 A notable model for this wandering, almost Cain-like figure is Petrarch's self-depiction as the shepherd Silvius (Petrarch I). 18 Forsake the soyle] Though Spenser was born in London, E. K. says this is 'vnfeynedly spoken of the Poete selfe, who for speciall occasion of priuate affayres ... and for his more preferment [greater advancement] remouing out of the Northparts came into the South'. 19 those hilles] of the 'North countrye' (E. K.). See 21n. 21 the dales] the 'Southpartes, where he [Colin] nowe abydeth' (E.K.), as being generally lower than the north country. Around this time, Spenser was employed by John Young, Bishop of Rochester in Kent. 23 night Rauene] An indeterminate or imaginary bird, supposedly of ill omen: 'tokens' of 'all misfortunes' (E.K.). 25 frendly Faeries] Not all fairies were friendly in rustic superstition. many Graces] E. K. notes that unlike the usual three (or at most four), Musaeus speaks of a hundred. 27 Heydeguyes] 'a country daunce or rownd' (E. K.). 28 systers nyne] the Muses. 31 Phœbe] Diana as moon-goddess. 40 derives new pleasures in or from old age. 43 Queene apples] 'an early variety of apple' (OED queen C2). Imitates Virgil II.51. 
To crowne her golden locks, but yeeres more rype,

And losse of her, whose loue as lyfe I wayd,

Those weary wanton toyes away dyd wype.

weighed, valued

tedious, irksome; trifles

Hobbinol. Colin, to heare thy rymes and roundelayes,

Which thou were wont on wastfull hylls to singe,

I more delight, then larke in Sommer dayes:

Whose Echo made the neyghbour groues to ring,

And taught the byrds, which in the lower spring

Did shroude in shady leaues from sonny rayes,

Frame to thy songe their chereful cheriping,

Or hold theyr peace, for shame of thy swete layes.

I sawe Calliope wyth Muses moe,

Soone as thy oaten pype began to sound,

Theyr yuory Luyts and Tamburins forgoe:

And from the fountaine, where they sat around,

Renne after hastely thy siluer sound.

But when they came, where thou thy skill didst showe,

They drewe abacke, as halfe with shame confound,

Shepheard to see, them in theyr art outgoe.

accustomed; lonely, desolate

Whose: i.e., Colin's songs

shelter

put to shame by

more

run

confounded, overcome

exceed

Collin. Of Muses Hobbinol, I conne no skill:

know

For they bene daughters of the hyghest Ioue,

And holden scorne of homely shepheards quill.

For sith I heard, that Pan with Phoebus stroue,

Which him to much rebuke and Daunger droue:

I neuer lyst presume to Parnasse hyll,

But pyping lowe in shade of lowly groue,

I play to please my selfe, all be it ill.

Nought weigh I, who my song doth prayse or blame,

Ne striue to winne renowne, or passe the rest:

With shepheard fittes not, followe flying fame:

But feede his flocke in fields, where falls hem best.

I wote my rymes bene rough, and rudely drest:

The fytter they, my carefull case to frame:

Enough is me to paint out my vnrest,

And poore my piteous plaints out in the same.

The God of shepheards Tityrus is dead,

Who taught me homely, as I can, to make.

$\mathrm{He}$, whilst he liued, was the soueraigne head

Of shepheards all, that bene with loue ytake:

Well couth he wayle hys Woes, and lightly slake

The flames, which loue within his heart had bredd,

And tell vs mery tales, to keepe vs wake,

The while our sheepe about vs safely fedde.

Nowe dead he is, and lyeth wrapt in lead,

(O why should death on hym such outrage showe?)

even if it be bad music

judge, consider

fleeting

wherever they chance to be know; fashioned

sorrowful; set out, express

pour

compose poetry

And all hys passing skil with him is fledde,

The fame whereof doth dayly greater growe.

53 spring] 'not of water, but of young trees springing' (E. K.). Cf.150.17. 57 Calliope] the epic Muse. See 38.10on. $\quad 59$ Tamburins] A traditional attribute of the Muses, specifically Thalia the Muse of comedy. E. K. explains curiously as 'an olde kind of instrument, which of some is supposed to be the Clarion'. 60 fountaine] no doubt Hippocrene or Aganippe, springs sacred to the Muses at the foot of Mount Helicon. Their mother was Mnemosyne, goddess of memory. 66 Ioue] Zeus or Jupiter. 67 quill] (a) pipe (b) pen. $\quad 68$ Pan with Phœbus stroue] in song. The mountain-god Tmolus judged Apollo the winner, but Pan's devotee Midas demurred, to be gifted by Apollo with asses' ears (Ovid, Met. XI.146-93). The poet is afraid of the same fate if he, a humble shepherd, aspires to a loftier vein of poetry. Ovid does not speak of any direct 'rebuke and Daunger' to Pan. 81 God of shepheards] i.e. model or ideal poet, so called 'for his excellencie', as Cicero calls Lentulus the god of his life (E. K.). Tityrus] Chaucer: so E. K., who identifies his 'mery tales' (87) with The Canterbury Tales. The background allusion is to the shepherd Tityrus in Virgil I, identified with Virgil himself. 90 O why] 'a pretye Epanorthosis or correction' (E. K.). 
But if on me some little drops would flowe,

Of that the spring was in his learned hedde,

I soone would learne these woods, to wayle my woe,

the spring that was

And teache the trees, their trickling teares to shedde.

teach

Then should my plaints, causd of discurtesee,

As messengers of all my painfull plight,

Flye to my loue, where euer that she bee,

And pierce her heart with poynt of worthy wight:

As shee deserues, that wrought so deadly spight.

wit

And thou Menalcas, that by trecheree

Didst vnderfong my lasse, to wexe so light,

Shouldest well be knowne for such thy villanee.

But since I am not, as I wish I were,

Ye gentle shepheards, which your flocks do feede,

Whether on hylls, or dales, or other where,

Beare witnesse all of thys so wicked deede:

And tell the lasse, whose flowre is woxe a weede,

And faultlesse fayth, is turned to faithlesse fere,

That she the truest shepheards hart made bleede,

That lyues on earth, and loued her most dere.

Hobbinol. O carefull Colin, I lament thy case,

Thy teares would make the hardest flint to flowe.

melt

Ah faithlesse Rosalind, and voide of grace,

That art the roote of all this ruthfull woe.

But now is time, I gesse, homeward to goe:

pitiful

Then ryse ye blessed flocks, and home apace,

Least night with stealing steppes doe you forsloe,

And wett your tender Lambes, that by you trace.

waxed: grown, become companion, mate

Colins Embleme.

Gia speme spenta.

\section{Edmund Spenser The Shepherd's Calendar, 'July'}

One of three eclogues in SC (with 'Maye' and 'September') allegorizing the religious politics of the time along pro-Puritan lines in a debate between good and bad priestly shepherds, identified by their names. Morrell is an anagram for the anti-Puritan John Aylmer, Bishop of London. Thomalin may be Thomas Wilcox or Thomas Cartwright, eminent Puritan leaders, and Algrind Edmund Grindal, Archbishop of Canterbury. Grindal was sequestered (i.e., suspended from his functions) by Queen Elizabeth for his allegedly Puritan leanings, but later reinstated. Spenser was employed for a time by Grindal's close associate John Young, Bishop of Rochester. Thomalin had appeared in the March eclogue, though that was a tale of Cupid's darts; and Palinode in the first religious eclogue, 'Maye'. As in Mantuan VIII, Spenser is infusing religious allegory into a traditional encounter of upland and lowland shepherds.

Iulye. Egloga septima.

ARGVMENT.

This Æglogue is made in the honour and commendation of good shepeheardes, and to the shame and disprayse of proude and ambitious Pastours. Such as Morrell is here imagined to bee.

Thomalin. Morrell.

Thomalin. Is not thilke same a goteheard prowde, that sittes on yonder bancke,

97 discurtesee] (a) cruel or ungracious behavior (b) 'falsenesse' (E. K.). $\quad 100$ poynt ... wight] 'pricke of deserued blame' (E. K.). 103 vnderfong] seduce, ensnare (this sense only in Spenser and Spenserians). 120 wett] with dew. 121 Gia speme spenta] (Ital.) 'Hope is already extinguished.' As E. K. points out, this reverses the January emblem 'Anchôra speme', 'Yet [there is] hope.' 0.1-2 shepheardes ... Pastours] Obvious allegory for the priesthood. 1 goteheard] 'By Gotes in scrypture be represented the wicked and reprobate, whose pastour also must needes be such' (E. K.) Distinction between shepherds and (inferior) goatherds traditional in pastoral. $\mathbf{2}$ bancke] 'the seate of honor' (E. K.) 
Whose straying heard them selfe doth shrowde emong the bushes rancke?

shelter, hide

foul, poisonous

Morrell. What ho, thou iollye shepheards swayne, come vp the hyll to me:

Better is, then the lowly playne, als for thy flocke, and thee.

Thomalin. Ah God shield, man, that I should clime, and learne to looke alofte,

This reede is ryfe, that oftentime Great clymbers fall vnsoft.

In humble dales is footing fast, the trode is not so trickle:

And though one fall through heedlesse hast, yet is his misse not mickle.

And now the Sonne hath reared vp his fyriefooted teme,

Making his way betweene the Cuppe, and golden Diademe:

The rampant Lyon hunts he fast, raging, fierce with Dogge of noysome breath,

Whose balefull barking bringes in hast pyne, plagues, and dreery death.

also (E. K.), as well protect from, prevent, forbid

advice, wise saying; widely known

track, path; tricky, treacherous

harm, injury; much

Agaynst his cruell scortching heate where hast thou couerture?

shade, shelter

The wastefull hylls vnto his threate is a playne ouerture.

barren, open

But if thee lust, to holden chat with seely shepherds swayne,

'an open place' (E. K.), hence exposed, vulnerable
wish

Come downe, and learne the little what, that Thomalin can sayne.

Morrell. Syker, thous but a laesie loord, and rekes much of thy swinck,

That with fond termes, and weetlesse words to blere myne eyes doest thinke.

In euill houre thou hentest in hond thus holy hylles to blame,

lourd: lout or useless fellow [meaningless foolish; 'not vnderstoode' (E. K.), deceive me take in hand, undertake

For sacred vnto saints they stond, and of them han theyr name.

S. Michels mount who does not know, that wardes the Westerne coste?

guards

And of S. Brigets bowre I trow, all Kent can rightly boaste:

And they that con of Muses skill, sayne most what, that they dwell

(As goteheards wont) vpon a hill, beside a learned well.

And wonned not the great God Pan, dwelt

are learned in poetic skill for the most part are used to vpon mount Oliuet:

3 straying] 'which wander out of the waye of truth' (E. K.). 6-7 hyll ... playne] Moral contrast between hill (pride) and plain or valley (humility) traditional in pastoral. 18 fyriefooted teme] horses of the sun-chariot. 19-20 Cuppe, Diademe] 'two signes in the Firmament, through which the sonne maketh his course in the moneth of Iuly' (E. K.). Cuppe] Crater (Lat. for 'cup'), a spring constellation like Leo. Diademe] a star in the constellation Comae Berenices (Berenice's Hair), close to Leo. 21 Lyon] the zodiacal sign of Leo, which the sun enters in late July. 22 Dogge] Sirius or the dog-star, which rises with the sun in July and early August. 24 pyne ... death] associated with the hot 'dog days'. pyne] suffering, distress (OED pine $\mathrm{n}^{1}{ }^{2}$ ). 33 loord] lord: here a term of opprobrium, from the hatred aroused by the 'lurdanes' or 'lord Danes' when they ruled England (so E. K.). 34 rekes... swinck] 'counts much of thy paynes' (E. K.) - i.e. values your labour too highly. $41 \mathrm{~S}$ Michels mount] off the coast of Cornwall, site of an old monastery linked to the Order of $S$ Michel founded in France. $\quad 43 \mathrm{~S}$ Brigets bowre] No such place in Kent. J. W. Bennett suggests a hill in Greenwich. (J. W. Bennett, 'St Bridget, Queen Elizabeth, and Amadis of Gaul', ELH 43.1, 1943, 26-34.) But in view of Morrell's later errors $(50,51)$ he may ignorantly be referring to a non-existent hill. $\quad 47-8$ hill $\ldots$ well] Mount Helicon and either of the springs Aganippe and Hippocrene at its foot. 49 great God Pan] obviously Christ. $\quad 50$ Oliuet] where Christ preached and underwent his agony, but did not dwell. 
Feeding the blessed flocke of Dan, which dyd himselfe beget?

which begot him, in which he was born

Thomalin. O blessed sheepe, $\mathrm{O}$ shepheard great, that bought his flocke so deare,

And them did saue with bloudy sweat from Wolues, that would them teare.

Morell. Besyde, as holy fathers sayne, there is a hyllye place,

Where Titan ryseth from the mayne, to renne hys dayly race.

the sun run

Upon whose toppe the starres bene stayed, and all the skie doth leane,

There is the caue, where Phebe layed the shepheard long to dreame.

Whilome there vsed shepheards all to feede theyr flocks at will,

Till by his foly one did fall, that all the rest did spill.

And sithens shepheardes bene foresaid from places of delight:

For thy I weene thou be affrayd, to clime this hilles height.

Of Synah can I tell thee more, And of our Ladyes bowre:

But little needes to strow my store, suffice this hill of our.

Here han the holy Faunes resourse, and Syluanes haunten rathe.

Here has the salt Medway his sourse, wherein the Nymphes doe bathe.

The salt Medway, that trickling stremis adowne the dales of Kent:

Till with his elder brother Themis his brackish waues be meynt.

Here growes Melampode euery where, and Teribinth good for Gotes:

The one, my madding kiddes to smere, the next, to heale theyr throtes.

Hereto, the hills bene nigher heuen, and thence the passage ethe.

As well can proue the piercing leuin, the seeldome falls bynethe. destroy, harm since then

therefore; think

stock (of examples)

recourse, resort

?flowing slowly

'mingled' (E. K.)

51 flocke of Dan] Morrell's worst error. Christ belonged to the tribe (flocke) of Judah; the Antichrist was thought to come from the tribe of Dan. E. K. offers a different explanation: 'One trybe is put for the whole nation per Synecdochen': i.e. the 'flocke of Dan' is humankind, from which the incarnate Christ was born. 57-68 Loosely based on Mantuan VIII.45-9. 57-60 E. K. cites the account of the mountain range of Ida in Diodorus Siculus 17.7 (not a 'holy father'): an optical illusion from the hilltop appears to show the sun before it appears, its fire dispersed over a huge distance. 61 stayed] (a) supported, upheld (b) fastened, anchored. 63-4 Phebe] Diana or Cynthia the moon-goddess. She put her beloved shepherd Endymion to continual sleep on Mount Latmos, not Ida. $\quad \mathbf{6 7 - 8}$ Obvious reference to the Fall, so that the 'hyllye place' (58) is assimilated to Paradise. E. K. calls it an 'errour of shepheards vnderstanding' to say all shepherds fed their flocks there. $\mathbf{6 9}$ foresaid] forsaid, 'exclude(d) by command' (OED for-1b: only in Spenser). $\quad 73$ Synah] Sinai. 'A hill in Arabia, where God appeared' (E. K.) to Moses and granted him the Ten Commandments. 74 our Ladyes bowre] 'a place of pleasure so called' (E. K.), scandalously placed by Morell on a par with Mount Sinai. But perhaps Laureta, the Catholic place of pilgrimage, mentioned in Mantuan VIII alongside Sinai. 75 strow] strew: display (OED strew 1d, citing this passage only). $\quad$ 77-8 Faunes, Syluanes] wood-gods, often lascivious. holy] satirically identifying them with priests. $\mathbf{7 8}$ haunten] resort to, frequent (pl. ending in - en). rathe] quickly, ?hence readily, eagerly. 79 Medway] flows through Kent into the Thames (Themis, 83) at Rochester near the latter's estuary, hence 'salt' (81). About this time, Spenser was employed by the Bishop of Rochester. 85-6 Melampode, Teribinth] the black hellebore and turpentine tree respectively: 'hearbes good to cure diseased Gotes' (E. K., citing Mantuan VIII.17 for the first and Theocritus, Epigram 1 for the latter). $\quad \mathbf{8 9 - 9 2}$ E. K. notes Morell's 'simplenesse' in thinking that physical height implies nearness to heaven. Also strange to regard lightning-strikes as a sign of heavenly favour. E. K. quotes Horace, Odes 2.10. 
Thomalin. Syker thou speakes lyke a lewde lorrell, of Heauen to demen so:

How be I am but rude and borrell,

ignorant and worthless person yet nearer wayes I knowe.

To Kerke the narre, from God more farre, has bene an old sayd sawe.

And he that striues to touch the starres, oft stombles at a strawe.

Alsoone may shepheard clymbe to skye, that leades in lowly dales,

As Goteherd prowd that sitting hye, vpon the Mountaine sayles.

My seely sheepe like well belowe, they neede not Melampode:

For they bene hale enough, I trowe, and liken theyr abode;

But if they with thy Gotes should yede, they soone myght be corrupted:

Or like not of the frowie fede, like as not, very likely; 'mustye or mossie' (E. K.), damp as soon, as readily conducts himself, lives

How be: though; borrell: rustic, boorish

church; 'nearer' (E. K.) traditional saying, proverb or with the weedes be glutted.

The hylls, where dwelled holy saints, I reuerence and adore:

Not for themselfe, but for the sayncts, which han be dead of yore.

And nowe they bene to heauen forewent, theyr good is with them goe:

floats

healthy; believe, am sure

'goe' (E. K.)

Theyr sample onely to vs lent, that als we mought doe soe.

Shepheards they weren of the best, and liued in lowlye leas:

And sith theyr soules bene now at rest, why done we them disease?

Such one he was, (as I haue heard old Algrind often sayne)

That whilome was the first shepheard, and liued with little gayne:

As meek he was, as meeke mought be, simple, as simple sheepe,

Humble, and like in eche degree

example we too the flocke, which he did keepe.

Often he vsed of hys keepe a sacrifice to bring,

Now with a Kidde, now with a sheepe the Altars hallowing.

So lowted he vnto hys Lord, such fauour couth he fynd,

That sithens neuer was abhord, the simple shepheards kynd.

annoyance, disturbance

'did honour and reuerence' (E. K.)

And such I weene the brethren were, that came from Canaan:

The brethren twelue, that kept yfere the flockes of mighty Pan.

But nothing such thilk shephearde was, whom Ida hyll dyd beare,

That left hys flocke, to fetch a lasse, whose loue he bought to deare:

For he was proude, that ill was payd, (no such mought shepheards bee)

127 the first shepheard] Abel. 143 brethren twelue] Jacob's twelve sons, who kept their father's vast stock of cattle. 144 mighty Pan] not explained by E. K. Perhaps Jacob, patriarch and originator of the twelve tribes of Israel. $\quad \mathbf{1 4 5}$ thilk shephearde] Paris, who kept sheep on Ida. $\mathbf{1 4 7}$ a lasse] Helen of Troy. 149 proud] presumably for daring to sit in judgment over three goddesses. 
And with lewde lust was ouerlayd: pressed, overcome tway things doen ill agree:

But shepheard mought be meeke and mylde, well eyed, as Argus was,

With fleshly follyes vndefyled, and stoute as steede of brasse.

Sike one (sayd Algrin) Moses was, That sawe hys makers face,

His face more cleare, then Christall glasse, and spake to him in place.

This had a brother, (his name I knewe) the first of all his cote,

A shepheard trewe, yet not so true, as he that earst I hote.

Whilome all these were lowe, and lief, and loued their flocks to feede,

They neuer strouen to be chiefe, and simple was theyr weede.

But now (thanked be God therefore)

dress the world is well amend,

Their weedes bene not so nighly wore, such simplesse mought them shend:

They bene yclad in purple and pall, so hath theyr god them blist,

They reigne and rulen ouer all, and lord it, as they list:

Ygyrt with belts of gllitterand gold, (mought they good sheepeheards bene)

Theyr Pan theyr sheepe to them has sold, I saye as some haue seene.

For Palinode (if thou him ken) yode late on Pilgrimage

To Rome, (if such be Rome) and then he sawe thilke misusage.

went

For shepeheards (sayd he) there doen leade, as Lordes done other where,

Theyr sheepe han crustes, and they the bread: the chippes, and they the chere:

They han the fleece, and eke the flesh, (O seely sheepe the while)

The corne is theyrs, let other thresh, their hands they may not file.

They han great stores, and thriftye stockes, great freendes and feeble foes:

What neede hem caren for their flocks? theyr boyes can looke to those.

These wisards weltre in welths waues, pampred in pleasures deepe,

They han fatte kernes, and leany knaues,

amended, improved (ironical) in simple parsimonious fashion might; shame rich cloth, especially purple blest wish glittering parings of bread crusts; hearty meal defile prosperous, abundant

152 tway things] lust and pride on the one hand, and the shepherdly humility on the other. Argus] the hundred-eyed guard appointed by Hera (Juno) for Io transformed into a cow: exemplifying moral vigilance. 156 steede] stead: house or city. of brasse] with walls of brass. 158 sawe hys makers face] Exodus 24.10. See also Exodus 20. 161 a brother] Aaron, appointed priest of the Jews by God (Exodus 28). his name I knewe] E. K. says Thomalin's forgetting Aaron's name is in accord with pastoral decorum, 'lest his remembrance and skill in antiquities of holy writ should seeme to exceede the meanenesse of the Person'. This seems rather pointless, seeing as Thomalin can recall Moses' name. 163 yet not so true] Aaron led the people in an idolatrous revolt during Moses' absence (Exodus 32). $\quad 173$ purple and pall] the dress of kings and rulers: according to E. K., 'Spoken of the Popes and Cardinalles', whose vestments were also called 'palls'. A glance not only at the Catholic church but High Anglicanism. 178 May they be or prove good shepherds. 179 Theyr Pan] 'that is the Pope' (E. K.): referring to the sale of church offices for money. $\mathbf{1 8 3}$ if such be Rome] if such a place deserves the name of Rome. 197 wisards] 'greate learned heads' (E. K.), obviously ironical. 199-200 i.e., The upper clergy live in luxury, while the lowly priests looking after the common people are impoverished. 199 kerne] 'a Churle or Farmer' (E. K.; OED 2). knaues] servants, hirelings. 
their fasting flockes to keepe.

Sike mister men bene all misgone, they heapen hylles of wrath:

Sike syrlye shepheards han we none, they keepen all the path.

Morrell. Here is a great deale of good matter, lost for lacke of telling,

Now sicker I see, thou doest but clatter: harme may come of melling.

Thou medlest more, then shall haue thanke, to wyten shepheards welth:

When folk bene fat, and riches rancke, it is a signe of helth.

But say me, what is Algrin he, that is so oft bynempt.

Thomalin. He is a shepheard great in gree, but hath bene long ypent.

One day he sat vpon a hyll, (as now thou wouldest me:

But I am taught by Algrins ill, to loue the lowe degree.)

For sitting so with bared scalpe, an Eagle sored hye,

That weening hys whyte head was chalke, a shell fish downe let flye:

She weend the shell fishe to haue broake, but therewith bruzd his brayne,

So now astonied with the stroke, he lyes in lingring payne.

Morell. Ah good Algrin, his hap was ill, but shall be better in time.

Now farwell shepheard, sith thys hyll thou hast such doubt to climbe. 'such kinde of (E.K.); misguided, degenerate gather to themselves 'stately and prowde' (E.K.)

\author{
badly told \\ surely; chatter, gabble \\ 'medling' (E. K.), interfering, criticizing \\ than \\ censure, condemn \\ swollen, abundant
}

210

named, alluded to degree, rank

captive, imprisoned

wish me to do

220

thinking

broke, smashed

rendered insensible; paralysed

\section{Palinodes Embleme. \\ In medio virtus.}

Morrells Embleme.

In summo folicitas.

\section{Edmund Spenser from Colin Clout's Come Home Again}

This long poem (published 1595) presents Spenser (in his usual persona of Colin Clout) among the expatriate English community in Ireland, where Spenser lived from 1580 to 1599 as secretary to the Lord Deputy. The immediate subject is a visit to the court at London with his patron Sir Walter Ralegh in 1590-91, to present the first section of The Faerie Queene to the Queen in hope of preferment. The poem combines two conventional pastoral veins, viewing the court through a shepherd's eyes as a place of simultaneous distinction and corruption, occasion of both encomium and satire. The excerpts below represents lines 1-79, 178-263, 290-327, 584-687 of the poem.

202 wrath] presumably human as well as divine. 204 They stick to the right path: a concession to the English clergy, perhaps to balance the earlier attack. 209 No-one will thank you for meddling so much. 216 long ypent] Grindal (see headnote) was not imprisoned but sequestered (i.e. prevented from performing most duties) for his supposed (though mild) Puritan sympathies. 217 a hyll] i.e. position of eminence. Grindal was Bishop of London and Archibishop of York before becoming Archbishop of Canterbury. 230 better in time] Grindal was reinstated in 1582.233 In medio virtus] Virtue lies in the middle path. 234 In summo foelicitas] Happiness resides at the top. E. $\mathrm{K}$. has a long note on the opposite ideals of the golden mean and the highest or perfect happiness, as reflected respectively in the humility of Christ and the exalted bliss of God in heaven. 
The shepheards boy (best knowne by that name)

That after Tityrus first sung his lay,

Laies of sweet loue, without rebuke or blame,

Sate (as his custome was) vpon a day,

Charming his oaten pipe vnto his peres,

The shepherd swaines that did about him play:

Who all the while with greedie listfull eares,

Did stand astonisht at his curious skill,

Like hartlesse deare, dismayd with thunders sound.

At last when as he piped had his fill,

He rested him: and sitting then around,

One of those groomes (a iolly groome was he,

As euer piped on an oaten reed,

And lou'd this shepheard dearest in degree,

Hight Hobbinol) gan thus to him areed. Colin my liefe, my life, how great a losse

Had all the shepheards nation by thy lacke?

And I poore swaine of many greatest crosse:

That sith thy Muse first since thy turning backe

Was heard to sound as she was wont on hye,

Hast made vs all so blessed and so blythe.

Whilest thou wast hence, all dead in dole did lie:

The woods were heard to waile full many a sythe,

And all their birds with silence to complaine:

The fields with faded flowers did seem to mourne,

And all their flocks from feeding to refraine:

The running waters wept for thy returne,

And all their fish with languour did lament:

But now both woods and fields, and floods reviue,

Sith thou art come, their cause of meriment,

That vs late dead, hast made againe aliue:

But were it not too painfull to repeat

The passed fortunes, which to thee befell

In thy late voyage,we thee would entreat,

Now at thy leisure them to vs to tell.

To whom the shepheard gently answered thus,

Hobbin thou temptest me to that I couet:

For of good passed newly to discus,

By dubble vsurie doth twise renew it.

And since I saw that Angels blessed eie,

Her worlds bright sun, here heauens fairest light,

My mind full of my thoughts satietie,

Doth feed on sweet contentment of that sight:

Since that same day in nought I take delight

Ne feeling haue in any earthly pleasure,

But in remembrance of that glorious bright,

My lifes sole blisse, my hearts eternall threasure.

agog, eager to listen expert, meticulous a deer without her mate

beloved

absence

loudly, stridently

time

courteously, gracefully

Wake then my pipe, my sleepie Muse awake,

Till I haue told her praises lasting long:

Harke then ye iolly shepheards to my song.

With that they all gan throng about him neare,

With hungrie eares to heare his harmonie:

2 after] prob. 'following, imitating' rather than 'next in time'. Tityrus] Chaucer, as usually in Spenser, transferring the usual pastoral name for Virgil derived from Virgil I. 5 Charming] 'tempering, tuning, playing' (OED charm ${ }^{v}$ 7: first and chief examples from Spenser). 12 groomes] men; in 16-17c, especially shepherds $(O E D$ 2). $\quad 15$ Hobbinol] Identified with Gabriel Harvey in SC ('September' 176) and Colin Clout 735-6, where Hobbinol says he (like Harvey) once served Lobbin (the Earl of Leicester). Harvey was never in Ireland, but Spenser transfers him imaginatively to this setting. 18 of many greatest crosse] (had) suffered the most of all. 19-21We are all happy and blessed now that, for the first time since your return, you are singing as you used to do of old. 37 You are asking of me what I myself wish to do. $\quad 38-9$ To discuss past happiness again doubles the enjoyment derived from it. 4o that Angel] Elizabeth. 40-41 standard Petrarchan conceits. 43 sweet ... sight] the sweet pleasure drawn from that sight. 
The whiles their flocks deuoyd of dangers feare,

Did round about them feed at libertie.

One day (quoth he) I sat, (as was my trade)

Vnder the foote of Mole that mountaine hore,

Keeping my sheepe amongst the cooly shade,

Of the greene alders by the Mullaes shore:

There a straunge shepheard chaunst to find me out,

Whether allured with my pipes delight,

Whose pleasing sound yshrilled far about,

Or thither led by chaunce, I know not right:

foreign (i.e., from England)

sounded loudly

was called; name

And how he hight, himselfe he did ycleepe,

The shepheard of the Ocean by name,

And said he came far from the main-sea deepe.

He sitting me beside in that same shade,

Prouoked me to plaie some pleasant fit,

And when he heard the musicke which I made,

He found himselfe full greatly pleasd at it:

Yet æmuling my pipe, he tooke in hond

My pipe before that æmuled of many,

And plaid theron; (for well that skill he cond)

Himselfe as skilfull in that art as any.

He pip'd, I sung; and when he sung, I piped,

By chaunge of turnes, each making other mery,

Neither enuying other, nor enuied,

So piped we, vntill we both were weary.

When thus our pipes we both had wearied well,

(Quoth he) and each an end of singing made,

He gan to cast great lyking to my lore,

And great dislyking to my lucklesse lot:

That banisht had my selfe, like wight forlore,

Into that waste, where I was quite forgot.

The which to leaue, thenceforth he counseld mee,

Vnmeet for man in whom was ought regardfull,

And wend with him, his Cynthia to see:

Whose grace was great, and bounty most rewardfull.

Besides her peerlesse skill in making well

And all the ornaments of wondrous wit,

Such as all womankynd did far excell:

Such as the world admyr'd and praised it:

So what with hope of good, and hate of ill,

$\mathrm{He}$ me perswaded forth with him to fare,

Nought tooke I with me, but mine oaten quill:

Small needments else need shepheard to prepare.

So to the sea we came; the sea? that is

A world of waters heaped vp on hie,

Rolling like mountaines in wide wildernesse,

Horrible, hideous, roaring with hoarse crie.

And is the sea (quoth Coridon) so fearfull?

Fearful much more (quoth he) then hart can fear:

Thousand wyld beasts with deep mouthes gaping direfull

Therin stil wait poore passengers to teare.

Who life doth loath, and longs death to behold,

Before he die, alreadie dead with feare, called, invited; tune, song

knew he: Colin

being, man; forsaken

unfit; worthy of note

composing poetry

57 Mole] Spenser's name for the Ballahoura mountains near his Irish home. hore] hoar, white-headed. Called 'old father Mole' in Colin Clout 104, FQ VII.6.36.8. 59 Mulla] Spenser's name for the river Awbeg near his home in Kilcolma: flowing down from the Mole, hence called his daughter (Colin Clout 108, F.Q. VII.6.40.3). $\mathbf{6 6}$ shepheard of the Ocean] Walter Ralegh, who calls himself the Ocean or 'Oceanus' in his own poetry in allusion to his voyages. (See no.142.) One of the biggest landowners in Ireland, and familiar with Spenser. $\quad \mathbf{7 2}$ æmuling] emulating: imitating, attempting to rival (OED cites only this passage). $\quad \mathbf{8 2}$ cast] bestow. lore] (a) skill (b) tales, compositions. $\mathbf{9 6}$ quill] (a) pipe (b) pen. 
And yet would liue with heart halfe stonie cold,

Let him to sea, and he shall see it there.

110 And yet as ghastly dreadfull as it seemes,

Bold men presuming life for gaine to sell,

Dare tempt that gulf, and in those wandring stremes

Seek waies vnknowne, waies leading down to hell.

For as we stood there waiting on the strond,

i.e., the underworld

Behold an huge great vessell to vs came,

Dauncing vpon the waters back to lond,

As if it scornd the daunger of the same;

Yet was it but a wooden frame and fraile,

Glewed togither with some subtile matter,

120 Yet had it armes and wings, and head and taile,

strand, shore

And life to moue it selfe vpon the water.

Strange thing, how bold and swift the monster was,

That neither car'd for wynd, nor haile, nor raine,

Nor swelling waues, but thorough them did passe

So proudly, that she made them roare againe.

The same aboord vs gently did receaue,

And without harme vs farre away did beare,

So farre that land our mother vs did leaue,

And nought but sea and heauen to vs appeare.

130 Then hartlesse quite and full of inward feare,

That shepheard I besought to me to tell,

Vnder what skie, or in what world we were,

In which I saw no liuing people dwell.

Who me recomforting all that he might,

Told me that that same was the Regiment

Of a great shepheardesse, that Cynthia hight,

His liege, his Ladie, and his lifes Regent.

If then (quoth I) a shepheardesse she bee,

Where be the flockes and heards, which she doth keep?

140 And where may I the hills and pastures see,

On which she vseth for to feed her sheepe?

These be the hills (quoth he) the surges hie,

On which faire Cynthia her heards doth feed:

Her heards be thousand fishes with their frie,

Which in the bosome of the billowes breed.

Of them the shepheard which hath charge in chief,

Is Triton blowing loud his wreathed horne:

At sound whereof, they all for their relief

Wend too and fro at euening and at morne.

150 And Proteus eke with him does driue his heard

Of stinking Seales and Porcpisces together,

With hoary head and deawy dropping beard,

Compelling them which way he list, and whether.

And I among the rest of many least,

Haue in the Ocean charge to me assignd:

Where I will liue or die at her beheast,

And serue and honour her with faithfull mind.

Besides an hundred Nymphs all heauenly borne,

And of immortall race, doo still attend

To wash faire Cynthiaes sheep, when they be shorne,

And fold them vp, when they haue made an end.

Those be the shepheards which my Cynthia serue,

At sea, beside a thousand moe at land:

110 Although it seems so ghastly and fearsome.

the ship had escaped their clutches.

125 roare againe] out of anger and frustration that life's Regent] similarly combines allegiance as subject and as lover. 142-65 A celebration of England's nascent naval power. 147 Triton] Neptune's son, who herded and rode on sea-creatures. wreathed horne] the shell on which Triton is commonly shown as blowing. 150 Proteus] a sea-god capable of great changes of shape, tending flocks of seals. 151 Porcpisces] porpoises: false etymology, porc + pisces, pig + fish. $\quad 155$ Ralegh was appointed Vice-Admiral of Devon and Cornwall in 1585. 
For land and sea my Cynthia doth deserue To haue in her commandement at hand.

What land is that thou meanst (then Cuddy sayd)

And is there other, then whereon we stand?

Ah Cuddy (then quoth Colin) thous a fon,

That hast not seene least part of natures worke:

Much more there is vnkend, then thou doest kon,

And much more that does from mens knowledge lurke.

For that same land much larger is then this,

unknown; know

hide

170

than

And other men and beasts and birds doth feed:

There fruitfull corne, faire trees, fresh herbage is

And all things else that liuing creatures need.

Besides most goodly riuers there appeare,

No whit inferiour to thy Funchins praise,

Or vnto Allo or to Mulla cleare:

Nought hast thou foolish boy seene in thy daies.

But if that land be there (quoth he) as here,

And is theyr heauen likewise there all one?

And if like heauen, be heauenly graces there,

Like as in this same world where we do wone?

Both heauen and heauenly graces do much more

(Quoth he) abound in that same land, then this.

For there all happie peace and plenteous store

Conspire in one to make contented blisse:

No wayling there nor wretchednesse is heard,

No bloodie issues nor no leprosies,

discharges

No griesly famine, nor no raging sweard,

No nightly bodrags, nor no hue and cries;

The shepheards there abroad may safely lie,

On hills and downes, withouten dread or daunger:

No rauenous wolues the good mans hope destroy,

Nor outlawes fell affray the forest raunger.

attack

There learned arts do florish in great honor,

And Poets wits are had in peerlesse price:

Religion hath lay powre to rest vpon her,

Aduancing vertue and suppressing vice.

For end, all good, all grace there freely growes,

favours, blessings

Had people grace it gratefully to vse:

For God his gifts there plenteously bestowes,

But gracelesse men them greatly do abuse.

So hauing said, Aglaura him bespake:

Colin, well worthie were those goodly fauours

Bestowd on thee, that so of them doest make,

And them requitest with thy thankfull labours.

But of great Cynthiaes goodnesse and high grace,

Finish the storie which thou hast begunne.

More eath (quoth he) it is in such a case,

How to begin, then know how to haue donne.

For euerie gift and euerie goodly meed,

reward

Which she on me bestowd, demaunds a day,

And euerie day, in which she did a deed,

Demaunds a yeare it duly to display.

Her words were like a streame of honny fleeting,

The which doth softly trickle from the hiue:

177-8 Funchin (Funcheon), Allo, Mulla] rivers in Ireland. Allo] 'the little stream now called the Allo or Allow, flowing into the Blackwater ... though Spenser really intended it for the great Blackwater itself.' (P. W. Joyce, The Wonders of Ireland, 1911). Mulla] See 59n. 191-2 bodrags] raids (like those of insurgents or marauders in Ireland). $\quad 194-5$ wolues, outlawes] two major afflictions in Ireland. Cf $F Q$ 7.6.55: Ireland 'Doth to this day with Wolues and Thieues abound'. Wolves were extinct in England by Henry VII's time. 198 The English monarch is the head of the Church of England. 208 Cynthia] Diana the virgin moon-goddess - a common identity for Elizabeth. 
Hable to melt the hearers heart vnweeting,

unperceived, spontaneously

And eke to make the dead againe aliue.

Her deeds were like great glusters of ripe grapes,

clusters

Which load the bunches of the fruitfull vine:

Offring to fall into each mouth that gapes,

And fill the same with store of timely wine.

Her lookes were like beames of the morning Sun,

Forth looking through the windowes of the East:

When first the fleecie cattell haue begun

Vpon the perled grasse to make their feast.

Her thoughts are like the fume of Franckincence,

Which from a golden Censer forth doth rise:

230 And throwing forth sweet odours mounts fro thence

In rolling globes vp to the vauted skies.

There she beholds with high aspiring thought,

The cradle of her owne creation:

Emongst the seats of Angels heauenly wrought,

Much like an Angell in all forme and fashion. Colin (said Cuddy then) thou hast forgot

Thy selfe, me seemes, too much, to mount so hie:

Such loftie flight, base shepheard seemeth not,

From flocks and fields, to Angels and to skie.

240 True (answered he) but her great excellence,

Lifts me aboue the measure of my might:

That being fild with furious insolence,

I feele my selfe like one yrapt in spright.

For when I thinke of her, as oft I ought,

Then want I words to speake it fitly forth:

And when I speake of her what I haue thought,

I cannot thinke according to her worth.

Yet will I thinke of her, yet will I speake,

So long as life my limbs doth hold together,

250 And when as death these vitall bands shall breake,

Her name recorded I will leaue for euer.

Her name in euery tree I will endosse,

vaulted, overarching

her place of origin

That as the trees do grow, her name may grow:

And in the ground each where will it engrosse,

And fill with stones, that all men may it know.

The speaking woods and murmuring waters fall,

Her name Ile teach in knowen termes to frame:

And eke my lambs when for their dams they call,

Ile teach to call for Cynthia by name.

260 And long while after I am dead and rotten:

Amongst the shepheards daughters dancing rownd,

My layes made of her shall not be forgotten,

But sung by them with flowry gyrlonds crownd.

And ye, who so ye be, that shall surviue:

When as ye heare her memory renewed,

Be witnesse of her bountie here aliue,

Which she to Colin her poore shepheard shewed.

Much was the whole assembly of those heards,

Moov'd at his speech, so feelingly he spake:

270 And stood awhile astonisht at his words,

Till Thestylis at last their silence brake,

Saying, Why Colin, since thou foundst such grace

With Cynthia and all her noble crew:

Why dist thou euer leaue that happie place,

In which such wealth might vnto thee accrew?

And back returnedst to this barrein soyle,

237-46 Applies the common motif of paulo maiora ('a little grander', Virgil IV.1), when pastoral rises beyond its usual humble themes. $\quad 242$ furious] frenzied, inspired. insolence] 'exultation' (OED 2), citing only this passage, but 'exaltation' would be nearer the sense. 252 Echoes Virgil X.53.

herdsmen

bodily frame holding life together

inscribe

write in large letters 
Where cold and care and penury do dwell:

Here to keep sheepe, with hunger and with toyle,

Most wretched he, that is and cannot tell.

Happie indeed (said Colin) I him hold,

That may that blessed presence still enioy,

Of fortune and of enuy vncomptrold,

not ruled or dominated

Which still are wont most happie states t'annoy:

But I by that which little while I prooued,

Some part of those enormities did see,

The which in Court continually hooued,

And followd those which happie seemd to bee.

Therefore I silly man, whose former dayes

Had in rude fields bene altogether spent,

Darest not aduenture such vnknowen wayes,

Nor trust the guile of fortunes blandishment,

But rather chose back to my sheep to tourne,

Whose vtmost hardnesse I before had tryde,

Then hauing learnd repentance late, to mourne

Emongst those wretches which I there descryde. Shepheard (said Thestylis) it seemes of spight

Thou speakest thus gainst their felicitie,

Which thou enuiest, rather then of right

That ought in them blameworthie thou doest spie. Cause haue I none (quoth he) of cancred will

To quite them ill, that me demeand so well:

But selfe-regard of priuate good or ill,

Moues me of each, so as I found, to tell

And eke to warne yong shepheards wandring wit,

Which through report of that liues painted blisse,

Abandon quiet home, to seeke for it,

And leaue their lambes to losse misled amisse.

cankered, infected treated

\section{Edmund Spenser Astrophel}

This elegy for Sidney was prob. written long after Sidney's death in 1586, perhaps at the revival of the Sidney cult in the early 1590 os when his works began to be published. It appeared in 1595, heading a supplementary section to Colin Clouts Come Home Againe consisting entirely of laments for Sidney. Modelled on Ronsard's French poem Adonis, and that in turn on Bion's Greek lament for Adonis and the story of Venus and Adonis in Ovid, Met. X.519-739. Astrophel (or Astrophil, 'star-lover') is the name famously assumed by Sidney as the lover of Stella ('star'), Penelope Devereux (see 73n). Spenser seems to be transferring the name Stella to Sidney's wife Frances Walsingham, or conflating Penelope and Frances in a single symbolic figure of mourning.

ASTROPHEL.

A Pastorall Elegie vpon the death of the most Noble and valorous Knight, Sir Philip Sidney.

Dedicated

To the most beautifull and vertuous Ladie, the Countesse of Essex.

Shepheards that wont on pipes of oaten reed,

Oft times to plaine your loues concealed smart:

And with your piteous layes haue learnd to breed

Compassion in a countrey lasses hart.

Hearken ye gentle shepheards to my song,

And place my dolefull plaint your plaints emong.

To you alone I sing this mournfull verse,

The mournfulst verse that euer man heard tell:

279 is and cannot tell] is so placed, but cannot complain.

$\mathbf{2 8 4}$ by that ... prooued] from my brief experience. 300-4 I have no grudge against them, for they treated me well; but concern for my welfare makes me speak against them and warn other young shepherds against the court. $\quad 0.3$ the Countesse of Essex] Sidney's widow, Frances Walsingham. 
To you whose softened hearts it may empierse, With dolours dart for death of Astrophel.

To you I sing and to none other wight,

For well I wot my rymes bene rudely dight.

Yet as they been, if any nycer wit

Shall hap to heare, or couet them to read:

Thinke he, that such are for such ones most fit,

Made not to please the liuing but the dead.

And if in him found pity euer place,

Let him be moov'd to pity such a case.

A Gentle Shepheard borne in Arcady,

20 Of gentlest race that euer shepheard bore:

About the grassie bancks of Homony,

Did keepe his sheep, his litle stock and store.

Full carefully he kept them day and night,

In fairest fields, and Astrophel he hight.

fashioned, composed

more fastidious or sophisticated

desire

Let him think

Young Astrophel the pride of shepheards praise,

Young Astrophel the rusticke lasses loue:

Far passing all the pastors of his daies,

In all that seemly shepheard might behoue.

In one thing onely fayling of the best,

That he was not so happie as the rest.

For from the time that first the Nymph his mother

Him forth did bring, and taught her lambs to feed:

A sclender swaine excelling far each other,

In comely shape, like her that did him breed.

He grew vp fast in goodnesse and in grace,

And doubly faire wox both in mynd and face.

Which daily more and more he did augment,

With gentle vsage and demeanure myld:

That all mens hearts with secret rauishment

He stole away, and weetingly beguyld.

Ne spight it selfe that all good things doth spill,

Found ought in him, that she could say was ill.

His sports were faire, his ioyance innocent,

Sweet without sowre, and honny without gall:

And he himselfe seemd made for meriment,

Merily masking both in bowre and hall.

There was no pleasure nor delightfull play,

When Astrophel so euer was away.

For he could pipe and daunce, and caroll sweet,

Emongst the shepheards in their shearing feast:

As Somers larke that with her song doth greet

The dawning day forth comming from the East.

And layes of loue he also could compose,

Thrise happie she, whom he to praise did chose.

Full many Maydens often did him woo,

Them to vouchsafe emongst his rimes to name,

Or make for them as he was wont to doo,

For her that did his heart with loue inflame.

For which they promised to dight for him,

Gay chapelets of flowers and gyrlonds trim.

stock, ancestry

was called

highest object

that befits a proper shepherd

every other person

vsage: habitual behaviour, ways

with the subjects' full knowledge destroy

cleanly or fairly played

compose poetry or songs

15 such ones] mourners, too afflicted by grief to write finely. 19 Arcady] perhaps referring specially to Sidney's Arcadia. 21 Hæmony] Haemonia, the ancient name of Thessaly, a traditional pastoral locale. $\quad$ 41-2 Even malice, that attacks all good things, could not find any fault in him. $\quad$ 43-8 Sidney took prominent part in court spectacles and entertainments, and was valued by Elizabeth for that reason despite her reservations about him. Perhaps also recalls Sidney's introducing himself (under his other persona of Philisides) in the song-meets or 'Eclogues' in Arcadia. Sukanta Chaudhuri - 9781526143426 
And many a Nymph both of the wood and brooke,

Soone as his oaten pipe began to shrill:

Both christall wells and shadie groues forsooke,

To heare the charmes of his enchanting skill.

And brought him presents, flowers if it were prime,

Or mellow fruit if it were haruest time.

But he for none of them did care a whit,

Yet wood Gods for them oft sighed sore:

Ne for their gifts vnworthie of his wit,

Yet not vnworthie of the countries store.

For one alone he cared, for one he sight,

His lifes desire, and his deare loues delight.

Stella the faire, the fairest star in skie,

As faire as Venus or the fairest faire:

A fairer star saw neuer liuing eie,

Shot her sharp pointed beames through purest aire.

Her he did loue, her he alone did honor,

His thoughts, his rimes, his songs were all vpon her.

To her he vowd the seruice of his daies,

On her he spent the riches of his wit:

For her he made hymnes of immortall praise,

Of onely her he sung, he thought, he writ.

Her, and but her of loue he worthie deemed,

For all the rest but litle he esteemed.

Ne her with ydle words alone he wowed,

And verses vaine (yet verses are not vaine)

But with braue deeds to her sole seruice vowed,

And bold atchieuements her did entertaine.

For both in deeds and words he nourtred was,

Both wise and hardie (too hardie alas).

In wrestling nimble, and in renning swift,

In shooting steddie, and in swimming strong:

Well made to strike, to throw, to leape, to lift,

And all the sports that shepheards are emong.

In euery one he vanquisht euery one,

He vanquisht all, and vanquisht was of none.

Besides, in hunting such felicitie,

Or rather infelicitie he found:

That euery field and forest far away,

He sought, where saluage beasts do most abound.

No beast so saluage but he could it kill,

No chace so hard, but he therein had skill.

Such skill matcht with such courage as he had,

Did prick him foorth with proud desire of praise:

To seek abroad, of daunger nought y'drad,

His mistress name, and his owne fame to raise.

What need perill to be sought abroad,

Since round about vs, it doth make aboad?

64 charmes, enchanting] to be taken (though metaphorically) in the full magical sense.

The gifts were no fit tribute to his talents, though the best the countryside could afford. 73 Stella] Penelope Devereux, daughter of the Earl of Essex, finally married to Lord Rich; the subject of Sidney's Astrophil and Stella and other poems. Curiously brought into a poem dedicated to the woman Sidney later married, though of course Stella was a celebrated presence in his poetry. Spenser might be intending a transference of the name to Sidney's wife Frances (as $165 \mathrm{ff}$. implies), though she had remarried before the publication and prob. composition of Astrophel. 75-6 The fairest star that living eye that ever saw (punning on Stella, star). $\quad$ 91-6 pastoral parallels to Sidney's courtly sports and jousts. $\quad 97$ hunting] a trope for soldiering. 98 infelicitie] alluding to his death in battle. 
It fortuned as he, that perilous game

In forreine soyle pursued far away:

Into a forest wide, and waste he came

Where store he heard to be of saluage pray.

So wide a forest and so waste as this,

barren, deserted

Nor famous Ardeyn, nor fowle Arlo is.

There his welwouen toyles and subtil traines,

He laid the brutish nation to enwrap:

So well he wrought with practise and with paines,

That he of them great troups did soone entrap.

Full happie man (misweening much) was hee,

So rich a spoile within his power to see.

Eftsoones all heedlesse of his dearest hale,

Full greedily into the heard he thrust:

To slaughter them, and worke their finall bale,

Least that his toyle should of their troups be brust.

Wide wounds emongst them many one he made,

Now with his sharp borespear, now with his blade.

nets; ingenious traps

herds, large numbers greatly mistaken or deluded

well-being, hence safety

harm, destruction

burst

sword

His care was all how he them all might kill,

That none might scape (so partiall vnto none)

Ill mynd so much to mynd anothers ill,

As to become vnmyndfull of his owne.

But pardon that vnto the cruell skies,

That from himselfe to them withdrew his eies.

So as he rag'd emongst that beastly rout,

A cruell beast of most accursed brood

Vpon him turnd (despeyre makes cowards stout)

And with fell tooth accustomed to blood,

Launched his thigh with so mischieuous might,

That it both bone and muscles ryued quight.

So deadly was the dint and deep the wound,

And so huge streames of blood thereout did flow:

That he endured not the direfull stound,

But on the cold deare earth himselfe did throw.

The whiles the captiue heard his nets did rend,

And hauing none to let, to wood did wend.

Ah where were ye this while his shepheard peares,

To whom aliue was nought so deare as hee:

And ye faire Mayds the matches of his yeares,

Which in his grace did boast you most to bee?

Ah where were ye, when he of you had need,

To stop his wound that wondrously did bleed?

fierce, aggressive

lanced, pierced; destructive

blow

stunning blow

stop or impede them; go

peers, companions

companions of his youth

Ah wretched boy the shape of dreryhead,

And sad ensample of mans suddein end:

Full litle faileth but thou shalt be dead,

Vnpitied, vnplaynd, of foe or frend.

figure of sorrow

Whilest none is nigh, thine eylids vp to close,

And kisse thy lips like faded leaues of rose.

A sort of shepheards sewing of the chace,

As they the forest raunged on a day:

band, group; pursuing one day

110 forreine soyle] Sidney died at the battle of Zutphen in the Netherlands. 114 Ardeyn] prob. covering both Arden in Warwickshire and Ardennes in France, as later in Shakespeare's As You Like It. Arlo] Aherlow, a glen once held by English landowners but, by Spenser's time, taken over by the Irish, hence in Englishmen's view a fowle despoilt region. 131 But the cruel heavens are responsible for this (so pardon them if you wish). $\quad 132$ That distracted his attention towards them and away from his own safety. $\quad 145 \mathrm{~A}$ common pastoral motif going back to Theocritus I.66. 148 Which of you could boast of being his favourite? 157 sort of shepheards] probably alluding to the Dutch, in whose country Sidney died. He survived 26 days after his injury, hence this passage of time. 
By fate or fortune came vnto the place,

Where as the lucklesse boy yet bleeding lay.

Yet bleeding lay, and yet would still haue bled,

Had not good hap those shepheards thether led.

lucky chance

They stopt his wound (too late to stop it was)

And in their armes then softly did him reare:

Tho (as he wild) vnto his loued lasse,

then; wished

His dearest loue him dolefully did beare.

The dolefulst beare that euer man did see,

Was Astrophel, but dearest vnto mee.

She when she saw her loue in such a plight,

With crudled blood and filthie gore deformed:

That wont to be with flowers and gyrlonds dight,

And her deare fauours dearly well adorned

Her face, the fairest face, that eye mote see,

She likewise did deforme like him to bee.

Her yellow locks that shone so bright and long,

As Sunny beames in fairest somers day:

She fierly tore, and with outragious wrong

From her red cheeks the roses rent away.

And her faire brest the threasury of ioy,

She spoyld thereof, and filled with annoy.

rich store

pain, distress

His palled face impictured with death,

She bathed oft with teares and dried oft:

painted or marked over

And with sweet kisses suckt the wasting breath,

Out of his lips like lillies pale and soft.

And oft she cald to him, who answerd nought,

But onely by his lookes did tell his thought.

The rest of her impatient regret,

And piteous mone the which she for him made:

No toong can tell, nor any forth can set,

But he whose heart like sorrow did inuade.

At last when paine his vitall powres had spent,

His wasted life her weary lodge forwent.

(a) bier, hence corpse (b) burden

[defaced, made unsightly curdled, congealed; used; decked, adorned

Which when she saw, she staied not a whit,

But after him did make vntimely haste:

Forth with her ghost out of her corps did flit,

And followed her make like Turtle chaste.

To proue that death their hearts cannot diuide,

Which liuing were in loue so firmly tide.

The Gods which all things see, this same beheld,

And pittying this paire of louers trew:

Transformed them there lying on the field,

Into one flowre that is both red and blew.

It first growes red, and then to blew doth fade,

Like Astrophel, which thereinto was made.

$\mathbf{1 7 2}$ lent lustre to the love-tokens that she gave him to wear. $\mathbf{1 7 7}$ fiery] ?fiercely, violently (not in $O E D$ ). 179-80 Her heart, usually the repository of joy, was now filled with grief. 187 regret] in a very strong sense: lament, grief. 192 His spent life left the lodging (i.e., the body) it had grown weary of. Her] because Lat. vita (life) is feminine. 195 Sidney's widow Frances Walsingham not only survived him but married Robert, Second Earl of Essex, and bore him five children. She could not be shown openly as mourning her first husband. Penelope Rich, too, made a second marriage following a public affair with Charles Blount, Baron Mountjoy. Spenser creates a fictitious Stella combining Penelope and Frances - perhaps with overtones of Sidney's sister Mary, Countess of Pembroke, though in the continuation of this poem (see $234 \mathrm{n}$ ) she is Clorinda, presented in her true relationship to the dead (1.229). 196 Turtle-doves mate for life. 202 one flowre] probably imaginary, though the description fits the borage (Spenser Variorum 7.498). The names Starlight and Penthea (211-12) are not used of any known flower in Spenser's time. 'Starlight' obviously alludes to Stella, and 'Penthea', in Gk, would be 'the flower of sorrow'. 
And in the midst thereof a star appeares,

As fairly formd as any star in skyes:

Resembling Stella in her freshest yeares,

Forth darting beames of beautie from her eyes,

And all the day it standeth full of deow,

210

Which is the teares, that from her eyes did flow.

That hearbe of some, Starlight is cald by name,

Of others Penthia, though not so well:

But thou where euer thou doest finde the same,

Form this day forth do call it Astrophel.

And when so euer thou it vp doest take,

Do pluck it softly for that shepheards sake.

Hereof when tydings far abroad did passe,

The shepheards all which loued him full deare:

And sure full deare of all he loued was,

Did thether flock to see what they did heare.

And when that pitteous spectacle they vewed,

The same with bitter teares they all bedewed.

And euery one did make exceeding mone,

With inward anguish and great griefe opprest:

And euery one did weep and waile, and mone,

And meanes deviz'd to shew his sorrow best.

That from this houre since first on grassie greene

Shepheards kept sheep, was not like mourning seen.

But first his sister that Clorinda hight,

The gentlest shepheardesse that liues this day:

And most resembling both in shape and spright

Her brother deare, began this dolefull lay.

Which least I marre the sweetnesse of the vearse,

In sort as she it sung, I will rehearse.

\section{Edmund Spenser The Faerie Queene Book VI Canto IX.5-36}

In the last of the six completed books of The Faerie Queene, Sir Calidore, the knight exemplifying courtesy, spends some time among shepherds in cantos 9 and 10. In one sense, this marks a truancy from his mission to destroy the Blatant (bleating, braying) Beast, a monster allegorizing rumour. But it is also the spiritual climax of his quest: the vision of the Graces in Canto 10, with deep Neoplatonic implications, is often seen as an effective thematic conclusion to the formally incomplete $F Q$. Calidore's pastoral sojourn is also the romantic climax of his story, for he marries Pastorella, the shepherdess who proves to be of noble parentage. The virtue of courtesy comprises not only outward etiquette but, more centrally, an inner humane refinement expressed in one's total conduct towards all persons. Etymologically and historically, it is identified with the court, yet the Knight of Courtesy finds his most congenial milieu among shepherds in the country, courting a shepherd girl - who proves to be of noble birth. The virtue perfected in pastoral life emanates from the court and returns to it. Calidore is often identified with Philip Sidney, the iconic exemplar of courtesy. In his encounter with Colin Clout (Spenser, as usual), he also suggests Walter Ralegh on his visit to Ireland, as recounted in Colin Clouts Come Home Againe. Colin's presence suggests Spenser's own life in rural Ireland, and Melibœe's discourse on the virtues of the country a (perhaps resigned) acceptance of that life: a paradigm previously found in Colin Clout. As might be expected, the language of this pastoral episode often echoes SC.

There on a day as he pursew'd the chace,

He chaunst to spy a sort of shepheard groomes,

he: Calidore

Playing on pypes, and caroling apace,

The whyles their beasts there in the budded broomes

band, group

Beside them fed, and nipt the tender bloomes:

For other worldly wealth they cared nought.

To whom Sir Calidore yet sweating comes,

And them to tell him courteously besought,

If such a beast they saw, which he had thether brought.

broom plants

234 as she it sung] Suggests the 'Dolefull Lay of Clorinda' that follows is Lady Mary's composition; but it is closely integrated into the preceding verse, and commonly accepted as Spenser's own work. 
They answer'd him, that no such beast they saw,

Nor any wicked feend, that mote offend

Their happie flockes, nor daunger to them draw:

But if that such there were (as none they kend)

They prayd high God them farre from them to send.

Then one of them him seeing so to sweat,

After his rusticke wise, that well he weend,

Offred him drinke, to quench his thirstie heat,

And if he hungry were, him offred eke to eat.

knew, was practised in

also

The knight was nothing nice, where was no need,

And tooke their gentle offer: so adowne

They prayd him sit, and gaue him for to feed

Such homely what, as serues the simple clowne,

That doth despise the dainties of the towne.

Tho hauing fed his fill, he there besyde

Saw a faire damzell, which did weare a crowne

Of sundry flowres, with silken ribbands tyde,

Yclad in home-made greene that her owne hands had dyde.

Vpon a litle hillocke she was placed

Higher then all the rest, and round about

Enuiron'd with a girland, goodly graced,

Of louely lasses, and them all without

The lustie shepheard swaynes sate in a rout,

The which did pype and sing her prayses dew,

And oft reioyce, and oft for wonder shout,

As if some miracle of heauenly hew

Were downe to them descended in that earthly vew.

And soothly sure she was full fayre of face,

And perfectly well shapt in euery lim,

Which she did more augment with modest grace,

And comely carriage of her count'nance trim,

That all the rest like lesser lamps did dim:

Who her admiring as some heauenly wight,

Did for their soueraine goddesse her esteeme,

And caroling her name both day and night,

The fayrest Pastorella her by name did hight.

pretty, charming

outside (the ring of girls)

group

fare, 'somethings'; rustic

fastidious, snobbish; cause

Ne was there heard, ne was there shepheards Swayne

But did her honour, and eke many a one

Burnt in her loue, and with sweet pleasing payne

Full many a night for her did sigh and grone:

But most of all the shepheard Coridon

For her did languish, and his deare life spend;

Yet neither she for him, nor other none

Did care a whit, ne any liking lend:

Though meane her lot, yet higher did her mind ascend.

visible shape

truly, certainly

bearing, comportment; [pretty, elegant

call

herdsman

Her whyles Sir Calidore there vewed well,

And markt her rare demeanure, which him seemed

So farre the meane of shepheards to excell,

As that he in his mind her worthy deemed,

To be a Princes Paragone esteemed.

He was vnwares surprisd in subtile bands

Of the blynd boy, ne thence could be redeemed

By any skill out of his cruell hands,

Caught like the bird, which gazing still on others stands.

average, usual standard

match, consort seized, captured

forever, continuously

35 hew] hue, appearance $\left(O E D_{2}\right) . \quad 35-6$ Platonic implications, as throughout this episode and FQ generally, reaching a climax in Canto 10 (no.45). 60-61 Unknown to him, he was caught in the bonds of love. blynd boy] Cupid. $\quad 63$ gazing... stands] stands motionless at the sight of a predator. 
So stood he still long gazing thereupon,

$\mathrm{Ne}$ any will had thence to moue away,

Although his quest were farre afore him gon;

But after he had fed, yet did he stay,

quarry

And sate there still, vntill the flying day

Was farre forth spent, discoursing diuersly

Of sundry things, as fell to worke delay;

cause

And euermore his speach he did apply

To th'heards, but meant them to the damzels fantazy.

By this the moystie night approching fast,

Her deawy humour gan on th'earth to shed,

That warn'd the shepheards to their homes to hast

Their tender flocks, now being fully fed,

For feare of wetting them before their bed;

Then came to them a good old aged syre,

Whose siluer lockes bedeckt his beard and hed,

With shepheards hooke in hand, and fit attyre,

That wild the damzell rise; the day did now expyre.

He was to weet by common voice esteemed

The father of the fayrest Pastorell,

And of her selfe in very deede so deemed;

Yet was not so, but as old stories tell

Found her by fortune, which to him befell,

In th'open fields an Infant left alone,

And taking vp brought home, and noursed well

As his owne chyld; for other he had none,

That she in tract of time accompted was his owne.

She at his bidding meekely did arise,

And streight vnto her litle flocke did fare:

Then all the rest about her rose likewise,

And each his sundrie sheepe with seuerall care

Gathered together, and them homeward bare:

Whylest euerie one with helping hands did striue

Amongst themselues, and did their labours share,

To helpe faire Pastorella, home to driue

Her fleecie flocke; but Coridon most helpe did giue.

But Meliboee (so hight that good old man)

Now seeing Calidore left all alone,

And night arriued hard at hand, began

Him to inuite vnto his simple home;

Which though it were a cottage clad with lome,

And all things therein meane, yet better so

To lodge, then in the saluage fields to rome.

The knight full gladly soone agreed thereto,

willed: directed, asked

judged to be

(faculty of) apprehension

damp, dewy

moisture

passage

Being his harts owne wish, and home with him did go.

There he was welcom'd of that honest syre,

And of his aged Beldame homely well;

Who him besought himselfe to disattyre,

And rest himselfe, till supper time befell.

By which home came the fayrest Pastorell,

After her flocke she in their fold had tyde,

And supper readie dight, they to it fell

With small adoe, and nature satisfyde,

wild, dangerous

particular, for his own flock

The which doth litle craue contented to abyde.

aged woman, matron take off his armour

confined, shut in made, prepared

84 And she herself thought so. $\quad 95$ bare] bore, took along (OED bear $\left.\mathrm{v}^{1} 1 e\right) . \quad 104$ lome] loam: clay and sand mixed with straw to plaster walls. $\quad 110$ homely] (a) kindly (so OED for this passage) (b) simply, unpretentiously. $\quad \mathbf{1 1 7}$ which asks for little to be contented. 
Tho when they had their hunger slaked well, And the fayre mayd the table ta'ne away, The gentle knight, as he that did excell In courtesie, and well could doe and say, For so great kindnesse as he found that day, Gan greatly thanke his host and his good wife; And drawing thence his speach another way, Gan highly to commend the happie life,

Which Shepheards lead, without debate or bitter strife.

How much (sayd he) more happie is the state, In which ye father here doe dwell at ease, Leading a life so free and fortunate, From all the tempests of these worldly seas, Which tosse the rest in daungerous disease? Where warres, and wreckes, and wicked enmitie disturbance, suffering

Doe them afflict, which no man can appease,

That certes I your happinesse enuie,

And wish my lot were plast in such felicitie.

Surely my sonne (then answer'd he againe)

If happie, then it is in this intent,

That hauing small, yet doe I not complaine

Of want, ne wish for more it to augment,

But doe my selfe, with that I haue, content;

So taught of nature, which doth litle need

Of forreine helpes to lifes due nourishment:

The fields my food, my flocke my rayment breed; yield, provide

No better doe I weare, no better do I feed.

Therefore I doe not any one enuy,

Nor am enuyde of any one therefore;

They that haue much, feare much to loose thereby,

And store of cares doth follow riches store.

The litle that I haue, growes dayly more

Without my care, but onely to attend it;

My lambes doe euery yeare increase their score,

And my flockes father daily doth amend it.

What haue I, but to praise th'Almighty, that doth send it?

To them that list, the worlds gay showes I leaue,

And to great ones such follies doe forgiue,

Which oft through pride do their owne perill weaue,

And through ambition downe themselues doe driue

To sad decay, that might contented liue.

Me no such cares nor combrous thoughts offend,

Ne once my minds vnmoued quiet grieue,

But all the night in siluer sleepe I spend,

And all the day, to what I list, I doe attend.

Sometimes I hunt the Fox, the vowed foe

Vnto my Lambes, and him dislodge away;

Sometime the fawne I practise from the Doe,

Or from the Goat her kidde how to conuay;

Another while I baytes and nets display,

The birds to catch, or fishes to beguyle:

And when I wearie am, I downe doe lay

My limbes in euery shade, to rest from toyle,

await

tally, number

improve, add to

wish

burdensome

separate, i.e., wean

deceive, trap

And drinke of euery brooke, when thirst my throte doth boyle.

136-89 Meliboee's discourse closely imitates that of a shepherd who gives shelter to Erminia in Tasso's Jerusalem Delivered VII.8-13. $\quad \mathbf{1 5 0}$ if I only wait for it to grow, without troubling myself about it. 152 flockes father] the stud ram. 158 that ... liue] that might otherwise have lived in content. 160 I never regret my undisturbed peace of mind. 
The time was once, in my first prime of yeares,

When pride of youth forth pricked my desire,

That I disdain'd amongst mine equall peares

To follow sheepe, and shepheards base attire:

For further fortune then I would inquire.

And leauing home, to roiall court I sought;

Where I did sell my selfe for yearely hire,

And in the Princes gardin daily wrought:

There I beheld such vainenesse, as I neuer thought.

With sight whereof soone cloyd, and long deluded

With idle hopes, which them doe entertaine,

After I had ten yeares my selfe excluded

From natiue home, and spent my youth in vaine,

I gan my follies to my selfe to plaine,

And this sweet peace, whose lacke did then appeare.

Tho backe returning to my sheepe againe,

I from thenceforth haue learn'd to loue more deare

This lowly quiet life, which I inherite here.

Whylest thus he talkt, the knight with greedy eare

Hong still vpon his melting mouth attent;

Whose sensefull words empierst his hart so neare,

That he was rapt with double rauishment,

Both of his speach that wrought him great content,

And also of the obiect of his vew,

On which his hungry eye was alwayes bent;

That twixt his pleasing tongue, and her faire hew,

He lost himselfe, and like one halfe entraunced grew.

Yet to occasion meanes, to worke his mind,

And to insinuate his harts desire,

He thus replyde; Now surely syre, I find,

That all this worlds gay showes, which we admire,

Be but vaine shadowes to this safe retyre

Of life, which here in lowlinesse ye lead,

Fearelesse of foes, or fortunes wrackfull yre,

Which tosseth states, and vnder foot doth tread

The mightie ones, affrayd of euery chaunges dread.

That euen I which daily doe behold

The glorie of the great, mongst whom I won,

And now haue prou'd, what happinesse ye hold

In this small plot of your dominion,

Now loath great Lordship and ambition;

And wish th'heauens so much had graced mee,

As graunt me liue in like condition;

Or that my fortunes might transposed bee

From pitch of higher place, vnto this low degree.

In vaine (said then old Meliboe) doe men

The heauens of their fortunes fault accuse,

Sith they know best, what is the best for them:

For they to each such fortune doe diffuse,

As they doe know each can most aptly vse.

For not that, which men couet most, is best,

Nor that thing worst, which men do most refuse;

But fittest is, that all contented rest

With that they hold: each hath his fortune in his brest.

they: the heavens; them: men distribute 
It is the mynd, that maketh good or ill,

That maketh wretch or happie, rich or poore:

For some, that hath abundance at his will,

at his command or disposal

Hath not enough, but wants in greatest store;

And other, that hath litle, askes no more,

But in that litle is both rich and wise.

For wisedome is most riches; fooles therefore

They are, which fortunes doe by vowes deuize,

Sith each vnto himselfe his life may fortunize.

make fortunate or rewarding

Since then in each mans self (said Calidore)

It is, to fashion his owne lyfes estate,

Giue leaue awhyle, good father, in this shore

To rest my barcke, which hath bene beaten late

With stormes of fortune and tempestuous fate,

In seas of troubles and of toylesome paine,

That whether quite from them for to retrate

I shall resolue, or back to turne againe,

state, condition

boat

retreat, withdraw

I may here with your selfe some small repose obtaine.

Not that the burden of so bold a guest

Shall chargefull be, or chaunge to you at all;

For your meane food shall be my daily feast,

And this your cabin both my bowre and hall.

Besides for recompence hereof, I shall

You well reward, and golden guerdon giue,

That may perhaps you better much withall,

And in this quiet make you safer liue.

So forth he drew much gold, and toward him it driue.

costly; make a difference, affect

But the good man, nought tempted with the offer

Of his rich mould, did thrust it farre away,

And thus bespake; Sir knight, your bounteous proffer

Be farre fro me, to whom ye ill display

That mucky masse, the cause of mens decay,

That mote empaire my peace with daungers dread.

But if ye algates couet to assay

This simple sort of life, that shepheards lead,

Be it your owne: our rudenesse to your selfe aread.

So there that night Sir Calidore did dwell,

And long while after, whilest him list remaine,

Dayly beholding the faire Pastorell,

And feeding on the bayt of his owne bane.

During which time he did her entertaine

With all kind courtesies, he could inuent;

And euery day, her companie to gaine,

When to the field she went, he with her went:

So for to quench his fire, he did it more augment.

But she that neuer had acquainted beene

With such queint vsage, fit for Queenes and Kings,

Ne euer had such knightly seruice seene,

But being bred vnder base shepheards wings,

Had euer learn'd to loue the lowly things,

Did litle whit regard his courteous guize,

But cared more for Colins carolings

Then all that he could doe, or euer deuize:

His layes, his loues, his lookes she did them all despize.

intending to

270

refined

benefit
more securely
drove, thrust

earth, dirt

however

than

233 by vows deuize] try to obtain by prayers, as though good fortune was a divine gift. $\quad 261$ aread] ?take it as you will; ?make it your own. 265 bayt ... bane] the attraction that brought him to his own destruction. 
Which Calidore perceiuing, thought it best

To chaunge the manner of his loftie looke;

And doffing his bright armes, himselfe addrest

dressed

In shepheards weed, and in his hand he tooke,

In stead of steelehead speare, a shepheards hooke,

That who had seene him then, would haue bethought

On Phrygian Paris by Plexippus brooke,

When he the loue of fayre Oenone sought,

What time the golden apple was vnto him brought.

\section{Edmund Spenser The faerie Queene Book VI Canto X.5-30}

See headnote to no.44 and notes below.

One day as he did raunge the fields abroad,

he: Calidore

Whilest his faire Pastorella was elsewhere,

He chaunst to come, far from all peoples troad,

Vnto a place, whose pleasaunce did appere

trod: tread, path

To passe all others, on the earth which were:

beauty, attraction

For all that euer was by natures skill

Deuized to worke delight, was gathered there,

And there by her were poured forth at fill,

As if this to adorne, she all the rest did pill.

$r o b$

It was an hill plaste in an open plaine,

That round about was bordered with a wood

Of matchlesse hight, that seem'd th'earth to disdaine,

In which all trees of honour stately stood,

And did all winter as in sommer bud,

Spredding pauilions for the birds to bowre,

Which in their lower braunches sung aloud;

And in their tops the soring hauke did towre,

Sitting like King of fowles in maiesty and powre.

And at the foote thereof, a gentle flud

His siluer waues did softly tumble downe,

Vnmard with ragged mosse or filthy mud,

Ne mote wylde beastes, ne mote the ruder clowne

Thereto approch, ne filth mote therein drowne:

But Nymphes and Faeries by the bancks did sit,

In the woods shade, which did the waters crowne,

Keeping all noysome things away from it,

And to the waters fall tuning their accents fit.

And on the top thereof a spacious plaine

Did spred it selfe, to serue to all delight,

Either to daunce, when they to daunce would faine,

Or else to course about their bases light;

Ne ought there wanted, which for pleasure might

Desired be, or thence to banish bale:

So pleasauntly the hill with equall hight,

Did seeme to ouerlooke the lowly vale;

Therefore it rightly cleeped was mount Acidale.

might; peasant, rustic be immersed

overlook and adorn

tents, shades wish, be inclined run; lightly, nimbly

misery, suffering proportionate, balancing

286-8 Paris dwelt as a shepherd on Mount Ida, where he wooed the nymph Oenone. He was prince of Troy, which was often wrongly identified with Phrygia. 286 Plexippus] No such brook. Meaning 'driver of horses', may refer to Hippocrene, the fountain that sprang from the winged horse Pegasus' hoof; but one wonders whether a good Greek scholar like Spenser would have made this mistake. 14 all winter as in sommer bud] thus equating the setting with Paradise. 15 bowre] lodge, shelter (OED bower v2, from this passage only). 18 King of fowles] a distinction usually accorded the eagle. 30 they] the nymphs and fairies (24). $\quad 31$ Alluding to the popular rustic game of prisoners' base. 36 Acidale] from Acidalia (without care), a name for Venus, after the well Acidalius sacred to the Graces, associated with Venus (see 41). Acidale is where Venus comes to rest and sport, withdrawing from her 'royall court' (43) of Cytheron. 
They say that Venus, when she did dispose

Her selfe to pleasaunce, vsed to resort

Vnto this place, and therein to repose

And rest her selfe, as in a gladsome port,

Or with the Graces there to play and sport;

sport, relaxation

refuge, resort

That euen her owne Cytheron, though in it

She vsed most to keepe her royall court,

And in her soueraine Maiesty to sit,

She in regard hereof refusde and thought vnfit.

Vnto this place when as the Elfin Knight

Approcht, him seemed that the merry sound

Of a shrill pipe he playing heard on hight,

And many feete fast thumping th'hollow ground,

That through the woods their Eccho did rebound.

higher up the slope

He nigher drew, to weete what mote it be;

There he a troupe of Ladies dauncing found

Full merrily, and making a gladfull glee,

And in the midst a Shepheard piping he did see.

He durst not enter into th'open greene,

For dread of them vnwares to be descryde,

For breaking of their daunce, if he were seene;

But in the couert of the wood did byde,

Beholding all, yet of them vnespyde.

There he did see, that pleased much his sight,

That euen he him selfe his eyes enuyde,

An hundred naked maidens lilly white,

All raunged in a ring, and dauncing in delight.

All they without were raunged in a ring,

And daunced round; but in the midst of them

Three other Ladies did both daunce and sing,

The whilest the rest them round about did hemme,

And like a girlond did in compasse stemme:

And in the middest of those same three, was placed

Another Damzell, as a precious gemme,

Amidst a ring most richly well enchaced,

That with her goodly presence all the rest much graced.

discerned, spotted

For: for fear of

learn

a type of song

Looke how the Crowne, which Ariadne wore

Vpon her yuory forehead that same day,

That Theseus her vnto his bridale bore,

When the bold Centaures made that bloudy fray

With the fierce Lapithes, which did them dismay;

Being now placed in the firmament,

Through the bright heauen doth her beams display,

And is vnto the starres an ornament,

Which round about her moue in order excellent.

36-41 Here and later, Spenser evokes the description of Venus dancing with the Graces and nymphs in Horace, Ode I.4.5-7. Graces] Charites: goddesses of grace, beauty and refinement, associated with both Venus (92) and the Muses. In Renaissance Neoplatonic thought, they are richly symbolic figures, perhaps most notably in Botticelli's painting Primavera, where they appear alongside Venus. In FQ, the Graces thus link up with love in one direction, poetry in another, and a Neoplatonic exchange between the natural and ideal worlds in a third. $\quad 42$ Cytheron] Following Chaucer (Knight's Tale 1936), Spenser confuses the island of Cythera, sacred to Aphrodite or Venus, with Cythaeron, a mountain sacred to Jupiter and the Muses (with whom the Graces are often associated, so that Acidale also evokes Parnassus). $\quad 45$ in regard hereof refusde] rejected or considered inferior in comparison to this. $\quad 46$ Elfin] of the land or race of Faerie, to which the leading knights of FQ belong. Though human in virtually all traits and faculties, the Faerie race possesses a latent supernatural dimension to their being, and very much so in their milieu and actions. 66 Three other Ladies] the Graces: see 41n, $91 \mathrm{ff}$. 68 stemme] encircle (OED cites only this passage). 73-7 Ariadne, daughter of King Minos of Crete, was promised marriage by Theseus, with whom she fled her father's kingdom, but who abandoned her. She was taken to wife by the god Dionysos, who (not Theseus) gave her the wedding-crown which he later placed among the stars, as the constellation Corona Borealis. Ariadne is often associated or even identified with Aphrodite or Venus. The battle of the Centaurs and Lapiths actually took place at the marriage of Pirithous, king of the Lapiths, and Hippodamia. Theseus is sometimes said to have, aided Pirithous. 
Such was the beauty of this goodly band,

Whose sundry parts were here too long to tell:

But she that in the midst of them did stand,

Seem'd all the rest in beauty to excell,

Crownd with a rosie girlond, that right well

Did her beseeme. And euer, as the crew

About her daunst, sweet flowres, that far did smell,

And fragrant odours they vppon her threw;

But most of all, those three did her with gifts endew.

Those were the Graces, daughters of delight,

Handmaides of Venus, which are wont to haunt

Vppon this hill, and daunce there day and night:

accustomed to; resort, spend time

Those three to men all gifts of grace do graunt,

And all, that Venus in her selfe doth vaunt,

Is borrowed of them. But that faire one,

That in the midst was placed parauaunt,

Was she to whom that shepheard pypt alone,

That made him pipe so merrily, as neuer none.

She was to weete that iolly Shepheards lasse,

Which piped there vnto that merry rout,

That iolly shepheard, which there piped, was

Poore Colin Clout (who knowes not Colin Clout?)

He pypt apace, whilest they him daunst about.

Pype iolly shepheard, pype thou now apace

Vnto thy loue, that made thee low to lout;

Thy loue is present there with thee in place,

Thy loue is there aduaunst to be another Grace.

Much wondred Calidore at this straunge sight,

Whose like before his eye had neuer seene,

And standing long astonished in spright,

And rapt with pleasaunce, wist not what to weene;

Whether it were the traine of beauties Queene,

Or Nymphes, or Faeries, or enchaunted show,

With which his eyes mote haue deluded beene.

Therefore resoluing, what it was, to know,

Out of the wood he rose, and toward them did go.

But soone as he appeared to their vew,

They vanisht all away out of his sight,

And cleane were gone, which way he neuer knew;

All saue the shepheard, who for fell despight

Of that displeasure, broke his bag-pipe quight,

And made great mone for that vnhappy turne.

But Calidore, though no lesse sory wight,

For that mishap, yet seeing him to mourne,

Drew neare, that he the truth of all by him mote learne. retinue, followers

And first him greeting, thus vnto him spake,

Haile iolly shepheard, which thy ioyous dayes

Here leadest in this goodly merry make,

Frequented of these gentle Nymphes alwayes,

Which to thee flocke, to heare thy louely layes;

Which: the shepherd

bow, make obeisance

Tell me, what mote these dainty Damzels be,

Which here with thee doe make their pleasant playes?

Right happy thou, that mayst them freely see:

manner, state visited by

But why when I them saw, fled they away from me?

103 Colin Clout] as always, Spenser's own persona. At the climax of his magnum opus, in quasi-epic vein, he reasserts his basic identity as a pastoral poet. 108 another Grace] the pride of place granted to Queen Elizabeth in SC, 'Aprill'. The pastoral maiden now replaces the queen in a philosophically more exalted context. But the two are implicitly identified: see 190 on below. 
Not I so happy, answerd then that swaine,

As thou vnhappy, which them thence didst chace,

Whom by no meanes thou canst recall againe,

For being gone, none can them bring in place,

But whom they of them selues list so to grace.

Right sory I, (saide then Sir Calidore, )

That my ill fortune did them hence displace.

But since things passed none may now restore,

Tell me, what were they all, whose lacke thee grieues so sore.

Tho gan that shepheard thus for to dilate;

Then wote thou shepheard, whatsoeuer thou bee,

That all those Ladies, which thou sawest late,

Are Venus Damzels, all with in her see,

But differing in honour and degree:

They all are Graces, which on her depend,

Besides a thousand more, which ready bee

Her to adorne, when so she forth doth wend:

But those three in the midst, doe chiefe on her attend.

They are the daughters of sky-ruling Ioue,

By him begot of faire Eurynome,

The Oceans daughter, in this pleasant groue,

As he this way comming from feastfull glee,

Of Thetis wedding with Acidee.

In sommers shade him selfe here rested weary.

The first of them hight mylde Euphrosyne,

Next faire Aglaia, last Thalia merry:

Sweete Goddesses all three which me in mirth do cherry.

These three on men all gracious gifts bestow,

Which decke the body or adorne the mynde,

To make them louely or well fauoured show,

As comely carriage, entertainement kynde,

Sweete semblaunt, friendly offices that bynde,

And all the complements of curtesie:

They teach vs, how to each degree and kynde

We should our selues demeane, to low, to hie;

relate, explain

know

jurisdiction, command

To friends, to foes, which skill men call Ciuility.

Therefore they alwaies smoothly seeme to smile,

That we likewise should mylde and gentle be,

And also naked are, that without guile

Or false dissemblaunce all them plaine may see,

Simple and true from couert malice free:

And eeke them selues so in their daunce they bore,

That two of them still forward seem'd to bee,

But one still towards shew'd her selfe afore;

That good should from vs goe, then come in greater store.

appearance, demeanour;

[create bonds rank and nature behave

146 shepheard] Calidore is now so dressed. 150 all are Graces] Though the Graces usually number three (originally just one), their symbolic identity is sometimes dispersed over a larger number. 154-5 The usual parentage cited for the Graces (see Hesiod, Theogony 907-11). But the account in 157-9 is Spenser's own invention. 156 Ocean] the god Oceanus. 158 Thetis] sea-goddess, one of the Nereids, mother of Achilles. Æcidee] Peleus, king of the Myrmidons, son of Aeacus. 162 cherry] cheer, delight (OED cherry $\mathrm{v}^{2}$, from this passage only). 168 curtesie] the virtue exemplified by Sir Calidore. (See headnote to no. 44.) Though embodying courtly values, the qualities in 166-7 support a more basic humanity that makes the knight ask pardon of a shepherd (222), and that appears at its highest in a shepherdess (204). $\quad 171$ Ciuility] In its most basic sense, the quality distinguishing a cives or citizen: more socially oriented, taking stock of degree and kynde (rank and innate nature, 169) than the basic humane qualities ascribed to courtesy. But the two are obviously aspects of the same ideal. The highest flowering of humanity, even if best exemplified in shepherd life, relates to the most developed forms of society, the city and the court. 178-80 in greater store] conventionally double. Two Graces face the viewer (suggesting gifts received by him); while the third is nearer to the viewer but facing away, suggesting gitts bestowed by him. The Graces were traditionally associated with generosity and a cycle of giving and receiving; but this particular interpretation is from Servius, the commentator on Virgil. For this and other symbolism associated with the Graces, see Edgar Wind, Pagan Mysteries in the Renaissance (London: Faber, 1958), chs.2-3. 
Such were those Goddesses, which ye did see;

But that fourth Mayd, which there amidst them traced,

Who can aread, what creature mote she bee,

Whether a creature, or a goddesse graced

With heauenly gifts from heuen first enraced?

But what so sure she was, she worthy was,

To be the fourth with those three other placed:

Yet was she certes but a countrey lasse,

Yet she all other countrey lasses farre did passe.

So farre as doth the daughter of the day,

All other lesser lights in light excell,

So farre doth she in beautyfull array,

Aboue all other lasses beare the bell,

Ne lesse in vertue that beseemes her well,

Doth she exceede the rest of all her race,

For which the Graces that here wont to dwell,

Haue for more honor brought her to this place,

And graced her so much to be another Grace.

Another Grace she well deserues to be,

In whom so many Graces gathered are,

Excelling much the meane of her degree;

Diuine resemblaunce, beauty soueraine rare,

Firme Chastity, that spight ne blemish dare;

All which she with such courtesie doth grace,

That all here peres cannot with her compare,

But quite are dimmed, when she is in place.

She made me often pipe and now to pipe apace.

Sunne of the world, great glory of the sky,

That all the earth doest lighten with thy rayes,

Great Gloriana, greatest Maiesty,

Pardon thy shepheard, mongst so many layes,

As he hath sung of thee in all his dayes,

To make one minime of thy poore handmayd,

And vnderneath thy feete to place her prayse,

That when thy glory shall be farre displayd

To future age of her this mention may be made.

When thus that shepherd ended hath his speach,

Sayd Calidore; Now sure it yrketh mee,

That to thy blisse I made this luckelesse breach,

As now the author of thy bale to be,

Thus to bereaue thy loues deare sight from thee:

But gentle Shepheard pardon thou my shame,

Who rashly sought that, which I mote not see.

Thus did the courteous Knight excuse his blame,

And to recomfort him, all comely meanes did frame.

danced
interpret, judge

implanted disturbs, vexes break, interruption sorrow

apologize for console, assuage; him: Colin

190 daughter of the day] the sun. The unusual feminine identity suggests an implicit equation with Queen Elizabeth, brought out in 208-10. Colin Clout's beloved in FQ may or may not be Rosalind of the Calender; but in one of her aspects she is undoubtedly the Queen, conversely celebrated as a shepherd lass in The Shepheardes Calender, 'Aprill'. At the same time, the two are differentiated in 213-6. Their identities merge and diverge like those of the three Elizabeths - Queen, mother and wife - in Spenser's Amoretti 74.202 resemblaunce] appearance; or, in a deeper Platonic sense, likeness or image of the divine. Spenser repeatedly proposes (most elaborately in 'Hymne in Honor of Beautie') that physical beauty is a visible image of ideal or spiritual beauty. 203 that spight ... dare] that neither others' spite nor any defect in her can challenge. 213 minime] a note of the shortest duration (as opposed to the songs offered 'all his dayes' to Elizabeth). 
In such discourses they together spent

Long time, as fit occasion forth them led;

With which the Knight him selfe did much content,

And with delight his greedy fancy fed,

Both of his words, which he with reason red;

read, interpreted

And also of the place, whose pleasures rare

With such regard his sences rauished,

That thence, he had no will away to fare,

But wisht, that with that shepheard he mote dwelling share.

\section{Philip Sidney From The Lady of May}

Part of an entertainment presented to Queen Elizabeth at Wanstead House, owned by Sidney's uncle the Earl of Leicester, in May 1578 or 1579. In the pattern of an amoebean eclogue (the earliest in English, according to Ringler), a shepherd and a forester contend for the hand of the maiden chosen as May Queen, with Elizabeth as judge. The standard text (without a title) is among 'sundry new additions' in the 1598 edition of Sidney's Arcadia. Helicon prints 7-32 of the text below with the title 'Espilus and Therion, their contention in Song for the May-Ladie'. The Lady of May tells the Queen, 'in iudging me, you iudge more then me in it'. Scholars have looked for political implications, like the proposal for Elizabeth's marriage to the Duke of Anjou, or the general issue of a militarist continental policy; but no such concern can be clearly identified.

\section{There upon Therion chalenged Espilus to sing with him, speaking these sixe verses:}

Therion. Come Espilus, come now declare thy skill, Shew how thou canst deserue so braue desire, Warme well thy wits, if thou wilt win her will, For water cold did neuer promise fire:

Great sure is she, on whom our hopes do liue,

demonstrate, prove be worthy of such an ambitious love

Greater is she who must the iudgement giue.

hold promise of

But Espilus as if he had bene inspired with the Muses, began forthwith to sing, whereto his fellow shepheards set in with their recorders, which they bare in their bags like pipes, and so of Therions side did the foresters, with the cornets they wore about their neckes like hunting hornes in baudrikes.

baldrics: belts worn over the shoulder and chest

Espilus. Tune vp my voice, a higher note I yeeld,

To high conceipts the song must needes be high,

More high then stars, more firme then flintie field

Are all my thoughts, in which I liue or die:

thoughts, themes

Sweete soule, to whom I vowed am a slaue,

Let not wild woods so great a treasure haue.

Therion. The highest note comes oft from basest mind,

As shallow brookes do yeeld the greatest sound.

Seeke other thoughts thy life or death to find;

Thy stars be fal'n, plowed is thy flintie ground:

Sweete soule let not a wretch that serueth sheepe,

Among his flocke so sweete a treasure keepe.

Espilus. Two thousand sheepe I haue as white as milke,

Though not so white as is thy louely face,

The pasture rich, the wooll as soft as silke,

All this I giue, let me possesse thy grace,

But still take heede least thou thy selfe submit

To one that hath no wealth, and wants his wit.

'mercy', acceptance of love

14 As shallow ... sound] Proverbial, 1st cit. in Tilley's Dictionary of Proverbs from 1618.

15-16 addressed to Espilus. 
Therion. Two thousand deere in wildest woods I haue,

Them can I take, but you I cannot hold:

$\mathrm{He}$ is not poore who can his freedome saue,

Bound but to you, no wealth but you I would:

But take this beast, if beasts you feare to misse,

For of his beasts the greatest beast he is.

preserve, retain wish for lack

Espilus kneeling to the Queene. Iudge you to whom all beauties force is lent.

Therion. Iudge you of Loue, to whom all Loue is bent.

[There follows a debate on the merits of the respective songs, with the comic schoolmaster Rombus playing a part. Finally the Queen judges the shepherd Espilus the winner.]

\section{Philip Sidney 'Come, shepherd's weeds'}

First published in The Covntesse of Pembrokes Arcadia (1590). From Book I of both the Old and the New Arcadia. Sung by Prince Musidorus after he exchanges clothes with the shepherd Menalcas in order to be near his beloved Pamela, who is in pastoral retreat with her family.

Come shepheards weedes, become your masters minde:

Yeld outward shew, what inward chance he tryes:

Nor be abasht, since such a guest you finde,

garments; match experiences

Whose strongest hope in your weake comfort lyes.

i.e., the wearer

Come shepheards weedes, attend my woefull cryes:

listen to

Disuse your selues from sweete Menalcas voice:

For other be those tunes which sorrow tyes, de-familiarize,

From those cleere notes which freely may reioyce.

Then power out plaint, and in one word say this:

\section{Philip Sidney 'My Sheep ARe thoughts'}

Musidorus, disguised as the shepherd Dorus, sings these verses to his beloved Pamela in Book II of both the Old and the New Arcadia. In the latter, the song is reported at a later date by Musidorus to his cousin Pyrocles disguised as the Amazon Zelmane. The text below is from the first printed edition (1590).

My sheepe are thoughts, which I both guide and serue:

Their pasture is faire hilles of fruitlesse Loue:

On barren sweetes they feede, and feeding sterue:

starve

I waile their lotte, but will not other proue.

My sheepehooke is wanne hope, which all vpholdes:

My weedes, Desire, cut out in endlesse foldes.

What wooll my sheepe shall beare, whiles thus they liue,

In you it is, you must the iudgement giue.

25-6 As Duncan-Jones and Van Dorsten point out, the comparison of the beloved to an elusive deer is common in medieval and Petrarchan love-poetry. 2 Present the desired outward appearance: i.e. let him look like a shepherd, whatever his inward state. $\quad 10$ If a person deprives himself of happiness (i.e. if his sorrow is within him), nothing can ease his complaint. 3 They feed on the beloved's sight, but this brings them no comfort. 4 I lament their state, but will not exchange it for any other. 


\section{Philip Sidney 'And are you there old Pas?'}

This earthy, comic exchange between two 'jolly younkers' is from the Second Eclogues, a sequence of singing and celebrations in both the Old and, by editorial insertion, the 1590 edition of the New Arcadia. The poem recalls the comic pastoralism of Virgil III. Robertson (p.449) notes the same four sections: 'the preliminary banter, the wager, the singing match, and the judgement'. The names Dorcas (8: nowhere else in the Old Arcadia) and Lalus (14) also occur in The Lady of May (1578-9: no. 46), and are considered a sign of early composition, in advance of the Arcadia as a whole.

Nico. Pas. Dorus.

Nico. And are you there old Pas? in troth I euer thought,

Among vs all we should find out some thing of nought.

Pas. And I am here the same, so mote I thriue and thee,

Despairde in all this flocke to find a knave, but thee.

Nico. Ah now I see, why thou art in thy selfe so blind:

Thy gray-hood hides the thing, that thou despairst to find.

Pas. My gray-hood is mine owne, all be it be but gray,

Not like the scrippe thou stol'ste, while Dorcas sleeping lay.

Nico. Mine was the scrippe: but thou, that seeming raid with loue,

Didst snatch from Cosmas hand her greeny wroughten gloue.

Pas. Ah foole; so Courtiers do. But who did liuely skippe,

When for a treene-dish stolne, thy father did thee whippe?

Nico. In deed the witch thy dam her crouch from shoulder spred,

For pilfring Lalus lambe, with crouche to blesse thy head.

Pas. My voice the lambe did winne, Menalcas was our iudge:

Of singing match was made, whence he with shame did trudge.

Nico. Couldst thou make Lalus flie? so nightingales auoide,

When with the kawing crowes their musicke is annoide.

Pas. Nay like to nightingales the other birds giue eare:

no worth or goodness
might
frustrated, unable

My pipe and song made him both pipe and song forsweare.

Nico. I thinke it well: such voice would make one musicke hate:

But if I had bene there, th'adst met another mate.

Pas. Another sure as is a gander from a goose:

But still when thou dost sing, me thinkes a colt is loose.

Nico. Well aimed by my hat: for as thou sangst last day,

The neighbours all did crie, alas what asse doth bray?

Pas. But here is Dicus old; let him then speake the woord,

To whether with best cause the Nymphes faire flowers affoord.

Nico. Content: but I will lay a wager hereunto,

That profit may ensue to him that best can do.

although

green; embroidered

[wooden

made from a tree,

crutch

he: Lalus

flee, depart

disturbed

as

I haue (and long shall haue) a white great nimble cat,

A king vpon a mouse, a strong foe to the rat,

Fine eares, long taile he hath, with Lions curbed clawe,

Which oft he lifteth vp, and stayes his lifted pawe,

Deepe musing to himselfe, which after-mewing showes,

Till with lickt beard, his eye of fire espie his foes.

If thou (alas poore if) do winne, then winne thou this,

And if I better sing, let me thy Cosma kisse.

Pas. Kisse her? now mayst thou kisse. I haue a fitter match;

A prettie curre it is; his name iwis is Catch,

No eare nor taile he hath, least they should him disgrace,

A ruddie haire his cote, with fine long specled face:

He neuer musing standes, but with himselfe will play

Leaping at euery flie, and angrie with a flea:

He eft would kill a mouse, but he disdaines to fight,

And makes our home good sport with dauncing bolt vpright.

where, i.e. to whom

curved

1-2 I euer ... nought] I knew there would be one bad or worthless person in our company. 3 the same] in the same position. 6 The person you are seeking in vain is covered by your own hood i.e. yourself. But gray-hood might also imply gray-headedness or old age. 9 raid] berayed: diseased, disfigured (Robertson). Ringler emends to raged. 10 Cosma] named Hyppa in early mss. 11 so Courtiers do] take their lady's glove as a love-gauge. 14 bless] pun: (a) give blessing (ironical) (b) hurt, wound $\left(O E D\right.$ bless $\left.\mathrm{v}^{2}\right)$. 15-6 i.e. He won it in a singing-contest. 22 th'adst ... mate] you would have faced a more formidable opponent. mate] (a) companion (i.e. opponent) (b) checkmate, defeat. $\quad \mathbf{2 8}$ To whom admiring nymphs most deservedly bring gift or tribute of flowers. 30 So that he who wins the contest might have some reward. $\quad \mathbf{3 1}$ and long shall havel implying he will retain it by winning the contest. 
This is my pawne; the price let Dicus iudgement show:

Such oddes I willing lay; for him and you I know.

Dicus. Sing then my lads, but sing with better vaine then yet.

Or else who singeth worst, my skill will hardly hit.

prize; adjudge, indicate

Nico. Who doubts but Pas fine pipe againe will bring

The auncient prayse to Arcad shepheards skill?

Pan is not dead, since Pas beginnes to sing.

Pas. Who euermore will loue Apollos quill,

Since Nico doth to sing so widely gape?

Nico his place farre better furnish will.

Nico. Was not this he, who did for Syrinx scape

Raging in woes teach pastors first to plaine?

Do you not heare his voice, and see his shape?

60 Pas. This is not he that failed her to gaine,

Which made a Bay, made Bay a holy tree:

But this is one that doth his musicke staine.

Nico. O Faunes, O Fairies all, and do you see,

And suffer such a wrong? a wrong I trowe,

disgrace

That Nico must with Pas compared be?

strongly berate or criticize

Pas. O Nymphes. I tell you newes, for Pas you knowe:

While I was warbling out your woonted praise,

Nico would needes with Pas his bagpipe blowe.

Nico. If neuer I did faile your holy-dayes,

With daunces, carols, or with barlybreake:

Let Pas now know, how Nico makes the layes.

Pas. If each day hath bene holy for your sake

Vnto my pipe, O Nimphes, helpe now my pipe,

For Pas well knowes what layes can Nico make.

Nico. Alas how oft I looke on cherries ripe,

Me thinkes I see the lippes my Leuca hath,

And wanting her, my weeping eyes I wipe.

Pas. Alas, when I in spring meete roses rathe,

And thinke from Cosmas sweet red lips I liue,

I leaue mine eyes vnwipte my cheekes to bathe.

Nico. As I of late, neer bushes vsde my siue,

I spied a thrush where she did make her nest,

That will I take, and to my Leuca giue.

Pas. But long haue I a sparrow gailie drest,

As white as milke, and comming to the call,

To put it with my hand in Cosmas brest.

Nico. I oft doo sue, and Leuca saith, I shall,

But when I did come neere with heate and hope,

She ranne away, and threw at me a ball.

Pas. Cosma once said, she left the wicket ope,

For me to come, and so she did: I came,

But in the place found nothing but a rope

Nico. When Leuca dooth appeare, the Sunne for shame

Dooth hide himselfe: for to himselfe he sayes,

If Leuca liue, she darken will my fame.

Pas. When Cosma doth come forth, the Sun displaies

His vtmost light: for well his witte doth know,

Cosmas faire beames emblemish much his raies.

Nico. Leuca to me did yester-morning showe

not attend; holidays, festivals a popular country game songs

early blooming

sieve, net to catch birds

court, offer my love

In perfect light, which could not me deceaue,

48 for ... know] I know Dicus is a fair judge and you an unworthy opponent. $\quad$ 51-62 Abraham Fraunce in The Arcadian Rhetoric cites this series of sarcastic exchanges as 'a continued Ironia'. $57-8$ he, who... plaine] Pan, who first taught shepherds to sing love-laments when he was crazed with grief at Syrinx's escape from his pursuit. 6o-61 he that ... tree] Apollo, who failed to gain the woman (Daphne) that became a laurel (Bay), and who therefore made the laurel sacred to him. $\quad 84-5$ a sparrow ... white as milke] as in Skelton's The Book of Philip Sparrow. 89 a ball] ?signifying her rolling or changing disposition; ?asking him to 'roll away'. 92 rope] perhaps an incitement to despair, asking him to hang himself. $\quad 98$ emblemish] Three manuscripts have embellish, which also makes sense. 100 which ... deceaue] So that I could not have been mistaken in what I saw. 
Her naked legge, more white then whitest snowe.

Pas. But yesternight by light I did receaue which I received From Cosmas eyes, which full in darkenes shine, I sawe her arme, where purest Lillies cleaue.

Nico. She once starke nak'd did bathe a little tine; But still (me thought) with beauties from her fell, She did the waters wash, and make more fine.

Pas. She once, to coole her selfe, stood in a well, But euer since that well is well besought, And for Rose-water sould of rarest smell.

Nico. To riuers banke, being a walking brought, She bad me spie her babie in the brooke, Alas (said I) this babe dooth nurce my thought.

Pas. As in a glasse I held she once did looke, I said, my hands well paide her for mine eyes, Since in my hands selfe goodly sight she tooke.

Nico. O if I had a ladder for the skies, I would climbe vp, and bring a prettie starre, To weare vpon her neck, that open lies.

Pas. O if I had Apollos golden carre,

I would come downe, and yeeld to her my place,

That (shining now) she then might shine more farre.

Nico. Nothing (O Leuca) shall thy fame deface, While shepheards tunes be heard, or rimes be read, a short while Or while that shepheards loue a louely face.

Pas. Thy name (O Cosma) shall with praise be spread, As farre as any shepheards piping be: As farre as Loue possesseth any head.

Nico. Thy monument is layd in many a tree, With name engrau'd: so though thy bodie die, The after-folkes shall wonder still at thee.

Pas. So oft these woods haue heard me Cosma crie, That after death, to heau'n in woods resound, With Echoes help, shall Cosma, Cosma flie.

Nico. Peace, peace good Pas, thou weeriest euen the ground With sluttish song: I pray thee learne to blea, For good thou mayst yet prooue in sheepish sound.

Pas. My father hath at home a prettie Iay, Goe winne of him (for chattering) praise or shame: For so yet of a conquest speake thou may. That hath foure legs, and with two onely goes, That hath foure eyes, and onely two can frame.

Pas. Tell me (and Phoebus be) what monster growes With so strong liues, that bodie cannot rest In ease, vntill that bodie life forgoes.

Dicus. Enough, enough: so ill hath done the best, That since the hauing them to neither's due, Let cat and dog fight which shall haue both you.

104 where ... cleave] Her hands are so white that lilies seem to cling to them. 106 fell] skin (Grosart, Ringler); beauties ... fell] fragments of her beauty washed away as she bathed, making the water 'more fine (Robertson). 112 spie her babie] exchange glances ('look babies') with her image in the water. 113 nurce my thought] put ideas into my head. Paradox: the baby is nursing and not being nursed. 115 my hands ... tooke] My hands repaid her for the pleasure her sight afforded my eyes, as she could view her own beauty in the mirror I held. The idea comes from a song in Montemayor's Spanish romance Diana, translated by Sidney in Certain Sonnets (Ringler 29). 133 woods resound] noun-phrase: 'woods' resound', echo among the woods. $\quad 137$ You may bleat well, even if you cannot sing. 141-3 Ringler suggests the answer might be a man on crutches wearing spectacles (hence 'frame'). be my Pan] be worshipped by me like Pan: so also and Phœbus be (144). 144-6 This editor, like Ringler, 'give[s] up' on this one. $\quad \mathbf{1 4 7 - 8}$ so ill ... due] Even the better (best) has fared so badly that neither deserves the prizes. 149 cat and dog] Obviously alluding to the contestants as well as the prizes. Several mss carry this text soon after the poem ends: 'But this eclogue of all other was counted the sportfullest they yet had heard; and a greater question, whether [i.e., which of the two] indeed had won the wager: Dicus still demanding justice, that since he had been lawfully appointed judge, the cat and dog might be sent for to try the duello between them.' [Spelling standardized and moderninized P781526143426 


\section{Sir Philip Sidney 'O sweet woods'}

Missing from the first printed edition of Arcadia (1590), but included in the next (1593). Sung by Prince Musidorus, disguised as the shepherd Dorus, before his beloved Pamela. The theme, contrasting the dangers and disquiets of court life with the contemplative peace of the countryside, is specially apt for the audience of King Basilius and his family, who have fled to the country to escape the dangers prophesied at court. The last of four exercises in quantitative verse concluding the Second Eclogues of the Old Arcadia. The metrical pattern is the Asclepiadic, used by Horace: - - _ Arcadian Rhetoric, Abraham Fraunce cites 15-22 to illustrate the metre.

O sweet woods the delight of solitarines!

O how much I do like your solitarines!

Where mans mind hath a freed consideration

Of goodnes to receiue louely direction.

Where senses do behold th'order of heau'nly hoste,

rank, array

And wise thoughts do behold what the creator is:

Contemplation here holdeth his only seate:

Bownded with no limitts, borne with a wing of hope

Clymes even vnto the starres, Nature is vnder it.

Nought disturbs thy quiet, all to thy seruice yeelds,

Each sight draws on a thought, thought mother of science,

Sweet birds kindly do graunt harmony vnto thee,

Faire trees shade is enough fortification,

Nor danger to thy selfe if be not in thy selfe.

wisdom

O sweete woods the delight of solitarines!

O how much I do like your solitarines!

Here nor treason is hidd, vailed in innocence,

Nor enuies snaky ey finds any harbor here,

Nor flatterers venomous insinuations,

Nor conning humorists puddled opinions,

Nor courteous ruin of proffered vsury,

Nor time pratled away, cradle of ignorance,

Nor causelesse duty, nor comber of arrogance,

Nor trifling title of vanity dazleth vs,

Nor golden manacles stand for a paradise.

Here wrongs name is vnheard: slander a monster is.

Keepe thy sprite from abuse, here no abuse doth haunte.

What man grafts in a tree dissimulation?

O sweete woods the delight of solitarines!

O how well I do like your solitarines!

Yet deare soile, if a soule closed in a mansion

As sweete as violetts, faire as a lilly is,

Streight as Cedar, a voice staines the Cannary birds,

Whose shade safety doth hold, danger auoideth her:

Such wisedome, that in her liues speculation:

Such goodnes that in her simplicitie triumphs:

Where enuies snaky ey winketh or els dyeth,

Slander wants a pretext, flattery gone beyond:

$\mathrm{Oh}$ ! if such a one haue bent to a lonely life,

Her stepps gladd we receaue, gladd we receaue her eys.

And thinke not she doth hurt our solitarines,

For such company decks such solitarines.

neither

winning ways, ingratiation

frittered, idled

earth; the body

shames by outvying

contemplation, philosophy

shuts

3 consideration] contemplation, thought $(O E D$ 1). 4 louely] Usually read as 'lovely', but perhaps 'lowly', as befits the pastoral context. 5 Where the angels of the heavenly host can be observed by the physical senses (i.e. sight). $\quad 9$ under it] Nature belongs to the sublunary world. 12 kindly] instinctually, of their native musical faculty. 2o humorists] crazy or eccentric people: conning might imply they only pretend to be such for their own ends. puddled] muddied, confused. 21 courteous] (a) decorous, urbane: usury ruins its victims in a sedate, non-violent way, unlike war (b) belonging to the court: courtiers notoriously ran up debts for their finery. 23 causelesse] without cause or objective. comber] cumber, burden (to the viewer or recipient). 25 golden manacles] wealth that binds or ties one down. stand for] pretend to be. $\mathbf{2 6}$ monster] unnatural creature (in these settings). 27 If you guard your own spirit from wrongdoing, no wrong will pursue you. $\mathbf{3 4}$ shade] continuing the image of the cedar. danger] ?'love-daunger', affected coyness or aloofness to love (cf. simplicitie, 36). $\quad 38$ flattery gone beyond] She is beyond flattery - i.e. no praise is too great for her. 


\section{Philip Sidney 'You goat-herd gods'}

First published in the first edn of the Arcadia (1590). Formally, a 'double sestina': twelve six-line stanzas repeating the same line-end words in varying order. Strephon and Klaius are two gentlemen turned shepherds because of their common love for Urania, thought to be a shepherdess though actually of 'farr greater byrthe'. This common situation is differently presented in the mss and the 1590 and 1593 edns, as indicated by their different locations (First Eclogues in 1590, Second Eclogues in 1593, and Fourth Eclogues in all Old Arcadia mss). Strephon and Klaius do not appear at this point in the printed edns: their song is reported by Lamon in 1590 and by Histor and Damon in 1593.

Strephon. Klaius.

Strephon. You Gote-heard Gods, that loue the grassie mountaines,

You Nimphes that haunt the springs in pleasant vallies,

You Satyrs ioyde with free and quiet forrests,

Vouchsafe your silent eares to playning musique,

Which to my woes giues still an early morning:

And drawes the dolor on till wery euening.

Klaius. O Mercurie, foregoer to the euening,

$\mathrm{O}$ heauenlie huntresse of the sauage mountaines,

O louelie starre, entitled of the morning,

While that my voice doth fill these wofull vallies,

Vouchsafe your silent eares to plaining musique,

Which oft hath Echo tir'd in secrete forrests.

Strephon. I that was once free-burges of the forrests,

Where shade from Sunne, and sports I sought at euening,

I that was once esteem'd for pleasant musique,

Am banisht now among the monstrous mountaines

Of huge despaire, and foule afflictions vallies,

Am growne a shrich-owle to my selfe each morning.

Klaius. I that was once delighted euery morning,

Hunting the wilde inhabiters of forrests,

I that was once the musique of these vallies,

So darkened am, that all my day is euening,

Hart-broken so, that molehilles seeme high mountaines,

And fill the vales with cries in steed of musique.

Strephon. Long since alas, my deadly Swannish musique

Hath made it selfe a crier of the morning,

announcer, herald

And hath with wailing strength clim'd highest mountaines:

Long since my thoughts more desert be then forrests:

Long since I see my ioyes come to their euening,

And state throwen downe to ouer-troden vallies.

deserted, solitary

Klaius. Long since the happie dwellers of these vallies

Haue praide me leaue my strange exclaiming musique,

Which troubles their dayes worke, and ioyes of euening:

Long since I hate the night, more hate the morning:

Long since my thoughts chase me like beasts in forrests,

And make me wish my selfe layd vnder mountaines.

Strephon. Me seemes I see the high and stately mountaines

Transforme themselues to lowe deiected vallies:

Me seemes I heare in these ill-changed forrests,

The Nightingales doo learne of Owles their musique:

changed for the worse, ravaged

Me seemes I feele the comfort of the morning

Turnde to the mortall serene of an euening.

1 Gote-heard Gods] (a) gods of the goatherds (b) gods who are goatherds, sylvan gods. 6 wery] weary, but ?misprint for very. 7 foregoer] herald, harbinger. The planet Mercury can be seen only in the early evening. 8 heauenlie huntress] Diana. 9 louelie starre] Venus. entitled of] named after - i.e. the morning star. 13 free-burges] not in $O E D$ : freeburgher (OED 1st cit. 1624), free citizen. 25 Swannish musique] The swan was thought to sing at the time of its death. 30 I have been cast down from my lofty station into the crowded valleys. 32 exclaiming] 'that exclaims' (OED, citing this passage), but perhaps 'complaining, lamenting' (cf. OED exclaim $\left.\mathrm{v}^{2} 2 \mathrm{a}, \mathrm{c}\right)$. 35 like beasts in forrests] as either hunters or hunted. Ringler recalls the myth of Actaeon, transformed to a deer and hunted down by his own dogs. $\quad \mathbf{4 2}$ serene] dew, esp. the 'harmful dew of summer evenings' (Robertson). 
Klaius. Me seemes I see a filthie clowdie euening,

As soon as Sunne begins to clime the mountaines:

Me seemes I feele a noysome sent, the morning

scent

When I doo smell the flowers of these vallies:

Me seemes I heare, whenn I doo heare sweete musique,

The dreadfull cries of murdred men in forrests.

Strephon. I wish to fire the trees of all these forrests;

burn

I giue the Sunne a last farewell each euening;

I curse the fidling finders out of Musicke:

With enuie I doo hate the loftie mountaines;

And with despite despise the humble vallies:

I doo detest night, euening, day, and morning.

Klaius. Curse to my selfe my prayer is, the morning:

My fire is more, then can be made with forrests;

My state more base, then are the basest vallies:

I wish no euenings more to see, each euening;

Shamed I hate my selfe in sight of mountaines,

(a) playing the fiddle as they sing

[(b) trifling, frivolous

Strephon. For she, whose parts maintainde a perfect musique,

Whose beautie shin'de more then the blushing morning,

Who much did passe in state the stately mountaines,

In straightnes past the Cedars of the forrests,

(sur)passed

Hath cast me wretch into eternall euening,

By taking her two Sunnes from these darke vallies.

Klaius. For she, to who compar'd, the Alpes are vallies,

She, whose lest word brings from the spheares their musique,

least

At whose approach the Sunne rose in the euening,

Who, where she went, bare in her forhead morning,

Is gone, is gone from these our spoyled forrests,

Turning to desarts our best pastur'de mountaines.

bore (as in some mss.) violated, destroyed endowed with pastures

Strephon. Klaius. These mountaines witnesse shall, so shall these vallies,

These forrests eke, made wretched by our musique,

Our morning hymne is this, and song at euening.

\section{Philip Sidney 'Since that to Death'}

First published in Book III of the first edn of Arcadia (1590) as a lament for the dying prince Amphialus by an unnamed member of the gathered multitude. In most other versions, placed in the Fourth Eclogues as the shepherd Dicus' dirge for the supposedly dead King Basilius. Eclogue XI in Sannazaro's Italian Arcadia has been cited as a model, but there is only a broad resemblance, most obviously in the refrain.

Since that to death is gone the shepheard hie,

Whom most the silly shepheards pipe did pryse,

Your dolefull tunes sweete Muses now applie.

value, extol ply, employ, practise

And you ô trees (if any life there lies

In trees) now through your porous barkes receaue

The straunge resounde of these my causefull cries:

And let my breath vpon your braunches cleaue, My breath distinguish'd into wordes of woe, That so I may signes of my sorrowe leaue.

But if among yourselues some one tree growe,

That aptest is to figure miserie,

Let it embassage beare your grieues to showe.

echo; justified

articulated, crystallized

[representative

serve as spokesman or

61 parts] (a) physical parts, limbs (b) powers, faculties (c) the 'parts' or elements of a harmony (perfect musique), said metaphorically of Urania's being. $\quad 66$ two Sunnes] i.e. her two eyes. 68 the spheares their musique] In the Ptolemaic astronomical system, the heavenly bodies were thought to be set in crystalline spheres that made celestial music as they revolved. 
The weeping Myrrhe I thinke will not denie Her helpe to this, this iustest cause of plaint. Your dolefull tunes sweet Muses now applie.

And thou poore Earth, whom fortune doth attaint stain, stigmatize In Natures name to suffer such a harme, As for to loose thy gemme, our earthly Sainct,

Vpon thy face let coaly Rauens swarme: coal-black Let all the Sea thy teares accounted be: Thy bowels with all killing mettals arme.

Let golde now rust, let Diamonds waste in thee: Let pearls be wan with woe their damme doth beare: Thy selfe henceforth the light doo neuer see.

And you, ô flowers, which sometimes Princes were, Till these straunge altrings you did hap to trie, Of Princes losse your selues for tokens reare.

Lilly in mourning blacke thy whitenes die: O Hiacinthe let $A i$ be on thee still. Your dolefull tunes sweet Muses now applie.

O Echo, all these woods with roaring fill, And doo not onely marke the accents last, But all, for all reach out my wailefull will:

One Echo to another Echo cast Sounde of my griefes, and let it neuer ende, Till that it hath all woods and waters past.

Nay to the heau'ns your iust complaining sende, And stay the starrs inconstant constant race, Till that they doo vnto our dolours bende: And aske the reason of that speciall grace,

That they, which haue no liues, should liue so long,

And vertuous soules so soone should loose their place?

Aske, if in great men good men doo so thronge,

That he for want of elbowe roome must die?

Or if that they be skante, if this be wronge?

Did Wisedome this our wretched time espie

In one true chest to rob all Vertues treasure?

Your dolefull tunes sweet Muses now applie.

And if that any counsell you to measure

Your dolefull tunes, to them still playning say,

To well felte griefe, plainte is the onely pleasure.

turn, address themselves

light of Sunne, which is entit'led day,

O well thou doost that thou no longer bidest;

For mourning night her blacke weedes may display.

O Phoebus with good cause thy face thou hidest,

Rather then haue thy all-beholding eye

Fould with this sight, while thou thy chariot guidest.

And well (me thinks) becomes this vaultie skie

A stately tombe to couer him deceased.

Your dolefull tunes sweet Muses now applie.

?secure

moderate, curb

deep, sincere

garments

Apollo as sun-god

vaulted, concave 
O Philomela with thy brest oppressed By shame and griefe, helpe, helpe me to lament Such cursed harmes as cannot be redressed.

Or if thy mourning notes be fully spent,

Then giue a quiet eare vnto my playning:

For I to teach the world complainte am bent.

You dimmy clowdes, which well employ your stayning This cheerefull aire with your obscured cheere, Witnesse your wofull teares with daily rayning.

And if, ô Sunne, thou euer didst appeare,

In shape, which by mans eye might be perceiued;

Vertue is dead, now set thy triumph here.

set, determined

dark; use effectively or aptly

(a) concealed faces

[(b) darkened light

triumphal procession

Now set thy triumph in this world, bereaued

Of what was good, where now no good doth lie;

And by thy pompe our losse will be conceaued.

$\mathrm{O}$ notes of mine your selues together tie:

With too much griefe me thinkes you are dissolued.

Your dolefull tunes sweete Muses now applie.

Time, euer old and yonge, is still reuolued

Within it selfe, and neuer tasteth ende:

But mankind is for aye to nought resolued.

The filthy snake her aged coate can mende,

And getting youth againe, in youth doth flourish:

But vnto Man, age euer death doth sende.

The very trees with grafting we can cherish,

So that we can long time produce their time:

But Man which helpeth them, helplesse must perish.

Thus, thus the mindes, which ouer all doo clime,

When they by yeares experience get best graces,

Must finish then by deaths detested crime.

90

We last short while, and build long lasting places:

Ah let vs all against foule Nature crie:

We Natures workes doo helpe, she vs defaces.

For how can Nature vnto this reply?

That she her child, I say, her best child killeth?

Your dolefull tunes sweete Muses now apply.

Alas, me thinkes, my weakned voice but spilleth

The vehement course of this iust lamentation:

Me thinkes my sound no place with sorrow filleth.

I know not I, but once in detestation

I haue my selfe, and all what life containeth,

Since Death on Vertues fort hath made inuasion.

One word of woe another after traineth:

$\mathrm{Ne}$ doo I care how rude be my inuention,

So it be seene what sorrow in me raigneth.

O Elements, by whose (men say) contention,

Our bodies be in liuing power maintained,

Was this mans death the fruite of your dissention?

O Phisickes power, which (some say) hath restrained

Approch of death, alas thou helpest meagerly,

When once one is for Atropos distrained.

Great be Physitions brags, but aid is beggerly, nurture

climb highest, achieve greatest

[success

offence, harmful deed buildings, edifices

destroys

creation, offspring

spoils, renders useless

once for all, conclusively

follows another

outcome of your conflict medicine's; delayed, blocked

meagre, poor

61 Philomela] Philomela was transformed into a nightingale after being raped by her brother-in-law Tereus. $\quad 72$ Why the sun should rejoice at the death of virtue remains mysterious. No previous editor has noted the problem. 75 The grandeur of your triumphal procession will indicate the extent of our loss. $\quad 79-80$ Time changes cyclically but never comes to an end. 81 for aye ... resolued] always destined to destruction. $\quad 82-3$ her aged ... flourish] slough off her skin and acquire a new one: often taken as a sign of eternal life or youth. $\mathbf{8 6}$ produce] extend (OED Ic). time] life, span. 89 When they achieve their best qualities through the experience of years. 99 My voice is not loud enough to reach everywhere with my lament. 100 I know not I] I do not know myself. 106-7 The four elements were thought to create all things by their conflicting and competing forces. 111 Atropos] One of the three Furies, who cut the thread of a man's life spun by Clotho and measured by Lachesis. distrained] seized. 
When rooted moisture failes, or groweth drie,

They leaue off al, and say, death comes too eagerlie.

They are but words therefore that men do buy,

Of any since God Esculapius ceased.

Your dolefull tunes sweete Muses now applie.

Iustice, iustice is now (alas) oppressed:

Bountifulnes hath made his last conclusion:

Goodnes for best attire in dust is dressed.

Shepheards bewaile your vttermost confusion;

burdened, threatened ceased to be for: instead of

And see by this picture to you presented,

Death is our home, life is but a delusion.

For see alas, who is from you absented?

Absented? nay I say for euer banished

From such as were to dye for him contented?

Out of our sight in turne of hand is vanished

Shepherd of shepherds, whose well setled order

Priuate with welth, publike with quiet garnished.

While he did liue, farre, farre was all disorder;

Example more preuailing then direction,

Far was homestrife, and far was foe from border.

His life a law, his looke a full corrrection:

As in his health we healthfull were preserued,

So in his sicknnesse grew our sure infection.

His death our death. But ah; my Muse hath swarued,

From such deepe plaint as should such woes descrie,

Which he of vs for euer hath deserued.

The stile of heauie hart can neuer flie

So high, as should make such a paine notorious:

Cease Muse therfore: thy dart ô Death applie;

And farewell Prince, whom goodnesse hath made glorious.

cry out, bemoan, deplore

stilus, pen destruction

removed

120

civil war

\section{Philip Sidney(?) 'Philisides, the Shepherd good ANd true'}

Found in the Ottley MS in the National Library of Wales, and BL MS Harley 7392. The Ottley MS consists chiefly, and MS Harley 7392 in good part, of poems by Philip Sidney. This, and the name Philisides, suggest Sidney's authorship. Ringler dismissed the attribution but was later inclined to accept it, as did Jean Robertson. Woudhuysen considers the poem Sidney's work, composed for the 1577 Accession Day tilts. * A note, thought to be by Sidney, in the Ottley MS says the poem was to be recited by a reveller dressed as a ploughman 'after that I had passed the Tilt with my rusticall musick'. It would be followed by a 'freemans songe', the next item in the ms. The text below is based on MS Harley 7392. Philisides ('star-lover', also Philip Sidney), his beloved Mirrha (Mira, 'the wonderful one'), and Menalcas are characters in both the Old and New versions of Sidney's Arcadia. Whoever the author, the names may stand for actual courtly characters.

113 rooted] Sidney's anglicization of Lat radical, of the root. 'Radical moisture is the humour or moisture inherent in all living creatures, and a necessary condition of vitality.' (Skretkowicz). 114 They abandon all attempts and say death is approaching too fast to halt. 115-6 Since the time of Aesculapius, god of medicine, doctors take fees for nothing more than words. 118-20 Alluding to Basileus' (or Amphialus') qualities as a ruler. 119 conclusion] 'a legal impediment or estoppel' (Ringler, who finds other legal tropes in the poem). 126 to dye for him contented] Who loved him so much that they would have been happy to die for (or instead of) him. 127 in turne of hand] ?readily, at the least provocation; ?'by sleight of hand' (Skretkowicz). $\quad 128$ Shepherd of shepherds] (a) the finest shepherd (b) the ruler of shepherds. 129 Brought prosperity to people's private lives and peace to the public order. $\quad 131$ He ruled not by commands but by his own example. $\quad 133$ The sight of him (or a glance from him) was enough to correct and punish wrongdoing. 136 swarued] (a) choked or blocked (b) swerved, gone astray or fallen short of. 140 notorious] widely known (not necessarily in a bad sense). * William A. Ringler, "The Text of The Poems of Sidney Twenty-Five Years After", in Sir Philip Sidney's Achievements, ed. M. J. B. Allen et al., New York: AMS Press, 1990; Jean Robertson, 'A Note on 'Poems by Sir Philip Sidney: The Ottley MS' ', The Library ser.6 vol.2, 1980, p.202; H. R. Woudhuysen, Sir Philip Sidney and the Circulation of Manuscripts, 1558-1640, Oxford: Clarendon Press, 1996, pp.268-78. Robertson was commenting on Peter Beal's note with the quoted title in The Library ser.5 vol.33, 1978, pp.286-9, where he cites strong arguments for Sidney's authorship but leaves the issue open. 
Philisides, the Shepherd good and true,

Came by Menalchas house the husbandman,

With songes of Love and praise of Mirrhaes hue,

Whose faire sweet lokes made him loke pale and wan.

Yt early was. Menalcha forth was bound,

With Horse and man, to sow and till the ground.

'Menalcha softe,' this Shepehard to him saies.

'Wilt thou with worke, this holy time defile?

This is the chief of Cupids Sabaothe daies,

The Wake of those that honour Samos Ile.

Where great and small, rich, poore, and eche degree,

Yeld fayth, Love, Ioy, and prove what in them bee.'

Menalcha who of longe his thought had tild,

With Fancies plow, that they might plesure beare,

And with his Love the empty Furrowes fild,

Which alwais sprange to him againe in feare,

Was well content the plow and all to yeeld,

Vnto this Sabothe day, and sacred feeld.

And on is past by course amonge the reste,

Wyth Layes of Ioy, and Lyrickes all of Praise,

His Hart as theirs in service of the beste,

For other Saintes, he knoweth not their daies.

Yf any Iuste, his whip must be his Speare,

And of his teeme the till horse must him beare.

(complexion, hence) appearance

When he runnes well, then well to her betide,

When yll, then ill. A plain faith is exprest,

Yf neither well nor ill light on his side,

His course is yet rewarded with the best:

For of all Runners, this the Fortune is,

That who runnes best, is fortunde on to misse.

joust
plough-horse

run, race (here, at tilt)

one

\section{Thomas Churchyard Of The Quietness That Plain Country Bringeth}

This poem, in the once-popular poulter's measure, is from A pleasaunte Laborinth called Churchyardes Chance (1580).

Of the quietnesse that plaine Countrey bryngeth.

Among the rustie rockes, bothe rough and harde by kinde,

Where weather beats, and stormes are brim, for eche small blast of winde: fierce, raging

Where spryngs no forraine fruites, nor deinties are not sought,

Where common pleasures made for man, are not in Marketts bought.

Where growes no grapes of wine, to glad the griped breast,

Nor stands no bowres to banket in, yong wantons for to feast:

pained, afflicted

Where people are not fine, nor yet no fooles I trowe,

But plaine as in the twoo pickt staffe, and plainly doe thei goe,

I settled am to liue, and likes my lotte as well,

4 pale and wan] through love. 5 Menalcha] The usual, correct form is Menalc(h)as. In 2, the possessive $s$ was omitted as commonly with names ending in $-s$; this may have led the scribe to take Menalcha as the actual name. The error indicates that the transcript, if not the poem, was not made or supervised by Sidney. 9 Sabaothe] confusing Sabaoth, the heavenly hosts, with Sabbath, hence festival. 10 Wake] festival (OED wake $\left.\mathrm{n}^{1} 4 \mathrm{a}\right)$. Samos] or Samothea, an old name for Britain in the legendary past. 16 in feare] 'in fere', together: i.e. the seeds of love he sowed sprang in clusters to yield him harvest. $\mathbf{1 8}$ feeld] (a) farmland, continuing the farming metaphor (b) field for jousting or tournaments. 21 the beste] No doubt the Queen. 23-4 Presumably a reference to the ploughman's costume of the reveller speaking these verses: see headnote. $\quad 24$ till horse] plough-horse. Alternative marginal reading mill horse, i.e., turning a mill-wheel in a circle, hence a committed lover: the impresa of a tilter in Sidney's New Arcadia (Skretkowicz p.256). Woudhuysen sees this as a link with Sidney and the courtly practice

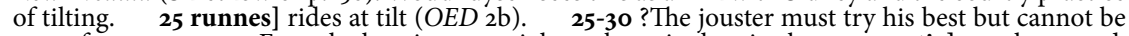
sure of success. 30 Even the best jouster might make a single mistake. 1 rustie] rough, rugged. kinde] nature. $\quad \mathbf{6}$ banket] a light outdoor repast (OED banquet 2). 7 fine] clever, cunning (OED 11): this sense best suits no fooles. 8 twoo pickt staffe] a two-pronged packstaff, the rod or staff on which a pedlar supports his pack. 9 likes] with 'I': singular verb with plural subject (cf. 'holds', $35)$. 
As thei that haue a richer home, or with greate Princes dwell:

Now finde I eache thyng sweete, that sowre I thought before,

That in tymes paste did please me moste, now me delites no more.

The toune and stony streets, I weary am to tread,

The feeld but asks a Motley cote, as homely folks are clead:

Now Frese and Kendall greene, maie serue in stead of Silke,

And I that fedde on Courtly fare, maie learne to feede on Milke

And take sutche countrey chere, as easily is maintainde,

No dishe of gift but sutche in deede, as sweat of browes haue gainde.

No platters full of bribes, these mountaines forthe doe bryng,

A quiet morsell there is cald, a bankett for a kyng:

To eate and slepe in rest, to laugh and speake from feare,

To be an honest neighbour namde, is all that men seeke theare:

No hollownesse of hartes, no hautie waies are likte,

No painted sheathes, no Peacocks proude, that haue their fether pikte,

Are seen vpon these hilles, nor in the dale likewise,

Where those that dwell in cottage poore, doe princely halls despise:

A cruse of cold sowre whey, the Sugred cupp doeth passe,

In gilted boules doeth poison lurke, that spied is in the glasse.

The poore man tastes hym self, the Prince dare not doe so,

Then better is the sured life, then doubtfull daies I troe:

secure; full of fear

that which

Did not Diogenes, set more store by his tonne,

Then of the worldly kyngdomes all, that Alexander wonne.

Did not that mighty prince, these wordes with tong expres,

If Alexander were I not, make me Diogenes:

Since kyngs would change their states, and holds the meane life best,

Then blame not me where I doe like, I seeke to finde some rest.

\section{Thomas Blenerhasset From A Revelation of the True Minerva}

From A Reuelation of the True Minerua (1582), a eulogy of Queen Elizabeth set against a council of the gods to locate a 'true Minerva' on the degenerate earth. In this passage, continental European (perhaps French) shepherds lament their condition and contrast the happy state of England, from which their interlocutor Epizenes comes. Led by blind ambition, he has travelled across Europe, and now repents having left England. The punctuation has been lightly modified.

Then Pan (when Neptune had Apollos place)

that rurall god and clownishe rustikes king,

with shepheardes three attending on his grace,

unsophisticated, crude

he plide his pipe, the one of them did sing,

the second sighth, the third his hands did wring,

when pastor Pan persaude their pitious plight,

his pipe laide down he made his men resight

sighed

perceived

their cause of care.

recite

[Bembus speaks]

From walled towne I Bembus wonted was

a mightie masse of money once a yeere

Full xl. crownes I did returne, alas

nowe xx. grootes I can not compasse cleere,

My stocke, my store, my houshold stuffe most deere,

I spend, and spoyle, and all to none auayle,

lawgh he that list, Bembus shall weep and wayle.

14 Motley a many-coloured cloth, referring to the flowers (OED A1b) 15 Frese] frieze, a coarse cloth. Kendall greene] a coarse green cloth. of gift] obtained gratis or without labour 24 sheathes] covers, exteriors. pikte] plucked: i.e. whose pride goes before a fall. 27 cruse] small jar or bottle. cupp] a sugared, flavoured drink. $\quad 28$ A golden bowl may hide poison, but clear glass reveals it. $\quad 29$ Princes had tasters or sewers who checked their food for poison. 31 tonne] the barrel in which the cynic philosopher Diogenes is said to have dwelt. His encounter with Alexander is narrated in 33-4. 35 meane] (a) lowly, humble (b) moderate, taking the middle path. 36 where] with implicit 'if. 1 Neptune ... Apollo] Just before this, Apollo is said to have yielded place to Neptune, god of the sea where the island kingdom of the 'true Minerva' (Elizabeth) is set. 9 wonted] used to ('returne', 11). 11 crownes] English gold coin worth 5 shillings; also a French coin (escu sol) widely current in England in the $16-\mathrm{c}$. 
On pleasant pipe to play did please me much,

I did delight sweete ditties to indight:

But nowe the woes of wretched warres be such

As nothing els but howe in fielde to fight,

And howe to keepe the flocke from souldiers' sight:

That rauening woolfe, whose neuer filled mawe

With rage doth make his wicked will a lawe.

[Colon speaks]

Poore Colon I, and careful Comma shee

My weded wife, once happie, nowe forlorne,

full of care

Let vs complayne of fortunes crueltie,

The countries grace, and nowe the countries scorne.

$\mathrm{X}$. men, v. flockes, v. plowes, to sowe my corne

I keept, but nowe the greater is my care

My flockes be stolne, my fruitfull fieldes be bare.

The people for the prince's pride are plagde,

It falleth to the faultlesse subiectes lot,

To double drinke in cruel cuppe of care,

When peruerse princes madding minde doth dote:

blameless, innocent

Bellona then doth sounde a dolefull note,

Then blooddie men of warre the sweete doth eate

Without regard of vs the shepheardes sweate.

mad, crazy

draws the benefit

My Bembus deare thou knowest this Sommer last,

Whose armie laide all leuell with the grounde

Our corne half ripe, our vines were spoild as fast,

Our townes be burnt, our woods worth many a pound

Be quite destroyde, and where may nowe be founde

One hedge, or ditch, not torne nor troden downe,

This cursed crop we reape from hie renowne.

In winter nowe when Boreas bitter blast

the north wind

Forbiddes in field that armed men shoulde meete,

A greater griefe we countrey men do tast,

Wee cessed are, the souldier eates the sweete

Of all our toile, a thing nor iust nor meete.

Such is my state: yet this my hireling,

when Pan doth pipe, what doth he then but sing.

proper, befitting

[Epizenes speaks]

And sing thy seruaunt must good Colon, he

Doth hope to haue (as he before hath had)

A place of rest exempt from miserie.

You both (I thinke) do sinne to be so sadde.

Take my aduise and be you euer glad,

do wrong

Do followe mee, forsake these fieldes though knowne,

My selfe can giue the like, they be mine owne.

For I Epizenes a pastor am;

Though nowe thy man, yet I my selfe keepe men,

60 With in my fieldes skipes many a lustie lambe,

I dwell where beefe and bacon meate for men,

where milke and honie floweth like the fenne:

I dwell where want of warre and quiet rest

Doth plainely proue Brittaine to be the best.

within

23 Colon] Variant of 'Colin', but allows pun with 'Comma'. 36 sweate] with play on sweete (35). 41-2 The sense requires another not. 43 hie renowne] apparently their region or nation's, but perhaps of certain persons. 47 cessed] (a) taxed (b) obliged to supply soldiers with provisions (cf. OED cess $\mathrm{n}^{1} 2, \mathrm{v}^{1} 4$, in an Irish context). 50 what ... sing] i.e. His hired boy can be merry while he is not. $\mathbf{6 1}$ meate] ?fit; ?flesh, or simply food (OED 1). $\quad 62$ fenne] fen, marsh. The fens of eastern England had not yet been drained. 
[?Bembus speaks]

Epizenes thou seemst to haue no sence,

Bembus shall proue thee mad or ignorant.

If so it be, why didst thou runne from thence?

wherefore? because all thinges they be so scant

where thou doest dwell, that naked neede and want

Did driue thee thence, my neighbour Colon can

Report thy state, when first thou wert his man.

[?Epizenes speaks]

Bembus, do heare the storie of my state,

Cloyd with the blisse which nowe I doe desire,

I know not what the frowarde force of fate

I being well, did make mee to aspire,

By trauell I did thinke to clime vp hier,

Thus not content in paradize to dwell,

servant or hireling

seeking for heauen, I founde out hatefull hell.

travail, labour

\section{William Warner Argentile and Curan}

From Bk. IV ch. 20 of William Warner's Albions England (1586). Closely linked to Havelok the Dane's story in medieval romance, whose earliest version (in Geoffrey Gaimar's Anglo-Norman History of the English) names the principal lovers as Argentille and Cuharan.

The Brutons thus departed hence, Seauen Kingdomes here begonne:

Where diuersly in diuers broyles the Saxons lost and wonne.

King Edell and King Adelbright in Diria joyntly rayne:

In loyall concorde during life these Kingly friends remayne.

When Adelbright should leaue his life, to Edell thus he saies:

By those same bonds of happie loue, that held vs friends alwaies,

By our by-parted Crowne, of which the Moyetie is myne,

By God, to whom my Soule must passe, and so in tyme may thyne,

I pray thee, nay I Coniure thee, to nourish as thyne owne

Thy Neece my Daughter Argentile, till she to age be growne,

divided in two; half

And then, as thou receiuest it, resigne to her my Throne.

put on oath

A promise had for this Bequest, the Testator he dyes:

But all that Edell vndertooke, he afterward denyes.

Yet well he fosters for a tyme the Damsell that was growne

The fayrest Lady vnder heauen: whose beautie being knowne,

A many Princes seeke her loue, but none might her obtaine:

For grippell Edell to himselfe her Kingdome sought to gaine,

And for that cause, from sight of such he did his Ward restraine.

By chaunce one Curan, sonne vnto a Prince in Danske did see

The Mayde, with whom he fell in loue as much as one might bee.

Unhappie Youth, what should he doe? his Sainct was kept in Mewe,

Nor he, nor any Noble-man admitted to her vewe.

One while in Malancholy fits he pynes himselfe away,

Anon he thought by force of Armes to winne her if he may,

And still against the Kings restraint did secretly inuay.

At length the high Controller Loue, whom none may disobay,

Imbased him from Lordlynes, vnto a Kitchin Drudge:

That so at least of life or death she might become his Judge.

$\mathbf{7 2} \mathbf{d o}$ ] a parodic rustic version of to: if you were to hear, if I were to tell you. $\quad 73$ which ... desire] which (I once had and) now am seeking again. 75 Although I was well, drove me to aspire higher. 1 Brutons] Britons: the spelling a reminder of Brut or Brutus of Troy, legendary founder and first king of Britain. Seauen Kingdomes] The heptarchy of Anglo-Saxon kingdoms after the Romans left Britain. 3 Edell, Adelbright] Edelsie and Adelbrit: In the Havelok story, Edelsie a Dane ruling Norfolk, Adelbrit a Briton ruling Lincoln. Diria] Deira, a subkingdom of Northumbria. 10 Neece] Adelbrit had married Edelsie's sister Orwain. 11 as thou receiuest it] i.e. Edell will be ruling on Argentile's behalf till she comes of age. 13 denyes] disallows, refuses to do $(O E D 4,5)$. 17 Kingdome] ?position or authority of a king $\left(O E D_{1}\right)$ rather than the actual territory, of which Edell is already joint ruler. 23-4 One while ... Anon] At one point ... but then again. 25 restraint] 'action of restricting or checking' (OED 2a) - i.e. hiding Argentile from her suitors. inuay] inveigh: condemn, rail against $(O E D$ s 5$)$. 
And (which was working to his wish) he did obserue with ioye

How Curan, whom he thought a Drudge, scapt many an amorous toye. shaped,

The King, perceiuing such his vayne, promotes his Vassall still,

Least that the bacenesse of the man should let perhaps his will.

Assured therefore of his loue, but not suspecting who

The Louer was, the King himselfe in his behalfe did owe.

obstruct

40 The Lady, resolute from loue, vnkindly takes that hee

And therefore, shifting out of doores, departed thence by stealth,

Preferring pouertie before a daungerous life in wealth.

When Curan heard of her escape, the anguish in his harte

Was more then much, and after her from Court he did departe:

Forgetfull of himselfe, his bearth, his Countrie, friends, and all,

And onely mynding (whom he mist) the Foundresse of his thrall.

Nor meanes he after to frequent or Court, or stately Townes,

But sollitarilie to liue, amongst the Countrie grownes.

A brace of yeres he liued thus, well pleased so to liue,

country-bred people, rustics

?uncertain, precarious

And Shepheard-like to feede a Flocke, himselfe did wholly giue.

So wasting loue, by worke, and want, grewe almost to the Waene:

But then began a second Loue, the worser of the twaene.

A Countrie wench, a Neatheards Mayd, where Curan kept his Sheepe

Did feede her Droue: and now on her was all the Shepheards keepe.

He borrowed, on the working daies, his holly Russets oft:

And of the Bacons fat, to make his Startups blacke and soft:

woo

And least his Tarbox should offend he left it at the Folde:

Sweete Growte, or Whigge, his Bottle had as much as it might holde:

60 A Sheeue of bread as browne as Nut, and Cheese as white as Snowe,

And Wyldings, or the Seasons fruite, he did in Skrippe bestowe:

And whilst his py-bald Curre did sleepe, and Sheep-hooke lay him by,

On hollowe Quilles of oten Strawe he pyped melodie.

But when he spyed her his Sainct, he wipte his greasie Shooes,

And clear'd the driuell from his beard, and thus the Shepheard owes.

I haue, sweete Wench, a peece of Cheese as good as tooth may chawe:

wane

And bread, and Wyldings, souling well: and therewithall did drawe

His Lardrie: and in eating, see yon Crumpled Ewe (quoth hee)

Did twinne this fall, and twinne should'st thou if I might tupp with thee.

70 Thou art to eluish, faith thou art to eluish, and to coye.

Am I, I pray thee, beggerlie that such a Flocke enioye?

Iwis I am not: yet that thou doest hold me in disdaine

holyday

a kind of rustic boot

Is brimme abroade, and made a gibe to all that keepe this Plaine.

There be as quaint (at least that thinke themselues as quaint) that craue

The Match, which thou (I wot not why) mayst, but mislik'st to haue.

How wouldst thou match? (for well I wot, thou art a female) I,

I knowe not her that willingly with Mayden-head would dye.

The Plowmans labour hath no end, and he a Churle will proue:

The Craftsman hath more worke in hand, then fitteth vnto loue:

The Marchant traffaquing abroade, suspects his wife at home:

35 toye] (a) 'amorous sport, dallying' $\left(O E D_{1}\right)(b)$ flirtatious song or speech $\left(O E D_{3}\right)$. $\quad$ 36-7 i.e. Edel advances Curan's state so that his (supposed) low station should not thwart Edel's plan to marry Curan to Argentile. 47 Foundresse of his thrall] source or originator of his captivity (in love). 52 His love began to wane because of his hard labour and want. want] (a) poverty (b) frustration in love. 55 keepe] care $\left(O E D_{1}\right) . \quad 56 \mathrm{He}$ began sporting his holiday clothes on working days. Russets] (garments of) a kind of coarse cloth. $\quad 58$ Tarbox] Tar was used to treat sheep's wounds. 59 Growte] (a) grout, infusion of malt before fermenting (OED grout $\left.\mathrm{n}^{1} 2 \mathrm{2}\right) \mathrm{b}$ ) 'a kind of coarse porridge made of whole meal' $\left(O E D_{3}\right)$. Whigge] any of various milk drinks. $\quad 60$ Sheeue] shive, sheave: slice (OED shive $\left.\mathrm{n}^{1} 1.\right) \quad \mathbf{6}_{7}$ souling] from sowl, 'To form or serve as a relish' (OED sowl $\mathrm{v}^{2}$, citing this line). 68 Lardrie] larder: store of food, prob. in his basket or scrip. breme, widely reported (OED breme 4). 70 eluish] peevish, difficult (cf. OED 2a). 73 brimme] 74 quaint] (a) refined, elegant $(O E D 4 \mathrm{a}, \mathrm{b})$ (b) proud, haughty $(O E D 7)(\mathrm{c})$ fastidious $(O E D$ 6). 
A Youth will play the Wanton, and an old-man proue a Mome:

fool, dolt

Then choose a Shepheard. With the Sunne he doth his Flocke vnfold,

And all the day on Hill or Plaine he merrie chat can hold:

And with the Sunne doth folde againe, then iogging home betyme,

He turnes a Crabb, or tunes a Rounde, or sings some merrie ryme:

Nor lackes he gleefull tailes to tell, whil'st that the Bole doth trot:

And sitteth singing care-away, till he to bed hath got:

There sleepes he soundly all the night, forgetting Morrowe caeres,

Nor feares he blasting of his Corne, or vttring of his wheres

Or stormes by Seas, or stirres on Land, or cracke of credit lost,

Not spending franklier then his flocke shall still defray the cost.

Well wot I, sooth they say, that say: more quiet nights and daies

The Shepheard sleepes and wakes then he whose Cattell he doth graize.

Beleeue me Lasse, a King is but a man, and so am I:

Content is worth a Monarchie, and mischiefes hit the hye.

As late it did a King and his, not dying farre from hence:

Who left a Daughter, (saue thy selfe) for faier, a matchles wench:

(Here did he pause, as if his tongue had made his harte offence.)

The Neatresse longing for the rest, did egge him on to tell

How faire she was, and who she was. She boore (quoth he) the bell

affect those of high rank

his family or near ones except for yourself

[drinking-bowl

[trot goes round

For beautie: though I clownish am, I know what beautie is,

Or did I not, yet seeing thee, I senceles were to mis.

\section{[There follows a long description of the beauties, and briefly the inner graces, of Argentile.]}

A Nimph, no tung, no harte, no Eye, might praise, might wish, might see,

For Life, for Loue, for Forme, more good, more worth, more fayre, then shee: than

Yea such an one, as such was none, saue only she was such:

Of Argentile to say the most, were to be scylent much.

I knewe the Lady very well, but worthles of such praes,

The Neatresse sayd: and muse I doe, a Shepheard thus should blaze

The Coote of Beautie. Credit me, thy latter speach bewraies

Thy clownish shape, a coyned shewe. But wherefore doest thou weepe?

(The Shepheard wept, and she was woe, and both did scylence keepe.)

In troth, quoth he, I am not such as seeming I professe:

But then for her, and now for thee, I from my selfe digresse. depart, i.e., disguise

Her loued I, (wretch that I am, a Recreant to bee)

I loued her, that hated loue: but now I dye for thee.

urge

bore

At Kirkland is my Fathers Court, and Curan is my name,

In Edels Court sometymes in pompe, till Loue contrould the same:

But now. What now? deare hart how now? what aylest thou to weepe?

(The Damsell wept, and he was woe, and both did scylence keepe.)

I graunt, quoth she, it was too much, that you did loue so much:

But whom your former could not moue, your second loue doth touch.

Thy twise beloued Argentile, submitteth her to thee:

And for thy double loue presents her selfe a single fee:

In passion, not in person chaung'd, and I my Lord am shee.

They sweetly surfeiting in ioye, and scylent for a space,

When as the Extasie had end, did tenderly imbrace:

And for their Wedding, and their wish, got fitting tyme and place.

84 iogging home betyme] coming home early. 85 turnes] ?pares the rind in a long narrow strip $\left(O E D{ }_{4 c}\right)$; ?'roasts (originally by turning meat on a spit). Rounde] Prob. the music for a round dance $\left(O E D\right.$ round $\left.\mathrm{n}^{1} 17 \mathrm{~b}\right)$ rather than a song for two or more singers (OED 19), as songs are mentioned separately. $\quad 87$ care-away] 'an exclamation of merriment or recklessness' $(O E D)$. 89 vttring of his wheres] loss or destruction of his flocks. vttring] destruction (cf. OED utterance $\mathrm{n}^{2} \mathrm{2b}$ ) wheres] wares: livestock, flocks (OED ware $\mathrm{n}^{3} 2 \mathrm{~d}$ ). Uttering wares (selling, vending) seems inapplicable. $\quad 98$ as if ... offence] as if he had said something that pained him. 102 I senceles .. mis] I would be foolish not to recognize it. 105 There was none to compare with her. 106 to say ... much] After saying all one could, much would be left unsaid. 108 muse] wonder, be puzzled $\left(O E D_{3}\right)$. 108-9 blaze the Coote] discourse of, extol: image from heraldry. blaze] 'to describe heraldically, to blazon' (OED blaze $\mathrm{v}^{2} 3$ ). Coote] coat (of arms). 116 Kirkland] ?the place of that name in Lancashire, a part of Danelaw or the English territory under Danish rule in the early Middle Ages. (Curan is prince of Denmark.). 117 contrould] curbed, stopped (OED $4 \mathrm{~b})$. 
Not England (for of Hengest then was named so this Land)

Then Curan had an hardier Knight, his force could none withstand:

130 Whose Sheep-hooke layd a parte, he then had higher things in hand.

aside

First, making knowne his lawfull claime in Argentile her right,

He warr'd in Diria: and he wonne Brenitia too in fight:

And so from trecherous Edell tooke at once his life and Crowne,

And of Northumberland was King: long raigning in renowne.

\section{Thomas Watson amyntas: The Second Lamentation \\ Translated from the Latin by Abraham Fraunce}

Thomas Watson's Latin Amyntas (1585) contained 11 lamentations (querelae) of the shepherd Amyntas for his dead love Phillis. These were translated in English hexameters by Abraham Fraunce as The Lamentations of Amyntas for the death of Phillis (1587), and expanded to 12 eclogues in Fraunce's The Countesse of Pembrokes Yuychurch (1591). The translation follows the original quite closely while adding or omitting some details. Contrary to some accounts, the story of Amyntas owes nothing except the lovers' names to Tasso's Italian pastoral play Aminta, though a rendering of the play precedes the Lamentations in Yuychurch. The text here follows 1587. Fraunce, author of The Arcadian Rhetorike (1588), was an admirer and imitator of Sidney. His verse style reflects something of the patterned repetitive structures of Sidney's 'Arcadian' prose.

When by the pleasant streams of Thames poore caitif Amintas Had to the dull waters his grief thus vainly reuealed,

wretch, Spending al that day and night in vainly reuealing,

As soone as morning her shining heares fro the mountains

Had shewn forth, and dryu'n al star-light quite fro the heauens,

Then that vnhappy shepheard stil plag'd with vnhappily louing,

Left those barren banks and waters no pity taking,

And on a crookt sheephooke his lims all weary reposing,

Climed a loft to the hills, but, alas, very faintily clymed,

Kiddes, and goats, and sheepe driuing, goodman, to the mountains,

[miserable person

For sheepe, goats, and kidds with pastures better abounding,

Then by the way thus he spake, to the sheep, to the goats, to the yong kidds. on the way

O poore flock, it seems you feele these pangs of a louer,

And mourne thus to behold your mournful maister Amyntas.

Your wont was, some part to be bleating, some to be skipping,

accustomed behaviour

Some with bended browes and horned pates to be butting,

Sheepe to be gnapping grasse, and goats to the vines to be climing.

But now no such thing, but now no lust to be liuely,

Sheepe and seelly sheepheard with lucklesse loue bee besotted,

You for Amintas mourne, for Phillis mourneth Amyntas,

$\mathrm{O}$ with what miseries poore mortal men be molested?

Now do I know right wel what makes you thus to be mourning,

Thus to be tyred, thus to be quailed, thus to be drooping:

Phillis while she remaynd, milkt my goates euer at euning,

Goats that brought home duggs stretcht with milk euer at euning.

Phillis brought them flowres, and them brought vnto the welsprings,

When dogdayes raigned, when fields were al to be scorched,

Whilst that I lay sleeping in cooling shade to refresh mee.

Phillis againe was woont with Amyntas, sheepe to be washing,

Phillis againe was wont my sheepe thus washt to be shearing,

Then to the sweete pastures my sheepe thus shorne to be driuing,

And from fox and woolfe my sheepe thus dryu'n to bee keeping

With watchfull bawling and strength of lustie Lycisca,

128 of Hengest ... Land] England actually means 'land of the Angles'. 132 Brenitia] or Bernicia, the other part (besides Deira) of the kingdom of Northumbria. 2 thus] i.e. in the First Lamentation. 4 morning] Lat. names Aurora, goddess of the dawn. heares] hairs, i.e. rays of light. Lat. has roseos capillos, 'rosy hairs'. 5 dryu'n] Lat. refers to the bigus or chariot of the dawn. 7 no pity taking] pitiless. Yuychurch prints as compound, 'noe-pyty-taking'. 8 all weary reposing] Lat. simply $m u$ nitus, 'armed' or 'equipped with'. 10 goodman] common in this conjoint form. 17 gnapping] 'bit[ing] in a snapping fashion' $(O E D)$. to the vines to be climing] reaching up on two feet to nibble at the vines. 27 dogdayes] hot summer days, when the dog-star or Sirius rises with the sun. 29-32 In Lat., Amyntas incorporates this account in an affectionate address to the sheep. The lines illustrate the figure contatenatio or chain-like linking of clauses by repeated words, a favourite device of Sidney's. 33 Lycisca] a female sheepdog (Virgil, III.18, Ovid, Met. III.220). 
And in folds and coates my flocke thus kept, to be closing:

Least by the Northern winds my sheepe might chance to be pinched

sheepcotes; shutting in

Least by the frost or snow my kids might chance to be grieued.

Phillis lou'd you so, so Phillis lou'd Amintas,

Phillis a guide of yours, and Phillis a friend of Amintas.

But sweete sheepe, sweete goates, spare not to be liuelie, for all this,

Looke not vpon my weeping face so sadly, for all this,

Harken not to my plaints and songs all heauie, for all this,

Harken not to my pipe, my pipe vnluckie, for all this.

But sweete sheepe, sweete goates, leaue of your maister Amintas,

Leape and skip by the flowring fields, and leaue of Amintas,

Climbe to the vines and tender trees, and leaue of Amintas,

Climbe to the vines, but runne for life, for feare of a mischiefe,

When th'old Silenus with his Asse comes lasilie trotting,

Let me alone, me alone lament and mourne my beloued,

Let me alone celebrate her death by my teares, by my mourning:

Like to the siluer swan, who seeing death to be comming,

Wandreth alone for a while through streames of louelie Caïster.

Then to the flowring bankes all faint at length he repaireth,

Singing there, sweet bird his dying song to Caiister,

Geuing there, sweet bird, his last farewell to Caïster,

Yeelding vp, sweete bird, his breath and song to Caiister.

How can Amintas liue, when Phillis leaueth Amintas?

What for fieldes, for woods, for medowes careth Amintas,

Medowes, woods, and fieldes if my sweete Phillis abandon?

Mightie Pales fro the fieldes, fro the medowes learned Apollo,

Faunus went fro the woods, when Phillis went from Amintas,

No good sight to my eyes, no good sound came to my hearing.

But let Phillis againe come backe, and stay with Amintas,

Then shall woods with leaues, and fields with flowers be abounding,

Medowes with greene grasse to the poore mans dailie reioicing,

Mightie Pales to the fields, to the medowes learned Apollo,

Faunus comes to the woods, if Phillis come to Amintas,

No bad sight to my eyes, no bad sound comes to my hearing.

Come then, good Phillis, come back, if destinie suffer,

Leaue those blessed bowers of soules alreadie departed,

Let those sparkling eyes most like to the fire, to the Christall,

Ouercome those hags and fiends of fearefull Auernus,

Which haue ouercome those stars of chearful Olympus.

And by thy speech more sweet then songs of Thracian Orpheus,

Pacify th'infernall furies, please Pluto the grim god,

Stay that bawling curre, that three throt horrible helhound,

For vertue, for voice, th'art like to Sibilla, to Orpheus.

Sweet hart, come, to thy friend, to thy friend come speedelie sweethart.

Speedelie come, least grief consume forsaken Amintas.

Phillis, I pray thee returne, if prayers may be regarded,

By these teares of mine, from cheekes aie rueful abounding,

By those armes of thine, which somtimes clasped Amintas,

35 pinched] shrunk or afflicted with cold.

37 For the second lou'd, Yuychurch has loued, which scans better. $\quad 39-42$ The figure epistrophe, closing each line with the same phrase. 47 Silenus] an elderly wood-god, a jovial drunken attendant of Dionysus, riding on an ass. 50 swan] Held to sing only at the time of its death. $5 \mathbf{1 C a i ̈ s t e r ] ~ C a y a s t r u s , ~ a ~ r i v e r ~ i n ~ L y d i a ~ ( i n ~ m o d e r n ~ T u r k e y ) ~ k n o w n ~ f o r ~ i t s ~}$ swans and other waterfowl. 59 Pales] a pastoral goddess. fieldes ... medowes] farmland and open land (Lat. agros, prata). medowes ... Apollo] i.e. Pastoral song vanished from the countryside.. See Homer, Iliad II.461; Virgil, Aen. VII.699. 6o Faunus] a wood-god. 64 poore mans ... reioicing] i.e. Farmers will be happy when the grief-ravaged countryside is green and fertile again. $69-72$ differing somewhat from the Lat. $\mathbf{7 1}$ Auernus] a lake considered the entrance to the underworld; hence the underworld itself. $\mathbf{7 2}$ ouercome ... Olympus] (Her eyes) which have outshone the stars of the sky. 73 Orpheus] Orpheus won back his dead wife Eurydice by pleasing Pluto, god of the underworld, with his song. 75 helhound] Cerberus, the three-headed dog guarding the entrance to Hades. $\mathbf{7 6}$ vertue ... voice] of 'Sibilla' and Orpheus respectively. Sibilla] probably the Cumaean Sibyl, one of several wise women so named. 77 Sweet hart ... sweethart] Both 1587 and Yuychurch print separately the first time and conjointly the next, suggesting a change of nuance. $80-85$ The figure anaphora, opening each line with the same word. 
By lips thine and mine, ioined most sweetly together,

By faith, hands, and hart with true sinceritie pledged,

By songs, by wedding with great solemnitie vowed,

By iests, and good turns, by pleasures all I beseech thee,

promised, pledged

Helpe and succor, alas, thy forlorne louer Amintas.

Or by thy teares intreat those nimphs of destenie fatall,

No pitie taking nimphs intreat, that I liue not alone thus,

Pind thus away with griefe, suffring vnspeakable anguish,

But let death, let death, come spedelie giue me my pasport,

So that I find faire fields, faire seats, faire groues by my dying,

And in fields, in seats, in groues faire Phillis abiding.

There shal Phillis againe, in curtesie striue with Amintas.

There with Phillis againe, in curtesie striue shal Amintas,

There shall Phillis againe make garlands gay for Amintas,

There for Phillis againe, gay garlands make shal Amintas,

There shal Phillis againe be repeating songs with Amintas,

Which songs Phillis afore had made and song with Amintas.

But what, alas, did I meane, to the whistling winds to be mourning?

As though mourning could restore what destenie taketh.

Then to his house, ful sad, when night approcht, he retorned.

\section{Thomas Watson amyntas: The Last Lamentation}

Translated from the Latin by Abraham Fraunce

Fraunce's English rendering in The Lamentations of Amyntas (1587) of the eleventh and last eclogue in Thomas Watson's Amyntas (1585), at the end of which Amyntas kills himself. 17 lines added in Fraunce's The Countesse of Pembrokes Yuychurch (1591), where it is the twelfth eclogue owing to an addition earlier on. The fuller Yuychurch version is followed here. Except for the extra lines, this follows the Latin fairly closely, with a few changes and omissions.

And now since Phillis dead corps was layd in a coffyn

Twelfth day came at last, when weake, yet wakeful Amyntas

Spy'de through tyles of his house fayre Phoebus beames to be shynyng:

Which when he saw, then in haste hymself he began to be stirring,

And with trembling knees, with mynde extreamely molested,

Passed along to the fyelds where graue of Phillis apeared,

Meanyng there to the graue, to the ghost, to the scattered ashes

His last lamenting in woeful wise to be making.

But when he saw fresh flowrs and new grasse speedyly start vp,

And Phillis sweete name ingrau'n by the hande of Amyntas,

Then did he stay, and weepe, with an inward horror amased:

And at length his knees on graue there fantyly bowing,

With dolorous groanyngs his fatall howre he bewayled.

troubled, afflicted

spirit, soul

This day, this same day, most blessed day of a thowsand,

Shall be the first of ioy, and last of anoy to Amyntas,

This shall bring mee myself to myself, and bring mee to Phillis.

Let neyther father nor mother mourne for Amyntas,

Let neyther kinsman, nor neighbour weepe for Amyntas,

For Venus, only Venus doth lay this death on Amyntas,

And Phillis sweete sowle in fayre fyelds stays for Amyntas.

Yf you needs will shew some signe of loue to Amyntas,

Then when life is gone, close vp these eyes of Amyntas,

84 wedding] The eleventh lamentation (added in Yuychurch) recounts how Amyntas had actually prepared the wedding ring. $\quad 87$ nimphs of destenie fatall] the Parcae or Fates. 88 no pitie taking] As in 7, Yuychurch hyphenates as 'Noe-pity-taking'. 91-8 In Lat., these wishes are addressed directly to Phillis. 93-8] Combines epistrophe, anaphora and much other patterning in a typically Sidneian or 'Arcadian' structure. 97 repeating] reciting, rendering (OED 5a): perhaps exchanging verses (Lat. repetemus ... parili versu). $\quad 99$ whistling] commonly used of the wind, waves etc. 1 dead corps ... coffin] Lat. talks of cremation - which matches the earthen pot containing her bones in the English Third Lamentation. 3 Spy'de through tyles] shows the neglected state of Amyntas' house. Earlier eclogues describe him as wearing ragged clothes, starving himself and neglecting his tasks. 9-10 name ingraven] The first mention of this, though the Third Lamentation describes the grave itself. 13 his fatall howre] He is about to kill himself. 
And with Phillis corps lay this dead corps of Amyntas,

This shal Phillis please, and Phillis louer Amyntas.

And thou good Thyrsis, dryue foorth those Sheepe of Amyntas,

Least that Amyntas Sheepe dy with theyr master Amyntas.

And thou good Daphne, when soe thou gang'st to the Mountayns,

Dryue on Phillis Goates, fayre Phillis Goates to the Mountayns;

For now, now at length, ile leaue this life for a better,

And seeke for mending in a most vnnatural ending.

Must then Amyntas thus but a stripling murder Amyntas?

cure, relief

O what an imperious princesse is Queene Cythercea?

For, stil-watching loue would neuer let me be resting,

Nor neuer sleeping since Phillis went from Amyntas.

ever-wakeful

And noe longer I can susteigne these infynit horrors

And pangs incessant, which now are freshly renued

And much augmented; therfore am I fully resolued

Of lingring loues wound to be speedily cur'd by a deaths-wound.

Thus when he had contryu'd in his hart this desperat outrage,

And meante fully to dy, with an hellish fury bewitched,

What doe I stay, quod he, now? tis losse of tyme to be lingring:

Then with a fatall knife in a murdring hand, to the heauens

Vp did he looke for a while, and groan'd with a deadly resounding,

With thease woords his life and lamentation ending.

Gods and ghosts forgiue, forget this fault of Amyntas,

Pardon I craue of both, this knife shall bring me to Phillis,

And end these myseries, though desteny flatly deny it.

Eu'n as he spake these woords, downe fell deepe-wounded Amyntas,

Fowling hands and ground with streames of blood that abounded.

And good-natur'd ground pytying this fall of Amyntas,

In most louing wise, very gently receaued Amyntas,

And when he fell, by the fall, in mournefull sort, she resounded.

Iupiter in meane-tyme, and th'other Gods of Olympus,

When they saw this case (though greate things were then in handling)

Yet lamented much, and then decree'd, that Amyntas

Sowle should goe to the fyelds where blessed Phillis abydeth,

And bloody corps should take both name and forme of a fayre flowre

Call'd Amaranthus then, for Amyntas fryendly remembrance.

Whil'st these things by the Gods were thus decree'd in Olympus,

Senses were all weake, and almost gone from Amyntas,

Eyes were quyte sightles, deaths-pangs and horror aproached.

Then with his head half vp, most heauyly groaned Amyntas,

And as he groan'd, then he felt his feete to the ground to be rooted,

And seeking for a foote could fynde noe foote to be sought for,

For both leggs and trunck to a stalk were speedily changed,

And that his ould marrow to a cold iuyce quickly resolued,

And by the same could iuyce this stalk stil lyuely apeared.

Which strange change when he felt, then he lifted his arms to the heauens,

And, when he lifted his armes, then his arms were made to be branches;

And now face and hayre of Amyntas lastly remayned;

$\mathrm{O}$ what meane you Gods to prolong this life of Amyntas?

$\mathrm{O}$ what meane you Gods? with an hollow sound he repeated,

Vntil his hollow sound with a stalk was speedily stopped,

31 'Must I kill myself at this tender age?' 32 Cytheræa] Venus or Aphrodite, early worshipped on the island of Cythera. 39 outrage] 'mad or passionate behaviour, fury; tumult of passion, disorder' (OED 1). 40 hellish fury] damnable madness: it is a sin to kill oneself. 41 What] why (OED 19). 45 ghosts] spirits, presumably holy or blessed souls. 58 Amaranthus] Prob. the love-lies-ableeding, with a purplish-red spume of flowers, or the related prince's-feather or Joseph's-coat, which actually has red foliage (cf. 75), both imported to England from America in 16-c. The amaranthus is also a legendary flower of immortality growing in heaven; significantly, the present flower is so named by Jupiter. Lat. adds, it 'will grow in the serene fields of famous country-seats'. Fraunce's patron Mary Herbert, Countess of Pembroke, was interested in chemistry and practical medicine: the plant may have been cultivated on the Pembroke estate at Wilton. $\quad 67$ Amyntas marrow-juice became the vital sap of the amaranthus plant. $\mathbf{6 9}$ branches] Lat. specifies sharp spikes or points as in the love-lies-ableeding and prince's-feather - in the latter, pointing upwards as here. 
And fayre face and hayre bare forme and shape of a fayre flowre,

Flowre with fayre red leaues, fayre red blood gaue the begynnyng.

Then with bow and shafts, and paynted quyuer about hym,

Vprose Lord of loue from princelyke seate in Olympus,

And, when t'was too late, laments this losse of a louer,

Speaking thus to the Gods of this new flowre of Amyntas.

Myrtle's due to Venus, greene laurel's deare to Apollo,

Corne to the Lady Ceres, and vines to the yong mery Bacchus,

But thou fayre Amaranthus, gentlest flowre of a thowsand,

Shalt be my flowre henceforth, and though thou camst from a bleeding,

Yet blood shalt thou staunch, this guyft wil I geue the for euer:

And by the pleasant parke where gentlemynded Amyntas

Lately bewayld his loue, there thy leaues louly for euer,

Boyes and gyrls and Nymphs, shall take a delite to be plucking,

Take a delyte of them theyr garlands gay to be making.

And now in meane tyme whylst these things were thus a working,

Good louing neighbours for a long tyme myssed Amyntas,

And by the caues of beasts, by the dungeons darck, by the deserts,

And by the hills and dales, by the wells and watery fountayns,

Sought for Amyntas long, but neuer met with Amyntas.

\section{[The following lines (without precedent in Watson's Latin) were added in The Countess of Pembroke's Yvychurch, 1591]}

Downe in a dale at last, where trees of state, by the pleasant

Yuychurches parck, make all to be sole, to be sylent,

Downe in a desert dale, Amaryllis found Amaranthus,

(Nymph, that Amyntas lou'd, yet was not lou'd of Amyntas)

Founde Amaranthus fayre, seeking for fayrer Amyntas;

And with fayre newe flowre fayre Pembrokiana presented.

Who, by a strayte edict, commaunded yearely for euer

strict

Yuychurches Nymphs and Pastors all to be present,

All, on that same day, in that same place to be present,

All, Amaranthus flowre in garlands then to be wearing,

And all, by all meanes Amaranthus flowre to be praysing,

And all, by all meanes his Amyntas death to be mournyng.

Yea, for a iust monyment of tender-mynded Amyntas,

With newfound tytles, new day, new dale she adorned,

Cal'd that, Amyntas Day, for loue of louer Amyntas,

Cal'd this, Amyntas Dale, for a name and fame to Amyntas.

\section{John Trussel(?) An Old-Fashioned Love, Epistle 1}

Thomas Watson's Latin Amintae Gaudia (posthumously published 1592) was a 'pre-quel' in epistolary form relating the love and courtship of Amyntas and Phillis before the latter's death as lamented in Watson's Amyntas (1585). This is the first of five eclogues from Amintae Gaudia translated by 'I. [ohn?] T.[russel?] gent' as An Ould Facioned Love (1594). It follows the general lines of the original quite closely. Punctuation and fonts have been regularized.

The First Epistle.

Countries delight, sweet Phillis, Beuties pride:

Vouchsafe to read the lines Amyntas writeth,

And hauing red, within your boosome hide,

What first of loue my fearefull muse inditeth.

75 leaues] perhaps petals $\left(O E D_{2}\right)$, but Lat. foliis can only mean leaves. The Joseph's-coat amaranth has red leaves. $\quad 77$ Cupid is actually not one of the twelve Olympian gods. $\mathbf{8 4}$ blood thou shalt staunch] a property of many amaranths, especially the Joseph's-coat. 85 parke] 1587 has 'fields'. The change in Yuychurch surely targets the Pembroke estate at Wilton, or the smaller grounds at Ivy Church, a retreat for the Countess that lent Fraunce's volume its title. 87 Nymphs] perhaps meaning the Graces, mentioned in Lat. alongside virgins and young men, adding 'and it shall be called the flower of love'. 99 Pembrokiana] Mary Herbert, Countess of Pembroke, to whom Yuychurch is dedicated. Uncertain whether Amaryllis stands for a real person. 
When once my mother set me flocks to keepe,

Bare fifteene yeres of age, in lether clad,

A maple hooke, to get and hould my sheepe,

A waiting dogge, a homely scrip I had.

No skill in beasts, on loue I neuer thought,

Yet but a boye, the friendly shepards route

rout, band

Admitted me, and countrie secrets taught:

To heale my flocks, to fould them round about.

In threatned stormes, to lead them to the lee,

To sheare in time, to driue the wolfe awaie,

To knowe the course of starres that fixed bee:

To pipe on meadow reeds, each holy-daie.

To sing in rime, as sometimes shepards vse,

are accustomed to

To daunce our Iiggs on pasture grac't with flowrs

What learnd I not, what toil did I refuse,

To quench loues flames, and passe o're idle houres?

At last; when heauen did women's callends shew,

And custome would that euery swain should profer

Vnto his choise, as they doe sit arewe,

Such fauours, as poore shepards vse to offer.

shelter from the wind

Silke garters Egon first began to tie

About the calues of her he loued best,

And lifting vp her clothes, she said Naie fie.

With blushing smils, his hand she downward prest.

nay

Then Titerus a ryband did bestow

On Driades his loue and whole delight.

In token of the ioyes they hope to knowe,

When wedding chamber giues the happie night.

Of marigoldes, with figured loue and name,

A chaplet Melibeus had deuised.

On Clitias head then pinned he the same,

And vowd his loue should neuer be demised.

To Glicery ould Mopsus fay rings giueth.

Menalcas and the rest gaue where they loued;

But who is he, that alwaies happie liueth?

What ioyes so firme, as griefe hath not remoued?

Faustulus, and Caridon, wel borne, and wel allyed,

Both rich, both strong, and both for vertues praised

Lou'de you alike, and were alike denied.

Yet for your sake, great strife there had they raised.

A gem the one, a whelpe the other bringeth,

Both faire enough, yet you did both refuse,

Lest hate which oft from riuall passion springeth,

This merrie meeting rudelie should abuse.

And yet these lads do striue, with words and deeds.

Loue gaue them staues, their blows ar strongly plac'd.

They call their frends, the best but badly speeds.

Full pale you rose (I markte how palenes graced).

8 waiting dogge] $i$ watchdog'; ?a dog accompanying or 'waiting upon' him. 15 fixed] either the courses or the stars themselves ('fixed stars' as opposed to planets). 21 women's callends] A fanciful English version of the Matronalia, the Roman festival of Juno on the first (kalends) of March, when women were given gifts by their husbands. 33 figured] ?spelling out her name and tracing the shape of a heart in flowers. Marigolds were a common love charm. $\mathbf{3 6}$ demised] (a) transferred to another (the original legal sense) (b) dead. $\quad 41$ wel allyed] with distinguished or influential relations. 51 the best ... speeds] Even the ablest of them fares badly in the strife. $\quad 52$ I markte ... graced] I saw how your paleness increased your beauty. 
And truce with mouing teares you did desire.

But all in vane, for teares, the fight increased:

Whereat (me thought) my hart began to fire,

And pittie longd to see this battell ceased.

for: in spite of

blaze, be aroused

Then rushed I, amidst this churlish fraie.

And war with war, I conquered at the last:

With force, or threats, the fearcest did I staie.

You gaue me thanks, when all the broile was past.

Oh had not sweetest Phillis thankfull beene,

And yet I wish too much against your kind.

But had not I those gracious gestures seene,

I might haue still enioyed a quiet mind.

For when your tempting eyes I did behold,

And heard your voice, more sweet then musiks sound,

The passions which I felt, may not be told;

Then, then, it was that first loues force I found.

The one mine eare, the other pleasd mine eye,

This pleasure bread such stormes within my hart

As poore Amintas wretchedlie must die:

Except faire Phillis shall redresse his smarte.

My doubtfull mind so too and froe doth moue,

Vnlike himselfe your seruaunt now abideth,

Constant in naught, but onely in your loue:

Feare presseth hope, and shame affection hideth.

Beleeue me sweete (newe louers cannot faine)

Awake, asleepe, still Phillis doe I see,

And from your looks I gather ioye or paine,

Euen which it please you, to bestow on me.

If merrilie Amintas you salute,

A merry hope doe make me happie straight,

But if you frowne, then doe I feare my sute:

And on my thoughts, a thousand cares do waight.

Confounded thus, and ouercome with griefe,

To fluds with teares, to ayre with sighes I melte,

In vaine I seeke each waie for my reliefe:

I thinke such torments, neuer louer felte.

Yet lest a coward iustly I were thought,

90 At first to yeeld vnto my first desire,

Fond rage with reason to suppresse I sought:

immediately

And with discretion, to quench out the fire.

I chide my selfe, and call into my mind

Such medicines, as our annals haue in store,

I prooue them all, and yet small ease I find:

For still my loue increaseth more and more.

(a) recounted (b) numbered

I sit vp late, I rise before the daie,

I doe repeate each vanitie in loue,

I checke faire beautie, by her quick decaie:

everywhere, in all directions

jostles, competes with

feign

heal his pain

fearful, insecure

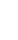

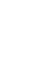


I thinke how Sirens catch the listning eare,

And how affection is increast by sight,

Sweet Phillis, pardon though the truth you heare:

And though against my will, loue kept your right.

For I did striue to free me from affection,

But beautie was too strong for mine endeuor,

Who hath so forst my loue to your subiection:

As till you free me, I am bound for euer.

To stop mine ears with wax, mine eyes to blind,

To hide me from your sight amidst the woode,

blindfold

In all these helps no helpe at all I find:

My loue is such, as they will doe no good.

As Pelias spere could hurt and healde againe,

So therefore let me craue but this of thee,

That as loue made, so loue may ease my paine:

And as you mine, so I your best may bee.

favourite, best loved

\section{John Finet(?) The Argument of Amyntas}

From Bodleian MS Rawlinson Poet. 85. Author's name torn and undecipherable: might be John Finet, principal compiler of the volume, or (as Woudhuysen conjectures) his Cambridge associate Robert Mills.* This curious piece testifies to the popularity and influence of Watson's Amyntas. It also links up with pastoral lyrics like no.115 and 120, and shows the spread of pastoral conventions across genres. Punctuation and capitalization marginally modified and regularized.

Verses made in manner of argument vpon 11: lamentationes of Amintas:

Sweet Phillis Venus sweetyng was, was none so swete as she:

Amintas Cupids darlynge to: was none so dere as he.

too

Sweet Phyllis kepte sheep one a downe, was neuer downe so freended:

on

Amintas helpte her tende her sheep, were neuer sheep so tended.

Sweet Phillis lykte Amintas thoe, and would not be remoued:

Amintas loued Phillis so, as none could more be loued.

Sweet Phillis flowring garlonds made and badd Amintas were them:

Amintas tender lambkins had, to Phillis did he bere them.

Sweet Phillis where she kepte her sheep the groaues and growndes she graced:

Amintas in those groaues and growndes sweet Phillis ofte embraced.

Sweet Phillis plyght her fayght and trouth the shepherd shoulde her wedd:

Amintas mynd clogde with despayre, with hope herof was fedd.

Sweet Phillis naythles was beguyld, death had the baynes forbydden:

Amintas hope quyte dashte, despayre no longer coulde lye hydden.

Sweet Phillis thus in freshest pryme of loue and lyfe bereued,

Amintas lefte disconsolate of loue and lyfe deceued.

Sweet Phillis dayes eleuen was dead, eleuen dayes so remayninge,

changed in her love

Amintas dayes eleuen complaynd, the 'leuenth day dyde complayninge.

Sweet Phillis soull (o happy soull) th' Elysean feelds contained:

Amintas corps o haples corps, a flowre with blood distayned.

101 Sirens] sweet-singing sea-nymphs who charmed Odysseus and other mariners. 104 kept your right] preserved your rightful claim to my love. 109 to stop my ears] like Odysseus against the Sirens (explicitly cited in Lat.). $\quad 113$ Pelias spere] Achilles' spear, which he alone could wield, made from an ash on Mt Pelion. No classical source for its both hurting and healing. $115 \mathrm{~A}$ common Petrarchan paradox: love alone can cure love's pain. $\quad{ }^{*}$ Henry Woudhuysen, Sir Philip Sidney and the Circulation of Manuscripts, 1558-1640, Oxford: Clarendon Press, 1996, p.260. 3 freended] benefited, advantaged. $\quad 5$ thoe] then: here virtually a space-filler. $\quad 17$ dayes eleuen] matching the eleven lamentations of Watson's poem. 


\section{Abraham Fraunce 'Arcadian Syrinx'}

Sung by the shepherd Menalcas at a shepherds' assembly in Abraham Fraunce's The Third Part of the Countess of Pembroke's Ivychurch (1592), which contains tales of the Graeco-Roman gods. Hexameters.

Arcadian Syrinx was a Nymph most noble, amongst all

Naiades and Dryades, that in olde times highly renowned

Arcadian fountaines and mountains euer aforded.

Fleshly Satyrs, Fauni, Siluani dayly desired

Braue bony Syrinx loue, yet loueles braue bony Syrinx

Fleshly Satyrs, Fauni, Siluani dayly deceaued.

Syrinx tooke noe ioy in ioyes of Queene Cytherea,

But vowd life and loue, and hart and hand to Diana.

Lyke to Diana she lyu'd, for a virgins lyfe she professed,

Lyke to Diana she went, for in hunting roabes she delighted,

And with bow and shafts stil practysd lyke to Diana;

Onely the diffrence was, that in-hunting-mighty Dianaes

Bow, was made of gowld, and Syrinx bow of a cornell:

Which noe great diffrence was not so greatly regarded,

But that Nymphs and Gods eu'n so were dayly deceaued,

And hunting Syrinx for mighty Diana reputed,

So nere by Syrinx was mighty Diana resembled.

Pan, with a garland greene of Pinetree gayly bedecked

lustful

beautiful, glamorous; bonny frustrated, disappointed

appeared, went about

small

near, closely

Saw this Nymph on a time come back from lofty Lycous,

And his rurall loue in rurall sort he bewraied.

Scarce had he sayd, Bony sweete; but away went braue bony Syrinx,

Went through hills and dales and woods: and lastly aryued

Where gentle Ladon with mylde streames sweetely resounded.

Ladon stopt her course, Ladon too deepe for a damsell.

Then quod Syrinx, Help, deare sisters; let not a virgin,

Immaculate virgin by a rurall Pan be defyled.

Rather let Syrinx be a mourning read by the ryuer,

Soe that Syrinx may be a mayden reade by the ryuer.

By and by Syrinx was turnd to a reade by the ryuer:

And there sight and sobd, that he found but a reade for a Syrinx.

Whilst Pan sighs and sobs, new tender reades by the whistling

Wyndes did shake and quake, and yeelded a heauy resounding,

Yeelded a dolefull note and murmur like to a playning.

Which Pan perceauing, and therewith greatly delighted,

Sayd, that he would thenceforth of those reades make him a Syrinx.

Then, when he had with wax, many reedes conioyned in order,

His breath gaue them life: and soe Pan framed a Pastors

Pipe, which of Syrinx is yet still called a Syrinx.

\footnotetext{
2 Naiades and Dryades] water-nymphs and wood-nymphs respectively: pronounced in two syllables to suit the metre. 4 Fauni, Siluani] wood-gods. Lat. plurals, presumably to suit the metre. 7 Queene Cytherea] Aphrodite or Venus, after Cythera, her early place of worship. 13 cornell] (wood of) the cornel cherry tree (Lat. cornum): Fraunce's reading of Lat. corneus in Ovid, Met., I.696-7, more usually taken in the sense 'made of horn' (Lat. cornu, horn). 18 Pinetree] Fraunce takes Ovid's pinu(s) (Met. I.699, XIV.638) in the usual sense of 'pine tree' and not, as meant here, a wreathe of pine needles. 19 Lycæus] a mountain in Arcadia, birthplace of Pan. 23 Ladon] a river in Arcadia. 25 sisters] nymphs of the Ladon. Syrinx was herself a nymph. 27-9 by] The meaning shifts subtly from 'beside' to 'by the agency of', with further play on 'by and by'. 30-31 for] (a) expecting, aiming at (b) instead of. Also play on Syrinx: nymph, reed and pipe.
} 


\section{A TAle of Robin Hood}

This curious poem from BL MS Harley 367 is unique in presenting Robin Hood, Little John and Adam Bell, another outlaw of popular legend, as allegorical figures for the Church, the universities and the monastic orders respectively; hence as icons of the establishment. Helen Cooper links this poem to the Martin Marprelate controversy of the 1580 os, though she does not rule out the early 17 th century.* Concluding part of ms. text missing. Punctuation, line initials, and lineation of paratext modified.

A tale of Robin Hoode dialouge wise beetweene Watt and Ieffry.

The morall is the overthrowe of the Abbyes, the like being attemted by the puritane, which is the wolfe: and the politician which is the Fox, agaynst the bishops.

Robin Hoode: bushop

Adam Bell: Abbot

Little Ihon: Colleauge or the vniversity.

Ieffry. Watt boy whether now so faste?

Why man what needs all this haste?

Frolicke, man, for I have seene

Both our flocks in yonder greene.

Hadst thou come but heere awaye,

Thou hadst seene a pretty fraye.

Watt. Who foughte heere, I pray the shewe.

Ieffry. Two fatt ramms for one leane ewe

With sucth force each other battred

That their heads were bothe beemattred;

So all three were in one plighte,

Shee with leanesse, they with fight.

Wat. Rest they then if they bee weary

And make wee a little mery

Tale - wee, Ieffry, in this shade

Till the soonn beeginn to glade:

sun; decline, set

Thy loves storye of thy Cyss

Wowlde delighte mee more than this.

Ieffry. Watt, stay there: for love I care not;

Leave out love and speake and spare not.

Talke of Bevis, fighter peerlesse,

Or of Ascleparte the fearlesse;

Talke of lyons and of wonders,

Lyghtning's flashe or roores of thonders,

Fyre and hayle, and stormes of blood:

Or tell a tale of Robin Hoode.

Watt. Pitty twere hee that showlde ease thee

Shoulde relate things cannot please thee.

Thy loves eager sawce, I feare,

Wowld wax sharper with this geare,

idle talk

Ieffry, and I durste not venter

Putt thy sorowes on the tenter:

Off Robin Hoode I cann thee tell

With little Ihon and Adam Bell.

Ieffry. Than tell mee of those iolly markmen

Whiles our flocks go feedinge. Watt.

Robin Hoode, as thou doste knowe,

Was the first that drewe the bowe;

\footnotetext{
* Helen Cooper, 'A Tale of Robin Hood: Robin Hood as Bishop', Medieval Cultural Studies: Essays in Honour of Stephen Knight, ed. Ruth Evans, Helen Fulton \& David Matthews, Cardiff: University of Wales Press, 2006, pp.75-90. 8 fatt ramms ... leane ewe] rams, Puritans and 'politicians' or secular rulers; ewe, the episcopal Anglican church, rendered leane after the suppression of the monastic orders. See 'The morall', 0.2-3. $\quad 10$ beemattred] ?brained, with grey matter spilling out. 21 Bevis] Bevis of Hampton, celebrated hero of medieval romance. 22 Ascleparte] Ascopart, giant who first opposes and then serves Bevis. $\quad 23$ lyons] 'Things of note, celebrity or curiosity' (OED lion 4a). 29-30 ?Your love would grow sourer for anything I could tell you. 37-40 Marginal note in ms.: 'Bushops were firste in the primitive churche, in the heate of persecution[;] then succeeded monasteryes in calmer tymes and laste of all colleages: of either which bushops wer principall and firste founders'.
} 
Adam Bell rose vp anonn:

Last of all came litle Ihon.

Robin in the greatest heate

ardour, vigour

Gott his livinge by his sweate;

Hee did encounter monsters fell

In forest wide and did them quell.

Him, ne're Chimaera cowld afrighte,

Nor monster men which giaunts hight;

are called

The flyinge dragon scap'te him not,

So stronge hee drewe, so righte hee shott.

Even that Leviathan remorcelesse,

Shott downe to hell, did feele his forces.

With bowe and arrowes by his side

Hee walkte the woods and forrests wide;

When the worlde for helpe did cry,

And good archers were sett by,

Hee taught Adam to deliver,

esteemed, valued

Hee, the firste that gave him quiver,

Gave him bowe and arrowes sure,

Gave him goodly furniture;

Hee tooke Adam by the hande,

60 Hee lead Adam throug the lande,

Hee plas'te Adam in the playne,

By the rivers christall veyne.

When the worlde was calme at laste

And all daunger now was paste,

Little Ihon, who doth not see

What good Robin did for thee?

On two mounteynes hee thee planted,

Full of springs which never scanted,

Whence large rivers rann amayne

Into Adams fruitfull playne.

Two fayre mounteynes thou doste holde

Full of pretious stones and goold

Which the worlde so mucth sets by

As the body doth the eye.

Adam Bell was ware and wise

astute, sagacious

When hee firste beegann to rise,

Till with fatnes of his fare

Hee grew iolly, past all care

As the bee in sommers prime

80 Sucks the marigoolde and thyme,

Sucks the rose and daffodill,

Leavinge, takinge what hee will:

And from flowre to flowre doth glyde

Sweetly by the rivers side,

Where christall streames delightfull ronninges

lacked (for water), dried up strongly, in full force

Ar ever sweetned with his hummings:

Sucth was Adam in his prime

In the flower of his tyme.

So hee tasted evry sweete

$90 \quad$ Till with fatt hee fell a sleepe.

As hee slombred on the dale

Spread vpon the gentle vale,

Chaun'ste a lyon came that way,

1-50 In accord with his role as the true Church, Robin becomes a hero of supernatural power, finally almost a type of Christ. $\quad 45$ Chimaera] a fire-breathing monster compounded of limbs appropriate to various animals. $\quad 49$ Leviathan] a sea-monster in the Bible: from Isaiah 27.1, identified with the dragon of the Apocalypse (Rev.12, 13), hence with Satan, cast down from heaven.

58 furniture] outfit, equipage, especially weapons or armour. $\mathbf{6 2}$ veyne] vein: 'a streamlet or rivulet; a current' $(O E D$ 6b). $\quad 67$ two mounteynes] Marginal note in ms.: 'univers: ox[ford]: Cam[bridge]:'. 68 loues force] Lat. speaks of Amyntas, a boy, struck by the 'boy's' (infant Cupid's) lethal bow. 69 The one ... the other] Phillis' voice and eyes respectively (see 65-6). 77-8 Marginal insertion in ms., prob. of later date. 93-106 Obvious allegory of the dissolution of the monasteries.93klyon] Marginalinote in 1526143426 ms.: 'kinge hen[ry]'. 
Hongry, seekinge for his pray:

In his graspinge pawes hee hente him, seized

And in pieces all to rente him;

Then his quiver by his side

As a spoile hee did divide,

And his bowe and arrowes sure,

And his goodly furniture.

Yeat his cabin doth remayne

Beaten with the wynde and rayne,

Spoyld of all the passers by,

Whose huge frame doth testify

Of that wondrous monyment,

All the world's astonishment.

When the wolves and foxes sawe

Adam in the lyons pawe,

Ours is Robin, streight they cryde,

And sett him round one evry side.

Thus

[Incomplete: the following page(s) missing]

\section{Angel Day From Daphis and Chloe}

This praise of Queen Elizabeth is obviously an original addition by Angel Day to his 1587 translation of the 2-c. Greek romance Daphnis and Chloe. Sung by the old shepherd Titerus (variously spelt) as part of the wedding celebrations of the principal characters.

Since first thy soile $\mathrm{O}$ countrie Pan I knewe,

rural

Since on the dales my sheepe long time I fed,

Since in my heart the sweete remembrance grewe,

Of all these valleis where the Nymphes do tread,

Since first thy groues and pleasant shadie topps,

Thy christall springs and scituate hie prospects,

The sacred dewes which from the braunches drops,

That fresh Pomonoe on thy groundes erects:

Since all these pleasures thousands mo then one

My auntient yeares partaked haue ere this,

The mightie Ioue doth know wherein alone,

I haue repozd the somme of all my blis.

To Tytirus not all the yeaned lammes,

Nor of his flock a rich encrease to gaine,

Ne sporting hops of young kiddes by their dams,

Are halfe so pleasing or to him so faine

As are (Eliza blisfull maiden Queene)

The sweete recorde of all thy happie daies,

Those thoughts to me, full oft haue gladsome beene,

And on these ioies consist my shepheards laies.

O happie soile long happie maiest thou stand

So sacred be thy mountaines and thy groues,

So be the walkes of that thy pleasant land,

Frequented eft with store of fatted droues,

Let be thy glorie like the shining sonne

?hilltops, ?treetops

situated, ?set in the landscape

several thousands

That glides as far as doth the whirling sphere,

And as the course from whence the riuers ronne

That through the earth a compasse round do beare.

97-100 Marginal insertion in ms., prob. of later date.

101 cabin] a shepherd's shack or shelter: as an image of the huge frame of the ruined abbeys, shows the self-contradictory nature of pastoral metaphor. 7 dewes] prob. sap or balm rather than simple dew. 8 Pomonæ] Pomona, goddess of fruit and orchards. Lat. possessive form for no clear reason. that] presumably the branches. 22 So] ?seeing that they are so sacred, frequented etc.; ?so that they remain sacred, frequented etc. $\mathbf{2 6}$ whirling sphere] All heavenly bodies 'whirl' or rotate in the Ptolemaic, as indeed the Copernican, system. Here perhaps the outermost sphere in the Ptolemaic system, the primum mobile or first mover, which imparts motion to the rest. $\quad 27-8$ the course] the sea held to surround the solid earth, from and into which the rivers flow. 
First faile the skies, first Phœbus cease to raunge, First christal dewes back to your springs returne, First heate and cold desist your daily chaunge, And let the fire leaue of his force to burne, Let Phœbe first by night her wandring staie And darkened be to vs the starrie pole, Let Phaeton lose againe the milkie waie And fishes leaue to swimme within the poole, Cease birdes to flie, cease Philomene thy song And yearely spring that yeldes of fruites encrease, And ycie drops that dangling vnderfong,

Thy frozen chin let (Saturne) euer cease,

Ere Brutus soile, thou seate of mightie kings,

The antient race of haughtie princes peeres,

Ere from thy lappe the slippe whence honor springs,

By this default do loose the sway it beares,

Ere thou the glorie of the present rule,

And honor tied long since to thy desert,

Thy stately conquests neere that didst recule

With cloked guile doost seeke for to insert,

But waste thy glory with the mightiest powres

And stay thine honor on the greatest fame,

And selfe-same time that al things els deuoures,

Renue thy faith, and yeeld thee glorious name.

As faire thy fate as are thy happie yeares,

As firme thy seate as euer Princes was,

Great be thy sway as any strength that reares

The mightiest force that euer man did pas:

And fairest thou of al the Nymphs that haunt

These sacred walkes, in which we shepheards wone,

So Ioue vouchsafe our springs of thee may vaunt, the sun-god, hence the sun

[raunge: move in its track or orbit

leave off, stop

the moon-goddess, hence the moon; stop

the nightingale

surround, ?cover

exalted, noble sprig or cutting for grafting lapse; power, authority

ne'er, never; recoil, turn back, diminish penetrate, infuse

fosters, maintains pass: experience, encounter frequent, dwell in dwell

\section{George Peele An Eclogue Gratulatory to Robert Earl of Essex}

In 1589, an 'English Armada' or 'Counter-Armada' under Sir Francis Drake and Sir John Norreys, with some Portuguese support, set sail against Spain. Defying the Queen's express command, Robert Devereux, second Earl of Essex, joined the expedition and fought with dramatic bravery. He took his time obeying the Queen's command to return, but seems easily to have made his peace when he did on 4 July.

Soon after (1 August 1589) Peele published An Eglogue Gratulatorie. Entituled [dedicated]: To the Right Honorable, and Renowmed Shepheard of Albions Arcadia: Robert Earle of Essex and Ewe, for His Welcome into England from Portugall. It is a pronouncedly Spenserian poem, with archaic-rustic diction drawn in good measure from $S C$ and anticipating $F Q$.

The Right Honorable Earle of Essex his welcom into England, from Portugall.

Piers. Palinode.

Dicite Io Prean, et Io bis dicite Prean,

In Patriam rediit magnus Apollo suam.

Palinode. Herdgrome, what gars thy pipe to goe so loud?

makes, causes

Why bin thy lookes so smicker and so proud?

Perdie plaine Piers, but this couthe ill agree,

With thilke bad fortune, that ay thwarteth thee.

could, here more broadly 'does'

34 starrie pole] one (presumably the northern) of the poles of the celestial sphere in Ptolemaic astronomy, around which the heavenly bodies appear to revolve. 35 Phaeton] the sun-god Helios' son, who drove the sun-chariot off its set path. 41 Brutus soile] Brutus, a Trojan leader, was said to have sailed west and founded the kingdom of Britain, named after him. 46 tied ... desert] which you have deservedly obtained for long. $\quad 49$ ?May your glory be spent only at the (slow) rate of the mightiest powers - i.e. may your fame last. waste] wear out, decay. 50 May your honour always remain at its highest repute. 57 And fairest thou] implicit construction, 'And may you be the fairest...' 59-60 i.e. May Eliza's fame spread across the waters to foreign lands as it already has throughout her own kingdom. 1-2 'Cry hurrah and praise, and again hurrah and praise: great Apollo has returned to his homeland.' Line 1 from Ovid, Ars Amatoria II.1. 4 smicker] smirking, gay: OED 2, citing this line. 6 thilke] the same; virtually 'this' or 'the', as in Spenser. 
Piers. That thwarteth me, good Palinode, is fate,

what, that which

Yborne was Piers to be infortunate.

Yet shall my Bagpipe go so loud and shrill,

That heauen may entertaine my kind good will.

Io io Pcean.

receive favourably, cherish

10

Palinode. Sot I say, Losel, leudest of all swaines,

Losel: rascal, worthless person; Singest thou proud Pceans on these open plaines? [leudest: (a) most foolish (b) most wicked So ill sitteth this straine, this loftie note,

With thy rude tire, and gray russet cote. befits, agrees attire

Piers. Gray as my cote is, greene all are my cares,

My grasse to drosse, my corne is turned to tares:

Yet euen and morrow will I neuer lin,

fresh, living

To make my crowd speake as it did begin.

cease

fiddle

Io io Pcean.

Palinode. Thou art too crancke, and crowdest all to hie,

pert, cocky

Beware a Chip fall not into thine eie:

(Man) if Triumphals heere be in request,

Then let them chaunt them, that can chaunt them best.

Piers. Thou art a sowre swaine Palinode perdie,

My Bagpipe vaunteth not of victorie:

Then giue me leaue, sonizance to make,

For chiualrie, and louely learnings sake.

Fr. par dieu, by God

\section{Io io Pcean}

Palinode. Thou hardy Herdsman, darest thou of Arms chaunt?

Sike verse I tell thee, ought haue a great vaunt:

Then how may thy boldnes scape a fine frumpe,

Warres Laud, is matter for the brasen Trumpe.

Piers. Of Armes to sing, I haue nor lust nor skill,

Enough is me, to blazon my good will:

To welcome home that long hath lacked beene,

One of the iolliest Shepherds of our Greene.

Io io Pcean.

bold, audacious dignity, solemnity mockery, derision

desire, inclination declare, display

Palinode. Tell me good Piers, I pray thee tell it me,

What may thilk iollie swaine or shepherd be?

Or whence ycomen? that he thus welcome is,

That thou art all so blithe to see his blisse.

Piers. Palinode, thou makest a double demaund,

Which I will answere, as I vnderstand.

Yet will I not forget, so God me mend,

To pipe lowd Peeans as my Stanzaes end.

Io io Pean.

as God may save me the burden of my song

Thilk Shepheard (Palinode) whom my pipe praiseth,

Whose glory, my reed to the welkin raiseth:

He is a great Herdgroome, certes, but no swaine,

pipe; sky

Saue hers that is the Flowre of Phœbes plaine.

$\mathbf{1 1}$ General exclamation of joy and praise. $\quad 13$ open plaines] as opposed to a court or palace. $\quad 15$ russet] Not the colour (which is gray) but a coarse material of that name. 21 crowdest] play your fiddle (metaphorically). 22 Beware ... eie] Proverbial expression warning against pride. 23 Triumphals] As Piers says in 26, 97-100, there is no victory to celebrate: the Spanish expedition was a disaster. The 'gratulation' is to express loyal admiration for Essex. 27 sonizance] ?a sounding forth, i.e. song or celebration. $O E D$ cites from this passage only, without definition, as 'perh[aps] an error'. $\quad 28$ louely learnings sake] crediting Essex with patronage of learning (and poetry?). 33 brasen Trumpe] a brass trumpet, not a rustic fiddle or pipe. $\quad 35$ Enough is me] It is enough for me. 36 that ... beene] [he] who has long been away. 37 iolliest] most (a) gay, cheerful (b) amorous (c) handsome. 41-2 that he ... blisse] seeing that you welcome him back, happy at his well-being and success. 43 thou ... demaund] You have asked two questions. 50 swaine] (a) servant (b) shepherd, rustic. Shows the implicit contradiction in all courtly pastoral. $\quad \mathbf{5 1}$ hers ... plaine] Elizabeth as virgin queen, fairest of 
Io io Pcean.

He is wel alied and loued of the best,

Well thewed, faire and francke, and famous by hys Crest:

His Raine Deere racking with proud and stately pace,

Giueth to his flocke a right beautifull grace.

Io io Pcean.

He waits where our great Shepherdesse doth wunne,

He plaieth in the shade, and thriueth in the Sunne:

6o He shineth on the plaines, his lustie flocke him by,

As when Apollo kept in Arcadie

Io io Pcean.

of high connexions

francke: generous,

[bountiful

is in attendance; dwell

stayed, dwelt; ?kept sheep

Fellow in Armes he was, in their flowing deies,

With that great Shepherd good Philisides:

And in sad sable did I see him dight,

Moning the misse of Pallas peereles Knight.

black mourning garments; decked, attired lamenting the loss

Io io Pcean.

With him he seru'd, and watcht and waited fate, awaited, abided

To keepe the grim Wolfe from Elizaes gate:

And for their Mistresse thoughten these two swains,

They moughten neuer take too mickle paines.

Io io Pcean.

much, great

But, ah for griefe, that iolly groome is dead,

For whome the Muses siluer teares haue shed:

Yet in this louelie swaine, source of our glee,

Mun all his Vertues sweet reuiuen bee.

Io io Poean.

shall, should, may

Palinode. So moughten they Piers, and happilie thriue,

To keepen this Herdsman after death aliue:

80

But whence I pray thee, tel me, come is hee,

For whome thy Pipe and Pceans make such glee?

Piers. Certes Sir Shepheard, commen he is fro far,

Fro wrath of deepest Seas and storme of War:

Safe is he come, O swell my Pipe with ioy,

To the olde buildings of Nue reared Troy.

Io io Pcean.

Fro Sea, fro Shore, where he with swinck and sweat

labour, toil

Felt Foemans rage, and Sommers parching heat:

Safe is he come, laden with Honors spoile,
Io io Pean.

54 Crest] Not Essex's 'crest' or coat of arms but its 'supporters', the animals holding it up: to the left, a 'reindeer' (see 56n). 55 Raine Deere] in heraldry, 'a stag with double attires [antlers], two of them turning down' (OED reindeer 2). racking] moving with a particular gait called a rack. 56 flocke] his army. Another instance of pastoral allegory contradicting the pastoral spirit. $\quad \mathbf{5 9}$ ?He succeeds in all circumstances. $\quad 61$ Apollo served as King Admetus' shepherd for a year, but in Thessaly, not Arcadia. He is also a pastoral shepherd-god, Apollo Nomios ('wandering'). $\mathbf{6 3}$ flowing] in full flood: youthful, lusty; sometimes emended to flowring. $\quad 64$ Philisides] Philip Sidney. Sidney and Essex fought together at the Battle of Zutphen where Sidney died. Essex married Sidney's widow Frances. First recorded reference to Sidney as 'Philisides': see Hugh Gazzard, " "Many a herdsman more disposde to morn": Peele, Campion, and the Portugal Expedition of $1589^{\prime}$, RES 57, 2006, p.27. 66 Pallas peereless Knight] referring to Sidney's learning. Pallas] Minerva, goddess of learning. 68 fate] sometimes emended to late - i.e. he stayed up late, stayed awake. $\mathbf{6 9}$ grim Wolfe] prob. the Catholic church. In their different ways, Sidney and Essex both fought against the Catholic powers. Anticipates Milton's Lycidas 128. 70, 71 thoughten,moughten] Plural verb-ending in -en: conventional rustic archaism. $\quad 74$ siluer] ?melodious (OED 6a), referring to the poetical laments for Sidney. $\quad 82$ Sir Shepheard] jocular or ironic use of the honorific 'Sir' for a shepherd. 85 Nue reared Troy] London, called 'Troynouvant' or the 'new Troy', as supposedly founded by the Trojan Brutus. Troynouvant had also featured in Peele's 'Farewell' when the expedition left England (see 124n), to which he added a poem on the Trojan War. $\quad \mathbf{8 7 - 8}$ alluding to Essex's celebrated, sometimes flamboyant feats during the Spanish campaign. 
Palinode. Thou foolish swaine that thus art ouerioied,

How soone may heere thy courage be accoyed:

If he be one come new fro Westerne coast,

subdued, silenced i.e., Spain

Small cause hath he or thou for him to boast.

I see no Palme, I see no Laurell bowes,

Circle his temples, or adorne his browes,

I heare no Triumphes for this late returne,

But many a Herdsman more disposde to morne.

Piers. Pale lookest thou like Spite, proud Palinode,

Venter doth losse, and warre dothe danger bode:

But thou art of those Haruesters I see,

Would at one shocke, spoile all the Philberd-Tree.

Io io Paan.

(ad)venture, expedition

For shame I say, giue Vertue honors due.

Ile please the Shepherd, but by telling true:

Palme maist thou see, and Baies about his head,

That all his flocke, right forwardly hath led.

Io io Prean.

But woe is me lewd lad, fames full of lies,

Enuie doth ay true honors deeds despise,

Yet chiualrie will mount with glorious wings,

Spite all and nestle neere the seat of kings.

Io io Pcean.

ignorant, foolish

rumours, gossip

despite

Base thrall is he, that is foule slaunders slaue,

To pleasen all, what wight may him behaue:

Yea, Ioues great sonne though he were now aliue,

Mought find no way thilk labour to atchiue.

Io io Pcean.

Palinode. Well plead'st thou (Gentle Lad) for this great peere,

Then tell me sith but thou and I am here?

Did not thilk Bagpipe man which thou dost blow

A farewell on our Souldiers erst bestow?

How yst then, thilke great Shepherd of the field,

To whome our swaines, sike humble beisance yeild

And thou these Laudes and labours seriouslie,

Was in that worke, not mencioned speciallie.

Piers. Harke Palinode, me dare not speake to lowd,

Hence was he raught, wrapt in a fierie cloud:

With Mars his Viceroy, and a golden Drake,

So that of him, me durst no notice take.

obeisance, reverence

an, if

too

rapt, snatched away

Io io Pean.

But now returnd, to royallize his fame,

Whose mightie thoughts, at Honors Tropheis aime:

Least worthily, I moughten witned bee,

I welcome him with Shepherds country glee.

'witened': accused, blamed

Io io Pcean.

102-3 i.e., You are one of those people who want to achieve everything at one go. $\quad \mathbf{1 1 6}$ Who can hope to please everyone? 117 Ioues great sonne] Hercules (hence labour, 118). 124 A farewell] $A$ Farewell. Entituled [dedicated] to the famous and fortunate Generalls ... Sir Iohn Norris \& Syr Frauncis Drake Knights: a short verse pamphlet written by Peele for the departure of the 'English Armada'. 124-31 Essex had to leave secretly for the expedition, as the Queen had forbidden his departure. 126 If you [carried out] your task seriously, why was Essex not mentioned in your earlier poem? Laudes and labours] additional objects of yeild, 125. $\quad 128$ dare] clearly in past tense. OED cites such 'careless' use from 18-c and 19-c. 130 Mars his Viceroy] presumably John Norreys, who led the army as Francis Drake did the navy. They did not locate the Swiftsure on which Essex was sailing, though it was part of the expedition. Drake] pun on drake, a dragon. 135 Lest I should be deservedly accused. 
And of his dread aduentures here sing I,

Equiuolent with the Punic Chiualrie:

140 That brake his Launce, with terror and renowne,

Against the gates of slaughtered Rhemus Towne.

Io io Pcean.

And was the first of many thousands more,

That at Penechia waded to the shore:

There couthe he lead his landed flocke so far,

Till a was left of men approoued in war.

Io io Pcean.

O Honors fire, that not the brackish Sea

Mought quench, nor Foemans fearefull Larums lay:

150 So high those golden flakes done mount and clime,

That they exceed the reach of Shepherds rime.

Io io Pcean.

Palinode. What boot thy welcomes, foolish hardie swaine,

Lowder pipes then thine, are going on this plaine:

bold, audacious

Faire Elizaes Lasses and her great Groomes,

Receiue this Shepherd with vnfaigned welcomes.

Honour is in him that doth it bestowe,

Thy Reed to rough, thy seat is all to lowe:

To writen sike praise, hadst thou blithe Homers quil

Thou moughtest haue matter equall with thy skill.

such

Piers. Twit me with boldnes, Palin as thou wilt,

My good mind be my glorie and my guilt:

Be my praise lesse or mickle, all is one,

His hie deserts deseruen to be knowen.

Io io Pcean.

So cease my pipe, the worthies to record,

Of thilke great Shepherd, of thilke faire yong Lord:

Leaue him with lucke, to those well tuned Laies,

That better ken to sound like Shepherds praies.

happily, fortunately know, are able

good intentions, worthy purpose guilt: gilt, adornment, quality

'herdgrooms', shepherds

$o$

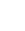

Now time is neere to pen our Sheepe in folde,

And Euening aire, is rumaricke and colde:

For my late Songs, plead thou my pure good will,

Though Newcome once (Braue Earle) yet welcome still.

Io io Paan.

\section{George Peele From Descensus Astraeae}

The Lord's Mayor's pageant of 29 October 1591, published the same year. The third and last (but only second extant) of Peele's devices for mayorial pageants. The sections below celebrate Queen Elizabeth, as so often, as Astraea, virgin goddess of justice. Astraea has been associated with the Golden Age since Virgil, Georg. II.473-4. Peele pastoralizes the topos by making Astraea/Elizabeth a shepherdess, though the pastoral component becomes more and more thin.

139 Punic Chiualrie] Hannibal of Carthage and his forces - who, like the English in Portugal in 1589, never stormed their target. 140-41 When the English besieged Lisbon, Essex dramatically thrust a lance through the city gates. This is compared to Hannibal's expedition against Rome (Rhemus Towne after Remus, co-founder of Rome, killed by his brother Romulus). Rome was never sacked or conquered by Hannibal, nor Lisbon by the English. his] usual possessive of its till end of 16-c. 144 Penechia] Peniche on the Portuguese coast. Essex was the first man to land here, wade ashore through shoulder-high surf, and fight in the English vanguard. 145 flocke] army (cf. 56n). 146 till he lost all his experienced followers. a] he. left] bereft, forsaken. approoued] (a) proven, experienced (b) ?commended, adjudged good. 150 done] archaic plural ending of do. 157 i.e. Those honouring Essex are themselves men of honour. 166 worthies] points of worth, good qualities $\left(O E D \mathrm{C}_{2}\right.$, citing only Love's Labour's Lost 2.3.36). $\quad 169$ ?that are too learned and accomplished to sound like a lowly pastoral; ?that know better how to offer fit praise to a shepherd. $\quad 174$ Newcome] Suggests a title held by Essex, but none such can be traced. Perhaps simply playing on Palinode's 'come new' (95). 
Astroea daughter of the immortall Ioue, Great Ioue defender of this antient towne, Descended of the Troian Brutus line:

Offspring of that couragious conquering king,

Whose pure renown hath pierced the worlds large eares,

In golden scrolls rowling about the heauens,

Celestiall sacred Nymph, that tendes her flocke

With watchfull eyes, and keeps this fount in peace:

Garded with Graces, and with gratious traines,

Vertues diuine, and giftes incomparable.

followers, retinue

Nor lets blind superstitious ignorance

Corrupt so pure a spring: O happie times

That do beget such calme and quiet daies,

Where sheep and shepheard breath in such content.

Astrcea with hir sheephook on the top of the pageant.

Feed on my flocke among the gladsome greene

Where heauenly Nectar flowes aboue the banckes.

Such pastures are not common to be seene,

Pay to immortall Ioue immortall thankes:

For what is good fro heauens hie throne doth fall.

And heauens great Architect be praised for all.

Superstition. A Friar sitting by the fountaine.

Stirre Priest, and with thy beades poyson this spring,

I tell thee all is banefull that I bring.

Ignorance. A Priest.

It is in vaine: hir eye keepes me in awe,

Whose heart is purely fixed on the law:

The holy law, and bootlesse we contend,

While this chast nimph, this fountain doth defend. Euphrosyne.

Whilom when Saturnes golden raigne did cease, and yron age had kindled cruel warres:

Enuie in wrath, perturbing common peace, engendring cancred hate and bloudy iarres:

Lo then Olympus king, the thundring Ioue, raught hence this gracious nymph Astreea faire,

Now once againe he sends hir from aboue, descended through the sweete transparent aire:

overflows

unending

prayer-beads, rosary

And heere she sits in beautie fresh and sheene, Shadowing the person of a peerelesse Queene. Aglaia.

in vain

cankered: corrupt, evil

withdrew

shining, radiant

figuring, imaging

A peerelesse Queene, a Royall princely dame,

Enrold in register of eternall fame.

Thalia.

The Graces through their balme about hir sacred head,

Whose gouernment hir realms true happines hath bred. Charitie.

That happinesse continue in her land,

Great Israels God, spring of all heauenly peace:

And let thine angels in her reskew stand,

throw

may it continue

?protection, preservation

3 the Troian Brutus] Brut or Brutus, a Trojan leader, said to have sailed to Britain with his followers after the fall of Troy and founded the kingdom of Britain, named after him. $\quad 9$ garded] (a) girded (b) guarded, protected. Graces] attending on Elizabeth in this pageant: see 27-40. Gratious] (a) graceful, elegant (a) courteous, kindly. 11 lets] either misprint for let, or continuing the earlier sentence with Nymph (7) as subject. 20.1 Superstition] clearly the Catholic church. 26.1, 36.1, 38.1 Euphrosyne, Aglaia, Thalia] the three Graces. Their Gk name, Charites, might have suggested the entry of Charity immediately after, preceding Faith and Hope. These three theological virtues supplement the personal or secular graces represented by the Charites, and are followed by Honour with her Champion, associated with rule and power. 27 Saturnes golden raigne] The Golden Age is associated with the reign of Saturn. (Virgil IV.6, Ovid, Met. I.113). 31-2 Ioue ... raught] Astraea is usually thought to leave the earth of her own accord. (Virgil IV.6, Georg. II.473; Ovid, Met. I.150). 35 sheene] (a) beautiful (b) shining, resplendent. 
With hir liues wane done Englands ioyes decrease.

O let hir princely daies neuer haue fine,

old plural of 'do'

finish, end

Whose vertues are immortall and deuine.

Hope.

Such vertues as her throne do beautifie,

And make hir honours mount and skale the skie.

Faith.

Where hope of hir eternall blisse doth rest,

Conceaued in hir sweete and sacred brest.

Honor.

With radiant beames, reflecting on the earth,

Euen from the snowie browes of Albion,

Beyond the vtmost verge of Christendome,

As bright as is the burning lampe of heauen,

Shineth my mistresse honour, in whose fame

The heathen carrols sing and all admire,

From Icy Tanais to the seuenfold Nyle,

wonder at, stand in awe

Her glorie that commands this Westerne Ile.

Champion.

In whose defence my colours I aduaunce,

And girt me with my sword, and shake my lance:

gird

These Brittish Lions rampant in this field,

That neuer learned in battails rage to yeeld:

Breath terror to the proud aspiring foe,

Ranging the world, commanding where they go.

Therefore in vaine this misproud Malecontent

Threatens hir state whose harms the heauens preuent.

Sit safe sweet Nymph among thy harmlesse sheep,

Thy sacred person angels haue in keep.

\section{From the Bisham Entertainment Apollo and Daphne}

From the second day's entertainment for Queen Elizabeth on her 1592 visit to Bisham in Berkshire, estate of Lady Russel. Unusual in presenting the story of Apollo and Daphne with the focus on Daphne's shepherd lover. This agrees with the general presentation of the locality as a sheepfarming and woolproducing centre. The first day's programme had 'Pan, and two Virgins keeping sheepe', and a speech of welcome by an old shepherd. On the third day, a person dressed like a sheep was to welcome the Queen on behalf of the High Constable of Cotswold, followed by a 'shepherds feast'. This plan was spoilt by rain. The text follows the account in Speeches Delivered to Her Majesty This Last Progress, at the Right Honorable the Lady Russels [etc] (1592). Punctuation and capitalization modified. The style is markedly euphuistic with patterned sentences, citing of proverbs, and references to animal lore.

Sunday, Apollo running after Daphne, a Shepheard followed vttering this.

Nescis temeraria; nescis,

Quem fugias; idioque fugis.

A short tale, but a sorrowfull; a just complaint, but remedelesse. I loued, (for shephardes haue their Saints) long I loued (for beauty bindeth prentices) a Nymph most faire and as chast as faire, yet not more faire, then I vnhappy. Apollo who calleth himselfe a god (a title among men, when they will commit iniuries, tearme themselves Gods), pursued my Daphne with bootlesse loue, and me, with endlesse hate; her he woed, with faire wordes, the flatteries of men; with great gifts, the sorceries of Gods; with cruell threates, the terrefiing of weake damosels. Nec prece nec pretio nec mouet ille minis. Me, he terrified with a monstrous word metamorphosing, saying that he would turne me into a woolfe and of a shepheard make me a sheepe-biter; or into a Cockatrice and cause mine eies which gazed

52 snowie browes of Albion] Prob. not mountains but the white cliffs of Dover, whence the name Albion (white land). $\quad 56$ carrols] religious hymns $\left(O E D_{3}\right) . \quad 57$ seuenfold] from the seven streams of its delta. (Ovid, Met. V.187). 65 Malecontent] Two 'Malcontents' appear immediately after this, but retreat at the sight of the Queen. Nescis temeraria etc.] 'You do not know, heedless woman, you do not know whom you flee: that is why you flee.' Apollo's words to Daphnis, Ovid, Met. I.505, 514-15. shephardes haue their Saints] ?Even the lowly can adore the exalted: apparently a proverb, with play on quasi-Petrarchan use of 'saint' for the beloved woman. beauty bindeth prentices] ?Beauty enthralls even the young and callow: another proverb? Nec prece etc.] 'He could not move [her] by prayers or rewards or threats.' Ovid, Fasti 2.806. Cockatrice] fabulous creature whose gaze caused death or (as here) blindness. 
on her to blind hers, which made mine dazell; or to a molde, that I sholde heare his flattering speech, but neuer behold her faire face: Tantoene animis coelestibus irce? Sometimes would he allure her with sweete musicke, but harmony is harsh when it is lusts broaker, often with promise of immortality; but chastetye is of itselfe immortall; euer pursuing her with swiftnes, but vertue tying wings to the thoughts of Virgins, swiftnes becommeth surbated. Thus liued he twixt loue and ielousy; I twixt loue and danger; she twixt feare and vertue. At last and alas, this day I feare of all my ioyes the last, I cannot as a Poet (who describing the morning, and before he tell what it is make it night,) stand on the time; loue coyneth no circumloquutions, but by the sunne, a Shepheardes Diall, which goeth as true as our harts. It was four of the clock, when she, flying from his treason, was turned into a tree; which made me stand, as though I had bene turned into a stone, and Apollo so enchanted as wounded with her losse, or his owne crueltye; the fingers which were wonte to play on the Lute, found no other instrument then his owne face; the goulden haire, the pride of his heade, pulde off in lockes and stampt at his feete; his sweete voice turned to howling; and there sitteth he, (long may he sorrowe,) wondring, and weeping, and kissing the lawrell, his late loue, and mine euer. Pleaseth your Maiestye to viewe the melancholy of Apollo, my distresse, and Daphne's mischance; it may be the sight of so rare perfection will make him die for griefe, which I wish; or Daphne returne to her olde shape, which must be your wounder; if neither, it shal content me that I have revealed my griefes, and that you may beholde his.

bootlesse fruitless sheepe-biter a sheepdog that attacks its own charges which i.e., her eyes molde mole tying wings i.e., lending speed as a Poet like a poet stand on the time waste time, take too long wounder wonder, miracle

This Speech ended, her Maiesty sawe Apollo with the tree, hauing on the one side one that sung, on the other one that plaide.

Sing you, plaie you; but sing and play my truth;

This tree my Lute, these sighes my notes of ruth:

The Lawrell leafe for euer shall bee greene,

And chastety shalbe Apolloes Queene.

If Gods maye dye, here shall my tombe be plaste,

And this engrauen, fonde Phobus, Daphne chaste.

After these verses, the song.

My hart and tongue were twinnes, at once conceaued,

The eldest was my hart, borne dumbe by destenie,

The last my tongue, of all sweete thoughts bereaued,

Yet strung and tunde to play harts harmonie.

Both knit in one, and yet asunder placed,

What hart would speake, the tongue doeth still discouer;

What tongue doth speake, is of the hart embraced,

And both are one to make a new found louer:

New founde, and onely founde in Gods and Kings,

Whose wordes are deedes, but deedes nor words regarded:

Chaste thoughts doe mount and flie with swiftest wings,

My loue with paine, my paine with losse rewarded:

Engraue upon this tree, Daphnes perfection,

That neither men nor gods, can force affection.

sorrow

The song ended, the tree riued, and Daphne issued out, Apollo ranne after, with these words.

Nimpha mane, per me concordant carmina neruis.

Faire Daphne staye, too chaste because too faire,

Yet fairer in mine eies, because so chaste;

And yet because so chaste, must I despaire?

Tantæne etc.] 'Is there so much anger in heavenly minds?' Virgil, Aen. I.11. promise of immortality] as the wooer is a god. euer ... surbated] The pursuer's swiftness cannot match his victim's speed. surbated] footsore, weary. sunne ... Diall] Shepherds do not have clocks but tell the time by the sun. Diall] clock or watch. 1ff. This song represents Apollo's utterance, though sung by the singer standing alongside (one that sang, 0.1). 6 fonde] pun: (a) loving (b) foolish. 21 Nimpha mane etc.] 'Stay, nymph: by me songs respond in harmony to the strings.' Apollo to Daphne, Ovid, Met. $1.505,518$. 
And to despaire I yeelded haue at last.

Shepheard possesse thy loue, for me too cruell,

Possesse thy loue, thou knowest not how to measure.

A dunghill cock doeth often find a Iewell,

Enjoying that, he knowes not to be treasure.

When broomy bearde to sweepe thy lips presume,

When on thy necke his rough hewen armes shall moue

And gloate on thee with eies that drizell reume,

drip gum or moisture

When that his toothlesse mouth shall call thee loue;

Noght will I saie of him, but pittie thee,

That beauty might, but would no wiser bee.

Daphne running to her Maiestie vttred this.

I stay, for whether should chastety fly for succour, but to the Queene of chastety. By thee was I enterred into a tree, that by crafte, way might be made to lust; by your highnes restored, that by vertue, there might be assurance in honor.

crafte: magic

[The entertainment ends in compliment to the Queen.]

\section{Arthur Gorges An Eclogue Between a Shepherd And a Herdman}

From the definitive BL MS Egerton 3165 of Gorges's poems. First published in Francis Davison's A Poetical Rhapsody (1602). Almost all punctuation added. 'Daphne' is the pastoral name for Gorges's wife Douglas Howard, mourned by Spenser in Daphnaida.

An Ecloge betwen a Shephearde and a Heardman

S[hephearde] Cumme gentle Heardman sitt with mee and tune thy Pype by myne

Heare vnderneth this wyllowe tree, too shylde the hoate sunnshyne,

Wheare I haue framde my sommers bowre for proofe of Phœbus beames

And deckte ytt upp with many a flowre sweete seatted by thes streames.

For Daphne euar once a daye

And in hir bosome beares awaye these flowringe bancks doth walke the pryde of many a stalke,

Butt leaues the humble harte behynde that would hir garlonds dyght, deck her with garlands

And Shee sweete sowle the more vnkinde shield (from) too sett true loue so lyght.

Yett thoughe that others beare the Bell as in hir favoure bleste,

Hir Shephearde loueth hyr as well protection from as those whom Shee loues beste.

H[eardman] Alas poore Pastore nowe I fynde thy love ys lodgd so hye

That of thy flockes thow haste no mynde butt feadste a wanton Eye.

Yf dayntye Daphnes lookes besott thy doatynge harts desyre

Bee sure that farr beyonde thy lott thy lykinge doth aspire.

To loue so sweete a Nymphe as shee and looke for loue agayne

Is fortune fyttinge hygh degree nott for a shephearde swayne

For shee of lordly ladds ys coyde amorous, lustful

27 Enjoy your love, though you cannot value it at its true worth. way ... lust] ?a solution or protection might be found against lust. 1 Heardman] not clear what animals he herds, or how he differs from the shepherd 
and soughte of greate Estates,

Hir fauoure scornes to be enjoyde of vs poore lowely mates.

I reade the thearefore, nowe be wyse, goe with me to our wake

Wheare louely lasses bee nott nyce:

rede, advise theare lyke and chuse thy make

coy, reluctant

Wheare are nor Pearles nor golde to veue nor pryde of sylken syghte,

Butt Pettycoats of scarlett hue that vayles the skynn snow white.

And though the muske and ambar fyne so lady lyke they cannot gett

Yet wyll they weare the sweete woodbyne, the prymerose and the vyolet.

Theare truest Turtles bynn too gett for loue and lyttle coaste,

Theare sweete desire ys payde his debte

cost and laboure seeldome loste.

rewarded, given its due

S[hephearde]. No heardman no, thow raueste too lowde our trade so vyle to holde.

My weede as hyghe a hart doth shrowd as his thats cladd in golde.

And take for trothe that I the tell, thys songe fayre Daphne synges

That Cupyde will be searude aswell

served of Shepheards as of kynges,

And dooth for proofe olde tales recorde how Venus Queene of loue

Woulde sett asyde hir warlyke lorde and youthfull Pastors proue:

How Parys was as well esteemd, a symple Shepheard Boye,

As after when that he was deemd kynge Pryams sonne of Troye.

And thearefore haue wee better hope as hadd those laddes of yore:

Our curadge takes as lardge a scope althoughe theyr happ weare more.

And for thow shalt nott deame I jeste nor beare a mynde more base,

No meaner hope shall haunte my breste then dearest Daphnes grace.

My mynde no other thoughts retaynes, myne Eye noughte els admyres,

My harte no other passion straynes nor other happ desires.

My muse of nothynge els entreats, my Pype noughte els dothe sownde,

My vaynes no other fevar heats:
such faythe in Shepheards fownde.

courage: spirits, passions good fortune, prosperity; were shephearde then I see with greefe thy care ys paste all cure:

No remedye for thy releefe

36 mates] fellows, companions. $\quad 38$ wake] village festival, especially the feast of the patron saint of the local church. 40 make] partner, companion. 43 scarlett] not only the colour but a cheap fabric. 45-8 Marginal insertion in ms, transplanted from Gorges's translation of a French poem by Desportes. 49 Turtles] turtle-doves. bynn too gett] are available or obtainable bynne]bene, old plural of is. 59-68 Familiar pastoral argument, found in Desportes's song translated by Gorges (see 45-8n). 63 hir warlyke lorde] presumably Mars, Venus' lover; her 'lord' or husband was Vulcan. 64 youthfull Pastors] like Anchises tending cattle on Mount Ida, by whom Venus bore Aeneas (Homeric Hymn V.55: 'To Aphrodite'). Adonis, too, is sometimes represented as a shepherd as well as a hunter. (See Theocritus I.109). 65 Parys] brought up by a shepherd on Mount Ida. 
butt patiently endure.

Thy wonted lybertye is fledd,

Thy sence of folly brought a bedd,

death, destruction thy witt ys in the wane.

I cann butt sorrowe for thy sake synce loue lulls the asleepe,

And tyll out of this dreame thow wake God shylde thy strayinge sheepe.

Thy happlesse flocks may rue and cursse this prowde desyre of thyne

Whose wreched plyght from bad too worsse

ambitious, high-aspiring

And euen as they, thy selfe lykewise with them shalt weare and waste

To see the sprynge before thyn eyes thow thyrstinge canst nott taste.

Content the thearefore with concayte whilst others gayne the grace,

And thynke thy fortune at the haight to see butt Daphnes face.

For though thy truthe deserueth well rewarde aboue the reste,

Thy happs shalbee but marks to tell how other men are bleste.

So gentle Shepheard farewell nowe, bee warned by my reade

For I see written in thy browe thy harte for loue doth bleade.

Yet longer with the woulde I staye yf oughte myght do the goode,

Butt nothinge cann the heat delaye wheare loue enflames the blood.

conceit: thoughts, imaginings (of love) obtain favour

loyalty, constancy

experiences, things befalling one; signs

rede, advice, admonition

thee allay, abate

S[hephearde]. Then Heardman synce it is my lott and my good lykinge suche,

Stryue not to loose the faythfull knott that thyncks no paynes to muche.

For what contents my Daphne best I neuar will dyspise

So Shee but wishe my sowle good reste when death shall close myne Eyes.

Adyeue good heardgrome once agayne for now the day is fledd.

$H$ [eardman] So mought thy cares, poore Shepheards swayn, flye from thy carefull headd.

full of care, burdened, anxious

\section{Arthur Gorges The Country Lass}

From Bl. MS Egerton 3165 of Gorges's poems. The ms text is entirely without punctuation, which has been added below.

Hence forth I will nott sett my loue on other then the Contrye lasse,

For in the Courte I see and proue fancye is brittle as the glasse.

The loue bestowed on the greate ys ever full of toile and cares,

Subject still to frowne and freate with sugred bayts in suttle snares. 
In good olde tymes ytt was the guyse

to shewe things in their proper kinde:

Loue painted owte in nakede wise to shewe his playne and single mynde.

But since into the Courte hee came, infected with a brauer stile,

Hee loste both propertie and name, attyred all in craft and guile.

true or original nature

Yett in the village styll hee kepes

dwells and merry makes with lytle coste

But never breakes their quyett slepes with Jelous thoughts or labour loste.

What thoughe in Sylvar and in golde the bony lass be nott so braue,

Yett are her lookes freshe to beholde, and that is hyt that loue doth crave.

Fayre fale the Pettycote off redde that vayles the skynne as white as mylke,

And such as woulde nott so bee speedde lett them goe Coye the gownes off sylke.

Keepe, ladyes, keepe for your owne turnes the spanishe redde to mende your lookes:

For when the Sunn my Daphnæ burnes shee seekes the water off the Brookes.

And thoughe the muske and amber fine so ladyelyke Shee cannott gett,

Yett will shee weare the sweet woodbyne, the Prymerose and the violett.

bonny; glamorous, resplendent

fair fall, may [it] prosper; of

sped, successful in obtaining win over, obtain by blandishments purposes, wiles

\section{William Byrd The Herdman's Happy Life}

First published in William Byrd's Superius. Psalmes, Sonets, \& songs of sadnes and pietie (1588), then in Helicon. The song-book repeats the last two lines of the first stanza, and by implication the others too, as a chorus or refrain. The text below follows 1588 in spelling and (with modifications) punctuation, but uses the Helicon title.

The Heard-mans happie life

What pleasure haue great princes,

more daintie to their choice,

then heardmen wild, who carelesse,

pleasing

in quiet life reioyce,

and fortunes fate not fearing,

sing sweet, in Sommer morning.

free of care

Their dealings plaine and rightfull

are voyd of all disceit:

they neuer know how spightfull

it is to kneele and waite

on fauorite presumptious,

whose pride is vaine and sumptious.

arrogant

costly, ostentatious

All day their flocks ech tendeth,

at night they take their rest,

more quiet than who sendeth

he who

his ship into the East,

where gold and pearle are plentie,

but getting very daintie.

9 guyse] custom, practice $\left(O E D_{2}\right) . \quad 25-6$ redde ... white] varying the standard topos of the beloved's complexion mingling red and white. 30 spanishe redde] 'Spanish paint', a cosmetic originating in Spain. 3 wild] (a) rude, uncultured (b) free, unconfined (OED 6). 9 spightfull] (a) shameful, humiliating $\left(O E D_{1} \mathrm{~b}\right)$; (b) distressing, annoying $\left(O E D_{3}\right)$. 
For Lawiers and their pleading the'steeme it not a straw, they think that honest meaning is of it selfe a law.

Where conscience iudgeth plainely, they spend no mony vainely.

O happie who thus liueth, not caring much for gold, with clothing which suffiseth, to keepe him from the cold, though poore and plaine his diet, yet merry it is and quiet.

\section{William Byrd 'Though Amarillis dance in Green'}

Song no.12 in Byrd's collection Superius. Psalmes, Sonets \& Songs of sadnes and pietie (1588), whose text is followed below, omitting repetitions of the refrain for musical reasons. Also in England's Helicon (1600).

Though Amarillis daunce in greene,

like Fayrie Queene,

And sing full cleere

Corina can with smiling cheere:

yet since their eyes make heart so sore,

hey ho, chil loue no more.

I will: standard rustic variant

My sheepe are lost for want of foode.

and I so wood:

mad, crazy

that all the day,

I sit and watch a heardmaid gaye:

who laughes to see me sigh so sore,

hey ho, chil loue no more.

Her louing lookes, her beautie bright,

is such delight:

that all in vaine,

I loue to like, and lose my gaine:

for her that thankes me not therefore,

hey ho chil loue no more.

Ah wanton eyes my friendlie foes,

and cause of woes:

your sweete desire,

breeds flames of Ise and freese in fire:

ye skorne to see me weepe so sore,

hey ho chil loue no more.

Loue ye who list I force him not,

sith God it wot,

since; knows

the more I wayle,

the lesse my sighs and teares preuaile:

what shall I doe but say therefore,

hey ho chil loue no more.

30 quiet] (a) moderate, temperate; (b) peaceful, relaxed. Possibly a general reference to the shepherd's life. 4 Corina can] Omitted in Helicon, and their (5) changed to her, so that the entire poem refers to Amarillis. 22 A standard Petrarchan paradox (Petrarch, Rime 134). freese in] Perhaps mistake for freezing, which would make for a more consistent construction. 25 Let whoever wishes to love you, do so; I don't care. force] care about (OED force $\left.\mathrm{v}^{1} 14\right)$. 


\section{Robert Greene The Shepherd's Ode}

From Greene's romance Ciceronis Amor. Tullies Loue (1589). A shepherd sings this song commemorating a 'vale of love', haunt of the shepherd couple Phillis and Coridon.

The Sheepeherds Ode.

Walking in a valley greene,

Spred with Flora summer queene:

Where shee heaping all hir graces,

Niggard seemd in other places.

Spring it was and here did spring,

All that nature forth can bring:

Groues of pleasant trees there grow,

Which fruit and shadowe could bestow.

Thick leaued boughes small birds couer,

Till sweete notes themselues discouer:

Tunes for number seemed confounded,

Whilst their mixtures musicke sounded.

Greeing well, yet not agreed,

That one the other should exceede.

A sweete streame here silent glides,

Whose cleare water no fish hides.

Slow it runs, which well bewraid,

The pleasant shore the current staid:

revealed, indicated

In this streame a rocke was planted,

Where nor art nor nature wanted.

Each thing so did other grace,

As all places may giue place.

Onely this the place of pleasure,

Where is heaped natures treasure.

Here mine eyes with woonder staide,

Eies amasd and minde afraide:

Rauisht with what was beheld,

From departing were withheld.

Musing then with sound aduise,

On this earthly paradise:

Sitting by the riuer side,

Louely Phillis was discride;

Golde hir haire, bright hir eyen,

Like to Phœbus in his shine.

White hir brow, hir face was faire,

Amber breath perfumde the aire,

Rose and Lilly both did seeke,

To shew their glories on hir cheeke.

Loue did nestle in hir lookes,

Baiting there his sharpest hookes.

Such a Phillis nere was seene,

More beautifull then Loues Queene,

Doubt it was whose greater grace,

Phillis beauty or the place.

Hir coate was of scarlet red,

All in pleates a mantle spred;

Fringd with gold, a wreath of bowes

To check the sunne from hir browes.

In hir hand a shepheards hooke,

In hir face Dianas looke:

rested, dwelt

?affrayed: overcome, agitated

good judgment, proper appreciation

seen, observed

eyes

Apollo the sun-god

2 spred with Flora] spread with flowers. Flora] goddess of flowers. 9-10 The foliage hides the birds till they reveal their presence by their song. 11-14 Because so many songs are heard together, their rhythms seem confused. They harmonize (gree, agree), but will not let one outvie (exceed) the others. 18 The current lingered, attracted by the beauty of the scene. 22 All places may yield to this in beauty. 29 Musing] May refer to the viewer or to Phillis. 34 Standard Petrarchan conceit for the mistress's eyes. $\quad 43$ It was uncertain which was the more beautiful. 50 Dianas looke] a chaste or modest expression. Diana was goddess of chastity. 
Hir sheepe grased on the plaines,

Shee had stolne from the swaines.

Vnder a coole silent shade,

By the streames shee garlands made.

Thus sate Phillis all alone,

Mist shee was by Coridon

Chiefest swaine of all the rest,

Louely Phillis likt him best.

His face was like Phœbus loue,

60 His necke white as Venus Doue,

A ruddy cheeke filde with smiles,

Such loue hath when he beguiles.

His lockes browne, his eies were gray,

Like Titan in a sommer day.

the sun

A russet Iacket, sleeues red,

A blew bonnet on his hed:

A cloake of gray fencst the raine,

Thus tyred was this louely swaine.

A shepheards hooke, his dog tide,

Bag and bottle by his side:

Such was Paris shepheards say,

When with Oenone he did play.

From his flocke straid Coridon,

Spying Phillis all alone:

By the streame he Phillis spide,

Brauer then was Floras pride.

Downe the valley gan he tracke,

Stole behinde his true loues backe:

The sunne shone and shadow made,

8o Phillis rose and was afraid.

When shee saw hir louer there,

Smile shee did and left hir feare:

Cupid that disdaine doth loth,

With desire strake them both.

The swaine did wooe, shee was nise,

Following fashion nayed him twise:

Much adooe, he kist hir then,

Maidens blush when they kisse men:

So did Phillis at that stowre,

$90 \quad$ Hir face was like the rose flowre.

Last they greed for loue would so,

Faith and troth they would no mo.

For shepheards euer held it sin,

To false the loue they liued in.

The swaine gaue a girdle red,

Shee set garlands on his hed.

Gifts were giuen, they kisse againe,

Both did smile for both were faine.

Thus was loue mongst shepheards folde,

When fancy knew not what was golde:

They woed and vowed, and that they keep,

And goe contented to their sheep.

that hates disdain (in love)

struck

nice: coy, fastidious

step, pass

agreed, accorded; so wished

betray

willing

that: the vows

59 Phœbus love] Phœbus or Apollo had two male loves, Cyparissus and Hyacinthus. 6o Venus Doue] Venus' chariot was drawn by doves. 65 russet] Referring less to the colour than the cloth, a coarse woollen material worn by country-folk. 69 tide] ?tidy (spelling current 14-15c): buxom, bonny. (OED tidy 2). $\quad$ 71-2 Paris, Oenone] Paris courted the nymph Oenone while living as a shepherd on Mount Ida. $\quad 76$ More beautiful than the flowers. 79 i.e. Coridon's shadow fell across Phillis, alerting her. $\quad \mathbf{8 6}$ Rejected his suit twice as a matter of form. 89 stowre] occasion, point (of time or place): misconstruing a Spenserian use (OED stour $3 \mathrm{~b})$. 90 like the rose flowre] implying blushes as well as beauty. $\quad 92$ They could not wish for greater faith and troth. 100 When love was not enticed by wealth. 


\section{Robert Greene Doron's Jig}

From Greene's romance Menaphon (1589). Doron, a simple shepherd, sings this roundelay to cheer up Melicertus, mourning the death of his love. Reprinted in Helicon, whose text is followed below.

The Sheepheard Dorons Iigge.

Through the shrubs as I can crack, for my Lambs little ones, mongst many pretty ones,

Nimphs I meane, whose haire was black

As the Crow,

Like as the Snow

Her face and browes shin'd I weene,

I think, I believe: a space-filler

I saw a little one,

a bonny pretty one,

As bright, buxome, and as sheene

beautiful

As was shee

On her knee

That lull'd the God, whose arrowes warmes

?excites, rouses, stimulates such merry little ones, such faire-fac'd pretty ones,

As dally in Loues chiefest harmes.

Such was mine,

Made me loue: I gan to wooe

Whose gray eyne

this sweete little one,

this bonny pretty one.

I wooed hard a day or two,

$$
\text { Till she bad, }
$$

Be not sad,

Wooe no more, I am thine owne,

thy dearest little one,

thy truest pretty one.

Thus was faith and firme loue showne,

As behooues

Sheepheards Loues.

\section{Robert Greene Doron's Eclogue Joined with Carmela's}

From Greene's romance Menaphon (1589). conventional comic treatment of the humbler order of rustics, esp. (in pastoral drama and romance) vis-à-vis courtiers masquerading as shepherds.

Dorons Eclogue ioynd with Carmelas.

Doron. Sit down Carmela here are cubbs for kings,

Slowes blacke as ieat, or like my Christmas shooes,

sloes; jet

Sweete Sidar which my leathren bottle brings:

Sit downe Carmela let me kisse thy toes.

Carmela. Ah Doron, ah my heart, thou art as white,

As is my mothers Calfe or brinded Cow,

Thine eyes are like the slow wormes in the night,

Thine haires resemble thickest of the snow.

The lines within thy face are deepe and cleere

Like to the furrowes of my fathers waine,

Thy sweate vpon thy face dooth oft appeare

Like to my mothers fat and Kitchin gaine.

1 can] gan, began to. crack] rush, move fast (cf. $\left.O E D_{21,22}\right)$

2-3] little... pretty] So in Menaphon, reversing the order in Helicon. The Menaphon order links the epithets to their intended subjects (little lambs, pretty nymphs). 7 Her] Prob. archaic for 'their': Doron is still talking of the whole group. 11-13 shee] Venus, mother of Cupid (the God). $\quad 16$ That play with the mischiefs worked by love. 1 cubbs] cob-nuts, a variety of hazel-nut (OED $\operatorname{cob} \mathrm{n}^{1}$ 5a, citing this passage). for] fit for. 6 brinded] brindled: streaked or spotted - i.e., not white at all. 7 slow wormes] malapropism for 'glow worms' 12 Kitchin gaine] kitchen-fee, 'the fat which drips from meat when roasting s part of the cook's, wages ${ }_{10}: 20: 40$ : (gain): $O E D$ kitchen $\mathrm{C}_{3}$, from this passage alone. 
Ah leaue my toe and kisse my lippes my loue,

My lippes are thine, for I haue giuen it thee:

Within thy cap tie thou shalt weare my gloue,

At foote ball sport thou shalt my champion be.

cord to tie the cap

Doron. Carmela deare, euen as the golden ball

That Venus got, such are thy goodly eyes,

When cherries iuice is iumbled therewithall,

Thy breath is like the steeme of apple pies.

Thy lippes resemble two Cowcumbers faire,

Thy teeth like to the tuskes of fattest swine,

Thy speach is like the thunder in the aire:

Would God thy toes, thy lips and all were mine.

Carmela. Doron what thing dooth mooue this wishing griefe.

painful desire

Doron. Tis Loue Carmela ah tis cruell Loue,

That like a slaue, and caitiffe villaine thiefe,

Hath cut my throate of ioy for thy behoue.

destroyed my joy; ?for your sake

Carmela. Where was he borne?

Doron.

In faith I know not where,

But I haue had much talking of his dart.

Ay me poore man, with manie a trampling teare,

I feele him wound the forthearse of my heart.

fortress

What, doo I loue? O no, I doo but talke.

What, shall I die for loue? O no, not so.

What, am I dead: O no my tongue dooth walke.

Come kisse Carmela, and confound my woe.

Carmela. Euen with this kisse, as once my father did,

I seale the sweete indentures of delight:

Before I breake my vowe the Gods forbid,

No not by day, nor yet by darkesome night.

Doron. Euen with this garland made of Holly-hocks

I crosse thy browes from euerie shepheards kisse.

Heigh hoe how glad am I to touch thy lockes,

My frolicke heart euen now a free man is.

protect, as with

[the sign of the cross merry

Carmela. I thanke you Doron, and will thinke on you,

I loue you Doron, and will winke on you.

I seale your charter pattent with my thummes,

Come kisse and part for feare my mother comes.

\section{Robert Greene The Description of the Shepherd and His Wife}

From Greene's romance Greenes Mourning Garment (1590). Greene's hero Philador meets this shepherd couple in Thessalia in course of his travels.

The description of the Shepheard and his wife.

It was neere a thickie shade,

That broad leaues of Beach had made:

Ioyning all their toppes so nie,

That scarce Phebus in could prie,

To see if Louers in the thicke,

Could dally with a wanton tricke.

the sun-god, hence the sun

16 foote ball] then a very plebeian game, here compared to a knightly tournament. 17-18 golden ball] awarded to Venus by Paris' judgment of the goddesses Juno, Minerva and Venus: not a complimentary comparison for eyes. 31 trampling] ?crushing, breaking down (the fortress, l.32); ?malapropism for 'trembling'. 35 walke] (of the tongue) 'to move briskly (OED $5 \mathrm{f}$ ). $37 \mathrm{my}$ father] an unexpected comparison from a woman. $\mathbf{3 8}$ surprisingly sophisticated (and elegantly phrased) legal metaphor: cf.l.47. $\quad 46$ winke on you] shut my eyes to you, let you do what you will with me. 47 with my thummes] as illiterate persons would do. 5 thicke] thickest or deepest part of the wód 
Where sate this Swayne and his wife,

Sporting in that pleasing life,

That Corridon commendeth so,

All other liues to ouer-go.

He and she did sit and keepe,

Flockes of kids, and fouldes of sheepe:

He vpon his pipe did play,

She tuned voyce vnto his lay.

And for you might her Huswife knowe,

Voyce did sing and fingers sowe:

He was young, his coat was greene,

With weltes of white seamde betweene,

Turned ouer with a flappe,

That breast and bosome in did wrappe,

Skirtes tide and plighted free,

Seemely hanging to his knee.

A whittle with a siluer chape,

Cloke was russet and the cape

Serued for a Bonnet oft,

To shrowd him from the wet aloft.

rain

A leather scrip of collour red,

With a button on the head,

A Bottle full of Countrie whigge,

By the Shepheards side did ligge,

loose lower part of coat; pleated, folded

And in a little bush hard by,

There the Sheapheards dogge did ly,

Who while his Maister gan to sleepe,

Well could watch both kides and sheepe.

The Shepheard was a frolicke swayne,

For though his parrell was but playne,

joyful, merry apparel

Yet doone the Authors soothly say,

His cullour was both fresh and gay.

And in their writtes playne discusse,

whey or buttermilk, often fermented and seasoned

Fayrer was not Tytirus,

Nor Menalcas whom they call,

The Alderleefest Swayne of all.

Seeming him was his wife,

Both in line and in life.

Faire shee was as faire might bee, *

Like the Roses on the tree:

Buxsame bliett, and young I weene,

Beauteous like to Sommers Queene,

For her cheekes were ruddie hued,

As if Lyllies were imbrued

With drops of bloud to make the white

Please the eye with more delight.

Loue did lye within her eyes,

In ambush for some wanton pryse.

A leefer Lasse then this had beene,

Coridon had neuer seene.

Nor was Phillis that faire may,

Halfe so gawdie or so gay:

She wore a chaplet on her head,

Her cassacke was of Scarlet red,

Long and large as straight as bent,

buxom; blithe

choicest of all, best beseeming, matching

9 Corridon] Presumably in Virgil II, commending the pastoral life to his beloved Alexis. 15 To prove herself good at domestic tasks. 18 weltes] frills, strips of cloth. seamde] sewn (dialect: $O E D$ seam $\mathrm{v}^{2} 1 \mathrm{c}$, only from 1833). $\quad 23$ whittle] knife. chape] scabbard, sheath (OED 1 b, citing this passage). 37 Jesting irony in citing authority for this simple pastoral description. 39 writtes] writings. 40 Tytirus] Presumably the shepherd in Virgil I, commonly identified with Virgil himself. 41 Menalcas] Shepherds of that name in Theocritus VIII, IX and XXVII, and Virgil III and V, but none of them seems to deserve this distinction. 44 Both in appearance and in conduct. line] outline, lineament: OED 14 , citing this passage). 56 Coridon] Perhaps the one who praises Phillis in Virgil VII.63-4. 
Her middle was both small and gent.

A necke as white as Whales bone,

Compast with a lace of stone,

necklace of coloured stones

Fine she was and faire she was,

Brighter then the brightest glasse.

Such a Shepheards wife as she,

Was not more in Thessalie.

There were no more

\section{Robert Greene The Shepherd's Wife's Song}

A song sung by the shepherd's wife described in no.74, to the tune of her husband's pipe, in Greene's romance Greene's Mourning Garment (1590).

The Shepheards wiues song.

Ah what is loue? is it a pretie thing,

As sweete vnto a Shepheard as a King,

And sweeter too:

For Kinges haue cares that waite vpon a Crowne,

And cares can make the sweetest loue to frowne:

$$
\text { Ah then ah then, }
$$

If Countrie loues such sweete desires do gaine,

What Lady would not loue a Shepheard swayne.

His flockes once foulded he comes home at night,

As merry as a King in his delight, And merrier too:

For Kinges bethinke them what the state require,

Where shepheards carelesse Carroll by the fire.

ponder, reflect carefree

If countrie loues such sweete desires gaine,

What Ladie would not loue a shepheard swaine.

He kisseth first, then sits as blyth to eate

His creame and curds, as doth the King his meate,

And blyther too:

For Kinges haue often feares when they do suppe,

Where Shepheards dread no poyson in their cuppe.

Ah then, ah then,

If countrie loues such sweete desires gaine,

What Ladie would not loue a shepheard swaine.

To bed he goes, as wanton then I weene,

As is a King in dalliance with a Queene,

$$
\text { More wanton too: }
$$

For Kinges haue many griefes affectes to mooue,

Where Shepheards haue no greater griefe then loue, Ah then, ah then,

If countrie loues such sweete desires gaine,

What Ladie would not loue a shepheard swaine.

Upon his couch of straw he sleepes as sound,

As doth the King vpon his beds of downe, More sounder too:

For cares cause Kinges full oft their sleepe to spill,

disturb, impair

Where wearie Shepheards lie and snort their fill, Ah then, ah then,

If country loues such sweete desires gaine, snore, sleep heavily

62 gent] shapely, slender $\left(O E D_{3}\right) . \quad 18$ meate] (a) food generally (b) flesh, as against 'creame and curds'. 28 griefes affectes to mooue] cares to disturb or upset them. Sukant a chaudhur 1 - 9781526143426 
Thus with his wife he spendes the yeare as blyth, As doth the King at euerie tyde or syth,

And blyther too:

For kings haue warres and broyles to take in hand,

When shepheards laugh and loue vpon the land.

Ah then, ah then,

If countrie loues such sweete desires gayne,

What Ladie would not loue a shepheard swayne.

\section{Robert Greene The Song of a Country Swain at the Return of Philador}

From Greene's romance Greenes Mourning Garment (1590). The text below follows the 2nd edn (1616), as the only extant copy of the first edition lacks the full text of this song. The romance, thought to fictionalize Greene's own career, is the prodigal-son story of Philador. This song is sung by one of a company of shepherds celebrating his return home after bitter experience of the dissolute city.

The Song of a country Swaine at the returne of PHILADOR.

The silent shade had shadowed euery tree,

And Phoebus in the west was shrowded low:

Ech hiue had home her busie laboring Bee,

Ech bird the harbour of the night did knowe,

Apollo: the sun-god, hence the sun

Euen then,

When thus:

All things did from their weary labour linne,

Menalcas sate and thought him of his sinne.

shelter

His head on hand, his elbowe on his knee,

And teares, like dewe, be-drencht vpon his face,

His face as sad as any Swaines might bee:

His thoughts and dumpes befitting wel the place,

dejection

Euen then,

When thus:

Menalcas sate in passions all alone,

He sighed then, and thus he gan to mone.

I that fed flockes vpon Thessalia plaines

And bad my lambs to feede on Daffadill,

That liued on milke and curdes, poore Shepheards gaines,

And merry sate, and pyp'd vpon a pleasant hill.

Euen then,

When thus:

I sate secure and fear'd not fortunes ire,

Mine eyes eclipst, fast blinded by desire.

cease, leave off

Then lofty thoughts began to lift my minde,

I grudg'd and thought my fortune was too low;

A Shepheards life 'twas base and out of kinde,

The tallest Cedars haue the fairest growe.

Euen then,

When thus:

resources, earnings

Pride did intend the sequell of my ruth,

Began the faults and follies of my youth.

I left the fields, and tooke me to the Towne,

Fould sheepe who list, the hooke was cast away,

Menalcas would not be a country Clowne,

Nor Shepheards weeds, but garments far more gay.

Euen then,

When thus:

Aspiring thoughts did follow after ruth,

darkened, blinded

Began the faults and follies of my youth.

not befitting (his) nature

growth

42 tyde or syth] time, occasion. (OED sithe $\left.\mathrm{n}^{1} 4\right)$. 31 Pride was planning the outcome of my degenerate career. $\quad 34$ Fould ... list] Let he who so wished herd sheep. 
My sutes were silke, my talke was all of State,

I stretcht beyond the compasse of my sleeue,

The brauest Courtier was Menalcas mate,

Spend what I would, I neuer thought on griefe.

Euen then,

When thus:

I lasht out lauish, then began my ruth,

And then I felt the follies of my youth.

most handsome and gallant feared a sad outcome

squandered money; ruin

I cast mine eye on euery wanton face,

And straight desire did hale me on to loue,

Then Louer-like, I pray'd for Venus grace,

That she my mistris deepe affects might moue. Euen then,

When thus:

Loue trapt me in the fatall bands of ruth,

Began the faults and follies of my youth.

No cost I spar'd to please my mistris eye,

No time ill spent in presence of her sight,

Yet oft we frownd, and then her loue must dye,

60 But when she smyl'd, oh then a happy wight.

Euen then,

When thus:

Desire did draw me on to deeme of ruth,

Began the faults and follies of my youth.

straightaway, immediately; pull, drag

emotions, passions

The day in poems often did I passe,

The night in sighs and sorrowes for her grace,

favour

And she as fickle as the brittle glasse,

Held Sun-shine showres within her flattering face.

Euen then,

When thus:

I spy'd the woes that womens loues ensueth,

I saw, and loath the follies of my youth.

loathed

I noted oft that beauty was a blaze,

I saw that loue was but a heape of cares,

That such as stood as Deare do at the gaze,

And sought their welth amongst affectious thares.

Euen such,

I sawe,

Which hot pursuit did follow after ruth,

8o And fostered vp the follies of their youth.

I considered no time, etc.

then (I was) a happy man

decide on, proceed to

Thus clogg'd with loue, with passions and with griefe,

I saw the country life had least molest,

I felt a wound and faine would haue reliefe,

And this resolu'd I thought would fall out best.

Euen then,

When thus:

I felt my senses almost solde to ruth,

I thought to leaue the follies of my youth.

adverbially: hellbent; ruin

encumbered, burdened
harm

this decision

42 I reached out farther than I could rightly go. Sleeve suggests the courtier's rich clothes. 71 ensueth] follows, results from (singular verb with plural subject). $\quad 73$ blaze] 'a sudden kindling up of passion' $(O E D)$, only a momentary outburst. $\quad 75$ at the gaze] in heraldry, the full-faced or frontal position of a deer: hence gazing intently (in love). 76 their welth] i.e. a rich haryest. affectious] relating to love: ?misprint for 'affection's'. 
To flockes againe, away the wanton towne,

Fond pride auaunt, giue me the Shepheards hooke,

A coate of gray, Ile be a country clowne:

Mine eye shall scorne on beauty for to looke.

No more

A doe:

Both Pride and loue are euer pain'd with ruth,

And therefore farewell the follies of my youth.

\section{Robert Greene Of the Vanity of Wanton Writings}

From Greene's Greenes Vision: Written at the Instant of His Death (1592): the last of his 'Repentance' works, sensational stories of wrongdoing, suffering and repentance purportedly based on his own life. This poem occurs near the start of Vision, reflecting the narrator's contemplation of the follies of his youth.

Greenes Ode, of the vanitie of wanton writings.

Though Tytirus the Heards swaine,

Phillis loue-mate, felt the paine

That Cupid fiers in the eie,

Till they loue or till they die,

Straigned ditties from his pipe,

With pleasant voyce and cunning stripe

Telling in his song how faire

Phillis eie-browes and hir haire,

How hir face past all supposes

For white Lillies, for red Roses.

Though he sounded on the hils

Such fond passions as loue wils,

That all the Swaines that foulded by,

Flockt to heare his harmonie,

And vowed by Pan that Tytirus

Did Poet-like his loues discusse,

That men might learne mickle good,

By the verdict of his mood,

Yet olde Menalcas ouer-ag'd,

That many winters there had wag'd,

Sitting by and hearing this:

Said, their wordes were all amisse.

For (quoth he) such wanton laies

Are not worthie to haue praise,

Iigges and ditties of fond loues,

Youth to mickle follie mooues.

And tould this old said saw to thee,

Which Coridon did learne to me,

traditional saying

teach

Tis shame and sin for pregnant wits,

To spend their skill in wanton fits.

Martiall was a bonnie boy,

He writ loues griefe and loues ioy.

He tould what wanton lookes passes

Twixt the Swaines and the lasses.

And mickle wonder did he write,

Of Womens loues and their spight,

But for the follies of his pen,

He was hated of most men:

For they could say, t'was sin and shame

For Schollers to endite such game.

Quaint was Ouid in his rime,

Chiefest Poet of his time.

What he could in wordes rehearse,

trifles

skilful, accomplished coarse unbleached material

ado: confusion, agitation

(sur)passed; ideas, notions

?judgement, hence impact, influence weathered, carried on through

6 stripe] measure, strain ( $O E D$ 2, citing this passage). $\quad 31$ Martiall] The Latin poet Martial (Martialis Valerius, 43-?101). $\quad 41$ Ouid] author of, inter alia, a series of love-elegies and the Art of Love (Ars amatoria): see 55, 60 . 
Ended in a pleasing verse.

Apollo with his ay-greene baies,

Crownd his head to shew his praise:

evergreen

And all the Muses did agree,

He should be theirs, and none but he.

This Poet chaunted all of loue,

Of Cupids wings and Venus doue:

Of faire Corima and her hew,

Of white and red, and vaines blew.

How they loued and how they greed,

And how in fancy they did speed.

His Elegies were wanton all,

Telling of loues pleasing thrall,

And cause he would the Poet seeme

agreed, interacted

That best of Venus lawes could deeme,

Strange precepts he did impart,

$60 \quad$ And writ three bookes of loues art.

There he taught how to woe,

What in loue men should doe,

How they might soonest winne

Honest women vnto sinne:

Thus to tellen all the truth,

He infected Romes youth

And with his bookes and verses brought

That men in Rome nought els saught,

But how to tangle maid or wife,

70 With honors breach throgh wanton life:

violation

The foolish sort did for his skill,

Praise the deepnesse of his quill:

And like to him said there was none,

Since died old Anacreon.

But Romes Augustus, worlds wonder,

Brookt not of this foolish blonder:

Nor likt he of this wanton verse,

That loues lawes did rehearse.

For well he saw and did espie,

$80 \quad$ Youth was sore impaird thereby:

And by experience he finds,

Wanton bookes infect the minds,

Which made him straight for reward,

Though the censure seemed hard,

To bannish Ouid quite from Rome,

This was great Augustus doome:

love-play, amorousness; fare, prosper

For (quoth he) Poets quils

Ought not for to teach men ils.

For learning is a thing of prise,

90 To shew precepts to make men wise,

And neere the Muses sacred places

Dwels the virtuous minded graces.

Tis shame and sinne then for good wits,

To shew their skill in wanton fits.

This Augustus did reply,

And as he said, so thinke I.

judgment

verdict

value 


\section{Thomas Lodge Old Damon's Pastoral}

\section{From Helicon.}

Olde Damons Pastorall.

From Fortunes frownes and change remou'd, wend silly Flocks in blessed feeding:

None of Damon more belou'd,

go, move feede gentle Lambs while I sit reading.

Carelesse worldlings, outrage quelleth all the pride and pompe of Cittie:

But true peace with Sheepheards dwelleth, (Sheepheards who delight in pittie.)

Whether grace of heauen betideth on our humble minds such pleasure:

violence destroys

Perfect peace with Swaines abideth, loue and faith is Sheepheards treasure.

On the lower Plaines the thunder little thriues, and nought preuaileth:

Yet in Citties breedeth wonder, and the highest hills assaileth.

Enuie of a forraigne Tyrant threatneth Kings, not Sheepheards humble:

Age makes silly Swaines delirant, thirst of rule garres great men stumble.

What to other seemeth sorrie, abiect state and humble biding:

Is our ioy and Country glorie, highest states haue worse betiding.

Golden cups doo harbour poyson, and the greatest pompe, dissembling:

Court of seasoned words hath foyson, treason haunts in most assembling.

Homely breasts doo harbour quiet, little feare, and mickle solace:

States suspect their bed and diet,

much feare and craft doo haunt the Pallace.

Little would I, little want I, where the mind and store agreeth,

Smallest comfort is not scantie, least he longs that little seeth.

Time hath beene that I haue longed, foolish I, to like of follie:

To conuerse where honour thronged, to my pleasures linked wholy.

the same kind or amount of attached, committed

Now I see, and seeing sorrow that the day consum'd, returnes not:

Who dare trust vpon to morrow, when nor time, nor life soiournes not?

stays, endures

9 betideth] bestows, causes to befall: transitive use not in OED. 19-2o Shepherds are crazed only through senility, great men by thirst for power. delirant] crazy, hence senile, lending the further sense 'stupid' to silly (simple, rustic, innocent). 27 seasoned] (a) spiced, flattering (b) ripe - hence foyson] (a) abundance (b) harvest. $\quad 31$ States] persons of state, rulers (OED 26). 34 where the mind is reconciled to one's (lack of) wealth. $\quad 35$ Even the smallest support is not too little. $\quad 36$ He who experiences little desires little. 39 conuerse] mix, associate with. 


\section{Thomas Lodge Coridon's Song}

From Lodge's romance Rosalynde (1590). Sung by the shepherd Coridon to entertain the company at the multiple wedding closing the work. Reprinted in Helicon, whose text is followed below.

\section{Coridons Song.}

A Blithe and bonny Country-Lasse, heigh hoe bonny-Lasse,

Sate sighing on the tender grasse, and weeping sayd: will none come woo me?

A smicker Boy, a lither Swaine, heigh hoe a smicker Swaine:

That in his loue was wanton faine, with smiling lookes straite came vnto her.

When as the wanton Wench espied,

heigh hoe when she espied,

The means to make her selfe a Bride, she simpred smooth like bonnie-bell:

The Swaine that sawe her squint-eyed kinde, heigh-hoe squint-eyed kinde,

His armes about her body twin'd and sayd, Faire Lasse, how fare ye, well?

The Country-Kit sayd, well forsooth,
heigh hoe well forsooth,

But that I haue a longing tooth, a longing tooth that makes me crie:

Alas (said he) what garres thy greefe, heigh hoe what garres thy greefe?

A wound (quoth she) without releefe, I feare a mayde that I shall die.

If that be all, the Sheepheard sayd, heigh hoe the Sheepheard sayd,

Ile make thee wiue it gentle Mayde, and so recure thy maladie:

Heereon they kist with many an oath, heigh hoe many an oath,

And 'fore God Pan did plight their troath, so to the Church apace they hie.

And God send euery pretty peate, heigh hoe the pretty peate,

That feares to die of this conceite, so kind a friend to helpe at last:

Then Maydes shall neuer long againe, heigh hoe to long againe,

When they finde ease for such a paine, thus my Roundelay is past.

5 smicker] (a) handsome (b) loose, wanton. lither] wicked, rascally. 12 bonnie-bell] a pretty woman (Fr. bonne et belle). 17 Country-Kit] 'light woman' (OED kit $\left.\mathrm{n}^{4} 2\right)$. 19 longing tooth] sexual desire: tooth] 'taste, liking' (OED 2). Presented as a toothache, hence greefe (21). 31 'fore God Pan] A remarkable fusion of Christian and pagan. 33 peate] girl (fondly and/or dismissively). 35 conceite] 'A (morbid) affection or seizure of the body or mind' (OED 11). 


\section{8o Thomas lodge A Pleasant Eclogue between Montanus AND CORIDON}

From Thomas Lodge's romance Rosalynde (1590): the common pattern of a dialogue between a young shepherd in love and a moralizing old shepherd, as in the February eclogue in Spenser's SC, which this poem richly echoes. The old shepherd Coridon's speech is markedly more archaic and rustic than the young Montanus'.

A pleasant Eglog betweene Montanus and Coridon.

Coridon. Say shepheards boy, what makes thee greet so sore?

Why leaues thy pipe his pleasure and delight?

Yong are thy yeares, thy cheekes with roses dight:

weep, mourn

Then sing for ioy (sweet swaine) and sigh no more.

This milke white Poppie and this climbing Pine

Both promise shade; then sit thee downe and sing,

And make these woods with pleasant notes to ring,

Till Phoebus daine all Westward to decline.

?see fit, decide

Montanus. Ah (Coridon) vnmeet is melodie

To him whom proud contempt hath ouerborne:

Slaine are my ioyes by Phoebes bitter scorne,

Farre hence my weale and nere my ieopardie.

Loue's burning brand is couched in my brest,

Making a Phoenix of my faintfull hart:

And though his furie doo inforce my smart,

Ay blyth am I to honour his behest.

decked, adorned

Preparde to woes since so my Phobe wills,

My lookes dismaid since Phoebe will disdaine:

I banish blisse and welcome home my paine;

So streame my teares as showers from Alpine hills.

?towering, rising upward

In errours maske I blindfolde iudgements eye,

I fetter reason in the snares of lust,

I seeme secure, yet know not how to trust;

I liue by that, which makes me liuing die.

Deuoyd of rest, companion of distresse,

Plague to my selfe, consumed by my thought;

How may my voyce or pipe in tune be brought?

Since I am reft of solace and delight.

Coridon. Ah Lorrell lad, what makes thee Herry loue?

worthless; praise

A sugred harme, a poyson full of pleasure,

unfit, inappropriate oppressed

lodged; ?hidden about to faint, ?moribund intensify, increase

ready to meet frustrated, desperate

A painted shrine ful-fild with rotten treasure,

A heauen in shew, a hell to them that proue.

A gaine in seeming, shadowed still with want,

A broken staffe which follie doth vpholde,

A flower that fades with euerie frostie colde,

An orient rose sprong from a wythred plant.

A minutes ioy to gaine a world of greefe,

A subtill net to snare the idle minde,

A seeing Scorpion, yet in seeming blinde,

A poore reioyce, a plague without releefe.

2 his] usual possessive of it till end-16-c. $\quad 5$ Poppie] unidentified. The only poppy plants tall enough to give shade belong to the Americas, and had prob. not been imported by this date. 14 Phœnix] which dies and rises again from its own death-pyre. 36 orient] ?bright red (OED orient $\left.\mathrm{B}_{3} \mathrm{~b}\right)$; ?radiant, resplendent. $\quad 39$ i.e. Love appears blind but can see to do harm. 
For thy Montanus follow mine arreede, (Whom age hath taught the traynes that fancie vseth)

therefore; advice Leaue foolish loue; for beautie wit abuseth,

And drownes (by follie) vertues springing seede. wiles, deceits

Montanus. So blames the childe the flame, because it burnes;

And bird the snare, because it doth intrap;

And fooles true loue, because of sorrie hap;

And saylers cursse the ship that ouerturnes:

But would the childe forbeare to play with flame,

And birdes beware to trust the fowlers ginne,

And fooles foresee before they fall and sinne,

And maisters guide their ships in better frame;

The childe would praise the fire, because it warmes;

And birds reioyce, to see the fowler faile;

And fooles preuent, before their plagues preuaile;

And saylers blesse the barke that saues from harmes.

Ah Coridon, though manie be thy yeares,

And crooked elde hath some experience left;

Yet is thy minde of iudgement quite bereft

The ploughman little wots to turne the pen,

on the subject of

Or bookeman skills to guide the ploughmans cart,

Nor can the cobler count the tearmes of Art,

Nor base men iudge the thoughts of mightie men;

knows

value, judge

Nor wythered age (vnmeete for beauties guide,

Vncapable of loues impression)

Discourse of that, whose choyce possession

May neuer to so base a man be tied.

But I (whom nature makes of tender molde,

And youth most pliant yeeldes to fancies fire)

Doo builde my hauen and heauen on sweete desire,

On sweete desire more deere to me than golde.

love's

Thinke I of loue, ô how my lines aspire?

How hast the Muses to imbrace my browes,

And hem my temples in with lawrell bowes,

And fill my braines with chast and holy fire?

Then leaue my lines their homely equipage,

Mounted beyond the circle of the Sunne;

Amaz'd I read the stile when I haue done,

And Herry Loue that sent that heauenly rage.

writing, composition praise

Of Phobe then, of Phobe then I sing,

Drawing the puritie of all the spheares,

The pride of earth, or what in heauen appeares,

Her honoured face and fame to light to bring.

unfit

In fluent numbers and in pleasant vaines,

I rob both sea and earth of all their state,

flowing verses

To praise her parts: I charme both time and fate,

To blesse the Nymph that yeeldes me loue sicke paines.

My sheepe are turnd to thoughts, whom froward will

Guides in the restlesse Laborynth of loue,

Feare lends them pasture wheresoere they moue,

And by their death their life renueth still, 
My sheephooke is my pen, mine oaten reede

My paper, where my manie woes are written;

Thus silly swaine (with loue and fancie bitten)

I trace the plaines of paine in wofull weede.

plaints, lamentations

Yet are my cares, my broken sleepes, my teares,

My dreames, my doubts for Phoebe sweete to me:

Who wayteth heauen in sorrowes vale must be,

And glorie shines where danger most appeares.

denigrates, dismisses

100

Then Coridon although I blythe me not,

Blame me not man, since sorrow is my sweete;

So willeth Loue, and Phoebe thinkes it meete,

And kinde Montanus liketh well his lot.

Coridon. Oh staylesse youth, by errour so misguided;

Where will prescribeth lawes to perfect wits,

Where reason mournes, and blame in triumph sits,

And follie poysoneth all that time prouided.

With wilfull blindnesse bleard, preparde to shame,

Prone to neglect Occasion when she smiles:

Alas that Loue (by fond and froward guiles)

Should make thee tract the path to endlesse blame.

Ah (my Montanus) cursed is the charme

That hath bewitched so thy youthfull eyes:

Leaue off in time to like these vanities;

Be forward to thy good, and fly thy harme.

As manie bees as Hibla daily shields,

As manie frie as fleete on Oceans face,

As manie heards as on the earth doo trace,

As manie flowres as decke the fragrant fields,

am not happy or merry

loving, affectionate

unstable, wayward

disposed, inured

[(a) wrongdoing (b) harm trace, tread;

spell

prompt, zealous

?shelters, houses

frie: of fish; swim, drift tread, pass or travel over

As manie starres as glorious heauen containes,

As manie stormes as wayward winter weepes,

As manie plagues as hell inclosed keepes;

So manie greefes in loue, so manie paines.

Suspitions, thoughts, desires, opinions, praiers,

Mislikes, misdeedes, fond ioyes, and fained peace,

Illusions, dreames, great paines, and small increase,

Vowes, hopes, acceptance, scornes, and deepe despaires,

Truce, warre, and woe doo waite at beauties gate;

Time lost, lament, reports, and priuie grudge,

secret sorrow or discontent

And last, fierce Loue is but a partiall Iudge,

Why yeeldes for seruice shame, for friendship hate.

Montanus. All Adder-like I stop mine eares (fond swaine)

So charme no more; for I will neuer change.

Call home thy flockes in time that stragling range:

For loe, the Sunne declineth hence amaine.

exhort, persuade

swiftly

Terentius.

In amore hæc omnia insunt vitia, induciæ, inimicitiæ, bellum, pax rursum: incerta hæc si tu postules, ratione certa fieri nihilo plus agas, quam si des operam, vt cum ratione insanias.

93-6 Interesting variant on the pastoral metaphor for poetic composition: the shepherd's activities are metaphorized into a poem. 117 Hibla] Hybla in Sicily, famous for its honey. 126 mislikes] conflicts, disagreements. fond] foolish, misguided. fained] feigned, false. 133 Adder-like] The adder is proverbially (and actually) deaf. $\quad \mathbf{1 3 7} \mathrm{ff}$. A confused version of Terence, The Eunuch I.i.59-63. The full text means: 'In this love inheres all vices: injuries, suspicions, hostilities, truces, war, then again peace. If you make these uncertainties certain by applying reason, you are doing nothing more than raving rationally.' 


\section{Thomas Lodge: Phillis Sonnet 4}

From Thomas Lodge's pastoral sonnet-sequence Phillis (1593).

Long hath my sufferance labored to inforce

One pearle of pittie from hir prettie eyes,

Whilest I with restlesse riuers of remorse,

Haue bathde the bankes where my faire Phillis lies.

The moning lines which weeping $I$ haue written,

And writing red vnto my ruthfull sheepe,

And reading sent with teares that neuer fitten,

To my loues Queene, that hath my heart in keepe:

Haue made my Lambkins lay them downe and sigh:

But Phillis sittes, and reades, and cals them trifles:

Oh heauens why clime not happie lines so high,

To rent that ruthlesse heart, that all hearts rifles?

None wrightes with truer faith, or greater loue,

Yet out alas I haue no power to moue.

\section{Thomas Lodge Phillis Sonnet 12}

From Thomas Lodge's pastoral sonnet-sequence Phillis (1593), though this poem has 16 lines, every fourth an alexandrine. Reprinted in Helicon. The text below follows Phillis.

Ah trees why fall your leaues so fast?

Ah Rocks where are your robes of mosse?

Ah flockes, why stand you all agast?

Trees, rocks, and flocks, what, are you pensiue for my losse?

The birdes me thinkes, tune nought but moane,

terrified, cowed sorrowful

The windes breath nought but bitter plaint,

The beasts forsake their dennes to groane,

Birdes, windes, and beastes, what, doth my losse your powers attaint? Floodes weepe their springes aboue their boundes,

And Eccho wailes to see my woe,

The roabe of ruth doth cloath the groundes:

Floodes, Eccho, groundes, why do you al these teares bestow?

The trees, the rockes, and flockes replie,

The birdes, the windes, the beastes report,

Floodes, Eccho, groundes, for sorrow crie,

We grieue since Phillis nill kinde Damons loue consort.

\section{Thomas Lodge To Reverend Colin}

From Lodge's A Fig for Momus (1595). No convincing identifications proposed for the shepherds.

To reuerend Colin.

Eclogue .I.

Ergasto. Damian.

Ergasto. Sing vs that carroll (Damian)

Amintas soung when he began

To follow Ringdes minstralsie,

And made vs merrie melodie.

Damian. Yong lad, my strings are broke and spent,

My harpe records no merriment,

The moderne and newfangled laies

From auncestrie beare hence the praise;

Such strange Terpanders now professe,

3 remorse] sorrowful recollection $\left(\mathrm{OED}_{4}\right)$, hence ?sorrow. 7 fitten] lie: i.e. the tears are genuine. 9 Rivers overflow their banks. 11 Floods (seen as tears) cover the ground. 16 nill] will not. consort] keep company with: i.e. match or return his love. o.1 reuerend Colin] presumably a dedication to Spenser. 7-8 New songs steal the praise from their predecessors. 9 Terpander] ancient poet and musician of 7 -c. BCE. 
To moue both mirth, and heauines,

(a) sadness (b) seriousness

By euery motion of the fingers,

That olde men seeme but sorie singers.

Ergasto. Let yong men boast what art they list,

wish

Mine eares chiefe pleasure doth consist

In hearing what concentfull laies

Our Fathers chaunted in their daies;

For often haue I found this true,

The sence is olde, the words be newe:

What ere the yonger boast and braue,

Their worth, and wit, from eld they haue:

Olde sence by vpstarts newlie suted

In words ill warpt, is not reputed

The deede of him that formd the stile,

But his that did the sence compile.

Damian. Since thou canst argue so for age,

My voice with harpe some warre shall wage:

And I will sing thee such a lay

As erst I heard my Ringde play,

At Galateas wedding feast,

(Where sea to heare his musicke ceast.)

$$
\begin{array}{r}
\text { stopped flowing } \\
\text { Song } \\
\text { i.e., Nature's }
\end{array}
$$

Wherein our partiall mothers ballance hung

With equall poise: and fish, wild beastes, and birds,

Had vse of reason, and of needfull words:

Wherein foure-footed beasts of sauadge field,

(Who sought the state of winged fowles to wield)

Conspir'd, (the better to defence their states)

To chuse the fish, to be their mutuall mates:

Who vainly trusting to their fraile defence,

Consented quickly to the beastes pretence,

Supposing nature equallie had lent

Like force in earth, as liquid element:

Hereon (ambition egging on the flocks

Of proud foure-footed beasts) the shoares, and rocks

Were fild with fish; and heauen, with shoutes and cries,

And gastlie breathings, almost lost his eies:

When all the foules, embatail'd in the aire

(Seeing their fortunes almost in despaire)

Besought the Gods, (who all iniustice hate)

To be assistant in this dire debate:

Ioue, by a thunderclap a signall gaue

Vpon their prayers, they should good fortune haue,

And speedily sent out the Southerne wind

To driue the waters from their bounds assind;

A murren on the beasts he thrilled downe:

Whilst thus the reuerend iudge doth threat and frowne,

The fowles they stoupe, and offering vrgent blowes,

Finde hartles beastes, and each where liueles foes:

The fish, on waueles shore disperst, and left,

Of pride, and life, were all at once bereft:

The fowles preuaild, and fed them fat with pray,

And after victors like did flie away;

And beating off the aire with open wings

They tun'd this carroll to the woods and springs,

To beasts, to fish, (reseru'd from brunt of warre)

To all, (that with both factions mortall are)

rule over

defend, protect

helping

hurled

hard

heartless: ?weak,

[demoralized; ?dead

gorged themselves

as victors do (a) olden times b) old people ?dressed in new or smart clothes (a) uttered (b) woven; ?twisted, ugly

26 warre shall wage] as his aged voice cannot easily blend with the music. 29 Galatea] presumably the sea-nymph of that name (see 30). 32 partiall] a surprising word, contrary to the context: perhaps 'fond, loving'. 41-2 Thinking they could survive on land as in the water. 55 murren] murrain: plague, esp. in cattle, ?hence in other animals. 
Beware (ô what soeuer race you bee)

(Too much ambitious in felicitie)

To striue to raise your fortunes through oppression,

Or count your neighbours purchase your possession,

For Gods reuenge each impious attempt

Before the plague or punishment be drempt:

Be sure the square whereby you build your states

Must breake and faile, in dangers and debates;

For Nemesis hath euery houre reseru'd

A plague for pride, that hath from iustice sweru'd:

Oh you, whose calme makes neighbours stormes seeme sore,

deviated, strayed

Trie you your tides, before you trust your ore,

The surge may rise on sodaine ere you thinke,

And force you, (whilst you swim, secure) to sinke.

Who trustes to choice of proud confederate,

And failes in choice of faithfull friends estate;

Let him disclaime his armes, and claime foresight;

Lest he with beastes, mannage a beastlie fight.

haughty or ambitious ally

relinquish, abjure; ?adopt

conduct

Ergasto. In sooth this is a wittie lay

More pleasant then the verrelay

The shepheard sings vnto his sheepe

As soone as day begins to peepe.

90

Damian. Waigh not the words, but marke the worth,

Great flouds doe often issue forth

From humble waters, and deepe skill

May flow from an impolisht quill.

Who waites for words, may get him hence,

For shepherds onely sing for sence.

seeks, expects

\section{Christopher Marlowe The Passionate Shepherd to His love}

First published in The Passionate Pilgrim (1599). Attributed to Marlowe in Helicon with the above title; and by Izaak Walton in The Compleat Angler (1653), where it is sung by a milkmaid whose mother sings the reply (no.85). There is also a ballad version. The text below follows Helicon. Except for a brief mention of shepherds in 6, the two stanzas added in Helicon $(13-16,21-4)$ are the only ones of specifically pastoral content.

The passionate Sheepheard to his loue.

Come liue with mee, and be my loue,

And we will all the pleasures proue,

That Vallies, groues, hills and fieldes,

experience, try out

Woods, or steepie mountaine yeeldes.

And wee will sit vpon the Rocks,

Seeing the Sheepheards feede theyr flocks,

By shallow Riuers, to whose falls,

Melodious byrds sings Madrigalls.

cascades, descents

And I will make thee beds of Roses,

And a thousand fragrant poesies,

A cap of flowers, and a kirtle,

Imbroydred all with leaues of Mirtle.

skirt

A gowne made of the finest wooll,

Which from our pretty Lambes we pull,

i.e., a myrtle-leaf design

68 ambitious in felicitie] made ambitious by their happy and secure state. $\quad$ 71-2 The gods punish wrongdoing before the doer even dreams it can light on him. drempt] dreamt (of). 73 square] rule, principle: from the square used by builders. $77-8$ Your peaceful state makes you think your troubled neighbours alone are in danger; but consider your situation before you take risks. 7 shallow rivers murmur more loudly than deep ones. 8 sings] Singular verb with plural subject, then accepted practice. 9 beds] Probably of rose petals to lie on, but perhaps flower beds. 10 poesies] posies; but spelling also suggests poesies, verses inscribed on rings. 
Fayre lined slippers for the cold:

With buckles of the purest gold.

A belt of straw and Iuie buds,

With Corall clasps and Amber studs,

And if these pleasures may thee moue,

Come liue with mee, and be my loue.

And if: old form of 'an if', if

The Sheepheards Swaines shall daunce \& sing,

For thy delight each May-morning,

If these delights thy minde may moue;

Then liue with mee, and be my loue.

\section{Walter Ralegh(?) The Nymph's Reply to the Shepherd}

First stanza published as 'Love's Answer' after no. 84 in The Passionate Pilgrim (1599). The full poem, ascribed to an unknown poet (Ignoto), first published in Helicon, again after no. 84. Walton's The Compleat Angler is the sole pointer to Ralegh's authorship. Also a ballad version (c.1629), accompanying that of no. 84. The text below follows Helicon.

The Nimphs reply to the Sheepheard.

If all the world and love were young,

And truth in euery Sheepheards tongue,

These pretty pleasures might me moue,

To liue with thee, and be thy loue.

Time driues the flocks from field to fold,

When Riuers rage, and Rocks grow cold,

And Philomell becommeth dombe,

The rest complaines of cares to come.

The flowers doe fade, and wanton fieldes

To wayward winter reckoning yeeldes,

A honny tongue, a hart of gall,

Is fancies spring, but sorrowes fall.

Thy gownes, thy shooes, thy beds of Roses,

Thy cap, thy kirtle, and thy poesies,

Soone breake, soone wither, soone forgotten:

In follie ripe, in reason rotten.

Thy belt of straw and Iuie buddes,

Thy Corall claspes and Amber studdes,

All these in mee no meanes can moue,

To come to thee, and be thy loue.

But could youth last, and loue still breede,

Had ioyes no date, nor age no neede,

Then these delights my minde might moue,

To liue with thee, and be thy loue.

\section{Another of the Same Nature}

First published in Helicon, after no.84 and 85.

Another of the same nature, made since.

Come liue with mee, and be my deere,

And we will reuell all the yeere,

In plaines and groaues, on hills and dales:

Where fragrant ayre breedes sweetest gales.

8 The rest ... to come] The other birds' songs take on a complaining note. wanton] 'profuse in growth, luxuriant' (OED $7 \mathrm{a}) \quad$ wayward] untoward, adverse (of natural conditions: $O E D$ 1b) 12 spring ... fall] (a) rise and fall (b) spring and autumn. 14 poesies] posies; but spelling also suggests poesies, verses inscribed on rings. 
There shall you haue the beauteous Pine,

The Cedar, and the spreading Vine,

And all the woods to be a Skreene:

Least Phobus kisse my Sommers Queene.

The seate for your disport shall be

entertainment, pleasure

Ouer some Riuer in a tree,

Where siluer sands and pebbles sing

Eternall ditties with the spring.

There shall you see the Nimphs at play,

And how the Satires spend the day,

The fishes gliding on the sands:

Offering their bellies to your hands.

The birds with heauenly tuned throates,

Possesse woods Ecchoes with sweet noates,

Which to your sences will impart

A musique to enflame the hart.

arouse, inspire

Vpon the bare and leafe-lesse Oake,

The Ring-Doues wooings will prouoke

A colder blood then you possesse,

To play with me and doo no lesse.

In bowers of Laurell trimly dight,

We will out-weare the silent night,

While Flora busie is to spread

Her richest treasure on our bed.

Ten thousand Glow-wormes shall attend,

And all their sparkling lights shall spend,

All to adorne and beautifie

Your lodging with most maiestie.

Then in mine armes will I enclose

Lillies faire mixture with the Rose,

Whose nice perfections in loues play

Shall tune me to the highest key.

Thus as we passe the welcome night,

In sportfull pleasures and delight,

The nimble Fairies on the grounds,

Shall daunce and sing mellodious sounds.

songs

If these may serue for to entice

Your presence to Loues Paradice,

Then come with me, and be my Deare:

And we will straite begin the yeare.

\section{Sir John Davies Psalm 23}

Among Davies's translations of the Psalms in the Laing MS, Edinburgh University Library. Punctuation added and line initials standardized.

The Lord my Sheaperd is, hee doth mee feed.

His bounty euermore supplies my need.

When I in pastures greene my fill haue tooke

Hee leads mee forth into the siluer Brooke.

Hee turnes my Soule when it is gon astray

For His names glory to his righteous way.

10 Ouer] above, looking down on (like the rocks above the rivers in 84.5-7). 12 spring] waterfall, cascade (cf. 84.7). 18 Possesse] ?command, engage; ?enchant, captivate. woods Ecchoes] the echoes in the woods. $\quad 27$ Flora] goddess of flowers. $\quad 34$ Lillies ... Rose] conventional for a delicate pink complexion. 
Therefore although my Soule detruded were

thrust, driven

Euen to hell gates, yet I noe ill should feare.

When thou art with mee, what should mee dismay?

Thy Crooke my comfort is, thy Staffe my stay.

My Table thou hast spread and furnisht soe

As glads my heart and greiues my enuious foe.

Thy Balme powr'd on my head doth sweetly smell.

Thou makst my cup aboue the brimms to swell.

Thy mercy while I breath shall follow mee

And in thy house my dwellinge place shallbee.

\section{Andrew Willett On Lazy ANd Sleeping Shepherds}

From Andrew Willett's collection of a hundred 'sacred emblems', Sacrorum Emblematum Centuria Una (?1592). Expands the conventional pastoral comparison for the priest's calling. A marginal note refers to John 10.10[-16], which intensively applies the pastoral metaphor to Christ, the good shepherd that lays down his life for his flock. The English text follows a Latin version with more specific detail (see notes). The title above is translated from the Latin; the English text is headed 'The same in English'.

The shepheard good doth watch his sheepe,

And from the wolfe them safe doth keepe:

The hireling from flocke doth goe,

And is the first that flieth from foe:

The Pastour which the soules doth feede,

And alwayes teacheth heauenly reede,

And doth not any daunger feare,

Is like the shepheard set foorth here.

But he that onely gaine doth minde,

Leaving his flocke and all behinde,

Running away so he safe be,

An idle shepheard sure is he.

\section{Edward Dyer(?) Coridon to His Phillis}

First published in The Phoenix Nest (1593), then with this title in Helicon, where it is first attributed to 'S[ir]. E[dward]. Dyer'. The text follows Helicon.

Coridon to his Phillis.

Alas my hart, mine eye hath wronged thee,

Presumptuous eye, to gaze on Phillis face:

Whose heauenly eye no mortall man may see,

But he must die, or purchase Phillis grace.

Poore Coridon, the Nimph whose eye dooth mooue thee

Dooth loue to draw, but is not drawne to loue thee.

earn, win

Her beautie, Natures pride, and Sheepheards praise,

Her eye, the heauenly Planet of my life:

Her matchlesse wit and grace her fame displaies,

As if that Ioue had made her for his wife.

Onely her eyes shoote fierie darts to kill:

Yet is her hart as cold as Caucase hill.

attract

My wings too weake to flye against the Sunne,

Mine eyes vnable to sustaine her light:

My hart dooth yeeld that I am quite vndone,

withstand, endure admit by way of surrender

2 Lat. more concrete: 'drives away the greedy wolf with his stick'. 4 from foe] Lat. 'the approaching foe', intensifying the cowardice. 6 Lat. 'who does not cease to teach them with his words' - i.e. with sermons. 9-10 Lat. much more detailed: 'The greedy man who, coveting wealth, leaves behind all charge of both flock and people'. 12 Lat. labours the comparison in a simile: 'That irresponsible man emulates the lazy herdsman. 4 (a) A man must either die or earn her favour (b) or] ere: A man will die before he earns her favour. 13-16 Sunne, light] Standard Petrarchan conceits for the mistress's eyes. her sight] prob. her gaze, the light from her eyes, rather than the sight of her. 
Thus hath faire Phillis slaine me with her sight.

My bud is blasted, withred is my leafe:

And all my corne is rotted in the sheafe.

blighted, destroyed

Phillis, the golden fetter of my minde,

My fancies Idoll, and my vitall power:

Goddesse of Nimphs, and honour of thy kinde,

This ages Phoenix, beauties richest bower.

Poore Coridon for loue of thee must die:

Thy beauties thrall, and conquest of thine eye.

Leaue Coridon to plough the barren field,

Thy buds of hope are blasted with disgrace:

For Phillis lookes no harty loue doo yeeld,

Nor can she loue, for all her louely face.

Die Coridon, the spoile of Phillis eye:

She cannot loue, and therefore thou must die.

imparting life
pride of your sex
dwelling, abode

lack of favour

sincere, from the heart

prey, victim

\section{O BARNABE BARNES 'ONE NIGHT I DID ATTEND MY SHEEP'}

Ode 12 in Barnes's collection Parthenophil and Parthenophe (1593).

One night I did attend my sheepe

(Which I with watchfull ward did keepe)

For feare of wolues assaulting

For many times they broake my sleepe,

And would into the cottage creepe,

Till I sent them out haulting.

sheepcote

limping

At length me thought about midnight

(What time cleare Cynthia shined bright)

Beneath I heard a rumbling:

At first the noyse did me affright,

But nought appeared in my sight, Yet still heard somewhat tumbling.

falling, rushing

At length good hart I tooke to rise,

And then my selfe crost three times thrise, Hence a sharpe shephooke raught:

I feard the wolfe had got a prise,

Yet how he might could not deuise: I for his entrance sought.

?on or under the ground

reached for, grabbed prey, capture

point of entry

cold, chilled

At length by moonelight could I espye

A little boy did naked lye

Frettish't, amongst the flocke:

I him aproched somewhat nye,

He gron'd as he were like to dye,

But falsely me did mocke.

deceive

For pittie he crye'd wella-day,

God maister helpe me (if you may)

For I am almost starued:

I pittied him when he did pray,

And brought him to my couch of hay, But gesse, as I was serued.

guess how

He bare about him a long dart,

Well guilded with fine painters art, And had a pyle of steele:

20 fancie] (a) love (b) imagination, the image-making power (OED 4). Idoll] (a) object of worship (b) image created by the fancy $(O E D$ 6). 22 Phoenix] There was only one Phoenix at a time. 28 louely] (a) beautiful (b) attracting love. $\quad 13$ I gathered the courage to get up. 17 I could not deduce how he might have done so. 
On it I looked euery part,

Said I, will this pyle wounde an hart:

all over

Tuch it (quoth he) and feele.

With that I tuch't the iauelinges point,

dart's

Eft-soones it perced to the ioynt,

And rageth now so fierce:

That all the balmes which it anointe,

Cannot preuaile with it a pointe, But it myne hart will perce.

a jot, in the least

\section{Barnabe Barnes 'Sing sing (Parthenophil)'}

This celebration of Philip Sidney's birthday (more a eulogy of the Queen) is Canzon 2 among the 'Odes' in Barnes's Parthenophil and Parthenophe (1593). Sidney's birthday was 30 November. From the reference to rebels (69-70), Doyno suggests the year 1591, when the Irish rebel Brian O'Rourke was executed on 3 November.* The device of the echo is used by Sidney himself in the poem 'Fair rocks, goodly rivers' in The Countess of Pembroke's Arcadia.

Sing sing (Parthenophil) sing, pipe, and play:

This feast is kept vpon this plaine

Amongst th'Arcadian shepheards euery where

For Astrophill's byrth-day: sweet Astrophil.

Arcadies honour, mightie Pan's cheefe pride:

Where be the Nymphs, the Nymphes all gathred bee

To sing sweet Astrophil's sweet prayse.

Eccho, recorde what feastes be kept to day

Amongst th'Arcadian shepheard swaine,

What keepe the whiles they do the muses cheare? Eccho, cheare.

He chear'de the muses with coelestiall skill,

All shepheard's prayse dye'd with him when he dye'd:

gladdened

He left no peere, then what deserued he

At whose pypes sounde the Lambe kinne bayes?

Eccho, bayes.

laurels

The Bullockes leape, the fawnes daunce in aray:

Kiddes skippe, the Satyres friskynes fayne,

Here standes an hearde of swaines, fair Nymphes stand there:

Swaines daunce, whiles Nymphes with flowers their baskets fill.

feign: assume, put on

What was he to those Nymphes which garlands tyed?

$$
\text { Eccho, tyed. }
$$

What ty'de him? hath he to tell there bound t'ee?

How? to report his martiall dayes? Eccho, bountee.

Eccho, all dayes.

Thrise happie man that found this happie way.

His prayse' all shepheard's glorie stayne:

What doth Parthenophe my purchase deare?

Eccho, chase deare.

What saith she to her Parthenophil?

$$
\text { Eccho, o fill. }
$$

Shepheardes, I fill sweet wines repurified,

And to his blessed soules this health heaue wee,

Singing sweet Odes, and roundelayes.

Barnabe Barnes, Parthenophil and Parthenophe, ed. Victor A. Doyno, Carbondale: Southern Illinois University Press, 197199 swaine] a collective plural. 15 bayes] 'seek[s] with open mouth, as the young of animals for the dugs' $\left(O E D\right.$ bay $\left.\mathrm{v}^{3}\right)$. 19 hearde] group: rare non-pejorative use for human beings. $\quad 23$ hath he ... t'ee?] ?Has he enjoined you to tell? t'ee] ?thee. 28 prayse'] Doyno suggests the apostrophe indicates the plural, justifiying the plural verb stayne. stayne] (a) obscure, eclipse (b) impart colour to: touch, permeate. 29 purchase] prize, precious gain; hence deare] (a) beloved (b) costly. 
Let euery man drinke round beside this bay: Where are the Nymphes and fayrie traine?

laurel tree

Stella, three garlandes in her hand doth beare,

And those for his sweet sake she proffer will

Vnto th'Elezian soules: And I haue spied

Parthenophe, with spoile returnes to mee:

Of three great hartes, sing virilayes.

Those golden dartes flye neuer voyde of praye And Stella sittes (as if some chaine

Of fancies bound her) by that mottley breere:

Where with sweet Eglantine, and Daffadil

She Capplettes makes, with gold and scarlet dye'd.

Here Colin sittes beneath that oken tree

Eliza singing in his layes.

virelays, a type of lyric or song missing their target

chaplets

singing of Eliza

reign

Blest is Arcadiaes Queene, kneele swaines, and say That she (which here cheefe Nymph doth rayne)

May blessed liue, to see th'extreamest yeare.

For sacrifice (then) Lambes and kiddlinges kill:

And be by them Eliza glorified,

The flower of loues, and pure virginitie:

This Delian Nymphe doth amaise.

The fairest deares which in the forestes stay,

Those harts (which proudest heards distaine

And raunge the forestes as without compeere)

Submissiue yeelde them selues, that if she will

She them may wounde, or on their swift backes ride.

Lyons, and Beares, with bewtie tameth she:

Shepheards, for her your voyces raise.

Eccho, this fauour if I purchase may

Do not herd-groomes there fayne?

Eccho, the're fayne.

What want they, speake, now they be blest, if eare. Eccho, feare.

What be the confines? rebells they be still. Eccho, they be still.

What is she, that so many swaines doth their guide? Eccho, there guide.

feign, invent, compose (songs) ready, eager lack; e'er, ever

borders, frontiers (of the kingdom) quiet, peaceful there their

None but her selfe, hath that abilitie

To rule so many blessed wayes:

Her thoughtes sure grounded on diuinitie,

For this sweet Nymphe, each shepheard prayes.

\section{Thomas Hey wood From Oenone and Paris}

Stanzas 55-70 of Heywood's epyllion Oenone and Paris (1594), comprising the nymph Oenone's lament at being deserted by Paris at the end of his stay as a shepherd on Mount Ida. Illustrates the setting and ambience of mythological pastoral. Punctuation modified.

And now at length this fit shee doeth recouer,

And riseth vp as wakened from a slumber,

Cleare shines the sunne when all the storme is ouer.

38 Stella] Penelope Devereux, Sidney's beloved. 40 th'Elezian soules] souls of the dead (like Sidney), in heaven or Elizium. $\quad 41$ spoile] gifts, riches. $\quad \mathbf{4 2}$ three great hartes] presumably Sidney, Stella, and the poet's beloved Parthenophe. 45 mottley breere] ?hawthorn. breere] various thorn-trees. Hawthorn blossom was called 'white motley'. $\quad 48$ Colin] Spenser. $\quad 52$ th'extreamest yeare] ?the greatest possible age; ?the end of time. 56 Delian Nymphe] Artemis or Diana (born in Delos), the virgin goddess to whom Elizabeth was routinely compared. $\quad \mathbf{5 7}$ deares] deer: plural in $-s$ then current. But like harts (58), also suggests amorous followers. $\quad \mathbf{5 8}$ distaine] 'cause to ... look dim; outshine' (OED distain $\mathrm{v}^{3}$ ). $\mathbf{6 4}$ this ... may] If I may request you to tell $\mathrm{me} . \quad \mathbf{1}$ this fit] Oenone had fallen in a fainting fit after Paris renounced his love. 
Salt teares, (as earst) doe not her minde accumber. Yet sighes, (a preface to ensuing talke.) She thus goeth on him in his speech to balke.

before; load, oppress

check, stop

This stately pine, wherein thou hast ingrauen

My name and thine, Lo where it springeth by thee,

These broad-spread beeches, (harbor for the Rauen)

shelter

Where vnder thou hast vowed neuer to deny me,

Beare in their barkes thy solemne protestations,

Which (nowe I finde) were meere dissimulations.

declarations (of love)

And loe, one poplar planted in this Arber,

In whose rough rhyne these verses thou hast carued:

When Paris thoughtes a second loue doe harber,

Sythe fayre Oenone hath so well deserued,

Neuer shall mylchie goate in Ida go,

Nor siluer swanne swimme in the streames of Po.

Xanthus swift waues shall runne against the head,

And clyme the toppes of hye ascending mountaines,

Runne backewarde Xanthus? I am ill bestead,

flow backward
placed, circumstanced
springs

Sweete Naiades haunt yee no more these fountaines.

And snow-white swannes come helpe me with your breath,

That I with you may sing against my death.

on the occasion of

Flint-hearted Phrygian, thou hast broke thy vowe,

Blush, and beholde a Nimph for loue that rages,

And thou fayre Poplare still increase and growe,

To be an historie to after-ages.

Witnesse this holly-oke, whereon thou leanest,

Thou hast dissembled, (tell me what thou meanest?)

record, memorial

Ah (Paris) when like to a simple groome,

Among the gote-heardes thou these groues frequented,

Seeing the skipping Satyres in the broome,

With bagpypes shrill and oten quills contented,

Then didst thou yeeld Oenone pricke and prayes,

Which now is buryed in eternall dayes.

for ever

Oft hast thou seene me in the meades below,

Liuely to leade the Nymphes about the trees,

And on these bankes, where Aesacus doth flow,

Dauncing to teach Dianaes Votaryes.

When Faunus, father of the rurall gods,

Swore that I did surpasse them all by odds.

Oft hath thou seene me, with thy selfe vnseene

Of any Nymph, saue of my selfe alone,

Whole after-noones to parlye in this greene,

But all these pleasures and delightes are gone.

Oft haue thy lippes ioynd with these lippes of mine,

Sending out sugred sighes to Paphos shrine.

Oft hast thou found me by this pleasant Myrtle,

(Greene myrtle) dedicate to loues fayre Queene,

Whose leauie branches stead me for a kirtle, stand in for, serve as

$\mathbf{1 1}$ in their barkes] i.e. in the love-verses he has carved on them. $\mathbf{1 4}$ rhyne] rind, bark. $\quad \mathbf{1 7}$ No goat on Ida will yield milk. $\quad \mathbf{1 8}$ Po] in north Italy, while Ida is in Asia Minor. Prob. introduced for rhyme. 19 Xanthus] river in Lycia, in Asia Minor. 22 Naiades] nymphs of fresh water. 23-4 Swans were said to sing at the moment of death. 25 Phrygian] loosely, Trojan: a section of Phrygians migrated from central Asia Minor to Troy. 31 groome] shepherd $(O E D$ 2): common in 16-17c. pastoral. 33 broome] the shrub so named, ?hence bushes generally. 34 quills] pipes, but also suggesting pens, i.e. poetry. 35 pricke and prayes] 'the praise of excellence or success (OED prick n 18). 39 Aesacus] Not a river but a person (Paris's brother, son of King Priam of Troy). Mistake for Aesepus, a river flowing from Mount Ida. 40 to teach] well enough to teach. Dianaes Votaryes] the band of virgins following the huntress-goddess Diana. $\quad 48$ Paphos] chief site of worship of Venus. 
Whose spreading toppe hath oft our shadow beene,

that which provides shade

When thou sat chaunting out thy loue-sick charmes,

Holding me deftly in thy limber armes.

You plants of Phebus, hunny-smelling bayes,

Witnesse with me of thy deceite and flatterie,

Whose compasse kept vs from the sunnes hotte rayes,

When my poore heart by thee sustein'd a batterie.

spread, extent; sheltered Ah leaue the court, full fraught with fortunes showres, And liue in loue among these leavie bowres.

assault, attack

The Dawlian byrd with thousand notes at least,

Reserues them till the grisping of the euen,

twilight

A prickle is prepared for her breast,

To celebrate this night, an happie steeuen.

The whistling blackebirds, and the pleasant thrushes,

With mirthfull Mauis flocke about the bushes.

The Satyres, and goat-footed Aegipines,

Will with their rural musicke come and meete thee,

With boxen pypes, and countrey Tamburines,

$70 \quad$ Faunus and olde Syluanus, they will greete thee.

Then leaue not them, which seem thus to admire thee,

And leaue not her, that doeth so sore desire thee.

The faire Napæe, beawtie of these bankes,

As once they daunced at thy wedding day,

So will they now, and yeelde thee thousand thankes,

Footing it finely to intreat thy stay.

The fountaine Nymphes, that haunt these pleasant springs,

One sort will trip it, while another sings.

The nimble Fayries taking hand in hand,

80 Will skippe lyke rather lambkins in the downes,

The tender grasse vnbended still shall stand,

Coole Zephyrus still flaring vp their gownes.

And euery shepheardes swayne will tune his ode,

And more than these, to welcome thy abode.

Woonder of Troy, Natures exactest cunning,

Glorie of shepheardes, Idaes chiefe Decorum,

most skilful creation

Directorie of my chusing and my shunning,

beauty, adornment

More then a man, saue in that fæx Amorum.

That trothlesse Tindaris thy faith defaceth,

That lust, thy loue, that fault thy fame disgraceth.

Then soiourne here, where louely Cupid raigneth,

Within the precinct of this countrey soyle,

Whose fruitfull fallowes, Mauors neuers staineth,

With bloodie massacres in any broyle.

Here Cinthia liues, that loues the painefull farmour,

Not braue Bellona, glistring in her armour.

made of box-wood

(born) early

occasion, event 


\section{Thomas Hey wood From Amphrisa the Forsaken Shepherdess}

From the short pastoral play Amphrisa the forsaken Shepheardesse in Heywood's Pleasant Dialogues and Dramma's (1637). The passages below consist of the Argument preceding the drama, and a song (divided by dialogue) sung by two shepherdesses, Amphrisa and Alope.

\section{(A) The Argument}

The Argument of AmpHrisa the forsaken Shepheardesse.

The innocence, truth, and simplicitie

Of countrey Damsels: What felicitie

They arrive to in their low estate;

What freedoms they participate,

What ioy, what solace, what content

To their innocuous life is lent.

The humble shed and cottage held

share in, partake of

More safe than gorgeous houses, swell'd

With pompe and wealth. It likewise proves

More simple truth in their chaste loves,

Than great Ladies, tympany'de

With much more honour, state, and pride.

Here's of the Willow wreath dispute,

How, and why worne, what best doth sute

Forsaken Virgins. Reade and finde

Their characters who prove vnkinde.

(B) The Song:

Amphrisa. We that have knowne no greater state

Than this we live in, praise our fate:

For Courtly silkes in cares are spent,

When Countrie's russet breeds content.

The power of Scepters we admire;

But sheep-hookes for our use desire.

Simple and low is our condition;

For here with us is no ambition.

We with the Sunne our flockes unfold,

Whose rising makes their fleeces gold.

"Our musick from the birds we borrow;

blameless, innocent

"They bidding us, we them, good morrow.

Our habits are but course and plaine,

Yet they defend from wind and raine.

As warme too, in an equall eye

As those be, stain'd in Scarlet dye.

Those that have plenty weare (we see)

But one at once; and so doe we.

Alope. The Shepheard with his home-spun Lasse

As many merry houres doth passe,

As Courtiers with their costly Girles,

Though richly deckt in gold and pearles:

And though but plaine, to purpose woo,

Nay oft-times with lesse danger too.

garments

impartial

11 tympany'de] swollen, puffed up ( $O E D$ cites this passage only). $\quad 13$ Willow wreath] Worn by Amphrisa as a sign of grief after being forsaken by her lover; also, as (metaphorically?) urged by her companion Alope, as a magic 'balm' for the resulting pain in her head. 4 russet] a coarse cloth worn by poorer rustics. $\quad 5$ admire] (a) wonder at, marvel at (b) regard with praise or respect (a very new meaning in Heywood's time). $\quad 10$ The beams of the rising sun make the fleeces appear golden. 12 Marginal note in original: 'These last two lines twice'. 16 Scarlet] The colour of ceremonial robes; originally referring to the richness of the material. 24 danger] ?'daunger', the aloofness or hauteur affected by the mistress. 


\section{Thomas Heywood Mercury's Song}

Sung by Mercury in the guise of 'a yong formal Shepheard' in the play Jupiter and Io in Heywood's Pleasant Dialogues and Dramma's (1637). Recounts Pan's frustrated love of Syrinx and her transformation into a reed as narrated in Ovid, Met. I.689-712. In the Table of Contents to Heywood's book, this play is described as 'A Drama from Ovid' (sig.A8v). In Ovid, as here, Mercury tells the story of Syrinx to lull Io's guard, the hundred-eyed Argus, to sleep. But Heywood abridges Ovid's narrative.

\section{Mercuries Song.}

Sirinx, one of Dian's traine,

Hunting with her on the plaine,

Arm'd alike with shafts and bow;

Each from other would you know?

alike: like Diana

Which from which could not be told,

Saue ones was horne, the others gold.

$P a n$ he sees, himselfe makes fine,

In his cap he pricks a Pine:

Now growes carelesse of his heard,

Sits by brookes to prune his beard,

Meets her, and hath minde to wooe,

Much he speakes, and more would doe.

Still he profers, she denies;

He pursues (for Syrinx flies).

Past her knees her coats vp flew,

He would faine see something new:

By the leg and thigh he guest

(It seemes) the vertue of the rest.

This addes wings vnto his pace,

The goale for which he is in chace.

She addes feathers to her speed;

Now it was no more than need.

Almost caught, Alas she cries,

Some chaste god my shape disguise.

Loedon heares, and girts her round,

Spies a reed that makes sweet sound:

Such is Syrinx. Wondring Pan

Puts it to his mouth anon:

This is called

Yet Syrinx thou art myne, he said,

And so of her his first pipe made.

adorns or trims himself

new: more, further

\section{Richard Barnfield From The Affectionate Shepherd, The Second Day}

From 'The second Dayes Lamentation' in 'The Teares of an affectionate Shepheard sicke for Loue. OR The Complaint of Daphnis for the Loue of Ganimede', in Richard Barnfield's The Affectionate Shepheard (1594). This long poem is an unusually explicit expression of homoerotic love; also a notable elaborate pastoral invitation typified by Marlowe's 'Come live with me'. The overtones of frustration echo Theocritus XI and, more closely, Virgil II.

If thou wilt loue me, thou shalt be my Boy,

My sweet Delight, the Comfort of my minde,

My Loue, my Doue, my Sollace, and my Ioy;

But if I can no grace nor mercie finde, Ile goe to Caucasus to ease my smart, And let a Vulture gnaw vpon my hart.

Yet if thou wilt but show me one kinde looke,

(A small reward for my so great affection)

Ile graue thy name in Beauties golden Booke,

engrave

1 of Dian's traine] Ovid simply says she modelled herself on Diana. 6 Exactly follows Ovid, Met. I.697. The bow of horn was Syrinx's, the golden Diana's. Ovid's word corneus usually translated as 'made of horn', though more likely to mean 'made of cornel-cherry wood' (cf.61.13n). 8 Pine] i.e. wreath of pine needles, as in Ovid. 25 Lædon] a river in Arcadia. 25-6 A reference to the suffering of Prometheus. 9-12 i.e. He will write poems in praise of Ganymede. 
And shrowd thee vnder Hellicons protection;

Making the Muses chaunt thy louely prayse:

(For they delight in Shepheards lowly layes.)

And when th'art wearie of thy keeping Sheepe

Vpon a louely Downe, (to please thy minde)

Ile giue thee fine ruffe-footed Doues to keepe,

And pretie Pidgeons of another kinde:

A Robbin-red-brest shall thy Minstrell bee,

species, breed

Chirping thee sweet and pleasant Melodie.

Or if thou wilt goe shoote at little Birds

With bow and boult, (the Thrustle-cocke and Sparrow)

Such as our Countrey hedges can afford's;

I haue a fine bowe, and an yuorie arrow:

And if thou misse, yet meate thou shalt not lacke,

Ile hang a bag and bottle at thy backe.

Wilt thou set springes in a frostie Night,

To catch the long-billd Woodcocke and the Snype?

(By the bright glimmering of the Starrie light)

The Partridge, Phæsant, or the greedie Grype?

Ile lend thee lyme-twigs, and fine sparrow calls,

Wherewith the Fowler silly Birds inthralls.

twigs smeared with birdlime

captures

Or in a mystie morning if thou wilt

Make pit-falls for the Larke and Pheldifare;

Thy prop and sweake shall be both ouer-guilt:

With Cyparissus selfe thou shalt compare

For gins and wyles, the Oozels to beguile;

Whilst thou vnder a bush shalt sit and smile.

Or with Hare-pypes (set in a muset hole)

Wilt thou deceaue the deep-earth-deluing Coney?

Or wilt thou in a yellow Boxen bole

Taste with a woodden splent the sweet lythe honey?

bolt, arrow afford us

food

snares, especially for birds

Clusters of crimson Grapes Ile pull thee downe;

And with Vine-leaues make thee a louely Crowne

fieldfare, a kind of thrush gilded over

ouzels, blackbirds

traps for hares; hare's form
rabbit
bowl made of boxwood

Or wilt thou drinke a cup of new-made Wine

Froathing at top, mixt with a dish of Creame;

And Straw-berries, or Bil-berries in their prime,

Bath'd in a melting Sugar-Candie streame:

Bunnell and Perry I haue for thee (alone)

When Vynes are dead, and all the Grapes are gone.

I haue a pleasant noted Nightingale,

(That sings as sweetly as the siluer Swan)

Kept in a Cage of bone as white as Whale,

Which I with singing of Philemon wan:

Her shalt thou haue, and all I haue beside;

If thou wilt be my Boy, or els my Bride.

Then will I lay out all my Lardarie

(Of Cheese, of Cracknells, Curds and Clowted-creame)

Before thy male-content ill-pleasing eye:

whalebone

won

'lardry', larder

a kind of light biscuit

10 shrowd] shelter $(O E D$ 2). Hellicon] Helicon, mountain in Boeotia sacred to the Muses. 15 ruffefooted] with frilly feathers round the legs. 28 Grype] gripe, vulture: unlikely bird to snare, especially in an English setting. Perhaps a dialectal name for some other bird, or simply used for the rhyme. 29 sparrow calls] Whistles imitating the call of a sparrow, to decoy birds. 32-3 pit-falls] bird-snares with trapdoors. The prop keeps the trapdoor open, and the baited sweake swings to shut it when pulled (sweak, to swing). OED sweek cites this passage. 34 Cyparissus] a young hunter, transformed into a cypress after immoderate grief at killing his pet stag. 35 Gins] traps. wyles] prob. a kind of trap. Cf. OED wile n 3a, 'Engines [to] take Deer' (1677). 4o lythe] lithe: smooth, thick (of liquids: OED 4, 1st cit. 1665). splent] splint, sliver of wood used as spoon. 47 Bunnell] a drink from crushed apples or pears. Perry] a drink from fermented pear juice. $\quad 52$ Won from Philemon in a singing-contest. 
But why doo I of such great follies dreame? Alas, he will not see my simple Coate; For all my speckled Lambe, nor milk-white Goate.

Against my Birth-day thou shalt be my guest:

Weele haue Greene-cheeses, and fine Silly-bubs;

And thou shalt be the chiefe of all my feast.

And I will giue thee two fine pretie Cubs,

With two yong Whelps, to make thee sport withall, A golden Racket, and a Tennis-ball.

A guilded Nutmeg, and a race of Ginger, A silken Girdle, and a drawn-worke Band, Cuffs for thy wrists, a gold Ring for thy finger,

And sweet Rose-water for thy Lilly-white hand, A Purse of silke, bespangd with spots of gold, As braue a one as ere thou didst behold.

A paire of Kniues, a greene Hat and a Feather,

New Gloues to put vpon thy milk-white hand

Ile giue thee, for to keep thee from the weather;

With Phœnix feathers shall thy Face be fand,

Cooling those Cheekes, that being cool'd wexe red,

Like Lillyes in a bed of Roses shed.

Why doo thy Corall Lips disdaine to kisse,

\section{And sucke that Sweete, which manie haue desired?}

That Baulme my Bane, that meanes would mend my misse:

Oh let me then with thy sweete Lips b'inspired;

When thy Lips touch my Lips, my Lips will turne

To Corall too, and being cold yce will burne.

\section{Richard Barnfield From 'The Shepherd's Content'}

Lines 1-14, 140-237, 273-93 from the long poem 'The Shepheards Content. or The happines of a harmles life' in Barnfield's The Affectionate Shepherd (1594). An unusually clear exposition of the metaphors implicit in the shepherd's life and activities; in particular, a very elaborate one of the shepherd as king.

Of all the kindes of common Countrey life,

Me thinkes a Shepheards life is most Content;

His State is quiet Peace, deuoyd of strife;

His thoughts are pure from all impure intent,

His Pleasures rate sits at an easie rent:

He beares no mallice in his harmles hart,

Malicious meaning hath in him no part.

intention, motive

He is not troubled with th'afflicted minde,

His cares are onely ouer silly Sheepe;

$\mathrm{He}$ is not vnto Iealozie inclinde,

(Thrice happie Man) he knowes not how to weepe;

Whil'st I the Treble in deepe sorrowes keepe:

(a whole) root with patterns of thread

spangled fine, pretty

fanned I cannot keepe the Meane; for why (alas)

Griefes haue no meane, though I for meane doo passe.

?a treble load

64 Cubs] young foxes $\left(O E D_{1}\right) . \quad 67$ guilded Nutmeg] a lavish gift, though the 'gilding' was of saffron. 77 being cool'd wexe red] became red even when cooled, presumably from bashfulness. wexe] wax, grow. 78 Inverts Spenser, FQ 2.3.22: 'Like roses in a bed of lillies shed.' 81 That balm would heal my suffering, that gain would make good my loss. misse] lack or loss, and regret thereat: OED miss $\mathrm{n}^{1} 1,2 . \quad 84$ yce ... burne] Unusually physical application of a common Petrarchan paradox (Petrarch, Rime 134). $\quad 5$ The price he pays for his pleasure or content amounts to a moderate fee. $\quad$ 12-13 I am sunk in intense sorrow, without moderation. Treble] (a) threefold, intense (b) the treble or soprano in music. 13-14 Meane] (a) middle or moderate degree (b) alto in music (OED mean $\mathrm{n}^{3} 8 \mathrm{a}$ ) (c) lowly or wretched. 
He sits all Day lowd-piping on a Hill,

The whilst his flocke about him daunce apace,

His hart with ioy, his eares with Musique fill:

Anon a bleating Weather beares the Bace,

wether; bass

A Lambe the Treble; and to his disgrace

Another answers like a middle Meane:

Thus euery one to beare a Part are faine.

Like a great King he rules a little Land,

Still making Statutes, and ordayning Lawes;

Which if they breake, he beates them with his Wand:

stick

He doth defend them from the greedy Iawes

Of rau'ning Woolues, and Lyons bloudy Pawes.

His Field, his Realme; his Subiects are his Sheepe;

Which he doth still in due obedience keepe.

First he ordaines by Act of Parlament,

(Holden by custome in each Country Towne)

That if a sheepe (with any bad intent)

Presume to breake the neighbour Hedges downe,

Or haunt strange Pastures that be not his owne; He shall be pounded for his lustines,

Vntill his Master finde out some redres.

adjacent, bordering his field frequent, visit regularly put in a pound; energy, activity

Also if any proue a Strageller

From his owne fellowes in a forraine field,

He shall be taken for a wanderer,

And forc'd himselfe immediatly to yeeld,

Or with a wyde-mouth'd Mastiue Curre be kild.

And if not claimd within a twelue-months space,

by; mastiff

He shall remaine with Land-lord of the place.

Or if one stray to feede far from the rest,

He shall be pincht by his swift pye-bald Curre;

If any by his fellowes be opprest,

The wronger (for he doth all wrong abhorre)

Shall be well bangd so long as he can sturre.

Because he did anoy his harmeles Brother,

That meant not harme to him nor any other.

And last of all, if any wanton Weather,

wether

With briers and brambles teare his fleece in twaine,

He shall be forc'd t'abide cold frosty weather,

And powring showres of ratling stormes of raine,

Till his new fleece begins to grow againe:

And for his rashnes he is doom'd to goe

without a new Coate all the Winter throw.

bitten, snapped at

he: the shepherd

beaten till he cannot stir

Thus doth he keepe them still in awfull feare,

And yet allowes them liberty inough;

So deare to him their welfare doth appeare,

That when their fleeces gin to waxen rough,

He combs and trims them with a Rampicke bough,

Washing them in the streames of siluer Ladon,

To cleanse their skinnes from all corruption.

through

awe-inspired

to endure, to suffer

19 to his disgrace] to the former's shame, by outperforming him. 20 middle Meane] i.e., neither bass nor treble: 'the middle voice in a musical composition' (Klawitter). Cf. 12-13n. 21 Part] a single line or element in the harmonized part-song. faine] willing, eager $\left(O E D_{3}\right)$. $29-42$ Unusually specific use of the legal metaphor. $\mathbf{4 4} \mathbf{h i s ]}$ Either the shepherd or the sheep, as the dog belonging to the

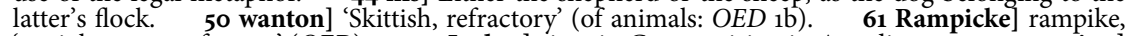
'upright stump of a tree' $(O E D)$. $\quad 62$ Ladon] river in Greece, rising in Arcadia. $\quad 63$ corruption] Then pronounced in four syllables, rough matching 62 in rhyme and metre. 
Another while he wooes his Country Wench

(With Chaplets crownd, and gaudy girlonds dight)

Whose burning Lust her modest eye doth quench,

Standing amazed at her heauenly sight,

(Beauty doth rauish Sense with sweet Delight) Clearing Arcadia with a smoothed Browe When Sun-bright smiles melts flakes of driuen snowe.

Thus doth he frollicke it each day by day,

And when Night comes drawes homeward to his Coate,

Singing a Ijgge or merry Roundelay;

(For who sings commonly so merry a Noate,

As he that cannot chop or change a groate.)

And in the winter Nights (his chief desire)

He turnes a Crabbe or Cracknell in the fire.

make merry, enjoy life cote, cottage

four pence, a small sum

crab apple

He leads his Wench a Country Horne-pipe Round,

About a May-pole on a Holy-day;

80 Kissing his louely Lasse (with Garlands Crownd)

With whoopping heigh-ho singing Care away;

Thus doth he passe the merry month of May:

And all th'yere after in delight and ioy,

(Scorning a King) he cares for no annoy.

harm, vexation

What though with simple cheere he homely fares?

food

He liues content, a King can doo no more;

Nay not so much, for Kings haue manie cares:

But he hath none; except it be that sore

Which yong and old, which vexeth ritch and poore,

disease

The pangs of Loue. O! who can vanquish Loue,

That conquers Kingdomes, and the Gods aboue?

Deepe-wounding Arrow, hart-consuming Fire;

Ruler of Reason, slaue to tyrant Beautie;

Monarch of harts, Fuell of fond desire,

Prentice to Folly, foe to fained Duetie,

Pledge of true Zeale, Affections moitie;

If thou kilst where thou wilt, and whom it list thee,

(Alas) how can a silly Soule resist thee?

By thee great Collin lost his libertie,

By thee sweet Astrophel forwent his ioy.

By thee Amyntas wept incessantly,

By thee good Rowland liu'd in great annoy;

O cruell, peeuish, vylde, blind-seeing Boy:

How canst thou hit their harts, and yet not see?

(If thou be blinde, as thou art faind to bee).

A Shepheard loues no ill, but onely thee;

He hath no care, but onely by thy causing:

Why doost thou shoot thy cruell shafts at mee?

Giue me some respite, some short time of pausing:

Still my sweet Loue with bitter lucke th'art sawcing:

$\mathrm{Oh}$, if thou hast a minde to shew thy might,

Kill mightie Kings, and not a wretched wight.

person, creature

65 gaudy] ornate, elaborate (no bad sense). dight] decked, adorned. $70-71$ As the sun clears the atmosphere after a snowstorm. melts] Plural subject with singular verb, then common practice. 73 Ijgge] jig, both a song and a dance. 75 chop or change] buy and sell, or barter: put on the market. 77 Cracknell] (a) fried pork or crackling (b) a type of biscuit. 96 moitie] half (loosely, a large part) of our emotions. 99 Collin] Colin, Spenser's pastoral name. 100 Astrophel] or Astrophil: Sidney, lover of the star (Stella). There is extended praise of Sidney earlier in the poem. 101 Amyntas] Thomas Watson, author of the Latin poem Amyntas translated by Abraham Fraunce. Watson too (as Amyntas) is praised earlier in the poem. 102 Rowland] Drayton's commonly assumed pastoral name. 103 blind-seeing Boy] Cupid. Blind-seeing] blind yet seeing . 110 sawcing] saucing, flavouring, like sauce to meat. 
Thus haue I showed in my Countrey vaine

vein, manner

The sweet Content that Shepheards still inioy;

The mickle pleasure, and the little paine

That euer doth awayte the Shepheards Boy:

His hart is neuer troubled with annoy.

He is a King, for he commaunds his Sheepe;

He knowes no woe, for he doth seldome weepe.

$\mathrm{He}$ is a Courtier, for he courts his Loue;

$\mathrm{He}$ is a Scholler, for he sings sweet Ditties;

$\mathrm{He}$ is a Souldier, for he wounds doth proue;

$\mathrm{He}$ is the fame of Townes, the shame of Citties:

He scornes false Fortune, but true Vertue pitties.

$\mathrm{He}$ is a Gentleman, because his nature

Is kinde and affable to euerie Creature.

\section{Richard Barnfield Cynthia Sonnet Xv}

From Barnfield's sonnet-sequence Cynthia (1598). Reprinted in Helicon. The text below follows 1598. Barnfield's poems express a homoeroticism notable in the age.

A fairest Ganymede, disdaine me not,

Though silly Sheepeheard I presume to loue thee,

Though my harsh songs and Sonnets cannot moue thee,

Yet to thy beauty is my loue no blot.

Apollo, Ioue, and many Gods beside,

S'daind not the name of cuntry shepheards swains,

disdained

Nor want we pleasure, though we take some pains,

suffer, undergo

We liue contentedly: a thing call'd pride,

Which so corrupts the Court and euery place,

(Each place I meane where learning is neglected,

And yet of late, euen learnings selfe's infected)

I know not what it meanes, in any case:

Wee onely (when Molorchus gins to peepe)

Learne for to folde, and to vnfold our sheepe.

\section{Richard Barnfield Cynthia Sonnet XVIII}

From Barnfield's sonnet-sequence Cynthia (1598).

Not Megabotes, nor Cleonymus,

(Of whom great Plutarck makes such mention,

Praysing their faire with rare inuention)

As Ganymede were halfe so beauteous.

They onely pleas'd the eies of two great Kings,

But all the worlde at my loue stands amazed,

Nor one that on his Angels face hath gazed,

But (rauisht with delight) him Presents brings.

Some weaning Lambs, and some a suckling Kyd,

116 Shepheards Boy] prob. 'young shepherd', not specifically a boy assisting or apprenticed to a shepherd. 120 Courtier ... courts] obvious pun. 122 wounds] Obviously of love. 123 Townes] villages $\left(O E D_{3}\right.$ ), in contrast to 'Citties'. $\quad 125$ Gentleman] (a) mild and courteous person; (b) a person of accredited lineage. 4 My humble love need not shame your beauty. 5 Apollo tended the flocks of Admetus, and turned shepherd to seduce Isse (Ovid, Met. 6.124). Ioue] Zeus or Jupiter: seduced Mnemosyne in shepherd's guise (Ovid, Met. 6.114) to father the Muses. 13 Molorchus] An old shepherd whose son was killed by the Nemean lion later slain by Herakles. Perhaps identified with the constellation of Leo, reigning in midsummer, as a sign to shepherds when to 'folde, and to vnfold' their sheep. (Klawitter). 1 Megabœes] a youth loved secretly by Agesilaus, king of Sparta. Cleonymus] friend and prob. lover of Agesilaus' son Archidamus. 2 Plutarck] whose Life of Agesilaus reports on both Megabœtes and Cleonymus. $\mathbf{6}$ my loue] probably the person loved, Ganymede. 
As lately Ægons man (Damotas) did:

But neither he, nor all the Nymphs beside,

Can win my Ganymede; with them t'abide.

\section{Robert Parry From Moderatus}

Part of a long love-address by the shepherd Hymon to his beloved Mersa in Parry's romance Moderatus (1595). A good example of the many imitations of Polyphemus' invitation to Galatea in Theocritus XI and Corydon's invitation to Alexis in Virgil II.

O Mersa stay, flye not so fast from me,

Faire Mersa stay, no Lestrigonian bruit

brute

Doth make pursuit to feed his lust on thee:

But one, if thou him knew, whose honest suit

Is worthy of the same he doth desire,

And burnes for thee with chast and holy fire.

what he desires

And though my corps doth sauage seeme with haire,

And beard vnkempt an vgly thing to see:

Yet am not I deform'd, for beard is faire,

And hayres decent for such as valiant be.

When strong men fight nyce meacocks they do feare,

And Schools to daunce, and not to fence they reare.

If ought for wealth thou likest, a shepheard's flocke

I haue, and few doth more then I possesse:

For heards I keepe, and eake full many a flocke,

A thousand kine do feed on finest grasse,

Of swine greate store, and cattell fat withall,

And goates in rockes their bleating kiddes to call.

Store of throme milke in season still I haue,

My chest is full of cheeses new and olde,

Take what thou wilt, thou need'st not ought to craue,

For all I haue is thine, whereof be bolde.

want, lack

My selfe also (though thou the same refuse)

Is at thy becke, thereof to take the vse.

If thou would'st daine to walke sometimes with me,

Gather I would the Apples mellowe fine,

And clustring grapes with full ripe figges for thee,

And Filberds kernels eake if thou were mine:

With these I would thee cramme my prettie peate,

hazelnuts

darling, sweeting

body; embrace

?bind, embrace

And eke the same in folded armes combine,

With thousand kisses would I presse thy lippe:

Doubt not of these: to pittie eke incline,

And come with me (least that my paine increase)

To cure my care, and thraldome to release.

revoke, remit

By pleasant springs our ease then we will take,

Embracing there, fweete sleepe will vs depriue

Of wanton sport: when semblance we do make,

12 Damotas] A shepherd in Virgil III. He offers a heifer (colour unspecified) as stake in a singingcontest (III.29-31), not a gift to his love. 2 Lestrigonian] monstrous like the cannibal race of that name in Odyssey X. 10 decent] fitting, appropriate: root Lat. sense. 11-12 When strong men fight, cowards are afraid, and set up dancing- rather than fencing-schools (i.e. practise the effeminate arts of peace). 19 throme] curdled, clotted: from Gk thrombos, a clot or lump - artificial rusticity from a learned source. $\quad 39$ semblance ... make] ?provide a model or example. 
Not howe with gaine and lucre for to thriue,

(In silent shades) but of meane mirth and ioye,

When greatest minde we haue to wanton toye.

The hanging boughes and murmuring streame will striue,

compete

Who best may please and worke our sweete content,

While raging force of Summers heate doeth driue.

Howe deare to me would be thy sweet consent:

Alas thou nought doest weigh my giftes, nor loue,

Whose heart faire speach, nor weeping teares may mooue.

\section{Francis Sabie Damon's Ditty}

Part of Eclogue III in Francis Sabie's Pan's Pipe (1595). Coridon's rejoinder to Damon in a singing contest. Quantitative metre. Punctuation modified.

Damons dittie.

When Ioue first broken had the Chaos ancient,

And things at variance had set at vnity:

When first each element, fire, aire, and water,

And earth vnmooueable were placed as you see:

A plow-man then he made, he made a sheep-feeder,

The plow-man he made of stonie progenie,

Rebelling to the plough, like to the flinty field,

Hard-hearted, full of hate: The noble sheepfeeder

He made of a milde and lowlie progenie,

Gentle and very meeke, like a sheep innocent,

Oft times he to the Gods sacrifice offered,

One while he gaue a Lambe, one while a tidy calfe,

Since that time sillie swaines and noble sheepfeeders

Haue bene much visited and loued of the gods.

Go to my merie Muse, sound out vpon a pipe

Shepheards antiquities, and noble progenie.

A shepheard was Abram, Lot was a sheep-keeper,

Great Angels, from aboue came many times to these,

Yea Ioue omniregent leauing his heauenly seat

Talkt with them, men affirm, as they sate by their heards.

Of them sprung valiant and noble nations.

Go to my merie muse, sound out vpon a pipe,

Heardsmens antiquitie, and noble progenie.

Paris sate with his flocke, in Ida redolent,

stock, origin with a grudge against his own plough

When he was made a Iudge to Venus and Iuno,

And Pallas beautiful, three mighty goddesses.

Go to my merie muse, sound out vpon a pipe

Heardsmens antiquity and noble progenie.

Dauid sate with his heard, when as a Lyon huge

And eke a Beare he slew, this little pretie swaine

Kild a victorious and mightie champion,

Whose words did make a king and al his host to feare

And he ful many yeares raign'd ouer Israell.

Go to my merie Muse, sound out vpon a pipe,

Heardsmens antiquitie, and noble progenie.

Moses fed sillie sheep, when like a fiery flame

Iehouah called him out from a bramble bush,

41 (In silent shades) referring to what follows, not what precedes. meane] (a) lowly, humble (b) mod-

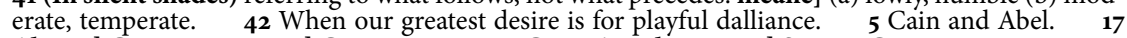
Abram] Genesis 12.16. Lot] Genesis 13.5. 18 Great Angels ... came] See e.g. Genesis 18, 19. 19-20 God talks and appears to Abraham in Genesis $12.7,17,18.19$ omniregent] ruling over all things (not in $O E D) . \quad 24$ Paris ... in Ida] Paris, prince of Troy, was brought up by shepherds on Mount Ida, where he judged the contest in beauty between Juno, Venus and Pallas or Minerva. 29 David 'keepeth the sheep' in 1 Samuel $16.11,16.19,17.15$. Lyon ... Beare] 1 Samuel 17.34-6. 31-2 mightie champion] Goliath. For his striking terror in King Saul and his men, see 1 Samuel 17.1-11. 36 Moses kept his father-in-law Jethro's sheep: Exodus 3.1. sillie] a customary epithet for sheep, combining meanings like 'innocent', 'harmless', 'helpless'.

37 Iehouah called him] Exodus 3.2-4.17. 
$\mathrm{O}$ what great monuments and mightie miracles

In Egypt did he shew, and to king Pharao.

Iordans waues backe he droue, Iordan obeyed him.

Go to my merie muse, sound out vpon a pipe,

Heardsmens antiquitie, and noble progenie.

Angels brought (men afirm) to busie sheepfeeders,

In fields of Bethlehem newes of a Sauiour,

Before Magicians and noble Emperours,

Th'infant laid in a crib, Ioues mightie progenie,

Mankinds ioy, life, and health cuntrie swains viewed:

Cease now my mery Muse to tune vpon a pipe

salvation Heardsmens antiquity and noble progenie.

\section{Robert Sidney 'SHePherd, I'FAITH NOW SAY'}

'Pastoral 2' in an autograph notebook of Robert Sidney's poems, originally at Warwick Castle and now in BL MS Addl 58435. Punctuation largely added in this edition.

Pastoral 2. Shepheard, Nymphe.

Nymphe. Shepheard, iffaith now say how wel thow doest loue me.

Shepheard. Wonder and ioye kan onely tel how I loue thee.

Nymphe. Tel me how much?

Shepheard. O neuer such heauenly fayre mayde owr feelds did bless nor euer wil, O to me vnkind Shepherdess but $\mathrm{O}$ deer stil.

Nymphe. These are but words, I must proue thee test Now doe not mocke Whether doest thow loue better mee or thy good flocke.

Shepheard. My sheep alas My loue once was. Now my best wool growes on thy care, thow art my stocke. thy rosy cheekes, my ritch feelds are: thine eyes, my flocke.

Nymphe. Ye retchless felloes often doe their goods despyse,

But mee doest thow beare more loue to or to thine eyes?

Shepheard. Mine eyes to mee no pleasure bee Since that they kannot thee stil see, wealth of my sight, or that they kan, astraide from thee, see other light.

Nymphe. Thine eyes perhaps thow doest reproue for their bad choice.

but in thy lyfe more or thy loue doest thow reioice?

monuments] ?memorable deeds (not in $O E D$ ), ?covenants, events signifiying alliance with God (cf. $O E D_{3}$ ). $\quad 40$ It was Joshua who made the Jordan recede (Joshua 3-4). Moses parted the Red Sea (Exodus 14.21-2). See also Psalms 114.3-5. 45 Magicians] Taking magus/magi in the usual sense of 'magician'. 6-7 heauenly fayre mayde] Either describing or addressing the shepherdess. 17 my best wool] my greatest wealth or profit. thy care] my thoughts about you, which I tend like sheep. 25-30 I feel sorry that my eyes cannot see you all the time, but that they see other things instead. 
Shepheard. My lyfe is that

I least ioye at,

Since all the time I lou'd not thee

as lost I holde:

and what remains, few howers wil bee

thee to beholde.

Nymphe. What's past thow hast forgot, nor now

Knowst what wil bee.

but at this time more louest thow

thyself or me?

Shepheard. Myself I nere

shall loue, I feare.

ne'er, never

Thy cares are mine, thow art my wil:

I loue with thee.

myself I shall not loue vntil

thow louest mee.

Nymphe. Tush, these fine words do no whit please.

make known thy loue,

for if thow car'st for none of these, what kanst thow loue?

Shepheard. My cares are one,

for thee alone.

Nymphe. Like what then doest thow loue, tel this. thow weariest mee.

Shepheard. Like thyself: like nothing els is my loue to thee.

Nymphe. Like me? how's that? Shepheard. fayre as Sunbeames,

louely as day,

sweet as fresh flowers, fine as cleer streames,

ioyful as May.

lips of cherries,

hands of lillies,

Eyes stars of fyre, brest fram'd in snow,

hart (ah) heauen hy:

Blessed Nymphe, shepheards thus thee know and thus loue I.

\section{Robert SIDNEY 'DAY WHICH SO BRIGHT DIDST SHINE'}

'Pastoral. 9' in an autograph notebook of Robert Sidney's poems, originally at Warwick Castle and now in BL MS Addl 58435. Punctuation modified and line initials standardized. The specifically pastoral features are confined to the fifth stanza, which appears to have been added later.

Pastoral. 9

Day which so bright didst shyne, how darck art thow?

Ayre euen now sweet, how doe mists in thee growe?

Sea late so calme, how high wrowght are yow now?

Brooke once so cleer, how doth sand in thee flowe?

Trees so full blowen, how bare now is each bow?

Feelds how doe weeds, your ritch corn ouergrowe?!

Day, ayre, sea, brooke, trees, feelds: say, vain's all trust.

The fayrest proues vntrew, the best vniust.

Frosts how yow print the earth with witherd face!

Storms, how with lightning yow heauens mantle lyne!

Fluds, how all to deuowr, yow hast yowr pace!

Fyre, how in beames of ruin yow doe shyne!

Plague, how with killing arms, yow all embrace! 
Dearth, how what death hath spared, in yow doth pine!

Frosts, storms, fluds, fyre, plague, dearth, answer with mee

echo, repeat

Our goods are ghests, owr losses homemates bee.

Thus whyle the worlds fayre frame such chang approues

Shee will as fals as it bee, as as fayre.

Thus from one mischeef, whyle another moues,

I feel the ils, which worst cannot impayre.

Whyle shee her fayth a prize sets to new loues,

In mee faith raines on wrongs, loue on despayre.

Day, ayre, sea, brooke, trees, feelds, her falshood knowe.

Frosts, storms, fluds, fyre, plague, dearth my merites showe.

Hencefowrth then may Fyre giue light to the Day:

And cleerest Ayre, a nurse to Plagues bee fownd.

Hencefowrth may Frosts shutt vp the Seas large way

And Storms all usefull Trees teare from the grownd.

Hencefowrth no frutes of Feelds Dearth banish may,

And smalest Brookes, in Fluds all may surrownd,

Since beauty growes the bed where treason lyes

And faith is made the stayre to miseryes.

comes out, originates

This sayd, the Shepheard, as now with new eyes

Lookd vp and saw his flock which had not strayde,

His owne, which hee for vnknown did despise

Whyle it stil kept his steps, his voice obeyde.

Then in his sowl the images did ryse

Of due and vniust loues: and greeuing sayde

Ah Flock so louing, so regarded not:

How my faults are your praise, your wrongs my blott.

path, way up

So hee whose senses foyld, no ease could breed,

In her faults, safety to his ruine fownd.

Those the good Dolfin were, the sauing threed,

Which stayde the seas deep iawes, the maze vnwound.

He sees, how sweet did Innosens poisons feed,

How strongly follyes easy fetters bownd.

Now loues his wrongs: sais, vnder shame and sinn

I had bin lost, if lost I had not bin.

\footnotetext{
$\mathbf{1 6}$ ghest] guests, i.e. temporary visitors (cf. homemates, 15). 18] She will be both as fair and as false as the world itself. 20 which ... impayre] which the worst cannot make any worse. $21-2$ While she offers her faith as a reward to new lovers, my own faith results in ill-treatment and my love leads to despair. 24 merites] (ironically) deserts, requital. 25 People will have to light fires by day in the absence of the sun. 27 Ice block the open seas. 29-30 May no harvest henceforth banish dearth, and let the smallest brooks flood everything. 31 bed] breeding-ground, with a play on the usual sense. $\quad 33$ as now ... eyes] as though seeing for the first time. $\quad 35-6 \mathrm{He} \mathrm{had} \mathrm{neglected}$ his familiar flock for an unknown love, yet it remained faithful to him. 40 my faults ... blott] My faults (i.e, my neglect of you) show your virtue (in remaining faithful to me); the wrongs you have suffered are my shame. $\quad$ 41-2 The harm he suffered could not be made good, but his mistress's unjust neglect (her faults) saved him from further ruin. 43 Dolfin] Said to lead sailors to safety in a storm. Perhaps alluding to the musician Arion, saved from drowning by a dolphin. threed] like Ariadne's thread guiding Theseus through the labyrinth (maze, 44). 45-6 He sees how pleasingly innocence leads to vices, and how strongly and easily one is enchained by folly. $\quad 47-8 \mathrm{He}$ is now grateful for the wrongs he has suffered, declaring that if he had not been 'lost' (disappointed) in love, he would have been 'lost' (destroyed) through shame and sin.
} 


\section{William Smith Chloris Sonnet 3}

From William Smith's sonnet-sequence Chloris, or the Complaint of the Passionate Despised Shepheard (1596).

Feede silly sheepe although your keeper pineth,

Yet like to Tantalus doth see his foode.

Skip you and leape, now bright Apollo shineth,

Whilst I bewaile my sorrowes in yon wood.

Where wofull Philomela doth record,

repeat, narrate

And sings with notes of sad and dire lament,

The tragedie wrought by hir sisters Lord,

Ile beare a part in hir blacke discontent.

That pipe which erst was woont to make you glee,

Vpon these downes whereon you carelesse graze,

Shall to hir mournfull musicke tuned be.

give you joy or pleasure carefree

Philomela's

Let not my plaints poore lambkins you amaze

There vnderneath that darke and duskie bowre,

Whose showres of teares to Chloris I will powre.

pour

\section{William Smith Chloris Sonnet 5}

From William Smith's sonnet-sequence Chloris, or the Complaint of the Passionate Despised Shepheard (1596).

You Fawnes and Siluans, when my Chloris brings

Hir flocks to water in your pleasant plaines,

Sollicite hir to pitie Corins stings,

pains, sufferings

The smart whereof for hir he still sustaines.

For she is ruthlesse of my wofull song.

My oaten reede she not delights to heare.

O Chloris, Chloris, Corine thou dost wrong,

Who loues thee better than his owne hart deere.

The flames of Aetna are not halfe so hot,

As is the fire which thy disdaine hath bred.

Ah cruell fates, why do you then besot

Poore Corins soule with loue when loue is fled.

Either cause cruell Chloris to relent,

Or let me die vpon the wound she sent.

\section{John Dickenson Description Of Arcadia, From The Shepherd's Complaint}

John Dickenson's The Shepheardes Complaint (1596) links a number of poems by a thin romance narrative. The poem below, inset in the prose near the start of the work, describes Arcadia, where the narrator is transported in a dream.

Fields were ouer-spred with floures,

Fairest choyce of Floraes treasure:

Shepheards there had shadie bowers,

Where they oft repos'd with pleasure:

Meadowes flourish'd fresh and gay,

Where the wanton heards did play.

frisky, playful

Springs more cleare than chrystall streames,

Seated were the Groues among,

Thus nor Titans scortching beames,

placed, located the sun's

2 It was Tantalus' punishment in Hades to stand amidst the fruit and water that he could not reach. The lover sees Chloris but cannot win her love. 3 Apollo] the sun-god, hence the sun. 5-7 Philomela ... hir sisters Lord] Philomela, turned into a nightingale, mourns her ravishment by her brother-in-law Tereus. 12 amaze] alarm, frighten $\left(O E D_{3}\right)$. $\quad 2$ Flora] goddess of flowers. 5 flourish'd] ?in root sense, 'bloomed full of flowers'. 
Nor earthes drouth could shepheards wrong,

Faire Pomonaes fruitful pride,

Did the budding branches hide.

Flockes of sheepe fed on the plaines,

Harmelesse sheepe that rom'd at large:

innocent

Here and there sate pensiue Swaines,

Waiting on their wandring charge:

Pensiue while their Lasses smil'd,

Lasses which had them beguil'd.

Hils with Trees were richly dight,

Valleis stor'd with Vestaes wealth:

Both did harbour sweet delight,

Nought was there to hinder health.

Thus did heauen grace the soile,

well-being, ?happiness

Not deform'd with workemens toile.

Purest plot of earthlie mould,

Might that land be iustly named.

Art by Nature was controul'd,

Art which no such pleasures framed:

Fairer place was neuer seene,

\section{John Dickenson From The Shepherd's Complaint}

Lament of an unnamed 'mournful shepherd' in Dickenson's The Shepheardes Complaint (1596). Quantitative metre. The unhappy lover's obtaining consolation from nature is a common Petrarchan theme.

If plaints could penetrate the sun-bright top of Olympus,

Whose light's sweet comfort these eies, eies moist with abundance

Of down-streaming teares since wrong'd by Fancy, beheld not:

Or th'earth yeild passage to my voice, voice hoarse with a thousand,

More then a thousand mones, sending them downe to the deepe vawts,

Where Pluto Lord of Acheron enioyeth his Empire,

vaults,

Or some blustring blasts conuey by force of a whirle-wind,

[caverns

These my sad laments to the wide world there to be talk'd of:

Gods that dwell on high, and Fiends that lurke in Auernus:

Men that liue on earth, or saile through watery Tethys.

Gods, whose diuine shapes loues force hath oft metamorphos'd,

Fiends, whose hellish hearts no remorse, no regard euer entred,

Men whom loues deepe wounds haue prostrate laid at his altars,

All these would pitie me, but vaine wish can litle helpe me:

Yet though wish be vaine, my sad complaints I will vtter:

Though to my selfe I repeat as oft ere now I repeated,

Mones mix'd with salt teares for th'ease of harts heauy burthen,

Heart prest with sorrow, heart with care heauily loaden.

When Fortunes doome was equall, and loues fury forcelesse,

Arcadian pastures tending my flocke I frequented

Chiefe mongst the shepheards for wit, for beauty, for all things.

Venus

Oft did I win both prize and palme, when our ioly meetings

And yearly feastings solemnisd were to the great God

Pan, the God of shepheards soueraigne defender of all flockes,

And Laurell garland hath crown'd me conqueror often.

11 Pomona] goddess of fruits and orchards. 11-12 The branches were hidden by the abundant fruit. 15 pensiue] gloomy, melancholy, in contrast to the smiling shepherdesses. 20 Vesta] goddess of the hearth, thus of the prosperity of both the home and the state or commonwealth. Arcadia is presented as a prosperous land, unlike its reality. $\quad 24$ As in the Golden Age and in Paradise, the soil spontaneously

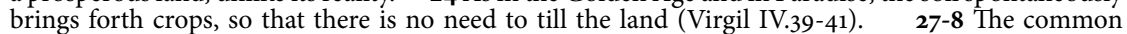
Renaissance theme of art in accord with nature, as against art that defies or destroys nature. $\quad 28$ i.e. Art alone could not create such delights. 6 Acheron] a river of the underworld, Pluto's realm. 9 Auernus] a lake near Naples, supposedly the entrance to the underworld. $\quad$ 10 Tethys] wife of the god Oceanus, hence the ocean. 25 conqueror] in singing contests. 
Dametas pend sweet ditties, with comely Paloemon:

And with him Lycidas, and mongst Neat-heards many gallants:

But none of these durst, though each of these had a mistresse,

Striue in praise of them with me, fearing to be vanquish'd:

Yet Lycidas had a choyce, a faire choyce, louely Felisa.

Nymphes would sit in a round comming fro the chase to refresh them

chosen or beloved person

Listning vnto my songs, and vnto the tunes that I gaue them.

With the Satyres lightly skipping, where Flora reuested,

And with sommers pride, earthes faire greene mantle adorned,

And th'hornfeet halfe-gods, with all the progeny rurall:

The wind-wing'd Naiads spring-haunting Naiades, all these

Did me requite, whose pen with praise they gently rewarded.

Each faire shepheardesse was with my company gladded:

Me Galathea fauourd, yet was Galathea reiected:

Me faire Phillis lik'd, but Phillis could not I fancy.

Thestylis and Daphne, both faire, both woo'd me with offers:

Thestylis and Daphne, both faire, were fondly repulsed:

Kind girles, fit epithete for girles so kind, but vnhappy.

The snow-white Hyalus worlds wonder, faire as Adonis,

Scornd Nymphes allurements, and Heardmens gifts he refused:

But me the boy did loue, and in coole shade I remember,

With me reposing oft, Philomeles cleare notes he resembling,

With voyce Angelicall, my ditties sweetly recorded.

But nor he, nor they could my fond affection alter,

Whose care-cras'd hart, and loue-pierc'd thoughts fair Amaryllis

Held in pleasing thrall: for then it seem'd so: but aie me,

Now I repent too late, too late I repent that I thought so.

Her did I greet, and fairly salute each morne with a present:

But proud girle, coy girle, though presents some she receiued,

Yet she refus'd the most, and better not be receiued,

Then be receiued so: with feigned smiles she rewarded,

My not feind good-will: and when by chance I beheld her,

Walking on the plaines, if I did draw neere to salute her:

Then wing'd with desdaine, more swift in pace she returned,

Then light-foot Daphne shunning the sight of Apollo,

Flying his pursute and bootlesse chase, with a stubborne

And peruerse conceit: like her was coy Amaryllis.

put on new garments

For me she loath'd, although her I lou'd, and in many ditties,

(Few such ditties were) her beauties praise I recounted.

Fames shrill eternall trumpet through Arcadie sounded

Her matchlesse vertues, and gentle fame the reuenger

Of my causeless wrongs, her coynes hath so recorded.

(Fame which from my penne large matter fully receiued)

That sea-bred Dolphins, and misform'd waterie Monsters,

Shall in the welkin sport them with loftie Laualtos,

And saile-bearing pine glide through thin aire with a Syren

Swimming neere the sterne, and Ioues bird lodg'd in Olympus,

The royall Eagle, chiefe Lord and lordly regarder

Of the featherd brood with his wing'd army repairing

Downe to the late-left boure of Nereus and Thetis and all,

That lodge in watrie cabinets, shall sooner abide there,

graciously, nobly

foolishly

imitating

And for euer dwell there then fames sound, which memorised

Her desdainefull pride, be cleane forgot by the shepheards,

Or mongst th'Arcadians my sorrowes not be remembred.

Yet vaine was my labour, small comfort thence I receiued;

futile

report

lavoltas, a lively dance

ruler, overlord

passing, resorting

chambers

33 Flora] goddess of flowers. 35 hornfeet] with feet like horned beasts, hooved: the wood-gods. 48 recorded] sang, especially like a bird $(O E D \quad 3$ b). $\quad 60$ Daphne] who fled Apollo's pursuit and was transformed into a laurel. $\quad 64$ Few ... were] Few songs were so fine. $\quad \mathbf{7 1}$ saile-bearing pine] masts made of pine trunks, hence ships. $\quad 73-5$ The eagle and all other birds will descend to the depths of the ocean. 75 Nereus] an ocean god. Thetis] one of his daughters the Nereides, sea-nymphs. 77 memorised] recorded, preserved the memory of. 
For she lou'd an other though farre vnfit to be riuall

With me which did surpasse him that nor very witty,

Nor verie comely was: all Arcadie knowes that I feine not,

Nor fond boasting vse, yet was he receiu'd, I reiected.

Pardon faire, fairer then any fairest Amaryllis,

Pardon sweet, more sweet then any most sweet Amaryllis,

Though thou absent be, yet craue I pardon O pardon,

Those my wrathfull lookes ore-cast with frownes neuer vsed,

Till thy misdeeming censure did wrong so the shepheard,

Whose match for loyall seruice wide world neuer harbourd:

not habitual,

Except loues martyr, loues wonder gentle Amintas.

O pardon those impatient thoughts which I did vtter

In blasphemous words, blaspheming thee Amaryllis,

Cursing those graces wherewith nature did adorne thee,

And on thy pride exclaiming: fond passion vrg'd me,

Then when I saw my riual speed, my selfe so reiected,

Then did it vrge me so, that mou'd with more than a wonted

Griefe of mind, I vowd to renounce the state of a shepheard,

State too good for me: which vow too well I remembred.

For leauing all the pleasures which Arcadie yeelded,

Cleare springs, faire fountaines, greene meadows, and shady valleis

Where, while flocke did graze, sometimes I sweetly reposing,

Did meditate on loue, when loue was friend to my fancy,

Leauing these, loathing my selfe, looking for a speedy

End of care, I remaind alone, all companie shunning.

To grace th' assemblies of Shepheards oft I refused,

Sheep were left a pray to the wolfe, sheep which me beholding,

Droupt in deepe sorrow, with bleating seemd to bemone me,

Gentle sheepe, kinde beasts, more kinde then coye Amaryllis.

Thus I resolu'd to seeke a place, fitte place for an abiect,

Found this darksome groue, since when still heere I remained,

outcast or miserable person

Heer to the woods I waild: woods seemd to grone when I wailed,

Heer to the trees I mon'd, trees seemd to bend when I mon'd me,

Heer to the winds I mournd, winds sent calme blasts to releiue me.

[uncharacteristic

succeed, prosper (in love)

Thus to the woods, to the winds, to the trees, to the flouds, to the fountains

And to the thinnest aire, to the valleis and to the mountains,

Framing sad laments, more comfort haue I received

From these, then from the coye lookes of proud Amaryllis.

Kinde Eccho was mou'd, her like mishap she remembring,

Ioyn'd her mones to mine, my last words gently repeating:

And the chirping birds attentiue vnto my sorrowes,

Chang'd their pleasant notes for mournfull tunes to bewaile me.

But why talke I thus? all these could smally relieue me,

Slowe death when com'st thou? slow death can wholy release me.

'small-ly', little

\section{7 'IN A FIELD FULL FAIR OF FLOWERS'}

From BL MS Harley 6910, where it is attributed to 'P. S.'. Punctuation largely supplied in this edn.

In a field full fayer of flowers

Where the Muses made their bowers

And more sweeter hony grew

Then the sence of Nature knew,

Preerie sweete with heartsease springing

'prairie', meadow

While sweet Philomel was singing,

Coridon and Phillis fayer

Went abroad to take the ayer,

81 an other] Later in the story, Amaryllis repents of marrying this other, unworthy lover, and is brought to death by her pride, which had made her compare herself to Diana. 85-90 He begs Amaryllis' pardon for the 'wrathfull lookes' he finally cast on her after she grossly misjudged him. 91 Amintas] the hero of Thomas Watson's Amyntas. 95 exclaiming] upbraiding, condemning (OED 2a). 108 Droupt] Applies to both shepherd and sheep. 4 Than the sense(s) had ever experienced. 
Each in absence long diseasde

But in presence either pleased.

unhappy, afflicted

Where begun their pritle pratle:

Ther was prety title tatle.

Coridon quoth shee a tryall

Must in truth haue no denyall.

True quoth he and then he, proved,

well I hope shalbe beloued.

Yea Quoth shee but where is true loue?

Where quoth hee both you and I loue.

Yea quoth shee but truly tell me

And in these fewe letters spell me.

\section{O R I D O N}

Where was I when these were gon?

Sweet quoth hee how to devise the

and by letters to suffice the?

P H I L L I S

All my ioye both was and is.

In my hart thou art inclosed

Where thy loue cannot be losed.

Trust me Phillis, in good sadnes,

Is it not a very maddnes

seriously speaking

To refuse a good thing offered

when it was of good will proffered?

And what better thing to prooue

Then how good a thing is loue?

Many a wench, and if shee knew it,

What it were and how to vse it,

In her hart full soone woud rue it

When shee thought shee did refuse it.

It is a humor that doth tickle

And like Thistle downe doth prickle

Veines and sinnewes, witts and senses

tingle, excite

With the sweete of such deffences

Which dame Nature gaue to me

Onely to bestowe on thee.

Take it duly euen and morrowe,

It will driue out care and sorrowe.

Vse it kindly, sweetly trie it,

Then vnto thine hart applye it.

\section{The Unknown Shepherd's Complaint}

First published in Thomas Weelkes's Madrigals to Three, Four, Five, and Six Voices (1597), then in the section 'Sonnets to sundry notes of Musicke' in The Passionate Pilgrim (1599), and in Helicon. No author named in any source. Helicon text followed below. Its title suggests a narrative source, but none has been found.

The vnknowne Sheepheards complaint.

My Flocks feede not, my Ewes breede not,

My Rammes speede not, all is amisse:

Loue is denying, Faith is defying,

Harts renying, causer of this.

All my merry liggs are quite forgot,

renaying: denying, renouncing

10 But each pleased by the other's presence. 13-16 She tells Coridon that if he puts his love to trial, he must abide by the outcome. Coridon agrees, hoping that, if he proves his love, he will be loved by Phillis in turn. $\quad 20$ spell (a) tell $\left(O E D\right.$ spell $\left.\mathrm{v}^{1}\right)(\mathrm{b})$ spell out by letters. 22 when these were gon] i.e. while Coridon was absent. these] the letters spelling his name. 33-4 i.e. The fact that love is of good will proffered' indicates what a good thing it is. 39 humour] fluid, juice: perhaps a 'simple' extracted from a plant, hence medicine to be 'taken duly' (45), but obvious sexual innuendo. $\quad \mathbf{4 2}$ sweete](a) pleasure, delight (b) ?sweat, exertion (c) ?literally sweat, exudation, with sexual innuendo. deffences] weapon(s). $\quad 2$ speede] (a) thrive, prosper' (b) run swiftly. $\quad 5$ Iiggs] songs as well as dances; also jests or sports. Weelkes has gigs (fun, merriment: OED 6b). 
All my Ladies loue is lost God wot.

Where her faith was firmely fixt in loue,

There a nay is plac'd without remoue.

One silly crosse, wrought all my losse,

O frowning Fortune, cursed fickle Dame:

trifling misfortune or affliction

For now I see, inconstancie

More in women then in men remaine.

In black mourne I, all feares scorne I,

Loue hath forlorne me, liuing in thrall:

Hart is bleeding, all helpe needing,

$\mathrm{O}$ cruell speeding, fraughted with gall.

My Sheepheards pipe can sound no deale,

My Weathers bell rings dolefull knell.

My curtaile dogge that wont to haue plaide,

Playes not at all, but seemes afraide:

With sighs so deepe, procures to weepe,

In howling-wise, to see my dolefull plight:

How sighs resound, through hartlesse ground,

Like a thousand vanquish'd men in bloody fight.

lot, outcome; laden, burdened

not at all

wether's

cut-tailed

affects, contrives

Cleare Wells spring not, sweet birds sing not,

Greene plants bring not foorth their die:

Heards stand weeping, Flocks all sleeping,

Nimphs back peeping fearefully.

All our pleasure knowne to vs poore Swaines,

All our merry meeting on the Plaines,

All our euening sports from vs are fled,

All our loue is lost, for Loue is dead.

Farewell sweete Loue, thy like nere was

For sweete content, the cause of all my moane:

Poore Coridon must liue alone,

Other helpe for him, I see that there is none.

\section{Thomas Bastard To Thomas Strangways}

Sonnet no.23 in the seventh book of Bastard's Chrestoleros. Seuen bookes of Epigrames (1598).

Strangwaies leaue London and her sweet contents,

Or bring them downe to me to make me glad,

And give one month to country meriments,

Giue me a fewe daies for the yeeres I had.

The Poets songs and sports we will reade ouer,

Which in their goolden quire they haue resounded

And spill our readings one vpon another,

And read our spillings sweetly so confounded.

mixed

Nulam shall lend vs night in midst of day,

When to the euen valley we repaire,

When we delight our selues with talke or play,

Sweete with the infant grasse and virgine ayre.

These in the heate, but in the euen later,

Weele walke the meads, and read trowts in the water.

smooth, level

evening

trace

[the movements of

$\mathbf{1 4}$ forlorne] destroyed, ruined (See OED forlese 2a). $\quad 23$ hartlesse] Weelkes has the attractive reading harcklesse (not harking, unheeding). $\quad 26$ die] dye, colour: i.e. green plants grow pale. their] MS Harley 6910 has your, making 25-6 a series of commands or injunctions rather than a report. sleeping] ?inert or motionless (OED sleep v4, n4b). $\quad 33^{-4}$ thy like ... moane] No-one can induce or inspire sweet content as you do, though you make me suffer. 34 moane] grief. 4 I have spent years here, you can spend a few days with me. 6 quire] pun: (a) choir (b) book. 7 spill ... another] read passages in quick succession. 9 Nulam] From the context, an (unidentified) forest in a valley, perhaps in Dorset where Bastard held a living. 


\section{Henry Lok Sonnet from Sundry Christian Passions}

Henry Lok's series of religious sonnets, Sundry Christian Passions (1593), was reprinted as an appendix to Ecclesiastes, Otherwise Called the Preacher (1597), a paraphrase of the Book of Ecclesiastes. The text below follows the latter. The poem inverts the imagery of Psalms 23, making it explicitly allegorical with reference to New Testament theology of sacraments and grace.

Among thy sheepe ô Lord I seemd to feed,

By Sacraments receiu'd into thy flocke,

By preached word I watred was indeed,

And works with fleece did seeme inritch my stocke:

enrich

But at my doore true faith did neuer knocke,

(Which should be shepheard of my soules defence)

But (thiefelike) fond affections reason mocke,

And by the window of my wilfull sence

Do enter to my heart, and steale from thence

Each motion of amendment which doth rise,

And shepheardlesse of grace, transported hence

repentance, reform

10

By Sathan (rau'ning woolfe) in fearefull wise,

I call to thee (sweet Sauiour) shepheard true,

Teach me to know thy voice and thee insue.

follow

\section{Nicholas Breton 'The LoRd he is My SHePherd'}

A free rendering of Psalm 23 from Breton's The Soules Heavenly Exercise (1601).

The lord he is my sheepheard, that doth feede

My soule full sweetely by the riuer side,

And will not let mee nibble on a weede,

Where hee doth knowe there may my hurt abide.

dwell, be present

He will not let the Wolfe come neere the folde,

Where he hath laide His louing flocke to rest,

Nor will hee let them bide the bitter colde,

But sweetly warmes them from his sunny breast.

suffer

Along the pastures faire, and fresh, and greene,

He leades them forth, for their best liues behoue,

Nor euer yet was there confusion seene

Of any flocke, that hee doth fairely loue.

behoof, benefit ruin, perdition fully, truly

Hee doth not robbe them of a locke of wooll,

But kindely calles them to their fairest folde,

Nor doth he vse the cunning how to cull

The fat from leane, nor young ones from the old.

But all alike hee loues whom he doth keepe,

And if that any stray out of the plaine,

Vpon his shoulders hee brings home that sheep,

And sings for ioy to haue his lambe againe.

The winters worme, nor yet the summers flie

Can once anoy the smallest lambe of his:

But they shall still encrease, and neuer die,

But euer liue in euerlasting blisse.

He giues them water from the liuing rocke,

Where neuer yet did harmefull thought arriue:

2 Sacraments] no doubt chiefly baptism, whereby the Christian is received into the Church (flock). 7 affections] emotions: the familiar conflict between reason and passion. $\mathbf{8}$ by the window] making surreptitious entry, whereas true faith enters by the door (5). Cf. John 10.1-2. sence] Window (10) specifically suggests the eye. 4 which he know may harm me. 15-16 i.e. He does not destroy or eliminate anyone. 21 winters worme] ?a parasite that afflicts sheep shut indoors in winter. 25-6 Breton's rendering clearly suggests baptismal water, which makes the Christian a member of the Church or body of Christ, and thus saves him from original sin (harmefull thought). 
Yea hee so dearely lou'd his little flocke,

That hee did die, to saue his sheepe aliue.

But shall (oh Lord) this sinfull soule of mine,

So many waies with miseries opprest,

Become a lambe of that faire flocke of thine,

And feede with them when they are fairely blest?

Then, when I heare my louing sheepeheard call

My faithfull soule vnto her fairest folde,

I will forsake these worldly pleasures all,

And only ioy my Iesus to beholde.

\section{Nicholas BRETON 'UPON A DAINTY HILL'}

From BL MS Addl. 34064. Punctuation and line-initials regularized.

Vpon a deintie hill sumtime did feede a flocke of sheepe

pretty, pleasant

Wher Coridon woulde learne to clyme his litle lambes to keepe.

tend

Wher Roses with the viollettes sweete did growe amonge the bryres,

Where muses and the nymphes did meete to talke of loues desires.

There Choridon when corne was ripe for his sweete Phillis sake

Wolde playe vpon his countrey pipe and all his musicke make.

Now when he had but sounded owte the begger and the kinge,

The birdes wold all be flockt aboute to helpe the Shepperde singe.

And euerie one began to frame to sett in tune her throate

Till daintie Philomela came who kild them with a note.

For she, sweete mowse, had suche a vaine within a hawthorne bushe

As made the sellie Shepperde swayne himselfe to be at hushe.

But as thus Philomela satt recordinge of a grownde,

And all the rest did murmure att the sweetnes of her sownde

Came Phillis sweete owte of the wood and in her hand a lute

Who when she playde but Robin Hoode strooke Philomela mute.

And when she but began to singe Of shepperdes and their sheepe

She made the litle woodes so ringe They wakte me from my sleepe.

14 the begger and the kinge] prob. ballad of King Cophetua and the beggar-maid. 20 kild them with a note] silenced them with her singing. mowse] a term of endearment. 26 recordinge] (of a songbird) singing softly $(O E D$ 2). grownde] plain-song, melody (OED 6c). $\quad 31$ Robin Hoode] any of numerous songs and ballads on the subject. but] only, no more than. Suggests a specially simple or commonplace piece. 


\section{Nicholas Breton 'In time of yore'}

From BL MS Addl 34064. Punctuation added and regularized.

In time of yor when shepperds dwelt vpon the mountaine rockes

and simple people neuer felte the paine of louers mockes,

But litle birdes wowld cary tales twixte Susan and her Sweetinge

And all the dainty Nightingals
dyd singe at louers meetinge,

Then might yow see what lookes did pas pleasing, delightful (general term of approbation) wher sexes dyd assemble

And wher the lif of true loue was when hartes could not dissemble.

Then yea and nay was thought an oathe that was not to be dowted,

and when it came to faith and troathe we were not to be flowted.

Then did they talke of Curds and creame, of butter, cheese and milke,

?dismissed, treated with scorn

There was no speach of sonny beame nor of the golden silke.

Then for a guifte a rowe of pinnes, a purse, a paire of knyves

Was all the waie that love beginns, and so the Shepperd wyves.

But now we haue so muche a doe and are so sore agreued,

that when we goe aboute to woe we cannot be beleued.

Such choise of Ieuells, ringes and chaines that maie but fauor move,

And suche Intollerable paines ere one can hitt on love,

That if I still shall bide this life

aggraved: burdened, oppressed woo twixt loue and deadly hate,

I wyll goe learne the countrey life or leave the louers state.

light on, achieve, get

\section{Nicholas Breton 'FAir In A MORN'}

First published in Helicon. All other ms and print versions run every two lines into one. Though 'Astrophell' in the Helicon title suggests a connexion with Sidney, no convincing link has been found.

Astrophell his Song of Phillida and Coridon.

Faire in a morne, (ô fairest morne) was neuer morne so faire:

There shone a Sunne, though not the Sunne that shineth in the ayre.

For of the earth, and from the earth, (was neuer such a creature:)

Did come this face, (was neuer face, that carried such a feature).

Vpon a hill, (ô blessed hill,

was neuer hill so blessed)
There stoode a man, (was neuer man for woman so distressed.) 
This man beheld a heauenly view, which did such vertue giue

As cleares the blind, and helps the lame, and makes the dead man liue.

This man had hap, (ô happy man more happy none then hee;)

For he had hap to see the hap, that none had hap to see.

This silly Swaine, (and silly Swaines are men of meanest grace:)

Had yet the grace, (ô gracious guest) vto hap on such a face.

He pitty cryed, and pitty came, and pittied so his paine:

As dying, would not let him die, but gaue him life againe.

For ioy whereof he made such mirth,

as all the woods did ring: *

And Pan with all his Swaines came foorth, to heare the Sheepheard sing.

But such a Song sung neuer was, nor shall be sung againe:

Of Phillida the Sheepheards Queene, And Coridon the Swaine.

\section{Nicholas Breton 'Fair Phillis Is the Shepherds' Queen'}

First published in Helicon. Also found in three mss. In every case, directly follows no.114, and Helicon prints them as a single item. But there is a gap between them in the mss, and they are metrically quite different. 'The last line of no.114 reads like a conclusion, and the first line of no.115 like a new opening. They also occur separately elsewhere. (See Textual Notes, in the Companion volume.) Hence they are printed separately here, though they may be linked as in Bod. MS Rawl. Poet. 85, where no.114 concludes 'Finis. / The songe followethe.' and no.115 is headed 'The songe'. Every two lines of the Helicon text run together as a single line in the mss.

Faire Phillis is the Sheepheards Queene, (was neuer such a Queene as she,)

And Coridon her onely Swaine, (was neuer such a Swaine as he.)

Faire Phillis hath the fairest face, that euer eye did yet behold:

And Coridon the constantst faith, that euer yet kept flocke in fold.

Sweete Phillis is the sweetest sweete,

that euer yet the earth did yeeld:

And Coridon the kindest Swaine, that euer yet kept Lambs in field.

Sweete Philomell is Phillis bird, though Coridon be he that caught her:

And Coridon dooth heare her sing, though Phillida be she that taught her.

Poor Coridon dooth keepe the fields, though Phillida be she that owes them:

And Phillida dooth walke the Meades, though Coridon be he that mowes them.

The little Lambs are Phillis loue, though Coridon is he that feedes them:

cleares] gives sight to (not in $O E D$, but cf. $O E D_{3}$ ). $\quad$ 17-20 Pun on hap: (a) happen(ing) (b) good fortune. 23 guest] (a) recipient (of gift or benefit) (b) ?gest, action, event; (c) ?misprint for grace (the reading in one $\mathrm{ms}$ ), given the repetition of words throughout the poem. 27 dying] Prob. in sexual sense: she granted him her favour. $\quad 31$ Swaines] (a) shepherds (a) followers, retinue (OED 2), i.e. the wood-gods. 
The Gardens faire are Phillis ground, though Coridon be he that weedes them.

Since then that Phillis onely is the onely Sheepheards onely Queene:

And Coridon the onely Swaine, that onely hath her Sheepheard beene,

Though Phillis keepe her bower of state, shall Coridon consume away?

No Sheepheard no, worke out the weeke, and Sunday shall be holy-day.

\section{Nicholas Breton A Pastoral of Phillis and Coridon}

First published in Brittons Bowre of Delights (1591), then elsewhere including Helicon, whose text is followed below. An additional stanza in BL MS. Addl. 34064 is placed at the end, and a ballad version given in an Appendix.

\section{A Pastorall of Phillis and Coridon}

On a hill there growes a flower, faire befall the dainty sweete:

By that flower there is a Bower, beautiful or pleasing object where the heauenly Muses meete.

In that Bower there is a chaire, frindged all about with gold:

Where dooth sit the fairest faire, that euer eye did yet behold.

It is Phillis faire and bright, shee that is the Sheepheards ioy:

Shee that Venus did despight, and did blind her little boy.

defy, treat with contempt

This is she, the wise, the rich, that the world desires to see:

This is ipsa quoe, the which there is none but onely shee.

she herself, a unique woman

Who would not this face admire? who would not this Saint adore?

Who would not this sight desire, though he thought to see no more?

Oh faire eyes, yet let me see, one good looke, and I am gone:

Looke on me, for I am hee, thy poore silly Coridon.

Thou that art the Sheepheards Queene, looke vpon thy silly Swaine:

By thy comfort haue beene seene dead men brought to life againe.

support, encouragement

27-8 Cambridge MS Dd.5.75 has 'her only swayn', 'a sheapheard byn', stressing Coridon's rise from a hireling shepherd to his mistress's beloved. 1 flower] prob. flowering plant (OED 4). 2 faire befall] may it prosper or fare well. $\quad 11$ Phillis is a Petrarchan 'tyraness' refusing to admit love. She has herself blinded the blind Cupid, presumably as a punishment. The ballad version reads differently: see below. 20 Even if it were the last thing he saw. 21-2 good looke] (a) at the lady by the lover (b) the lady's kind look towards the lover, as clearly in the ballad. $\quad \mathbf{2 4}$ silly]?deserving of pity or compassion (the root sense: $O E D_{1}$ ). 


\section{[Additional stanza in MS 34064 ]}

Make him liue that dying longe neuer durst for comfort seeke,

Thow shalte heare so sweete a songe neuer shepperde sounge the like.

\section{The Ballad Version}

From a broadside printed by Thomas Symcocke c.1620.

The Shepheards Delight.

To the Tune of Frog Galliard.

On yonder Hill there springs a flower, faire befall those daintie sweets,

And by that flower there stands a bower, where all the heauenly Muses meetes,

And in that Bower there stands a Chayre, fringed all about with gold,

And therein sits the fairest faire, that ever did mine eies behold.

It was Phillida faire and bright, and the Shepheards onely ioy,

She whome Venus most did spight, and the blinded little Boy.

It was she the wisest rich, whome all the world did ioy to see.

It was Ipsa quoe, the which, there was none but onely she.

Thou art the Shepheards Queene, pittie me thy wofull Swaine,

For by thy vertue haue been seene, dead men restord to life againe:

Look on me now with thy faire eyes, one smiling looke and I am gone.

Looke on me for I am he, thy poore afflicted Corridon,

Dead am I to all delights, except thy mercy quicken me,

Grant oh Queene, or else I die, a salue for this my malady:

The while we sing with cheereful noyse, wood Nymphes and Satyres all may play,

With siluer sounding Musicks voice, reioycing at this happy day.

29 dying longe] in a state of lingering death. Frog Galliard] composed by John Dowland: the only composition by a well-known musician to be used as a ballad tune. (See Chappell, Popular Music, I.127.) 25-32 Notably different from the printed version, and only faintly mirrored in the ms. Given the woodcut of Queen Elizabeth accompanying the ballad, suggests the poem was adapted, if not written in the first place, as a compliment to the Queen, perhaps by a disgraced courtier. Note the complimentary 'vertue' (19) instead of 'comfort', and the tone of 25-8. 29-32 suggest an outdoor entertainment for the Queen. 


\section{Nicholas Breton 'IN The MERry MONTH OF MAY'}

Sung by 'three excellent Musicians ... disguised in auncient countrey attire' to greet the Queen outside her window at the start of the Third Day's entertainment (22 September 1591) during her visit to Elvetham, the Earl of Hertford's estate. Titled 'The Plowman's Song' in the original printing of the Entertainment (1591), changed in the 3rd edn (also 1591) to 'The Three Mens Song'. Reprinted in Helicon, whose text is followed below. Also in several mss (sometimes with music) and printed song-books. BL Royal Music 24.d.2 presents as a song for three voices, divided into two parts at 12.

Phillida and Coridon.

In the merry moneth of May,

In a morne by breake of day,

Foorth I walked by the Wood side,

When as May was in his pride:

There I spied all alone,

Phillida and Coridon.

Much a-doo there was God wot,

He would loue, and she would not.

She sayd neuer man was true,

He sayd, none was false to you.

He sayd, he had lou'd her long,

She sayd, Loue should haue no wrong.

Coridon would kisse her then,

She said, Maides must kisse no men,

Till they did for good and all.

Then she made the Sheepheard call

All the heauens to witnesse truth:

Neuer lou'd a truer youth.

Thus with many a pretty oath,

Yea and nay, and faith and troth,

Such as silly Sheepheards vse,

When they will not Loue abuse;

Loue, which had beene long deluded,

Was with kisses sweete concluded.

And Phillida with garlands gay:

Was made the Lady of the May.

\section{Nicholas BREton 'The fields ARE GREeN'}

From BL MS Addl. 34064 .

The fieldes are grene, the springe growes on a pace and natures arte beginns to take the ayre.

Each herb her sent, ech flowre doth shewe her grace and beawtie braggeth of her bravest fayre.

The Lambes and Rabbottes sweetely runne at base, the fowles do plume, and fishes fall to playe,

The muses all haue chose a settinge place to singe and play the shepperdes rundeley.

Poore Choridon the onlie sillye swaine that only liues and doth but onlie liue

Ys now become, to finde the heavnely vaine where happie hope dothe highest comfort gyve.

boasts of, flaunts;

[most splendid beauty start to, set about seat, site

The litle wren that neuer songe a note is peepinge nowe to proue how she can singe, cheeping, squeaking (OED peep $v^{2}$ )

2 After this line, BL MS Addl. 34064 has these additional lines (as does like Bod MS Rawl. Poet 85, with variants): With a troope of damsells playinge forthe the wood for sooth amaying When anon by the wood side where that may was in his pride 12 haue no wrong] suffer harm: equivocal, depending on whether applied to Phillida or to Coridon. 18 Some mss. read (with variants) 'ne'r was lov'd a fairer youth', giving Phillida a more active role in the relationship. 19 pretty] Bod. MS Mus.d.8 reads 'petty' (mild, harmless). 23 deluded] frustrated, eluded (OED 4); ?deceived (by false promises, by earlier lovers). $\quad 5$ runne at base] run about like players in the game of prisoners' base. plume] trim their feathers, preen themselves. $\quad 10$ who is barely alive (owing to his suffering in love). 9-11 i.e. Choridon has become the only swain to find, etc. 
The Nightingale hath sett in tune her throte and all the woods with litle Robins ringe.

Loue is abroade as naked as my nayle and litle byrdes doe flycker from their nestes.

flutter

Diana sweete hath sett aside her vaile and Phillis shewes the beawtie of her brestes.

Oh blessed brestes, the beawtie of the springe, oh blessed springe that suche a beawtie showes.

Of highest trees the hollye is the kinge and of all flowres faire fall the Quene the Rose.

may good luck befall (her)

\section{Nicholas Breton(?) A Shepherd's Dream}

First published in Brittons Bowre of Delights (1591), and then with the same title in Helicon. The text below follows Helicon.

A Sheepheards dreame.

A Silly Sheepheard lately sate among a flock of Sheepe:

simple, rustic, humble

Where musing long on this and that, at last he fell a sleepe.

And in the slumber as he lay, he gaue a pitteous groane:

He thought his sheepe were runne away, and he was left alone.

He whoopt, he whistled, and he call'd, but not a sheepe came neere him:

Which made the Sheepheard sore appall'd, to see that none would heare him.

But as the Swaine amazed stood, in this most solemne vaine:

Came Phillida foorth of the wood, and stoode before the Swaine.

Whom when the Sheepheard did behold, he straite began to weepe:

And at the hart he grew a cold, to thinke vpon his sheepe.

For well he knew, where came the Queene, the Sheepheard durst not stay:

And where that he durst not be seene, the sheepe must needes away.

To aske her if she saw his flock, might happen pacience mooue:

And haue an aunswere with a mock, that such demaunders prooue.

Yet for because he saw her come alone out of the wood:

He thought he would not stand as dombe, when speach might doo him good.

And therefore falling on his knees, to aske but for his sheepe:

He did awake, and so did leese the honour of his sleepe.

$\mathbf{1 7}$ image of a naked infant Cupid. 23-4 from a popular country carol, providing a rustic touch. Kinge, Quene suggest Choridon and Phillis. 26 Might try her patience, might annoy her. 28 As people who ask such questions find out. $\mathbf{3 6}$ the honour of his sleepe] the honour (of encountering the Queen) obtained in his sleep. 


\section{Nicholas Breton Coridon's Supplication To Phillis}

First published in Brittons Bowre of Delights (1591), then in Helicon. The text below follows Helicon.

Coridons supplication to Phillis.

Sweete Phillis, if a silly Swaine may sue to thee for grace:

See not thy louing Sheepheard slaine, with looking on thy face.

But thinke what power thou hast got, vpon my Flock and mee:

Thou seest they now regard me not, but all doo follow thee.

And if I haue so farre presum'd, with prying in thine eyes:

Yet let not comfort be consum'd, that in thy pitty lyes. exhausted, absent

But as thou art that Phillis faire, that Fortune fauour giues:

So let not Loue dye in despaire, that in thy fauour liues.

The Deere doo brouse vpon the bryer, the birds doo pick the cherries:

And will not Beauty graunt Desire one handfull of her berries?

If it be so that thou hast sworne, that none shall looke on thee:

Yet let me know thou doost not scorne to cast a looke on mee.

But if thy beauty make thee proude, thinke then what is ordain'd:

The heauens haue neuer yet alow'd that Loue should be disdain'd.

Then least the Fates, that fauour Loue, should curse thee for vnkind:

Let me report for thy behooue the honour of thy mind.

Let Coridon with full consent set downe what he hath seene:

That Phillida, with Loues content, is sworne the Sheepheards Queene.

as being, because you are behoof, benefit, good readily, with all his heart

\section{Nicholas Breton The Second Shepherd's Song}

The song of the Second Shepherd ('Past[or] 2') from Breton's The Passionate Shepherd (1604). The book seems to reflect a personal love: it is dedicated, in an obvious anagram of the poet's name, by 'Bonerto the faithfull Shepheard, to Aglaia his faire Shepheardesse'. Aglaia (Gk. 'beauty or 'joy') is also the name of one of the Graces.

Siluan Muses can yee sing

Of the beautie of the spring?

Haue yee seene on earth that Sunne,

That a heauenly course hath runne?

i.e., his beloved

Haue yee liu'd to see those eyes

Where the pride of beautie lies?

Haue yee heard that heauenly voice,

That may make loues heart reioyce?

Haue yee seene Aglaia, shee

Whome the world may ioy to see?

If yee haue not seene all these

$\mathbf{1 4}$ fauour giues] (a) endows with beauty (b) grants favours. $\quad \mathbf{3 2}$ the honour of thy mind] i.e. That you are not neglectful of love. 
Then yee doe but labour leese, loose, waste

While yee tune your pipes to play

But an idle Roundelay.

And in sad discomforts denne

Euerie one goe bite her penne

That she cannot reach the skill,

How to clime that blessed hill

Where Aglaiaes prayses dwell

Whose exceedings doe excell,

And in simple truth confesse,

Shee is that faire Shepheardesse,

To whome fairest flockes afielde

Doe their seruice duely yeelde:

On whome neuer Muse hath gazed,

But in musing is amazed,

Where the honour is to much

overwhelmed, stupefied

For their highest thoughtes to touch.

This confesse, and get yee gone,

To your places euery one,

And in silence onely speake

When yee find your speech to weake,

Blessed be Aglaia yet,

Though the Muses die for it.

Come abroad you blessed Muses,

Yee that Pallas chiefly choses,

When shee would commend a creature,

Minerva, goddess of wisdom

In the honour of loues nature.

For the sweet Aglaia faire,

40 All to sweeten all the ayre,

Is abroad this blessed day,

Haste yee therefore, come away:

And to kill Loues Maladies,

Meete her with your Melodies.

Flora hath bin all about,

And hath brought her wardrope out,

With her fairest sweetest flowers,

All to trimme vp all your Bowers.

50 See the beautie of their plaines,

futile, as not directed to Aglaia's praise

Bid the Shepheards and their Swaynes

And commaund them with their flockes

i.e., Aglaia

To doe reuerence on the rockes,

Where they may so happie be

As her shadowe but to see.

Bidde the Birdes in euery bush,

Not a bird to be at hush:

But to sit, chirip, and sing,

To the beautie of the spring,

Call the siluan Nimphes together,

60 Bid them bring their musickes hither,

Trees, their barky silence breake,

Cracke yet though they cannot speake.

Bid the purest whitest Swanne,

Of her feathers make her fanne:

Let the Hound the Hare goe chase,

Lambes and Rabbets runne at bace.

Flies be dauncing in the Sunne:

While the Silke-wormes webbes are spunne.

Hange a fish on euerie hooke,

18 blessed hill] presumably Parnassus or Helicon, both sacred to the Muses. 20 Whose virtues or qualities exceed all others. 26 musing] (a) thinking, contemplating (b) invoking the Muses, writing poetry. 34 Though you cannot write poetry, being too overwhelmed. $\mathbf{6 1}$ as though their speech were confined by their bark. $\quad 64$ her ... her] the swan and Aglaia respectively. 66 runne at bace] play the game of prisoners' base - i.e., run about. $\mathbf{6 9} \mathrm{A}$ common conceit: fish (and other edible play the game of prisoners base - i.e., run about. 69 A common conceitianta (anaudnur e-g/81526143426
animals) willingly sacrifice themselves for the person being praised. 
As shee goes along the brooke:

So with all your sweetest powers,

Entertaine her in your bowers.

Where her eare may ioy to heare,

How yee make your sweetest quire:

And in all your sweetest vaine,

Still Aglaia strike the straine.

But when shee her walke doth turne,

for ever, continuously

Then begin as fast to mourne:

All your flowers and Garlands wither,

Put vp all your pipes together:

Neuer strike a pleasing straine

Till shee come abrode againe.

turns back

\section{Nicholas Breton A Farewell to the World}

'Sonet 1' from Nicholas Breton's collection of linked pastorals, The Passionate Shepheard (1604). The poems seem to reflect a personal love: they are dedicated, in an anagram of the poet's name, by 'Bonerto the faithfull Shepheard, to Aglaia his faire Shepheardesse'. Punctuated modified and obvious misprints silently corrected.

A farewell to the world and the pleasures thereof. Sonet. 1.

Now for the last farewell I meane to make

To all the troubles of my tired thought:

This leaue at last, and this last leaue I take,

Of some and all that haue my sorrowe sought.

First, youth, farewell, the fore Runner of wit:

A time more staide hath taught me better stages,

sober, mature

Then where repentance doth with sorrow sit,

To shew the ruines of vnbridled Ages.

reckless or dissolute years

Next farewell Beautie, thou bewitching glasse,

That blind'st the eye of all vnseasond seeing:

mirror

Mine eye now sees wherein my blindnesse was,

I could not see my blindnesse in thy being.

Friendship farewell, where faith doth finde no trust,

For men are Monsters, and then what are women?

Experience now prooues Iudgement was vniust,

Where wit was folly, that made slaues of free-men.

untrue, incorrect

And loue farewell, the Laborinthe of time,

Which killes the spirits with continuall care,

I now haue found the Snaile out by his slime,

And will not come, where such slye creepers are.

And power farewell, the perill of conceite,

Where pride is hellish in impatience:

Strong is my weakenes, that now bids me waite,

But on the blessing of obedience.

And hope farewell, the weakest holde of wit,

That euer help't the heart to happinesse:

For wisdomes care, that well hath sounded it,

Findes it a flatterer but of idlenes.

pride, vanity

And farewell fortune, the moste idle fiction

The euer fancy laide her labour on:

Truth, against whome there is no contradiction,

Showes one of force, but fortune there is none.

serve (instead of exercising power)

support, sustenance

encouraging idle fancies

exercised her powers

5 fore Runner] i.e. coming before wit (wisdom), not accompanying it. $\quad \mathbf{6}$ stages] resting-places on a journey: i.e. he now wishes to live more circumspectly. $\quad 10$ ?Does not let the eye register anything that does not please it. 31-2 Truth, being consistent, is necessarily (of force) single (one), but fortune changes continually. 
And arte farewell, the onely woe of wit,

That beates the Anuile of a busy braine;

affliction, curse

With simple skill I now had rather sit

Then worke for grace, and other get the gaine.

(literally) gratis, without reward

And farewell time, that neuer giuest rest

Vnto the body or the spirits paine:

Eternall blisse hath so my spirite blest,

I will not harken vnto time againe.

And farewell all that may be bid farewell,

Within this world of wretchednes and woe:

My spirit seekes but only there to dwell,

Where purer truth doth no corruption knowe.

A Gowne of Veluet and a chaine of pearle

Shall not bewitche mine eyes with folly gazes

When vnderneath, an idle headed girle

May feede the minde but with dishonors mazes.

foolish

confusions, disorders

The seate of power too neere the Sin of pride

Shall with Ambition not infect my minde:

A ioyfull peace within my soule hath tride,

The sweetest life is in the meane to finde.

The filed tongue of fayning eloquence

Shall now no more abuse my simple trust:

In yea and nay, I finde that excellence,

Where perfect iudgements cannot prooue vniust.

The sound of warre shal not inchaunt mine ear

With honours musicke, to abuse my heart:

The blessed peace, that patient spirits beare,

In heauenly consorts haue no bloudy parte.

harmonies

The long delaying studdie of the lawe

Shall beate no hammers in my wearie braine,

Nor loose my Corne in striuing for a strawe,

But keepe my right, and hate a wrongfull gaine.

The greedie labours of the grumbling Chuffe

I will not followe, for a rustye wealth:

But in discretion thinke that worke enough,

That cloathes the flesh, and keepes the soule in health.

And I will leaue Court, Cittie, towne and fielde,

Warres, Lawe and traffique, pollycie and paine:

trade

And see what life the country loue will yeelde,

Where Shepheards keepe the flockes vpon the plaine.

There will I sit and in the sacred sence

Of heauenly vertues high instructions

Learne in Aglaias natures excellence,

Of Loues conceites to make the best constructions.

Where God alone shall in my soule be loued,

the middle path, moderation

And faithes affection in true fancy proued.

Which done, my heart shall lie vpon my brest,

That truth shall shewe the secret of my thought;

Where patience prooues the spirit onely blest,

miser, avaricious man

That lookes at heauen and sets the world at nought.

51 tride] proved true, experienced (that 'The sweetest life', etc.). discontented (hence greedy for more) (b) rootling and muttering. 66 rustye wealth] metallic wealth: coins, money. $\quad 69$ towne] village $\left(O E D_{3}\right) . \quad 78$ The fervour of holy faith will be expressed in true love (of Aglaia). 
Thus will I sit, and set my pipe in tune, And plaie as merry as the day is long: And as in Aprill, so againe in Iune,

Fit both my spring and haruest with a song.

My Pipe shall bee but of a dainty reede,

That growes within the Riuer of delight:

Where euerie stop shall stand my heart in steed, in a position to To guide the spirrit of my musicke right.

And for my ditties, they shall be diuine

When time shall onely on Aglaia rest,

While fancy so shall euerie note refine,

That euerie passion shall be well exprest.

And when the Musicke of my pipe is done,

Then what is needefull to my flocke goe see:

And from the plant that prospers in the Sunne,

Cut of the succors least they spoyle the tree.

suckers, new shoots

And then goe looke vnto the worme and flie,

That may annoy my Lambkins, or their Dambes,

And to each griefe such presente helpe apply,

As may preserue the smallest of my Lambes.

malady, affliction; ready

And if I see the Wolfe, the Brocke, the Foxe,

Or any varmin stealing downe a furrowe

badger

To make a praye among my prettie flockes,

Send out my Dog, and beate him to his borough.

burrow

And when I heare the Nightingale recorde

The Musicke, wherein Nature pleaseth Arte:

To trie how loue can with her tune accorde,

To sound the passions of a panting heart:

And when that shee her warbling Tunnes doth ease,

And shades her selfe from parching sommers heate,

lay off, stop

Then learne of her, how I may holde my peace,

While lesser Birdes the idle ayre doe beate:

i.e., sing dully

And when I sit vpon that sweetest mountaine,

Where growes the grasse that feedes my fairest flockes,

And there beholde that Christall cleerest fountaine,

That sendes her streames distilling through the Rockes,

And seeing there the heartes-ease growing by it,

The onely flower of fancies best affection,

And thinke how Nature in her pride doth die it,

To put downe painting in her Artes perfection.

Then lift mine eye vnto that hande on high,

That worketh all thinges by his holy will:

And giue all glory to this Maiestie:

Whose onely wisdome shewes all wonder skill.

wonderful, marvellous

Then on the earth fall humbly on my face,

And pray to him that made both day and night:

First to inspire me with his holy grace,

And then to blesse me in Aglaias light.

And when I see the Trees beginne to Bud,

And euerye grasse put foorth his fairest greene,

And euerie kidde begin to chew the Cudde,

And Flora haunt it like a Medowe Queene,

the goddess of flowers; resort there

92 ?Because Aglaia's beauty is eternal, like the divine. But time also ?the beat or rhythm of the songs. 126 Whose onely wisdome] (a) his singular wisdom (b) the wisdom he alone has. 
And all the Muses dresse vp all their bowers,

And set their Consorts in so high a Key:

harmonies, music

As if they met in Musickes sweetest powers,

To play and sing some Princely Roundelay,

Then still againe vnto my God on high

Aglaia blessed in his gratious eye,

That so doth liue of Creatures all beloued.

\section{3 'Peace, Shepherd'}

From BL MS Addl.15232, associated with the Sidney family. Virtually all punctuation added, and indentation of alternate lines regularized. Parts of 1, 121-2 missing as the ms is damaged.

Peace sheppheard [...] now heare Amintas mone,

With withered fearne whoe wypes his cheekes soe ouerflowne:

When sythes will lett hime speake and sobbes not stoppe his voyce,

sighs

with breathe both sadde and weake

Amintas loude a mayde As good, as fayre of hewe,

Her manye monethes hee prayde vnto hime to bee trewe.

As younge, and frayle her yeares soe did hee feare her fayth:

Orion starre appeares, then stormes, the seaman sayth.

Soe shee did fyrste retyre before shee fledde a waye,

denyinge his desyre by sayinge bashfull naye,

Wherby hee did perceave shee woulde not longe abyde,

But shortlye sure deceave And lay her love asyde.

As tyme that gave bereaves and doth uncloth the tree

Of blossomes, frute, and leaves, soe hath shee done to mee.

Why shoulde I then bewayle, seeth nature willes it so?

Shee did not more me fayle then kynde compelde her to.

(womanly) nature

But $\mathrm{O}$ kinde most vnkinde, to geive to take awaye:

A little sweete to finde is worse then sower allway.

Wee feele the winter worse when sommer hath beene hotte,

And cuninge most wee curse when neare we misse the plotte.

But will you have the truthe? when shee hadd toucht to trye,

13-14 He feared her faith would be as frail as her youth. 15 Orion starre] Orion's appearance in the autumn sky in is a signal for storms. (Hesiod, Works and Days 618-21). 17 fyrste retyre] Made an initial pretence of withdrawing before actually doing so. 39-40 We most curse our skill when we narrowly miss the mark. 
Shee founde a waveringe youthe vnworthye for her eye:

One whiche did beare a shewe some good for to deserve,

Yett hee forgotte to knowe his bevell coulde but swearue.

Hee drewe to weake a draughte soe highe a marke to hitt:

A heavye leaden shafte can never mounte a whitt.

arrow

Amintas was to base, his flockes weare over fewe

For Amarilles grace soe lowe a stoope to shewe.

Yett was shee once contente to looke and saye shee likte:

From looke and like shee wente, and former choyce dislikte.

Excusinge by constraynte, shee coulde not will nor choose,

But lett her love to faynt as other weomen vse.

weaken, decline customarily do

Not satisfised with this vnkinde and faythlesse parte,

shee sayes I coulde but misse. shee loved not from her harte,

Whoe did desemble nowe, althoughe shee doubted mee,

sayinge I woulde not bowe in meeknes minde and knee.

But I, poore soule, still fell all flatte before her feete,

And humbly did refell that error soe vnmeete.

Soe farre was I from pryde as ofte I kiste the grounde

Where her stepps I discryde, and pipte when I them founde.

My pipes did alwayes playe fayre Amarillis prayse,

And all what I coulde saye was her alofte to rayse.

A garlaunde did I weare of akers and of leaves

refute, disprove improper, unbefitting

discerned, spotted

Wheare willowe nowe I beare, sadd signes shee me deceaves.

The fatteste of my foulde I offered to her feaste,

And thoughte it better soulde then ever I soulde beaste.

On her my chieffe contente, my greatest good I layed:

Shee leaste when most I mente, truth with deceypte she payed.

My loue I did assure by sheddinge bloode and teares,

?reposed, ?wagered leased, lied; was sincere

pledge, warrant

43 wavering] Precisely what Amintas is not. May convey Amarillis' impression, not the reality, or imply 'weak, insecure' in a general way. 48-56 Sustained metaphor of the flight of arrows. 48 bevell] slanting line or path (of an arrow). 49 draughte] ?bow-shot, ?range of a bow (OED 10). stoope $]$ descending path or flight $\left(O E D\right.$ stoop $\left.n^{2} 4\right)$, here of an arrow. 61-2 She excused her betrayal $\begin{array}{ll}\text { by saying it was beyond her control. } \quad 65 \text { satisfised] recognized variant in 16-c. } & 67 \text { I coulde but }\end{array}$ misse] continuing the metaphor of an arrow's flight. 68-72 Although she had deceived me herself, she now called my faith in question, saying I could not sufficiently humble myself before her. 
Her pittye to procure,

$$
\text { to putt away my feares. }
$$

And pittye once I founde, for shee did me assure

Her loue soe faste to grounde as it to death shoulde dure.

be grounded or based endure

I did beleeue shee sayed and spake but as shee me mente,

And woulde my liffe haue layed her loue was firmely bente.

But nowe I finde to trewe this proverbe of them all,

They like all what is newe, and loue in generall.

Whoe trustes vnto theire loue and restes vppon theire reason,

Deceaved ofte muste proue and seldom have in season.

Butt you my mates I make cheiffe Iudges of my cawse:

Imparciall I you take,

[...]me respectinge moste the lawes.

Your verditt juste to frame and rightfull judges proue.

If I have sounge or sayed of weomen oughte amisse,

As I before you prayed, iudge wheare the fault most is.

Nowe if you please, pype on and playe some prettye toye,

For hee hath made his mone whoe kepte you from your Ioye.

\section{Nicholas Breton(?) 'When I WAS A LitTle SWAin'}

From Cambridge University Library MS. Dd.5.75. The ms editor Steven W. May tentatively links this poem with Breton's known work. Each two lines in the text below form a single line in the ms. Capitals and punctuation almost wholly editorial.

When I was a little swain

keping shepe vppon a plain, playing on an oaten pipe

in the tyme that nuttes were ripe,

by chaunce I saw a bonny lasse

lightly tripping on the grasse,

weghing scarse a daisey down,

in a short vnlaced gown,

wearing on a tawdry lace,

platted hear in carelesse grace.

a kind of silk necktie worn by women

hair

She was fair and louely brown,

she had no peere in all the town.

Down she stowpt to gather flowres,

she stowping down surprisd my powres.

Every stalke her sweete hand brake

coldnes to my hart yt strake.

When her handes had flowres plentie

in her lap she did them emptie.

Then I wisht I were a flowre, 
to haue place in such a bowre.

But alas she was so wight,

she sylent shrunke out of my sight.

swift, agile

Since that tyme I never slept,

I never laught but ever wept.

But and my maister me misvse,

my service then she shall refuse

for I had rather be in her bowers

then be lord of many towres.

But yf yt please her me to call,

farewell shepehooke, lambes and all.

\section{A Pastoral Riddle}

This curious piece is from Cambridge University Library MS Dd.5.75. In the ms, every two lines are written as one, obscuring the sonnet form. Virtually all other punctuation added in this edition, and line initials uniformly capitalized.

Nere to a sheapheard did a damsell sit

As leane as withered sticke by scorching flame,

Her body as full of eyes as mighte be, in yt

A tongue she had, but could not moue the same.

Her wynd she drew aboue and eke beneathe,

But from on part she never yet did change.

one

A wofull sheapheard came to kisse her breathe,

Then made she plaintes most sorowfull and strange.

The more the sheapheard put his mouthe vnto

Her mouthe, in stopping yt she cried amain,

Opening her eyes and shutting them again.

See now what this dumbe sheapherdess could doe:

That when her mouthe he did but touche or kisse,

He wexeth dumb, but she still speaking is.

[Answer, in the right margin of the manuscript:]

a bagpipe or flute

\section{John Lilliat Upon a Kiss Given}

From Bod. MS Rawl. Poet. 148. See headnote to no.127 for likely authorship.

Vpon a kisse giuen.

The shepperd

Sweet shepperdisse,

Thy kindely Kisse,

Bestowd vpon a silly swayne;

I can no whit,

Tell how to quit,

requite, reciprocate

But for thy kisse, giue kisse agayne.

If I be falce, of faith reproue me:

Doe thou but like, and I will loue thee.

with respect to faith, for lack of faith

Thy milke white flockes,

rangeinge the rockes,

That feed their fill all vncontrowld;

Thy little lambs, amonge their dams,

which skipp and skice abowt the fowlde:

doe shew (by this their pleasant vayne:)

Ech one to other, loue agayne.

25-6 ?She will not spurn my love unless my master falsely speaks ill of me to her. 25 and] 'an', if, unless. misvse] deride, vilify (OED 5 ). 
In seemely sight,

thow takst delight,

with oten pipe to make them skipp:

20

Thy tyme thus spent,

shewes sweet content,

And I, if I vntrue approue:

Amidst the bushes,

vpon greene rushes,

I know to knit true louers knot:

which I will make,

for thy sweet sake,

And teach it thee, elc trust me not.

A hatt of straw,

a whood of Haw,

And garters fine, of greene wodebine,

A garland all of Mirtle greene;

For, likinge growes,

as goodwill flowes,

which thinge if thow

vouchsafe t'allow,

If I of Loue

vnloyall proue,
In bottle, and poore shepperds scripp.

Leaue thow to like, and I to loue.

Only allowe me (Sweet) to loue thee:

To whom if falce, of faith reproue me.

Becomes the comely shepperdes Queene;

Thy swayne will deale for thy behoue:

Then lend me likinge, for my loue.

from fowntayne of my Synthea fayre:

Then to my Cabbyn (Sweet) repayre.

wher loue for loue, il'e giue agayne:

for likinge soe a shepperd swayne.

In torture all to rack my fayth:

Then be thow true,

As I to you,

And builde vpon what sheppard sayth.

Of price in me This, estimat:

As faithfull, as affectionat. pleasing spectacle (of frisking lambs)

prove, turn out

do what will benefit or please you

If my faith is tested on the rack 
And if of Shepperds thow wert kinge,

And I the poorest Neaters Mayde:

Yet lawelesse love of any thinge

To harbour I should be a frayde,

And therfore kinges in this denayde.

Yet did my Mother singe this songe:

For kisse, doe Shepperd never wronge.

To this her sweet perswasion,

She ads this clause conditionall:

And sayes, In kindenes kisse but one,

And him to kisse for good and all,

For afterclapps that may befall.

To HEBE, kissinge ys assignde:

Truely then sayde, Vnkist, Vnkinde.

conclusively, decisively: i.e., by way of marriage

denied

But kisses teach an other thinge,

(If Cupids method doe not misse)

And Venus, other sport doth bringe,

Then may beseeme chaste Shepperdisse.

Yet louely Swayne, be sure of this,

For kisses only, I haue store:

Kisse then (sweet Shepperd) and no more.

\title{
128 John Ramsey(?) An Excellent Pastoral Ditty
}

From Bod. MS Douce 280, the commonplace-book of John Ramsey (1578-?), minor statesman, voyager and poet. This is one of the poems ascribed to 'Sheepheard Montanus', apparently Ramsey himself. Though some of these are patently by other hands, this is a relatively original piece. It is loosely based on 'Shepherd Tonie' or Anthony Munday's poem in Helicon, 'A carefull Nimph, with carelesse greefe opprest', but closely echoes only a few lines from that poem in lines 4, 17-18, 22, 27-30 below. ${ }^{\star}$ Line initials regularized.

\section{An Excellent Pastorall Dittye}

Mated with greefe a faithfull sheephearde sate, ?matched, twinned; ?overcome, paralysed in shadye groue (fitt place for sorrowes guest)

And thus him playned still earlye and late, with pipe in hande payntinge out his vnrest.

When havinge sob'd and sigh'd and mourn'd his fill:

He tunes this Dittye to his Oaten Quille.

$O$ all yee Sheepheardes swaines which on these downes, soe many thousande milke-white heardes doe feede:

If ever you haue bene in these sad stoundes, lett pittye moue to lende some teares att neede.

For loue forsaken cannott chuse but weepe:

When woe, with woe doth thus vppon him creepe.

O dreadfull god of loue which nowe doest lye, carelesly smilinge att my sore mischance:

Doth it befitt soe greate a Dyetye, thus in a wretches miserye to Daunce.

Thy fire it was (before the hurte I spide)

rejoice

\begin{abstract}
Neater] Not in OED. ?neatherd; ?neatery, cattleshed. $\quad 14$ (a) Do not ill-treat a shepherd simply for kissing you. (b) Do not wrong a shepherd to extract a kiss from him. 19 afterclapps] unexpected consequences, here pregnancy. 2o HEBE] Marginal note in ms: 'HEBE, es. Daughter to Juno and Jupiter before he fell in love with Ganimedes. She ys of Poets, called the goddesse of Youth.' Also cupbearer to the gods till her marriage to Heracles. Kissing may be 'assignde' to her as goddess of youth, or as a kind of celestial barmaid. 27 store] For (rather than of) suggests the meaning 'place or means of storage' $(O E D 10,11)$ - i.e. I can accommodate kisses but nothing more. ${ }^{\star}$ See Edward Doughtie, 'John Ramsey's Manuscript as a Personal and Family Document', New Ways of Looking at Old Texts, ed. W. Speed Hill, Binghampton: Renaissance English Text Society, 1993, pp.281-8. 15 Dyetye] Marginal note in ms: 'Egregiam vero laudem et spolia ampla refertis / Tuque puerque tuus: etc.' ('Truly splendid is the praise and abundant the spoils you have won, you and your boy [Cupid]': Juno's words to Venus,
\end{abstract} Virgil, Aeneid IV.93-4). 
Which through mine eyes into my breast did glide.

And there o there such life and spirite it bredd, such ioye of harte, such stirringe of my blood:

As everye thought with pleasure still it fedd, to reape the fruite of my desiered good.

But shee whose memorye my very soule doth vexe,

Basely forsooke me vilefiinge her sex.

disgracing, casting in disrepute

Thus in my Mournefull songe I playne of loue, for loue hath broke me of my wonted sleepe:

complain, lament

And sleepe is hindred by the paines I proue, and paine doth force me piteouslye to weepe.

Then farewell loue, sleepe, paine, and every sore:

And farewell weepinge, I can waile no more.

\section{On the Reported Death of the Earl of Essex}

This anonymous poem from BL MS Harley 6910 follows a longer piece where an unnamed speaker (Menalcas in the ensuing dialogue) sits by the roadside lamenting the reported death of the Earl of Essex. A 'Viator' (wayfarer) assures him that the report is untrue. Essex returned ignominously in September 1599 from his term as Lord Lieutenant of Ireland. He was confined to York House, fell seriously ill there, and was freed only in August 1600 . This poem was probably written during his imprisonment.*

Viator. God speede my freend, why sittst thou heere so sadd?

Thy lookes bewraye a discontented mynd.

Menalcas. Indeed my freend, more cause I neuer had.

I seeke for that whiche in no place I fynd.

Viator. Why what? if I so much may freely craue.

Menalcas. Nay nought but that which I alreadie haue.

ask frankly

Viator. Why seekest thou that of which thou art possest, And yet to fynd thou makest so much adoe?

Menalcas. I seeke it farre though heere I sitt and rest: I haue it not and yet I haue it to.

Viator. And hauinge it why doest thou seeke it more?

Menalcas. For more I want it then I did before.

Viator. How canst thou want the thing that now thou hast?

Thou hast it not, and yet thou hast it to?

Menalcas. I haue it now but cannot hould it fast. I hauing haue it not and want it so.

Viator. Thou hast, hast not. I pray thee tell me plaine.

Menalcas. I haue not now, and now I haue againe.

Viator. I pray thee man deale plainly with thy freend.

Why sitst thou heere, why doest thou weepe so sore?

Menalcas. Still must I weepe, my teares must haue no end.

Here must I sitt and I must rise no more.

Viator. No more. - alas, what art thou let mee know.

Menalcas. Attend a while, that I shall quickly shew.

Whilome I was, till fortune cross'd my fate

A shepheard happye for my fruitfull flocke.

And on those playnes pipinge I dayly sate,

I fed my sheepe and they increasd my stocke.

Here had I tyme to tune my oaten reeds,

Whilst my poore flocke did round about me feede.

I knowe there dwells no shephard on this coast

25-8 loue ... sleepe ... paines] the figure concatenatio, joining clauses or phrases by repeated words like links in a chain. ${ }_{\star}$ See Katherine K. Gottschalk, 'Discoveries concerning British Library MS Harley 6910', Modern Philology 54, 1979, p.122. 
Whose flocke did yeeld him more encrease then myne.

There was no one that had more cause to boast

Till fortune turnde her wheele and ganne declyne.

My Ewes came euery day twise to the payle

But now scarce once, I know not what they ayle.

Vnless they sighe, because I nought but weepe

And will not feede because I cannot eate,

Alas poore soules, alas poore sillye sheepe;

Why do you for my sake forsake your meate.

Feede on my lambes, feede on my tender kidds:

Spare not to eate, spare not, your master bidds.

Let not the cause that keepes myne eyes from sleepe

Cause you refraine your foode thus euery day.

Let not the cause that makes my hart to weepe

Cause you alas thus causles pyne away.

Then cease to sighe poore sheepe: ye do me wrong.

Myne onely is the greife, to me it doth belong.

Oh how I lou'd my flocke, what care I tooke -

I love it still yet once I lou'd it more.

Both loue and hope made mee more nearely looke.

I loue it still though not as earst before.

I lou'd my flock although it was but smale,

Yet one poore one I loued best of all.

The leader of my heard for him I weepe.

My selfe haue lost my hope, my flocke their guide.

My hope is gone, the stay of all my sheepe:

So hee had liued, would all the rest had dyed.

Hee kept the rauenous wolfe and fox away:

And whilst he liued my flock did nere decay.

Now hee is gon the wolfe is waxen bould.

The Fox doth dare molest my tender lambes,

And fetch my kiddes out of the very fould,

And steale my simple sheepe out of my hands.

The wolfe and fox (thee dead) now dare do more:

(a) slow of wit (b) helpless, vulnerable

They dare doe that they durst not doe before.

Poore shepheard I, how my poore sheepe do stray:

And wander vp and downe they know not whither.

Alas they know not in what place to stay,

Nor where to shrowd themselues from winters weather.

shelter

The wind, the rayne, snow, hayle and euery showre

To kill my Kiddes, and tender Lambes haue powre.

Alas my hope, my deare, my onely ioye:

O ESSEX, ESSEX, whither art thou gon.

And what about shall I my witts employ?

To wayle thy death, thy abscence to bemone

Heare must I sitt and still bewayle thy death,

Whilst poore Menalcas liues and drawes his breath.

Viator. What doest thou mumble thus? speake, speake it plaine!

Reueale thy greife, and so thou mayst fynd ease:

To keepe it in doth more augment thy payne.

To make it knowne doth it in part apease.

Reueale thy greife, impart me halfe thy care.

Bee rulde by me and let me beare my share.

55 the leader of my heard] the bell-wether, i.e. Essex. Shows the inherent contradictions of pastoral allegory: Essex, the speaker's leader and patron (putative 'shepherd'), becomes a sheep in his charge, and a 'poore one' at that. $\quad 58$ so ... dyed] Would that he had lived, even if all the rest were to die. 59 wolfe and fox] Perhaps Essex's political adversaries (e.g., Robert Cecil and Ralegh) or, respectively, the Catholic Church (cf. 64.69, 230.128), and the Puritans. 
To men may with more ease a burthen beare:

Two riuers do receue more store of rayne:

Two oxen with more ease the ground do reare:

Two Barnes do receiue more store of graine:

Then let two beare which is to much for one.

90

And let vs greeue alike, or both, or none.

Menalcas. Why should I doubt my seacrets to reveale?

fear, hesitate

Why should I hyd them from so true a freend?

Why should I to my selfe my greifes conceale?

Why should I not bewray what I intend?

My paynes are ripe, my teares not farre behynde:

reveal, express

Yet still more cause of griefe and teares I fynde.

at their height

Longe haue I wept, longe haue my watry eyes

Streamd forth there sea salt teares adowne my face.

Long haue I mourn'd, the woodes haue heard my cryes.

The trees haue seene my teares that flowd apace.

The woodes and trees shall with me wittnes beare.

They heard mee weepe when all refused to heare.

They sawe mee weepe, they saw mee bownde to dye,

See in these barkes, see where my plaints are carued.

They heard mee nought but ESSEX ESSEX crye,

And weepe for him that best my teares deserued:

I wept for him, for him my teares I spend.

For him still must I weepe, my teares must haue no end.

Viator. What meanst thou man, why doest thou ESSEX name?

Or why is ESSEX wholy in thy mouth?

Menalcas.. Because hee was a man of mickle fame,

Whose like hath neuer liued in all the south.

Viator. Because hee was: why doest thou say because?

As though he is not now, as ere before he was.

What though hee liues a prisoner for a tyme!

What though his body they in prison pend!

pen, shut in

The name of prisoner nought augmentes his cryme.

The bones obey, the mynd will neuer bend.

Nor doth this dimme at all, or clipse his fame,

But soone shall adde more honoure to his name.

Looke how the sonne, when first hee shewes his face

Out of a misty cloude doth shine most cleare:

So likewise after this supposd disgrace

The name of ESSEX greater shall apeare.

A flaming fyre is farthest seene by night.

In clowdy tymes shall vertue shine most bright.

Because hee was? thou doest him double wronge

As though his worthy fame were ought decayd.

He yet surviues, and shall I hope liue Longe

To helpe his freendes, and make his foes afraid.

He yet suruiues, he liues, his name doth liue,

Whose life doth life to many thousandes giue.

Menalcas. What doth Melancas heare! Alas hee dreames,

His eares but flatter him, hee is deceaued.

His eyes are dimmed, gazeing on Titans beames.

the sun's

Each obiect hath eche sence of sence bereaued.

And can he liue? Oh no it cannot bee:

And could hee dye? Dead, dead, alas is hee. 
Viator. What sayest thou man! whome doest thou meane is dead?

Know this that ESSEX liues, how could hee dye?

Each member dyes when they haue lost their head,

Had hee bin dead, I should not now bin I.

$\operatorname{limb}$

He liues, I liue, his life is life to mee.

have been

Had hee bin dead, dead should I also bee.

Menalcas. Alas let not vaine hope my hart beguile,

Thou flatterest mee, how shall I trust myne eyes?

Let not vayne hope reuiue me for a while,

But let me end my wreatched dayes with teares.

If ESSEX liue, tell true, Oh then liue I.

If he be dead: Oh then alas I dye.

Viator. Why should I iest? Hee liues, by heauen I sweare,

Nor do I flatter thee but tell thee troth.

Then blest art thou, thou needst no longer feare,

And blest am I, so are wee happy boath.

Then sith suche happie newes Menalcas heares,

Cease now to weepe, at lenght abstayne from teares.

since

Menalcas. O Heauens, $\mathrm{O}$ Earth, $\mathrm{O}$ all ye powers diuine:

Great JOVE, what sacrifice shall please thy mynde?

What shall I offer at thy holy shryne?

A Kydd, a Lambe, or ells a tender hinde.

Great JOVE, and hast thou heard my wofull prayer?

And doth my deare enioy the common Ayer.

full of woe

beloved - i.e., Essex

Now is the tyme that I could wish to dye

Sith that my deare doth yet aliue remayne.

I neede not weepe, I need no longer crye,

Why haue I wepte, giue mee my teares agayne.

Could teares doe this, I haue moe teares in store.

Then keepe them still, I will not haue them more.

\section{John Mansell(?) Votum Primum}

Printed here for the first time from Bodleian MS. Don.d.152, among a group of poems transcribed c.1599-1601 by John Mansell, later President of Queens' College, Cambridge, and perhaps written by him. The 'shepherdess' is surely Queen Elizabeth.

\section{Votum Primum}

the first prayer

Fair sheperdess that feedest thy fair flocks,

All on the fairest Lawns of faire England

Enclosed with the bulwarks of fair rocks,

Gainst which French, Spanish, Scot, nor Kern can stand.

O leaue us not untill our shepherd come

Our greatest sheaperd, long it will not be.

O see us safely driuen to our home.

Giue us to him, that gaue us unto thee.

$\mathbf{1 6 7}$ If my lament has restored him to life, I will lament again if need be. poem is followed by a second prayer for the long life of an unnamed ruler. foot-soldier, here no doubt the Irish generally. 


\section{The Page's Pleasant Rustick}

From the anonymous romance The Heroicall Adventvres of the Knight of the Sea ... Oceander (1600). Sung by the page boy Curio to cheer his master Olbiocles, son of the Emperor of Constantinople, pining for his abducted wife Almidiana.

The Pages pleasaunt Rusticke.

Vppon the hilles of Arcadie,

Where olde God Pan melodiously

His pipe of reede full sweetely strainde,

Whilest on fell Fortune hee complainde,

played tunes or strains on

Which did his beauteous Sirinx change

cruel

Into the whistling reede (so strange

An accident was neuer seene,

Vnto Gods, Paramours to beene)

At what time Flora in her prime,

old infinitive of 'be'

Obseruing it was summer time,

With fragrant flowers of each dye,

Had diapred most gorgeously

The face of mother Tellus faire;

So as thereby she did declare

Th'approaching sacred festiuall

Of God Siluanus nuptiall,

Vnto faire goddesse Clarida:

Wherefore this Sheepheards holiday

Was clepid of each country swaine,

That to Siluanus did pertaine.

Thilke day of mirth and mery cheere

named, designated; by

Each sheepehearde knew approaching neere:

this

Wherefore they gathered euery one,

Together to king Caucus stone:

About the which they place the flockes

Of Sheepe and Goats, about the rockes

Which skip and leape wilde thyme to brouse,

Which growes thereon most plenteouse. Then with Pastoraes hand in hand,

Each Rusticke doth in roundell stand;

Which is intrenched in the ground,

patterned, adorned

With seates of turues yplaced round;

On which poore Sheepeheards louingly

Declared their true constancy,

Vnto their loues: who them inuested

With coronets of greene bowes wrested.

In lieu whereof, to Sheepeheardesses,

In courteis wise each swaine addresses

His hand, his heart, his cappe, his coyne,

And all the good hee can conioyne

Vnto his true loues courtesie;

Who giues againe most louingly,

All kinde of token shee did take,

And then as to her louing make

Shee yieldes herselfe obedient

In all that is expedient:

mate, partner

boughs; twisted, woven

?money, wealth join (to hers), match

fitting, proper

o.1 Rusticke] ? country song or poem: not in OED. 4 Fortune] Links up with the general theme: love is one of the few ways in which Fortune afflicts shepherds and shepherd-gods. Cf. 87-8. 5 Sirinx] Escaped Pan's pursuit by being turned into a reed, from which Pan made his pipe. 8 Paramours to beene] when gods turned lovers. 9 Flora] goddess of flowers and the spring. 13 Tellus] or Gaea, the earth-goddess. 16-17 Siluanus] one of the principal wood-gods. Clarida] appears to be the poet's invention. 24 king Caucus stone] apparently another piece of pastoral mythology supplied by the poet. 29 Pastoraes] shepherdesses. Curiously combines Lat. and English plurals. 39 cappe] An unexpected item, perhaps alliterating with coyne to mean 'belongings and money'. $\quad$ 42-3 She gives him matching tokens of love. 
When if he likes her, he doth gin

begin

To vowe to her, and shee to him,

For euermore continually

To liue with him obediently.

Thus they conclude, and thus agree,

Both louing man and wife to bee;

So Cloden did to Coladine,

So Ferin to faire Eglantine,

So Chloris did to Coridon:

And so dealt sheepeheards euery one;

Solemnizing their nuptials,

Vpon such holy festiuals.

Thus in disport, while they them held,

They sodainely mongst them beheld

A Nimph in strange attier drest,

Which putting in among the rest,

Had kept their day of frolicking,

With a strange kinde of wondering:

Sometime her face they might perceiue,

Readie to smile, and then deceiue

Their louing expectation,

With other kinde of fashion.

For sometime laugh, and sometime cry,

Now right, now houlding necke awry,

With leering kinde of scoyning eye,

She chang'd her face so diuersly,

As soone each seely sheepeheard boy

Gan feare she meant them some annoy,

In that she came in such disguise,

Vnto their sheepeheards sacrifice.

Wherefore they gan for to suspect her,

And cast about them to detect her:

Of her they did inquiry make:

But no man of her knowledge spake:

But euery one did murmur much,

To see her change and gesture such:

Wherefore they did determine straight,

Her to intrappe, for to lay waite.

Therefore on her their hands they lay;

But there they did their selues betray;

For some lost sheepe, and some their good,

Others for want of loue were wood:

Yet doe what euer she could do,

Shee was at length oppressed so,

By such a rusticke multitude,

As being brought to seruitude,

Her selfe false Fortune shee confest;

behaved, conducted themselves

Which knowen, the Swaines her so detest,

As presently with all their might,

They proffer her most fell despight;

And stripping her from her attyre,

To whippe her they done all conspire:

Which they did so performe indeed,

straight, upright

sidelong-glancing; 'squoyning', swooning

simple, innocent

As soone they made her body bleede:

And for she wrought their miseries,

They reaued her of both her eyes:

reft, deprived

53-5 The names (most obviously Chloris and Coridon) are typically pastoral, seemingly not drawn from legend or history. $\quad \mathbf{7 2}$ chang'd her face] reflecting Fortune's volatile change of favours. 80 No one claimed to know her. 102-4 eyes, wheel] Fortune is traditionally presented as blind, being undiscriminating in her favours. She turns (or is seated on) a wheel representing the turns of fortune. 
Then setting her vpon a wheele,

Which forward could (not backward) reele,

roll, turn

They sent her from their rurall store;

To which she vowed to come no more:

Which is the cause that euer sence

?company, community.

She doth to sheepeheards none offence;

since

But bendes her power gainst kinge and princes,

Whom to her thraldome shee conuinces.

conquers

\section{Edmund Bolton(?) Theorello. A Shepherd's Idyllion}

From Helicon, ascribed to an 'E.B.' usually identified with Edmund Bolton, scholar and historian. Clear Neoplatonic allegory. Cosma is the feminine of kosmos, the entire ordered universe. Her beauty incorporates the shapes of all created things. The description broadly conforms to the celebrated account in Alain de Lille's 12-c. work De Planctu Naturae (The Complaint of Nature). Her lover Theorello (literally 'viewer': theoria, viewing, hence contemplation) is a philosopher. His pure pastoral love suggests the ideal love enjoined by Nature in Alain's poem.

Theorello. A Sheepheards Edillion.

You Sheepheards which on hillocks sit, like Princes in their throanes:

And guide your flocks, which else would flit, your flocks of little ones:

Good Kings haue not disdained it, but Sheepheards haue beene named:

A sheepe-hooke is a Scepter fit, for people well reclaimed.

This Sheepheard's life so honour'd is and praised:

That Kings lesse happy seeme, though higher raised.

The Sommer Sunne hath guilded faire, with morning rayes the mountaines:

The birds doo caroll in the ayre, and naked Nimphs in Fountaines.

The Siluanes in their shagged haire, with Hamadriades trace:

The shadie Satires make a Quiere, which rocks with Ecchoes grace.

All breathe delight, all solace in the season:

Not now to sing, were enemie to reason.

run away, stray

it: the shepherd's state

Cosma my Loue, and more then so, the life of mine affections:

Nor life alone, but Lady too, and Queene of their directions.

wood-nymphs; dance satyrs; quire, choir

take comfort or delight

Cosma my Loue is faire you know, and which you Sheepheards know not:

Is (Sophi said) thence called so, but names her beauty showe not.

Yet hath the world no better name then she:

And then the world, no fairer thing can be.

The Sunne vpon her fore-head stands, (or iewell Sunne-like glorious,)

Her fore-head wrought with Ioues owne hands, for heauenly white notorious.

famous (in a good sense)

104 not backward] A person's lot or fortune cannot be reversed. 105 store] company, community (OED 3, 'a body of persons', last cit. 1563). 8 reclaimed] reformed, virtuous; perhaps 'redeemed' in the Christian theological sense: in a state of moral innocence, free of original sin. 27 Sophi] Sophia, divine wisdom. thence called so] i.e. so named for her beauty. Gk. kosmos, literally 'order', commonly means the ordered system of the created universe, but also adornment, decoration, hence ?beauty. In any case, the Neoplatonic notion of beauty is rooted in its reflection of the divine order. 29 the world] the basic meaning of kosmos. 
Her golden lockes like Hermus sands, (or then bright Hermus brighter:)

A spangled Cauill binds in with bands, then siluer morning lighter.

?clasp or fastening

And if the Planets are the chiefe in skies:

No other starres then Planets are her eyes.

Her cheeke, her lip; fresh cheeke, more fresh, then selfe-blowne buds of Roses:

Rare lip, more red then those of flesh, which thousand sweetes encloses:

Sweet breath, which all things dooth refresh, and words than breath farre sweeter:

Cheeke firme, lip firme, not fraile nor nesh, as substance which is fleeter

In praise doo not surmount, although in placing,

Her christall necke, round breast, and armes embracing.

The thorough-shining ayre I weene, is not so perfect cleare:

As is the skie of her faire skinne, whereon no spots appeare.

The parts which ought not to be seene, for soueraigne woorth excell:

Her thighs with Azure braunched beene, and all in her are well.

Long Iuorie hands, legges straighter then the Pine:

Well shapen feete, but vertue most diuine.

Nor cloathed like a Sheepheardesse, but rather like a Queene:

Her mantle dooth the formes expresse, of all which may be seene.

Roabe fitter for an Empresse, then for a Sheepheard's loue:

Roabe fit alone for such a Lasse, as Emperours doth moue.

Roabe which heauens Queene, the bride of her owne brother,

Would grace herselfe with, or with such another.

pleasures, delights

soft, hence weak, delicate thinner, lighter surpass, excel

think, believe, 'guess'

Who euer (and who else but Ioue) embroidered the same:

Hee knew the world, and what did moue, in all the mightie frame.

So well (belike his skill to proue) the counterfeits he wrought:

Of wood-Gods, and of euery groaue, and all which else was ought.

Is there a beast, a bird, a fish worth noate?

Then that he drew, and picturde in her coate.

A vaile of Lawne like vapour thin vnto her anckle trailes:

Through which the shapes discerned bin, as too and fro it sailes.

Shapes both of men, who neuer lin to search her wonders out:

pass, occur

images, likenesses

aught, anything, i.e., whatever exists

a kind of fine linen

stop, desist

35 Hermus] the river Gediz in ancient Lydia (in modern Turkey), among whose tributaries was the gold-bearing stream of Paktolos. 40 The Petrarchan mistress's eyes are commonly compared to stars, but Cosma's eyes actually are heavenly bodies. $\mathbf{4 2}$ self-blowne] blooming naturally, not through cosmetics. 49 although in placing] i.e. They are placed higher than the neck, breast and arms (50), but are not superior in beauty. 57 with Azure braunched] with delicate blue veins. 65 Empresse] The metre demands three syllables: perhaps should be written Emperesse. 69 This line has an extra syllable. Perhaps the initial Roabe, wrongly following 65 and 67 , should be omitted. bride of her owne brother] Hera or Juno, heauens Queene, was sister as well as wife to Zeus. 
Of monsters and of Gods a kin, which her empale about.

A little world her flowing garment seemes:

For heere and there appeare forth towers, among the chalkie downes:

Citties among the Country bowers, which smiling Sun-shine crownes.

Her mettall buskins deckt with flowers, as th'earth when frosts are gone,

Besprinckled are with Orient showers of hayle and pebble stone.

a kind of high knee-length boots lustrous, shining

Her feature peerelesse, peerelesse her attire, I can but loue her loue, with zeale entire.

$\mathrm{O}$ who can sing her beauties best, or that remaines vnsung?

Doe thou Apollo tune the rest, vnworthy is my tongue.

To gaze on her, is to be blest, so wondrous fayre her face is;

Her fairenes cannot be exprest, in Goddesses nor Graces.

I loue my loue, the goodly worke of Nature:

110 Admire her face, but more admire her stature.

On thee (ô Cosma) will I gaze, and reade thy beauties euer:

Delighting in the blessed maze, which can be ended neuer.

For in the luster of thy rayes, appeares thy parents brightnes:

Who, himselfe infinite, displaies in thee his proper greatnes.

\section{Edmund Bolton(?) The Shepherds' Song for Christmas}

First published in Helicon as by 'E.B.', generally taken as Edmund Bolton. Spoken by one of the shepherds of the Nativity (Luke 2. 8-20): he has seen the angels announce the birth of Christ, and is reporting the event to his 'peeres'.

The Sheepheards Song: a Caroll or Himne for Christmas.

Sweete Musique, sweeter farre

Then any Song is sweete:

Sweete Musique heauenly rare,

Mine eares (ô peeres) dooth greete.

study, peruse

wonder, amazement

You gentle flocks, whose fleeces pearl'd with dewe,
Resemble heauen, whom golden drops make bright:

companions

Listen, ô listen, now, ô not to you

Our pipes make sport to shorten wearie night,

89 little world] The human entity was seen as a microcosm, exactly reproducing the structure and components of the macrocosm or 'great world'. As a human form, Cosma is a microcosm; as the created universe, the macrocosm. $\quad 95$ mettall] shining like metal, especially gold. $\quad$ 97-8 Orient ... pebble stone] combines the images of a hailstorm in spring and scattered or studded jewels. Pebble] a colourless quartz $\left(O E D_{2}\right.$ b) or various semi-precious stones $\left(O E D_{2} 2 \mathrm{c}\right) . \quad$ 101-2 sing ... vnsung] best praise her visible beauties as well as (a) her hidden charms (b) what has not yet been said. 108 Goddesses nor Graces] Perhaps so phrased for the alliteration: the Graces (Charites) are goddesses. 116 thy parents] God's. The Neoplatonic kosmos is an emanation of the ideal and inexpressible One. The concept is placed within a Christian framework here as commonly in the Renaissance. 7 not] goes with pipes (9): 'not our pipes, but most divine voices make harmony'. 
But voyces most diuine,

Make blisfull Harmonie:

Voyces that seeme to shine,

For what else cleares the skie?

lights up, illumines

Tunes can we heare, but not the Singers see:

The tunes diuine, and so the Singers be.

Loe how the firmament,

Within an azure fold

The flock of starres hath pent,

That we might them behold.

penned, confined (like sheep in a fold)

Yet from their beames proceedeth not this light,

Nor can their Christalls such reflection giue:

What then dooth make the Element so bright?

The heauens are come downe vpon earth to liue.

sky or air

But harken to the Song,

Glorie to glories King:

And peace all men among,

These Queristers doo sing.

Angels they are, as also (Sheepheards) hee,

Whom in our feare we doo admire to see.

wonder at, feel awe

Let not amazement blinde

Your soules (said he) annoy:

stupefaction, bewilderment trouble, vex

To you and all mankinde,

My message bringeth ioy.

For loe the worlds great Sheepheard now is borne

A blessed Babe, an Infant full of power:

After long night, vp-risen is the morne,

Renowning Bethlem in the Sauiour.

Sprung is the perfect day,

By Prophets seene a farre:

Sprung is the mirthfull May,

Which Winter cannot marre.

In Dauids Cittie dooth this Sunne appeare:

Clouded in flesh, yet Sheepheards sit we heere.

covered, hidden

\section{Phillida's Love-Call to Her Coridon, and His Replying}

First published in Helicon. Also found with draft-like variations and emendations (and musical setting) in Bodleian MS Rawl. Poet.148, c.1598-9 - i.e. earlier than Helicon - suggesting that the author may be John Lilliat, the progenitor of the manuscript. Helicon text followed below.

Phillidaes Loue-call to her Coridon, and his replying

Phillida. Coridon, arise my Coridon, Titan shineth cleare:

Coridon. Who is it that calleth Coridon, who is it that I heare?

Phillida. Phillida thy true-Loue calleth thee, arise then, arise then; arise and keepe thy flocks with me:

Coridon. Phillida my true-Loue, is it she?

I come then, I come then,

I come and keepe my flock with thee.

20 Christalls] i.e. stars. Cf. OED crystal 3a: '(poet.) matter that has the clarity or transparency of crystal'. 27 hee] apparently the leader or spokesman of the angels. 35 morne] i.e. the sun, with play on Son (of God). $\quad 39$ May] spring, with play on Sprung. $\quad 41$ Dauids Cittie] Jerusalem. $\quad 2$ Titan] the sun: referring to Helios, the sun-god among the old gods or Titans. 
Phillida. Heere are cherries ripe my Coridon, eate them for my sake:

Coridon. Heere's my Oaten pipe my louely one, sport for thee to make.

Phillida. Heere are threeds my true-Loue, fine as silke, to knit thee, to knit thee a paire of stockings white as milke.

Coridon. Heere are Reedes my true-Loue, fine and neate, to make thee, to make thee a Bonnet to with-stand the heate.

Phillida. I will gather flowers my Coridon, to set in thy cap:

Coridon. I will gather Peares my louely one, to put in thy lap.

Phillida. I will buy my true-Loue Garters gay, for Sundayes, for Sundayes, to weare about his legs so tall:

Coridon. I will buy my true-Loue yellow Say, for Sundayes, for Sundayes, to weare about her middle small.

Phillida. When my Coridon sits on a hill, making melodie:

Coridon. When my louely one goes to her wheele singing cherilie.

Phillida. Sure me thinks my true-Loue dooth excell for sweetnes, for sweetnes, our Pan that old Arcadian Knight:

Coridon. And me thinks my true-Loue beares the bell for clearenes, for clearenes, beyond the Nimphs that be so bright.

Phillida. Had my Coridon, my Coridon, beene (alack) my Swaine:

Coridon. Had my louely one, my louely one, beene in Ida plaine.

Phillida. Cinthia Endimion had refus'd, preferring, preferring my Coridon to play with-all:

Coridon. The Queene of Loue had beene excus'd, bequeathing, bequeathing, my Phillida the golden ball.

Phillida. Yonder comes my Mother, Coridon, whether shall I flie?

Coridon. Vnder yonder Beech my louely one, while she passeth by.

Say to her thy true-Loue was not heere, remember, remember, to morrow is another day:

Phillida. Doubt me not, my true-Loue, doo not feare, farewell then, farewell then,

28 Say] 'a cloth of fine texture' (OED say $\left.\mathrm{n}^{1} 1 \mathrm{a}\right) . \quad 38$ beares the bell] takes first place, like the bell-wether or leading sheep in a flock. 41-8 41-2, 45-7 go together, as do 43-4, 48-50. 42 Had Coridon my swain been there. 44 Ida plaine] actually a mountain. Paris dwelt there as a shepherd when called to judge the contest for beauty between three goddesses, awarding Venus the prize. 48 excus'd] dismissed, dispensed with (not in OED: nearest sense $O E D$ v8). 


\section{John Wootton Dametas' Jig in Praise of His Love}

From Helicon. The title suggests a narrative or dramatic source, not identified so far.

Damotas Iigge in praise of his Loue.

Iolly Sheepheard, Sheepheard on a hill on a hill so merrily, on a hill so cherily,

Feare not Sheepheard there to pipe thy fill,

Fill euery Dale, fill euery Plaine: both sing and say; Loue feeles no paine.

Iolly Sheepheard, Sheepheard on a greene on a greene so merrily, on a greene so cherily,

Be thy voyce shrill, be thy mirth seene,

Heard to each Swaine, seene to each Trull: both sing and say; Loues ioy is full.

Iolly Sheepheard, Sheepheard in the Sunne, in the Sunne so merrily, in the Sunne so cherily,

Sing forth thy songs, and let thy rimes runne

Downe to the Dales, to the hills aboue: both sing and say; No life to loue.

Iolly Sheepheard, Sheepheard in the shade, in the shade so merrily, in the shade so cherily,

Ioy in thy life, life of Sheepheards trade;

Ioy in thy loue, loue full of glee: both sing and say; Sweet Loue for me.

Iolly Sheepheard, Sheepheard heere or there, heere or there so merrily, heere or there so cherily,

Or in thy chat, eyther at thy cheere,

In euery ligge, in euery Lay: both sing and say; Loue lasts for aye.

whether ... or by for ever 30

Iolly Sheepheard, Sheepheard Daphnis Loue, Daphnis loue so merrily, Daphnis loue so cherily,

Let thy fancie neuer more remoue,

Fancie be fixt, fixt not to fleete, still sing and say; Loues yoake is sweete.

1 Iolly] A general term of approbation combining nuances of 'gay, cheerful' (OED 1), 'amorous' (OED 7), 'handsome' $\left(O E D_{10}\right)$. $\quad 11$ Trull] girl, wench $\left(O E D_{2}\right)$ : no pejorative sense. 18 No life to loue] No life can compare with the lover's. 25 heere or there] ?moving here and there, moving among people. $\quad 28$ By your speech and your happy countenance. 29 Iigge] (a) a dance (b) a song (c) a jest or sport. 31 Sheepheard Daphnis Loue] Syntax unclear. Probably means the shepherd being addressed is Daphnis' love. 


\section{6 'W.H.' Wodenfride's Song in Praise of Amargana}

First published in Helicon. Ascribed to an unidentified 'W.H.', perhaps William Hunnis, in both Helicon and Francis Davison's ms list of authors of Helicon poems. The unusual title, the refrain, and the reference to 'This feast and meeting' (26) suggest a narrative context, perhaps in some outdoor pageant or entertainment for Queen Elizabeth; but if so, that has not been identified either. There is a general resemblance to a passage in England's Parnassus (1600), p.366 ascribed to 'D. Lodge', but this too is otherwise untraced.

Wodenfrides Song in praise of Amargana.

The Sunne the season in each thing

Reuiues new pleasures, the sweet Spring

Hath put to flight the Winter keene:

To glad our louely Sommer Queene.

seasoning or enlivening element

The pathes where Amargana treads,

With flowrie tap'stries Flora spreads.

And Nature cloathes the ground in greene:

To glad our louely Sommer Queene.

The Groaues put on their rich aray,

With Hawthorne bloomes imbroydered gay,

And sweet perfum'd with Eglantine:

To glad our louely Sommer Queene.

The silent Riuer stayes his course,

ceases to flow

Whilst playing on the christall sourse,

The siluer scaled fish are seene,

To glad our louely Sommer Queene.

The Woods at her faire sight reioyces,

The little birds with their lowd voyces,

In consort on the bryers beene,

To glad our louely Sommer Queene.

The fleecie Flocks doo scud and skip,

The wood-Nimphs, Fawnes, and Satires trip,

run, dart

And daunce the Mirtle trees betweene:

To glad our louely Sommer Queene.

Great Pan (our God) for her deere sake,

This feast and meeting bids vs make,

Of Sheepheards, Lads, and Lasses sheene:

piercing, bitingly cold

To glad our louely Sheepheards Queene.

beautiful

And euery Swaine his chaunce dooth proue,

try out, test

To winne faire Amarganaes loue,

In sporting strifes quite voide of spleene:

To glad our louely Sommer Queene.

All happines let Heauen her lend,

And all the Graces her attend.

Thus bid me pray the Muses nine,

Long liue our louely Sommer Queene.

14 While flowing at its clear source. playing] dancing, rippling (OED play $\mathrm{v} 7 \mathrm{~b}$ ). 19 beene] The old plural in -en. 28 Sheepheards] perhaps misprint (suggested by Sheepheards in 1.27) for the usual Sommer, to which the 1614 edn of Helicon reverts. 


\section{Robert Chester A Poor Shepherd's Introduction}

Part of a Christmas entertainment at the home of the Salusbury family in North Wales, from a family ms now in Christ Church College, Oxford. Chester was an employee and protégé of John Salusbury (1566/7-1612). All punctuation inserted in this edition, and line initials uniformly capitalized.

A poore Sheapheards introduction made in A merem[en]t of christmas at the house of the Right Worshipfull John Salusbury of Lleweny Esq ${ }^{\mathrm{r}}$

Sheapheards be sylent, and our musick cease:

Heare duells our frolique freind of Arcady

Whose dogges defend our sheep from greedy wolues,

Whose sheep doth cloth our silly sheapheard swaines,

Whose oxen tills the grownd that yelds vs corne,

Whose corne doth reliue the fatherles,

relieve

And fatherles still pray for his relieffe.

We of Arcadia, sometime frolique swaines,

Swaines that delight in homely pleasaunt mirth,

In due obedience and regard of loue

Shold heare present as newe yeares homely gifte

Peares Apples fildbierds or the hazell nutt

Or other fruite that this faire clymatt yelds;

But nipping winter and a forward spring

Blasted our trees and all our sommer budds

whose blossomes shold haue yelded dainty fare.

Therefore seing all these giftes that shold befreind vs

The balesome weather and cold spring denied,

In signe of honor and obedience

To the whight Lyon of Arcadia

That doth defend our liues from ravenous bears

And feeds vs with the pray that he persues,

A homely cuntry hornepipe we will daunce,

A sheapheards prety Gigg to make him sport,

And sing A madringall or roundelay

To please our Lordlike sheapheard lord of vs.

Take hands, take hands, our hartes lett vs Advaunce

And strive to please his humour with A daunce.

\section{8 'A.W.' Eclogue upon the Death of Sir Philip Sidney}

First published in Francis Davison's collection A Poetical Rhapsody (1602). Sidney died in 1586, and Davison says in his preface that some pieces on Sidney in the volume were written 'almost twentie yeeres since'. This poem is ascribed to 'A. W.' in the book and (like 67 others there cited as anonymous or by other poets) in a ms list compiled by Davison (BL MS 280 fols.99-100). A. W. has been variously but inconclusively identified as Andrew Willett, Arthur Warren and Davison himself.

EgLOGVe.

Made long since vpon the death of Sir Phillip Sidney.

Thenot. Perin.

Thenot. Perin, arreed what new mischance betide,

Hath rast thee of thy wonted meriment?

Faire feeds thy flock this pleasant spring beside,

Nor Loue, I ween, hath made thee discontent,

Sild Age and Loue, to meet in one, consent.

inform, tell; befallen razed, deprived

seldom

Perin. Ah Thenot, where the Ioy of hart doth faile, What maruaile there, if mirth and musick quaile?

2 frolique] (a) merry, sportive (b) liberal, bountiful (OED 2). $\quad 12$ fildbierds] filberts, a kind of hazelnut, distinguished from the 'hazell nutt' by the greater length of the fruit. 17 giftes] i.e. the fruit of the trees. 20 whight Lyon] Salusbury had earned the sobriquet 'the Strong'. 
See how the flowrets of the field do spring,

The Purple Rose, the Lilly white as Snow;

With smell and colour for an Haruest King,

May serue to make vs yong againe, I trow.

believe, think

Yet all this pride is quickly laid full low,

Soon as the root is nipt with northerne cold,

What smell, or beauty, can we then behold?

Thenot. As good not heare, as heard, not vnderstand,

My borrell braines through eld beene all too dull,

Sike mister meaning nill by mee be scand,

All as my Face, so wrinckled is my skull:

Then say me Perin, by thy hope of wull,

So not one Aneling in thy flock be found.

ignorant, boorish; old age

just like

hope of abundant wool full udders

most beloved

Perin. Ah Thenot, by thine alderliefest Lasse,

Or whatsoeuer is more deere to thee;

No Bagpipe name, let song and sollace passe,

Death hath vndon my flock, my pipe, and mee.

Dead is the Sheeps delight, and Shepheards glee, Broke is my Pipe, and I myselfe forlorne, My Sheep vnfed, their fleeces rent and torne.

Thenot. I mickle muz'de such vncouth change to see, My flockes refuz'de to feed, yet hale they weare:

The tender Birds sate drooping on the tree,

The carelesse Lambs went wandring here and there:

My selfe vnknowne a part of griefe did beare, Ne wist I why, yet heauy was my hart, Vntimely Death was cause of all this smart.

Vp, Perin, vp, aduaunce thy mournfull layes,

Sound loud thy pipe, but sound in dolefull wise.

Perin. Who else, but Thenot, can the Muses raise,

And teach them sing and dance in mournfull guise?

My fingers stiffe, my voice doth hoarsely rise.

Thenot. Ah, where is Collin, and his passing skill?

For him it sits our sorrow to fulfill.

suits, befits

greatly wondered
[vncouth: unknown, unprecedented

Perin. Tway sore extreames our Collin presse so neere,

(Alas that such extreames should presse him so)

The want of wealth, and losse of loue so deere,

Scarse can he breathe from vnder heapes of woe,

He that beares heau'n, beares no such weight I trow.

Thenot. Hath he such skill in making all aboue, And hath no skill to get or Wealth, or Loue?

Perin. Praise is the greatest prise that Poets gaine,

A simple gaine that feeds them ne're a whit.

The wanton lasse for whom he bare such paine,

Like running water loues to change and flit.

But if thee list to heare a sorry fit,

Which Cuddy could in dolefull verse endite,

Blow thou thy Pipe while I the same recite.

two

Thenot. Ginne when thou list, all-be my skill but small, My forward minde shall make amends for all.

bare, without advantage

(part of a) poem or tale knows how to, is able to

begin; although ready, eager

15 proverbial. 17 I cannot understand this kind of meaning.

21 Aneling] eanling: a newborn lamb, here weak or orphaned. 41 Collin] Spenser. 45 want of wealth] There was a widespread but exaggerated belief that Spenser spent his last days in neglect and want. losse of loue] Colin's unhappy love for Rosalind in SC. 47 He that beares heau'n] the Titan Atlas. surpassing all others. making] poetic composition.

48 skill ... above] poetic skill 
Perin. Yee Nimphs that bathe your bodies in this spring:

Your tender bodies white as driuen Snow:

Yee Virgins chaste which in this Groue doe sing,

Which neither griefe of Loue, nor Death do know:

So may your streames runne cleere for ay,

So may your trees giue shade alway.

Depart a space,

And giue me place,

To wayle with griefe my restlesse woe alone,

For feare my cries

Constraine your eyes

To shed forth teares, and help lament my mone.

And thou, my Muse, that whilome wont to ease

Thy Maisters minde with layes of sweete delight,

for ever

Move some distance away

Now change those tunes, no ioy my hart can please,

Gone is the day, come is the darkesome night,

Our Sunne close hid in cloudes doth lie,

We liue indeede, but liuing, die:

No light we see,

Yet wander wee,

We wander farre and neere without a guide:

And all astray,

We loose our way,

For in this world n'is such a Sunne beside.

were once accustomed

Ye Shepheards Boyes that leade your flocks a field,

The whilst your sheepe feede safely round about,

Breake me your Pipes that pleasant sound did yeeld,

Sing now no more the Songs of Collin Clout:

Lament the end of all our ioy,

Lament the source of all annoy.

WILLY is dead,

That wont to leade

Our flockes and vs in mirth and Shepheards glee:

Wel could he sing,

Wel dance, and spring;

Of all the Shepheards was none such as hee.

How often hath his skill in pleasant Song.

Drawn al the water-nimphs from out their bowers?

How haue they laine the tender grasse along,

And made him Garlands gay of smelling flowers?

Phoebus himselfe that conquer'd Pan,

Striuing with Willy, nothing wan.

Me thinkes I see,

The time when hee

Pluckt from his golden lockes the Laurell crowne; And so to raise

Our Willies praise,

Bedeckt his head, and softly set him downe.

The learned Muses flockt to heare his skill,

And quite forgot their water, wood, and mount;

They thought his Songs were done too quickly stil,

Of none but Willies Pipe they made account.

Hee sung; they seemd in ioy to flowe:

He ceast; they seemd to weep for woe;

The Rurall rout,

All round about,

\section{is not; other than this}

fragrant

won

100

ended

61-4 Evokes a paradisal or Parnassian setting. Virgins] ?Muses.

in a song-contest (Ovid Met. XI.146-93). 108 water, wood, and mount] the Castalian spring on Mount Parnassus, or the springs Aganippe and Hippocrene beneath Mount Helicon. Both 'mounts' were wooded, with a grove sacred to the Muses beside the Hippocrene. 
Like Bees came swarming thicke, to heare him sing:

Ne could they thinke

On meate or drinke,

While Willies musicke in their eares did ring.

But now (alas) such pleasant mirth is past,

Apollo weepes, the Muses rend their haire.

No ioy on earth that any time can last,

See where his breathlesse corps lies on the beare.

That selfe same hand that reft his life,

Hath turned Shepheards peace to strife.

turmoil, distress

Our ioy is fled,

Our life is dead,

Our hope, our help, our glory all is gone:

Our Poets praise,

Our happy dayes,

And nothing left but griefe, to thinke thereon.

What Thames, what Seuerne, or what westerne Seas,

Shall giue me floods of trickling teares to shed?

What comfort can my restlesse griefe appease?

$\mathrm{O}$ that mine eies were Fountaines in my head!

Ah Collin! I lament thy case,

For thee remaines no hope of grace.

The best reliefe

Of Poets griefe

Is dead, and wrapt full colde in filthy clay,

And nought remaines

To ease our paines,

But hope of death, to ridde vs hence away.

remove, release

Phillis, thine is the greatest griefe aboue the rest:

Where beene thy sweetest Posies feately dight,

Thy Girlonds with a true-loues Knot addrest,

And all that erst thou Willy didst behight?

Thy labour all is lost in vaine,

The griefe whereof shall ay remaine.

The Sunne so bright,

That falles to night,

To morrow from the East againe shall rise:

But we decay,

And waste away,

Without returne, alas, thy Willy dies.

See how the drooping Flockes refuse to feede,

The Riuers streame with teares aboue the bankes,

The Trees do shed their leaues, to waile agreede,

The beasts vnfed, go mourning all in rankes.

The Sunne denies the Earth his light,

The Spring is kill'd with winters might:

The flowers spill,

The birds are still:

No voyce of ioy is heard in any place.

The Meddows greene

A change haue seene,

And Flora hides her pale disfigur'd face.

135-9 Referring to Sidney's patronage of Spenser. 143 Phillis] Sidney's wife Frances, daughter of Francis Walsingham; or Penelope Devereux (Rich), the 'Stella' of his poems; or perhaps Sidney's sister Mary, Countess of Pembroke. 149-54 Closely echoes some famous lines in Catullus (usually numbered poem 5): 'Suns may set and rise again; but when our brief light is once quenched, there remains only an endless night to sleep in'. 
Watch now, ye shepheards boyes, with waking eie,

And loose your time of sleepe, to learne to sing.

Vnhappy skill, what good is got thereby,

But painted praise that can no profite bring?

If Skill could moue the Sisters three,

Our Willy still aliue should be.

The woolfe so wood,

Amazed stood

At sound of Willies pipe, and left his pray:

artificial

170

rabid, mad, violent

Both Pipe and Skill

The Sisters spill,

So, worse then any wicked Wolfe are they.

O flatt'ring hope of mortal mens delight,

So faire in outward shew, so foule within!

The deepest streames do flow full calme to sight,

The rau'ning Woolues do jet in Weathers skin;

Wee deem'd our Willy ay should liue,

So sweete a sound his Pipe could give:

But cruel death

Hath stopt his breath:

Dumbe lies his Pipe that won so sweete to sound:

Our flockes lament

His life is spent,

And careless wander all the woods around.

Come now, ye shepheards daughters, come no more

To heare the Songs that Cuddy wont to sing:

Hoarse is my Muse, my throate with crying, sore;

These woods with Eccho of my griefe doe ring.

Your Willies life was Cuddies ioy,

Your Willies death hath kill'd the Boy:

Broke lies my Pipe,

Till Reedes be ripe

To make a new one, but a worse, I feare:

Saue yeere by yeere,

To waile my Deere,

All Pipe and Song I vtterly forsweare.

Thenot. Alacke and welladay may shepheards cry,

Our Willy dead, our Collin killd with care:

Who shall not loathe to liue, and long to die?

And will not griefe our little Cuddy spare,

But must he too of sorrow haue a share?

Ay, how his ruefull Verse hath prickt my hart!

How feelingly hath hee exprest my smart!

Perin. Ah Thenot, hadst thou seene his sory looke,

His wringed hands, his eies to heau'n vpkest;

His teares, that stream'd like water in the Brooke;

His sighes, that made his Rimes seeme rudely drest,

To teares thou wouldsst haue melted with the rest.

But hie we homeward, night approcheth neere,

And rainie cloudes in southerne skies appeere.
180

(a) swagger, strut (b) go about for ever

attained, achieved

heedless, distracted

171 Sisters three] the Parcae or Fates. 182 The wolf in sheep's clothing derives from Matthew 7.15. 


\section{Mary Herbert, Countess of Pembroke A Dialogue between Two Shep- herds in Praise of Astraea}

First published in Francis Davison's A Poetical Rhapsody (1602). Hyder Rollins proposes (citing the $D N B$ ) that the occasion may have been the Queen's 1599 visit to the Earl of Pembroke's seat at Wilton. Nichols (Progresses of Elizabeth, III.529) prefers ' 1600 , when the Queen meditated a Progress into North Wiltshire... and [the poem] was perhaps recited in 1601 in Aldersgate Street.' If the projected visit was before Lady Day (23 March) 1600, it could have been recorded as 1599.

A Dialogve betweene two shepheards, Thenot, and Piers, in praise of Astrea, made by the excellent Lady, the Lady Mary Countesse of Pembrook, at the Queenes Maiesties being at her house at Anno 15 .

Thenot. I sing diuine Astreas praise,

O Muses! help my wittes to raise, And heaue my Verses higher.

Piers. Thou needst the truth but plainely tell,

Which much I doubt thou canst not well, Thou art so oft a lier.

Thenot. If in my Song no more I show,

Than Heau'n, and Earth, and Sea do know,

Then truely I haue spoken.

Piers. Sufficeth not no more to name,

But being no lesse, the like, the same, Else lawes of truth be broken.

Thenot. Then say, she is so good, so faire,

With all the earth she may compare, Not Momus selfe denying.

Piers. Compare may thinke where likenesse holds,

Nought like to her the earth enfoldes, $I$ lookt to finde you lying.

expected to

Thenot. Astrea sees with Wisedom's sight,

Astrea workes by Vertue's might,

And ioyntly both do stay in her.

Piers. Nay take from them, her hand, her minde,

The one is lame, the other blinde,

Shall still your lying staine her?

Thenot. Soone as Astrea shewes her face,

Strait euery ill auoides the place,

And euery good aboundeth.

Piers. Nay long before her face doth showe,

The last doth come, the first doth goe, How lowde this lie resoundeth!

latter ... former

Thenot. Astrea is our chiefest ioy,

Our chiefest guarde against annoy,

Our chiefest wealth, our treasure.

Piers. Where chiefest are, there others bee,

To vs none else but only shee;

When wilt thou speake in measure?

?in a sober or fitting way

Thenot. Astrea may be iustly sayd,

A field in flowry Roabe arrayd, In Season freshly springing.

Piers. That Spring indures but shortest time, This neuer leaues Astreas clime,

o.1 Astraea] the virgin goddess of justice, with whom the virgin Queen was often compared. Astraea dwelt on earth in the Golden Age and left thereafter. (Virgil IV.6, Georg. II.473; Ovid, Met. I.150). o.2-0.3 The venue, and last two digits of the date, are left blank. 10 It is not enough to say so little. 15 Momus] god of satire, hence a carping critic. 16-17 Comparisons are between like things, but there is nothing like her. $\quad 34-5$ 'Chiefest' implies there are others to compare; but she is incomparable. $\quad 41$ Eternal spring is a common topos in pastoral and the Golden Age myth, linking up with Paradise and hence with man's state of innocence before the Fall. Astraea's clime] see o.1n. 
Thou liest, instead of singing.

Thenot. As heauenly light that guides the day,

Right so doth shine each louely Ray,

That from Astrea flyeth.

Piers. Nay, darknes oft that light enclowdes,

Astreas beames no darknes shrowdes;

How lowdly Thenot lyeth!

Thenot. Astrea rightly terme I may,

A manly Palme, a Maiden Bay,

Her verdure neuer dying.

Piers. Palme oft is crooked, Bay is lowe,

Shee still vpright, still high doth growe,

Good Thenot leaue thy lying.

Thenot. Then Piers, of friendship tell me why,

My meaning true, my words should ly,

And striue in vaine to raise her.

Piers. Words from conceit do only rise,

Aboue conceit her honour flies;

But silence, nought can praise her.

\section{Fiction How Cupid Made a Nymph Wound Herself with His Arrows}

First published in Francis Davison's collection A Poetical Rhapsody (1602). Also with the title 'Cupids Pastime' in an appendix to Le Prince d' Amour, ed. Sir Rudyerd Benjamin (1660).

Fiction how Cupid made a Nymph wound her selfe with his Arrowes.

It chaunst of late a Shepheardes swaine,

That went to seeke a strayed sheepe,

Within a thicket on the plaine,

Espide a daintie Nymph asleepe.

beautiful, graceful: general term of approbation

Her golden Haire ore-spread her face,

Her carelesse Armes abroad were cast,

Her Quiuer had her Pillowes place,

heedless, unawares (in sleep)

Her breast lay bare to euery blast.

The Shepheard stood and gazde his fill,

Nought durst hee doo, nought durst he say:

When Chance or else perhaps his Will,

Did guide the God of Loue that way.

The crafty boy that sees her sleep,

Whom if shee wakte, he durst not see,

Behinde her closely seekes to creepe,

Before her nap should ended bee.

(a) close, near (b) secretly, stealthily

There come, he steales her shaftes away,

And puttes his owne into their place,

Ne dares he any longer stay,

But ere she wakes, hies thence apace.

Scarce was hee gone, when shee awakes,

And spies the Shepheard standing by;

Her bended Bowe in haste shee takes,

And at the simple Swaine let fly.

Foorth flew the shafte, and pierst his hart,

That to the ground hee fell with paine:

so that

50 Palme ... Bay] both evergreen. manly] as standing erect. maiden] as languishing or clinging to a tree like the laurel (bay), hence feminized 14 Because he is afraid of her fierce chastity. 
Yet vp againe forthwith hee start,

And to the Nymphe hee ran amaine:

Amaz'de to see so strange a sight,

She shot, and shot, but all in vaine,

The more his wounds, the more his might,

Loue yeeldeth strength in midst of paine.

Her angry Eyes are great with teares,

She blames her hands, she blames her skill;

The bluntnesse of her Shaftes she feares,

And try them on her selfe she will.

suspects, doubts

Take heed, sweet Nimph, try not the shaft,

Eache little touch will pricke the harte,

Alas, thou knowest not Cupids craft,

Reuenge is ioy, the End is smart.

Yet try she wil, and prick some bare,

Her Hands were glou'd, and next to hand

Was that faire Breast, that breast so rare,

That made the shepheard sencelesse stand.

That brest she prickt, and through that brest,

Loue findes an entry to her hart:

At feeling of this new-come Guest,

Lord how the gentle Nimph doth start!

Shee runnes not now, she shootes no more,

Away she throwes both shaftes and bowe, 50

Shee seekes for that she shun'd before,

She thinks the Shepheards haste too slowe.

Though mountaines meet not, Louers may:

So others doo, and so doo they.

The God of Loue sittes on a tree,

And laughes that pleasant sight to see.

\section{Francis Davison 'A Shepherd poor'}

First published in A Poetical Rhapsody (1602), edited by Davison himself. Eubulus is the poet's father, the statesman Sir William Davison, used and then unjustly denounced by Elizabeth for the execution of Mary Queen of Scots. The poem shows interesting political application of Petrarchan love-conceits, presenting the disgraced courtier as a scorned lover.

\section{EgLogve.}

A Shepheard poore, Eubulus call'd he was,

(Poore now alas, but erst had iolly beene)

One pleasant morne whenas the Sunne did passe

The fiery hornes of raging Bull betweene, His little Flocke into a Meade did bring, As soone as day-light did begin to spring.

Fresh was the Meade, in Aprils liuerie dight,

Deckt with green Trees, bedewd with siluer Brooks,

But ah! all other was the shepheards plight,

All other were both sheepe and shepheards lookes.

garb; decked, adorned

entirely different

For both did shew by their dull heavy cheere,

They tooke no pleasure of the pleasant yeere. pleasing

1 Eubulus] Gk euboulos, prudent, of good counsel; also the name of an actual statesman of ancient Athens. On both counts, an apt name for the elder Davison. 2 Poore] literally true: Elizabeth fined Davison ten thousand marks. 4 Bull] the zodiacal sign of Taurus, through which the sun passes in late spring / early summer (April 21 - May 21), hence 'fiery ... raging'. 
He weeping went, ay me that he should weepe!

They hung their heads as they to weep would learn.

His heauy Heart did send forth sighings deepe.

They in their bleating voyce did seeme to yearne.

He leane and pale, their fleece was rough and rent:

They pinde with paine, and he with dolors spent.

exhausted, weary

His pleasant Pipe was broke, (alas the while)

pleasing, cheerful

And former meriment was banisht quite.

His shepheards Crooke that him vpheld ere-while,

He erst had throwne away with great despite.

Tho leaning gainst a shrubbe that him sustained,

To th'earth, sun, birds, trees, Eccho thus he plained.

Thou all-forth-bringing earth, though winter chill

With boystrous blasts blow off thy Mantle greene,

And with his Snowe and hoary Frosts doe spill

destroy, kill

Thy Flora-pleasing flowers, and kill them cleene:

Yet soone as Spring returnes againe

To driue away thy Winters paine,

Thy Frost and Snowe

Away doe goe.

Sweete Zephyres breath cold Boreas doth displace,

And fruitfull showers

Reuiue thy flowers,

And nought but Ioy is seene in euery place.

But ah! how long, alas, how long doth last

My endlesse Winter without hope of Spring?

How haue my sighes, my blustring sighes, defaste

The flowers and buds which erst my youth did bring.

Alas the tops that did aspire,

Lie troaden now in filthy mire.

Alas! my head

Is all bespread

With too vntimely snow: and eke my hart

$\mathrm{Al}$ sence hath lost,

Through hardned frost

earlier; indignation, resentment 
Both flower and roote, with most vnkindely dew.

What Sun or Winde

A way can finde,

The roote once dead, the flowers to renew?

Thou. though the scorching heate of Summer Sun,

(While ill-breath'd Dog the raging Lyon chaceth)

Thy peckled flower do make of colour dun,

And pride of all thy greeny haire defaceth;

speckled, parti-coloured

i.e., grass

And in thy moysture-wanting side

Deepe wounds do make, and gashes wide:

Yet as thy weate,

By Phobus heate,

To turne to wholsome drynesse is procured,

So Phoebus heate

By south-winds weate,

Is soone asswaged, and all thy wounds recured.

cured, healed

Such heate as Phoebus hath me almost slaine.

As Phobus heate? ah no, farre worse then his.

It is Astreas burning-hot Disdaine

That parched hath the roote of all my blis:

That hath (alas) my youth defaced,

That in my face deep wounds hath placed.

Ah that no Heate

Can dry the weate,

The flowing weate of my still-weeping Eies!

Ah that no weate

Can quench the heate,

The burning heate within my Hart that lies!

Thou dost, poor Earth, beare many a bitter stound,

While greedy Swaines forgetting former neede,

With crooked plowes thy tender backe do wound,

With harrowes biting teeth do make thee bleede.

But earth (so may those greedy Swaines

With pitteous Eye behold thy paines)

O Earth, tel mee,

When thou dost see

Thy fruitfull Back with golden Eares beset, Doth not that ioy

Kil all annoy,

And make thee all thy former wounds forget?

And I, if once my tired Hart might gaine

If once I might AsTREAs grace regaine:

If once her hart would on my sorrows rue,

Alas, I could these plaints forgo,

And quite forget my former wo.

But $(\mathrm{O}$ ! to speake

My Hart doth breake)

For all my seruice, faith, and patient minde,

A crop of greefe,

Without releefe,

A crop of scorne, and of contempt, I finde.

wet, moisture: rain or flood

caused, made to be

than

wet: moisture, tears

pain, injury

Soone as the Shepheards Star abroad doth wend

(Nights harbinger) to shut in bright-some Day;

comes out

$69 \mathrm{dew}]$ tears $\left(\mathrm{OED}_{3} \mathrm{~b}\right) . \quad 74 \mathrm{Dog}$, Lyon] The sun is in the sign of Leo or the Lion in midsummer (July 23 to August 22: hence hot or 'raging'), and Sirius or the Dog Star is close to it. $77-8$ i.e., The soil is parched and cracked. $\quad \mathbf{8 7}$ Astrea] the virgin goddess of justice, with whom Queen Elizabeth was routinely equated. 91-6 A common Petrarchan conceit: simultaneous heat and moisture, or heat and cold. 98 forgetting ... neede] ?forgetting how little they earlier made do with. $\quad 121$ Shepheards Star] Hesperus, the evening star (cf. Virgil X.77). 
And gloomy Night, on whom black clouds attend,

\section{Doth Tirant-like through skie vsurpe the sway,}

Thou art (poore Earth) of Sunne depriued

Whose beames to thee all Ioy deriued:

But when Aurore

Doth ope her Dore,

Her purple dore to let in Phobus waine,

The night giues place

Vnto his race,

(sun's) course in the sky

rule, authority

conveyed, imparted

And then, with ioy, thy Sun returnes againe.

O would my Sunne would once returne againe!

Returne and driue away th'infernall night,

In which I die, since she did first refraine

Her heauenly beames, which were mine only light.

In her alone all my light shinde,

And since she shinde not, I am blinde.

Alas, on all

Her beames doe fall,

Saue wretched me, whome she doth them deny.

And blessed day

She giues alway,

To all, but me, who still in darkenesse lie.

In mournefull darkenesse I alone doe lie,

And wish, but scarcely hope, bright day to see,

For hop'd so long, and wisht so long haue I,

As hopes and wishes both are gone from mee.

My night hath lasted fifteene yeeres,

And yet no glimpse of day appeeres.

$\mathrm{O}$ do not let

Him that hath set

His ioy, his light, his life in your sweete Grace!

Be vnrelieu'd,

And quite depriu'd

Of your deere sight, which may this night displace.

Phobus, although with firy-hoofed steedes,

Thou daily doe the steepy Welkin beate,

And from this painefull taske art neuer freed,

But daily bound to lend the world thy heate:

hold back, withdraw

Though thou in fiery Chariot ride,

And burning heate thereof abide,

Yet soone as night

Doth dim the light,

And hale her sable Cloake through vaulted skie,

Thy iournie's ceast,

And thou doost rest,

In cooling waues of Tethis soueraigntie.

Thrice happy Sun, whose pains are eas'de by night,

$\mathrm{O}$ haplesse I, whose woes last night and day.

My paines by day do make me wish for night,

My woes by night do make me cry for day.

By day I turmoyle vp and downe,

By night in Seas of teares I drowne.

O paineful plight!

O wretched night,

Which neuer findes a morne of ioyfull light!

127 Aurore] Aurora, goddess of the dawn. 129 Phœbus waine] the chariot of the sun-god. 136 Her heauenly beames] the light of her eyes compared to the sun: a standard Petrarchan image. 149 fifteene yeeres] from 1587 , when William Davison was imprisoned, to 1602 , when this poem appeared. 153-4 The sentence continues across the interjection.

168 Tethis] Tethys, wife of Oceanus, hence identified with the ocean. 
180

\author{
O sad decay, \\ O wretched day,
}

That neuer feeles the ease of silent night!

Ye chirping Birds, whose notes might ioy my minde,

(If to my minde one drop of ioy could sinke,)

Who erst, through Winters rage were almost pinde,

And kept through barren frost from meat or drinke,

A blessed change yee now haue seene,

That changed hath your woefull teene.

By day you sing,

And make to ring

The neighbour groues with Eccho of your Song:

In silent night,

Full closely dight,

You soundly sleepe the bushes greene among.

But I, who erst (ah woefull worde to say)

Enioy'd the pleasant spring of her sweete grace,

And then could sing and dance, and sporte and play;

Since her fierce anger did my Spring displace,

My nightly rest haue turn'd to detriment,

To plaints haue turn'd my wonted meriment.

The Songs I sing

While day doth spring,

Are bootlesse plaints till I can plaine no more.

The rest I taste,

While night doth last,

Is broken sighes, til they my hart make sore.

Thou flowret of the field that erst didst fade,

And nipt with Northerne cold didst hang the head,

Yee Trees whose bared bowes had lost their shade,

Whose with'red leaues by western blasts were shed,

Yee gin to bud and spring againe,

Winter is gone that did you straine.

But I, that late

With vpright gate

Bare vp my head, while happy fauour lasted;

Now olde am growne,

Now ouerthrowne,

With wo, with griefe, with wailing now am wasted.

Your springing stalke with kindly iuice doth sprout, My fainting legs do waste and fall away:

Your stretched armes are clad with leaues about,

My griefe-consumed armes do fast decay.

Yee gin againe your tops lift vp;

I downe to earth-ward gin to stoope.

Each bowe and twig

Doth waxe so big,

That scarce the rinde is able it to hide;

I so do faint,

And pine with plaint,

That slops and Hose, and Galage wax too wide.

hang loose

Eccho, how wel may she that makes me mone,

By thy example learne to rue my paine?

Thou hear'st my plaintes when as I waile alone,

And wailing accents answerest againe.

When as my brest through greefe I beate, wasted away, starved

suffering hurt, afflict

gait

bore, carried

natural, hence vital, vigorous

223-5 The expanding boughs stretch or split the bark. 228 slops] (a) a jacket or mantle (a) a kind of wide hose (but 'Hose' is mentioned separately). Galage] galosh: types of rustic boot or shoe, often of wood or with a wooden sole. 
That wofull sound thou dost repeate.

When as I sob,

And hartly throb,

inwardly, at the heart

A dolefull sobbing sound againe thou sendest:

And when I weep,

And sigh full deep,

A weepy sighing Voice againe thou lendest.

But ah! how oft haue my sad plaints assaide

To pierce her Eares, deafe only vnto mee?

assayed, attempted

How oft my Woes in mournfull inke arraide

Haue tride to make her Eies my griefe to see?

And you, my Sighs and Teares, how often

Haue ye sought her hard hart to soften?

And yet her Eye

Doth still denie

For all my Woes, one bitter teare to shed.

And yet her Hart

Will not impart

One harty sigh, for griefe her self hath bred.

heartfelt

Nor I, alas, do wish that her faire Eyes,

Her blessed-making Eies should shed a teare,

Nor that one sigh from her deere Breast should rise,

For all the paines, the woes, the wrongs I beare.

First let this weight oppresse me still,

Ere shee, through mee taste any ill.

Ah if I might

But gaine her sight,

And shew hir, e're I die, my wretched case!

$\mathrm{O}$ then should I

Contented dy;

But ah I dy, and hope not so much grace.

With that his fainting legs to shrinke begun,

And let him sinke with gastly look to ground

And there he lay as though his life were don,

Till that his Dog, seeing that wofull stound,

With pitteous howling, kissing and with scraping,

Brought him again from that sweet-sowre escaping.

pain, suffering

release

270

Then gan his Teares so swiftly for to flow,

As forst his Ey-lids for to giue them way.

Then blust'ring sighes too boyst'rously gan blow,

As his weake lips could not their fury stay.

And inward griefe withall so hugely sweld,

As tears, sighes, griefe had soon al words expeld.

At last, whenas his teares began to cease,

And weary sighes more calmely for to blowe:

As he began with words his griefe to ease,

And remnant of his broken plaint to show:

He spide the skie o're-spread with nightly clouds,

So home he went, his flocke and him to shrowde.

shelter

Eubulus his Embleme.

VNi Mini Pergama Restant.

241-4 William Davison addressed many appeals to Elizabeth, including a letter that she refused to accept. 253-6 Through all his trials, William did not betray the Queen's private injunction to him to arrange for Mary's assassination rather than official execution. 283 Vni mihi Pergama restant] The words of Hecuba, queen of Troy, in Ovid, Met. XIII.507: 'For me alone, Pergama [Troy] remains' - i.e. though Troy is destroyed, I retain the sorrowful memory. 


\section{Walter Ralegh From The Ocean to Cynthia}

An extract from the only complete book of Ralegh's poem The Ocean to Cynthia in a ms among the Cecil Papers in Hatfield House. The poem is an allusive lament addressed to Queen Elizabeth for her neglect and persecution of Ralegh. He projects himself as the 'Ocean', no doubt on account of his many voyages. The poem as a whole has no specific setting. This passage evokes a country setting in conventional Petrarchan terms. Line initials have been uniformly capitalized.

Lost in the mudd of thos hygh flowinge streames

Which through more fayrer feilds ther courses bend,

Slayne with sealf thoughts, amasde in fearfull dreams,

Woes without date, discumforts without end,

crazed, perplexed

From frutfull trees I gather withred leues

And glean the broken eares with misers hands,

Who svmetyme did inioy the waighty sheves.

I seeke faire floures amidd the brinish sand.

All in the shade yeven in the faire soon dayes

Vnder thos healthless trees I sytt a lone

Wher ioyfull byrdds singe neather lovely layes

Nor phillomen recounts her direfull mone.

No feedinge flockes, no sheapherds cumpanye

That might renew my dollorus consayte

While happy then, while loue and fantasye

Confinde my thoughts onn that faire flock to waite.

No pleasinge streames fast to the ocean wendinge

The messengers svmetymes of my great woe,

But all onn yearth as from the colde stormes bendinge

Shrinck from my thoughts in hygh heauens and below.

\section{Walter Ralegh Epitaph on Robert Cecil}

A rare example of pastoral in a satirical epigram. Found in at least 20 mss in notably varying texts. All ascriptions to Ralegh are posthumous, but his authorship is very probable. Robert Cecil, Earl of Salisbury (1563-1612) was Principal Secretary and chief spymaster of England under Elizabeth (from 1590) and James I. Active in prosecuting and imprisoning Ralegh for his alleged involvement in the 'Main Plot' of 1603 to dethrone James I. If this poem was written soon after Cecil's death, Ralegh would still have been in prison. The text below follows the very full version in BL MS Harley 1221. Punctuation supplied and line initials regularized.

Heere Hobbinoll lyes, our shepeheard whilere

Who once a yeare duly our fleeces did sheere

And made vs so subiect at last to his call

Hee needed no sheepehooke to fetch vs in all.

His Curr he might fasten at home to a clogge

And properly serue for sheepheard and dogge.

For oblations to Pan his custome was thus,

Himselfe gaue a tryfle and offered vp vs.

And so by his craft this pollitick swayne

Kept himselfe on the mountaine and vs on the plaine,

Contented with hornpipes whilest he and his Phillis

Dayly sunge Walsingham and Amarillis.

3 sealf thoughts] thoughts of oneself, introspection. 6 misers hands] small handfuls such as a miser might take; but perhaps miser] wretch, miserable person. 12 phillomen] Philomel, the nightingale. 14 renew ... consayte] revive my sad thoughts. 16 Held my thoughts to linger on that fair flock (a pastoral image of the court or courtly company). 19 bendinge the force of the gale, bending everything low. 2 our fleeces did sheere] Perhaps, like 5, an allusion to Cecil's raising rents on
crown lands in 1608 (Rudick). 5 clogge] block of wood to which an animal is tied. $\mathbf{6}$ serue for] i.e. serve as both. Other mss contain the word 'both'. 7 Pan] James I. 10 mountaine ... plaine] conventional distinction between high and low station, or wealth and poverty: in pastoral, associated with dangerous pride and humble but secure station respectively. 11, 12 Phillis] prob. Queen Elizabeth. $\quad 12$ Walsingham] a traditional ballad, a later version of which has been ascribed to Ralegh: here playing on the name of Sir Francis Walsingham, Cecil's predecessor as Elizabeth's Principal Secretary and spymaster. sunge Walsingham] acted as Walsingham used to do. Amarillis] prob. the popular tune of that name. (See Chappell, Popular Music, though the recorded instances are later in date). 
Meane time neyther wolfe nor Tygeer feard wee

For neuer could worse thing come neere vs then hee.

But hee that our God so highly displeases

As to taste of our blood, must take our diseases.

So though he scapt booth the stroke and the stabbe,

In spight of his Tarbox he died of the scabb.

\section{Henry Chettle 'Feed on my flocks'}

First published in Chettle's Piers Plainnes Seauen Yeres Prentiship (1595). Sung by Piers Plainness, the herdsman employed by the master-shepherd Menalcas. Also in Helicon, whose text is followed here.

Feede on my Flocks securely,

Your Sheepheard watcheth surely, securely, ensuring your safety

Runne about my little Lambs,

Skip and wanton with your Dammes,

Your louing Heard with care will tend ye:

play, gambol

Sport on faire flocks at pleasure, herdsman

Nip Vestaes flowring treasure,

I my selfe will duely harke,

When my watchfull dogge dooth barke, From Woolfe and Foxe I will defend ye.

\section{Henry Chettle(?) A Pastoral Song between Phillis and Amarillis}

First published in Helicon; attributed to 'H. C.' like no.144, undoubtedly by Henry Chettle. An amoebean eclogue presenting an encounter between two attitudes or viewpoints, Phillis dispraising men and Amarillis women. (Conjectural speech-headings inserted in this edition.) 'Line-by-line' in the title probably means that in each verse-unit, the lead singer sings a line (i.e. the odd-numbered lines), with the other responding, as in the August roundelay in Spenser's SC.

A Pastorall Song betweene Phillis and Amarillis, two Nimphes, each aunswering other line for line.

[Phillis]

Fie on the sleights that men deuise, heigh hoe sillie sleights:

When simple Maydes they would entice,

[Amarillis] Maides are yong mens chiefe delights.

Nay, women they witch with their eyes, eyes like beames of burning Sunne:

bewitch

And men once caught, they soon despise, so are Sheepheards oft vndone.

[Phillis]

If any young man win a maide, happy man is he:

By trusting him she is betraide,

[Amarillis] fie vpon such treacherie.

If Maides win young men with their guiles, heigh hoe guilefull greefe:

They deale like weeping Crocodiles,

$\begin{array}{ll}\text { that murther men without releefe. } & \text { (a) respite (b) remedy }\end{array}$

[Phillis]

I know a simple Country Hinde, heigh hoe sillie Swaine:

18 Tarbox ... scabb] Tar was used to salve sheep's wounds, but also to treat venereal disease (the scabb), to which Cecil's detractors attributed his death. 7 Vesta] Roman goddess of home and hearth, also identified with the earth (Ovid, Fasti VI.267). $\quad 5$ they] the women. 6 beams of burning Sunne] conventional Petrarchan conceit. 
To whom faire Daphne prooued kinde, was he not kinde to her againe?

He vowed by Pan with many an oath, heigh hoe Sheepheards God is he:

Yet since hath chang'd, and broke his troath, troth-plight broke, will plagued be.

[Amarillis]

She had deceaued many a Swaine, fie on false deceite:

And plighted troath to them in vaine, there can be no greefe more great.

Her measure was with measure paide,

heigh hoe, heigh hoe equall
She was beguil'd that had betraide,

reward, recompense so shall all deceauers speede.

[Phillis]

If euery Maide were like to me, heigh hoe hard of hart:

Both loue and louers scorn'd should be,

[Amarillis] scorners shall be sure of smart.

If euery Maide were of my minde, heigh hoe, heigh hoe louely sweete:

They to their Louers should prooue kinde, kindnes is for Maydens meete.

[Phillis]

Me thinks loue is an idle toy, heigh hoe busie paine:

Both wit and sence it dooth annoy,

[Amarillis] both sence and wit thereby we gaine.

harm, injure

Tush Phillis cease, be not so coy, heigh hoe, heigh hoe coy disdaine:

I know you loue a Sheepheards boy, fie that Maydens so should faine.

[Phillis]

Well Amarillis, now I yeeld,

Sheepheards pipe aloude:

Loue conquers both in towne and field,

like a Tirant, fierce and proude.

The euening starre is vp ye see,

Vesper shines, we must away:

Would euery Louer might agree,

so we end our Roundelay.

\section{Henry Chettle The Shepherds' Spring Song}

From Henry Chettle's Englandes Mourning Garment (1603), a lament for Queen Elizabeth's death followed by this song celebrating the accession of James I. Punctuation considerably modified.

The Shepheards Spring Song, in gratulation of the royall, happy, and flourishing Entrance, to the Maiestie of England, by the most potent and prudent Soueraigne, Iames king of England, France and Ireland.

Collin. Thenot and Chloris, red lipt Driope,

Shepheards, Nymphs, Swaines, al that delight in field,

Liuing by harmelesse thrift your fat heards yeelde,

28 greefe] wrong, offence $\left(O E D_{2}\right) . \quad 42$ busie paine] diligent exertion (OED 6b, last cit.1502), countering 'idle toy'. Cf. the opposition in 43-4. 50 Not a description but an injunction to sing the 'maxim' in 51-2. 54 Vesper] the evening star. $\quad 0.1$ Spring Song] Elizabeth died, and James succeeded, on 24 March 1603 . 3 Living by the innocent profit from your well-fed herds. harmelesse] not involving wrongdoing or depriving others. thrift] earnings, profit. 
Why slacke yee now your loued company?

Vp sluggards, learne, the larke doth mounted sing

His cheerefull Carrolls, to salute our King.

The Mauis, blacke-bird, and the little Wren,

The Nightingale vpon the hawthorne brire,

song-thrush

And all the wingd Musitions in a Quire,

Do with their notes rebuke dull lazie men.

Vp sheperds, vp; your sloth breeds al your shames.

You sleep like beasts, while birds salute King Iames.

The gray eyde morning with a blustring cheeke,

Like Englands royall Rose mixt red and white,

Summons all eies to pleasure and delight,

Behold the euenings deaws doe vpward reeke,

Drawn by the Sun, which now doth gild the skie,

With his light-giuing and world-cheering eie.

$\mathrm{O}$ thats well done; I see your cause of stay

Was to adorne your temples with fresh flowers:

And gather beautie to bedecke your bowers,

That they may seeme the Cabinets of Maie:

Honor this time, sweetest of all sweete Springs,

That so much good, so many pleasures brings.

For now alone the liuery of the earth

Giues not life, comfort to your bleating Lambes,

Nor fills the strowting vdders of their dams,

It yeeldes another cause of gleesome mirth.

This ground weares all her best embrodery,

To entertaine her Soueraignes maiestie.

And well she may, for neuer English ground

Bore such a Soueraigne as this royall Lord:

Looke vpon all Antiquities Record;

In no Inrollment such a King is found.

Beginne with Brute (if that of Brute be true,)

As I'le not doubt, but giue old Bards their due.

He was a Prince vnsetled, sought a Shore

To rest his long-tosst Troyan scattred Race:

And (as tis sed) found here a resting place:

Grant this: but yeeld, he did false gods adore.

The Nations were not calld to Christ that time,

Blacke Pagan clouds darkned this goodly Clime.

So, when dissention brought the Romans in,

No Coesar till the godly Constantine,

(Descended truely from the Brittish line)

Purgde this Iles aire from Idoll-hated sinne;

Yet he in care of Rome left Deputies.

Our Iames maintaines (himselfe) his dignities.

rise

swollen

The Saxon, and the Dane, scourgd with sharp steele,

duties of office

(So did the Norman Duke) this beauteous Land.

Inuading Lords raigne with an yron hand:

A gentler ruling in this Change we feele;

Our Lion comes as meekely as a Doue,

Not conq'ring vs by hurt, but harty loue.

heartfelt, sincere

13 blustring] blown-out, puffy - i.e. with stormy winds. 22 Cabinets] (a) display cases; (b) ?rooms for displaying objects (OED ist cit. 1676). 25-8 Now the flowering earth not only gives life [etc.] but also yields another cause for joy. liuery] dress, i.e. spring flowers. 31-4 James was the first Scottish king to rule England. 35 Brute] Brut or Brutus, the Trojan warrior said to have settled on the island of Albion, named Britain after him. 37 vnsetled] After the fall of Troy, Brut voyaged through the Mediterranean world before reaching Britain. 40 Grant ... yeeld] Accept this account, but also admit. 43 dissention] Both Julius Caesar's campaign and the Roman conquest of 43 CE exploited conflicts between local rulers. The latter was induced by the fugitive British ruler Verica. 44 godly] as being the first Christian Roman emperor. 45 Of course Constantine was not of British stock, but spent much time in Britain both before and after becoming Emperor. 47 Rome ... Deputies] after setting up his chief capital and residence in Constantinople. James, by contrast, rules both England and Scotland in his own person. 51 Inuading Lords] military conquerors, not hereditary successors like James. 
Euen as a calme to tempest tossed men,

As bread to the faint soule with famine vext;

As a coole Spring to those with heate perplext,

As the Sunnes light into a fearefull denne,

So comes our King: euen in a time of neede,

fearsome cavern

To saue, to shine, to comforte and to feede.

O Shepheards, sing his welcome with sweete notes,

Nymphs, strew his way with Roses Red and White,

Prouide all pastimes that may sense delight,

Offer the fleeces of your flockes white cotes:

He that now spares, doth in that sauing, spill;

Where Worth is little, Vertue likes good will.

Now from the Orchades to the Cornish Iles,

From thence to Cambria, and the Hyberian shore,

The sound of Ciuill warre is heard no more;

Each Countenance is garnished with smiles,

All in one hymne with sweet contentment sing

The praise and power of Iames their onely King.

Our onely King, one Ile, one Soueraigne;

O long-desired, and perfected good!

By him the heate of wrath, and boyling blood,

Is mildely quencht; and Enuie counted vaine,

One King, one people, blessed vnitie,

That ties such mightie Nations to agree.

Shepheardes, Ile not be tedious in my Song,

$80 \quad$ For that I see you bent to actiue sport;

Though I perswade me all time is too short,

To welcome him, whome we haue wisht for long.

Well done, dance on; looke how our little lambs

Skippe as you spring, about their fleecie dams.

Thus were yee wont to trip about the Greene,

And dance in ringlets, like to Fairie Elues,

Striuing in cunning to exceede your selues,

In honour of your late falne summer Queene:

circles of dancers

skill, expertise

But now exceede; this Maie excelles all Springs,

$90 \quad$ Which King and Queene, and Prince and Princesse brings.

Showt ioyfully, ye Nymphs, and rurall Swaines,

Your maister Pan will now protect your foldes,

Your Cottages will be as safe as Holdes,

Feare neither Wolues nor subtill Foxes traines.

A Royall King will of your weale take keepe,

Hee'le be your Shepheard, you shalbe his sheepe.

He comes in pompe; so should a King appeare,

Gods Deputie should set the world at gaze;

Yet his milde lookes driue vs from all amaze,

Clap hands for ioy, our Soueraigne draweth neere,

Sing Iô, Iô, shepheards dance and sing,

Expresse all ioy, in welcoming our King.

The aire, the season, and the Earth accord

In Pleasure, Order, both for sight and sense:

All things looke fresh to greet his Excellence,

And Collin humbly thus salutes his Lord:

Drad and beloude, liue Englands happy King,

dread, feared While seasons last fresh as the liuely spring. strongholds, fortresses
sly, cunning; tricks, wiles

cause to gaze in wonder confusion (through terror or panic)

expression of joy from classical $G k$

65 doth ... spill] waste by such saving: i.e. it would be false economy to stint on the celebrations. $\mathbf{6 6}$ Where Worth is little] among humble or unworthy people. $\mathbf{6 8}$ Cambria] Wales. Hyberian] ?Iberian, i.e. Spanish; but very likely a misprint for Hybernian (Irish). $\quad \mathbf{7 8}$ such mightie Nations] England and Scotland. $\quad \mathbf{8 8}$ summer Queene] Elizabeth, especially as presented in songs and entertainments on her country progresses. $\quad 92$ Pan] as so often, the king or ruler. 98 Gods Deputie] an appellation specially welcome to James, who championed the doctrine of the divine right of kings. 


\section{THE GOOD SHEPHERD's SORROW}

This elegy for Prince Henry (died 6 November 1612), eldest son of James I, is put on the lips of the King himself and was popularly atrributed to him; but it may be by Richard Johnson, in whose collection The Crown Garland of Golden Roses (2nd edn) it appeared in 1631. It reworks an earlier poem, perhaps on the death of the Earl of Arundel in 1595. The first part is found in a transcript by Anne, Countess of Arundel, made around this time. (See Lodge, Illustrations of British History, 1838, III.241; William Chappell, Popular Music I.201.) The text below follows a broadside in the Pepys collection, Magdalene College, Cambridge.

The good Shepheards sorrow for the death of his beloued Sonne. To an excellent new tune.

In sad and Ashy weeds,

I sigh, I pine, I grieue, I mourne:

My Oates and yellow reeds, I now to Iet and Ebon turne.

My vrged eyes like winter skies,

My furrowed cheekes ore-flow,

All heauen knows why men mourne as I and who can blame my woe?

In Sable roabes of night,

My dayes of ioy apparreld bee,

My sorrow sees no light, my light through sorrowes nothing see,

For now my sonne his date hath runne,

And from his Sphere doth goe,

To endlesse bed of foulded lead, and who can blame my woe?

My flockes I now forsake,

That senceles sheep my griefs may know

And lillies loath to take, that since his fall presum'd to growe:

I enuy ayre because it dare

Still breath and he not soe,

Hate earth that doth intombe his youth, and who can blame my woe?

has completed the term of his life

Not I poore Lad aloane,

Aloane, how can such sorrows bee?

Not onely men make moane, but more then men make mone with me:

The Gods of greenes, the mountaine Queenes

The Faries circled Row:

The Muses nine the Nimphs diuine, and all condole my woe.

You awfull Gods of skie,

If Shepheards may you question thus,

awe-inspiring, grand

What Diety to supply, tooke you this gentle Starre from vs?

Is Hermes fled? is Cupid dead?

Doth $\mathrm{Sol}$ his seate forgoe,

Or Ioue his ioy he stoole from Troy, or who hath fram'd this woe?

Did not mine eyes, Oh heauen

Adore your light as well before,

3 Oates and yellow reeds] of which his pipes are made. 13 sonne] pun on sun, heightened by the reading $\operatorname{day}(s)$ for date in some texts. 15 foulded lead] wrapping his corpse. 29 mountaine Queenes] presumably the Oreades or mountain nymphs. 34 If shepherds can make so bold as to ask you. 35-6 To replace which god did you take this noble star from us? $\quad 38$ Sol] the sun or sun-god, Phoebus or Apollo. 39 his ioy ... Troy] Jove or Jupiter's favourite Ganymede, son of Tros, after whom Troy takes its name. $\quad$ 41-4 O heaven, did I not worship you as much earlier as I do now you have added a new planet to the earlier seven (i.e. sun, moon and the five planets then known). 
But that amidst your seauen, you fixed haue one Plannet more:

You well may raise now double dayes,

On this sad earth below,

Your powers haue won from vs a Sonne and who can blame my woe?

At your great hands I aske,

This boone, which you may easily graunt

That till my vtmost maske of death, I still may moane his want,

Since his Diuine parts with you shine

Too bright for vs below:

And earths sad brest entombes the rest Yet mine entombes his woe.

The Second Part of the good Shepheard, or Coridon's Comfort. To the same tune.

Peace Shepheard cease to mone, in vaine is all this greefe and woe,

For him thats from vs gone,

And yet indeede,

The Oaten Reede, and mirth thou late didst know:

I blame thee not,

If now forgot, for who can blame thy woe?

The breath, had once a sound that had harmonious, is in sighing spent:

The temples once were bound, with Chaplets of a pleasing sent,

Now Cypresse weare,

Thy greefe and care to all the world to show:

The pipe so sweet,

Thy lippes nere meet, and who can blame thy woe?

The murmure of the Brook hath beene delightfull to thine eare,

Much pleasure hast thou tooke,

sweet Philomelaes note to heare,

To see that Quire,

From bush to brier, leape lightly too and fro:

The Summers Queene,

Attird in greene, but now tis nothing so.

To see this Queene of flowers, when hoary Hyems' part is done,

winter

Deck vp those Summer Bowers, defend vs from the parching Sun,

To see the ground

Embroydered round, and euery tree to show:

His Virid dye

Hath pleas'd thine eye, but now tis nothing so.

45 double dayes] as there are now two suns in the sky (see 47). $\quad 47$ Sonne] again, pun on son and sun. $\quad 51$ vtmost] final. maske] (a) performance, pageant, like the court masques beloved of James (b) (time to assume, or for someone to mould, his) death-mask. 74-5 Your pipe never touches your lips. $\quad 84$ Implicit 'and to see' at the start of this line. Summer's Queene] probably the May Queen , $_{1526143426}$ but perhaps Flora, the goddess of flowers (see 87) Queen] used for 'goddess earlier too (29). Queene of flowers] see $84 \mathrm{n}$. 
Too well I know thy sheepe, at randome graze vppon the plaine:

uncontrolled, straying

Greefe luls thee now asleepe, and now thou wakst to grieue againe.

Asleepe, awake

For his deere sake, some signe thy sorrowes show:

No bed of rest

Can ease thy brest, and who can blame thy woe?

No man (the man that knew for whome our fainting bodies were

wear

These robes of sadest hue, and woes more black imbrested bere)

Can well forbeare

To shed a teare, griefes tide will ouerflow:

Pale sorrwes course

Hath still some force: then who can blame thy woe?

Thy woes I cannot blame, but in thy sorrowes beare a part,

Yet now to patience frame, and see the salue cures all our smart:

medicine that cures

This bud is dead,

Is gone, is fled, but in his place doth grow

A Flower as faire,

As fresh as rare, and he cures all our woe.

\section{The Shepherd's LAMENTATION}

Broadside ballad (c.1615) in the Pepys Library, Magdalene College, Cambridge. A few words in stanza 5 lost owing to a tear: the gaps, with some conjectural readings, in angular brackets.

The Shepheards Lamentation.

To the tune of the plaine-dealing Woman.

Come Shepheards, decke your heads no more with bayes but willowes;

Forsake your downy beds, and make your ground your pillowes:

And mourne with me, since crost crossed, afflicted as I, was neuer no man:

Nor neuer shepheard lo, lo, lo, lost, so plaine a dealing woman.

honest, simple

All you forsaken woers, that euer were distressed,

And all you lusty Louers, that euer loue molested,

Your losse I must condole, and all together summon,

To mourne for the poore so, so, soule, of my plaine dealing woman:

101-3 Whether you are awake or asleep, you always show some sign of sorrow. $\quad$ 110 imbrested] within the heart: perhaps recalling Hamlet 1.2.77-86. $\quad 0.2$ the plaine-dealing Woman] Given the refrain of the poem, may be a new tune composed for it. 2 bayes] laurels, emblem of poetry. willowes] associated with mourning. $\quad 3$ downy] stuffed with down, hence soft. 
Faire Venus made her chast, and Ceres beauty gaue her:

Pan wept when she was lost, and Satyres stroue to haue her:

But oh she was to them so nice, so coy, that no man

Could iudge but he that knew, knew, knew, she was plaine dealing woman.

For all her pretty parts, I neuer enough shall wonder.

She ouercame all hearts, and all hearts made to wonder. Her breath it is so sweet,
so sweet the like felt no man,

Oh, Shepheards neuer lo, lo, lost, so plaine a dealing woman.

Her eyes did shine like glasse, to grace her comely feature:

Faire Venus she did farre surpasse, she was a comely creature.

$<$ But $>$ oh she was so coy, $<$ as $>$ neuer yet was no one:

$<$ ???> Cupid that blind bo, bo, boy, $<$ ??? > my plaine dealing Woman.

So beautifull was she, in fauour and in feature:

Her well shapt limbs did shew, she was a comely creature:

What griefe was this to me, iudge all true hearted yong men:

To haue so great a lo, lo, losse, of my plaine dealing woman.

Diana faire and chast, on her might well attend,

A Nimph she was at least, and to Shepheards a great friend:

And oh she was so kind, as neuer yet was no one,

A man could hardly fi, fi, find, so plaine a dealing woman.

So courteous eke she was, I and so kind to all men:

What better pleasure could you wish,

But now alas shees gone then so plaine a dealing woman: it makes my heart to pitty:

Oh there was neuer such an o, o, other wench in Country as in Citty.

Alas Shepheards all farewell, since death hath me ore taken:

Unto the world may tell, that I am quite forsaken,

And so to all adue,

$\mathbf{1 7}$ i.e., She was both lovable and chaste. $\quad 18$ Ceres] goddess of harvests. Her unusual role here as giver of beauty may imply that the beloved's beauty was entirely the product of nature and country life. 20-22 Satyrs were seen as lecherous, but she could resist their advances. 23 nice] strict, scrupulous $(O E D$ 3). coy] reserved, distant. $\quad 51 \mathrm{~A} \mathrm{Nimph} \mathrm{...} \mathrm{at} \mathrm{least]} \mathrm{if} \mathrm{not} \mathrm{a} \mathrm{goddess} \mathrm{like} \mathrm{Diana.}$ 
goe forth I pray and summon,

The flanting crew to mourne for me,

flaunting: winsome, attractive; band (of shepherds) and my plaine dealing woman.

Put on your mourning weeds, and bring the wreath of willow:

Goe tell the world I am dead, and make the ground my pillow.

And ring, ding dong, ding dong, ding dong, adew,

Loue you no more so so long, but change each day a new.

Come Shepheards leaue your sighing and wipe away your teares,

And let vs fall to piping, to driue away all cares:

For though that she be gone, that was so faire a good one,

Yet once more may we find as plaine a dealing woman.

The Second Part of the Plaine dealing woman.

Ye Siluan Nimphes come skip it, and crowne your heads with Mistle:

mistletoe

Yee faire Ewes come trip it, on earths imbroydered kirtle.

And O you Driades, which haunt the coolest Fountaines:

Come leaue your silken shadie groues, and sport it in the Mountaines.

i.e., field covered with flowers dryads, wood-nymphs

?soft, soothing

For lo the Gods obtaine it, that wonders shall possesse her:

And Nature did decree it, when she with life did blesse her.

The Quene of Loue disdaind not faire Phillis for her feature,

For all the world containd not so rare a comely creature.

Diana made her chast, and Pallas made her witty:

The Goddesse Ceres grac't her heart with loue and pitty.

The Muses did select her, to grace their learned number:

And Venus did elect her, the onely beautious wonder.

When Ioue beheld her beauty, his Leda did repent him:

Ioue thought that in loues duty, she onely did content him.

And Phoebus blusht to know it, that Daphne had abus'd him, misled, deceived

For lo, her worth did show, that desertles she refus'd him.

98 She will be endowed with marvellous qualities. 101-2 Phillis' features attracted or won the favour of Venus herself. 106 Pallas] Minerva or Athena, goddess of wisdom. 107 Ceres] Even vaguer reference to Ceres than in $18 . \quad 114$ He regretted having courted Leda instead of Phillis. 117 Phœbus] Apollo, who pursued Daphne till she turned into a laurel. 119-20 The plain-dealing woman's worth shows that by contrast, Daphne did not have enough merit or desert to refuse Apollo's love. 12o she] Daphne. 
Pan was enamoured on her, his Sirynx could not please him:

And when he lookt vpon her, her very sight did ease him:

comfort, please

The Satyre mournd to misse her, whom all the world admired:

Siluanus wisht to kisse her, whom greatest Gods desired.

Cupid his Psyche left, to feed his eies vpon her,

Of Godlike power bereft, that her he more might honour.

His bow and shafts he gaue her, wherewith she wounds all hearts

So well she doth behaue her, like loue in all his parts.

conduct herself

I list no more to praise her, whom heauen and earth admire,

wish

A loftier Muse must raise her,

whose verse can mount vp higher:

A golden pen must write it, dipt in the Muses Fountaine,

And they themselues indite it, vpon their sacred Mountaine.

Then O yee Shepheard Swaines, with garlands deck your bonnets,

And let th'Arcadian plaines ring forth with Lyrick Sonets:

Come tune your rurall voyces,

songs, especially of love

fairness, beauty

Whose faire exceeds all beauties the spacious world inherits.

\section{Fair Dulcina Complaineth}

From the Shirburn Ballads, BL, a ms collection from James I's reign apparently transcribed from printed broadsides, though for about half the poems (including this one), the printed versions have not been found. The formal tone, classical allusions and intricate stanza-form distance this poem from the run of broadside ballads. Punctuation lightly modified (including the median comma in the refrain) and line-initials regularized. Cf. refrain with no.159.

An excellent newe dyttye, wherein fayre Dulcina complayneth for the absence of her dearest Coridon, but at length is comforted by his presence.

To the tune of Dulcina.

The golden god Hyperion by Thetis is saluted

Yet comes as Shepard Coridon in Brydall cloothinge suited.

Dulcina then did say that men

were chaunging like the silver moone.

$\mathbf{1 2 2}$ Sirynx] Syrinx, the nymph transformed into a reed to escape the pursuit of Pan. $\quad 127$ Siluanus] one of the chief wood-gods. 129 Psyche] secretly loved by Cupid, until she disobeyed his injunction not to look at him when he visited her. $\mathbf{1 3 6}$ She is as effective in handling Cupid's bows and arrows as Cupid (loue) himself. $\quad \mathbf{1 4 2 - 4}$ Muses Fountaine ... sacred Mountaine] Aganippe or Hippocrene, springs sacred to the Muses at the foot of Mount Helicon. o.3 Dulcina] a popular tune, used in at least 4 ballads as well as other songs, the earliest from 1615. Also known as 'From Oberon in fairyland' and 'Robin Goodfellow': see Chappell, Popular Music I.142-3, II.771. 1-2 The rising sun is reflected in the sea. 1 Hyperion] father of Helios the sun-god, but often identified with the latter; hence the sun. 2 Thetis] a Nereid or sea-nymph, hence the sea. 6 chaunging like the silver moone] Reverses the usual topos of women being fickle and changeable like the moon. But the refrain invests the woman with changing and contrary moods. 
And now I feare, I buy too deare,

forgoe me now, come to me soone.

leave

Wandring by the silver mountaines seking my sweet Sheppards swaine,

I hard the christall humming fountaines morningly with me complaine.

How I am slayne, By loves disdaine,

and all my musicke out of tune.

Yet will I singe, No other thinge,

forgoe me now, come to me soone.

Love is in her blooming blasted deceaved by a golden tongue.

Vaine delightes haue fondly tasted sweetes that bringe me bytter wrong.

Yet hees a creature, For his feature,

more iocund then the sunne or moone.

Sweet turne againe, The flowre of men,

forgoe me now, come to me soone.

Let Satyres sing the Rundelayes and fayryes daunce their twilights round,

Whilst we in Venus sugred playes doe solace on the flowery ground.

The darkest night, For our delight

is still as pleasant as the moone.

Within thy armes When Cupid charmes

Dulcina cannot be to soone.

A sheephooke all of good red gould my Coridon Ile the provide

To drive my lambes vnto their fold, soe I may be thy wedded bride:

And for thy sake, Ile garlands make

Of Rosye buds and Hawthorne bloome.

Make noe delay, But sweetly say

Ile come to my Dulcina soone.

heard

?mourningly, ?every morning

looks, appearance

As shee in sorrow thus sat weeping goulden slumber closd her eyes,

The shepard came and found her sleeping saying fayre Dulcina rise.

Let love adorne Our bridall morne,

now bels doe ring a silver tune

And prety faunes Daunce ore the Lawnds

to thinke what ioyes will follow soone.

The second part to the same tune

A hundreth shephards come with him, attyred all in cuntry gray:

With oaten reedes they piped trime in honour of Loves holy day:

cheap unbleached material trimly: expertly, finely

Their bonnets fayre Embrodred were

In beauty lyke a winters moone,

Which set on fire The sweet desire

Of wished ioyes that followd soone.

Loyalty with loves requited yf that lovers haue contentinge

And pleasure stolne will be affrighted

content, satisfaction (with each other)

7 buy too deare] pay too high a price, do something I will regret. 9 silver] presumably with mist. 2o sweetes ... wrong] pleasures that bring me deep suffering. 33 red] a conventional epithet for gold $\left(O E D_{3}\right)$. $\quad 47$ faunes] probably wood-gods rather than young deer. 50 gray] coarse unbleached cloth of that colour $\left(O E D_{1}, 2\right)$. 
soone by iealous head tormentinge.

For styll their lyes, In lovers eyes

a fancy changing like the moone

Yet in my brest, A constant rest

resting-place, abode

of sweet delight that comes full soone.

Our woodnymphs on their sommer greenes

God Cupid kindly to content,

Will foote it like the nymble Queenes that daunst in Lady Venus tent:

And Hymens hands Tye holy bandes

70 this bridall day, before hye noone,
A fayrer dame,
Did never Swain

say, come Dulcina to me soone.

The day is spent with sweet desires, our wishes welcome gentle night,

And virgins lampes of Hymens fires doe lead the way to loves delight.

Come nymph and rest Vpon my brest

tyll cockes do crow their morning tune.

Then letes awake, And pastime make

80 and tast the ioyes we shall haue soone.

Aurora blushing white and redde now lends vs pleasure in our sleepes,

And bright Appollo from his bed, betweene the silken Curtaines keepes,

And with his face Giues sweter grace

then Phoebus doth at cheerefull noone.

Leaue of to say Away away,

and Ile be still thy comfort soone.

Thus hand in hand desire did meete, as men and maydens vse to doe, If yow attempt a Lady sweete

come learne of Coridon to woe.

The cuntry Swaine Is alwayes plaine

and singes to love the sweetest tune,

Be not to coy But say with ioy

forgoe me nowe, come to me soone.

are accustomed to

\section{A Pleasant Country Maying Song}

Broadside ballad (c.1625) from the Pepys collection, Magdalene College, Cambridge.

A pleasant Countrey Maying Song. To the tune of the Popes Machina

In this merry Maying time,

Now comes in the Sommer prime.

Countrey Damsels fresh and gay,

Walke abroade to gather May:

In an euening make a match,

In a morning bowes to fatch.

Well is she that first of all,

Can her louer soonest call,

?early summer

agreement, appointment (with one's lover) boughs; fetch

67-8 nymble ... tent] an unusual way of referring to the Graces. 75 virgins lampes] ?torches carried by virgins in a wedding procession, in honour of Hymen the god of marriage. The phrase also recalls the five wise virgins, brides of Christ, in the parable in Matthew 25.1-13. 79 awake] stay awake $(O E D$ 4). O.1 Pope's Machina] Tune otherwise unknown. 4 gather May] 'go Maying', go to the woods to gather flowers and branches for May-day festivities. 
Meeting him without the towne,

Where he giues his Loue a gowne.

Tib was in a gowne of gray,

Tom he had her at a bay.

Hand in hand they take their way,

Catching many a rundelay,

Greeting her with a smile,

Kissing her at euery stile.

Then he leades her to the Spring,

Where the Primrose reigneth king.

Upon a bed of Violets blew,

Downe he throwes his Louer true.

She puts finger in the eye,

And checkes him for his qualitie.

She bids him to her mothers house,

To Cakes and Creame and Country souce.

souse: pickles, especially of

[pigsmeat

He must tell her all his mind,

But she will sigh and stay behind.

Such a countrey play as this,

The maids of our town cannot mis.

They will in a morning gay,

Decke themselues and gather May.

Then they will goe crop the flowers,

Mongst the leaues and Country bowers.

When our maidens meet together,

There is praying for faire weather.

Glad are they to see the Sunne,

That they may play when work is don.

Some at Dancings make a show,

If they can get leaue to goe.

Young men will for maidens sakes,

Giue them Sugar, Creame and Cakes

to obtain or win a maiden

With a cup of dainty Wine,

And it must be neate and fine.

Some of them for their good cheare,

Payes three quarters of a yeare.

'Thou at the first I liked well,

Cakes and Creame do make me swell.'

though

This pretty maiden waxeth big:

See what 'tis to play the Rig.

Up she deckes her white and cleene,

To trace the medowes fresh and green:

herself

Or to the good towne she will wend

Where she points to meet her friend.

appoints, arranges

9 towne] village $\left(O E D_{3}\right) . \quad 11$ gray] specifically, cloth of that colour, perhaps unbleached cloth (OED gray adj 1.1.d.(a), (b)). 12 at a bay] cornered like a hunted animal; but used more lightly and neutrally of a lover's close proximity to his beloved $\left(O E D\right.$ bay $\left.\mathrm{n}^{4} 3 \mathrm{~b}\right)$. 14 Catching ... rundelay] Singing a catch or round, where several persons sing simultaneously but in staggered or deferred fashion, each singing the line the previous one has concluded. $\quad 17$ Spring] a grove of young trees $(O E D 7) . \quad \mathbf{2 1 - 2}$ puts ... qualitie] makes a pretence of weeping in order to test his love. 27 countrey play] rural sport, with suggestion of play, play-acting, drama (see 21-2n). $\quad 28$ No maiden in our village can miss such an experience. 41 dainty] choice in taste $\left(O E D_{3}\right)$. 44 Payes] Pays the price, after 'three quarters of a yeare' or the period of pregnancy. $\quad 48 \mathrm{Rig}$ ] a wanton woman; but also as in play the rig, sport or frolick. 
Her gowne was tuckt aboue the knee,

Her milkwhite smock that you may see.

Thus her amorus Loue and she,

Sports from eight a clocke till three:

All the while the Cuckow sings,

Towards the euening home she flings,

And brings with her an Oaken bow, With a Country Cake or two.

Straight she tels a solemne tale,

How she heard the Nightingale,

And how ech medow greenly springs:

But yet not how the Cuckow sings.

In the merry Maying time,

Loue is in her chiefest prime.

What for Gentlemen and Clownes,

rustics

Our country maids can want no gownes.

Sillibubs and dainty cheare,

Yong men lacke not all the yeere.

All the maidens in the street

With the bonny Yonkers meet.

young men

All the while the grasse is greene,

And the Dasies grow betweene,

Dicke and Tom doe walk the fields,

Still to trip vp maidens' heeles.

Thus the Robin and the Thrush,

Musicke make in euery bush.

While they charme their prety notes,

Young men hurle vp maidens cotes.

drink of flavoured milk

But 'cause I will do them no wrong,

Here I end my Maying song,

And with my friends take heed in time,

How they spend their Summer's prime.

\section{Martin Parker(?) The Country Lass}

Broadside ballad (c.1628) ascribed to Martin Parker, the celebrated ballad-writer, from the initials 'M.P.' in one copy. A notably different Scottish version appears (in modern spelling) in Herd's Ancient and Modern Scottish Songs (1776). Although much later in date, this version is added below to indicate the continuing popularity of the ballad.

The Countrey Lasse.

To a dainty new note, Which if you cannot hit,

There's another tune which doth as well fit.

That's the Mother beguiles the Daughter.

Although I am a Countrey Lasse, a lofty mind I beare a,

I thinke my selfe as good as those, that gay apparell weare a:

My coate is made of homely gray,

57 Cuckow] specially held to announce cuckoldry, but here promiscuity generally. $\quad$ 67-8 Between the gifts of high-ranking and rustic lovers, the maids cannot lack for clothes; perhaps also implying they do not need clothes, i.e. they are undressed by the men. 67 Gentlemen] whose advances to and seductions of rustic women were the stuff of much literature in various keys, including the pastourelle. 69-70 In return for those gifts, the girls feed the young men dishes they have prepared. 8o hurle up] pull up violently $(O E D$ 6). $\quad 0.3$ the Mother beguiles the Daughter] a tune used in many ballads, linked to the popular 'Gramercy': see Chappell, Popular Music I.356. 5 gray] coarse unbleached cloth of that colour (OED gray adj 1.1.d.(a), (b)). 
yet is my skin as soft a,

As those that with the chiefest wines do bathe their bodies oft a.

Downe, downe, derry, derry downe, hey downe a downe a downe a,

A derry, dery dery, dery, downe, heigh downe a downe a derry.

What though I keepe my Fathers sheepe, a thing that must be done a,

A Garland of the fairest Flowers shall shrowd me from the Sun a,

And when I see they feeding be, where grasse and flowers spring a,

Close by a chrystall fountaine side, I sit me downe and sing a,

Downe, downe etc:

Dame Nature crownes vs with delight, surpassing Court or City;

Wee pleasures take from morne to night, in sport and pastimes pretty:

Your Courtly Dames in Coaches ride abroad for recreation;

We Countrey Lasses hate their pride, and keepe the Countrey fashion.

Downe, downe, etc.

shield, protect

Your City Wiues lead wanton liues, and if they come i' th' Countrey,

They are so proud, that each one striues for to out-braue our Gentry:

We Countrey Lasses homely be, for seate nor wall we striue not;

We are content with our degree, our debtors we depriue not:

Downe, downe, etc.

I care not for a Fanne nor Maske, when Tytans heate reflecteth,

the sun's

A homely Hat is all I aske, which well my face protecteth,

Yet am I in my Countrey guise esteemed a Lasse as pretty,

As those that euery day deuise

Downe, etc. new shapes in Court and City:

In euery season of the yeere, I vndergoe my labour,

Nor showre nor wind at all I feare, my limmes I doe not fauour:

If Summers heate my beauty staine, it makes me nere the sicker,

Sith I can wash it off againe with a cup of Christmas liquor:

Downe, downe derry derry downe, heigh downe a downe a downe a,

A derry derry, derry derry downe, heigh downe a downe a derry.

26 Coaches] a new and derided luxury at that time (as opposed to riding on horseback). 36 seate] authority: rank, position. wall] a walled city, fortifications: military targets. $\quad 38$ our debtors ... not] unlike courtiers, who notoriously did not pay their debts, esp. for clothes and other luxuries. $\quad 41$ reflecteth] shines, beats down (OED 4). 
The second Part. To the same tune.

At Christmas time in mirth and glee, I dance with young men neatly adeptly, daintily And who i' th' City, like to me shall pleasure tast compleatly?

No sport but pride and luxury i' th' City can be found then,

But bounteous hospitality i' th' Countrey doth abound then.

Downe, downe, etc.

I' th' Spring my labour yeelds delight, to walke i' th' merry morning,

When Flora is, to please my sight, the ground with Flowers adorning.

With merry Lads to make the Hay I goe and do not grumble;

My worke doth seeme to me but play,

Downe, etc. when with young men I tumble.

The Larke and Thrush from bryar to bush doe leape and skip and sing a,

And all is then to welcome in the long and lookt-for Spring a:

We feare not Cupids arrowes keene, Dame Venus we defie a,

Diana is our honoured Queene,

Downe, etc. and her wee magnifie a.

That which your City Damsells scorne, we hold our chiefest Jewell,

Without, to worke at Hay and corne, within, to bake and brew well:

out of doors

To keepe the Dayry decently, and all things cleane and neatly,

Your city Minions doe defie, their scorne we weigh not greatly:

Downe, etc.

When we together a milking goe, with payles vpon our heads a,

And walking ouer woods and fields, where grasse and flowers spreds a,

In honest pleasure we delight, which makes our labour sweet a,

And mirth exceeds on euery side, when Lads and Lasses meete a:

Downe, etc.

Then doe not scorne a countrey Lasse, though shee be plaine and meanely:

Who takes the countrey Wench to wife, (that goeth neate and cleanely)

Is better sped, then if hee wed a fine one from the city,

For there they are so nicely bred,

Downe, etc. they must not worke for pitty.

77 I tumble] an activity often accompanying haymaking, the soft hay offering a convenient bed. 90 come] ? OED come $\mathrm{n}^{2}$, a radicle of barley, hence barley. (The 'coomb' or brewing vat would be operated indoors, hence does not appear a likely meaning.). 107 meanely] humble (adjectival use not in $O E D)$. $\mathbf{1 1 3}$ for pitie] a general exclamation. 
I speake not this to that intent,

(as some may well coniecture)

As though to wooing I were bent, no, I nere learn'd Loues lecture:

lesson, instruction

But what I sing is in defence of all plaine countrey Lasses,

Whose modest, honest innocence, all city Girles surpasses.

Downe, downe, derry derry downe, heigh downe a downe a downe a,

A derry derry derry derry downe, heigh downe a downe a derry.

\section{Alternative version, from Herd's Ancient and Modern Scottish Songs (1776) \\ Country Lass.}

Altho' I be but a country lass, Yet a lofty mind I bear-O,

And think mysell as good as those That rich apparel wear-O,

Altho' my gown be hame-spun grey, My skin it is as soft-O,

As them that sattin weeds do wear, And carry their heads aloft-O.

What tho' I keep my father's sheep? The thing that must be done- $\mathrm{O}$,

With garlands of the finest flow'rs To shade me frae the sun-O,

When they are feeding pleasantly, Where grass and flowers do spring-O,

Then on a flow ry bank at noon, I set me down and sing-O.

My Paisley piggy cork'd with sage, Contains my drink but thin-O,

No wines do e'er my brain enrage, Or tempt my mind to sin-O.

My country curds and wooden spoon I think them unco fine-O,

And on a flowery bank at noon I set me down and dine-O.

Altho' my parents cannot raise Great bags of shining gold-O,

Like them whose daughters now-a-days Like swine are bought and sold-O;

Yet my fair body it shall keep An honest heart within-O,

And for twice fifty thousand crowns I value not a pin-O.

I use nae gums upon my hair, Nor chains about my neck-O,

Nor shining rings upon my hands, My fingers straight to deck-O,

But for that lad to me shall fa', And I have grace to wed-O,

I'll keep a jewel worth them a', I mean my maidenhead-O. 
If canny Fortune give to me The man I dearly love-O,

Tho' we want gear I dinna care, My hands I can improve-O,

Expecting for a blessing still

Descending from above-O,

Then we'll embrace and sweetly kiss,

Repeating tales of love-O.

\section{The Obsequy of Faire Phillida}

Broadside ballad (c.1630) in the Roxburghe collection, BL. The poem repeats a theme found in many ballads (e.g. 'The Lover's Delight' above), of the chaste shepherdess who follows the virgin goddess Diana and therefore has Venus as her enemy.

The Obsequy of faire Phillida With the Shepheards and Nymphs lamentation for her losse. To a new Court Tune.

The fairest Nymph that vallyes

Or Mountaines euer bred,

The shepheards joy,

So beautifull and coy,

Faire Phillida is dead;

On whom they oft haue tended,

And carol'd on the Plaines

And for her sake

Sweet Roundelayes did make,

Admir'd by rurall Swaines:

But cruell Fates the beauties enuying

Of this blooming Rose,

So ready to disclose,

With a frost vnkindly

Nipt the bud vntimely,

So away her glory goes.

modest (no bad sense)

attended, paid their services

The Sheep for woe goe bleating,

That they their Goddesse misse,

And sable Ewes,

By their mournfull shewes,

Her absence, cause of this;

The Nymphs leaue off their dancing,

Pans Pipe of joy is cleft;

For great's his griefe,

He shunneth all reliefe,

Since she from him is reft.

Come, fatall Sisters, leaue there your spooles

Leaue mourning altogether,

That made this flower to wither:

Let enuy, that foule Vipresse,

Put on a wreath of Cypresse,

Singing sad Dirges altogether.

Diana was chiefe mourner,

At these sad Obsequies,

Who with her traine

Went tripping ore the Plaine,

(a) unnatural, untimely (b) cruel

Singing dolefull Elegies:

Menalchus and Amintas,

And many Shepheards moe,

With mournefull Verse,

13 disclose] open, bloom - i.e. she was nearing the prime of her youth. 27 fatall Sisters] the Parcae or Fates, who spin (no doubt on spooles or bobbins), measure and cut the thread of men's lives. The line has an extra syllable: perhaps 'there' should be omitted.

followers, retinue 
Did all attend her Hearse,

And in sable sadly goe:

Flora, the Goddes that vsed to beautify

Faire Phillis louely bowers,

With sweet fragrant flowers,

Now her graue adorned,

And with flowers mourned.

Teares thereon in vaine she powres.

pours

Venus alone triumphed,

To see this dismall day,

Who did despaire,

That Phillida the faire

Her lawes would nere obey.

The blinded boy his arrowes

And Darts were vainely spent:

Her heart, alas,

Inpenetrable was,

And to loue would nere assent:

At which affront Citharea repined,

'Cause death with his Dart,

Had pierc't her tender heart:

But her noble spirit

Doth such joyes inherit,

Which from her shall nere depart.

\section{The Shepherd ANd The King}

Broadside ballad of $c .1640$ in the BL.

The Shepheard and the King, and of Gillian the Shepheards Wife, with her Churlish answers: being full of mirth and merry pastime. To the tune of Flying Fame.

An Elder time there was so yore, when gyves of Churlish glee

Were us'd amongst our Country Carles,

former, earlier; old, ancient sports of rustic merriment though no such thing now be:

The which King Alfred liking well, forsooke his stately Court:

And in disguise unknowne went forth, to see that Ioviall sport.

Now Dick and Tom in clouted shoone, patched shoes and coats of russet Gray,

Esteem'd themselves more brave then those that went in Golden ray.

In Garments fit for such a life, our good King Alfred went,

All rag'd and torne, as from his backe, the Begger his clothes had rent.

A Sword and Buckler good and strong to give Jack-sauce a rap:

And on his head in stead of a Crowne, he wore a Monmouth Cap;

Thus coasting thorow Somerset Shire, neere Newton Court he met

A shepherd swaine, of lusty limbes, that up and downe did jet.

a saucy ruffian, a vulgar fellow

a kind of round woollen cap going, travelling

strut, swagger

59 Citharea] Venus, so called from her ancient shrine at Cythara in Laconia. $\quad 60$ death with his Dart] in contrast to Cupid's unavailing dart (54-5). $\quad$ o.2 Flying Fame] The tune of at least 9 ballads, prob. an older name for 'Chevy Chase': see Chappell, Popular Music I.198-9. 9 Dick and Tom] i.e. typical rustics. 10 russet] a kind of coarse cloth, not necessarily russet in colour. 15-16 as from ... rent] like what was left after a beggar had stolen the better items. Sukanta Chaưdhuri - 9781526143426 
He wore a Bonnet of good gray, close button'd to his chin:

coarse unbleached cloth

And at his backe a leather Scrip, with much good meate therein.

food

God speed good Shepheard (quod our King) I come to be thy Guest,

To taste of thy good victuall here. and drinke that's of the best.

Thy scrip I know hath cheare good store, What then, (the Shepheard said)

in plenty

Thou seem'st to be some sturdy Theefe, and mak'st mee sore afraid.

Yet if thou wilt thy dinner winne, thy sword and buckler take:

And if thou canst, into my Scrip therewith an entrance make.

I tell thee Roister it hath store of Beef and Bacon fat,

With shives of Barley bread to make thy chaps to water at:

Here stands my bottle, here my Bag, if thou canst win them, Roister.

Against the Sword and Buckler here, my sheep-hooke is my waster.

Benedicite now (quoth our King) it never shall be said,

That Alfred of the Shepheards hooke, will stand a whit afraid.

So roundly thus they both fell toot, where giving bang for bang,

At every blow the shepheard gave, King Alfreds sword cride twang.

His Buckler prov'd his chiefest fence, for still the Shepheards hooke

Was that, the which good Alfred could in no good manner brooke.

wooden sword, cudgel, staff may God so bless us

At last when they had fought four houres, and it grew just mid-day,

And wearyed both, with right good will, desir'd each other stay.

Kings truce I cry, quoth Alfred then, good Shepheard hold thy hand:

A sturdier fellow then thy selfe, lives not within this Land:

Nor a Lustier Roister then thou art, the churlish Shepheard said:

To tell thee plaine, thy Theevish lookes now make my heart afraid.

Else sure thou art some Prodigall, that hast consum'd thy store:

And here com'st wandring to this place, to rob and steal for more.

Deeme not of me, then (quoth our King) good Shepheard, in such sort:

A Gentleman well knowne I am, in good King Alfreds Court. endure, withstand

43 shives] slices. 56 cride twang] rang sharply or metallically (unlike the shepherd's wooden crook). 65 Kings truce] 'a cry for the discontinuance of a game' (OED truce $2 \mathrm{~b}$ ): ironical when spoken by the

king. 73-4 Prodigall ... store] referring to Christ's parable of the prodigal sont (Luke thentriz). 9781526143426 
The Devill thou art, the Shepheard said, thou goest in ragges all torne:

Thou rather seem'st (I thinke) to be some Beggar basely borne:

But if thou wilt mend thy estate, and here a Shepheard be,

At night to Gillian my old wife, thou shalt goe home with mee.

For shee's as good a toothlesse Dame, as mumbleth on browne Bread:

Where thou shalt lye in harden sheetes, upon a fresh straw bed:

Of Whig and Whay, we have great store, and keepe good Peat-straw fires:

And now and then good barly cakes, when better day requires.

made of hards, the coarser fibres of flax or hemp

for a special occasion

But for my Master, which is chiefe and Lord of Newton Court:

He keepes (I say) us Shepheard Swaines in farre more braver sort:

We there have Curds and clouted Cream better, more prosperous of red Cowes morning milke:

And now and then fine Buttered Cakes, as soft as any silke.

Of Beefe, and reefed Bacon store, that is most fat and greazie,

?reeved, crinkled

Wee have likewise to feed our Chops, to make them glib and easie.

Thus if thou wilt my man become, this usage thou shalt have.

If not adue, goe hang thy selfe, and so farewell sir knave.

King Alfred hearing of this glee the churlish Shepheard said,

Was well content to be his man, and so the bargaine made:

A penny round the Shepheard gave, in earnest of the match:

to seal the agreement

To keepe his sheepe in Field and Fold, as Shepheards use to watch.

His wages should be full ten Groates, for service of a yeare:

Yet was it not his use, old Lad, to hire a man so deare:

Groat: four pence

custom, practice; old fellow, 'old boy'

For did the King himselfe (quoth he) unto my Cottage come:

He should not for his twelve-months pay. receive a greater summe.

Hereat the bonny King grew blythe, to heare this Clownish jest:

amused, merry

How silly Sots, as Custome is, doe descant on the best.

But not to spoile the following sports he was content (good King)

To fit the Shepheards humor right, in every kind of thing. 
A Sheep-hooke then, with Patch his Dog, and Tar-box by his side,

He with his Master cheek by jowle, unto old Gillian hyed:

Unto whose sight no sooner come, whom have you here (quoth she?)

A fellow I doubt will cut our throats, fear So like a knave looks hee.

Not so old dame, quoth Alfred straight, of mee, you need not feare:

My Master hath hired me for ten Groates, to serve you one whole yeare,

So good Dame Gillian grant me leave within your house to stay:

For by Saint Anne doe what you can, I will not yet away.

Her churlish usage pleas'd him still, but put him to such proofe

That he that night was almost choakt within that smoakie roof.

But as he sate with smiling cheere, the event of all to see:

His Dame brought forth a piece of Dowe, which in the fire throwes she.

Where lying on the Harth to bake, by chance the Cake did burne:

What canst thou not, thou Lowt, quoth she take paines the same to turne?

Thou art more quick to rake it out, and eat it up halfe Dowe,

Then thus to stay till't be enough, and so thy manners show.

But serve mee such another tricke, Ile thwack thee on the snout:

Which made the patient King, good man, of her to stand in doubt.

But to be briefe, to bed they went, the good-man and his Wife:

But never such a lodging had King Alfred in his life.

For he was laid on white Sheepes woll, new pull'd from tanned Fells:

And ore his head hung spiders webs, as if they had been Bells:

Is this the Country guise, thought he? then here I will not stay:

But hence be gone as soone as breakes the peeping of next day.

The cackling Geese and Hens kept roost, and pearcht by his bed side:

Where at the last the wrathfull Cocks made knowne the morning tide:

Then up got Alfred, with his horne, and blew so long a blast,

That made Gillian and her Groome in bed full sore agast. 
Arise, quoth she, we are undone, this night we lodged have,

At unawares within our house, a false dissembling Knave.

Rise, husband, rise, hee'll cut our throats, he calleth for his Mates,

Ide give (old Wil) our good Cade-Lambe he would depart our Gates.

But still King Alfred blew his horne, before them more and more:

Till that a hundred Lords and Knights alighted at their doore.

Which cryed all hayle, all hayle good King, long have we look't your Grace:

And here you find (my merry men all) your Soveraigne in this place.

We shall be surely hang'd up both, old Gillian, I much feare,

The Shepheard said, for using thus our good King Alfred here:

A pardon my Liege (quoth Gillian then) for my Husband and for mee:

By these ten bones, I never thought the same that now I see.

And by my hooke, the Shepheard said, and Oath both good and true,

Before this time, O Noble King, I never your highnesse knew:

Then pardon me, and my old Wife, that we may after say:

When first you came into our house, it was a happy day.

It shall be done, said Alfred straight, and Gillian my old Dame,

For this thy churlish using me, deserveth not much blame:

For this thy Countrey guise, I see, to be thus bluntish still,

And where the plainest meaning is, remaines the smallest ill.

And Master, so I tell thee now, for thy late manhood showne,

A thousand Weathers Ile bestow upon thee for thine owne:

With pasture grounds, as much as will suffice to feed them all:

And this thy cottage, I will change into a stately Hall.

As for the same (as dutie bindes) the Shepheard said, good King,

A milke white Lambe once every Yeere, Ile to your Highnesse bring:

And Gillian my old Wife likewise, of wooll to make your Coates,

Will give so much at New-yeeres tide, as shall be worth ten Groates.

199 Cade-Lambe] a lamb reared by hand as a pet, thus a special object of affection. $\quad 215$ ten bones] a common oath of uncertain meaning: perhaps the ten fingers. 231-2 Where one's conduct is most open and simple, there is least offence. $\quad \mathbf{2 4 8}$ ten Groates] the payment he had promised the king (121). 
And in your prayse, my Bag-pipe shall sound sweetly every yeere:

How Alfred our renowned King, most kindly hath beene here.

Thanks, Shepheard, thanks, quod he againe, the next time I come hither,

My Lords with me here in this house, will all be merry together.

\section{The Lover's Delight}

Broadside ballad (prob. c.1640) from the Roxburghe Collection, BL. The first three stanzas appeared earlier in Henry Youll's song-book Canzonets to three Voyces (1608). The names 'Strephan' and 'Clayes' derive from Strephon and Claius in Sidney's Arcadia, both in fruitless love with Urania, but warm friends despite their rivalry.

The Lovers delight: OR, A pleasant Pastorall Sonnet To a new Court Tune.

Come love, lets walke into the springe, where wee will heare the blackbird singe;

spring, a copse of young trees

The Robin Redbrest, and the Thrush, the nightingale on thornie bush,

Their musick sweetely Carrowling, that to my love Content may bring.

In yonder dale there are sweete flowers, with many pleasent shadie bowers;

A pearling brooke with silver streames, all beautified with Phebus beames:

I stood behind a tree for feare, to see Dyana bathe her there.

See where the nimph, with all her traine comes tripping ore the Parke a maine:

In yonder grove there will they stay at barlie-breake to sport and playe:

Where wee will sitt us downe and see faire beautie mixt with Chastitie.

The youthfull shephard with delight will tune a pleasant oaten pipe:

Each neatresse fine with heavenly note will stretch and straine her varied throate;

So loud and cleare their nimphs will sing that hills and vallies all will ringe.

The shepheard Strephan with his friend the faithfull Clayes will attend

By playe before the Queene, to prove who best deserves Vranias love:

the sun-god's, purling

A most strange sight there shall you see rivalls of love and amitie.

Menalcas and Amintas young, brave Coridon, and Thersis strong

Your minds would unto pleasure move to have them plead for Phillis love:

Iudge of these tryumphs who shall be but the faire Queene of chastity?

o.1 Sonnet] song. 5 Their musick] Youll has the Mauis (song-thrush), which gives a richer reading. 11-12 Reflecting the myth of Actaon, who saw the naked Diana bathing and, for this intrusion, was turned to a stag hunted down by his own hounds. 13 the nimph] presumably the Queene (27), a shepherdess presiding over maying or some other festival: named as Cilrana (81). $\quad 16$ barlie-breake] a country game. 23 their nimphs] unclear. Perhaps a misprint for the nimphs. 30 rivalls... amitie] i.e. vying in friendly feeling for each other as well as in love for Urania. 
Under the shade of yonder pine you see a Royall throne devine

Prepared for the Iudge to sit, the Queene of beauty and of wit,

Wise Pallas in her Majesty the pavid Iudge is chose to be.

The Queene of love is banisht thence for feare that Phoebe take offence;

Her wanton sonne must not come there, nor Cytharea once appeare:

It grieves my heart to thinke that shee from this aspect exempt must be.

For if the Queene of love should spie the splendour of thy heavenly eye,

Shee should perswade her winged Sonne to wound thy heart as hee hath done

My silly breast with dreade and feare, but $\mathrm{O}$ the chaince, shee is not here.

See where the wood-Nimphs rankt do stand with each a garland in her hand,

Compact of mirtle and sweete bayes; for who deserved the chiefest prayse

In pleading of their passions here, the Lawrell Crowne away must beare.

Upon this bed of vyolets blew a seate most fit for lovers true:

Here may wee sit us downe and see love tryumph in his Majesty:

By the sweete eclogs that are sung, wee shall perceive, who suffred wrong.

But stay, the Iudge is come to sit, the Queene of chastity and wit:

The Shepheards all are ready here in comly habits to appeare.

All wrongs here righted wee shall see by the faire Queene of chastity.

The second part, To the same tune.

Sweet heart come tel me whose soft layes in your conceit deserves most prayse?

Or who did set forth passions best? how Cupid wounded his brest?

I know you have noted all that's past, from the first man unto the last.

Me thought it great content did bring, to heare the Shepheards carrowling,

To Crowne, Cilrana made her choise Menalcas, for his heavenly voyce;

Which glory did small pleasure move, since Coridon had Phillis love.
Venus
Diana the virgin goddess Cupid

chance

in a row

constructed, woven

wrongs suffered in love. Cf.66.

thought, judgement

passed, happened, been enacted

4o The May Queen gradually merges into a mythic goddess. The scene suggests the judgment of Paris, though the goddesses here are the chaste Pallas (Minerva) and Diana. Also recalls many pastoral and mythological scenes in poetry and court entertainments, presided over by the virgin Queen Elizabeth, identified with both goddesses. $\mathbf{4 2}$ pavid] Only recorded sense 'fearful, timid', which hardly suits the context. Perhaps awesome, fear-inspiring'. 46 Cytharea] Venus, after her early shrine on the island of Cythera. 49-54 Seeing a fit subject for love, Venus would have instructed Cupid to fire a dart at the beloved, as he has at the lover. But it is the lover's ill luck that Venus is not there. 58-9 who deserved ... here] i.e. those who fare best in the song contest. 68 Queene of chastity and wit] Either another reference to Minerva (cf. 40), or a shift to Diana. 
To wrastle and throw barres of length, all men gave place to Thersis strength:

His stedfast footing none could move, yet for all this hee lost his love.

No strength or harmony of voyce could Phillis move to make her choyce.

If it had rested in my power, there to have chose a paramour:

Hee whom I thought deserv'd most grace, was young Amintas; whose sweet face,

And nimble feete could not be matcht. The Deities I feare were catcht.

smitten

Did you not note how Pallas swore the like shee never saw before?

Had Meliager made such hast,

In token of deserved praise, she crowned him with lasting bayes.

Then Phrebe unto Phillis said,

For if I were the Nimph to choose, Amintas I would not refuse:

But all in vaine they did exhort, for Corridon had Phillis heart.

Both Pallas and Diana chast did almost straine with breathles hast,

Who could their prayses farther heape, on young Amintas and his sheepe,

His person, gesture, and his grace they did applaud, and his sweete face.

But tell mee love the reason, why faire Phillis with the Christall eye,

Did all the youthfull swaines refuse, and Corridon a love did chuse?

Since they in beauty did excell, and for each prayse did beare the bell.

It seemes the beauty of the mind, did in this case strike Phillis blind:

His eloquence of tongue and wit, in place whereas the Iudge did sit

Was his chiefe gaine, and their foule losse, Vlisses so did Ajax crosse.

where

thwart, ?defeat

But one thing much doth make mee muse, why sweete Vrania did refuse

Her two beloved Ryvalls there? in whom such friendship did appeare,

That still they wil'd her with one voyce, in friendly wise to make her choyce.

willed, wished

How prettily they laid the ground, how shee at first their heart did wound,

When shee by them her Neate did keepe,

99-100 Atalanta had sworn to marry the man who could beat her in a race, which Milanion (in some versions, Meleager) did by distracting her attention with golden apples given him by Venus. Atalanta is more famously associated with Meleager in the slaying of the Calydonian boar. 119 prayse] point of praise or excellence $\left(O E D_{3}\right) . \quad \mathbf{1 2 6}$ Ulysses ... Ajax] Their contrast appears in, e.g., Iliad Bk.9, where Ulysses plays the leading role in their joint embassy to Achilles, or even in the sports contests in Bk.23. Cf. also Shakespeare's Troilus and Cressida (e.g. 2.3.154-260). 133 laid the ground] recounted by way of introduction or preparation. 
and leaving the men halfe asleepe,

Her bird out of her pocket ranne, and unto Strephans hand did come.

The pretty neatresse did awake, heareing her fluttering bird escape,

And unto Strephans hand did hye, hie, hasten he did restore imediatly

Her bird, and eke his heart she got, and in her snow white bosome put.

The silly bird but for his love her passions could in no wayes move,

Neither for himselfe nor his trew friend, as it appeared in the end,

That neither party should grow wroth, shee most unkinde refused them both.

And now mee thinkes the sun growes low. If you be mist, your friends will know

That you and I have beene alone, which to prevent Ile bring you home,

To part it is a second hell, loth to depart bids oft farewell.

\section{Phillida Flouts Me}

Broadside ballad (c.1650) from the Roxburghe collection, BL, but prob. harking back at least to the start of 17-c. (See Chappell, Roxburghe Ballads VII.460.) Cited in Walton's The Compleat Angler (1653).

Phillida flouts me. OR, THE Country Lovers Complaint.

Who seeks by all means for to win his Love,

But she doth scorn him, and disdainful prove;

Which makes him for to sigh, lament and cry,

He fears for Phillida, that he shall dye.

To a pleasant Tune, Or, Phillida flouts me.

$\mathrm{O}$ what a Plague is Love, how shall I bear it?

She will unconstant prove, I greatly fear it:

It so torments my mind, that my strength faileth,

She wavers with the wind, as the ship saileth,

Please her the best you may,

She looks another way,

Alas and well a day, Phillida Flouts me.

At the Fair, yesterday, she did pass by me,

She lookt another way, and would not spy me.

I woo'd her for to dine, I could not get her.

Dick had her to the wine:

$\mathbf{1 4 6}$ i.e. Strephon could not stir Urania's passions by restoring the bird. $\mathbf{1 5 6} \mathrm{He}$ who is reluctant to leave repeatedly bids farewell (to delay the moment of departure). o.6 Phillida flouts me] First cited as 'a new tune' in The Crown Garland of Golden Roses, 1612: see Chappell, Popular Music, I.182, II.773. 
20 he might intreat her,

With Daniel she did dance

On me she would not glance

O thrice unhappy chance, Phillida Flouts me.

Fair maid be not so coy, do not disdain me.

I am thy Mothers boy: sweet, entertain me.

Shee'l give me when she dies

all things thats fitting
Her Poultry and her Bees, and her Geese sitting.

A pair of Mallerds beds

A barrel ful of Shreds

And yet for all these goods Phillida Flouts me.

The second part, to the same Tune.

Thou shalt eat curds and cream all the year lasting,

And drink the Chrystal stream pleasant in tasting,

Wig and whey till thou burst and bramble Berries:

Pye-lid and Pasty crust Pears Plums and Cherries.

Thy Garment shall be thin,

Made of a Wethers skin,

All is not worth a Pin. Phillida Flouts me.

Cupid hath shot his Dart and hath me wounded,

It prick't my tender heart, and ne'r rebounded:

I was a fool to scorn his Bow and Quiver,

I am like one forlorn, sick of a Feaver:

Now I may weep and mourn

Whilst with loves flams I burn

Nothing will serve my turn, Phillida Flouts me.

I am a lively Lad how e're she take me,

I am not half so bad, as she would make me.

Whether she smile or frown, she may deceive me,

Ne'r a Girl in the Town, but fain would have me.

Since she doth from me flye, Now I may sigh and dye,

And never cease to cry Phillida Flouts me. beds or mattresses stuffed with mallard down

for: despite a bun or cake of fine flour

i.e., soft and delicate 
In the last moneth of May, I made her Posies,

I heard her often say, that she lov'd Roses.

Cowslips, and Jilly-flowers, and the white Lilly,

I brought to deck the bowers, for my sweet Philly.

But she did all disdain,

And threw them back again,

Therefore its flat and plain, Phillida Flouts me.

Fair Maiden have a care and in time take me,

I can have those as fair, if you forsake me.

For Doll the Dairy Maid laught at me lately,

And wanton Winifred favours me greatly.

in good time, before it is too late

One cast milk on my cloaths,

T'other plaid with my nose,

What wanton toys are those: Phillida Flouts me.

I cannot work and sleep all at a season,

Grief wounds my heart so deep without all reason,

I fade and pine away with grief and sorrow,

I fall quite to decay like any shaddow,

I shall be dead I fear

Within a thousand year,

All is for grief and care. Phillida Flouts me.

She hath a clout of mine wrought with good Coventry,

handkerchief or kerchief decorated, embroidered

?at the due or regular time

Which she keeps for a sign of my Fidelity.

But in faith if she frown she shall not wear it.

I'le give it Doll my maid, and she shall tear it.

Since t'will no better be

I'le bear it patiently

Yet all the world may see Phillida Flouts me. 


\section{Robin Hood AND THE SHepherd}

A very popular broadside ballad, reprinted well into the 18-c. The text below follows a Bodleian copy (c.1655).

Robin Hood and the Shepheard: Shewing, How Robin Hood, Little John, and the Shepheard fought a sore Combat.

The Shepheard fought for twenty pound, and Robin for Bottle and Bag;

But the Shepheard stout, gave them the rout, so sore they could not wag.

stir, move

The Tune is, Robin and Queen Katherine.

All Gentlemen and Yeomen good, down adown, adown, adown,

I wish you to draw near, for a story of gallant bold Robin Hood

Unto you I will declare, down $a$, \&c

As Robin Hood walkt the Forrest along, down a, \&c.

Some pastime for to spie,

there was he aware of a jolly Shepherd

That on the ground did lie, down $a$, \& $c$.

Arise, arise, cried jolly Robin, down $a, \mathcal{Q} c$.

And now come let me see what is in thy bag and bottle (I say)

Come tell it unto me, down $a$, \& $c$.

What's that to thee thou proud fellow, down $a$, \&c.

Tell me as I do stand what thou hast to do with my bag and bottle,

Let me see thy command, down a erc.

My sword which hangeth by my side, down a \&c.

Is my command I know, come and let me taste of thy bottle,

Or it may breed thy wo, down a ecc.

Tut the Devil a drop thou proud fellow, down a erc.

Of my bottle thou shalt see, until thy valour here be tried

Whether thou wilt fight or flee, down a occ.

What shall we fight for, cries bold Robin Hood down a \& $c$.

Come tell it soon to me, here is twenty pounds in good Red Gold

Win it and take it thee, down a \&c.

The Shepherd stood all in amaze, down a \&c.

And knew not what to say: I have no money thou proud fellow

But bag and bottle Ile lay, down a \& c.

o.5 Robin and Queen Katherine] 'Robin Hood and Queen Katherine', a ballad using the old tune of 'The Three Ravens', dating back at least to 1611 and prob. much earlier. See Chappeli, Popular Music

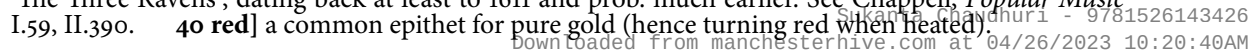


I am content thou Shepherd Swain, down a ecc.

Fling them down on the ground, but it will breed thee mickle pain much

To win my twenty pound, down a erc.

Come draw thy sword thou proud fellow, thou stands too long to prate,

This hook of mine shall let thee know a coward I do hate,

Down a \&c.

The second part, To the same Tune.

So they fell to it full hardy and sore, down adown adown adown,

It was on a Summers day, From four till ten in the Afternoon,

The Shepherd held him play, down a occ.

Robins Buckler proved his chiefest defence, down a bc.

And saved him many a bang, for every blow the Shepherd gave

Made Robins sword cry twang, down a \&c.

Many a sturdie blow the Shepherd gave, down a \&c.

And that bold Robin found, till the bloud ran trickling from his head,

And then he fell to the ground, down a ecc.

Arise, arise thou proud fellow, down a \& $c$.

And thou shalt have fair play, if thou wilt yield before thou go

That I have won the day, down a \&c.

A boon a boon cried bold Robin, down a ecc.

If that a man thou be, then let me take my beugle horn

And blow but blasts three. down a ecc.

I will not thee deny, for if thou shouldst blow till to morrow morn

I scorn one foot to flie, down a \&c.

Then Robin set his horn to his mouth, down a \&c.

And he blew with mickle main, until he espied little John

Come tripping over the plain. down a \&c.

great force running nimbly

$\mathrm{O}$ who is yonder thou proud fellow,

That comes down yonder hill; yonder is little John, bold Robin Hoods man,

Shal fight with thee thy fill. down a ecc.

What is the matter saies little John, down a \&c. 
Master come tell to me; my case is great cries Robin Hood,

I am glad of that cries little John, down a ecc.

Shepherd turn thou to me; for a bout with thee I mean to have,

Either come fight or flee. down a erc.

With all my heart thou proud fellow, down a \&c.

For it never shall be said, that a Shepherds hook of thy sturdy look,

Will one jot be dismaied. down a \&c.

So they fell to it full hardy and sore, down a \&c.

Striving for victorie, Ile know, saith John, ere we give ore,

Whether thou wilt fight or flee, down a \& $c$.

The Shepherd gave John a sturdie blow, down a ecc.

With his hook under the chin, beshrew thy heart said Little Iohn,

Thou baselie dost begin. down a ecc.

Nay that's nothing said the Shepherd, down a \& c .

Either yield to me the daie, or I will bang thee back and sides

Before thou go'st thy way. down a ec.

What doest thou think thou proud fellow, down a ecc.

That thou canst conquer me: nay thou shalt know before thou go,

Ile fight before ile flee. down a \&c.

The Shepherd he began: hold, hold, cried Bold Robin Hood,

I will yield the wager won, down a \& c .

With all my heart said Little John, down a ecc.

To that will I agree, for he is the flower of Shepheards swains,

The like I did never see. down a \&c.

Thus have you heard of Robin Hood, down a \&c.

Also of Little Iohn, how a Shepherd Swain did conquer them,

The like did never none. down, adown, adown, adown. 


\section{The Arcadian Lovers}

Broadside ballad from the Ewing Collection, Glasgow University Library, variously dated 1650-1655 (ESTC) and 1660-65 (EEBO).

The Arcadian Lovers or, Colin and Amarillis. Being a Composure, Richly Illustrated with the indeared expressions of a Shepherd and Shepherdess, for the pleasure and delight of all amorous Fancies.

To be sung in a Tune of great rarity.

Vpon the smooth Arcadian plain, Where the Lambs do frisk amain,

Faire Amarillis and her Swain,

With hand in hand, were walking;

The Sweets to prove, of harmless Love,

They Amorously were talking.

vigorously

She was cloathed all in green,

And surpast the Fairy Queen,

Which made poore Colin for to seem

Amazed with her Beauty;

To prize his Dear, beyond compare

He took't to be his duty.

She for joy did neatly trip,

Whilest their flocks about them skip,

When Colin sat, a while to prate,

She courteously sat by him;

And for to finde, if he were kinde,

Thus prettily she did try him.

Amarillis told her Swain,

To compleat their joyes again,

That he should love her and be plain,

frank, honest

And think not to deceive her;

Then he protested by his troath,

That he would never leave her.

O Colin if thou constant prove,

And that thou wilt not slight my love,

There's ne're a Swain upon this plain,

That ever shall come near thee;

For Garlands and Embroidered Scrips,

O Colin, I love thee dearly.

But Colin if thou change thy Love,

And seek my fury once to move,

A Tygress unto thee I'le prove,

When er'e thou dost come near me;

$\mathrm{O}$ Amarillis fear not that,

For I doe love thee dearly.

The Second Part, to the same Tune.

Oh Colin if thou provest kind,

And never more will change thy mind

I'le deck your bowers, with fragrant flowers,

Whose pleasure shall invite thee;

talk, chat (no bad sense)

With boughes to shroud thee from the showrs

Whilst Colin I will delight thee.

O Amarillis I rejoyce,

For to hear thy pleasing voice,

Then never think my onely Dear,

17 kinde] loving (OED 6). 29 Garlands and Embroidered Scrips] gifts from Colin. 
That I will er'e deceive thee;

But cast aside such doubts and fear,

I vow I will never leave thee.

O Colin, how it ioyes my heart,

That our Loves shall never part.

Amintas and his Chloris faire,

Did ne're injoy such pleasure;

Nor Coridon and Philis rare.

I prize thee above all treasure.

O Amarillis change a kisse,

In token of a further blisse,

Whilst every Swain, upon this plain,

Doth envy our imbraces;

I'le sound thy praises in high strain,

To keep thee from all disgraces.

My Colin if a kisse be all,

I'le not refuse what ere befall,

I am inclin'd, our Loves to bind,

On such a harmless fashion;

Since ne're a Swain, could yet ere stain,

My innocent reputation.

O my dearest Love quoth he

Now our hearts do both agree,

No Shepherd on Arcadia's Ground,

Shall ever prove so loyal;

Now Amarillis thou hast found,

My love will abide the tryal.

Then Colin streight began to Sing,

And made the hills with eccho's ring,

In Amarillis lofty praise,

He pleasant rimes composes;

Whil'st she makes garlands of green bays

For Colin bedeckt with Roses.

Thus they past their time in sport,

And still thought it was but short,

Till young and old, their flocks did fold,

To keep them safe from straying;

And so the night did part them quite,

Which merrily had been playing.

\section{The Beautiful Shepherdess of Arcadia}

Broadside ballad based on an old story, also known as 'The Knight and the Shepherd's Daughter' (Child's Ballads no.110). Percy says it was 'popular in the time of Q. Elizabeth, being usually printed with her picture before it; ${ }^{*}$ but the earliest surviving, imperfect copy (first part only) dates from $c .1660$. The text below follows a copy (?c.1670) in the Douce Ballads, Bodleian Library.

The Beautiful Shepherdess of Arcadia: A new Pastoral Song of a courteous young Knight, and a supposed Shepheards Daughter. To a galland new Tune, Called: The Shepherds delight.

There was a Shepheards Daughter, came triping on the way,

And there she met a courteous Knight, which caused her to stay: Sing trang dil do lee.

stepping lightly or daintily down the road made her stop, blocked her path

51, 52 These shepherds and shepherdesses cannot be linked to any specific pastoral work, nor Colin with Spenser. Amintas in Thomas Watson's poem loved Phillis. *Thomas Percy, Reliques of Ancient English Poetry, Dublin, 1766, vol.3 p.63 0.2 The Shepherds delight] also called the Frog Galliard, composed by John Dowland. See headnote to no.112. 
Good-morrow to you beautious Maid, these words pronounced he,

O I shall die this day he said, trang, \&c . if i've not my will of thee:

The Lord forbid, the Mayd reply'd, that such a thing should be,

That ever such a courteous Knight should dye for love for me:

sing trang, \& c .

He took her about the middle so small, and laid her on the Plain,

And after he had had his will, he took her up again:

sing trang, \& $c$.

Now you have had your will good sir, and put my body to shame,

Even as you are a courteous Knight, tell me what is your name:

sing trang, \&c.

Some do call me Iack Sweet-heart, and some do call me Iohn,

But when I come to the Kings Court, they call me sweet William:

sing trang, \& $c$.

He set his foot into the stirrop, and away then he did ride.

She tuckt her kirtle about her middle, and ran close by his side:

sing trang, \&c.

But when she came to the broad water she took her breast and swam,

And when she was got out again, she took her heels and ran:

sing trang, \& $c$.

?breasted it, plunged into it

He never was the courteous Knight, to say fair maid will you ride;

Nor she never was so loving a maid, to say, sir Knight abide:

sing trang, \&c.

stay: i.e., go slowly, wait for me

But when she came to the King's fair Court she knocked at the Ring,

So ready was the King himself, to let this fair Maid in:

sing trang, \& $c$.

O Christ you save my Gracious Leige, your body Christ save and see,

You haue a Knight within your Court, this day hath robbed me:

sing trang, \& $c$.

What hath he rob'd thee off fair maid, of Purple or of Pall,

Or hath he took thy gay gold ring, from off thy finger small:

sing trang, \& $c$.

47 ring] 'a circular door knocker' (OED $3 \mathrm{~d})$. catch-phrase.

57 pall] a rich cloth. 'Purple or pall', standard poetic 
He hath not robbed me my Liege, of Purple nor of Pall,

But he hath got my maiden-head, which grieves me worst of al.

sing trang dil do lee.

Now if he be a batchelor his body Ile give to thee,

But if he be a married man high hanged shall he be:

$70 \quad$ sing trang dil do lee.

He called down his merry men all by one, by two and by three:

Sweet William was wont to be the first, but now the last comes he: sing trang dil do lee.

He brought her down full forty Pound ty'd up within a glove;

Fair Maid I give the same to thee, and seek another Love:

$80 \quad$ sing trang dil do lee.

O I'le have none of your gold, she said, nor i'le have none of your fee;

But I must haue your fair body, the King hath given me.

sing trang dil do lee.

Sweet William ran and fetcht her then five hundred pound in gold,

Saying fair Maid take this to thee, thy fault will ne'r be told:

$90 \quad$ sing trang dil do lee.

'Tis not thy gold that shall me tempt, these words then answered she;

And I must have your own body, so the King hath granted me. sing trang dil do lee.

Would I had drank the fair water, when I did drink the Wine,

That ever any Shepherds Daughter sholde be a fair Lady of mine:

$100 \quad$ sing trang dildo lee.

Would I had drank the puddle Water when I did drink the Ale,

That ever any Shepherds Daughter would have told me such a tale:

sing trang dil do lee.

A Shepheards daughter as I was you might have let me be:

I'd never came to the Kings fair Court to have crav'd any love of thee.

$110 \quad$ sing trang dil do lee.

He set her on a milkwhite Steed and himself upon a gray,

He hung a bugle about his neck, and so they rode away,

sing trang dil do lee. 
But when they came unto the place where marriage Rites were done,

She prov'd herself a Dukes Daughter and he but a Squires Son:

sing trang dil do lee.

Now you have married me sir Knight, your pleasures will be free;

If you make me Lady of one good town Ile make you Lord of three.

sing trang dil do lee.

Accursed be the gold, he said, if thou hadst not been true:

That should have parted thee from me to haue changd thee for a new.

sing trang dil do lee.

Their hearts being then so linked fast, and joyned hand in hand:

He had both purse and person too, and all at his command.

sing trang dildo lee.

\section{9 'As AT NOON Dulcina RESTED'}

From BL MS. Addl.24,665 (Giles Earle's Song Book, 1615-26). The stanza-form has been standardized below, and punctuation and line initials regularized. Cf. refrain with no. 149. Also printed as a ballad, and mentioned in Walton's The Compleat Angler.

As att noone Dulcina rested

In a sweete and shadie bower,

Came a sheppard and requested

In her lap to sleepe an houre.

But from her looke, a wound he tooke,

Soe deepe that for a farther boone

The Nimphe hee pray'd, whereto she say'd,

Forgoe mee nowe, come to mee soone.

But in vaine shee did coniure him

for to leaue her presence soe,

Hauinge a thousand meanes t'alure him,

And but one to lett him goe.

Where lipps delighte and eyes inuite,

And cheeks as fresh as rose in June

Perswade to staie, what bootes to saye,

Forgoe mee nowe, etc.

avails, does good

Words whose hope might haue enioyned

Him to lett Dulcina sleepe

Could a mans loue haue confyned

been restrained

Or a maid her promise keepe.

Noe, for her waste hee held soe faste,

As she was constant to her tune

Though still shee spake, for Cupids sake,

Forgoe mee nowe etc:

He demaunds what time or leisure

Can there be more fitt then nowe

She saies night giues loue that pleasure,

122 You will have all you want. $\quad \mathbf{1 2 4 - 8}$ 'Accursed be the gold that, had you not held out, would have made me reject you and take a new love' - i.e. he now recognizes her worth. 8 Forgoe] leave (OED 4). 9 coniure] entreat $(O E D 4)$. $\quad 17-18$ Given her promise of future indulgence, he might have let her alone to sleep for the time being. $\quad 23$ Though ... for Cupids sake] There are clear limits to her resistance. 
Which the day cannot alowe.

The sunns cleere light shyneth more bright,

Quoth hee, more fairer then the moone.

Soe her to praise he loues, shee saies,

Forgoe etc:

But noe promise nor perswation

From his armes could purchase scope,

Who would sell the sweet possession

Of such beauty for a hope

Or for the sight of lingring night

Forgoe the ioyes of present noone?

Though ne'r soe faire, her promise were

Forgoe etc:

Now att last agreed those louers,

She was faire and hee was young.

Tongue can tell what eye discouers,

Ioy in sinne is neuer sunge.

Did he relent, or she consent,

On that night or graunt the noone?

Dulcina praies and to him saies,

Forgoe etc:

$$
\text { finis primae partis }
$$

Day was spent and night approched,

Venus faire was louers freind,

She entreated bright Apollo

That his steeds their race might end

Hee could not saie this Goddesse nay

But granted loues faire queene her boone.

The shepheard came to his faire dame,

Forgoe etc:

When that bright Aurora blushed

Came the sheppard to his deare

Prettie birds most sweetly warbled

60 And the night approched neere.

Yet still awaie the Nimph did saie,

The shepheard he fell in a sowne

Att length shee sayd, be not afraid,

Forgoe etc:-

With greife of heart this shepheard hasted

$\mathrm{Vp}$ the mountaine to his flocks

Then he tooke a reed and piped

Th'echo sounded through the rocks.

Thus did he plaie and wishe the day

Were spent, and night were come ere noone,

For silent night is loues' delight

He goe to faire Dulcina soone.

Beauties Darling faire Dulcina

Like to Venus for her loue

Spent the day away in passion

Mourninge like the Turtle Doue

31 She says he is only praising her to indulge his own love. purchase] obtain. scope] ?freedom, release (cf. $O E D$ 7, 8) $44^{-6}$ It is best not to divulge what 'joy in sin' they enjoyed, whether she yielded or not. 48.1 End of the first part. 50 Venus faire] Perhaps the planet Venus as the evening star. $\mathbf{5 2}$ his steeds] of the sun-chariot. $\quad 57$ Aurora] Goddess of the dawn light, hence the dawn. Puzzling in the context of evening. 
Melodiouslie, notes lowe and highe

Shee warbled forth this dolefull tune,

Ô come againe sweet sheppard Swaine,

Thou canst not be with mee to soone.

When as Thetis in her pallace

Had receiu'd the prince of light

Came in Coridon the shepheard,

To his loue and hearts delight

Then Pan did plaie, the wood Nimphes they

Did skipp and daunce to heare the tune,

Hymen did saie t'was holidaie

Forgoe etc:

Sweete he say'd as I did promise

I am nowe return'd againe

Longe delaie you knowe breeds daunger

And to lou[e]rs breedeth paine.

The Nimph say'd then, aboue all men

Still welcome shepheard morne and noone.

The shepheard praies, Dulcina saies,

Shepheard I doubt y'are come to soone.

fear; to soone, before marriage

Come you nowe to ouerthrowe mee -

Out alas I am betray'd -

Deare, is this the loue you shewe mee

To betraie a silly mayde?

Helpe helpe, ay mee, I dare not speake.

I dare not crie, my heart will breake.

What, all alone? Nay then I finde

Men are to stronge for woemen kinde.

too

Out vppon the wench that put mee

To this plunge to be alone.

Yet shee was noe foole to shutt mee

Where I might be seene of none.

Harke harke, ay mee, what noyes is that

Ô nowe I see it is my Catt.

Come Pus, I knowe thou wilt not tell.

Yf all be soe, all shalbe well.

Ô sillie foole whie doubt I telling

When I doubted not to truste.

Yf my bellie fall a swellinge

There's noe helpe but out it muste.

Ay mee the greife, Ay mee the shame

When I shall beare the common name,

Yet att the worst of my disgrace

I am not first, nor shalbe laste.

finis 2 dae partis.

81 Thetis] daughter of Nereus and mother of Achilles: a sea-goddess, hence the sea, into which the sun (prince of light) sinks. $\quad 87$ Hymen] god of marriage. $\quad 91$ daunger] (a) risk (that love will die) (b) 'love-daunger', aloofness or reluctance on the woman's part. 101-4 The change of rhyme-scheme indicates the new development. 105 the wench] ?an otherwise unmentioned friend or go-between; ?Dulcina herself. $\quad 106$ plunge] trouble, danger (OED 5). 112 Yf all be soe] If all do the same, i.e. do not tell. 118 the common name] viz. of a harlot (common woman, harlot: OED common 6b). 120.1 End of the second part. 


\section{Michael Drayton IDea the Shepherd’s Garland, Eclogue ViI}

First published in Drayton's Idea the Shepheards Garland (1593). Reprinted with radically new versions of the two songs in Drayton's Poemes lyrick and pastorall (1606), and then in his Poems (1619). The text below follows 1593, but adds the 1606 songs after the main text.

\section{The Seventh Eglog.}

Borrill an aged shepheard swaine, with reasons doth reprooue Batte a foolish wanton boy, But lately falne in loue.

just, only

Batte. Borrill, why sit'st thou musing in thy coate? like dreaming Merlyn in his drowsie Cell,

What, may it be with learning thou doest doate, or art inchanted with some Magick spell?

Or wilt thou an Hermites life professe?

And bid thy beades heare like an Ancoresse?

cottage
dull, soporific

pray with your rosary

See how faire Flora decks our fields with flowers, and clothes our groues in gaudie summers greene,

And wanton Ver distils rose-water showers, To welcome Ceres, haruests hallowed Queene,

Who layes abroad her louely sun-shine haires,

Crown'd with great garlands of her golden eares.

Now shepheards layne their blankets all awaie, and in their Iackets minsen on the plaines,

And at the riuers fishen daie by daie, now none so frolicke as the shepheards swaines.

Why liest thou here then in thy loathsome caue,

As though a man were buried quicke in graue.

Borrill. Batte, my coate from tempest standeth free, when stately towers been often shakt with wind,

And wilt thou Batte, come and sit with me? contented life here shalt thou onely finde,

Here mai'st thou caroll Hymnes, and sacred Psalmes,

And hery Pan, with orizons and almes.

praise; ?offerings, sacrifices

And scorne the crowde of such as cogge for pence, and waste their wealth in sinfull brauerie,

Whose gaine is losse, whose thrift is lewd expence, and liuen still in golden slauery:

Wondring at toyes, as foolish worldlings doone,

Like to the dogge which barked at the moone.

Here maist thou range the goodly pleasant field, and search out simples to procure thy heale,

What sundry vertues hearbs and flowers doe yeeld, gainst griefe which may thy sheepe or thee assaile.

Here mayst thou hunt the little harmeles Hare,

Or else entrap false Raynard in a snare.

Or if thou wilt in antique Romants reede, of gentle Lords and ladies that of yore,

In forraine lands atchieu'd their noble deede, and been renownd from East to Westerne shore:

Or learne the shepheards nice astrolobie,

To know the Planets moouing in the skie. merry

spreads out

alive

cote, cottage; unharmed cheat, grub finery, display

trifles

[health

medicinal extracts from plants; beneficial properties against the afflictions

romances, stories

7 Flora] the goddess of flowers. 8 gaudie] bright; also suggesting gaudy-green, a shade of green. 9 Ver] spring. 10 Ceres] the goddess of the harvest. 13-15 layne, minsen, fishen] Old plurals in -en: so all through. 14 minsen] ? walk, move: no suggestion of a 'mincing' gait. 27 thrift ... expence] Even their attempts at economy are extravagances. $\quad 41$ astrolobie] astronomy (not in $O E D)$. 
Batte. Shepheard these things been all too coy for mee, whose lustie dayes should still be spent in mirth,

These mister artes been better fitting thee, whose drouping dayes are drawing towards the earth:

What thinkest thou? my iolly peacocks trayne,

Shall be acoyd and brooke so foule a stayne?

vigorous, youthful obscure, esoteric declining

These been for such as make them votarie, suppressed; endure and take them to the mantle and the ring,

And spenden day and night in dotarie, hammering their heads, musing on heauenly thing,

And whisper still of sorrow in their bed,

And done despise all loue and lustie head:

monk

folly

taxing, straining old plural of 'do'

Like to the curre, with anger well neere woode, mad, crazed who makes his kennel in the Oxes stall,

And snarleth when he seeth him take his foode, and yet his chaps can chew no hay at all.

Borrill, euen so it fareth now with thee,

And with these wisards of thy mysterie.

wise men; irrational doctrine or belief

Borrill. Sharpe is the thorne, full soone I see by thee, bitter the blossome, when the fruite is sower,

And early crook'd, that will a Camock bee,

a crooked stick rough is the winde before a sodayne shower:

Pittie thy wit should be so wrong mislead,

And thus be guyded by a giddie head.

Ah foolish elfe, I inly pittie thee, misgouerned by thy lewd brainsick will:

The hidden baytes, ah fond thou do'st not see, nor find'st the cause which breedeth all thy ill:

evil, base; ignorant foolish (person)

Thou think'st all golde, that hath a golden shew,

And art deceiu'd, for it is nothing soe.

Such one art thou as is the little flie, who is so crowse and gamesome with the flame,

Till with her busines and her nicetie,

bold, audacious her nimble wings are scorched with the same,

Then fals she downe with pitteous buzzing note,

And in the fier doth sindge her mourning cote.

Batte. Alas good man I see thou ginst to raue, thy wits done erre, and misse the cushen quite,

Because thy head is gray and wordes been graue, thou think'st thereby to draw me from delight:

What, I am young, a goodly Batcheler,

And must liue like the lustie limmeter.

Thy legges been crook'd, thy knees done bend for age, and I am swift and nimble as the Roe,

Thou art ycouped like a bird in cage, and in the field I wander too and froe,

Thou must doe penance for thy olde misdeedes,

And make amends, with Auies and with creedes.

aves, prayers

For al that thou canst say, I will not let, for why my fancie strayneth me so sore, divert, lead away

That day and night, my minde is wholy set

43 coy] quiet, dull (OED 1b, citing this passage). $\quad 50$ the mantle and the ring ] used when taking a vow of chastity (properly by a wife or widow rather than a religous person). $\quad \mathbf{5 5 - 8}$ alluding to the fable of the dog in the manger. $\quad 67$ elfe] child, with connotations of mischief and/or pitiful foolishness or innocence. 80 misse the cushen (=cushion)] miss the mark. 84 limmeter] limiter, a mendicant friar: with lustie, a satiric oxymoron targeting the easy life and good cheer alleged of many friars. 'Lusty bachelor' is a favourite phrase of Chaucer, whose raunchy Friar is called a 'limiter' (Hebel). 
on iollie Loue, and iollie Paramore:

Only on loue I set my whole delight,

The summers day, and all the winters night.

That pretie Cupid, little god of loue, whose imped wings with speckled plumes been dight,

decked, adorned

Who striketh men below, and Gods aboue, rouing at randon with his feathered flight,

When louely Venus sits and giues the ayme,

And smiles to see her little Bantlings game.

guides his shots young child

Vpon my staffe his statue will I carue, his bowe and quiuer on his winged backe,

His forked heads, for such as them deserue, and not of his, an implement shall lacke,

And Venus in her Litter all of loue,

Drawne with a Swanne, a Sparrow, and a Doue.

And vnder him Thesby of Babylon, and Cleopatra somtime of renowne:

Phillis that died for loue of Demophôon, Then louely Dido Queen of Carthage towne,

Which euer held god Cupids lawes so deare,

And been canoniz'd in Loues Calendere.

attribute

Borrill. Ah wilfull boy, thy follie now I finde, and hard it is a fooles talke to endure,

Thou art as deafe euen as thy god is blinde, sike as the Saint, sike is the seruiture:

But wilt thou heare a good olde Minstrels song,

A medicine for such as been with loue ystong.

Batte. Borrill, sing on I pray thee let vs heare, that I may laugh to see thee shake thy beard,

But take heede Borrill that thy voyce be cleare, or by my hood thou'lt make vs all afeard,

Or els I doubt that thou wilt fright our flockes,

When they shall heare thee barke so like a foxe.

Borrill. O spightfull wayward wretched loue,

Woe to Venus which did nurse thee,

Heauens and earth thy plagues do proue, as ... so; worshipper stung, afflicted

list of saints

fear

witness, experience

revealer, divulger

waste

death to the living

that which enflames or kindles

?stealing or destroying good looks

94 iollie] pun: (a) merry (b) pretty, attractive. 98 imped] grafted with new feathers, hence stronger. 100 randon] ?random; more likely randan, rowdy behaviour, spree. flight] of Cupid's arrows rather than himself. 105 forked heads] play on (a) arrowheads (b) the horns ascribed to a cuckold. $\quad 107-8$ Litter ... Doue] apparently Venus' chariot - usually drawn by either swans or doves, rarely both. Sparrows, too, were sacred to her and often accompanied her chariot. $\quad$ 109-12 All these women figure in Chaucer's The Legend of Good Women. 109 Thesby] Thisbe, beloved of Pyramus. 111 Phillis] who killed herself owing to mistaken frustration in her love for Demophoōn. $\quad 112$ Dido] who died of frustrated love for Aeneas. $\quad 132$ languish] illness, weakness (OED 1a, last cit. 1450). 137 sullens sadness] ?the cause why people are sullen. $\quad 142$ Fortunes bayte] ?that which baits or provokes (ill) fortune. 
Selfes will, tongues treason,

Paynes pleasure, wrongs kindnes,

wilfulness, obstinacy

Furies frensie, follies reason:

With cursing thee as I began,

Cursing thee I make an end,

Neither God, neither man,

Neither Fayrie, neither Feend.

Batte. Ah worthy Borrill, here's a goodly song,

now by my belt I neuer heard a worse:

Olde doting foole, for shame hold thou thy tongue,

I would thy clap were shut vp in my purse.

It is thy life, if thou mayst scolde and braule:

Yet in thy words there is no wit at all.

And for that wrong which thou to loue hast done,

I will aueng me at this present time,

And in such sorte as now thou hast begonne,

I will repeat a carowlet in rime,

Where, Borrill, I vnto thy teeth will proue,

That all my good consisteth in my loue.

Borrill. Come on good Batte, I pray thee let vs heare?

Much will be sayd, and neuer a whit the near.

Batte. Loue is the heauens fayre aspect,

loue is the glorie of the earth,

Loue only doth our liues direct,

loue is our guyder from our birth.

Loue taught my thoughts at first to flie,

loue taught mine eyes the way to loue,

Loue raysed my conceit so hie,

loue framd my hand his arte to proue.

Loue taught my Muse her perfect skill,

loue gaue me first to Poesie:

Loue is the Soueraigne of my will,

loue bound me first to loyalty.

ruler, monarch

Loue was the first that fram'd my speech,

loue was the first that gaue me grace:

Loue is my life and fortunes leech,

loue made the vertuous giue me place.

Loue is the end of my desire,

loue is the loadstarre of my loue,

Loue makes my selfe, my selfe admire,

loue seated my delights aboue.

nothing to the purpose

Loue placed honor in my brest,

loue made me learnings fauoret,

Loue made me liked of the best,

loue first my minde on virtue set.

doctor, ?healer, reviver yield or defer to me

aim, goal

Loue is my life, life is my loue,

loue is my whole felicity,

Loue is my sweete, sweete is my loue,

I am in loue, and loue in me.

Borrill. Is loue in thee? alas poore sillie lad,

thou neuer couldst haue lodg'd a worser guest,

For where he rules no reason can be had, 
so is he still sworne enemie to rest:

It pitties me to thinke thy springing yeares,

Should still be spent with woes, with sighes, with teares.

Batte. Gramercy Borrill for thy company, for all thy iestes and all thy merrie Bourds,

I still shall long vntill I be with thee,

thanks

tales, jests

because I find some wisdome in thy words,

But I will watch the next time thou doost ward,

And sing thee such a lay of loue as neuer shepheard heard.

parry blows, enter the fray

Borrill's song in 1606 (replacing 11.127-150 above: punctuation heavily revised and capitalization of line initials regularized)

$127 \mathrm{~A}$

$130 \mathrm{~A}$

$140 \mathrm{~A}$

150A neither faiery, neither feend.

Batte's song in 1606 (replacing 11.165-192 above: punctuation heavily revised and capitalization of line initials regularized)

What is Loue but the desire of the thing that fancy pleaseth?

A holy and resistlesse fier weake and strong alike that ceaseth, Which not heauen hath power to let paths Sharp reproofe thy only kindnesse, in thy trust the highest treason. vexing with continuall anguish, Which dost make the ould complaine and the young to pyne and languishe. Who thee keepes his care doth nurse: that seducest all to folly, thing bitterly doest curse, Thus of thee as I began so againe I make an end: Neither god, neither man,

nor wise nature cannot smother,

seizes Whereby Phœbus doth begette on the vniuersall mother.

That the everlasting Chaine which together al things tied, And vnmooued them retayne and by which they shall abide: That concent we cleerely find all things doth together drawe, And so strong in euery kinde subiects them to natures law. stop, block Whose hie virtue number teaches

143A He who entertains you feeds his sorrow. 145A Places a curse on a blessing. $\quad$ 171A-2A Identifying love with the universal force of procreation, whereby Phoebus (the sun-god or sun) impregnates the earth (the vniuersall mother). $\quad$ 173A the everlasting Chaine] From this point, love is identified with universal concord or the harmony of nature, as classically expressed in Boethius' Consolation of Philosophy, II metrum 8. This is the province of the higher or heavenly Venus (Venus Urania). $\quad \mathbf{1 8 1 A}$ number] the rhythm or mathematics of nature. 
in which euery thing dooth mooue, From the lowest depth that reaches to the height of heauen aboue: Harmony that's wisely found when the cunning hand doth strike, Whereas euery amorous sound whereby sweetly marryes with his like. The tender cattell scarcely take from their damm's the feelds to proue, But ech seeketh out a make, nothing liues that doth not loue:

mate Not soe much as but the plant as nature euery thing doth payre, By it if the male it want, doth dislike and will not beare: Nothing then is like to loue, in the which all creatures be. From it nere let me remooue nor let it remooue from me.

beside it, next to it is displeased; bear fruit

move away, part

\section{Michael Drayton IDEa the Shepherd's Garland, Eclogue ViII}

First published in Drayton's Idea the Shepheards Garland (1593). Reprinted as Eclogue IV, with a radically new version of the song, in Drayton's Poemes lyrick and pastorall (1606), and then in his Poems (1619). 1593 and 1606 versions given separately here to illustrate both the evolution of Drayton's own pastoral, and the increasing refinement of the mode as a whole. The 1606 version only has additional notes to lines occurring there alone.

\section{(A) The 1593 Version}

\section{The Eighth Eglog.}

Good Gorbo of the golden world, and Saturns raigne doth tell, And afterward doth make reporte, of bonnie Dowsabell.

Motto. Shepheard why creepe we in this lowly vaine, as though our muse no store at all affordes,

Whilst others vaunt it with the frolicke swayne, and strut the stage with reperfumed wordes.

stock, supply (of poetry)
strut about; merry
(old and) refurbished

See how these yonkers raue it out in rime, who make a traffique of their rarest wits,

And in Bellonas buskin tread it fine, like Bacchus priests raging in franticke fits.

Those mirtle Groues decay'd, done growe againe, their rootes refresht with Heliconas spring,

Whose pleasant shade inuites the homely swayne, to sit him downe and heare the Muses sing.

Then if thy Muse hath spent her wonted zeale, with luie twist thy temples shall be crownd,

Or if she dares hoyse vp top-gallant sayle, amongst the rest, then may she be renownd. trade, merchandise

crazed, inspired

Whose: the groves'

accustomed

strike a lofty or inspired vein

185A-6A wisely ... strike] created by the (musician's) skilled hand; but wisely and cunning suggest a deeper wisdom. $\quad 189 \mathrm{~A}-90 \mathrm{~A}$ take ... proue] leave their mothers and start grazing on their own. o.1 golden world] the Golden Age. under Saturn (also seen as a legendary king of Latium), identified with the Golden Age (Ovid, Met. I.113). $\quad 5$ yonkers] young men, especially smart or fashionable ones. 7 Bellonas buskin] tragedies concerning war. Bellona] goddess of war. buskin] a kind of boot worn by tragic actors. Echoes Spenser, $S C$ 'October' 112-14. 9, 14 mirtle, Iuie] associated with immortality, hence fame. 9-12 Evokes the revival of English poetry in the age. 10 Helicon] a mountain sacred to Apollo and the Muses. The fountains Aganippe and Hippocrene, also sacred to the Muses, sprang from it. 
Gorbo. My boy, these yonkers reachen after fame, and so done presse into the learned troupe,

With filed quill to glorifie their name, which otherwise were pend in shamefull coupe.

But this hie obiect hath abjected me, aim, purpose and I must pipe amongst the lowly sorte,

Those little heard-groomes who admir'd to see, when I by Moone-shine made the fayries sporte.

wondered, were awestruck

Who dares describe the toyles of Hercules, and puts his hand to fames eternall penne,

Must inuocate the soule of Hercules, attended with the troupes of conquered men.

Who writes of thrice renowmed Theseus, a monster-tamers rare description,

Trophies the iawes of vglie Cerberus, and paynts out Styx, and fiery Acheron.

?records, celebrates

My Muse may not affect night-charming spels, whose force effects th'Olympicke vault to quake,

Nor call those grysly Goblins from their Cels, the euer-damned frye of Limbo lake.

in extended sense of 'hell'

And who erects the braue Pyramides, of Monarches or renowned warriours,

Neede bath his quill for such attempts as these, in flowing streames of learned Maros showres.

For when the great worlds conquerer began to proue his helmet and his habergeon,

The sweat that from the Poets-God Orpheus ran, foretold his Prophets had to play vpon.

i.e., foretold what

When Pens and Launces sawe the Olympiad prize, those chariot triumphes with the Lawrell crowne,

Then gan the worthies glorie first to rise, and plumes were vayled to the purple gowne.

of service to, valued by

The grauest Censor, sagest Senator, with wings of Iustice and Religion,

Censor: ruler, magistrate

Mounted the top of Nimrods statelie Tower, soring vnto that hie celestiall throne:

Where blessed Angels in their heauenly queares, chaunt Anthemes with shrill Syren harmonie,

Tun'd to the sound of those aye-crouding sphears, which herien their makers eternitie.

loud, resounding

Those who foretell the times of vnborne men, and future things in foretime augured,

Haue slumbred in that spell-gods darkest den, which first inspir'd his prophesiyng head.

earlier times

17-18 reachen, done] old plural verbs ending in $-(e) n . \quad 19$ filed] (a) polished, smooth (b) sharpened, ready. 29-32 Theseus visited the underworld, but not as 'monster-tamer': he was imprisoned there till rescued by Herakles. $\quad 31$ Cerberus] the three-headed dog guarding hell. $\quad 32$ Styx, Acheron] rivers of the underworld. $\quad 34$ Olympicke vault] the heavens, where the Olympian gods dwell. 37 Pyramides] memorials, here in poetry. 39 bath] i.e. dip in ink. 40 Maro] Virgil (Publius Vergilius Maro), here as poet of the Aeneid. 41 conquerer] 'Alexander the Great' (marginal note in 1619). When he set out on his expedition, a statue of Orpheus at Leibethra near Olympus began to sweat, foreshadowing the labour poets and historians would have to record Alexander's exploits. 44 prophet] inspired bard or poet $\left(O E D_{1 c}\right) . \quad 45$ The ancient Olympic games had competitions for poetry as well as for sports and martial skills. $\mathbf{4 8}$ purple gown] the ruler's robe. Purple was worn by patricians in ancient Rome. 51 Nimrods statelie Tower] Traditionally (though not biblically) identified with the Tower of Babel, unusually presented here in a positive light as a seat of language and poetry. 54 Syren] ?alluring, attractive: strangely applied to angels' songs. 55 aye-crouding] for ever playing music (crowd, a fiddle). $\quad 59$ spell-gods darkest den] probably Delphi, seat bf Apollo. 
Sooth-saying Sibels sleepen long agone, we haue their reede, but few haue cond their Arte,

Welch-wisard Merlyn, cleueth to a stone, no Oracle more wonders may impart.

teachings, lore; learnt

Welsh

The Infant age could deftly caroll loue, till greedy thirst of that ambitious honor,

Drew Poets pen, from his sweete lasses gloue, to chaunt of slaughtering broiles and bloody horror.

Then Joues loue-theft was priuily discri'd, how he playd false play in Amphitrios bed,

And how Apollo in the mount of Ide, gaue Oenon phisick for her maydenhead.

The tender grasse was then the softest bed, the pleasant'st shades were deem'd the statelyest hals,

No belly-god with Bacchus banqueted, nor paynted ragges then couered rotten wals.

Then simple loue with simple vertue wayd, flowers the fauours which true fayth reuayled,

Kindnes with kindnes was againe repay'd, with sweetest kisses couenants were sealed.

love-tokens; revealed, [displayed

Then beauties selfe with her selfe beautified, scornd payntings pergit, and the borrowed hayre,

Nor monstrous formes deformities did hide, nor soule was vernisht with compounded fayre.

painted over, glossed over

The purest fleece then couered purest skin, for pride as then with Lucifer remaynd:

at that time

Deformed fashions now were to begin nor clothes were yet with poysned liquor staynd.

But when the bowels of the earth were sought, and men her golden intrayles did espie,

This mischiefe then into the world was brought, this fram'd the mint which coynd our miserie.

Then lofty Pines were by ambition hewne, and men, sea-monsters, swamme the brackish flood

In waynscot tubs, to seeke out worlds vnknowne, for certain ill to leaue assured good.

The starteling steede is manag'd from the field, and serues a subiect to the riders lawes,

He whom the churlish bit did neuer weeld, now feels the courb controll his angrie iawes.

without artificial aid

a kind of oaken wood

broken in, trained

rule, govern

61 Sibels] Sybils, wise women and prophetesses of ancient times. $\mathbf{6 5}$ the Infant age] the Golden Age, the first major period of human history. The poem now changes direction: epic is rejected for humbler (and potentially pastoral) love-poems; but at least briefly in 69-72, these too are devalued by association with the sordid amours of the gods. $\quad 69$ discri'd] disclosed, revealed (OED descry $\mathrm{v}^{1} 2 \mathrm{2c}$ ); priuily implies the matter was formerly secret. 7o Amphitrio] Amphitrion, husband of Alcmena, who became by Zeus (Jove) the mother of Herakles. 72 Oenon(e)] a nymph on Mount Ida, espoused by Paris. Her rape by Apollo is a late addition to the myths about her. phisick] medicine, cure (for the 'illness' of virginity). $\quad 75$ ?There was no greedy drunkenness. $\quad 76$ paynted ragges] the cheap alternative to woven tapestries. 77 wayd] weighed: (a) were balanced or matched (b) carried weight, was valued. $\mathbf{8 2}$ pergit] parget, wall colouring and decoration, here facetiously applied to cosmetics. $\quad 83$ Physical blemishes were not covered with uglier devices. Cf. deformed fashions (87). $84 \mathrm{~A}$ sinful soul did not hide under a painted face. compounded fayre] manufactured beauty. $\mathbf{8 8}$ poysned liquor] dye; but suggesting the poisoned shirt of Nessus worn by Herakles. In the Golden Age, sheep naturally yielded wool of various colours (Virgil IV.42-5). 89-90 A reference to gold mining. 92 Giving a metaphorical dimension to the minting of gold coins. 93 Pines] from which ships' masts were made, hence ships. Sea voyages, for conquest or commerce, were thought to begin after the Golden Age: see Virgil IV.37-9. 94 men, sea-monsters,] This punctuation, from 1619, makes the meaning clear: humans turned monsters by sailing on the sea. 97 startling steed] a stock phrase.

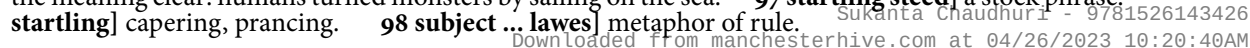


The hammering Vulcane spent his wasting fire, till he the vse of tempred mettals found,

His anuile wrought the steeled cotes attire, and forged tooles to carue the foe-mans wound.

armour

i.e., swords

planted, set on a firm base walled fights, encounters in battle and wald his wealth within the fenced towne,

Which afterward in bloudy stormy stours, kindled that flame which burnt his Bulwarks downe.

And thus began th' Exordium of our woes, the fatall dumbe shewe of our miserie:

beginning

Here sprang the tree on which our mischiefe growes, the drery subiect of worlds tragedie.

bloody, dire

Motto. Well, shepheard well, the golden age is gone, wishes may not reuoke that which is past:

It were no wit to make two griefes of one, our prouerb sayth, Nothing can alwayes last.

It is not wise

Listen to me my louely shepheards ioye, and thou shalt heare with mirth and mickle glee,

A pretie Tale, which when I was a boy, my toothles Grandame oft hath tolde to me.

Gorbo. Shepheard say on, so may we passe the time, There is no doubt it is some worthy ryme.

Motto. Farre in the countrey of Arden,

There wond a knight hight Cassemen, as bolde as Isenbras:

Fell was he and eger bent,

In battell and in Tournament, as was the good sir Topas.

He had as antique stories tell,

dwelt; named

Fell: bold, doughty called; Fr. douce at belle, sweet and pretty because marzipan a mayden fayre and free:

And for she was her fathers heire,

Full well she was ycond the leyre of mickle curtesie.

The silke wel couth she twist and twine,

And make the fine Marchpine, and with the needle werke,

And she couth helpe the priest to say

His Mattens on a holyday, and sing a Psalme in Kirke.

She ware a frock of frolicke greene,

Might well beseeme a mayden Queene, which seemly was to see.

A hood to that so neat and fine,

In colour like the colombine, ywrought full featuously.

Her feature all as fresh aboue,

As is the grasse that growes by Doue, prettily, elegantly

101-2 Vulcan did not make proper use of his fire till he learnt to make alloys. 103-4 Both uses of metal relate to war. 115 two griefs] once by suffering, again by lamenting. $123 \mathrm{ff}$. The exaggeratedly archaic language of the song recalls and sometimes echoes Spenser's SC. 123 Arden] ?suggested by the locale of Lodge's romance Rosalynde (Newdigate). To make the Forest of Arden a 'countrey' suits Motto's naïveté. 125 Isenbras] hero of a popular medieval romance. 128 sir Topas] referring to the burlesque tale of Sir Thopas in Chaucer's Canterbury Tales, composed in the same metre as Motto's 'ryme'. 133 was ... leyre] had learnt the lesson (cf. Spenser, SC 'May' 262). 134 curtesie] interesting application of this chivalric ideal to feminine refinement, even feminine activities like those in 135-7. 141 frolicke] bright, cheerful ( $O E D$ 1b, citing this passage). 145 colombine] a pink and purple flower, according to Spenser, $S C$ 'April' $136 . \quad 148$ Doue] a river in the Peak District, and others elsewhere in England. The details that follow range over England. 
as lyth as lasse of Kent:

gentle, agreeable

Her skin as soft as Lemster wooll,

As white as snow on peakish hull,

or Swanne that swims in Trent.

This mayden in a morne betime,

Went forth when May was in her prime, to get sweete Cetywall,

The hony-suckle, the Harlocke,

The Lilly and the Lady-smocke, to deck her summer hall.

Thus as she wandred here and there,

Ypicking of the bloomed Breere, she chanced to espie

A shepheard sitting on a bancke,

Like Chanteclere he crowed crancke, and pip'd with merrie glee:

He leard his sheepe as he him list,

When he would whistle in his fist, to feede about him round:

Whilst he full many a caroll sung,

Vntill the fields and medowes rung,

and that the woods did sound:

In fauour this same shepheards swayne,

briar, here ?wild rose

was like the bedlam Tamburlayne, which helde prowd Kings in awe:

But meeke he was as Lamb mought be,

Ylike that gentle Abel he, whom his lewd brother slaw.

?sang; lustily, vigorously

trained

This shepheard ware a sheepe gray cloke,

which was of the finest loke that could be cut with sheere,

His mittens were of Bauzens skinne,

His cockers were of Cordiwin, his hood of Meniueere.

His aule and lingell in a thong,

His tar-boxe on his broad belt hong, his breech of Coyntrie blew:

Full crispe and curled were his lockes,

curled

His browes as white as Albion rocks, so like a louer true.

And pyping still he spent the day,

So mery as the Popingay: which liked Dowsabell,

That would she ought or would she nought,

This lad would neuer from her thought: she in loue-longing fell.

At length she tucked $v p$ her frocke,

White as the Lilly was her smocke, she drew the shepheard nie,

But then the shepheard pyp'd a good,

a-good, (so) well

\begin{abstract}
149 Kent] Seems dictated solely by the rhyme 150 Lemster wool] the wool of the prized Ryeland sheep, traded from Leominster. 151 peakish] of the Peak District $\left(O E D\right.$, peakish adj $\left.^{2}\right)$; or simply with a peak, high. hull] hill: archaic and dialectal variant. $\quad 155$ Cetywall] setwall or valerian. Also a ginger-like plant (as in Chaucer, Sir Thopas 1951). 156 Harlocke] not identified; perhaps the charlock or field mustard, but it flowers in the winter. 157 Lady-smocke] the cuckoo-flower. 163 Chanteclere] a cock, especially as a character in beast-fables including Chaucer's Nun's Priest's Tale. 172 bedlam] madman, crazed vagrant. Tamburlayne was not such, though of humble shepherd stock. 177 sheepe gray] the natural colour of the fleece. $\quad 181$ Cordiwin] 'Cordovan' or cordwain, a kind of (originally Spanish) leather: an expensive item for a shepherd. $\mathbf{1 8 2}$ Meniueere] miniver, squirrel fur: another unexpectedly fashionable item. $\quad \mathbf{1 8 3}$ aule] awl: bodkin or needle. lingell] thread; both used for sheep's surgery. 185 Coyntrie blew] Coventry blue, a blue thread normally used for embroidery, not to make breeches. They may be so embroidered, as another luxury item. 187 Albion rocks] the white rocks of Kent which gave the name 'Albion' (Lat. albus, white) to England.
\end{abstract}


200
That all his sheepe forsooke their foode, to heare his melodie.

Thy sheepe quoth she cannot be leane,

That haue a iolly shepheards swayne, the which can pipe so well.

Yea but (sayth he) their shepheard may,

If pyping thus he pine away, in loue of Dowsabell.

Of loue fond boy take thou no keepe,

Quoth she, looke well vnto thy sheepe, lest they should hap to stray.

Quoth he, so had I done full well,

Had I not seene fayre Dowsabell, come forth to gather Maye.

With that she gan to vaile her head,

Her cheekes were like the Roses red, but not a word she sayd.

With that the shepheard gan to frowne,

He threw his pretie pypes adowne, and on the ground him layd.

Sayth she, I may not stay till night,

And leaue my summer hall vndight, and all for long of thee:

My Coate sayth he, nor yet my foulde,

Shall neither sheepe nor shepherd hould, except thou fauour me.

Sayth she yet leuer I were dead,

Then I should lose my maydenhead, and all for loue of men:

Sayth he yet are you too vnkind,

If in your heart you cannot finde, to loue vs now and then:

And I to thee will be as kinde,

As Colin was to Rosalinde, of curtesie the flower:

Then will I be as true quoth she,

As euer mayden yet might be, vnto her Paramour:

With that she bent her snow-white knee,

Downe by the shepheard kneeled shee, and him she sweetely kist.

With that the shepheard whoop'd for ioy,

Quoth he, ther's neuer shepheards boy, that euer was so blist.

Gorbo. Now by my sheep-hooke here's a tale alone,

Learne me the same and I will giue thee hier,

This were as good as curds for our Ione,

When at a night we sitten by the fire.

teach; hire, employment i.e., as good as a gift or diversion

Motto. Why gentle hodge I will not sticke for that, when we two meeten here another day,

But see whilst we haue set vs downe to chat, yon tikes of mine begin to steale away.

object to

liefer: sooner, rather

unnatural

And if thou wilt but come vnto our greene, on Lammas day when as we haue our feast,

Thou shalt sit next vnto our summer Queene, and thou shalt be the onely welcome guest. 
(B) The 1606 Version

Printed as in 1606; 1619 prints as 4-line stanzas (except for the song). Punctuation inserted or regularized where necessary, and line initials uniformly capitalized. [Notes also relevant to the 1593 version placed there.]

\section{The fourth Eglog.}

Motto. Sheapheard, why creepe we in this lowly vaine

As though our store no better vs affoords?

And in this season when the stirring swain

Makes the wyde fields sound with great thundring words?

Not as twas wont now rurall be our rymes,

Sheapheards of late are waxed wondrous neate.

Though they were richer in the former tymes,

We be inraged with more kindly heate.

The withered Laurell freshly growes agayne

Which simply shadowed the Pierian spring

Which oft inuites the solitary swayne

Thether, to heare those sacred virgins sing:

Then if thy muse haue spent her wonted zeale

With withered twists thy forehead shal be bound,

But if with these she dare aduance her sayle

Amongst the best then may she be renown'd.

Gorbo. Sheapheards, these men at mighty things do aym

And therefore presse into the learned troope

With filed phraze to dignifie their name,

Els with the world shut in this shamefull coope.

finely turned, elegant; glorify

But such a subiect ill beseemeth me,

For I must pipe amongst the lowly sort,

Those silly heardgrooms who haue laught to see

When I by moonshine made the fayries sport.

Who of the toyles of Hercules will treat,

And put his hand to an eternall pen,

In these hie labours it behooues him sweat,

To soare beyond the vsuall pitch of men.

Such monster-tamers who would take in hand,

As haue tyde vp the triple-headed hound,

Or of those Gyants which gainst heuen durst stand

Whose strength the gods it troubled to confound?

Who listeth with so mighty things to mell,

And dares a taske so great to vndertake,

Should rayse the black inhabitants of Hell,

And stir a tempest on the Stygian Lake.

He that to worlds Pyramides will build

On those great Heroes got by heauenly powers,

Should haue a pen most plentifully filld

In the full streams of learned Maro's showers.

Who will foretell mutations, and of men,

Of future things and wisely will enquire,

Before should slumber in that shady den

That often did with prophesie inspyre.

Southsaying Sybells sleepen long agon,

We haue their reed but few haue cond their art,

refined, elegant, smart

?more sumptuous or elaborate inspired, full of poetic frenzy; natural,

[innate; heate: inspiration, 'fire'

?fully, totally; shaded, overlooked

the Muses

accustomed

twigs, branches

And the welch wisard cleaueth to a stone:

No oracles more wonders shall impart.

When him this round that neerest ouerran,

destroy

wishes; meddle

changes, vicissitudes

earlier, first

soothsaying; plural ending in $-n$

7-8a Seems to contradict 5-6. May imply that the new poetry values inspiration over poetic craft. $\quad$ 10a Pierian spring] poetic inspiration: Pieria in Macedonia was a seat of the Muses. No such actual spring. 26a eternall pen] transferred epithet: a pen to write poems of eternal fame. 30a triple-headed hound] Cerberus, guarding the entrance to hell. 31a Gyants] the Gigantes, a race of giants who attacked heaven. 38a Heroes... heauenly powers] The 'heroes' of classical mythology had one (usually male) divine parent and one human. 43a that shady den] Perhaps the cavern in the ground that was the seat of the Delphic oracle. 47a welch wisard] Merlin: named in 1593, and in a marginal note in 1619. 49a him ... ouerran] He who most nearly conquered the entire world (round, globe).
Sukanta Chaudhur $\mathrm{i}$ - 
$50 \mathrm{~A}$

$60 \mathrm{~A}$

$70 \mathrm{~A}$

$8 \mathrm{OA}$

$90 \mathrm{~A}$

100A
His labouring mother to the light did bring,

The sweat that then from Orpheus statue ran,

Foretould the prophets had whereon to sing.

When virtue had alotted her a prize,

The Oaken garlands and the laurell Crown,

Fame then resumd her lofty wings to rise,

And plumes wear honored with the purple gown.

Then when religion with a goulden chayne,

Men vnto fayre ciuility did draw,

Who sent from heauen brought iustice forth again

To keep the good, the viler sort to awe.

That simple age as simply sung of loue,

Till thirst of Empire and of earthly swayes

Drew the good shepheard from his lasses loue,

To sing of slaughter and tumultuous frayes.

Then Ioues loue-theft was priuily discri'd,

How he playd false play in Amphitrio's bed,

And yong Apollo in the mount of Ide

Gaue Oenon physick for her maydenhead:

The tender grasse was then the softest bed:

The pleasant shades esteemed stateliest halls,

No belly churle with Bacchus banqueted,

Nor painted rags then couered rotten walls:

Then simple loue by simple virtue waied,

Flowrs the fauours equall faith reuealed,

Kindnes againe with kindnes was repayd,

And with sweet kisses couenants were sealed.

Then Beauties self by her selfe beautified,

Scorn'd paintings, pergit and the borowed hayr,

Nor monstrous formes deformities did hide

The foul to varnish with compounded faire.

The purest fleece then couered purest skin,

For pride as then with Lucifer remaynd,

Ill fauoured fashions yet did not begin,

Nor wholsome cloaths with poysoned liquor staynd.

But when the bowels of the earth were sought

Whose golden entrailes mortalls did espy,

Into the world all mischiefe then was brought:

This fram'd the mint that coynd our misery.

The lofty pines then presently cut downe

And men, sea-monsters, swam the bracky flood

In wainscote tubs to seeke out worlds vnknowne,

For certain ill to leaue assured good.

The steede was tamde and fitted to the field

That serues a subiect to the riders lawes,

He that before ran in the pastures wilde

Felt the stiffe curb controwle his angry iawes.

The Cyclops then stood sweating to the fire,

The vse thereof in softning metalls found

That did streight limbs in stubborne steele attyre

Forging sharp tooles the tender flesh to wound.

The Citty-builder then intrencht his towers

And layd his wealth within the walled towne,

Which after ward in rough and stormy stowres

Kindled the fire that burnt his bulwarks downe.

This was the sad beginning of our woe

That was from hell on wretched mortalls hurld,

And from this fount did all those mischiefes flow

Whose inundation drowneth all the world.

Motto. Well shepheard well, the golden age is gon, something to sing about

raise

were

Who: i.e., religion protect

power, rule

immediately, forthwith

(a) rigid (b) narrowly confined

57a goulden chayne] precious or attractive bonds or curbs. 74a equall] (a) steady, constant (b) 
Wishes no way reuoketh what is past,

$110 \mathrm{~A}$

Small wit there were to make two griefes of one

And our complaints we vainly should but wast.

Listen to me then louely shepheard lad,

And thou shalt heare, attentiue if thou be,

A prety tale I of my Grandame had,

One winters night when there wer none but we.

Gorbo. Shepheard say on, so may we passe the time,

There is no doubt it is som worthy rime.

Motto. Far in the country of Arden,

There wond a knight hight Cassamen, as bould as Isenbras.

$120 \mathrm{~A}$

Fell was he and eager bent,

In battell and in tournament, as was the good Sir Topas.

He had as antique stories tell,

A daughter cleaped Dowsabel, a mayden faire and free.

And for she was her fathers heyr

Ful well she was ycond the leyr of mickle curtesie.

The silke well couth she twist and twine,

And make the fine Marchpine, and with the needle werke:

And she couth helpe the priest to say

His Mattens on a holyday and sing a Psalme in Kirke.

She ware a frock of frolicke green,

Might well becom a Mayden queen, which seemly was to see.

A hood to that so neat and fine,

In colour like the Columbine, Ywrought full featuously.

Her feature all as fresh aboue,

As is the grasse that growes by Doue, and lyth as lasse of Kent.

Her skin as soft as Lemster wooll,

As white as snow on Peakish hull or swan that swims in Trent.

This mayden in a morn betime,

Went foorth when May was in the prime, to get sweet Setywall.

The hony-suckle, the harlock,

The Lylly and the Lady-smock, to deck her summer hall.

Thus as she wandred here and there

And picked of the bloomy brier, she chanced to espy,

A shepheard sitting on a banke,

Like Chanteclere he crowed crancke, and pip'd full merrily.

He leard his sheep as he him list,

When he would whistle in his fist, to feed about him round.

Whilst he full many a carroll sang,

Vntill the fields and meadowes rang, and that the woods did sound.

In fauour this same shepheard swayne,

Was like the bedlam Tamberlayne, which held proude Kings in awe.

But meeke as any Lamb mought be, 
$180 \mathrm{~A}$

190A

200A

210A

And innocent of ill as he, whom his lewd brother slaw.

This shepheard ware a sheep gray cloke,

Which was of the finest loke

that could be cut with sheere.

His mittens were of Bauzens Skin,

His Cockers were of cordiwin, his hood of Miniueere.

His aule and lingell in a thong,

His tarbox on his broad belt hong, his breeche of Cointry blew.

Full crispe and curled were his locks,

His browes as white as Albion rocks, so like a louer true.

And piping still he spent the day,

So merry as the Popingay, which liked Dowsabell.

That would she ought or wold she noght,

This lad would neuer from her thought, she in loue-longing fell.

At length she tucked $v p$ her frocke,

White as the Lilly was her smock, she drew the shepheard ny:

But then the shepheard pip'd a good,

That all his sheepe forsooke theyr foode, to heare his melody.

Thy sheepe quoth shee, can not be leane,

That haue a iolly sheepheards swayne, the which can pipe so well:

Yea but (saith he) their shepheard may,

If piping thus he pine away in loue of Dowsabell.

Of loue fond boy take thou no keepe

Quoth she, looke wel vnto thy sheepe, least they should hap to stray:

Quoth he; so had I done full well

Had I not seen faire Dowsabell come foorth to gather May.

With that she gan to vaile her head,

Her cheekes were like the Roses redde, but not a word she said.

With that the shepheard gan to frowne,

He threw his prety pipes adown, and on the ground him layd.

Saith she I may not stay till night,

And leaue my summer hall vndight, and all for loue of thee:

My coat saith he, nor yet my fould,

Shall neither sheep nor shepheard hould except thou fauour mee.

Saith she, yet leuer I were dead,

Then I should loose my maidenhead and all for loue of men:

Saith he, yet are you too vnkind,

If in your hart you cannot find, to loue vs now and then.

And I to thee will be as kind,

As Colin was to Rosalind, of curtesie the flower:

Then will I be as true quoth she,

As euer maiden yet might be, vnto her paramour.

With that she bent her snow-white knee, 
Downe by the shepheard kneeled shee, and him she sweetlie kist.

With that the shepheard whoop'd for ioy,

Quoth he ther's neuer shepheards boy, that euer was so blist.

Gorbo. Now by my sheephook, heer's a tale alone,

Learn me the same and I wil giue thee hyer.

This were as good as curds for our Ione,

When at a night we sitten by the fire.

Motto. Why gentle Gorbo ile not stick for that,

When we shall meet vpon som mery day.

But see whilst we haue set vs downe to chat,

Yon tykes of myne begin to steale away.

And if thou please to come vnto our green,

On Lammas day, when as we haue our feast,

Thou shalt sit next vnto the shepheardes queene,

And ther shalt be the only welcom guest.

\section{Michael Drayton Eclogue ix, 1606}

First published in Drayton's Poemes Lyrick and pastoral (1606), with the earlier eclogues repeated from 1593; but the first two songs had already appeared in Helicon (1600). Reprinted with the rest in 1619, shortening the second line in each stanza of the last song. The text below follows 1606. Line initial capitals standardized and punctuation regularised. As Tillotson and Newdigate point out, this later addition to Drayton's eclogues strikes a more realistic vein, reflecting the actual shearing-feast of Cotswold shepherds. The latter is described in Poly-olbion Bk.XIV, with a lively illustration in the accompanying map - the only full-fledged scene of rustic life in the book. This indicates the centrality of the pastoral in Drayton's concept of England as well as of poetry.

Late t'was in June the fleece when fully grown

In the full compasse of the passed year,

The season wel by skilful shepheards known

That them prouide immediatly to sheare.

prepare themselves

Their Lambs late wax'd so lusty and so strong,

That time did them theyr mothers teats forbid,

grown

And in the fields the common flocks among,

Eat of the same grasse that the greater did.

Now not a shepheard any thing that could,

But greazd his startvps black as Autums sloe,

And for the better credit of the Would

In their fresh russets euery one doth go.

any ability at all

a kind of rustic boot

wold: land, region, countryside garments of russet, a kind of cloth

Who now a posie pins not in his cap:

And not a garland Baldrick wise dooth weare?

Some, of such flowers as to his hand dooth hap,

a belt worn across the chest

Others, such as a secret meaning beare:

He from his lasse him Lauander hath sent

Shewing her Loue, and doth requitall craue,

has had sent

Him Rosemary his sweethart, whose intent

return (of gift)

Is that he her should in remembrance haue.

Roses his youth and strong desire expresse,

Her Sage doth show his souerainty in all,

The Iuly-flower declares his gentlenes,

Tyme trueth, the Pansie Hartseas maydens call:

thyme

In cotes such simples simply in request,

Wherwith proude courts in greatnes scorn to mel,

For country toyes become the cuntry best,

And please poor shepheards and becom them wel.

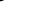


When the new washd flock from the riuers side,

Comming as white as Ianuaries snow,

The Ram with nosegayes beares his horns in pride,

And no less braue, the Belwether doth go.

adorned, decked out

After their fayr flocks in a lusty rowte,

Came the Gay swaynes with Bagpipes strongly blown,

group, band

And busied though this solemn sport about

Yet had eache one an eye vnto his own.

i.e., own flock

And by the auncient statutes of the field,

$\mathrm{He}$ that his flocks the earliest lamb should bring

(As it fell out now Rowlands charge to yeeld)

Alwayes for that yeare was the shepheards king.

And soon preparing for the shepheards Board,

Vpon a green that curiously was squard,

With Country cates that plentifully stoard:

carefully, exactly; laid out as a square

And gainst their comming hansomly prepard.

New whig, with water from the clerest streame,

Green plums, and wildings, Cheries chief of feast,

Fresh cheese, and dowsets, Curds and clowted cream,

Spice Syllibubs, and Syder of the best:

And to the same downe solemnly they sit,

In the fresh shadow of their summer Bowers,

With sondry sweets which euery way to fit,

The Neighb'ring Vale dispoyled of her flowrs.

And whilst together mery thus they make,

The Sunne to West a little gan to leane,

Which the late feruor soon agayn did slake,

When as the nymphs came foorth vpon the plain.

Here might you many a shepherdesse haue seene,

Of which no place as Cotswold such doth yeeld,

Some of it natiue, some for loue I ween

60

Thether were come from many a fertill field.

There was the widows daughter of the Glen,

Deare Rosalynd, that scarsely brook'd compare,

The Moreland mayden, so admyr'd of men,

Bright Gouldy-locks, and Phillida the fayre.

Lettice and Parnell prety louely peats,

Cusse of the Fould, the Virgine of the well,

Fayre Anbrie with the alablaster Teats,

white breasts

And more whose names were heere to long to tell,

wild apples (or other wild fruit) doucets, a sweet dish

Which now came forward following their sheep,

Their Batning flocks on grassy leaes to houlde,

Thereby from skathe and perill them to keepe

Till euening come that it were time to foulde.

harm, damage

When now at last as lik'd the shepheards King

(At whose commaund they all obedient were)

Was poynted who the Roundelay shoold singe

And who againe the vndersong should beare.

designated, assigned

39 Rowland] Drayton's own pastoral persona.

45 whig] applied to various milk drinks and preparations. $\quad 51$ sweets] ?fragrant flowers ?pleasures generally. which euery way to fit] filling or adorning every side. 55 which diminished their earlier enthusiasm. $\quad 61-2$ widows daughter ... Rosalynd] Colin Clout's beloved Rosalind in Spenser's SC ('April' 26). 65 peat] term of endearment for girl or young woman. $\quad \mathbf{7 6}$ vndersong] minor interventions accompanying the main singer. 
The first whereof he Batte doth bequeath,

A wittier wag on all the wold's not found.

Gorbo the man, that him should sing beneath

Which his lowd Bagpipe skilfully should sound.

When amongst all the nimphs that wear in sight

were

His best beloued Daffadill he mis'd,

he: Batte

Which to enquire of doing all his might

Whome his companyon kindly doth assist.

fittingly, appropriately

Batte. GORBO as thou cam'st this waye

by yonder little hill

Or as thou through the fields didst straye

sawst thou my Daffadill?

wander, roam

Shee's in a frock of Lincolne greene

the colour maides delight

And neuer hath her beauty seen

but through a vale of white.

Then Roses richer to behold

that trim $v p$ louers bowers,

The Pansy and the Marigould

tho Phobus Paramours.

allows to be seen

than

Gorbo. Thou well describ'st the Daffadill,

it is not full an hower

Since by the spring neare yonder hill

I saw that louely flower.

Batte. Yet my faire flower thou didst not meet,

Nor news of her didst bring,

And yet my Daffadill more sweete,

Then that by yonder spring.

Gorbo. I saw a shepheard that doth keepe

in yonder field of Lillies,

Was making (as he fed his sheepe)

a wreathe of Daffadillies.

Batte. Yet Gorbo thou delud'st me stil,

mislead, evade the issue my flower thou didst not see,

For know my pretie Daffadill

Is worne of none but me.

To shew it selfe but neare her seate,

No Lilly is so bould,

Except to shade her from the heate,

Or keepe her from the colde:

protect, shelter

Gorbo. Through yonder vale as I did passe,

Descending from the hill,

I met a smerking bony lasse,

They call her Daffadill:

smiling; bonny

Whose presence as she went along,

The prety flowers did greet,

As though their heads they downward bent,

With homage to her feete.

And all the shepheards that were nie,

From toppe of euery hill,

Vnto the vallies lowe did crie,

There goes sweet Daffadill.

83 exercising all his skill to ask after her. $\quad 89$ Lincolne greene] 'a bright green stuff made at Lincoln' $(O E D)$. 96 Phœbus Paramours] because they turn to the sun. Phœbus] Apollo as sun-god. 
Gorbo. I gentle shepheard, now with ioy

That's she alone, kind shepheards boy,

Let $v s$ to Daffadill.

The easie turnes and queyntnes of the song,

And slight occasion whereupon t'was raysed

Not one this iolly company among,

(As most could well iudge) hiely that not praysed.

When Motto next with Perkin pay their debt,

The Moreland maiden Syluia that espied,

From th'other nymphes a little that was set,

In a neer vally by a riuers side.

Whose souerain flowers her sweetnes wel expresd

And honored sight a little them not mooued:

To whom their song they reuerently addresd

Both as her louing, both of her beloued.

Motto. Tell me thou skilfull shepheards swayne,

Who's yonder in the vally set?

Perkin. O it is she whose sweets do stayne the Lilly, Rose, or violet.

Motto. Why doth the Sunne against his kind stay his bright Chariot in the skies?

Perkin. He pawseth almost stroken blind, with gazing on her heauenly eies:

Motto. Why do thy flocks forbeare their foode, which somtyme was their chiefe delight,

Perkin. Because they neede no other good, that liue in presence of her sight:

Motto. How com these flowers to florish still, not withering with sharpe winters breath?

Perkin. She hath robd nature of her skill, and comforts all things with her breath.

Motto. Why slide these brookes so slow away, as swift as the wild Roe that were?

Perkin. O muse not shepheard that they stay, when they her heauenly voice do heare.

Motto. From whence com all these goodly swayns and louely nimphs attir'd in greene?

Perkin. From gathering garlands on the playnes, to crowne thy Siluia shepheards queen.

Motto. The sun that lights this world below, Flocks, Brooks and flowers, can witnesse bear,

Perkin. These shepheards, and these nymphs do know thy Syluia is as chast, as fayre.

Lastly it came vnto the clownish king, dim, put in the shade

most beautiful or prominent

Who to conclude this shepheards yearely feast,

Bound as the rest his Roundelay to sing

As all the other him were to assist.

134 slight occasion] The singer's ingenuity in exploiting such 'slight occasion' is cause for praise. 151-2 i.e. Her eyes are brighter than the sun: a common Petrarchan conceit. 157-8 The Helicon text implies Silvia's absence: 'Why looke these flowers so pale and ill, / That once attir'd this goodly Heath?'This gives a better rhyme, but 1606 a sharper conceit and a sense of Silvia's presence. 159 robd ... skill] acquired nature's life-giving force. 163-4 i.e. Her voice is sweeter than the murmur of the brooks. 
When she (whome then, they little did expect, The dearest nimphe that euer kept in field) Idea, did her sober pace direct Towards them, with ioy that euery one beheld.

And whereas other draue their carefull keepe,

Hers did her follow, duly at her will,

For through her patience she had learnt her sheep

Where ere she went to wait vpon her still.

A milkewhite Doue vpon her hand she brought,

So tame, t'would go, returning at her call,

About whose neck, as in a choller wrought,

Only like me, my mistris hath no gaule.

gall

To whom her swaine (vnworthy though he were)

Thus vnto her his Roundelay applies,

To whom the rest the vnder part did beare,

Casting vpon her their still-longing eyes.

Rowland. Of her pure eyes (that now is seen)

Chorus. Help vs to sing that be her faithful swains.

Rowland. Ô she alone the shepheards Queen,

Chorus. Her flocke that leades,

the goddess of these medes,

these mountaines and these plaines.

Rowland. Those eyes of hers that are more cleere,

Chorus. Then silly shepheards can in song expresse,

bright, shining

Rowland. Then be his beams that rules the yeare,

Chorus. Fy on that prayse,

in striuing things to rayse

that doth but make them lesse.

Rowland. That doe the flowery spring prolong,

Chorus. So much the earth doth in her presence ioy,

Rowland. And keeps the plenteous summer young:

Chorus. And doth asswage

the wrathfull winters rage,

that would our flocks destroy.

Rowland. Ioue saw her brest that naked lay,

Chorus. A sight alone was fit for Ioue to see:

Rowland. And swore it was the milkie way,

Chorus. Of all most pure,

the path (we vs assure)

vnto Ioues court to be.

heaven

Rowland. He saw her tresses hanging downe

Chorus. That too and fro were mooued with the ayre,

Rowland. And sayd that Ariadnes crowne,

Chorus. With those compar'd,

the gods should not regard

nor Berenices hayre.

Rowland. When she hath watch'd my flockes by night,

Chorus. O happie were the flockes that she did keepe:

Rowland. They neuer needed Cynthia's light,

Diana as moon-goddess

179 Idea] Drayton's usual persona for his patron Anne Goodere. $\quad \mathbf{1 8 1}$ carefull keepe] their charges (flocks), kept with care. $\mathbf{1 8 8}$ The dove was thought to have no gall or bile, hence its meek and peaceful nature. 196 She who leads her flocks (instead of driving them: cf. 181-4). 201 his ... that rules the yeare] the sun. $\quad \mathbf{2 0 2 - 4}$ i.e. Such a comparison only shows how inadequate the object of comparison (the sun) is. 219 Ariadne's crowne] After Ariadne was abandoned by Theseus, Dionysos married her, and placed her wedding-crown among the stars. 222 Berenice] wife of Ptolemy III. She dedicated her hair at a temple to ensure the safe return of her husband from war. The hair was placed among the stars, in a constellation so named. 225-8 Idea's light is brighter than the moon's (cf. 202-4). 
Chorus. That soone gaue place, amazed with her grace that did attend thy sheepe.

Rowland. Aboue where heauens hie glorious are,

Rowland. She shall be calld the shepheards starre,

Chorus. And euermore, we shepheards will adore

her setting and her rise.

\section{Michael Drayton From Poly-Olbion}

Poly-olbion is a vast chorographical poem, a geographical and historical survey of England and Wales. The first 18 'Songs' were published in 1612, and reprinted with 12 new ones in 1622. The first three extracts follow the 1612 text, the last 1622. Marginal notes and 'Illustrations' (annotations) in the original are so indicated in parentheses.

(A) Song IX Lines 71-96

[From the account of Merionethshire in Wales. Sung by the Oreades or mountain nymphs to calm the tumult among the mountains on hearing Mervinia's (Merionethshire's) account of her rivers.]

Thrice famous Saxon King, on whom Time nere shall pray,

prey

O Edgar! who compeldst our Ludwall hence to pay

Three hundred Wolues a yeere for trybute vnto thee:

And for that tribute payd, as famous may'st thou bee,

O conquer'd British King, by whom was first destroy'd

The multitude of Wolues, that long this Land annoy'd;

Regardlesse of their rape, that now our harmlesse Flocks

Securely heere may sit vpon the aged Rocks;

Or wandring from their walks, and straggling here and there

Amongst the scattred Cleeues, the Lambe needs neuer feare,

But from the threatning storme to saue it selfe may creepe

Into that darksome Caue where once his foe did keepe:

That now the clambring Goat all day which hauing fed,

And clyming vp to see the sunne goe downe to bed,

Is not at all in doubt her little Kid to lose,

Which grazing in the Vale, secure and safe she knowes.

Where, from these lofty hills which spacious heauen doe threat,

Yet of as equall height, as thick by nature set,

We talke how wee are stor'd, or what wee greatly need,

that: so that

Or how our flocks doe fare, and how our heards doe feed,

When else the hanging Rocks, and Vallyes dark and deepe,

The Sommers longest day would vs from meeting keepe.

Yee Cambrian Shepheards then, whom these our Mountaines please,

And yee our fellow Nymphs, yee light Oreades,

Saint Hellens wondrous way, and Herberts let vs goe,

And our diuided Rocks with admiration showe.

1-3 King Edgar (reigned 959-75) rid Wales of wolves by exacting tribute of 300 wolfskins a year from King Ludwall or Idwall of Wales (Holinshed, Chronicles, 1577, III.7. In Drayton's quasi-pastoral context, the extermination of wolves threatening the flocks has symbolic meaning. 1 on ... pray] who will never be destroyed by time, i.e. forgotten. 5 British] Welsh. The ancient Welsh called themselves Brythoniaid (Brythons or Britons), descendants of Brut, the legendary Trojan prince who ruled Britain and gave the land its name. The conquered king is Ludwall. 7 Regardlesse of their rape] Not afraid of being carried away or attacked 17-22 i.e. The Oreades converse by calling from one mountain top to another. 17-18 The peaks of Aran Fawddwy (Drayton's 'Raran') and Cadair Idris ('Cadoridric'), almost equal in height. 17 these lofty hills] 'The wondrous Mountaines in Merionethshire' (marginal note). 24 Oreades] 'Nymphs of the Mountains' (marginal note). 25 Saint Hellens wondrous way 'By Festeneog [Festiniog] the confines of Caernarvan and Merioneth is this high way of note; so call'd by the British [i.e. Welsh], and supposed made by that Helen, mother to [Emperor] Constantine' [more likely Helen, consort of the Emperor Maximus]. ('Illustration'). An ancient Roman road in this region was known by this name at least till the 19-c. 'Herbert's way' cannot be identified. 26 diuided Rocks] Aran Fawddwy and Cadair Idris (see 17-18n). 
(B) Song XIII.13-236

[From the account of the forest of Arden in Warwickshire, Drayton's native county. In the 'Illustrations', Drayton explains: 'By reason of this her [Arden's] greatnes ioyn'd with Antiquity, Hee ['the Author'] also made choise of this place for description of the Chase, the English simples, and Hermit, as you read in him.' In other words, Drayton uses this account of his native county to illustrate many important ramifications of the pastoral.]

Muse, first of Arden tell, whose foot-steps yet are found

In her rough wood-lands more then any other ground

That mighty Arden held euen in her height of pride;

Her one hand touching Trent, the other, Severns side.

The very sound of these, the Wood-Nymphs doth awake:

these: the rivers

When thus of her own selfe the ancient Forrest spake:

My many goodly sites when first I came to showe,

Here opened I the way to myne owne ouer-throwe:

For, when the world found out the fitnesse of my soyle,

The gripple wretch began immediatly to spoyle

greedy, avaricious

By which, in little time my bounds I came to lose.

When Britaine first her fields with Villages had fild,

Her people wexing still, and wanting where to build,

They oft dislodg'd the Hart, and set their houses, where

He in the Broome and Brakes had long time made his leyre.

Of all the Forrests heere within this mightie Ile,

If those old Britains then me Soueraigne did instile,

I needs must be the great'st; for greatnesse tis alone

That giues our kind the place: else were there many a one

For pleasantnes of shade that farre doth mee excell.

But, of our Forrests kind the quality to tell,

We equally partake with Wood-land as with Plaine,

Alike with Hill and Dale; and euery day maintaine

The sundry kinds of beasts vpon our copious wast's,

That men for profit breed, as well as those of chase.

Here Arden of her selfe ceast any more to showe;

And with her Sylvan ioyes the Muse along doth goe.

When Phoebus lifts his head out of the Winters waue,

No sooner doth the Earth her flowerie bosome braue,

At such time as the Yeere brings on the pleasant Spring,

But Hunts-vp to the Morne the feath'red Sylvans sing:

And in the lower Groue, as on the rising Knole,

Vpon the highest spray of euery mounting pole,

Those Quirristers are pearcht with many a speckled breast.

Then from her burnisht gate the goodly glittring East

Guilds euery lofty top, which late the humorous Night

Bespangled had with pearle, to please the Mornings sight:

On which the mirthfull Quires, with their cleere open throats,

Vnto the ioyfull Morne so straine their warbling notes,

That Hills and Valleys ring, and euen the ecchoing Ayre

Seemes all compos'd of sounds, about them euery where.

The Throstell, with shrill Sharps; as purposely he song

T'awake the lustlesse Sunne; or chyding, that so long

He was in comming forth, that should the thickets thrill:

The Woosell neere at hand, that hath a golden bill,

As Nature him had markt of purpose, t'let vs see

That from all other Birds his tunes should different bee:

growing in numbers [wanting where: lacking space

enstyle, name

display, flaunt

30

pearl: i.e., dew

moist

1 foot-steps] 'Diuers Towns expressing her name: as Henly in Arden, Hampton in Arden, etc.' The forest had shrunk even by Drayton's day: the map in Poly-olbion shows it as 'The old forrest of Arden Now the Woodland of Warwick Shyre' (marginal note).

4 Trent ... Seuerns side] may not be meant literally: 'That comprehensiue largenes which this Arden once extended ... makes the Author thus limit her with Seuerne and Trent.' ('Illustrations'). 11 inclose] for sheep-farming. Drayton celebrates Warwickshire sheep-farming later in Song XIII. 29 Phobus] Apollo the sun-god, hence the sun. 32 Hunts-vp] a song or tune to awake from sleep, especially to call to a hunt, like that described in $75 \mathrm{ff}$. 43-50 Throstell, Woosell, Merle] Used for various members of the thrush family, like the blackbird, ring ousel, song thrush and mistle thrush. 
For, with their vocall founds, they sing to pleasant May;

Vpon his dulcet pype the Merle doth onely play.

When in the lower Brake, the Nightingale hard-by,

In such lamenting straines the ioyfull howres doth ply,

As though the other Birds shee to her tunes would draw.

And, but that Nature (by her all-constraining law)

Each Bird to her owne kind this season doth invite,

They else, alone to heare that Charmer of the Night

(The more to vse their eares) their voyces sure would spare,

That moduleth her tunes so admirably rare,

modulates, attunes

As man to set in Parts, at first had learn'd of her.

To Philomell the next, the Linet we prefer;

And by that warbling bird, the Wood-Larke place we then,

The Red-sparrow, the Nope, the Red-breast, and the Wren,

The Yellow-pate: which though shee hurt the blooming tree,

Yet scarce hath any bird a finer pype then shee.

And of these chaunting Fowles, the Goldfinch not behind,

That hath so many sorts descending from her kind.

The Tydie for her notes as delicate as they,

The laughing Hecco, then the counterfetting Iay,

The Softer, (with the Shrillsome hid among the leaues,

Some in the taller trees, some in the lower greaues)

Thus sing away the Morne, vntill the mounting Sunne,

Through thick exhaled fogs, his golden head hath runne,

And through the twisted tops of our close Couert creeps

next: after the nightingale

yellowhammer

voice, song

songbirds; not the least

?wren ?blue tit

woodpecker; mimicking (other

[birds' calls)

thickets, bushes

To kisse the gentle Shade, this while that sweetly sleeps.

And neere to these our Thicks, the wild and frightfull Heards,

Not hearing other noyse but this of chattering Birds,

Feed fairely on the Launds; both sorts of seasoned Deere:

Here walke the stately Red, the freckled Fallowe there:

The Bucks and lusty Stags amongst the Rascalls strew'd,

As sometime gallant spirits amongst the multitude.

Of all the Beasts which we for our veneriall name,

The Hart amongst the rest, the Hunters noblest game:

Of which most Princely Chase sith none did ere report,

Or by description touch, t'expresse that wondrous sport

(Yet might haue well beseem'd th'ancients nobler Songs)

To our old Arden heere, most fitly it belongs:

Yet shall shee not invoke the Muses to her ayde;

But thee Diana bright, a Goddesse and a mayd:

In many a huge-growne Wood, and many a shady Groue,

90 Which oft hath borne thy Bowe (great Huntresse) vs'd to roue

At many a cruell beast, and with thy darts to pierce

The Lyon, Panther, Ounce, the Beare, and Tiger fierce;

And following thy fleet Game, chaste mightie Forrests Queene,

With thy disheueld Nymphs attyr'd in youthfull greene,

About the Launds hast scowr'd, and Wastes both farre and neere,

Braue Huntresse: but no beast shall proue thy Quarries heere;

Saue those the best of Chase, the tall and lusty Red,

The Stag for goodly shape, and statelinesse of head,

Is fitt'st to hunt at force. For whom, when with his hounds

The laboring Hunter tufts the thicke vnbarbed grounds

Where harbor'd is the Hart; there often from his feed

suited, been appropriate

glades
speckled, spotted male deer without antlers

all this time, up till now

thickets

50 different] 'Of all Birds, only the Blackbird whistleth' (marginal note). 56-7 If nature did not impel each bird to sing its own tune, they would all have fallen silent to listen to the nightingale. 59 set in Parts] compose 'part-songs', where several voices sing separate 'parts' simultaneously. 62 Red-sparrow] Prob. 'reed-sparrow', the sedge warbler (also reed bunting, which does not sing). Nope] bullfinch. 66 A curious idea that many other species are descended from, or varieties of, the goldfinch. 69 Softer ... Shrillsome] soft and shrill singers. 77 seasoned] in the best state for eating or hunting $\left(O E D_{3 a}\right)_{1} \quad 79$ Bucks] male fallow deer. Stags] male red deer. 81 veneriall] 'Of hunting, or Chase (marginal note). 88 Diana] as goddess of hunting. 90 vs'd to roue] referring to Diana. 99 'A description of hunting the Hart' (marginal note). 100 vnbarbed] 'unmown, uncut' (OED unbarbed $\operatorname{adj}^{1} 2$, citing this passage). 
The dogs of him doe find; or thorough skilfull heed,

The Huntsman by his slot, or breaking earth, perceaues,

Or entring of the thicke by pressing of the greaues densest part of the wood; thickets

Where he hath gone to lodge. Now when the Hart doth heare

The often-bellowing hounds to vent his secret leyre,

He rouzing rusheth out, and through the Brakes doth driue,

As though vp by the roots the bushes he would riue.

And through the combrous thicks as fearefully he makes,

scent out (OED vent $\left.v^{2} 14 a\right)$

rising from cover

Hee with his branched head, the tender Saplings shakes,

thickets

That sprinkling their moyst pearle doe seeme for him to weepe; dew

When after goes the Cry, with yellings lowd and deepe,

That all the Forrest rings, and euery neighbouring place:

And there is not a hound but falleth to the Chase.

Rechating with his horne, which then the Hunter cheeres,

Whilst still the lustie Stag his high-palm'd head vp-beares,

His body showing state, with vnbent knees vpright,

Expressing (from all beasts) his courage in his flight.

But when th'approaching foes still following he perceiues,

That hee his speed must trust, his vsuall walke he leaues;

And or'e the Champaine flies: which when th'assembly find,

Each followes, as his horse were footed with the wind.

But beeing then imbost, the noble stately Deere

When he hath gotten ground (the kennell cast arere)

Doth beat the Brooks and Ponds for sweet refreshing soyle:

That seruing not, then prooues if he his sent can foyle,

And makes amongst the Heards, and flocks of shag-wooll'd Sheepe,

Them frighting from the guard of those who had their keepe.

But when as all his shifts his safety still denies,

Put quite out of his walke, the wayes and fallowes tryes. usual haunts; ploughed land

Whom when the Plow-man meets, his teame he letteth stand

T'assaile him with his goad: so with his hooke in hand,

The Shepheard him pursues, and to his dog doth halow:

When, with tempestuous speed, the hounds and Huntsmen follow;

Vntill the noble Deere through toyle bereau'd of strength,

His long and sinewy legs then fayling him at length,

The Villages attempts, enrag'd, not giuing way

To any thing hee meets now at his sad decay.

The cruell rauenous hounds and bloody Hunters neer,

This noblest beast of Chase, that vainly doth but feare,

Some banke or quick-set finds: to which his hanch oppos'd,

He turnes vpon his foes, that soone haue him inclos'd.

The churlish throated hounds then holding him at bay,

And as their cruell fangs on his harsh skin they lay,

With his sharp-poynted head he dealeth deadly wounds.

The Hunter, comming in to helpe his wearied hounds,

He desperatly assailes; vntill opprest by force,

He who the Mourner is to his owne dying Corse,

Vpon the ruthlesse earth his precious teares lets fall.

To Forrests that belongs; but yet this is not all:

which: the hounds'

[pursuit

carried with dignity

differently from all other

open ground

tries to see

when that attempt fails;

goes to join

charge, protection

With solitude what sorts, that here's not wondrous rife?

Whereas the Hermit leades a sweet retyred life,

From Villages repleate with ragg'd and sweating Clownes,

resorts to, tries to reach

[hope of rescue futilely, without hedge

103 slot] 'The tract of the foote' (marginal note). tract] track, imprint. $\quad 115$ Rechating] 'One of the Measures in winding the horne' (marginal note). 116 high-palm'd] branched. The red deer's antlers are not actually palmate like the fallow deer's. 119 perceiues] dual construction: refers back to foes and forward to That hee... 123 imbost] driven to extremity, hence foaming at the mouth (OED embossed $\left.\mathrm{adj}^{2}\right) . \quad 124$ the ... arere] leaving the dogs behind. kennell] pack of hounds. 125 beat] (of a hunted animal) take to the water, seeking escape (OED 2ob). 127 his sent can foyle] throw (the dogs) off his scent. 130 wayes] paths through woods and fields. 141 his hanch oppos'd] staving himself against it by his haunch. 148-9 'The Hart weepeth at his dying: his teares are held to be precious in medicine.' (marginal note) The 'teares' are a secretion from a gland near the eye. 151 Everything conforming to a life of solitude is plentiful here. 153 'A description of the afternoone' (marginal note). 
And from the lothsome ayres of smoky cittied Townes.

Suppose twixt noone and night, the Sunne his halfe-way wrought

(The shadowes to be large, by his descending brought)

Who with a feruent eye lookes through the twyring glades,

And his dispersed rayes commixeth with the shades,

Exhaling the milch dewe, which there had tarried long,

And on the ranker grasse till past the noone-sted hong;

When as the Hermet comes out of his homely Cell,

Where from all rude resort he happily doth dwell:

Who in the strength of youth, a man at Armes hath been;

Or one who of this world the vilenesse hauing seene,

Retyres him from it quite; and with a constant mind

Mans beastliness so loathes, that flying humane kind,

The black and darksome nights, the bright and gladsome dayes

Indifferent are to him, his hope on God that staies.

Each little Village yeelds his short and homely fare:

To gather wind-falne sticks, his great'st and onely care;

Which euery aged tree still yeeldeth to his fire.

This man, that is alone a King in his desire,

By no proud ignorant Lord is basely ouer-aw'd,

Nor his false prayse affects, who grosly beeing claw'd,

Stands like an itchy Moyle; nor of a pin he wayes

What fooles, abused Kings, and humorous Ladies raise.

fevered, glowing

(sun's position at) noon

His free and noble thought nere envies at the grace

That often times is giuen vnto a Baud most base,

Nor stirres it him to thinke on the Impostour vile,

180 Who seeming what hee's not, doth sensually beguile

The sottish purblind world: but absolutely free,

His happy time he spends the works of God to see,

In those so sundry hearbs which there in plenty growe:

Whose sundry strange effects he onely seeks to knowe.

And in a little Maund, beeing made of Oziars small,

Which serueth him to doe full many a thing withall,

He very choicely sorts his Simples got abroad.

Heere finds he on an Oake Rheume-purging Polipode;

And in some open place that to the Sunne doth lye,

He Fumitorie gets, and Eye-bright for the eye:

The Yarrow, where-with-all he stops the wound-made gore:

The healing Tutsan then, and Plantan for a sore.

And hard by them againe he holy Vervaine finds,

Which he about his head that hath the Megrim binds.

The wonder-working Dill hee gets not farre from these,

Which curious women vse in many a nice disease.

For them that are with Newts, or Snakes, or Adders stong,

He seeketh out an hearbe that's called Adders-tong;

As Nature it ordain'd, its owne like hurt to cure,

And sportiue did her selfe to niceties invre.

subtleties, witticisms; practise, accustom

Valerian then he crops, and purposely doth stampe,

T'apply vnto the place that's haled with the Crampe.

As Century, to close the wideness of a wound:

i.e., for fuel

\author{
does not care a pin \\ moody, capricious; \\ [excite, delight \\ feels envy \\ Baud: any villainous person \\ nor does he feel disturbed
}

basket

out of doors, in the fields polypody, a fern

blood from a wound

migraine

?fussy, hypochondriac in a special way; pound, crush drawn, pulled centaury

154 cittied Townes] villages that have come to resemble cities. 154 Townes] villages (OED 3 ). 155 his halfe-way wrought] having travelled half his course. 157 twyring] peeping: transferred epithet. 159 milch] 'resembling milk, milky' (OED $3 \mathrm{~d}$, citing only this passage) 161 'Hermits haue oft had their aboads by waies that lie throgh Forests.' (marginal note) The hermit, as in many other works, is a disillusioned courtier seeking the peace of pastoral life. $\mathbf{1 7 4}$ Moyle] sore (cf. OED mole $2 \mathrm{~b}$ ). 180 sensually] through man's baser or lower nature. 185 Oziars] osiers, a kind of willow used in basket-making. $\quad \mathbf{1 8 6}$ serueth... withall] serves him for many uses. $\quad 187$ Simples] extracts from medicinal plants. 190 Eye-bright] euphrasy, thought to improve weak eyesight. 192 Tutsan] Fr. toute-saine, 'all-healing', a name for various medicinal plants. Plantan] plantain: of the genus Plantago, not the banana-like plant. 196 nice] (a) delicate, feminine (b) private, embarrassing. 197 Newts] then generally regarded as venomous. $199-200$ As if Nature had fancifully arranged to extract a cure from the affliction itself (cure the adder's bite with a plant looking like its tongue). 
The belly hurt by birth, by Mugwort to make sound.

His Chickweed cures the heat that in the face doth rise.

For Physick, some againe he inwardly applyes.

For comforting the Spleene and Liuer, gets for iuce,

Pale Hore-hound, which he holds of most especiall vse.

medicine

to extract juice from

So Saxifrage is good, and Harts-tongue for the Stone,

With Agrimony, and that hearbe we call S. Iohn.

To him that hath a flux, of Sheepheards purse he giues,

And Mous-eare vnto him whom some sharpe rupture grieues.

And for the laboring wretch that's troubled with a cough,

Or stopping of the breath, by fleagme that's hard and tough,

Campana heere he crops, approoued wondrous good:

As Comfrey vnto him that's brused, spetting blood;

And from the Falling-ill, by Fiue-leafe doth restore,

And Melancholy cures by soueraigne Hellebore.

Of these most helpfull hearbs yet tell we but a few,

To those vnnumbred sorts of Simples here that grew.

Which iustly to set downe, euen Dodon short doth fall;

Nor skilfull Gerard, yet, shall euer find them all.

But from our Hermit heere the Muse we must inforce,

And zealously proceed in our intended course: ...

dysentery

210

phlegm

proven

epilepsy; cinquefoil

out of, compared to

220

draw away forcefully

(C) Song XIV.217-78

[From the account of the Vale of Evesham in Worcestershire, and the Cotswolds. This section is preceded by Evesham's discourse on the superiority of valleys to hills - a theme integral to pastoral. The account of the shearing-feast is rather brief: perhaps Drayton did not want to repeat the elaborate account in Eclogue IX of 1606.]

But, noble Muse, proceed immediatly to tell

How Eushams fertile Vale at first in liking fell

With Cotswold, that great King of Shepheards: whose proud site

When that fair Vale first saw, so nourisht her delight,

That him she onely lov'd: for wisely shee beheld

The beauties cleane throughout that on his sur-face dweld:

Of iust and equall height two banks arising, which

fine, 'fair'

Grew poore (as it should seeme) to make some Valley rich:

Betwixt them thrusting out an Elbowe of such height,

As shrowds the lower soyle; which, shadowed from the light,

Shootes forth a little Groue, that in the Sommers day

Invites the Flocks, for shade that to the Couert stray.

A Hill there holds his head, as though it told a tale,

Or stooped to looke downe, or whisper with a Vale;

Where little purling winds like wantons seeme to dally,

And skip from Bank to Banke, from Valley trip to Valley.

Such sundry shapes of soyle where Nature doth deuise,

That she may rather seeme fantasticall, then wise.

T'whom Sarum's Plaine giues place: though famous for her Flocks,

Yet hardly doth she tythe our Cotswolds wealthy locks. provide a tenth part of

Though Lemster him exceed for finenesse of her ore,

Yet quite he puts her downe for his aboundant store.

locks of wool

A match so fit as hee, contenting to her mind,

Few Vales (as I suppose) like Eusham hapt to find:

Nor any other Wold, like Costwold euer sped,

So faire and rich a Vale by fortuning to wed.

210 Agrimony] liverwort. S. Iohn] probably St John's wort or hypericum. $\quad 212$ Mous-eare] various plants, here prob. a kind of hawkweed. 213 laboring] prob. 'suffering' generally, not specifically of a woman in childbirth. 215 Campana] 'some bell-shaped flower, [perhaps] the pasque flower' (OED, citing only this passage). $\quad 216$ Comfrey] Latin conferva, a medicinal plant. brused] battered, contused (OED bruised 2). 221-2 Dodon, Gerard] 'The Authors of two famous Herbals' (marginal note): Rembert Dodoens (Dodonaeus) and John Gerard. Gerard's Herball (1597) is basically a translation of Dodoens's Herbal (1554). 3 King of Shepheards] the Cotswolds being famous for sheep-farming and wool production. 7 'A nice description of Cotswold' (marginal note). $\mathbf{8}$ i.e. They slope gently down to a fertile valley. 19 Sarum's Plaine] Salisbury Plain. 21 Lemster, ore] Leominster in Herefordshire. The Ryland sheep of this region yielded Lemster ore, a superior wool. 
Hee hath the goodly Wooll, and shee the wealthy Graine: Through which they wisely seeme their houshold to maintaine. He hath pure wholesome Ayre, and daintie crystall Springs.

To those delights of his, shee daily profit brings:

As to his large expense, she multiplies her heapes:

Nor can his Flocks deuour th'aboundance that shee reaps;

As th'one with what it hath, the other stroue to grace.

And, now that euery thing may in the proper place

Most aptly be contriu'd, the Sheepe our Wold doth breed

(The simplest though it seeme) shall our description need,

And Shepheard-like, the Muse thus of that kind doth speak;

No browne, nor sullyed black the face or legs doth streak,

Like those of Moreland, Cank, or of the Cambrian hills

That lightly laden are: but Cotswold wisely fills

with less wool

Her with the whitest kind: whose browes so woolly be,

As men in her faire Sheepe no emptiness should see.

The Staple deepe and thick, through, to the very graine,

Most strongly keepeth out the violentest raine:

A body long and large, the buttocks equall broad;

As fit to vnder-goe the full and weightie load.

And of the fleecie face, the flanke doth nothing lack,

But euery-where is stor'd; the belly, as the back.

The faire and goodly Flock, the Shepheards onely pride,

As white as Winters snowe, when from the Riuers side

He driues his new-washt Sheepe; or on the Sheering day,

When as the lusty Ram, with those rich spoyles of May

His crooked hornes hath crown'd; the Bell-weather, so braue

As none in all the Flock they like themselues would haue.

But Muse, returne to tell, how there the Sheepheards King,

Whose Flock hath chanc't that yeere the earliest Lambe to bring,

In his gay Bauldrick sits at his lowe grassie Bord,

With Flawns, Curds, Clowted-creame, and Country dainties stor'd:

And, whilst the Bag-pipe playes, each lustie iocund Swaine

And to their Country-Girles, whose Nosegayes they doe weare. [drinking healths to
[

Some Roundelayes doe sing: the rest, the burthen beare.

But Cotswold, be this spoke to th'onely praise of thee,

That thou of all the rest, the chosen soyle should'st bee,

Faire Isis to bring-forth (the Mother of great Tames)

With those delicious Brooks, by whose immortall streames

Her greatnesse is begunne: so that our Riuers King,

When he his long Descent shall from his Bel-sires bring,

Must needs (Great Pastures Prince) deriue his stem by thee,

From kingly Cotswolds selfe, sprung of the third degree:

As th'old worlds Heroës wont, that in the times of yore,

On Neptune, Ioue, and Mars, themselues so highly bore.

splendid, decked out

fibre

load: of wool surface

covered with wool belt worn across the chest 
(D) Song XIX.13-66

[From the account of Waltham and Hatfield forests in Essex. One of the major 'ecological' passages in Poly-olbion, where Drayton laments the destruction of the countryside, especially the forests, to meet the demand for domestic and industrial fuel.]

But Muse, from her so low, diuert thy high-set song

To London-wards, and bring from Lea with thee along

The Forrests, and the Floods, and most exactly show,

rivers

How these in order stand, how those directly flow:

For in that happy soyle, doth pleasure euer wonne,

Through Forrests, where cleere Rills in wild Meanders runne;

Where daintie Summer Bowers, and Arborets are made,

Cut out of Busshy thicks, for coolenesse of the shade.

Fooles gaze at painted Courts, to th' countrey let me goe,

To climbe the easie hill, then walke the valley lowe;

No gold-embossed Roofes, to me are like the woods;

No Bed like to the grasse, nor liquor like the floods:

A Citie's but a sinke, gay houses gawdy graues,

these: forests; those: rivers

dwell

gentle

10

sewer, cesspit

The Muses haue free leaue, to starue or liue in caues:

But Waltham Forrest still in prosperous estate,

As standing to this day (so strangely fortunate)

Aboue her neighbour Nymphs, and holds her head aloft;

A turfe beyond them all, so sleeke and wondrous soft,

Vpon her setting side, by goodly London grac'd,

Vpon the North by Lea, her South by Thames embrac'd.

Vpon her rising point, shee chaunced to espie

A daintie Forrest-Nymph of her societie.

Faire Hatfield, which in height all other did surmount,

And of the Dryades held in very high account;

Yet in respect of her stood farre out of the way,

Who doubting of her selfe, by others late decay,

Her sisters glory view'd with an astonish'd eye,

Whom Waltham wisely thus reprooueth by and by.

Dear Sister rest content, nor our declining rue,

What thing is in this world (that we can say) is new;

The Ridge and Furrow shewes that once the crooked Plow

Turn'd vp the grassy turfe, where Okes are rooted now:

And at this houre we see, the Share and Coulter teare

The full corne-bearing gleabe, where sometimes forrests were;

And those but Caitifes are, which most doe seeke our spoyle,

Who hauing sold our woods, doe lastly sell our soyle;

Tis vertue to giue place to these vngodly times,

When as the fostred ill proceeds from others crimes;

Gainst Lunatiks, and fooles, what wise folke spend their force;

For folly headlong falls, when it hath had the course:

And when God giues men vp to wayes abhor'd and vile,

Of vnderstanding hee depriues them quite, the while

They into errour runne, confounded in their sinne,

As simple Fowles in lyme, or in the Fowlers gynne.

And for those prettie Birds, that wont in vs to sing,

They shall at last forbeare to welcome in the Spring,

When wanting where to pearch, they sit vpon the ground,

And curse them in their Notes, who first did woods confound.

soil; superior to them western, where the sun sets

type, community

fearing for

Share: ploughshare

(a) destruction

$[(b)$ booty

avoid, shun

trap

were accustomed

destroy

1 her so low] Canvey Island in the Thames, described in the preceding lines. $\quad 2$ Lea] the 'second river' of London. 8 thicks] thickets - i.e. the bushes are fashioned by nature into bowers. 15 'The braue scituation of Waltham Forrest' (marginal note). 23 'Hatfield Forestt lying lower towards the East betweene Stortford and Dunmow' (marginal note). 25 out of the way] ?inadequate, not to be compared (to Waltham): cf. OED way $37 \mathrm{~d}$. 33 Coulter] a vertical blade fixed in front of the ploughshare. $\quad 37-8$ ?I is best to avoid all contact with the times, when one is tainted by others' misdeeds. 43 confounded ... sinne] destroyed by their own misdeeds. 
Deare Sister Hatfield, then hold vp thy drooping head,

We feele no such decay, nor is all succour fled:

For Essex is our dower, which greatly doth abound

With euery simple good, that in the Ile is found:

And though we goe to wracke in this so generall waste,

This hope to vs remaines, we yet may be the last.

\section{Michael Drayton The Shepherd's Sirena}

First published in Drayton's The Battle of Agincourt volume (1627). Apparently composed in stages, the song in the middle earlier than the sections before and after. From the geographical refs., Hebel has identified Sirena as Mary Curzon, wife of Drayton's patron Sir Edward Sackville, later Earl of Dorset. Her separated lover Dorilus would then be her husband, self-exiled after a duel in which he killed his opponent, and able to approach her only at extreme risk. But esp. in the last section, Dorilus seems to reflect something of Drayton himself. Olcon is usually taken (as in Ecl. VIII of 1606) as James I, a failed poet and enemy of poetry. The literary politics are a reflection, almost a trope, of broader national politics where the Spenserians favoured the more radically Protestant 'country party opposed to the King and court: cf. the openly political content of William Browne's Ecl. II in The Shepherd's Pipe, and Wither's The Shepherd's Hunting. This may also explain why Drayton delayed publication till after James's death and the escalation of anti-court politics. There are problems with this interpretation, esp. in assuming that Drayton could allude to the King and court in the abusive terms of $355-8$. Alternatively, Olcon may be the leader of a rival band of poets, perhaps Ben Jonson. The allusions seem irrecoverable in good part, but the poem provides an instance of the striking union of delicate lyric fancy with serious, even aggressive topical concerns in Drayton and in pastoral generally. Punctuation regularized.

\section{THE SHEPHEARDS SIRENA.}

Dorilvs in sorrowes deepe,

Autumne waxing olde and chill, growing, turning

As he sate his Flocks to keepe,

Vnderneath an easie hill: gently sloping

Chanc'd to cast his eye aside

On those fields, where he had seene

Bright Sirena, Natures pride,

Sporting on the pleasant greene:

To whose walkes the Shepheards oft

Came her god-like foote to finde,

And in places that were soft,

Kist the print there left behinde;

Where the path which she had troad

Hath thereby more glory gayn'd,

Then in heau'n that milky rode,

Which with Nectar Hebe stayn'd:

But bleake Winters boystrous blasts

Now their fading pleasures chid,

And so fill'd them with his wastes,

That from sight her steps were hid.

Silly Shepheard, sad the while

For his sweet SIRENA gone,

All his pleasures in exile:

Layd on the colde earth alone.

Whilst his gamesome cut-tayld Curre

With his mirthlesse Master playes,

Striuing him with sport to stirre,

As in his more youthfull dayes,

DorILvs his Dogge doth chide,

Layes his well-tun'd Bagpype by,

And his Sheep-hooke casts aside,

There (quoth he) together lye.

51 dower] the portion of an estate left to the owner's widow - i.e. what remains to Waltham and Hatfield after the country has been spoliated. 15-16 milky rode ... stayn'd] A relatively obscure myth says the milky way was formed from nectar spilt by Hebe the divine cupbearer. 18 pleasures] flowers or other beauties of the field, now chid or rebuked as a frivolous indulgence. 19 wastes] ?ravages; snow or floods (OED 6a, b); land covered with snow (OED 1b). 
When a Letter forth he tooke,

Which to him SiRENA writ,

With a deadly downe-cast looke,

And thus fell to reading it.

Dorilvs my deare (quoth she)

Kinde Companion of my woe,

Though we thus diuided be,

Death cannot diuorce vs so:

Thou whose bosome hath beene still

Th'onely Closet of my care,

And in all my good and ill,

Euer had thy equall share:

Might I winne thee from thy Fold,

Thou shouldst come to visite me,

But the Winter is so cold,

That I feare to hazard thee:

The wilde waters are waxt hie,

So they are both deafe and dumbe,

Lou'd they thee so well as I,

They would ebbe when thou shouldst come;

Then my coate with light should shine,

Purer then the Vestall fire:

deathlike, as though he were dying

Nothing here but should be thine,

That thy heart can well desire:

Where at large we will relate

From what cause our friendship grewe,

And in that the varying Fate,

Since we first each other knewe:

changing, i.e., turning adverse

Of my heauie passed plight,

As of many a future feare,

Which except the silent night,

None but onely thou shalt heare;

My sad heart it shall releeue,

When my thoughts I shall disclose,

For thou canst not chuse but greeue,

When I shall recount my woes;

There is nothing to that friend,

To whose close vncranied brest

We our secret thoughts may send,

And there safely let it rest:

And thy faithfull counsell may

My distressed case assist,

Sad affliction else may sway

Me a woman as it list:

rule, oppress

wants

Hither I would haue thee haste,

Yet would gladly haue thee stay,

When those dangers I forecast

That may meet thee by the way.

Doe as thou shalt thinke it best,

nothing compared to, nothing as good as without crannies: impervious, sealed

cote, cottage

Let thy knowledge be thy guide,

Liue thou in my constant breast,

Whatsoever shall betide.

He her Letter hauing red,

Puts it in his Scrip againe,

Looking like a man halfe dead,

By her kindenesse strangely slaine;

And as one who inly knew

Her distressed present state,

And to her had still been true,

54 Vestall fire] the fire at the sanctuary of Vesta, goddess of the hearth, tended by the vestal virgins (hence Purer). The vestal virgins seem to be equated with the virgin priestesses of Aphrodite or Venus, of whom Hero, beloved of Leander, was one. Sirena's dismissing the idea of Dorilus swimming to reach her recalls the death of Leander on a similar errand. 
Thus doth with himselfe delate.

I will not thy face admire,

Admirable though it bee,

Nor thine eyes whose subtile fire

So much wonder winne in me:

But my maruell shall be now,

(And of long it hath bene so)

Of all Woman kind that thou

100

Wert ordain'd to taste of woe;

To a Beauty so diuine,

Paradise in little done,

executed, made

$\mathrm{O}$ that Fortune should assigne

Ought but what thou well mightst shun.

But my counsailes such must bee,

(Though as yet I them conceale)

By their deadly wound in me,

They thy hurt must onely heale.

Could I giue what thou do'st craue,

110 To that passe thy state is growne,

I thereby thy life may saue,

I am in such a situation

But am sure to loose mine owne.

To that ioy thou do'st conceiue,

Through my heart the way doth lye,

Which in two for thee must claue

Least that thou shouldst goe awry.

Thus my death must be a toy,

Which my pensiue breast must couer;

Thy beloued to enioy,

120 Must be taught thee by thy Louer.

Hard the Choise I haue to chuse:

To my selfe if friend I be,

I must my Sirena loose,

If not so, shee looseth me.

Thus whilst he doth cast about

cleave, divide

?suffer harm, fall in trouble

What therein were best to doe,

Nor could yet resolue the doubt,

Whether he should stay or goe:

In those Feilds not farre away,

130 There was many a frolike Swaine,

In fresh Russets day by day,

That kept Reuells on the Plaine

Nimble ToM, sirnam'd the Tup,

For his Pipe without a Peere,

And could tickle Trenchmore vp,

As t'would ioy your heart to heare.

RALPH as much renown'd for skill,

That the Taber touch'd so well;

For his Gittern, little GILL,

140 That all other did excell.

Rock and Rollo euery way,

Who still led the Rusticke Ging,

And could troule a Roundelay,

That would make the Feilds to ring,

Collin on his Shalme so cleare

Many a high-pitcht Note that had,

If I choose to protect myself

consider, plan

merry, playful

garments of russet, a coarse country cloth

(music for) a kind of lively dance

a guitar-like instrument

band, company troll, sing

shawm, a wind-instrument

95 subtile] (a) delicate, refined (b) secret, insidious - though in 270, the light from her eyes is said to be blazing. 104 shun] surprising in place of the expected 'like'. The meaning might be 'anything (by way of hurt or affliction) that you could not easily avoid'. $\quad \mathbf{1 0 7 - 8}$ i.e. I will rescue you by sacrificing myself. 117-18 I must count my death as a trifle (toy) that my burdened heart must keep concealed. 119-20 Cryptic. Perhaps 'Your lover (i.e. Dorilus) must decide how (at risk to his life) he can fulfil your wish by coming to you'. 133 Tup] ram: apparently a compliment for his pipe 'without a Peere', though the English Dialect Dictionary defines tup as a stupid person. 135 tickle] "to touch (a stringed instrument, etc.) lightly' (OED 6). 
And could make the Ecchos nere

almost

Shout as they were wexen mad.

waxed, grown

Many a lusty Swaine beside,

That for nought but pleasure car'd,

Hauing DoRILvs espy'd,

And with him knew how it far'd,

Thought from him they would remoue

knew how things stood with him

This strong melancholy fitt,

Or so, should it not behoue,

Quite to put him out of s witt;

Hauing learnt a Song, which he

Sometime to Sirena sent,

Full of Iollity and glee,

When the Nimph liu'd neere to Trent,

They behinde him softly gott,

Lying on the earth along,

And when he suspected not,

Thus the Iouiall Shepherds song.

creeping

Neare to the Siluer Trent, Sirena dwelleth:

Shee to whom Nature lent

All that excelleth:

By which the Muses late, And the neate Graces,

Haue for their greater state

Taken their places:

Twisting an Anadem,

Wherewith to Crowne her,

As it belong'd to them

Most to renowne her.

Chorus: On thy Bancke,

In a Rancke,

Let thy Swanes sing her,

And with their Musick, along let them bring her.

conferred, bestowed

of late graceful, elegant

wreath, chaplet

Tagus and Pactolus are to thee Debter,

Nor for their gould to vs are they the better:

Henceforth of all the rest, be thou the Riuer

Which as the daintiest, puts them downe euer,

For as my precious one o'r thee doth trauell,

She to Pearle Parragon turneth thy grauell.

Chorus: On thy Bancke, In a Rancke, Let thy Swanns sing her,

And with their Musicke, along let them bring her.

Our mournefull Philomell, nightingale that rarest Tuner,

Henceforth in Aperill

155-6 Or if that was not possible, to make him totally mad. 169-72 The Muses and Graces have come to dwell with Sirena for their own greater honour. 169 which] the Trent. 175 As they were best fitted or entrusted. $\quad 182$ Tagus and Pactolus] rivers in Portugal and Lydia respectively, carrying gold in their waters. But the silver $(165,323)$ and pearl $(192)$ of the Trent is daintiest $(188)$ or most precious. 196 The earlier Swanes (?swains) changes to Swanns(?swans), and the two words alternate from here on. 201 Aperill] 3-syllable form presumably for rhyme and metre. 
210 shall wake the sooner,

And to her shall complaine from the thicke Couer,

Redoubling euery straine ouer and ouer:

For when my Loue too long her Chamber keepeth;

As though it suffered wrong, The Morning weepeth.

Chorus: On thy Bancke, In a Rancke, Let thy Swanes sing her,

And with their Musick, along let them bring her.

Oft haue I seene the Sunne, to doe her honour,

Fix himselfe at his noone, to looke vpon her,

And hath guilt euery Groue, euery Hill neare her,

With his flames from aboue, striuing to cheere her,

And when shee from his sight hath her selfe turned,

$\mathrm{He}$ as it had beene night, In Cloudes hath mourned:

\section{Chorus: On thy Bancke,} In a Rancke, Let thy Swanes sing her,

And with their Musick, along let them bring her.

The Verdant Meades are seene, when she doth view them,

In fresh and gallant Greene, straight to renewe them,

And euery little Grasse broad it selfe spreadeth,

Proud that this bonny Lasse vpon it treadeth:

Nor flower is so sweete in this large Cincture

But it vpon her feete Leaueth some Tincture.

Chorus: On thy Bancke, In a Rancke, Let thy Swanes sing her,

And with their Musick, along let them bring her.

The Fishes in the Flood, when she doth Angle,

For the Hooke striue a good them to intangle,

And leaping on the Land from the cleare water,

Their Scales vpon the sand lauishly scatter;

Therewith to paue the mould whereon she passes, gilt, gilded

swells with pride

colour, presumably of petals

So her selfe to behold,

earnestly, heartily

soil, earth

203 complaine] of Philomel's rape by Tereus, after which she was changed into a nightingale. $\mathbf{2 4 2}$ Cincture] surrounding area. $O E D$ questionably defines as 'enclosure, enclosed area', citing this passage alone. 
as in her glasses.

Chorus: On thy Bancke, In a Rancke,

Let thy Swanns sing her,

And with their Musicke, along let them bring her.

When shee lookes out by night, the Starres stand gazing,

Like Commets to our sight Fearefully blazing,

As wondring at her eyes, with their much brightnesse,

Which so amaze the skies, dimming their lightnesse,

The raging Tempests are Calme when she speaketh,

Such most delightsome balme from her lips breaketh.

Chorus: On thy Bancke,

In a Rancke, \&uc.

[Refrain abridged in this stanza alone]

In all our Brittany, ther's not a fayrer,

Nor can you fitt any should you compare her.

Angels her eye-lids keepe all harts surprizing,

Which looke whilst she doth sleepe like the Sunnes rising:

She alone of her kinde knoweth true measure

And her vnmatched mind is Heauens treasure:

Chorus: On thy Bancke, In a Rancke, Let thy Swanes sing her,

And with their Musick, along let them bring her.

Fayre Doue and Darwine cleere boast yee your beauties,

To Trent your Mistres here yet pay your duties,

light, brightness

find anyone to match

guard, protect overpowering, captivating

My Loue was higher borne tow'rds the full Fountaines,

Yet she doth Moorland scorne, and the Peake Mountaines;

Nor would she none should dreame where she abideth,

Humble as is the streame, which by her slydeth.

Chorus: On thy Bancke, In a Rancke, Let thy Swanns sing her,

And with their Musicke, along let them bring her.

261 glasses] mirrors: the fishes' scales shine as brightly. $\quad 269$ Commets] i.e. her eyes, 'blazing' brighter than the stars. $\quad 281$ Brittany] Britain. $\quad$ 285-8 Even when her eyes are shut, her eyelids are as bright as the rising sun. 290 true measure] balance or proportion, of both mind and body. $\quad 303-6$ i.e. Sirena's first home was higher upriver than the Dove and Derwent (Darwine)'s confluences with the Trent, but not near the latter's source in the moors and Peak country. This fits Croxall on the river Mease, Mary Curzon's home till her marriage (Hebel). 307-8 She does not wish her abode to be

known - i.e. she is modest and retiring. Nor ... none] a double negative. Sukanta Chaudhur 1 - 9781526143426 
Yet my poore Rusticke Muse nothing can moue her,

not at all

Nor the meanes I can vse, though her true Louer:

Many a long Winters night haue I wak'd for her,

Yet this my piteous plight nothing can stirre her.

All thy Sands siluer Trent downe to the Humber,

The sighes that I haue spent Neuer can number.

Chorus: On thy Banke In a Ranke, Let thy Swans sing her

And with their Musicke along let them bring her.

Taken with this suddaine Song,

Least for mirth when he doth look

His sad heart more deepely stong,

Then the former care he tooke.

At their laughter and amaz'd,

For a while he sat aghast

But a little hauing gaz'd,

Thus he them bespake at last. Is this time for mirth (quoth he)

To a man with griefe opprest?

Sinfull wretches as you be,

May the sorrowes in my breast

Light vpon you one by one,

And as now you mocke my woe,

When your mirth is turn'd to moane,

May your like then serue you so. When one Swaine among the rest

Thus him merily bespake,

Get thee vp thou arrant beast,

Fits this season loue to make?

Take thy Sheephooke in thy hand,

Clap thy Curre and set him on,

For our fields 'tis time to stand,

Or they quickely will be gon.

Rougish Swinheards that repine

At our Flocks, like beastly Clownes,

Sweare that they will bring their Swine,

And will wroote vp all our Downes:

They their Holly whips haue brac'd,

And tough Hazell goades haue gott;

?stunned, confused

Soundly they your sides will baste,

If their courage faile them not.

Of their purpose if they speed,

Then your Bagpypes you may burne,

It is neither Droane nor Reed

Shepheard, that will serue your turne:

Angry OLCON sets them on,

And against vs part doth take

Euer since he was out-gone,

Offring Rymes with vs to make.

Yet if so our Sheepe-hookes hold,

Dearely shall our Downes be bought,

For it neuer shall be told,

336 And amazed at their laughter. 358 Swine] By the conventional contrast with shepherds, swineherds are at the bottom of the pastoral hierarchy. 
We our Sheep-walkes sold for nought.

And we here haue got vs Dogges,

Best of all the Westerne breed,

Which though Whelps shall lug their Hogges,

Till they make their eares to bleed:

Therefore Shepheard come away,

When as DoriLvs arose,

Whistles Cut-tayle from his play,

And along with them he goes. pastureland for sheep; surrendered

[without a fight

even if young puppies; bait, worry

calls up with a whistle

\section{Michael Drayton The Description of Elizium}

A prelude to Drayton's The Muses Elizium (1630). Elizium is an idealized, mythologized landscape, modifying and extending the pastoral mode, but implicitly commenting on the real world and degenerate times. The last is linked to Stuart rule: the spelling 'Elizium' contrastingly evokes Elizabeth's reign. The contrast was a strategy of the oppositional politics of the 'Country party', supported by Drayton and actively advanced by some younger Spenserians. The politics behind the fantasy becomes explicit in Nimphal X, as in The Shepheards Sirena.

The Description of Elizivm.

A Paradice on earth is found,

Though farre from vulgar sight,

Which with those pleasures doth abound

That it Elizium hight.

is called

Where, in Delights that neuer fade,

The Muses lulled be,

soothed

And sit at pleasure in the shade

Of many a stately tree,

Which no rough Tempest makes to reele

Nor their straight bodies bowes,

Their lofty tops doe neuer feele

The weight of winters snowes;

In Groues that euermore are greene,

No falling leafe is there,

But Philomel (of birds the Queene)

In Musicke spends the yeare.

The Merle vpon her mertle Perch,

There to the Mavis sings,

blackbird

Who from the top of some curld Berch

song-thrush

Those notes redoubled rings;

There Daysyes damaske euery place

Nor once their beauties lose,

embroider, adorn

That when proud Phoebus hides his face

Themselues they scorne to close.

The Pansy and the Violet here,

As seeming to descend,

Both from one Root, a very payre,

For sweetnesse yet contend,

And pointing to a Pinke to tell

Which beares it, it is loath

To iudge it; but replyes, for smell

That it excels them both,

11-14 perpetual spring, a basic condition of the Earthly Paradise. 19 curld] with toothed or serrated leaves. 23-4 They continue to bloom even when the sun has set. Phœbus] the sun-god, hence the sun. 26 descend] spring from. 
Wherewith displeasde they hang their heads

So angry soone they grow

And from their odoriferous beds

Their sweets at it they throw.

The winter here a Summer is,

No waste is made by time,

Nor doth the Autumne euer misse

decay, destruction

The blossomes of the Prime.

lack

The flower that Iuly forth doth bring

In Aprill here is seene,

The Primrose that puts on the Spring

In Iuly decks each Greene.

The sweets for soueraignty contend

And so abundant be,

That to the very Earth they lend

And Barke of euery Tree:

Rills rising out of euery Banck,

In wilde Meanders strayne,

And playing many a wanton pranck

Vpon the speckled plaine,

In Gambols and lascivious Gyres

Their time they still bestow

Nor to their Fountaines none retyres,

Nor on their course will goe

springs, origins

Those Brooks with Lillies brauely deckt,

So proud and wanton made,

That they their courses quite neglect:

60

And seeme as though they stayed

Faire Flora in her state to viewe

Which through those Lillies looks,

?starts off, inaugurates

scents of flowers

impart themselves

Or as those Lillies leand to shew

Their beauties to the brooks.

That Phoebus in his lofty race

Oft layes aside his beames

And comes to coole his glowing face

In these delicious streames;

speckled with flowers

Oft spreading Vines clime vp the Cleeues,

70 Whose ripned clusters there

Their liquid purple drop, which driues

A Vintage through thee yeere.

Those Cleeues whose craggy sides are clad

With Trees of sundry sutes,

suits, garb

Which make continuall summer glad,

goddess of flowers

Euen bending with their fruits,

Some ripening, ready some to fall,

Some blossom'd, some to bloome,

Like gorgeous hangings on the wall

80

Of some rich princely Roome:

Pomegranates, Lymons, Cytrons, so

Their laded branches bow,

Their leaues in number that outgoe

Nor roomth will them alow.

course on high - i.e. the circuit of the sun

delightful, pleasing

cliffs, hillsides

6 Even conflicts in Elizium use no harder missiles than the scent of flowers. 49-72 An incipient sexuality in the description, neutralized by the delicacy and innocence of the ambience Ad $_{255} \mathbf{6}$ The Ty 1526143426 neither advance nor retreat, but wind about the same place, 81 Cytrons] a lime-like fruit (formerly 1526143426 including the lemon and lime). $\quad \mathbf{8 3 - 4}$ The fruit are more plentiful than the leaves. 
There in perpetuall Summers shade,

Apolloes Prophets sit

Among the flowres that neuer fade,

But flowrish like their wit;

To whom the Nimphes vpon their Lyres

Tune many a curious lay,

And with their most melodious Quires

Make short the longest day.

The thrice three Virgins heauenly Cleere

the Muses

Their trembling Timbrels sound,

Whilst the three comely Graces there

Dance many a dainty Round.

Decay nor Age there nothing knowes,

There is continuall Youth,

As Time on plant or creatures growes,

So still their strength renewth.

The Poets Paradice this is,

To which but few can come;

The Muses onely bower of blisse

Their Deare Elizium.

Here happy soules, (their blessed bowers

Free from the rude resort

Of beastly people) spend the houres,

In harmelesse mirth and sport.

Then on to the Elizian plaines

Apollo doth invite you

Where he prouides with pastorall straines,

In Nimphals to delight you.

\section{Michael Drayton The Muses’ Elizium, Nymphal vi}

See headnote to 'The Description of Elizium'. For the contest between rustic occupations, cf. Sidney's The Lady of May and Phineas Fletcher's Piscatory Ecl. VII.

The sixt Nimphall.

\section{SiLvivs}

Halcivs.

Melanthvs.

A Woodman, Fisher, and a Swaine

This Nimphall through with mirth maintaine,

Whose pleadings so the Nimphes doe please,

That presently they giue them Bayes.

Cleere had the day bin from the dawne,

All chequerd was the Skye,

Thin Clouds like Scarfs of Cobweb Lawne

Vayld Heauen's most glorious eye.

The Winde had no more strength then this,

That leasurely it blew,

To make one leafe the next to kisse,

That closly by it grew.

The Rils that on the Pebbles playd,

Might now be heard at will;

This world they onely Musick made,

Else euery thing was still.

The Flowers like braue embraudred Gerles, 
Lookt as they much desired

To see whose head with orient Pearles

Most curiously was tyred;

And to it selfe the subtle Ayre

Such souerainty assumes,

That it receiu'd too large a share

From natures rich perfumes.

When the Elizian Youth were met,

That were of most account,

And to disport themselues were set

Vpon an easy Mount:

Neare which, of stately Firre and Pine

There grew abundant store,

The Tree that weepeth Turpentine,

the terebinth

And shady Sicamore;

Amongst this merry youthfull trayne

A Forrester they had,

A Fisher, and a Shepheards swayne

A liuely Countrey Lad:

Betwixt which three a question grew,

Who should the worthiest be,

Which violently they pursue,

Nor stickled would they be.

That it the Company doth please

This ciuill strife to stay,

Freely to heare what each of these

For his braue selfe could say:

When first this Forrester (of all)

That Silvius had to name,

To whom the Lot being cast doth fall,

Doth thus begin the Game.

Silvius. For my profession then, and for the life I lead

All others to excell, thus for my selfe I plead;

I am the Prince of sports, the Forrest is my Fee,

He's not vpon the Earth for pleasure liues like me;

neatly, elegantly; attired, adorned

The Morne no sooner puts her Rosye Mantle on,

But from my quyet Lodge I instantly am gone,

When the melodious Birds from euery Bush and Bryer

Of the wilde spacious Wasts, make a continuall quire;

The motlied Meadowes then, new vernisht with the Sunne

Shute vp their spicy sweets vpon the winds that runne,

In easly ambling Gales, and softly seeme to pace,

That it the longer might their lushiousnesse imbrace:

I am clad in youthfull Greene, I other colours scorne,

My silken Bauldrick beares my Beugle, or my Horne,

Which setting to my Lips, I winde so lowd and shrill,

As makes the Ecchoes showte from euery neighbouring Hill:

My Doghooke at my Belt, to which my Lyam's tyde,

My Sheafe of Arrowes by, my Woodknife at my Syde,

My Crosse-bow in my Hand, my Gaffle or my Rack

To bend it when I please, or it I list to slack,

quelled, subdued

My Hound then in my Lyam, I by the Woodmans art

Forecast, where I may lodge the goodly Hie-palm'd Hart;

To viewe the grazing Heards, so sundry times I vse,

Where by the loftiest Head I know my Deare to chuse,

And to vnheard him then, I gallop o'r the ground

Vpon my wel-breath'd Nag, to cheere my earning Hound.

Sometime I pitch my Toyles the Deare aliue to take,

Sometime I like the Cry, the deepe-mouth'd Kennell make,

estate, territory

dog leash

wish

with erect antlers

practise, am in the habit of

separate from the herd

nets

pack of hounds

56 it] the sun. The meadows shut their perfumes up in the winds and set them adrift to preserve them longer in the heat. $\quad 58$ Bauldrick] a belt worn diagonally across the chest. $\quad 63$ Gaffle, Rack] devices for bending a cross-bow. 70 wel-breath'd] vigorously exercised. earning] crying, baying. 
Then vnderneath my Horse, I staulke my game to strike,

And with a single Dog to hunt him hurt, I like.

The Siluians are to me true subiects, I their King,

The stately Hart, his Hind doth to my presence bring,

The Buck his loued Doe, the Roe his tripping Mate,

Before me to my Bower, whereas I sit in State.

The Dryads, Hamadryads, the Satyres and the Fawnes

Oft play at Hyde and Seeke before me on the Lawnes,

The frisking Fayry oft when horned Cinthia shines

Before me as I walke dance wanton Matachynes.

sylvans, forest-dwellers

fleet, light-footed

The numerous feathered flocks that the wild Forrests haunt

Their Siluan songs to me, in cheerefull dittyes chaunte,

The shades like ample Sheelds, defend me from the Sunne,

Through which me to refresh the gentle Riuelets runne,

No little bubling Brook from any Spring that falls

But on the Pebbles playes me pretty Madrigals.

I'th' morne I clime the Hills, where wholsome winds do blow

At Noone-tyde to the Vales, and shady Groues below,

T'wards Euening I againe the Chrystall Floods frequent,

In pleasure thus my life continually is spent.

As Princes and great Lords haue Pallaces, so I

Haue in the Forrests here, my Hall and Gallery

The tall and stately Woods, which vnderneath are Plaine,

The Groues my Gardens are, the Heath and Downes againe

My wide and spaciouis walkes; then say all what ye can,

The Forester is still your only gallant man.

He of his speech scarce made an end,

But him they load with prayse,

The Nimphes most highly him commend,

And vow to giue him Bayes:

He's now cryde vp of euery one,

And who but onely he,

The Forrester's the man alone,

The worthyest of the three.

When some then th'other farre more stayd,

Wil'd them a while to pause,

For there was more yet to be sayd,

That might deserve applause,

When Halcius his turne next plyes,

And silence hauing wonne,

Roome for the fisher man he cryes,

And thus his Plea begunne.

Halcius. No Forrester, it so must not be borne away,

But heare what for himselfe the Fisher first can say,

The Chrystall current Streames continually I keepe,

Where euery Pearle-pau'd Foard, and euery Blew-eyd deepe

With me familiar are; when in my Boate being set,

My Oare I take in hand, my Angle and my Net

About me; like a Prince my selfe in state I steer,

Now vp, now downe the Streame, now am I here, now ther,

The Pilot and the Fraught my selfe; and at my ease

Can land me when I list, or in what place I please.

The Siluer-scaled Sholes, about me in the Streames,

As thick as ye discerne the Atoms in the Beames,

Neare to the shady Banck where slender Sallowes grow,

And Willows their shag'd tops downe t'wards the waters bow

than the rest; sober, sagacious

74 hunt him hurt] hunt him down once he is wounded. 79 Fawnes] fauns or wood-gods, not young deer. 81 horned Cinthia] A crescent moon, resembling horns, was an attribute of Cynthia or Diana in her aspect as moon-goodess. $\mathbf{8 2}$ Matachynes] matachin, a popular dance allied to the morris. 94 Gallery] of the kind overlooking the great hall of a palace or stately home. 95 which ... Plaine] which stand on flat ground. 123 I am the boat's pilot as also the load it carries. Fraught] freight, cargo. 126 Atoms in the Beames] motes of dust in sunbeams. 
I shove in with my Boat to sheeld me from the heat,

The goodly well growne Trout I with my Angle strike,

And with my bearded Wyer I take the rauenous Pike,

Of whom when I haue hould, he seldome breakes away

Though at my Lynes full length, soe long I let him play

Till by my hand I finde he well-nere wearyed be,

When softly by degrees I drawe him vp to me.

The lustly Samon to, I oft with Angling take,

Which me aboue the rest most Lordly sport doth make,

Who feeling he is caught, such Frisks and bounds doth fetch,

140 And by his very strength my Line soe farre doth stretch,

As drawes my floating Corcke downe to the very ground,

And wresting of my Rod, doth make my Boat turne round.

I neuer idle am, some tyme I bayt my Weeles,

With which my night I take the dainty siluer Eeles,

And with my Draughtnet then, I sweepe the streaming Flood.

And to my Tramell next, and Cast-net from the Mud,

I beate the Scaly brood, noe hower I idely spend,

But wearied with my worke I bring the day to end:

The Naijdes and Nymphes that in the Riuers keepe,

Which take into their care, the store of euery deepe,

Amongst the Flowery flags, the Bullrushes and Reed,

That of the Spawne haue charge (abundantly to breed)

Well mounted vpon Swans, their naked bodys lend

To my discerning eye, and on my Boate attend,

And dance vpon the Waues, before me (for my sake)

To th'Musick the soft wynd vpon the Reeds doth make.

wicker traps for fish, esp. eels

And for my pleasure more, the rougher Gods of Seas

From Neptunes Court send in the blew Neriades,

Which from his bracky Realme vpon the Billowes ride

160 And heare the Riuers backe with euery streaming Tyde,

Those Billowes gainst my Boate, borne with delightfull Gales

Oft seeming as I rowe to tell me pretty tales,

Whilst Ropes of liquid Pearle still load my laboring Oares,

As streacht vpon the Streame they stryke me to the Shores:

The silent medowes seeme delighted with my Layes,

As sitting in my Boate I sing my Lasses praise,

Then let them that like, the Forrester vp cry,

Your noble Fisher is your only man say I.

This Speech of Halcius turn'd the Tyde,

And brought it so about,

That all vpon the Fisher cryde,

That he would beare it out;

Him for the speech he made, to clap

Who lent him not a hand,

And said t'would be the Waters hap,

Quite to put downe the Land.

This while Melanthus silent sits,

(For so the Shepheard hight)

And hauing heard these dainty wits,

Each pleading for his right;

To heare them honor'd in this wise,

His patience doth prouoke,

When for a Shepheard roome he cryes,

And for himselfe thus spoke.

Melanthus. Well Fisher you haue done, and Forrester for you

132 bearded Wyer] 'wire' or fishing line with 'beard' or bait. 145 Draughtnet] a net trailed along the water. 146 Tramell] trammel, a combination of several nets with different meshes. Cast-net] a net thrown in and drawn up immediately. 158 Neriades] Nereides: sea-nymphs, esp. the fifty daughters of the sea-god Nereus. 163 liquid Pearle] i.e. water-drops dripping from the oars. 173-4 to clap ... hand] Interrogative: Who was there that did not applaud him? 
Your Tale is neatly tould, s'are both, to give you due,

so are

And now my turne comes next, then heare a Shepherd speak:

My watchfulnesse and care giues day scarce leaue to break,

But to the Fields I haste, my folded flock to see,

Where when I finde, nor Woolfe, nor Fox, hath iniur'd me,

I to my Bottle straight, and soundly baste my Throat,

Which done, some Country Song or Roundelay I roate

So merrily; that to the musick that I make,

I Force the Larke to sing ere she be well awake;

Then Baull my cut-tayld Curre and I begin to play,

He o'r my Shephooke leapes, now th'one, now th'other way,

Then on his hinder feet he doth himselfe aduance,

I tune, and to my note, my liuely Dog doth dance,

Then whistle in my Fist, my fellow-Swaynes to call,

Downe goe our Hooks and Scrips, and we to Nine-holes fall,

At Dust-point, or at Quoyts else are we at it hard,

All false and cheating Games, we Shepheards are debard;

Survaying of my sheepe if Ewe or Wether looke

As though it were amisse, or with my Curre, or Crooke

I take it, and when once I finde what it doth ayle,

It hardly hath that hurt, but that my skill can heale;

And when my carefull eye I cast vpon my sheepe,

I sort them in my Pens, and sorted soe I keepe:

Those that are bigst of Boane, I still reserue for breed,

My Cullings I put off, or for the Chapman feed.

When the Euening doth approach I to my Bagpipe take,

And to my Grazing flocks such Musick then I make,

That they forbeare to feed; then me a King you see,

I playing goe before, my Subiects followe me,

My Bell-weather most braue, before the rest doth stalke,

The Father of the flocke, and after him doth walke

My writhen-headed Ram, with Posyes crowd in pride

Fast to his crooked hornes with Rybands neatly ty'd

repeat, go over

And at our Shepheards Board that's cut out of the ground,

My fellow Swaynes and I together at it round,

With Greencheese, clouted Cream, with Flawns, and Custards stord,

with curling horns

Whig, Sider, and with Whey, I domineer a Lord.

When shering time is come I to the Riuer driue

My goodly well-fleec'd Flocks: (by pleasure thus I thriue)

Which being washt at will; vpon the shering day,

My wooll I foorth in Loaks, fit for the wynder lay,

Which vpon lusty heapes into my Coate I heaue,

That in the Handling feeles as soft as any Sleaue,

When euery Ewe two Lambes, that yeaned hath that yeare,

About her new shorne neck a Chaplet then doth weare;

My Tarboxe, and my Scrip, my Bagpipe, at my back,

My sheephooke in my hand, what can I say I lacke;

He that a Scepter swayd, a sheephooke in his hand

Hath not disdaind to haue, for Shepheards then I stand;

Then Forester and you my Fisher cease your strife.

I say your Shepheard leads your onely merry life.

They had not cryed the Forester

And Fisher vp before,

So much: but now the Nimphes preferre

The Shephard ten tymes more,

200 Nine-holes] a game of rolling balls into nine holes in the ground. 201 Dust-point] a game of throwing stones at 'points' set in a heap of dust. $\quad 204-5$ or with ... take it] I either draw it to me with the sheep-hook or have my dog bring it to me. 206 It can scarcely have an illness that I cannot cure. 210 Cullings] old or diseased sheep to be eliminated. for ... feed] keep them only to sell. 215 Bell-weather] the leading sheep of the flock, with a bell round its neck to guide the others. $\mathbf{2 2 1}$ Flawn] a kind of custard or cheesecake. $\quad 222$ Whig] various milk-based drinks. $\quad 226$ wynder] person who winds wool into yarn.

229 two Lambes] instead of the usual one. 
And all the Ging goes on his side,

Their Minion him they make,

company

favourite

side, cause

To him themselues they all apply,
And all his partie take;

Till some in their discretion cast,

Since first the strife begunne

In all that from them there had past

None absolutly wonne:

That equall honour they should share:

And their deserts to showe,

For each a Garland they prepare,

Which they on them bestowe,

Of all the choisest flowers that weare,

Which purposly they gather,

With which they Crowne them, parting there,

As they came first together.

\section{Michael Drayton The Muses’ Elizium, Nymphal X}

The political concerns implicit throughout Elizium come into the open in this piece. See headnote to 'The Description of Elizium'.

The tenth Nimphall.

NAIIS

Claia

Corbilvs

SATYRE.

A Satyre on Elizium lights,

Whose vgly shape the Nimphes affrights,

Yet when they heare his iust complaint,

They make him an Elizian Saint.

Corbilus. What, breathles Nimphs? bright Virgins let me know

What suddaine cause constraines ye to this haste?

What haue ye seene that should affright ye so?

What might it be from which ye flye so fast?

I see your faces full of pallid feare,

As though some perill followed on your flight;

Take breath a while, and quickly let me heare

Into what danger ye haue lately light.

Naijs. Neuer were poore distressed Gerles so glad,

As when kinde, loued Corbilus we saw,

When our much haste vs so much weakned had,

That scarcely we our wearied breathes could draw.

In this next Groue vnder an aged Tree,

So fell a monster lying there we found,

savage, fearsome

As till this day, our eyes did neuer see,

Nor euer came on the Elizian ground.

Halfe man, halfe Goat, he seem'd to vs in show,

His vpper parts our humane shape doth beare,

But he's a very perfect Goat below,

His crooked Cambrils arm'd with hoofe and hayre.

hocks, hind leg-joints

Claia. Through his leane Chops a chattering he doth make

Which stirres his staring beastly driueld Beard,

And his sharpe hornes he seem'd at vs to shake,

Canst thou then blame vs though we were afeard.

Corbilus. Surely it seemes some Satyre this should be,

Come and goe back and guide me to the place,

Be not affraid, ye are safe enough with me,

Silly and harmelesse be their Siluan Race. 
Claia. How Corbilus; a Satyre doe you say?

How should he ouer high Parnassus hit?

Since to these Fields ther's none can finde the Way,

reach, find his way

But onely those the Muses will permit.

Corbilus. Tis true; but oft, the sacred Sisters grace

The silly Satyre, by whose plainesse, they

Are taught the worlds enormities to trace,

By beastly mens abhominable way;

Besyde he may be banisht his owne home

By this base time, or he so much distrest,

That he the craggy by-clift Hill hath clome

climbed

To finde out these more pleasant Fields of rest.

Naijs. Yonder he sits, and seemes himselfe to bow

At our approch, what, doth our presence awe him?

Me thinks he seemes not halfe so vgly now,

As at the first, when I and Claia saw him.

Corbilus. Tis an old Satyre, Nimph, I now discerne,

Sadly he sits, as he were sick or lame:

His lookes would say, that we may easly learne

How, and from whence, he to Elizium came.

Satyre, these Fields how cam'st thou first to finde?

What Fate first show'd thee this most happy shore?

When neuer any of thy Siluan kinde

Set foot on the Elizian earth before?

Satyre. O neuer aske, how I came to this place,

What cannot strong necessity finde out?

Rather bemoane my miserable case,

Constrain'd to wander the wide world about.

With wild Silvanus and his woody crue,

In Forrests I, at liberty and free,

Liu'd in such pleasure as the world ne'r knew,

Nor any rightly can conceiue but we.

simple, innocent-minded

This iocond life we many a day enioy'd,

Till this last age, those beastly men forth brought,

That all those great and goodly Woods destroy'd,

Whose growth their Grandsyres with such sufferance sought,

That faire Felicia which was but of late

Earth's Paradice, that neuer had her Peere,

Stands now in that most lamentable state,

That not a Siluan will inhabit there;

Where in the soft and most delicious shade,

In heat of Summer we were wont to play,

When the long day too short for vs we made,

The slyding houres so slyly stole away;

By Cynthia's light, and on the pleasant Lawne,

The wanton Fayry we were wont to chase,

Which to the nimble clouen-footed Fawne,

Vpon the plaine durst boldly bid the base.

The sportiue Nimphes, with shouts and laughter shooke

The Hils and Valleyes in their wanton play,

Waking the Ecchoes, their last words that tooke,

Till at the last, they lowder were then they.

The lofty hie Wood, and the lower spring,

Sheltring the Deare, in many a suddaine shower;

Where Quires of Birds, oft wonted were to sing,

39 by-clift Hill] Parnassus, which has a double peak. 47 easly] old variant of easily. 57 Silvanus] one of the chief forest gods. $\quad 62$ this last age] the Iron Age. 63 Woods destroy'd] Drayton shows an ecological awareness beyond his age, expressed several times in Poly-olbion. 65 Felicia] literally 'happy land': England, once happy and prosperous under Elizabeth. 75 Fawne] faun, a minor wood-god. $\mathbf{7 6}$ bid the base] throw out a challenge in the game of prisoners sbase. Chaudhur 1 - 9781526143426 
The flaming Furnace wholly doth deuoure;

Once faire Felicia, but now quite defac'd,

Those Braueries gone wherein she did abound,

With dainty Groues when she was highly grac'd,

With goodly Oake, Ashe, Elme, and Beeches croun'd:

But that from heauen their iudgement blinded is,

In humane Reason it could neuer be,

But that they might haue cleerly seene by this,

Those plagues their next posterity shall see.

The little Infant on the mothers Lap

For want of fire shall be so sore distrest,

That whilst it drawes the lanke and empty Pap,

The tender lips shall freese vnto the breast;

The quaking Cattle which their Warmstall want,

And with bleake winters Northerne winde opprest,

Their Browse and Stouer waxing thin and scant,

The hungry Crowes shall with their Caryon feast.

Men wanting Timber wherewith they should build,

And not a Forrest in Felicia found,

Shall be enforc'd vpon the open Field,

To dig them Caues for houses in the ground:

The Land thus rob'd of all her rich Attyre,

Naked and bare her selfe to heauen doth show,

Begging from thence that Iove would dart his fire

Vpon those wretches that disrob'd her so;

This beastly Brood by no meanes may abide

The name of their braue Ancestors to heare,

By whom their sordid slauery is descry'd,

So vnlike them as though not theirs they were.

Nor yet they sense, nor vnderstanding haue,

Of those braue Muses that their Country song,

But with false Lips ignobly doe depraue

The right and honour that to them belong;

This cruell kinde thus Viper-like deuoure

That fruitfull soyle which them too fully fed;

The earth doth curse the Age, and euery houre

Againe, that it these viprous monsters bred.

I seeing the plagues that shortly are to come

Vpon this people cleerely them forsooke,

And thus am light into Elizium,

To whose straite search I wholly me betooke.

beauties, adornments

fodder

robbed

decried, denounced

defame, disparage

Naijs. Poore silly creature, come along with vs,

Thou shalt be free of the Elizian fields:

Be not dismaid, or inly grieued thus,

This place content in all abundance yeelds.

We to the cheerefull presence will thee bring

Of Ioues deare Daughters, where in shades they sit,

Where thou shalt heare those sacred Sisters sing

Most heauenly Hymnes, the strength and life of wit.

Claia. Whereto the Delphian God vpon their Lyres

His Priests seeme rauisht in his height of praise:

Whilst he is crowning his harmonious Quiers,

With circling Garlands of immortall Bayes.

84 The flaming Furnace] The greatest cause of deforestation was the use of timber to smelt iron (Poly-olbion XVII.379-408) or, sometimes, to boil salt (Poly-olbion XIV.49-6o). Hebel cites William Harrison, Description of England (1577) and John Norden, Surveyors Dialogue (1607) for accounts of this destruction. $\quad 89$ Were it not that Heaven has blinded their judgement. 97 Warmstall] wormstall, a shelter for cattle (usually outdoors in the summer: here, perhaps simply 'warm stall'). $\quad 117$ Viper] proverbially treacherous. 133 the Delphian God] Apollo, with a shrine at Delphi. 134 His Priests] poets. But Elizium actually has a temple of Apollo, whose rites are described in Nimphal IX. 
Corbilus. Here liue in blisse, till thou shalt see those slaues,

Who thus set vertue and desert at nought,

Some sacrific'd vpon their Grandsires graues,

And some like beasts in markets sold and bought.

Of fooles and madmen leaue thou then the care,

That haue no vnderstanding of their state:

For whom high heauen doth so iust plagues prepare,

That they to pitty shall conuert thy hate.

And to Elizium be thou welcome then,

Vntill those base Felicians thou shalt heare

By that vile nation captiued againe,

That many a glorious age their captiues were.

\section{William Basse From Pastoral Elegy iII}

The opening of the last of Basse's Three Pastoral Elegies (1602). The elegies (not clear why so called) narrate the love of the courtly Anander (perhaps Basse's patron Sir Richard Wenman) for Muridella. To further his love, Anander retreats to the country (?Wenman's estate at Thame Park, Oxfordshire) and uses the shepherd Anetor (prob. Basse) as his confidant. The passage below focuses on Anetor and the shepherd's life.

The Sunne that had himselfe a Courtier beene,

And for his beautie lou'd of Ladies faire,

Spread forth his yellow beames vpon the greene,

And with attentiue eye, and Courtly care,

Flourisht his wandring torch, till he had seene

This troup arriue the place where now they are:

Which done, he hies him thence, and takes his rest

Behinde the furthest Mountaines of the West.

Blinde drouzie night, all clad in misty ray,

Began to ride along the welkins round, circuit of the sky

Hangs out his gazing Lanthornes by the way,

And makes the outside of the world his bound,

The Queene of starres in enuy of the daye,

moon

Throwes the cold shadow of hir eyes to ground,

And supple grasse opprest with heauy dew,

Doth wet the Sheepe, and licke the shepheards shooe.

weighed down

There as I dwelt there dwelled all my sheepe,

And home we went togither, flocks and I,

As euen where I rest, and take my sleepe,

There are my flocks asleepe and resting by,

And when I rise to go to field and keepe,

beside me

stay

So will my flocks, that can no longer lie:

Thus in the Sheepe is all the Shepheards care,

And in the Shepheard is the flocks welfare.

While did the yeare let slip his tender Spring,

And merry Moones went merrily away,

I with this happy flocke alone did sing,

And pipe the oaten galliard euery day,

As well content as Pan himselfe our King,

With a new Carroll or a Roundelay,

For he (as good a Minstrell as he is)

Couth neuer tune a better Lay then this.

147 that vile nation] probably France. $\quad 5$ Flourisht] shot out, radiated (OED 11a, of the sun). 6 troup] A company of courtly ladies, including Muridella, whom Anetor meets at the end of Ecl. II. 12 outside of the world] probably the same as welkin's round (10): the outer circle or perimeter of the universe, the course of the sun. 25-6 As the months and seasons went by. 29-31 Pan ... Minstrell] Tempting to see an allusion to James I, who fancied his poetic powers, were it not that the poem was published in 1602 . 
When Shepheards sit vpon the hills,

Nursed in their Swainish wills,

Young, and in desires vnripe,

Curious of the flocke and pipe,

taking care

Then is Swaynish life the best,

And he that cares and loues the lest

least

Thinkes he fares aboue the rest.

Then our ioyes beguile our ruthes,

Shepheards boyes be merry youthes,

Loues do dwell in Courti'rs beds,

Peace doth swell in Shepheards heads,

Lusts are like our flocks ypent,

Want of age doth barre consent,

Youth doth flourish with content.

But when elder dayes shall show

Whether Swaines be men or no,

Loue shall rule in shepheards braines,

Grauitie shall guide the swaines.

Wanton thoughts shall then be checkt,

Shepheards shall no playes respect,

Age shall conquer youths defect.

Sing I then, heigh ho for ioy,

Cause I yet am but a boy,

But when shepheards boyes be men,

Ho my hart, what sing I then?

Heigh-ho, sorrow, Ioyes away,

60

Conqu'ring Loue ha's won the Day,

This is all my Roundelay.

Whilome when I was Collins loued boy,

(Ah Collin, for thee Collin, weep I now,)

For thou art dead, ah, that to me didst ioy,

?made me happy

As Coridon did to Alexis vow.

But (as I sed,) when I was Collins boy,

His deare young boy, and yet of yeares inow,

To leade his willing heard along the plaine,

I on his pipe did learne this singing vaine.

vein

And oh (well mote he now take rest therfore,)

70 How oft in pray'rs and songs he pray'd and sung,

That I (as had himselfe full long before,)

Mought liue a happy shepheard and a young;

And many vowes, and many wishes more,

When he his Pipe into my bosome flung:

And said, though Collin ne're shall be surpast,

Be while thou liu'st, as like him as thou maist.

Much was my deare therefore when Collin died,

When we (alacke) were both agreed in griefe:

He for his infant swaine that me affide,
Yet happed not to liue to see my priefe.

'dere', hurt, injury

34 Indulging their shepherd-like tastes and inclinations. $\quad 40$ beguile] assuage, comfort. ruthes] sorrows $(O E D$ 3). $\quad 44$ Lust is kept under check like sheep in their pens. 45 They do not incline to love in their extreme youth. 47-53 As they grow and mature, they will fall in love, but conduct themselves soberly. 52 playes] 'dalliance, sexual indulgence' (OED 6c). $\quad 61$ Collin] No doubt Spenser. But though Basse writes in Spenserian mode, he was 17 when Spenser died, and there is no evidence of the intimate connexion suggested here. The tribute to Spenser in the Dedication to Basse's ms Eclogues is more formal. 64 Coridon, Alexis] Alluding to Virgil II. 75-6 A curiously immodest remark: presumably Anetor's expanded paraphrase. 79 He who engaged me as his young servant or follower. 
And I that to his gouernance had tide

My bounden youth, in loosing such a chiefe:

Ah how wou'd he haue sung, and with what grace,

Ananders Loue, and Muridellaes Face.

He wou'd haue blazed in eternall note,

blazoned: recounted, celebrated

Ananders Loue and worthy Manlines;

And then recorded with a wondrous throte,

His Muridellaes louely worthines,

And by those witching tunes he had by wrote,

Cur'd his Loues griefe with his desires succes:

And by his loftie pipe, and pleasing ditty,

Molted hir hearts hardnes with her Loues pitty.

Then mought full well these hils of Shepheards feed

Beene priuy to loues secret discontent,

And all these quarrels might ha beene agreed

And ended, by a Iudge so reuerent:

For he was letter'd well, and well couth reed,

And was a swaine profound and eloquent,

But now is left of him but bare report,

And I in fields, must sing the Loues in Court.

\section{William Basse Laurinella, of True and Chaste love}

The first of nine eclogues in a press-read ms copy of The Pastorals and other workes, prepared for publication from Oxford in 1653 but never printed. Six eclogues (except II, V and IX) are linked to days of the week. Their structure is also modelled on Spenser's SC, down to the concluding Emblems. Basse seems to appear as Colliden, a diminutive of Spenser's pastoral name Colin. Punctuation modified.

Munday.

Laurinella \{Eglogue $\}$ of true and chast Loue:

Colliden. Wilkin.

The Shepheard Colliden, who ere him know,

(who know him not, that Shepheards liues do fare.)

lead, conduct

He that was wont, with siluer sheep-hooke goe,

And by his belt, the silken scrip to weare,

A iolly Shep-heard, to the outward showe,

Till sadly crazed, with loues youthfull care, Low kept his flock, in humble vale where hye Upon a hill, kept Laurinella by.

Scarce cou'd he looke so hye, so weake was he

Yet when he could, hee weakely looked hye:

Though she but seldome would looke downe, to see

The wofull plight of him now waxen, by

His loue to her, almost as faire as shee.

This onely diff' rence seene to euery eye,

Her natiue white with rosey ioy was spread,

His louesick pale had little hopefull red.

His sheepe that bore the brand of his neglect

On their bare ribbes, resembled his desire,

As if perceiuing where he did affect,

From their owne vale, attempt to clamber higher.

love, devote himself

But like their gentle keepers loue soon check't,

To his and their owne miseries retire;

While her proud lambs mark'd with her like disdaine

Shew careles lookes to the despised playne.

grown, become

$\mathbf{8 9}$ by wrote] by rote, by heart (this spelling not in $O E D$ ). $\quad 93$ feed] (right to) pasture ( $O E D$ 2). 96 a Iudge so reuerent] i.e. Collin. $\quad 100$ Loues in court] i.e. of Anander and Muridella. $\quad$ 7-8 vale ... hill] Common pastoral contrast symbolizing pride versus humility. 
Looke home, (quoth he) you my ungraced heard,

And on your owne soile, chew your harmeles cuds.

Tis for your Shepheards sake, you thus haue er'd,

For no such heate boyles in your chiller bloods.

Or if it could, although a sweeter sweard

Growes on the hill, the vale has cooler floods.

Water your thirst may quench: but my desire,

Drinking loue dry, yet drinkes it self the dryer.

O Laurinella! Little dost thou wot

How fraile a flower thou dost so highly prize.

Beauty's the flower, but Loue, the flower-pot

That must preserue it, els it quickly dyes.

As care and sorrow, (thou see'st) mine can blot,

Lonesse and time'ore thine will tyrannize.

Joyes wast asunder that would thriue togither

waste

As double daisyes last, when single wither.

View all my stock of pineing sheep: and see

In their gaunt wombs, the fulnes of my woe.

My carelesnes of them's my care for thee.

Thy neglect mine, and mine their ouerthrow.

Loyall desire is true-loue's husbandrie,

Which till it gaines, it lets all other goe.

Admiring thee, what wealth can I affect?

Had I thy Loue, what els could I neglect?

The Shepheard that hath once well understood

What 'tis to keepe so neare the groues, (he may

Winter his cattell under sheltring wood.)

No more will much for naked pasture pray:

So yeild to loue would beauty, if she cou'd

Foresee her louers care, or her decay:

For what, (when ages winter shall take place.)

But Loue, can shelter beauty from disgrace?

I am not faire. If euer so I were,

I lost my beauty after thine to seeke:

Which 'ere I sought (unlesse our riuers here

Dissemble much,) I had a liuely cheeke.

But now my suit, that might make thee more cleare,

(If thou didst want it,) makes me wan and meeke.

Such force hath loue, beauty to make or marre,

lack (any beauty); debased, abject

That they are onely faire, that loued are.

O that thou would'st come downe to me, that I

With Pomenarcha might bring thee acquainted,

To waite on her and learne to beare an eye

Of humblenes, that thou so long has't wanted.

bellies

neglect

best conduct or management

desire, be drawn to

As in more danger is the Cedar high,

Then Jilly-flower, that under wall is planted:

High mindes to fate are subiect most of all.

They surest stand, that can no lower fall.

Or, (if thou would'st) I could thee recommend

To the great Lady of the house of Thame:

And, by those holy ‘stories she hath pen'd,

histories

25 ungraced] (a) not favoured, neglected (b) 'graceless' or bedraggled in appearance. $\quad 44$ Your neglect is my ruin, and my neglect theirs. $\quad 59$ our riuers] used as a mirror. $\quad 61-2$ more cleare ... want it] still more beautiful, if that were possible. 66 Pœmenarcha] Mary Herbert, Countess of Pembroke. No doubt this poem predates the Countess's death in 1621, lamented in Eclogue VIII. From this point, various high-ranking women are cited to impress Laurinella with a sense of her relatively humble station. $\quad \mathbf{7 4}$ great ... Thame] Lady Agnes Wenman, wife of Basse's patron Sir Richard (later Viscount) Wenman of Thame, Oxfordshire. 75 holy 'stories] a translation, from Greek through French, of John Zonaras' Histories and Chronicles of the World. The manuscript is in the Cambridge University Library. 
Shew how she hath immortaliz'd her name.

On her I for her vertues doe attend.

More free are such as wait on worthy fame,

Then such as their owne humors vaine obey,

Although they haue no Mistresses but they.

Or I could bring thee, (beauteous Laurinell)

Hard by to old Antaprium, where is found

Another such Penelope to dwell

As was in Ithaca, so much renown'd.

One that in bounty, doth (like her) excell

In workes alike and chastity as sound.

If thou wert louingly, or humble hearted,

Then wert thou both, for they cannot be parted.

Come Laurinell, come downe the haughty hill

Into this vale, where thou on beds shalt sit

Of yellow hyacynth and Daffadill

And lillies chast, that therein best befit

My loyall thoughts and thy long-wooed will,

And neuer blemish beauty, birth, nor wit.

For wisedome, birth, and beauty their owne graces

Euer encrease, by graceing humble places.

While to the stately hill thou doest repaire

With thy faire flock and fairer guifts thou hast,

Be thou as Cytherea spruce and faire,

majestic, imposing; resort, make your way

As Pallas wise, and as Diana chast,

Venus; spruce: attractive, beautiful Minerva

Yet should'st thou here a wonder be more rare:

The highest starres, the lesser light doe cast.

But, as a chrystall in a marble mine,

Rare graces doe in lowly places shine.

Come downe, and weare my scrip of azure hue

(Too fine for mee, but onely for thy sake,)

For no requitall but affection true,

And such exchange us both shall richer make.

For all that Lovers haue to both is due,

And tis no losse to giue, nor gaine to take.

When in thy Swayne thou shalt thy selfe possesse,

And I mine owne in mine owne Shepheardesse.

Wilkin. Now Colliden, good day. I stood behinde

Yon little haw thorne bush and heard thee say

Such plaint to Laurinella, that I finde

Thou art in loue, (I thinke in honest way).

If it be so, though yet she seeme unkinde,

Shepheard, let that not thee too much dismay.

Young Maidens that mens suits too eas'ly grant,

Wit, modesty or both may seeme to want.

As thy affection, the more thou doest sue,

The more doth shew it self both true and strong,

So her delays do promise her more true

When she shall yeild, (though she to yeild be long).

We feare we doe for wares bid more then due,

When Merchant takes first offer of our tongue.

Holds easily won, haue little prize within,

The truest heart may hardest be to win.

plead, press your suit

82 Antaprium] (from Gk aper, boar) Boarstall in Oxfordshire. $\quad 83$ Penelope] Lady Penelope Dynham, Wenman's eldest daughter by his first wife. The original Penelope was Odysseus' wife, dwelling in their kingdom Ithaca. 86 workes alike and chastity] The original Penelope held off her suitors during her husband's absence in the Trojan War by weaving an endless cloth. 106 Too fine for mee] Colliden's scrip is of silk (4). $\quad \mathbf{1 2 5 - 6}$ If a merchant accepts the first price we offer him, we think we have offered too much. 
But gentle Swayne, if thou wilt counsell take,

(None counsell need, so much as Louers doe,

Though none lesse apt thereof true use to make.)

Doe as Amyntas did when he did wooe:

Frame to thy pipe a Ditty for her sake,

And sing it in her eares, and praises too.

His song (if thou canst second) I'le begin.

back up with matching verses

Where speeches faile, sometimes examples win.

Wilkin. As Amyntas young did ad

His lip unto his liuely reed,

When'as in her bower he had

join, apply

animated, expressive; pipe

Of louely Phyllis taken heed,

Mee thought I thus ore-heard the Lad:

observed

Come let our flockes together feed.

Colliden. Little seeme thy lambes alone,

And mine, (like mee), of mates haue need:

Let thy sheep amend the mone

Of mine: and mine amend their breed.

insignificant, not amounting to much

So both our flocks shalbe thine owne,

And wee will them together feed.

Wilkin. What although so black I shew

With flames that from Sun-shine proceed,

When as yonder milke-white ewe

My best and blackest lamb did breed,

What couler'd locks (I faine would know)

Had he, that then did with her feed?

Colliden. Match thou canst none like thee faire

Or if thou could'st, it would but breed

Jealous thoughtes: let Nymph be rare

In face, and swayne in faith exceed.

So full of loue and free'd of care,

Both shall their flocks together feed.

Wilkin. Looke upon this garland gay

Which here I giue thee for thy meed.

cure the grief

Marigoldes are match'd with May,

Pinkes and Panseys are agreed:

Why should not wee as well as they

Agree? and flockes together feed.

Colliden. In mine armes a fairer light

Will from thine eyes then now proceed.

Starres at Noone-tide shew not bright,

Tis blacknes doth their brightnes breed.

Come be my starre, I'le be thy night,

While both our flocks together feed.

Wilkin. Whether Phyllis had no power

To deny so kinde a deed,

Or Amyntas chose an hower

When fortune would that loue should speed,

Amyntas liues in Phyllis bower,

And both their flockes together feed.

Colliden. How euer in my suite I shall succeed, I ioy Amyntas loue succeeded so.

132, 140 Amyntas, Phyllis] Both names occur in Watson's Amyntas, but are, of course, generally common in pastoral. 143-8 Conceals an obvious sexual proposition. 153-4 An implicit plea to Laurinella to overlook his homely appearance, like Colliden's own (57). 155 You cannot find any partner to match your beauty. $\quad 167-70$ If she lets him embrace her, her beauty will show up the brighter by contrast with his appearance. $\quad 174$ To rebuff such a sincere offer. 176 When fate wished love to succeed. 
Wilkin. And so doe I: he merits not to speed

In his owne wish, that wishes others woe.

succeed, prosper

Colliden. Neuer to enuy others shall hee need

That could in Laurinella's favour grow

Who now (I see) retir'd is to her bower.

So (now tis noone) let us: Dayes brightest hower

To Loue (in Beauties absence) seemes to lower.

Wilkins Embleme

Vulnus non herbis, esset medicabile verbis.

Colliden's Emblem

Falsa libido procul: noster honestus amor.

17o Giovan Battista (Giambattista) Marino Phillis

Translated from the Italian by William Drummond of Hawthornden.

From Drummond's Hawthornden MS, vol.X, in the National Library of Scotland. A version of Marino's madrigal beginning 'Mentre Lidia premea' ['While Lidia presses'], where the shepherdess is called Lidia.

Epig.[ram]

In peticot of Greene,

Her haire about her eiene,

eyes

Phillis beneath an oake

Sate Milking her faire Flocke:

Mong that sweet strained moysture, rare delight,

Her hand seem'd milke, in milke it was so white.

\section{Girolamo Preti A Shepherd Inviting a Nymph to His Cottage}

Translated from the Italian by Edward Sherburne.

From Sherburne's Poems and Translations (1651). Closely translated from the Italian Marinist poet Girolamo Preti's sonnet 'Un Pastore invita la sua Ninfa alla Montagna' ('A Shepherd invites his Nymph to the Mountains').

Deer! on yond' Mountain stands my humble Cot,

'Gainst Sun and Wind by spreading Oaks secur'd;

cottage

And with a Fence of Quickset round immur'd,

That of a Cabban, make't a shady Grot.

My Garden's there: o'r which, the Spring hath spread

A flowry Robe; where thou may'st gather Posies

Of Gilliflowers, Pinks, Jelsomines, and Roses,

Sweets for thy Bosome, Garlands for thy Head.

protected

Down from that Rocks side runs a purling Brook

In whose unsullied Face,

(Though thine needs no new Grace,)

Thou mayst, as thou think'st best, compose thy Look.

And there thine own fair Object made,

Try which (judg'd by the River) may be said

The greater Fire:

That which my Brest feels, or thy Eyes inspire.

jasmines (Ital. Gelsomin)

186-7 Dayes ... lower] In the absence of the beloved's beauty, the brightest noontide seems cloudy in the eyes of love. 188 (Lat.) A wound can be cured not with herbs but with words. 189 (Lat.) Hence, false lust: our love is chaste. 1 Deer] In Ital., beloved named Cintia. yond' Mountain] Ital. names the Alps. humble] Ital. has opaca, ombrosa (dark, shady). 3 Quickset] live cuttings of plants, especially of whitethorn etc. used for hedges. 4 That transform a humble cottage into a shady bower. 7 Gilliflowers, Pinks] Ital. names the water arum and the crocus. 8 sweets] fragrant adornments (cf. OED sweet 7). 9 side] Ital. has grembo, lap. $\quad 11$ No equivalent in Ital.. Grace] beautiful feature, adornment $\left(O E D_{2}\right) . \quad 13$ Object] of vision, hence attention $\left(O E D_{3}\right)$ : Ital. oggetto. 


\section{Thomas Ravenscroft 'Jolly ShePherd AND UPON A HILL AS He SAT'}

Song no.3 (one of the 'Rounds of Catches of three Voices') in Ravenscroft's Pammelia. Musicks Miscellanie (1609).

Iolly shepheard and vpon a hill as he sate,

so lowd he blew his little horne,

and kept right well his gate:

Earely in a morning, late in an Euening,

and euer blew this little boy, so merily piping:

Tere liter lo. ii

terli terlo, terli ter liter lo, ii.

ter liter lo terli.

Ioly shepheard, $v t$ supra.

\section{Thomas Ravenscroft 'COME Follow Me Merrily'}

Song no.75 (one of the 'Rounds or Catches of fiue Voyces') in Ravenscroft's Pammelia. Musicks Miscellanie (1609). Repetitions apparently for musical reasons omitted below.

Come follow me merily my mates,

lets all agree and make no faults.

Take heed of time, tune and eare,

And then without all doubt,

wee need not feare

to sing this catch throughout:

Malkin was a country maid,

tricke and trim as she might be,

she would needes to the Court shee said

to sell milke and firmenty,

hey hoe, haue with you now

to Westminster,

but before you come there,

because the way is farre

some prety talke lets heare.

Adew you dainty dames,

goe whether you will for me,

you are the very same

I tooke you for to be.

Come vt supra.

neat; spruce and personable frumenty, wheat boiled in seasoned milk

\section{George Chapman To His loving Friend Master John Fletcher}

One of the commendatory poems prefacing John Fletcher's pastoral play The Faithful Shepherdess (?1610). Like most of Chapman's verse, even this short complimentary piece is involved in thought and phrasing. It equates the pastoral world with the Golden Age in an unusually direct way, and finds serious intellectual content in the simplicities of pastoral.

To his louing friend M[aster]. Io[hn]. Fletcher concerning his Pastorall, being both a Poeme and a Play:

There are no suerties (good friend) will be taken

For workes that vulgar-good-name hath forsaken:

A Poeme and a play too! why tis like

A scholler that's a Poet: their names strike

Their pestilence inward, when they take the aire,

6, 7 ii] Indicates the line is to be repeated. 9 vt supra] as above. Not clear how much of the opening lines is meant to be repeated. 20 vt supra] as above. Prob.1-6 meant to be repeated. 0.1-2 both a Poeme and a Playe] ?It appeals both to literate, educated readers (as Poeme) and to the common multitude seeing it on stage (as Playe). Chapman does not allude to the other paradox associated with pastoral plays like The Faithful Shepherdess and its Italian models, that it controversially combines comedy and tragedy. 2 vulgar] general, widespread. 4-5 strike ... aire] When they go out of doors, they strike people inwardly with the plague, 
And kill outright: one cannot both fates beare.

But, as a Poet thats no scholler, makes

Vulgarity his whiffler, and so takes

Passage with ease and state, through both sides prease

Of Pageant seers: or as schollers please

dignity; press, crowd

That are no Poets, more then Poets learnd,

than

Since their Art solely is by soules discernd;

The others fals within the common sence

And sheds (like common light) her influence:

So, were your play no Poeme, but a thing

That euery Cobler to his patch might sing:

A rout of nifles (like the multitude)

With no one limme of any Art indude:

Like would to like, and praise you: but because

Your poeme onely hath by vs applause,

Renews the golden world; and holds through all

The holy lawes of homely pastorall;

Where flowers, and founts, and Nimphs, and semi-Gods,

And all the Graces finde their old abods:

Where forrests flourish but in endlesse verse;

And meddowes, nothing fit for purchasers:

This Iron age that eates it selfe, will neuer

Bite at your golden world, that others euer

Lou'd as it selfe: then like your Booke do you

Liue in ould peace: and that for praise allow.

endued: endowed, invested

\section{John Fletcher Hymn to Pan, from The Faithful Shepherdess}

From Fletcher's play The Faithfull Shepherdess (performed c.1608/9, printed ?1610). Sung by the assembled shepherds after the priest's blessing concluding the festival of Pan.

Sing his praises that doth keepe

Our Flockes from harme,

Pan the Father of our sheepe,

And arme in arme

Tread we softly in a round,

Whilst the hollow neighbouring ground

Fills the musicke with her sound.

Pan, o great God, Pan to thee

Thus do we sing:

Thou that keepest us chaste and free,

As the young spring,

Ever be thy honor spoke,

From that place the morne is broke,

To that place Day doth unyoke.

8 whiffler] one who clears the path for a procession or pageant. 8-10 Such a poet writes plays that find smooth passage through the audience. Such plays are implicitly compared to street pageants, an inferior kind of entertainment that literally 'takes passage' through the viewers. Perhaps also play on seers, (a) viewers and (b) (ironically) prophets, wise men. 12 soules] sarcastically suggesting 'pure souls', the esoteric or abstract-minded (with a pun on 'solely'): unlike the true poet, whose work is widely appreciated. $\quad 16$ Cobler ... patch] suggesting (a) an actual cobbler patching shoes (b) a botcher or untidy worker putting together a patchwork composition. The same expression occurs in the epistle to Mathew Royden prefacing Chapman's long poem Ovid's Banquet of Sense, even more clearly implying a light and trivial composition. $\quad 17$ rout] crowd, band. nifles] trifles, worthless things or (rarely, as here) persons. 25-8 i.e. As your pastoral setting is purely imaginary, it will not be devoured by the materialistic world. 28 bite] like fishes at bait. 30 and that ... allow] Being ignored by the corrupt and ignorant world is itself a compliment (cf. 19-20). 13-14 from east to west 14 unyoke] loose his horses from the chariot of the sun. 
176 Honoré D’Urfé A SonNet

Translated from the French by John Pyper(?)

From Honoré d'Urfe's French pastoral romance L'Astrée (1607), Part 1 Bk 9. Sung to Galathée by her lover Palemas after she asks him to conceal his love for her, owing to their unequal status. (He is her brother's serving-man.) Translated (perhaps by John Pyper, publisher and signatory to the dedicatory letter) in The History of Astraea: The First Part in Twelve Books (1620). The original poem is a sonnet, but the sense of the translation closely follows the original.

\section{A Sonnet.}

Wherefore if you loue me,

Feare you the world should know?

Then honest Amity,

What can make fairer shew?

The spirits vertuous,

It each to other ties,

And far from humane hearts

Expelleth vanities.

But if your choice be such,

That you displeased are, view, opinion

And that you thinke me vile,

Vnworthy such a share:

Disdainfull beauty, that

Liest hid from all mens eyes,

And neuer mad'st appeare

That in thee pitty lies:

Yet Dido did not scorne

A wanderer by sea.

Paris, a shepheard yong,

Wonne loue from Oenone,

Diane found some griefe

suffering, disturbance

For her Endimion.

Loue not regards the state,

Or pompe of any one.

The sheepehooke with the mace

Of Kings he equall makes:

And in the purest Loue,

All his contentment takes.

\section{Honoré D’Urfé 'Close by a River Clear' Translated by John Davies(?)}

From Honoré d'Urfe's French pastoral romance L'Astrée, Part I Bk 4. Celadon loves Astrée, but is advised by her to dissemble his love by paying court to other shepherdesses. He addresses this song to the shepherdess Phillis as part of this ploy. It is being reported later by Astrée to Diana. Translated by 'A Person of Quality' (perhaps J[ohn] D[avies], signatory to the dedicatory letter) in Astraea. A Romance (1657). The translation tends to expand the original (especially in the second stanza and the start of the last) but follows its general tenor fairly closely.

Close by a River cleare, whose bankes were clad

With Mossie cussions, and a channell had;

Which like a Serpent wreathed, and did glide

A long a lovely plaine with swelling pride,

12 share] portion, lot $\left(O E D\right.$ share $\left.\mathrm{n}^{3} 5 \mathrm{~b}\right)$. $\quad 15$ mad'st appeare] allowed to show. $\quad 18$ wanderer by sea] i.e., Aeneas. 19-20 Paris, prince of Troy, was brought up by shepherds and tended sheep on Mount Ida. But by the usual account, his identity was revealed before he married Oenone, daughter of the river-god Cebron. 21-2 The shepherd Endimion won the love of Diana (Selene or Cynthia, the moon-goddess). The 'griefe' is for their unequal status. 21 Diane] Two syllables, for scansion. 28 Finds all his joy. $\quad 4$ pride] splendour, magnificence (OED 6a). 
Did sit a Shepheard, chanting it in verse,

And with his Pipe did these sad Lines rehearse.

render, recite

Cease, Fair one, Cease; cease once your cruelty,

Let me enjoy one day before I die.

The torments I endure for loving you

Are greater farr, then is for hatred due;

If gods be good, and infinitely kind

Then Love and Hate a difference will find.

Is't possible a pure and perfect Love

Should never, never any pitty move?

Are animals insensible as stones,

Which never moved are with sighes and groanes?

Those amorous glances of your winning eyes,

Have oft encourag'd up my hopes to rise,

And since they swell with promises so fair

If they do violate, they perjured are;

Oft have they told me, that your stony heart

Would melt; and from severitie depart:

Each charming part of your fair face did say,

In their false Language, they would ne're betray.

But how? Does shepheardesses eyes outvie

The glistering Court in all its falsitie?

Can they who live and only haunt the fields

Use any art, but what plaine nature yeilds?

Has rurall beauties found a subtile art

Though not their faces, yet to paint the heart?

Are these the Doctrines that your Schoole affords

Only to flatter, and to give good words?

No no, my Fair one, these are fallacies

And far unsutable with your fair eyes;

Learne to be kind, and banish cruelty;

This cometh neerest to a Deitie;

Beauty that bringes not sweetnesse with it, might

Be likned to an eye that wanteth sight.

To her that has no Love and yet is fair,

A Corps without a Soul I will compare.

\section{Giles Fletcher From Christ's Victory and Triumph}

This extract from Giles Fletcher's Christs Victorie, and Triumph in Heauen, and Earth, over, and after death (1610) comprises stanzas 1-2, 16, and 46-51 (wrongly numbered 45-50 in the first edition) of the last section, entitled Christs Triumph after Death. Foreshortening the narrative, Fletcher passes swiftly from Christ's resurrection to his ascension to heaven, expanding the account in Acts 1.9-11 with elements from Revelation and apocryphal sources. But his real originality lies in setting this amalgam in a pastoral landscape of his own devising, better integrated with his theme than the pastoral-framed narrative of the human body in his brother Phineas's The Purple Island (referred to here). The last stanza is a line short.

But now the second Morning, from her bowre, second after Christ's death

Began to glister in her beames, and nowe

The roses of the day began to flowre

In th' easterne garden; for heau'ns smiling browe

Halfe insolent for ioy begunne to showe:

The early Sunne came liuely dauncing out,

And the bragge lambes ranne wantoning about,

That heau'n, and earth might seeme in tryumph both to shout. 
Th'engladded Spring, forgetfull now to weepe,

Began t' eblazon fro her leauie bed,

The waking swallowe broke her halfe-yeares sleepe,

And euerie bush lay deepely purpured

With violets, the woods late-wintry head

empurpled

Wide flaming primroses set all on fire,

And his bald trees put on their greene attire,

Among whose infant leaues the ioyeous birds conspire.

Hearke how the floods clap their applauding hands,

rivers

The pleasant valleyes singing for delight,

And wanton Mountaines daunce about the Lands,

The while the fieldes, struck with the heau'nly light,

Set all their flowr's a smiling at the sight,

The trees laugh with their blossoms, and the sound

Of the triumphant shout of praise, that crown'd

The flaming Lambe, breaking through heau'n, hath passage found.

Ah foolish Sheapheards, that wear woont esteem white (with snow) till recently

Your God all rough, and shaggy-hair'd to bee;

And yet farre wiser Sheapheards then ye deeme,

For who so poore (though who so rich) as hee,

When, with vs hermiting in lowe degree,

He wash't his flocks in Iordans spotles tide,

And, that his deere remembrance aie might bide,

Did to vs come, and with vs liu'd, and for vs di'd?

were accustomed to

But now so liuely colours did embeame

His sparkling forehead, and so shiny rayes

Kindled his flaming locks; that downe did streame

In curles, along his necke, whear sweetly playes

(Singing his wounds of loue in sacred layes)

His deerest Spouse, Spouse of the deerest Lover,

Knitting a thousand knots ouer, and ouer,

And dying still for loue, but they her still recover.

Faire Egliset, that at his eyes doth dresse

Her glorious face, those eyes, from whence ar shed

Infinite belamours, whear to expresse

His loue, high God all heav'n as captive leads,

And all the banners of his grace dispreads,

And in those windowes, doth his armes englaze,

at his eyes: to please or attract his gaze

the Church Triumphant

And on those eyes, the Angels all doe gaze,

And from those eies, the lights of heau'n do gleane their blaze.

But let the Kentish lad, that lately taught

His oaten reed the trumpets siluer sound,

Young Thyrsilis, and for his musique brought

9 forgetfull ... weepe] i.e., It did not rain. 1o eblazon] 'shine forth in bright colours' (OED). 11 halfe-yeares sleepe] The old explanation for the disappearance of swallows in the winter. Here, their awakening figures Christ's resurrection. 19 Echoes Psalm 114.4. 24 Lambe] Christ, the Lamb of God (see, e.g., John 1.29, Rev.21.22, 22.1). In Rev. 21.23, the Lamb lights up the City of God. 26 Your God all rough] Pan, whom the shepherds had earlier taken as their God. But Christ seems to be conceived as a new aspect of Pan rather than his replacement: cf. Milton's Nativity Ode 89. 30 wash't his flocks] See John 4.1-2, though the disciples, not Jesus, carried out these baptisms. 39 Pledging her allegiance in marriage a thousand times over. $\quad 41$ Egliset] the Church (Fr. eglise). 43 belamours] loving looks $\left(O E D_{2}\right)$. 48 the lights ... blaze] the heavenly bodies derive their light. 49 the Kentish lad] the poet's brother Phineas. The ensuing reference is to his The Purple Island, which ends with the rescue of Eclecta by Christ, and their marriage. Eclecta is 'Choice', daughter of Intellect and Will, but also 'the elect', generally identified with the Church and its body of the faithful. 5o the trumpet] symbolizing the martial and epic vein, contrasted with the pastoral 'oaten reed': recalls Virgil IV.1. The Purple Island concludes in an allegorical battle between good and evil forces, with Christ the knight finally defeating the dragon Satan. 51 Thyrsilis] or Thirsil, Phineas Fletcher's pastoral name in The Purple Island and elsewhere. 
The willing sphears from heav'n, to lead a round

Of dauncing Nymphs, and Heards, that sung, and crown'd

Eclectas hymen with ten thousand flowrs

Of choycest prayse, and hunge her heav'nly bow'rs

With saffron garlands, drest for Nuptiall Paramours.

shepherds
marriage (see 49n)

adorned; wedded lovers

Let his shrill trumpet, with her siluer blast,

Of faire Eclecta, and her Spousall bed,

Be the sweet pipe, and smooth Encomiast:

But my greene Muse, hiding her younger head

Vnder old Chamus flaggy banks, that spread

Their willough locks abroad, and all the day

With their owne watry shadowes wanton play,

Dares not those high amours, and loue-sick songs assay.

Impotent words, weake sides, that striue in vaine,

flanks, sinews

In vaine, alas, to tell so heau'nly sight,

So heav'nly sight, as none can greater feigne,

Feigne what he can, that seemes of greatest might,

Might any yet compare with Infinite?

Infinite sure those ioyes, my words but light,

Light is the pallace whear she dwells, O blessed wight!

covered with flags (the water-plant)

imagine, envisage

\section{David Murray The Complaint of the Shepherd Harpalus}

First published in Murray's Ceelia. Containing certaine Sonets, accompanying his play The Tragicall Death of Sophonisba (1611).

The complaint of the Shepheard Harpalus.

Poore Harpalus opprest with loue,

Sate by a christall brooke:

Thinking his sorrowes to remooue, Oft-times therein did looke.

And hearing how on pibble stones, The murmuring riuer ran,

As if it had bewail'd his grones, Vnto it thus began.

Faire streame (quoth he) that pitties me, And heares my matchlesse moane,

If thou be going to the sea, As I do so suppone,

unmatched, greater than others'

Attend my plaints past all releefe,

suppose Which dolefully I breath,

Acquaint the sea Nymphes with the greefe,

Which stil procures my death.

hear

Who sitting on the cliffy rockes,

May in their songs expresse,

While as they combe their golden lockes, Poore Harpalus distresse.

And so perhaps some passenger,

That passeth by the way,

May stay and listen for to heare

Them sing this dolefull lay.

52 sphears from heav'n] In the Ptolemaic system, the heavenly bodies were set in crystalline spheres that made sweet music as they revolved, inaudibly to the human ear (but now heard). 53 Heards] shepherds. Hence (and given the Christian context) the 'Nymphs' prob. shepherdesses rather than goddesses of nature. 59 pipe] conduit (of praise) as well as musical instrument. $\quad 61$ Chamus] the river Cam, hence Cambridge University, to which the Fletcher brothers and their father, Giles Fletcher the Elder, belonged. $\quad 21$ passenger] ?voyager; ?ship carrying voyagers $(O E D 2)$. 
Poore Harpalus a shepheard swaine, More rich in youth then store,

Lou'd faire Philena, haplese man, Philena, oh! therefore

Who stil remorceles-hearted maide, Tooke pleasure in his paine:

And his good will (poore soule) repayd With vndeseru'd disdayne.

Ne're shepheard lou'd a shepherdesse More faithfully then he:

Ne're shepheard yet beloued lesse Of shepheardesse could be.

How oft with dying lookes did he To her his woes impart?

How oft his sighes did testifie The dolor of his hart?

How oft from valleis to the hils, Did he his griefes rehearse?

How oft re-eccho'd they his ills, Abacke againe (alas)?

How oft on barkes of stately Pines, Of Beech, of Holen greene,

Did he ingraue in mournfull lines, The dole he did sustaine?

Yet all his plaints could haue no place To change Philena's mind:

The more his sorrowes did increase, The more she prou'd vnkind.

The thought whereof through verie care, Poore Harpalus did moue:

That ouercome with high despaire, He quat both life and loue.

quitted, gave up

\section{0 'A JOLLY SHEPHERd THAT SAT ON Sion Hill'}

From BL MS.Addl. 15225. Transforms the conventional topos of the 'jolly shepherd' into an allegory of the Church. Licensed for publication on 15 August 1586 despite its Catholic implications, clearest in the fifth stanza and in the doctrine of the Eucharist implicit in 29-32. The fifth stanza may have been deleted by the censor (as Hyder Rollins suggests), or not placed before him. The Catholic overtones may explain why no printed copy appears to survive. In the ms, every two lines as printed here are written as one, separated by a colon or comma. Nearly all other punctuation added and line initials regularized.

A Jollie sheppard that sate on Sion hill,

That with his rod and sheppardes crooke his sheepe derecteth still,

conducts, guides

His Church it is the fould, in tender grasse they feede,

And to the fountaines faire they goe, which is his word indeede.

1 A Jollie sheppard] a conventional phrase. Cf., e.g., the Helicon poem 'Jolly sheepheard, sheepheard on a hill' and Thomas Ravenscroft's song 'Iolly shepheard and vpon a hill as he sate' (no.172). Jollie] handsome and lively: conventionally used of shepherds in pastoral. 2 Sion hill] hill in Jerusalem, site of the temple of Solomon. Cf 11n, 49-5on. 5-8 Echoes and allegorizes Psalm 23. 
The way vnto the holie church, if anie list to knowe,

By sheppardes tabernacle past, they must on footestepes goe;

Where sheppardes ould were wonted accustomed to walke right reverently,

And there this sheppardes spouse soe sweete at noone dayes sure doth lye.

This Church is like a Citie faire that builded is on hye;

Like to a candle shininge bright to all that passed by;

Where truth shall never fade away, but virtue still abyde,

And where this sheppard dwellinge is, both church and sheepe doth guide.

The holie scriptures sure to keepe, this Church she hath in charge;

And power eike to bynd and lose, to keepe and let at large;

eke, also; loose confine, imprison

And with the holie sacramentes his sillie flocke to feede,

Which is his blood and bodie both to them in time of neede.

And, for the glorie of his Church, this shepard did prouide

Both Prophets and Appostles eake, and marteres trulie tryde,

With virgins and confessors pure and docters manie moe,

tested, put to trial (of their faith)

The praises of this holie Church throughout the world to shoe.

teachers, learned men

And more then this he promissed: when he should passe away

The holie ghost, the comforter, to send with her to stay,

Whoe in all truth should her defend in virtue euermore,

Although the waues of wickednesse should wash her wales full sore.

walls

This Church did at Jerusalem

full visiblie appeare

An afterward confirmed was by Christ our sauiour deere

When breade and wine he blessed and to his Appostles plaine

Said, 'take and eate, this is my flesh which for you shall be slaine.'

11 tabernacle] ?the temple of Solomon in Jerusalem, an Old Testament 'type' or prefigurement of the Christian Church. Cf. 49-50. 12 on footestepes] i.e. not on horseback: humbly and reverently. 15 sheppardes spouse] The Church, held to be the bride of Christ. 17-20 After Christ's parables in Matthew 5.14-16. 25-6 The Church has charge of keeping the holy scriptures in safe protection. 27 bynd and lose] the power vouchsafed by Christ (Matthew 16.19) to Peter, his chosen custodian of the Church. 30 sillie] simple and innocent: conventionally used of shepherds and sheep. $\quad \mathbf{3 1}$ blood and bodie] Suggests literal transubstantiation - i.e. actual change of the bread and wine of the Eucharist into Christ's flesh and blood - as advocated by the Catholic Church, in contrast to various types of symbolic representation advanced by most Protestant churches. 37 confessors] those who declare their faith and suffer for it short of martyrdom. $\left(O E D_{2}\right)$. $\quad 49-50$ Cf. $11 n$. 54 plaine] plainly. Again suggests literal transubstantiation: see 3in. 
For to confirme what he hath said the cruel Jewes that night,

With clubs and staues, and weapons sharpe, with toarch and lantorn bright,

Came for to take this shepard sweete, as he at prayer was,

If that his father's will it were that cup from him might pas.

They bound him fast, they beat him sore, they stroake him on the face,

They spit at him, they raild on him, with spite and vile disgrace.

By witnes false, they him accusd, for to put downe their lawes,

Although the Judg did answer them, 'I finde in him noe cause.'

In stid of princlie Cepter in his hand they put a reede,

And like a foole they him araid in whiteish cloathes, indeede;

They whipt him soe the blood ran downe, his blessed bones were seene,

And on his head a crowne they set of thornes bothe sharpe and keene.

'Behould the man,' the Judg did say; they 'crucifie' did crye.

And Barabas they did let goe, but Jesus iudgd to dye;

Although the Judg did answere them, 'I finde in him noe ill.

You haue a law, and by that law, goe kill him if you will.'

Away they led him wickedlie and on his backe they cast

The cross of our offences all, that downe he fell at last.

And on a roode betwixt two theeues they did him crucifie.

His loue and likinge to his Church, these thinges did trulie trye.

test, make trial of call

To witnes cale those rageinge words the two theeues they did vse;

To witnes cale the blasphemies then spoken by the Jewes;

To witnes cale his bloodie woundes in handes, in feete, and hart;

To witnes cale his mother deere, that thereof had her part.

63-4 Christ's cry during his agony in the garden of Gethsamane before his arrest: Matthew 26.42, Luke 22.42. 71 the Judg] Pontius Pilate: Luke 23.14-16, John 19.6-7. 73-80 The details correspond to Matthew 27.26-30 and Mark 15.17-19. But the robe in which he was mockingly clothed is red or purple in all gospel accounts. 83-4 The Jews exercised their choice of one prisoner freed at Passover by favouring the murderer and conspirator Barabas over Jesus: Matthew 27.15-26, Mark 15.6-15, Luke 23.18-25, John 18.39-40. 87 You haue a law] Jesus was found innocent by Pilate under Roman law but dubiously condemned under the Jewish. $\quad 91$ By Christian doctrine, Christ died to take the original sin of all mankind upon himself. 92 downe he fell] Deduced from the report of Simon of Cyrene being made to carry Christ's cross: Matthew 27.32, Mark 15.21, Luke 23.26. thief railed at Jesus; the other hailed and worshipped him (Luke 23.39-43). 97-8 Actually, only one 104 thereof] of his wounds. Mary was said to have suffered the pains at Jesus' death that, miraculously, she was spared at his birth. 
To witnes cale the bloodie speare, which at his syde did runne;

To witnes cale both heaven and earth before whome it was done;

To witnes call both sunne and moone, whoe then Eclipsed went;

To witnes call the Temple vaile that all in sunder rent.

To witnes calle the darknes great that couered earth and skyes;

To witnes cale the dead men's bones which from the graues did ryse;

To witnes cale his bitter drinke and Joyfull wordes he saide;

To witnes cale his charitie, when for his foes he praid.

To witnes cale his coate vnseamd for which the loates were cast;

To witnes cale his dath and paine which euerie lime did tast;

To witnes cale his goeinge downe to hell through his greate might;

To witnes calle his assendinge vp to heauen in glorie bright.

Then sith this sheppard paid soe deare to buy our freedome lost,

His scornes, his bloes, his blood and life was price of that it cost;

And heere doth giue vs all we haue and after Joyes for aye,

And doth requeere our seruice true, in humble wise to pray.

'O come away, come away,' this shepard cales and cryes,

'Take vp your crosse, and follow me, and doe this worled dispise.'

Like sheepe in humble sort let vs vnto his voice giue eare

And in his lawes still walke vpright while we abyden heere.

'O come away, come away,' this shepard cales and cryes:

'Take vp your crosse and follow me, and doe this world dispise,

And in his house and truth abyde, what ever shale befalle,

And in its truth both liue and dye.' Amen, amen, say all!

105 bloodie speare] thrust into the dead Christ's side by a soldier: John 19.34. 110 Eclipsed went] The sun was darkened at the time of Christ's death: Matthew 27.45, Mark 15.33, Luke 23.44-45. $\quad$ 111-12 Temple vaile ... rent] So Matthew 27.51, Mark 15.38, Luke 23.45. 113 darknes great] See 110n. $115-6$ dead men's ... ryse] So Matthew 27.52. 117 bitter drinke] the vinegar in a sponge offered to Christ on the cross: Matthew 27.48, Mark 15.36, Luke 23.36, John 19.29. 118 Joyfull wordes] Can only be Christ's words to the penitent thief, Luke 23.43. 120 'Father, forgive them; for they know not what they do': Luke 23.34. 121-2 The soldiers divided Christ's garments among themselves, but cast lots for a coat without a seam: John 19.23-4. 125-6 goeinge downe to hell] the 'harrowing of hell', whereby between entombment and resurrection, Christ is said to have stormed hell, released certain Old Testament figures and taken them up to heaven, and chained Satan to the pit of hell. There is no clear scriptural source but a number of contributory passages. 147-551 The succession of $m e$, his and its, shifting between Christ's direct speech and the poet's report, is not strictly logical, but the meaning is clear. 


\section{William Alabaster 'Alas, our shepherd'}

A poem on Christ's Passion and crucifixion, the eighth of 64 manuscript sonnets bound in at the start of a printed French Book of Hours in St John's College Library, Cambridge. Dates in the ms indicate they were written (or at least transcribed) between 16 January 1627 (?1628 new style) and 1628. The poem reflects Matthew 26.31: 'I will smite the shepherd, and the sheep of the flock shall be scattered abroad.' Punctuation almost wholly inserted and line-initial capitals supplied in this edition.

Alas our sheappeard now is strocke againe:

See how the sillie flocke away doth hye,

Do hye away themselues to saue thereby

As if they might bee safe, when hee is slaine.

Whether, o whether runn yee soe in vaine?

For whilst yee with your sheappeard shunn to dye

Into the Jawes of wolues yee doe but fly,

Who of dispersed sheepe doe make there gaine.

Knowe yow not the stroakes which on him light

Are aym'd att vs to putt vs all to flight?

Whose members shall those bee that want a heade,

Whose flockes that from the folds are scattered,

Which dyinge with your sheapeard should reviue

Butt liuinge from your sheapeard dye aliue?

\section{Anthony Munday The Shepherd's Speech from Himatia-Poleos}

Part of a shepherd's speech in Munday's Himatia-Poleos. The Triumphs of olde Draperie, or the rich Cloathing of England (1614), a pageant at the instalment of Sir Thomas Hayes of the Company of Drapers (to which Munday himself belonged) as Lord Mayor on 29 October 1614. As Munday explains, the title means 'The Cloathing or garments of the Cittie', i.e. its walls, but is applied by Munday to the actual fabrics or drapery on which London's wealth and distinction is based. The pageant incorporates 'a goodly Ramme or Golden Fleece, with a Sheepheard sitting by it'. He speaks on behalf of the Cotswold sheep farmers who provide the wool used by drapers.

From the Ramme we haue the Lambe

From both our finest woolles are shorne.

Wooll had thus from the Ramme and Lambe,

Makes the best Cloath, that can be worne.

Thanke then the Draper that began

To make such Cloathing, meete for man.

For, if wee haue no Ramme, wee are sure to haue no Lambe: no Lambe, no Wooll: no wooll, no Cloth: no Cloth, no Draper.

Heauen graunt that we may neuer see these noes, 'no's: negatives, lacks For we shall then feele twise as many woes:

But that of Ram, Lambe, Wooll, Cloth, still we may haue store:

So shall the Drapers then thriue more and more.

1 againe] The previous sonnet had described Christ's sufferings during his Passion. 11 members] limbs: implicit concept of the Church as the mystical body of Christ. 12 To what owner will scattered and straying sheep be said to belong? 


\section{Christopher Brooke To His Much loved Friend Master W Browne}

First published in The Shepheards Pipe (1614). While Drayton, Brooke and Davies of Hereford formed a trio of older poets holding Browne and Wither in affectionate esteem, the friendship between Browne (Willy) and Brooke (Cuttie) seems specially close. They both belonged to the Inns of Court, wrote companion elegies for Prince Henry, and addressed eclogues to each other in The Shepheards Pipe. They are also associated in Wither's The Shepherd's Hunting.

To his much loued friend Master W. Browne of the Inner Temple. D. D.

Cuttie. Willy well met, now whiles thy flockes do feed

So dangerlesse, and free from any feare;

Lay by thy Hooke, and take thy pleasant Reed,

And with thy melody reblesse mine eare,

Which (vpon Lammas last) and on this plaine,

Thou plaidst so sweetly to thy skipping Traine.

1st August, a harvest festival

Willy. I Cutty, then I plaid vnto my sheepe

Notes apt for them, but farre vnfit for thee;

How should my layes (alas) true measure keepe

With thy choyce eares, or make thee melodie:

For in thy straine thou do'st so farre exceede,

Thou canst not relish such my homely Reede.

Cuttie. Thy nicenesse shewes thy cunning, nothing more,

Yet since thou seem'st so lowly in thy thought;

(Who in thy Pastorall veine, and learned lore

Art so much prais'd; so farre and neere art sought.)

Lend me thine eares, and thou shalt heare me sing

In praise of Shepheards, and of thee their King.

My loued WiLLY, if there be a Man

That neuer heard of a browne colour'd Swan;

Whose tender Pinions scarcely fledg'd in show

Could make his way with whitest Swans in Poe;

Or if there be among the Spawne of earth,

That thinkes so vilely of a shepheards birth,

That though he tune his Reed in meanest key,

Yet in his braine holds not heauen, earth, and sea:

Then let him know, thou art that yong browne Swan,

That through the winding streames of Albion

Taking thy course dost seeme to make thy pace

With flockes full plum'd equall in loue and grace;

And thou art he (that though thy humble straines

Do moue delight to those that loue the plaines:)

Yet to thy selfe (as to thy sort) is giuen

A IACOBS staffe, to take the height of Heauen;

And with a naturall Cosmography,

To comprehend the earths rotunditie:

Besides the working plummet of thy braine,

Can sound the deepes, and secrets of the maine:

For if the Shepheard a true figure be

Of Contemplation (as the learn'd agree)

Which in his seeming rest, doth (restlesse) moue

coyness, shyness (to sing)

About the Center, and to Heau'n aboue;

And in his thought is onely bounded there,

See's Natures chaine fastned to Ioves high Chaire,

9-10 true measure ... eares] Match the expectations of your refined ear. $\mathbf{1 2}$ such my homely Reede] a reed (pipe) as homely as mine. 15 Pastorall veine, and learned lore] perhaps contrasted, though of course associated too. lore] ?punning on 'law', the subject of Browne and Cuttie's studies. Cf. no.184.210. 20 browne colour'd Swan] punning on Browne's name. 22 Poe] Po, the river in Italy. $\quad 25$ meanest key] alluding to the lowly themes and style of pastoral. $\quad 30$ full plum'd] fully fledged, mature, in contrast to the 'yong browne Swan'. flockes] of swans (cf. 'flock of wild geese', Shakespeare, 1 H IV 3.4.136). Pun on plume, pen. 34 IACOBS staffe] instrument used to measure the height of the sun or the pole star. 44 Natures chaine] the 'great chain of being', the hierarchic order of nature emanating from the divine creative source: usually metaphoric, but could be visualized, after Iliad 8.19-27. See Natalis Comes, Mythologiae, II.4, and Spenser, FQ IV.i.3o. 
Then thou (that art of PAN the sweetest Swaine

And farre transcending all his lowly traine)

In thy discoursiue thought, do'st range as farre

Nor canst thou erre, led by thine owne faire starre.

Thought hath no prison and the minde is free

Vnder the greatest King and tyrannie.

Though low thou seem'st, thy Genius mounts the Hill

Where heauenly Nectar doth from Ioue distill;

Where Bayes still grows (by thunder not struck down)

The Victors-Garland, and the Poets-Crowne,

And vnderneath the Horse-foote-fount doth flow,

Which giues Wit verdure, and makes learning grow.

To this faire Hill (from stormes and tempests free)

Thou oft repair'st for Truthes discouery,

A prospect vpon all times wandring mazes,

6o Displaying vanity, disclosing graces;

Nay in some cliffe it leades the eye beyond

The times horizon stripping sea and land,

And farther (not obscurely) doth deuine

All future times: Heere do the Muses shine,

Heere dignity with safety do combine,

Pleasure with merite make a louely twine.

Vitam vitalem they shall euer leade

That mount this hill and Learning's path do treade:

Heere admiration without enui's wonne,

70 All in the light, but in the heate sit none.

And to this Mount thou dost translate thine Essence

Although the plaines containe thy corporal presence,

Where though poore peoples misery thou shewe

That vnder griping Lords they vndergoe,

And what content they (that do lowest lye)

Receiue from Good-men that do sit on hye.

And in each witty Ditty (that surpasses)

Dost (for thy loue) make strife 'mongst Country lasses,

Yet in thy humble straine, Fame makes thee rise

8o And strikes thy mounting forehead 'gainst the skies.

Renowned friend, what Trophe may I raise

To memorize thy name; would I could praise

(In any meane) thy worth, strike enuy dumbe,

But I dye heere; thou liu'st in time to come.

viewpoint, perspective

States haue their Period, statues lost with rust:

Soules to Elizium, Nature yeelds to dust,

All monuments of Armes and Power decay,

But that which liues to an Eternall day,

Letters preserue; Nay, Gods with mortall men

90 Do simpathize by vertue of the penne.

And so shalt thou: sweete Willy then proceede

And in eternall merite fame thy Reede.

$P A N$ to thy fleeced numbers giue increase

rapacious, extortionate

outstripping
darkly, indistinctly

twin: match, partner

\author{
memorial structure or edifice \\ commemorate \\ by any means
}

And Pales to thy loue-thoughts giue true peace.

concur, resemble

make famous Pan] here specially as god of pastoral poets.
46 lowly traine] other poets and their run of pastorals,
which Browne is 'transcending' in the long, loosely epic-like structure of his Britannia's Pastorals (1616, but perhaps partly composed by 1614, when this poem appeared). 47 discoursiue] wandering, far-ranging (literal Lat. sense). $\mathbf{4 8}$ faire starre] continuing the metaphor of the Jacob's staff (34). 51 the Hill] Mount Helicon, sacred to the Muses (see 55). 55 Horse-foote-fount] Literal meaning of Hippocrene, a spring beneath Mount Helicon where the winged horse Pegasus struck his foot. 56 giues ... verdure] makes green, induces growth. $\quad 67$ Vitam vitalem] (Lat.) living life: 'eternal life' through lasting fame. $\quad 71-2$ i.e. a state of Platonic ecstasy, where the soul leaves the body. $73-6$ Alluding to the satirical and political strand of Browne's poetry. 94 Pales] goddess of the sheepfold and shepherds. 
Let faire Feronia (Goddesse of the woods)

Preserue thy yong Plants, multiply thy buds.

And whiles thy Rams do Tup, thy Ewes do twyn

Do thou in peacefull shade (from mens rude dyn)

away from; tumult

Adde Pinyons to thy Fame: whose actiue wit

With Hermes winged cap doth suite most fit.

\section{John Davies Of Hereford An Eclogue between Willy AND WERNOCKE}

From The Shepheards Pipe (1614). Willy, as usual, is William Browne, and Wernocke, Davies himself. The language is thickly dialectal, with (sometimes false) archaisms and rusticities, often drawn from Spenser's SC, especially 'October'. A general feature is the archaic verbal ending -en for both plural and infintive.

An Eclogue between yong Willy the singer of his natiue Pastorals, and old Wernocke his friend.

Wernocke. WiLLY, why lig'st thou (man) so wo-be-gon?

What? been thy rather Lamkins ill-apaid?

Or, hath some drerie chance thy Pipe misdone?

Or, hast thou any sheep-cure mis-assaid?

Or, is some conteck'twixt thy loue and thee?

Or, else some loue-warke arsie-varsie tane?

Or, fates lesse frolicke than they wont to be?

What gars my WiLly that he so doth wane?

If it be for thou hast mis-said, or done,

Take keepe of thine owne councell; and, thou art

As shoene and cleare fro both-twaine as the Sunne:

For, all Swaines laud thine hauiour, and thine Art.

Ma hap thine heart (that vnneath brooke neglect,

And iealous of thy fresh fame) liggs vpon

Thy rurall songs, which rarest Clarkes affect,

Dreading the descant that mote fall thereon.

Droope not for that (man) but vnpleate thy browes,

And blithly, so, fold enuies vp in pleats:

For, fro thy Makings milke and mellie flowes

To feed the Songster-swaines with Arts soot-meats.

Willie. Now, siker (Wernocke) thou hast split the marke

Albe that I ne wot I han mis song:

But, for I am so yong, I dread my warke

Woll be misualued both of old and yong.

Wernocke. Is thilke the cause that thou been ligge so laid,

Who whilom no encheson could fore-haile;

And caitiue-courage nere made misapaid,

But with chiefe yongsters songsters bar'st thy saile?

liest

distressed, sick

sad; harmed, damaged misapplied

is there; disagreement, conflict

topsy-turvy, awry; taken, turned out joyful, happy

causes, affects; dwindle

As swoot as Swans thy straines make Thames to ring

Fro Cotswould where her sourse her course doth take,

To her wide mouth which vents thy caroling

Beyond the hether and the further lake.

Than vp (sad swaine) pull fro thy vailed cheeke

take heed bright

behaviour, conduct

it may be; scarcely

protective; is absorbed with

learned men; like, are attracted by criticism, censure; might

unfold, smoothen out

compositions, poems; honey poet-shepherds; sweetmeats,

[dainties

sure; hit the target

work

underpriced

the same, this

cause, motive; conceal

bearest

from
pours out, sounds forth

lowered, downcast

95 Feronia] goddess of plants and fruits (rather than 'the woods'). 97 twyn] exceptional bounty: a ewe commonly gives birth to only one lamb. 100 Hermes winged cap] Hermes or Mercury was commonly depicted with wings on his broad-brimmed cap and sandals. 2 rather] early born, hence delicate. $\quad \mathbf{6}$ ? Has some pain caused by love upset you? (warke, pain); ?Has some move or strategy in love turned out badly? (warke, work). 9-10 If ... councell] If it is because you have said or done something wrong, be guided by your own judgement. 11 both-twaine] both (what you have said and done: see 9). 13 vnneath brooke] will scarcely accept or tolerate. $\mathbf{1 8}$ fold ... pleats] wrap up (i.e. forget) the envy others feel towards you. pleats] folds. 22 Though I am not aware that I have ever sung badly. $\quad 25$ been ... laid] Have lain so low, been so cast down or withdrawn. 27 And never felt depressed because of your feeble spirits. misapaid] discontented (OED, citing this passage alone). $\mathbf{2 8}$ But hold your own with the best young singers. 30 her sourse] The Thames rises at Thames Head near Cirencester in the Cotswolds. $\quad 32$ the hether ... lake] perhaps the English Channel and the Mediterranean. $\quad 33-4$ Stop resting your downcast cheek on your palm. 
Hur prop, thy palme: and let thy Virilaies

Kill enuious cunning swaines (whom all do seeke)

With enuy, at thine earned gaudy praise.

Vp lither lad, thou reck'st much of thy swinke,

When swinke ne swat thou shouldst ne reck for fame;

At Aganip than, lay thee downe to drinke

$40 \quad$ Vntill thy stomacke swell, to raise thy name.

What though time yet han not bedowld thy Chin?

Thy Dams deere wombe was Helicon to thee;

Where (like a Loach) thou drew'st thilke liquor in,

Which on thy heart-strings ran with musickes glee.

Than vp betimes, and make the sullen swaines

With thy shrill Reed such iolly-iovisance

That they (entranc'd) ma wonder at thy straines;

So, leaue of thee ne're ending souenance.

Willie. Ah Wernocke, Wernocke, so my sp'rits been steept

In dulnesse, through these duller times missawes

Of sik-like musicke (riming rudely cleept)

That yer I pipe well, must be better cause.

Ah, who (with lauish draughts of Aganip)

Can swill their soule to frolick so their Muse,

Whan Courts and Camps, that erst the muse did clip,

Do now forlore her; nay, her most abuse?

Now, with their witlesse, causelesse surquedry

They been transpos'd fro what of yore they were,

That Swaines, who but to looser luxurie

60 Can shew the way, are now most cherisht there.

These times been crimefull (ah) and being so,

Bold Swaines (deft Songsters) sing them criminall;

So, make themselues oft gleefull in their woe:

For thy tho Songsters are misween'd of all.

Mecoenas woont in blonket liueries

Yclad sike chanters; but these miser times

Vncase hem quite, that all may hem despise,

As they don all their best embellisht Rimes.

And Haruest-queenes, of yore, would Chaplets make

To crowne their scalpes that couth most swootly sing,

And giue hem many a gaude at Ale or Wake,

But now ne recke they of foot carrolling.

Enaunter they should be as seeme they would,

Or songen lowdly for so deere desart;

Or else be peregall to Nymphes of old,

From which their beastlihed now freely start.

Than must they latch the blowes of Fates too fell

With their too feeble clowches as they con:

For, none regards or guards hem for their spell,

skilled; seek after, praise deserved; bright, glowing downcast, spiritless; toil

$$
\begin{array}{r}
\text { then } \\
\text { win glory } \\
\text { mother's }
\end{array}
$$

to a musical tune

pipe; pleasing joy

may

eternal memory

slander, ill-judgement

such

ere

i.e., poetic inspiration

drench, immerse

embrace, love

forsake

arrogance

transformed

more dissolute pleasures

therefore; ill-judged, maligned used to; blunket, a greyish-blue cloth dress, provide garb to; such; wretched

strip; them

heads; knew how to, could;
[sweetly
care nothing for; dancing and singing

if, in case

equal, match, ?companion

receive

?clutches, hands; can learning, skill

34 Virilaies] virelays, songs: strictly, with only two interlaced rhymes. 35 enuious ... seeke] i.e. His envious rivals are themselves fine and reputed singers. $\quad 37-8$ thou reck'st ... fame] You think too much of your labour and suffering, when you should not care for such things in your quest for fame. Aganippe] one of two springs, sacred to the Muses, at the foot of Mount Helicon (42). $\quad 41$ bedowld] put a beard on (dowl, fibre, fluff). 43 Loach] a kind of fish. Willy drank in poetic inspiration from the water in his mother's womb, as fish drink the water they live in. 49-52 I am so depressed because of these dull times' abuse and ill-judgement of such music (which they boorishly term no better than 'rhymes'), that I must find some better motive to pipe well. $\mathbf{5 4}$ Steep their souls in inspiration so as to lend joy and spirit to their muse. $\quad 55$ Courts and Camps] seats of power. $\quad \mathbf{6 2}$ criminall] criminally: wrongfully, dissolutely. $\quad 63$ make ... woe] draw pleasure from their sorry state. $\quad 65$ Mecænas] Gaius Maecenas, famous patron of the arts in ancient Rome. 68 As they (the people of these times) despise the poets' best-composed verses. 69 Haruest-queenes] young women chosen as 'queen' of the harvest feast. $\mathbf{7 1}$ gaude] trinket given as gift or love-token. Ale] village festival where ale is drunk $\left(O E D_{2}\right)$. Wake] festival, esp. of patron saint of village church $(O E D 4 \mathrm{~b})$. $73-6$ Very cryptic. Perhaps 'If they (poets) would be what they wish, they must either exert themselves unduly for hard-won reward, or seek out as companions the chaste nymphs of old, from whose model the beastly nature of today's women recoil'. 79 guards] adorns, decorates (cf. OED 7 ). 
Tho they, on point-deuice, empt Helicon!

There nis thilke chiuisance they whilome had

For piping swoote; sith, with an Heydeguies,

Pipt by Tom-piper, or a Lorrel-lad,

(So be he clawes hem they idolatrize.

And those that should presse proper songs for sale,

Bene, in their doomes, so dull; in skill, so crude,

That they had leauer printen Iacke a vale,

Or Clam o' Clough (alacke), they beene so rude!

And sith so few feate Songsters in an age

Bene founden, few do weigh hem as they been,

For Swaines, that con no skill of holy-rage,

Bene foe-men to faire skils enlawrel'd Queen.

Enough is mee, for thy, that I ma vent

My wits spels to my selfe, or vnto thee

(Deere Wernock) which dost feel like miscontent

Sith thou, and all vnheeded, singt with mee.

Wernock. Vartue it's sed (and is an old said-saw)

Is, for hur selfe, to be forsought alone:

Then eftsoones from their case thy shrill pipes draw,

And make the welkin ringen with their tone.

Of world ne worly men take thou no keepe,

What the one doth, or what the other say;

For should I so, I so should Eyne out-weepe:

Than, with mee, Willy, ay sing care-away.

It's wood to be fore-pinde with wastefull carke

In many a noyfull stoure of willing bale

For vading toyes: But trim wits poorest wark

The vpper heau'n han hent fro nether Dale.

Thilks all our share of all the quelling heape

Of this worlds good: enough is vs to tell

How rude the rest bene, caduke, and how cheape;

But, laude for well-done warks don all excell!

For thy we shoulden take keepe of our Race

That here wee rennen, and what here we doon

That whan wee wenden till an other place,

Our souenance may here, ay-gayly wonne.

For, time will vnderfong vs; and our voice

Woll woxen weake; and our deuising lame;

For, life is briefe; and skils beene long, and choise:

Than, spend we Time, that Time may spare our Fame.

Look how breme Winter chamfers Earths bleeke face;

So, corbed Eld accoyes youths surquedry;

And, in the front, deepe furrowes doon enchase,

Inueloped with falling snow a hy.

Then nought can be atchieu'd with witty shewes,

Sith griefe of Elde accloyen nimble wit; perfectly, totally; drain, exhaust

reward

sweetly; a popular dance

worthless, good for nothing

print

decisions, powers of judgement

liefer: sooner, for preference

since; skilful, good

judge, value; at their true worth

know

is it for; therefore

discourses, compositions

the same grief

proverbial saying

worldly; heed

100

eyes

ay: always

fading trifles

drawn, pulled up; hell

this is; quailing, languishing

property, wealth

the rest of this ' $g o o d$ '; fleeting

take heed, conduct with care

run

go; i.e., the next world

trap, overcome

wax, grow; planning, thinking

then

hard, bitter; wrinkles, shrivels bent, bowed; daunts, silences; pride forehead; engrave

afflictions of old age; choke, impede
84 So be ... hem] even if he scrapes 87-8 Iacke a vale, Clam o'Clough] 83 Tom-piper] A bad singer in Spenser's SC, 'October' 78 crudely at the fiddle. $\mathbf{8 5}$ presse] impress, print (OED 5). heroes of popular tales, here dismissed as vulgar. 91 holy-rage] the 'sacred madness' of poetic inspiration. 92 faire skils enlawrel'd Queen] an unspecified muse-like figure. 103 Were I to do so (take heed of worldly men), I would weep my eyes away. 104 care-away ' an exclamation of merriment or recklessness' $(O E D)$. $\quad 105-8$ It is crazy to destroy oneself by useless worry, willingly sought to win ephemeral trifles, while even the poorest work of an adept intelligence is rescued by heaven from hell and borne upwards. (Almost implies that poetry can redeem humankind from the Fall.) 105 wood] mad, crazy. fore-pinde] destroyed, pined away ?totally; ?in advance. wastefull] ?wasting; ?useless. carke] worry, distress. 106 noyfull] harmful, evil. stoure] 'A time of turmoil and stress' (OED 3 , as specific to Spenser and Spenserians). willing bale] evil that is willed or desired. 113-4 our Race ... rennen] i.e. the course of our lives. 116] Our memory may dwell bright for ever. $\quad 119$ A famous saying of the ancient Gk. physician Hippocrates. Davies preserves the Gk. structure, reversed in Lat. and English ('Art is long, life is short'), and translates Gk tēchnê correctly as 'skils' rather than 'art'. 120 spend we Time] devote time to ensure, take care. on top (b) from above. 
Than, vs behouen, yer Elde sick accrewes,

Time to forelay, with spels retarding it.

I not what blisse is whelm'd with heau'ns coape

So bee the pleasance of the Muse be none:

For, when thilk gleesome ioyes han hallowed scope

They beene as those that heau'ns-folke warble on.

I con my good; for, now my scalpe is frost

Yeelding to snow; the crow-feete neere mine Eyne

Beene markes of mickle preefe I haue, that most

Of all glees else alow, han suddaine fine.

O how it garres old Wernock swynck with glee

In that emprise that chiuen featest fame,

It heats my heart aboue ability

140 To leaue parduring souenance of my name.

And whan mine Engine han heau'd hy my thought,

An that on point-deuice eftsoones y fell,

$\mathrm{O}$ ! how my heart's ioy-rapt, as I had cought

A Princedome to my share, of thilk Newell.

They beene of pleasances the alderbest:

Than, God to forne; I wol no mo but tho:

Tho beene the summe of all I louen best:

And for hem loue I life; else nold I so.

Driue on thy flocke than, to the motley plaines

Where by some prill, that 'mong the Pibbles plods,

Thou, with thyne Oaten reede, and queintest straines,

Maist rapt the senior Swaines, and minor Gods:

That as on Ida that mych-famed Mount,

A Shepheard Swaine; that sung lesse soote than thou,

By light loues Goddesse, had the grace to mount

To owe the sheenest Queene that Earth did owe:

So, thou maist, with thy past'rall Minstralsy

Beating the aire, atweene resounding Hils,

Draw to thee Bonibels as smirke, as hy,

And wrap hem in thy loue begrey their wils:

For (ah) had Phobus Clarkes the meanes of some

Worse Clarkes (paravnter) so to sing at ease;

They soone would make high long-wing'd haggards come

do not know; covered; cope, vault if it be that; delight delightful; have

know; head

strong proof

makes; labour

cheves, gains

lasting memory

ingenuity, skill; raised

caught, obtained

best of all

before God

them; I would not do so variegated (with flowers) rill; ?flows slowly

most skilful or elegant wood-gods, not the Olympians

and vaile vnto their Lures: so, on hem seise.

For, bright Nymphes buxume Breastes do eas'ly ope

To let in thirling notes of noted laies,

For, deftly song they han a charming scope;

So, Nymphs themselues adore Brows girt with Bayes.

Than, Willy (ah for pitty of thine heart

That drouping yearnes, at misses of these times)

boon, favour; rise

own, possess; most beautiful

?striking the air with your notes beauties; attractive, smart; high-born

127] It behoves us, before we are overtaken by old age. accrewes] gathers. $\mathbf{1 2 8}$ forelay] (a) frustrate (b) anticipate, guard against. spels] (a) magic spells (b) compositions, poems. 129-32 I do not know what bliss there might be under heaven if not the joy of poetry: for if those joys (poems) are given blessed scope, they resemble the songs that the angelic choirs sing. 133-4 frost / yeelding to snow] grizzled, turning to white. 135-6 most ...fine] Almost all earthly pleasures other than poetry have sudden end. 136 alow] down below, earthly. 138 In the enterprise that gains fittest or highest fame. $\mathbf{1 4 2}$ If it quickly achieves perfection. $\quad \mathbf{1 4 4} \mathrm{Newell}]$ novelty $\left(O E D\right.$ newel $\mathrm{n}^{2}$, citing this passage): ?value, lustre. 146 I wol ... tho] I wish for nothing but that. 153-6 Paris, prince of Troy, while living as a shepherd on Mount Ida for love of the nymph Oenone, judged Venus the fairest of three contending goddesses and was granted Helen of Troy as reward. 160 begrey] ?by grace of (OED, citing this passage only, suggests error for malgré, in spite of.) $\quad$ 161-8 If poets had the wealth that priests have, they would draw proud high-born women to them as falconers call hawks, for the soft breasts of pretty young women are easily affected by fine songs as by a magic spell, and they adore poets crowned with laurels. 161-62 Phobus Clarkes] priests of Phoebus or Apollo, god of poetry - i.e. poets. the meanes of some / Worse Clarkes] the wealth of worse (i.e. actual) priests. The Spenserians inclined to Puritanism and attacked the Anglican establishment. 163 high] proud. long-wing'd] Long-winged falcons (as opposed to short-winged hawks) were 'noble' birds that could only be kept by the aristocracy, to hunt for sport and not for food. haggards] female hawks caught as adults in the wild state, hence the most spirited. 164 vaile] descend. Lure] a device of a bunch of feathers, used by falconers to recall their birds. 
Take thou thy Pipe, and of glee take thy part;

Or cheere thy selfe with cordials of thy Rimes.

(a) joy (b) glee-song, song of many 'parts'

Before the worlds sterne face, the world backe-bite

So slyly that her parts ne'it perceiue:

do not perceive it

Morall thy matter so, that, tho thou smite,

Thou maist with tickling her dull sence deceiue.

Than hy thee, Willy, to the neighbour wasts

Where thou (as in another world alone)

Maist (while thy flocke do feede) blow bitter blasts

On thy loudst Pipe, to make ils pertly knowne.

For, sith the rude-crude world doon vs misplease

That well deseruen, tell wee hur hur owne;

And let her ken our cunning can, with ease,

Aye shend, or lend hur sempiterne renowne.

Willy. Ah Wernocke, so thy sawes mine heart downe thril

With loue of Muses skill in speciall,

That I ne wot, on mould what feater skill

Can bee yhugg'd in Lordings pectorall.

Ne would I it let-bee for all the store

In th'vncoth scope of both-twain hemispheres;

Ynough is mee, perdy, nor striue for more

But to be rich in hery for my leeres.

Ne would I sharen that soule-gladding glee

In th'euer gaudy Gardens of the blest

Not there to han the Muses companee,

Which, God to-fore, is of the best, the best.

Now, Wernock, shalt thou see (so mote I thee)

That I nill vsen any skill so mytch

(Faire fall my swinck) as this so nice, and free,

In case I may my name to Heauen stitch.

For why, I am by kind so inly pulde

To these delices; that when I betake

My selfe to other lore I more am dul'd;

And therefro, keenely set, I fall to make.

But, well-away, thy nis the way to thriuen;

And my neer kith for that wol sore me shend,

Who little reck how I by kind am giuen

But hur wold force to swinck for thriftier end.

Hence forward then I must assay, and con

My leere in leefull lore, to pleasen them

That, sib to mee, would my promotion,

And carke for that to prancke our common Stemme:

For, now (as wends the world) no skill to that

(Or rather but that) thriues; sith Swaines are now

So full of contecke, that they wot ne what

They would; so, if they could; they all would owe.

So fares it in calme seasons with curst men;

If freenes forbeare, at home, hem to inuade,

their (the objects of satire)

neighbouring, adjoining

[wasts: wastes, commons, open fields

apertly, openly

180

speak frankly to her

know; skill, learning

shame, disgrace; eternal

doon, old plural of do

do not know; soil, earth; fitter

embraced; breast

wealth, treasures

praise, fame; learning, skill

bright, beautiful

have

before God; the very best of all and so may I (see) you

do not wish to; much

labour; dainty, elegant; noble

?so that; ?attach, reach up

nature; drawn from the heart

delights

eagerly; devote myself to composing poetry alas; is not

near relations, family; scold consider; nature, temperament her, i.e. nature; toil; more lucrative con My leere: ply my studies (a) lawful, approved (b) legal (studies) related; wish for; advancement, success labour; adorn, glorify;

[family, lineage goes

shepherds, rustics strife, contention; know wish for

(a) foreigners (b) enemies

172 cordial] drink or medicine to strengthen the heart. $\quad$ 175-6 Put moral (i.e. satirical) matter in your poems in such a way that, though you hit hard, the foolish targets think you are flattering (tickling) them. $\quad \mathbf{1 8 5}$ so ... thril] Your utterances thrill my heart to the core in such a way. $\mathbf{1 8 7 - 8}$ I do not know what better skill on earth can be contained within an aristocrat's breast. $\quad \mathbf{1 9 0}$ across the unknown expanse of both hemispheres. 191 This is enough to make me desist from seeking more. 199 Faire ... swinck] So may my labours prosper. 201-12 Therefore I am, of my nature, so deeply attracted to these pleasures (of poetry) that I am bored when I turn to other matters; hence I eagerly turn to composing poetry. But alas, poetry does not bring wealth; hence my relatives scold me, caring little for my natural bent, and would force me to turn to some more lucrative pursuit. So I must proceed with their approved studies, to please my relatives that wish for my advancement, toiling for the greater glory of my family line. 213-6 The world is now such that no skill thrives as much as that (making money), or indeed except that. Even common rustics have grown so contentious that they do not know what they want; hence they wish to possess everything if they can. 218-20 If foreign powers do not invade them, they disturb their peace by bringing lawsuits against each other until they die. 
They wry their peace to noy each other then

twist, distort

By plees, till they decease, or fall, or fade.

So times beene keener now with common Swaynes

Than whan as forraigne foe-men with hem fought:

For, now they swyncke, but for slye Law-mens gaines

pleas, lawsuits

more harsh or distressful

Or seld they should possessen what they ought.

But, what for this? to mee it little longs

To gab of sikliche notes of misery;

Ynough is mee to chaunten swoote my songs,

And blend hem with my rurall mynstrelsy.

But, ô (my Wernock) how am I to thee

230 Obligen, for thy keene reencouragements

encouragements

To skill so mickle lou'd and sought of mee

As this of making with Arts Elements?

I not how I shall thriue therein; ne how

I shall be dempt of in these nicer times:

But how soere so thou my workes alow,

I nill bee ill-apaiden with my Rimes.

Wernock. Thou nedst not, Willy; wretch were I to laude

Thee in thy misses: for, I so should bee

To th'adultries of thy wits-scapes, but a Baude

$\mathrm{Ne}$, as a friend, in sentence, should bee free.

Than, wend thou fairely on, with thyne emprise;

Sing cleerely, Will, on mine encouragement,

And other Swaines, more able to deuise;

go, proceed; enterprise, programme

And, fixe thee for it, in the firmament.

compose (poetry)

Ynough is mee so I may beare a part

Aye in the Muses Quire with those and thee;

Il'e sing (at ease) aloud, with cheerefull hart,

No base ne meane but Tenor of best glee. No ... ne neither ... nor; middle; tune, melody

Willy. And I, with thee, woll chaunt each counter-verse

So shrilly that wee'l make thilk Quire to ring

As euer do the Angels; who rehearse

do not know; nor

deemed, judged; more fastidious or critical

The loudest lauds of heau'ns-Lord whan they sing.

So, farewell, Wernock, mickle thankes to thee

For thy freedome, that canst so well deuise:

Phobus now goes to glade; than now goe wee,

toil

belongs, befits

chatter, babble; suchlike

Vnto our sheddes to rest vs till he rise.

Wernock. Agree'd, deere Willy, gent and debonaire,

Wee'l hence: for, rhumaticke now fares the Aire.

\section{George Wither The Shepherd's Hunting, Eclogue V}

First published in the collection The Shepheards Pipe (1614, with eclogues by William Browne, Christopher Brooke and John Davies of Hereford); then as Eclogue V in Wither's The Shepherds Hunting (1615), whose text is followed below. Roget is (George) Wither; Alexis, William Ferrar, Wither's contemporary at the Inns of Court. In Wither's Juvenilia (1622 et seqq.), Roget becomes Philarete (lover of virtue), the name of Wither's persona in Fair-Virtue. A notable combination of pastoral and satire: apparently poles apart, but sharing the humbler end of the spectrum of literary genres, with a common legacy of rude, rustic diction. The shepherd and the hunter were also sometimes compared though more usually contrasted. Wither associates the two in a sharper paradox than usual.

To Master W. F. of the Middle Temple.

The fift Eglogue.

$\mathbf{2 2 4}$ Otherwise they could seldom retain possession of what they own. $\quad 232$ making ... Elements] writing poetry with the qualities of, or in accord with the principles of, art. 235 alow] ?allow, praise (OED 1); ?a-low, lower or denigrate. General sense: 'however you may judge of my work'. 236 I will not be ill-repaid by my verses - i.e. they will be their own reward. 237-40 You need not be afraid of not obtaining reward; for if your songs were really bad, I would be a wretch to praise your defects in this way. In that case, I would be nothing better than a bawd to your prostituted wit, whereas a friend $\begin{array}{lr}\text { should be frank in his judgement. } \quad 244 \text { And turn you into a star (the ultimate mark of fame). } & 257\end{array}$ gent] gentle, noble: significantly used of a lowly shepherd. debonaire] 'gracious, kindly' $(O E D) . \quad 0.1$. W.F. William Ferrar 
Argvment.

Roget here ALEXIS moues,

To embrace the Muses loues;

Bids him neuer carefull seeme

full of care, distressed

Of anothers disesteeme:

Since to them it may suffize,

That themselues can iustly prize.
Roget.
Alexis.

Roget. Alexis if thy worth doe not disdaine

The humble friendship of a meaner Swain;

Or some more needful busines of the day

Vrge thee to be too hasty on thy way;

Come (gentle Shepheard) rest thee here by me,

Vnder the shadow of this broad-leau'd tree:

For though I seeme a stranger, yet mine eye

Obserues in thee the markes of curtesie:

And if my iudgement erre not, noted too

More then in those that more would seeme to doe;

Such vertues thy rare modesty doth hide

Which by their proper luster I espy'd;

And though long mask'd in silence they haue beene

I haue a wisedome through that silence seene:

Yea, I haue learned knowledge from thy tongue,

And heard when thou hast in concealement sung:

Which me the bolder and more willing made

Thus to inuite thee to this homely shade.

And though (it may be) thou couldst neuer spye

Such worth in me I might be knowne thereby,

In thee I doe; for here my neighbouring sheepe

Vpon the border of these downes I keepe:

Where often thou at Pastorals and playes,

Hast grac'd our Wakes on Summer Holy-dayes:

And many a time with thee at this cold spring

Met I to heare your learned shepheards sing,

Saw them disporting in the shady groues,

And in chaste Sonnets wooe their chaster loues:

When I, endued with the meanest skill,

Mongst others haue beene vrg'd to tune my quill,

Where (cause but little cunning I had got)

Perhaps thou saw'st me, though thou knew'st me not.

Alexis. Yes Roget, I doe know thee and thy name,

Nor is my knowledge grounded all on fame,

Art not thou hee, that but this other yeere,

Scard'st all the Wolues and Foxes in the sheere?

And in a match at Foot-ball lately try'd

(Hauing scarce twenty Satyres on thy side)

Held'st play; and though assailed, kept'st thy stand

Gainst all the best-try'd Ruffians in the land?

Did'st thou not then in dolefull Sonnets mone,

When the beloued of great Pan was gone;

And at the wedding of faire Thame and RHine,

Sing of their glories to thy Valentine?

I know it, and I must confesse that long

In one thing I did doe thy nature wrong:

o.8-9 They that can appreciate their own true worth are sufficiently rewarded. $\quad 10$ More worth in you than those who apparently promise more. 35-40 Alluding to his earlier satires, chiefly the twenty (38) in Abuses Strip and Whipt (1613: perhaps an earlier, suppressed edition in 1611), which landed him in prison. $\quad \mathbf{4 2}$ beloued of great Pan] Prince Henry, whose death Wither mourned in Prince Henries Obsequies (1612). Great Pan] ?God; ?King James. 43 wedding of faire ThAME and RHINE] of King James's daughter Elizabeth and Frederick V, Count Palatine, celebrated by Wither in Epithalamia or Nuptiall Poems (1612). $\quad 44$ to thy Valentine] The wedding took place on Valentine's Day. Wither's Epithalamia includes an address to a supposed valentine. 
For till I markt the aime thy Satyres had,

I thought them ouerbold and Roget mad;

But since I did more neerely on thee looke

closely

I soone perceiu'd that I had all mistooke;

I saw that of a Cynicke thou mad'st show

Where since I finde that thou wert nothing so,

And that of many thou much blame hadst got

When as thy Innocence deseru'd it not.

But this too good opinion thou hast seem'd

To haue of me (not so to be esteem'd)

Preuailes not ought to stay him who doth feare

Hee rather should reproofes then praises heare.

'Tis true, I found thee plaine and honest to,

Which made me like, then loue, as now I doe.

And Roget, though a stranger, this I say,

Where I doe loue I am not coy to stay.

Roget. Thankes gentle Swaine that dost so soone vnfolde

What I to thee as gladly would haue tolde

And thus thy wonted curtesie exprest

In kindely entertaining this request:

Sure I should iniury my owne content

Or wrong thy loue to stand on complement,

Who hast acquaintance in one word begunne

As well as I could in an age haue done:

Or by an ouerweaning slownesse marre

What thy more wisedome hath brought on so farre.

Then sit thou downe and Il'e my minde declare

As freely, as if wee familiars were:

And if thou wilt but daigne to giue me eare

old friends, boon companions

Something thou maist for thy more profit heare.

Alexis. Willingly Roget I thy wish obey.

Roget. Then know Alexis from that very day

When as I saw thee at that Shepheards Coate

Where each I thinke of other tooke first noate,

I meane that Pastor who by Tauies springs

Chast Shepheards loues in sweetest numbers sings,

And with his Musicke (to his greater fame)

Hath late made proud the fairest Nimphs of Thame.

E'ne then mee thought I did espy in thee

Some vnperceiu'd and hidden worth to be,

Which in thy more apparant vertues shin'd

And among many I in thought deuin'd,

By something my conceit had vnderstood

That thou wert markt one of the Muses brood,

That made me loue thee: And that loue I beare

judgement, understanding

bare, bore

Begat a Pitty, and that Pitty Care:

Pitty I had to see good parts conceal'd,

Care I had how to haue that good reueal'd,

Since 'tis a fault admitteth no excuse

To possesse much and yet put nought to vse:

Heereon I vow'd (if wee two euer met)

The first request that I would striue to get

Should be but this, that thou wouldst shew thy skill,

And thou could'st

And teach thy Muse in some well trained song,

To shew the Art thou hast supprest so long:

Which if my new acquaintance may obtaine

Roget will euer honour this dayes gaine.

(a) sheepcote (b) cottage

shy, reluctant

accustomed, habitual

destroy my own peace of mind compliment, ceremony 
Alexis. Alas! my small experience scarce can tell

So much as where those Nimphes the Muses dwell,

Nor (though my slow conceit still trauels on)

Shall I ere reach to drinke of Hellicon;

Or if I might so fauour'd be to taste

What those sweet streames but ouer-flow in waste,

And touch Parnassus, where it low'st doth lye,

I feare my skill would hardly flagge so hye.

Roget. O spayre not Man, the Gods haue prized nought

fly, flutter

So deere that may not be with labour bought,

Nor need thy paine be great since Fate and Heauen

That (as a blessing) at thy birth haue giuen.

Alexis.

Why, say they had?

That: the prize

Roget. Then vse their gifts thou must,

Or be vngratefull, and so be vniust:

For if it cannot truly be deny'd,

Ingratitude mens benefits doe hide;

Then more vngratefull must he be by oddes

Who doth conceale the bounty of the Gods.

Alexis. That's true indeed, but Enuy haunteth those

Who seeking fame their hidden skill disclose:

Where else they might (obscur'd) from her espying,

Escape the blasts and danger of enuying:

Critickes will censure our best straines of Wit,

And purblinde Ignorance misconster it.

All which is bad, yet worse then this doth follow,

Most hate the Muses, and contemne Apollo.

Roget. So let them: why should we their hate esteeme?

Is't not enough we of our selues can deeme?

Tis more to their disgrace that we scorne them

Then vnto vs that they our Art contemne;

Can we haue better pastime then to see

Their grosse heads may so much deceiued be,

As to allow those doings best where wholly

We scoffe them to their face, and flout their folly:

Or to behold blacke Enuy in her prime,

Die selfe-consum'd whilst we vie liues with time:

And in despight of her, more fame attaine

Then all her malice can wipe out againe?

Alexis. Yea but if I apply'd me to those straines,

Who should driue forth my flocks vnto the plaines,

Which whilst the Muses rest and leasure craue,

Must watering, folding, and attendance haue.

For if I leaue with wonted care to cherish

Those tender heards: both I and they should perish.

leave off, neglect

Roget. Alexis now I see thou dost mistake,

There is no meaning thou thy charge forsake;

Nor would I wish thee so thy selfe abuse

As to neglect thy calling for thy Muse:

But let these two so of each other borrow,

That they may season mirth, and lessen sorrow.

Thy flocke will helpe thy charges to defray,

Thy muse to passe the long and tedious day.

Or whilst thou tun'st sweet measures to thy Reed

Thy sheep to listen will more neere thee feed,

The wolues will shun them, birds above thee sing,

And Lambkins dance about thee in a Ring;

Nay which is more: in this thy low estate

Thou in contentment shalt with Monarkes mate:

match

108 Hellicon] Helicon, the spring beneath Mount Parnassus, sacred to the Muses. $\quad 132$ of ...deeme] judge truly of our own worth. $\quad \mathbf{1 4 0}$ vie liues with time] compete in longevity with time, strive for immortal fame. 
For mighty Pan, and Ceres to vs grants

Our fields and flockes shall helpe our outward wants.

The Muses teach vs songs to put off cares,

Grac'd with as rare and sweet conceits as theirs:

And we can thinke our Lasses on the greenes

As faire, or fairer, then the fairest Queenes;

Or what is more then most of them shall doe,

170

180
Wee'le make their iuster fames last longer to,

Hauing our Lines by greatest Princes grac'd

When both their name and memory's defac'd.

Therefore Alexis though that some disdaine

The heauenly musicke of the Rurall plaine,

What is't to vs, if they (or'e seene) contemne

The dainties which were nere ordain'd for them?

And though that there be other some enuy

The praises due to sacred Poesie,

Let them disdaine and fret till they are weary,

We in our selues haue that shall make vs merry:

Which he that wants, and had the power to know it,

Would giue his life that he might dye a Poet.

Alexis. A braue perswasion.

Roget.

Here thou see'st me pent

Within the iawes of strict imprisonment;

A forlorne Shepheard, voyd of all the meanes,

Whereon Mans common hope in danger leanes:

Weake in my selfe, exposed to the Hate

Of those whose Enuyes are insatiate:

Shut from my Friends, banish'd from all delights,

Nay worse: excluded from the sacred Rites.

Here I doe liue (mongst out-lawes markt for death)

As one vnfit to draw the common breath,

Where those who to be good did neuer know

Are barred from the meanes should make them so.

I suffer, cause I wish'd my Countrey well,

And what I more must beare I cannot tell.

I'me sure they giue my body little scope,

And would allow my Minde as little Hope.

I wast my Meanes, which of it selfe is slender,

Consume my Time (perhaps my Fortunes hinder)

And many Crosses haue, which those that can

Conceaue no wrong that hurts another man

Will not take note of, though if halfe so much

Should light on them, or their owne person touch,

Some that themselues (I feare) most worthy thinke

With all their helpes would into basenesse shrinke.

But spight of Hate, and all that spight can doe,

I can be patient yet, and merry to;

That slender Muse of mine, by which my Name,

Though scarce deseru'd hath gaind a little fame,

Hath made me vnto such a Fortune borne,

That all misfortunes I know how to scorne;

Yea, midst these bands can sleight the Great'st that be

As much as there disdaine misteemes of me.

This Caue whose very presence some affrights

I haue oft made to Eccho forth delights,

And hope to turne, if any Iustice be,

Both Shame and Care on those that wisht it me:

For while the world ranck villanies affords, eloquent argument

lacking, bereft

be aware of

resources, support

bonds, fetters

their; misjudges

prison cell, dungeon

i.e., songs

163 Ceres] goddess of farming and harvests (cf. fields, 170). 166, 169-70 theirs, them, their] presumably the monarchs (162). 175 or'e seene] mistaken (OED overseen 1). 184 imprisonment] at the Marshalsea prison, for the offence given by Abuses Stript and Whipt. 190 sacred Rites] It seems he cannot carry out religious worship in prison, or maybe not in accord with his Puritan bent. 
I will not spare to paint them out in words;

Because I thus into these troubles runne,

I knew what man could act, e're I begun:

And I'le fulfill what my Muse drawes me to,

Maugre all Iayles, and Purgatories to.

For whil'st she sets me honest task's about,

Vertue or shee I know will beare me out:

And if by Fate th'abused power of some

Must in the worlds eye leaue me ouercome,

They shall finde one fort yet so fenc'd I trow,

It cannot feele a mortals ouerthrow.

This Hope and trust that great power did infuse,

what people might do to me

despite

That first inspir'd into my brest a Muse,

By whom I doe, and euer will contemne

All these ill haps, my foes despight, and them.

Alexis. Thou hast so well (young Roget) playd thy part

I am almost in loue with that sweet Art:

And if some power will but inspire my song,

Alexis will not be obscured long.

Roget. Enough kinde Pastor: But oh! yonder see

Two honest Shepheards walking hither be,

Cutty and Willy, that so dearely loue,

Who are repayring vnto yonder Groue:

Let's follow them: for neuer brauer Swaines

Made musicke to their flockes vpon these plaines.

They are more worthy, and can better tell

What rare contents doe with a Poet dwell.

Then whiles our sheep the short sweet grasse do shear,

And till the long shade of the hils appeare,

Wee'le heare them sing: for though the one be yong,

Neuer was any that more sweetly sung.

defeated

\section{George Wither From Fair-Virtue}

The opening section of Wither's Faire-Virtue, the Mistresse of Philarete (1622), a philosophical allegory cast as a pastoral romance: Philarete (lover of virtue) loves the shepherdess Fair-Virtue. There is a Platonic undercurrent, extending to the common Neoplatonic premise (not Plato's own) that aspiration to ideal virtue inspires poetry: Fair-Virtue is also Philarete's muse (see 264.) There is also a vivid recreation of Wither's native Hampshire countryside.

Two prettie Rills doe meet, and meeting make

Within one vally, a large siluer lake:

About whose bankes the fertile mountaines stood,

In ages passed brauely crownd with wood;

Which lending Cold-sweet-shadowes, gaue it grace,

To be accounted Cynthia's Bathing place.

And from her father Neptunes brackish Court,

handsomely, splendidly; timber, big trees

Faire Thetis thither often would resort,

Attended by the Fishes of the Sea,

Which in those sweeter waters came to plea.

There would the daughter of the Sea-God diue;

And thither came the Land-Nymphs euery Eue,

To wait vpon her: bringing for her browes,

Rich garlands of sweet flowres, and Beechy boughs.

Diana's

229-30 one fort ... ouerthrow] a defence so strong that it is not affected by mundane defeat. 241 Cutty] Christopher Brooke, another associate from the Inns of Court. 1 Two prettie Rills] the rivers Itchen and Arle (Alre); or perhaps the Arle and Candover Brook, both flowing into the Itchen. 2 lake] Arlesford Pond, excavated in 13-c. 8 Thetis] sea-goddess, mother of Achilles: daughter of the sea-god Nereus, but Neptune may be called her 'father' in a general patriarchal sense. 
For, pleasant was that Poole; and neere it, then,

Was neither rotten Mersh, nor boggy Fen.

It was nor ouergrowne with boystrous Sedge,

Nor grew there rudely then along the edge

A bending Willow, nor a pricky Bush,

Nor broadleafd Flag, nor Reed, or knotty Rush.

But here, wel order'd was a groue with Bowers:

There grassy plots set round about with Flowers.

Here, you might (through the water) see the land

Appeare, strowd o're with white or yellow sand.

Yonn, deeper was it; and the wind by whiffes

Would make it rise, and wash the little cliffes,

On which, oft pluming sate (vnfrighted than)

The gagling Wildgoose, and the snow-white Swan:

With all those flockes of Fowles, which to this day,

Vpon those quiet waters breed, and play.

For, though those excellences wanting be,

Which once it had; it is the same, that we

By Transposition name the Ford of Arle.

And out of which along a Chalky Marle

That Riuer trils, whose waters wash the Fort,

In which braue Arthur kept his royall Court.

North-east (not far from this great Poole) there lies

A tract of Beechy mountaines, that arise

With leasurely-ascending to such height,

40 As from their tops the warlike Ile of Wight

You in the Oceans bosome may espie,

Though neere two hundred furlongs thence it lie.

The pleasant way, as vp those hils you clime,

Is strewed o're, with Mariarome, and Thyme,

Which growes vnset. The hedge-rowes do not want

The Cowslip, violet, Primrose, nor a plant,

That freshly sents: as Birch both greene and tall;

Low Sallowes, on whose bloomings Bees doe fall;

Faire Woodbinds, which about the hedges twine;

Smooth Priuet, and the sharpesweete Eglantine.

With many moe, whose leaues and blossomes faire,

The Earth addorne, and oft perfumes the ayre.

When you vnto the highest doe attaine,

An intermixture both of Wood and Plaine

You shall behold: which (though aloft it lye)

Hath downes for sheepe, and fields for husbandry.

So much (at least) as little needeth more,

If not enough to marchandize their store.

In euery Rowe hath Nature planted there

60 Some banquet, for the hungry passenger.

For here, the Hasle-nut and Filbird growes;

There Bulloes, and a little further Sloes.

On this hand, standeth a faire weilding-tree;

On that, large thickets of blacke Cherries be.

The shrubbie fields are Raspice Orchards there,

The new fel'd woods, like Strabery-gardens are:

And, had the King of Riuers blest those hills

With some small number of such prettie Rills

As flow elsewhere, Arcadia had not seene

A sweeter plot of Earth then this had beene.

17 boystrous] ' Strong- or coarse-growing, rank' (OED 6, citing this passage). 28 Swan] As late as 1785, The Complete Gazetteer of England and Wales (London, G. Robinson \& R. Baldwin: entry on 'Alresford'), speaks of 'an abundance of swans' here. 33 Transposition] The river was originally called Alre. Ford of Arle] the town of Arlesford. 35 That Riuer] the Itchen. 35-6 the Fort ... Court] Winchester. 57-8 Enough to meet local needs, though not for sale. $\quad 61$ Filbird] filbert or cultivated hazel, often distinguished from the 'hazel' as such. 
For what offence this Place was scanted so

Of springing waters, no record doth show:

Nor haue they old tradition left, that tels;

But till this day, at fiftie fathome Wels

The Shepherds drink. And strange it was to heare

Of any Swaine that euer liued there,

Who either in a Pastorall-Ode had skill,

Or knew to set his fingers to a quill.

For, rude they were who there inhabited,

And to a dull contentment being bred,

They no such art esteem'd, nor tooke much heed

Of any thing, the world without them did

Eu'n there; and in the least frequented place

Of all these mountaines, is a little space

Of pleasant ground hemd in with dropping trees,

And those so thicke, that Phoebus scarcely sees

The earth they grow on once in all the yeere,

Nor what is done among the shaddowes there.

Along those louely pathes (where neuer came

Report of Pan, or of Apollo's name,

Nor rumour of the Muses till of late)

Some Nymphs were wandring: and by chance, or Fate

Vpon a Laund ariued, where they met

The little flocke of Pastor Philaret.

They were a troupe of Beauties knowne well nigh

Through all the Plaines of happy Britany.

A Shepheards lad was he, obscure and young,

Who (being first that euer there had sung)

In homely Verse, expressed Countrey loues;

And onely told them to the Beechy groues:

As if to sound his name he neuer ment,

Beyond the compasse that his Sheep-walke went.

They saw not him; nor them perceiued he:

For, in the branches of a Maple-tree

He shrouded sate, and taught the hollow hill

To Eccho foorth the Musique of his quill:

Whose tatling voice redoubled so the sound,

That where he was conceald, they quickly found.

And there, they heard him sing a Madrigall,

That soone betrayd his cunning to them all.

Full rude it was no doubt, but such a Song,

revealed, gave evidence of

Those rusticke and obscured shades among

Was neuer heard (they say) by any eare,

Vntill his Muses had inspir'd him there.

Though meane and plain his Country habit seemd,

Yet by his Song the Ladies rightly deemd,

That either he had trauailed abrode,

Where Swaines of better knowledge make abode.

Or else, that some braue Nimph who vs'd that Groue,

Had dained to inrich him, with her loue.

Approaching nearer, therefore, to this Swaine, outside their locality

drooping
sun-god, hence sun

lawn, clearing, glade

Britain

100

(a) travelled (b) worked
They him saluted; and he, them againe:

In such good fashion, as well seemd to be

According to their state and his degree.

Which greetings being passed, and much chat,

Concerning him, the place, with this and that;

$\mathrm{He}$, to an Arbor doth those beauties bring;

Where, he them prayes to sit, they him to sing:

And to expresse that vntaught Country Art,

In setting forth the Mistresse of his hart;

106 quill] reed-pipe, but also suggesting a pen (which becomes the dominant meaning later: see 251). 107 tatling] (a) babbling (b) tell-tale, betraying his position. $\quad 124$ i.e. mindful of his humbler station in respect of their rank. 
Which they oreheard him practise, when vnseene,

He thought no eare had witnesse of it beene.

At first (as much vnable) he refusd;

And seemed willing to haue beene excusde,

From such a taske. For, trust me Nimphs (quoth he)

I would not purposely vnciuill be,

Nor churlish in denying what you craue;

But, as I hope Great Pan my flocke will saue,

I rather wish, that I might, heard of none,

140 Enioy my Musick by my selfe alone:

Or, that the murmers of some little Flood

(Ioynd with the friendly Ecchoes of the wood)

Might be th'impartiall Vmpires of my wit,

Then vent it, where the world might heare of it.

And doubtlesse, I had sung lesse loud while-ere,

Had I but thought of any such so neere.

Not that I either wish obscurifide

Her matchlesse Beauty; or desire to hide

Her sweet perfections. For, by Loue I sweare,

150 The vtmost happinesse I ayme at here,

Is but to compasse worth enough to raise

A high-built Trophee equall with her praise.

Which (fairest ladies) I shall hope in vaine:

For, I was meanly bred on yonder Plaine.

And, though I can well prooue my Blood to be

Deriu'd from no ignoble Stems to me:

Yet Fate and Time them so obscur'd and crost,

That with their Fortunes their esteeme is lost.

And whatsoere repute I striue to win,

160 Now, from my selfe alone, it must begin.

For, I haue nor estate, nor friends, nor fame,

To purchase either credit to my name,

Or gaine a good Opinion; though I doe

Ascend the height I shall aspire vnto.

If any of those virtues yet I haue,

Which honour to my Predecessors gaue,

Ther's all that's left me. And though some contemne

Such needy lewels; yet it was for them,

My Faire-one did my humble suit affect,

170 And dayned my aduenturous loue respect.

And by their helpe, I passage hope to make

Through such poore things as I dare vndertake.

But, you may say; what goodly thing alas!

Can my despised meannesse bring to passe?

Or what great Monument of honour raise

To Virtue, in these Vice abounding dayes?

In which (a thousand times) more honor finds

Ignobly gotten meanes, then noble minds?

Indeed, the world affoordeth small reward

For honest minds; and therefore her regard

I seeke not after: neither doe I care,

If I haue blisse, how others thinke I fare.

For, so my thoughts haue rest, it yrkes not me,

Though none but I doe know how blest they be.

Her: his mistress Fair-Virtue's

Here therefore, in these groues and hidden plaines,

I pleased sit alone; and many straines

I carroll to my selfe, these hills among:

Where no man comes to interrupt my Song.

Whereas, if my rude layes make knowne I should 
Beyond their home, perhaps, some Carpers would

(Because they haue not heard from whence we be)

Traduce, abuse, and scoffe both them and me.

For, if our great and learned Shepheards (who

Are grac't with wit, and fame, and fauours to,)

With much adoe, escape vncensured may;

What hopes haue I to passe vnscoft I pray,

Who yet vnto the Muses am vnknowne?

And liue vnhonoured, heere among mine owne?

A gadding humour seldome taketh me,

To range out further then yonn mountaines be:

Nor hath applausiue Rumour borne my name

Vpon the spreading wings of sounding Fame.

Nor can I thinke (faire Nymphs) that you resort

For other purpose, then to make a sport

At that simplicitie which shall appeare

Among the rude vntutor'd Shepheards here.

I know that you my Noble Mistresse weene

At best, a homely Milk-maid on the Greene;

Or some such Country Lasse, as tasked stayes

At seruile labour vntill Holy dayes.

For, poore mens vertues so neglected grow,

And are now prized at a rate so low,

As tis impossible, You should bee brought

To let it with beleefe possesse your thought,

That any Nymph whose loue might worthy be,

Would daigne to cast respectiue eyes on me.

You see I liue, possessing none of those

Gay things, with which the world enamor'd grows.

To woo a Courtly Beautie, I haue neither

Rings, Bracelets, Iewels, nor a Scarfe, nor Feather.

I vse no double dyed Cloth to weare;

No Scrip embroydered richly doe I beare:

No silken Belt, nor Sheephooke layd with pearles,

To win me fauour from the Shepherds Girles.

No place of office, or Command I keepe,

But this my little Flocke of homely sheepe.

And in a word; the summe of all my pelfe

Is this; I am the Master of my selfe.

No doubt, in Courts of Princes you have beene,

And all the pleasures of the Palace seene.

There, you beheld braue Courtly passages,

Betweene Heroës and their Mistresses.

You, there perhaps (in presence of the King)

Haue heard his learned Bards and Poets sing.

And what contentment then, can wood, or field,

To please your curious vnderstandings yeeld?

I know, you walked hither, but to prooue

What silly Shepheards doe conceiue of loue:

Or to make triall how our simplenesse

Can passions force, or Beauties power expresse:

And when you are departed, you will ioy

To laugh, or descant on the Shepheards boy. But yet (I vow) if all the Art I had

Could any more esteeme or glory add

To her vnmatched worth; I would not weigh

What you intended. Prethee lad, quoth they,

Distrustfull of our Courtsie doe not seeme.

Her Noblenesse can neuer want esteeme;

Nor thy concealed Measures be disgrac't,

respectful, appreciative

my total wealth 
Though in a meaner person they were plac't:

If thy too-modestly reserued Quill,

i.e., someone even more lowly than you held back, hidden

But reach that height, which we suppose it will.

Thy meannesse or obscurenesse cannot wrong

The Nymph thou shalt eternize in thy Song.

For, as it higher reares thy glory, that

A noble Mistresse though hast aymed at:

So, more vnto her honour it will prooue,

That whilst deceauing shaddowes others moue,

Her constant eyes could passe vnmoued by

The subtill times bewitching brauery;

And those obscured virtues loue in thee,

That with despised meannesse clouded be.

Now then, for her sweet sake, whose Beautious eye,

Hath filled thy soule with heauenly Poesie,

Sing in her praise some new inspired straine:

And, if within our power there shall remaine

A fauour to be done may pleasure thee:

Aske, and obtaine it, whatsoere it be.

\section{George Wither Hymn for a SHEeP-Shearing}

From Wither's Haleluiah or, Britans Second Remembrancer (1641). This is Hymn XLII among the 'Hymns Occasional' constituting the first part of the book.

Hymne XLII. For a Sheep-shearing.

Sheep-shearing, is a Time of rurall Merriment, in which good-cheare is afforded to neighbors and servants; among whose Refreshings, if this or the like Meditation were sometime sung; both Knowledge and Piety, might be increased thereby.

Sing this as the 23. Psalme.

Refreshings: refreshments, feasting

Vnworthy, though, ô LoRD, we are,

Of that which thou dost give:

Yet, we much more unworthy were, Of what we do receive

If any Blessing we let slip, For which we do not pay

Such cheap Oblations of the Lip, As we present this day.

We, through thy favour now have had the Fleeces of our Sheep;

And, they are almost naked made, Our Bodies warme to keep.

Before their shearers, dumb they lay, Whil'st from their backs were shorne

Their finest Wooll; and we now may Possesse what they have worne.

Dear LAMBE of God to thee be praise, Who dost refreshings give,

So freely, and so many waies, Thy Servants to relieve.

O! let our thankfulnesse appeare, Not in bare Words alone;

But in those Works, which reall are And needfull to be done:

When any of thy Members lacks A Coat his flesh to gard;

Let us bestow, ev'n from our backs,

3-8 We fail to receive properly what you undeservedly give us, if we do not offer a prayer of thanks. 
As much as may be spar'd.

And, as our Sheep do skip as glad

When they their Fleeces give;

So, let us joy that means we had

Our Brethren to relieve.

Vs, let their Meeknesse mindfull make,

(By thinking thereupon)

How meekly, thou didst all things take,

Which were to Thee misdone.

That, all we suffer, say, or do,

May grow, in some Degree,

Reform'd, by thine Example, so,

That Blamelesse we may be.

\section{George Wither Hymn for a Shepherd}

No.XLI of Part 3, comprising 'Hymns Personall', of Wither's Haleluiah or, Britans Second Remembrancer (London, 1641). The many commas in the original have been reduced, but the haphazard italics and hyphens generally left as they stand.

Hymn XLI. For a Shepherd.

That Shepherds might not muse altogether on Drudgerie or impertinent vanities, while they are all alone, attending their Flocks, we have prepared, for them, a Pastorall-Song, to acquaint and exercise them with nobler Meditations.

Sing this as the Lamentation.

Renowned men their Herds to keep,

Delighted much in elder dayes:

And to attend their Flocks of sheep,

Great Princes thought it no dispraise,

And, while they so employed were,

Sometime, oh GoD! it pleased thee

In wondrous manner to appear,

And gracious unto them to be.

The Joyfullest-news that ere was told,

Was unto Shepherds first declar'd,

And they did also first behold

The blessing, whereof they, first, heard.

LORD! I am thine, as much as they,

(Although unworthy such respect)

Oh, let thy mercies, glorious Ray,

Vpon my low-estate reflect.

Whilst all alone, I here attend

This harmlesse Flock; let into me

Thy holy-Ghost, oh Christ! descend;

That I may therewith filled be.

And, though my heart a Stall hath bin,

Where Vice at Rack and manger lay;

Vouchsafe thou to be born therein:

That better guests possesse it may.

Lest Idle-Musings Thoughts beget

That stir up longings which are ill,

And make me my endeavour set

Forbidden Actions to fulfill,

o.2 impertinent] idle, frivolous $\left(\mathrm{OED}_{3}\right)$. $\quad 0.5$ Lamentation] presumably the musical setting for a hymn to or on the dead Christ; or for a section of the Lamentations of Jeremiah, popular with people of Puritan or low-church persuasion like Wither. 8-12 Alluding to the angels' announcing the birth of Christ to shepherds, and the shepherds' adoration of the Christ-child (Luke 2. 8-20). 22 at Rack and manger] feeding greedily, 'at the trough'. 
Vpon thy Love, and on thy Law, Let me my lovely houres employ, That I may serve with Joy-full-awe; And love thee with an awfull-Joy.

When I my stragling-sheep behold, Let me conceive what I had bin; Hadst thou not brought me to thy Fold, And fed and succour'd me therein.

And when I well consider those Who Spoilers of those creatures be; Me let it mindfull make, what Foes Do seek, to make a spoile of me.

When, likewise, I behold them shorn, And meekly yeelding up their fleece; Or, when to slaughter they are born, How patiently their lives they leese: That holy-Lambe, let me, I pray, Thereby in thankfull minding have, Who, dumbe before the Shearer lay; And slaughtred was my life to save.

Yea, whilst I watch and guide my sheep,

Be thou my Shepherd, and my Guide,

Both me, and them, from harm to keep;

And all things needfull to provide.

That when both Goats and Sheep shall stand

Before thy face, their doomes to bear;

I may be plac'd at thy Right-hand,

And Joy when I my Sentence hear.

\section{William Browne From Britannia's Pastorals Book I}

Lines 195 to the end of Book I, Song 3 of Britannia's Pastorals, prob. first published in 1613. In the preceding Song 2, Doridon was offering love to Marina when a 'cruel swain' wounds him with his sling and carries Marina away. Doridon is taken home to his mother Marinda, who obtains herbs from a hermit to cure him. This passage describes the events of the next morning, when he takes out his flock.

Two nights thus past: the Lilly-handed Morne

Saw Phobus stealing dewe from Ceres Corne.

The mounting Larke (daies herauld) got on wing

Bidding each bird chuse out his bow and sing.

bough, perch

The lofty Treble sung the little Wren;

Robin the Meane, that best of all loues men;

The Nightingale the Tenor; and the Thrush

The Counter-tenor sweetly in a bush:

And that the Musicke might be full in parts,

Birds from the groues flew with right willing harts:

But (as it seem'd) they thought (as do the Swaines,

Which tune their Pipes on sack'd Hibernia's plaines)

There should some droaning part be, therefore will'd

Some bird to flie into a neighb'ring field,

In Embassie vnto the King of Bees,

To aide his partners on the flowres and trees:

Who condiscending gladly flew along

29 Love, Law] the New and Old Testaments respectively. $\quad 53$ when ... stand] at the Last Judgement. Goats and Sheep] the saved and the damned: Matthew 25.31. 55 at thy Right-hand] with the 'sheep' or redeemed souls. $\quad 2$ i.e. The sun was drying the dew on the crops. 5 Note in margin of original text: 'A description of a Musicall Consort of birds'. 9 full in parts] containing all the 'parts of a harmonized composition. 12 Hibernia] Ireland. sack'd] ravaged, as Ireland was through unrest. 13 part] in the musical sense: the sequence in a composition sung by a particular singer. $\quad 17$ condiscending] agreeing, consenting (OED condescend 5). 
To beare the Base to his well tuned song.

The Crow was willing they should be beholding

For his deepe voyce, but being hoarse with skolding,

He thus lends aide; vpon an Oake doth climbe,

And nodding with the head, so keepeth time.

$\mathrm{O}$ true delight, enharboring the brests

Of those sweet creatures with the plumy crests.

Had Nature vnto man such simpl'esse giuen,

He would like birds be farre more neere to heauen.

But Doridon well knew (who knowes no lesse?)

"Mans compounds haue o'er throwne his simplenesse."

None-tide the Morne had woo'd, and she gan yeeld,

When Doridon, (made ready for the field,)

Goes sadly forth (a wofull Shepheards Lad)

Drowned in teares, his minde with griefe yclad,

To ope his fold and let his Lamkins out,

(Full iolly flocke they seem'd, a well fleec'd rout)

Which gently walk'd before; he sadly pacing,

Both guides and followes them towards their grazing.

When from a Groue the Wood-Nymphs held full deare

Two heauenly voyces did intreat his eare,

And did compell his longing eyes to see

What happy wight enioyd such harmonie.

Which ioyned with fiue more, and so made seauen,

Would paralell in mirth the Spheares of heauen.

To haue a sight at first he would not presse,

For feare to interrupt such happinesse:

But kept aloofe the thicke growne shrubs among,

Yet so as he might heare this wooing Song.

FIDA. Fye Shepheards Swaine, why sitst thou all alone, Whilst other Lads are sporting on the leyes?

REMOND. Ioy may haue company, but Griefe hath none: Where pleasure neuer came, sports cannot please.

FIDA. Yet may you please to grace our this dayes sport, Though not an actor, yet a looker on.

$R E M O N D$. A looker on indeed, so Swaines of sort

Cast low, take ioy to looke whence they are throwne?

FIDA. Seeke ioy and finde it.

REMOND. Griefe doth not minde it.

\section{BOTH.}

Then both agree in one,

Sorrow doth hate

To haue a mate;

"True griefe is still alone."

his: the bird's

brawling, railing

dwelling in feathered

slowly, subduedly

appeal to, address

leas, meadows

as; by fate

care for, think of doing

FIDA. Sad Swaine areade, (if that a Maide may aske?)

What cause so great effects of griefe hath wrought?

tell, inform

REMOND. Alas, Loue is not hid, it weares no maske;

To view 'tis by the face conceiu'd and brought.

FIDA. The cause I grant: the causer is not learned:

Your speech I doe entreat about this taske.

REMOND. If that my heart were seene, 'twould be discerned;

And Fida's name found grauen on the caske.

purpose, end

exterior

28 Pun on compound and simple in the chemical sense. compound] ?dealings, negotiations (no such noun in $O E D$, but many relevant senses of the verb). 34 rout] herd (of animals: $O E D$ 1b). 4 1-2 Spheares of heauen] In the Ptolemaic system, the crystalline spheres in which the heavenly bodies were thought to be set. seauen] sun, moon, and the five planets then known (excluding the spheres of the fixed stars and the first mover or primum mobile). mirth] melody (OED 2). The spheres made sweet music as they turned, though inaudible to human ears. 45 aloofe] apart, at a distance (OED 2). 64 It is made visible in the [lover's] face. 65 i.e. I can see you are in love, but do not know for whom. 
FIDA. Hath Loue young Remond moued? REMOND. 'Tis Fida that is loued. BOTH.

Although 'tis said that no men Will with their hearts, Or good chiefe parts Trust either Seas or Women.

FIDA. How may a Maiden be assur'd of loue, Since falshood late in euery Swaine excelleth? REMOND. When protestations faile, time may approue Where true affection liues, where falshood dwelleth.

FIDA. The truest cause elects a Iudge as true: Fie, how my sighing, my much louing telleth.

$R E M O N D$. Your loue is fixt in one whose heart to you Shall be as constancy, which ne'er rebelleth.

FIDA. None other shall haue grace.

$R E M O N D$. None else in my heart place. BOTH.

Go Shepheards Swaines and wiue all, For Loue and Kings Are two like things Admitting no Corriuall.

As when some Malefactor iudg'd to die For his offence, his Execution nye, Casteth his sight on states vnlike to his, And weighs his ill by others happinesse: So Doridon thought euery state to be Further from him, more neere felicitie.

O blessed sight, where such concordance meetes,

Where truth with truth, and loue with liking greetes.

Had (quoth the Swaine) the Fates giuen me some measure

Of true delights inestimable treasure,

I had bene fortunate; but now so weake My bankrupt heart will be inforc'd to breake.

Sweet Loue that drawes on earth a yoake so euen;

Sweet life that imitates the blisse of heauen;

Sweet death they needs must haue, who so vnite

That two distinct make one Hermaphrodite:

Sweet loue, sweet life, sweet death, that so do meet

On earth; in death, in heauen be euer sweet!

Let all good wishes euer waite vpon you,

And happinesse as hand-maid tending on you.

Your loues within one centre meeting haue!

One houre your deaths, your corps possesse one graue!

Your names still greene, (thus doth a Swaine implore)

Till time and memory shall be no more!

Herewith the couple hand in hand arose,

And tooke the way which to the sheep-walke goes.

And whilst that Doridon their gate look'd on,

His dogge disclos'd him, rushing forth vpon

A well fed Deere, that trips it o'er the Meade,

As nimbly as the wench did whilome tread

On Ceres dangling eares, or Shaft let goe

By some faire Nymph that beares Diana's Bowe.

When turning head, he not a foote would sturre,

Scorning the barking of a Shepheards curre:

So should all Swaines as little weigh their spite, higher or worthier faculties

exceeds, is preponderant declarations, avowals; prove

take wives, marry with partners so evenly balanced

104 Hermaphrodite] the composite bisexual form iconographically presented as the highest fulfilment of love: see, e.g., Spenser, FQ III.xii.46 (1590 text), IV.x.41. 109 May your two loves meet at a single point. 118-19 Like the young woman who had run lightly over the growing crops a while ago. Ceres] goddess of harvests. 
Who at their songs do bawle, but dare not bite.

Remond, that by the dogge the Master knew,

Came backe and angry bad him to pursue;

Dory (quoth he) if your ill-tuter'd dogge

Haue nought of awe, then let him haue a clogge.

Do you not know this seely timerous Deere,

(As vsuall to his kinde) hunted whileare,

[awe: respect, sense of fitness

a device to restrain an animal

simple and innocent

a while ago

The Sunne not ten degrees got in the Signes,

Since to our Maides, here gathering Columbines,

She weeping came, and with her head low laid

In Fida's lap, did humbly begge for aide.

Whereat vnto the hounds they gaue a checke,

And sauing her, might spie about her necke

A Coller hanging, and (as yet is seene)

These words in gold wrought on a ground of greene:

Maidens: since 'tis decreed a Maid shall haue me,

Keepe me till he shall kill me that must saue me.

But whence she came, or who the words concerne,

We neither know nor can of any learne.

Vpon a pallat she doth lie at night,

Neere Fida's bed, nor will she from her sight:

Vpon her walkes she all the day attends,

And by her side she trips where ere she wends.

Remond, (replide the Swaine) if I haue wrong'd

Fida in ought which vnto her belong'd:

I sorrow for't, and truely doe protest,

As yet I neuer heard speech of this Beast:

Nor was it with my will; or if it were,

Is it not lawfull we should chase the Deere,

That breaking our inclosures euery morne

Are found at feede vpon our crop of corne?

Yet had I knowne this Deere, I had not wrong'd

Fida in ought which vnto her belong'd.

I thinke no lesse, quoth Remond; but I pray,

Whither walkes Doridon this Holy-day?

Come driue your sheepe to their appointed feeding,

And make you one at this our merry meeting.

Full many a Shepheard with his louely Lasse,

Sit telling tales vpon the clouer grasse:

There is the merry Shepheard of the hole;

Thenot, Piers, Nilkin, Duddy, Hobbinoll,

Alexis, Siluan, Teddy of the Glen,

Rowly, and Perigot here by the Fen,

With many more, I cannot reckon all

That meet to solemnize this festiuall.

I grieue not at their mirth, said Doridon:

Yet had there beene of Feasts not any one

stopped, called off

relate or refer to

Appointed or commanded, you will say,

"Where there's Content 'tis euer Holy-day."

Leaue further talke (quoth Remond) let's be gone,

Ile helpe you with your sheepe, the time drawes on.

Fida will call the Hinde, and come with vs.

Thus went they on, and Remond did discusse

Their cause of meeting, till they wonne with pacing

The circuit chosen for the Maidens tracing.

It was a Roundell seated on a plaine,

That stood as Sentinell vnto the Maine,

count

Enuiron'd round with Trees and many an Arbour,

explain, inform of

dancing ring; situated

130 As ... kinde] as is the common fate of his species. $\quad \mathbf{1 3 1}$ i.e. before the day was advanced. Signes] zodiac. 133 She] So henceforth, though earlier 'he': explicitly a 'Hinde' in $175 . \quad 170-72$ Even if there were no formal feasts or holidays, the happy mind would create such. 178 tracing] dancing $\left(O E D\right.$ trace $\left.\mathrm{v}^{1} 2\right)$. $\quad \mathbf{1 8 0}$ Maine] ?plain, stretch of ground $(O E D 5 \mathrm{c})$. But the later narrative indicates the setting is not far from the sea, so maine might refer to that. 
Wherein melodious birds did nightly harbour:

And on a bough within the quickning Spring,

take shelter

Would be a teaching of their young to sing;

Whose pleasing Noates the tyred Swaine haue made

To steale a nappe at noone-tide in the shade.

Nature her selfe did there in triumph ride,

And made that place the ground of all her pride.

Whose various flowres deceiu'd the rasher eye

In taking them for curious Tapistrie.

A siluer Spring forth of a rocke did fall,

That in a drought did serue to water all.

Vpon the edges of a grassie bancke,

A tufte of Trees grew circling in a rancke,

row

As if they seem'd their sports to gaze vpon,

Or stood as guard against the winde and Sunne:

So faire, so fresh, so greene, so sweet a ground

The piercing eyes of heauen yet neuer found.

Here Doridon all ready met doth see,

(Oh who would not at such a meeting be?)

Where he might doubt, who gaue to other grace,

Whether the place the Maides, or Maides the place.

Here gan the Reede, and merry Pag-pipe play,

Shrill as a Thrush vpon a Morne of May,

(A rurall Musicke for an heauenly traine)

And euery shepheardesse danc'd with her Swaine.

As when some gale of winde doth nimbly take

A faire white locke of wooll, and with it make

Some prettie driuing; here it sweepes the plaine:

There staies, here hops, there mounts, and turnes againe:

(a) place, location (b) cause (more) careless

Yet all so quicke, that none so soone can say

That now it stops, or leapes, or turnes away:

So was their dancing, none look'd thereupon,

But thought their seuerall motions to be one.

A crooked measure was their first election,

growing, burgeoning

Because all crooked tends to best perfection.

And as I weene this often bowing measure,

Was chiefly framed for the womens pleasure.

Though like the ribbe, they crooked are and bending,

220 Yet to the best of formes they aime their ending:

Next in an (I) their measure made a rest,

Shewing when Loue is plainest it is best.

Then in a $(Y)$ which thus doth Loue commend,

Making of two at first, one in the end.

And lastly closing in a round do enter,

Placing the lusty Shepheards in the center:

About the Swaines they dauncing seem'd to roule,

As other Planets round the Heauenly Pole,

Who by their sweet aspect or chiding frowne,

230 Could raise a Shepheard vp, or cast him downe.

Thus were they circled till a Swaine came neere,

And sent this song vnto each Shepheards eare:

The Note and voyce so sweet, that for such mirth,

The Gods would leaue the heauens, and dwell on Earth.

fit for a heavenly company

wafting, blowing

separate, individual

choice

placed in a circular order

203 Pag-pipe] bagpipe (not in $O E D$ ). 216 Because curves and windings are parts of a circle, the symbol of perfection. $\quad 217$ bowing] (a) bending or curving (b) the male dancers' bows to their partners. 219 ribbe] Eve was created out of Adam's rib. 227 roule] trace a circular course (OED roll $\mathrm{v}^{2} 10 a$, with ref. to heavenly bodies). 229 aspect] astrological influence of stars and planets. 
Happy are you so enclosed,

May the Maides be still disposed

In their gestures and their dances,

always

So to grace you with intwining,

That Enuy wish in such combining

Fortunes smile with happy chances.

Here it seemes as if the Graces

Measur'd out the Plaine in traces,

In a Shepheardesse disguising.

Are the Spheares so nimbly turning?

Wandring Lampes in heauen burning, To the eye so much intising?

enticing, attractive

Yes Heauen meanes to take these thither,

And adde one ioy to see both dance together.

thither: to heaven

Gentle Nymphes be not refusing,

Loues neglect is times abusing;

They and beauty are but lent you,

Take the one and keepe the other:

Loue keepes fresh, what age doth smother.

Beauty gone you will repent you.

Twill be said when yee haue proued,

Neuer Swaines more truely loued:

$O$ then flye all nice behauiour.

Pitty faine would (as her dutie)

Be attending still on beautie

Let her not be out of fauour.

tested, experienced

coy, fastidious

disdained, neglected

Disdaine is now so much rewarded,

That Pitty weepes since shee is vnregarded.

The measure and the Song here being ended:

Each Swaine his thoughts thus to his Loue commended.

The first presents his Dogge, with these:

When I my flocke neere you doe keepe,

And bid my Dogge goe take a Sheepe,

He cleane mistakes what I bid doe,

catch, seize, round up

And bends his pace still towards you.

Poore wretch, he knowes more care I keepe

To get you, then a seely sheepe.

The second, his Pipe, with these:

Bid me to sing (faire Maide) my Song shall proue

There ne'er was truer Pipe sung truer Loue.

The third, a paire of Gloues, thus:

These will keepe your hands from burning,

Whilst the Sunne is swiftly turning;

But who can any veile deuise

To shield my Heart from your faire Eyes?

239 That Enuy wish] i.e. even Envy wishes. $\quad \mathbf{2 4 2}$ covered the entire plain with their dance-tracks. $\mathbf{2 4 8}$ both] the shepherds' dance alongside the 'dance' of the planets. 250 To neglect love is to abuse the gift of time, i.e. youth. $\quad 251$ They] presumably love and time or youth. $\quad \mathbf{2 5 4}$ Once your beauty has gone, you will be sorry. 
The fourth, an Anagram.

MAIDEN

AIDMEN.

Maidens should be ayding Men,

And for loue giue loue agen:

Learne this lesson from your Mother,

One good wish requires another.

They deserue their names best, when

Maides most willingly ayd Men.

The fift, a Ring, with a Picture in a Iewell on it.

Nature hath fram'd a Iemme beyond compare,

The world's the Ring, but you the Iewell are.

The sixt, a Nosegay of Roses, with a Nettle in it.

Such is the Posie, Loue composes;

A stinging Nettle mixt with Roses.

The seauenth, a Girdle.

This during light I giue to clip your wast,

Faire, grant mine armes that place when day is past.

daylight; engird, embrace

The Eight

You haue the substance, and I liue

with the design of a heart

But by the shadowe which you giue.

Substance and shadowe, both are due

And giuen of me to none but you.

Then whence is life but from that part

Which is possessor of the hart.

The Nynth

This Hooke of right belongs to you, for when

I take but seelie Sheepe, ye still take Men.

with a sheephook

capture

The Tenth

Louelie maiden best of any

Of our plaines though thrice as many:

Vaile to loue, and leaue denyeing,

Endles knotts lett fates be tyeing.

Such a face, so fyne a feature

(Kindest fairest sweetest creature)

Neuer yet was found, but louing:

$O$ then lett my plaintes be mouing.

Trust a shepheard though the meanest.

Truth is best when shee is plainest.

I loue not with vowes contesting:

Fayth is fayth without protesting.

Time that all thinges doth inheritt

Renders each desert his merritt.

If that faile in me, as noe man,

Doubtles tyme nere wonne a woman

Maidens still should be relentinge,

And once flinty, still repentinge.

Youth with youth is best combyned.

Each one with his like is twyned.

Beauty should haue beautious meaning.

with a comb

Vaile: submit, surrender

except it be

swearing on oath

Euer the hope easeth playninge.

293 Posie] (a) a bunch of flowers or nosegay (b) a short verse for a ring or device. $\quad 310$ Even if (a) there had been three times as many maidens (b) our plains had been three times as extensive. $\quad 316$ Let my pleas move you. $\quad 317$ meanest] ?among shepherds; ? among men $\quad \mathbf{3 2 6}$ And if they are once hard-hearted, they will always regret it. 330 Hope always eases grief. 
Vnto you whome Nature dresses

Needs no combe to smooth your tresses.

This way yt may doe his dutie

In your locks to shade your beautie.

Doe soe, and to loue be turninge

Else each hart it will be burninge.

The Elleuenth.

This is loue and worth commending,

with a love-knot

Still beginning neuer ending,

Like a wilie net insnaring

In a round shuts $v p$ all squaring.

In and out, whose euerie angle

More and more doth still intangle.

Keepes a measure still in mouing,

And is neuer light but louinge.

Twyning armes exchanging kisses,

Each partaking others blisses.

Laughing, weepinge still togeather,

Blisse in one is mirth in either.

Neuer breaking neuer bending,

This is loue and worth commending.

The Twelfth

Loe Cupid leaues his bowe, his reason is

with a figure of Cupid with a bow

Because your eyes wounde when his shafts doe misse.

Whilst euery one was offring at the shrine

Of such rare beauties might be stil'd diuine:

This lamentable voyce towards them flyes:

O Heauen send aid, or else a Maiden dyes!

Herewith some ranne the way the voyce them led;

Some with the Maidens staid which shooke for dread:

What was the cause time serues not now to tell.

Hearke; for my iolly Wether rings his bell,

And almost all our flockes haue left to graze,

Shepheards 'tis almost night, hie home apace.

When next we meet (as wee shall meet ere long)

Ile tell the rest in some ensuing Song.

[The figures in the original edition are given on the following pages] 
The firft prefents his Dogge, with thefe:

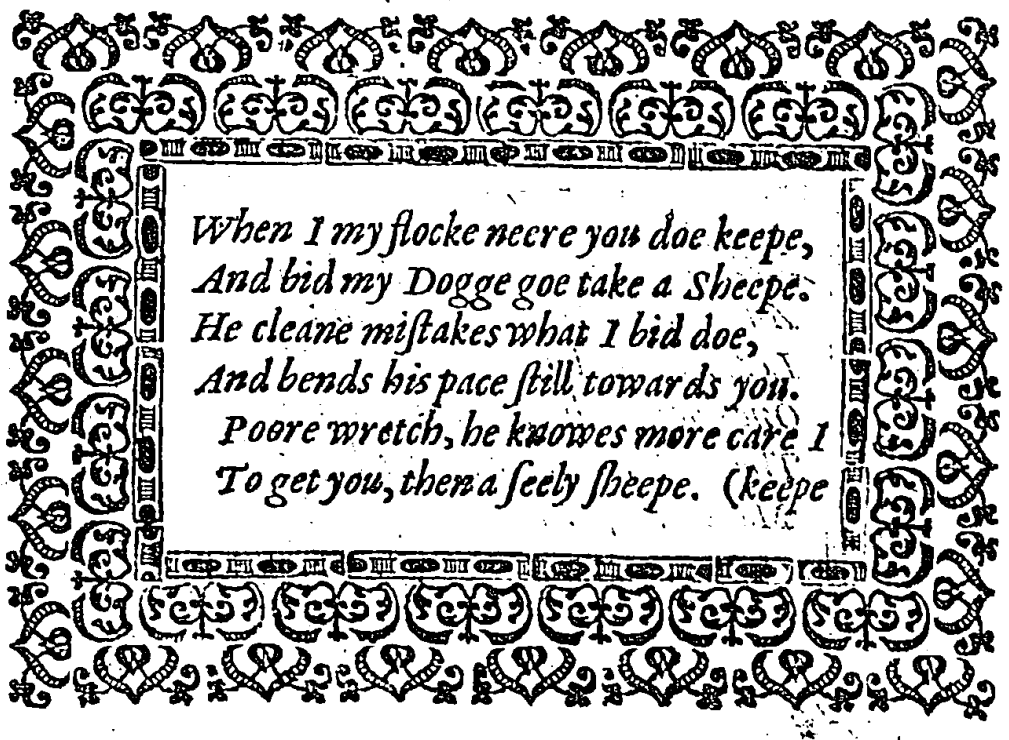
The fecond, his Pipe, with thefe:

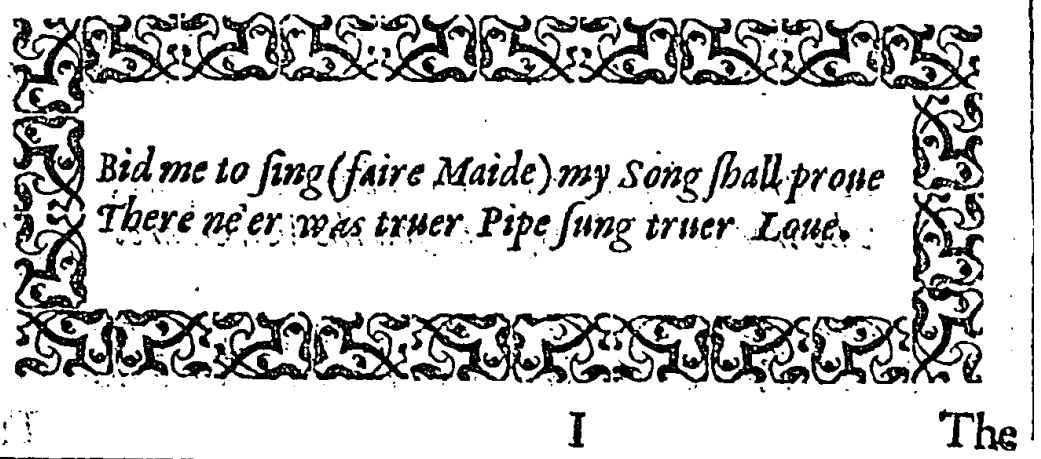

Figure 1 
The third, a paire of Gloues, thus :

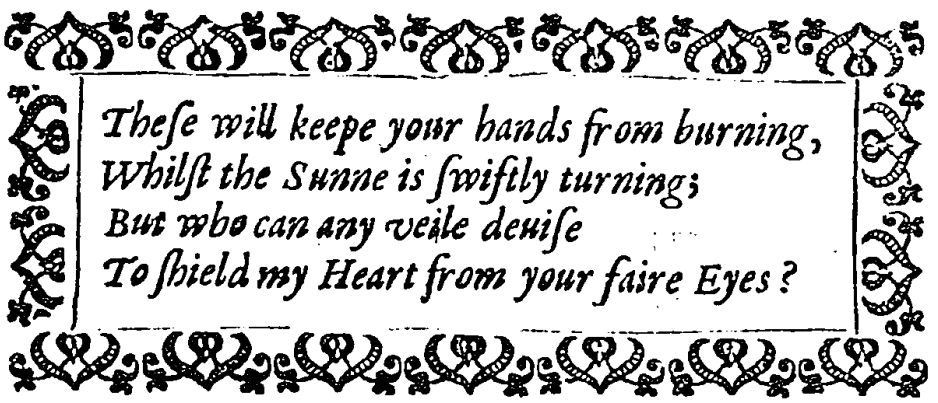

The fourth, an Anggram. MAIDEN A ID $M E N$.

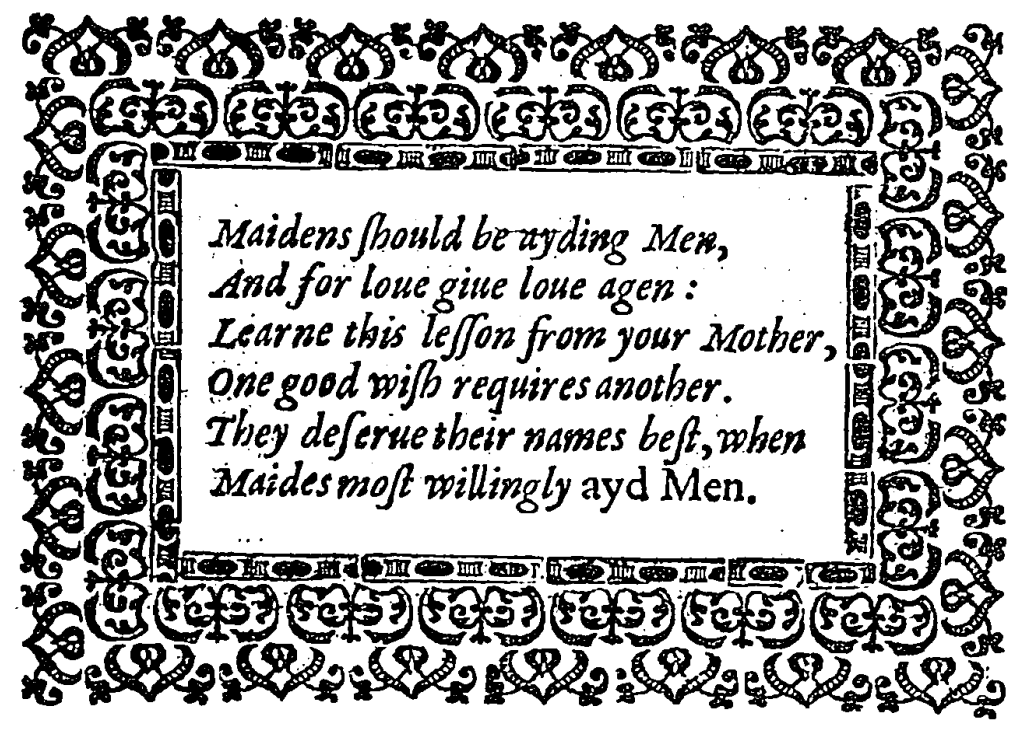

Figure 2 


\title{
The fift, a Ring, with a Piqure in a lewell on it.

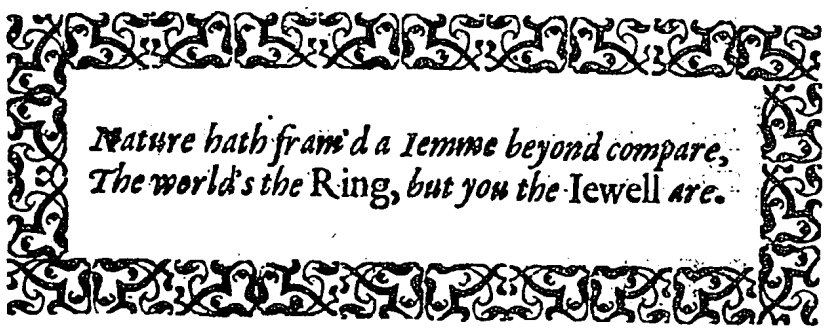

Figure 3

\author{
The fixt, a Nofegay of Rofes, with \\ a Nettle in it.
}

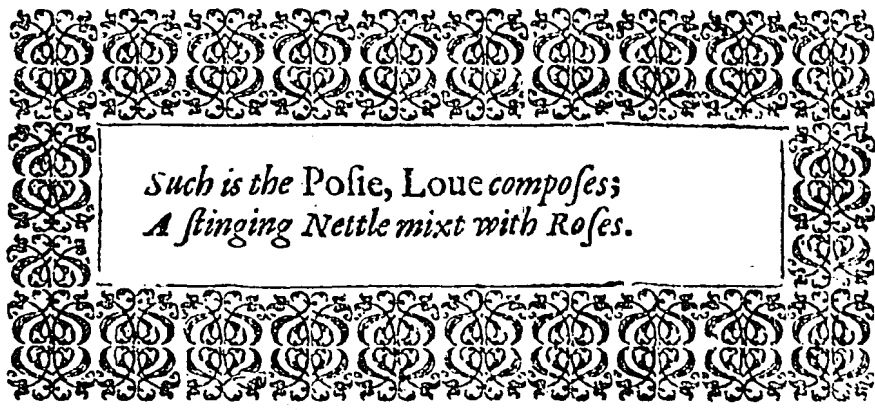

Figure 4

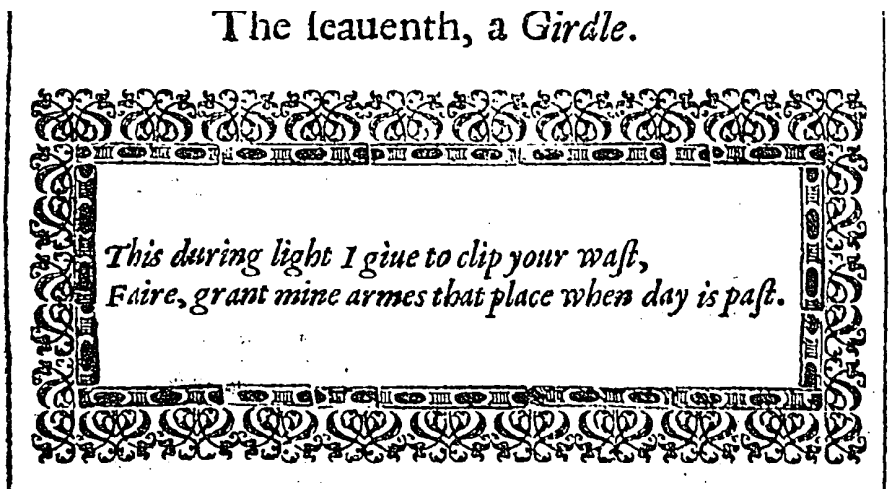

Figure 5 

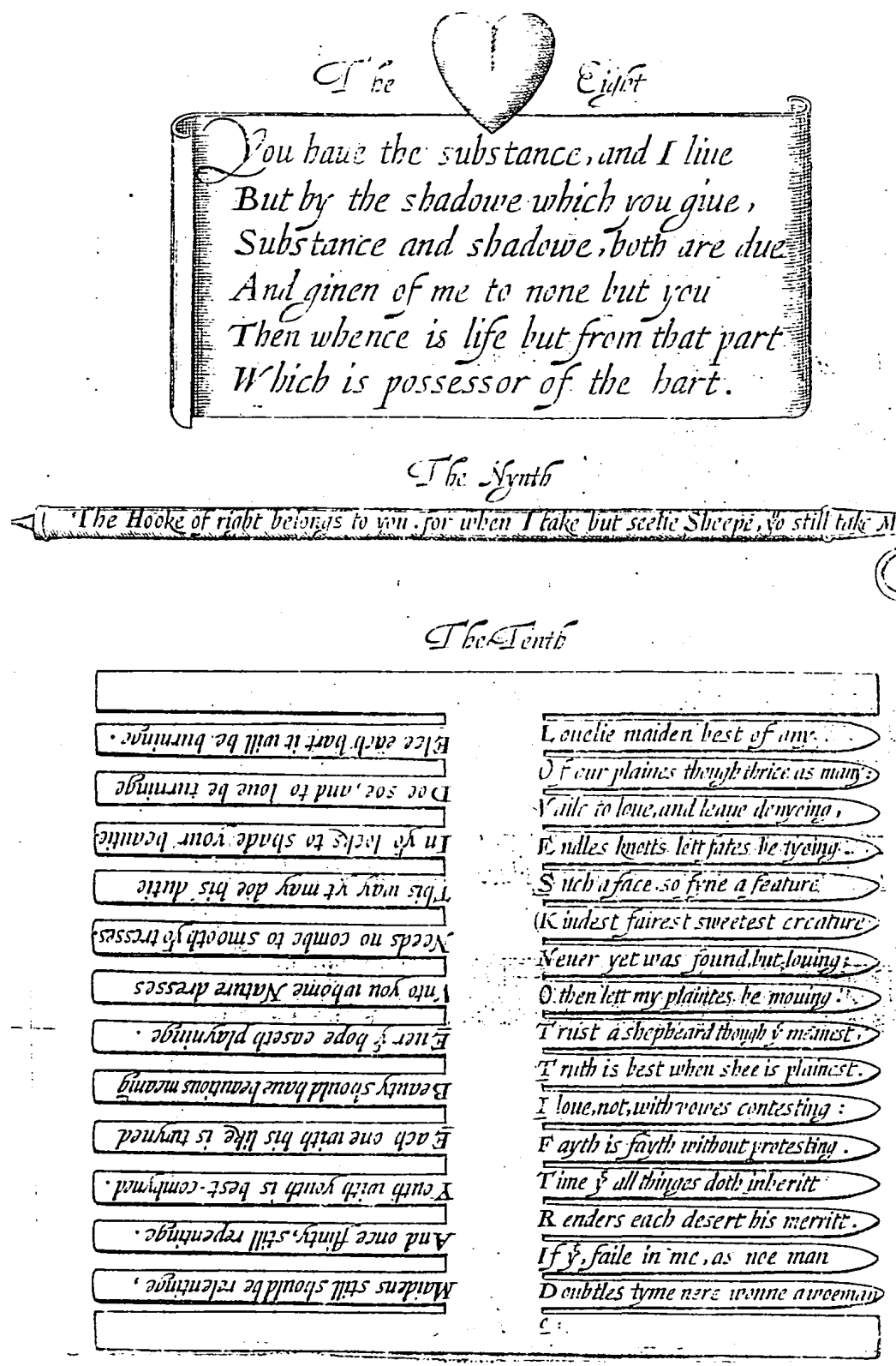

Figure 6: Eighth device, with the image of heart; Ninth device, in a frame shaped like a sheephook; Tenth device, in a frame shaped like a comb. 


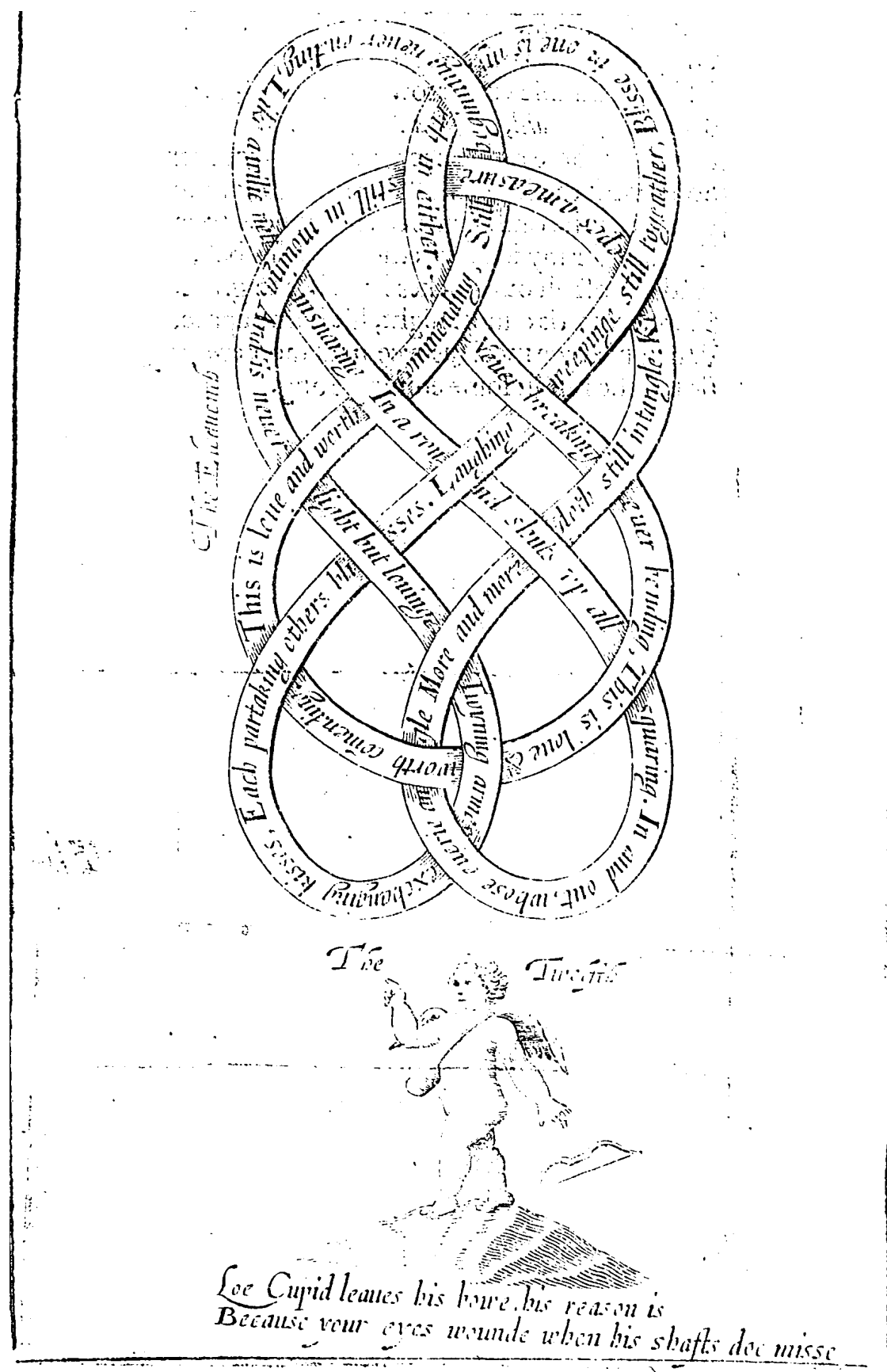

Figure 7: Eleventh device, a love-knot. Twelfth device, with an image of Cupid casting aside his bow. 


\section{William Browne From Britannia's Pastorals Book II}

Lines 817-1050 of Song 1 in Browne's Britannia's Pastorals. The second Booke (1616). Marks a new turn in the action, with a voyage by the sea-goddess Thetis that brings her to England and the shepherds of Browne's narrative; and within that, one of many long excursus where Browne suspends the narrative to introduce topical and moral concerns.

Faire siluer-footed Thetis that time threw

Along the Ocean with a beautious crew

Of her attending Sea-nymphes (Ioues bright Lamps

Guiding from Rockes her Chariots Hyppocamps.)

A iourney onely made, vnwares to spye

stars

If any Mighties of her Empery

Opprest the least, and forc'd the weaker sort

To their designes, by being great in Court.

$\mathrm{O}$ ! should all Potentates whose higher birth

Enroles their titles, other Gods on earth,

Should they make priuate search, in vaile of night,

For cruell wrongs done by each Fauorite;

Here should they finde a great one paling in

A meane mans land, which many yeeres had bin

His charges life, and by the others heast,

The poore must starue to feede a scuruy beast.

If any recompence drop from his fist,

His time's his owne, the mony, what he list.

There should they see another that commands

His Farmers Teame from furrowing his lands,

To bring him stones to raise his building vast,

The while his Tenants sowing time is past.

Another (spending) doth his rents inhance,

Or gets by trickes the poores inheritance.

But as a man whose age hath dim'd his eyes

Vseth his Spectacles, and as he pryes

Through them all Characters seeme wondrous faire,

Yet when his glasses quite remoued are

(Though with all carefull heed he neerly looke)

Cannot perceiue one tittle in the Booke,

So if a King behold such fauourites

(Whose being great, was being Parasites,)

With th'eyes of fauour; all their actions are

To him appearing plaine and regular:

But let him lay his light of grace aside,

And see what men hee hath so dignifide,

They all would vanish, and not dare appeare,

Who Atom-like, when their Sun shined cleare,

Danc'd in his beame; but now his rayes are gone,

Of many hundred we perceiue not one.

Or as a man who standing to descry

formally affirms
under cover of
fencing, enclosing
humble, poor
dependents', family's; hest, command
beast: i.e., sheep

formally affirms
under cover of
fencing, enclosing
humble, poor
dependents', family's; hest, command
beast: i.e., sheep

powerful people

beast: i.e., sheep

letters, writing

closely

according to the rules, legal

favour

How great floods farre off run, and vallies lye,

Taketh a glasse prospectiue good and true,

By which things most remote are full in view:

If Monarchs, so, would take an Instrument

Of truth compos'd to spie their Subiects drent

In foule oppression by those high in seate,

(Who care not to be good but to be great)

In full aspect the wrongs of each degree

Would lye before them; and they then would see.

The diuelish Polititian all conuinces,

(1)


In murdring Statesmen and in poisning Princes;

The Prelate in pluralities asleepe

Whilst that the Wolfe lyes preying on his sheepe;

The drowsie Lawyer, and the false Atturnies

Tire poore mens purses with their life-long-iournyes;

The Country Gentleman, from's neighbours hand

Forceth th'inheritance, ioynes land to land,

And (most insatiate) seekes vnder his rent

To bring the worlds most spacious continent;

The fawning Citizen (whose loue's bought deerest)

Deceiues his brother when the Sun shines clearest,

Gets, borrowes, breakes, lets in, and stops out light,

And liues a Knaue to leaue his sonne a Knight;

The griping Farmer hoords the seede of bread,

Whilst in the streets the poore lye famished:

And free there's none from all this worldly strife,

Except the Shepheards heauen-blest happy life.

But stay sweet Muse! forbeare this harsher straine,

Keepe with the Shepheards; leaue the Satyres veyne,

Coupe not with Beares; let Icarus alone

To scorch himselfe within the torrid Zone,

Let Phaëton run on, Ixion fall,

And with a humble stiled Pastorall

Tread through the vallies, dance about the streames,

The lowly Dales will yeeld vs Anadems

To shade our temples, tis a worthy meed,

prises, seizes

jurisdiction as landlord

all that is contained, the whole expanse

in broad daylight

No better girlond seekes mine Oaten Reede;

80

Let other climbe the hils, and to their praise

(Whilst I sit girt with Flowres) be crown'd with Bayes.

Shew now faire Muse what afterward became

Of great Achilles Mother; She whose name

The Mermaids sing, and tell the weeping strand

A brauer Lady neuer tript on land,

Except the euer liuing Fayerie Queene,

Whose vertues by her Swaine so written beene,

That time shall call her high enhanced story

In his rare song, The Muses chiefest glory.

So mainely Thetis droue her siluer throne,

Inlaid with pearles of price and precious stone,

(For whose gay purchase, she did often make

The scorched Negro diue the briny Lake)

That by the swiftnesse of her chariot wheels

(Scouring the Maine as well-built English Keels)

She, of the new-found World all coasts had seene,

The shores of Thessaly, where she was Queene,

Her brother Pontus waues, imbrac'd with those

rapacious

wreathes

reward

laurels

She: Thetis

stepped, trod

i.e., Spenser

exalted

energetically, swiftly; throne i.e., chariot

53 pluralities] more than one church office held at the same time. $\quad 54$ the Wolfe] Satan; or perhaps the Anglican Church, virtually identified by Puritans with the Catholic. Browne, like most Spenserians, was a confirmed Protestant tending towards puritanism, though not as strongly as Wither. $\mathbf{5 5}$ drowsie] sleepy, tardy: a reference to the law's delays (cf. 56). $\mathbf{5 8}$ ioynes land to land] acquires more and more land to create a large estate. 63 lets in, and stops out light] referring to the right of 'ancient lights' or windows in city houses. $\quad 64$ Knaue] (a) servant, person of low rank (b) villain, wrongdoer. 71 Coupe not with Beares] Do not consort with dangerous companions. Coupe] confine yourself: active use not in $O E D$. 71-3 Icarus, Phaëton, Ixion] over-reachers destroyed by pride. Icarus flew too near the sun, so that his waxen wings melted. Phaëton drove the sun's chariot too close to the earth, and was destroyed by Zeus or Jupiter to save the earth. Ixion attempted to win Hera or Juno, queen of his benefactor Zeus. 85 Fayerie Queene] Elizabeth, identified with the nodal figure in Spenser's poem. Nostalgic idealization of Elizabeth's reign was a political strategy of the opposition 'Country' party to which Browne and most Spenserians belonged. $\quad 92$ diue] for pearls. briny Lake] sea. 94 Ranging across the seas like stout English ships. 95 new-found World] presumably the Americas. The Old World places of $96 \mathrm{ff}$. are added items. 96 Thessaly] Thessaly proper is landlocked. Perhaps Magnesia, on the Aegean coast and a part of Thessaly; perhaps a mistake. 97 Pontus] the Black Sea, linked to the Aegean and thus 'brother' of Thetis (the Mediterranean). imbrac'd] embraced, flanked. Browne's geography is a little out, as Tenedos is on the Hellespont, south of the Black Sea. 
Mceotian fields and vales of Tenedos,

Streit Hellespont, whose high-brow'd cliffes yet sound

The mournefull name of young Leander drownd,

strait, narrow

Then with full speede her Horses doth she guide

Through the Agrean sea, that takes a pride

In making difference twixt the fruitfull lands,

Europe and Asia almost ioyning hands,

But that shee thrusts her billowes all affront

To top their meeting through the Hellespont.

The Midland Sea so swiftly was shee scouring,

The Adriaticke gulfe braue Ships deuouring.

To Padus siluer streame then glides she on

(Enfamoused by rekeles Phaëton)

Padus that doth beyond his limits rise,

When the hot Dog-starre raines his maladies,

And robs the high and ayre-inuading Alpes

Of all their Winter suites and snowy scalpes,

To drowne the leuel'd lands along his shore,

And make him swell with pride. By whom of yore

beside

The sacred Heliconian Damsels sate

(To whom was mighty Pindus consecrate)

And did decree (neglecting other men)

Their height of Art should flow from Maro's pen.

And prattling Eccho's euermore should long

For repetition of sweet Naso's song.

It was inacted here, in after days

What wights should haue their temples crown'd with Bayes.

Learn'd Ariosto, holy Petrarchs quill,

And Tasso should ascend the Muses hill.

Diuinest Bartas, whose enriched soule

Proclaim'd his Makers worth, should so enroule

His happy name in brasse, that Time nor Fate

That swallow all, should euer ruinate.

Delightfull Salust, whose all blessed layes

The Shepheards make their Hymnes on Holy-dayes.

And truely say thou in one weeke hast pend

What time may euer study, ne're amend.

Marot and Ronsard, Garnier's buskind Muse

Should spirit of life in very stones infuse.

And many another Swan whose powerfull straine

Should raise the Golden World to life againe.

But let vs leaue (faire Muse) the bankes of $P o$ :

Thetis forsooke his braue streame long agoe,

98 Mœtian fields] Moesia, west of the Black Sea. Tenedos] island in the Aegean Sea near the entrance to the Hellespont. 100 Leander] drowned in the Hellespont while swimming across to his beloved Hero. 106 top] ?thwart, override (cf. OED to $p \mathrm{v}^{1} 16 \mathrm{~b}$ ). Hellespont] Dardanelles, the strait dividing the Asian and European parts of Turkey. 107 Midland Sea] literally translating Mediterranean. 108 braue Ships deuouring] The Adriatic was notorious for storms and shipwrecks. 109 Padus] the river Po, flowing into the Adriatic. 110 Phaëton] son of Helios the sun-god: see 71n. Cast by Zeus into the river Eridanus, identified with the Po. 112 Dog-starre] Sirius, high in the sky in the hottest days of summer, hence supposed to cause infections ('maladies'). This is when Alpine snows melt and flood the Po (111-16). $\quad 116$ pride] linking Padus to Icarus, Phaëton and Ixion. By whom] Alluding to the golden age of classical Latin poetry in Italy; but Browne progresses to Renaissance poets - first of Italy, then elsewhere (140). 117 Heliconian Damsels] the Muses. Mount Helicon was sacred to them. 118 Pindus] mountain range in northern Greece: no special association with the Muses. 120 Maro] Virgil (Publius Virgilius Maro). $\quad 121$ Eccho's] italicized like a proper noun, but presumably not meaning the mythological character. 122 Naso] Ovid (Publius Ovidius Naso). 127 Bartas] Guillaume de Salluste du Bartas, French author of Les Semaines (The [Divine] Weeks) about the creation of the world. 129 in brasse] echoing a phrase from Horace, Odes 3.30. 131 Salust] Du Bartas's middle name. 133 one weeke] Du Bartas treats chiefly of the week during which God created the world. 135 Marot] Clément Marot (1496-1544), French poet. Ronsard] Pierre de Ronsard (1524-85), most acclaimed of French Renaissance poets. Garnier] Robert Garnier (1544-90), French writer of Senecan tragedies. buskind] buskin, a type of high boot worn by tragic actors. 138 Golden World] All Renaissance poetry is thus presented in quasi-pastoral terms. 140 Thetis is seen as a muse or goddess of poetry. 
And we must after. See in haste shee sweepes Along the Celtick shores, th'Armorick deepes

She now is entring: beare vp then a head

And by that time she hath discouered

Our Alablaster rockes, we may discry

And stem with her, the coasts of Britany.

There will she Anchor cast, to heare the songs

Of English Shepheards, whose all tunefull tongues

So pleas'd the Nayades, they did report

Their songs perfection in great Nereus Court:

Which Thetis hearing, did appoint a day

When she would meet them in the Brittish Sea,

And thither for each Swaine a Dolphin bring

To ride with her, while she would heare him sing.

The time prefixt was come; and now the Starre

Of blissefull light appear'd, when she her Carre

Staid in the narrow seas. At Thames faire port

The Nymphes and Shepheards of the Isle resort.

And thence did put to sea with mirthfull rounds,

Whereat the billowes dance aboue their bounds,

And bearded Goates, that on the clouded head

Of any sea-suruaying Mountaine fed,

Leauing to crop the Iuy, listning stood

At those sweet ayres which did intrance the flood.

In iocound sort the Goddesse thus they met.

And after reu'rence done, all being set

Vpon their finny Coursers, round her throne,

And shee prepar'd to cut the watry Zone

Ingirting Albion; all their pipes were still,

And Colin Clout began to tune his quill,

With such deepe Art that euery one was giuen

To thinke Apollo (newly slid from heau'n)

Had tane a humane shape to win his loue,

Or with the Westerne Swaines for glory stroue.

He sung th'heroicke Knights of Faiery land

In lines so elegant, of such command,

That had the Thracian plaid but halfe so well

He had not left Eurydice in hell.

But e're he ended his melodious song

An host of Angels flew the clouds among,

And rapt this Swan from his attentiue mates,

To make him one of their associates

In heauens faire Quire: where now he sings the praise

Of him that is the first and last of dayes.

Diuinest Spencer, heau'n-bred, happy Muse!

Would any power into my braine infuse

Thy worth, or all that Poets had before,

I could not praise till thou deseru'st no more.

A dampe of wonder and amazement stroke

?English Channel

appointed earlier

halted

pass through

ta'en, taken

poets of England

to your full desert

Thetis attendants, many a heauy looke

Follow'd sweet Spencer, till the thickning ayre

Sights further passage stop'd. A passionate teare

142 Celtick shores] prob. old Roman territory of Gallia Celtica, a large tract embracing Brittany. Armorick] of Brittany (Armorica). 143 beare vp then a head] sail ahead (OED bear $\left.\mathrm{v}^{1} 37\right) .149$ Nayades] Naiads, the fifty daughters of the sea-god Nereus (150). 157 narrow seas] Straits of Dover. port] gate, entrance, hence river-mouth. 159 rounds] type of song where several singers sing in turn. 167 finny Coursers] sea-horses (5) and/or dolphins (153). 170 Colin Clout] Spenser. This is one of the most eloquent tributes to Spenser even from the Spenserian poets. 175-6 referring to FQ. $\quad 177$ the Thracian] 'Orpheus' (marginal note in original text). Regained his dead wife Eurydice from Hades by impressing Pluto with his music, but lost her again by glancing back at her on his way back to the world. $\quad \mathbf{1 7 9}$ e're he ended] Spenser completed just over half of FQ. $\mathbf{1 8 4}$ first and last of dayes] Perhaps alluding to the address to God closing the fragmentary FQ Bk.VII (Mutability Cantos). $\quad$ 186-7 infuse Thy worth] instil your (poetic) power. $\quad 189$ dampe] exhalation, a sudden vapour or mist $\left(O E D_{1}\right)$. 
Fell from each Nymph, no Shepheards cheeke was dry,

A dolefull Dirge, and mournefull Elegie

Flew to the shore. When mighty Nereus Queene

(In memory of what was heard and seene)

Imploy'd a Factor, (fitted well with store

Of richest Iemmes, refined Indian Ore)

To raise, in honour of his worthy name

A Piramus, whose head (like winged Fame)

Should pierce the clouds, yea seeme the stars to kisse,

And Mausolus great toombe might shrowd in his.

Her will had beene performance, had not Fate

(That neuer knew how to commiserate)

Suborn'd curs'd Auarice to lye in waite

For that rich prey: (Gold is a taking baite)

Who closely lurking like a subtile Snake

Vnder the couert of a thorny brake,

Seiz'd on the Factor by fayre Thetis sent,

And rob'd our Colin of his Monument.

Yee English Shepheards, sonnes of Memory,

For Satyres change your pleasing melody,

Scourge, raile and curse that sacrilegious hand,

That more then Fiend of hell, that Stygian brand,

All-guilty Auarice: that worst of euill,

That gulfe deuouring, off-spring of a Diuell:

Heape curse on curse so direfull and so fell,

?craftsman, artisan

gold

pyramid, hence monument

200

Their waight may presse his damned soule to hell.

Is their a spirit so gentle can refraine

To torture such? O let a Satyres veyne

Mixe with that man! to lash this hellish lym,

Or all our curses will descend on him.

For mine owne part although I now commerce

With lowly Shepheards in as low a Verse;

If of my dayes I shall not see an end

Till more yeeres presse mee; some few houres Ile spend

In rough-hewn Satyres, and my busied pen

Shall ierke to death this infamy of men.

And like a Fury, glowing coulters beare,

With which ... But see how yonder fondlings teare

Their fleeces in the brakes; I must goe free

Them of their bonds; Rest you here merrily

Till my returne: when I will touch a string

Shall make the Riuers dance, and Vallyes ring.

whip, scourge; disgrace, scandal iron blade, knife foolish creatures bushes stay; agreeably, contentedly

deal or associate

?sword, destructive weapon

with a vast gape or maw

195 Nereus Queene] Doris, mother of the Nereides: here Queen Elizabeth (see 205-10n). 202 Mausolus] ruler of Caria (4-c. BCE), renowned for his sumptuous tomb. 205-10 One of many unfounded stories of Spenser's poverty in his last years and the neglect of his memory after death. (See 221.85n.) In fact, he received a government pension, and was buried at Westminster Abbey after an impressive funeral. This passage is the only testimony to the embezzlement of funds granted by Elizabeth for a monument to him. 214 Stygian] of Styx, a river of the underworld or hell. 221 Mixe with] be instilled (into that 'spirit so gentle'). lym] limb, i.e. of Satan, agent or 'imp of hell' (OED $3 \mathrm{~b}, \mathrm{c})$.

Fury] in the precise sense of an avenging goddess. 


\section{Ben Jonson To Penshurst}

Poem II of The Forrest in the 1616 Folio of Jonson's Works. Penshurst in Kent was the seat of the Sidney family. At this time, the owner was Sir Philip's brother Robert Sidney, Viscount L'Isle and later Earl of Leicester. With Jonson's 'To Sir Robert Wroth', this is considered the type and model of the countryhouse poem.

\section{TO PENSHVRST.}

Thou art not, Penshvrst, built to enuious show, Of touch, or marble; nor canst boast a row

Of polish'd pillars, or a roofe of gold: Thou hast no lantherne, whereof tales are told; glazed structure crowning a building

Or stayre, or courts; but stand'st an ancient pile, And these grudg'd at, art reuerenc'd the while.

Thou ioy'st in better markes, of soyle, of ayre, Of wood, of water: therein thou art faire.

Thou hast thy walkes for health, as well as sport: Thy Mount, to which the Dryads doe resort,

Where PAN, and BACCHVs their high feasts haue made, Beneath the broad beech, and the chest-nut shade;

That taller tree, which of a nut was set, At his great birth, where all the Muses met.

There, in the writhed barke, are cut the names Of many a SYlvane, taken with his flames.

And thence, the ruddy Satyres oft prouoke The lighter Faunes, to reach thy Ladies oke.

Thy copp's, too, nam'd of GAMAGE, thou hast there, copse That neuer failes to serue thee season'd deere,

When thou would'st feast, or exercise thy friends. The lower land, that to the riuer bends,

Thy sheepe, thy bullocks, kine, and calues doe feed: The middle grounds thy mares, and horses breed.

Each banke doth yeeld thee coneyes; and the topps Fertile of wood, Ashore, and Sydney's copp's,

To crowne thy open table, doth prouide The purpled pheasant, with the speckled side:

The painted partrich lyes in euery field, And, for thy messe, is willing to be kill'd.

And if the high-swolne Medway faile thy dish, Thou hast thy ponds, that pay thee tribute fish,

Fat, aged carps, that runne into thy net. And pikes, now weary their owne kinde to eat,

As loth, the second draught or cast to stay, Officiously, at first, themselues betray.

Bright eeles, that emulate them, and leape on land, Before the fisher, or into his hand.

Then hath thy orchard fruit, thy garden flowers, Fresh as the ayre, and new as are the houres.

The earely cherry, with the later plum, Fig, grape, and quince, each in his time doth come:

The blushing apricot, and woolly peach Hang on thy walls, that euery child may reach.

And though thy walls be of the countrey stone, They'are rear'd with no mans ruine, no mans grone,

2 touch] black granite or marble. 4-5 i.e. Penshurst is not famous for any special architectural feature. 10 Mount] a high point on the estate, 'still called by that name' (Herford \& Simpsons). 11 PAN, and B ACCHvs] following Martial, Epig. .IX.lxi.11-16. 14 his] Philip Sidney's. Herford \& Simpsons note a tree in the park 'still shown as Sidney's oak'. Waller too refers to it in his poem 'At Penshurst'. 18 thy Ladies oke] from a tradition that Lady Leicester, wife of Robert Sidney, was taken in travail under this tree. 19 copp's ... GAMAGE] where Barbara Gamage, Robert Sidney's first wife, was said to have fed the deer. 26 AsHORE and SYDNEY's copp's] 'These woods still exist, the former spelt 'Ashour'.' (Herford \& Simpsons). 35-6 They do not wait for the second dredging or casting of the net, but surrender to the first one. A common conceit of the country-house poem is that plants and animals willingly offer themselves to be eaten. 
There's none, that dwell about them, wish them downe;

But all come in, the farmer, and the clowne:

And no one empty-handed, to salute

Thy lord, and lady, though they haue no sute.

Some bring a capon, some a rurall cake,

Some nuts, some apples; some that thinke they make

The better cheeses, bring 'hem; or else send

By their ripe daughters, whom they would commend

This way to husbands; and whose baskets beare

An embleme of themselues, in plum, or peare.

But what can this (more then expresse their loue)

Adde to thy free prouisions, farre aboue

The neede of such? whose liberall boord doth flow,

With all, that hospitalitie doth know!

Where comes no guest, but is allow'd to eate,

Without his feare, and of thy lords owne meate:

Where the same beere, and bread, and selfe-same wine,

That is his Lordships, shall be also mine.

And I not faine to sit (as some, this day,

At great mens tables) and yet dine away.

Here no man tells my cups; nor, standing by,

A waiter, doth my gluttony enuy:

But giues me what I call, and lets me eate,

He knowes, below, he shall finde plentie of meate,

Thy tables hoord not vp for the next day,

Nor, when I take my lodging, need I pray

For fire, or lights, or liuorie: all is there;

As if thou, then, wert mine, or I raign'd here:

There's nothing I can wish, for which I stay.

That found King IAMES, when hunting late, this way,

With his braue sonne, the Prince, they saw thy fires

Shine bright on euery harth as the desires

Of thy Penates had beene set on flame,

To entertayne them; or the countrey came,

With all their zeale, to warme their welcome here.

What (great, I will not say, but) sodayne cheare

Did'st thou, then, make 'hem! and what praise was heap'd

On thy good lady, then! who, therein, reap'd

The iust reward of her high huswifery;

To haue her linnen, plate, and all things nigh,

When shee was farre: and not a roome, but drest,

As if it had expected such a guest!

These, Penshvrst, are thy praise, and yet not all.

Thy lady's noble, fruitfull, chaste withall.

His children thy great lord may call his owne:

A fortune, in this age, but rarely knowne.

They are, and haue beene taught religion: Thence

Their gentler spirits haue suck'd innocence.

Each morne, and euen, they are taught to pray,

With the whole houshold, and may, euery day,

Reade, in their vertuous parents noble parts,

The mysteries of manners, armes, and arts.

Now, Penshvrst, they that will proportion thee

With other edifices, when they see

glad, thankful

as though somewhere else counts how much I drink

ask for, demand

save or put by food

household gods

ready, prepared

Those proud, ambitious heaps, and nothing else,

May say, their lords haue built, but thy lord dwells.

62 lords own meate] not inferior food for unbidden guests

73 liuorie] allowance of provisions. 76 King IAMES] Recorded as having lodged at Penshurst, where a room is still called after him. 77 braue sonne, the Prince] Henry, James I's elder son, who died in 1612. 102 Echoes Martial, Epigrams XII.l.8. 


\section{Ben Jonson To Sir Robert Wroth}

Poem III of The Forrest in the 1616 Folio of Jonson's Works. Robert Wroth (1576-1614) was Robert Sidney's son-in-law and husband of Lady Mary Wroth. His country home was Loughton House in Essex.

To Sir Robert Wroth.

How blest art thou, canst loue the countrey, Wrотн, Whether by choice, or fate, or both;

And, though so neere the citie, and the court, Art tane with neithers vice, nor sport:

That at great times, art no ambitious guest

taen, taken Of Sheriffes dinner, or Maiors feast.

Nor com'st to view the better cloth of state, The richer hangings, or crowne-plate;

Nor throng'st (when masquing is) to haue a sight Of the short brauerie of the night;

To view the iewells, stuffes, the paines, the wit There wasted, some not paid for yet!

you who can

But canst, at home, in thy securer rest, Liue, with vn-bought prouision blest;

Free from proud porches, or their guilded roofes, 'Mongst loughing heards, and solide hoofes:

Along'st the curled woods, and painted meades, Through which a serpent riuer leades

To some coole, courteous shade, which he calls his, And makes sleepe softer then it is!

Or, if thou list the night in watch to breake, A-bed canst heare the loud stag speake, show, splendour fabrics ceremonial occasions In spring, oft roused for thy masters sport, Who, for it, makes thy house his court;

Or with thy friends; the heart of all the yeere, Diuid'st, vpon the lesser Deere;

In autumne, at the Partrich mak'st a flight, And giu'st thy gladder guests the sight;

And, in the winter, hunt'st the flying hare, More for thy exercise, then fare;

While all, that follow, their glad eares apply To the full greatnesse of the cry:

Or hauking at the riuer, or the bush, Or shooting at the greedie thrush,

Thou dost with some delight the day out-weare, Although the coldest of the yeere!

The whil'st, the seuerall seasons thou hast seene Of flowrie fields, of cop'ces greene,

The mowed meddowes, with the fleeced sheepe, And feasts, that either shearers keepe;

The ripened eares, yet humble in their height, And furrowes laden with their weight;

The apple-haruest, that doth longer last; The hogs return'd home fat from mast;

The trees cut out in log; and those boughes made

i.e., produced on the estate

(a) shaggy, leafy (b) tossed by the wind serpentine, winding ?soft, refreshing wish; ?interrupt (sleep) call

the summer assign, allocate swift, fleet separate, each in its time chopped into logs

7 cloth of state] 'a cloth spread over a throne or other seat of dignity; a canopy' (OED cloth 4 ). 8 crowne-plate] gold or silver utensils stamped with the hallmark of a crown. 11 the paines, the wit] the labour and thought spent on such trivial matters. 12 The aristocracy notoriously ran up debts to procure their luxuries. 16 solide] (a) heavy, sturdy (b) crowded, packed (in a herd). 22 A-bed] while lying in bed - i.e. the deer come right up to the house. $\quad 23$ thy masters] the King's. 24 makes ... court] lodges here. The court is where the king is. $\mathbf{2 6}$ lesser Deere] the fallow and roe deer. The red deer is reserved for the king. $\quad 27$ flight] hunting with hawks (OED 1c). The other sense, 'flight-shooting' birds flying overhead, does not suit the ground-dwelling, low-flying partridge. 28 gladder] made gladder by the sight: a proleptic use. $\quad 30$ More for sport than to acquire food. 32 full ... cry] the baying of a full pack of hounds. 34 greedie] Winter-starved, hence eager to eat the bait laid out for them. 40 either] 'each (of more than two things)', OED 2c: here, shearers of either hay or sheep. 41 eares] of grain. humble in their height] tall but bowing (with the wind). 
A fire now, that lent a shade!

Thus Pan, and Sylvane, hauing had their rites,

Comvs puts in, for new delights;

And fills thy open hall with mirth, and cheere, As if in SATURNES raigne it were;

Apollo's harpe, and Hermes lyre resound,

Nor are the Muses strangers found:

The rout of rurall folke come thronging in,

(Their rudenesse then is thought no sinne)

band, crowd

rough manners

Thy noblest spouse affords them welcome grace;

And the great Heroes, of her race,

Sit mixt with losse of state, or reuerence.

Freedome doth with degree dispense.

The iolly wassall walkes the often round,

And in their cups, their cares are drown'd:

They think not, then, which side the cause shall leese,

Nor how to get the lawyer fees.

Such, and no other was that age, of old,

Which boasts t'haue had the head of gold.

And such since thou canst make thine owne content,

Striue, Wroth, to liue long innocent.

Let others watch in guiltie armes, and stand

The furie of a rash command,

face, suffer

madness

Goe enter breaches, meet the cannons rage,

That they may sleepe with scarres in age

rank

(cup of) liquor to drink healths in; frequent

And shew their feathers shot, and cullors torne,

And brag, that they were therefore borne.

Let this man sweat, and wrangle at the barre, For euery price, in euery iarre,

And change possessions, oftner with his breath, Then either money, warre, or death:

lawsuit; lose

Let him, then hardest sires, more disinherit,

And each where boast it as his merit,

To blow vp orphanes, widdowes, and their states;

And thinke his power doth equall Fates.

Let that goe heape a masse of wretched wealth, Purchas'd by rapine, worse then stealth,

And brooding o're it sit, with broadest eyes,

Not doing good, scarce when he dyes.

Let thousands more goe flatter vice, and winne,

By being organes to great sinne,

Get place, and honor, and be glad to keepe.

The secrets, that shall breake their sleepe:

And, so they ride in purple, eate in plate,

Though poyson, thinke it a great fate.

But thou, my Wroth, if I can truth apply,

prize, reward; dispute, litigation (ownership of) property; talk

than

destroy; estates, properties

that: another man acquired wide open, unsleeping

instruments of positions at court

47 Sylvane] Sylvanus, a wood-god 48 Comus] god of revelry (Gk. komos, revelry). 5o SATURNE] King of the gods before Zeus; also seen as an old king of Latium. His reign was identified with the Golden Age. 51-2 i.e. There is music and poetry. 51 Hermes] Mercury, who invented the lyre from a tortoise-shell $\mathbf{5 5}$ thy noblest spouse] Lady Mary Wroth, poet and author, daughter of Robert Sidney. 56 Heroes, of her race] the Sidney family. 57 Sit mixt] ?in spirit; ?in portraits. with losse of state] i.e., stooping from their position. $\mathbf{6 2}$ get the lawyer fees] make more business for the lawyer. $\quad \mathbf{6 4}$ head of gold] A conventional symbolic figure with a head of gold but a body of increasingly baser materials (i.e. the later ages of human history). $\quad 65$ make ... content] ensure your own happiness. 66 innocent] Implying freedom from original sin, the state of man before the Fall. Wroth's estate is implicitly equated with Paradise. $\quad 67$ guiltie] ?violent, murderous; ?immorally or criminally employed. $\quad \mathbf{7 1}$ feathers ... torne] trophies of battle. feathers] arrows. cullors] colours: flags, standards. $\quad 72$ they ... borne] This justifies their existence. $77-8$ then ... merit] Deprive more men of their patrimony than the sternest of fathers disinheriting their children, and boast of it everywhere as a great achievement. $\quad 82$ rapine ... stealth] open force, worse than secret theft. 84 Reluctant even to bequeath his money after his death. Echoes a line marked by Jonson in his copy of the Epigrammata (1590) of Pierre Pithou, French scholar and lawyer. 87-8 i.e. They obtain favour by keeping other people's guilty secrets (and perhaps blackmailing them). $\quad 89-90$ So long as they ride in state and eat off gold or silver utensils, even if what they eat is poison, they think themselves fortunate. 
Shalt neither that, nor this enuy:

Thy peace is made; and, when man's state is well,

Tis better, if he there can dwell.

condition of life

God wisheth, none should wracke on a strange shelfe:

To him, man's dearer, then t'himselfe.

And, howsoeuer we may thinke things sweet,

He alwayes giues what he knowes meet;

100

Which who can vse is happy: Such be thou.

Thy morning's, and thy euening's vow

Be thankes to him, and earnest prayer, to finde

A body sound, with sounder minde;

To doe thy countrey seruice, thy selfe right;

That neither want doe thee affright,

Nor death; but when thy latest sand is spent,

Thou maist thinke life, a thing but lent.

only

\section{Ben Jonson Hymn From Pan's ANNIVERSARY}

From the masque Pan's Anniversary, first printed in the Second Folio of Jonson's Works, vol.2 (1640). The Folio dates the performance in 1625, but scholars favour 19 June 1620, the birthday of James I or 'Pan'. Some lines were closely repeated in 'A New-yeares-Gift sung to King Charles, 1635' (no.194). These Hymns are sung by the Arcadians, punctuated by dances and action as indicated below. In the first Hymn, '1'. ' 2 ' etc. indicate the successive Arcadian singers.

\section{HYMNE I.}

1. Of PAN we sing, the best of Singers Pan

That taught us swaines, how first to tune our layes,

And on the pipe more aires then Phobus can.

Chorus. Heare $\mathrm{O}$ you groves, and hills resound his praise.

2. Of Pan we sing, the best of leaders, Pan

That leads the Nayads, and the Dryads forth;

And to their daunces more then Hermes can.

Chorus. Heare O you groves, and hills, resound his worth.

can join or contribute

3. Of Pan we sing, the best of Hunters, Pan

That drives the Heart to seeke unused wayes,

And in the chace more then Sylvanus can,

than

Chorus. Heare O you groves, and hills resound his praise.

4. Of Pan we sing, the best of Shepherds, Pan,

That keepes our flocks, and us, and both leads forth

To better pastures then great Pales can:

Chorus. Heare O you groves, and hills resound his worth.

And while his powers, and praises thus we sing

The Valleys let rebound, and all the rivers ring.

is able to (render or perform)

The Masquers descend, and dance their Entrie.

HYMNE II.

PAN is our All, by him we breath, wee live,

Wee move, we are; 'Tis he our lambes doth reare,

Our flocks doth blesse, and from the store doth give

The warme and finer fleeces that we weare.

He keepes away all heates, and colds,

Drives all diseases from our folds:

Makes every where the spring to dwell,

95 wracke on a strange shelfe] suffer shipwreck on an unfamiliar coastline. $\quad 102$ A body ... minde] echoes Juvenal, Satire X.356. This entire passage reflects Juvenal's poem. 105 sand] years, store of life (like sand in an hourglass). 106 but lent] not one's own possession, therefore to be given up without regret. 6 Nayads] Naiads, nymphs of rivers and streams. Dryads] wood-nymphs. 10 seeke unused wayes] to escape the hunters. unused] unaccustomed, secluded. 11 Sylvanus] a god of the forest, but also of homesteads, fields and flocks. $\quad 15$ Pales] goddess of flocks and shepherds. 18.1 Entrie] a dance between two parts of an entertainment $\left(O E D_{3}\right)$; here ?opening or 'entering' dance. 
The Ewes to feed, their udders swell;

But if he frowne, the sheepe (alas)

The Shepheards wither, and the grasse.

Strive, strive, to please him then by still increasing thus

The rites are due to him, who doth all right for us.

The Maine Daunce.

\section{HYMNE III.}

If yet, if yet

Pans orgies you will further fit,

serve, contribute to, join in

See where the silver-footed Fayes doe sit,

The Nymphes of wood and water;

Each trees and Fountaines daughter,

Goe take them forth, it will be good

To see some wave it like a wood,

And others wind it like a flood;

In springs,

And rings,

stream, river

leaps

Till the applause it brings,

Wakes Eccho from her seate,

The closes to repeate.

(Echo. The closes to repeate.)

Eccho the truest Oracle on ground,

Though nothing but a sound.

(Echo. Though nothing but a sound.)

Belov'd of Pan, the Vallyes Queene

(Echo. The Valleyes Queene)

And often heard, though never seene,

(Echo. Though never seene.)

closes: of the music, cadences

[There follows an antimasque where the Arcadians repel an attack by a band of Boetian swordsmen led by a 'Fencer'. The rites of Pan then close with the Fourth Hymn.]

\section{HYMNE IIII.}

Great Pan the Father of our peace, and pleasure,

Who giv'st us all this leasure,

Heare what thy hallowd troope of Herdsmen pray blessed by, dedicated to (Pan)

For this their Holy-day,

And how their vowes to Thee, they in Lycoum pay.

So may our Ewes receive the mounting Rammes,

And wee bring thee the earliest of our Lambes:

So may the first of all our fells be thine,

And both the beestning of our Goates, and Kine As thou our folds dost still secure,

And keep'st our fountaines sweet and pure

Driv'st hence the Wolfe, the Tode, the Brock,

Or other vermine from the flock.

That wee preserv'd by Thee, and thou observ'd by us

May both live safe in shade of thy lov'd Monalus.

first fleeces shorn in the season first milk after giving birth

tod, fox; badger

30 rites ... right] obvious pun. $\mathbf{3 2}$ orgies] rites, ceremonies (no bad sense). Jonson's marginal note in the masque Hymenoi: ' with the Greekes value the same, that Ceremonice with the Latines; and imply all sorts of rites. $\quad 34$ Nymphes of wood and water] Naiads and Dryads (cf. 6). $\quad 37$ like a wood] like swaying trees in a forest. $\quad 48$ Belov'd of Pan] By one legend, Echo spurned Pan's love and was therefore torn in pieces by shepherds: only her voice survived. 53 leasure] holiday, hence respite from work: cf. 1l.67-74. $\quad 56$ Lycæum] the Lycæan mountains in Arcadia, sacred to Pan. $\mathbf{6 6}$ Mænalus] mountain in Arcadia, Pan's favourite haunt. 


\title{
SHEPHERD
}

Now each returne unto his Charge,

And though to day you have liv'd at large,

And well your flocks have fed their fill,

Yet doe not trust your hirelings still.

See, yond' they goe, and timely doe

The office you have put them to,

task, duty

But if you often give this leave,

Your sheepe and you they will deceave.

\section{Ben Jonson A New Year's Gift Sung to King Charles, 1635}

From Jonson's The Under-wood, first published in vol.2 of the second Folio of his Works (1640). As Evelyn Simpson pointed out, ${ }^{*}$ the poem reproduces material from Jonson's masque Pan's Anniversary (c.1620-25: no.193), recycling praise of James I to address his son: cf. esp. 20-23, 28-31, 40. The later part (46-66) was further recycled for Charles II $c .1663$ by Nicholas Lanier (d.1666): see Textual Notes in the Companion to this volume.

The date in the title is 'old style' - i.e., 1636 by present reckoning. The Folio speech-headings are ambiguous and have been modified. In 14-19, the numbers indicate the successive speakers (shepherds and nymphs).

New yeares, expect new gifts: Sister, your Harpe, Lute, Lyre, Theorbo, all are call'd to day.

Your change of Notes, the flat, the meane, the sharpe, To shew the rites, and t' usher forth the way

Of the New Yeare, in a new silken warpe

To fit the softnesse of our Yeares-gift: When

We sing the best of Monarchs, Masters, Men;

For, had we here said lesse, we had sung nothing then.

\section{A New-yeares-Gift sung to King Charles, 1635.}

Rector Chori. To day old Janus opens the new yeare,

And shuts the old. Haste, haste, all loyall Swaines,

That know the times, and seasons when $t^{\prime}$ appeare,

And offer your just service on these plaines;

show; shew the rites celebrate

Best Kings expect first-fruits of your glad gaines.

proper, fitting, due

1. PAN is the great Preserver of our bounds.

lands, fields

2. To him we owe all profits of our grounds.

3. Our milke.

4. Our fells.

5. Our fleeces.

skins, pelts

$6 . \quad$ and first Lambs.

7. Our teeming Ewes,

$8 . \quad$ and lustie-mounting Rammes.

9. See where he walkes with MIRA by his side.

Chorus. Sound, sound his praises loud, and with his, hers divide.

Sheph[erds]. Of PAN wee sing, the best of Hunters, PAN,

That drives the Hart to seeke unused wayes,

And in the chase, more than SYLVANUS can,

Chorus. Heare, ô you Groves, and Hills, resound his praise.

can do or achieve

\begin{abstract}
*Evelyn Simpson, 'Ben Jonson's A New-Yeares-Gift', RES 14, 1938, 175-8. See also Rosamond McGuinness, 'The Origins and Disappearance of the English Court Ode', Proceedings of the Royal Musical Association, 87th session, 1960-61, 69-82. 1 Sister] ?misprint for 'Sisters', i.e. the Muses, whose instruments (2) indicate appropriate genres or veins of poetry. 2 Theorbo] a large lute, 'much in vogue in the 17 th century' $(O E D)$. 5 warpe] Folio follows with a full stop, offering an alternative construction. 7 To say less were to say nothing - i.e. he deserves this high praise. 9-10 Rector Chori] leader of the chorus. Janus] usually depicted with two faces, hence god of the new year as well of births and other commencements or changes, and of doors and gates: hence opens / shuts. $13 \mathrm{~A}$ good king has the right to the first-fruits of the prosperity brought about by his reign. 18 MIRA] Henrietta Maria, Charles's queen; in Herford and the Simpsons view, presented as his sister (25) in view of the 'sensuous character of the classical Pan'. 21 seeke unused wayes] to escape the hunters.
\end{abstract} unused] unaccustomed, secluded. 
Nym[phs]. Of brightest MIRA, doe we raise our Song, Sister of PAN, and glory of the Spring:

Who walkes on Earth as May still went along,

Chorus. Rivers, and Vallies, Eccho what wee sing.

Sheph[erds'] Chor[us]. Of PAN we sing, the Chiefe of Leaders, PAN, That leades our flocks and us, and calls both forth

To better Pastures then great PALES can: Heare, O you Groves, and Hills, resound his worth.

Nymp[hs'] Chor[us]. Of brightest MIRA, is our Song; the grace Of all that Nature, yet, to life did bring;

And were shee lost, could best supply her place, Rivers, and Valleys Eccho what wee sing.

1. Where ere they tread th' enamour'd ground, The Fairest flowers are alwayes found;

2. As if the beauties of the yeare, Still waited on 'hem where they were.

1. Hee is the Father of our peace; echo his praises

2. Shee, to the Crowne, hath brought encrease.

1. Wee know no other power then his,

Chorus. PAN only our great Shep'ard is,

Our great, our good. Where one's so drest

In truth of colours, both are best.

Haste, haste you hither, all you gentler Swaines,

That have a Flock, or Herd, upon these plaines;

This is the great Preserver of our bounds,

To whom you owe all duties of your grounds;

Your Milkes, your Fells, your Fleeces, and first Lambes,

Your teeming Ewes, aswell as mounting Rammes.

Whose praises let's report unto the Woods,

That they may take it eccho'd by the Floods.

'Tis hee, 'tis hee, in singing hee,

And hunting, PAN, exceedeth thee.

Hee gives all plentie, and encrease,

Hee is the author of our peace.

Where e're he goes upon the ground,

The better grasse, and flowers are found.

To sweeter Pastures lead hee can,

Then ever PALES could, or PAN;

Hee drives diseases from our Folds,

The theefe from spoyle, his presence holds.

PAN knowes no other power then his,

This only the great Shep'ard is.

'Tis hee, 'tis hee, e'c c.

26 as May ... along] as if spring were still continuing (in January). 27 Eccho] italicized in the Folio (also in 35), probably through confusion with the mythological character. 30 PALES] goddess of flocks and shepherds. $\quad 34$ shee] Nature. If everything in nature were lost, Mira could replace or replenish it. $\quad \mathbf{4 1}$ Either (a) she has given birth to children to continue the royal family (the future Charles II and James II, and a daughter Mary, later married to William Prince of Orange, all born by this date); or (b) she has added lustre or dignity to the British crown: she was daughter of King Henri IV of France. 44-5 Where ... best] Where one of these persons (Charles and Henrietta) matches the other in proving rhetorical conceits (colours) literally true, both are supremely excellent. $46 \mathrm{~A}$ radical change of direction here. The praise that follows is of one greater than Pan. Herford and the Simpsons take him as Charles the Christian monarch, now distinguished from the pagan god. But he may also be the Christian God. This alone would justify the repetition of $14-17$ in 48-51, the second This (48) implying 'This is truly such'. Cf. also shift from 'profits' (15) to 'duties' (49). $\quad 49$ For whose sake you perform all pastoral tasks. grounds] lands, fields ( $O E D$ 1Oc). 53 Floods] rivers, which will echo Pan's praises in their murmur. $\quad 60$ sweeter Pastures] presumably heaven. $\quad 63$ His presence prevents the thief from stealing. 


\section{Thomas Goffe From The Careless Shepherdess}

From Act 2 sc. 1 of The Careless Shepherdess, published in 1656 though Goffe died in 1629. Sylvia is the priestess of Pan.

Sylvia discovered in her Bower singing.

The Song.

Come Shepherds come, impale your brows

encircle, wreathe

With Garlands of the choicest flowers

The time allows.

Come Nymphs deckt in your dangling hair,

And unto Sylvia's shady Bowers

With haste repair:

Where you shall see chast Turtles play,

And Nightingales make lasting May,

turtle-doves

As if old Time his youthfull minde,

To one delightful season had confin'd.

growing in this season

Enter Shepherds and Shepherdesses.

1 Shepherd. What Musick's this doth reach our ears?

Which sounds like that made by the Sphears,

Aned so affects the eager sence,

'Tis ravisht with its excellence.

2 Shepherd. The ayr doth smell of Indian spice,

Or that the sences stupifies,

Which by Arabian winds is spread

From the ashes of a Phœenix dead.

Whence is this wonder.

3 Shepherd. See, see, where

The lovely Goddess doth appear:

Fair Sylvia, she that orders how

Before Pans Altars we should bow,

And for propition every year

Of the choice fleece our sheep do bear

Pay thankfull Sacrifice, that he

May keep our flocks from danger free.

Instruct us Goddess what's thy will.

Sylvia. Vpon this leavy wood-crown'd hill,

I do invite you to Pans feast,

Where each shall be a welcome guest.

Then to the musique of my voice,

Move gently on each with his choice,

But so that no malicious eye

See ought to task your modesty;

For your delights must alway be

Attended on by chastity.

\section{Dance.}

Sylvia. 'Tis time the Sacrifice begin,

Devotion must be done within;

Which done, you may of Ceres tast,

And Bacchus gifts, but make no wast:

For oft where plenty injur'd stands,

The bounteous Gods do shut their hands:

overwhelms, enchants

The snowy fleeces you have shorn,

And cropt the golden ears of corn;

chosen partner

take to task, upbraid

inside the temple

abused, exploited

9-10 As if old Father Time has turned young, and decided to enjoy spring the year round. 12 Sphears] In the Ptolemaic astronomical order, the stars and planets were thought to be embedded in crystalline spheres that made music as they revolved. 17-18 The phoenix, of which there was only one at a time reborn from its own ashes, was said to dwell in an Arabian setting sometimes identified with Paradise or the garden of Eden. $\quad 39$ Ceres] the goddess of harvests; her 'gift' is grain or bread. 
Lyoeus blood is prest and put

Into the safe preserving Butt:

There when the cold and blustring ayr

Invites you from the Plains, (yet fair)

To take Warm shelters, that may keep

Your selves in health, and eke your sheep,

Will into your numb'd limbs inspire

An active and preserving fire;

Let your expeessions then be free,

And gently moving follow me.

Ascends to her Bower singing.

She sings.

On Shepherds on, wee'l Sacrifice

Those spotless Lambs we prize

At highest rate, for Pan doth keep

From harm our scatt'ring sheep:

And hath deserved

For to be served

With those ye do esteem the best

Amongst the flock, as fittest for his feast.

Come Virgins, bring your garlands here,

And hang them every where:

Then let his Altars be o'respread

With Roses fresh and red;

Burn Gums and Spice,

Rich Sacrifice.

The Gods so bounteous are, ye know

Ye mortals cannot pay them what ye owe.

\section{William Drummond of Hawthornden Damon and Moeris}

From Drummond's Hawthornden MSS, vol.X in the National Library of Scotland. Draft ms with many deletions and revisions. Punctuation modified. May contain personal allusion: Damon is Drummond's usual pastoral name.

Damon and Moeris by a christal spring

Vher a greene sicamour did make a schade,

And fairest flours the banckes all couering,

Theer oft to stay the vandring Nymphes had made

Vhile voods musicians from the trees aboue

On eurye branche did varble furth ther loue,

On grassie bed tyrd them selues did lay

To schune suns heat and passe the tedious houres

Delyting now to see theer lambkins play

shun, avoid

Then to veaue garlands for theer paramours.

Damon tormentet vas vith Amarillis

And Moeris brunt in loue of farest Phillis.

Phillis the louliest lasse that flockes ere fed

By Tanais siluer streames, vhos heaunlie eie

In chaines of gold this shephard captiue led,

Or he knew vhat vas loue or libertie.

Sweet Amarillis far aboue the rest

Of Aska loua maids estimed the best.

ere, before

45 Lyæus] Bacchus or Dionysus; his 'gift' is wine.

Damon ... Amarillis] But later, Damon loves Phillis.

48 yet fair] not yet laid bare by winter. $\quad \mathbf{1 1}$

14 Tanais] The river Don, but Drummond seems to have a Scottish river in mind: phonetically and geographically, perhaps the North Tyne. 15 gold] i.e. the radiance of her eyes: a common Petrarchan conceit. 18 Aska loua] ?the river Esk, whose tributary the North Esk flows past Hawthornden. Cf. 14n. 'Tanais' and 'Aska loua' would then be two river valleys whose respective belles are loved by the two shepherds. 
In curious knots vhile thay theer vorke adorne

Mixing pyed dezies with sad violets,

Vhit lilies, vith that flour vhich like the morne

white

Doth blush and beautie to the garland sets,

Damon, vhom loue and voes had sore dismaid,

Thus gan to say, or Loue thus for him said.

Faire Tanais Nymphes and ye Nymphes of the voods

Vhich usse in schadie growes to dance and sing,

Ye Montaine Sisters, Sisters of the floods

On softest sand vhich oft ar carroling,

Heere bring your flours and this garland make faire

To set vpon my Phillis amber haire.

Do not disdaine to be a schade, sweet flours,

To fairest tresses vnder vhich doth grow

The rose and lilie far excelling yours,

The red cinabre and the milke vhit snow. About her temples vhen I sal yow place

Them you can not (sweet flowres), they shall yow grace.

Suouft-vinged archers and ye sea-borne queene,

use, are accustomed to mountain-dwelling; Sisters: i.e., nymphs

In Mirrhas child if yee tooke ere delight,

If ere vith flames your hart hath touched beene,

Enambushd lie you by this red and vhit, That vhen her lockes this coronet anademe sal part,

A hundred cupids may steal to her hart.

Her hart then coldest Alpine yce more cold,

Mor hard, yet precious as the diamond,

The noblest conquest that vith dart of gold

Loue euer made since he culd shoot or vound.

But he that fort not darring to essay

Contents you vith her eies and ther doth play.

appear dull in contrast with

Nou Ceres tuise hath cut her yellow lockes,

The swellow tuise the spring about hath brocht,

Tuise hath ve waind the yonglins of our flockes

cinnabar, vermilion or dark red

Since I alas vas forc't, and al for naught,

Be cruel her to cry, veep and complaine

Vnto this montaine, forrest, riuer, plaine.

soft

My flockes sem'd partneres of ther masters voe:

The Bell-bearer the troupes that vsd to lead

His vsuall feading places did forgoe

And lothing three-leu'd grasse held vp his head;

The walkes, the groues which I did hant of yore

My fate and Phillis hardnesse seemd deplore.

The Goate-foote Syluans vnder shadie trees

Did solemniz the accents of my plent

Vith grones, the vatrie Nymphes with veeping eies

And vide spred lockes I oft haue seen lament.

than

Among the rest a Nymphe sueet, vanton, gay,

Rising aboue the streame thus hard I say.

attempt, attack

twice

weaned

by 
Phillis sueet honor of thes suetest voods,

Vert thou but pitiful as thow art faire,

The vorthiest gem of al our Tanais floods;

But as in beautie so in hardness rare.

To al thes graces that so do grace the, Ah learne to loue, and no mor cruel be!

adding to, besides

The flowres, the gemmes, the mettales, all behold,

The lambes, the doues, the gold spangl'd bremes in streames,

$\mathrm{Al}$ thes be vorkes of loue; the Tygresse bold

Made mild by loue her inbred furie teames;

In heauen, earth, aire, since all where loue we see,

$\mathrm{O}$ learne to loue and no more cruel be.

In toilesome paines to vast our virgin yeares

And louelesse liue, is not to liue but breath;

breams (fish)

innate, natural

everywhere

Loue is the tree vhich most contentment beares,

waste

breathe

Vhose fruits euen makes vs liue beyond our death;

Sweet loue did make thy Mother bring forth thee;

$\mathrm{Ah}$, learne to loue, and no more cruel be!

Earths best perfections doth but last short time,

Riche Aprils treasure pleaseth much the eie,

But as it grows it passeth in its prime.

Thinke, and vel thinke, thy beautie thus must dye;

Vhen vith wan face thow sal loke in thy glasse

Then sal thow sigh: would I had lou'd alas!

Looke but to Cloris, louing, loud againe,

How glad, how merrillie sche spends each daye,

Like cherful vine vhom chaste elme doth sustaine

Vhile her sweet yonglings doe about her playe;

Vhen thow the want sal find of such a grace

Then sal thow sigh: vould I had lou'd alas!

But vho is Damon vhom thow suld disdaine:

The heauens on him some gifts hath euen let fal;

Gay is hee; vealth his cabane doth containe;

He loues the much, and that is more then al.

If crueltie thy loue in him deface

Then sal thow sigh: vould I had lou'd alas!

passes by, goes beyond

Flora him lou'd, if ere in clearest brooke

Narcissus-like thy face thow did admire,

As faire as thow; yet Flora he forsooke

Vith al her gifts, and foole, did the desire.

If he his thochts againe on Flora place

Then sal thow say: would I had lou'd, alas!

support, bear up

This said the Nymphe, and ther vith al sche sanke

The clearest streame beneath, vho al dismaid

At her depart come plaining to the banke,

And on his face a hundred frownes bevrayed.

I lay as on vhom some strange dreame makes vake,

Then homvard to my cabane did me take.

The floods sal backuard to ther fontaines rune,

The spring shall vant its flours, the pleasant flours

On barren rockes sal grow depriu'd of sune,

cabin, cottage

efface, destroy

would that

e'er, ever

thee

complaining, grieving

springtime; want, lack

76 teames] tames. Unrecorded spelling, perhaps to underscore the rhyme with streames. 103-5 if ere ... thow] i.e. Flora's face is as fair as your own that you might have seen in the brook. $\quad \mathbf{1 1 0 - 1 2}$ i.e. As the nymph plunged beneath the water, the waves or ripples were swept to the shore, the disturbed surface of the water like a hundred frowns on the river's face. 112 his] Damon's. bevrayed] bewrayed: revealed, expressed (OED 4). $\quad \mathbf{1 1 5 - 1 9}$ floures ... sune ... heauns ... starres] Linking of clauses in the figure concatenatio, perhaps suggested by a punning link of fontaines with spring. 
The sune sal leaue the heauns tueliueff shining boures;

Heauns vithout starres sal be, starrs cease to moue, zodiacal signs Ere euer I my Phillis leaue to loue.

Pant my hart doth vhen I thinke on that day, That fatal day, vhen sche vith looshung haire And vhitest petticot in new borne may

To gather flours did to our meeds repaire Vhile I did rest beneath an ancient oke, Caring for nocht but how to fead my flocke.

loose-hung early May, springtime

I saw her rune and as sche ran me thocht

The feilds about did smyle; beside the streames

Then sat schee down, vhere sune to kisse her sought;

130 But schee with vaile eclipsd his vanton beames. I hard her breath few vords, vith loue and feare

To vhich vinds, mountaines, voods, did leane their eare.

heard; breathe strain to hear

Deceu'd perchance vith that most liulie hew,

A bee did hurt her lip that mad her veep,

And moisten cheeke and chin with sweetest due

Vhich semed to fal, but Cupid did it keep.

For vhen rebellious harts ganstands his dart

He steeps it in thes teares, and then thay smart.

Vithal sche rose, and in floods vatrie glasse

Angerlie mild the litl vound to looke,

Her selff sche drest, but Kala comming vas

Vho made her stay, and so her mande sche tooke,

Of golden vonderes to make poore the Mead,

Vhile on her face my hungry eyes did feed.

At sight of her plump lips blush did the rose,

To see her vaines the violets grew paile,

The Marigold her precious leaues did close,

Amazd to find her haire so farre preuaile;

The lilies in her hand apeard not vhit.

Thus dazel'd vas my sight vith sueet delight.

Ouercharg'd at last sche to her village vent,

Leauing a thousand diuerse thoughts in mee

Lke ciuill foes tumultouslie vhich vent

All their best strenghtes til all enuasseld be.

Then tyrd vith vo I layd me in my bed

Vher al the Nyt the Hyacynthe I red.

Vhat vonder her sueet eies culd me beguile

Vhich kendle desire then vhen thay vtter breath,

And euen vhen sche vald froune yet seme to smile, lifelike colour (of a rose)

dew, i.e. tears gather, preserve gainstands, resists

mild even in anger addressed, directed her steps ?command, resolved task

precious: i.e. like gold her: i.e. Phillis'; surpass, excel

weary, exhausted

For these faire tuines I rather stil be sad

Then by an vthers loue euen be made glad.

\section{[Followed by this cancelled stanza in the manuscript:]}

Vhat Nature had dysperst in diuers vayes

To diuers vorlds in diuers time and place

Of suetest schape and coulour vorthie praise,

130 She shut out the sun's heat with a veil, as though spurning his lascivious advances. 141-2 but Kala ... stay] She stopped on seeing Kala approach. stay] hold back, withdraw. 145 plump lips] presumably plumper and redder from the bee-sting. $\quad 146$ i.e. Her veins were delicately purple. 149 i.e. The lilies appeared dull in contrast with her white hand. $\mathbf{1 5 3}$ ciuill foes] contending sides in a civil war or internal conflict. 154 enuasseld] made vassals: captured, defeated (by each other's attack). 156 the Hyacynthe I red] After Apollo accidentally killed his beloved Hyacinthus, he transformed him into the hyacinth, whose marks are read as AI, a Gk word of lament (Ovid, Met. X.162-219). Hence to 'read the hyacinth' is to mourn. 
$\mathrm{Al}$ at one time sche plac'st in phillis face.

And vundrus at her vorke so passing rare,

Sche sueare then by her selff that it vas faire.

swore

[Followed by three uncancelled stanzas as below. The first two, of which parts are illegible, seem intended as additions to be inserted into appropriate point(s) earlier on.]

Phebus, vhen as to vesterne vorld thow glids,

Thy flamie chariot lighting atlas streames,

Or vhen thow thruch Auroras pallace rids,

Chearing our sad vorld vith thy staff of beames,

Vhen thow hath gaz'd on <???>

Hath thow seene ocht so faire as phillis is?

[The next stanza has five lines only, and is hard to decipher, let alone interpret. It may represent a kind of plot outline rather than a draft stanza.]

Daphnis began his song but amarillis

Came neare to them with a heale crew here vnder

hale, merry

Vhich he espying in steed of songs began to giue vay

To sighes and Coridon tooke him away to the wood

The forester Coridon or some thing like this.

[The last stanza is in different ink and writing: apparently a later insertion meant to formally wind up the narrative, taking up the thread from 162]

Heere Moeris stayd; and Damon straight began

To make the woods his amarilis sound

Vhen from the Neighbouring bushes panting ran

A timorous Hare persued by Alcons hound

Alcon whose presence did their passiones tame

And made those shepheards follow Dianas Game.

\section{William Drummond of Hawthornden Erycine at the Departure of AleXis}

May be Drummond's side of a farewell exchange with Sir William Alexander (see 201.28n) before the latter set out on a journey; no.198 would then be Alexander's reply. However, the two poems are published together (this one for the first time) only in Drummond's 1616 Poems (followed here) and the 1711 Works. The ?1614 and 1656 Poems carry no.198 only, entitled 'Alexis'. Fogle argues that this poem is a conventional exercise, not linked to no.198.* In any case, Drummond does not speak in his own person but through Erycine, Alexander's real or imaginary beloved. Alexis was Drummond's poetic name for Alexander.

ERYCINE at the departure of AlEXis.

And wilt thou then, Alexis mine, depart?

And leaue these flowrie Meads, and christall Streames?

These Hills as greene as great with Gold and Gemmes,

Which courte thee with rich Treasure in each Part?

Shall nothing hold thee? not my loyall Heart,

That burstes to lose the Comfort of thy Beames?

Nor yet this Pipe which wildest Satyres tames?

Nor Lambkins Wayling? nor old Dorus Smart?

O ruethlesse Shepheard, Forrests strange among

What canst thou else but fearfull Dangers finde?

rays (of light from the eyes)

But $a h$ ! not thou, but Honour doth mee Wrong;

O cruell Honour! Tyrant of the Mind,

This said sad Erycine, and all the Flowres

Empearled as shee went, with Eyes salt Showres.

168 by her selff] upon herself, i.e. upon Nature. $\quad 172$ Image of clearing an unwelcome crowd with a rod. 173 Some words illegible or lost in the binding. 175 Daphnis] presumably in error for Damon - another indication that this 'stanza' is a rough jotting. Cf. 'Moeris', $180 . \quad \mathbf{1 8 1}$ Clear echo of Virgil I.5. $\quad{ }^{*}$ French Rowe Fogle, A Critical Study of William Drummond of Hawthornden (New York: King's Crown Press, 1952), pp.88-9. 8 old Dorus] perhaps a teacher or other father-figure. 


\section{William Alexander Alexis to Damon}

May or may not be a companion to no.197 (see headnote there), but with a markedly different publication history. Although not by Drummond, it appears in his Poems of ?1614, 1616 and 1656 and his 1711 Works, but no.197 (by Drummond himself) only in 1616 and 1711 . The text below follows 1616 to match no.197.

\section{Alexis to Damon}

The Loue Alexis did to Damon beare,

Shall witness'd bee to all the Woods, and Plaines,

As singulare, renown'd by neighbouring Swaines,

That to our Relicts Time may Trophees reare:

unique; celebrated, extolled

Those Madrigals wee sung amidst our Flockes,

With Garlands guarded from Apollos Beames,

On Ochells whiles, whiles neare Bodotrias Streames,

Are registrate by Ecchoes in the Rockes.

Of forraine Shepheards bent to trie the States,

Though I (Worlds Guest) a Vagabond doe straye,

Thou mayst that Store, which I esteeme Suruaye,

remains

As best acquainted with my Soules Conceits:

What euer Fate Heauens haue for mee design'd,

I trust thee with the Treasure of my Mind.

\section{William Drummond of Hawthornden A Pastoral Elegy on the Death of Sir ANTHONy AleXANDer}

Sir Anthony Alexander, Master of the King's Works in Scotland and second son of Drummond's old friend Sir William Alexander, died in London in 1637. This elegy was printed early in 1638 in a separate volume, of which only a fragmentary copy remains. The text below follows Drummond's Poems of 1656 . This edition, like Drummond's 1711 Works, names the dead person as Sir William Alexander, but the 1638 title is obviously correct. The elegy adapts, and at points closely echoes, Baldassare Castiglione’s Latin elegy Alcon on the death of his friend Doimizio Falcone.

In sweetest prime, and blooming of his Age,

Deare Alcon ravish'd from this mortall Stage,

The Shepheards mourn'd, as they him lov'd before;

Among the Rout him Idmon did deplore.

Idmon, who whether Sun in East did rise,

registered, recorded intent to examine the condition literally 'wanderer'

Or dive in West, pour'd Torrents from his Eyes

Of liquid Chrystall, under Hawthorne shade,

At last to Trees and Rocks this plaint he made.

Alcon, delight of Heaven, desire of Earth,

Off-spring of Phoebus, and the Muses birth,

The Graces darling, Adon of our Plaines,

Flame of the fairest Nymphs the Earth sustaines,

What Power of thee hath us bereft? What Fate

By thy untimely fall would ruinate

seized, snatched as much as, in proportion as gathering, company

Our hopes? O Death! what treasure in one houre

Hast thou dispersed? How dost thou devoure

What we on earth hold dearest? All things good,

Too envious Heavens, how blast ye in the Bud?

The Corne the greedy Reapers cut not down

Before the Fields with golden Eares it crown;

Nor doth the verdant Fruits the Gardener pull:

But thou art cropt before thy yeares were full.

beloved

destroy

green, unripe

7 Ochells] the Ochil hills, north of the Forth valley. Bodotria] the Firth of Forth. $\quad 11$ that store] the riches of their homeland, or perhaps of their study and poetry (of my Mind, 14). 2 Deare ... ravish'd] An absolute construction: 'Dear Alcon having been ravish'd...' 4 Idmon] This pastoral name appears in another poem by Drummond ('Idmon to Venus'). Probably a fictitious figure, seemingly of the same age as Alcon or Alexander, whereas Drummond was a generation older. 10 birth] offspring, child (OED 3). 11 Adon of our Plaines] The Adonis of our countryside. 20 with golden ... crown] i.e. before it is ripe. 
With thee (sweet youth) the Glories of our Fields

Vanish away, and what contentments yields.

The Lakes their silver look, the woods their shades,

The Springs their Christall want, their Verdure Meads,

The yeares their early seasons, cheerfull Dayes,

Hills gloomy stand now desolate of Rayes:

Their amorous whispers Zephires not us bring,

Nor do Aires Quiresters salute the Spring;

The freezing winds our Gardens do defloure.

Ah, Destinies! and you whom Skies embow'r,

To his faire Spoiles his Spright againe yet give,

And like another Phonix make him live.

sunbeams

zephyrs, spring breezes

'air's choristers' i.e., singing birds

beautiful dead body

The Herbs, though cut, sprout fragrant from their stems,

And make with Crimson blush our Anadems:

The Sun when in the West he doth decline,

Heavens brightest Tapers at his Funeralls shine;

His Face, when washt in the Atlantick Seas,

Revives, and cheeres the Welkin with new Raies:

Why should not he, since of more pure a Frame,

Returne to us againe, and be the same?

But wretch, what wish I? To the winds I send

These Plaints and Prayers, Destines cannot lend

Thee more of Time, nor Heavens consent will thus,

Thou leave their starry World to dwell with us;

Yet shall they not thee keep amidst their Spheares

Without these lamentations and Teares.

Thou wast all Vertue, Courtesie, and Worth,

And as Suns light is in the Moon set forth,

World's supreame Excellence in thee did shine:

Nor, though eclipsed now, shalt thou decline,

But in our Memories live, while Dolphins streames

Shall haunt, whilst Eaglets stare on Titans beames,

Whilst Swans upon their Christall Tombes shall sing,

Whilst Violets with Purple paint the Spring.

A gentler Shepheard Flocks did never feed

On Albions Hills, nor sung to oaten Reed:

While what she found in Thee my Muse would blaze,

Griefe doth distract Her, and cut short thy Praise.

How oft have we, inviron'd by the Throng

Of tedious Swaines, the cooler shades among,

Contemn'd Earths glow-worme Greatnesse, and the Chace

Of Fortune scorn'd, deeming it disgrace

To court unconstancy? How oft have we

Some Chloris Name graven in each Virgin Tree,

And, finding Favours fading, the next Day

What we had carv'd we did deface away?

Woefull Remembrance! Nor Time nor Place

Of thy abodement shadows any Trace,

But there to me Thou shin'st: late glad Desires,

And ye once Roses, how are ye turned Bryers?

Contentments passed, and of Pleasures Chiefe,

Now are ye frightfull Horrours, Hells of Griefe?

plural form current at this date

the Fates

chase, pursuit

24 what ... yields] whatever yields happiness or satisfaction. 31 defloure] strip of flowers, but with further sinister sense.

27 early seasons] spring and summer. 32 you] i.e. the gods. The Destinies were also seen as goddesses, the Parcae or Fates. 34 another Phoenix] A new Phœenix was supposed to spring from the ashes of the old. 39 in the Atlantick Seas] i.e. The farthest western point of the known universe: more suited to a classical than a British context. 52 Continuing the metaphor of heavenly bodies. $\quad 54$ Eaglets ... beames] The eagle, king of birds, was thought the only bird that could look straight into the sun's rays. 55 Christall Tombes] the crystal-clear waters where they die. 58 Albion] traditional name for Britain, from the white cliffs of Dover (Lat. albus, white). $\quad 64$ scorn'd] perhaps error for 'scorned' (two syllables, suiting the scansion). 
When from thy native Soyle Love had Thee driven,

(Thou safe returne Prefigurating) a Heaven

anticipating, envisaging

Of flattering Hopes did in my Fancy move,

Then little dreaming it should Atomes prove.

'These Groves preserve will I, these loved Woods,

These Orchards rich with Fruits, with Fish these flouds:

My Alcon will returne, and once againe

His chosen Exiles he will entertaine;

The populous City holds him, amongst Harmes

Of some fierce Cyclops, Circe's stronger Charmes.

These Bankes (said I) he visit will and Streames,

These silent shades ne're kist by courting Beames.

Far, far off I will meet him, and I first

Shall him approaching know, and first be blest

With his Aspect, I first shall heare his voice,

90 Him find the same he parted, and rejoyce

To learne his passed Perills, know the Sports

Of foaraine Shepheards, Fawns, and Fairy Courts.

No pleasure to the Fields, an happy State

The Swaines enjoy, secure from what they hate:

Free of proud Cares they innocently spend

The Day, nor do black Thoughts their ease offend;

Wise Natures Darlings they live in the World,

Perplexing not themselves how it is hurld.

These Hillocks Phobus loves, Ceres these Plaines,

These Shades the Sylvans, and here Pales straines

Milke in the Pailes; the Maids which haunt the Springs

Daunce on these Pastures, here Amintas sings:

Hesperian Gardens, Tempe's shades are here,

Or what the Easterne Inde and West hold deare.

Come then, deare Youth, the Wood-nymphs twine thee Boughs

With Rose and Lilly, to impale thy Brows.

Thus ignorant, I mus'd, not conscious yet

Of what by Death was done, and ruthlesse Fate:

Amidst these Trances Fame thy losse doth sound,

And through my Eares gives to my Heart a wound;

With stretched-out Armes I sought thee to embrace,

But clasp'd (amaz'd) a Coffin in thy Place.

A Coffin! of our Joyes which had the Trust,

fragments - i.e., it would shatter

Which told that Thou wert come; but chang'd to Dust:

Scarce, even when felt, could I beleeve this wrack,

Nor that thy Time and Glory Heavens would breake.

Now since I cannot see my Alcons Face,

And find nor Vows, nor Prayers to have place

With guilty Stars, this Mountaine shall become

To me a sacred Altar, and a Tombe

To famous Alcon: here, as Daies, Months, Yeares

Do circling glide, I sacrifice will teares:

Here spend my remnant Time, exil'd from Mirth,

Till Death at last turne Monarch of my Earth.

Shepheards on Forth, and you by Doven Rocks,

Which use to sing and sport, and keep your Flocks,

Pay Tribute here of Teares, ye never had

rapturous dreams; report, news

confused, perplexed

malign or unjust fate

are accustomed to

75 from thy native Soyle] Alexander died in London; his embalmed corpse was brought by sea to Stirling. Love had Thee driven] a pastoral fiction. Alexander had married a Scotswoman. 82 Exiles] perhaps in extended sense of 'travelling companions' (who will return with him). $\quad \mathbf{8 4}_{4}$ Cyclops, Circe] Comparing Alexander's experiences in the 'populous city' with those of Odysseus. 93 No pleasure ... Fields] There is no pleasure to compare with that of country life. 98 hurld] moved, driven, with implication of violence and confusion. 101 Maids ... Springs] Naiads or water-nymphs. 103 Hesperian Gardens] the garden with golden apples guarded by the Hesperides. Tempe] a beautiful valley in Thessaly, associated with Apollo. 104 what ... deare] spices and gold respectively. 106 impale] encircle $(O E D 2)$. $\quad 113$ of ... Trust] which held charge of or power over our happiness. 115 wrake] harm, disaster (OED wrake $\left.\mathrm{n}^{1} 4\right)$. 125 Forth] a river in Scotland. Doven] Dovan or Devon, a tributary of the Forth. 
To aggravate your Moanes a cause more sad;

And to their sorrows hither bring your Mands,

Charged with sweetest flow'rs, and with pure Hands

charge, lend weight to

(Faire Nymphs) the blushing Hyacinth and Rose

filled, laden

Spred on the Place his Relicts do enclose,

Weave Garlands to his Memory, and put

Over his Hearse a Verse in Cypres cut:

Vertue did dye, Goodnesse but harme did give,

After the noble Alcon ceas'd to live,

Friendship an Earthquake suffer'd; losing Him,

Loves brightest Constellation turned Dim.

\section{William Drummond of Hawthornden Fragment of a Greater Work}

This piece from Drummond's Hawthornden MSS, vol.X in the National Library of Scotland anticipates Wordsworth's mystical vein. It is not a pastoral poem, but links a pastoral topos, however lightly, to a notable spiritual experience. Virtually all punctuation added and line initials regularized.

fragment of a greter vorke

As vhen a sheaphard boy from fearful hight

Of steepie rocke lookes to some groundless deep,

Each thing semes dance vnto his dazeld sight

bottomless

seems to

And trembling feare doth thruch his sinnowes creep.

If he hath lyff or no he knowes not ryt,

His mind her pouers, his hands ther gripe scarce keepe,

Com'd to himselfe and sune afraid doth vonder

The gostlie vatters that he saw him vnder.

Even so vhen I vith troublet thochts behold

Beyond vorlds firie clostere dec vith beames,

decked

Him in eternitie vho did vnfold

Of naughts darke curtens t'erth and brinie streames

And vhat about thes tuo is daylie rold,

And thinkes (ai me, me thinkes my thochts ar dreames)

He suld him vrap in flesh, I quake, I sound;

Amaz'd, I'm mad like to the sensles ground.

wrap; swound, swoon

made

Do not vaine mortals, do not fooles improue

$\mathrm{Al}$ that your bastard reason can not see,

Your vit but serves your ignorance to proue

And vho knowes lest your errors most knowes he.

least

$\mathrm{O}$, foolish vise like to the seeled doue

Vho higher goes the blinder that sche be,

wise; with the eyelids sewn up

Giganticol race, how vil ye scal heuens toures

Vhen your blunt braines can not vel know earth's flowres.

129 their] prob. alluding to the 'Moanes', but perhaps to Forth and Doven. Mands] maunds, baskets (OED maund 1). 132 the Place ... enclose] the place that encloses or contains his relics. 134 Cypres] cypress wood, a symbol of eternity, hence paradoxically evoked in contexts of death and mourning, and used to make coffins. 7 vonder] wonder: then used transitively $\left(O E D_{3}\right)$. 8 vatters] waters. Best guess at an unclear word in the ms; may be 'valley'. 10 vorlds ... beames] the firmament or sphere of the stars: God dwells in the Empyrean beyond. $\quad \mathbf{1 1 - 1 2}$ vnfold ... streames] create the land and sea out of the void. vnfold] draw out, extend, reveal. naught] void, nothingness. 13 And all that moves every day across these two (land and sea). 15 vrap in flesh] appear in human form, incarnated as Christ. $\quad 17$ improue] disallow, condemn (OED improve $\mathrm{v}^{1} 2$ ). $\quad 18$ bastard] spurious: perhaps the limited human faculty of 'reason', inferior to the spontaneous apprehension or 'intelligence' of the angels. $\quad 20$ The wisest man is he who has least of your erroneous knowledge - i.e. the unlearned man is the wisest. 21 foolish vise] an oxymoron. 23 Giganticol] Fogle's reading of an unclear word in the ms. Apparently a coinage: ?foolish giant; ?puny being aspiring to be a giant. 24 floors] prob. 'floors', opposed to towers (23); perhaps 'flowers'. 


\section{George Lauder From 'Damon: or a Pastoral Elegy'}

Lines 103-18, 231-86 of a poem first published in Drummond's 1711 Works. The editors' preface describes the author as 'the ingenious Colonel George Lawder of Hatton, the Author's intimate Acquaintance', and Damon as the name by which Drummond 'passed frequently in his Writings, and among his Comrads'. The poem presents Lauder (Lysis), who dwells abroad (for much of his life in Breda in the Netherlands), hearing of the Civil War in Britain from the newly-arrived Alcydon. They are both Royalists, like Drummond (Damon), who is reported here as dying of grief for Charles I. In fact, Charles was executed on 30 January 1649, and Drummond died on 4 December that year of a long-standing illness.

DAMON: OR A PASTORAL ELEGY, on the Death of his Honoured Friend William DRUMMOND Of HAWTHORNDEN

Ah! when I call to Mind that happy Time,

When my fresh Youth was in her Flow'ry Prime,

Ere Beauty's Force I found, or felt Love's Flame,

And first a Stripling 'mongst the Shepherds came,

Kind Damon was the Peer of all the Plains,

The Valley's Honour, Glory of the Swains;

And when his Reed or sweet Rebeck was heard,

Our Flocks forgot to Feed, they stood and star'd,

The Nightingales came near new Notes to learn,

The Stags were roused from the brushy Fairn,

The wanton Wood-Nymphs were no longer wild,

fern, bracken

But danc'd about, and on him sweetly smil'd:

Or did he Sing, the Shepherds all were still,

The Birds were hush'd, Brooks sleept, from Dale nor Hill

if he sang

No Noise was heard, lost Silence shut up all,

To Muse on his Melodious Madrigal.

Dear Damon! Is it true that thou art dead?

And Lysis lives a loathed Life to lead?

My Thoughts alace! were always set on Thee,

With Hope at last thy long wish'd Look to see,

That my poor Muse might do Thee Homage due,

And, after Absence long, old Love renew;

Which since Thou hast born hence to Heav'n with Thee

Thy Lysis still shall love Thy Memory,

And make both Maes and Rhine thy Name resound,

As far as Shepherds by their Banks are found.

Ay me! why have not I old Ayton's Vein?

Or great Alexis stately Tragick Strain?

To sound thy Vertues, sing thine Obsequies

In Panegyricks and sad Elegies?

Earth's farthest Climates with thy Worth should ring,

And worship Thee, where Fame can stretch a Wing.

Yet with that Vigour my poor Verse can fly,

It shall record to after-times that I

So dearly lov'd thy Worth, thy Name ador'd,

Thy Friendship honour'd, and thy Death deplor'd;

That wheresoe're the World my Rhimes shall read,

There Damon's Love shall live, when we're both dead:

Nor shall I fear Antiquity to wrong,

With our own home-bred Haunts to stuff my Song,

And say our Forth, which doth so winding wander,

As Famous is by Thee, as old Moeander:

20 thy long wish'd Look] your face, which I had longed to see. $\quad 25$ Maes] the river Maas or Meuse. 27 Ayton] Robert Aytoun (1570-1638), court poet of James VI/I: one of the first Scottish poets to write in English. 28 Alexis] Sir William Alexander, Drummond's friend: Earl of Stirling, early colonizer and writer of the classical tragedies Croesus, Darius, The Alexandrean and Julius Caesar. 39-40 I will not wrong antiquity if I compare our Scottish landscape to that of classical times.

Meander or Buyuk Menderes, a winding river in Turkey. 
Thy murmuring Esk and Ora's rushy Hair, With Mincius and old Tiber to compare? And why shall I not freely venture then To match with Helicon thy Hawthornden? Thy Grotte, in which grim Saturn still remains, Bound to the Rock with mighty Metal'd Chains;

The same Prophetick Spirit doth inspire

That in Trophonius Cave set Souls on Fire;

And if the Earth from hence a Passage yields,

It is the Entry to th' Elysian Fields:

A fitter Place the Fates could never find

To lay thy sacred Reliques up enshrin'd;

There all the Nymphs and Shepherd Swains can come

And Yearly sing sad Hymns before thy Tomb,

Which on the Marble cold these Lines shall keep,

For Pilgrims all to read, and parting weep,

That once thy Care commanded should be cut

Upon thy Grave, if I have not forgot,

Here DAMON lies, whose SONGS DID SOMETIMES GRACE

The Murmuring ESK, may Roses shade the Place.

But soft my Sorrow, now the setting Sun,

To Thetis kind Embrace doth posting run;

Good-night Alcydon, all good Luck attend thee,

And what thy Soul doth wish, thy Fortune send thee.

This said, they parted, and poor Lysis Grief

So seis'd his Soul, which look'd for no Relief,

That while he Careless and Cross-armed went, With staggering Steps his Loss for to lament,

He often stood to Sigh, and at the Name

Of Damon Fainted: So he lov'd his Fame. Sunt artibus arma decori.

\author{
his chest \\ with arms crossed against \\ [reputation \\ i.e., Damon's posthumous glory or
}

\section{Edward Fairfax Hermes and Lycaon}

One of three surviving eclogues (one incomplete) of the twelve said to have been written in 1603 by Edward Fairfax, translator of Tasso's Jerusalem Delivered. From a transcript by his nephew Thomas, third Baron Fairfax, in Bod. MS Fairfax 40. A debate between Lycaon, a Catholic priest, and Hermes, a Protestant one. The phrasing and imagery draw heavily on the Bible, especially the Book of Revelation. Virtually all punctuation added and some spellings standardized, including Psyche for Phyche or Phyches.

The Argument

Lycaon his false church extends

through all the world, with pompe and pride.

Hermes the church of Christ comends

And to her spouse brings home his bride.

The sweatie sith-man with his rasor keene

Shore the perfumed beard from medowes greene

scythe

old past tense of 'shear'

43 Esk] the river flowing past Hawthornden. Ora] the river Ore, flowing into the Leven in Fife. $\quad 44$ Mincius] a river near Mantua, Virgil's native region. Tiber] flowing past Rome. 47 Thy Grotte] 'probably the cave at the foot of the rock on which the house of Hawthornden is built' (Kastner). These lines closely echo Drummond's 'Forth Feasting' 259-60, though the context is quite different. 'Saturn' may be a statue, or a subterranean sound so explained. 50 Trophonius] With his brother Agamedes, built the temple at Delphi, seat of the famous oracle (in an underground chamber); also associated with an oracle in a cave in Boeotia. 59 That ... commanded] that you once took care to command. 64 Thetis] a Naiad or sea-nymph, hence the sea. 65 Alcydon] see headnote. 73 Sunt ... decori] (Lat.) Arms are adorned by arts. o.1 Lycaon] Ancient king transformed into a wolf for sprinkling the blood of slain children on the altar of Zeus; here the Catholic church, implicitly charged with violent sacrilege. For Protestants, the wolf was a common image of the Catholic church. In the pastoral context, Lycaon, in shepherd's guise, is actually a wolf preying on his sheep. $\quad \mathbf{0 . 3}$ Hermes] Mercury, conductor of the souls of the dead, thus a mediator between God and man; here the Protestant church, with associations of Christ himself. Lea and Gang point out that the Lycaonians, when wishing to worship the apostles, called Paul Mercurius (i.e., Hermes): Acts 14.8-18. o.4 her spouse] Christ. Christ and the Church were traditionally bridegroom and bride.

2 perfumed beard] i.e. hay. 
And on each bush and euery mossie stone

Iarred Maies littel daughter Tettrigone

When to the shadowes of a mountaine steepe

Lycaon droue his Goats, Hermes his sheepe.

The shepards both were Louers, both were younge.

Ther skill was like in piping, like in songe.

The other groomes thatt hard, hid in the dales,

Were dume for shame, like conqured Nightingales.

Oft came the Nimphs, the Farie sisters oft

Forsooke ther mossie beds and liards soft,

And oft the halfe-gods att ther musick sound

Came, and ther browes with Iuie garlands crownd.

Yee sedgie lakes and peble-paued wells,

And thou great Pales in these feilds that dwells,

How oft haue you, hid in the shadie spraies,

Listned Lycaon's songes, his Loues and Laies.

And you, high stretched Pines and Oakes of Joue,

Thou wanton Eccho, tel-clock of this groue,

How oft did you faire Psyches praise resound,

When Hermes charmd with songes loues bleeding wound.

They sunge by Course and praised ther loues by turnes:

chirped; cicada, grasshopper

Each Crickett loues the flame wherein she burnes.

And whilst ther flocks bruze on the shrubs and briers,

They tune ther pipes, and thus they sing their fiers.

unrestrained, playful

dumb; defeated (in song)

liarts, balsam poplar trees

Lycaon. Flora, my queene, my ioy, my heauen of bliss,

Se what my merit and deseruing is.

I build the Temples and I feed thy sheepe,

I bring thee gifts, thy words as Lawes I keepe.

My bed is ashes, sackcloth is my weede,

I drink with Rechabs sonnes, with Job I feede.

For all my seruice and this suffring longe

Loue me, sweet Flora, or thou dost me wronge.

Hermes. Psyche, my deare, my vndefild, my doue,

ô Comfort me, for I am sick of loue.

Thy sacred temple is this wounded brest:

Sin, error, folly my seruice is att best.

Foule leper spotts on all my body growe:

Wipe out these staines and wash me white as snow.

Clothe me with Linien, crowne my head with gold:

First make me worthie Loue, then Loue me bold.

Lycaon. Flora was younge and faire, few goats she kept.

Ten Kings espide her, loued her, with her slept,

And in her sweet imbrace such ioy they found

That with three Diadems her head they crownd,

6 Goats, sheepe] Shepherds rank above goatherds, in classical convention reinforced by Matthew 25.32. 13 halfe-gods] wood-gods: fauns, sylvans etc. 16 Pales] goddess of flocks and sheep. 18 Listned] listened to: transitive use current till 19-c. $\quad 20$ tel-clock] one who 'tells the clock', an idler. 21 Psyche] the soul as well as the Church, both traditionally brides of Christ. In classical myth, Psyche was loved by Cupid; hence Hermes / Christ is the ideal lover or god of love. 25 bruze] browse: spelling not in OED. $\quad 27$ Flora] Roman goddess of flowers, sometimes associated with a famous harlot and the dissolute festivities of the Floralia: for Protestants, a suitable figure of the Catholic church. 28 merit and deseruing] Catholics believe in justification by works, Protestants by faith: see 77, 107, 174. 29 build the Temples] Lea and Gang see a specific reference to the building of St Peter's in Rome from the sale of indulgences. $\quad 31$ ashes, sackcloth] perhaps alluding to the Catholic practice of confession. $\quad 32$ Rechabs sonnes] the Rechabites, descended from Rechab through Jehonadab, who forbade his descendants to drink wine (Jeremiah 35.6). Job] No doubt in his days of abjection. Lea and Gang cite Job 3.24, 'For my sighing cometh before I eat'. 35-6 Evoking the love between Christ and the soul (and/or the church), mystically read into the Songs of Songs (see 6.9, 2.5). 37 Echoes Psalms 51.17-18 conflated with 1 Cor. 3.16. $\quad 41$ Linien, gold] See Rev. 4.4., 19.8. 44 Ten Kings] associated with the beast of the Apocalypse (Rev. 17.12), commonly identified by Protestants with the Catholic church. These kings commit fornication with the woman seated on the beast (Rev. 18.3), also a figure of the Catholic church. $\quad 46$ three diadems] the triple crown of the Pope. Protestants made this an attribute of the woman seated on the beast in Revelation: see Spenser, FQ I.8.25. 
And on seauen heapes ther wealth and tresure laid,

Sett her ther on, fell att her feet and praide.

She forty months and tow ther seruice proues,

two

And takes them for her slaues, not for her loues.

Hermes. Psyche my virgen bare a blessed sonne:

The dragon chastd her, she to desart runne,

chased

The feend a streame of water att her flings:

Earth drunk the flood, she scapt with eagles wings.

Crownd with twelue stars, clothd with the glorious Sun,

She doth with Roes and Hindes in Eden wonne.

Ther Psyche liues and reignes in safty plast

Till time and times and halfe a time be past.

Lycaon. Out of the sea a scarlet beast appeard:

Ten hornes he had and seauen heads proudly reard.

His forked taile gainst all the world made wars

And smote the third of trees, of floods, of stars.

Flora this monster caught and tamde his pride,

And on his back as on a mule doth ride.

All nations feare the beast and serue the dame,

And sealed are with's number, marke, and name.

dwell

Hermes. Before the gates of Psyches shepcote lies

Fowre wonderous beasts all full of wings and eyes,

And round about them fowre and twentie Kings

Offer vp gold and mirrh and pretious things.

All these do Psyches lambes keepe, cure and feed,

And thousand thousands clad in milk-white weed

protect; (a) look after (b) heal illness

clothes

Sings himmes of loue and faith, and neuer ceace,

And on his brow each weares the seale of peace.

Lycaon. Flora once found me sick and hurt to death.

Thrice did she cross me, thrice vpon me breath.

Three times she dipt me in a liuing streame

And salued my wounds with spitle, salt and creame.

And thousand saints she for my garde apoints

And all my head with oyle and baulme anoynts,

Then makes me maister of her flocks and fould,

Her goats to keepe or kill or sell for gold.

with his (its)

Hermes. Psyche first tooke me, soild with mire and clay,

Washd in the well of life my filth away.

Theeues robd me, slew me; of a Lambe new slaine

On me she powerd the blood, I liued againe.

Sence that with bread of heauen, wine of grace,

She diets me her lapp my resting place,

Her sheepe my playfelowes, heauen our fould,

Her spouse the doore, his voyce the key of gould.

[breathe

make the sign of the cross over;

chrism, ceremonial oil

(n)


Lycaon. Itt was the fifteth yeare. Flora a feast

Made for all those that loued and serued her beast.

Her gests were Kings and Lords of highest bearth,

All that were wise and rich vpon the earth.

And that Land, that Sea or ayre affords,

Her caters tooke and ther with fild her bords,

And drunk with wine, suckt from her cup of gold,

Were Kings and nations, rich, poore, young and old.

Hermes. Psyche to super cald the weak, the poore,

The sick, the lazer from the rich-mans doore,

And att her bord sett them with Lords and Kings:

Her holy stewards wine and wafers brings.

They eat and drinke by faith and thirst noe more,

Except some guests forechargd with Floras store

Sitt ther, and spider like from roses new

Draw poyson wher the Bee sucks hunny dew.

Lycaon. Flora an orchard had of fruitfull treene.

She parde the mosse, she kept the branches cleane,

old plural of 'tree' scraped off

She lett the fountains in, she kild the worme,

110

She scard the birds, she saued the bloomes from storme.

Flourisht the trees, the bowes with aples bent:

She cald her seruents, to her orchard went,

Gethered to eat, but when she cutt the skin

The fruit was ashes, imbers, dust within.

embers, smouldering ashes

Hermes. Last yeare my Psyche had a feild of corne.

She skourd the ditches, stopt the gaps with thorne.

She tild the land enough, she grew good seed,

She stubd the briers, pluckt vp the tares and weed,

She fraid the crowes, she kept the wild bore out,

And when the Sun turned the years wheele about,

She reapt her crop, and when her gaine she tould

Found thirty, sixty and a hundred fould.

Lycaon. A flock of goats astray from Flora went.

Doris her handmade after them she sent,

But whilst the lass with Thirsis sporting laid,

Her dogs rann forth alone and soone they straid,

And like the kind of wolues of which they sprung,

They slew and eat the goats and sucklings young.

Yet some escapt, saued in the woods and rocks. guests; birth, ?also berth, rank

[tables servants who buy provisions; boards, 
Lycaon. King Salomon a Cedar pallace built,

Thackd with tyles of Floras tresses guilt.

Her legs were siluer posts the house to beare,

Her glorious thoughts the purple hangings were,

Her brest the presence, and her hart his throne.

Her triple Crowne as Lord ther sitts alone.

Her holy doors she opes to each that knocks,

Her hands pure Myrrh drop on the bars and locks.

Hermes. Psyches faire locks, wrapped in gold of proufe,

Of gods high Temple is the guilded roufe,

Her eyes the Cristal windowes: through each light

A smiling saint shoots in daies arrows bright.

Her Corall Lips the doores that turne and twine

On Rubie hookes, her mouth the quire deuine,

Her teeth the Iuorie seats built euen and thin,

thatched, roofed; gilt, golden

140

Her tongue the siluer bell that rings all in.

Lycaon. That roial towne wher Flora hath her seat

Stands on seauen hills, well peopled, pleasant, great,

Rich in all blessings, all delights that can

Be giuen by fortune or be wished by man.

Quinzey the large, Dorado yitt scant seene

Her hand mads be: she is the worlds sole queene.

Ioy in her streets, life in her Temples wide,

And dead and lost is all the world beside.

presence: ?sanctuary

Hermes. Psyches cleare Citty was nott raised from dust

But came from heauen, pure, immortal, iust,

Stands on twelue pretious stones: Iasper the wall,

Streets gold, gates Pearles bee, still ope to all

Who tast the tree of Life which ther do grow.

About the towne two blessed riuers flow

Of Grace and Mercy, ouer ether flood

tested, of proven quality

opening, window

hinges

Lies the faire bridge of faith, hope, doing good.

either

Lycaon. Of shrill Heptaphones thou daughter cleare,

Tell not these rocks of Floras doubte and feare.

Write nott, Phanetas, in tomorrows stars

Her future troubles, dangers, losses, warrs,

Least Psyches shepards should foreknow her doome

And kill her goats before her day be come.

These woods are hers, these feilds and folds about:

Then keepe them Flora, till thy lease weare out.

139-46 Cedar pallace] a palace built of cedar wood, like Solomon's temple (1 Kings 6), to which the Catholic church is being compared. As the church is also equated with Flora's body, the image acquires a sensual dimension. 141-2 Takes details from Song of Songs 3.10, 5.5. 145 Suggests promiscuity. 147-53 Psyche's face (rather than her entire body) is equated with the physical structure of a Temple, now clearly a Christian church. $\quad 149$ Cristal] clear, transparent; in this context, also suggests chrystal. 150 saint] As depicted in a stained-glass window: a holy context for the common Petrarchan image of the mistress's eyes rivalling the sun. 156 seauen hills] obviously suggesting Rome. 159 Quinzey] Quinsai in China. Marco Polo reported that the name means 'City of Heaven', and the place resembles paradise (Purchas, Pilgrims 2.2.4.8). Dorado] El Dorado, the legendary city of gold in South America. 16o Her hand mads] i.e. of inferior rank. 163-9 Follows the account of the New Jerusalem, Rev.21.10 22.5. 168 two blessed riuers] Revelation mentions only one 'river of water of life' (22.1). 170 doing good] Interestingly, Fairfax brings back the principle of good works, earlier dismissed as Catholic. 171 Heptaphones] or Heptaphonos, a colonnade in ancient Olympia with a sevenfold echo. Hence Echo is called the 'daughter' of Heptaphonos. Here, she is being asked not to resound and spread the prophecy of Flora's impending doom, though even Lycaon himself seems sure of it. 173 Phanetas] garbled form of Phanes, an Orphic god whom Fairfax associates without warrant with astrological prophecy. 175-9 lest the Roman priests, foreseeing their doom, should kill off their flock in despair. 
180

190

Hermes. Sitting on Isis flowrie banke, I spied

On a white horse a crowned Monarch ride.

Vpon his thigh was write his wonderous name,

Out of his mouth a sword two-edged came.

Flora, hir beast, and all her goats he slew,

And in a lake of fire ther bodys threw.

This king is Psyches spouse: with him she went

And rul'd the world, for Floras lease was spent.

Thus much did Hermes and Lycaon singe.

The heifer lett the hearbs vntouched spring,

Forgott to feed, the stags amazed stood,

The siluer riuer staid her speedie flood.

Charmed was the Adder deafe, tamde was the Lion:

So trees hard Orpheus, Dolphins hard Arion.

grow, sprout

stopped her swift current

heard

\section{Antoine Girard Saint-Amant The Solitude}

Translated from the French by Thomas, Third Baron Fairfax.

A rendering of Saint-Amant's French poem 'La Solitude. À Alcidon' (?1617). Text follows Bodleian MS Fairfax 40. Line initials uniformly capitalized. Punctuation largely introduced in this edition. There are other mss., and another trans. by Katherine Philips.

O how I love these solitudes

And places silent as the night,

Ther wher noe thronging multituds

Disturbe with noyse ther sweet delight.

their: of the 'solitudes' and 'places'

O how myn eyes are pleas'd to see

Oakes that such spreadinge branches beare,

Which from old time's natiuity

And th'envy of so many yeares

Are still greene, beautifull and faire,

malice, damage

As att the world's first day they were.

Naught but the highest twiggs of all

Wher zephyrus doth wanton play

Doe yett presage ther future fall

sportively, in dalliance

Or shew a signe of ther decay.

Times past, Fawnes, satyrs, Demy-Gods

Hither retird to seeke for Aide

When Heauen with earth was soe att odds

As Jupiter in rage had laide

Or'e all a Deluge: these high woods

Preseru'd them from the sweling floods.

Ther vnder a flowry thorne alonge,

Of springs delightfull plant the cheife,

Sadd Philomela's mournfull songe

Doth sweetly entertaine my greefe.

And to behold is noe less rare

These hanging Rocks and Precepies,

hawthorn

the nightingale

precipices (old variant)

179 Isis flowrie banke] An unexplained reference, as the Isis flows past Oxford. There is some uncertain evidence that Fairfax might have been at Clare College, Cambridge. 180 a crowned Monarch] See Revelation 19.11-16, 20.1-3, 7-10. This figure represents Christ (the spouse of Psyche, who can be both the church and the individual devotee), who now conclusively defeats Satan and his band, and judges all living and dead humans. 191 Charmed ... deafe] The adder is thought to stop its (actually non-existent) ears so as not to be charmed by its catcher's music; but now it agrees to hear such sweet song, and is charmed (spellbound) by it. See Psalms 58.4. 192 Arion] a musician, cast into the sea but carried ashore by dolphins, whom he charmed with his music. 7 old time's natiuity] the birth of time itself. 11-14 Only the highest branches are disturbed by the breeze, reminding us that the trees might fall one day. 12 zephyrus] the west (spring) breeze. 
Which to the wounds of sadd dispare

Are soe propitious to giue ease,

When soe oprest by cruel fate,

Death's sought for att another gate.

How pleasant are the murmuring streams

In shady vallyes runinge downe,

Whose raginge torrents as itt seemes

Just measurs keepe in skipps and bounds,

Then glidinge vnder th'arbored banks

As windinge serpents in the grass.

The sportfull Naides playes ther pranks

Vpon the watry plaines of Glass,

The christal elements wherin

These watry Nimphes delight to swime.

The quiet Marshe of Loue to see

That bounded is with willowes round,

With Sallow, Elme, and Popler tree

Which Iron yett hath giuen noe wound:

The Nimphes that come to take fresh Ayre

beat, rhythm, as in a dance

Here Rocks and spindles them prouide.

Mongst Sedge and Bulrush we may heare

The lepinge Froggs: se wher they hide

Themselves for feare when they espye

A Man or Beast approachinge nye.

A hundred thousand Fowle her lye

All voyd of feare makinge ther Nest,

Noe treachrous Fowler here comes nye

With mortal ginnes to breake ther rest.

Some ioying in the sunn's warme beames

Ther fethers buisily doe plume,

Whilst others findinge Loue's hott flames

In waters allsoe can consume,

And in all pastimes Inocent

Are pleased in this element.

How pleasant is itt to behold

These ancient Ruinated Towers,

'Gainst which the Giants did of old

With Insolence imploye ther Powers.

Now Sayters here ther Sabath keepe,

And sperits which our sence inspire

i.e., axes

With frightinge dreames whilst we doe sleepe,

Doe here againe all day retire.

In thousand chinkes and dusty holes

Lyes vgly Batts and scritchinge owles.

These Mortal Augurs of Mischance

Who fune'rall notes as Musick makes,

The Goblins singe and skipp and dance

In valts orespred with toads and snakes.

Ther in a cursed beame might see

The horred skeliton of some poore louer

traps

dress their feathers, preen

[the water
burn, i.e., they disport with their mates in

Which for his Mistress Cruelty

Hanged himselfe sence naught could moue her,

Or with a glance nott once to daine

satyrs; sinister orgy or festival

To ease him of his mortal paine.

30 another gate] another doorway or means (for an unhappy man to take his own life). 34 They seem to go dancing. $\quad 38$ of Glass] i.e., reflecting the landscape as in a mirror. 46 Rocks] distaffs $\left(O E D\right.$ rock $\left.\mathrm{n}^{2}\right)$ : nymphs shown in a rare domestic light. them prouide] provide themselves with, obtain. 63-4 The ruins are grand enough to seem the work of gods or ancient heroes, against whom the Titans or the Old Testament giants (Genesis 6.4) waged war. 
The marble stones here strew'd about Of carracters leaue yett some signe, But now are almost eaten outt letters (carved on them) By teeth of all deuouring time. The planks and timber from aboue Downe to the lowest Valts are fa'une, Wher Toads and Vipers 'mongst them moue, fallen Leauinge theron ther deadly spawne, And Harths that once were vs'd for fyers Now shaded are with scratchinge Bryers.

Yet louer an Arched-Valt extends,

Soe hiddious darke and deepe doth sinke That did the sun therin desend, I thinke he scarce could se a winke. Slumber, that from heauy cares With drowsiness inchants our sence, Sleepes here secure, as far from feares, Lul'd in the Armes of Negligence And on her back in sluggish sort Vpon the pauement lyes and snort.

When from these Ruings I doe goe $\mathrm{Vp}$ an aspiring Rock nott farre, Whose topp did seeme ast were to know Wher mists and stormes ingendred are, And then desending att my Leasure Downe paths made by the storming waues, I did behold with greater pleasure How they did worke the hollow caues: A worke soe Curious and soe rare As if that Neptuns court were ther.

Tis a delightfull sight to see Standinge on the murmuringe shore, When calmer seas begin to bee After the stormes which raginge roare, How the blew Trytons doe appeare Vpon the rollinge curled waues, Beatinge with hiddious tunes i'the Ayre With crooked Trumpets, sea-men braue, All whose shrill notes the winds doe seeme By keepinge still to beare esteeme.

Sometimes the sea with Tempests rore, Frettinge itt can rise noe higher, Roulinge or'e the flinty shore, Throwes them vp, againe retire's. Somtimes through itt's deuouringe Iawes, When Neptun's in an angry moode, Poore mariners finde his cruel lawes, Made to his finy subiects foode:

But Diamonds Amber and the Jett To Neptune they doe consecrate.

Sometimes soe cleare and soe serene Itt seemes ast were a looking glass, And to our vewes preuenting seemes As heauens beneath the waters was. The sun in it's soe clearely seene That contemplatinge this bright sight,

100 snort] sic, singular form, no doubt for the rhyme. 115 Trytons] sea-gods, half human and half fish. 118 crooked Trumpets] the curved shells on which Tritons are depicted as blowing. 120 to show respect by falling silent. 133 preuenting] (a) literally 'coming before', meeting the eye (b) anticipating a look at the sky itself. 
As 't was a doubt whether itt had beene

Himselfe or image gaue the light:

Att first appearing to our eyes

As if he had fa'lne from the skyes.

Thus Alcidon, whose loue inioynes

To thinke for thee noe labor paine,

he whose, i.e. the poet

Receaue thewse Rustick Shepheards lines,

That's from ther liuinge obiects ta'ine:

Sence I seeke only desart places,

Wher all alone my thoughts doe use

Noe entertainment, but what pleases

The genius of my Rural muse:

But noe thoughts more delighteth mee

Then sweet Remembrances of thee.

\section{Christopher Morley Amor Constans}

Found along with 16 sonnets in Bod. MS Eng.misc.d.239, described in 1850, lost to sight thereafter, and printed only in 1988. The initials 'Ch.M.' were associated with Christopher Marlowe, but appear to indicate Christopher Morley, Fellow of Trinity College, Cambridge, and prob. half-brother to Thomas Morley the composer.* The poet appears as 'Bonnyboots', a name also found in several songs of the period by various composers. The identity of Carimell remains uncertain. Punctuation regularised.

Ecgloga.

Amor constans

Dickye. Bonnybootes.

Dickye. For shame man wilt thou neuer leaue this sorrowe?

Nor from noone till night nor from night till morrowe:

So hangeth on thy cragge thy heavye heade

All as were tyed therto a ponde of leade,

Thy cullor that wonted be as fresh as Maye,

Is waste and withered like yonder cocke of haye,

And on thy face thy beard so ouer spreads,

As done amonge the flowers the wicked weades.

Alonge thy cheekes as snowe from downe the mountaynes

Distill thy tears whose streames drowne vp ther fountaynes.

Bonnibootes. Ah (Dickye) yet am I behouldinge to the

Who to ease me of greife semest to pittye me,

But whence pittye should springe, ande grace should growe,

There pittye and grace are deade longe agoe.

Dickye. Many a vengeance I saye mought on him befall,

That in wronginge the hath wronged vs all.

For with thy dapper songs, and deuises quent

Wontest thou of yoare to make vs merryment,

And euermore thy songs such creditte bare,

As neuer towne durst with our towne compare.

But since theise hammers late bredde in thy heade,

Both they in the, and thou in them art deade.

Bonnibootes. Ah (Dickie) for deathe to me were liefer then life.

But I longer live to adde more to my grief.

Eache other man complaynes his life may ne laste,

And I wish myne had winges to flye awaye as faste.

No sooner wakes the Larke within her neste

But wake my woes at once within my breste.

138 Whether the light of day is coming from the sun or from its reflection in the water. 141 Alcidon] Saint-Amant's dedicatee, Charles de Bernières, President of the Parliament of Rouen or Normandy. 144 That describes actual objects as seen. ${ }^{\star}$ See Sukanta Chaudhuri, 'Marlowe, Madrigals, and a New Elizabethan Poet', RES n.s.39, 1988, pp.199-216. Amor constans] constant love. 10 streames drowne vp ther fountaynes] i.e. The tears flow so copiously that one cannot see the eyes. 17 dapper] ?lively, smart - general term of approval. 20 towne] village $\left(O E D_{3}\right) . \quad 21$ hammers] ?disturbances, agitation. Not in $O E D$. 25 complaynes his life may ne laste] i.e. grieves at the prospect of death. 
I weene that man half the payne ne tasted

Whose harte grewe as muche by night as by daye it wasted.

Dickie. Areede, who hath wrowght our Bonnibootes this spighte?

The greif disburthened makes the harte more light,

As when the rayne is fallen from the skye,

The clowdes waxen cleare and bright by an by.

Who thinkes to quenche fyer by keepinge close the same,

Addes thrice as much more fewell to the flame.

Bonnibootes. Franke shephearde, nowe force me not to displaye

The wounde that once opened thou ne cure maye.

My present state all hope renownces,

For woe comes by poundes and goes awaye by ownces.

Dickie. What? dothe thy lowe estate procure thy payne?

Or is some fonde affection harboured in thy brayne?

If fortune frowne, with wisdome weighe

How she doth geue and take awaye.

Thou seest the sea that whilom raged,

How soone his courage he hathe asswaged.

And as the floodes bene highe and lowe,

So fortunes goodes doone ebbe and flowe.

Who so after the worldes pipe will daunce

Mowght not bene daunted with any mischaunce,

But as done reedes that with the winde bende,

Mought he all one with the worlde his waye wende,

For poore in this world perdy is none

But he that deemeth himself poore alone.

And to nowght (clerkes sayne) nature life doth geue,

But it teacheth it wayes how the same should liue.

The vilest Creature findeth to eate

In rayne, in drowght, in colde, and in heate.

A tyme there is to laughe and a tyme to weepe,

60 A tyme to spend, and a tyme to keepe.

One tyme hath made thy state so poore,

And another maye eeke as much thy stoare.

Bonnibootes. I graunte sicker tymes maye once appeare,

Yet Maye I weene comes but once a yeare.

But sorrowe men sayne comes neuer alone,

But bringes with him a thousande more on.

A woe is me that this has preeud to well,

And woe is thou the cause false Carimell.

Dickye. Now shephearde I coniure the by all loues,

Vnfoold the greife that the so pensiue prooues.

Neuer yet was wounde so deepe I weene

But might be cured whilest it was greene.

But gif the same were suffered to spread

The venyme woulde rancle in tyme to the heade.

And so at the first for sicke fonde foollerye

Menn haue often incurred great ieoperdye.

Bonnybootes. Carimell thou kenst that was to me so liefe

Thilke ladde (Dickye) hath wrought me this greif.

His sollemne vowes he falselye hath broken

And me, whome he loved, he hath forsooken.

The dittyes I wonte deuise for his sake,

He rendes in peeces and hates like a snake,

All because I am a shepheard in degree,

Doth he my lucklesse love disdayne and me.

Ah foolish ladde whome thou thus disdaynes,

grow, become (plural in-en) shutting it in

tell me; done this [mischief gives up, relinquishes

lowly state, poverty

(a) foolish (b) loving consider, judge

force, energy

may not, should not; be: [infinitive in-(e)ne

learned men

increase, augment secure, peaceful

been proved, come true; too

entreat, implore thee; presents as, renders

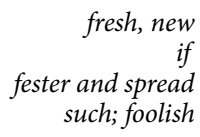

know; dear, loved the same

The godds themselues haue benne shephards swayns,

3o Like Prometheus' liver, which grew and was devoured by an eagle in this way. 37 Franke] noble, 'good' - general term of praise or courtesy. $\quad 52 \mathrm{He}$ should do as the rest of the world does. 55-6 Any creature endowed with life is also endowed with the means of survival. $\quad \mathbf{8 2}$ The songs may have been hung on trees in conventional pastoral fashion, or sent as love-letters. 
And as I haue harde a shephearde was he,

That loved the nymphe changed to the baye tree.

And that ladde a shephearde was I weene,

Whose death was so wayled of bewtyes queene.

And he a shephearde was that had the fayre wife,

Which satt the world to winne her, at strife.

And wonted not he to keepen sheepe,

Whome Poetes fayned so lange to sleepe?

Yet woulden oft the sister of the sonne

Have come frome heauen to see how he had donne.

But thou false harte more harde then flynt

Laughest at my moanes with teares besprinte.

Alas that thou shouldest so gracelesse bee,

To kill him, that killes himselfe to loue the.

Dickie. Sicker nowe (Bonnibootes) I see thou nis wise,

That seekest for loue whence no loue will rise.

Nowe by my sawle gife Carimell loued me,

Would I at once loue as fast as he.

But gife I saw not my loue regarded,

Should he I trowe bene with the same sawce rewarded.

Wherfore if thow will my counsell prove,

Forsake like follyes, and forbeare to loue.

Bonnybootes. Seest thou yon oake that is dryed with heate?

Well may from his bowghes sweete amber sweate,

The roses may on nettells growe,

And siluer streams out of marble maye flowe,

The North to the South may well remoue,

But neuer may Bonnybootes leaue to loue.

Dickie. Then if thy faythe beene rooted as thow sayne,

Why seekest thou no meanes to alegge thy payne.

Thy mynde thus still to melancholy bent

Thy pyteous plyght doth more augment:

And cooles as much thy enflamed desyre,

As to cast water on the smithes fyer.

Wherfore if thou mynde to ease thy greife,

Beste were yt seeke some other releife.

Bonnybootes. So haue I done, and therfore alone,

Of late to death I made my moane.

So well pleased him my wist requeste,

As he did graunte me to doe his beste.

His sturdye bowe in his hande he hent,

He feircely pulled, and oute the shafte went,

But it light (alas, my woe is the more)

Just in that place, where loue had before.

Thus did my loue afresh begine,

For deathes shafte droue loues the deeper in.

Dickie. Now desperat I wene bene that mans greife

Who seekes to deathe for his releife.

But if thou none other waye to warke wende,

Neuer wilbe thy sorrowes at ende.

I see so enflamed is with loue thy liuer,

That scarse will coole the all the water in the riuer.

Bannishe man sike vayne follyes from thy brayne,

\author{
old past tense of 'set' \\ used to \\ imagined, fabled, narrated; long \\ how he was faring \\ sprinkled, ?interspersed
}

surely; ne + is, are not

soul; if

valued, appreciated

believe, think

try out, put to prove

such

withered, shrivelled

be: subjunctive in -ene allay, mitigate

think, intend

only for that reason

seized, grasped

alighted, landed

go to work, set about things

(the first) 'the' : thee

87-8 he ... baye tree] Apollo, who loved Daphne. Apollo served as King Admetus' shepherd. 89-90 that ladde] Adonis, beloved of Venus. A hunter, but sometimes presented as a shepherd in pastoral: see Theocritus I.109. 91-2 he ... at strife] Paris, who stole away Helen. He was brought up by shepherds and kept sheep on Mount Ida. 93-6 he ... had donne] Endymion, beloved of Cynthia the moon-goddess (Diana, sister of Apollo the sun-god). He was cast into eternal sleep. 95 woulden] The final -en has no syntactical function, unlike the other instances in this poem. It shows the loose use of old inflexions in this period. 106 with ... rewarded] paid back in kind. $\quad \mathbf{1 2 0}$ The fire in the smithy is too intense to be quenched by water. 125 wist] ?intent, sincere. 131-2 The prospect of death made his love more intense. 137 enflamed] heated, fevered, producing the burnt or 'adust' humours thought to cause melancholy. liuer] seat of the passions in the old physiology. 
Who seeks to accorde loue and hate together,

His labor will not be worth a fether.

And vndertake as harde a matter,

As to knitt in one the fyer and water.

But if the ladde benne so lightly gone

Set free thy thoughts and lett him alone.

Bonnybootes. Dickye, thy wastfull wordes doe not please

The galled mynd that can brooke no ease.

The more thou weenest to comfort me,

The lesse myne ears doe harken to the.

The deepe conceyts in me were they but thyne

Would rauishe thy witte and make thy thoughts deuine,

So that if it might be I durst aduenture

To wende with him a lange downe the darke center.

Therfore hartely the I beseeche

Turne some other waye thy haplesse speche.

Who so is free hath a wonderous quicke sight,

And easylye he can an others fawlts wyte,

But into himself he ne can

combine, merge

be: subjunctive in -ene

idle, worthless

benefit from, enjoy

think, intend, aim

thought, ideas - i.e., of love

free: of love, unencumbered 'wit', know, perceive

cannot

160 Se any further then an other man.

But if that men, diuells, and the gods aboue

Han benne sett on fyer by the flame of loue,

How should poore shepheards from him fly awaye,

But if they deeme hemselfes wiser then they.

Alas thy pratlinge doth but little boote,

And my harte has taken to deepe roote.

That from the same might not me recall

All the exhortations in Saint Pawle.

Dickie. Ah fonde what rage should the thus induce

Neuer with thy woes to taken treuce?

If to me thou wilt hearken, for euer

Will I teache the to expell this lurdan feuer.

Wende hardly to thy werke, and learne to sweate,

Yoake thine oxen, and geue thye swine meate,

Sheare thy sheepes fleece, and loppe thy trees arounde,

Thrashe, mowe thy meddowes and plant well thy grounde,

For sicker yt is which most menne sayne,

That loue firste sprange of an idle brayne.

Nowe Bonnibootes lett thyne headlesse will gange,

And stoppe the springe whence first thy woes sprange.

Love who loue the, has beenne an old sawe,

Els to loue is nor reason nor lawe.

Who so loueth in such loue does daylye dye,

For that he is bereaued of his libertye.

For thy, take thy pipe and wende with me,

And with thy songs doe sett thyne harte free.

Better is one ownce of merry delighte

Then a thowsand weight of sorrowe and spighte.

Bonnybootes. Shepharde, now I praye the leaue of thy preache

Vnlesse thy texte coulde better teache.

Thy words into my harte may ne gett,

For that an other keepes the keyes of ytt.

In vayne thou wytest loues highe dyetye,

thee; saying, maxim

bereft, deprived

therefore; come

rancour, ?grievance

thee; worthless, idle, foolish go; vigorously, energetically

food

thresh sure, certain; old plural in-(e)ne

fool

make peace, call a halt

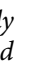

.


That nere yet kyddst of yt the mysterye.

ne'er; knew

But if his godheade shoulde once thy harte inspyre,

Oh, how woulde mounte thy highe desyre.

The basenes of the shepheardes vayne

Thy loftye muse would then disdayne,

Thy winged thoughts wolde thinke to flye

Aboue the reache of the heauens highe.

Thy mynde would ofte leese herself in delighte

Wanderinge in blisse withe Angells bright.

lose

But ah (Carimell) more then most vnkinde

Thy faythlesse loue stickes still in my mynde,

My throate is hoarce callinge still for grace,

But thou nill regarde my wretched case.

Dickie. Ah (Bonnybootes) thy trustye trewthe

Might moue the craggy rockes to rewthe.

But now wendes the bright sonne to the west,

And thy sorrowes aye demaunden rest.

For thy take thy pype and singe vs some songe,

To shorten the waye as we gange alonge.

will not

firm faith

ruth, pity

goes, proceeds indeed, surely therefore

go

Fui non esse dolet.

Infortunatus. quondam Ch: $M$.

\section{The Shepherds' Dialogue of Love}

First published in The Golden Garland of Princely Pleasures and Delicate Delights (1620). The only known copy being mutilated, missing readings in lines 14 and 40 have been supplied from the mss; but 27-9 not found there.

The Shepheards Dialogue of loue betweene Willy and Cuddy.

To the tune of Maying time.

Willy. How now shepheard what meanes that,

Why wearst thou willow in thine hat,

Why are thy Scarfes of red and yellow

Turnde to branches of greene willow?

Cuddy. They are changd and so am I,

Sorrow liues but pleasure dyes;

She hath now forsaken me,

Which makes me weare the Willow tree.

Willy. What, that Phillis loude thee long,

Is that the Lasse hath done thee wrong:

Shee that loude thee long and best,

Is her loue turned to a jest.

Cuddy. Shee that loued me long and best,

Bad me set my heart at rest:

For she a new Loue loues (not me)

That makes me weare the Willow tree.

Willy. Com then shepheard let vs ioyne,

Since thy hap is like to mine:

For the wight I thought most true,

Now hath changed me for a new.

Cuddy. Well then since thy hap is so

Take no care but let her go:

Thy hard hap doth mine appease.

Company dothe sorrowes ease.

$\mathbf{2 1 3}$ It is sad to have been (once), but not to be (now). $\quad 214$ quondam] sometime, once: he was 'Ch.M.' before love made him 'Infortunatus'. A conjectural expansion of the scribal contraction. $\quad$ o.2 Maying Time] Chappell (Popular Music I.377) cites only this song for this tune, but the manner of reference here suggests a tune of earlier currency. 2 willowe] traditional emblem of mourning. 14 set ... at rest] ?be still (not in OED): i.e., cease to love, ?know once and for all (OED rest ${ }^{\mathrm{i}} \mathrm{P}_{5} \mathrm{~d}$ ) audhur 1 - 9781526143426 
Willy. Then I will forget her loue,

Since wantonly she false will proue:

[...] for her sake bid all adue,

[...] seldome women do proue true.

[Cuddy]... for her sake Ile sit and pine,

For she was once a Loue of mine:

Which shall nere forgotten be,

Though I weare the willow tree.

Cuddy. Heards man be aduised by me,

Cast of griefe and willow tree:

For thy greeffe breeds her content,

Shee is pleasde if thou lament.

Willy. Then I will be rulde by thee,

There lies griefe and willow tree:

Henceforth I will do as they,

Loue a new loue euery day.

\section{Richard Brathwait Technis' Tale}

Part of the First Eclogue in Brathwait's The Shepherds' Tales, Part I (1621). The shepherds seem to represent Brathwait and his associates; but only Technis can be clearly identified, as Brathwait himself. As the eldest of the company, he agrees to start the exchange of stories about their own lives.

Technis. Attend then Shepheards, now I doe begin,

Shewing you first where I had nurturing,

Which to vnfold the better, I will chuse

No other words then home-spun Heardsmen vse.

First then, because some Shepheards may suppose

By meere conjecture, I am one of those

Who had my breeding on this flowrie Plaine,

I must confesse that they are much mista'ne,

For if I would, I could strange stories tell

Of Platoes and of Aristotles Well,

From whence I drain'd such drops of diuine wit,

As all our Swaines could hardly diue to it:

penetrate, understand

Doricles. Indeed I'ue heard much of thee in thy youth.

Technis. Yes Dorycles, I say no more than truth,

A Prentiship did I in Athens liue,

Not without hope but I might after give

Content and comfort where I should remaine,

And little thought I then to be a Swaine:

For I may say to you, I then did seeme

One of no small or popular esteeme,

But of consort with such, whose height of place

Aduanced me, because I had their grace:

Though now, since I my Lambkins gan to feede,

Clad in my russet coat and countrey weede,

Those broad-spred Cedars scarce afford a nest

Vpon their shadie Boughes, where I may rest.

Sapphus. It seemes, they're great men Technis.

Technis.

And for inferiour groundlins, little care.

So they are,

But may they flourish; thus much I am sure,

shrubs

7 this flowrie Plaine] Probably Brathwait's theatrical circle in London, who might be reflected in the shepherds. From the context, cannot be Brathwait's native place, Kendal in Westmoreland, nor Oxford, the haunt of his youth. From Oxford, Brathwait went to Cambridge, and then to Gray's Inn to study law at his father's wish. The later part of this Tale (not included here) indicates his distaste for the law, which he abandoned after his father's death to write for the theatre, and gradually to become a person of standing in Westmoreland. 10 Of Platoes and of Aristotles Well] Contradicts Anthony Wood in Athenae Oxonienses that at Oxford, Brathwit neglected logic and philosophy for poetry and history. 15 Athens] Oxford, which Brathwait entered at sixteen in 1604. He had hopes of a fellowship there. 18 Swaine] rustic - i.e. not of the academic community. 25 Cedars] eminent men (at Oxford). 
Though Shrubs be not so high, they're more secure.

Linus. High states indeed are subiect to decline.

Technis. Yes Linus yes, in this corrupted time

We may obserue by due experience

That where a Person has preeminence,

He so transported growes, as he will checke carried away (with pride); challenge, defy

Ioue in his Throne, till Pride has broke his necke,

Whereas so vertuous were precedent times,

earlier

As they were free not only from the crimes

To which this age's exposed, but did liue

As men which scorn'd Ambition.

Dymnus.

Now I diue

Into thy meaning Technis; thou do'st grieue

That those who once endeer'd thee, now should leave

Thy fellowship.

Technis. Nay Dymnus I protest

I neuer credited what they profest;

For should I grieue to see a surly Lout,

Who for obseruance casts his eye about;

In nothing meriting, saue only $\mathrm{He}$

Is rich in acres, to disvalue me?

Dorycles. No Technis no, th'art of a higher spirit

Than these inferiour Gnats, whose only merit

Consists in what they haue, not what they are.

Technis. No Dorycles, for these I little care,

Nor euer did: though some there be that feede

On such mens breath.

Dymnus.

Good Technis now proceed.

Technis. Hauing thus long continued, as I said,

And by my long continuance Graduate made,

I tooke more true delight in being there,

Than euer since in Court or Country ayre.

Sapphus. Indeed minds freedome best contenteth men.

Technis. And such a freedome I enjoyed then,

As in those Beechie shades of Hesperie,

I planted then my sole felicitie.

So as howsere some of our rurall Swaines

Prerogatiue aboue all others claimes,

valued, loved

valued, gave credit to

That they haue nought, want nought, nor care for ought,

Because their minde vnfurnisht is of nought

That may accomplish man: I could averre,

(Howsere I doubt these in opinion erre)

That in my breast was treasured more blesse,

Then euer sensuall man could yet possesse.

For my delights were princely, and not vaine,

Where height of knowledge was my only ayme,

Whose happy purchase might enrich me more,

Then all this trash which worldly men adore.

So as if Pan were not the same he is,

He'de wish himselfe but to enioy my blisse,

Whose choice content afford me so great power,

As I might vye with greatest Emperour.

Corydon. It seemes thy state was happie;

Technis.

And did my present state so farre surpasse,

So it was,

disparage, underprize

As th' high top'd Cedar cannot beare more show

Aboue the lowest Mushrom that doth grow,

46 ?who looks arrogantly in every direction. 61 Hesperie] prob. the garden of the Hesperides (cf. 110). Beechie] perhaps from the beech trees under which shepherds rested contentedly, as in Virgil I.1. 70 sensual] (a) endowed with sensation, alive (b) sensually or materially inclined. $\mathbf{7 1}$ princely, and not vaine] truly grand, not vacuous or trivial. 75 Pan] no doubt the King. 77 afford] plural verb with singular subject. Cf. the opposite in 'hops' and 'sings' (114-5). $\quad$ 81 Cedar] clashes with the cedar image of 25 . 
Or more exceed in glory, than that time

Outstripp'd this present happinesse of mine.

For tell me Shepheards, what's esteem'd 'mongst men

The greatest ioy, which I enioy'd not then!

For is there comfort in retired life?

I did possesse a life exempt from strife,

Free from litigious clamour, or report

Sprung from commencement of a tedious Court.

Is contemplation sweete, or conference,

Or ripe conceits? why there's an influence,

Drawne from Minerua's braine, where euery wit

Transcends conceit, and seemes to rauish it.

Is it delightfull, Shepheards, to repose,

And all-alone to reade of others woes?

Why there in Tragick Stories might we spend

Whole houres in choice discourses to a friend,

And reason of Occurrents to and fro,

rumour, gossip
source, origin
conversation, discussion
outflow, hence affective power

exceeds or defies thought; enrapture,

[transport

events, phenomena

unhappy, disturbed

Might it content man, to allay the loade

Of a distemperd minde to walke abroad,

That he might moderate the thought of care

By choice acquaintance, or by change of ayre?

What noble consorts might you quickly finde

To share in sorrow with a troubled minde?

What cheerfull Groues, what silent murmuring springs,

Delicious walkes, and ayrie warblings,

Fresh flowrie Pastures, Gardens which might please

The senses more then did th' Hesperides,

Greene shadie Arbours, curled streames which flow,

On whose pure Margins shadie Beeches grow,

Myrtle-perfumed Plaines, on whose rer'd tops

The merry Thrush and Black-bird nimbly hops

raised, tall; tops: presumably of trees

And carols sings, so as the passers by

Would deeme the Birds infus'd with poesie?

Sapphus. Sure Technis this was earthly Paradise.

Technis. Sapphus it was; for what can Swaine deuise

To tender all delight to eye or eare,

Taste, Smell, or Touch which was not frequent there?

Besides;

Linus.

What could be more, pray Technis say?

Technis. We had more ioyes to passe the time away.

Dorycles. What might they be good Technis?

Technis.

'Las I know

They'r such a Shepheards cannot reach vnto.

Dymnus. Yet let vs heare them.

Technis.

So I meane you shall,

And they were such as we internall call.

Corydon. Infernall, Technis, what is meant by that?

Technis. Infernall, no; thou speakst thou knowst not what:

I meane internall gifts which farre surmount

All these externall bounties in account:

For by these blessings we shall euer finde

Rich Treasures stored in a knowing minde,

Whose glorious inside is a thousand fold

More precious than her Case though cloath'd in gold

And all Habilliments: for by this light

Of Vnderstanding, we discerne whats right

From crooked error, and are truly said

To vnderstand by this, why we were made.

(a) inspired (b) filled

93 Minerua] goddess of learning. 101-2 allay ... abroad] walk forth to lighten the burden of an unhappy mind. 128 Infernall] This mistake shows Brathwait's frustration with his associates, presented as boorish rustics. 138 why we were made] i.e. first causes, the origins of things. 
Sapphus. Why, we nere thought of this.

Linus.

Nay, I may sweare

I haue liu'd on this Downe, this twentie yeare,

And that was my least care.

Coridon.

Linus, I vow

To feed our Sheepe, was all that we need doe

I euer thought.

Dorycles. So Coridon did I.

Dymnus. The cause of this, good Technis, now descrie.

Technis. Heardsmen I will; with purpose to relate,

Lest my Discourse should be too intricate,

In briefe, (for length makes Memorie to faile)

The substance of your wishes in a Tale.

Within that pitchie and Cymmerian clyme,

Certaine Inhabitants dwelt on a time,

pitch-dark

Who long had in those shadie Mountaines won, [dwelt

Yet neuer saw a glimpse of Sunne or Moon.

Yet see what custome is, though they were pent

From sight of Sunne or Moone they were content,

Sporting themselues in vaults and arched caues,

Not so like dwelling Houses, as like graues.

Nor were these men seene ere so farre to roame

At any time as halfe a mile from home;

For if they had, as th'Historie doth say,

They had beene sure right soone to lose their way:

For darke and mistie were those drerie caues

Where they repos'd, so that the wretchedst slaues

Could not exposed be to more restraint,

Than these poore snakes in th'ragged Mountaines pent;

And thus they liu'd.

Linus.

But never lou'd.

Technis.

To tell

Their loues I will not: but it thus befell,

That a great Prince, who to encrease his fame

Had conquer'd many Countries, thither came.

Sapphus. For what good Technis?

Technis.

Only to suruey it.

Coridon. Why sure he had some Torch-light to display it,

euer: always

describe, recount

For th'Coast you say was darke.

Technis.

But yet attend me how it came to passe:

And so it was;

By meanes he vs'd, hauing this coast suruei'd,

With all perswasiue reasons he assaid,

Partly by faire meanes to induce them to it,

Sometimes by threats, when he was forc't vnto it,

That they would leaue that forlorne place, and giue

Way to perswasion, and resolue to liue

Neere some more cheerefull Border, which in time

They gaue consent to, and forsooke their Clime.

But see the strength of Habit, when they came

To see the light they hid themselues for shame,

Their eyes grew dazled, and they did not know,

Where to retire or to what place to goe:

Yet was the Region pleasant, full of groues,

Where th'airy Quiristers expresse their loues

One to another, and with Melodie

desolate, remote

Cheer'd and refresh'd Siluanus Emperie.

The warbling Goldfinch on the dangling spray,

149 Cymmerian] The Cimmerii were a mythical race in Homer, dwelling on the extreme western edge of the ocean amid mists and darkness. The story seems Brathwait's own invention, prob. with some lost topical allusion. $\quad 155$ Sporting themselues] luxuriating, living happily. 173 By meanes he vs'd] using his own methods. 186 th'airy Quiristers] i.e. birds. $\quad 188$ Siluanus Emperie] the domain of the wood-god Silvanus. 
Sent out harmonious Musicke euery day;

The prettie speckled Violet on the Banke

With Pinke and Rose-bud placed in their ranke;

Where chafed Violets did so fresh appeare,

As they foretold the Spring-time now drew neare;

Whose borders were with various colours dy'd,

And Prim-rose bankes with odours beautifi'd;

Where Cornell trees were planted in great store,

Whose checkerd berries beautifi'd the shore.

Besides, such gorgeous buildings as no eye

Could take a view of fuller Maiestie;

Whose curious pillers made of Porphyrite

Smooth to the touch, and specious to the sight,

Sent from their hollow Cell a crispling breath,

Arched aboue and vaulted vnderneath.

Yet could not all these choyce varieties

(Which might haue giuen content to choicer eyes)

Satisfie these Cimmerians, for their ayme

Was to returne vnto their Caues againe,

And so they did: for when the Prince perceiu'd

How hard it was from error to be reau'd,

Where ignorance discerns not what is good,

Because it is not rightly vnderstood;

Hee sent them home againe, where they remain'd

From comfort of Societie restrain'd.

Dymnus. Apply this Tale, my Technis;

Technis.

Heare me then.

pleasing, lovely

rippling, ?emanating outwards

more discerning

parted, separated

interpret, point the moral

You may be well compar'd vnto these men,

Who ignorant of knowledge, doe esteeme

More of your Flocks, how they may fruitfull seeme,

Then of that part, whereby you may be sed

From sauage beasts to be distinguished.

Dorycles. Technis you are too bitter;

Technis.

Not a whit,

Shepheards should tell a Shepheard what is fit:

Though I confesse that Heardsmen merit praise,

When they take care vpon the Flockes they graze.

Yet to recount those Swaines of elder time,

recall

How some were rapt with Sciences diuine,

Others adorn'd with Art of Poesie,

Others to reason of Astrologie;

Swaines of this time might think't a very shame,

230 To be so bold as to retaine the name

Of iolly Heardsmen, when they want the worth

Of those braue Swaines which former times brought forth.

Coridon. Why, what could they?

Technis.

Endorse their Names in trees,

And write such amorous Poems as might please

Their deerest loues.

Dymnus.

Why Technis what was this,

Can we not please our loues more with a kisse?

Dorycles. Yes Dymnus, thou know'st that;

Dymnus.

Perchance I doe,

For Dymnus knowes no other way to wooe.

But pray thee Technis let vs say no more,

240 But hie thee now to where thou left before.

Technis. I'me easily entreated; draw then neere,

And as I lend a tongue, lend you an eare.

Hauing long liued in Minerua's Groue,

My life became an Embleme of pure loue.

type, figure

193 fresh] in scent rather than appearance. The violet emits its scent when chafed. 244 pure] morally or spiritually, as the following lines bring out. 
Dymnus. Of Loue my Technis, pray thee say to whom?

Technis. As thou mean'st Dymnus, I did fancie none:

No; my affection soared higher farre,

Than on such toyes as now affected are:

trifles; liked, favoured

I doated not on Beautie, nor did take

My aime at faire, but did obseruance make,

How humane things be shar'd by diuine power,

Where fickle faith scarce constant rests one houre;

How highest states were subiect'st to decline;

How nought on Earth but subiect vnto Time;

How vice though clad in purple was but vice;

How vertue clad in rags was still in price;

How Common-weales in peace should make for warre;

How Honour crownes such as deseruing are.

Dorycles. And yet we see such as deserued most,

What ere the cause be, are the oftest crost.

Technis. Ile not denie it (Swaine) and yet attend,

For all their crosse occurrents, but their end,

And thou shalt see the fawning Sycophant

Die in disgrace, and leaue his Heire in want:

While th'honest and deseruing Statesman giues

Life to his Name and in his dying liues.

This I obseru'd and many things beside,

Whilst I in famous Athens did abide.

\section{Richard Brathwait The Shepherds' Holiday}

This wedding-song concludes Part II of Brathwait's The Shepherds' Tales (1621). The two parts of Brathwait's Tales relate the unhappy loves of a company of six shepherds. At the end, they see Mopsus and Marina approach, singing as they go to a wedding. The shepherds join them to 'allay' their own 'care'.

The shepheards holy-day, reduced in apt measures to Hobbinalls Galliard, or Iohn to the May-pole.

[Marginal note:] Forth of a curious Spinet graced with the best rareties of Art and Nature, Mopsus a shepheard, and Marina a shepheardesse, singing a Nuptiall hymne in the way to the Bridall.

Mopsus. Come Marina let's away,

For both Bride and Bridegroome stay,

Fie for shame are Swaines so long,

Pinning of their head-geare on?

Pray thee see,

None but we,

Mongst the Swaines are left vnreadie,

Fie, make hast,

Bride is past,

Follow me and I will leade thee.

?the bridal hour

Marina. On my louely Mopsus, on,

I am readie, all is done,

From my head vnto my foote,

I am fitted each way to't;

Buskins gay,

Gowne of gray,

Best that all our flocks do render,

Hat of stroe,

Platted through,

Cherrie lip and middle slender.

unbleached cloth

straw

253 subiect'st] 'subject-est', most subject. $\quad \mathbf{2 6 1 - 2}$ yet ... end] Note their (happy) ends despite all their adverse experiences. o.1 reduced] fitted, adapted. Hobbinalls Galliard] either an alternative tune or another name for 'John to the Maypole'. Iohn to the May-pole] A popular tune, perhaps linked to 'Joan to the Maypole': see Chappell, Popular Music I.301, II.778. O.2 Mopsus] so here, though 'Mopso' in 1 (abbreviated as 'Mop.' thereafter). 
Mopsus. And I thinke you will not find

Mopsus any whit behind,

For he loues as well to go,

As most part of shepheards do.

Cap of browne,

Bottle-crowne,

With the leg I won at dancing,

And a pumpe

a light shoe worn for dancing

Fit to iumpe,

When we shepheards fall a prancing.

And I know there is a sort

Will be well prouided for't,

For I heare, there will be there

Liueliest Swaines within the Shere:

$$
\text { Ietting Gill, }
$$

Iumping Will,

there are people prepared, ready (to dance)

jetting: strutting, flaunting

Ore the floore will haue their measure:

Kit and Kate,

There will waite,

Tib and Tom will take their pleasure.

Marina. But I feare;

Mopsus. What doest thou feare?

Marina. Crowd the fidler is not there:

And my mind delighted is,

With no stroake so much as his.

Mopsus. If not he,

There will be

Drone the piper that will trounce it.

Marina. But if Crowd

Strucke aloud,

Lord me thinks how I could bounce it!

Mopsus. Bounce it Mall, I hope thou will,

For I know that thou hast skill,

And I am sure thou there shalt find,

Measures store to please thy mind;

Roundelayes,

Irish-hayes,

Cogs and rongs and Peggie Ramsie, Spaniletto, The Venetto,

Iohn come kisse me, Wilsons fancie.

Marina. But of all there's none so sprightly

To my eare, as tutch me lightly:

For it's this we shepheards loue,

Being that which most doth moue;

There, there, there,

To a haire,

O Tim Crowd, me thinks I heare thee,

Young nor old,

Nere could hold,

But must leake if they come nere thee.

26 Bottle-crowne] presumably referring to the cap's shape. $\quad 27 \mathrm{leg}$ ] ?hose or trousers (OED 10). 42 Crowd the fidler] a generic name, after crowd, a fiddle. 47 Drone] another generic name, after the sound of the pipe. 56 Irish-hayes] The hay is a popular country dance, with a recognized Irish version. 57 Cogs and rongs] (rungs) a dance tune. Peggie Ramsie] a ballad tune first recorded in 1586. 58 Spaniletto] ?the Spanish pavan, a popular dance (and accompanying tune). 59 Venetto] obviously a dance of real or supposed Venetian origin. $\quad 60$ Iohn come kisse me] 'John [or Jack] come kiss me now', a popular tune found inter alia in Queen Elizabeth's Virginal Book. Wilsons fancie] on the lines of 'Wilson's Tune', 'Wilson's Delight', 'Wilson's World' and 'Wilson's Wile', the last probably the same as 'Wolsey's Wild' in Queen Elizabeth's Virginal Book. See Chappell, Popular Music, I.86-7. 62 tutch me lightly] by the Scottish composer Tobias Hume: see his The First Part of Ayres, London, 1605, sig.Hir. 
Mopsus. Blush Marina, fie for shame,

Blemish not a shepheards name;

Marina. Mopsus why, is't such a matter,

Maids to shew their yeelding nature?

$\mathrm{O}$ what then,

Be ye men,

That will beare your selues so froward,

reluctant

When you find

Vs inclin'd,

To your bed and boord so toward?

willing, receptive

Mopsus. True indeed, the fault is ours,

Though we tearme it oft-times yours;

Marina. What would shepheards haue vs do,

But to yeeld when they do wo?

And we yeeld

Them the field,

And endow them with our riches.

Mopsus. Yet we know,

Oft-times too,

You'le not sticke to weare the breches.

Marina. Fooles they'le deeme them, that do heare them

Say, their wiues are wont to weare them:

For I know there's none has wit,

Can endure or suffer it;

But if they

Haue no stay,

Nor discretion (as tis common)

Then they may

Giue the sway,

As is fitting, to the woman.

Mopsus. All too long (deare loue) I weene,

Haue we stood vpon this theame:

Let each lasse, as once it was,

Loue her Swaine, and Swaine his lasse:

So shall we

Honor'd be,

In our mating, in our meeting,

While we stand

Hand in hand,

Honest Swainling, with his Sweeting.

\section{Richard BrathWAit 'Tell ME LOVE What THOU CANST Do?'}

Sung at the end of the third and last Eclogue of Part I of Brathwaite's The Shepherds' Tales (1621), by a group of shepherds who had fallen prey to love but are now free.

Technis. Tell me Loue what thou canst doe?

Dorycles. Triumph ore a simple Swaine;

Dymnus. Binding him to such a vow

Corydon. As to make his griefe thy gaine.

Saphus. Doe thy worst thou canst doe now;

Linus. Thou hast shot at vs in vaine.

All. For we are free, though we did once complain.

suffer

Dorycles. Free we are as is the ayre;

Technis. Or the siluer-murm'ring spring.

Dymnus. Free from thought or reach of care

Corydon. Which doe haplesse Louers wring. 
Saphus. Now we may with ioy repaire Linus. To our gladsome Plaines and sing All. And laugh at Loue, and call't an idle thing.

Dymnus. Sport we may and feede our Sheepe, Dorycles. And our Lamkins on this Downe; Technis. Eat and drinke, and soundly sleepe, Corydon. Since these stormes are ouer blowne; Saphus. Whilst afflicted wretches weepe, Linus. That by loue are ouerthrowne: All. For now we laugh at follies we haue knowne.

Corydon. Here we rest vpon these rocks Dymnus. Round with shadie Iuy wreath'd, Dorycles. Ioying in our woolly flocks, Technis. On these Mountaines freely breath'd, Saphus. Where though clad in russet frocks, Linus. Here we sport where we are heath'd: All. Our only care to see our Pastures freath'd.

exercised, sustained a coarse cloth; a man's long coast ?living on a heath or open countryside

Saphus. Thus we may retire in peace,

Corydon. And though low, yet more secure

Dymnus. Then those Men which higher prease;

Dorycles. Shrubs than Cedars are more sure:

press, rush forward safe, secure

Technis. And they liue at farre more ease,

Linus. Finding for each care a cure,

All. Their loue as deare and liker to endure.

more likely

Linus. For wherein consists earths blisse,

Saphus. But in hauing what is fit?

Corydon. Which though greater men doe misse,

Dymnus. Homely Swaines oft light of it.

Dorycles. For who's he that liuing is,

Technis. That in higher place doth sit,

All. Whose sly Ambition would not higher git.

Technis. Let vs then contented be,

Dorycles. In the portion we enioy;

Corydon. And while we doe others see

Saphus. Toss'd with gusts of all annoy,

Dymnus. Let vs say this feele not we:

Linus. Be our wenches kinde or coy,

All. We count their frownes and fauours but a toy.

\section{MARY Wroth Song: 'LOVE AS WELl CAN MAKe Abiding'}

Among the poems grouped under the title 'Pamphilia, to Amphilanthus' appended to Wroth's romance The Countesse of Montgomeries Urania (1621).

Song.

Loue as well can make abiding

In a faithfull Shepheards brest

As in Princes: whose thoughts sliding

Like swift Riuers neuer rest.

slipping, changing, unstable

Change to their minds is best feeding,

To a Shepheard all his care,

Who when his Loue is exceeding,

Thinks his faith his richest fare.

28 freath'd] fenced $\left(O E D\right.$ frith $\left.\mathrm{v}^{2}\right)$. $O E D$ last cit. 1400 in the broader sense 'peaceful, protected' (OED frith $\left.\mathrm{v}^{1}\right)$. 5-8 Princes thrive on change, but to a shepherd that is the greatest cause of care: he, when he is deeply in love, considers faith in love to be his chief sustenance. Sukanta chaudhur 1 - 9781526143426 
Beauty, but a slight inuiting,

attraction, diversion Cannot stirre his heart to change;

Constancye his chiefe delighting, Striues to flee from fant'sies strange,

fancies, light loves

Fairnesse to him is no pleasure, If in other then his loue;

Nor can esteeme that a treasure, Which in her smiles doth not moue.

This a Shepheard once confessed, Who lou'd well, but was not lou'd:

Though with scorne and griefe oppressed could not yet to change be mou'd.

But himselfe he thus contented, While in loue he was accurst:

This hard hap he not repented, Since best Louers speed the worst.

regretted, lamented

\section{Mary Wroth 'A Shepherd Who no Care did take'}

From Book IV of Wroth's prose romance The Countesse of Mountgomeries Urania (1621). This poem was written by the lady Lycencia and given to Dorileus, Duke of 'Wirtenberg'. Lycencia, who has entertained many lovers, is in love with the Duke, but has just heard him tell of his relationship with another woman. Feeling her own love to be hopeless, Lycencia presents her situation through that of the Shepherd in her poem. Punctuation modified at many points. Speakers' names introduced in brackets to help in following the intricate exchanges.

A Sheephard who no care did take of ought but of his flock,

Whose thoughts no pride could higher make, Then to maintaine his stock,

Whose sheepe his loue was, and his care, Their good, his best delight:

The Lambs his ioy, their sport his fare, His pleasure was their sight.

food, sustenance

Till Loue (an enuier of mans blisse)

Did turne this merry life

To teares, to wishes which nere misse Incombrances with strife.

For whereas he was best content With looking on his sheepe:

His time in woes must now be spent, And broken is his sleepe.

Thus first his wofull change beganne, A Lamb he chanc't to misse,

Which to finde out, about hee ran, Yet finds not where it is.

But as he past ( $\mathrm{O}$ fate vnkind) his ill led him that way,

Whereas a willow Tree behind, A faire young Maiden lay.

Her bed was on the humble ground, her head vpon her hand,

While sighs did shew, her heart was bound In Loue's vntying band.

Cleere teares her cleerest eyes let fall, Vpon her Loue-borne face:

Which Heauenly drops did sorrow call, proud witnes of disgrace.

bond, fetters
(most) bright or sparkling

call forth, provoke 
The Shephard stay'd, and fed his eyes, no farther might he passe,

But there his freedome to sight tyes, His bondage, his ioy was.

His Lambe he deemes not halfe so faire, Though it were very white:

And liberty he thinkes a care, burdensome or unwelcome thought

His former life is alter'd quite, His Sheepe feede in her eyes,

Her face his feild is of delight, And flocks he doth despise.

The rule of them he leaues to none, His Script he threw away:

And many he forsakes for one, One, he must now obey.

Vnhappy man, whose loosing found What better had bin lost:

Whose gaine doth spring from such a ground, Whereby he must be crost.

The worldly care he now neglects, for Cupids seruice tyes,

Care only to his fond respects, where waue-like treasure lyes.

As this lost man still gazing stood, Amaz'd at such a sight:

Imagining no heauenly food To feede on but her sight;

Wishing but her beames to behold, Yet grieu'd he for her griefe,

When mournfully he did vnfold Her woes without reliefe.

His new Sun rose, and rysing said,

[The maiden speaks] Farwell faire Willow tree,

The roote of my estate decay'd, The fruit for haplesse me:

What though thy branch a signe be made, Of labour lost in loue?

Thy beauty doth no sooner vade, Then those best fortunes proue.

My songs shall end with willow still, Thy branches I will weare:

Thou wilt accompany my ill, And with me sorrow beare,

True friend, said she, then sigh'd, and turn'd, Leauing that restlesse place,

And Sheephard, who in passions burn'd lamenting his sad case.

35 his freedome to sight tyes] enslaves his freedom to the sight of the maiden. $\quad \mathbf{4 2}$ His Sheepe feede in her eyes] Her eyes are the only 'pasture' he tends, i.e. his sole object of attention. 49 loosing] ?his losing himself in love; ?his loss of gain and interest in his occupation. $\mathbf{5 2}$ crost] crossed: thwarted, frustrated, $O E D 3^{\mathrm{a}}$, first recorded elsewhere in Urania 55 Care ... respects] (Having) care only for his loving and/or foolish concerns. fond] (a) loving, affectionate (b) foolish. respects] matters of attention or concern, preoccupations. 56 where... lyes] Meaning uncertain: perhaps that the treasure or reward of his love rises and subsides like waves. Or waue might be an error for wane, want, lack, poverty $(O E D 1,2)$, contrasting with treasure: the poem has many such paradoxes. 61 beames] radiance, perhaps the light from her eyes: a common Petrarchan conceit. $\mathbf{6 3}$ vnfold] lay open, think over, with nuance of 'release like sheep from a fold'. 71-2 i.e. Even those who experience (proue) the best fortune in love do not enjoy their happiness longer than it takes for the willow branch to wither: their state is little better than that of failed lovers. 
The Maid now gone, alone he left, Still on her footsteps gaz'd,

And heartlesse growne, by loue bereft of mirth, in spirit rais'd,

To satisfie his restlesse thought, He after her will hye,

His ruine to be sooner brought, And sooner harme to try.

Then thus his latest leaue he tooke,

[The shepherd speaks] My Sheepe (said he) farwell,

Let some new Shepheard to you looke Whose care may mine excell.

I leaue you to your freedome now, Loues lawes so fast me bind,

As no time I can you allow, Or goe poore flock, and find

The Maid whom I so dearely loue, Say it was her deare sight,

Which from your keepe doth me remoue, And kills my first delight.

charge, custody

Goe you my Dog, who carefull were To guard my Sheepe from harme,

Looke to them still, no care forbeare, Though loue my senses charme.

But you my Pipe that musick gaue, And pleasd my silent rest,

Of you I company will craue, Our states now suteth best.

For if that Faire no pity giue, My dying breath shall cry

fair or beautiful person, i.e., the maiden

spare, withhold put under a spell, hence render inactive

Through thee the paines wherein I liue, Whereby I breath to dye.

breathe

Madly he ran from ease to paine Not sicke, yet farre from well,

Heart robd by two faire eyes, his gaine Must prooue his worldly Hell.

reward or outcome of his love

After his heart he fast doth hie, His heart to her did flie,

And for a biding place did crie, Within her breast to lie.

She that refusd, when he her spide, Her whom he held most deare,

Lie weeping by a Riuers side Beholding papers neare.

Her ruling eyes must yet be dimbd, While pearle like teares she shed,

Like shadowes on a Picture limbd; At last these words she read.

reigning, sovereign, hence bright or radiant limned, painted

\section{[The words written]}

When I vnconstant am to thee Or false doe euer proue,

Let happinesse be banisht me, Nor haue least taste of loue.

$\mathbf{8 3}$ heartlesse] spiritless, dejected $\left(O E D_{1} \mathrm{~b}\right) . \quad \mathbf{8 4}$ rais'd] agitated, disturbed $\left(O E D_{3} \mathrm{~b}\right) . \quad \mathbf{9 2}$ Who may look after you better than I did. 95 That I cannot spare the time to look after you. 100 first delight] his original source of delight, in looking after his sheep. 117-18 His heart left his body and pursued her, so that he in turn had to pursue it. $\quad 127$ shadowes] shading to moderate the bright colours of a picture. 
[She speaks]

But this alas too soone, cryd she, Is $\mathrm{O}$ by thee forgot,

My hopes and ioyes now murtherd be, And falsehood is my lot.

Too late I find what tis to trust To words, or oathes, or teares,

Since they that vse them prooue vniust

And colour but our feares.

Poore fooles ordaind to be deceiu'd And trust to be betrayd,

Scornd when our hearts are vs bereau'd, Sought to, a while delayd.

Yet though that thou so false hast been, I still will faithfull be;

And though thou thinkst to leaue no sinne, Ile make my loyalty

To shine so cleare, as thy foule fault To all men shall be knowne,

Thy change to thy changd heart be brought, My faith abroad be blowne.

brought home, laid at your door

This hauing said, againe she rose The papers putting by,

And once againe a new way chose Striuing from griefe to fly:

But as she going was along That pleasant running streame,

She saw the Sallow trees among, willow

For so this wofull Lad was call'd, But when she him beheld,

[She speaks]

What witchcraft hath thee now inthral'd, And brought thee to this field?

What can the cause, or reason be, That thou art hither come:

Where all must tast of misery, And mirth with griefe intombe?

[He speaks]

If mirth must heere intombed be, Faire Sheephardesse, said he,

This place the fittest is for me, If you vse cruelty:

practise, display

For know I hither come, to see Your selfe, wherein now lyes

My life, whose absence martir'd me, Whose sight my power tyes.

whose: the beloved's binds, enthralls

Giue me but leaue to liue with you, It is the life I craue:

To you I bound am to be true, My life to you I gaue;

When first I did behold you lye, In shade of willow tree:

That time my soule did to you tye, Those eyes did murther me. 140 colour] ?'gloss over, falsely placate' (OED 6b); ?lend colour to, justify. 141-4 Referring to
womankind. 143 We are scorned when bereft of our hearts, i.e. when we fall in love. 144 ?sought for a while, then put off or stopped (OED delay $\left.\mathrm{v}^{1} 1 \mathrm{c}, 2\right)$. $\quad 147$ Though you do not think it a sin to abandon me. 
[She speaks]

Is this the reason, ah? (cryd she)

The more I waile your case,

Who thus partaker needs will be

In griefe, and in disgrace.

I pitty you, but cannot ayd You, nor redresse your ill,

Since ioy and paine together pay'd, Scarce satisfies the will.

paid (as the price of love)

If I doe tye you, I release

The bond wherein you are,

Your freedome shall not find decrease,

Nor you accuse my care.

The paine I haue is all my owne,

None can of it beare part,

Sorrow my strength hath ouerthrowne,

Disdaine hath killd my heart.

And Sheepheard if that you doe loue,

This counsell take of me,

This humor fond in time remoue,

Which can but torture thee;

Take it from her who too too well

Can witnesse it is so:

Whose hope seem'd Heauen, yet prou'd a Hell, And comfort chang'd to woe.

For I was lou'd, or so I thought, And for it lou'd againe,

But soone those thoughts my ruine brought,

And nourish'd all my paine,

They gaue the milke that fed beleife

Till wean'd, they proued dry:

Their latter nourishment was griefe, So famish't I must dye.

Then see your chance, I cannot change, Nor my affection turne,

Disdaine which others moues to range, Makes me more constant burne,

My sighs I'me sure cannot you please, My griefe no Musicke prooue,

My flowing teares your passions ease, Nor woes delight your Loue.

If my sight haue your freedome wonn, Receiue it back againe;

So much my selfe I finde vndone,

By gifts which proue no gaine.

As I lament with them that loue,

So true in Loue I am,

And liberty wish all to proue,

Whose hearts waste in this flame.

take the opportunity (to free yourself of love) wander, stray (in their affections)

[He speaks]

Yet giue me leaue (sigh'd he with teares)

To liue but where you are,

My woes shal waite vpon your feares, My sighs attend your care:

Ile weepe when euer you shall waile, If you sigh, I will cry,

When you complaine, Ile neuer faile To waile my misery. 
I will you guard, and safely keepe From danger, and from feare,

Still will I watch when you doe sleepe, And for both, sorrowes beare.

Make me not free, I bondage craue, Nor seeke else but to serue,

This freedome will procure my graue, anything except These bonds my life preserue.

For life, and ioy, and ease, and all Alasse lyes in your hands:

Then doe not cause my only fall, I ty'd am in such bands.

Part hence I cannot, nor loue leaue, But heere must euer bide:

Then pitty let my paine receiue, Doe not from mercy slide.

[She speaks]

If that (said she) you constant are, Vnto your comming ill,

Ile leaue this place, yet let all care Accompany me still:

And Sheepheard liue, and happy be, Let iudgment rule your will,

Seeke one whose hart from loue is free, And who your ioy may fill.

For I loue's bond-slaue am, and ty'd In fetters of Disdaine:

My hopes are frozen, my Spring dry'd, My Sommer drown'd with paine:

I lou'd, and worse, I said I lou'd, Free truth my ruine brought,

And so your speech the like hath mou'd and losse for gayning bought.

With that away she hasted fast, Left him his cares to holde,

Who now to sorrow makes all hast, Woes driue his hopes to fould:

Now he can see, and weeping say His fortune blind he finds,

A heart to harbour his decay, A state which mischeife binds.

This now he feeles, and wofully His birth and life he blames,

Yet passions rules, when reasons lye in darke, or quenched flames:

That place he first beheld her in, his byding he doth make:

The Tree his liberty did win, He cals his Martyr stake.

And pleasingly doth take his fall, his griefe accoumpts delight:

Freedome and ioy this bitter thrall, His food her absent sight. 
In contraryes his pleasures be, While mourning giues him ease,

His Tombe shall be that haplesse Tree, Where sorow did him ceaze.

And thus did liue, though daily dy'd, The Sheephard Arideame,

Whose causlesse teares which neuer dry'd spontaneous were turnd into a streame,

Himselfe the head, his eyes the spring Which fed that Riuer cleere,

Which to true harts this good doth bring When they approch it neere,

And drinke of it, to banish quite All fickell thoughts of change,

But still in one choyce to delight, And neuer thinke to range:

Of this sweete water I did drinke, Which did such faith infuse,

As since to change, I cannot thinke, Loue will death sooner chuse.

\section{MARY Wroth 'You PLEASANT FLOWERY MEAD'}

From the play Love's Victory, found in a holograph ms at Penshurst Place, Kent. This song opening the main action is sung by the shepherd Philisses, lamenting that his beloved Musella has switched her affections to Lissius. Punctuation largely supplied and line-initials regularized.

You pleasant flowrie mead

Which I did once well loue,

Your pathes noe more Ile tread,

Your pleasures noe more proue,

Your beauty more admire,

Your colours more adore,

Nor grass with daintiest store

Of sweets to breed desire.

prettiest, most pleasing

Waulks, once soe sought for, now

I shun you for the dark.

Birds to whose song did bow

Mine ears, your notes nere mark.

ne'er, never

Brook which soe pleasing was,

Vpon whose bank I lay,

And on my pipe did play,

Now unreguarded pas.

Meadowes, paths, grass, flowrs,

Waulks, birds, brook, truly find

All proue butt as vaine showrs,

Wish'd wellcome, els unkind.

You once I loved best,

Butt love makes mee you leaue.

By loue I loue deceaue,

Joy's lost for liues unrest.

betray

299-312 May indicate a literal metamorphosis or a metaphor of tearful grief. $\quad \mathbf{8}$ sweets] fragrances; fragrant flowers $(O E D$ sweet $\mathrm{n} 7)$. $\quad 12$ mark] The implicit subject is 'I' or 'ears'. 20 Welcome to someone wanting it, otherwise irksome. $\quad 23$ My unhappy love for my beloved makes me betray or renege on my love for you. $\quad \mathbf{2 4}$ Joy is lost because of the turmoil in my life. 


\section{JAMES I OF JACK AND TOM}

Composed in February or March 1623, this poem records the last of several attempts at marrying Prince Charles (later Charles I) to the Infanta or Spanish princess. In early 1623 Charles himself, with the Marquis (soon to be Duke) of Buckingham, disguised and with only one servant, set off for Spain to seal the marriage in person, without success. They travelled under the names of Jack and Tom Smith. BL MS Addl 28640 has a prefatory note (fol.128v): 'In Feb. 1622 stilo Angl. [February 1623, modern style] The prince, marques of Buckingham and some others entending a secret iourney for Spaine, it is said that the Prince at Dover disguised did terme him selfe Jacke Smith the Marq. Tom Smith.' A marginal note in a different hand adds: 'Prince Charles returned with the ioy of all true hearts Octo.5.' There are many contemporary testimonies to James's authorship of such a poem, though he may simply have overseen or appropriated someone else's work. ${ }^{*}$ Found in several mss. The text below follows BL MS Harley 837. Punctuation heavily revised (inserted in good part), and line initials standardized.

Off Jacke, and Tom

Whatt suddaine Chaunce hath darkt of late

The glorye of th' Arcadian State?

The Fleecye fflockes reffuse to Fede,

The Lambes to playe, the Ewes to breede.

The Altars smoake, the offeringes Burne

That Jacke and Tom may saffe Returne.

The Springe neglects his Course to keepe,

The Ayre Contynuall stormes doth weepe,

The prettye Byrdes disdayne to singe,

The Meades to smyle, the Woodes to springe.

The Mountaynes droppe, the Fountaynes mourne

Tyll Jacke and Tom doe safe Returne.

Whatt maye they bee that move this woe,

Whose want afflicts Arcadia soe?

The hope of Greece, the propp of Artes

support, patron

Was princely Jacke, the joye of hartes,

And Tom was to our Royall Pan

His truest Swayne and cheiffest Man.

The loftye toppes of Menalus

Did shake with wynde ffrom Hesperus,

Whose freshe delitious Ayre did fflye

Through all the Boundes of Arcadye,

Which mou'd a vayne in Jacke and Tom

To see the Coast this wynde came ffrom.

pleasant, refreshing

vein, inclination, desire

This wynd was Love, which princes stoute

To pages turnes, butt whoe cann doubte

Where equall Fortune Love procures

And equall Love, successe assures?

Butt ventrous Jacke shall bring to Greece

The Beauteous prize, the golden Fleece.

daring, intrepid

Love is a world of manye Spaynes

Where Coldest Hilles and hottest playnes,

With Barren Rockes and Fertyle Feildes,

\footnotetext{
*See Curtis Perry,' "If Proclamations Will Not Serve": The Late Manuscript Poetry of James I and the Culture of Libel', in Royal Subjects: Essays on the Writings of James VI and I, ed. D. Fischlin \& M. Fortier, Detroit: Wayne State University Press, 2002, pp.212, 217-18, 220-24. 11 droppe] ?collapse, tumble down; but as the general tone is not so cataclysmic, perhaps a mistake for droope (as in BL MS. Addl. 34324), i.e. bow their heads. 15 Greece] In accord with the classical-pastoral geography of the poem: either Scotland, the dynasty's original home, or England, or both. 17 our Royall Pan] James I. 19 Menalus] Maenalus, a mountain in Arcadia, Pans favourite haunt. 20 Hesperus] the planet Venus, especially as the evening star; hence the west, where it appears. To Romans, Hesperus meant Spain. 26 pages] Charles and Buckingham assumed the disguise of servants. 27-8 (Though they were dressed as servants), who can doubt their success when the partners are of equal rank and love each other equally? 30 golden Fleece] referring to the legend of Jason and the Argonauts. 31 manye Spaynes] Obviously referring to the Infanta's homeland, its 'many' terrains symbolizing different phases or aspects of love.
} 
By turne dispayre and Comffort yeildes.

Butt whoe can doubte of prosperous lucke

Where Love and Fortune doth conducte.

guide or direct matters

Thie grandsire greate, thie Father to

Were thine examples, this to doe,

Whose brave Attempts, in heate of Love,

Both Fraunce and denmarke did approve.

Soe Jacke and Tom doe nothing newe

When Love and Fortune they pursue.

Kinde Sheappeardes, that haue lou'd them longe,

Bee not soe Rashe, in Censuringe wronge.

Correct your Feares, leave of to mourne:

The Heavens will Favor their Returne.

Remitt the Care to Royall Pan

Of Jacke his Sonne, and Tom, his Man

\section{John TAYlor From Taylor's Pastoral}

The opening and closing items of the curious work Taylors Pastorall (1624) by John Taylor 'the WaterPoet', containing much varied and curious material about sheep-farming and the wool trade, and accounts of eminent drapers and wool traders. The first extract offers an elaborate list of biblical figures and events assimilable to the pastoral. The second draws on urban, satiric, and thoroughly un-idyllic associations of sheep and sheepkeeping. Punctuation rationalized. Substantive marginal notes in the original have been cited, but not mere names of persons repeated in the margin.

\section{Passage (A)}

Taylors Pastorall, being both Historicall and Satyricall.

Apollo (father of the Sisters nine,

I craue thy aide t'inspire this Muse of mine,

Thou that thy golden Glory didst lay by

(As Ouid doth relate most wittily)

And in a Shepheards shape, didst deigne to keepe

Thy Loues beloued Sire, Admetus sheepe.

And rurall Pan, thy helpe I doe intreate,

That (to the life) the praise I may repeate

Of the contented life, and mightie stockes

Of happy Shepheards, and their harmlesse flockes.

But better thoughts my Errors doe controule

For an offence, most negligent and foule,

In thus inuoking, like a heathen man,

Helpe, helplesse, from Apollo, or from Pan:

When as the subiect, which I haue in hand,

Is almost infinite, as starres, or sand,

Grac'd with Antiquitie, vpon Record

In the Eternall, neuer-failing Word.

There 'tis ingrauen true and manifest,

That Sheepe and Shepheards, were both best and blest.

I therefore inuocate the gracious aide

Of Thee, whose mightie Word hath all things made,

I Israels great Shepheard humbly craue

That his assur'd assistance I may haue:

That my vnlearned Muse no verse compile,

Which may be impious, prophane or vile,

37 Thie grandsire ... thie Father] Charles's grandfather James V of Scotland had sailed to France, and his father James VI/I to Denmark, to marry their brides. 44 Censuringe wronge] misjudging or criticizing them. The Infanta marriage proposal was widely unpopular in Britain as enhancing Catholic influence. 1 Sisters nine] the Muses. Their father usually said to be Zeus (Jupiter), sometimes Uranus or Pierus, but never Apollo. 6 More inaccuracies. Apollo kept Admetus' sheep not to advance his love, but as penance for having slain the Cyclops; and Ovid does not tell the story. absolute construction: 'I being helpless'. 18 Eternall, neuer-failing Word] the Bible. 14 helplesse] great Shepheard] See 161n. 
And though through Ignorance, or negligence,

My poore inuention fall into offence,

I doe implore that boundlesse Grace of his,

Not strictly to regard what is amisse:

But vnto me belongeth all the blame,

And all the Glory be vnto his Name.

Yet as this Booke is verse, so men must know,

I must some Fictions and Allusions show,

Some shreds, some remnants, reliques, or some scraps,

The Muses may inspire me with perhaps,

Which taken literally, as lies may seeme,

And so mis-vnderstanding may misdeeme.

Of Sheepe therefore, before to worke I fall,

$40 \quad$ Ile shew the Shepheards first originall:

Those that the best Records will reade and marke,

Shall finde iust Abel was a Patriarke,

Our father Adams second sonne, a Prince,

(As great as any man begotten since)

Yet in his function he a Shepheard was:

And so his mortall pilgrimage did passe.

And in the sacred Text it is compilde,

That he that's father of the faithfull stilde,

Did as a Shepheard, liue vpon th'encrease

Of Sheepe, vntill his daies on earth did cease.

And in those times it was apparent then

Abel and Abram both were noble men:

The one obtain'd the title righteously

For his vnfeigned seruing the most HiGH,

He first did offer Sheepe, which (on Record)

Was sacrifice accepted of the Lord.

He was (before the infant world was ripe)

The Churches figure, and his Sauiours type.

60 Did first of all feele persecutions rod.

A murdered Martyr, who for seruing God,

And Abraham was in account so great,

Abimelech his friendship did intreate.

Faiths paterne, and Obedience sample, he

Like starres, or sand, was in posteritie:

In him the Nations of the earth were blest,

And now his bosome figures heau'nly REST.

His Sheepe almost past numbring multiplide,

And when (as he thought) Isaack should haue dide,

Then by th'Almighties Mercies, Loue, and Grace

A Sheepe from out a Bush supplide the place.

Lot was a Shepheard, (Abrams brothers sonne)

And such great fauour from his God he wonne,

That Sodom could not be consum'd with fire,

Till he and his did out of it retire,

They felt no vengeance for their foule offence,

Till righteous Lot was quite departed thence.

obedience's; example i.e. extremely prolific

33-8 Conflates the figurative function of all poetic language with the allusive function of pastoral. $\quad \mathbf{4 2}$ Marginal note in original: 'Abel, a Prince, a Patriarke, a figure of the true Church, a type of Christ, and a Shepheard. Abraham a Prince, a Patriarke, intituled with the Glorious title of father of the faithfull, a Shepheard'. $\quad 45$ a Shepheard] See Genesis 4.2. $\quad 48$ father of the faithfull] Abraham. $\quad$ 55-6 See Genesis 4.4. $\quad 58$ his Sauiours type] See Hebrews 12.24. type] an item in the Old Testament prefiguring something in the New. Abel doubly suggests Christ: in himself, and in the sheep he offered as sacrifice. 61-2 This episode (Genesis 20) is not as edifying as Taylor suggests. $\mathbf{6 6}$ alluding to the phrase 'Abraham's bosom' (Luke 16.22). 68-70 Gen. 22.1-14. 71-6 Lot as shepherd, Gen. 13.5; his escape from Sodom, Gen. 19.1-29. 
And Iacob, as the holy Ghost doth tell,

Who afterwards was called Israel,

Who wrastled with his God, and (to his fame)

Obtain'd a Name, and Blessing for the same,

$\mathrm{He}$ (vnder Laban) was a Shepheard long,

And suffred from him much ingratefull wrong.

For Rachel and for Leah, he did beare

The yoke of seruitude full twentie yeare.

He was a Patriarke, a Prince of might,

Whose wealth in sheepe was almost infinite.

His twice sixe sonnes (as holy writ describes,

Who were the famous fathers of twelue tribes)

Were for the most part Shepheards, and such men

Whose like the world shall ner'e containe agen.

Young Ioseph, 'mongst the rest, especially,

A constant mirrour of true Chastity:

Who was in his affliction, of behauiour

A mortall Type of his immortall Sauiour:

And Truth his mother Rachel doth expresse

To be her father Labans Shepheardesse.

Meeke Moses, whom the Lord of hosts did call

To leade his people out of Egypts thrall,

Whose power was such, as no mans was before,

Nor since his time hath any mans beene more,

Yet in the sacred text it plaine appeares,

That he was Iethroes Shepheard fortie yeares.

Heroicke Dauid, Ishayes youngest sonne,

Whose acts immortall memorie hath wonne:

Whose valiant vigour did in pieces teare

A furious Lion and a rauenous Beare:

Who (arm'd with faith and fortitude alone)

Slew great Goliah, with a sling and stone,

Whose victories the people sung most plaine,

Saul hath a thousand, He ten thousand slaine:

$\mathrm{He}$ from the sheepfold came to be a King,

Whose fame for euer through the world shall ring:

$\mathrm{He}$ was another Type of that blest $\mathrm{He}$

That was, and is, and euermore shall be.

His vertuous Acts are writ for imitation,

His holy Hymnes and Psalmes for consolation,

For Reprehension and for Contemplation,

And finally to shew vs our saluation.

The Prophet Amos, vnto whom the Lord

Reueald the sacred secrets of his Word:

God raisd him from the sheepfold, to foretell

What plagues should fall on sinfull Israel.

True Patience paterne, Prince of his affections,

Most mightie tamer of his imperfections,

Whose guard was God, whose guide the holy Ghost,

Blest in his wealth, of which Sheepe was the most,

77-90 Jacob's wrestling with an angel, then being blessed and named Israel, Gen.32.24-9, 35.10; his serving Laban for twenty years (presumably as shepherd, as Laban owned large flocks), Gen.29.20, 28, 30, Gen.31.41; Laban's deceit in bestowing his daughters Leah and Rachel on Jacob, Gen.29.24-29; Jacob's 'wealth in sheepe', Gen.30.43; his twelve sons, Gen.35.23-6; their founding the twelve tribes of Israel, Gen.49, Num. 1.20-44; their being shepherds, Gen.46.32. 94 Joseph is a type (see 58n) of Christ: most clearly in being named 'Zaphenath-paneah' ('healer/saviour of the world', or 'bread of life') by the Pharaoh (Gen.41.45); more generally, in bringing shelter and prosperity to the tribes of Israel. 96 Labans Shepheardesse] Gen. 29.9. 102 Iethroes ... yeares] Gen. 3.1, Acts 7.29-30. 103 Ishaye] Jesse of Bethlehem. $\quad 105-8$ 1 Samuel 31-51. $\quad 1101$ Samuel 18.7. $\quad 111$ Samuel 16.11. 113-4 As deliverer of Israel, David was a major type of Christ, who was given the messianic title 'Son of David' (Matthew 1.1). 116 Hymnes and Psalmes] David is held to have written many other hymns besides the Psalms. 119 Amos] 'among the herdsmen of Tekoa' (Amos 1.1). 126 Sheepe was the most] 7,000, more than any other kind of livestock (Job 1.3). 
Iust Iobs lost riches doubled was agen,

Who liu'd belou'd of God, admir'd of men.

The first of happy tidings on the earth,

Of our all onely Sauiours blessed birth,

The glorious Angels to the Shepheards told,

As Luke th'Euangelist doth well vnfold.

And should my verse a little but decline

To humane stories, and leaue diuine:

There are some mightie Princes I can name,

Whose breeding (at the first) from Shepheards came.

ancestry

Romes founder (Romulus) was bred and fed

Mongst Shepheards, where his youthfull daies he led.

The Persian Monarch (Cyrus) he did passe

His youth with Shepheards, and a Shepheard was.

The Terrour of the world, that famous man

Who conquer'd Kings, and kingdomes ouer-ran,

His stile was, (as some stories do repeate)

The Scythian Shepheard, Tamberlaine the great.

Tis such a title of preeminence,

Of reuerence, and such high magnificence,

That Dauid, (who so well his words did frame)

Did call our great Creator by that name.

Our blest Redeemer (Gods eternall Sonne)

Whose onely merits our saluation wonne,

He did the harmlesse name of Shepheard take

For our protection, and his mercies sake.

Those that will reade the sacred Text, and looke

With diligence, throughout that heauenly Booke,

Shall finde the Ministers haue Epethites,

And named Angels, Stewards, Watchmen, Lights,

Salt, Builders, Husbandmen, and Starres that shine,

(Inflamed with the Light which is Diuine)

And with these names, within that Booke compilde,

They with the Stile of Shepheards are instilde.

Thus God the Sire, and Sonne, the Scriptures call

innocent

Both Shepheards, mysticall and litterall,

And by similitudes comparing to,

All Kings and Churchmen beare that title do.

127 Marginal note in original cites two more figures: 'Seth and Noah, were shepheards and feeders of cattell.' Seth might be taken as a shepherd, from having been born to Eve in place of Abel (Gen.4.25), and Noah for having sheltered all beasts in the Ark (Gen. 9.20). 132 Luke th'Euangelist] Marginal note in original: 'Luk.2.8'. $\quad 134$ stories] perhaps pronounced in three syllables, for the metre. $\quad \mathbf{1 3 7 - 8}$ Romulus and his brother Remus were rescued from death and brought up by the shepherd Faustulus. Their first public role concerned a dispute between the shepherds of their grandfather Numitor and uncle Amulius. 139-40 Cyrus was of noble family, but consigned to death at birth and brought up by a shepherd. Marginal note in the original names two more figures: 'Valerius Maximus and Aurelius were raisd from being heardmen to the imperiall dignitie.' The first is probably the emperor Galerius (Gaius Galerius Valerius Maximianus, emperor 305-11), a herdsman's son. No Roman emperor named 'Aurelius' was of humble origin. Taylor may be confusing the emperor Marcus Aurelius with the grammarian Opilius Aurelius, whose first name resembles opilio, shepherd (Latin). 141-4 Taylor may be recalling a printed text of Marlowe's play: there is no recorded Renaissance performance after 1595 . 148 call our great Creator] Psalm 80.1 (cited in marginal note in original); also Psalm 23. 151-2 John 10.14 (marginal note in original cites 'Ioh.10.11,12'). See John 10 generally. 155-60 Taylor might be speaking of the ninefold hierarchy of heavenly beings, though it is uncertain which of them is designated 'Shepheards' (or by many of the other names). 155 Ministers] Christ's apostles. The 'epithets': angels Gal.4.14; stewards Luke 12.42, 1 Cor. 4:1; watchmen Isaiah 6.17, 62.6, Micah 7.4; lights Phil.2.15; salt Luke 14.34, Mark 9.49-50; builder 1 Cor. 3; husbandmen 2 Tim. 2.6; stars Daniel 12.3. The Old Testament passages are about the faithful and the prophets generally. 161 Sire, and Sonne] References to God the Father and/or Son as shepherd include Ps. 23.1, 40.11, 44.28, 80.1; Jer.31.10; Ez. 34.12. Christ calls himself the Good Shepherd in John 10.11-14. See also Matt.25.32, Heb. 13.20, 1 Peter 5.4. 162 mysticall] allegorical, figurative. Of course, the scriptures nowhere describe either God the Father or God the Son as 'litterall' shepherds. 


\section{Passage (B)}

\section{[This section is introduced by the following note in the margin.]}

Here followeth a touch of paltry Scabbed infectious kinde of Sheepe, which I thinke fit to place by themselues in the lagge end of my Booke, as farre as I can from the clean, sound, and profitable Sheepe before mentioned, for feare the bad should infect the good.

And now from solid Prose I will abstaine

To pleasant Poetrie, and mirth againe.

The Fable of the Golden Fleece began,

'Cause Sheepe did yeeld such store of Gold to Man:

For he that hath great store of woolly fleeces,

May (when he please) haue store of golden peeces.

Thus many a poore man dying, hath left a Sonne,

That hath transform'd the Fleece to Gold, like Iason:

And heere's a mystery profound and deepe,

There's sundry sorts of Mutton, are no Sheepe:

Lac'd Mutton, which let out themselues to hire,

Like Hackneys, who'le be fir'd, before they tire.

The man or men which for such Mutton hungers,

Are (by their Corporation) Mutton-mongers:

Which is a brotherhood so large and great,

That if they had a Hall, I would intreat

To be their Clarke, or keeper of accounts,

To shew them vnto what their charge amounts;

My braines in numbring then would grow so quicke,

I should be master of Arithmeticke:

All States, Degrees, and Trades, both bad and good,

Afford some members of this Brotherhood:

Great therefore needs must be their multitude,

When euery man may to the Trade intrude:

It is no freedome, yet these men are free,

Not sauers, but most liberall spenders be:

For this is one thing that doth them bewitch,

That by their trading they waxe seldome rich:

The value of this Mutton to set foorth,

The flesh doth cost more than the broth is worth:

They all are Ewes, yet are exceeding Ramish,

And will be dainty fed, whos' euer famish.

Nor are they mark'd for any man, or no man,

As mine, or thine, but euery mans in common,

Fine heads, and neckes, and breasts, they yeeld some store,

But scarcely one good liuer in nine score:

The liuers being bad, 'tis vnderstood,

The veines are fild with putrified blood,

Which makes them subiect to the scab, and then

They proue most dang'rous diet vnto men.

syphilis

And then the prouerbe proues no lie or mocke,

One scabbed sheepe's enough to spoyle a flocke.

But yet for all this, there is many a Gull,

Loues Mutton well, and dips his bread i' the wooll.

And were a man put to his choyce to keepe,

\footnotetext{
1 Prose] in which the preceding praise of drapers and their trade was written. 3 Golden Fleece] hanging from a tree and guarded by a dragon in Colchis. Jason and his companions voyaged on the ship Argo to obtain it. 11 Lac'd Mutton] cant for a loose woman or prostitute. 12 fir'd] To 'fire' or 'feague' a horse (OED 1st cit. 18th cent.) is to put ginger up its fundament to make it perk up its tail and appear more lively. So also these women keep up their youth and sex-drive artificially rather than retire from their trade. May merge with the earlier sense of fire, beat, whip (as prostitutes were publicly). 14 Corporation] fanciful trade guild of these traffickers in flesh, like that of actual Mutton-mongers or butchers. Taylor ironically presents the consumers of such 'mutton' as its purveyors, to their loss (25-30). 16 Hall] guild headquarters. $\quad 36$ liuer] seat of passions in the old physiology: i.e., such women are not capable of genuine love. $\quad 37-40$ This malady is linked to sexually transmitted disease. $\mathbf{4 4}$ i.e., Does not get what he wants, but an unwelcome consequence.
} 
'Tis said, a Shrew is better then a Sheepe.

But if a man be yok'd with such an Ewe,

She may be both a scabbed Sheepe and Shrew.

And he that is so match'd, his life may well

Compared be vnto an earthly hell.

But to my Theame which I wrote of before,

I at this Mutton must haue one cut more.

These kinde of Sheepe haue all the world o'regrowne,

And seldome doe weare fleeces of their owne:

For they from sundry men their pelts can pull,

Whereby they keepe themselues as warme as wooll.

Besides, in colours, and in shape, they varie

Quite from all profitable sheepe contrarie:

White, Blacke, Greene, Tawny, Purple, Red and Blue,

Beyond the Raine-bow for their change of hue:

Camelion like in alteration,

But that base Aire they cannot liue vpon.

The Moones mutation's not more manifold,

Silke, Veluet, Tissue, Cloth, and cloth of Gold:

These are the Sheepe that Golden fleeces weare,

Who robe themselues with others wooll or haire:

And it may be, 'twas such a Beast and Fleece,

Which Iason brought from Cholcos, into Greece.

Were it no more but so, I dare be bold

To thinke this Land doth many Iasons hold:

Who neuer durst to passe a dang'rous waue,

Yet may (with ease) such Golden fleeces haue.

Too much of one thing's good for nought (they say)

Ile therefore take this needlesse dish away:

For should I too much, of Lac'd Mutton write,

I may o're come my Readers stomacke quite.

Once more vnto the good Sheepe Ile retire,

And so my Booke shall to it's end expire:

Although it be not found in Ancient writers,

8o I finde all Mutton-eaters are sheepe-biters.

And in some places I haue heard and seene,

That currish sheepe-biters haue hanged beene,

If any kinde of Tike should snarle or whine,

Or bite, or woorry this poore Sheepe of mine.

Why, let them barke and bite, and spend their breath,

Ile neuer wish them a sheepe-biters death.

My Sheepe will haue them know, her innocence

Shall liue, in spight of their maleuolence:

I wish them keepe themselues and me from paine,

$90 \quad$ And bite such Sheepe as cannot bite againe.

For if they snap at mine, I haue a pen,

That (like a trustie Dogge) shall bite agen.

And in Conclusion, this I humbly craue,

That euery one the honestie may haue,

That when our fraile mortalitie is past,

We may be the good Sheapheards sheepe at last.

46 Better marry an aggressive woman than a submissive one. 55 i.e., They 'fleece' their clients. 57-60 Contrary to Taylor's intent, such natural growth of wool in various colours occurred in the Golden Age (Virgil IV.42-5). $\quad 62$ Pliny (Natural History 8.51) thought the chameleon lived on air. See Hamlet 3.2.101. 65 Marginal note in original: 'They are as soft as Silkewormes'. 68 from Cholcos, $\begin{array}{lll}\text { into Greece] actually the reverse. } \quad 80 \text { sheepe-biters] sheepdogs that attack their own charges. } & \mathbf{8 7}\end{array}$ My Sheepe] presumably his poems. 


\section{JAMES SHIRLEY 'WOODMEN SHEPHERDS'}

From Act 5 of Shirley's play Love Tricks: or, The School of Complements (performed 1625, printed 1631). The first two stanzas may be sung respectively by shepherdesses and shepherds entering 'with garlands', and the third stanza in chorus.

Wood-men Shepheards, come away,

This is Pans great holy-day, Throw off cares,

With your heauen aspiring aires Help vs to sing

While valleyes with your Ecchoes ring.

Nymphes that dwell within these groues,

Leave your Arbours, bring your loues, gather poesies,

Crowne your golden haire with Roses, As you passe

Foote like Fayries on the grasse.

Joy drowne our bowers, Philomell,

Leaue of Tereus rape to tell, Let trees dance,

As they at Thracian Lire did once, Mountaines play,

This is the Shepheards holiday.

Dance. The song ended, Enter a mask of Satyres etc. and dance.

Enter a Shepheardesse with a white rod.

1 Shep. Post hence Satyres and giue way,

For fairer soules to grace the day,

And this presence, whip the aire

With new rauishings, hence with care,

By the forelock hold Time fast,

Lest occasion slip too fast

Away from vs, joys here distill.

Pleasures all your bosomes fill. Exit.

\section{Nicholas Oldisworth An Eclogue between a Carter and a Shepherd}

From Bod. MS Don.c.24, a book of poems by Nicholas Oldisworth, written between 1628 and 1634 while he was at Christ Church College, Oxford, and transcribed and presented long after to his wife. Their daughter Margaret later filled many blank pages of the volume with recipes. Nicholas's cousin Michael Oldisworth, whose coming (to Oxford?) the poem celebrates, was fellow of Magdalen College, Oxford, and later secretary to the Earls of Pembroke. This and other poems express Nicholas's deference to a successful relative with courtly connexions.

An eglogue betweene a Carter and a Sheapard, made on M[aste]r Mic[hael] Oldisworth's Comming into the country

Carter. Now a Botch take thee, Tom: where hast thou beene

These hundred yeares? why (man) you mightst have seene

plague

One that shines braver then a Summer's day;

I scarce know whom: but I heard Tahah say,

Not all the Horses in my landlord's teeme

So many Vertues have, as are in Him;

The nobles bragge (hee sayes) and statesmen boast

That goodnesse amongst Courtyers is not lost.

1 Wood-men] Either shepherds or a separate category of forest-dwellers, perhaps the satyrs who enter at 18.1. 13-14 Philomell ... Tereus] Philomela was raped by her brother-in-law Tereus and later transformed into a nightingale. 16 Thracian Lire] Orpheus' lyre. Orpheus came from Thrace. $\quad \mathbf{1 8 . 2}$ white rod] no doubt a magic device to dispel evil. 20 fairer soules] The humans (chiefly of 'gentle' stock) who enter after the satyrs. $\quad 21$ presence] imposing or venerable company (see OED $4 \mathrm{~b}, 5 \mathrm{a}$ ). 
Sheapard. Marry I thought 'twas somthing, when old Guerim

Left singing, and ranne home-wards. I could heare him

Downe in a Vallie, neare a litle Brooke,

(As hee leant on the noddle of his crooke)

head, handle

Such sorrowes from the Pleasures of the Yeare,

And there grieve most, where most hee ought to cheare.

A shepard's Song.

"Thou happy Earth (quoth hee) though nipping Cold

Wrinkled thy skinne, and caus'd thee to looke old,

Though raging Windes did pierce thee, and the spight

Of hoary Raine did change thy greene to white,

Yet now againe fresh youth adornes thy face,

And blest Delight straws flowrs in every place;

strews

But (woe to mee!) my sadd misfortunes bring

An endlesse Winter, without hope of Spring,

My sighes are alwaies blustring, and my head

With everlasting Frost and Snow is spredd:

Noe thawing Joy, noe Heate to ridd my heart

Of chill Despaire, noe Cure to ease my Smart.

Yee torrents, though your banks yee oft ore-passe,

And rudely wash away the meadow-Grasse,

Yet when warme Sunnes return, the grounds waxe drie,

And grow more fertile by your injurie;

But ah! my Teares, with their rebellious force,

Drowning my cheekes, doe never cease their course:

Or if they stopp a while, they onely shew mee

How wither'd I am, while they thus bedeaw mee.

The fields, though with the wounds of ploughs they bleed,

Are well apayd, when they newe Harvests breede;

But I, for all my pangs and restlesse minde,

Nought but a Croppe of Scorne and Hatred finde.

Fire dissolves pitch, and Water falling often

Melts stones; but neither her hard Breast will soften.

Wherfore both Fire and Water I'l consume,

And quench my hott affection with cold rheume."

Carter. Old Guerim is the Creditt of our times;

Hee charmes his Sheepe with such transcendent rymes,

That hee drawes rurall Nymphs from out their Bowers

To make him Garlands of their sweetest flowers:

And heard-groomes, flocking round to hear his skill,

Thinke that his Layes are done too quickly still;

When hee beginnes, they seeme in mirth to flowe,

When hee concludes, they seeme to mourn for Woe.

Sheepheard. But in an angry moode the foole forswore

To sing of Love and Beauty any more;

Hee shakes off Women, and applies his Penne

To paint the worthy acts of famous men:

Well are they spedd, whose Praises hee shall write,

Whose quill can nought but tarbox-lines endite.

Carter. Nay, Tom, believe mee, Guerim can doe well,

Tahah commends him; and our Ralph can tell,

60

That gallant man, whom wee were speaking of,

His verses tooke, and did nor frown, nor scoffe:

I think, I have the Paper in my pocket;

Why dost thou laugh? I preethee doe not mock it.

A sheapheard's Complement.

"Accept our paines, great Sir, and daigne to read

Things simple, as the place where they were bredd.

What though wee cladd our meaning in low wordes?

57 tarbox-lines] lines fit for a shepherd, dipping his quill not in an inkwell but in the tarbox he carries to dress his sheep's injuries. 
Humilitie with highnesse best accordes.

Dales become mountaines, and the stouping neck

Suits fairest with the lofty lordling's beck:

They doe but shew their dimnesse, which shine bright

To you, and to a Torch a Candle light;

Darknesse and shade most fitts the Sunne, since Hee

Besides himselfe sight-worthy nought can see.

Pan crown your mighty partes, Sir: you can doe

More than some Doctors, and some Captaines too:

Tut, you scorne trifles, you can write and reade,

And if you please, an Army you can leade;

But this to mee appeares the strangest thing

That you can, when you list, behold the King."

\section{William Herbert, Earl of Pembroke A Sonnet}

First published posthumously in Herbert's Poems (London, 1660). The elite extreme of the 'shepherd's invitation' of which Marlowe's 'Come live with me' provides the type. The setting is clearly the park surrounding a stately home, with grazing deer besides sheep and cattle.

A Sonnet.

Dear leave thy home and come with me,

That scorn the world for love of thee:

Here we will live within this Park,

A Court of joy and pleasures Ark.

container, receptacle

Here we will hunt, here we will range,

Constant in Love, our sports wee'l change:

Of hearts if any change we make,

I will have thine, thou mine shalt take.

Here we will walk upon the Lawns,

And see the tripping of the Fawns;

And all the Deer shall wait on thee,

Thou shalt command both them and me.

The Leaves a whispering noise shall make,

Their Musick-notes the birds shall take,

And while thou art in quiet sleep,

And the green wood shall silence keep.

And while my herds about thee feed,

Love's lessons in thy face I'le read,

And feed upon thy lovely look,

For beauty hath no fairer book.

skipping, gambolling

It's not the weather, nor the air,

It is thy self that is so fair;

Nor doth it rain when heaven lowers,

But when you frown, then fall the showers.

One Sun alone moves in the skye,

Two Suns thou hast, one in each eye;

Onely by day that sun gives light,

Where thine doth rise, there is no night.

Fair starry twins, scorn not to shine

Upon my Lambs, upon my Kine;

My grass doth grow, my Corn and wheat,

My fruit, my vines thrive by their heat.

Sonnet] in the extended sense of any lyric,especially a love-song. 16 And] Perhaps a mistake for 'All', by eye-slip with 'And' in 15. eyes.
2 scorn] with 'I' as implicit subject. 32 their] of the twin 'suns' of the 
Thou shalt have wool, thou shalt have silk,

Thou shalt have honey, wine and milk;

Thou shalt have all, for all is due,

Where thoughts are free, and love is true.

noble, generous $\left(\mathrm{OED}_{3} b\right)$

\section{Richard Fanshawe An Ode upon Occasion of His Majesty's Proclamation}

Written in 1630, published 1647 with Fanshawe's translation of Guarini's Italian pastoral play Il pastor fido. The Thirty Years' War had engulfed much of Europe. Fanshawe contrasts the peaceful state of England, though the poem's occasion reflects political tensions. 1630 saw the last of several proclamations directing the landed aristocracy and gentry to stay in the countryside, to regulate and develop it properly and reduce pressure on the cities. The edict was widely unpopular, adding to the tension between the King and the political front nominally called the 'Country' party but increasingly influential at court.*

An Ode vpon occasion of His Majesties Proclamation in the yeare 1630. Commanding the Gentry to reside upon their Estates in the Country.

Now warre is all the world about,

And every where Erynnis raignes,

Or else the Torch so late put out,

The stench remaines.

i.e. smell of burning

Holland for many years hath beene

Of Christian tragedies the stage,

Yet seldome hath she play'd a Scene

Of bloudyer rage.

And France that was not long compos'd

With civill Drummes againe resounds,

at harmony, peaceful

And ere the old are fully clos'd

Receives new wounds.

The great Gustavus in the west

Plucks the Imperiall Eagles wing,

Than whom the earth did ne're invest

A fiercer King,

Revenging lost Bohemia,

And the proud wrongs which Tilly dud,

And tempereth the German clay

With Spanish bloud.

What should I tell of Polish Bands,

And the blouds boyling in the North?

Gainst whom the furied Russians

Their Troops bring forth.

Both confident: This in his purse,

*See Isaac Disraeli, 'Buildings in the Metropolis, and Residence in the Country', citing this poem in full: Curiosities of Literature (1-vol. edn., New York: Leavitt \& Allen, 1857), pp.361-4. 2 Erynnis] The Erinnyes or Furies, goddesses of retribution: mistaken as a single figure, or using a singular verb with plural subject. 3 Absolute construction: 'The torch being so late put out...' 5 Holland] divided between Spanish (Catholic) possessions and an alliance of Protestant states, hence the site of prolonged religious war. 1629-30 saw heightened conflict followed by a political stalemate. 9 France] After the death of King Henri IV, originally a Protestant, the Huguenots or French Protestants felt threatened under the new king Louis XIII and broke out in rebellions. 11 the old] The conflict between Catholics and Protestants in France before Henri IV's reign. 13 Gustavus] Gustavus Adolphus, king of Sweden, who entered the Thirty Years' War decisively on the Protestant side and won significant gains from the Catholic Ferdinand II, Holy Roman Emperor. 14 Eagle] the insignia of Imperial Rome and its notional successor, the Holy Roman Empire. 17 Bohemia] Its tolerant regime ended under the Catholic rule of Ferdinand II. The Protestant initiative under Gustavus Adolphus could be seen as a 'revenge' for this. $\quad \mathbf{1 8}$ Tilly] Johann Tserclaes, Count of Tilly: Catholic leader active in Germany. Gustavus Adolphus checked his advance and later crushed him in the Battle of Brietenfeld (1631). 19-20 German clay ... Spanish bloud] Spanish forces in Italy moved west to capture much of Germany and threaten Protestant Netherlands. Gustavus opposed them, culminating in the Battle of Brietenfeld. 21-4 Prince Wladyslaw of Poland (nominally declared Tsar) invaded Russia and attempted to establish his rule there. 25-7 Although Russia (This) was in disarray, Tsarist wealth was still considerable. Till 1629, Poland (He) was in continual conflict with the Turkish Ottoman Empire, as with Russia. But This and He might also refer to Gustavus Adolphus and the Holy Roman Emperor respectively. A long purse and 'needy valour' certainly marked Gustavus, and the Habsburg emperors were in constant hostility with the Turks. 
And needy valour set on worke; He in his Axe; which oft did worse ?courage called forth by need; motivated, activated Th'invading Turke

Who now sustaines a Persian storme:

There hell (that made it) suffers schisme. worst, defeat endures, undergoes

This warre (forsooth) was to reforme Mahumetisme.

Onely the Island which wee sowe,

(A world without the world) so farre

From present wounds, it cannot showe An ancient skarre.

White Peace (the beautiful'st of things)

Seemes here her everlasting rest

To fix, and spreads her downy wings Over the nest.

As when great Jove usurping Reigne

From the plagu'd world did her exile

And ty'd her with a golden chaine To one blest Isle:

Which in a sea of plenty swamme

And Turtles sang on ev'ry bowgh,

A safe retreat to all that came As ours is now:

Yet wee, as if some foe were here,

Leave the despised Fields to clownes,

And come to save our selves as twere In walled Townes.

Hither we bring Wives, Babes, rich clothes

And Gemms; Till now my Soveraigne

The growing evill doth oppose:

Counting in vaine

His care preserves us from annoy

Of enemyes his Realmes to'invade,

Vnlesse hee force us to enjoy The peace hee made.

To rowle themselves in envy'd leasure

He therefore sends the Landed Heyres,

qultivate, hence inhabit outside

came: seeking refuge

as if the country were threatened by an enemy rustics, peasants, boors

roll: wrap, envelop

Whilst hee proclaimes not his owne pleasure

So much as theirs.

The sapp and bloud o'th land, which fled

Into the roote, and choackt the heart,

And bid their quickning pow'r to spread Through ev'ry part.

$\mathrm{O}$, 'twas an act, not for my muse

To celebrate, nor the dull Age

Vntill the country aire infuse

$$
\text { A purer rage! }
$$

And if the Fields as thankfull prove

For benefits receiv'd, as seed,

They will, to quite so great a love,

$$
\text { A Virgill breed. }
$$

A Tytirus, that shall not cease

Th' Augustus of our world to praise

In equall verse, author of peace

enlivening, vitalizing

28-32 The late 16-c and early 17-c saw repeated hostilities between the established Turkish and emergent Persian empires. 30 hell] The entrenched Christian view of Islam in that age. schisme] The Ottoman Turks were Sunni, the Safavid Persians Shiite. 35-6 present ... skarre] It does not have even an old scar, let alone a present wound. 41 Jove usurping Reigne] Zeus or Jupiter seizing power from Saturn. England is seen as preserving the Saturnian or Golden Age. (Ovid, Met. I.113-14). 65-8 Image of a tree whose sap has retreated to its roots, leaving the trunk or central part dry. 77 Tytirus, Augustus] In Virgil I, the shepherd Tityrus is usually taken as the poet, thanking the Emperor Augustus for his patronage. 


\footnotetext{
And Halcyon dayes.

Nor let the Gentry grudge to goe

Into those places whence they grew,

But thinke them blest they may doe so. Who would pursue

The smoaky glory of the Towne,

That may goe till his native earth,

And by the shining fire sit downe Of his owne hearth,

Free from the griping Scriveners bands,

90 And the more byting Mercers books;

Free from the bayt of oyled hands And painted looks?

The country too ev'n chopps for raine:

You that exhale it by your power

Let the fat dropps fall downe againe In a full showre.
}

And you bright beautyes of the time,

That waste your selves here in a blaze,

Fixe to your Orbe and proper clime Your wandring rayes.

Of natures feathered quire: and all
Let no darke corner of the land

Be unimbellisht with one Gemme,

And those which here too thick doe stand Sprinkle on them.

Beleeve me Ladies you will finde

In that sweet life, more solid joyes,

More true contentment to the minde Than all Town-toyes.

Nor Cupid there lesse bloud doth spill,

But heads his shafts with chaster love,

Not feathered with a Sparrowes quill But of a Dove.

There shall you heare the Nightingale

(The harmelesse Syren of the wood)

How prettily she tells a tale Of rape and blood.

The lyrricke larke, with all beside

The Common-wealth of Flowres int's pride Behold you shall.

The Lillie (Queene) the (Royall) Rose,

The Gillyflowre (Prince of the bloud)

The (Courtyer) Tulip (gay in clothes) The (Regall Budd)

The Vilet (purple Senatour)

How they doe mock the pompe of State, greedy, rapacious; bonds hurtful, harmful

chaps, cracks like soil in dry weather; for want of trivialities, distractions

nation or population; in its

8o Halcyon dayes] calm peaceful days, like those at the winter solstice when the legendary bird halcyon was thought to nest on the calm sea. $\mathbf{8 5}$ smoaky] no doubt both literal and metaphorical, ironically evoking the literal meaning of glory: effulgence, ring of light (OED 9c). 9o Mercers books] proverbial phrase for debts incurred by aristocrats for fine clothes and luxuries. Mercer] dealer in cloth. 91 oyled] Smeared with perfume or ointment, but with obvious metaphoric implication of hypocritical sycophancy. 93 raine] obviously metaphorical: relief. 98 blaze] like a comet or meteor, unlike the stars in their fixed orbits. 99 Orbe] The spheres in which heavenly bodies were thought to be set in Ptolemaic astronomy; hence the latter's orbits. $102 \mathrm{Gemme}$ ] i.e. aristocratic women: they should be spread across the land instead of congregating at court. 104 sprinkle] shine, sparkle (OED sprinkle $\mathrm{v}^{2}$ ) as well as 'scatter, spread'. $\quad \mathbf{1 0 9 - 1 1 2}$ i.e. There is love in the country, but of a chaster kind. 111 Sparrowes quill ... Dove] Both sparrow and dove were sacred to Venus. The sparrow was considered promiscuous, but the dove exemplified faithful love between partners. 114 Syren] Because of her sweet song, but harmlesse unlike the seductive Sirens who led mariners to destruction. 116 rape and blood] Philomela was transformed into a nightingale after being raped by her brother-in-law Tereus. 117 lyrricke] 'given to song; singing' $\left(O E D_{2} 2\right)$. 121-8 Continuing the motif of country life offering all courtly delights and gains, but in chaster or more virtuous form. 125 purple] colour reserved for patricians in Rome, hence all ruling classes or aristocrats. 
And all that at the surly doore

Of great ones waite.

Plant Trees you may, and see them shoote

Vp with your Children, to be serv'd

To your cleane boards, and the fair'st Fruite

To be preserv'd:

And learne to use their several gummes,

T'is Innocence in the sweet blood

healing or perfuming balm or sap

Of Cherrye, Apricocks and Plummes

To be imbru'd.

\section{JASPER Fisher Songs from Fuimus Troes}

A song from the play Fuimus Troes, acted at Magdalen College, Oxford, published in 1633. The play is set at the time of Julius Caesar's invasion of Britain. The songs are sung by a 'Chorus of [ancient Britons comprising] fiue Bardes laureate, foure voyces, and an Harper'. Between the two songs comes the news of the Roman landing, followed by the appearance of Caesar's emissary.

\section{[First Song]}

At the Spring

Birdes doe sing:

Now with high,

Then low cry:

Flat, acute;

And salute

The Sunne borne,

Euery morne.

All. Hees no Bard that cannot sing

The praises of the flowry Spring.

Flora Queene

All in greene,

Doth delight

To paint white,

And to spred

Cruell redd,

With a blew,

Colour true.

All. Hees no bard, \&c.

Woods renew

Hunter's hue.

shout, clamour

Shepheards gray

Crownd with bay,

With his pipe

Care doth wipe,

Till he dreame

By the streame.

All. Hees no bard, \&c.

Faithfull loues,

Turtle Doues,

Sit and bill,

On a hill.

Country Swaynes

On the plaines,

Runne and leape,

Turne and skip.

All. Hees no bard, \&c.

run about as in sport or dance, ?turn somersaults.

134 Innocence] as opposed to the violence of war. 12-17 greene, white, redd, blew] Colours of spring flowers. Red is cruell as the colour of blood, green of hope, and blue of faith (hence true?). 29-30 birds and/or human lovers. 
Pan doth play

Care-away.

40

Fayries small

Two foote tall,

With caps red

On their head

Daunce around

On the ground.

All. Hees no bard, \&c.

Phyllis bright

Cloath in white,

clothed

With necke faire,

Yellow haire:

Rockes doth moue

With her loue,

And make mild,

Tygers wild.

All. Hees no Bard that cannot sing

The praises of the flowry spring.

\section{[Second Song]}

Thus spend we time in laughter,

While peace and spring doe smile:

60

But I heare a sound of slaughter,

Draw neerer to our Ile.

Leaue then your wonted prattle,

The Oaten reed forbeare:

For I heare a sound of battell,

And Trumpets teare the ayre,

Let bag-pipes dye for want of wind,

Let Crowd and Harpe be dumbe;

Let little Taber come behind:

For I heare the dreadfull drumme.

Let no Birds sing, no Lambkins daunce,

No fountaines murmuring goe:

Let Shepheards crooke be made a launce:

For the martiall hornes doe blow.

\section{Phineas Fletcher Piscatory Eclogue vi}

The last of the Piscatory Eclogues appended to Fletcher's The Purple Island (1633). As in Fletcher's other works, the characters represent his Cambridge circle. Thomalin is John Tomkins, his contemporary at King's College, Cambridge, later organist there and at St Paul's, London. Thirsil is Fletcher himself. He left Cambridge in 1616 after conflict and bitterness, as testified in lines 48,282 and in other poems. The poem pitches the shepherd of standard pastoral directly against the fisherman of its piscatory variant. This may represent a real encounter, or at least the general rivalry, between Cambridge and Oxford. The piscatory eclogues being set on the river Cam, the fishermen might represent Cambridge and the shepherds Oxford, close to the sheep-keeping Cotswolds. The possibility does not seem to have been noted, though Bouchard talks generally of "collegiate rivalries, both within and outside of the university'*

39 Care-away] a cry of merriment, or a merry person or reveller; here perhaps a game. $\quad 57,59$ laughter, slaughter] The old pronunciations allow a rough rhyme. (See Alexander Ellis, On Early English Pronunciation, Pt.III, London: Trubner, 1871, pp.viii, 963.) $\quad{ }^{*}$ Gary M. Bouchard, Colin's Campus (Selinsgrove: Susquehanna University Press, 2000), p.116. 
Eclog. VII.

The PRIZE.

Thirsil, Daphnis, Thomalin.

Aurora from old Tithons frosty bed

(Cold, wintry, wither'd Tithon) early creeps;

Her cheek with grief was pale, with anger red;

Out of her window close she blushing peeps;

Her weeping eyes in pearled dew she steeps,

Casting what sportlesse nights she ever led:

She dying lives, to think he's living dead.

tallying, counting

Curst be, and cursed is that wretched fire,

That yokes green youth with age, want with desire.

Who ties the sunne to snow? or marries frost to fire?

The morn saluting, up I quickly rise,

And to the green I poste; for on this day

Shepherd and fisher-boyes had set a prize,

Upon the shore to meet in gentle fray,

Which of the two should sing the choicest lay;

Daphnis the shepherds lad, whom Mira's eys

Had kill'd; yet with such wound he gladly dies:

Thomalin the fisher, in whose heart did reigne

Stella; whose love his life, and whose disdain

Seems worse then angry skies, or never quiet main.

There soon I view the merry shepherd-swains

March three by three, clad all in youthfull green:

And while the sad recorder sweetly plains,

Three lovely Nymphs (each several row between,

a flute-like instrument; makes a plaintive

[sound

More lovely Nymphs could no where els be seen,

Whose faces snow their snowy garments stains)

With sweeter voices fit their pleasing strains. Their flocks flock round about; the horned rammes And ewes go silent by, while wanton lambes

Dancing along the plains, forget their milky dammes.

match, sing in tune with

frisky, playful

Scarce were the shepherds set, but straight in sight

seated

The fisher-boyes came driving up the stream;

Themselves in blue, and twenty sea-nymphs bright

In curious robes, that well the waves might seem:

All dark below, the top like frothy cream:

Their boats and masts with flowres, and garlands dight;

And round the swannes guard them with armies white:

Their skiffes by couples dance to sweetest sounds,

Which running cornets breath to full plain grounds,

That strikes the rivers face, and thence more sweet rebounds.

And now the Nymphs and swains had took their place;

First those two boyes; Thomalin the fishers pride,

Daphnis the shepherds: Nymphs their right hand grace;

And choicest swains shut up the other side:

So sit they down in order fit appli'd;

Thirsil betwixt them both, in middle space:

(Thirsil their judge, who now's a shepherd base,

But late a fisher-swain, till envious Chame

Had rent his nets, and sunk his boat with shame;

So robb'd the boyes of him, and him of all his game).

intricately fashioned

decked, adorned

1 Aurora] goddess of the dawn. Married to Tithonus, who was gifted with immortality but not with eternal youth: hence Aurora's frustration as described here. $\mathbf{8}$ fire] love, sexual ardour (Aurora's for Tithonus). $\quad 24$ each several row between] in alternating rows with the shepherds. 39 ground] 'The plain-song or melody on which a descant is raised' $(O E D 6 \mathrm{c}) . \quad 47$ now's a shepherd base] Unable to obtain a permanent position at Cambridge, Fletcher became a clergyman (metaphorically shepherd) in Derbyshire and then Norfolk. 
So as they sit, thus Thirsil 'gins the lay;

Thirsil. You lovely boyes, (the woods, and Oceans pride)

Since I am judge of this sweet peacefull fray,

First tell us, where, and when your Loves you spied:

And when in long discourse you well are tried,

Then in short verse by turns we'l gently play:

In love begin, in love we'l end the day.

Daphnis, thou first; to me you both are deare:

Ah, if I might, I would not judge, but heare:

Nought have I of a judge, but an impartiall eare.

Daphnis. Phobus, if as thy words, thy oaths are true;

Give me that verse which to the honour'd bay

(That verse which by thy promise now is due)

To honour'd Daphne in a sweet tun'd lay

(Daphne thy chang'd, thy love unchanged aye)

Thou sangest late, when she now better staid,

More humane when a tree, then when a maid,

settled, lodged, in (better) state

Bending her head, thy love with gentle signe repaid.

What tongue, what thought can paint my Loves perfection?

So sweet hath nature pourtray'd every part,

That art will prove that artists imperfection,

Who, when no eye dare view, dares limme her face.

tested, exercised

Phoebus, in vain I call thy help to blaze

More light then thine, a light that never fell:

Thou tell'st what's done in heav'n, in earth, and hell:

Her worth thou mayst admire; there are no words to tell.

limn, paint

She is like thee, or thou art like her, rather:

Such as her hair, thy beams; thy single light,

As her twin-sunnes: that creature then, I gather,

8o Twice heav'nly is, where two sunnes shine so bright:

So thou, as she, confound'st the gazing sight:

Thy absence is my night; her absence hell.

Since then in all thy self she doth excell,

What is beyond thy self, how canst thou hope to tell?

First her I saw, when tir'd with hunting toyl,

In shady grove spent with the weary chace,

Her naked breast lay open to the spoil;

The crystal humour trickling down apace,

Like ropes of pearl, her neck and breast enlace:

The aire (my rivall aire) did coolly glide

Through every part: such when my Love I spi'd,

So soon I saw my Love, so soon I lov'd, and di'd.

Her face two colours paint; the first a flame,

(Yet she all cold) a flame in rosie die,

Which sweetly blushes like the mornings shame:

was dimmed or quenched

count, calculate

The second snow, such as on Alps doth lie,

And safely there the sunne doth bold defie:

Yet this cold snow can kindle hot desire.

Thou miracle; mar'l not, if I admire,

How flame should coldly freez, and snow should burn as fire.

as soon as

i.e., beads of sweat

dye, colour

marvel

61 Phœebus] Apollo, god of poetry and song. $\quad 62$ bay] laurel, the plant to which Daphne (64), pursued by Apollo, was changed. $\quad 65$ chang'd] metamorphosed (into a laurel), though Apollo's love for her remains 'unchanged'. 73 blaze] (a) enflame, set alight (b) blazon: describe, proclaim, celebrate. 77 thee] Apollo, i.e. the sun. The comparisons that follow (as in 93-100) are Petrarchan commonplaces. 81 confound'st] (a) dazzles (b) bewilders (by presenting two suns). 87 to the spoil] ?to being viewed and enjoyed, like spoil or plunder. $\quad 95$ like the mornings shame] putting the morning sunlight to shame. 
Her slender waste, her hand, that dainty breast,

Her cheek, her forehead, eye, and flaming hair,

And those hid beauties, which must sure be best,

In vain to speak, when words will more impair:

Of all the fairs she is the fairest fair.

Cease then vain words; well may you shew affection,

beautiful things or persons

But not her worth: the minde her sweet perfection

Admires: how should it then give the lame tongue direction?

Thomalin. Unlesse thy words be flitting as thy wave,

Proteus, that song into my breast inspire,

With which the seas (when loud they rore and rave)

Thou softly charm'st, and windes intestine ire

(When 'gainst heav'n, earth, and seas they did conspire)

Thou quiet laid'st: Proteus, thy song to heare,

Seas listning stand, and windes to whistle fear;

The lively Delphins dance, and brisly Seales give eare.

Stella, my starre-like love, my lovely starre:

Her hair a lovely brown, her forehead high,

And lovely fair; such her cheeks roses are:

Lovely her lip, most lovely is her eye:

And as in each of these all love doth lie,

So thousand loves within her minde retiring,

Kindle ten thousand loves with gentle firing.

And let me love my Love, not live in loves admiring!

internecine, against each other

fleeting, transient

dolphins; bristly, furry

At Proteus feast, where many a goodly boy,

And many a lovely lasse did lately meet;

There first I found, there first I lost my joy:

Her face mine eye, her voice mine eare did greet;

While eare and eye strove which should be most sweet,

That face, or voice: but when my lips at last

Saluted hers, those senses strove as fast,

Which most those lips did please; the eye, eare, touch, or taste.

The eye sweares, never fairer lip was eyed;

The eare with those sweet relishes delighted,

Thinks them the spheares; the taste that nearer tried

Their relish sweet, the soul to feast invited;

The touch, with pressure soft more close united,

Wisht ever there to dwell; and never cloyed,

(While thus their joy too greedy they enjoyed)

Enjoy'd not half their joy, by being overjoyed.

(a) fuel (b) the act of kindling

Her hair all dark more clear the white doth show,

And with its night her faces morn commends:

Her eye-brow black, like to an ebon bow

Which sporting Love upon her forehead bends,

And thence his never-missing arrow sends.

But most I wonder how that jetty ray,

Which those two blackest sunnes do fair display,

Should shine so bright, and night should make so sweet a day.

So is my love an heav'n; her hair a night:

Her shining forehead Dian's silver light:

Her eyes the starres; their influence delight:

110 Proteus] a sea-god of changeable shape. $\quad 117$ Stella] Here Fletcher retains this name for Thomalin's beloved, though in Ecl. VI 'Stella' in the ms is changed to 'Melite' in the printed text. See Abram Barnett Langdale, Phineas Fletcher, Man of Letters, Science and Divinity, New York: Columbia University Press, p.84. starre-like] punning on 'Stella', literally a star. $\mathbf{1 2 4}$ Let me enjoy Stella's love, not simply admire or wonder at her from afar. 134-6 Pun: relishes] a kind of musical embellishment $\left(O E D\right.$ relish $\left.\mathrm{n}^{3}\right)$. relish] taste, savour. 143-5 Another conventional conceit: the beloved's arched eyebrow is like Cupid's bow, her glances being the arrows. 150 Dian's silver light] the moon. Diana is goddess of the moon as well as of chastity. 'in-flowing' from the stars to affect human lives.

151 influence] In astrology, the fluid supposedly 
Her voice the sphears; her cheeks Aurora bright:

Her breast the globes, where heav'ns path milkie-white

bright as the dawn (see in)

Runnes 'twixt those hills: her hand (Arions touch)

As much delights the eye, the eare as much.

Such is my Love, that, but my Love, was never such.

Thirsil. The earth her robe, the sea her swelling tide;

The trees their leaves, the moon her divers face;

The starres their courses, flowers their springing pride;

Dayes change their length, the Sunne his daily race:

Be constant when you love; Love loves not ranging:

Change when you sing; Muses delight in changing.

changing (with the phases)

Daphnis. Pan loves the pine-tree; Jove the oak approves;

High populars Alcides temples crown:

Phoebus, though in a tree, still Daphne loves,

And hyacinths, though living now in ground:

Shepherds, if you your selves would victours see,

Girt then this head with Phoebus flower and tree.

Thomalin. Alcinous peares, Pomona apples bore:

Bacchus the vine, the olive Pallas chose:

Venus loves myrtils, myrtils love the shore:

Venus Adonis loves, who freshly blowes,

Yet breathes no more: weave, lads, with myrtils, roses

And bay, and hyacinth the garland loses.

Daphnis. Mira, thine eyes are those twin-heav'nly powers,

Which to the widowed earth new offspring bring:

No marvel then, if still thy face so flowers,

And cheeks with beauteous blossomes freshly spring:

So is thy face a never-fading May:

So is thine eye a never-falling day.

Thomalin. Stella, thine eyes are those twin-brothers fair,

Which tempests slake, and promise quiet seas:

No marvel then if thy brown shadie hair,

dark, shadowy

Like night, portend sweet rest and gentle ease.

Thus is thine eye an ever-calming light:

Thus is thy hair a lovers ne'r-spent night.

roving, inconstancy
ary, modulate (notes)

poplars; Hercules'

Daphnis. If sleepy poppies yeeld to lilies white;

If black to snowy lambes; if night to day;

If Western shades to fair Aurora's light;

Stella must yeeld to Mira's shining ray.

In day we sport, in day we shepherds toy:

The night, for wolves; the light, the shepherds joy.

Western: associated with the sunset

dally in love

Thomalin. Who white-thorn equalls with the violet?

What workman rest compares with painfull light?

Who weares the glaring glasse, and scorns the jet?

Day yeeld to her, that is both day and night.

In night the fishers thrive, the workmen play;

Love loves the night; night's lovers holy-day.

152 the sphears] In Ptolemaic astronomy, the stars and planets were embedded in concentric crystalline spheres that made sweet music as they revolved. 154 Arion] a legendary musician. Stella's hand plays music as skilfully, and also prettily to the eye. 156 that ... such] i.e. there was never another like her. 161 Love] Cupid, the god of love. 163 pine-tree] The pine, or more strictly fir, was sacred to Pan. approves] ?favours. The oak is sacred to Jove or Jupiter. 165 though in a tree] referring to Daphne. See 62n. 166 hyacinths] The youth Hyacinthus, changed into a hyacinth, was also loved by Apollo. 168 Phobus flower and tree] the hyacinth and the laurel. 169 Alcinous] the ruler of the Phaiakians in the Odyssey. His rich orchard (Od. 7.112-32) contains pears among many other fruit trees. Pomona] goddess of trees and orchards. 170 olive] Pallas or Athena is said to have given the olive plant to Athens. 172 blowes] blooms: Adonis was transformed into the anemone. 174 garland loses] a garland of praise or celebration (OED lose $\mathrm{n}^{1}$, praise). 193-6 Thomalin praises dark things in view of his beloved's dark hair and eyes. $\quad 195$ jet] semi-precious stone, better than glass. glaring] shiny, tawdry. 
Daphnis. Fly thou the seas, fly farre the dangerous shore:

Mira, if thee the king of seas should spie,

He'l think Medusa (sweeter then before)

With fairer hair, and double fairer eye,

Is chang'd again; and with thee ebbing low,

In his deep courts again will never flow.

Thomalin. Stella, avoid both Phobus eare, and eye:

His musick he will scorn, if thee he heare:

Thee Daphne, (if thy face by chance he spie)

Daphne now fairer chang'd, he'l rashly sweare:

And viewing thee, will later rise and fall;

Or viewing thee, will never rise at all.

Daphnis. Phœebus and Pan both strive my love to gain,

And seek by gifts to winne my carelesse heart;

$P a n$ vows with lambes to fill the fruitfull plain;

Apollo offers skill, and pleasing art:

But Stella, if thou grant my suit, a kisse;

Phoebus and Pan their suit, my love, shall misse.

Thomalin. Proteus himself, and Glaucus seek unto me;

And twenty gifts to please my minde devise:

Proteus with songs, Glaucus with fish doth woo me:

Both strive to winne, but I them both despise:

For if my Love my love will entertain,

Proteus himself, and Glaucus seek in vain.

Daphnis. Two twin, two spotted lambes, (my songs reward)

With them a cup I got, where Jove assumed

New shapes, to mock his wives too jealous guard;

where: painted or carved on the cup

Full of Joves fires it burns still unconsumed:

But Mira, if thou gently deigne to shine,

Thine be the cup, the spotted lambes be thine.

Thomalin. A pair of swannes are mine, and all their train;

With them a cup, which Thetis self bestowed,

As she of love did heare me sadly plain;

A pearled cup, where Nectar oft hath flowed:

But if my Love will love the gift, and giver;

Thine be the cup, thine be the swannes for ever.

Daphnis. Thrice happy swains! thrice happy shepherds fate!

Thomalin. Ah blessed life! ah blessed fishers state!

Your pipes asswage your love; your nets maintain you.

Daphnis. Your lambkins clothe you warm; your flocks sustain you:

You fear no stormie seas, nor tempests roaring.

Thomalin. You sit not rots or burning starres deploring:

rot: a disease of sheep

In calms you fish; in roughs use songs and dances.

Daphnis. More do you fear your Loves sweet-bitter glances,

Then certain fate, or fortune ever changing.

complain, lament adorned with pearls

Thomalin. Ah that the life in seas so safely ranging,

Should with loves weeping eye be sunk, and drown'd!

Daphnis. The shepherds life Phobus a shepherd crown'd,

200-201 According to one legend, Medusa was once beautiful, and beloved of Poseidon or Neptune (the king of seas); Athena later changed her into a fearsome Gorgon. Neptune might consider Mira to be Medusa restored to, or bettering, her original beauty. 203-4 i.e. Neptune will withdraw with Mira to the depths of the sea and not reappear. 209-10 Apollo the sun-god will either make the sun rise and set late, or not rise at all. 217 Glaucus] a sea-god, specially revered by fishermen and sailors. 224-5 The cup is adorned with the stories of Jove's metamorphoses to attain the various women he loved. $\quad 226$ The cup appears to be of adamant, a vaguely defined substance combining hardness with magnetism and thus resistant to lightning (Joves fires). $\quad \mathbf{2 2 7}$ if you deign to shine on me gently (favourably): continuing the sun image for Mira. 229 train] ?the cygnets following their parents. 230 Thetis] a sea-goddess: one of the Nereids, mother of Achilles. 237 asswage] soothe, comfort (the pains of love). $\quad 240$ burning starres] comets and meteors, presaging bad weather. 244-5 Another commonplace: the lover's tears out-flood the sea. 
His snowy flocks by stately Peneus leading.

Thomalin. What herb was that, on which old Glaucus feeding,

Grows never old, but now the gods augmenteth?

Daphnis. Delia her self her rigour hard relenteth:

To play with shepherds boy she's not ashamed.

Thomalin. Venus, of frothy seas thou first wast framed;

The waves thy cradle: now Love's Queen art named.

flowing majestically

adds to their number

fashioned, created

poor, inadequate

Daphnis. Thou gentle boy, what prize may well reward thee?

So slender gift as this not half requites thee.

May prosperous starres, and quiet seas regard thee;

But most, that pleasing starre that most delights thee:

May Proteus still and Glaucus dearest hold thee;

But most, her influence all safe infold thee:

260 May she with gentle beams from her fair sphear behold thee.

Thomalin. As whistling windes 'gainst rocks their voices tearing;

As rivers through the valleys softly gliding;

As haven after cruel tempests fearing:

Such, fairest boy, such is thy verses sliding.

Thine be the prize: may Pan and Phoebus grace thee;

Most, whom thou most admir'st, may she embrace thee;

And flaming in thy love, with snowy arms enlace thee.

flow

above all

Thirsil. You lovely boyes, full well your art you guided;

That with your striving songs your strife is ended:

So you your selves the cause have well decided;

And by no judge can your award be mended.

Then since the prize for onely one intended

You both refuse, we justly may reserve it,

And as your offering in Love's temple serve it;

Since none of both deserve, when both so well deserve it.

neither

Yet, for such songs should ever be rewarded,

Daphnis, take thou this hook of ivory clearest,

Giv'n me by Pan, when Pan my verse regarded:

your decision be improved

This fears the wolf, when most the wolf thou fearest.

But thou, my Thomalin, my love, my dearest,

Take thou this pipe, which oft proud storms restrained;

Which, spite of Chamus spite, I still retained:

Was never little pipe more soft, more sweetly plained.

And you, fair troop, if Thirsil you disdain not,

Vouchsafe with me to take some short refection:

Excesse, or daints my lowly roofs maintain not;

Peares, apples, plummes, no sugred made confection.

So up they rose, and by Love's sweet direction

Sea-nymphs with shepherds sort: sea-boyes complain not

That wood-nymphs with like love them entertain not.

And all the day to songs and dances lending,

Too swift it runnes, and spends too fast in spending.

With day their sports began, with day they take their ending.

light meal

dainties

consort, keep company

247 Peneus] the chief river of Tempe, a region favoured by Phoebus or Apollo. Apollo tended the flocks of Admetus, king of Thessaly: Tempe is in northern Thessaly. $\mathbf{2 4 8}$ Glaucus, originally a human, became immortal by eating a magic herb sown by Cronos or Saturn. 250 Delia] Artemis or Diana: she fell in love with the shepherd Endimion. $\quad 252$ Venus was born from the sea. 257 that pleasing starre] i.e. Stella (literally 'star'), his beloved. 260 her fair sphear] continuing the star imagery: Stella, the star, occupies the sphere of the stars as postulated in Ptolemaic astronomy. See 152n. 261 A surprising comparison. Its point may be the safety and shelter afforded by rocks in a storm. $\quad \mathbf{2 8 1}$ proud storms restrained] Its music calmed tempests. $\quad \mathbf{2 8 2}$ Chamus spite] Fletcher also speaks of 'spiteful Chame' in 'To Thomalin' in Poeticall Miscellanies. Both he and his father, Giles Fletcher the Elder, failed to obtain permanent fellowships there. Fletcher's grief and disappointment are expressed at length in Eclogue II. $\quad \mathbf{2 8 3}$ There was never a little pipe that lamented (of love) more softly or sweetly. 


\section{Phineas Fletcher To My Beloved Thenot in Answer of His Verse}

From Poeticall Miscellanies, the last section of Phineas Fletcher's Purple Island volume (1633). Features Fletcher's Cambridge circle under pastoral names, often also found in The Purple Island. Thenot (also appearing in The Purple Island VI.2) cannot be identified. Langdale suggests he is Francis Quarles, Fletcher's younger contemporary at Cambridge. ${ }^{*}$ In a prefatory poem (perhaps the 'verse' of the title) to The Purple Island, Quarles addresses Fletcher as the 'Spencer of this age' - a compliment Fletcher may be modestly declining in 9-10 below. The last stanza may be a response to another prefatory poem, by an 'A. C.' generally taken as Abraham Cowley.

To my beloved Thenot in answer of his verse.

Thenot my deare, how can a lofty hill

To lowly shepherds thoughts be rightly fitting?

An humble dale well fits with humble quill:

There may I safely sing, all fearlesse sitting,

My Fusca's eyes, my Fusca's beauty dittying;

My loved lonenesse, and hid Muse enjoying: secluded, retired

Yet should'st thou come, and see our simple toying,

Well would fair Thenot like our sweet retired joying.

sports, pleasures

But if my Thenot love my humble vein,

(Too lowly vein) ne're let him Colin call me;

$\mathrm{He}$, while he was, was (ah!) the choicest swain,

That ever grac'd a reed: what e're befall me,

Or Myrtil, (so 'fore Fusca fair did thrall me,

played well on a pipe

either

Most was I know'n) or now poore Thirsil name me,

Thirsil, for so my Fusca pleases frame me:

But never mounting Colin; Colin's high stile will shame me.

style, name

Two shepherds I adore with humble love;

Th' high-towring swain, that by slow Mincius waves

His well-grown wings at first did lowly prove,

Where Corydon's sick love full sweetly raves;

But after sung bold Turnus daring braves:

And next our nearer Colin's sweetest strain;

Most, where he most his Rosalind doth plain.

Well may I after look, but follow all in vain.

Why then speaks Thenot of the honour'd Bay?

Apollo's self, though fain, could not obtain her;

She at his melting songs would scorn to stay,

Though all his art he spent to entertain her:

Wilde beasts he tam'd, yet never could detain her.

Then sit we here within this willow glade:

Here for my Thenot I a garland made

With purple violets, and lovely myrtil shade.

\footnotetext{
*Abram Barnett Langdale, Phineas Fletcher: Man of Letters, Science and Divinity,New York: Columbia University Press, 1936, p.46. 5 Fusca] 'the brown one'. Fletcher refers to his brunette love elsewhere too, e.g. in 'To Master W. C.' and 'To E. C. in Cambridge, my sonne by the University' in Poeticall Miscellanies, and the Latin eclogue 'Fusca' in Sylva poetica. Langdale (pp.48-51) identifies her as Lady Elizabeth Colpeper of Hollingbourn, Kent, where Fletcher spent holidays. $\mathbf{6}$ hid Muse] Grosart sees a reference to Fletcher's authorship (now generally accepted) of Britain's Ida, published in Spenser's name. 7 should'st thou come] if you should come. 10 Colin] Spenser. The attribution of Britain's Ida to Spenser (see 6n) might have led to the identification. 17-24 Close parallel in The Purple Island VI.5. 18 high-towring swain] Virgil. Mincius] river in Mantua, Virgil's native region. swain] with a pun on 'swan', hence wings. 19 lowly] i.e. in pastoral. Virgil's Eclogues provided the model for starting a poetic career with pastoral. 20 In Virgil II, traditionally thought the earliest of the Eclogues. $\quad 21$ bold ... braves] in the Aeneid. Turnus was Aeneas' chief opponent. 22 nearer] closer, geographically and in time. 23 Rosalind] Colin's beloved in Spenser's SC. plain] complain (of her cruelty in love). $\quad \mathbf{2 6}$ her] i.e. Daphne, who escaped Apollo's pursuit by changing into a laurel
} or bay tree. 


\section{Phineas Fletcher from The Purple Island}

Extracts from the pastoral framework of The Purple Island (1633), Phineas Fletcher's curious allegorical account of the human body. Besides presenting a typical pastoral setting and some philosophic and metaphoric pastoral topoi (including Christ as shepherd), the first passage is markedly autobiographical, with Fletcher as the young shepherd-poet Thirsil, and other shepherds standing for his Cambridge circle. The seven-line stanza, with closing alexandrine, adapts the nine-line stanza of Fletcher's master Spenser.

\section{(A) Canto I Stanzas 1-9, 16-22, 28-33.}

The warmer Sun the golden Bull outran,

And with the Twins made haste to inne and play: inn, lodge, rest

Scatt'ring ten thousand flowres, he new began

To paint the world, and piece the length'ning day:

(The world more aged by new youths accrewing)

Ah wretched man this wretched world pursuing,

Which still grows worse by age, and older by renewing!

The shepherd-boyes, who with the Muses dwell,

Met in the plain their May-lords new to chuse,

(For two they yearely chuse) to order well

Their rurall sports, and yeare that next ensues:

Now were they sat, where by the orchyard walls

The learned Chame with stealing water crawls,

And lowly down before that royall temple falls.

Among the rout they take two gentle swains,

Whose sprouting youth did now but greenly bud:

Well could they pipe and sing; but yet their strains

Were onely known unto the silent wood:

Their nearest bloud from self-same fountains flow,

Their souls self-same in nearer love did grow:

So seem'd two joyn'd in one, or one disjoyn'd in two.

Now when the shepherd-lads with common voice

Their first consent had firmly ratifi'd,

A gentle boy thus 'gan to wave their choice;

Thirsil, (said he) though yet thy Muse untri'd

Hath onely learn'd in private shades to feigne

Soft sighs of love unto a looser strain,

Or thy poore Thelgons wrong in mournfull verse to plain;

Yet since the shepherd-swains do all consent

To make thee lord of them, and of their art;

And that choice lad (to give a full content)

Hath joyn'd with thee in office, as in heart;

Wake, wake thy long (thy too long) sleeping Muse,

And thank them with a song, as is the use:

Such honour thus conferr'd thou mayst not well refuse.

make up, constitute

Sing what thou list, be it of Cupids spite,

(Ah lovely spite, and spitefull lovelinesse!)

Or Gemma's grief, if sadder be thy sprite:

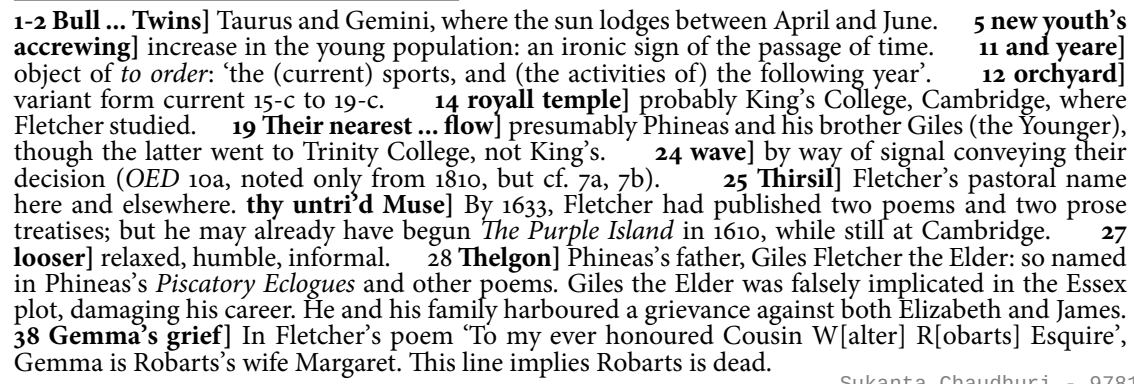

invent, compose

were where

flowing softly

company, gathering

function, duty (as singer)

custom 
Begin, thou loved swain, with good successe.

Ah, (said the bashfull boy) such wanton toyes

A better minde and sacred vow destroyes,

Since in a higher love I setled all my joyes.

New light new love, new love new life hath bred;

A life that lives by love, and loves by light:

A love to him, to whom all loves are wed;

A light, to whom the Sunne is darkest night:

Eyes light, hearts love, souls onely life he is:

Life, soul, love, heart, light, eye, and all are his:

He eye, light, heart, love, soul; he all my joy, and blisse.

But if you deigne my ruder pipe to heare,

(Rude pipe, unus'd, untun'd, unworthy hearing)

These infantine beginnings gently bear,

inexperienced, unpractised tolerate, accept

Whose best desert and hope must be your bearing.

But you, O Muses, by soft Chamus sitting,

(Your daintie songs unto his murmures fitting,

Which bears the under-song unto your chearfull dittying;)

pleasing

Tell me, ye Muses, what our father-ages

Have left succeeding times to play upon:

What now remains unthought on by those Sages,

Where a new Muse may trie her pineon?

What lightning Heroes, like great Peleus heir,

(Darting his beams through our hard-frozen aire)

May stirre up gentle heat, and vertues wane repair?

test her wings, prove her abilities shining, illustrious

waning, decline; amend,

[ make good

Happy, thrice happy times in silver age!

When generous plants advanc't their lofty crest;

When honour stoopt to be learn'd wisdomes page;

When baser weeds starv'd in their frozen nest;

When th'highest flying Muse still highest climbes;

And vertues rise keeps down all rising crimes.

Happy, thrice happy age! happy, thrice happy times!

But wretched we, to whom these iron daies,

(Hard daies) afford nor matter, nor reward!

Sings Maro? men deride high Maro's layes;

Their hearts with lead, with steel their sense is barr'd:

Sing Linus, or his father, as he uses,

Our Midas eares their well tun'd verse refuses.

What cares an asse for arts? he brayes at sacred Muses.

But if fond Bavius vent his clowted song,

Or Mevius chaunt his thoughts in brothell charm;

The witlesse vulgar, in a numerous throng,

Like summer flies about their dunghills swarm:

42-49 higher love] Suggests a recent religious awakening in Fletcher, but may simply refer to his taking religious orders. Cf. 148-9. 45 to whom ... wed] The devout soul (like the congregation of such souls, the Church) is considered the bride of Christ. $\mathbf{5 6}$ under-song] a subsidiary song accompanying the main one. $\quad 57$ father-ages] (a) earlier times (b) specifically, our fathers' times. 59 What theme have the wise poets of old left untreated, for a young poet to attempt today? 60 trie her pineon] test her wings. $\quad 61$ Peleus' heir] Achilles. $\mathbf{6 4}$ silver age] Interestingly, not the Golden, though it was a common pastoral topos that shepherds' lives preserve or reflect that age. 66-7 When rank and power yielded place to learning, and inferior people could not flourish. 67 starv'd] died of cold $(O E D$ 5). $\quad 68$ climbes] The present tense for a vanished era prob. dictated by the rhyme. 73 Maro] Virgil (Publius Virgilius Maro). 75 Linus] originally a harvest god, but closely associated with song. his father] Apollo the god of music, by one influential tradition. 76 Midas eares] King Midas grew ass's ears for preferring Pan's songs to Apollo's. 78-9 Bavius, Mævius] Bad poets and malicious critics who attacked Virgil (III.90) and Horace (Epode 10.2, naming Maevius only). brothell] worthless, rascally (OED brothel $\mathrm{C} 1$, citing this passage), but suggesting crude sexual themes. 
They sneer, they grinne. Like to his like will move.

Yet never let them greater mischief prove

Then this, Who hates not one, may he the other love.

Witnesse our Colin; whom though all the Graces,

And all the Muses nurst; whose well taught song

Parnassus' self, and Glorian embraces,

And all the learn'd, and all the shepherds throng;

Yet all his hopes were crost, all suits deni'd;

Discourag'd, scorn'd, his writings vilifi'd:

expert, accomplished

Poorly (poore man) he liv'd; poorly (poore man) he di'd.

And had not that great Hart, (whose honour'd head

Ah lies full low) piti'd thy wofull plight;

There hadst thou lien unwept, unburied,

Unblest, nor grac't with any common rite:

Yet shalt thou live, when thy great foe shall sink

Beneath his mountain tombe, whose fame shall stink;

And time his blacker name shall blurre with blackest ink.

$O$ let th'Iambick Muse revenge that wrong,

Which cannot slumber in thy sheets of lead:

Let thy abused honour crie as long

As there be quills to write, or eyes to reade:

On his rank name let thine own votes be turn'd,

Oh may that man that hath the Muses scorn'd,

Alive, nor dead, be ever of a Muse adorn'd!

Oft therefore have I chid my tender Muse;

Oft my chill breast beats off her fluttering wing:

Yet when new spring her gentle rayes infuse,

All storms are laid, I'gin to chirp and sing:

At length soft fires disperst in every vein,

Yeeld open passage to the thronging train,

And swelling numbers tide rolls like the surging main.

opinion, here disapproval

But (ah!) let me under some Kentish hill

Neare rowling Medway'mong my shepherd peers,

With fearlesse merrie-make, and piping still,

Securely passe my few and slow-pac'd yeares:

While yet the great Augustus of our nation

Shuts up old Janus in this long cessation,

Strength'ning our pleasing ease, and gives us sure vacation.

thwarted, frustrated

There may I, master of a little flock,

Feed my poore lambes, and often change their fare:

My lovely mate shall tend my sparing stock,

rolling, flowing secure, free from fear; ever, continually

[vacancy secure leisure or

food, diet

84 who hates ... love] Said of Bavius and Maevius in Virgil III.9o. $\quad 85$ Colin] Spenser's pastoral name (as noted in margin of original). Reports of Spenser's eventual poverty and distress seem exaggerated. He had a pension, some worldly support, and ample recognition as a poet. His body was carried to Westminster Abbey by poets who cast verses and pens in his grave. 87 Glorian] Gloriana, i.e. Queen Elizabeth. embrace 'accept gladly or eagerly (OED embrace $\left.{ }^{2} 2 \mathrm{~d}\right)$ : value, cherish. 92 that great Hart] the Earl of Essex, who paid for Spenser's funeral. Called a 'dear-loved hart'in Fletcher's 'To my ever honoured Cousin W. R. Esquire'. 96 great foe] probably William Cecil, Lord Treasurer. Spenser satirizes him and his son Robert in Mother Hubbard's Tale. In retaliation, Cecil is said to have induced the Queen to reduce Spenser's pension. 97 Neither William nor Robert Cecil was buried in the mountains. Perhaps mountain] mountainous, unlike the alleged sparseness of Spenser's burial. A heavy tomb would suit sink (96). 99 th'Iambick Muse] satiric poetry. Classical satire was written in iambs. $\quad 100$ sheets of lead] In costly burials, bodies were wrapt in lead before placing in the coffin. This does not suit Fletcher's account of Spenser's funeral. 103 Let the force of your censure be turned against him. $\quad 113$ Kentish hill] Kent was Fletcher's native county. The Medway (114) flows through Kent. 117 Augustus of our nation] Charles I. 118 Janus] two-faced god of doorways and of beginnings and endings, hence god of the new year. The peace of James's reign does not change with the years. cessation] inactivity, leisure $\left(O E D_{3}\right) . \quad 122$ sparing stock] limited household resources. 
And nurse my little ones with pleasing care;

Whose love and look shall speak their father plain.

Health be my feast, heav'n hope, content my gain:

So in my little house my lesser heart shall reigne.

The beech shall yeeld a cool safe canopie,

While down I sit, and chaunt to th' echoing wood:

Ah singing might I live, and singing die!

So by fair Thames, or silver Medwayes floud,

The dying swan, when yeares her temples pierce,

In musick strains breathes out her life and verse;

And chaunting her own dirge tides on her watry herse.

What shall I then need seek a patron out,

Or begge a favour from a mistris' eyes,

To fence my song against the vulgar rout,

Or shine upon me with her Geminies?

What care I, if they praise my slender song?

Or reck I, if they do me right, or wrong?

A shepherds blisse nor stands nor falls to ev'ry tongue.

Great prince of shepherds, then thy heav'ns more high,

Low as our earth, here serving, ruling there;

Who taught'st our death to live, thy life to die;

Who when we broke thy bonds, our bonds would'st bear;

Who reignedst in thy heav'n, yet felt'st our hell;

Who (God) bought'st man, whom man (though God) did fell;

Who in our flesh, our graves, (and worse) our hearts would'st dwell:

Great Prince of shepherds, thou who late didst deigne

To lodge thy self within this wretched breast,

(Most wretched breast such guest to entertain,

Yet oh most happy lodge in such a guest!)

Thou first and last, inspire thy sacred skill;

Guide thou my hand, grace thou my artlesse quill:

So shall I first begin, so last shall end thy will.

\section{(B) Canto XI Stanzas 1-4}

The early Morn lets out the peeping day,

And strew'd his paths with golden Marygolds:

The Moon grows wanne, and starres flie all away,

Whom Lucifer locks up in wonted folds,

Till light is quencht, and heav'n in seas hath flung

The headlong day: to th' hill the shepherds throng,

And Thirsil now began to end his task and song.

Who now (alas!) shall teach my humble vein,

That never yet durst peep from covert glade;

But softly learnt for fear to sigh and plain,

And vent her griefs to silent myrtils shade?

accustomed, usual

$\mathbf{1 2 6}$ lesser] humbler, adapted to the house. $\quad 131$ years her temples pierce] Perhaps referring to greying temples, oddly ascribed to a bird. $\quad 133$ tides] floats, drifts $\left(O E D\right.$ tide $\left.\mathrm{v}^{2} 4\right)$. 136 fence] protect (against the general neglect). $\quad 137$ Geminies] twins, i.e. two eyes (plural $-s$ redundant). Given the standard comparison of the mistress's eyes to the sun, perhaps alluding to the sun being in Gemini in early summer (see 2). $\quad 141$ Great prince of shepherds] Christ. 141-3 Christ lived and died as a man so that humankind might be revived (live) after its 'death' or damnation through original sin. 144 bonds] pun: (a) laws, rules, obligations (b) custody, imprisonment, hence ?punishment. 146 Who redeemed mankind, though men destroyed him even though he was God. bought'st] redeemed (OED buy 4: cf. buy 3). 148-9 See 42-9n. 151 lodge] abode, place of stay. in such a guest] in having such a guest. 153 artlesse] unpractised, inexpert. 2 strew'd] perhaps misprint for strews: all nearby verbs are in present tense. 4 Lucifer] the morning star. folds] pastoral image, comparing the stars to sheep. $\quad 10$ for fear ... plain] i.e. Did not have the boldness to utter his griefs loudly. 
Who now shall teach to change my oaten quill

For trumpet 'larms, or humble verses fill

With gracefull majestie, and loftie rising skill?

Ah thou dread Spirit, shed thy holy fire,

rain down

Thy holy flame into my frozen heart;

Teach thou my creeping measures to aspire,

verses

And swell in bigger notes, and higher art:

Teach my low Muse thy fierce alarums ring,

And raise my soft strain to high thundering:

Tune thou my loftie song; thy battels must I sing.

Such as thou wert within the sacred breast

Of that thrice famous Poet-Shepherd-King;

And taught'st his heart to frame his Canto's best

Of all that e're thy glorious works did sing:

Or as those holy Fishers once amongs

Thou flamedst bright with sparkling parted tongues,

And brought'st down heav'n to earth in those all-conqu'ring songs.

\section{(C) Canto XII stanzas 1-8}

The shepherds guarded from the sparkling heat

shielded, protected

Of blazing aire, upon the flowrie banks,

(Where various flowers damask the fragrant seat,

And all the grove perfume) in wonted ranks

Securely sit them down, and sweetly play:

At length thus Thirsil ends his broken lay,

Lest that the stealing night his later song might stay.

songs

Thrice, oh thrice happie shepherds life and state,

When Courts are happinesse unhappie pawns!

His cottage low, and safely humble gate

happiness's

Shuts out proud fortune, with her scorns, and fawns:

No feared treason breaks his quiet sleep:

Singing all day, his flocks he learns to keep;

Himself as innocent as are his simple sheep.

No Serian worms he knows, that with their threed

Draw out their silken lives; nor silken pride:

His lambes warm fleece well fits his little need,

Not in that proud Sidonian tincture di'd:

No emptie hopes, no courtly fears him fright;

No begging wants his middle fortune bite:

But sweet content exiles both miserie and spite.

In stead of musick and base flattering tongues,

Which wait to first-salute my Lords uprise,

The cheerfull lark wakes him with early songs,

And birds sweet whistling notes unlock his eyes:

open his eyes, i.e. awake him

12-14 change ... skill?] Thirsil is commencing the last movement of his poem, about a battle in the soul between virtues and vices. He uses the common topos of the pastoral poet singing in a somewhat higher strain ('paulo maiora', Virgil IV.1). $\quad 15$ dread Spirit] The Holy Spirit, third member of the Trinity, seen as the inspiration for Christian poetry. 19 thy ... ring] (to) resound your fierce call to battle. 23 Poet-Shepherd-King] David, author of the Psalms. $\mathbf{2 6}$ holy Fishers] Christ's apostles, originally fishermen and later metaphorically fishers of souls (see Matthew 4:18-19, Mark 1:16-18). 27 sparkling parted tongues] At Pentecost, the Holy Spirit entered the apostles in forked tongues of fire and imparted the gift of tongues (Acts 2.3-4). 28 all-conqu'ring] spreading to all nations. 1 sparkling] fiery, as though throwing out sparks. 4 wonted] accustomed. ranks] (a) rows, tiers (b) rank, status. 7 his later ... stay] Might put a stop to the last part of his song. 10 safely humble] too low for 'proud fortune' to stoop and enter. 11 scorns and fawns] Fortune makes people the target of either scorn or flattery. 15 Serian worms] silkworms. 18 Sidonian tincture] purple, worn only by the ruling patrician class in ancient Rome. Sidon was a city of Tyre, the chief exporter of purple dye derived from the murex or shellfish. 20 middle fortune] the classic ideal of a 'golden mean'. bite] ?wound, afflict. $\quad 21$ Sweet content shuts out or banishes misery and spite. 23 uprise] (a) rise from sleep (b) ?levée, meetings with visitors immediately on rising. 
In countrey playes is all the strife he uses,

Or sing, or dance unto the rurall Muses;

And but in musicks sports, all difference refuses.

His certain life, that never can deceive him,

Is full of thousand sweets, and rich content:

The smooth-leav'd beeches in the field receive him

With coolest shades, till noon-tides rage is spent:

His life is neither tost in boist'rous seas

Of troublous world, nor lost in slothfull ease:

Pleas'd and full blest he lives, when he his God can please.

His bed of wool yeelds safe and quiet sleeps,

While by his side his faithfull spouse hath place:

His little sonne into his bosome creeps,

The lively picture of his fathers face:

Never his humble house or state torment him;

Lesse he could like, if lesse his God had sent him:

And when he dies, green turfs with grassie tombe content him.

The worlds great Light his lowly state hath blest,

And left his heav'n to be a shepherd base:

Thousand sweet songs he to his pipe addrest:

Swift rivers stood; beasts, trees, stones ranne apace,

And serpents flew to heare his softest strains:

He fed his flock, where rolling Jordan reignes;

There took our rags, gave us his robes, and bore our pains.

Then thou high Light, whom shepherds low adore,

Teach me, oh do thou teach thy humble swain

To raise my creeping song from earthly floor:

Fill thou my empty breast with loftie strain;

That singing of thy warres and dreadfull fight,

My notes may thunder out thy conqu'ring might,

And 'twixt the golden starres cut out her towring flight.

\section{George Herbert Christmas, Part iI}

The second part of a two-part poem in Herbert's The Temple (1633). The two parts differ in form and theme, and the second clearly marks a new start. Vaughan Williams set it separately to music in Hodie: A Christmas Cantata (1953). The poem opens with the shepherds to whom Christ's birth was announced by angels (Luke 2). Herbert uses the pastoral image for the state of his own mind, approaching the language and imagery of Psalm 23.

The shepherds sing; and shall I silent be?

My God, no hymne for thee?

My soul's a shepherd too; a flock it feeds

Of thoughts, and words, and deeds.

The pasture is thy word: the streams, thy grace

Enriching all the place.

Shepherd and flock shall sing, and all my powers

Out-sing the day-light houres.

Then we will chide the sunne for letting night

Take up his place and right:

Christ

We sing one common Lord; wherefore he should Himself the candle hold.

$\mathbf{2 8} \mathrm{He}$ avoids all conflict or contention except in singing-contests. $\quad \mathbf{4 1}$ If God had sent him even less wealth, he would be content with that. $\quad 44$ Familiar topos of Christ as shepherd: John 10.14, Hebrews 13.20, 1 Peter 2.25, 5.4. 46 Recalls the effects of Orpheus' songs. 47 serpents flew] ?oblique ref. to John 3.14. 50 shepherds low adore] extending the adoration of the Christ child by shepherds to a general topos of Christian worship. 53-6 Again the call to sing paulo maiora: see passage B 12-14n. 1 The shepherds sing] The shepherds of the Nativity, having seen and adored the Christ child, 'returned, glorifying and praising God' (Luke 2.20). 5 thy word] the scriptures; but also Christ as the incarnate Word of God (John 1.14). 
I will go searching, till I finde a sunne Shall stay, till we have done;

A willing shiner, that shall shine as gladly, As frost-nipt sunnes look sadly.

Then we will sing, and shine all our own day, And one another pay:

His beams shall cheer my breast, and both so twine,

Till ev'n his beams sing, and my musick shine.

\section{William Habington To My Noblest Friend, I. C. Esquire}

First published in Habington's Castara, 2nd edn (1635). Punctuation regularized at many points.

To my Noblest Friend, I. C. Esquire.

Sir.

I Hate the Countries dust and manners, yet

I love the silence; I embrace the wit

And courtship flowing here in a full tide,

But loath the expence, the vanity of pride.

No place each way is happy. Heere I hold

Commerce with some, who to my care unfold

courtly/courteous behaviour; here: at court emptiness, futility both ways, in all respects

(After a due oath ministred) the height

And greatnesse of each star shines in the state.

The brightnesse, the eclypse, the influence,

With others I commune, who tell me whence

discuss

The torrent doth of forraigne discord flow,

Relate each skirmish, battaile, overthrow,

Soone as they happen, and by rote can tell

Those German townes, even puzzle-me to spell.

The crosse or prosperous fate of Princes, they

Ascribe to rashnesse, cunning or delay

And on each action comment, with more skill

Then upon Livy, did old Machavill.

O busie folly! Why doe I my braine

Perplex with the dull pollicies of Spaine,

Or quicke designes of France? Why not repaire

To the pure innocence oth' country ayre:

And neighbor thee, deare friend? Who so dost give

Thy thoughts to worth and vertue, that to live

Blest, is to trace thy ways. There might not wee

Arme against passion with Philosophie;

And by the ayde of leisure so controule

What-ere is earth in us to growe all soule?

Knowledge doth ignorance ingender, when

Wee study miseries of other men

And forraigne plots. Doe but in thy owne shade

(This head upon some flowrie pillow layde,

Kind Natures huswifery) contemplate all

His stratagems, who labors to inthrall

The world to his great Master, and youle find

Ambition mocks it selfe, and grasps the wind.

Not conquest makes us great. Blood is to deare

A price for glory. Honor doth appeare

inquisitive, seeking knowledge

energetic, active

\section{like a schoolboy repeating a lesson} riddle, mystery

13 sunne] punning on son, i.e. the Son of God. Play on sun and Son is implicit all through. 14 stay, till we have done] as the sun did in Joshua 10.13 till the Israelites had defeated their opponents. 17 all our own day] all our lives, i.e. eternally. o.1 I. C.] not identified. 7-8 height and greatnesse] rank and lineage. 9 brightnesse, eclypse, influence] i.e. current strength and standing at court: astronomical / astrological metaphors for a star. influence] supposed ethereal fluid flowing from a star and affecting the mundane world. $10-14$ alluding to the Thirty Years' War. 15 crosse] adverse, contrary (OED cross adj 4). 18 Livy ... Machavill] Machiavelli wrote a commentary on the Roman historian Livy. $\quad 31$ plots] (a) plots of ground, territories (b) conspiracies. $\quad 34$ inthrall ... Master] subjugate all territories to the ruler he serves. 
To statemen like a vision in the night, And jugler-like workes oth' deluded sight.

Th' unbusied onely wise, for no respect Indangers them to error. They affect Truth in her naked beauty, and behold Man with an equall eye, not bright in gold Or tall in title; so much him they weigh As Vertue raiseth him above his clay.

Thus let us value things. And since we find Time bends us toward death, lets in our mind Create new youth; and arme against the rude Assaults of age; that no dull solitude

Oth' country dead our thoughts, nor busie care

Oth' towne make us not thinke, where now we are

And whether we are bound. Time nere forgot

His journey, though his steps we numbred not.

conjuror disengaged, at leisure; factor, consideration love, are drawn to

impartial, dispassionate judge, esteem

\section{Abraham Cowley That a Pleasant Poverty Is To Be Preferred before Discontented Riches}

The second Ode in the section entitled Sylva or Divers Copies of Verses in Cowley's Poetical Blossomes, 2nd edn (1636).

That a pleasant poverty is to bee preferred before discontented riches.

Why ô doth gaudy Tagus ravish thee,

Though Neptunes treasure-house it bee?

Why doth Pactolus thee bewitch,

Infected yet with Midas glorious Itch?

Their dull and sleepy streames are not at all

Like other Flouds, Poeticall,

They have no dance, noe wanton sport,

No gentle murmur, the lov'd shore to court.

No fish inhabite the adulterate floud,

Nor can it feede the neighboring wood, impure (with gold)

No flower or herbe is neere it found,

But a perpetuall winter sterves the ground.

Give me a river which doth scorne to shew

An added beauty, whose cleere brow

counted

May bee my looking-glasse, to see

added: to the water itself; face

What my face is, and what my mind should bee.

Here waves call waves, and glide along in ranke,

And prattle to the smiling banke.

Here sad Kingfishers tell their tales,

And fish enrich the Brooke with silver scales.

Dasyes the first borne of the teeming spring,

On each side their embrodery bring,

Here Lillies wash, and grow more white,

And Daffadills to see themselves delight.

41-2 Th'unbusied ... error] Only those not caught up in worldly affairs can be called wise, as they are not led into wrongdoing by any consideration. error] going astray (the root sense). 46 As his virtue raises him above the fleshly or worldly level of existence. 53-4 Time ... numbred not] Time does not cease to pass even if we ignore his passage. 1-3 The waters of the Tagus in Portugal and the Pactolus in Lydia (in modern Turkey) contained gold. 2 Neptune] the god of waters. 4 Midas] the Phrygian king whose touch turned everything to gold. $\quad$ 5-8 i.e. The gold makes the water heavy and sluggish. 12 sterves] starves: (a) withers or makes barren (cf. OED 6b, 8) (b) (in view of winter) destroys with cold $(O E D$ 9). 15-16 The clear water becomes a metaphor for a frank and innocent mind. 19 sad Kingfishers] Alcyone, daughter of the wind-god Aeolus, and her husband Ceyx were transformed into alcyons or halcyon birds, sometimes identified with kingfishers. No doubt it is that 'tale' that makes them 'sad'. 20 enrich, silver] in modest contrast to the earlier gold. 
Here a fresh arbor gives her amorous shade,

Which Nature, the best gard'ner, made.

Here I would set, and sing rude layes,

sit; artless, rustic

Such as the Nimphes and me my selfe should please.

spend; carefree

Thus I would wast, thus end my carelesse dayes,

For pious birds, should when I dye,

Make both my monument and Elegie.

\section{Abraham Cowley (Translated by Himself) The Country life}

From the opening of Book IV of Cowley's Latin Plantarum libri sex (Six Books on Plants) in his Poemata Latina (1668). The translation was appended to Cowley's essay 'Of Agriculture' in his Works (1669).

The Country Life.

Libr. 4. Plantarum.

(from) Of Plants, Book 4

Blest be the man (and blest he is) whom'ere

(Plac'd far out of the roads of hope or Fear)

A little Field, and little Garden feeds;

The Field gives all that Frugal Nature needs,

The wealthy Garden lib'rally bestows

All she can ask, when she luxurious grows.

The specious inconveniences that wait

Upon a life of Business, and of State,

He sees (nor does the sight disturb his rest)

By fools desir'd, by wicked men possest.

Thus, thus (and this deserv'd great Virgils praise)

The old Corycian Yeoman past his daies,

passed

Thus his wise life Abdolonymus spent:

Th'Ambassadors which the great Emp'ror sent

To offer him a Crown, with wonder found

The rev'rend Gard'ner howing of his Ground,

Unwillingly and slow and discontent,

From his lov'd Cottage, to a Throne he went:

And oft he stopt in his tryumphant way,

And oft lookt back, and oft was heard to say

Not without sighs, Alas, I there forsake

A happier Kingdom than I go to take.

Thus Aglaus (a man unknown to men,

But the gods knew and therefore lov'd him Then)

Thus liv'd obscurely then without a Name,

Aglaus now consign'd t'eternal Fame.

For Gyges, the rich King, wicked and great,

Presum'd at wise Apollos Delphick seat,

Presum'd to ask, Oh thou, the whole Worlds eye,

See'st thou a Man, that Happier is than I?

The God, who scorn'd to flatter Man, reply'd,

Aglaus Happier is. But Gyges cry'd,

In a proud rage, Who can that Aglaus be?

W' have heard as yet of no such King as Hee.

And true it was through the whole Earth around

No King of such a name was to be found.

Is some old Hero of that name alive,

32 monument and Elegie] by adorning his grave and singing to his memory. $\quad 1$ Blest be the man] Reflects the celebrated opening of Horace's Epode II. 6 luxurious] i.e. beyond the bare needs of life, which the field supplies. 11-12 Virgils ... Corycian yeoman] who 'matched in contentment the wealth of kings'(Virgil, Georg. IV.125-48). 13. Abdolonymus] a gardener of royal descent, made king of Sidon by Alexander. 23. Aglaus] a poor citizen of Psophis in Arcadia. The ensuing story is told by Pliny (Natural History VII.151) and Pausanius (Itinerary of Greece VIII.33.7). 27 Gyges] a fabulously wealthy king of Lydia. $\quad 28$ Presum'd] May be a mistake, inserted by eye-slip with Presum'd in the next line. 37 Hero] in the exact sense: a being with one divine (38) and one human parent. 
Who his high race does from the Gods derive?

Is it some mighty Gen'ral that has done

Wonders in fight, and God-like honours wonn?

Is it some man of endless wealth, said he?

None, none of these; who can this Aglaus bee?

After long search and vain inquiries past,

In an obscure Arcadian Vale at last,

(Th' Arcadian life has alwayes shady been)

Near Sopho's Town (which he but once had seen)

This Aglaus who Monarchs envy drew,

Whose Happiness the Gods stood witness to,

This mighty Aglaus was labouring found,

With his own hands in his own little ground.

So, gracious God, (if it may lawful be,

Among those foolish Gods to mention Thee)

So let me act, on such a private stage,

The last dull Scenes of my declining Age;

After long toiles and voyages in vain,

This quiet Port let my tost Vessel gain,

Of Heavenly rest, this Earnest to me lend,

Let my life sleep, and learn to love her End.

\section{Thomas Randolph Eclogue to Master Jonson}

Addressed to Ben Jonson, and first published in Randolph's Poems with the Muses Looking-Glasse: and Amyntas (1638). Randolph was held chief among the 'sons of Ben', his literary adherents and convivial companions. (See 11-14n, and Damon's repeated addresses to Tityrus as 'Father'.) Damon is Randolph and Tityrus Jonson - aptly, as the original Tityrus in Virgil I (echoed in this poem) is commonly taken as Virgil. Many echoes of Spenser's SC, 'October', and of Virgil's Eclogues, especially I and III.

\section{An Eglogue to Mr Iohnson.}

Tityrus. Vnder this Beech why sit'st thou here so sad

Son Damon, that wast erst a joviall lad?

These groves were wont to Eccho with the sound

Of thy shrill reed, while every Nymph danc'd round.

Rowse up thy soule, Parnassus mount stands high,

And must be climb'd with painefull industrie.

Damon. You Father on his forked top sit still,

(a) unmoving (b) always

And see us panting up so steepe a hill;

But I have broke my reed, and deeply swore

Never with wax, never to joynt it more.

Tityrus. Fond boy 'twas rashly done; I meant to thee,

Of all the sons I have, by legacie

To have bequeath'd my pipe, thee, thee of all,

I meant it should her second Master call.

Damon. And doe you thinke I durst presume to play

Where Tityrus had worne his lip away!

Live long thy selfe to tune it; 'tis from thee,

It has not from it self such Harmony.

But if we ever such disaster have

As to compose our Tytirus in his grave;

Yonder upon yon aged Oak, that now

Old trophies bears on every sacred bow,

We'le hang it up a relique, we will doe it,

And learned swains shall pay devotion to it.

Tytirus. Canst thou farewell unto the Muses bid?

Then bees shall loath the Thyme, the new wean'd Kid

44 obscure] (a) in literal sense, shady (b) unknown. Cf. shady (45). 46 Sopho's Town] Psophis. (See 23n.) 52 foolish] pagan, hence false or misguided objects of belief. $\quad 57$ Earnest] assurance, pledge. $\quad 1$ Tityrus] So spelt here, and indifferently 'Tit[yrus]' or 'Tyt[irus]' subsequently. 7 forked top] Tithorea and Lycorea, the highest peaks of the Parnassus range. 10 with wax ... to joynt it] cf. Virgil III.25-6. 2o compose] lay, set out (in a grave, $O E D$ 15b, only from 1677). 
Browze on the buds no more; the teeming ewes

pregnant

Henceforth the tender sallows shall refuse.

Damon. I by those Ladies now do nothing set;

Let 'em for me some other servant get:

instead of

They shall no more be Mistresses of mine,

No, though my pipe had hope to equall thine.

Thine which the floods have stopt their course to hear;

rivers, streams

To which the spotted Linx hath lent an eare.

Which while the severall Ecchoes would repeat,

The Musick has been sweet, the Art so great

That Pan himself amaz'd at thy deep aires,

Sent thee of his own bowl to drown thy cares.

Of all the Gods Pan doth the Pipe respect,

The rest unlearned pleasures more affect.

Pan can distinguish what thy Raptures be

From Bavius loose lascivious Minstralsie,

Or Mavius windy Bagpipe, Mavius, he

Whose wit is but a Tavern Tympanie.

If ever I flock of my own doe feed,

My fattest Lambs shall on his Altar bleed.

Tytirus. Two Altars I will build him, and each yeare

Will sacrifice two wel-fed Bullocks there.

Two that have horns; that while they butting stand

Strike from their feet a cloud of numerous sand.

But what can make thee leave the Muses man,

That such a Patron hast as mighty Pan?

Whence is thy fury? Did the partiall eare

plentiful, copious

Of the rude Vulgar, when they late did heare

Ægon and thee contend which best should play,

Him Victour deem, and give thy kid away?

Does Amarillis cause this high despaire?

Or Galatea's coynesse breed thy care?

Damon. Neither of these, the Vulgar I contemn;

Thy pipe not alwaies Tytirus wins with them:

And as for Love, in sooth I doe not know

Whether he wears a bow and shafts, or no.

Or did I, I a way could quickly find,

To win the beauteous Galatea's mind,

Or Amarillis: I to both could send

Apples that with Hesperian fruit contend:

And on occasion could have quickly guest

Where two fayr ring-doves built their amorous nest.

Tytirus. If none of these, my Damon then aread

What other cause can so much passion breed!

Damon. Father I will, in those indulgent ears

I dare unload the burden of my fears.

The Reapers that with whetted siccles stand,

Gathering the falling eares i'th' other hand;

Though they endure the scorching summers heat,

Have yet some wages to allay their sweat:

The Lopper that doth fell the sturdy Oak

separate, one after another

biased, prejudiced

or if I did

guessed

advise, inform

29 those Ladies] the Muses. 33-5 recalls Orpheus' song. 37 Pan] From the probable date (see 176n.), Charles I. Both James and Charles patronized Jonson as a composer of masques. 42-3 Bavius, Mavius] inferior poets, said to have attacked Virgil and Horace: satirized in Virgil III.9o. 44 Tavern Tympanie] drum played at drunken revels. 45 flock of my own] which Golden-Age shepherds conventionally had. By an unusually realistic touch, Damon is a hireling (168), though Tityrus has cattle of his own (48). $\quad$ 47-8 Virgil's Tityrus sacrificed one lamb at a single altar (Virgil I.7-8). 52 Moore Smith sees a reference to Randolph's play The Jealous Lovers, performed before the King (Pan) at Cambridge in 1632. (G. C. Moore Smith,'Thomas Randolph', Warton Lecture, British Academy, London: OUP, 1927, p.28). 55 Ægon] Named in a satirical context in Virgil III.2-4. Here, G. Thorn-Drury suggests Peter Hausted, a fellow of Cambridge whose play was also performed before the King. 56 thy kid] Presumably Damon's stake in the song-contest with Ægon. 61-2 i.e. I have never been struck by the arrows of love. $\mathbf{6 6}$ Hesperian fruit] the golden apples in the garden guarded by the Hesperides: cf. Virgil III.71. $\quad \mathbf{6 8}$ two fayr ring-doves] echoing Virgil III.69. 
Labours, yet has good pay for every stroke.

The Plowman is rewarded: only we

That sing, are paid with our own melody.

Rich churls have learn't to praise us, and admire,

But have not learn't to think us worth the hire.

So toyling Ants perchance delight to hear

The summer musique of the Grassopper,

But after rather let him starve with pain,

Then spare him from their store one single grain.

As when great Iunos beauteous Bird displaies

Her starry tail, the boyes doe run and gaze

At her proud train; so look they now adaies

On Poets; and doe think if they but praise,

Or pardon what we sing, enough they doe:

I, and 'tis well if they doe so much too.

My rage is swel'd so high I cannot speak it,

Had I Pan's pipe, or thine, I now should break it!

Tityrus. Let moles delight in Earth; Swine dunghils rake;

Crows prey on Carrion; Frogs a pleasure take

In slimy pools; And Niggards wealth admire;

But we, whose souls are made of purer fire,

Have other aimes: Who songs for gain hath made,

Has of a liberall Science fram'd a Trade.

Hark how the Nightingale in yonder tree,

Hid in the boughes, warbles melodiously

Her various musique forth, while the whole Quire

Of other birds, flock round, and all admire!

But who rewards her? will the ravenous Kite

Part with her prey, to pay for her delight?

Or will the foolish, painted, pratling Iay

Now turn'd a hearer, to requite her play

Lend her a straw? or any of the rest

Fetch her a feather when she builds her nest?

Yet sings she ne're the lesse, till every den

Doe catch at her last notes: And shall I then

His fortunes Damon 'bove my own commend,

Who can more cheese into the market send?

Clowns for posterity may cark and care,

That cannot out-live death but in an Heire:

By more then wealth we propagate our Names,

That trust not to successions, but our Flames.

Let hide-bound churls yoak the laborious Oxe,

Milk hundred goats, and shear a thousand flocks;

Plant gainfull Orchards, and in silver shine;

Thou of all fruits should'st only prune the Vine:

Whose fruit being tasted, might erect thy brain

To reach some ravishing, high, and lofty strain;

The double birth of Bacchus to expresse,

First in the grape, the second in the presse.

And therefore tell me boy, what is't can move

Thy mind, once fixed on the Muses Love?

Damon. When I contented liv'd by Cham's fair streams,

Without desire to see the prouder Thames,

I had no flock to care for, but could sit

Vnder a willow covert, and repeat

reward, recompense

cavern, remote and inaccessible place

strive

than

inheritance; poetic inspiration

productive, profitable; money

raise, uplift

wine-press

84 Grassopper] expanding the briefer allusion to Aesop's fable in Spenser, SC 'Oct.' 11. 87 Iuno's .. Bird] the peacock. Closely echoes $S C$ 'Oct.' 31-3. $\quad 91$ pardon] ironical: poetry is an offence they kindly tolerate or condone. 97 Niggards] misers. admire] value, esteem 100 Has turned a humane or liberating pursuit into a trade. 108 Now turn'd a hearer] i.e. no longer 'prattling' itself. play] ?musical performance (OED 18a), or any entertainment or performance. ${ }_{115}$ Clowns] (a) fools, boors (b) rustics, peasants - ironically, as only rich men would leave an inheritance. 123-6 Extending the account of the inspirational effects of wine in Spenser, SC 'Oct.' 106-12. 126 in the grape ... presse] i.e. as fruit and wine, perhaps with a play on press, printing press. $\quad 129$ Cham's fair streams] Randolph was first a student and then a fellow at Trinity College, Cantbridge haurzon Thames 1526143426 i.e. London or the court. 
Those deep and learned layes, on every part

Grounded on judgment, subtil'ty, and Art,

That the great Tutour to the greatest King,

The shepheard of Stagira, us'd to sing:

The shepheard of Stagira, that unfolds

All natures closet, shows what e're it holds;

The matter, form, sense, motion, place, and measure

140

Of every thing contain'd in her vast treasure.

How Elements doe change; What is the cause

Of Generation; what the Rule, and Laws

The Orbs doe move by; Censures every starre,

Why this is fixt, and that irregular;

Knows all the Heavens, as if he had been there,

And help't each Angell turn about her spheare.

The thirsty pilgrim travelling by land,

When the feirce Dog-starre doth the day command,

Half choak't with dust, parch't with the soultry heat;

Tir'd with his journey, and o'recome with sweat,

Finding a gentle spring, at her cool brink

Doth not with more delight sit down and drink,

Then I record his songs: we see a cloud,

And fearing to be wet, doe run and shroud

take cover, shelter

Vnder a bush; when he would sit and tell

The cause that made her mystie wombe to swell;

Why it sometimes in drops of rain doth flow,

Sometimes dissolves her self in flakes of snow:

Nor gaz'd he at a Comet, but would frame

160 A reason why it wore a beard of flame.

Ah Tytirus, I would with all my heart,

Even with the best of my carv'd mazers part,

To hear him as he us'd divinely shew,

What 'tis that paints the divers-colour'd bow:

wooden bowls

Whence Thunders are discharg'd, whence the winds stray,

rainbow

What foot through heaven hath worn the milky way!

And yet I let this true delight alone,

Call'd thence to keep the flock of Corydon.

Ah woe is me, another's flock to keep;

The care is mine, the master shears the sheep!

A flock it was that would not keep together;

A flock that had no fleece, when it came hither.

Nor would it learn to listen to my layes,

For 'twas a flock made up of severall strayes:

And now I would return to Cham, I hear

A desolation frights the Muses there!

With rustique swains I mean to spend my time;

Teach me there father to preserve my rime.

Tytirus. Tomorrow morning I will counsel thee,

Meet me at Faunus Beech; for now you see

How larger shadows from the mountains fall,

And Corydon doth Damon, Damon, call.

Damon, 'tis time my flock were in the fold,

More then high time; did you not erst behold

How Hesperus above yon clouds appear'd,

Hesperus leading forth his beauteous heard?

135-6 Tutour ... Stagira] Aristotle, born at Stagira in Macedonia, and tutor of Alexander (the greatest king). 137-59 are an elaborate presentation of the 'wise shepherd', pastoralizing general learning into shepherd lore. $\quad 143$ Censures] judges, estimates; ?analyses the movements of. 146 Angell ... spheare] In the Ptolemaic system, the crystalline spheres in which the heavenly bodies were set were each governed by a 'spirit', identified in Christianity with the orders of angels. $\mathbf{1 5 6} \mathbf{6 h e r ]}$ the cloud's: Lat. nubes, cloud, is feminine. 167-74 Here G. C. Moore Smith detects Randolph's frustration with the 'undisciplined and impecunious company of actors' (p.29). 170 shears the sheep] i.e., reaps the profit from their wool. $\quad \mathbf{1 7 6}$ A desolation] Parry takes to mean the shutdown of Cambridge from April to November 1630 owing to the plague. But may also allude to the growing Puritan influence there. 180 Faunus Beech] a beech tree sacred to the wood-god Faunus. S18dlargerna. fall] echoing 1526143426 Virgil I.83. $\quad \mathbf{1 8 5}$ Hesperus] the planet Venus, hereasise often the revening star . co 186 his beauteous $10: 20: 40 \mathrm{AM}$ 


\section{Thomas Randolph An Eclogue Occasioned by Two Doctors Disputing UPON PREDESTINATION}

First published in Randolph's Poems with the Muses Looking-Glasse: and Amyntas (1638). Found in several mss, where the contending shepherds are called Thenot and Col(l)in Clout. Tityrus often taken as Ben Jonson, as in no.226; but Randolph would not have presented his poetic 'father' as a wrangling shepherd overrruled by another. The Christian doctrine of predestination holds that God, in his freely given mercy, selects some (the elect) for redemption while condemning the rest (the reprobate) to damnation. A specially pronounced and influential version occurs in the radical Protestant theology of Jean Calvin, adopted by the English Puritans. The theological issue was thus also a political one in Randolph's day. The poem offers no doctrinal solution; but its celebration of God's love and mercy, as exemplified in Christ's sacrifice, argues for a liberal and humane position.

An Eglogue occasion'd by two Doctors disputing upon predestination. Doctors: of theology

Corydon. Ho jolly Thirsis whither in such hast?

I'st for a wager that you run so fast?

Or past your houre below yon hawthorne tree

Does longing Galatea looke for thee?

Thirsis. No Corydon, I heard young Daphnis say

Alexis challeng'd Tityrus to day

Who best shall sing of Shepheards Art, and praise;

merit, praiseworthiness

But hearke I heare 'em, listen to their laies.

Tityrus. Alexis read, what means this mistique thing;

strange, mysterious

An Ewe I had two lambs at once did bring:

Th' one black as Iett; the other white as snow:

Say in just providence how it could be so?

Alexis. Will you Pan's goodnesse therefore partiall call,

That might as well have given thee none at all?

Tityrus. Were they not both eand by the selfe same Ewe?

How could they merit then so different hewe?

Poore lamb alas; and couldst thou, yet unborne,

Sin to deserve the Guilt of such a scorne?

Thou hadst not yet fowl'd a religious spring,

Nor fed on plots of hallowed grasse, to bring

Staines to thy fleece; nor browz'd upon a tree

Sacred to Pan or Pales Deitie.

The Gods are ignorant if they not foreknow;

And knowing, 'tis unjust to use thee so.

Alexis. Tytir, with me contend, or Corydon;

But let the Gods, and their high wills alone.

For in our flocks that freedome challenge wee,

This kid is sacrific'd, and that goes free.

Tityrus. Feed where you will my Lambs, what boots it us

To watch, and water, fold, and drive you thus.

This on the barren mountaines flesh can gleane,

That fed in flowry pastures will be leane.

Alexis. Plow, sowe, and compasse, nothing boots at all,

Vnlesse the dew upon the Tilth's doe fall.

So labour sylly Shepheards what wee can

All's vaine, unlesse a blessing drop from Pan.

Tityrus. Ill thrive thy Theves if thou these lyes maintaine:

Alexis. And may thy Goats miscarry sawcy swaine.

Thyrsis. Fie, Shepheards fie! while you these strifes begin,

Here creepes the woolfe; and there the fox gets in.

To your vaine piping on so deepe a reed

The Lambkins listen, but forget to feed.

It gentle swains befits of Love to sing,

How Love left heaven; and heav'ns immortall King,

His Coæternall Father. O admire,

sacred

yeaned, given birth to

Love is a Sonne as ancient as his sire.

13 Pan] God: used not only for pastoral effect but, as often, to avoid charges of blasphemy for directly naming the Christian God. Cf. 23n. 14 A common argument: any man's salvation is owing to God's freely granted mercy, so we cannot question why it was not granted to others. 23-4 Being omniscient, God has foreknowledge of a soul's salvation or damnation; in which case, as he is also omnipotent, he should ensure salvation. 23 The Gods] often used instead of God to avoid charges of blasphemy. challenge] demand, claim (OED 5). $\quad 34$ dewl a common image for God grace or mercy. Tilth

spread compost or manure

theaves, young ewes 
His Mother was a Virgin: how could come A birth so great, and from so chast a wombe! His cradle was a manger; Shepheards see

True faith delights in poore simplicite.

He pres'd no grapes, nor prun'd the fruitfull vine,

But could of water make a brisker wine. agreeably sharp ... to the taste (OED brisk 4)

Nor did he plow the earth, and to his Barne

The harvest bring, nor thresh, and grind the Corne.

Without all these Love could supply our need;

And with five Loaves, five thousand Hungers feed.

More wonders did he, for all which suppose

ow he was crown'd, with Lilly, or with Rose?

The winding Ivy, or the glorious Bay,

6o Or mirtle, with the which Venus, they say,

Girts her proud Temples? Shepheards none of them

But wore (poore head) a thorny Diadem.

Feet to the Lame he gave, with which they run

To worke their Surgeons last destruction.

The blind from him had eyes; but us'd that light

Like Basylisques to kill him with their sight.

Lastly he was betray'd (ô sing of this)

How Love could be betray'd! 'twas with a kisse.

And then his Innocent hands, and guiltlesse feet

Were nayl'd unto the Crosse, striving to meet

In his spread armes his spouse, so mild in showe

He seem'd to court th' Imbraces of his foe.

Through his pearc'd side, through which a spere was sent,

A torrent of all flowing Balsame went.

Run Amarillis run: one drop from thence

Cures thy sad soule, and drives all anguish hence.

Goe sunburnt Thestylis, goe, and repaire

Thy beauty lost, and be againe made faire.

Love-sick Amyntas get a Philtrum here,

$80 \quad$ To make thee Lovely to thy truly deare.

But coy Licoris take the Pearle from thine,

And take the bloodshot from Alexis eyne.

Weare this an Amulet 'gainst all Syrens smiles,

The stings of snakes, and Teares of Crocodiles.

Now Love is dead: Oh no, he never dyes;

Three dayes he sleepes, and then againe doth rise

(Like faire Aurora from the Easterne Bay)

And with his beams drives all our clouds away:

This pipe unto our flocks, this sonnet get.

But hoe, I see the Sun ready to set,

Good night to all; for the great night is come;

Flocks to your folds and shepheards hye you home!

To morrow morning, when we all have slept,

Pan's Cornet's blowne, and the great Sheepshears kept.

52 of water make ... wine] Christ's first miracle, at a marriage feast in Cana (John 2.1-11). $\quad 56$ five Loaves] In another miracle, Christ fed 5,000 people with five loaves and two fishes (Matthew 14.13-21, Mark 6.31-44, Luke 9.10-17, John 6.5-15). 62 thorny Diadem] the crown of thorns with which the soldiers mocked Christ during his Passion (Matthew 27.29, Mark 15.17, John 19.2, 5). 66 Basylisque] basilisk, a mythical monster that could kill people with its gaze. 68 a kisse] with which Judas identified Jesus to his captors (Matthew 26.47-50, Mark 14.43-45, Luke 22.47-48). 71 his spouse] the body of the faithful, or the Church. 74 Balsame] a healing balm. But when a soldier pierced the side of the crucified Christ, only blood and water poured out (John 19.31-7).
$\mathbf{8 1 - 2}$ i.e. End both your reluctance and your lover's sleepless suffering. Sheepshears] sheepshear's, the shearing-feast is. 


\title{
228 Thomas Randolph An Eclogue on the Palilia on Cotswold Hills
}

One of the complimentary pieces in Annalia Dubrensia (1636), a collection by various hands celebrating an annual festival of games set up in the Cotswold Hills $c$. 1612 by Robert Dover, captain and attorney. Reprinted in Randolph's Poems (1638). The text below follows Annalia.

An Eglogve on the Palilia And Noble Assemblies revived on Cotswold Hills, by Mr. RoberT DOVER

\author{
Collen, Thenot.
}

Collen. What Clod-pates Thenot are our Brittish swaines?

How lubber-like they loll upon the Plaines,

No life, no spirit in um! Every Clowne,

Soone as hee layes his Hooke and Tarbox downe,

That ought to take his Reed, and chant his Layes,

Or nimblie run the windings of the Maze,

Now gets a Bush to roame himselfe, and sleepe,

Tis hard to know the Sheepheard from the sheepe:

And yet me-thinks our English pastures bee

As flowery as the Lawnes of Arcadye,

Our Virgins blithe as theirs, nor can proud Greece

Boast purer Aire, nor sheare a finer fleece.

Thenot. Yet view their out-side Collen, you would say,

They have as much brawne in their necks, as they

Faire Tempe braggs of lustie Armes, that swell

With able sinews, and might hurle as well

The weightie Sledge; their Leggs, and Thighs of bone,

Great as Colossus, yet their strengths are gone;

They looke like yonder man of wood that stands

To bound the limits of the Parish lands:

boorish rustic sheephook

Dost thou ken Collen, what the cause might bee

Of such a dull, and generall Lethargie?

Collen. Swaine! with their sports, their soules were tane away,

Till then they all were active; every day

They excercis'd to weild their limbes, that now

Are numb'd to every thing, but flaile, and Plowe.

Early in May up got the Iolly route,

Cal'd by the Larke, and spread the fields aboute:

One, for to breath himselfe, would coursing bee

From this same Beech, to yonder Mulberie;

A second leapt, his supple nerves to trie,

warm up; running

A third, was practicing his Melodie;

This, a new ligg was footing; Others, were

Busied at wrastling, or to throw the Barre;

Ambitious which should beare the bell away,

And kisse the Nut-browne-Lady of the Maie:

This stirr'd 'um up, a Iolly Swaine was hee,

Whom Pegg and Susan, after victory,

Crown'd with a Garland they had made, beset

With Dazies, Pincks, and many a Violet,

Cow-slipp, and Gilliflowre; Rewards, though small,

Encourage vertue: But if none at all

Meete her, shee languisheth, and dies, as now,

Where worth's denied the honour of a bough;

room, lodge

And, Thenot, This the cause I read to bee,

Of such a dull, and generall Lethargie:

Thenot. Ill thrive the Lowt, that did their mirth gaine-say,

4 Tarbox] container for the tar used to dress sheep's wounds. 13-20 Unclear construction but obvious meaning: today's English shepherds are muscular, but lack the energy and athletic spirit of those of ancient Greece. 17 Sledge] sledge-hammer, thrown as a sport. 18 Colossus] the giant statue of the Titan Helios straddling the ancient harbour of Rhodes. 19-20 man ... lands] wooden figure of a watchman marking the parish boundary. 34 throw the Barre] a traditional country game, with a bar or rod designed for the purpose. 35 beare the bell] lead (like the bell-wether of a flock), hence come first, win. 44 bough] ?wreath or chaplet; ?bow, honour or obeisance. 
Wolves haunt his flocks, that tooke those sports away.

Collen. Some melancholly Swaines about have gone,

To teach all Zeale their owne Complection.

Choler they will admit sometimes, I see;

But Fleagme, and Sangvine, no Religions bee;

These teach that Dauncing is a Iezabell,

And Barley-breake, the ready way to Hell,

The Morrice, Idolls; Whitson-ales can bee

But profane Reliques of a Iubilee:

These in a Zeale, t'expresse how much they doe

The Organs hate, have silenc'd Bagg-pipes too,

And harmlesse May-poles, all are raild upon,

60 As if they were the Towers of Babilon:

Some thinke not fit, there should be any sport

I' the Citie, Tis a dish proper to'th Court;

Mirth not becomes 'um, let the sawcie swaine

Eate Beefe, and Bacon, and goe sweate againe,

Besides, what sport can in their pastimes bee

When all is but rediculous fopperie.

Thenot. Collen! I once the famous Spaine did see,

A Nation glorious for her Gravitie,

Yet there an hundred Knights, on warlike Steedes

bourgeoisie, hence all common people

'em, them

$\operatorname{proud}\left(O E D_{1}\right)$

Did skirmish out a fight, arm'd but with Reeds,

At which a Thousand Ladies Eies did gaze:

Yet was no better, then our Prison base.

What is the Barriers, but a Courtly way

Of our more downe right sport, the Cvdgell-play?

Foote-ball with vs, may bee with them, Baloone;

As they at Tilt, so wee att Quintain runne,

And those old-pastimes relish best with mee,

That have least Art, and most Simplicitye.

Collen! They say, at Court there is an Art,

To dance a Ladies honor from her hart;

Such wiles poore Sheephards know not, all their sence

Is dull to any thing, but Innocence:

The Country Lasse, although her Dance bee good,

Stirs not an others Galliard in the Blood;

And yet their sports by some contrould have bin,

Who thinke there is no mirth, but what is Sin.

O might I but their harmlesse Gambolls see

Restor'd unto an ancient Libertye,

Where spottlesse daliance traces ore the Playnes,

And harmlesse Nimphes jet it with harmlesse Swaynes.

To see an age againe of Innocent Loves

Twine close as Vines, yet kisse as chast as Doves.

Me thinkes I could the Thracian Lyre have strung,

Or tun'd my Whistle to the Mantuan song.

50 Zeale] a word specially associated with the Puritans. The Puritan opposition to traditional rural sports is also attacked in, e.g., Jonson's play The Sad Shepherd. Complection] constitution, as determined by the four humours (see 51-2n). $\quad \mathbf{5 1 - 2}$ Of the humours, choler or yellow bile was said to induce anger and domination, while phlegm made a person relaxed and contented, and blood (whence Sangvine: Lat. sanguis, blood) spirited and sociable. 53 Iezabell] wife of King Ahab; associated with idolatry, persecution of prophets, finery and promiscuity (1 Kings 18.4 etc., 2 Kings 9.30-37). 54 Barley-breake] a popular rustic game. Hell] part of the ground in this game. 55 Morrice] morrisdance. Whitson-ales] parish festivities at Whitsuntide (seventh Sunday after Easter). 56 Iubilee] a joyful celebration or revel: perhaps suggesting the Roman Catholic jubilee, which (though not festive) would be anathema to the Puritans. 58 Organs] characterizing high-church or episcopal worship, hence hated by Puritans. 6o Babilon] Biblically an evil power, captor and destroyer of Jerusalem (2 Kings 25). Its Towers, conflated with the Tower of Babel, exemplified sinful pride. 70 a fight, arm'd but with Reeds] the juego de cañas, a Spanish sport using reeds for combat instead of lances. 72 Prison base] or prisoners' base, a popular rural game. 75 Foote-ball] Then considered a vulgar, rowdy game. Baloone] a game where a leather ball is driven with wooden pieces. $\mathbf{8 4}$ Does not sexually provoke her partner. Galliard] a dance. $\quad 89$ traces] passes, moves; (especially) dances. 93 Thracian] Orpheus lived in Thrace. 94 Mantuan] Virgil hailed from Mantua. 
Collen. Then tune thy Whistle Boy, and string thy Lyre,

That age is come againe, thy brave desire

Pan hath approv'd; Dauncing shall bee this yeare

Holy, as is the motion of a Spheare.

Thenot. Collen! With sweeter breath Fame never blewe

Her sacred Trump, if this good newes bee true!

report (personified)

Collen. Know'st thou not Cotswold-hils.

Thenot. Through all the land,

No finer wooll runnes through the Spinsters hand.

But silly Collen, ill thou do'st devine,

Can'st thou mistake a Bramble, for a Pine?

Or thinke this Bush a Cedar? or suppose

Yon Hamlet where to sleepe each Sheapheard goes

In circuit, buildings, people, power, and name

Equalls the Bow-string'd by the silver Thame?

Aswell thou maiest, their Sports with ours compare,

As the soft wooll of Lambes, with the Goats haire.

Collen. Last evening Lad, I met a noble Swayne,

That spurr'd his spright-full Palfrey ore the playne:

His head with Ribbands crown'd, and deck't as gay

As any Lasse, upon her Bridall day.

I thought (what easie faiths we Sheepheards prove!)

This, not the Bull, had beene Europaes love.

I ask't the cause, they tould mee this was hee,

Whom this dayes Tryumph crown'd with victory.

Many brave Steeds there were, some you should finde

So fleete, as they had bin sonnes of the winde.

Others with hoofes so swifte beate ore the race,

As if some Engine shot 'um to the place.

So many, and so well wing'd Steeds there were,

As all the broode of Pegasus had bin there,

Rider and horse could not distinguish'd bee,

Both seem'd conjoyn'd, a Centaures Progeny.

A numerous troupe they were, yet all so light,

Earth never groon'd, nor felt 'um in their flight.

Such Royall pastimes Cotswold mountaines fill,

When Gentle-swaines visit her glorious Hill:

Where with such packs of Hounds, they hunting go,

As Cyrus never woon'd his Bugle too;

extent, ambit

Whose noise is musicall, and with full cries,

Beat's ore the Field's, and ecchoes through the skies.

Orion hearing, wish'd to leave his Spheare;

And call his Dogge from heaven, to sport it there.

Watt though he fled for life, yet joy'd withall,

So brave a Dirge sung forth his Funerall.

Not Syrens sweetlier rill: Hares, as they flie,

Looke backe, as glad to listen, loth to die.

sing, trill

Thenot. No doubt, but from this brave Heroicke fire

In the more noble hearts, sparkes of desire

May warme the colder Boores, and emulous strife,

Give the old mirth, and Innocence a new life;

evince, exhibit

machine

groaned

When thoughts of Fame their quickned soules shall fill,

97 Pan] King Charles I. motion of a Spheare] In the Ptolemaic system, the heavenly bodies were set in concentric crystalline spheres, which made celestial (hence Holy) music as they turned. 108 the Bow-string'd] There is a bend in the Thames west of the old City of London. 111-12 Uses the idiom of chivalric romance in a pastoral context, recalling the opening of Spenser's FQ: 'A Gentle Knight was pricking on the plaine'. 116 Zeus or Jupiter courted Europa in the shape of a bull. But the 'Swayne' resembles Zeus in the god's true shape. 121 race] racing-ground (OED race $\mathrm{n}^{1} 6 \mathrm{~d}$ ). 130 Gentle-swaines] gentlemen, persons of proven lineage and income. The Cotswold Games were organized by the upper orders to inspire their social inferiors. (See 141-4). 132 Cyrus] prob. the younger Cyrus (d. 401 BCE), Persian leader and general, and a celebrated hunter (Xenophon, Anabasis 1.9). 135-6 Orion] a great hunter, transformed to a constellation, with Canis Major and Canis Minor (Greater and Lesser Dogs, the former with the dog-star Sirius) as his hunting dogs. 137 Watt] hare or rabbit, especially as the prey of hunters. 
At ev'ry glaunce that shewes vm Cotswold Hill.

Collen. There Shepheard, there the solem-games bee plaide,

Such as great Theseus or Alcides made,

Alcides: Hercules

Such as Apollo wishes hee had seene,

And Iove desires, had his invention beene.

The Nemoean and the Isthmian pastimes still,

Though dead in Greece, surviue on Cotswold Hill.

Thenot. Happy oh hill! The gentle graces nowe

Shall tripp ore Thine, and leave Citherons browe,

Pernassus Clift shall sinke below his spring,

And every Muse shall on thy front'let sing;

The Goddesses againe, in strife shall bee,

And from mount $I d a$, make appeale to thee:

Olympus pay the homage; and in dread,

160 The aged Alpes shall bow his snowie head:

Flora with all her store thy Temples Crowne,

Whose height shall reach the starres; gods looking downe,

Shall blesse the Incence that thy flowers exhale,

scent

And make thee both a Mountaine, and a Vale.

How many Ladies on thy Topp shall meete,

And presse thy Tresses with their Od'rous feete,

Whose Eyes, when wondring men see from afarre,

They'le thinke the heaven and each of them a starre.

But gentle Collen say, what god or man

Fame wee for this great worke, Daphnis, or Pan?

Collen. Daphnis is dead, and Pan had broke his Reed,

forehead, brow

from: abandoning, instead of

thee

Tell all your Flocks 'tis Ioviall DOVER's deede.

Behold the Shepheards in their Ribbands goe;

And shortly, all the Nimphes shall weare 'um too;

Amaz'd to see such Glorie met together,

Blesse DOVER's Pipe, whose musicke call'd 'um hether.

Sport you, my Rams, at sound of DOVERS name;

Bigg-bellied Ewes, make hast to bring a Lambe

For DOVERS fould; Goe maides, and Lillies get,

To make him up a glorious Coronet.

Swaines keepe his Holy-day; and each man sweare

To Saint him in the Shepheards Kalender.

\section{Thomas Randolph A Dialogue betwixt a Nymph and a Shepherd}

From Randolph's Poems with the Muses Looking-glasse: and Amyntas (1638).

A Dialogue betwixt a Nymph and a Shepheard.

Nymph. Why sigh you swain? this passion is not common; Is't for your kids, or Lambkins?

Shepheard.

For a woman.

Nymph. How faire is shee that on so sage a brow Prints lowring looks?

Shepheard

Nymph. Is shee a maid?

Shepheard.

Nymph. Or widdow?

Iust such a toy as thou.

what man can answer that?

$\mathbf{1 5 0}$ Jove wishes he had thought of the idea. $\quad 151$ Nemea and the Isthmus of Corinth held celebrated games in ancient Greece. 154 Citheron] The Graces conventionally dwelt on Olympus. Randolph transfers them to a hill sacred to Cytherea or Venus, following Spenser's solecism (FQ 3.6.29), though the actual Mt Cythaeron was sacred to Zeus (Jupiter) and the Muses. 155 his spring] The Castalian spring beside Mt Parnassus. $\quad$ 157-8 Alluding to the Judgement of Paris: while dwelling as a shepherd on Mt Ida, the Trojan prince was called to judge the beauty of Hera (Juno), Athena (Minerva) and Aphrodite (Venus). 161 Flora] the goddess of spring and flowers. 164 both ... Vale] as tall as a mountain but as gentle and fertile as a valley. 170 Daphnis] a legendary shepherd-poet, the subject of Theocritus I. 4 toy] ?pet, darling. OED toy $8 \mathrm{a}$, 1st cit. 1822 for this affectionate, non-pejorative use. 
Shepheard.

Nymph.

No.

Shepheard.

what then?

Saint-like she lookes, a Syren if shee sing.

Her eyes are starres, her mind is every thing.

Nymph. If shee be fickle, Shepheard leave to wooe,

Or fancy mee.

Shepheard.

No, thou art woman too.

Nymph. But I am constant.

Shepheard.

Nymph. Bright as the morning.

Shepheard.
Nymph. What grows upon this cheeke?

Shepheard.

Nymph. Come tast a kisse.

Shepheard.

O sweet, ô sweet Temptation!

Chorus. Ah Love, and canst thou never loose the feild?

Where Cupid layes a seige, the towne must yeild.

Hee warmes the chiller blood with glowing fire,

And thaws the Icy frost of cold desire.

?(even) the colder kind of

\section{John Milton Lycidas}

A lament for Edward King, Milton's contemporary at Cambridge, drowned at sea in August 1637. Composed in November 1637 and first published in a collection of Latin and English memorial poems, Justa Edovardo King naufrago (Cambridge, 1638). Division of verse-paragraphs modified.

In this Monody the Author bewails a learned Friend, unfortunatly drown'd in his Passage from Chester on the Irish Seas, 1637. And by occasion foretels the ruine of our corrupted Clergy then in their height.

Yet once more, $\mathrm{O}$ ye laurels, and once more,

Ye myrtles brown, with ivy never-sere,

I come to pluck your berries harsh and crude,

And with forc'd fingers rude

Shatter your leaves before the mellowing yeare.

Bitter constraint, and sad occasion deare

Compells me to disturb your season due:

severe, grievous

For Lycidas is dead, dead ere his prime,

(Young Lycidas!) and hath not left his peere.

Who would not sing for Lycidas? he knew

Himself to sing, and build the lofty rhyme.

He must not flote upon his watry biere

Unwept, and welter to the parching wind

Without the meed of some melodious tear.

never withering, evergreen

Begin then, Sisters of the sacred well

That from beneath the seat of Jove doth spring;

Begin, and somewhat loudly sweep the string:

Hence with deniall vain, and coy excuse.

So may some gentle Muse

With lucky words favour my destin'd urn,

And as he passes, turn

And bid fair peace be to my sable shroud.

roll, toss; drying, shrivelling reward, tribute

noble, generous

black

1 Yet once more] Milton has eight earlier poems of lament for various people. $\quad$ 1-2 laurels ... myrtles ... ivy] associated respectively with poetry, love and learning. 5 the mellowing yeare] summer, when the berries will ripen. King died an untimely death. $\mathbf{8}$ prime] The context revives the word's latent metaphor of springtime. 10 Who would not sing] Echoes Virgil X.3. 10-11 King left behind some Latin verses. 12-3 watry ... parching] The contrast anticipates other disturbing paradoxes: see 119. 15-16 Sisters] the Muses. sacred well] Hippocrene, at the foot of Mount Helicon, sacred to the Muses. seat of Jove] Helicon also had an altar to Zeus or Jupiter. Poetry is endowed with the highest divine origin, foreshadowing the 'heavenly Muse' Urania in Paradise Lost. 20 lucky] (a) of good omen (b) fortuitous, obtained by happy chance. destin'd urn] i.e. containing his ashes. destin'd] fated. 21 he] presumably a poet favoured by the Muse (19). 
For we were nurst upon the self-same hill,

Fed the same flock, by fountain, shade, and rill;

Together both, ere the high lawns appear'd

Under the glimmering eye-lids of the morn,

We drove a-field, and both together heard

What time the gray-fly winds her sultry horn,

Batt'ning our flocks with the fresh dews of night,

Oft till the ev'n-starre bright

Toward heav'ns descent had slop'd his burnisht wheel.

Mean while the rurall ditties were not mute

Temper'd to th' oaten flute:

Rough Satyres danc'd, and Fauns with cloven heel

From the glad sound would not be absent long,

And old Dametas lov'd to heare our song.

But oh the heavy change, now thou art gone,

Now thou art gone, and never must return!

Thee shepherds, thee the woods, and desert caves

With wild thyme and the gadding vine oregrown,

deserted, empty

And all their echoes mourn.

The willows and the hasil-copses green

took our flocks

Shall now no more be seen

Fanning their joyous leaves to thy soft layes.

As killing as the canker to the rose,

Or taint-worm to the weanling herds that graze,

Or frost to flowers that their gay wardrobe wear,

When first the white-thorn blowes;

Such, Lycidas, thy losse to shepherds eare.

Where were ye Nimphs, when the remorselesse deep

Clos'd ore the head of your lord Lycidas?

For neither were ye playing on the steep,

Where the old Bards the famous Druids lie,

Nor on the shaggie top of Mona high,

Nor yet where Deva spreads her wisard stream:

Ah me, I fondly dream!

Had ye been there - for what could that have done?

What could the Muse her self that Orpheus bore,

The Muse her self, for her inchanting sonne?

Whom universall nature did lament,

When by the rout that made the hideous rore

His goary visage down the stream was sent,

Down the swift Hebrus to the Lesbian shore.

Alas! what boots it with uncessant care

To tend the homely slighted shepherds trade,

And strictly meditate the thanklesse Muse?

Were it not better done as others do,

To sport with Amaryllis in the shade,

feeding to advantage, fattening
evening star

modulated, attuned

hazel

waving, fluttering

an intestinal worm in cattle;

[newly-weaned

i.e., in spring

slopes

wooded

magical, enchanted

crowd, band

profits, avails

rigorously

23 the self-same hill] i.e., Cambridge. 25 high lawns] upland pastures, lit up only after the sun has climbed some distance. 28 gray-fly] cockchafer, a kind of beetle. winds her ... horn] buzzes or drones. sultry] suggests the hot mid-day. 31 wheel] Hesperus, the evening-star, is not commonly presented as driving a chariot. 34 Satyres ... Fauns] ?the younger members of the Cambridge community; ?rustics and the non-academic 'town'. 36 Dametas] presumably a teacher or tutor, perhaps William Chappell. $\quad 44$ An Orphic touch, anticipating 58. 50-55 Echoes Theocritus I.66-9, Virgil X.9-12. 53 Where ... Druids lie] Probably Kerig i Druidion or 'Druids' Stones' in Denbighshire. This and the following places are on or near the Welsh coast, off which King was drowned. 54 Mona] the island of Anglesey, off the Welsh coast; associated with the Druids (Drayton, Poly-olbion IX.417-29). 55 Deva] the river Dee, thought to be enchanted because the shifting of its fords supposedly had prophetic implications for the land (Drayton, Poly-olbion X.200-210). 58 the Muse] Calliope, the Muse of epic, Orpheus' mother. $\quad \mathbf{6 1 - 2}$ Orpheus was torn to pieces by Thracian women in their Bacchanalian orgies when, distracted by grief for his wife Eurydice, he ignored their advances. 63 Hebrus] a river in Thrace. The Bacchantes threw Orpheus' severed head into this stream, which carried it across the Aegean Sea to the island of Lesbos. $\mathbf{6 6}$ meditate the ... Muse] compose or practise poetry, after Virgil I.2, VI.8. 68-9 Amaryllis, Neera] conventional names of shepherdesses: Amaryllis repeatedly in Theocritus and Virgil, Neaera in Virgil III. 3 and elsewhere including Tibullus, whose Elegy III.ii.11-12 refers to her tangled hair. Here, standing for sensual and worldly pleasures. 
Hid in the tangles of Neera's hair?

Fame is the spurre that the clear spirit doth raise,

(That last infirmitie of noble mind)

pure-minded, lofty

To scorn delights, and live laborious dayes;

But the fair guerdon where we hope to find,

And think to burst out into sudden blaze,

Comes the blind Furie with th' abhorred shears,

And slits the thin-spun life; But not the praise,

Phebus repli'd, and touch'd my trembling eares.

Fame is no plant that growes on mortall soil,

Nor in the glistring foil

Set off to th' world, nor in broad rumour lies;

But lives, and spreads aloft by those pure eyes

And perfect witnesse of all-judging Jove:

As he pronounces lastly on each deed,

Of so much fame in heav'n expect thy meed.

Oh fountain Arethuse, and thou honour'd floud,

Smooth-sliding Mincius, crown'd with vocall reeds;

That strain I heard was of a higher mood.

But now my oat proceeds,

And listens to the herald of the sea

That came in Neptunes plea.

He ask'd the waves, and ask'd the felon winds,

What hard mishap hath doomd this gentle swain?

And question'd every gust of rugged wings,

That blowes from off each beaked Promontorie:

They knew not of his storie;

And sage Hippotades their answer brings,

That not a blast was from his dungeon stray'd;

The aire was calm, and on the level brine

Sleek Panope with all her sisters play'd:

It was that fatall and perfidious bark,

Built in th'eclipse, and rigg'd with curses dark,

That sunk so low that sacred head of thine.

Next Chamus (reverend sire) went footing slow,

His mantle hairie, and his bonnet sedge,

Inwrought with figures dim, and on the edge

Like to that sanguine flower inscrib'd with wo;

Ah! who has reft (quoth he) my dearest pledge?

Last came, and last did go,

The Pilot of the Galilean lake,

Two massie keyes he bore of metalls twain,

(The golden opes, the iron shuts amain)

gold or silver leaf, setting for a jewel broadcast, widespread

defence
guilty, offending

projecting
his: Lycidas'; history

defence

ship
fitted with sails

fitted with sails

patterned, embroidered

firmly, with full force

75-6 Conflating the Furies (Erinyes), spirits of retribution, with their allies and controllers the Fates (Moirae or Parcae), who determine the span of human life. Atropos, the third Fate, cuts the thread of life, spun by Clotho and measured by Lachesis. blind] suggests further conflation with the Graeae, who had one eye and one tooth among them. $\quad 77$ Phebus] Apollo, god of poetry. trembling] (a) resonating (to Phoebus' voice) (b) quivering in rapture or ecstasy. 78-84 Distinguishing true fame, determined by merit and heavenly reward, from mere worldly acclaim. 85 Arethuse] Arethusa, a fountain in Ortygia off the coast of Sicily. Virgil X.1 invokes its nymph as the muse of pastoral poetry. 86 Mincius] Virgil's native river, hence sacred to pastoral. See Virgil VII.13 and Georg. III.14, which mention reeds or sedge on its banks. vocall reeds] Conflating the plant with both shepherd's pipe and poet's reed-pen. 89 herald of the sea] Triton, son of Poseidon or Neptune, so called because of his trumpet shaped from a shell. 96 Hippotades] Aeolus, god of winds. 97 dungeon] Aeolus imprisoned the winds in caverns beneath the mountains (Virgil, Aen. I.52-63). 99 Panope] one of the fifty Nereids or daughters of the sea-god Nereus. 101 th'eclipse] traditionally an inauspicious time, heralding disaster. 103 Chamus] the river Cam, hence Cambridge University. 104 hairie] Presumably referring to the trees on the banks, though Carey suggests 'the fur of the academic gown'. 106 flower inscrib'd with wo] the hyacinth, sprung from the blood of Apollo's beloved Hyacinthus. Its streaks were read as the Greek exclamation of mourning AI, expressing Apollo's grief at the death. 107 pledge] (a) promise, hope (b) also (following Spenser) offspring (of the 'sire', 103). 109 Pilot of the Galilean lake] St Peter,originally a fisherman on Lake Galilee. 110 keyes] of heaven, entrusted to Peter by Christ (Matthew 16.19). 
He shook his mitred locks, and stern bespake,

How well could I have spar'd for thee, young swain,

Enough of such as for their bellies sake

Creep and intrude and climbe into the fold?

Of other care they little reckoning make,

Then how to scramble at the shearers feast,

And shove away the worthy bidden guest.

Blind mouthes! that scarce themselves know how to hold

A sheephook, or have learn'd ought else the least

That to the faithfull herdmans art belongs!

What recks it them? what need they? they are sped;

And when they list their lean and flashie songs

Grate on their scrannel pipes of wretched straw,

The hungry sheep look up, and are not fed,

But swoln with wind, and the rank mist they draw,

Rot inwardly, and foul contagion spread:

Besides what the grimme wolf with privy paw

Daily devoures apace, and little said.

130 But that two-handed engine at the doore,

Stands ready to smite once, and smites no more.

Return, Alpheus, the dread voice is past

That shrunk thy streams; return, Sicilian Muse,

And call the vales, and bid them hither cast

Their bells, and flowrets of a thousand hues.

Ye valleys low, where the mild whispers use

Of shades and wanton winds and gushing brooks,

On whose fresh lap the swart starre sparely looks,

Throw hither all your quaint enammell'd eyes,

140 That on the green turf suck the honied showres,

And purple all the ground with vernall flowers.

Bring the rathe primerose that forsaken dies,

The tufted crow-toe, and pale gessamine,

The white pink, and the pansie freakt with jeat,

The glowing violet,

The musk-rose, and the well-attir'd wood-bine,

With cowslips wan that hang the pensive head,

And every flower that sad embroidery wears:

Bid Amaranthus all his beauty shed,

150 And daffadillies fill their cups with tears,

To strew the laureat herse where Lycid lies.

For so to interpose a little ease,

Let our frail thoughts dally with false surmise;

the least other thing

[thriving

concerns, matters to; successful, wish; poor, scanty; insipid, trivial thin, shrivelled

stealthy

bell-shaped flowers resort, frequent

shines little or not at all

of springtime

early

wild hyacinth; jasmine

flecked, variegated; jet, black

adorned

bring some relief to our grief

Ay me! whil'st thee the shores and sounding seas

Wash farre away, where ere thy bones are hurl'd,

112 mitred] The mitre is a bishop's headgear. The earliest bishop-like Church functionaries were Timothy and Titus. But as Christ entrusted his church to St Peter (Matthew 16.18), he might be considered the first bishop (of Rome). Remarkable for the Puritan Milton to invoke him. He seems to represent a lost, ideal bishophood, unlike the degenerate episcopacy he condemns in 113-31. His tirade recalls 2 Peter 2. $\quad 115$ Cf. John 10.1-2. 119 Blind mouthes] Episkopos (bishop) literally means 'one who sees' (supervisor), so blind indicates a sad failure of role. mouthes] suggests greed. 120 sheephook] the original of the bishop's crozier. The priestly metaphor of 'pastoral care' is prominent in this passage. $\mathbf{1 2 6}$ wind ... mist] i.e. empty rhetoric. 126-7 As in sheep-rot, a liver disease in sheep. 128 grimme wolf] the Catholic Church, especially its proselytizing agents the Jesuits: the arms of their founder, St Ignatius Loyola, include two grey wolves. 130 two-handed engine] Many explanations, none conclusive and some tenuous. Clearly a retributive mechanism, perhaps a version of the sword of God, esp. the two-edged sword of Rev.1.16, 19.15. at the doore] at hand, imminent. $\quad 132$ Alpheus] river in Arcadia, hence symbolic of pastoral poetry. $\quad 133$ Sicilian Muse] the pastoral muse: see Virgil IV.1. 138 swart starre] the dog-star Sirius, rising with the sun in the hottest summer. swart] blackened by heat. 139 enammell'd eyes] Flowers: a conceit going back to Sidney (New Arcadia, Bk.I, ed. Skretkowicz 11.1). $\quad 149$ Amaranthus] To which Watson's Amyntas was transformed in grief for Phillis: cited by Spenser, FQ III.vi.45. 151 laureat] adorned with laurels, befitting a poet. 153 false surmise] Imagined conceits, delusions - like the pathetic fallacy of weeping flowers, or simply the prospect of decking King's hearse with flowers, as his body was never found. 154 shores] cannot literally 'wash away' a body. Perhaps ?the sea bounded by shores; or ?currents, streams (cf. shore OED $\mathrm{n}^{4}$, a sewer or channel). The Trinity MS originally had 'floods'. 
Whether beyond the stormy Hebrides,

Where thou perhaps under the humming tide

Visit'st the bottom of the monstrous world;

Or whether thou to our moist vowes deni'd,

Sleep'st by the fable of Bellerus old,

murmuring, babbling

tearful prayers

160

Where the great vision of the guarded mount

Looks toward Namancos and Bayona's hold;

Look homeward Angel now, and melt with ruth,

And, O ye dolphins, waft the helplesse youth.

Weep no more, wofull shepherds, weep no more;

For Lycidas your sorrow is not dead,

Sunk though he be beneath the watry floore:

So sinks the day-starre in the Ocean bed,

And yet anon repairs his drooping head,

And tricks his beams, and with new spangled ore

Flames in the forehead of the morning skie:

So Lycidas sunk low, but mounted high

Through the dear might of him that walk'd the waves;

Where other groves, and other streams along,

With Nectar pure his oazie locks he laves,

And heares the unexpressive nuptiall song;

There entertain him all the Saints above

In solemn troups and sweet societies,

That sing, and singing in their glory move,

And wipe the tears for ever from his eyes.

Now, Lycidas, the shepherds weep no more;

Henceforth thou art the Genius of the shore

In thy large recompense, and shalt be good

To all that wander in that perillous floud.

Thus sang the uncouth swain to th' oaks and rills,

While the still morn went out with sandals gray;

He touch'd the tender stops of various quills,

With eager thought warbling his Dorick lay:

oozy, dripping (with sea-water); washes clean inexpressible

adorns; shining, glittering; ?gold

170

180

guardian spirit

large: generous, liberal

(a) untaught, rude

$[(b)$ unknown

(a) pipes, flutes (b) pens

And now the sunne had stretch'd out all the hills,

And now was dropt into the western bay;

At last he rose, and twitch'd his mantle blew,

To morrow to fresh woods and pastures new.

\section{CASimir SARbiewski Ode IV.21: From the Song of Songs} Translated from the Latin by George Hills

From The Odes of Casimire Translated by G. H. (1646). A remarkable amalgamation of Song of Songs 2.8-13 with the Horatian country ode. The translation follows the Latin fairly closely. Modifications are indicated in the notes. The nature-setting of the Song of Songs, an evocative background to Christ's wooing of his beloved, becomes an independent spiritual force here. As Røstvig observes: 'Nature woos man, just as Christ woos man. Nature, in this fashion, becomes Christ. The entire poem, barring the first two lines, is spoken by Christ to his beloved (the soul of man). ${ }^{\star}$

158 monstrous world] the sea, full of monsters unlike land animals. 160 Bellerus] an imaginary figure, invented (and rejected as a 'fable') by Milton as the spirit of Bellerium or Land's End. 161 vision] sight, spectacle; perhaps St Michael, who appeared in a vision to the monks on St Michael's Mount, according to Camden. guarded mount] St Michael's Mount, near Land's End, which had both a monastery and a fortress (hence guarded). $\quad 162$ Namancos] Nemancos, the ancient name for a district in north-western Spain. Bayona] a fortress town in Spain. hold] fort. These refs. hint at the threat to England from Spanish Catholicism. 163 homeward] facing inland. Angel] St Michael. 164 dolphins] In ancient belief, dolphins transported the souls of the dead to the next world. Also, the musician Arion was rescued from drowning by dolphins. 173 dear] (a) glorious, noble $\left(O E D_{1}\right)(\mathrm{b})$ precious $(O E D$ 4). him that walk'd the waves] Christ: Matthew 14.25, Mark 6.48, John 6.19. 174 other groves] i.e. in heaven. 176 nuptiall song] celebrating the 'marriage' of the blessed soul to the Lamb or Christ (Rev.19.7-9). The whole passage is full of echoes of Revelation. 177 entertaine] receive, welcome $(O E D$ 12). $\quad 183$ recompense] for his untimely death. 188 Dorick] pastoral. Theocritus wrote in the Doric dialect. 189 stretch'd out all the hills] by casting long shadows. 191 twitch'd] drew tightly around him (OED 6). blew] the colour of hope. ${ }^{\star}$ Maren-Sofie Røstvig, The Happy Man: Studies in the Metamorphoses of a Classical Ideal, vol.1, 2nd edn., Oslo: Norwegian Universities Press, 1962 , p.126. 
Out of Salomon's sacred marriage song.

My beloved spake and said unto mee, rise up my love, my Dove, my faire one, and come away; for loe the winter is past, the raine is over and gone: the flowers appeare on the earth, the time of singing of birds is come, and the voice of the Turtle is heard in our Land. The figtree putteth forth, etc.

Turtle turtle dove

Doe I mistake? or from Elyzium cleare

bright, luminous My life's call doe I heare?

Sister arise, and harnesse thy sweet paire Of Doves, thy selfe more faire;

Mount and drive hither, here let thy Chariot stop, From Libanus hye top;

At thy approach the falling showres doe fly,

vanish, cease Tempestuous stormes passe by,

The lightning's quench'd under thy harmlesse feet,

sinless

While in the sacred Green, a bow're we see Doth spread it selfe for thee.

The Earth new Turffs it selfe for thee to tread, The straying starrs fresh fields make glad.

Here with their dams, of Kids th'amazed flocks Hang on steep sides of Rocks;

Here as they swim, the wanton Hinds do play In the coole streames all day.

The Lion with the Libard downe is l'ed Tame and well governed;

Each with his Lamb about the Mountaines skip, O're Hills they lightly trip.

By these a spacious brooke doth slowly glide, Which with a spreading tyde

Through bending Lilyes, banks of Violets From th'hollow Pumice sweats.

The rivers gently flow, and a still sound From mossie Rocks doth bound.

The sporting fish dance in the christall Mayne, The Birds sweetly complaine,

The ayre, if dolefull comforts please, doth ring with mournfull murmuring.

For when the Doves eccho each other's cry That sound doth hither fly.

As they with widowed notes themselves do please, Just so, our joyes increase.

No want appeares; th'officious Vine doth stand With bending clusters to our hand.

Here, thou shalt pick sweet Violets, and there Fresh Lillyes all the yeare:

The Apple ripe drops from its stalke to thee, From tast of death made free.

The luscious fruit from the full Figtree shall Into thy bosome fall.

3-4 paire Of Doves] Assimilates the biblical beloved to Venus, whose chariot was drawn by doves. 6 Libanus] the Lebanon mountains. 7 falling showres] Lat. has 'the footsteps (traces) of clouds'. 11-12 Lat. has 'a pavilion [scena] appears beneath your tread'. 14 straying starrs] flowers, like stars that have strayed to earth. 17 Hinds] Lat. has hinnulei, young stags. The biblical 'roe or a young hart', used as comparisons for the beloved, become actual animals. 19-2o Lat. has 'The lion with the leopard, king of the green Senirian mountains, both [made] mild'. Senir occurs in Song of Songs 4.8, in the context of 'the mountains of the leopards'. 19 The Lion with the Libard] Isaiah 11.6. 21 Each, his] the lion and leopard: in Isaiah 11.6, they consort with lambs, kids and calves. 25 Lilyes] Lat. hyacinthos, which could also mean the fleur-de-lys. $\quad \mathbf{2 6}$ springs from the volcanic rock. 27 still] soft, subdued $\left(O E D_{3}\right)$. 29 Mayne] properly the sea, but here obviously the river. 30 complaine] sing mournfully. Cf. the mournful overtones in the next few lines. 39-40 Lillyes] Lat. mentions the 'white-fingered privet'. 41-4 Anticipates Marvell's 'The Garden' 33-8, written a few years later. $\mathbf{4 2}$ Lat. is more reticent: 'the (taste of its) earlier juice now forgotten'. This is the fruit of innocence, as before the Fall. 
Meane while, the Vine no pruning knife doth know, The wounded earth no plow.

The Corne growes green alone, and th'unhurt land

Doth white with harvest stand.

The grasse affords a stately bed, the Plane Spreads thee to entertaine.

Arabian mists sweat from the gummy tree Of Balme, and all for thee;

Which through the ayre, a rich perfume doe throw, Fann'd with each neighb'ring bough.

Arise my Sister deare, why dost thou stay, And spend th'unwilling day?

Behold thy harness'd Doves, at thy delay Doe sigh, come, drive away.

Put on, and hither drive thy beauteous paire Of Doves, thy selfe more faire.

magnificent, luxurious play host, offer comfort

tedious, dragging on

\section{Casimir Sarbiewsit The Praise of a Religious Recreation Translated from the Latin by George Hills}

From The Odes of Casimire Translated by G. H. (1646). Casimir's Epode III is a palinode or response to Horace's Epode II, matching its structure but introducing a pronounced religious and philosophical note. As generally in Casimir, Neoplatonic and Hermetic elements infuse traditional Christian doctrine.

\section{A Palinode}

To the second Ode of the booke of Epodes of Q. H. Flaccus.

The praise of a Religious Recreation.

Ode 3. Lib[er]. Epod[on].

But Flaccus, now more happy he appeares,

Who, with the burthen of his cares,

Farre off hath left his father's ground, set free

From the fierce wrangling Lawyer's fee;

No scorching heat, nor blasts of Winter Jove,

Doth hurt his fruit, or him can move:

Hee shuns all strifes, and never doth resort

trouble, perturb frequent, haunt

The sinfull gates o'th' greedy Court.

But either doth bewayle those dayes and nights,

Lost by him in prophane delights;

Or else retyr'd, strives to collect and find

The dispers'd flock of 's wandring mind;

Having first fairly pois'd the recompence

And gaines of a good conscience.

At evening, when the harbinger of night

The torches of the sky doth light,

45-8 As in the Golden Age, when the earth brought forth crops without tilling. 46 wounded] proleptic: the earth that was later wounded (by the plough). 47 growes green] over-literal rendering of 'virent' - grows green, but also simply 'flourishes'. alone] by itself, without tending. unhurt] not wounded by the plough. 49 Plane] ?plain; ? plane tree. $\quad 51-2$ gummy tree Of Balme] the balsam. Lat. has 'The balsam, whose bark can be cut without injuring it, exudes a Panchaian vapour.' (Panchaia, a fabulous island credited with jewels, incense and other riches). and all for thee] Not in the original. 53 a rich perfume] Lat. specifies nuptial perfume, genialis odor. 58 sigh] The Lat. is stronger: 'bewail, lament' (ingemuere). 6o Lat. directs this call to a 'foreign' or 'exotic sister', Hospita ... soror. See 3-4n. o.1 Palinode] A religious reversal or recantation of a secular (especially amorous or erotic) poem, or a Christian reversal of a pagan poem: here the latter with respect to Horace's Epode. $\quad \mathbf{0 . 3}$ Translates Lat. Laus otii religiosi, 'Praise of Religious Otium' (roughly, pious leisure). 1 Flaccus] Horace (Quintus Horatius Flaccus). now] in Christian times. more happy] than the man at the start of Horace's Epode II: Beatus ille, 'Blessed or happy the man'. 2-3 Unclear translation: the countryman possesses his paternal land free of cares. 5 blasts of Winter Jove] winter thunderbolts (after Horace, Epode II.29). Jove (Zeus, Jupiter) was the god of thunder. 12 Interesting use of a pastoral metaphor within a literal pastoral setting. 15 harbinger] One who goes before an important person to make the place ready: here, lighting lamps (stars) at the approach of night. 
How he admires th'immortall rayes breake forth, And their bright Orbes, more large then earth; than

How through his trickling teares, he helps his sight Unto the open Courts of light,

Which with thy selfe, ô Christ, thy selfe in pray'r He'Adores, t'Eternall life an heire!

The Starres with golden wheeles are hurried by, And let their prostrate exile lye,

Over whose face, the plenteous teares doe stray, Which chase all drowsie sleepe away;

Assoone as Phoebus head begins t'appeare, Lately in Indus streames made cleare,

From depth of soule, lesse then himselfe he lies, And bends the angry pow'rs with cryes:

Or when the Sun shines cleare, the aire serene, And Aprill Festivals begin,

His eyes, so us'd to Heaven, he downe doth throw, On a large prospect here below:

He views the fields, and wondring stands to see In's shade the shining Deitie.

See how (saies he) each herb with restlesse leaves To th' starres doth strive and upward heaves:

Remov'd from heaven they weep, the field appeares All o're dissolv'd in pious teares:

The white-flowr'd Woodbine, and the blushing Rose Branch into th'aire with twining boughs;

The pale-fac'd Lilly on the bending stalke, To th'starres I know not what doth talke;

At night with fawning sighes they'expresse their fears And in the morning drop downe teares.

Am I alone, wretch that I am, fast bound And held with heavy weight, to th'ground? Thus spake he to the neighbouring trees, thus he
To th'Fountaines talk'd, and streames ran by,

And after, seekes the great Creator out By these faire traces of his foot.

But if a lightsome Country house that's free From care, such as Luciscus' be,

Or Nemicini's, if Besdan's fruitfull field Can Grace to his rude table yeild,

To his plaine board with country dainties set, In August's dry and parching heat;

Even at his dore, under a private shade By a thick pleasant Poplar made,

Provision of all sorts expect their guest: A shell with salt, pure and the best,

New bread, for which, 'midst the thin bryars, the Mayd Picks Strawberries, and's gladly payd.

Cheese newly press'd. Close by, the friendly Cann

abject, downcast i.e., dew

trail, steps merry, cheerful

secluded

19 trickling teares] presumably of emotion or rapture: cf. 25.

linquunt exulem 'And leave behind the sluggish exiled pers, 24 Unclear translation of Pigrumque linquunt exulem, And leave behind the sluggish exiled person' - i.e. the spiritual-minded country(I.78) notes that the stars stand for the 'Platonic or Hermetic ... world of pure mind'. 28 Indus] The rising sun is imagined to have bathed in this eastern river. The original also names the Ganges. 29-30 He humbles himself from the depth of his heart, and placates the powers of retribution with his tears. 30 bends] makes relent. 35-50 Hermetic note particularly strong in these lines. 35-6 shade ... Deitie] Contrast added by translator. 37-44 i.e. The flowers originally grew in heaven and are anxious to return there, hence they reach upward with their petals. 52 Recasts Virgil, Georg. II.473-4: Astraea the goddess of justice planted her last footsteps among shepherds and countrymen, before leaving the corrupt world after the Golden Age. 55 Nemicini] possessive of Lat. Nemicinus. Emended to Nemicin's by Fordoński and Urbański. Luciscus and Nemicinus may be real persons, perhaps Casimir's associates. Besdan] ?Bezdan, in present-day Serbia. 6o pleasant] suggesting a 'pleasance', a secluded part of a garden. 65 Cann] vessel (holding drink). The original mentions an amphora or two-handled jug. 
With Cup cleane wash'd, doth ready stan'.

With me the Lucrine dainties will not downe,

The Scare, nor Mullet that's well growne;

But the Ring-dove plump, the Turtle dun doth looke,

Or Swan, the sojourner o'th' brooke;

A messe of Beanes which shuns the curious pallet;

The cheerfull and not simple sallet;

Clusters of grapes last gathered, that misse

And nothing owe to th'weighty presse.

Then after noone he takes a kind of pride

To th'Hills to walke, or River side,

And 'midst the pleasant Okes, a shade doth find,

T'avoyd the blasts o'th' Southern wind;

To th' darksome shore, by the deep poole he goes,

And through, with nimble Boat he rowes;

Sometimes the sporting fish, his baite thrown in,

Hee plucks up with his trembling line.

Meane while th' spacious woods with ecchoing note

Doe answer to the Bulls wide throat,

The shady rivers bleat; the Nightingale

I'th' bushes chirps her dolefull tale.

With's hastning pipe the sheapheard drives away

His flocke, which through the thickets stray:

To which as from the field they passe along,

Each mower sings by course, his song;

O're yeilding furrowes, carts full press'd with corne

Groane, and are like to breake the barne.

Our worke once done, we doe not silent sit,

When knots of our good fellowes meet;

Nor is our talke prolong'd with rude delay;

In harmlesse jests we spend the day;

Jests dip'd in so much salt, which rubbing shall

Onely make fresh our cheeks, not gall.

If that rich churle this had but seen, when hee

A Country man began to be,

The money which i'th' Ides hee scraped in

Next month hee'd not put out agen.

salt: wit

cheering, gladdening; salad lately, freshly;

call, voice

in turn seem as though they will

\section{Thomas Carew The Spring}

First published in Carew's Poems (1640). A popular poem, also found in many mss.

Now that the winter's gone, the earth hath lost

Her snow-white robes, and now no more the frost

Candies the grasse, or castes an ycie creame

Vpon the silver Lake, or Chrystall streame:

frosts over, coats with ice

But the warme Sunne thawes the benummed Earth,

And makes it tender, gives a sacred birth

To the dead Swallow; wakes in hollow tree

67 Lucrine] from the Lucrine Lake in Campania, famous for its oysters. 68 Scare] the scarus or parrot-fish: OED 1st cit. 1706. 69 Lat. has 'The wax-coloured ring-dove and dark turtle-dove'. looke] ?to be expected (cf. OED 3c, 6g) or ?sought (cf. OED 6d, though this active use of the verb is not recorded). $\quad 71$ shuns] Unusual reversal, as in Lat.: the food shuns eaters. curious pallet (palate)] fastidious taste. $\quad 72$ not simple] i.e. a mixture of many herbs. $73-4$ The grapes are served as fruit, not pressed into wine. 73 misse] escape, do not end up in (the wine-press). The original talks of a heaped serving-dish which 'owes nothing to the market' - i.e. contains only home-grown produce. $\mathbf{8 5}$ bleat] As with Lat. balant, unusual for the murmur of a river: not in OED. $\mathbf{8 6}$ her dolefull tale] Of Philomela's rape by Tereus, whereupon she was turned into a nightingale. 87 hastning] hurrying (the flock) on: not in original. 99 that rich churle] The money-lender Alfius in Horace's Epode II, who praises the country but immediately returns to plying his trade in the city. 101 Ides] a date in the middle of each month in the Roman calendar. $\mathbf{6}$ sacred birth] The migrating swallow was anciently thought to lie in its nest all winter as though dead, and revive in the spring. It was therefore held sacred: Dunlap cites Thomas Browne, Pseudodoxia Epidemica 5.23.3. The mss read simply 'second birth'. 
The drowzie Cuckow, and the Humble-Bee.

Now doe a quire of chirping Minstrels bring

In tryumph to the world, the youthfull Spring.

The Vallies, hills, and woods, in rich araye,

Welcome the comming of the long'd for May.

Now all things smile; onely my Love doth lowre:

Nor hath the scalding Noon-day-sunne the power,

To melt that marble yce, which still doth hold

Her heart congeald, and makes her pittie cold.

The Oxe which lately did for shelter flie

Into the stall, doth now securely lie

In open fields; and love no more is made

By the fire side; but in the cooler shade.

Amyntas now doth with his Cloris sleepe

Vnder a Sycamoure, and all things keepe

Time with the season, only shee doth carry

Iune in her eyes, in her heart Ianuary.

\section{Thomas Carew To Saxham}

From Carew's Poems (1640). Saxham in Suffolk was the home of his friend Sir John Crofts.

To Saxham.

Though frost, and snow, lockt from mine eyes,

That beautie which without dore lyes,

Thy gardens, orchards, walkes, that so

I might not all thy pleasures know;

Yet (Saxham) thou within thy gate,

Art of thy selfe so delicate;

So full of native sweets, that blesse

Thy roofe with inward happinesse;

As neither from, nor to thy store

Winter takes ought, or Spring addes more.

The cold and frozen ayre had sterv'd

Much poore, if not by thee preserv'd;

Whose prayers have made thy Table blest

With plenty, far above the rest.

The season hardly did afford

Course cates unto thy neighbours board,

Yet thou hadst daintyes, as the skie

Had only been thy Volarie;

coarse; victuals, food

Or else the birds, fearing the snow

Might to another deluge grow,

The Pheasant, Partiridge, and the Larke,

Flew to thy house, as to the Arke.

The willing Oxe, of himselfe came

Home to the slaughter, with the Lambe,

And every beast did thither bring

Himselfe, to be an offering.

The scalie herd more pleasure tooke,

Bath'd in thy dish, then in the brooke.

Water, Earth, Ayre, did all conspire,

30 To pay their tributes to thy fire,

Whose cherishing flames themselves divide

Through every roome, where they deride

The night, and cold abroad; whilst they

indoors

pleasing

belonging to the place; pleasures, delights

Like suns within, keepe endlesse day.

Those chearfull beames send forth their light, 
To all that wander in the night,

And seeme to becken from aloofe,

afar

The weary Pilgrim to thy roofe;

Where if refresh't, he will away,

Hee's fairly welcome, or if stay

Farre more, which he shall hearty find,

Both from the Master, and the Hinde.

The strangers welcome, each man there

servant

Stamp'd on his chearfull brow, doth weare;

Nor doth this welcome, or his cheere

Grow lesse, 'cause he staies longer here.

There's none observes (much lesse repines)

How often this man sups or dines.

Thou hast no Porter at the doore

T'examine, or keep back the poore;

Nor locks, nor bolts; thy gates have bin

Made onely to let strangers in;

Vntaught to shut, they doe not feare

To stand wide open all the yeare;

Carelesse who enters, for they know,

Thou never didst deserve a foe;

And as for theeves, thy bountie's such;

They cannot steale, thou giv'st so much.

\section{William Strode On Westwell Downs}

From Strode's autograph ms in Corpus Christi College, Oxford. Strode was a member of Oxford University; this poem presents the surrounding countryside.

When Westwell downes I gan to treade

Where cleanly windes the Greene doe sweepe,

Methought a Landskipp there was spred Here a bush and there a sheepe.

The pleated wrinkles on the face

Of waue-swoln Earth did lend such grace

As shaddowings in Imagrie

Which both deceaue and please the Eye.

i.e., grass blown by the wind shading (in painting)

The sheepe sometimes doe treade a Mase By often winding in and in,

welcome offered to the stranger

unworried

And sometimes rounde about they trace,

Which Milk-maides call a Fairy ring.

Such Semicircles they haue run,

Such lines acrosse soe trimly spun

That sheapheards learne whenere they please

A new Geometry with ease.

The slender foode vpon the downe

As allway euen, allway bare,

Which nether spring nor winters frowne

Can ought improue or ought impayre.

Such is the barren Eunuchs chin

Which thus doth euermore begin

With tender downe to be orecast

Which never comes to hayre at last.

39 if ... away] If he wishes to leave after refreshing himself. $\quad 40$ if stay] i.e., If he wishes to stay. 3 It looked like a painted landscape. 7 Imagrie] 'The pictorial elements of a natural scene or landscape' $(O E D 7) . \quad 9$ treade a Mase] tread out the shape of a maze by their winding movements. $\quad 10$ in and in] 'further and further in' $(O E D)$. 12 Fairy ring] A circle of grass differing in colour from the rest: caused by fungi, but here ascribed to the movements of sheep. 
Here and there two hilly Crests

Amidst them hugg a pleasant Greene

And these are like two swelling brests

That close a tender Vale betweene.

Here could I reade or sleepe or play

From early morne till flight of day

But harke! a Sheepe-bell calls me vp

Like Oxford Colledg bells to supp.

\section{Thenot's Aвode}

One of three poems (all unascribed) featuring the shepherd Thenot, found in BL MS Harley 6917, a miscellany from early and mid-17-c. Printed here for the first time. Initial capitals standardized.

Thenots Abode:

Come neere and view my pallace how it stands,

Not built by Architects more curious hands,

Noe parian stone here sweates to be

The subiect of mans gorgeous vanitie.

The watry sedge,

And relicts of each hedge

With Cobwebbs interwoven make my Canopy:

remains, scraps, salvage

Why then alas doe mightiest potentates

Robbe wretched silkewormes to adorne their states?

The proudest and exaltedst prince

When struck by death, he goes away from hence

To dwell below,

May he this warning know,

Wormes from his liuelesse corpes will haue their recompence:

What though my weake built roofe be ouerthrowne,

And by some tempests from its rafters blowne,

So that whole cloudy stormes of rayne

Upon my mossy pillow powre amayne,

I shall not keepe

Accompt, how much I weepe,

Since with my teares I doe a fresher water dreyne:

pour

Nor shall I want my change of coverings,

The worst outvyes the greatest wealth of kings,

The best in natures Cabinett.

In cloudy nights my house is arched with Jeatt,

Otherwise then

When starres appeare agen,

My Canopy with twinkling spanglets is besett:

Nor is my mother Earth so base and poore,

But she can furnish me a gratis floore;

What need I be so curious then

To search in marble bowelld quarries, when

(a) eager, painstaking (b) probing, inquisitive From basest Earth

The richest tooke their birth,

My floore then which I spurne is the same mould with men:

What need I then that costly farre fetcht meate

Which greedy gluttons so delight to eate?

I can be well content

2 curious] skilful, expert $\left(O E D_{4}\right) . \quad 3$ parian stone] the renowned white marble of the island of Paros. sweates] toils, labours: metaphor from the actual 'sweating' of stones in a moist atmosphere. 14 recompence] ?gain, reward; perhaps with a sense of the proud man meeting his due end. 32 marble bowelld] marble-bearing. $\quad 35$ the same mould with men] God formed man from the dust of the ground (Genesis 2.7). 
With whatsoere brings with it nourishment;

$$
\text { I digge, and straight }
$$

Finde rootes, my chiefest Cate,

And would men neuer digged for worse intent:

What doe I care grapes lushious Iuice to swill?

Water will serue t'inspire my humble quill,

Wine Kings doth disenthrone,

From Kings it makes them men, from men makes none;

My water can

Quench thirst, make me more man,

While my owne King, I sitt upon some mole-hills Throne:

My sheepe and I, poore sheepe of humble swayne

Take our repast upon the verdant plaine;

If any doe offend

To them my curtayld messenger I send, Who for th'offence

Pay fleecy recompence,

Whose Innocence, and wooll me from all stormes doe shend:

protect

Yet doe I neuer mulct so cruelly

As to adiudge them by my knife to dye,

They too too simple be

To doe such crimes as men commit we see,

$$
\text { Nay I should hate }
$$

My selfe as one Ingrate,

To take all heate from them, which earst gaue heate to me:

If then my Chlorin will but be content

To liue with me in pleasing banishment,

I then of force must doe

What I reiected, and haue dainties too, Come graunt my blisse

punish

sentence like a judge

Make paradise of this;

Then I noe more shall grieue, then I noe more shall wooe.

pleasures

\section{All Hail to Hatfield}

The first of two 'Hail to Hatfield' poems, opening a group of poems about Hatfield House that form part of a ms now in the Brotherton Library, Leeds University. Hatfield in Hertfordshire was the site of a bishop's, and later royal, palace where Queen Elizabeth spent much of her childhood. James I presented it to his chief minister Robert Cecil, First Earl of Salisbury, who built a new stately home on the site, opened in 1611. This poem by an unknown author, from the time of William Cecil the second Earl, is a very elaborate example of a country house poem, modelled on and alluding to Jonson's 'To Penshurst'. Stanza division, punctuation and line-initials regularized.

\section{His first all Hayle to Hatfeild}

Should Cronicles wherein thy founders name

Stands like a statue in the house of fame,

Should all records into one flame bee turn'd,

All historie, by chance or enuie burn'd,

Should after tymes hold in suspition

What they receiue from graue Tradition,

Should memorie decay and letters bee

Henceforth forbidden to posterity,

Yett whilst the world retaynes but judging eyes,

Hatfeild shall speake him most profound, most wise. pronounce, declare

42 for worse intent] i.e. for gold or other precious metals. Cf. Ovid, Met. I.138-40. For the contrast with roots, cf. Shakespeare, Timon of Athens 4.3.23-45, prob. predating this poem. 44 humble quill] pastoral verse: challenging the common premiss that wine unlocks poetic inspiration. 46 makes none] i.e. dehumanizes them, makes them beasts. 53 curtayld messenger] his dog. curtayld] with tail cut or docked. 66-7 In her company, I will lead the life of pleasure that I had hitherto rejected. 70 wooe] (a) court, offer love to (Chlorin) (b) seek, strive for reward (in a more general senset. 9781526143426 
Tis not a mightie pile or costly guilding,

Nor yett the antique fashon of a building That speakes the owners wisdom; to bee neate

(Which is a better praise then to bee greate)

Is not enough: the builders arte is knowne

Euen in the laying his foundation stone.

Houses like bodies, if compleate they bee,

Must in a proportionable degree

Inioy of euery Elament a share.

Ayre thats too cold is too congelatiue,

Catarrhes and Asthmas there too much doe thriue;

Or if too hott, it doth relaxe the joynts

And weaken the faculties in all poynts.

If it bee moyst, it too much lenifies,

Causeth distillations, Cramps and palsies.

softens
discharges, catarrhs

But thy ayre, Hatfeild's, like the breath Aurora

In Sommer mornes sucks from the lipps of Flora.

Thy winds are gentle, calme, as pure, as thinn,

As that the god of wynds desended in,

When hee with mortall man was dayn'd to talke;

Thy Euenings coole, as when hee pleas'd to walke In quest of that most disobedient paire

Whose fall corrupted had both earth and ayre.

When Phebus to the South his hott carr brings And flaming Squibbs att Sweating mortalls flings,

the sun-god; chariot

When neighboring swaynes forsake the feilds and run

To hide them from the furie of the Sun,

When other Sheepheards fly to shadie trees,

Hatfeild doth neuer want a cooling breese

That from the west or north with gentle gale

Kisses each blushing cheeke, makes them looke pale.

Coole winds about thy dores and windowes play,

And with theire downy wings all heates alay.

Thou neither art too moyst, too hott, too dry,

Nor yett more cold then serues to rarifie

Corrupted bodies, if any such appeare

thinn: clear, delicate

deigned, graciously inclined

From other partes, for noe such are bredd here.

Thy founder, Hatfeild, had not dyde if hee

Had bine begott, or borne, or bredd in thee.

But my prophetick soule bidds mee proclame

Hee still shall liue here in his honord name.

This world to eternity shall giue place

Ere Hatfeild want an Heyre of that blest race.

Here could my locund muse for euer soare,

In this ayre dwell, desend to Earth noe more,

For whilst about thy towers thus shee houers,

19 euery Elament] The following stanzas describe Hatfield's advantages with respect to air, fire, earth

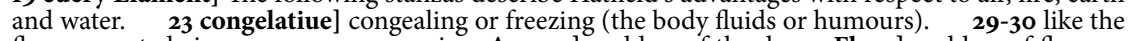
flower-scented air on a summer morning. Aurora] goddess of the dawn. Flora] goddess of flowers. 32 god of wynds] In classical myth, Aeolus. Here the Christian God talking to Adam and Eve in Paradise (33-6) after the Fall of man (Genesis 3.8); but the deeper implicit comparison is with Paradise before the Fall. $\quad 38$ Squibbs] a kind of burning missile or explosive. 43 gale] (poetical for) gentle breeze $\left(O E D\right.$ gale $\left.\mathrm{n}^{3} \mathrm{~b}\right)$. $\quad \mathbf{5 1 - 2}^{-2}$ Again implying a paradisal state, free of the mortality associated with the Fall. 57-62 A state akin to ecstasy, when the soul leaves the living body. The poet thus approaches the state of the 'intelligences', spiritual or angelic beings of a mental order superior to human reason. 
Whose purenes cannot bee exprest by tongues.

Such sweete breath'd prayers, carried by perfum'd winds,

Arising from such soules, such harts, such mynds,

Such pure white doues, wing'd with such Innocence,

Each bredd in the Arke of a cleare conscience,

Such sighes of true repentance ryding post

chamber, vessel

To fetch downe blessings from the god of host,

As now me thinkes I hang in clouds of smoake,

Stuft with such woole as made Elias cloake.

This cloude to heauen from Hatfeild hourly flying

Shall euer keepe thy ayre from putrifying.

Thou hast a Temple, Hatfeild, soe well built,

Soe pure an Alter, Candlesticks soe guilt,

Gods house thou hast soe deckt, adorn'd soe well,

As hee with thee and thine must euer dwell.

But I must whistle downe my muse and try

How shee among thy woods and groues can fly.

It is thy Scituation I should blaze-on

Thy other beauties are too bright to gaze-on.

blazon, describe poetically

travelling swiftly, like post-horses

Since then thy Ayre's soe cleare, soe pure, soe good,

Fyer, or fyers best materiall, wood

Is next to bee preferd, for knowe that heate

That wants it, bee't neare soe faire soe greate,

Is like a rich lanthorne in a smoakie hall,

Or curious pictures hung on a naked wall.

For as the blood in bodies life mayntaynes,

And beautifies the Temples, Cheekes and vaines,

Soe wood is life and ornament: Trees grace

A house, as hayre the head or face.

Nor ought wee prise good water att less rate:

Tis noe less vsefull, doth noe less ornate.

Edens imbroderie of trees consisted,

The skirts and borders were with riuers twisted.

considered

ne're, never

(otherwise) ?gloomy, dark

elaborate, finely painted

prize, value

wreathed, interwoven

Earth, on whose back howses are erected,

The quallity of that should bee respected.

For nature her best treasure euer locks

Either in barren hills or fruiteles Rocks,

In gaudie meads her gold shee neuer hords.

(Rich outsides, seldome pretious mynds affords.)

The parents of deseased Mists and foggs

Deriue themselues from Marshes, fenns and boggs,

Whilst health and pleasure, for which wisemen build,

Are the blest issue of the barren feild.

Thy eare then Hatfeild lend, whilst my muse sings

Of those thy pleasant groues, thy woods, thy springs.

Had famous Johnson but thy Limeyard seene

In that his progress, Pentshurst had not beene

Soe much as nam'd: noe noe, his muse had stroue

To gett thee for his mistris, for his loue.

Hee would haue hung each bow, each twig, each tree

With Songes and Sonetts made in prayse of thee;

65 doues] Suggests the Holy Spirit, as Innocence suggests the prelapsarian state. 69-70 Combines references to the prophet Elias or Elijah translated to heaven in a whirlwind (2 Kings 2) and his appearance at the transfiguration of Christ (Matthew 17.3 etc.). His cloak or mantle figures in 2 Kings 2.8, 13-14, though not as the agent of his translation. 73 Temple] the chapel at Hatfield House, or a metaphor for its spiritual state. 77 whistle downe] set off, activate like a falcon sent after prey with a whistle of command. $\quad \mathbf{8 2}$ Of the four elements (19), fire is obviously hardest to link to an extant building. Hence the poet treats of its ingredient, wood, and hence the woods around the house. 90 Metrically short. A word may have dropped out in transcription. 107 Limeyard] ?grove of lime or linden trees. 107-8 Johnson] Ben Jonson. his progress] his 1618 journey to Scotland. Penshurst] See Jonson's 'To Penshurst' (no.191). 
The euer honor'd Sydney, soe much famde, His sweete Arcadian Sceane att Hatfeild framde. The winged Pegasus here found the well, And here the muses all the Sommer dwell.

Whoe with the early larke salutes the morne, he who Saluted is againe from euery thorne By feathered queresters, that to the day choristers Bidds kind good morrow with some Roundelay. The nightingale awakes the sluggard Thrush, The Robin redbrest flyes from bush to bush, And being euermore a freind to men, The chanting blackbird and the Chirping wren Hee carefully doth summon to the Quire, Thus all the day each tree, each bush, each brier Affords those times for which the gods doe call Att euery tryumph, euery festiuall; And whoe in musick hath a judging Eare Must needs confess theire notes more sweete, more cleare, More strong, more shrill, then birds els where declare, Which much approues the purenes of the ayre.

The malancholy man that dearely loues

The vnfrequented pathes, the sylent groues, That noe companion likes, noe walking mate, But what hee caryes with him in his pate, May in thy verge each hower, Hatfeild, find A walke that strainger is to Sunn or wind, Where well cloath'd oakes shall serue him for a skreene, And neither lett him see nor yett bee seene.

There shall hee find fitt obiects to intice His labring soule the way to Paradice: A posting streame that tells him here's noe byding, rhythms, hence type(s) of [music Man to the graue as it to'th Sea's still glyding: Now as in armes the flowry bankes it lockes, And in a moment beaten is gainst rocks; Now through pure earth it runs, but strayte's saluteth With mudd, and flaggs, and Seadge, and things polluted. Such is mans passage through this fickle world, Now hee imbraces pleasure, strayte hee's hurld Vpon a Thousand daingers, and att last, Into the Oceans gulph, the graue, hee's cast.

A bedred Oake theire on his stumps doth sitt, And on his shriueld Barke perhaps is wrytt Three hundred yeares, yett tyme, and blasts, and stormes, Converted hath his gaudie leaues to wormes.

His head is bald, his limmes are growne with mosse, His sapp is turn'd to dust, his hart to dross. When sturdie oakes thus fall, what man goes by, And thinkes not of his owne mortallity? Such Emblemes euery well disposed mynd May in thy wildest walkes with pleasure find.

But least this humor should bee too much fed, Become adust, soe dangerous, hee's led By fine deceauing windings to some playne, Whose mantle is like that the Poetts fayne 
Flora putts on when with the spring she meetes,

Or Ceres when the god of wind shee greetes.

Here tyme, then whats more precious, wyldly groes:

There the hart cheering Cowslipp, here primrose,

There honisockles, and strawberries here,

As thick as Speckled dayses doe els where.

daisies

This playne is peopled with a heard of deare

Whose heads and hanches doe proclame what cheere,

Hatfeild, thy feilds affords, for in each flanck

A man may read that swete grass, not the ranck,

Commends the goodnes of the Soyle, the earth,

(Though feeding here bee short, yett heres noe dearth).

The Quinticence of things, not things in gross,

Growe here in euery feild, in euery closs.

close, enclosed field

Whoe sees a peece wherein the Paynter stroue

To faigne a landskip here, and there a groue,

painting

imitate (in art)

Here rising hills from whence his pencell brings

Into a neighboring Vallie diuers springs,

And in theire passage wyndinge many wayes

Here fashons out a moone, and there a maze:

Here in a Snakie forme hee makes them wind,

Till they haue shapte an Iland to his mynd,

In midst whereof hee drawes a hill or mountaine

On which is plact a quainte conceited fountaine;

Att this hills foote a wood as darke as night,

Where hee those streames a while sceales from your sight,

And makes them by straing pathes this mount to scale;

Then here hee drawes a Mearemaid, there a whale,

One from his mouth a Torrent seemes to spout,

And from the others breastes hee forces out

Two slender streames: here Niobe doth lye

And sends a weeping brooke from either eye,

And on the top hee faignes a tree to growe,

Whose euery leafe letts fall a kind of deawe,

And this by pipes from Cesterns hee convayes

Downe to the Vale, and thence a Thousand wayes

Hee makes theise new borne Riuers seame to trauell:

This glides on golden sands, and that on grauell,

This cutts out curious knotts, this figures makes,

Those in direct lynes run, and these like snakes;

Then hand in hand into a meade they glide

(Where fruitfull nature sitts in all her pride),

Where heauen and earth soe prodigall haue bine

As to expect more from them were a sin.

crescent

Here lyes a scrole, soe framde by'th' paynters witt,

It may be thought a bridge; on this is wrytt,

Mere Arte to nature yeilds, truely, confessing

Tis past the power of man to painte her dressing.

167 ?Flora at the coming of spring, her mantle being the spring flowers. She is not associated with any god of spring. 168 Prob. referring to fields of crops swaying in the wind. Again, no tradition linking Ceres, goddess of the earth and agriculture, to Aeolus, god of winds. 169 tyme] pun: (a) time, hence precious (b) thyme. $\quad \mathbf{1 7 8}$ The grass is not lush, but there is plenty of it. 179-80 Everything is so perfect that it seems to represent its Quinticence (quintessence, 'fifth essence' or core substance of being) rather than its crude material shape (in gross, compounded of all the elements). 182 landskip] landscape, ?a vista as opposed to the enclosed grove. Illustrates the new convention of aesthetizing a natural landscape in terms of a painting: implying either the human ability to design a landscape as wished (to his mynd, 188), in reality or imagination, or God's own identity as an artist, guided by human aesthetic principles. 193 straing pathes] as seeming to make the streams flow uphill. straing strange, ?straying $\quad \mathbf{1 9 4 - 2 0 7}$ May allude to the illustrated maps of the time, with figures representing natural features, or to actual landscape engineering and sculpture. The Hatfield gardens were laid out by the naturalist and horticulturist John Tradescant, who began life as gardener there. 197 Niobe] Her children were destroyed by Apollo and Artemis, and she herself turned to a rock that continued to shed tears: a common theme for fountain statuary. 213 Mere Arte to nature yeilds] Paradoxical, considering the poet's attempt to present nature in terms of art. But nature finally defeats all attempts to confine her in terms of art, which can only imitate her $(215-26)$. 
When such a peece you find with such a scrole, Knowe this (soe much transported) Painter stole His plott from Hatfeild Parke; but haueing trac'd Those streames along vntill they had imbrac'd

(Great natures maisterpeece) our Vineyard here,

Then this Art blusht: then, then it did appeare

That Arts but natures foole, her Ape, her zanye,

Not to bee painted to the life by any.

Then, then this scrole hee writt, and gainst a Tree

His pencell dasht, and left the rest to mee.

Vnder a bush this halfe done peece hee laid,

And then went hence, run madd, and quitt his trade.

And in this fitt about the Parke hee throes

His box of curious cullors, since here growes

Ten thousand painted flowers such as stayne

The gaudie Rayneboe, or the Peacocks trayne. The greate lord here payes for noe plants, no dressing:

Apolo waters, and god giues the blessing.

And now att last I find the Painters error,

Whence his distraction rose and whence his terror.

Twas not the Vineyards beauty that did craze him

(Though that alone I grant might much amaze him):

Noe, noe, the Vineyards goddess with her freind,

The farest Cinthia, there some howers spend;

The greate Commaundress of this blessed place,

Juno her selfe, was there; it was her face,

That face that many painters hath strock blind,

Was it that soe disturb'd the Painters mynd.

Nor doe I wonder much att his mistaking:

For nature, when a curious peece shees makeing,

When shee a matchless creature meanes to frame

By her owne Image, she creates the same:

'Twas natures best Idea then hee sawe,

Whose picture lett noe mortall striue to drawe.

The little springs that hee pursude soe fast

Vnto this Paradice made all that hast.

They fly from hills and poste them to this Vallie,

That in our Vineyard they may sporte and dallie.

Nor can I thinke those streames were much more cleare

That Eden had, then are the streames run here:

For in that curse that followed Adams fall,

The waters are not spoken of att all;

And if they scapte that sentence, then Ile sweare,

That theis in all poynts are as pure, as cleare.

Here needes noe grates to keepe the wantone trout,

For if they might they would not sure swim out.

The streames themselues doe many turnings make,

And murmor, when this place they must forsake.

Here one would seeme to glide away amayne,

But strayt you meete it posting back againe.

colour

i.e., mindless imitator

rapt, inspired
design, composition

madness

companion

Here they would euer weaue, and turne, and wind,

224 mee] the poet. It was then commonly held (though contested by, e.g., Leonardo da Vinci) that poetry, presenting ideas, was superior to painting, presenting material appearances. $231-2$ i.e. These are wild flowers, growing spontaneously. 232 Apolo] As Phoebus the sun-god, might be expected to provide light, not water. 237,240 goddess] prob. Catherine Cecil, wife of William, second Earl of Salisbury: Juno] as queen of the estate's 'god'. 238 Cinthia] prob. Lady Diana Maxwell (Cynthia being another name for Diana), Catherine's daughter-in-law. 246 By her owne Image] looking like the goddess Nature herself. There is no such prototype among extant beings, so she has to create it. $\quad 247$ Idea] in the Platonic sense: the ideal form or principle of Catherine's being, not her mere material body. 265-6 Each stream would stay for ever, if others did not crowd it out through jealousy (malice). 
But for theire malice crowde soe fast behinde:

For as att Tryumphs the multitude striue

?rivalry, competition

Which shall his fellow from a standing driue,

public processions

Euen soe theis Streames each other doe pursue

(Ambitious from theire birth) this place to vewe.

I will not say the tree of life growes here,

But health and pleasure, that comes something neare,

In Hatfeilds Vineyard cheefely doth abound,

In euery Arbor, euery walke is found.

To tell how richly euery banck is cladd,

Were with the frighted painter to run madd;

Or but to giue a taste of euery Tree

daunted, afraid to continue his

Would make you surfett, if not wearie mee.

The Persian Monarch in his royaltie,

When hee would showe most state, most Iollitye,

On noe such Carpetts eates as here are throwne

For wayting groomes to sitt or walke vpon.

They neither can come neare them for a story,

Nor equall them by farr in Pompe and glorie.

A strawberie here will hang the head and pine

And wither, because the creeping woodbyne

Clymbs higher vp and hangs more in the eye

Of theire great mistris (when she daynes walke by).

The primrose showes a kind of discontent

Because the violett hath a better sent.

deigns to

The full blowne rose his leaues letts fall and dyes,

Because a budd's more gratious in her eyes.

A cherry there his red cheekes turnes vnto her,

Blushes and dropps if that want power to woe her;

This a hart presents, which by Cynthia taken,

The next lookes pale, for greefe it is forsaken.

A kind of Emulation here is seene

Betwyxt the damsone and the damozene.

[work

The peare plum thinkes that hee shall weare the crowne,

But then the plum Imperiall putts him downe;

And whilst theis two doe thus contend for place,

The Apricock lookes out and getts the grace.

With him the red flesht Peach striues for the wall:

The Mallacottoone would bee best of all,

But then a Medler from a bush doth start

And pleads his holsomnes, though hee bee tart.

Att last the grapes looke bigg and put on state

And hope for grace, when all are out of date.

But see, presumption still with enuie meetes:

In the next bed in curious cutworke sheetes

scent

charming, attractive

heart, central part or flesh

competition, rivalry

Lyes the perfumde Muskmelloone, here Iuno stopps

(Att which the big swolne grapes declynes and dropps);

The bearded Raspace brisling by doth stand

And couetts with the rest to kiss her hand,

Whilst the poore gooseberry and little curront

Looke very sad, as if they would demur on't.

A thousand other fruites are here neglected

Which in another place would bee respected.

What stories fuller of morality

Finde you in Arras or in Tapestry?

Noe vncleane thing about it ere was seene,

268 from ... driue] oust from his position. 279 Persian Monarch] The context of gardens suggests Cyrus the Great (6-c. BCE), the legendary garden-builder. 281 Carpetts] i.e. lawns. 298 damsone, damozene (damascene)] two varieties of plum. 299 peare plum] a somewhat pear-shaped variety of plum. 304 Mallacottoone] melocoton, a peach grafted on a quince. 310 cutworke sheetes]
3 alluding to the shape of the leaves $\mathbf{3 2 0}$ Arras] tapestry, originally from Arras in France. Tapestries and cloth hangings were commonly adorned with mottos and scenes of biblical or moral intent. 
Vnless a Lawyer or a Cittizen, Whoe in that idle long vacation Doe crawle abroade for recreation, And here admitted, doe soe gluttonize That strayte the Marchant breakes, the lawyer dyes. But see, the Supreame lord of this blest place To meete his mistris here hath left the chace. Who see's them walke and enter conference, See's Eue and Adam in theire Innocence: About them birds doe fly and fishes swim (As if they would receiue newe names from him). Come downe, my muse, and with those Creatures meete, And cast thy first all Hayle at both there feete: There fynding grace, bee bould to say next flight Somethinge thou wilt produce shall bring delight. About faire Hatfeilds house next vse thy wing, Of it, and of the Chapell thou shalt sing, And from gods house, as next in place it lyes, The nursery Ile veiw with humble eyes.

There, there the Iewells are by which the giuer Proclaymes (blest payre) your names shall liue for euer: Those six small Cabonetts more wealth contaynes Then is in both the Indies, both the Spaynes. In those little volumes my soule deuines Gods finger wrytten hath a Thousand lynes. Which tyme, nor fate, nor malice cancell shall Till the great crack of Thunder Cancell all.

i.e., the Cecil children cabinets, jewel-cases discovers, discerns

\section{Sidney Godolphin(?) Tom ANd Will}

The first extant version (c.1655) of a popular broadside ballad. Also found in the collection Sportive Wit (1656). In Examen Poeticum (1693), ed. John Dryden, attributed to Sidney Godolphin, and Tom and Will identified with the dramatist Thomas Killigrew and William Murray, first Earl of Dysart.

Tom and Will. or, The Shepherds Sheepfold.

Both doated on a beautiful Lass, Both were alike respected;

Both thought themselves i'th better case, Both were at last neglected.

regarded, treated (by the lass) having the advantage

To a pleasant new Country Tune.

Tom and Will were Shepherds Swains, who lov'd and liv'd together;

When fair Pastora grac'd the Plains, alack why come she thither?

For though they fed two several Flocks, they had but one desire,

Pastora's eyes, and amber locks, set both their hearts on fire.

Tom came of honest gentle race, by Father and by Mother,

Will was noble, but alas, he was a younger Brother.

322 Cittizen] city-dweller, especially a burgher or merchant (see 326). (b) turns bankrupt. $\quad 332$ Adam named all plants and animals in Paradise.

326 breakes] (a) collapses next poem - prob. the 'Second All Hail' that follows in the ms. 343 six] omitting the Cecils' eldest offspring, James, who died the year he was born. As the fourth child and second daughter Diana died in 1633, the poem must have been written before that date. 0.1 Tom and Will] Seems to indicate a new tune composed for this piece. 'The Shepherds Sheepfold' may be another tune, or an alternative name for the same one. 
Tom was toysom, Will was sad, no Hunts-Man, nor no Fowler,

merry, playful; serious

Tom was held the proper Lad, but Will the better Bowler.

The scorching flames their hearts did bear, then they could no longer smother,

Although they knew they Rivals were, they still lov'd one another.

Tom would drink her health and swear, this Nation will not want her,

Will would take her by the ear, and with his voice inchant her.

Tom keeps always in her sight, and ne'r forget his duty;

Will was witty and could write some sonnets on her beauty.

The second Part, to the same Tune.

Thus did she handle Tom and Will, who both did dote upon her;

For graciously she us'd them still, and still preserv'd her honour.

Yet she was so sweet a she, and of so sweet behaviour,

That Tom thought he, and Will thought he, was chiefly in her favour.

Pastora was a loving Lass, and of a comely feature,

Divinely good and fair she was, and kind to every creature.

Of favour she was provident, and yet not over-sparing,

She gave no less encouragement, yet kept them from despairing.

Which of these two she loved best, or whether she lov'd either,

'Tis thought they'l find it to their cost, that she indeed lov'd neither.

She dealt her favour equally, they both were well contented,

She kept them both from jealousie, not easily prevented.

Tale-telling fame hath made report of fair Pastora's beauty,

Pastora's sent for to the Court, there for to perform her duty.

Unto the Court Pastora's gone, it had been no Court without her,

Our Queen amongst all her train had none not half so fair abour her. 
Tom hung his Dog, and threw away his Sheep-crook and his Wallet,

Will burst his Pipes, and curst the day broke that e're he made a Sonnet.

Their nine-pins and their bowls they break, their joys are turn'd to tears;

'Tis time for me an end to make, let them go shake their ears.

\section{Francis Quarles The Shepherd's Oracle}

First printed separately as The shepheards oracle: delivered in an eglogue (1644), then as the eleventh and last eclogue in two of three editions of The shepheards oracles: delivered in certain eglogues (1646). A staunch Anglican and Royalist, Quarles pours scorn on the Puritans, especially the Separatists who would break from the Church and split the faithful into individual congregations. The basic theme is the ideal of good priesthood and a responsible church, using the metaphor of the shepherd as priest. Philarchus ('lover of the king') and Philorthus ('lover of the right' or the Anglican Church) share the same basic stand, though Philarchus pleads for strong action against the Puritans while Philorthus advises patience and tact. The speakers finally encounter Anarchus, the Separatist who would overthrow all authority. (He also appears in Ecl. VIII of The shepheards oracles.)

A note at the end of the 1644 volume states that Anarchus' song was already being 'nos' $\mathrm{d}$ by the Balad-singers about the streets of London, with some additions of their owne'.

Eglogve

Philarchus, Philorthus, Anarchus

Philarchus. Shepheard, ah Shepheard, what sad dayes have we

(More sad then these sad dayes) surviv'd to see!

How is the guilt of our forefathers crimes,

Revengd on us in these distracted times!

How is the Shepheards honour, that while ere

earlier, once

Shone like the morning Star; and did appeare

To all the world, like Heraulds to make knowne

Th' aproaching Glory of the rising Sun!

How is that honour dim! how is her light

Clouded in shades of Ignorance and night!

How is our Calling slighted, and that power

Our Master lent us, threatned every howre!

How are our worried Names become the scorne

Christ

Of every base Mechanick! rent and torne

In every vulgar mouth? reproacht and made

Delinquents, judgd by every triviall Trade!

How are our persons scornd, contemnd, revild,

Nay even by him whose schoole-instructed child

Jeeres at his ignorance; and oft by him

Whose sinking fortunes teaches how to swim

With zealous Bladders, being apt to steale

Advantage from the times, and trade in Zeale.

How are we growne the By-word of the land,

Commanded now, where late we did command!

Prest like a Vintage, banded like a Ball?

Despisd of many, and disprisd of all!

Philorthus. True my Philarchus; Shepheards never found

So hard a time; Ah fortune never frownd

So sterne till now; Presumptious Ignorance

Had nere till now the boldnesse to advance

Her beetle browes, or once to tread the Stage

Of this blest Island in so bright an Age.

2 More sad then these sad days] presumably thinking of the future. 8 Sun] punning on 'Son' (of God) or Christ, whom priest-shepherds should glorify. 14 Mechanick] artisan or manual worker. Separatists and other religious radicals belonged to the lower social orders. 16 triviall Trade] (practitioners of) a lowly occupation.

22 Zeale] a term often associated with Puritans. 
But ah! when Lights grow dim and dull, what hand

Can keep out darknesse? who can countermand

The melancholly shades of ugly night

When heaven wants Lamps, or when those Lamps want light?

Come Shepheard come, (here's none but Thee and I)

We taxe the Times, but could the times reply

They'd vindicate their evils, and lay their crimes

On us poore Shepheards that thus taxe the Times.

Had we burnt bright, had our refulgent Rayes

Given lustre to the world, and fill'd our dayes

With glorious brightnesse, how had darknesse found

A place for entrance? where could shadowes ground

Their ayery errands? or what soule could taint

Our Sun-bright names? what evill could cause complaint?

How blest! how more then blest had Shepheards been,

Had Shepheards beene so happy to have seene

But their owne happinesse; Had the waxen wings

Of their ambitious thoughts not aymd at things

Beyond their pitch; Had they beene wise to move

In their owne Orbes, and not like Phaeton rove

Through the wilde Labyrinth of th' Olimpick Tower,

And search'd the secrets of too vast a power,

Their Glory had not found so short a date,

Nor causd combustion in so calme a State.

blame, criticize
justify
burden, impose on

40

base, justify

Consider frailty and not think of Man?)

Shall some few staines in the full Lampe of night

Cry down the Moone, and wooe the Stars for light?

What if thy too neglected Soyle abound

With noysome Weeds? wilt thou disclaime the ground?

Or wouldst thou dry the earths full breast, that feeds

Thy fragrant Flowers, because it Fosters Weeds?

Ah, my Philorthus, thus the cause now stands

With us poore Swaynes, The power of our hands,

Entrusted there by our all-wise God Pan,

(To whom the frailties of collapsed Man

Was knowne too well) for some disorders growne

Among us Swaines is cry'd, is voted downe;

And that faire Livelyhood that late maintaind

Those love-preserving Festivals which chaind

Our mutuall hearts in links of love; which clad

The naked Orphan, and reliev'd the sad

Afflicted Widow, and releas'd the bands

Of the leane Prisoner grip'd with the hard hands

Of his too just Oppressor; this they say

Is to be shortned, if not snacht away.

Philorthus. Ah, gentle Shepheard, heaven, ah, heavens forefend,

Those Tydes should ebb that flow to such an end;

But some we feare bin more corrupt then so;

They'r two things, what they should, and what they do.

Philarchus. True my Philorthus, some lewd Swaines there be

That have more Bags then Bowels, that can see

Pale misery panting at their Lordly gates, limit, span

moon

lapsed, fallen

decried, deplored

bonds

over-rigorous

so those named above

wicked

more wealth than heart

38, 40 taxe] pun: (a) criticize (b) oppress, trouble.

45 errands] messages, reports (OED 1$).$

waxen wings] referring to Icarus, who flew so close to the sun that the wax on his wings melted: referring to churchmen with high political ambitions. Cf. Phaeton (52). 52 Phaeton] Phaethon, son of Helios the sun-god, who drove the sun-chariot too near the earth till Zeus destroyed him. 53 wilde ... Tower] conflates details of Ovid's account (Met. I.747-II.405) of the sun-chariot hurtling through 'unknown regions of the air' (auras ignotae regionis, II.202-3), and Jupiter/Zeus climbing the tower of Olympus (II.306, 401) to slay Phaethon and survey the ravaged earth. 56 combustion] disorder, tumult $(O E D 5 \mathrm{~b})$. $\quad 60$ Make us deride the moon and turn for light to the stars. 71 Livelyhood] manner of living; custom, social practice. $\quad$ 72-8 Puritans were often charged with opposing traditional festivals and community life. Here, they are also said to have destroyed communal charity. 
Answerd with Statutes, and repulsive Rates;

Whose hard, whose Adamantine eare can brooke

tolerate, endure

The sad Complaints of those (who cannot looke

Beyond the Prospect of consuming Griefe)

Without Remorse at all, without Reliefe;

Whose wanton tables, deckt with costly fare,

Pamper their idle bodies, and prepare

Oyle for their Lust, whose craving thoughts, made poore

With too much wealth, condemne themselves to more;

And such they be Philorthus whose lewd fames

And lives have poysond the illustrious names

Of reverend Shepheards, whose ambitious Pride

Hath brought contempt, and made the world deride

What late it honour'd; now disdaind, abhord

By whom they were as much, ere while, ador'd.

Ah Shepheard these are they whose vaine Ambition

Made us sad Partners in the worlds derision;

But that which wounds my soule beyond redresse,

And aggravates my griefe above excesse,

Those Past'rall staves wherewith those reverend Sages

Of former times have rul'd so many ages,

And by a settled Government, exilde

Confus'd disorder, the prodigious Childe

Of factious Anarchie, Those Rods of power

That rul'd our swaines by day, and did secure

Their Folds by night, are threatned from our hands,

And all our Flocks to bow to new Commands.

Philorthus. It cannot be, the great Assembly's wise;

Has many Heads, and twice as many Eyes,

Eyes bright as day, that view both things and times,

Fast closd to Persons, open to their Crimes;

Judgement, not Fancy, moves in that bright Sphere;

There are no Ends, no by-Respects are there:

The care of Truth and zeale of publique Rest

Rests in their restlesse, their united brest:

Heav'n be their Guide, and may their paines encrease

Heav'n's glory, and this glorious Islands peace;

Ah, thinkst thou Shepheard, their heav'n-guided heart

Will venture to decline his wayes, or start

From Heav'n's Example? Heav'n was pleasd to beare

With very Sodom, had but ten been there

That had beene righteous; loath to mixe the blood

Of guilty thousands with some few of good:

No question Shepheard but the enormous crimes

130 Of our Profession, heightened with the times,

Are foule enough; nor could such Actions lye

Conceald and clos'd before so cleare an Eye;

And being seene, how could they choose but grate

The groaning Feoffees of our tottering State?

How could our growing greatnesse choose but blow

And quicken up their zealous flames? or how

Could our untam'd Ambition hope to stand

Against the power of so great a hand?

But they are just and wise, and wisdome still

earlier

banished

?seized by threats

Fast closd: impartial

[considerations

ulterior motives; extraneous

peace

untiring

labours, efforts

monstrous

perceptive, discerning offend, displease trustees

?power, worldly status

105 Those Past'rall staves] Bishop's crosiers, modelled on the sheephook. Puritans, above all Separatists, were anti-episcopalian. 109 Anarchie] Within the Church, as later exemplified in Anarchus; but also political anarchy, challenging the King's authority. The Civil War was raging by $1644 . \quad 113$ great Assembly] Parliament, more specifically that convened at Oxford from 1644 to 1645 . Consisting chiefly of the lords and only a third of the commons, it expressed loyalty to the King, made overtures to the full Westminster Parliament, and sought a national synod on the status of the Church (hence Philorthus' trust in it), but to no effect. $\quad \mathbf{1 2 4}$ decline his wayes] lapse from its accustomed conduct. his] old possessive of it. $\quad 126$ Sodom ... but ten] Genesis 18.32. 139-42 Wise authorities hint at their power rather than exercise it easily. Even their threats are aimed to correct rather than destroy the offender. 
Shews rather what it can, then what it will.

When publique Justice threatens, it propounds

Way for amendment, rather then confounds:

And far lesse cost and dammage will ensue

To weede old Gardens, then to dig a new.

Philarchus. True, Shepheard, But they plead for want of dressing

Our Garden's forfeited, and they are pressing

Hard for Reentry; They have seald a deed

Upon the ground, intending to proceed

Next Tearme t' Ejectment, by wich meanes they'l stand

Anew possest and re-enjoy the Land.

Philorthus. Shepheard, we hold in Ferme from great god Pan;

His Counsell drew the Lease; If wiser Man

Can find a flaw, our weaknesse must appeale

To Pan's Vicegerent; He will vouch the Seale

Faire and authentick: If the Common Lawes

Condemne our Right, by vertue of that Clause

Of heedlesse Forfeiture, $\mathrm{O}$ then we flye

To be reliev'd in the high Chancery,

That uncorrupted Court that now does rest

In the great Chamber of th'Assemblies brest:

Ther's Judgment there, which idle heapes of gold

Despaires to bribe, And Conscience there's unsold:

Poore Shepheards, there, shall find as faire accesse,

As Peeres, as Princes, and as just redresse.

Philarchus. Heav'n be our great Protection, and close

Their suits-attending eares against all those,

Whom rayling Ignorance, and frantick Zeale

Hath onely taught the way to say, and seale,

And set their marks, not having skill to shape

about, concerning

Tearme of the law courts

[God generally

Christ, or

drew up, drafted

A letter; or, without a Lye, to scape

The danger of Non legit, whose profession

Is onely to scorne Lambeth, and discretion:

These be fit men Philorthus to descend

Into these Lists, sweet Champions to contend

About these Myst'ries, likely to confound

Those famous Worthies that have searcht the ground

Of Sage Antiquity; wherein of old,

Our Government was wrapt, and still enroll'd.

Philorthus. Come Shepheard come, our great Assemblie's wise,

And for a while, in policy complies

With the rude Multitude, who must have day,

To breath their Humours, which would else breake way,

Like earth-imprisoned Aire, whose sudden birth

Startles the world, and shakes the shivering earth:

It is the nature of the vulgar brest

Still to mislike, and count that State the best

Which they enjoy not; Pleas'd with Novelties,

145 dressing] manure, compost (OED dressing 4c); or generally tilling, tending (OED dress v13c). 146 Our Garden] the Church, but also suggesting Eden. 146-150 forfeited ... Reentry ... deed ... Ejectment] continuous legal metaphor of repossession of forfeited land. 151 in Ferme] 'in firm', ?securely, permanently. The 1646 texts have in Terme', for a fixed period or lease. 152 Counsell] legal advice, but perhaps also 'the advisory declarations of Christ and the apostles' (OED $2 \mathrm{~b}) . \quad 154$ Pan's Vicegerent] the King, head of the Church of England. Pan] God. The divine right of kings was a favourite doctrine of James I, Charles's father. 155-60 If the House of Commons wishes to disband the Church, they will appeal to the House of Lords. 169 marks] signs made on documents by illiterate persons by way of signature. $\quad$ 170-71 i.e. who cannot truthfully claim 'benefit of clergy' (exemption from certain penalties by a test of literacy). 172 Lambeth] the London palace of the Archbishop of Canterbury. $\quad 174$ Lists ... Champions] Metaphor of jousting at tilt, to indicate tackling or 'attacking' the mysteries of religion and the function of the Church. 175 confound] refute, stump: obviously ironical. $\mathbf{1 7 8}$ enroll'd] registered, committed. $\mathbf{1 8 2}$ breake way] break forth, burst out: referring to the risk of provoking civil war by too much oppression. By 1644, this faith in moderation and parliamentary restraint was under severe strain. $\quad \mathbf{1 8 3 - 4}$ The so-called 'boiler theory' of earthquakes, that they are caused by the bursting forth of underground steam or lava. 
They grow impatient of the old, and prize

What's next in hope; more happy in expectation

190 Then when possest; all fire to Alteration:

full of enthusiasm

But Shepheard know; our grave Assembly pryes

Where they nere view'd, and lookes with clearer eyes;

Their wisdomes know, what sudden Change portends:

Things rash begun, too oft in danger ends;

But unavoided Ruine daily waites

On suddaine change of fundamentall States.

Philarchus. I but Philorthus, whilst the State complies

With the tumultuous Vulgar, tumults rise,

And rude disorder creeps into our playnes,

Swaines will be Shepherds, Coblers will be Swaines;

Flocks are disturb'd, and pastures are defac'd;

Swaines are despis'd, and Shepheards are disgrac'd,

Orders are laught to scorne; and, in conclusion,

Our Kingdome's turn'd a Chaos of confusion.

Philorthus. Why Shepheard, there's the Plot: the surest way

To take the Fish, is give her leave to play,

And yeild her line; He best can cure the Cause

That markes th' effect; Evill manners breed good Lawes:

The wise Assembly knowing well the length

Of the rude popular foote, with what a strength

The vulgar fancy still pursues the Toy

That's last presented, leaves them to enjoy

Their uncontrolled wils, untill they tyre

And quickly surfeit on their own desire,

Whose wild Disorders secretly confesse

Needfull support of what they'd most suppresse:

But who comes here? Anarchus?

Philarchus.

'Tis the same;

Philorthus. How like a Meteor made of Zeale and flame

The man appeares?

Philarchus. Or like a blazing Star

Portending change of State, or some sad Warre;

Or death of some good Prince.

Philorthus.

Of three sad Kingdomes.

Philarchus.

The froth of troubled waters;

Philorthus.

Fill'd with Errata's of the present Age;

He is the trouble

Philarchus. The Churches Scourge;

Philorthus.

The devils Enchiridion.

Philarchus. The Squib, the Ignis fatuus of Religion:

But hee's at hand: Anarchus what's the newes?

Philorthus. In a Browne studie?

Philarchus.

Philorthus.

Anarchus. Man, if thou be'st a Babe of Grace,

Speechlesse?

In a Muse? And of an holy Seed, I will reply incontinent,

they: the 'vulgar'; ne'er, never

inevitable

aye; accommodates, tolerates

destroyed, laid waste

pay out, allow

comet, thought to presage calamities

Even the very Bubble,

$$
\text { Hee's a Page }
$$


And in my words proceed;

But if thou art a Childe of wrath, And lewd in conversation,

I will not then converse with thee,

conduct Nor hold communication.

(a) talk (b) deal, interact

Philorthus. I trust Anarchus, we all three inherit

The selfe same Gifts, and share the selfe same Spirit.

Anarchus. Know then my brethren, heav'n is cleare

And all the Clouds are gon;

The Righteous now shall flourish, and

Good dayes are comming on;

Come then, my Brethren, and be glad And eke rejoyce with me;

Lawn sleeves and Rochets shal go down, And, hey! then up go we.

a bishop's vestment

Wee'l breake the windowes which the Whore

Of Babilon hath painted,

And when the Popish Saints are downe

Then Barow shalbe Sainted;

Ther's neither Crosse nor Crucifixe

Shall stand for men to see;

Romes trash and trump'ries shall goe down, And, hey! then up go we.

What ere the Popish hands have built

Our Hammers shall undoe;

Wee'l breake their Pipes and burne their Copes, And pull downe Churches too:

Wee'l exercise within the Groves, And teach beneath a Tree,

Wee'l make a Pulpit of a Cart, And, hey! then up go we.

Wee'l downe with all the Varsities Where Larning is profest,

Because they practise and maintaine The language of the Beast:

Wee'l drive the Doctors out of doores, And Arts what ere they be,

Wee'l Cry both Arts and Larning downe, And, hey! then up go we.

Wee'l down with Deanes and Prebends too, But I rejoyce to tell ye,

How then we will eate Pig our fill, And Capon by the belly:

Wee'l burne the Fathers witty Tomes, And make the Schoole-men flee,

Wee'l down with all that smels of wit, And, hey! then up go we.

If once that Antichristian crew Be crusht and overthrowne,

Wee'l teach the Nobles how to croutch, And keep the Gentry downe;

scholars, teachers

clever, intellectual scholastic philosophers wisdom, intelligence

crouch, stoop

245 Lawn] a kind of fine linen, used in bishops'vestments; also suggests a woman's finery, hence luxury and carnality. 247-8 Whore Of Babilon] the Catholic Church, by the common Protestant interpretation of the female figure in Rev. 17; also applied by Puritans to the Anglican Church. The reference is to Puritan iconoclasts destroying stained-glass windows. 250 Barow] Henry Barrow, another Separatist leader. $\quad 251$ neither Crosse nor Crucifixe] Iconoclasm carried to an openly anti-Christian point. 257 Pipes] (a) organ-pipes (b) pastoral oaten pipes. 261 Cart] another innuendo. Criminals were paraded on a cart. 266 the Beast] of Rev. 13, 14.3, also identified by Protestants with the Catholic Church. Its language is Latin, used in Catholic but not Puritan worship. 268 Arts what ere they be] whether Bachelors or Masters. $\quad \mathbf{2 7 9 - 8 2}$ Once the Church is subdued, the other estates will follow. 
Good manners have an evill report, conduct And turnes to pride we see,

Wee'l therfore cry good manners down, And, hey! then up go we.

The name of Lord shall be abhor'd, For every man's a brother,

No reason why in Church or State, One man should rule another:

But when the change of Government Shall set our fingers free,

Wee'l make the wanton Sisters stoope, And, hey! then up go we.

Our Coblers shall translate their Soules move, convey From Caves obscure and shady,

Wee'l make Tom T-- as good as my Lord And Ioane as good as my Lady.

Wee'l crush and fling the marriage Ring Into the Roman See;

Wee'l ask no bands, but even clap hands And, hey! then up go we.

Philarchus. Heaven keep such vermin hence: If sinfull dust

May boldly chuse a punishment, and trust

Their own desires, let famin plague or Sword,

A treacherous friend, or (what is more abhor'd)

A foolish-faire contentious wife, first seize

On our sad soules, then such wild beasts as these.

Anarchus. Surely thou art an Hypocrite,

A lewd false hearted Broth
I find thou art a Child of Rome,

And smell the whore thy Mother.

Philorthus. Away false varlet; come not neere my flocks;

Thou taint'st my pastures; Neither Wolfe nor Fox

Is halfe so furious; They, by stealth, can prey,

crazy, demented

Perchance, upon a Lambe, and so away;

But thy blood-thirsty malice is so bold,

Before my face to poyson all my fold:

I warn thee hence; come not within my list;

Be still, what thou art thought, a Seperatist.

Anarchus. Thou art the spawne of Antichrist,

And so is this thy Brother;

Thou art a man of Beliall,

And he is such another:

I say thou art a Priest of Baal,

And surely I defie thee;

To Satan I will leave thy soule,

And never more come nigh thee.

Philarchus. A gentle riddance: O may never crosse

Fall heavier on this Land, then such a losse.

Philorthus. But thinkst thou, Swaine, the great Assemblies eye

Beholds not these base Sycophants that lye

$\mathbf{2 8 3}$ report] ?repute ( $O E D_{5}$ ); echo, effect, consequence (cf. $O E D_{7}$ ). $\quad$ 287-90 A hit at the egalitarianism favoured by the more extreme Puritans. Lord] as a social rank, but with the nuance that Anarchus is opposed to God. 293 Sisters] the Puritans' egalitarian address for women. stoope] makes crudely physical the implications of croutch $(281)$. The refrain up go we now acquires its full phallic force, as in 302. 297 Tom T--] no doubt 'Turd', rhyming with 'Lord'. 298 Ioane ... Lady] A profession made quite soberly in the popular literature of the age. 300 See] confused with sea: indicates the speaker's ignorance. $\quad 307$ foolish-faire] pretty but foolish. 312 whore] See 247-8n. 319 list] bounds, territory ( $O E D$ list $\left.\mathrm{n}^{3} 8 \mathrm{~b}\right)$. 320 Seperatist] punning on the literal meaning, one who keeps to himself. 323 Beliall] a devil, one of Satan's chief followers. Perhaps a pun on Balliol College, Oxford, a Royalist centre like most Oxford colleges in the Civil War, moreover with a history of supporting Catholics. Quarles was a Royalist, but had been to Christ's College, Cambridge. 325 Baal The collective Old Testament name for several gods regarded by the Israelites as false idols, condemned by the prophets. 332 Sycophants] slanderers, calumniators (OED 2). 
Close gnawing at the roote, as well as those,

That with the Romish Axe, strike down right blows

On the maine body of Religions tree?

Think'st thou their sharp ey'd Providence can see

The Chamber Councels, and the close designes

Of forraigne Princes, and their secret Mines

Of State Invention? Can their wisdomes rome

Through all the world, and yet be blinde at home?

No, no; Philarchus, the Assemblies hand

Feeles but, as yet, the Pulses of the Land,

Seeks out the ev'll; and, with a skilfull eye,

Enquiers where the peccant humours lye:

But when th'apparent Symptomes shall disclose

The certaine griefes that vexe and discompose

Our universall Body; then, no doubt,

Their active Wisdomes soone will cast about,

To make a glorious Cure, which shall enhaunce

Heav'n's greater glory, settle and advaunce

The rest of groaning Sion, to th'encrease

Of their own honour, and great Britains peace.

Philarchus. My bended knee shall never rise till then.

Philorthus. Heav'n nere shall rest, till Heav'n shall say Amen.

i.e., the Anglican church foresight, prudence hidden, secret

evident, visible

devise means

\section{Jane Cavendish and Elizabeth Brackley Scenes from a Pastoral Play}

From a play prob. composed c.1641-9 by the sisters Lady Jane Cavendish and Lady Elizabeth Brackley and preserved in two ms presentation volumes (now in the Bodleian and Yale University Libraries) to their father William Cavendish, Duke of Newcastle. Previously ascribed to Brackley alone, but the $\mathrm{ms}$ pages carry initials of both sisters. The text below follows the Bodleian ms. In the first passage, the speakers are humble rustics named Naunt (Aunt) Henn, Gossopp (Gossip, boon companion) Pratt, Goodman Rye and Goodman Hay. Their plight is not caused simply by poverty, but by the spells of witches and satyrs. Margaret Ezell sees a reference to marauding Puritan armies as viewed from a Royalist perspective: the sisters suffered directly from the turmoil of the times.* The second passage presents romantic shepherd-lovers. Their full names are not given in the ms. Virtually all punctuation supplied in this edition.

\section{Passage (A)}

Henn. I haue lost my melch Cow.

milch

Pratt. And I haue lost my Sow.

Rye. And for my Corne I cannot keepe.

?as for

Hay. Nether can I my pritty sheepe.

Henn. And I haue lost fowre dozen of Eggs.

Pratt. My Pigs are gone, and all their Heads.

Rye. Come let us wishe for Health.

Hay. For wee can haue noe wealth.

Henn. Now I will hope for Ioy.

333 Close ... roote] i.e. destroying the Church from within, as against the Catholics, who attack it openly (334-5). $\quad 336$ Meaning obvious, but logic requires a 'not'. 337-9 Protestant powers on the continent attempted to aid the English Puritans. 338 secret Mines] Perhaps with Guy Fawkes's Gunpowder Plot (1605) in mind. That was in the Catholic cause, but Quarles is equating Puritans with Catholics. $\quad 341-9$ an image of medicine to heal the body politic. 344 peccant] morbid, diseased (OED 1a). humours] the supposed four chief fluids of the body, whose imbalance or corruption caused illness. 345-9 Parliament is looking for the real heads behind the visible offenders. Once it has identified them, it will act. 351 Sion] Zion, the hill in Jerusalem on which Solomon's temple stood; hence Jerusalem itself, or other homelands of the faithful. Ironically, most commonly applied to England by the Puritans, with respect to the dispensation they sought to bring about. ${ }^{*}$ Margaret J. M. Ezell, "To Be Your Daughter in Your Pen": The Social Functions of Literature in the Writings of Lady Elizabeth Brackley and Lady Jane Cavendish', Huntington Library Quarterly 51.4, 1988, p.287. 6 and] used in an explanatory or amplifying way (OED 9a): 'every single one'. 
Rye. Since that wee haue noe plenty

Hay. And our Purses, they are empty.

Henn. Since that wee haue noe plenty

Pratt. And our Purses they are empty.

\section{Passage (B)}

[From the abbreviated speech-headings, the shepherdess appears to be called Innocence and the shepherd Persiu[s?]. All the shepherdesses have moral-allegorical names.]

Per. Come let vs walke that wee may sweetely heare

The Birds to singe their seuerall noted tunes

As if the yeare was onely made for wee

attuned or composed to various notes

Where nature courts vs to each finer shade.

Inn. O noe, the innocence of sheepe,

Shall bee my onely care to keepe.

Per. What pleasure is in them to please you soe

That you inuite your selfe onely to heare

The bleatings of each Lambe that loues it Pap

And afterward, doth lye it downe to sleepe.

Inn. The milke of Kine, I'le huswife, for to make

Butter to keepe my thoughts awake.

Per. But I should rather thinke to make a prize

Of Garlands for to crowne our selues with all,

And if in loue you did become your vow

You should my Garland haue and mee withall.

Inn. I owe myselfe to noe ambitious foe

For all my thoughts are truely humble low.

Per. I pray thee bee my Saint and heare my prayer

For certainly I haue noe other way

To hope that you will euer graunt to mee

Vnlesse I should my forme of man put of.

Inn. I dedicate my selfe to each sweete feild

For to your Sex I'm very loth to yeild.

Per. I am resolu'd from you I will not goe

Till that your resolution I doe know.

Inn. What in a verse doe you begin to speake

And if then witt ther's none can owne you weak.

Per. I sweare as loue you nothinge will I say

If I may knowe, what's your ambitious way.

Inn. I darr not that relate for feare some wynn

Out my designe, then hate my selfe as sinn.

Per. Whisp'rit in my Eare, for further shal't not goe

But to my thoughts, for then my selfe a foe.

Inn. If that your promise you will keepe

I will then singe, but first you'st bee a sleepe.

Per. Well I will appeare like a dead witherd leafe

And soe conuert my selfe to a sleepe stupid deafe.

10 Toy] a piece of fun or sport, an entertainment: referring to the ensuing play, to which this is the second preliminary Antemasque. 5-6 (a) I will only look after the innocent sheep (b) I will guard my own innocence, equal to that of the sheep. $\quad 22$ unless I set aside my identity as a male lover and address you as a devotee. 27 verse] rhymed verse. She herself has been speaking verse right through, but is surprised to find her lover doing so. $\quad 28$ No-one can say you lack wit. $\quad 31-2$ for feare ... sinn] lest someone (presumably her lover) comes to know her mind (i.e. that she loves him) and scorns her in consequence. $\quad 34$ for then my selfe a foe] In that case (i.e. if I divulge your secret love for me), I will prove my own enemy. $\mathbf{3 8}$ a sleepe stupid deafe] syntax uncertain: perhaps the adjectives 'asleep, stupid, deaf, or 'a deaf person made stupid by sleep'. 


\section{Robert Herrick A Pastoral upon the Birth of Prince Charles}

Presumably written soon after 29 May 1630, when the future Charles II was born. Tom Cain in ODNB suggests Herrick was at Whitehall at the time. First published in Herrick's Hesperides (1648). There is also a ms version with a different structure, indicating a more obvious musical setting. This has been printed separately below. It may be the original version, actually sung at the time.

A Pastorall upon the birth of Prince Charles, Presented to the King, and Set by Mr. Nic: Laniere.

Amintas. Good day, Mirtillo.

Mirtillo. And to you no lesse:

And all faire Signs lead on our Shepardesse.

Amarillis. With all white luck to you.

Mirtillo. But say, What news

good luck

Stirs in our Sheep-walk?

Amintas. None, save that my Ewes,

My Weathers, Lambes, and wanton Kids are well,

Smooth, faire, and fat, none better I can tell:

Or that this day Menalchas keeps a feast

For his Sheep-shearers.

Mirtillo. True, these are the least.

But dear Amintas, and sweet Amarillis,

minor items of news

Rest but a while here, by this bank of Lillies.

And lend a gentle eare to one report

The Country has.

Amintas.

Amarillis.

Mirtillo.

From whence?

From whence?

Three dayes before the shutting in of May,

The Court.

(With whitest Wool be ever crown'd that day!)

To all our joy, a sweet-fac't child was borne,

More tender then the childhood of the Morne.

close, end

Chorus. Pan pipe to him, and bleats of lambs and sheep

Let Lullaby the pretty Prince asleep!

Mirtillo. And that his birth sho'd be more singular,

At Noone of Day, was seene a silver Star,

Bright as the Wise-mens Torch, which guided them

To Gods sweet Babe, when borne at Bethlehem;

While Golden Angels (some have told to me)

Sung out his Birth with Heav'nly Minstralsie.

Amintas. O rare! But is't a trespasse if we three

Sho'd wend along his Baby-ship to see?

Mirtillo. Not so, not so.

Chorus. But if it chance to prove

At most a fault, 'tis but a fault of love.

Amarillis. But deare Mirtillo, I have heard it told,

Those learned men brought Incense, Myrrhe, and Gold,

From Countries far, with store of Spices, (sweet)

And laid them downe for Offrings at his feet.

Mirtillo. 'Tis true indeed; and each of us will bring

Unto our smiling, and our blooming King,

A neat, though not so great an Offering.

Amarillis. A Garland for my Gift shall be

Of flowers, ne'r suckt by th'theeving Bee:

And all most sweet; yet all lesse sweet then he.

0.2 Laniere] Nicholas Lanier, musician and painter, appointed Master of the King's Music in $1626 . \quad 2$ May all auspicious signs (?stars, zodiacal signs) attend our shepherdess, i.e. Amarillis. 17 Chorus] prob. the three speakers together, but perhaps a separate group. 20 silver Star] There are many reports (e.g. in Britanniae natalis, 1630) of a noonday star or light in the sky at the time of Charles's birth. 21 Wise-mens Torch] the star that guided the magi (wise men) to Christ's birthplace. 25-6 The shepherds wish to emulate the magi: is't a trespasse suggests they sense the potential blasphemy in the parallel with Christ's birth. $\quad 37$ ne'r suckt ... Bee] i.e. retaining all their nectar and scent. $\quad 38$ In Noble Numbers ('The New-yeeres Gift, or Circumcisions Song'), Herrick applies a very similar line to Christ. 
Amintas. And I will beare along with you

Leaves dropping downe the honyed dew,

With oaten pipes, as sweet, as new.

Mirtillo. And I a Sheep-hook will bestow,

To have his little King-ship know,

As he is Prince, he's Shepherd too.

Chorus. Come let's away, and quickly let's be drest,

And quickly give, The swiftest Grace is best.

And when before him we have laid our treasures,

We'll blesse the Babe, Then back to Countrie pleasures.

\section{Alternative Manuscript Version}

Based on MS 239-23 in the Rosenbach Foundation collection, Philadelphia. There are other mss as well.

Mirtillo, Aminta, and Amarillis

Aminta. Good daie Mirtillo.

Mirtillo. And to you noe lesse.

Ambo. And crownes of wheate fall on our Shepherdesse.

Amarillis. And mirthfull pipes to yow.

Mirtillo.

Stirres in our Sheepewalkes?

$$
\text { But saye what newes }
$$

Ambo.

$$
\text { None. }
$$

Aminta.

Saue that myne Ewes

My weathers, lambs and kidds are well.

I noething els can tell.

Amarillis. Or that this daie Menalcas maks a feast To his Sheepeshearers.

Mirtillo These are the least.

But deare Amynta and faire Amaryllis

List but a while here on this Banke of Lillies

And lend an Eare to a report

Ambo. The Countrey has.

Mirtillo.

$$
\text { From whence? }
$$

The Court.

Two dayes before the shutting vpp of Maye

(With whiter wooll be cladd the daie,)

To Englands ioye a Prince was borne

Softe as the Childhood of the Morne.

Ambo. Pan pipe to him, and bleates of lambes and sheepe Lett Lullabie this prettie Prince asleepe.

Mirtillo. And that his Birth might bee more singular, Att noone of daie appear'd a starre

Bright as the Wisemens torch that guided them

To Gods Babe borne att Bethelem.

Amarillis. But ist a sinne if wee

Should goe this Child to see?

Mirtillo. Not soe, not soe. But if soe bee it proue

Allmost a fault, tis but a fault of loue.

Aminta. Yea, but Mirtillo, I haue heard it tould

Those Learned men brought Incense, Myrrh, and gold

And Spices sweete

And lay'd them downe att their Kings feete.

Amarillis. Tis true.

Mirtillo.

Omnes.

$$
\text { Tis true. }
$$

Vnto our Blooming Kinge

A Neat

Though not soe great

$$
\text { An Offeringe. }
$$

Amarillis. A Garland for my guifte shalbee

46 The swiftest ... best] A gift is best given swiftly and readily. Italicized in the original, as a maxim or 'saw'. 
Of flowers new suckt by Theeuing Bee

And all most Sweete, yett all lesse sweete then hee.

Aminta. And I will laye before his viewe

Leaues dropping downe the honey dewe.

Mirtillo. And I a Sheephooke will bestowe

To make his little Kingshipp knowe

As hee's a Prince, hee's Shepheard too.

Chorus. Come lettes make hast and tymely lettes be drest

And quickly giue: the swiftest Grace is best.

And when before him wee haue layd our treasures

Weele blesse his face, then backe to Countrey pleasures.

\section{Robert Herrick A Pastoral Sung to the King}

First published in Hesperides (1648). Like L. C. Martin before him, J. Max Patrick suggests (citing Herrick's 'To the King and Queene, upon their unhappy distances') that Amarillis is Queen Henrietta Maria, who left the court temporarily in 1642 and permanently in 1644 to escape the gathering Civil War. There may be a personal plane of allusion too. Herrick has two poems presenting Elizabeth Wheeler, a childhood neighbour and friend, as Amarillis: 'Upon Mrs. Eliz: Wheeler, under the name of Amarillis', and 'A Dialogue betwixt himselfe and Mistresse Eliza: Wheeler, under the name of Amarillis'. In the latter, Elizabeth is leaving the court for the country. This suggests the present poem also pastoralizes the court, from which Elizabeth (or indeed Henrietta Maria) has departed. Herrick spent much time at court, even before losing his living during the Civil War.

A Pastorall sung to the King: Montano, Silvio, and Mirtillo, Shepheards.

Montano. Bad are the times.

Silvio.

And wors then they are we.

Montano. Troth, bad are both; worse fruit, and ill the tree:

The feast of Shepheards fail.

Of Wassaile now, or sets the quintell up:

And $\mathrm{He}$, who us'd to leade the Country-round,

Youthfull Mirtillo, Here he comes, Grief drownd.

Ambo. Lets cheer him up.

Silvio. Behold him weeping ripe.

Mirtillo. Ah! Amarillis, farewell mirth and pipe;

fully, copiously

Since thou art gone, no more I mean to play,

To these smooth Lawns, my mirthfull Roundelay.

Dear Amarillis!

Montano. Hark!

Silvio. Hark! Mark:

Mirtillo.

This earth grew sweet

Where, Amarillis, Thou didst set thy feet.

Ambo. Poor pittied youth!

Mirtillo. And here the breth of kine

Ambo: both together; pitiable, deserving pity

And sheep, grew more sweet, by that breth of Thine.

This flock of wooll, and this rich lock of hair,

This ball of Cow-slips, these she gave me here.

Silvio. Words sweet as Love it self. Montano, Hark.

Mirtillo. This way she came, and this way too she went;

How each thing smells divinely redolent!

Like to a field of beans, when newly blown;

Or like a medow being lately mown.

Montano. A sweet-sad passion. ---

Mirtillo. In dewie-mornings when she came this way,

Sweet Bents wode bow, to give my Love the day:

3 feast of Shepheards] J. Max Patrick cites the Roman festival of Parilia or Palilia, the feast of the pastoral goddess Pales (see 31n). 4 quintell] quintain: an object, often on a swivel, used as a target for tilting at both court and country festivities. 15 flock] lock, tuft $\left(O E D\right.$ flock $\left.\mathrm{n}^{2}\right)$. 17 Montano] may be a speech-heading for the exclamation 'Hark'. This would make the line short in length, but so is 22. In any case, 17 has no rhyming line. $\quad 20$ beans] The bean plant is known for its fragrance. 24 Bents] a type of grass. 
And when at night, she folded had her sheep,

Daisies wo'd shut, and closing, sigh and weep.

Besides (Ai me!) since she went hence to dwell,

The voices Daughter nea'r spake syllable.

But she is gone.

Silvio. Mirtillo, tell us whether.

30 Mirtillo. Where she and I shall never meet together.

Montano. Fore-fend it Pan, and Pales do thou please

To give an end:

Mirtillo. To what?

Silvio. Such griefs as these.

Mirtillo. Never, O never! Still I may endure

Still: for ever

The wounds I suffer, never find a cure.

Montano. Love for thy sake will bring her to these hills

And dales again:

Mirtillo

No, I will languish still;

And all the while my part shall be to weepe;

And with my sighs, call home my bleating sheep:

And in the Rind of every comely tree

bark

Ile carve thy name, and in that name kisse thee:

Montano. Set with the Sunne, thy woes:

Silvio.

The day grows old:

And time it is our full-fed flocks to fold.

Chorus. The shades grow great; but greater growes our sorrow,

But lets go steepe

Our eyes in sleepe;

And meet to weepe

To morrow.

\section{Robert Herrick To His Muse}

The first poem (after the 'Argument') in Herrick's collection Hesperides (1648). Identifies the pastoral as Herrick's basic vein. Critics have compared Martial, Epig I.3, warning the Muse against scorn and neglect at court; but Martial is more admonitory and satirical.

To His Muse.

Whither Mad maiden wilt thou roame?

Farre safer 'twere to stay at home:

Where thou mayst sit, and piping please

The poore and private Cottages.

Since Coats, and Hamlets, best agree

cotes, cottages

With this thy meaner Minstralsie.

There with the Reed, thou mayst expresse

The Shepherds Fleecie happinesse:

And with thy Eclogues intermixe

Some smooth, and harmlesse Beucolicks.

There on a Hillock thou mayst sing

Unto a handsome Shephardling;

Or to a Girle (that keeps the Neat)

cattle

With breath more sweet then Violet.

There, there, (perhaps) such Lines as These

May take the simple Villages.

may (thy woes) set

But for the Court, the Country wit

Is despicable unto it.

Stay then at home, and doe not goe

Or flie abroad to seeke for woe.

Contempts in Courts and Cities dwell;

Ai] The spelling suggests Gk ai, the word of lament supposedly inscribed on the hyacinth, as well as ay. $\quad 28$ The voices Daughter] Echo. 31 Pales] goddess of flocks and shepherds. 9-10 Eclogues, Beucolicks] distinction unclear: ?eclogues allusive, bucolics simple rustic pieces. $\mathbf{1 8}$ despicable] in a light sense: mean, contemptible. unto it] compared to it. 
No Critick haunts the Poore mans Cell:

Where thou mayst hear thine own Lines read

By no one tongue, there, censured.

That man's unwise will search for Ill,

And may prevent it, sitting still.

\section{Robert Herrick The Hock-Cart}

From Herrick's Hesperides (1648). The extravagant feudal celebration of the lord's bounty, allegedly freely given to the labouring poor irrespective of desert, is touched towards the end by a perhaps unintended irony.

The Hock-cart, or Harvest home: To the Right Honourable, Mildmay, Earle of Westmorland.

Come Sons of Summer, by whose toile,

We are the Lords of Wine and Oile:

By whose tough labours, and rough hands,

We rip up first, then reap our lands.

Crown'd with the eares of corne, now come,

And, to the Pipe, sing Harvest home.

Come forth, my Lord, and see the Cart

Drest up with all the Country Art.

See, here a Maukin, there a sheet,

As spotlesse pure, as it is sweet:

The Horses, Mares, and frisking Fillies,

(Clad, all, in Linnen, white as Lillies.)

The Harvest Swaines, and Wenches bound

For joy, to see the Hock-cart crown'd.

About the Cart, heare, how the Rout

Of Rurall Younglings raise the shout;

Pressing before, some coming after,

Those with a shout, and these with laughter.

Some blesse the Cart; some kisse the sheaves;

Some prank them up with Oaken leaves:

rip up: plough

Some crosse the Fill-horse; some with great

Devotion, stroak the home-borne wheat:

While other Rusticks, lesse attent

To Prayers, then to Merryment,

Run after with their breeches rent.

Well, on, brave boyes, to your Lord's Hearth,

Glitt'ring with fire; where, for your mirth,

Ye shall see first the large and cheefe

Foundation of your Feast, Fat Beefe:

With Upper Stories, Mutton, Veale

And Bacon, (which makes full the meale)

With sev'rall dishes standing by,

As here a Custard, there a Pie,

And here all tempting Frumentie.

And for to make the merry cheere,

If smirking Wine be wanting here,

There's that, which drowns all care, stout Beere;

Which freely drink to your Lords health,

Then to the Plough, (the Common-wealth)

Next to your Flailes, your Fanes, your Fatts;

Then to the Maids with Wheaten Hats:

wheat boiled in seasoned milk

(source of) general prosperity (winnowing) fans; vats

25-6 Only a foolish man will actively seek for ill when he can avoid it by staying where he is. $\mathbf{0 . 1}$ Hock-cart] the cart carrying home the last of the harvest. Mildmay] Mildmay Fane, the poet and Herrick's friend. 2 Wine and Oile] Un-English produce, no doubt suggested by classical sources. 9 Maukin] malkin, a pole wrapped in cloth at one end to represent a human figure. 21 crosse the Fill-horse] bestride the shaft-horse drawing the cart. $\quad 36$ smirking] sparkling ( $O E D_{3}$, only from this passage). $\quad \mathbf{4 1}$ Maids] harvest-maiden(s): the last handful of harvested grain, roughly fashioned into a female figure. 
To the rough Sickle, and crookt Sythe,

Drink frollick boyes, till all be blythe.

Feed, and grow fat; and as ye eat,

Be mindfull, that the lab'ring Neat

(As you) may have their fill of meat.

And know, besides, ye must revoke

The patient Oxe unto the Yoke,

And all goe back unto the Plough

And Harrow, (though they'r hang'd up now.)

And, you must know, your Lords word's true,

Feed him ye must, whose food fils you.

And that this pleasure is like raine,

Not sent ye for to drowne your paine,

But for to make it spring againe.

\section{Robert Herrick A New-Year's Gift Sent to Sir Simeon Steward}

From Herrick's Hesperides (1648). Simeon Steward, minor poet and politician, was Herrick's friend and patron. Presumed topical allusions at the start suggest the poet was writing from London on New Year's Day 1624 to Steward on his Cambridgeshire estate. The opening disavows the usual themes of the newsletters, printed or personalized, sent in those days from London to people in the country.

A New-Yeares gift sent to Sir Simeon Steward.

No newes of Navies burnt at Seas;

No noise of late spawn'd Tittyries:

No closset plot, or open vent, ?outburst, revolt

That frights men with a Parliament:

No new devise, or late found trick,

To read by th' Starres, the Kingdom's sick:

No ginne to catch the State, or wring

The free-born Nosthrill of the King,

We send to you; but here a jolly

Verse crown'd with Yvie, and with Holly:

That tels of Winters Tales and Mirth,

That Milk-maids make about the hearth,

Of Christmas sports, the Wassell-boule,

That tost up, after Fox-i'th'hole:

Of Blind-man-buffe, and of the care

That young men have to shooe the Mare:

Of Twelf-tide Cakes, of Pease, and Beanes

Wherewith ye make those merry Sceanes,

When as ye chuse your King and Queen,

And cry out, Hey, for our town green.

Of Ash-heapes, in the which ye use

Husbands and Wives by streakes to chuse:

5o hang'd up] a Roman, not an English custom: see Ovid, Fasti I.665, Tibullus II.i.6. Cf. 245.45-6n. Parts of Tibullus' poem, on the Ambarvalia or Roman country festival, provide a general model for Herrick's. 51 Lords word] Perhaps 1 Corinthians 9.7: 'who feedeth a flock, and eateth not of the milk of the flock?' 2 Tittyries] = Tityre-tu's: 'an association of well-to-do 'roughs' who infested London streets in the 17th c.' $(O E D)$, more specifically around 1623-4. The name, suggesting ease and leisure, derives ironically from the opening of Virgil I. 4 frights men with a Parliament] Herrick, a staunch Royalist, feared the operations of Parliament, already much in evidence in James I's last days. On 24 December 1623, the Privy Council decided to convene a Parliament, elected in January 1624 and assembled on 12 February. 7-8 wring ... Nosthrill] tweak the nose. The King is free-born but undesirably controlled by Parliament. 14 Fox-i'th'hole] a game where players hop on one leg. 16 shooe the Mare] a Christmas game where a man sits astride a suspended beam (the 'Mare') and strikes it with a hammer. 17 Twelf-tide] Twelfth Night (6 January), the last day of Christmas festivities, when a cake or pie was served containing a bean and a pea. Their finders became king and queen of the festivities (19). See Herrick's 'Twelfe Night, or King and Queene'. 20 No good explanation. L. C. Martin and J. Max Patrick observe that village lovers would meet on the town (i.e. village) green, but presumably not in mid-winter. Perhaps simply a merry shout. The choric cry 'Hey for our town' occurs in Beaumont and Fletcher's The Knight of the Burning Pestle, Interlude IV.54 (Revels Plays edn). 21-2 The superstition is clear from the account given. 
Of crackling Laurell, which fore-sounds

A Plentious harvest to your grounds:

Of these, and such like things, for shift,

We send in stead of New-yeares gift.

Reade then, and when your faces shine

With bucksome meat and capring Wine:

Remember us in Cups full crown'd,

And let our Citie-health go round,

Quite through the young maids and the men,

To the ninth number, if not tenne;

Untill the fired Chesnuts leape

For joy, to see the fruits ye reape,

From the plumpe Challice, and the Cup,

That tempts till it be tossed up:

foretells, promises

Then as ye sit about your embers,

Call not to mind those fled Decembers;

But think on these, that are t'appeare,

As Daughters to the instant yeare:

Sit crown'd with Rose-buds, and carouse,

Till Liber Pater twirles the house

About our eares; and lay upon

The yeare (your cares) that's fled and gon.

And let the russet Swaines the Plough

And Harrow hang up resting now;

And to the Bag-pipe all addresse;

Till sleep takes place of wearinesse.

And thus, throughout, with Christmas playes

Frolick the full twelve Holy-dayes.

roasted in the fire

full, abundant tossed down, drunk

successors, progeny; current

replaces, succeeds

\section{Mildmay fane A Dialogue Weeping the loss of Pan}

From Harvard MS Houghton 645. Original speech-headings preserved. Punctuation considerably modified. Pan is obviously Charles I. One of many Royalist pastorals mourning his execution.

A Dialogue between a Hunting Swayn and a Shephardes weeping the loss of Pan.

Hunt: Fair Shepardes why dost thou weep

shepherdess

Since ther's an end of winters could?

The season now inuites thy Sheep

To blanch the Mountaines, quit their fould.

Shep: Ô tis too sad for to be tould.

whiten (with their fleeces)

Hunt: Make me acquainted with the cause

Of this distemper, and I'le vowe

disorder, affliction

To tear out of the fell wolfs iawes

What s'euer Lamb h'hath tain from you.

Shep: This might proou test, wer't not too true.

he hath

be tried out or put to the test

Hunt: Yet cause thy greef speaks thus in tears,

Torture me not with long delay

But tel, soe rid me of those Fears

O're all affections now bear sway.

Shep: Why then in short, thus I obey

because

emotions; that now dominate over all other

23 crackling Laurell] 'The Bolognese put laurel leaves in the fire: if they crackled, the harvest would be good, otherwise bad.' (Encyclopedia of Superstitions, ed. C. L. Daniels \& C.M. Stevens, 1903, II.808) Old England may have shared the superstition. $\quad 28$ capring] making one dance or caper: unusual instrumental sense not in $O E D$. Suggests bucksome might mean 'making one buck or leap', i.e. dance. 3o Citie-health] ?health drunk to persons living in the city, like Herrick at the time. $\quad 32$ the ninth ... tenne] nine if not ten rounds of drink or toasts. 42 Liber Pater] ancient Roman god of wine, hence the wine itself. twirles] to the drunken vision. 43-4 Lay all your cares upon the year that's fled and gone, to be carried away. 45-6 a Roman, not an English custom: see Ovid, Fasti I.665, Tibullus II.i.6. Cf. 244.50. 45 russet] clad in russet, a coarse rustic fabric. 49 playes] (a) games, sports, delights (b) dramatic entertainments, in which case with] together with, in addition to. 
Ther was a time when our Great Pan And Flocks Protector kept these plains,

Making them like th'Arcadian, Wher all securety stil reignes.

Hunt: Let me partake of what remaines.

Shep: You shall: ther stept out of a wood (As they were mad) of Giants race,

Who enuijng our Kidds that good, Chas't all protection from this place.

\section{people of benefit, i.e. peace and security}

Hunt: That was a sad and dismall case.

Shep: Thus euer since we open lie

To what blast the intemperat wind

Can threaten towrds our misery,

Afflicting vs in corps \& mind.

Hunt: How could the Fates proue soe vnkind?

whatever

body

Shep: Only for this, as I suppose,

Our offrings did displeas the Gods,

Who in their anger did impose

For our correction these rods.

Hunt: T'was soe, t'was soe, without all ods.

Then for to dry thy tear-drownd eyes,

I shall aduise, for time to come

We offer better sacrefize

To bring our Pan back to vs home.

40

Shep: That should pleas all, but will not some.

Wherfore I'le craue thy hunting art

To tuft the thicks and find those out

Who thus haue causd my Lambs to smart, That they may safer feed about.

beat game out of a covert; thickets suffer, feel pain

Hunt: These are but foxes without doubt.

But were they wolu's, though clad like sheep,

Lions in Lamb-skins to beguile,

I'le not dispair, nor think of sleep

Til I this diffrence reconcile, provided; heavens; 'stand surety for'
Prouide the Heuns subscribe the while.

Shep: Thanks, noble Swain: my greefs Alay,

That buried hast in hopes my sorrow.

All happines attend thy way,

And cause vs t'meet again tomorrow.

The rest let expectation borrow.

guarantee, be responsible for

\section{Mildmay Fane My Happy Life, to a Friend}

First published in Fane's Otia sacra (1650). Loosely based on a much shorter poem attributed to Martial (no.13).

My happy Life, to a Friend.

Dearest in Friendship, if you'll know

Where I my self, and how bestow,

lodge, dispose

Especially when as I range,

Guided by Nature, to love change:

Beleeve, it is not to advance

Or add to my inheritance;

Seeking t'engross by Power (amiss)

What any other Man calls his:

wrongly 
But full contented with my owne,

I let all other things alone;

Which better to enjoy 'thout strife,

I settle to a Countrey life;

And in a sweet retirement there,

Cherish all Hopes, but banish fear,

Offending none; so for defence

Arm'd Capapee with Innocence;

I doe dispose of my time thus,

To make it more propitious.

First, my God serv'd; I doe commend

The rest to some choice Book or Friend,

Wherein I may such Treasure finde

T'inrich my nobler part, the Minde.

And that my Body Health comprise,

Use too some moderate Exercise;

Whether invited to the field,

To see what Pastime that can yield,

With horse, or hound, or hawk, or t'bee

More taken with a well-grown Tree;

Under whose Shades I may reherse

The holy Layes of Sacred Verse;

Whilst in the Branches pearched higher,

The wing'd Crew sit as in a quier:

This seems to me a better noise

Then Organs, or the dear-bought voice

From Pleaders breath in Court and Hall

At any time is stockt withall:

For here one may (if marking well)

Observe the Plaintive Philomel

Bemoan her sorrows; and the Thrush

Plead safety through Defendant Bush:

The Popingay in various die

Performes the Sergeant; and the Pie

Chatters, as if she would revive

The Old Levite prerogative,

And bring new Rotchets in again;

Till Crowes and Jackdaws in disdain

Of her Pide-feathers, chafe her thence,

To yeeld to their preheminence:

For you must know't observ'd of late,

That Reformation in the State,

Begets no less by imitation,

Amidst this chirping feather'd Nation;

Cuckoes Ingrate, and Woodcocks some

Here are, which cause they't seasons come,

May be compar'd to such as stand

At Terms, and their returns command;

And lest Authority take cold,

Here's th'Ivyes guest of wonder, th' Owl,

Rufft like a Judge, and with a Beak,

As it would give the charge and speak:

rest: of my time

acquire

Old Fr 'cap a pie', head to foot

Then 'tis the Goose and Buzzards art

19 my God serv'd] once my God has been served, i.e. after I have prayed. $\quad$ 34-5 Pleaders breath] the depositions of lawyers: initiating a long legal motif. 41 Popingay] green woodpecker $(O E D 7)$ : usually the parrot, not present in the English countryside. 44 Levite] the traditional priestly tribe in ancient Judea. The magpie (by its black-and-white plumage like a rotchet) resembles a high-church priest, reinstating the vestments abolished by the Puritans (?'Crowes and Jackdaws', 46). 52 chirping feather'd Nation] drawing on the 'parliament of fowls' convention, where birds imitate human political debates and actions. Here the parallel is with law courts. 56 Terms] (a) limiting conditions (b) periods when courts are in session. returns] Sending back a writ to the court where it was originally issued: a metaphor for bird migration. $\quad 58$ th'Ivy] Growing on old buildings frequented by owls.

61 Goose and Buzzards] Suggesting, respectively, gullible and vindictive litigants. 
Alone, t'perform the Clients part;

For neither Dove nor Pigeon shall,

Whilst they are both exempt from gall.

The Augur Hern, and soaring Kite,

Kalendar weather in their flight;

As doe the cleanlier Ducks, when they

Dive voluntary, wash, prune, play;

With the fair Cygnet, whose delight

Is to out-vie the snow in white,

And therefore alwayes seeks to hide

Her feet, lest they allay her pride.

The Moor-hen, Dobchick, Water rail,

With little Washdish or Wagtail;

The Finch, the Sparrow, Jenny Wren,

With Robin that's so kinde to men;

The Whitetail, and Tom Tit obey

Their seasons, bill and tread, then lay;

The Lyrick Lark doth early rise,

And mounting, payes her sacrifice;

Whilst from some hedg, or close of furrs,

The Partridge calls its Mate, and churrs;

And that the Countrey seem more pleasant,

Each heath hath Powt, and wood yeelds Phesant;

Iunoes delight with Cock and Hens

Turkies, are my Domestick friends:

Nor doe I bird of Prey inlist,

But what I carry on my Fist:

Now not to want a Court, a King-

Fisher is here with Purple wing,

Who brings me to the spring-head, where

Crystall is Lymbeckt all the yeere,

And every Drop distils, implies

An Ocean of Felicities;

Whilst calculating, it spins on,

And turns the Pebles one by one,

Administring to eye and eare

New Stars, and musick like the Sphere;

When every Purle Calcin'd doth run,

And represent such from the Sun:

prophet, soothsayer; heron

record, study

preen

dabchick or little grebe pied wagtail

wheatear, a small thrush tread: copulate (of birds) singing, melodious offers worship furze

the call of a partridge so that grouse

that is distilled; enfolds, contains

Devouring Pike here hath no place,

Nor is it stor'd with Roach or Dace;

The Chub or Cheven not appeare,

Nor Millers Thumbs, nor Gudgeons here,

But nobler Trowts, beset with stones

Of Rubie and of Diamonds,

Bear greatest sway; yet some intrench,

As sharp-finn'd Pearch, and healing Tench;

i.e., the sparkling water and pebbles

The stream's too pure for Carp to lie,

Subject to perspicuitie,

For it must here be understood,

There are no beds of sand and Mud,

64 exempt from gall] hence not engaging in lawsuits. $\mathbf{6 8}$ voluntary] legal action or declaration made without compulsion; hence in high spirits, energetically. $\mathbf{7 6}$ kinde to men] The robin lives close to human habitations. 85 Iunoes delight] the peacock, sacred to Juno: introduced in England by this time. $\quad \mathbf{8 6}$ Turkies] introduced in England c.1525. $\quad \mathbf{8 8}$ i.e. his tame falcon. $\quad \mathbf{9 2}$ Crystall is Lymbeckt] Crystal-clear water is distilled. 95-6 Pebbles were used to calculate sums. 98 Stars] the shining pebbles. musick] the stream's murmur. Sphere] In the Ptolemaic astronomical system, the heavenly bodies were embedded in crystalline spheres that made celestial music as they revolved.

99-10o Struck by the sunlight, the pebbles (or water?) resemble burning pearls. Calcin'd] burnt to a substance like lime. 105 nobler Trowts] Cf. Walton, The Compleat Angler, ch.4: 'The trout is ... a generous fish: ... a fish that feeds clean and purely, in the swiftest streams'. 106 Rubie, Diamonds] cf. Walton, ch.4: 'the best trouts are either red or yellow'.

109 lie] an obvious pun. 
But such a Gravell as might pose

The best of Scholars to disclose,

And books and learning all confute,

reject, declare false

Being clad in water Tissue sute.

These cool delights help'd with the air

Fann'd from the Branches of the fair

Old Beech or Oak, enchantments tie

To every senses facultie,

And master all those powers should give

The will any prerogative:

Yet when the scorching Noon-dayes heat

Incommodates the Lowing Neat,

Or Bleating flock, hither each one

Hasts to be my Companion.

And when the Western Skie with red-

Roses bestrews the Day-stars bed:

The wholsome Maid comes out to Milk

In russet-coats, but skin like silk;

Which though the Sun and Air dies brown,

Will yeeld to none of all the Town

For softness, and her breaths sweet smell,

Doth all the new-milcht Kie excell;

She knows no rotten teeth, nor hair

Bought, or Complexion t'make her fair;

But is her own fair wind and dress,

Not envying Cities happiness:

Yet as she would extend some pitty

To the drain'd Neat she frames a ditty,

overcome; should that should

Which doth inchant the beast, untill

It patiently lets her Paile fill;

This doth the babbling Eccho catch,

And so at length to me't doth reach:

Straight roused up, I verdict pass,

Concluding from this bonny Lass,

And the Birds strains, 'tis hard to say

Which taught Notes first, or she, or they:

Thus ravish'd, as the night draws on

Its sable Curtain, in I'm gon

To my poor Cell; which 'cause 'tis mine,

I judge it doth all else out-shine,

Hung with content and weather-proof,

Though neither Pavement nor roof

Borrow from Marble-quarr below,

Or from those Hills where Cedars grow.

There I embrace and kiss my Spouse,

Who like the Vesta to the house,

A Sullibub prepares to show

By care and love what I must owe.

Then calling in the Spawn and frie,

Who whilst they live ne'r let us die;

But every face is hers or mine,

Though minted yet in lesser Coin,

She takes an Apple, I a Plumbe,

Encouragements for all and some:

Till in return they crown the herth

With innocent and harmless merth,

Which sends us Joyfull to our rest,

kine, cattle

vexes, causes discomfort to; cattle

sun's

a cheap rustic fabric

?energy, driving force; adornment

milked

More than a thousand others blest.

113 Gravell] pun on gravelled, confused or flummoxed. The literal gravel of the stream-bed is so clear that it might prompt a scholar to give up his turgid learning. 116 water Tissue] pun on 'watered' textiles, with a wavy lustrous pattern. $\quad$ 135-6 hair ... Complexion] a wig or cosmetics 158 Vesta] goddess of the hearth and its fire, hence of domesticity. 159 Sullibub] syllabub, a drink of spiced and flavoured milk. $\quad 162$ Because the parents' life and appearance continues in the children.

quarry; below in the flooring

By: in terms of, in return for children 


\section{Mildmay Fane In Praise of a Country Life}

From a ms at Fulbeck Hall, the seat of the Fane family. Text below based on Cain's edn.

Who so Enjoyes the Cuntry Ayer

With Hounds in Couples, Frends a Payer

Or more, and seriously can looke

Sometimes into a Harmles Booke

Need not contemplat what the Barr

Molests, or stratagems of warr

Produce, nor on Ambition's winge

Seek to sore up to Court and Kinge

But with a Comp'tency Content

Pass All his Dayes in Merriment

Yet with such Care, Those let not in

Temptation or the least of Sin

But both to Body and the minde

Like Solaces appeer most kinde

Infeofing either with such Health

Is prisable above all wealth.

soar

Non est vivere sed valere vita

\section{Joseph Beaumont From Psyche}

An extract from Beaumont's Psyche (1648), an allegorical epic about the progress of the soul. Here, one of the shepherds come to adore the Christ-child describes to Mary and Joseph the appearance of the angels announcing the birth of Christ (Luke 2.8-20).

Whil'st in the open Field our Watch we kep'd

Befriended by the Moon and Stars, that no

Perill might wake our tender Flocks, which slep'd

Together with their tenderer younglings: Loe

There rush'd from Heav'n a sudden mighty Light

Which out of all the wide field chased Night.

The Frighted Moon and Stars flew all away,

With unexpected Gold the Skie grew bright:

We never yet beheld the entring Day

Break from the East with such commanding Light.

commencing, dawning

'Twas Glories Morning this, and in our eyes,

No Sun but Majesty did seem to rise.

With that, and with Amazement blinded, we

Fell down, supposing Heav'n had done so to, done so: fallen down, descended to earth; too

And that the Beauties of Sublimitie

Came poste on some grand Businesse below.

And here we see what fetch'd them down; thy Son

swiftly

May well wooe all Heav'n after Him to run.

But as poor Bats, and wretched Birds of Night

Surprised by a sudden-rushing Flame,

Are strook with horror at the glorious Sight,

as is

Which seals their eyes, and open sets their shame:

So wee by this strange Apparition were

Besieg'd no lesse with lustre, than with Fear.

When, as we trembling lay, a radiant Friend

Who gently hover'd in the neighbour Aire,

Did fan fresh comfort with his Wings, and lend

Our Hearts new Courage: 'Tis no Night of Fear

Said he, Look up, and view this Sceen of Joy

Set forth in Heav'ns most festivall Array.

15 Infeofing] enfeoffing: investing, putting in possession. live but to live in good health'. Martial, Epigrams 6.70.15. literally, an effulgence of light (OED 6). 
We op'd our Eyes, and round about beheld

How Smiles and Comforts had bedeck'd the Place,

Which seem'd no more a common Countrey Field,

But Paradise's own delicious face:

And such wee should have thought it still, had we

Not hither come, and seen thy Son, and Thee.

But yet a Beauty next to yours wee saw,

Almost as bright, as sweet, as milde, as grave,

That Angel which did upon Us bestow

That courteous Item; His Attire was brave,

His Looks, the Glass of Heav'n, most sweet his Tongue;

From which these blessed Words of Comfort rung:

mirror, reflection,

[image

BEHOLD, I bring you News of greater Joy

Than kindest Heaven till now did ever send;

Joy which through every Heart shall melt its way,

And with the Sun its equall Course extend: Joy which shall know no Limits, but through all The World display its gallant Festivall.

For unto you, and your grand blisse, this Morn

In royall Davids City, Christ the Lord

Of Him, and You, and this whole World is born:

A mighty King, who cometh to afford The often-promis'd long-desir'd Salvation Unto his fainting, and decayed Creation.

Stagger not at the News; but let this Signe

be amazed

Assure your Faith, and banish needlesse Doubts:

You shall at Bethlehem finde this divine

Infant wrapp'd up in simple swadling Clouts, And in a plain and correspondent Bed, The Asses Manger, resting his sweet Head.

joy, celebration

As we for Joy at these strange Tidings started,

Behold, a sudden Globe of flaming Light

Into a stranger Apparition parted,

And to new Wonders summoned our sight:

For at a diamond Table fair and wide

A numerous Quire of Angells we descri'd.

discerned, saw

Soul-charming Melodie amongst them sate,

At her left hand Applause, Joy at her right,

Behinde her Glory, Praise before her, at

Her foot luxuriant, but pure Delight.

The Spectacle alone was ravishing;

But ô what Raptures when they'gan to sing!

?luxuriating, stretched out; only, none other than [pure: (a) unmixt (b) chaste, virtuous

Glory to God in all Sublimity,

Peace upon Earth, and unto Men Good Will:

This was their Dittie; but their lofty Key

Did not our mortall reach alone excell,

the words of the song

surpass

But surely pos'd the Sphears, though these, they say,

In soveraign Musick spend both night and day.

supreme, sublime

O how our pretty Lambs did leap and dance!

What Troops of merrie Wolves came tripping in!

How were the Bears seiz'd with a gentle Trance! running lightly

34 Paradise] Christ restored humankind to the Paradise from which the Fall of Adam and Eve had exiled them. 40 Item] ?statement, announcement; news (cf. OED B1). 50 Davids City] Bethlehem, David's birthplace, though often used of Jerusalem. 68 Applause] presumably praise, adoration; but cf. Praise (69). 77 pos'd] transcended, exceeded (OED pose v ${ }^{2} 2$ b). Sphears] In the Ptolemaic system, the heavenly bodies were embedded in spheres that made celestial music as they revolved. 
How did this Harmony the Lyons win! All Salvagnesse was quickly charm'd asleep, And every Beast was now a gentle Sheep.

The Stones look'd up and seem'd to wish for feet,

The Trees were angry that they stuck so fast;

All Things desir'd the Melody to meet,

And, as they could, unto the Dance made haste.

With that, our silly oaten Pipes wee broke,

And then our Parts with cheerly Nature took.

match, respond to

feeble, scanty blithe, happy

And though our Feet never more nimbly flew

Than in their Answer to this Musicks Pleasure,

Doing their best indeavour to trip true

To every Turn, and Point, and Aire, and Measure; Yet in our joyous Breasts we felt our Hearts

dance With more Activity, dancing their Parts.

The Anthem finished: That glorious Fire

About the Company its Arms did spread,

And homeward convoy'd the illustrious Quire.

100

We saw how wide a Gate Heav'n opened

To let them in: We saw it shut and yeild

Back to the Stars their free etheriall Field.

Thence came We hither, and the Promise found

As true and noble as our Expectation:

Which from this Cave shall by our Tongues rebound

To every Ear we meet: By this Narration

Our Hearts shall eased be, least by the Wonder

Of this Heav'n-crowned Morn they split in sunder.

But when the Yeares fresh youth returns, to deck

110 The Bed of Aprill in its vernall Hue;

The choysest sweets and Beauties We will pick,

And wreath a Chaplet for the fairer Brow

Of this our blooming Lord. Till when We place

Our hopes of safety in his onely Grace.

Here, with three Adorations to the Sonne,

They of the Mother and good Joseph, take

Their humble leave. But she, when they were gone,

Deep in her Bosome prints what they had spake,

The News, the Quire, the Song, the glorious Light,

Which duely she reads over Morn and Night.

records, memorizes

Point: short strain or musical phrase

And well she div'd into the Reason why

That glorious Hoste kept distance from the Cave,

And to these Creatures of Humility,

These simple honest Swains, the honour gave

Of being his first Visiters, who came

To be at once a Sheepheard, and a Lamb.

his: Christ's

9o Parts] the separate sections or strands of a harmonized 'part-song'. $\quad 126$ a Sheepheard, and a Lamb] Christ is both the Good Shepherd (John 10.14, Hebrews 13.20, 1 Peter 2.25: cf. Psalms 23.1, Isaiah 40.11) and the Lamb of God (John 1.29, 36, Revelation 12.11, 22.1). 


\section{A Pastoral Dialogue between Coridon and Thyrsis}

The first item in BL MS. Harley 393, lamenting the nation's miseries since Charles I's execution and hoping for the restitution of monarchy. Punctuation, line initials and speech-headings standardized.

A Pastorall Dialogue Betweene Corridon and Thyrsis occasioned by the Thirtieth of January 1648

Corydon. Deare Thyrsis! tell thy Corydon,

What's the sad cause of all thy Moane,

That I may either beare a Part,

Or wholly Ease my Troubled heart;

Greife which vnvented, eates the Breast,

Communicated, may find Rest.

Thyrsis. Rather forsake me Corydon:

My Sorrow then will kill but one.

My sad heart labours with a Woe

Would destroy us and many moe.

Corydon. Tell it how ere, for thy Distresse

however, nonetheless

Has made my Life so comfortlesse:

And the whole World to me alone,

Were such a Trifle, thou being gone,

That I by odds, had rather haue

by a big margin

Thy Company, though in the Graue.

Thyrsis. Then Corydon prepare to heare

The Dismall'st chance that any Eare

Heard since times Birth. None ever knew

event, fall-out

A Tale so sad, so strange, so true.

In rich Arcadia whilome blest

With all great Blessinge, Crown'd with Rest,

There was (woes me I cannot say

There is, for then t'were happy day)

There Was a Shepheard Damon hight

The best that ere was brought to light,

Descended from the noblest Race,

That ere did Shepheards life Embrace.

Never was Shepheard so so good

Soe sparing of his poor Flocks blood.

The Draught by day, and carefull Breast,

The Frost by night consum'd his Rest;

Yet seem'd this Shepheard well at Ease,

If thus he might his Flocks but please.

By Damons care they thriue amaine,

Every faire Feild and Fertile Plaine

Gladly receiu'd these sheep, which are

Growne numerous by th' Shepheards care.

The Wolues that other Flocks Invade,

Of Damons watchfulnesse afrayde,

First consult how they may swallow

that would truly have been fortunate

named

born

Damon, and the sheep will follow:

At last it is Resolv'd that one

The Sheepes warme cloathing should put on

And midst the Flock unwary keepe,

Who well could personate the Sheep.

The disguis'd Wolfe soone vndertakes

The Wolues Decree, and Journey makes

To the large Flock, who mixt among

'Twas hard to know him in the Throng.

Forward he was to sport, and play,

And use all Arts, that might make way,

To gett the Love, Applause and Fame,

o.1-2 Thirtieth of January 1648] the date of Charles I's execution (1649 by modern reckoning). $\quad 28$ Shepheards life] metaphor for the king's. 31 Draught] ?cold winds; ?removal of the weakest or worst animals, culling (OED draft n C1). carefull] (a) concerned, full of care (b) sad, depressed. 
Of them, to ruine whom he came.

At first he scatters hatefull Seeds

Of Hemlock, and destroying Weeds,

Which grew apace, for they were bad,

And tasted, made the Taster mad.

Some Sheep, whose happ it was, to light

luck

On those curs'd weeds, grew mad out right;

These he too easily perswades,

Twas Damons fault, and then Invades

The trembling Flock, with Jealousie,

And Feares of greater Dangers nigh,

Assumes the Conduct of the Sheep,

Forsakes the place where they did keep

And thriue into such Numbers, soe

They're left, they know not where they goe;

At last he brings them, hungry growne

By the hast, which their Feares put on,

Where Poyson was their onely Food,

Which heats the old, breeds new bad blood,

Whilst silley They thinke, but for his

Care, they had been all dead, ere this.

To the Oracle he feines to goe,

That he Infallibly might know

The way to cure them, by some Spell,

Who but for him, had been too well.

The wolues that close in Counsell sate,

8o While he did his Successe relate,

Vote him thankes, and rewards to boott,

For empty Gratitude won't doo't.

Instruct him, what advice to giue,

That they upon the Spoile may liue.

Meen time the carefull Shepheard finds

His wandring Flocks distracted Mindes,

Discovers the Impostors Arts

Who long seduced had their hearts,

Applyes a cure, and lends them Eyes

90 To see their growing Miseryes.

Some whom the Taint had faintly strooke,

Resolved to escape the Hooke,

Knew and obey'd the Shepheards voyce,

Others rais'd Murmurs, whose loud Noyse

Amaz'd the faithfull Shepheards Eares.

When loe the disguis'd Wolfe appeares,

Finds now or never is the tyme

To aggrauate the Shepheards crime.

By his Returne the Flocks are more

Inraged, then they were before.

From him they quickly understood,

Unlesse they drink their Shepheards blood

No phisicke could be found to ease

The burnings of their mad Disease.

And this he told in holy Guise

(Mixt with true-teare-dissembling Eyes).

To Murder Damon, all are driuen,

As if the Counsell came from Heaven.

Large Contribucions they all giue,

That he may dye, by whom they liue.

'Tis time the Shepheard now should flye,

When Innocence is doom'd to dye.

struck

stunned, deafened

make it appear graver

55 hatefull Seeds] i.e. schismatic doctrines. hatefull] inducing hate. 73 silley] simple, innocent, shading off into the sense 'foolish'. 83 what advice to giue] i.e. to the sheep. 89 Applyes a cure] perhaps the convening of the Oxford Parliament. (See 239.113n.). 
The cheated Flock incens'd pursue, The Shepheards flight makes his Guilt new.

Hard is his happ, who either way

Is guilty Made, goe $\mathrm{He}$, or stay:

At last betray'd and sold to those,

Who from his Care became his foes,

Damon is murther'd; the sheep smile,

The Wolues keep holyday the while.

The faithfull Shepheard butcherd so,

Th'abused Flock to wrack must goe;

The Wolues themselues their Pastors are,

Kill whom they please, whom they please, spare:

The Cozened Flocks deluded Eyes

Open'd at last by Miseryes,

Now see their Ruine and make Moane

But too too late, for him that's gone:

Thou fell'st untimely, the sheep cry

And each Eye weeps his Elegie.

At length they goe to ease their Greife,

To th' Oracle to fynd Releife.

Whence after three dayes' sacrifice

They receiu'd answer in this wise.

Oracle.

"When the First borne of Damon dead

With Hooke in hand Laurell on Head

Shall lead you to the Pastures where

You at the first infected were,

Then, not till then, Heavens Blessings yeild

To every Flock in every Feild."

The Sheep returne, are made a Prey,

The Wolues command, while they obey,

Know not how long they must endure,

But know the Oracle is sure.

Their greifes and Miseries were done

Could they once see the Shepheards sonne.

Corydon. Dry up thy Eyes, Dear Thyrsis! I

Am concern'd in this Tragedie.

My natiue Soyle's the Fatall Scene,

Where this fowle Play has acted been.

Where teares won't help, let Patience cure,

He conquers greife, that can endure.

Let's humbly supplicate our God,

Hee'l free us from't and burne the Rod.

Arcadia now is full of Woe,

Let's hope ere long, Twill not be so.

\section{Henry Vaughan The Shepherds}

From Vaughan's Silex Scintillans, Part I (1650). The shepherds are those to whom angels announced the birth of Christ; but they are shown as receiving the honour because of the general nature of shepherds' lives, with some telling Old Testament associations.

Sweet, harmles lives! (on whose holy leisure

Waits Innocence and pleasure;)

Whose leaders to those pastures, and cleer springs,

Were Patriarchs, Saints, and Kings,

How happend it that in the dead of night

136 Hooke, Laurell] suggesting the Bishop's crozier and royal crown, i.e. the future Charles II as head of the Anglican Church as well as the state. Hooke] sheephook. 3 pastures, and cleer springs] echoing Psalms 23.2, but now it is the shepherds rather than the sheep who are being led there.

Patriarchs, Saints, and Kings] a common topos that shepherds held such positions, most specifically Abraham, Moses and David. 5-6 The shepherds were the first people to be told of Christ's birth. 
You only saw true light,

While Palestine was fast a sleep, and lay

Without one thought of Day?

Was it because those first and blessed swains

Were pilgrims on those plains

When they receiv'd the promise, for which now

'Twas there first shown to you?

'Tis true, he loves that Dust whereon they go

That serve him here below,

And therefore might for memory of those

His love there first disclose;

But wretched Salem once his love, must now

No voice, nor vision know,

Her stately Piles with all their height and pride Now languished and died,

And Bethlems humble Cotts above them stept While all her Seers slept;

Her Cedar, firr, hew'd stones and gold were all Polluted through their fall,

And those once sacred mansions were now Meer emptiness and show,

This made the Angel call at reeds and thatch, Yet where the shepheards watch,

And Gods own lodging (though he could not lack,) To be a common Rack;

No costly pride, no soft-cloath'd luxurie In those thin Cels could lie,

Each stirring wind and storm blew through their Cots Which never harbour'd plots,

cottages; raised, ranked

Only Content, and love, and humble joys

Lived there without all noise,

Perhaps some harmless Cares for the next day

Did in their bosomes play,

As where to lead their sheep, what silent nook, What springs or shades to look,

But that was all; And now with gladsome care They for the town prepare,

They leave their flock, and in a busie talk All towards Bethlem walk

To see their souls great shepheard, who was come To bring all straglers home,

Where now they find him out, and taught before That Lamb of God adore,

That Lamb whose daies great Kings and Prophets wish'd And long'd to see, but miss'd.

The first light they beheld was bright and gay And turn'd their night to day,

But to this later light they saw in him, Their day was dark, and dim.

? narrow, ?thin-walled conspiracies, as at court

9-12 God appeared to Abraham on his journey to Canaan and granted him the promised land (Genesis 12.7). 13-16 He loves the humble people who serve him, and therefore first told humble shepherds of Christ's birth. 17 Salem] Jerusalem: presented as a city of opulence and corruption, seat of the Jews opposed to Christ, contrasting with the cattle-shed at Bethlehem. 22 her] Jerusalem's. Seers (false) prophets, who could not foretell Christ's birth. $\quad 29$ though ... lack] though he could command all wealth. $\quad 30$ Rack] a receptacle for fodder. $\quad 47$ taught before] informed earlier (by the angels). $\quad 51$ first light] that seen by a child at birth; here probably the 'light' seen by Abraham and his companions when God appeared to them (see 9-12n). But this Old Testament vision fades before the actual appearance of Christ in the New (later light). 


\section{Henry Vaughan Daphis: an Elegiac Eclogue}

The last piece by Henry Vaughan in the collection Thalia Rediviva (1678), followed by his brother Thomas's poems. This has prompted the view that the poem might be mourning Thomas's death; but the dead man's youth, and certain topical references, suggest a lament for Henry's younger brother William, written shortly after his death in 1648 . Several laments for William, with spiritual consolation, appear in Vaughan's earlier two-part collection Silex Scintillans $(1650,1655)$.

DAPHNIS. An Elegiac Eclogue. The Interlocutors, Damon, Menalcas.

Damon. What clouds, Menalcas, do oppress thy brow?

Flow'rs in a Sunshine never look so low.

Is Nisa still cold Flint? or have thy Lambs

Met with the Fox by straying from their Dams?

Menalcas. Ah! Damon, no; my Lambs are safe, and she

Is kind, and much more white than they can be.

But what doth life, when most serene, afford

Without a worm, which gnaws her fairest gourd?

Our days of gladness are but short reliefs,

Giv'n to reserve us for enduring griefs.

So smiling Calms close Tempests breed, which break

Like spoilers out, and kill our flocks, when weak.

I heard last May (and May is still high Spring,)

The pleasant Philomel her Vespers sing.

And all the West like Silver shin'd; not one

Black cloud, no rags, nor spots did stain

The Welkin's beauty: nothing frown'd like rain;

But e're night came, that Scene of fine sights turn'd

To fierce dark showrs; the Air with lightnings burn'd;

pleasing, sweet; nightingale; evening prayers

i.e., in fierce heat

The wood's sweet Syren rudely thus opprest,

Gave to the Storm her weak and weary Breast.

I saw her next day on her last cold bed;

And Daphnis so, just so is Daphnis dead!

Damon. So Violets, so doth the Primrose fall,

At once the Spring's pride and its funeral.

Such easy sweets get off still in their prime,

And stay not here, to wear the foil of Time.

While courser Flow'rs (which none would miss, if past)

preserve, save

hidden, unsuspected destroyers, pillagers

To scorching Summers, and cold Autumns last.

Menalcas. Souls need not time, the early forward things

Are always fledg'd, and gladly use their Wings,

Or else great parts, when injur'd, quit the Crowd,

To shine above still, not behind the Cloud.

And is't not just to leave those to the night,

That madly hate, and persecute the light?

Who doubly dark, all Negroes do exceed,

And inwardly are true black Moores indeed

Damon. The punishment still manifests the Sin,

As outward signs shew the disease within.

While worth opprest mounts to a nobler height,

And Palm-like bravely overtops the weight.

So where swift Isca from our lofty hills

With lowd farewels descends, and foming fills

A wider Channel, like some great port-vein,

With large rich streams to feed the humble plain:

I saw an Oak, whose stately height and shade 3 Nisa] Name taken from Virgil VIII. 8 worm, gourd] Jonah 4.6-7. 16 The line is short by a foot:
there may be words missing. 21 wood's sweet Syren] the nightingale, which sings as sweetly as the Sirens. $\quad 22$ ? was left exposed to the storm; ?sang feebly against the fury of the storm. 27 easy] gentle, ?tender, delicate. sweets] delights, pleasing objects. get off] depart. 32 fledg'd] feathered, like adult birds capable of flight. $\quad \mathbf{4 2}$ As a palm tree grows upward, pushing aside anything weighing it down. Vaughan gives the image a spiritual turn in 'The Palm-tree' (Silex Scintillans, Part II). 43 Isca] the river Usk in Breconshire, Vaughan's native region. 45 port-vein] the principal vein carrying blood to the liver. 
Projected far, a goodly shelter made,

And from the top with thick diffused Boughs

In distant rounds grew, like a Wood-nymph's house.

Here many Garlands won at Roundel-lays

Old shepheards hung up in those happy days,

With knots and girdles, the dear spoils and dress

spoils: tokens, mementos

Of such bright maids, as did true lovers bless.

And many times had old Amphion made

His beauteous Flock acquainted with this shade;

A Flock, whose fleeces were as smooth and white

As those, the wellkin shews in Moonshine night.

Here, when the careless world did sleep, have I

60 In dark records and numbers noblie high

The visions of our black, but brightest Bard

From old Amphion's mouth full often heard;

With all those plagues poor shepheards since have known,

And Ridles more, which future times must own.

While on his pipe young Hylas plaid, and made

Musick as solemn as the song and shade.

But the curs'd owner from the trembling top

To the firm brink, did all those branches lop,

And in one hour what many years had bred,

The pride and beauty of the plain lay dead.

The undone Swains in sad songs mourn'd their loss,

While storms and cold winds did improve the Cross.

But Nature, which (like vertue) scorns to yield

Brought new recruits and succours to the Field;

For by next Spring the check'd Sap wak'd from sleep

And upwards still to feel the Sun did creep,

Till at those wounds the hated Hewer made,

There sprang a thicker and a fresher shade.

Menalcas. So thrives afflicted Truth! and so the light,

When put out, gains a value from the Night.

How glad are we, when but one twinkling Star

Peeps betwixt clouds more black than is our Tar?

And Providence was kind, that order'd this

To the brave Suff rer should be solid bliss;

Nor is it so till this short life be done,

But goes hence with him, and is still his Sun.

Damon. Come Shepherds then, and with your greenest Bays

Refresh his dust, who lov'd your learned Lays.

Bring here the florid glories of the Spring,

And as you strew them pious Anthems sing,

Which to your children and the years to come

May speak of Daphnis, and be never dumb.

While prostrate I drop on his quiet Urn

My Tears, not gifts; and like the poor, that mourn

With green, but humble Turfs; write o're his Hearse

For false, foul Prose-men this fair Truth in Verse.

"Here Daphnis sleeps! and while the great watch goes

Of loud and restless Time, takes his repose.

Fame is but noise, all Learning but a thought:

55 Amphion] Legendary musician, brought up as a shepherd: here probably Matthew Herbert, the Vaughans' old schoolmaster and local priest. 61 our black ... Bard] Perhaps Merlin Ambrosius (Myrddin Emrys), a legendary figure identified with the wizard Merlin. See L. I. Guiney, Quarterly Review, April 1914, p.356. 65 Hylas] a boy beloved of Herakles, with no pastoral associations. The unexpected name suggests a personal allusion. $\mathbf{6 8}$ brink] obviously foot or roots, but no such sense in $O E D$. $\quad 72$ improve the Cross] aggravate the suffering (OED improve v $\left.{ }^{2} 4 \mathrm{~b}\right)$. 8o gains a value] i.e. by contrast. $\mathbf{8 2}$ Tar] used to dress sheep's wounds. $\mathbf{8 3}$ this] Truth (79), symbolized by the star. 95 green, but humble Turfs] grassy patches, as they cannot afford costly gravestones or monuments. 97-8 watch] ?a wake or revel (OED 2b), contrasting with Daphnis' repose. 
Which one admires, another sets at nought.

Nature mocks both, and Wit still keeps adoe;

But Death brings knowledge and assurance too."

labours fruitlessly

Menalcas. Cast in your Garlands, strew on all the flow'rs

Which May with smiles, or April feeds with show'rs.

Let this day's Rites as stedfast as the Sun

Keep pace with Time, and through all Ages run,

The publick character and famous Test

Of our long sorrows and his lasting rest;

And when we make procession on the plains,

Or yearly keep the Holyday of Swains,

Let Daphnis still be the recorded name

And solemn honour of our feasts and fame.

For though the Isis and the prouder Thames

Can shew his reliques lodg'd hard by their streams,

And must for ever to the honour'd name

Of Noble Murrey chiefly owe that fame:

Yet, here his Stars first saw him, and when fate

Beckon'd him hence, it knew no other date.

Nor will these vocal Woods and Valleys fail,

Nor Isca's lowder Streams this to bewail,

But while Swains hope and Seasons change, will glide

With moving murmurs, because Daphnis di'd.

Damon. A fatal sadness, such as still foregoes,

Then runs along with publick plagues and woes,

Lies heavy on us, and the very light

Turn'd Mourner too, hath the dull looks of Night.

Our vales like those of Death, a darkness shew

More sad than Cypress, or the gloomy Yew,

And on our hills, where health with height complied,

Thick drowsie Mists hang round and there reside.

Not one short parcel of the tedious year

In its old dress and beauty doth appear;

Flow'rs hate the Spring, and with a sullen bend

Thrust down their Heads, which to the Root still tend,

And though the Sun like a cold Lover, peeps

A little at them, still the Days-eye sleeps.

But when the Crab and Lion with acute

And active Fires their sluggish heat recruit,

Our grass straight russets, and each scorching day

Drinks up our Brooks as fast as dew in May,

Till the sad Heardsman with his Cattel faints,

And empty Channels ring with loud Complaints.

Menalcas. Heaven's just displeasure and our unjust ways

Change Nature's course, bring plagues, dearth and decays.

This turns our lands to Dust, the skies to Brass,

Makes old kind blessings into curses pass,

And when we learn unknown and forraign Crimes,

Brings in the vengeance due unto those Climes.

The dregs and puddle of all ages now

Like Rivers near their fall, on us do flow.

proof, evidence

Ah happy Daphnis! who, while yet the streams

Ran clear and warm (though but with setting beams,)

Got through: and saw by that declining light

107 character] mark, token (OED 8a). 113-6 Thomas Vaughan was buried by the offices of his friend Robert Moray ('Noble Murrey') at Albury, on the river Thame (not Thames) in Oxfordshire. The Thame flows into the Thames, called the Isis at Oxford. 113-8 i.e. Although Thomas was buried elsewhere, Breconshire remains his home. 121 hope] hard to explain. Perhaps 'hope for better things'. 128 Cypress, Yew] trees associated with death and mourning. 129 where ... complied] where the great height made for a clear healthy atmosphere. $\quad 137 \mathrm{Crab}$, Lion] zodiacal constellations of the hot summer. 150 fall] mouth (OED 6). 152 setting beams] The beams of the setting sun - i.e.. when Daphnis died, the times were still happy, though already on the decline. 
His toil's and journey's end before the Night.

Damon. A night, where darkness lays her chains and Bars,

And feral fires appear instead of Stars.

But he along with the last looks of day

Went hence, and setting (Sun-like) past away.

What future storms our present sins do hatch

Some in the dark discern, and others watch;

Though foresight makes no Hurricane prove mild;

Fury that's long fermenting, is most wild.

But see, while thus our sorrows we discourse,

Phoebus hath finish't his diurnal course.

The shades prevail, each Bush seems bigger grown:

Darkness (like State) makes small things swell and frown.

The Hills and Woods with Pipes and Sonnets round

And bleating sheep our Swains drive home, resound.

shuts in completely

Menalcas. What voice from yonder Lawn tends hither? heark!

'Tis Thyrsis calls, I hear Lycanthe bark.

His Flocks left out so late, and weary grown

Are to the thickets gone, and there laid down.

Damon. Menalcas, haste to look them out, poor sheep

When day is done, go willingly to sleep.

And could bad Man his time spend, as they do,

He might go sleep, or die, as willing too.

Menalcas. Farewel kind Damon! now the Shepheards Star

With beauteous looks smiles on us, though from far.

All creatures that were favourites of day

Are with the Sun retir'd and gone away.

While feral Birds send forth unpleasant notes,

And night (the Nurse of thoughts,) sad thoughts promotes.

But Joy will yet come with the morning-light,

Though sadly now we bid good night!

Damon.

Good night!

\section{William Denny From The Shepherd's Holiday}

This description by the shepherd Bilkin of a grove called the Lovers' Maze is from near the start of Denny's manuscript pastoral play The Shepherd's Holiday (BL MS. Addl. 34065, dated 1 June 1651 in the dedicatory epistle). According to the prefatory account of 'The Morall' of the work, Bilkin is 'The Character of Temperance, Moderation, Discretion and Judgement who vnder the Sheepeard's Life commendes Innocence of Life and Retirement from the World.' (fol.4r) But the Lovers' Maze he describes 'representes The World; wherein there are Varietie of Pathes, of Temptations, and Turnings'. Pastoral idyllism and worldly complexity are linked in a subtle counterplay.

Bilkin enters; and takes a Seate vnder the side of the Groue, call'd Lover's Maze. Birds singing.

This is the Seate of sweet Repose for Swaines

Backt with a Groue; And fac't with smoothed Plaines.

This Boscarie of Soules, The Lovers Maze,

With musicke giues new birth to dawning Dayes.

Harke! Eu rie Spray tunes forth a various Note;

While All concording seeme one warbling Throate.

boscage, arbour or grove

Thus as They All together sing, and vie,

Each winnes, each looses the Supreamacie.

So azure Heaven with thinne Clowds chamletted,

Which borrow Scarlet from Sol's rising Head,

Who gildes Aurora's Blushes that do play,

bush; different

156 feral funereal $\left(O E D\right.$ feral adj $\left.^{1} 2\right) . \quad 166$ State] pride of state, worldly importance or power. $\quad 177$ Shepheard's Star] Probably Hesperus or the evening star, as in Virgil X.77; but possibly the bright star Capella in the constellation Auriga or Charioteer, often depicted as a shepherd. feral] (a) wild, savage (b) funereal. Cf.156n. 183 Psalms 30.5: 'Weeping may endure for a night, but joy cometh in the morning'. 4-6 Referring to birdsong. All the songs seem to unite in a single melody. 11 Aurora] the goddess of the dawn or, more strictly, the redness of the dawn. 
And daunce vpon her Cheekes to sport the Day.

Rest on this greene silke Shagge of Cammomill;

Now th'art an Emperour, vpon this Hill.

Thy Crowne excelleth That of beaten Gold.

Sweet Briar's Rose, flowr'd Eglantine behold:

Which twineing o're thy Head shew forth theire Gemmes.

Theire fragrant Lustre outshines Diadems.

Rest here thy vndisturbed Limbes. Here rest

In contemplation of a Life most blest.

Happie! Thrice Happie Sheepheards! that do dwell

Cloathed with Russet in a Lowlie Cell.

Our frequent Vigils mint vs Houres to pray:

Accosting Heauen, when we salute the Day,

When freelie we vnfold our spreading Sheep,

Observing stepping Time, and Them to keep.

Our Lonelines is clept Philosophy,

By which we read Th'Allmightie Power on high.

Sunne, Moone, and Starres plac't in the Loftie Spheare

Are the bright Almanackes for Day, and Yeare.

Those flaming Torches we yclepe by names.

Custom han made vs kinne vnto theire Flames.

Is't not a Wise man's Part to guard the Flockes

From rage of cruell Wolfe, or wilie Foxe?

The Lambes do skippe, while Pipes theire Dammes allure.

More than Physitians Sheepheards safelie cure.

Our chast-hatcht Loue is warm'd by pure Desire.

Our shamefac't Embers kindle modest Fire.

Which mind-enchaunting Songs do quicklie turne

To rising Flames, that Constencie makes burne.

Our Freindship kennes ne Fraud, ne subtile Saw.

Our blamelesse Life is to it's selfe a Law.

We seldome spend, for well we know to spare.

Our sleepe is sound. 'Tis Backe to Backe to Care.

Our Beds are softer, than Those Neasts of Downe.

Content's best Riches, a Good Name, Renowne.

A peacefull Conscience sings within the Breast;

Which gain'd, no Labour but enjoyeth Rest.

Ne list we, what is Envie's venom'd Dart;

$\mathrm{Ne}$ con we Pride, that filles with Barme the Heart.

neither ... nor; sly or deceitful speech

call, designate

familiar with

charm, delight

a type of cheap rustic cloth

drive out of the fold

named, characterized as

Our seldomenes of Feasts does whet our Joy;

And easie Dainties do no Health destroy.

Our comelie Sports showne vnto Freedome's Eye

Do louelie Innocence to Sweetnes tye.

simple, light

12 sport] ?divert, entertain (OED 5). Aurora, goddess of the dawn, is blushing to be observed by the day. 13 Shagge] a cloth with a velvet nap (OED shag $\left.\mathrm{n}^{1} 2\right)$. 18. Diadems] whose lustre is not fragrant like the flowers. $\quad 23$ mint] produce, like coin: perhaps implying that this is the shepherd's wealth. 26 stepping] brisk, at a good pace (cf. OED step v6). 29 Spheare] the vault of the sky. Not the spheres of Ptolemaic astronomy, where the moon, sun and stars are in separate spheres. 30 Almanackes] Like the 'shepherds' calendars' popular in the 16-c. 32 han] has. OED cites only as plural. $\quad 38$ shame-fac't] modest, shy $\left(O E D_{1}\right)$. Embers] i.e. the heat or stimulus kindling love. 44 Backe to Backe] ?contrary or opposite to (not in $O E D$ ) - i.e., shepherds can sleep soundly because they have no cares. 49 list] ?heed, pay attention to (cf. OED list $\mathrm{v}^{2} 2$ ). 50 con] (a) know (b) study, practise. Barme] froth, hence ?swelling, effusion. $\quad 52$ Our health is not destroyed by an excess of ready pleasures. 53 comelie] (a) pleasing, delightful (b) proper, decorous. showne vnto Freedome's Eye] ?made visible or accessible only to those who are free. 


\section{Patrick Cary 'Jack! nay Prithee Come away'}

From a ms book of Cary's poems dating $c .1651$ (probably soon after composition) now in the Walter Scott Library at Abbotsford. First printed in full at Scott's initiative in Trivial Poems and Triolets (1820), the text followed here.

To the Tune,- "Will, and Tom, etc."

Dicke. Jacke! nay prithee come away,

This is noe time for sadnesse;

Pan's cheife feast is kept to day,

Each shepeard showes his gladnesse:

W'are to meete all on the greene,

To dance and sport together;

O what brau'ry will bee seene!

I hope 'twill proue fayre weather.

splendour, show

Looke I'ue got a new suit on;

Say man! how likest the colour?

Will't not take Nell's eyes anonne?

anon, at once

All greenes then this are duller.

Marcke how trimm'd up is my hooke,

sheephook

This Ribband was Nell's fauour:

love-token

Jacke the wench has a sweet looke,

I'le dye but I will haue her.

Jacke. Dicke, eene goe alone for mee;

By Nell thou art expected:

I noe loue haue there to see,

Of all I am reiected.

Att my ragges each mayd would flout,

If seene with such a shiner;

Noe. I'le n'ere sett others out;

I'le stay till I am finer.

Shall I go to sitt alone,

Scorn'd eene by Meg o'th'dayry?

Whilst proud Tom lyes hugging Joane,

And Robin kisses Mary.

Shall I see my riuall Will

Receave kind lookes from Betty?

Both of them I'de sooner kill:

Att thought on't, Lord, how fret I?

Cause hee has a flocke of sheepe,

And is an elder brother;

Cause (poore hireling!) those I keepe

Belong unto another,

I must loose what's mine by right,

And lett the rich foole gayne her:

I'le att least keepe out of sight,

Since hopelesse e're t'obtayne her.

Dicke. Courage man, thy case is not

Soe bad as thou doest take itt:

Yett 'tis ill; could I (God wott!)

if I could

Much better would I make itt.

Hee is rich; thou, poore; 'twere much

Wer't thou preferr'd by a woeman;

Woemen though keepe sometimes touch,

But (sooth) 'tis not soe common.

22 Shiner] ?impressive fellow, a 'hit'; ?knave; ?sweetheart. 23 sett out] ?embellish, set off to advantage (by accompanying someone: $\mathrm{cf}$. OED set ${ }^{v} 1$, to set off 6); ?embarrass, inconvenience (=put out). 34 elder brother] who inherits the paternal wealth. 47 keepe touch] keep faith (OED touch n24a). 
Thou, unto thy pipe can'st sing

Loue-songs of thine own making;

Hee, nor that, nor any thing

Knowes how to doe, that's taking.

She did loue thee once, and swore

charming, attractive

Ne're (through her fault) to loose thee;

If She keepe her oath, before

The richer, she will choose thee.

Jacke. Neuer, neuer, lasse! such oathes

alas

Haue force but for few howers:

If she lik'd once, now she loathes;

And smiles noe more, but lowers.

Scarce his suit had hee apply'de,

But she lou'd mee noe longer:

Soone my fayth she gan deride;

For wealth, then fayth, is stronger.

Farewell, shepeard, then. Bee gonne;

The feast noe stay here brooketh:

Prithee marcke Besse there anonne,

If kind on Will she looketh.

Who loues truely, loues to heare

Tales, that encrease his fier;

I, alasse! bade tydings feare,

And yett for newes enquier.

\section{Edward Benlowes The Pleasure of Retirement}

From Edward Benlowes' curious poem of allegorical mysticism, Theophila. or Loves Sacrifice. A Divine Poem (1652), published by Benlowes himself with a unique combination of woodcuts for each copy. The poem has two separable, virtually stand-alone cantos (12 and 13), 'The Sweetnesse of Retirement, or The Happinesse of a Private Life', and 'The Pleasure of Retirement. The Reinvitation'. The passage below consists of the first 78 lines of the latter (after a Latin exordium).

\section{THE ARGUMENT}

Who Chance, Change, Hopes, and Fears can under bring; Who can obey, yet rule each Thing,

And sleight Misfortune with a brave Disdain, He's King.

overcome, subdue

slight, scorn

When lavish Phoebus pours out melted Gold; And Zephyrs breath does Spice unfold;

And we the blew-ey'd Skie in Tissue-Vest behold.

release fragrance (of flowers)

Then, view the Mower, who with big-swoln Veins, Wieldeth the crooked Sythe, and strains

To barb the flowrie Tresses of the verdant Plains.

cut, trim

Then view we Valleyes, by whose fringed Seams A Brook of liquid Silver streams,

Whose Water Chrystal seems, Sand Gold, and Pebbles Gems;

Where bright-scal'd gliding Fish on trembling Line We strike, when they our Hook entwine:

Thence do we make a Visit to a Grave Divine.

strike: hook by jerking the line religious man, ?hermit

With harmlesse Shepherds we sometimes do stay,

Whose Plainnesse does outvie the Gay,

While nibling Ewes do bleat, and frisking Lambs do stray.

4 Phœbus] Apollo as sun-god. 5 Zephyr] (god of) the west wind, blowing in spring. 6 Tissue-Vest] a rich cloth interwoven with gold or silver: here referring to the sun's beams. 13-4 Implicit moral allegory of temptation by the world's snares. Each subsequent item of natural description carries such a moral. 
With Them, we strive to recollect, and finde

Disperst Flocks of our rambling Minde;

Internal Vigils are to that due Work design'd.

No puffing Hopes, no shrinking Fears Them fright;

No begging Wants on Them do light;

They wed Content, while Sloth feels Want, and Brav'ry Spite.

swelling up

glamour, show

While Swains the burth'ning Fleeces shear away,

Oat-pipes to past'ral Sonnets Play,

And all the merry Hamlet Bells chime Holy Day.

In neighbring Meads, with Ermin Mantles proud,

Our Eyes and Ears discern a Crowd

Of wide-horn'd Oxen, trampling Grass with Lowings loud.

Next Close feeds many a strutting udder'd Cow;

Hard by, tir'd Cattle draw the Plough,

in the next field

Whose galled Necks with Toil and Languishment do bow.

Neer which, in restlesse Stalks, wav'd Grain promotes

The skipping Grashoppers hoarse Notes;

While round the aery Choristers distend their Throats.

i.e., birds

Dry Seas, with golden Surges, ebbe and flow;

The ripening Ears smile as we go,

With Boasts to crack the Barn, so numberless they show.

When Sol to Virgo Progresse takes, and Fields

With his prolonged Lustre gilds;

When Sirius chinks the Ground, the Swain his Hope then builds.

cracks open.

Soon as the Sultrie Month has mellow'd Corn,

Gnats shake their Spears, and winde their Horn;

The Hindes do sweat through both their Skins, and Shopsters scorn.

Their Orchards with ripe Fruit impregned be, laden (as with child) Fruit that from Taste of Death is free,

And such as gives Delight with choice Varietie.

Yet who in's thriving Minde improves his State, And Virtue Steward Makes, his Fate

Transcends; He's rich at an inestimable Rate.

He shuns Prolixer Law-suits; nor does wait

At Thoughtful Grandies prouder Gate;

Nor 'larming Trumpets him, nor drowning Storms a-mate.

[dismay

drenching, flooding;

From costly Bills of greedy Emp'ricks free,

From Plea of Ambo-dexters Fee,

From Vicar Any Thing, the worst of all the Three.

He in Himself, Himself to rule, retires;

And can, or blow, or quench his Fires:

21 Internal Vigils] matching the literal vigils to protect the flock. 28 Ermin Mantles] presumably the cattle's white hide. 37 Dry ... flow] Fields with ripe crops wave in the wind. 39 With ... Barn] as though trying to burst the barn with their abundance. $\quad \mathbf{4 0}^{-42}$ Sol] the sun, in the sign of Virgo from 23 August to 22 September. Sirius] the dog star, rising with the sun in the hottest days of summer. 44 Spears] stings. Horn] droning sound. 45 both their Skins] actual skin and garments. Shopsters] tradesmen, people in soft indoor jobs. 47 Taste of Death] damnation. The paradisal dimension of the landscape, implicit from 12 on, is explicit here and in 67-72, passing into heaven itself in 73-4. 50

And ... Makes] Puts Virtue in charge of the estate (State, 49) of his mind. The following lines reflect Horace's Epode II. 54 'larming] alarming, sounding the alarm or battle-cry. 55 Emp'ricks] empirics: physicians, especially quacks going by experience rather than training. 56 Ambo-dexter] lawyer who takes bribes from both sides. 57 Vicar Any Thing] clergyman of no principled faith, changing with the religious politics of the time. 60 All blessings are reliant on your being able to curb your desires. 
His little World commands the Great: He there

Rich Mem'ry has for Treasurer;

The Tongue is Secretary to his Heart, and Ear.

While May-Dayes London Gallants take a Pride,

Coacht through Hide Park, to eye, be ey'd,

Which Dayes vain Cost might for the Poor a Yeer provide;

He may to Groves of Myrrhe in Triumph pace,

Where Roots of Nature, Flow'rs of Grace,

And Fruits of Glory bud. A Glimps of Heav'N the Place.

This the Spring-Garden to spiritual Eyes,

Which fragrant Scent of Gums out-vies;

Three Kings had thence their triple mystick Sacrifice.

$\mathrm{O}$, happier Walks, where CHRIsT, and none beside

Is Journeies End, and Way, and Guide!

Where from the humble Plains are greatest Heights descry'd.

Heav'nward his Gaze. Here does a Bowere display His Bride-room, and SCRIPTURIA

Her self is Bride; Each Morn presents his Marriage-Day.

What Ecstasie's in this delicious Grove! Th' unwitnest Witnes of his Love!

What Pow'r so strongly can as flam'd Affections move!

enflamed, aroused

\section{Margaret Cavendish A Description of Shepherds and Shepherdesses}

This elegant piece of anti-pastoral is from Cavendish's Poems and Fancies (1653).

A Description of Shepherds, and Shepherdesses.

The Shepherdesses which great Flocks doe keep,

Are dabl'd high with dew, following their Sheep,

Milking their Ewes, their hands doe dirty make;

spattered, stained

For being wet, dirt from their Duggs doe take.

The Sun doth scorch the skin, it yellow growes,

Their eyes are red, lips dry with wind that blowes.

Their Shepherds sit on mountain's top, that's high,

Yet on their feeding sheep doe cast an eye;

Which to the mounts steep sides they hanging feed

On short moyst grasse, not suffer'd to beare seed;

Their feet though small, strong are their sinews string,

Which make them fast to rocks and mountains cling:

clinging, apparently suspended

cord, fibre

The while the Shepherds leggs hang dangling down,

And sets his breech upon the hills high crown.

Like to a tanned Hide, so was his skin,

No melting heat, or numming cold gets in,

And with a voyce that's harsh against his throat,

He straines to sing, yet knowes not any Note:

And yawning, lazie lyes upon his side,

Or strait upon his back, with armes spred wide;

Or snorting sleeps, and dreames of Joan their Maid,

Or of Hobgoblin wakes, as being afraid.

61 His little World] (a) humble rural world (b) microcosm or 'little world' of man, whose structure was thought to mirror in each detail the macrocosm or great world. 67 Groves of Myrrhe] recalling the classical Elysian fields and Christian Paradise (as later in Milton, Paradise Lost 5.292). 68-9 Nature ... Grace ... Glory] the path of salvation: fallen nature redeemed by God's grace leading to heaven. 72 Three Kings] who offered the Christ-child gifts of gold, frankincense and myrrh, all of which are worked into the descripton of this setting. 77 SCRIPTURIA] scripture or the written word of God: reflecting the newly popular idea that God's wisdom and goodness is written in the 'Book of Nature' no less than in revealed scripture. The marriage of Christ and Scripturia reflects the traditional marriage between Christ and his bridegroom, the Church or the individual devout soul. 10 not suffer'd to beare seed] from being cropped too close by the sheep. suffer'd] allowed, made fit. 22 Hobgoblin] a mischievous or fearsome spirit, especially Puck or Robin Goodfellow. 
Motion in their dull braines doth plow, and sow,

Not Plant, and set, as skilfull Gardners doe.

Or takes his Knife new ground, that half was broke,

And whittles sticks to pin up his sheep-coat:

Or cuts some holes in straw, to Pipe thereon

cote

Some tunes that pleaseth Joan his Love at home.

Thus rustick Clownes are pleas'd to spend their times,

And not as Poets faine, in Sonnets, Rhimes,

Making great Kings and Princes Pastures keep,

And beauteous Ladies driving flocks of sheep:

Dancing 'bout May-poles in a rustick sort,

When Ladies scorne to dance without a Court.

For they their Loves would hate, if they should come

With leather Jerkins, breeches made of Thrum,

And Buskings made of Freeze that's course, and strong,

waste thread or yarn, odds and ends

With clouted Shooes, tyed with a leather thong.

Those that are nicely bred, fine cloaths still love,

A white hand sluttish seemes in dirty Glove.

frieze, coarse woollen cloth

patched

\section{Margaret Cavendish A Shepherd's Employment Is Too Mean an Allegory FOR NOBLE LADIES}

A companion to no.256, which precedes it in Cavendish's Poems and Fancies (1653). The context is of pastoral romances where noble lovers court ladies in pastoral disguise. Cavendish proposes a setting of chivalric allegory instead of this inadequate pastoral one.

A Shepherds imployment is too meane an Allegory for Noble Ladies.

To cover Noble Lovers in Shepherds weeds,

Of high descent, too humble thoughts it breeds:

dress, garb

Like Gods, when they to Men descend down low,

Take off the reverence, and respect we owe.

Then make such persons like faire Nymphs to be,

Who're cloath'd with beauty, bred with modesty:

Their tresses long hang on their shoulders white,

Which when they move, doe give the Gods delight.

Their Quiver, Hearts of men, which fast are ty'd,

And Arrowes of quick flying eyes beside.

Buskings, that's buckl'd close with plates of gold,

Which from base wayes their legs with strength doe hold.

buskins, a type of boot

Men, Champions, Knights, which Honour high doe prize,

Above the tempting of alluring eyes,

That seeke to kill, or at the least to binde

All evil Passions in a wandring minde,

To take those Castles kept by scandals strong,

That have by errours been inchanted long,

Destroying monstrous Vice, which Vertues eate,

These Lovers worthy are of praises great.

So will high Fame aloud those praises sing,

Cupid those Lovers shall to Hymen bring,

At Honours Altar joyne both hearts and hands,

The Gods will seale those Matrimoniall bands.

23-4 Their minds work slowly, like plants springing from seed rather than seedlings. 29 Clownes] (a) rustics (b) comically foolish people. 33 sort] (a) manner, fashion (b) band, group (OED sort $\mathrm{n}^{2} 17$ ). 34 Court] ?dancing-space; nuances of 'royal court, courtly society' and 'courtship, homage'. 0.1 for] (a) standing for, allegorizing (b) intended for, meant to be read by. 4 Take off] ironically juxtaposed with 'cover' (1). The reference is to gods assuming human shape to woo mortal women. 5 Nymphs] i.e. noblewomen: ironically contrasted with the rustics or shepherdesses conventionally called nymphs in pastoral. $\quad 12$ Which securely protect their legs from dirty roads (and metaphorically, their honour from lowly men). 13-20 Honourable men who can overcome all temptation and scandal and win the virtuous ladies. 15-19 They destroy fortresses of vice and scandal: the traditional allegory of Psychomachia or mental battle between virtue(s) and vice(s). 22 Hymen] god of marriage. 


\section{Margaret Cavendish Similizing the Sea to Meadows and Pastures}

From Cavendish's Poems and Fancies (1653). The 'similizing' also incorporates a running contrast.

Similizing the Sea to Meadowes, and Pastures, the Marriners to Shepheards, the Mast to a May-pole, Fishes to Beasts.

The Waves like Ridges of Plow'd-land lies high,

Whereat the Ship doth stumble, downe doth lye.

But in a Calme, levell as Meadowes seem,

And by its Saltnesse makes it look as green.

When Ships thereon a slow, soft pace they walke,

Then Mariners, as Shepheards sing, and talke.

Some whistle, and some on their Pipes do play,

Thus merrily will passe their time away.

And every Mast is like a May-pole high,

Round which they dance, though not so merrily,

As Shepheards do, when they their Lasses bring,

Whereon are Garlands tied with Silken string.

But on their Mast, instead of Garlands, hung

Huge Sailes, and Ropes to tye those Garlands on.

Instead of Lasses they do dance with Death,

And for their Musick they have Boreas Breath.

Instead of Wine, and Wassals, drink salt Teares,

And for their Meat they feed on nought but Feares.

For Flocks of Sheep great sholes of Herrings swim,

As ravenous Wolves the Whales do feed on them.

As sportfull Kids skip over Hillocks green,

So dancing Dolphines on the Waves are seen.

The Porpoyse, like their watchfull Dog espies,

And gives them warning when great Windes will rise.

Instead of Barking, he his Head will shew

Above the waters, where they rough do flow.

When showring Raines power downe, and Windes do blow:

Then fast Men run for Shelter to a Tree;

So Ships at Anchor lye upon the Sea.

\section{Thomas Robins(?) Jack the Plough-Lad's Lamentation}

Under cover of a common peasant's distress, this ballad is a lament for the execution of Charles I and abolition of the monarchy. The text follows the earliest copy (in the British Library), dating from 1654. The writer's initials T. R. suggest Thomas Robins, a prolific ballad-maker of mid-17c. The publisher Richard Burton was a bold Royalist.

\section{JACK the Plough-Lads LAMENTATION:}

His Master has forsaken the Plough and the Cart,

Which grieves poor IACK unto the heart,

For night and day he doth sorely complain,

And doth wish that his Master would come home again.

To the Tune of, Prentices fuddle no more.

drink, tipple

Gentlemen, Gentlemen, listen to my Ditty,

And a prety new story I to you will sing,

No harm I do mean to Town nor to City;

But I wish us good tydings to come this Spring:

Or he that has most will soon have but little.

Poor England to gotten to such a mad strain,

Rich Jack with poor Gill may walk to the Spittle.

To pray for good tydings to come o're the main.

keeps watch 
For I am a poore Plough-lad, and in great distresse

My Master is gone alas! what shall I do,

And I a poore Servant here sorely opprest,

Great loads and taxations I am brought unto;

Yet ou't I liu'd well as many can tell,

My land is good tillage my self to maintain;

Now every Man threatens me for to pillage,

But I would that my Master would come home again.

Gentlemen, Gentlemen, I could well think on it,

If that my Master would come home again,

Though it may be there is some would look sadly on it,

Yet he that is honest would never complain:

A Servant thats true, his joys would renew;

But he that is rotten be sure would complain,

But if it were faulty, it were best to be packing. If that my Master would come home again.

Countrey-man, Cuntrey-man, that hears my Ditty,

Listen unto me, mark what I shall say,

Ther's no honest man in Town nor in Citty,

But if he be bound then he must obey:

His gold and his money he must not spare,

The Cause of poor England for to maintain,

And the weeping-crosse may fall to his share,

But I would that my Master would come home again.

Yeomandry, Yeomandry, to you I call,

Listen unto me as well as the rest;

Your lands and your livings be they great or small,

Your fortune's to pay here as well as the rest:

Though Canons be roaring, and Bullets be flying,

And legs and Armes doth fly in the main,

Man still must stand to it and never fear dying.

But I would that my master would come home again.

The second part, To the same Tune.

And as for us Plough-men as well as the rest,

Much sorow comes to us: yet for us now pray,

We do not withstand, but must pay with the best,

If for it we work, I say, both night and day:

To the Plough and Cart with a heavy heart,

To stir up our ground, and to save our Grain;

So small is our share that fals to our part,

Would God that my Master would come home again.

Thus like to the Ant and the painful Bee,

We labor and toyl all the days of our life,

Though small to be got, we must give a great fee,

Nay, I could say more, but I love no strife:

Yet few there be, but may understand

The truth of my Ditty why I do complain:

Yet I wish true Peace would pity this Land,

Would God that my Master would come home again.

13 ou't] ?out, alas; ?variant of ord, in the beginning, earlier. 17 Gentlemen] socially established persons of proven forebears. $\quad 23$ If there is any such disloyal servant, he is best sent packing. 25 Countrey-man] any peasant or rustic, as distinct from 'gentleman' (22) and yeoman (38). 31 And] ?an, if, lest. weeping-crosse] a public cross at whose foot penitents would weep: i.e. such a person will repent his disloyalty. 33 Yeomandry] yeomanry, small freeholders below the rank of gentlemen (22): a major prop of England's army and political system. 36 Your fortune's to pay] ?You must give up your wealth and well-being. $\quad 37$ Echoes the refrain of another popular ballad. $\mathbf{3 8}$ main] ?battle. Cf. $O E D$ main $\mathrm{n}^{2} 1,2,3$ for various sporting matches or encounters. $\quad \mathbf{4 2 f f}$. The Royalist cause is astutely linked to the economic plight of the common rustic. 
And now for all Trades-men that lives in the City,

I wish you good fortune as well as the rest;

I pray you consider well of this my Ditty,

And then you may see who is the most opprest:

For we with hard labor our money do get,

With toyling and moyling in sorrow and pain,

No sooner we have it, but from us its fet.

But I would that my Master would come home again.

$\mathrm{O}$ my Master is gone, and my Mistris too,

And I am despised by every Clown.

My sorrows increase, alas! what shall I do,

No pleasure I finde in City nor Town:

For I do lament, and sorely repent,

repent: mourn, grieve

The losse of my Master it will be my bane.

Though some do rejoyce, I am discontent Would God that my Master would come home again.

And now to conclude, and end this my Ditty,

The truth of my minde I here have made known,

All honest Plough-men in Town or in City,

May well understand why I make this mone:

For my master is fled, and Love vanished,

Small truth in this world I see for to rain,

No pleasure I find at bed nor at boord,

Vntil that my Master doth come home again.

\section{Thomas Weaver A Pastoral Dialogue}

First published in Weaver's Songs and Poems of Love and Drollery (1685).

A Pastoral Dialogue.

Thirsis. Dear Silvia, let thy Thirsis know

What 'tis that makes those tears to flow.

Is the kid that us'd to play

And skip so nimbly, gone astray?

Hath Cloris flowers more fresh and green?

Or is some other Nymph made Queen?

reign

Silvia. Thirsis, dost thou think that I

May Queen

Could grieve for these, when thou art by?

Thirsis. What is it then?

Silvia.

That I no longer feed my kids

My father bids

With thine, but Corydons; and wear

None but his Garlands on my hair.

Thirsis. Why so (my Silvia) will he keep

Thy Lambs more safe whilst thou dost sleep?

Will the Nymphs envy more thy praise

When chaunted in his Roundelayes?

Silvia. No Thirsis, I my Kids must joyn

With his, 'Cause they are more then thine.

(Chorus)

Parents, cruel as the Rocks,

Joyn not their children, but their flocks.

And Hymen's call'd to light his Torches there

Where Fortunes, not Affections equal are.

63 its fet] it is taken away. fet] fetched. $\quad 66$ Clown] (a) rustic, yokel; (b) boor, uncultured person. 75 Locating 'Plough-men' in town and city brings out the political allegory (though Town could also mean village). 21 Hymen] god of marriage. 


\title{
261 Thomas Weaver The Isle of Man
}

From Weaver's Songs and Poems of Love and Drollery (1654). A curious variant on the conjoint themes of the Golden Age and the ideal estate. The Isle of Man was, and still largely is, a sovereign territory under the 'Lord of Mann and the Isles' (though owing allegiance to the English Crown). It retained this status even during the Protectorate, when Cromwell endowed Thomas Fairfax as Lord of Mann. But the Isle's history during this time was not as uniformly Royalist as Weaver suggests, especially after the death of the earlier Lord, James Stanley, seventh Earl of Derby, in 1651. The poem was clearly written in Stanley's lifetime, and refers to him and his wife Charlotte de la Trémouille, left in charge of Man in her husband's absence and after his death.

The Isle of MAN.

From England, Scotland, Wales and Ireland,

By equal Leagues divided there doth stand

An Isle in circuit not so great as fame,

To elder times known by Eubonia's name.

The Soil is not luxuriant nor ingrate,

Being neither Natures fondness nor her hate:

unrewarding, unyielding

The Sugar canes, the Vine and Fig-tree there

No Natives are, nor strangers; but what e're

To sport mans nicer appetite is scant,

Comes there the price of what he cannot want;

more refined or fastidious

Few ages since he that chief Rule did hold,

Was thence a King: the same power, but less bold,

In Title, whilst twelve Monarchs raign'd,

Hath in the Noble Stanlies blood remain'd.

But under none hath it enjoy'd a bliss

More eminent then it does under this,

Whose prudent care preserves it from the stain

Of foul Rebellion 'gainst its Soveraign.

And as in Swounings, life, when it is gone

From all parts else, stayes in the heart alone:

So in this place, which, if to our Kings sway

You'l Members give, for its fit site, best may

Express the heart; still breathing you may see

All that's alive of his great Monarchy.

And though this Isle appear but as a Star

Of the least magnitude 'mongst those that are

In Charles his constellation, yet doth shee

Keep motion stil in due conformity

To th'Primum Mobile, nor is at all

Seduc'd or forc'd by the Eccentrical

Circumvolutions of the rest, but now

Doth thence more regular and constant grow.

Just so a vigorous heat that closely is

Besieg'd by an Antiparistasis

Of hostile cold, conformes not to the same,

But still growes more it self, and turnes to flame;

Nor hath the King alone his old and due

Observance here, but ev'n the Kings King too.

Religious duties, which in other Lands

swoonings, fainting fits

rule, kingdom limbs

i.e., turns very hot

God

\begin{abstract}
4 Eubonia] a name found in ancient and medieval texts, usually taken to refer to the Isle of Man. $\mathbf{8}$ No Natives ... nor strangers] i.e. imported but naturalized. 9-10 i.e. It may lack luxuries but is well stored with necessities. 11-14 The rulers of the Isle were earlier called kings. But when Henry IV offered the rule to Sir John Stanley, he declined the title in favour of 'Lord'. The Stanleys ruled Man till the death of James Stanley in 1651, and again after the Restoration. 13 twelve Monarchs] from Henry IV to James I. 16 this] James Stanley. He pulled back the Isle from the brink of rebellion, though it joined the Parliamentarians soon after his death. 21-2 if ... give] if you wish to designate various parts of the kingdom as its limbs: reflecting the idea of the 'body politic'. 27-32 In Ptolemaic astronomy, the primum mobile (first mover) was the outermost heavenly sphere, imparting motion to the rest. This basic motion could be offset by local or secondary motions (Eccentrical Circumvolutions). The rest of the kingdom has been disturbed in this way, but the Isle remains faithful to the king. 27 Charles] either Charles I, or the notional or titular Charles II-to-be. 34 Antiparistasis] antiperistasis, an opposite or resisting force or action. 39-50 The Manx Church, a branch of the Church of England, appears to have been dominant in Man even during Puritan rule in Britain.
\end{abstract}


Are cast by th' wanton strife of tongues and hands

In new prodigious moulds, do in this place

Retain their Prim'tive comeliness and Grace;

Temples are Houses here (and they alone)

Of publike Worship and Devotion,

And such at the Altar wait as are endu'd

With Science, and are call'd to't, not intrude.

So that sound Doctrine, clad in a rich sense

Flowes from their Pulpits, which with Reverence

The people heard, and to this giving due

Respect, a thousand blessings more ensue.

The Husbandman buryes his seed 'thout fear

O'th' Sequestrators sickle, nor does e're

Doubt who shall share the Flock, or milk the Kine

He fosters, or shall eat the fruit of s Vine:

(For though that Plant springs not in this cold clay,

Yet where so fat a Peace dwels, we may say,

(With Reverence to the Sacred Page) that now

Grapes upon thornes, and figs on thistles grow.)

Wives moan not their fled Husbands, who t'eschew

Their enemies, forsake their best friends too:

Their pregnant wombs by Times due Midwifry,

Not by affrights or griefs, disburdned be,

And their maturer Issues there escape

The barbarous Souldiers sword and Lustfull rape.

But that which doth most happiness afford,

Is the lov'd presence of their noble Lord

And Lady, not more eminent in blood

Then Vertue, and their Pledges fair and good.

That spot, alas, is now their whole estate,

Which was but an Appendix to't of late,

Swelling great Derby's Title, more then's Rent.

But 'twas by Providence that he was sent

From's Richer Territories, there to be

The refuge of distressed Loyalty,

Where now the good he doth with what remains,

Comforts th' unequal losses he sustains:

His sufferings he surveyes, as they express

His Loyalty, not his unhappiness.

And may not they nor th'time be long till's eyes

See his good deeds, his wrongs, and enemies

Fully requited; and in the intrim

May this small part of his Kings sway, by him

Be still preserv'd, as it is now, in fit

Obedience, till the rest conform to it.

evade, escape

serve, administer

learning; intrude usurp office

meaning, purport

sows, casts in the soil

shear (so spelt in autograph ms.)

Pledges: i.e., children

then's: than his

From's: from his

(a) unjust (b) excessive he sees them as proof of

till his

his wrongs: those done to him

rule, territory 


\section{William Hammond Upon Cloris Her Visit after Marriage}

From Hammond's Poems (1655). The full title line explains the narrative situation, but little is known of Hammond's life, and the allusions remain unclear.

Upon Cloris her visit after Marriage, A pastorall Dialogue betwixt Codrus and Damon forsaken rivalls.

Codrus. Why (Damon) did Arcadian Pan ordain

To drive our Flocks from that Meridian plain

lit by the noonday sun

Where Cloris perpendicular shot beames

Scorch'd up our lawnes but that cool Charwells streams

Might here abate those flames which higher were

Then the faint moisture of our Flocks could bear?

Damon. Codrus, I wot the dog that tended there

Our Flocks was he which in the heavenly sphear

So hotly hunts the Lyon that the trace

Of Virgo scarse his fiery steps allaies;

Into our vaines a feavour he convey'd,

And on our vitall Spirits fiercely prey'd.

Codrus. Oh why then brought she back her torred Zone?

Conquer'd her Trophyes? Let us not alone

After so many deaths? renew'd our flame

When twas impossible to quench the same?

It is the punishment of Hell to show

The torturd soules those joyes they must not know.

Damon. Though my Flock languish under her aspect;

My panting Dog his office too neglect;

Though I refuse repast, and by her eyes

Inflam'd, prostrate my selfe her sacrifice,

I shall yet covet still her dubious rayes,

Whose light revives as much as her heat slayes.

desire, long for

Codrus. If Thyrcis slept not in her shady haire,

If in his armes her snow not melted were,

We might expect a more successfull day,

And to some hopes our willing hearts betray,

Which now live desperate without joy of light;

Her black eyes shed on us perpetuall night.

Damon. Codrus because his ragged flock was thin,

His Sheep walk bare, and his Ewes did not yene,

His noble Love (hear this O Swaines) resignd

His eyes delight a wealthier mate to find;

But she (rash in her choice) gave her embrace

To one whose bread courser then Codrus was.

know, hence believe, think

Codrus. Damon (then whom none e're did longer burne;

Nor at his rate, upon so small returne)

Damon (the pride and glory of the mead

When Nymphs and Swaines their tuned measures tread)

Begg'd of her that a better choice might prove

She lov'd her selfe, since him she could not love.

1 Pan] Prob. God. There was no king in England since long before 1655, and no record of a royal command sending Hammond to Oxford. 4 Charwell] The Cherwell, a river joining the Thames at $\begin{array}{ll}\text { Oxford. } 6 \text { moisture] liquid components of the body; humours (OED 1a). } & \text { 7-8 dog ... heavenly }\end{array}$ sphear] Sirius the dog-star, rising with the sun in the hot summer when the constellations of Leo (Lyon) and Virgo are in the ascendant. The charms of Cloris were as unbearable as the summer's heat to the spurned lovers, so they had withdrawn to restful Oxford; but Cloris' visit there has renewed that heat. 14 Conquer'd her Trophyes] re-conquered those she has already vanquished. 17 It is] Perhaps a misprint for 'Is it', as 18 ends with a question mark in 1655 . 19 aspect] the 'face' of a star, exerting astrological influence. $\quad 22$ Inflam'd] heated, or even set on fire like a sacrifice. 23 dubious] uncertain, paradoxical (killing and reviving at the same time). rayes] the light emitted by her eyes. 25 Thyrcis] Cloris' husband. 31-4 i.e. Codrus gave up his love for Cloris so that she might marry a wealthier suitor. $\quad 38$ Nor so intensely, with so little reward. $\quad 41-2$ a better choice ... her selfe] She might choose better for her own good, even if she did not choose Damon. 
Damon. Had Thyrsis flocks in milke abounded more,

I should not with such grief my losse deplore.

Codrus. Could Thyrsis pipe more worthily resound

Cloris, oh Cloris, I had comfort found.

Both. That our heart-wracking sighs no gaine bequeath

To Cloris, is a dying after death.

\section{A Pastoral Song: With the Answer}

Variously but inconclusively attributed to Robert Aytoun and Henry Hughes. First published in the collection Sportive Wit: The Muses Merriment (1656). The first part, without the 'Answer', is found in many mss. Bod. MS. Ashmole 38 has a rhyming Latin version alongside the English.

A Shepherd fallen in love.

A Pastoral Song: With the Answer.

Cloris, since thou art fled away,

Amyntas sheep are gone astray,

And all the joys he took to see

His pretty Lambkins follow thee,

They're gone, they're gone; and he alway

Sings nothing now, but Well-a-day, well-a-day.

Th' embroyder'd Scrip he us'd to wear,

Neglected lies, so doth his hair:

His Crook broke, his Dog howling lies,

While he laments with woful cries,

Oh Cloris, Cloris, I decay,

And forced am to cry, Well-a-day, well-a-day.

His Oaten Pipe whereon he plays

So oft to his sweet Roundelays,

Is flung away, and not a Swain

Dares sing or pipe within his plain:

'Tis death for any one to say

One word to him, but Well-a-day, well-a-day.

The way wherein her dainty feet

In even measure us'd to meet,

Is broken down; and no content

Came neer Amyntas since she went:

For all that ere I heard him say,

Was Cloris, Cloris, well-a-day, well-a-day.

On the ground whereon she us'd to tread,

He ever since hath laid his head;

Still breathing forth such pining woes,

That not one blade of grass there grows.

Ah Cloris, Cloris, come away,

And hear Amyntas well-a-day, well-a-day.

\section{The Answer}

Cloris, since thou art gone astray,

Amyntas Shepherd's fled away;

And all the joys he wont to spye

I' th' pretty babies of thine eye,

Are gone; and she hath nought to say,

But who can help what will away, will away?

The Green on which it was her chance

To have her hand first in a dance,

Among the merry Maiden-crue, 
40

Now making her nought but sigh and rue

The time she ere had cause to say

Ah, who can help what will away, will away?

The Lawn with which she wont to deck

And circle in her whiter neck;

Her Apron lies behinde the door;

The strings wo'nt reach now as before:

Which makes her oft cry well-a-day:

But who can help what will away?

He often swore that he would leave me,

Ere of my heart he could bereave me:

But when the Signe was in the tail

He knew poor Maiden flesh was frail;

And laughs now I have nought to say,

But who can help what will away?

But let the blame upon me lie;

I had no heart him to denie:

Had I another Maidenhead,

I'd lose it ere I went to bed:

For what can all the world more say,

60

Than who can help what will away?

\section{A Pastoral Song}

First published in Sportive Wit: The Muses Merriment (1656). A conventional type of bawdy parody of serious pastoral, ridiculing the shepherd and viewing the shepherdess as a sexual object.

A Pastorall Song.

A Silly poor Sheepherd was folding his sheep,

He walked so long, he got cold in his feet,

He laid on his coales by two and by three,

The more he laid on The cuc-colder was he.

But alas, good wife

To buy some more fewell We'll sell the brown cow,

To buy some more coales, to warm thee and me;

But the more he laid on the cuc-colder was he.

Some sheepherds, quoth she, themselves can warm keep,

By fleecing their flock,

But when you come home with your tar-box and crook,

It grieves me to see how cuc-cold you doe look. 
Alas (wife) I walk through dew, dirt and mire,

While you perhaps warm your self without fire,

With a friend in a corner, in such a sort, as whereby,

The warmer you are, the cuc-colder am I.

\section{A SoNG}

First published in the collection Sportive Wit (1656).

A Song.

As Colin went forth his sheep to unfold,

In a morning of April as gray as twas cold,

In a thicket he heard a voyce it self spread, Which was, Oh, oh, I am almost dead.

He peep'd in the bushes, and spy'd where there lay His Mistress, whose countenance made April May; But yet in her looks some sadness was read, Crying $\mathrm{Oh}$, \&c.

He rush'd in unto her, and cry'd what's the matter?

Ah Colin, quoth she, why will you come at her,

Who by the false Swain hath oft been mislead? To which, $\mathrm{Oh}, \& \mathrm{c}$.

He turn'd her Milk-paile, and down there he sat,

His hand stroak'd his beard, on his knee hung his hat;

But yet still Mopsa cry'd, before ought was sed, Colin, Oh, oh, \&c.

Be God quoth stout Colin, I ever was true,

Thou gav'st me a handkerchief all hemm'd with blew, A pin-box I gave thee, and a girdle so red, And yet she cry'd, Oh, \&c.

Delaying, quoth she, hath made me thus ill,

I ever fear'd Sarah that dwelt at the mill,

Since in the Evenings late her hogs thou hast fed.

For which, Oh, oh, \&c.

Colin then chuckt her under the chin,

Cleare up, for to love thee I never will lin;

Qoud she Ile believe it when the Parson has read.

Till then, $\mathrm{Oh}, \mathrm{oh}, \& \mathrm{c}$.

Uds bores, quoth Colin, Ile new clout my shoon,

And ere a week pass, by the mass 't shall be done.

You might have done before then, she said:

But now, $\mathrm{Oh}, \mathrm{oh}, \mathrm{\& c}$.

He gave her a twitch that quite turn'd her round,

And said, I am the truest that ere trod on ground,

Come settle thy milk-paile fast to thy head:

No more Oh, oh, \&c.

Why then I perceive thou'lt not leave me in the lurch,

Ile don my best cloaths, and straight goe to Church.

Jog on merry Colin, jog on before,

For yfaith, yfaith Ile dye no more.

29 Uds bores] [By] God's wounds. bores] holes (made by the nails of Christ's cross). 


\section{Eldred Revett The Land-Schap between Two Hills}

From Revett's Poems (1657). A notable instance of the new cultivation of landscape painting, and its extension to a new vein of nature-poetry. The natural landscape is viewed as though it were a painting, but language is seen as a better way to present it.

The Land-schap between two hills.

Plac'd on yon' fair, though beetle brow

That on the pleasures frowns below,

Let us with sprightly phancie thence

Teach the dumb Rhetorick, Eloquence;

And leave the Painters Art out-gone

Inliv'ning by transcription.

exceeded, excelled

First then observe with levell'd sight

writing

Arising to this opposite;

As if the wind in billow drave

drove, rushed

Here, and had rowld the earth in wave:

The Aspen and the Bramble heaves

And a white foam froth's in the leaves:

That spot beneath, that lies so plain

Schorch'd here and there, hath lost the grain:

As Sol there dried the Beams he swet

grain: of the wood or timber

And stain'd the gras-green coverlet;

the sun

That Goat the bushes nigh doth browse

Seems the un-ravell'd plush to frowse;

And now let fall the eye it sees

A pretty storm of clowdy trees,

To us seem black and full of rain,

As they would scatter on the plain:

From hence the hill declineth spent,

With imperceptible descent,

'Till un-awares abroad it flow

Lost in the deluge spreads below.

An Age-bow'd oak doth under-root

As it would prostrate at it's foot;

Whose thrown-out armes in length display

And a fair shady carpet lay,

On it a lad in russet coat,

His soul melts through the vocal oate;

And hear that black eyed Nymph doth draw

As if her eyes hung on the straw:

The scrip and leathern Bottle nigh,

(With guardian too Melampo) lie:

The flocks are round about them spread

In num'rous fleece have clad the Meade;

And now our eyes but weakly see

$40 \quad$ Quite tippled with varietie:

intoxicated

Here the grass rowls, and hills between

Stud it with little tufts of green:

There in the midst a tree doth stray

Escap'd, as it had lost the way,

And a winding river steals

1-2 i.e. The rugged peak seems to disapprove of the pleasanter landscape below. $\quad$ 7-8 with ... opposite] looking straight across the valley to the opposite slope (from where the poet's sight gradually turns downward). 9-10 As if the wind had tossed the earth up into waves, like water. 12 white foam] From the underside of the aspen leaves and the white bramble blossom: continuing the imagery of water or the sea. 15-16 As though the sun used the grass like a towel to dry his sweat (i.e. the beams he exudes). 18 The 'carpet' of the grass is unravelled by the nibbling goat. plush] a rich soft fabric. 19 let fall] if you let fall. 23 spent] continuing the water-imagery. The 'rain' from 'clouds' of foliage on the slopes flows into a 'deluge' of trees down in the valley. 27 under-root] ?bend double so that its boughs dig into the ground. 31 russet] prob. the fabric, not the colour. 36 Melampo] Melampus was one of Actaeon's dogs in Ovid, Met. 3.206, and a sheepdog in Sidney's Old Arcadia, First Eclogues. But the It. form 'Melampo' suggests the dog in Sannazaro's Arcadia, Eclogue 2. 
That with it self drunk curling reels,

A cheaper flood than Tagus goes

And with dissolved silver flowes.

Some way the field thence swells at ease

And lifts our sight up by degrees

To where the steep side dissie lies

dizzying, vertiginous

Supinely fast in precipices,

Till with the bank oppos'd it lie,

In a proportion'd Harmonie,

As Nature here did sit and sing

About the cradle of the spring.

around

\section{The Milkmaids}

First published in Wit Restor'd in severall Select Poems (1658). A shorter and substantially different version from BL MS Harley 4286 follows at the end.

The Milk-maids.

Walkeing betimes close by a green wood side,

early in the morning

Hy tranonny, nonny with hy tranonny no;

A payre of lovely milk maides there by chance I spide

With hy tranonny nonny no, with tranonny no,

One of them was faire

As fair as fair might bee;

The other she was browne,

With wanton rowling eye.

Syder to make sillibubbs,

They carryed in their pailes;

And suggar in their purses,

Hung dangling at their tailes.

drink of flavoured milk

pouches, scrips (OED6a)

skirts

Wast-coats of flannell,

And petty-coats of redd.

Before them milk white aporns,

And straw-hats on their heads,

Silke poynts, with silver taggs,

A bout their wrists were shown;

(pieces of) a kind of lace

And jett-Rings, with poesies

Yours more then his owne.

And to requite their lovers poynts and rings,

They gave their lovers bracelets,

And many pretty things.

And there they did get gownes

All on the grasse so green,

But the taylor was not skilfull,

For the stitches they were seen.

Thus having spent the long summers day,

They took their nut browne milk pailes,

And so they came away.

Well fare you merry milk maids

That dable in the dew

For you have kisses plenty,

When Ladyes have but few.

playfully get wet

47 Tagus] whose waters carried gold. $\quad 52$ supinely] sloping backwards. fast] fixed, solid. $\quad \mathbf{5 3} \mathbf{~ o p -}$ pos'd] opposite. There is a flatter stretch or bank beyond or at the top of the steep hillside opposite. 15 aporns] aprons: $O E D$ records forms in $-r n$ from $16-17$ cent. 19 poesies] inscriptions on rings. 24-7 They lay down with their lovers, exposing their flesh beneath 'gowns' of green grass. 33-4 Interestingly combines two conventions, of praise for the rustic woman's simple frank nature (contrasting with the city or court lady's), and its exploitation for sexual gratification. Sukanta chaudhuri - 9781526143426 


\section{Another version from BL MS Harley 4286. Virtually all punctuation supplied and line- initial capitals regularized.}

As I me walked hard by A riueers side,

To cuntryy milck maydes I chanced to espye

hey no no

hey no no.

two

The on wase as fayre as fare might be,

The other wase of nut browne with A rowling eye.

Much talcke ther passed them betwene

Of ther cuntry maypoles and of ther sommerry queene.

May Queen

Ther petecotes of scarlet ther wascotes of red

With milck white Aprones and strawen hates on ther heades,

Long poyntes with siluer tages Aboute her armes they wore,

Jeate ringes with poses more yowers then my owne.

her: their

And to requite ther poyntes and ther ringes

They gaue ther louers garlandes with many tricksy thinges.

decorative, pretty, smart

Thus they did passe the longe sommeres daye

Thaye tocke ther nut browne milck pales and so they went ther way.

\section{Aston Cokayn Coridon ANd STREPhon}

The First Eclogue in Cokayn's Small Poems of Divers Sorts (1658). Obvious personal allusion, especially in the references to playwrights: Cokayne was a minor dramatist. From Cokayn's Epigram 35, Tityrus is his cousin the poet Charles Cotton, in which case Coridon should be Cokayn.

The first Eglogue. Coridon, and Strephon.

Coridon. Why Strephon, art thou melancholy grown

And wilt not use thine oaten pipe? hast known

play, practise on

Any ill news of late hath dul'd thy wit,

Made us unhappy, and thy self unfit?

ill, incapacitated

Strephon. 'Tis no Report, kinde Coridon, hath made

Me cloud my brow with sorrow and be sad;

It is a cause more high, a cause that can

Destroy the joy of the most fortunate man.

Coridon. And may I know it Strephon? Dare you trust

Me with a Secret, and conceive me just,

Believe I will be silent? If you dare,

know I will be true to my word risk telling me

I should desire this Novelty to hear.

Strephon. Ah, Coridon! I am in love with one,

The fairest Shepherdess was ever knowne;

Her Face is beauties abstract, wherein we

May (at perfection) every beauty see.

Coridon. And art thou sad because thou art in love?

So Jove should grieve because he reigns above;

There is no fate so high befalls a Swain,

As to love where he is belov'd again.

Tell me (my Strephon) therefore why art sad?

Is it because thy Dear will not be had?

Strephon. She cannot (Coridon) for she is wed,

And fine young Perigot hath her maiden-head,

As blithe a Shepherd as did ever sing

Neat Roundelayes unto our Goat-foot King;

He is an happy man, and doth enjoy

That beauty which I languish for, and dy.

Coridon. Strephon, I grieve thou art enthralled so;

Desist betimes, and forward do not go;

Thy flames extinguish whilst they do begin,

26 Goat-foot King] Pan: either God or (in 1658, absent and future) king. Perigot is either a priest or (like Cokayn) a Royalist. 
For such a Love is against Pan a Sin.

And while yong Perigot lives what hope have you,

If she unto him do not prove untrue?

Strephon. I do confess I have none; neither would

Commit so great an evil, if I could;

I am enamour'd neither more nor less

Then Thenot, on the faithful Shepherdess:

I love her vertues, and if she should fall,

My love to her would be no love at all.

Coridon. Thou art an honest Swain, and our Feild-God

Will bless thee in thy Cottage and abroad.

Strephon. As I have faithfully to you replide,

So let none of my questions be denide.

Coridon. They shall not (Strephon;) I should be unjust

Unto your merits, if I did distrust

Your secresie in any thing I speak;

He that doth doubt his friend, doth friendship break.

Strephon. Is there no lass whom Coridon doth like?

You, did the Paphian Archer never strike?

Or are you such a man as never car'd

Whether a womans heart were soft or hard?

Coridon. Strephon, I love, but I do fear in vain,

Because rich Melibe intends to gain

A wealthier Shepherd for his daughter, one

Whose fortune must prevent thy Coridon.

Strephon. And would he merchandize his daughter? may

He long expect and never see that day.

Steal her, young Shepherd; never let her be

(Whom thou affect'st) subject to salarie.

Coridon. But ere I saw my Mira, or did know

What beauties made her perfect, I did owe

My love to Galatea; but I lost

My labour, which good old Palomon crost,

Because he did believe that I would prove

A careless Shepherd, and the Downs not love:

Judge (Strephon) that know'st me above report,

If I be justly censur'd by him for't;

Do I not love the fields, and use to play

On Oaten reedes many a Roundelay?

go before, supersede, impede

at home and outside

Strephon. He that says otherwise, he doth not know

Thy Nature truly, but becomes thy foe;

Because (being Ignorant) he doth undertake

So bold a Character of thee to make;

Were he acquainted with thy wayes, to thee

Palcemon would give Galatea free;

And think his age more happy then his youth,

That made a Shepherd his of so much truth.

Coridon. Flatter not (Strephon) I do want those parts

That make a man be lov' $\mathrm{d}$ for his deserts;

Could I but sing such neat fine Lays, as you,

I might believe these praises were my due.

Strephon. And so you can if Tityrus says right,

Who told me Dities you did well endite.

Coridon. Now you do mention Tityrus, I must

Be to his merits, and our friendship just;

$\mathrm{He}$ is a Shepherd (would he please to sing)

Might lengthen with his voice the speedy Spring:

negligent, feckless

judged, assessed

be accustomed to, do habitually

such a vivid characterization

freely, willingly

his: akin to him by marriage

32 Pan] here clearly God. 38 Thenot] In John Fletcher's play The Faithful Shepherdess, the loyal but hopeless lover of Clorin, who is devoted to the memory of her own dead lover. Here, may be Cokayn's brother Thomas. (D. P. Raychaudhuri, The Life and Work of Sir Aston Cokain, London Univ. M.A. dissertation, 1933). 5o Paphian Archer] Cupid, son of Venus, originally worshipped at Paphos in Cyprus. 60 salarie] recompense, hence price, monetary arrangements. 64 Palæmon] presumably Galatea's father. $\quad \mathbf{8 3}$ Tityrus] See headnote. 
Did he but know how much the downs he wrongs,

The woods and dales would eccho with his songs;

He knows when Notes are over-sharp, or flat,

And is the ablest Boy that ever sat

Upon an Hillock, would he use his Reed,

And joy his wanton flock while it doth feed.

Strephon. He is an able Lad indeed, and likes

give joy to, delight

Arcadian Pastorals, and (willing) strikes

A Plaudite to th'Epilogues of those

Happy Inventions Shakesphere did compose;

Beaumont and Fletcher he will listen to,

And allow Johnsons method high and true.

He prais'd you to me, and I do believe

approve, praise

$\mathrm{He}$ his own Judgement would not wrong to give

Feign'd Commendations; Do not (therefore) fear

Sith he approves your pipe, who doth it hear.

Coridon. Strephon, I thank both you, and him, and will

Be proud hereafter to make known my skill:

If I but please the few I mean it for,

To seek for vulgar praise I shall abhor.

Strephon. Coridon it is late: Farewel untill

We meet again upon this flowry Hill;

My Master will make wonder at my stay,

I otherwise would not so soon away.

Coridon. Thy Master's happy in thy care, Adieu:

As I will be in absence, be thou true.

fortunate in your service

\section{The Old Ballet of Shepherd Tom}

From the collection Wit Restor'd (1658). Stanza-breaks regularized. Pastoral Petrarchism of almost parodic exaggeration, aligned with rustic simplicity and folly. Illustrates a pastoral subgenre presenting a comic or lampoon-like version of shepherd life.

The old Ballet of shepheard Tom.

As I late wandred over a Plaine,

Upon a hill piping I spide a shephards swaine:

His flops were of green, his coat was of gray,

And on his head a wreath of willow and of bay.

coarse cloth of those colours

He sigh'd and he pip't,

His eyes he often wip't,

He curst and ban'd the boy,

That first brought his annoy:

Who with the fire of desire, so inflam'd his minde,

To doate upon a lasse; so various and unkinde.

laurel

Then howling, he threw his whistle a way,

And beat his heeles agen the ground whereon he lay.

He swore and he star'd, he was quite bereft of hope,

And out of his scrip he pulled a rope:

Quoth he, the man that wooes,

With me prepare his noose;

or rather then I'le fry,

be tormented, especially by strong passion

By hemp Ile choose to dy.

Then up he rose, and he goes streight unto a tree,

Where he thus complaines of his lasses cruelty,

89 the downs he wrongs] presumably by remaining silent. $\left(O E D_{3}\right.$ d), with a touch of homely endearment (cf. 'lad', 95).

92 Boy] dialect or rustic for 'man' solicited in the epilogue to a play. 100 allow ... true] Acknowledge that Jonson's style is high and true. method] style, practice, especially of an ordered and graceful nature as associated with Jonson. 3 flops] flaps of a hat, hence the hat itself. 4 willow, bay] symbols of mourning and poetic inspiration

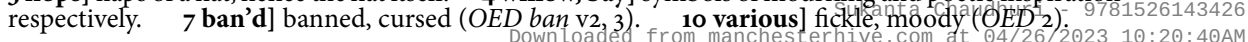


A pox upon the divell, that ever twas my lot, To set my love upon so wooddish a trot.

Had not I been better tooke Ione of the mill,

Kate of the creame house, or bony bouncing Nell:

crazy, senseless; hag

A Proud word I speak:

I had them at my beck;

And they on holydayes

Would give me prick and praise.

But Phillis she was to me dearer then my eyes,

For whom I now indure these plaguy miseryes.

Oft have I woo'd her with many a teare,

With ribband for her head tire, and laces from the fayre,

With bone-lace and with shoone, with bracelets and with pinns,

And many a toy besides: good god forgive my sinns.

And yet this plaguy flirt

Would ding them in the dirte

And smile to see mee tear

The locks from of my haire.

To scratch my chops, rend my flops, and at wakes to sit

Like to a sot bereft both of reason sense and witt.

village festivals

shoes

trifle, trinket

fling down

Therefore from this bough Tom bids a dew

To the shepherds of the valley, and all the joviall crew.

adieu

Farewell Thump, my ram, and Cut my bobtaild curre,

Behold your Master proves his owne murtherer.

Goe to my Phillis, goe,

Tell her this tale of woe.

Tell her where she may finde

Me tottering in the winde.

Say on a tree she may see her Tom rid from all care,

Where she may take him napping as Mosse took his Mare.

His Philis by chance stood close in a bush,

And as the Clowne did sprawle, she streight to him did rush.

She cut in two the rope and thus to him she said,

Dispairing Tom, my Tom, thou hast undone a maid.

Then as one amaz'd

Upon her face he gaz'd;

And in this wofull case,

She kist his pallid face,

He whoopt amaine, swore, no swaine ever more should be

Soe happy in his love, nor halfe so sweet as she.

\section{The Jolly Shepherd}

From the collection Wit and Drollery (2nd edn, 1661).

The jolly Shepherd.

The life of a Shepherd is void of all care-a,

With his bag and his bottle he maketh good fare-a,

He ruffles, he shuffles in all extreme wind-a,

His flocks sometimes before him, and sometimes behind-a.

He hath the green medows to walk at his will-a,

With a pair of fine bag-pipes upon the green hill-a;

Trang-dille, trang-dille, trang down a down dilla,

With a pair of fine bag-pipes upon a green hill-a.

28 prick and praise] praise (?and encouragement): a stock phrase. $\quad 32$ tire] a type of women's headgear. 33 bone-lace] a type of lace, originally knitted with bobbins made of bone. 39 chops] chaps, cracks in the skin. flops] flaps (of his garments). 50 as Mosse took his Mare] 'Wilbraham says Mosse took his mare napping, because he could not catch her when awake.' (Brewer's Dictionary of Phrase and Fable) Might imply that Tom and Phillis may unite only after his death, but probably a simple sexual innuendo. $\quad 52$ sprawle] struggle, toss about (at the end of the rope): OE $\dot{E}$ in 1 
His sheep round about him do feed on the dale-a,

His bag full of cake-bread, his bottle of ale-a,

A cantle of cheese that is good and old-a,

Because that he walketh all day in the cold-a,

With his cloak and his sheep-hook thus marcheth he still-a,

With a pair of fine bag-pipes upon a green hill-a.

Trangdille, etc.

If cold doth oppress him to cabin goeth he-a,

If heat doth molest him then under green tree-a,

If his sheep chance to range over the plain-a,

His little dog Lightfoot doth fetch them again-a,

For there he attendeth his master's own will-a,

With a pair of fine bag-pipes upon the green hill-a.

Trangdille, etc.

He list not to idle all day like a moam-a,

In spending his time though sitting alone-a,

Lingle, needle and thimble he hath still in store-a,

does not like; mome, dullard

To mend shoes and apparel he keeps them therefore-a,

leather strap or thong

Thus whistling and piping he danceth his fill-a,

With a pair of fine bag-pipes upon the green hill-a,

Trangdille, etc.

If Phillida chance come tripping aside-a,

A most friendly welcom he doth her betide-a,

He straightwayes presents her a poor shepherd's fees-a,

His bottle of good ale, his cake and his cheese-a,

He pipeth, she danceth all at their own will-a,

With a pair of fine bag-pipes upon the green hill-a.

Trangdille, etc.

But now wanton shepherd howsoever your meaning,

My harvest's not ripe, therefore leave your gleaning,

For if in my garden a Rose you would pull-a,

Perhaps it may cost you all your sheeps wool-a.

Thus do they both frolick and sport at their will-a,

With a pair of fine bag-pipes upon the green hill-a;

Trangdille, trangdille, trang down a down dilla,

With a pair of fine bag-pipes upon the green hill-a.

\section{IzaAk Walton To My Ingenious Friend Master Brome}

One of the prefatory pieces to the Royalist Alexander Brome's Songs and Other Poems (1661). Celebrates the Restoration of the monarchy with Charles II's accession: composed on 29 May 1660, Charles's birthday and the day he entered London as monarch. Use of roman and italic fonts standardized.

To my ingenious Friend Mr. Brome, on his various and excellent Poems: An humble Eglog. Daman and Dorus.

Written the 29. of May, 1660 .

Daman. Hail happy day! Dorus, sit down:

Now let no sigh, nor let a frown

Lodge near thy heart, or on thy brow.

The King! the King's return'd! and now

Let's banish all sad thoughts, and sing

We have our lawes, and have our King.

Dorus. 'Tis true and I wood sing, but oh!

would

These wars have shrunk my heart so low

Twill not be rais'd.

Daman.

What not this day?

10 cake-bread] 'bread made in flattened cakes' $(O E D)$. $\quad 31$ betide] ?give, offer: unusual meaning and transitive use, neither in $O E D$. 37-40 Obviously Phillis' words to the shepherd. 
Why tis the twenty ninth of May:

Let Rebels spirits sink: let those

That like the Goths and Vandals rose

To ruine families, and bring

Contempt upon our Church, our King,

And all that's dear to us, be sad;

But be not thou, let us be glad.

And Dorus, to invite thee, look,

Here's a Collection in this book

Of all those chearfull songs, that we

Have sung with mirth and merry-gle:

As we have march'd to fight the cause

merry glee: unusual compound form

Of God's anoynted, and our lawes:

Such songs as make not the least ods

Betwixt us mortals and the Gods:

Such songs as Virgins need not fear

To sing, or a grave Matron hear.

Here's love drest neat, and chast, and gay

As gardens in the month of May;

Here's harmony, and wit, and art,

Dorus. Written by whom?

To raise thy thoughts, and chear thy heart.

Daman.

A friend of mine,

And one that's worthy to be thine:

A Civil swain, that knowes his times

For businesses, and that done, makes rimes;

But not till then: my Friends a man

Lov'd by the Muses; dear to Pan;

He blest him with a chearfull heart:

And they with this sharp wit and art,

Which he so tempers, as no Swain,

they: the Muses

That's loyal, does or shou'd complain.

Dorus. I woo'd fain see him:

Daman. Go with me,

Dorus, to yonder broad beech tree,

There we shall meet him and Phillis,

Perrigot, and Amaryllis,

Tyterus, and his dear Clora,

Tom and Will, and their Pastora:

There we'l dance, shake hands and sing,

We have our Lawes,

God bless the King.

\section{Alexander Brome Pastoral on the King's Death}

Written in 1648 after the execution of Charles I. First published in Brome's Songs and Other Poems (1661). Brome was a staunch Royalist.

The Pastorall. On the Kings death. Written in 1648.

Where England's Damon us'd to keep,

In peace and awe, his flocks,

Who fed, not fed upon, his sheep,

There Wolves and Tygres now do prey,

There Sheep are slain, and Goats do sway,

There raigns the subtle Fox

While the poor Lamkins weep.

10 twenty ninth of May] See headnote. $\quad 12$ Goths, Vandals] Supposedly uncivilized tribes that invaded the Roman empire. $\quad 13$ families] i.e. ruling dynasties or aristocratic families. 22 God's anoynted] the King. Charles's grandfather James I specially supported the divine right of kings. 33 Civil] refined, cultured $(O E D 6 \mathrm{a}) . \quad 34$ businesses] Brome was an attorney by profession. 36 Pan] Here apparently God. 2 awe] 'power to inspire fear or reverence' (OED 5). 5. Inverting the conventional order: in the pastoral hierarchy, sheep were superior to goats. Sukanta chauanur 9781526143426 Downtoaded from manchesterhive.com at 04/26/2023 10:20:40AM 
The Laurell'd garland which before

Circled his brows about,

The spotlesse coat which once he wore,

The sheep-hook which he us'd to sway,

And pipe whereon he lov'd to play,

Are seiz'd on by the rout,

rabble

And must be us'd no more.

Poor Swain how thou lament'st to see

Thy flocks o're-rul'd by those

That serve thy Cattle all like thee,

Where hatefull vice usurps the Crown,

And Loyalty is trodden down; Down skrip and sheephook goes,

When Foxes Shepheards be.

\section{Katherine Philips A Dialogue betwixt lucasia and Rosania}

First published in Philips's Poems (1667). Philips is celebrated for instituting a circle of friends and family with quasi-pastoral names. She herself was Orinda. Rosania was her childhood friend Mary Aubrey, and Lucasia, Anne Owen. Philips seems to have had romantic but prob. Platonic relationships with both women in succession. Thyrsis is the musician Henry Lawes, who composed the music and played the shepherd of that name in Milton's Masque of Comus.

A Dialogue betwixt Lucasia, and Rosania, Imitating that of Gentle Thersis.

Rosania. My Lucasia, leave the Mountain tops,

And like a nearer air.

nearer: i.e., to Rosania

Lucasia. How shall I then forsake my Lovely Flocks

Bequeathed to my care?

Rosania. Shepherdess, thy Flocks will not be less, Although thou should'st come hither.

Lucasia. But I fear, the World will be severe, Should I leave them to go thither.

Rosania. O! my friend, if you on that depend, You'l never know content.

Lucasia. Rather I near thee would live and dye,

Would Fortune but consent.

Rosania. But did you ask leave to love me too,

That others should deprive me?

Lucasia. Not all Mankind a stratagem can find

Which from that heart should drive me.

Rosania. Better 't had been, I thee had never seen,

Then that content to lose.

Lucasia. Such are thy Charms, I'd dwell within thine arms

solace, satisfaction

Rosania. When Life is done, the World to us is gone,

And all our cares do end.

Lucasia. Nay I know there's nothing sweet below

Unless it be a Friend.

Rosania. Then whilst we live, this Joy lets take and give,

Since death us soon will sever.

Lucasia. But I trust, when crumbled into dust,

We shall meet and love for ever.

11 sway] 'wield as an emblem of sovereignty or authority' (OED 8).

o.1 that of Gentle Thersis]

Philips's poem 'A Dialogue of Absence 'txist Lucasia and Orinda', set to music by Lawes. Not specially close to this poem in form or theme. 1 Mountain tops] After marriage, Lucasia lived in Wales, Rosania in London. The poem is probably the latter's invitation to the former to visit her in London. 3 The punctuation in a ms in the National Library of Wales suggests the likely thrust: 'How, shall I then forsake ...'. Flocks] perhaps her children or family. 13-14 Seeing as others have power to deprive me of your company, did you ask their leave to love me in the first place? 


\section{Katherine Philips A Country Life}

The text follows the first authorized edn of Philips's Poems, 1667. A ms in the National Library of Wales dates the poem in 1650 , which would make it one of Philips's earliest works, perhaps reflecting her move from London to Wales after marriage.

A Country-life.

How Sacred and how Innocent A Country-life appears,

How free from Tumult, Discontent, From Flattery or Fears!

This was the first and happiest Life, When man enjoy'd himself;

Till Pride exchanged Peace for Strife, And Happiness for Pelf.

'Twas here the Poets were inspir'd, Here taught the multitude;

The brave they here with Honour fir'd, And civiliz'd the rude.

That Golden Age did entertain No Passion but of Love;

The thoughts of Ruling and of Gain Did ne're their Fancies move.

None then did envy Neighbour's wealth, Nor Plot to wrong his bed:

Happy in Friendship and in Health, On Roots, not Beasts, they fed.

They knew no Law nor Physick then, Nature was all their Wit.

And if there yet remain to men Content, sure this is it.

What Blessings doth this World afford To tempt or bribe desire?

Her Courtship is all Fire and Sword, Who would not then retire?

Then welcome dearest Solitude, My great Felicity;

Though some are pleas'd to call thee rude, Thou art not so, but we:

Them that do covet only rest, A Cottage will suffice:

It is not brave to be possest Of Earth, but to despise.

Opinion is the rate of things, From hence our Peace doth flow;

I have a better Fate then Kings, Because I think it so.

When all the stormy World doth roar How unconcern'd am I?

I cannot fear to tumble lower Who never could be high.

Secure in these unenvi'd walls I think not on the State,

And pity no man's case that falls From his Ambition's height.

Silence and Innocence are safe; A heart that's nobly true

At all these little Arts can laugh That do the World subdue.

While others Revel it in State,

20 Vegetarian diet was commonly associated with the Golden Age: see Ovid, Met. 1.103-6. 37-40 A version of these lines occurs in a poem by the Duke of Monmouth, hence wrongly ascribed to him. 46 These words open another poem by Philips, 'Upon the Double Murther of King Charles'. 
Here I'le contented sit,

And think I have as good a Fate As Wealth and Pomp admit.

Let some in Courtship take delight, And to th' Exchange resort;

Then Revel out a Winter's night, Not making Love, but Sport.

These never know a noble Flame, 'Tis Lust, Scorn, or Design:

While Vanity plays all their Game, Let Peace and Honour mine.

When the Inviting Spring appears, To Hide-parke let them go,

And hasting thence be full of fears To lose Spring-Garden shew.

Let others (nobler) seek to gain In Knowledge happy Fate,

And others busie them in vain To study ways of State.

But I, resolved from within, Confirmed from without,

In Privacy intend to spin My future Minutes out.

And from this Hermitage of mine I banish all wild toyes,

And nothing that is not Divine Shall dare to tempt my Joyes.

There are below but two things good, Friendship and Honesty,

And only those of all I would Ask for Felicity.

In this retir' $\mathrm{d}$ and humble seat Free from both War and Strife,

I am not forc'd to make retreat But chuse to spend my Life.

\section{Charles Cotton Eclogue.}

First published in Cotton's posthumous collection Poems on Several Occasions (1689). 'Clotten' appears to be the poet, lamenting his perennial financial difficulties.

Eclogue. Corydon, Clotten.

Corydon. Rise, Clotten, rise, take up thy Pipe and play,

The Sheepherds want thee, 'tis Pan's Holy-day;

And thou, of all the Swains, wert wont to be

The first to grace that great Solemnity.

Clotten. True, Corydon, but then I happy was,

And in Pan's favour had a Minion's place:

Clotten had then fair Flocks, the finest Fleece

These Plains and Mountains yielded then was his.

In these auspitious times the fruitfull Dams

Brought me the earliest and the kindli'st Lambs;

Nor nightly watch about them need I keep,

For Pan himself was Sheepherd to my Sheep;

But now, alas! neglected and forgot

Are all my off'rings, and he knows me not.

The bloudy Wolf, that lurks away the day,

58 th'Exchange] the first Royal Exchange building, built by Sir Thomas Gresham c.1566 and destroyed by fire in 1666. It was also a fashionable meeting-place and shopping centre. One ms has 'a Ball'. 67 , 69 Hide-parke, Spring-Garden] Already fashionable promenades for the London elite. Hyde Park, formerly a royal preserve, was opened to the public in 1632. The Spring Gardens later became 'New Spring Gardens' or Vauxhall Gardens. 12 Pan] the king: Charles II or James II, depending on the date. 
When night's black palm beckons him out to prey

Under the cover of those guilty shades,

No Folds but mine the rav'nous Foe invades;

And there he has such bloudy havock made,

That, all my Flock being devour'd or stray'd,

I now have lost the Fruits of all my pain,

And am no more a Sheepherd but a Swain.

Corydon. So sad a Tale thou tell'st me, that I must

Allow thy grief (my Clotten) to be just,

But mighty Pan has thousand Flocks in store,

$\mathrm{He}$, when it pleases him, can give thee more,

And has perhaps afflicted thee, to try

Thy Vertue onely, and thy Constancy.

Repine not then at him that thou art poor,

'Twas by his bounty thou wert rich before;

And thou should'st serve him at the same free rate,

When most distress'd, as when most fortunate.

Clotten. Thus do the healthfull still the sick advise,

And thus men preach when they would fain seem wise;

But if in my wretched Estate thou wert,

I fear me thy Philosophy would start,

And give thee o'er to an afflicted Sense,

As void of Reason as of Patience.

Had I been always poor, I should not be

Perhaps so discontent with Poverty,

Nor now so sensible of my disgrace,

Had I ne'er known what Reputation was;

But from so great a height of happiness

To sink into the bottom of distress

Is such a change as may become my care,

And more than, I confess, I well can bear.

Corydon. But art thou not too sensible, my Lad,

Of those few losses thou hast lately had?

Thou art not yet in want, thou still dost eat

Bread of the finest Flower of purest Wheat;

Who better Syder drinks, what Sheepherd's board

Does finer Curds, Butter, or Cheese afford?

Who wears a Frock, to grace a Holy-day,

Spun of a finer Wooll, or finer Grey?

Whose Cabin is so neatly swept as thine,

With Flow'rs and Rushes kept to sweet and fine?

Whose name amongst our many Sheepherds Swains

So great as thine is throughout all these Plains?

Who has so many Friends, so pretty Loves?

Who by our bubbling Fountains and Green Groves

Passes away the Summer heats so well?

And who but thee in singing does excell?

So that the Swains, when Clotten sings or plays,

Lay down their Pipes, and listen to his Lays?

Wherein then can consist, I fain would know,

The Misery that thou complain'st of so?

Clotten. Some of these things are true, but, Corydon,

That which maintain'd all these, alas! is gone.

The want of Wealth I reckon not distress,

But of enough to doe good offices;

Which growing less, those Friends will fall away;

Poverty is the ground of all decay;

With our Prosperities our Friendships end,

And to misfortune no one is a Friend,

Which I already find to that degree,

That my old Friends are now afraid of me,

22 Swain] a hireling, not a shepherd who owns his flocks. Cotton had to sell a part of his estate. 49-66

Bears out Cotton's reputation as a bon vivant despite his straitened circumstancesta C53 [Frock] man'\$1526143426 
And all avoid me, as good men would fly

The common Hangman's shamefull company.

Those who by Fortune were advanc'd above,

80 Being oblig'd by my most ready love,

benefited by, thanks to

Shun me, for fear least my necessity

Should urge what they're unwilling to deny,

And are resolv'd they will not grant; and those

Have shar'd my Meat, my Money, and my Cloaths,

Grown rich with others Spoils as well as mine,

The coming near me now do all decline,

Least shame and gratitude should draw them in,

To be to me what I to them have been;

By which means I am stripp'd of all supplies,

And left alone to my own Miseries.

Corydon. In the relation that thy grief has made,

The World's false friendships are too true display'd;

But, courage man, thou hast one Friend in store,

Will ne'er forsake thee for thy being poor:

I will be true to thee in worst estate,

And love thee more now than when Fortunate.

Clotten. All goodness then on Earth I see's not lost,

I of one Friend in misery can boast,

Which is enough, and peradventure more

Than any one could ever do before;

And I to thee as true a Friend will prove,

Not to abuse but to deserve thy love.

\section{Charles Cotton An Invitation to Phillis}

First published posthumously in Cotton's Poems for Several Occasions (1689). Another elite variant of the pastoral invitation to love, recasting the pastoral setting around a country mansion. It also describes the natural setting through the year around the river Dove in Cotton's native region of Beresford, Staffordshire.

An Invitation to Phillis.

Come live with me, and be my love,

And thou shalt all the pleasures prove,

The Mountains' towring tops can show

Inhabiting the Vales below.

From a brave height my Star shall shine

T'illuminate the desart Clime.

Thy Summer's bower shall overlook

The subtil windings of the Brook,

For thy delight which only springs,

And cuts her way with Turtles Wings.

The Pavement of thy Rooms shall shine

With the bruis'd Treasures of the Mine,

And not a Tale of Love but shall

In Minoture adorn thy wall.

Thy closet shall Queens Caskets mock

With rustick Jewels of the Rock,

And thine own light shall make a Gemm,

As bright of these, as Queens of them.

From this thy Sphear thou shalt behold

A tender Lamb, and silver Fleece.

$\mathbf{5}$ my Star] i.e. the beloved. $\quad \mathbf{6}$ desart] deserted, lonely. clime] region, tract $\left(O E D_{2}\right) . \quad 7$ Summer's
bower] Apparently a pleasure-house set high on a slope, with a view of the entire estate. bower] Apparently a pleasure-house set high on a slope, with a view of the entire estate. 10 Turtles]
turtle-dove's, referring either to the curved shape of the wings (like the river's windings), or to its swiftness in flight. 16 Jewels of the Rock] coloured, perhaps semi-precious, stones. $17-8$ The radiance of your presence will make these humble stones shine as brightly as queens' jewels. 19 Sphear] In the Ptolemaic system, the heavenly bodies were thought to be embedded in crystalline 1526143426 spheres. Here, the beloved's room or presence. 
And when Sols Rayes shall all combine

the sun-god, hence the sun

Thine to out-burn, though not outshine,

Then, at the foot of some green Hill,

Where crystal Dove runs murm'ring still,

We'll angle for the bright-ey'd Fish,

To make my Love a dainty dish;

delectable, delicate

Or, in a Cave, by Nature made,

Fly to the covert of the shade,

Where all the pleasures we will prove,

Taught by the little God of love.

And when bright Phobus scorching beams the sun-god Apollo, hence the sun

Shall cease to guild the Silver streams,

Then in the cold arms of the Flood

We'll bathing cool the factious Blood,

Thy beautious Limbs the Brook shall grace,

Like the reflex of Cynthia's Face,

Whilst all the wond'ring Fry do greet

reflection; the moon-goddess Diana, hence the moon

The welcome Light, adore thy Feet, small fish, swarm of such

Supposing Venus to be come

To send a kiss to Thetis home.

And following Night shall trifled be

Sweet; as thou know'st I promis'd thee,

Thus shall the Summers Days, and Nights,

Be dedicate to thy delights.

Then live with me, and be my love,

And all these pleasures shalt thou prove.

But when the sapless Season brings

Cold Winter, on her shivering Wings,

Freezing the Rivers liquid face,

Into a crystal Looking-glass,

And that the Trees their naked bones

Together knock, like Skeletons,

Then, with the softest, whitest Locks,

Spun from the tribute of thy Flocks,

We will o're-cast thy whiter Skin,

Winter without, a Spring within.

At the first peep of Day I'le rise,

To make the sullen Hare thy prize,

And Thou with open Arms shalt come,

To bid thy Hunter welcome home.

The Partridge, Plover, and the Poot,

I'le with the subtle Mallard shoot;

The Fell-fare, and the greedy Thrush

Shall drop form ev'ry Haw-thorn Bush,

And the slow Heron down shall fall,

To feed my Fairest Fair withall,

The feather'd People of the Air,

Shall fall to be my Phillis fare,

No Storm shall touch thee, Tempest move;

Then live with me, and be my love.

But from her Cloister when I bring

My Phillis to restore the Spring,

The ruffling Boreas shall withdraw,

the following, the ensuing

The Snow shall melt, the Ice shall thaw;

The Aguish Plants fresh Leaves shall shew,

The earth put on her verdant hue,

And thou (Fair Phillis) shalt be seen

Mine, and the Summer's beautious Queen.

poult, young pheasant or other game-bird wily, elusive fieldfare, a species of thrush

These; and more pleasures shalt thou prove;

Then live with me, and be my love.

24 i.e. The sun's rays may be more corrosive than but not as radiant as the beloved's eyes. $\quad 26$ Dove] The river flowing through Cotton's native Staffordshire. $\quad 34$ guild the Silver $]$ a not uncommon paradox. $\mathbf{3 6}$ factious] perhaps misprint for fractious: unruly, turbulent. $\mathbf{4 2}^{2}$ Thetis $\mathrm{A}$ Naiad or 1526143426 sea-nymph; her home is the sea. $\quad 60$ sullen] ? grey or dull in colour (OED 4$)$. 


\section{Anthony Spinedge On the Execrable Murder of Charles I}

From Bod. MS Tanner 306. Actually entitled 'On the Same. An Eclogue. Corydon. Thyrsis' - 'the same' being the subject of the preceding poem, 'On the execrable Murther of that Glorious Martyr Charles .1. of blessed memory'. Written long after the Restoration: Anthony Spinedge (1651-1694) was born after Charles I's execution. He sent this poem to William Sancroft (later Archbishop of Canterbury) while the latter was Dean of St Paul's (1664-8).

On the Same. An Eclogue. Corydon. Thyrsis

Corydon. T'was yerst (my sweet) I on my oaten reede

Pip'd as the nibling flocks did gently feede:

You sang the story of our loves, while they

The pretty Lambkins danc'd a Roundelay:

T'was whilome, Thyrsis, that yon teltale grove

Cry'd rostmeat when he saw our happy love:

Yon babling hill glad of a tale to tell,

Was made the neighbouring valley's centinell:

Those silver streames as they were passing by,

Stood still to gaze upon my sweet and I,

Kiss'd the blest banks, wheron wee kissing lay,

Making still musicke as they went away,

But oh! that blisse is gone, nor must wee more

Quaffe streams of Nectar till our cares run o're,

Picke pleasant strawberries on the hill, and then

Goe chat and eat, and eat and chat againe.

No more must wee meet in the twines of love,

embraces

Billing each other like the harme-lesse dove.

Lye basking on the mountains, or that done,

Bath in a brooke i'th' nonage of the Sun:

Sit under beachen bowers, and view the flocks

erst, once, earlier

Hang by the teeth upon the dangerous rocks:

Gaze on the skipping kids, and stalking dams,

Water the comely ewes, and tender lambs.

Pipe out the day, and when the night is come

Summon the bleating troops to pad it home.

No, Thyrsis, No, all these sweet ioys are fled,

The sheeps great deity great Pan is dead,

The only patriot of rurall Swaines,

The glory of the hills, the pride of plaines,

once, earlier

God Pan is dead; those swaines that sought his fate,

Tooke him and slew him at his temple-gate.

They all must goe to pot, none finde release,

Though some bee decimated by a fleece.

?spy, one who watches and reports

Thyrsis. Weep not, my sweeting, what that chrystall teare?

Tis prodigall to spend such every where,

T'will serve upon Pans tombe, and yonder cave

Shall bee the witnesse of the griefe we have.

Let's leave these plaines, let Edghill and Dunbar

Bee blotted out o'th' Sheapheards Calendar.

o.1 the Same] See headnote. $1 \mathbf{m y ~ s w e e t ] ~ T h e ~ f i r s t ~ o f ~ s e v e r a l ~ d e e p l y ~ i n t i m a t e , ~ a m o r o u s ~ a d d r e s s e s : ~}$ either expressing a strikingly explicit homoeroticism, or (unusually and wrongly) taking 'Thyrsis' as a woman's name. 6 Cry'd rostmeat] announced to others our private good fortune and happiness $(O E D$ roast meat $2 \mathrm{~b}$ ). The murmur of the teltale grove announced the lovers' presence, like the babling (echoing) hill. 12 still] soft $\left(O E D_{3} \mathrm{~b}\right) . \quad 23$ stalking] applied to the gait of deer etc. (OED 4b). 32 temple-gate] Charles I was executed in his own palace at Whitehall. $\mathbf{3 4}$ decimated by a fleece] ?destroyed easily, by something as soft as a fleece. 39 Edghill] in Warwickshire, the site of the first major battle of the English Civil War, on 23 October 1642. Dunbar] A battle on 3 September 1650, well after Charles's death, where Oliver Cromwell defeated Scottish forces loyal to Charles II. 


\section{Index of authors}

All references are to poem numbers; translators are indicated by 'tr'.

Alabaster, William 181

Alexander, William 198

Anonymous ('A.W.') 138

Anonymous (?Robert Aytoun ?Henry Hughes) 263

Anonymous 29, 30, 31, 62, 66, 86, 107, 108, $123,125,129,130,140,147,148,149,150$, $152,153,154,155,156,157,158,159,180$, $205,236,237,250,263,264,265,267$, 269, 270

Ashmore, John 13tr, 2otr

$\mathrm{B}$ [olton], E[dmund] 132, 133

Barclay, Alexander 16tr, 25, 26, 27, 28

Barnes, Barnabe 90, 91

Barnfield, Richard 95, 96, 97, 98

Basse, William 168, 169

Bastard, Thomas 109

Beard, Thomas 35 tr

Beaumont, Joseph 249

Beffa, Antonio 37

Benlowes, Edward 255

Blenerhasset, Thomas 55

Boethius 14

Bolton, Edmund(?) 132, 133

Brackley, Elizabeth and Jane Cavendish 240

Brathwait, Richard 206, 207, 208

Breton, Nicholas 111, 112, 113, 114, 115, 116, $117,118,119(?), 120,121,122,124(?)$

Brome, Alexander 272

Brooke, Christopher 183

Browne, William 189, 190

Byrd, William 69, 70
Carew, Thomas 233, 234

Cary, Patrick 254

Casimir, see Sarbiewski

Cavendish, Jane and Elizabeth Brackley 240

Cavendish, Margaret 256, 257, 258

Chapman, George 174

Chassanion, Jean 35

Chester, Robert 137

Chettle, Henry 144, 145(?), 146

Churchyard, Thomas 54

Cokayn, Aston 268

Cotton, Charles 275, 276

Cowley, Abraham 1otr, 224, 225

Daniel, Samuel 33tr

Davies, John(?) 177tr

Davies, John, of Hereford 184

Davies, Sir John 87tr

Davison, Francis 141

Day, Angel 63

Denny, William 253

Dickenson, John 105, 106

Drayton, Michael 160, 161, 162, 163, 164, $165,166,167$

Drummond, William 21tr, $36 \mathrm{tr}, 37 \mathrm{tr}$, $170 \mathrm{tr}$, 196, 197, 199, 200

D’Urfé, Honoré 176, 177

Dyer, Edward(?) 89

Elizabeth I 14tr

Fairfax, Edward 202

Fairfax, Thomas 203tr

Fane, Mildmay 246, 247, 248 
Fanshawe, Richard 12tr, 34tr, 217

Finet, John(?) 60

Fisher, Jasper 218

Flaminio, Marcantonio 20

Fleming, Abraham 8tr, 9tr

Fletcher, Giles 178

Fletcher, John 175

Fletcher, Phineas 219, 220, 221

Fraunce, Abraham 7tr, 57tr, 58tr, 61

Godolphin, Sidney(?) 238

Goffe, Thomas 195

Googe, Barnabe 32

Gorges, Arthur 67, 68

Greene, Robert 71, 72, 73, 74, 75, 76, 77

Guarini, Giambattista 34

H.C. (?Henry Chettle) 145

Habington, William 223

Hammond, William 262

Harvey, Thomas 17tr

Henryson, Robert 18

Herbert, George 222

Herbert, Mary (Countess of Pembroke) 139

Herbert, William (Earl of Pembroke) 216

Herrick, Robert 241, 242, 243, 244, 245

Heywood, John(?) 19

Heywood, Thomas 92, 93, 94

Hills, G[eorge] 231tr, 232tr

Horace (Quintus Horatius Flaccus) 12

James I 212

Jonson, Ben 191, 192, 193, 194

Lauder, George 201

Lilliat, John 126, 127

Lodge, Thomas $78,79,80,81,82,83$

Lok, Henry 110

Mansell, John (?) 130

Mantuan (Battista Spagnuoli) 15, 16, 17

Marino, Giovan Battista 170

Marlowe, Christopher 84

Martial (attrib.) 13

Milton, John 230

Montemayor, Jorge de 22, 23

Morley, Christopher 204

Moschus 5

Munday, Anthony 182
Murray, David 179

Oldisworth, Nicholas 215

Parker, Martin(?) 151

Parry, Robert 99

Passerat, Jean 36

Peele, George 64, 65

Perez, Alonso 24

Philips, Katherine 273, 274

Preti, Girolamo 171

Pyper, John 176tr

Quarles, Francis 239

Ralegh, Walter 85(?), 142, 143

Ramsey, John(?) 128

Randolph, Thomas 226, 227, 228, 229

Rastell, John(?) 19

Ravenscroft, Thomas 172, 173

Revett, Eldred 266

Robins, Thomas(?) 259

Robinson, Richard 11tr

Sabie, Francis 100

Saint-Amant, Antoine Girard 203

Sarbiewski, Casimir 231, 232

Sherburne, Edward 3tr, 171tr

Shirley, James 214

Sidney, Philip 46, 47, 48, 49, 50, 51, 52, 53(?)

Sidney, Robert 101, 102

Smith, William 103, 104

Spenser, Edmund 38, 40, 41, 42, 43, 44, 45

Spinedge, Anthony 277

Stanley, Thomas 5 tr

Strode, William 235

T.B. 4 tr

Tasso, Torquato 33

Taylor, John 213

Theocritus 1, 2, 3(?), 4

Theocritus/Virgil trans. T.B. Gent 4

Trussel, John(?) 59

Turberville, George 15tr

Vaughan, Henry 251, 252

Virgil (Publius Virgilius Maro) 4, 6, 7, 8, $9,10,11$ 
W.H. 136

Weaver, Thomas 260, 261

Walton, Izaak 271

Warner, William 56

Watson, Thomas 57,58

Webbe, William 6tr, 39

Willet, Andrew 88
Wither, George 185, 186, 187, 188

Wootton, John 135

Wroth, Mary 209, 210, 211

Yong, Bartholomew 22tr, 23tr, 24tr

Zanchi, Basilio 21 


\section{Index of titles and first lines}

All references are to poem numbers. Spellings of titles have been modernized. First lines in old spelling, but alphabetized according to equivalent modern spellings. ' $A$ ' and 'The' are retained at the start of the entry, and taken into account in the alphabetical sequence, in first lines but not in titles. Speech-headings in dialogue are omitted.

A Blithe and bonny Country-Lasse 79

A fairest Ganymede, disdaine me not 97

A Jollie sheppard 180

A Paradice on earth is found 165

A Shepheard poore, Eubulus call'd he was 141

A Sheephard who no care did take 210

A Silly poor Sheepherd 264

A Silly Sheepheard lately sate 119

Affectionate Shepherd, The, from 'The

Second Day' 95

Affectionate Shepherd, The, from 'The

Shepherd's Content' 96

Ah trees why fall your leaues so fast? 82

Ah what is loue? is it a pretie thing 75

Ah! when I call to Mind that happy

Time 201

Alas our sheappeard now is strocke againe 181

Alas my hart, mine eye hath wronged thee 89

Alexis if thy worth doe not disdaine 185

'Alexis to Damon' 198

All Gentlemen and Yeomen good 156

$\mathrm{Al}$ hayle Minalcas, nowe by my fayth well met 28

'All Hail to Hatfield' 237

Along the verdant fields all richly dide 35

Although I am a Countrey Lasse 151

Among the rustie rockes, bothe rough and harde by kinde 54

Among thy sheepe ô Lord I seemd to feed 110

'Amor Constans' 204

Amphrisa the Forsaken Shepherdess, extracts 93

Amyntas, The Argument 60

Amyntas, 'Lamentation II' 57

Amyntas, 'Last Lamentation' 58

An Elder time there was so yore 153

And are you there old Pas? in troth I euer thought 49

And now at length this fit shee doeth recouer 92

And now from solid Prose I will abstaine 213

And now since Phillis dead corps was layd in a coffyn 58

And wilt thou then, Alexis mine, depart? 197

'Another of the same nature' 86

'Apollo, Daphne and the Shepherd' 66

Apollo (father of the Sisters nine 213

Arcadia, Old, poem 447

Arcadia, Old, poem 1748

Arcadia, Old, poem 2949

Arcadia, Old, poem 3450

Arcadia, Old, poem 7151

Arcadia, Old, poem 7552

Arcadian Lovers, The 157 
'Arcadian Syrinx' 61

Arcadian Syrinx was a Nymph most noble, amongst all 61

'Argentile and Curan' 56

As att noone Dulcina rested 159

As Colin went forth 265

As I late wandred over a Plaine 269

As vhen a sheaphard boy from fearful hight 200

Asks thou, ith'Country how I spend the Day? 13

Astrcea daughter of the immortall Ioue 65 Astrophel 43

Attend then Shepheards, now I doe begin 206

At the Spring 218

Aurora from old Tithons frosty bed 219

Bad are the times 242

'Beautiful Shepherdess of Arcadia, The' 158

Because thou recountest of thy fidelitie 27

Blest be the man (and blest he is) whom'ere 225

Borrill, why sit'st thou musing in thy coate? 160

Britannia's Pastorals, extracts 189,190

But Flaccus, now more happy he appears 232

But Muse, from her so low, diuert thy highset song 163

But, noble Muse, proceed immediatly to tell 163

But now the second Morning, from her bowre 178

Careless Shepherdess, The, extract 195

Chloris Sonnet 3103

Chloris Sonnet 5104

'Christmas' Part II 222

Christ's Victory and Triumph, extracts 178

Cleere had the day bin from the dawne 166

Cloris, since thou art fled away 263

Close by a River cleare, whose bankes were clad 177

Colin Clout's Come Home Again, extracts 42

Come Espilus, come now declare thy skill 46

Come follow me merily my mates 173

Cumme gentle Heardman sitt with mee 67
Come let vs walke that wee may sweetely heare 240

Come liue with mee, and be my deere 86

Come live with me, and be my love (Cotton) 276

Come liue with mee, and be my loue (Marlowe) 84

Come love, lets walke into the springe 154

Come Marina let's away 207

Come neere and view my pallace how it stands 236

Come Shepherds come, impale your brows 195

Come Shepheards, decke your heads 148

Come shepheards weedes, become your masters minde 47

Come Sons of Summer, by whose toile 244

'Complaint of the Shepherd Harpelus, The' 179

Consolation of Philosophy, The, Bk II Poem 514

Cool Shades, Air-fanning Groves 20

'Coridon and Strephon' 268

Coridon, arise my Coridon 133

'Coridon to his Phillis' 89

'Coridon's Song' 79

'Coridon's Supplication to Phillis' 120

Countries delight, sweet Phillis, Beuties pride 59

'Country Lass, The' 68

'Country Lass, The' 151

'Country life, A' 274

'Country Life, The' 225

Cynthia Sonnet 1597

Cynthia Sonnet 1898

'Damextas' Jig in Praise of His Love' 134

'Damon: Or a Pastoral Elegy', extracts 201

'Damon and Moeris' 196

Damon and Moeris by a christal spring 196

'Damon's Ditty' 100

'Daphnis: An Elegiac Eclogue' 252

Day which so bright didst shyne, how darck art thow? 102

Dearest in Friendship, if you'll know 247

Dear leave thy home and come with me 216

Deer! on yond' Mountain stands my humble Cot 171 
Dear Silvia let thy Thirsis know 260

Deare Thyrsis! tell thy Corydon 250

Descensus Astraeae, extracts 65

'Description of Arcadia' 106

'Description of Shepherds and Shepherdesses, A' 256

'Description of the Shepherd and His Wife' 74

'Dialogue between Two Shepherds in Praise of Astraea' 139

'Dialogue betwixt A Nymph and A Shepherd, A' 229

'Dialogue betwixt Lucasia and Rosania, A' 273

'Dialogue Weeping the Loss of Pan, A' 246

Doe I mistake? or from Elyzium cleare 231

DoRILvs in sorrowes deepe 164

'Doron's Eclogue Joined with Carmela's' 73

'Doron's Jig' 72

Eclogue I (Barclay), extract 26

Eclogue I (Basse) 169

Eclogue I (Cokayn) 268

Eclogue I (Virgil) 6

Eclogue I.1-8 (Virgil) 4

Eclogue II (Googe) 32

Eclogue II (Virgil) 7

Eclogue III (Barclay), extract 27

Eclogue IV (Barclay), extracts 28

Eclogue IV (Mantuan), extract 15

Eclogue IV (Virgil) 8

Eclogue VI (Mantuan), extract 16

Eclogue VII (Mantuan), extract 17

Eclogue IX, 1606 (Drayton) 162

Eclogue X (Virgil) 9

'Eclogue between a Carter and a Shepherd, An' 215

'Eclogue between a Shepherd and a Herdman, An' 67

'Eclogue between Willy and Wernocke, An' 184

'Eclogue: Corydon, Clotten' 275

'Eclogue Gratulatory to Robert Earl of Essex, An' 64

'Eclogue Occasioned by Two Doctors Disputing upon Predestination, An' 227

'Eclogue on the Palilia on Cotswold Hills, An' 228

'Eclogue to Master Jonson' 226
'Eclogue upon the Death of Sir Philip Sidney' 138

Eclogues, Prologue (Barclay) 25

Elegy III (Basse), extract 168

'Epitaph on Bion' 5

'Epitaph on Robert Cecil' 143

Epode II (Horace) 12

Epode III (Casimir) 232

'Erycine at the Departure of Alexis' 197

'Excellent Pastoral Ditty, An' 128

Faerie Queene, The, extracts 44, 45

Fair Dulcina Complaineth 149

Fair golden Age! when milk was th' onely food 34

Faire in a morne, (ô fairest morne) 114

Faire Phillis is the Sheepheards Queene 115

Fair Shepardes why dost thou weep 246

Fair sheperdess that feedest thy fair flocks 130

Faire siluer-footed Thetis that time threw 190

Fair Virtue, extract 186

'Farewell to the World, A' 122

Feede on my Flocks securely 144

Feede silly sheepe although your keeper pineth 103

'Fiction How Cupid Made a Nymph Wound Herself with His Arrows' 140

Fie on the sleights that men deuise 145

Fields were ouer-spred with floures 106

'For a Sheep-shearing' 187

'For a Shepherd' 188

For shame man will thou never leave thy sorrow 204

Forsooth frende Cornix nought can my heart make light 26

Fragment of a Greater Work 200

From England, Scotland, Wales and Ireland 261

From Fortunes frownes and change remou'd 78

From the Ramme 182

Fuimus Troes, songs 218

Gentlemen, Gentlemen, listen to my Ditty 259

Georgic II (Virgil), extract 10

Georgic III (Virgil), extract 11 
God speede my freend, why sittst thou heere so sadd? 129

Golden Age Chorus (Guarini) 34

Golden Age Chorus (Tasso) 33

Good day, Mirtillo 241

'Good Shepherd's Sorrow, The' 147

Great Pan the Father of our peace, and pleasure 193

Gvarda mi las vaccas 24

Hail happy day! Dorus, sit down 271

Happy is He, that free from Mental Toil 12

Happy to muche the formar Age 14

'Harpelus' Complaint' 31

He suffers in warme Cottages 11

Hence forth I will nott sett my loue 68

Herdgrome, what gars thy pipe to goe so loud? 64

'Herdman's Happy Life, The' 69

Heere Hobbinoll lyes, our shepeheard whilere 143

'Hermes and Lycaon' 202

Hey troly loly lo mayde, whether go you? 30

Himatia-Poleos, Song from 182

'Hock-Cart, The' 244

Ho jolly Thirsis whither in such hast? 227

How blest art thou, canst loue the countrey, WROTH 192

How now shepheard what meanes that 205

How Sacred and how Innocent 274

'[Hymn] For a Sheep-shearing' 187

'[Hymn] For a Shepherd' 188

'Hymn to Pan' 175

I Hate the Countries dust and manners, yet 223

I have lost my melch cow 240

I pray thee, keepe my kine for mee 24

I sing diuine ASTREAS praise 139

Idea the Shepherd's Garland VII 160

Idea the Shepherd's Garland VIII 161

Idyll I.4-6 (Theocritus) 4

Idyll VIII (Theocritus) 1

Idyll XI (Theocritus) 2

If all the world and love were young 85

If he shall choose the horned Scire 4

If plaints could penetrate the sun-bright top of Olympus 105

If thou wilt loue me, thou shalt be my Boy 95
If yet, if yet 193

In a field full fayer of flowers 107

In peticot of Greene 170

'In Praise of a Country Life' 248

In sad and Ashy weeds 147

In seemely sorte I like to love 127

In sweetest prime, and blooming of his Age 199

In the merry moneth of May 117

In this merry Maying time 150

In time of yor when shepperds dwelt 113

'Invitation to Phyllis, An' 276

Iolly shepheard and vpon a hill as he sate 172

Iolly Sheepheard, Sheepheard on a hill 134

Is not that the noblyst thyng in dede 19

Is not thilke same a goteheard prowde 41

'Isle of Man, The' 261

It chaunst of late a Shepheardes swaine 140

It was neere a thickie shade 74

Jack! Nay prithee come away 254

'Jack the Plough-Lad's Lamentation' 259

'Jolly Shepherd, The' 270

Kala old Mopsus wife 21

'Kala's Complaint' 21

Lady of May, The, extract 46

'Lamentation II' (Amyntas) 57

'Land-schap between Two Hills, The' 266

'Last Lamentation' (Amyntas) 58

Late t'was in June the fleece when fully grown 162

'Laurinella, of True and Chaste Love' 169

Libri 4 Plantarum, extract 225

Lo Collin, here the place, whose pleasaunt syte 40

Long hath my sufferance labored to inforce 81

Lost in the mudd of thos hygh flowinge streames 142

Loue as well can make abiding 209

Lover's Delight, The 154

Love's Victory: Song 211

'Lycidas' 230

Mated with greefe a faithfull sheephearde sate 128

'Mercury's Song' 94 
'Milkmaids, The' 267

Moderatus, extract 99

More leane (Oh Ianus) seemes thy Goate 15

Mourn, and your grief ye Groves in soft sighs breath 5

Muse, first of Arden tell, whose foot-steps yet are found 163

Muses' Elizium, The: 'Description of Elizium' 165

Muses' Elizium, The: Nymphal VI 166

Muses' Elizium, The: Nymphal X 167

My beasts, go fede vpon the plaine 32

My Flocks feede not, my Ewes breede not 108

'My Happy Life, to a Friend' 247

My Lucasia, leave the Mountain tops 273

My sheep are thoughts, which I both guide and serve 48

Nere to a sheapheard did a damsell sit 125

New yeares, expect new gifts: Sister, your Harpe 194

'New-Year's Gift Sung to King Charles, A' 194

'New-Year's Gift to Sir Simeon Steward, A' 245

No newes of Navies burnt at Seas 245

Not Megabotes, nor Cleonymus 98

Now a Botch take thee, Tom: where hast thou beene 215

Now for the last farewell I meane to make 122

Now that the winter's gone, the earth hath lost 233

Now warre is all the world about 217

'Nymph's Reply to the Shepherd, The' 85

O Arethusa, graunt this labour be my last in deede 9

O eies that see not him, who look'd on yow 22

O happie art thou Tityrus 4

O Happie golden Age 33

O how I love these solitudes 203

O Mersa stay, flye not so fast from me 99

O Muses of Sicilia ile let's greater matters sing 8

O Nicias, there is no other remedie for loue 2
O sweet woods the delight of solitarines 50

$\mathrm{O}$ what a Plague is Love 155

O ye Nymphes most fine who resort to this brooke 39

Obsequy of Fair Phillida 152

Ocean to Cynthia, extract 142

'Ode Upon Occasion of His Majesty's Proclamation' 217

Ode IV.21 (Casimir) 231

Oenone and Paris, extract 92

Of all the kindes of common Countrey life 95

Of Gentylnesse and Nobility, extracts 19

'Of Jack and Tom' 212

Of PAN we sing, the best of Singers Pan 193

'Of the Quietness that Plain Country

Bringeth' 54

'Of the Vanity of Wanton Writings' 77

Oh happy, (if his Happiness he knows) 10

Oh! shepherd, oh! shepherd, will you come home 29

'Old Ballet of Shepherd Tom, The' 269

'Old Damon's Pastoral' 78

Old-Fashioned Love, An, Eclogue I 59

On a hill there growes a flower 116

'On Lazy and Sleeping Shepherds' 88

'On the Execrable Murder of Charles I' 277

'On the Reported Death of the Earl of Essex' 129

'On the Rustic Life' 13

'On Westwell Downs' 235

One day as he did raunge the fields abroad 45

One night I did attend my sheepe 90

'Page's Pleasant Rustick, The' 131

'Pan and Syrinx' 61

$P_{A N}$ is our All, by him we breath, wee live 193

Pan's Anniversary, Hymns I, II, III, IIII 193

Paris the Swain, away coy Helen bare 3

Passed contents 23

'Passionate Shepherd to his Love, The' 84

Passionate Shepherd, The, extracts 121, 122

Pastoral Play, Scenes from a 240

'Pastoral Dialogue, A' 260

'Pastoral Dialogue between Coridon and

Thyrsis, A' 250

'Pastoral Elegy on the Death of Sir Antony Alexander, A' 199 
'Pastoral on the King's Death' 272

'Pastoral Riddle, A' 125

'Pastoral Song, A' 264

'Pastoral Song between Phillis and Amarillis, A' 145

'Pastoral Song: with the Answer, A' 263

'Pastoral sung to the King, A' 242

'Pastoral upon the Birth of Prince Charles, A' 241

'Pastorall Wooing, The' 3

Peace sheppheard 123

Perin, arreed what new mischance betide 138

Philisides, the Shepherd good and true 53

'Phillis' 170

Phillida Flouts Me 155

Phylida was a fayer mayde 31

'Phillida's Love-Call to Her Coridon and

His Replying' 133

Phillis Sonnet 481

Phillis Sonnet 1282

Piscatory Eclogue VII (Phineas Fletcher) 219

Plac'd on yon' fair, though beetle brow 266

Pleasant Country Maying Song, A 150

'Pleasant Eclogue between Montanus and Coridon, A' 80

'Pleasure of Retirement, The' 255

Poly-olbion, extracts 163

Poore Harpalus opprest with loue 179

'Poor Shepherd's Introduction, A' 137

'Praise of a Religious Recreation, The' 232

Psalm 23 87, 111

Psyche, extract 249

Purple Island, The, extracts 221

Renowned men their Herds to keep 188

Revelation of the True Minerva, A, extract 55

Rise, Clotten, rise, take up thy Pipe and play 275

'Robene and Makyne' 18

Robene sat on gud grene hill 18

Robin Hood and the Shepherd 156

Say shepheards boy, what makes thee greet so sore? 80

Seelly shepheard Corydon lou'd hartily faire lad Alexis 7
'Second Shepherd's Song, The' 121

Shepheard, ah Shepheard, what sad dayes have we 239

Shepherd and the King, The 153

Shepheard, iffaith now say how wel 101

'Shepherd Inviting a Nymph to His Cottage, A' 171

Shephard loueth thow me vell? 36

Shepheard why creepe we in this lowly vaine 161

'Shepherds, The' 251

Sheapheards be sylent, and our musick cease 137

Shepherd's Calender, The, 'April' 38

Shepherd's Calender, The, 'July' 41

Shepherd's Calender, The, 'June' 40

Shepherd's Complaint, The, extracts 105, 106

Shepherd's Content, The 1-14, 140-237, 273-9396

'Shepherd's Dialogue of Love, The' 205

'Shepherd's Dream, A' 119

'Shepherd's Employment Is Too Mean an Allegory for Noble Ladies, A' 257

'Shepherds' Holiday, The' (Brathwait) 207

Shepherd's Holiday, The, extract (Denny) 253

Shepherd's Hunting, The, Ecl.V 185

Shepherd's Lamentation, The 148

'Shepherd's Ode, The' 71

Shepherd's Oracle, The 239

'Shepherd's Sirena, The' 164

'Shepherds' Song for Christmas' 135

'Shepherds' Spring Song, The' 146

Shepherds' Tales, extracts 206, 207, 208

Shepheards that wont on pipes of oaten reed 43

'Shepherd's Wife's Song, The' 75

'Shepherdess Her Reply, The' 127

Should Cronicles wherein thy founders name 237

Siluan Muses can yee sing 121

'Similizing the Sea to Meadows and Pastures' 258

Since first thy soile O countrie Pan I knewe 63

Since that to death is gone the shepheard hie 52

Sing his praises that doth keep 175

Sing sing (Parthenophil) sing, pipe, and play 91 
Sing vs that carroll (Damian) 83

Sing you, plaie you; but sing and play my truth 66

Sirinx, one of Dian's traine 94

Sit down Carmela here are cubbs for kings 73

'Solitude, The' 203

'Song' (Passerat) 36

'Song' (Wroth) 209

'Song, A' ('As Colin went forth') 265

'Song in praise of Eliza, A' 63

'Song of a Country Swain at the Return of Philador, The' 76

'Sonet, A' (William Herbert) 216

'Sonnet, A' (D’Urfé) 176

'Spring, The' 233

Strangwaies leaue London and her sweet contents 109

Sundry Christian Passions, Part I Sonnet 9110

Sweet, harmles lives! (on whose holy leisure 251

Sweete Musique, sweeter farre 135

Sweete Phillis, if a silly Swaine 120

Sweet Phillis Venus sweetyng was, was none so swete as she 60

Sweet shepperdisse 126

'Tale of Robin Hood, A' 62

Taylor's Pastoral, extracts 213

'Technis' Tale' 206

Tell me good Hobbinoll, what garres thee greete? 38

Tell me Loue what thou canst doe? 208

'That a pleasant poverty is to bee preferred before discontented riches' 224

The Brutons thus departed hence, Seauen Kingdomes here begonne 56

The early Morn lets out the peeping day 221

The fairest nymph that vallyes 152

The famous Poetes with the Muses nine 25

The fieldes are grene, the springe growes on a pace 118

The golden god Hyperion 149

The innocence, truth, and simplicitie 93

The life of a Shepherd is void of all care-a 270

The Lord my Sheaperd is, hee doth mee feed 87
The lord he is my sheepheard, that doth feede 111

The Loue Alexis did to Damon beare 198

The Shepheard Colliden, who ere him know 169

The shepheard good doth watch his sheepe 88

The shepherds guarded from the sparkling heat 221

The Shepherdesses which great Flocks doe keep 256

The shepheards boy (best knowne by that name) 42

The shepherds sing; and shall I silent be? 222

The silent shade had shadowed euery tree 76

The Sunne that had himselfe a Courtier beene 168

The Sunne the season in each thing 136

The sweatie sith-man with his rasor keene $2 \mathrm{O} 2$

The warmer Sun the golden Bull outran 221

The Waves like Ridges of Plow'd-land lies high 258

Then Pan (when Neptune had Apollos place) 55

Thenot and Chloris, red lipt Driope 146

Thenot my deare, how can a lofty hill 220

'Thenot's Abode' 236

Theophila's Love Sacrifice, extract 255

'Theorello the Shepherd's Idillion' 132

There are no suerties (good friend) will be taken 174

There on a day as he pursew'd the chace 44 There was a Shepheards Daughter 158

There where the pleasant Eske 37

This great difference and first diuersitie 16

This is the Seate of sweet Repose for Swaines 253

Thou art not, Penshvrst, built to enuious show 191

Though Amarillis daunce in greene 70

Though frost, and snow, lockt from mine eyes 234

Though Tytirus the Heards swaine 77

Thrice famous Saxon King, on whom Time nere shall pray 163

Through the shrubs as I can crack 72 
Thus spend we time in laughter 218

Tityrus, happilie thou lyste tumbling vnder a beech tree 6

'To Amarillis' 70

To cover Noble Lovers in Shepherds weeds 257

'To his Little Field' 20

'To his Loving Friend Master John Fletcher' 174

'To His Much Loved Friend Master W. Browne' 183

'To His Muse' 243

'To My Beloved Thenot in Answer of His Verse' 220

'To my Ingenious Friend Master Brome' 271

'To My Noblest Friend, I.C. Esquire' 223

'To Penshurst' 191

'To Reverend Colin' 83

'To Saxham' 234

'To Sir Robert Wroth' 192

'To Thomas Strangways' 109

Tom and Will 238

Tom and Will were Shepherds Swains 238

T'was yerst (my sweet) I on my oaten reede 277

Two nights thus past: the Lilly-handed Morne 189

Two prettie Rills doe meet, and meeting make 186

Vnder this Beech why sit'st thou here so sad 226

'Unknown Shepherd's Complaint, The' 108

Vnworthy, though, ô LORD, we are 187

Vpon a deintie hill sumtime 112

'Upon a Kiss Given' 126

'Upon Cloris Her Visit after Marriage' 262

Vppon the hilles of Arcadie 131

Vpon the smooth Arcadian plain 157

'Votum Primum' 130

Walkeing betimes close by a green wood side 267

Walking in a valley greene 71

We that have knowne no greater state 93

Watt boy whether now so faste? 62

What, breathles Nimphs? bright Virgins let me know 167

What Clod-pates Thenot are our Brittish swaines? 228

What clouds, Menalcas, do oppress thy brow? 252

What pleasure haue great princes 69

Whatt suddaine Chaunce hath darkt of late 212

What think'st O Galbula, that where of yore 17

When by the pleasant streams of Thames poore caitif Amintas 57

When I was a little swain 124

When Ioue first broken had the Chaos ancient 100

When Westwell downes I gan to treade 235

Where England's Damon us'd to keep 272

Wherefore if you loue me 176

Whil'st in the open Field our Watch we kep'd 249

Whither Mad maiden wilt thou roame? 243

Who Chance, Change, Hopes, and Fears can under bring 255

Who so Enjoyes the Cuntry Ayer 248

Why (Damon) did Arcadian Pan ordain 262

Why ô doth gaudy Tagus ravish thee 224

Why sigh you swain? this passion is not common 229

Why Strephon, art thou melancholy grown 268

Willy well met, now whiles thy flockes do feed 183

WILLY, why lig'st thou (man) so wo-begon? 184

With louely Netehearde Daphnis on the hills, they saie 1

'Wodenfride's Song in Praise of Amargana' 136

Wood-men Shepherds, come away 214

Yet once more, $\mathrm{O}$ ye laurels, and once more 230

You Fawnes and Siluans, when my Chloris brings 104

You Gote-heard Gods, that loue the grassie mountaines 51

You pleasant flowrie mead 211

You Sheepheards which on hillocks sit 132 